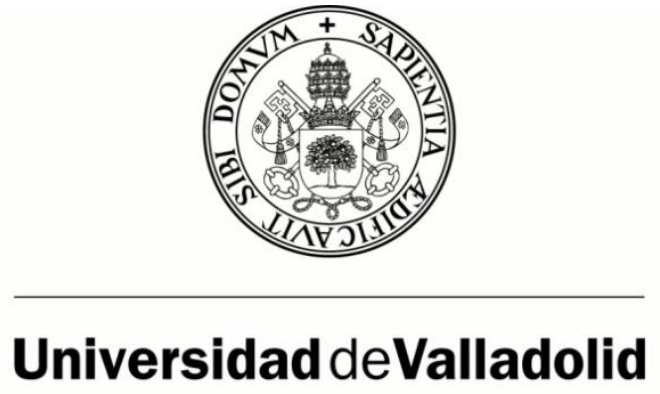

FACULTAD DE FILOSOFÍA Y LETRAS

Departamento de Historia Moderna, Contemporánea, de América, Periodismo y Comunicación Audiovisual y Publicidad

TESIS DOCTORAL

\title{
LA DIPUTACIÓN PROVINCIAL DE VALLADOLID EN EL SIGLO XIX (1813-1874)
}

Presentada por ANTONIO DE ANTA MUÑOZ para optar al grado de Doctor por la Universidad de Valladolid

Dirigida por el Doctor Pedro Carasa Soto 


\section{INDICE}

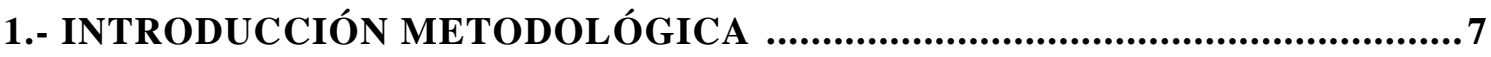

1.1.- PRIMERA HISTORIOGRAFÍA ............................................................. 7

1.2.- HISTORIA DE LA ADMINISTRACIÓN PROVINCIAL …..................... 10

1.3.-HISTORIOGRAFÍA SOCIAL Y CULTURAL .................................... 11

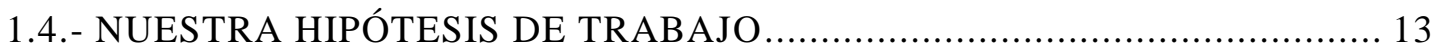

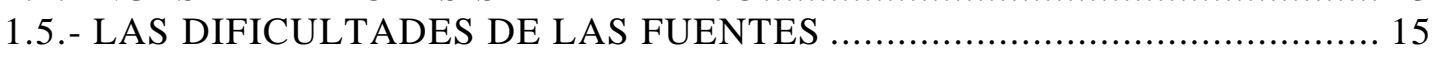

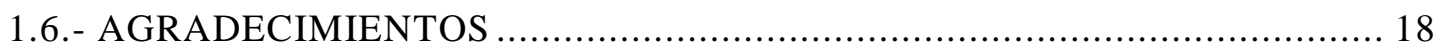

2.-LEGISLACIÓN SOBRE EL RÉGIMEN PROVINCIAL ............................... 19

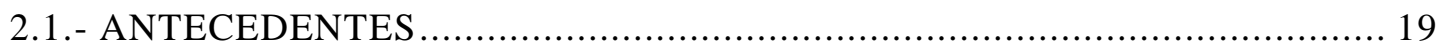

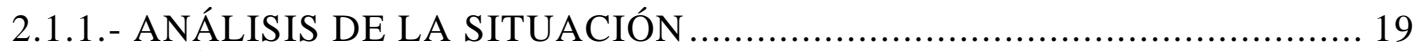

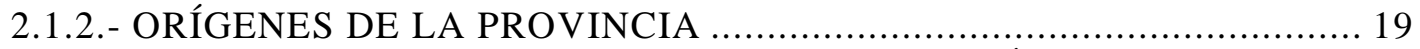

2.1.3.- ANTECEDENTES INTERNOS DE LA DIPUTACIÓN ....................... 20

2.1.4.- REFERENCIAS EXTERNAS DE LA DIPUTACIÓN ........................... 21

2.2.- LA LEGISLACIÓN GADITANA $(1812-1814)$....................................... 22

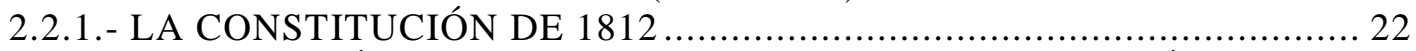

2.2.2.- LEGISLACIÓN COMPLEMENTARIA A LA CONSTITUCIÓN ............ 24

2.2.3.- INSTRUCCIÓN PARA EL GOBIERNO ECONÓMICO-POLÍTICO DE

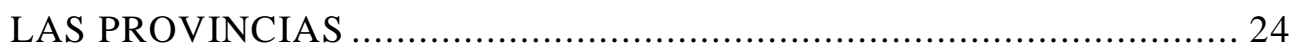

2.2.4.- EVOLUCIÓN LEGISLATIVA EN LA ÉPOCA GADITANA ................. 25

2.3.- LA LEGISLACIÓN DEL TRIENIO LIBERAL (1820-1823) ..................... 25

2.3.1.- LA NUEVA PUESTA EN MARCHA ............................................ 25

2.3.2.- LOS PROYECTOS ............................................................... 26

2.3.3.- LEY DE 3 DE FEBRERO DE 1823 "SOBRE EL GOBIERNO ECONÓMICO-POLÍTICO DE LAS PROVINCIAS" ......................... 26

2.4.- LA LEGISLACIÓN ISABELINA ........................................................ 28

2.4.1.- PROYECTOS Y LEYES EN LOS PRIMEROS AÑOS ......................... 28

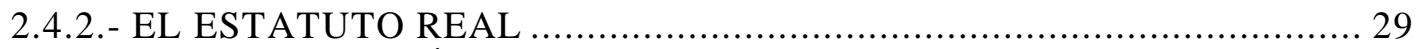

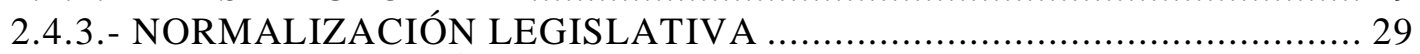

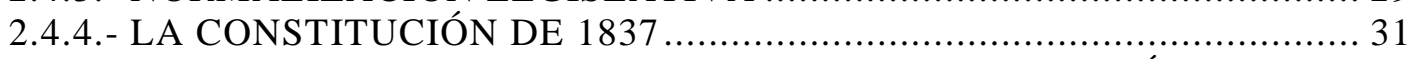

2.4.5.- LEYES COMPLEMENTARIAS SOBRE LA CONSTITUCIÓN .............. 33

2.4.6.- LEY MODERADA DE ORGANIZACIÓN Y ATRIBUCIONES DE LAS DIPUTACIONES PROVINCIALES DE 8 DE ENERO DE 1845 ............ 36

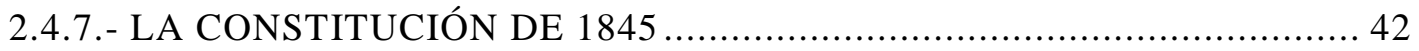

2.4.8.- NUEVA LEY UNIONISTA PARA EL GOBIERNO Y ADMINISTRACIÓN DE LAS PROVINCIAS DE 25 DE SEPTIEMBRE

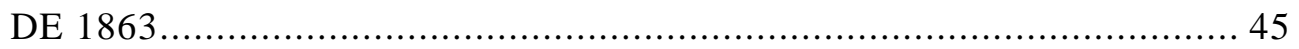

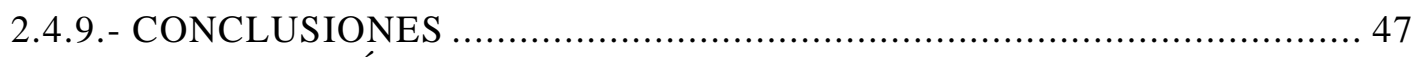

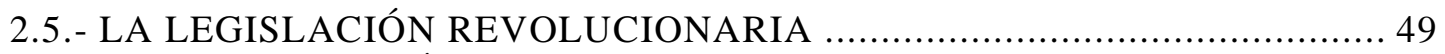

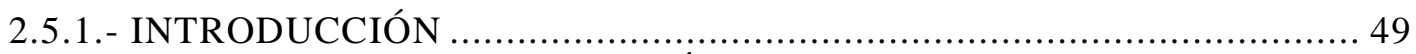

2.5.2.- LEY DE ORGANIZACIÓN Y ATRIBUCIONES DE LAS

DIPUTACIONES PROVINCIALES ........................................................ 50

2.5.3.- DECRETO SOBRE EL EJERCICIO DEL SUFRAGIO UNIVERSAL ...... 51

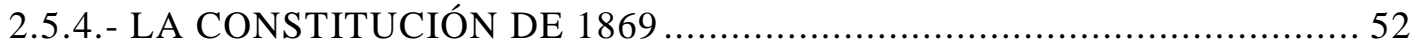

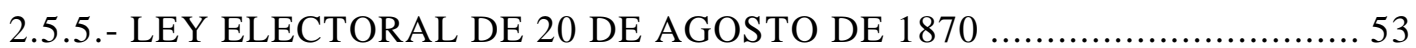

2.5.6.- LEY ORGÁNICA PROVINCIAL DE 20 DE AGOSTO DE $1870 \ldots \ldots \ldots . . .54$

2.5.7.- PROYECTO DE CONSTITUCIÓN FEDERAL DE 1873 ...................... 55

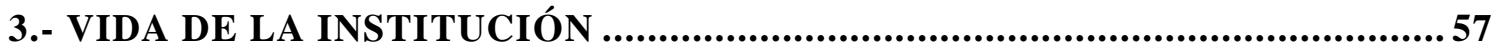


3.1.- LA PROVINCIA DE VALLADOLID. EXTENSIÓN Y TERRITORIO ......... 57

3.1.1.- VALLADOLID EN EL ANTIGUO RÉGIMEN ................................. 57

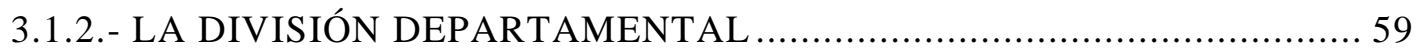

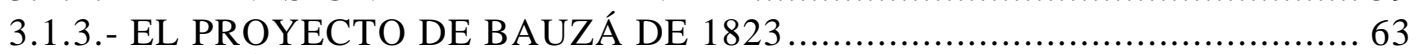

3.1.4.- LOS LÍMITES PROVINCIALES EN EL TRIENIO .......................... 66

3.1.5.- LA DIVISIÓN PROVINCIAL DE JAVIER DE BURGOS .................... 71

3.2.- LOS DIFÍCILES COMIENZOS DE LA DIPUTACIÓN ........................... 76

3.2.1. - SITUACIÓN A ESCALA NACIONAL …......................................... 77

3.2.2.- SITUACIÓN A ESCALA PROVINCIAL .......................................... 78

3.3.- LAS SEDES DE LA DIPUTACIÓN ….............................................. 79

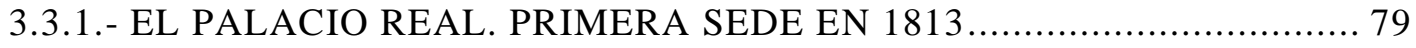

3.3.2.- EL PALACIO POLENTINOS EN EL TRIENIO LIBERAL ................... 81

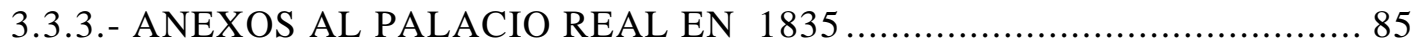

3.3.4.- PALACIO DEL DUQUE DE OSUNA ENTRE 1836 Y $1845 \ldots \ldots \ldots \ldots \ldots \ldots . . . . . . .66$

3.3.5.- PALACIO DE VILLASANTE EN LOS AÑOS 1845 A $1851 \ldots \ldots \ldots \ldots \ldots . . . . . .87$

3.3.6.- COLEGIO DE SAN GREGORIO DESDE 1851 HASTA $1874 \ldots \ldots \ldots \ldots . . . . . .89$

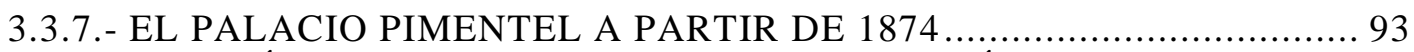

3.4.- EVOLUCIÓN INSTITUCIONAL DE LA DIPUTACIÓN ............................ 96

3.4.1.- LA PRIMERA DIPUTACIÓN Y LOS PRIMEROS DIPUTADOS ........... 97

3.4.2.- LAS TRES DIPUTACIONES DEL TRIENIO .................................... 104

3.4.3.- LAS TRES INICIALES DIPUTACIONES ISABELINAS $1835-40 \ldots \ldots \ldots 113$

3.4.4.- LA DIPUTACIÓN DE LA REGENCIA DE ESPARTERO 1841-43....... 123

3.4.5.- LAS CINCO DIPUTACIONES MODERADAS 1844-1854 ................ 128

3.4.6.- DOS DIPUTACIONES PROGRESISTAS EN EL BIENIO 1854-56 ...... 138

3.4.7.- VUELTA A LA DIPUTACIÓN CONSERVADORA. LAS OCHO DIPUTACIONES DEL “PERÍODO GRIS” 1856-68 ........................ 144

3.4.8.- LAS CINCO DIPUTACIONES DEL SEXENIO. 1868-74 _.................. 159

3.5.- ÍNDICE ONOMÁSTICO DE FUNCIONARIOS Y PERSONALIDADES .... 173

4.-ACTIVIDADES DE LA DIPUTACIÓN ................................................... 177

4.1.- FUNCIONES GENERALES Y AUTORIDAD POLÍTICA ….................... 177

4.1.1.- FUNCIONES EN LA ÉPOCA CONSTITUCIONAL GADITANA …..... 177

4.1.2.- ANTIVIDADES EN EL TRIENIO LIBERAL .................................. 178

4.1.3.- ACTIVIDADES EN LA ÉPOCA ISABELINA ….......................... 179

4.1.4.- ACTIVIDADES EN EL SEXENIO REVOLUCIONARIO ................... 188

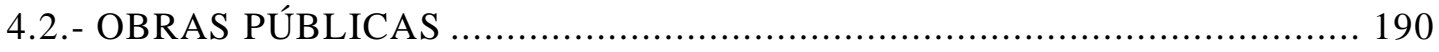

4.2.1.- CARRETERAS Y CAMINOS VECINALES ...................................... 191

4.2.2.- EL CANAL DE CASTILLA ….................................................. 200

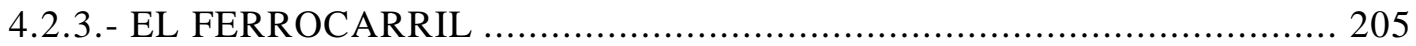

4.2.4.- OTRAS OBRAS PÚBLICAS .................................................... 212

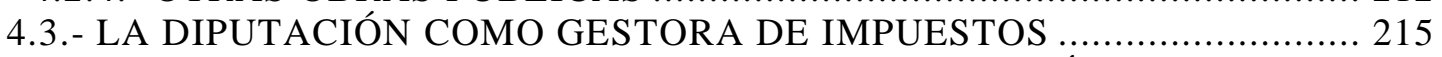

4.3.1.- LOS IMPUESTOS A PARTIR DE LA CONSTITUCIÓN DE $1812 \ldots \ldots .215$

4.3.2.- LOS IMPUESTOS EN EL TRIENIO LIBERAL .............................. 217

4.3.3.- LOS IMPUESTOS EN LA ÉPOCA ISABELINA ........................... 220

4.3.4.- LOS IMPUESTOS EN EL SEXENIO ........................................... 235

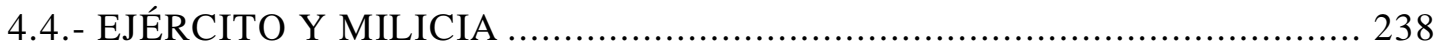

4.4.1.- EL EJÉRCITO Y LA DIPUTACIÓN FRENTE A FRENTE .................. 239

4.4.2.- REEMPLAZOS. LOS MOZOS CONTRA EL EJÉRCITO .................. 243

4.4.3.- SUMINISTROS Y BAGAJES .................................................... 255

4.4.4.- DE LA MILICIA NACIONAL A LA GUARDIA CIVIL ..................... 258

4.4.5.- LOS FACCIOSOS. RENEGADOS SOCIALES Y POLÍTICOS ............ 265

4.5.- SANIDAD Y BENEFICENCIA ......................................................... 268

4.5.1.-SANIDAD. DE LA INICIATIVA ECLESIÁSTICA A LA BENEFICENCIA

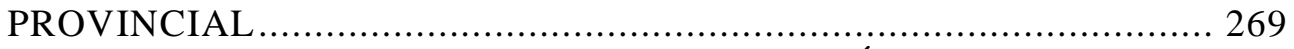

4.5.2.- LAS EPIDEMIAS, EL AZOTE DE LA POBLACIÓN ........................ 273 
4.5.3.- BENEFICENCIA. CONTROL PROVINCIAL DE POBRES Y DE

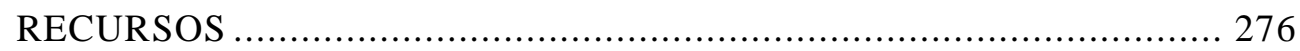

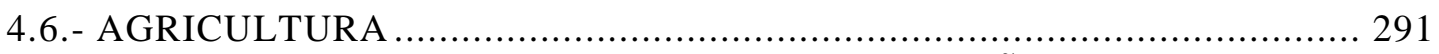

4.6.1.- LA AGRICULTURA EN LOS PRIMEROS AÑOS DE VIDA DE LA

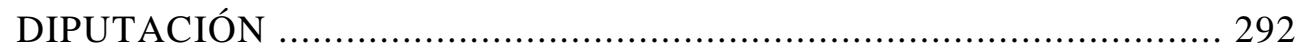

4.6.2.- LA AGRICULTURA EN EL TRIENIO LIBERAL ............................ 292

4.6.3.- LA AGRICULTURA EN LOS AÑOS ISABELINOS …...................... 294

4.6.4.- LA AGRICULTURA EN EL SEXENIO ......................................... 299

4.7.- INDUSTRIA Y COMERCIO ......................................................... 300

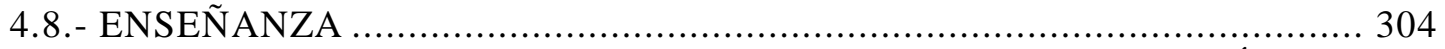

4.8.1.- LAS PRIMERAS LETRAS., INICIO DE LA ALFABETIZACIÓN ...... 304

4.8.2.- LA ENSEÑANZA MEDIA. LENTA CONSOLIDACIÓN .................... 311

4.8.3.- LA UNIVERSIDAD. DIFICULTADES DE SUPERVIVENCIA ........... 317

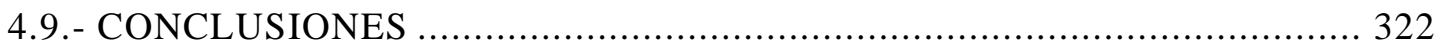

5.- ÉLITES PROVINCIALES EN TORNO A LA DIPUTACIÓN......................... 329

5.1.- PRESIDENTES DE LA DIPUTACIÓN. JEFES POLÍTICOS, GOBERNADORES Y ASIMILADOS ......................................... 329

5.1.1.- EN LA PRIMERA ÉPOCA LIBERAL ............................................ 329

5.1.2.- GOBERNADORES Y PRESIDENTES DE LAS REGENCIAS ............ 330

5.1.3.- LOS PRESIDENTES DEL TRIENIO ESPARTERISTA ...................... 330

5.1.4.- LOS JEFES POLÍTICOS-GOBERNADORES EN LA DÉCADA

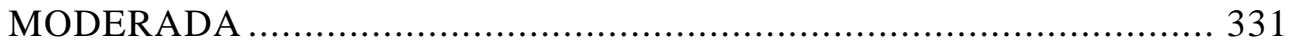

5.1.5.- ABUNDANTES GOBERNADORES EN EL BIENIO PROGRESISTA.. 332

5.1.6.- LOS GOBERNADORES-PRESIDENTES EN LA UNIÓN LIBERAL ... 333

5.1.7.- GOBERNADORES PROGRESISTAS EN EL SEXENIO ................... 334

5.2.- VICEPRESIDENTES DE LA DIPUTACIÓN, INTENDENTES DE LA PROVINCIA ....................................................................... 335

5.3.- ÍNDICE ONOMÁSTICO DE GOBERNADORES E INTENDENTES.

TITULARES, INTERINOS Y ASIMILADOS .................................... 336

5.4.- LOS DIPUTADOS PROVINCIALES .......................................... 378

5.4.1.- LOS DIPUTADOS LIBERALES 1813-14 Y 1820-23 ........................ 379

5.4.2.- LOS DIPUTADOS DE LOS PRIMEROS AÑOS ISABELINOS ........... 379

5.4.3.- LOS DIPUTADOS PROGRESISTAS 1840-43 Y 1854-56 ................. 380

5.4.4.- LOS DIPUTADOS DE LA DÉCADA MODERADA …..................... 381

5.4.5.- LOS ÚLTIMOS DIPUTADOS ISABELINOS ............................... 382

5.4.6.- LOS NUMEROSOS DIPUTADOS DEL SEXENIO ......................... 382

5.5.- ÍNDICE ONOMÁSTICO DE LOS DIPUTADOS PROVINCIALES ............ 383

5.6.- BIOGRAFÍAS DE TODOS LOS DIPUTADOS PROVINCIALES .............. 388

5.7.- ANÁLISIS POLÍTICO, SOCIAL Y CULTURAL DE LOS DIPUTADOS

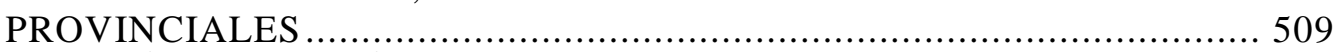

5.7.1.- RESÚMEN Y ANÁLISIS DE LAS ACTIVIDADES ....................... 517

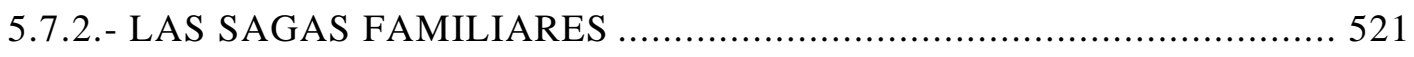

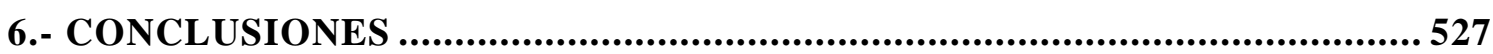

7.- ARCHIVOS. FUENTES IMPRESAS. BIBLIOGRAFÍA ............................. 541 


\section{1.- INTRODUCCIÓN METODOLÓGICA}

Los diversos estudios realizados sobre las actividades de las Diputaciones Provinciales, en principio, hablan de la finalidad y de las intenciones que tuvieron los promotores gaditanos para impulsar la creación de las citadas instituciones, así como de los inconvenientes que tuvieron que sufrir hasta conseguir su consolidación.

No podemos olvidar que el nacimiento de las Diputaciones se enmarca en un período convulso y revolucionario situado entre los años 1812 y 1814 , años en los que se dan cita el final del Antiguo Régimen, el inicio del constitucionalismo liberal y los graves problemas que ocasiona la Guerra de la Independencia.

A lo largo de los años la evolución de la historiografía tiene su incidencia en la forma de estudiar las actividades de las Diputaciones. Los sucesivos historiadores van reflejando en sus tesis y en sus estudios los nuevos puntos de vista sobre la actuación de las instituciones.

Así vemos que en un principio la historiografía refleja mayoritariamente el componente descriptivo y por eso mismo los diferentes historiadores hacen una descripción detallada de las actividades de las instituciones.

Posteriormente un nuevo grupo de historiadores se centrarán en el estudio de las Diputaciones desde un punto de vista legislativo y administrativo, es decir, abundarán en la importancia de las leyes como camino para el desarrollo de las instituciones provinciales, y al mismo tiempo estudiarán la evolución de las Diputaciones como consecuencia de la implantación de las citadas leyes.

Por último, una nueva fase historiográfica basa sus estudios en los desarrollos de los comportamientos sociales y culturales, lo que hace que los historiadores centren su interés en conocer con detalle los comportamientos de los individuos que conformaron las instituciones y su influencia en la sociedad de la época estudiada.

\section{1.- PRIMERA HISTORIOGRAFÍA}

Una primera generación de historiadores, pioneros de la vida y andanzas de las Diputaciones, presentan en su mayoría una versión uniforme de sus actividades.

Todos ellos destacan y detallan el liberalismo constitucional, el cambio necesario del Antiguo Régimen a las nuevas actuaciones liberales, el afán de las nuevas corporaciones por "hacer progresar a la provincia" y sobre todo resaltan lo positivo que resultaron para la provincia las actuaciones en los asuntos en los que tienen responsabilidad, como son los de beneficencia, enseñanza, obras públicas, Ayuntamientos y repartimientos de impuestos y de quintas. Sin olvidarse de dos constantes que, especialmente a lo largo del siglo XIX, serán las señas de identidad de la Diputación: la supremacía del jefe político, como presidente de la Diputación y representante del gobierno central, posición que va en detrimento de la libertad de acción de los diputados provinciales y los problemas que la penuria económica ocasiona, para la correcta actuación en lo concerniente a las actividades que les han sido encomendadas.

Carantoña Álvarez ${ }^{1}$, en su estudio sobre la Diputación Provincial de León, destaca en primer lugar el acierto en la creación de la institución por parte de las Cortes de Cádiz, por los beneficios que supusieron para las provincias en tres aspectos específicos: la consolidación del ente provincial y su representatividad ante los organismos estatales y en defensa de los intereses colectivos, la tutela, control y colaboración con los Ayuntamientos de la provincia, en especial con los pequeños núcleos rurales, y el fomento de las actividades de beneficencia, enseñanza y obras públicas, de las que se hace responsable la corporación.

Otro punto que resalta es que, tanto el gobierno como la Diputación estaban interesados en la reforma de las estructuras administrativas basadas en la

${ }^{1}$ CARANTOÑ ÁlvareZ, Francisco. Historia de la Diputación de León. Ed. Diputación de León. León, 1995. 
"uniformización y en la racionalización", especialmente a nivel provincial. Igualmente pone de relieve la evolución de los diputados provinciales entre la primera Diputación de 1813, formada por clérigos liberales y labradores de tendencia conservadora, que con el paso de los años van siendo reemplazados por la oligarquía provincial formada por abogados, comerciantes e industriales, ya con una clara asignación política. Finalmente, considera importante la actuación de la Diputación en el desarrollo provincial, tanto a nivel social como económico, aunque no es de la misma opinión en el plano político, ante el recuerdo del intento fallido de la comunidad autónoma de León en los años recientes.

Manuel Chust ${ }^{2}$, en su trabajo sobre la Diputación de Valencia, recuerda que la Constitución de 1812, en primer lugar, trata sobre la ordenación de las provincias y posteriormente sobre la creación de las Diputaciones, y mantiene que la Diputación se crea para reforzar la provincia y con la finalidad de mejorarla y de hacerla progresar a través de una serie de competencias que le son concedidas por el gobierno central. Constata cómo, en los primeros momentos de funcionamiento de la Diputación, la mayor preocupación del jefe político de aquellos días era la del "peligro de federalización de la provincia", según se pone de manifiesto en las actas de las sesiones. Al igual que otros historiadores, recuerda la evolución de los diputados que se inicia con una mayoría de clérigos liberales, hasta llegar a tener, con el paso de los años, una representación mayoritaria de la burguesía comercial e industrial.

Destaca especialmente el cambio social acaecido entre 1834 y 1843 , con el inicio de la actividad política, hasta esos años desconocida, y la aparición de la burguesía como clase dirigente, que pronto aprendió a controlar tanto las actividades económicas como las políticas, pasando a ejercer el monopolio del poder. A este grupo de burgueses se unirán los profesionales de la abogacía y los altos funcionarios, con lo cual queda completada la clase política dirigente de ámbito provincial predominante en estos años.

Afirma que la necesidad de la Diputación viene dada por la necesidad de la provincia y viceversa, ya que en el contexto histórico español de aquella época, cada una de las dos instituciones, provincia y Diputación provincial, supone la existencia de la otra. Sin una de ellas la existencia de la otra es impensable, la provincia con una base geográfica y la Diputación con una base administrativa. Al igual que en otros estudios anteriores sobre las Diputaciones, considera que las Cortes de Cádiz, para reemplazar a las instituciones del Antiguo Régimen, propugnan la uniformidad y la centralización a partir de la provincia y de la Diputación.

En los estudios realizados sobre la Diputación Provincial de Ciudad Real, dirigidos por José Luis Loarce Gómez ${ }^{3}$, se destaca que el proceso revolucionario de la Guerra de la Independencia facilitó la quiebra de las instituciones del Antiguo Régimen, y propició la transición hacia la implantación del liberalismo. Afirma que la provincia aparece como una necesidad de articular la nueva situación política, rechazando la idea de una copia del departamento francés, ya que este último es una división de estricto carácter técnico, y la provincia española respeta ciertos sedimentos históricos. Finalmente, concluye que con la organización administrativa, se define de una forma clara la situación de los Ayuntamientos y de las Diputaciones y la subordinación de los primeros a las segundas y todo bajo el control del jefe político como representante del poder central y autoridad suprema de la provincia.

En un somero repaso de las actividades en la citada provincia, se pone de manifiesto el carácter rural de la misma, remarcando que el predominio de la agricultura en este caso es sinónimo de subsistencia y pobreza.

\footnotetext{
${ }^{2}$ CHUST, Manuel (Dir.). Historia de la Diputación Provincial de Valencia. Ed. Diputación Provincial de Valencia. Valencia, 1995.

${ }^{3}$ LOARCE GÓMEZ, José Luis (Coord.). Historia de la Diputación Provincial de Ciudad Real. Ed. Diputación de Ciudad Real. Ciudad Real, 1999.
} 
Como un problema, que no era exclusivo, se destaca que el centralismo, la falta de representatividad por el sistema de sufragio censitario y la pronta aparición de grupos de poder que controlan la mayoría de las actividades del entorno provincial, hacen que la Diputación pierda su independencia y quede controlada por las élites políticas, que además fueron las grandes beneficiarias de la desamortización al ser las grandes compradoras de los bienes nacionales.

González Mariñas, en su trabajo sobre las Diputaciones provinciales de Galicia, realizado bajo un enfoque histórico-jurídico, recuerda en primer lugar, que la Diputación de Galicia está vigente desde el año 1480, que actúa con carácter representativo, que es una única Diputación para todo el reino de Galicia, y que con la llegada del liberalismo, adecúa sus actividades a las preconizadas en la Constitución de 1812. No admite que las Diputaciones creadas por las Cortes de Cádiz sean un simple calco de las prefecturas francesas, como también han mantenido otros historiadores, y remarca que "la historia del régimen local español tiene su propia dinámica y sus propias exigencias que impiden tan simplista explicación de sus orígenes".

No concibe la existencia de la provincia sin la Diputación y aunque critica la vinculación obligatoria de estas instituciones al poder central, destaca por su importancia la labor de fomento de las actividades que se le otorgan a la provincia, con la dificultad añadida en el caso de Galicia por su secular aislamiento del resto de España.

Pablo Martin Bobillo estudia los orígenes de la Diputación de Zamora entre los años 1812 y 1823 , y destaca la importancia que para el progreso de la provincia tuvo la Diputación, a la vez que se lamenta de la escasa producción historiográfica que existe sobre el tema. Remarca el protagonismo que mantuvieron los liberales en su empeño por dotar a la nación de una estructura de Estado moderno que reemplazara al Antiguo Régimen y permitiera al país salir del estancamiento y retraso en el que se hallaba sumido. La ordenación territorial y la capitalidad de la provincia fueron los principales problemas con los que se enfrentaron al inicio de sus actividades los diputados provinciales, en su mayoría clérigos (4 de 7), presididos por la incontestable autoridad del jefe político, además de hacer frente a las dificultades que arrostra la provincia por su penuria económica y la falta de comunicaciones.

Pastrana Morilla ${ }^{6}$, en su tesis sobre la Diputación Provincial de Valladolid entre 1875 y 1930, plantea en su Introducción una arriesgada afirmación al considerar que "desde su nacimiento hasta la llegada de la Restauración nos encontramos así con una ausencia total de estudio de las instituciones provinciales, que ha podido ser calificada de inmovilismo ortopédico, impuesto por la Administración Central". Planteamiento discutible, puesto que entre 1813 y 1874, independientemente de las dificultades por las que pasa la vida de la institución vallisoletana, es seguro que las Diputaciones, por mucho control a que estuvieran sometidas por los diferentes gobiernos centrales, evolucionaron y progresaron en la medida que las permitieron la situación social, la política y sobre todo la económica.

En estos años se insiste en la "provincialización" de la beneficencia, se fomentan las obras públicas con las nuevas carreteras y los ferrocarriles, se generaliza la enseñanza, y todas estas actividades son un ejemplo de buen hacer y de esfuerzo de las corporaciones provinciales. El caciquismo que estudia Pastrana en su tesis se inició en la época isabelina a partir de las sagas familiares, y refleja otros dos problemas a partir de la Restauración que son, más bien, endémicos desde su

\footnotetext{
${ }^{4}$ GONZÁLEZ MARIÑAS, Pablo. Las Diputaciones provinciales en Galicia. Diputación de La Coruña. La Coruña, 1978.

5 MARTín BOBILlo, Pablo. Los orígenes de la Diputación provincial de Zamora (1813-1823). Ed. Diputación Provincial de Zamora. Zamora, 1988.

${ }^{6}$ PASTRANA MORILLA, Heliodoro. La Diputación provincial de Valladolid 1875-1935. Política y gestión. Ed. Diputación Provincial de Valladolid. Valladolid, 1997.
} 
nacimiento: El control que ejerce el gobierno central y la penuria de medios económicos.

Pastrana hace un buen estudio de los diputados provinciales, de su dependencia de los diferentes partidos políticos, del control que realizan los caciques provinciales en pro de la política nacional y sobre todo de la política provincial, amén de un amplio repaso de las actividades y progresos que ejerció la Diputación en beneficio de la provincia.

Como resumen de los primeros estudios históricos, más bien descriptivos, que se han reseñado con anterioridad, aparecen una serie de actuaciones que se pueden considerar básicas en todas las provincias y que son repetidos por los diferentes historiadores:

El jefe político es el férreo conductor de la Diputación a partir de las directrices emanadas por los gobiernos centrales.

Los diputados provinciales son elegidos en la mayoría de los casos a través de elecciones censitarias y el número de electores se va ampliando con el paso de los años. También la ideología política de los diputados se va transformando desde los primeros clérigos liberales de 1813 a los burgueses encuadrados en los diferentes partidos políticos y sumisos a las directrices de los dirigentes provinciales, que fueron el "embrión" del entramado caciquil. La Diputación se convertía así en el trampolín adecuado para dar el salto cualitativo desde la política provincial a la nacional en el mejor de los casos, o como premio de consolación, pasar a la política local.

Los enfrentamientos entre la Diputación y los Ayuntamientos fueron una consecuencia de la lucha por el control de la provincia entre una institución, el Ayuntamiento, cargado de historia y acostumbrado a controlar sobre todo la gestión económica de su entorno y la bisoña y recién llegada institución provincial que quiere arrebatar el predominio y el protagonismo que con anterioridad poseían los Ayuntamientos.

\section{2.- HISTORIA DE LA ADMINISTRACIÓN PROVINCIAL}

Una segunda generación de historiadores enjuicia los cambios políticos, sociales y administrativos en los años coincidentes con el nacimiento del Estado liberal y de las Diputaciones. En sus estudios hacen hincapié en el cambio radical que supone pasar de las formas de gobierno del Antiguo Régimen a las nuevas formas que preconiza el constitucionalismo liberal y a las reformas administrativas y sociales que fueron necesarias para asentar las nuevas normas políticas.

El historiador Orduña Rebollo ${ }^{7}$ relata la evolución de la Diputación Provincial de Segovia, y plantea en un principio "que las Diputaciones provinciales desde su creación han sido organismos sin autonomía y con una gran dependencia del poder central, además de estar mal dotadas". Planteamiento admisible, sobre todo en los primeros años de existencia y, aunque se refiere a la institución segoviana, no deja de ser realidad en la mayoría de las Diputaciones. Abunda en los esfuerzos de la primera corporación "que no tenía medios económicos para atender debidamente los servicios fundamentales para los que había sido creada, pese a la austeridad en sus gastos, que lindaban con la tacañería". Reitera que, además de la insuficiencia económica, se produjo un olvido de la provincia, por parte del centralismo, lo que forzó a los ciudadanos a la emigración. En la Restauración, "los políticos nacionales sólo se acordaban de los pueblos segovianos a la hora de poner en marcha la maquinaria caciquil".

Mantiene la opinión de que la Diputación es una institución de origen francés, apoyando esta teoría en la clara dependencia que tiene del poder central a través del jefe político. Trata los temas habituales estudiados por la mayoría de los historiadores como el control de los Ayuntamientos, la ordenación del territorio provincial y las

\footnotetext{
${ }^{7}$ ORDUÑa REBOLLO, Enrique. Evolución histórica de la Diputación Provincial de Segovia. Diputación de
} Segovia. Segovia, 1991. 
mejoras en las habituales actividades que se desarrollan en la Diputación y que están referidas a la beneficencia, enseñanza, obras públicas y repartimientos. Finalmente, en lo referente a los diputados y a su filiación, considera que las Diputaciones y Ayuntamientos, estuvieron manejados por las oligarquías locales y éstas a su vez, lo fueron, en principio, por los gobiernos a través del jefe político y posteriormente a través de los partidos políticos, tanto a nivel provincial como nacional.

Pedro Ortego $\mathrm{Gil}^{8}$ es otro historiador administrativista que estudia en su tesis, por un lado, la evolución legislativa de las Diputaciones provinciales, y por otro lado, la evolución histórica de la Diputación de Guadalajara, entre los años 1812 a 1845. En una primera valoración concede una gran importancia a las Diputaciones, ya que a lo largo del citado período se produjo una gran actividad legislativa en los temas relacionados con estas instituciones, según se desprende de la gran cantidad de leyes, decretos y proyectos que se legislaron en estos años. Aunque las Diputaciones ya existían de tiempos anteriores, las que se forman a partir de la Constitución de 1812, son la génesis de las actuales corporaciones.

En una primera parte hace un exhaustivo desarrollo de las leyes que se tramitan en las Cortes, y que tienen una clara relación con las Diputaciones. Destaca como finalidad de su creación el progreso de las provincias, incide en la importancia que se concede al jefe político como garante del control de la ortodoxia en las actividades de la corporación, se lamenta de la poca libertad tanto en las elecciones de los diputados como en la toma de decisiones por los mismos, y al mismo tiempo va alertando de las diferentes etapas políticas en consonancia con las diferentes leyes y su mayor progresismo o conservadurismo en función del color de las Cortes correspondientes.

En la segunda parte entra Ortego en el tema político, y desgrana las actividades de la Diputación Provincial de Guadalajara entre los años 1812 a 1845. Destaca en primer lugar, al igual que han señalado otros historiadores, la importancia del jefe político, como pieza clave de la administración provincial, en la doble vertiente de delegado del gobierno y primera autoridad provincial. A la vez que desempeña el cargo de presidente de la Diputación, desarrolla otras actuaciones derivadas de la jefatura política, que pierden parte de su eficacia, a causa de la inestabilidad del cargo, ocasionada por los frecuentes cambios que efectúa el gobierno.

En segundo lugar, considera que uno de los pilares fundamentales de la nueva institución está formado por los diputados provinciales, concediendo gran importancia a los pasos que se dan para su nombramiento, como son las listas de electores, los requisitos para ser diputado, sus derechos y obligaciones. No habla en absoluto de quiénes fueron los diputados en estos años, pero considera que su nombramiento para la Diputación era un paso necesario para la promoción política y el acceso al cargo de diputado a Cortes. En sus conclusiones, considera a la Diputación como una institución beneficiosa para la provincia, que mejoró en su autonomía durante los gobiernos progresistas y que los consejos provinciales mermaron sus actividades. En definitiva nos plantea una tesis administrativista y con poco estudio sobre la vida social, política y cultural de la Diputación.

\section{3.- HISTORIOGRAFÍA SOCIAL Y CULTURAL}

Finalmente, un tercer grupo de historiadores se centran en la profundización de las Diputaciones bajo una visión social y cultural, en la que se da prioridad al estudio de las actividades provinciales y al conocimiento de las élites que las formaron.

Así vemos que para Concepción de Castro ${ }^{9}$ el nacimiento de las Diputaciones es una consecuencia del interés del gobierno de la nación por controlar todo el territorio nacional, a la vez que pretendía centralizar una serie de actividades que

\footnotetext{
8 ORTEGO GIL, Pedro. Evolución legislativa de la Diputación provincial en España 1812-1845. La Diputación Provincial de Guadalajara. Ed. Universidad Complutense. Madrid, 1990.

9 CASTRO, Concepción de. La revolución liberal de los municipios españoles. Alianza Editorial. Madrid, 1979. Pág. 57.
} 
estaban repartidas entre diversas instituciones y organizaciones como eran los Ayuntamientos y la Iglesia y por los que tenía un interés tanto económico como administrativo. También es de la opinión de que la revolución liberal era necesaria si España quería disponer de una organización provincial y local homogénea que cumpliera con una serie de requisitos como son la representatividad ciudadana, la división de poderes y la racionalización de la administración. Todo ello pretende llevarse a cabo a partir de un nuevo organismo provincial como es la Diputación, institución a la que le son delegadas diversas actividades como los repartimientos de impuestos, la beneficencia, las obras públicas, la enseñanza, el control de los Ayuntamientos, etc.

Para Francisco Tomás y Valiente ${ }^{10}$, una de las principales finalidades de la Constitución de 1812 es la de unificar y uniformizar el territorio a partir de la división territorial de la provincia y la consiguiente creación de las Diputaciones, con lo que se pasa de una concepción de provincia como entidad política y autónoma a una provincia geográfica con finalidad administrativa, y además controlada por el gobierno central.

Jorge Luengo Sánchez ${ }^{11}$ incide en la importancia que tuvieron los períodos progresistas del siglo XIX, cortos pero interesantes, en la construcción de los fundamentos del Estado liberal. Justifica los enfrentamientos entre el Ayuntamiento de Valladolid y su Diputación provincial, por el carácter progresista del primero frente al moderado de la segunda. Concede una gran importancia al progresismo como el motor de la transformación de la capital, que pasa de ser una ciudad de corte antiguo a transformarse en una ciudad moderna y desarrollada, tanto a nivel social como económico.

Sobre políticas locales y provinciales y su proyección a nivel nacional, nos habla Juan Antonio Cano García ${ }^{12}$, que analiza las élites políticas provinciales y el mantenimiento del control del poder tanto económico como político, concediendo además un plus de importancia a la política de matrimonios entre las grandes familias como forma de aumentar el patrimonio y la capacidad de influencia. En su opinión, el poder político se construye a partir de los ámbitos provinciales, para pasar posteriormente al ámbito nacional.

Pedro Carasa Soto ${ }^{13}$, investigador con numerosos trabajos sobre las élites y el poder político, tanto a nivel local como provincial así como sobre Castilla a nivel regional, analiza de una forma detallada las vicisitudes políticas, sociales y culturales que tuvieron relación con las Diputaciones castellanas. Mantiene la importancia de estos organismos y su influencia en el progreso de las diferentes provincias, como lo refleja en su tesis sobre el pauperismo en Burgos, en la que estudia el importante papel de la Diputación en el proceso de "provincialización" de la beneficencia y su consecuente progreso.

Posteriormente, ahonda en el estudio y prosopografía de las élites locales y provinciales y su protagonismo en el desarrollo político y económico de la provincia. Destaca la progresiva transformación del control provincial a través de las sagas familiares que, con el paso del tiempo, se transformaron en los controles caciquiles políticos en los años de la Restauración. Concede una gran importancia a estas sagas familiares, y al conocimiento de su influencia a través de los estudios prosopográficos

10 TOMÁS Y VALIENTE, Francisco. "Prólogo": CHUST, Manuel. Historia de la Diputación Provincial de Valencia. Ed. Diputación Provincial de Valencia. Valencia, 1995. págs. 19-22

${ }^{11}$ LUENGO SÁNCHEZ, Jorge. El nacimiento de una ciudad progresista. Valladolid durante la regencia de Espartero (1840-1843). Ayuntamiento de Valladolid. Valladolid, 2005.

12 CANO GARCÍA, Juan Antonio. Gamacistas y Albistas. La vida política en Valladolid durante la Restauración. Universidad de Valladolid. Secretariado de Publicaciones. Valladolid, 2008.

${ }^{13}$ CARAS A SOTO, Pedro. Pauperismo y revolución burguesa (Burgos, 1750-1900). Universidad de Valladolid. Secretariado de Publicaciones. Valladolid, 1987. ID. "Las élites políticas vallisoletanas durante la Restauración", en Valladolid Historia de una ciudad. III. Época contemporánea. Valladolid, 1999. pp. 909963. ID. "La recuperación de la historia política y los prosopografía" en Élites: prosopografía contemporánea .Universidad de Valladolid, Valladolid, 1994. 
y biográficos para descubrir la incidencia de estos comportamientos en el desarrollo del poder político en la provincia.

En su estudio sobre las élites políticas, centra el objetivo en definir los sujetos y la naturaleza del poder, investigar al personaje y tratar de descubrir las relaciones entre los distintos protagonistas que conforman el conjunto de las élites, es decir, presentar un nuevo marco para interpretarlas y lograr una nueva forma de la historia del poder. Mantiene que el poder de las élites en Castilla no es solamente político, sino más bien es de control social y económico. Defiende que la Diputación actúa como escuela de dirigentes y punto de partida para alcanzar el poder político a nivel nacional, o en su defecto y si no tiene posibilidades o capacidades para desenvolverse en la política nacional, le queda el recurso de llegar a la política local a través de los Ayuntamientos.

Destaca Carasa la importancia de la prosopografía para conocer las tendencias e interrelaciones existentes entre todos los individuos que conforman la Diputación a lo largo de los años, así como para conocer sus intereses personales tanto a nivel local, provincial y regional. Es de la opinión de que el caciquismo en la Diputación nace desde la base, es decir, el diputado una vez que domina su zona de influencia, la extiende hacia el resto de la provincia a través de la Diputación, llegando a alcanzar el nivel nacional, si su promoción política tiene éxito. Descarta que el caciquismo provincial sea sólo una imposición de los cabecillas políticos nacionales del partido.

\section{4.- NUESTRA HIPÓTESIS DE TRABAJO}

Después de efectuado el repaso a los diferentes estudios relacionados con el tema de las Diputaciones, vemos que en la mayoría de ellos los autores plantean una serie de actuaciones y una visión de cada una de las Diputaciones, todas ellas diferenciadas por matices pero con unas similares conclusiones. En el caso de la institución vallisoletana, objeto de este estudio, también haremos un recorrido por todas y cada una de las actividades protagonizadas por la Diputación, por su grado de eficacia, por la satisfacción de los habitantes de la provincia ante el trabajo realizado, por todos los individuos que de una forma u otra tuvieron relación con la Diputación. En definitiva, nuestra intención es la de dar a conocer la obra de la Diputación y el grado de satisfacción de los gobernantes y gobernados.

En conclusión, para mejor conocer a la Diputación y en un planteamiento previo al estudio nos hacemos una serie de preguntas con la finalidad de facilitarnos un mayor dominio de la institución y al mismo tiempo el de comprender mejor el sentido de las decisiones tomadas en los momentos y en los años precisos.

La primera pregunta que nos viene a la mente es la más clásica y natural que nos podemos hacer: ¿La Diputación promovió la prosperidad de la provincia? Es la justificación que se hace en la Constitución de 1812 para su creación, pero el interrogante que se nos plantea es el de que, una vez vistas las actuaciones entre 1813 y 1874, es el de dudar que esta finalidad básica se consiguiera.

¿Mejoró el nivel de vida de los vallisoletanos? Una vez que ponemos en duda la pregunta anterior, también es cuestionable que se consiguiera el que los habitantes de la provincia se sintieran satisfechos. Es posible que los vallisoletanos mejoraran, pero no el que haya sido por obra de la Diputación.

¿Qué papel jugó la Diputación en el progreso de la provincia? Un tema que no tiene discusión es el del progreso que se produce en la provincia y en especial a partir de los años 50, pero hay que enjuiciar qué tanto de "responsabilidad" e importancia tuvo la actuación de la institución en este progreso.

¿Supo enfrentarse al gobierno central en temas tan importantes como la división provincial, punto de partida de la existencia de la propia Diputación?

Los legisladores a través de las diferentes leyes aprobadas: ¿Ayudaron a la

Diputación a conseguir los objetivos propuestos? ¿Fue una ayuda para las Diputaciones, o sobre todo fue una forma de mantener el control de la Diputación, no 
por la provincia y por los diputados provinciales, sino por el gobierno y las Cortes nacionales?

Al hilo de esta última pregunta, también nos podemos interrogar sobre si la Diputación estuvo atenta para "exigir" a sus diputados a Cortes la defensa de los intereses provinciales, sobre todo en temas tan sensibles y de tanta importancia para su desarrollo como era la agricultura. La producción agrícola era la base de la riqueza provincial y una legislación favorable repercutía de una forma muy positiva en la evolución económica de la provincia.

En el tema de las comunicaciones la provincia es testigo de una gran transformación pero: ¿Qué incidencia tuvo el trabajo de la Diputación en el fomento de las obras públicas, con especial referencia a las obras del Canal de Castilla, las carreteras y a los ferrocarriles? Trabajos que se desarrollaron de una forma positiva a lo largo y ancho de la provincia, pero que fueron siempre a remolque de los acontecimientos por la grave y continua penuria de la economía.

Con referencia a los impuestos: ¿Qué repercusiones tuvo en la Diputación la gestión de los impuestos, la más impopular de las actividades a nivel ciudadano? ¿Supo "luchar" a favor y defensa de la provincia para ajustar los gravámenes contributivos en especial en los años de dificultades económicas por la mala coyuntura agrícola? ¿Fue además de recaudador de impuestos nacionales, recaudador de impuestos provinciales?

¿Realmente tuvo influencia en el progreso económico que se desarrolló en la provincia a lo largo de estos años?

Sus relaciones con el Ejército ¿Tuvieron un efecto beneficioso? ¿Fueron entre iguales? ¿No pudo la Diputación con la hegemonía militar?

La Sanidad y la Beneficencia tuvieron en estos años una evolución positiva. ¿Qué incidencia tuvo el trabajo de la Diputación en su progreso? ¿Supo "negociar" con las administraciones religiosas y las locales para conseguir un mayor progreso en estas áreas?

Con referencia a la agricultura, a la industria y al comercio, actividades que también tuvieron una evolución positiva: ¿Tuvo la Diputación parte importante en este progreso? ¿Hasta qué punto su gestión fue determinante, o más bien, se aprovechó de los trabajos positivos de la burguesía?

En lo referente a la enseñanza, punto importante de la política liberal: ¿Fue la Diputación consciente de su importancia? ¿Fue el "motor" de su generalización? El auge de la enseñanza: ¿Provenía de las decisiones gubernamentales y la Diputación "se dejó llevar", y no supo comprender que su difusión era básica para el progreso provincial? ¿Qué importancia tuvo la gestión de la Diputación en el mantenimiento de la Universidad vallisoletana?

Finalmente, y con referencia a los diputados, sus actuaciones, su dedicación y sus relaciones, tanto con el poder central como con el resto de los compañeros que conformaban la institución, así como con los diputados de otras corporaciones, una serie de preguntas quedan pendiente de respuesta:

¿Por qué no protestaron ante el control y la sumisión que padeció frente a la figura del jefe político? ¿Por qué se plegaron con tanta docilidad al mandato gubernamental? Los diputados: ¿Trabajaron por la provincia o por su interés? ¿Qué importancia tuvo la Diputación en el progreso de la burguesía? ¿Controló la Diputación a los incipientes caciques que aparecieron al final de estos años, o fue a la inversa, los caciques a la Diputación?

¿Qué importancia tuvieron las familias político-económicas en el desarrollo provincial y su grado de influencia en la Diputación? ¿Por qué las relaciones con el Ayuntamiento de la capital no fueron lo cordiales y positivas que debieron de ser? Sobre todo, teniendo en cuenta que en numerosas ocasiones los mismos individuos actuaban tanto como diputados como anterior o posteriormente lo hacían como representantes municipales. 
¿Hasta qué punto la Diputación actuó de escuela de formación de las élites en la nueva cultura política de la participación y la representación? ¿En qué medida la Diputación contribuyó al proceso de construcción del Estado liberal y a su implantación en los ámbitos locales? ¿Qué defectos, como el caciquismo o las limitaciones electorales, que fueron propios de la primera cultura política de las élites y habituales en los ámbitos estatales, influyeron de una manera decisiva en los trabajos de la Diputación?

En conclusión, el mayor interrogante que nos podemos plantear es el de saber si la actividad de la Diputación y su actuación a partir de todas las responsabilidades que le fueron encargadas, fue beneficiosa para la provincia: ¿Fue su actividad la causa del progreso? ¿Esta actividad propició la mejora de las estructuras provinciales? ¿Fue, en los años del estudio, una institución beneficiosa para la provincia? ¿Fue un referente de progreso y de buen hacer? ¿En definitiva, hizo lo que pudo o simplemente lo que la dejaron hacer?

Para intentar aclarar todos estos interrogantes nos involucramos en el estudio histórico de las actividades y actuaciones de la Diputación Provincial de Valladolid, correspondientes a los años comprendidos entre 1813 y 1874.

Articularemos nuestro análisis en sucesivos niveles de estudio, primero el legislativo-administrativo, luego abordaremos la historia institucional, más tarde profundizaremos en la función y eficacia de los logros conseguidos por su actuación, y finalmente analizaremos sus miembros realizando una aproximación biográfica y prosopográfica a sus élites, que nos desvele la naturaleza del poder y la influencia política que ejercieron.

En una primera etapa de desarrollo del trabajo y para tratar de explicar la importancia de las Diputaciones en la vida provincial y seguir y conocer los pasos que se dan para hacer realidad lo previsto en la Constitución de 1812, nos centramos en el estudio y análisis de la legislación a lo largo de todo el período, resaltando las más importantes leyes que mejoraron la eficacia y el progreso de la nueva institución.

Partiendo de la citada Constitución de 1812, efectuamos un recorrido legislativo de todas las leyes que se publicaron y que tuvieron a la Diputación como protagonista, o por lo menos como partícipe en la vida política nacional. Así podemos destacar en el período Constitucional, el decreto de 23 de mayo de 1812, sobre el "Establecimiento de las Diputaciones" y el decreto de 23 de junio de 1813 sobre la "Instrucción para el Gobierno Económico-Político de las Provincias". En el Trienio Liberal destaca sobre todo la ley de 3 de febrero de 1823 sobre el "Gobierno Económico-Político de las Provincias". En la época isabelina destacan las Constituciones de 1837 y de 1845, conjuntamente con la "Ley de Organización y Atribuciones de las Diputaciones Provinciales" de 8 de enero de 1845, que será modificada y actualizada con la "Nueva Ley para el Gobierno y Administración de las Provincias", publicada el 25 de setiembre de 1863. Durante el Sexenio Revolucionario destaca la publicación de la "Ley de Organización y Atribuciones de las Diputaciones Provinciales ", el 21 de octubre de 1868, la Constitución de 1869 y la "Ley Orgánica Provincial" de 20 de agosto de 1870. Finaliza de esta forma la amplia legislación que se realiza sobre las Diputaciones, sin tener en cuenta los numerosos proyectos y leyes redactadas y que no se llegaron a poner en práctica, sobre todo los realizados en los períodos progresistas.

\section{5.- LAS DIFICULTADES DE LAS FUENTES}

Una vez repasada la legislación, y para intentar conocer los avatares de la Diputación de Valladolid, la importancia de sus actuaciones, los trabajos que realiza, sus preocupaciones, la vida de sus políticos y de sus empleados y en definitiva, toda la gestión que realiza la institución entre los años estudiados de 1813 a 1874, buscamos la información en los archivos de la Diputación Provincial. En nuestra primera visita nos encontramos con la dificultad de que todos los fondos históricos relacionados con el funcionamiento de la Diputación entre los años 1813 hasta el año 1874, es decir, 
todo el período a estudiar, han desaparecido en el incendio de la sede de la institución en 1874 y en el consiguiente traslado de la Corporación a su definitiva sede, situada en el Palacio de Pimentel, en la que sigue ubicada en la actualidad.

A pesar de este inconveniente, para el desarrollo de los trabajos nos basamos en los libros de actas de la Diputación, conservados en su Secretaría General. Estos libros han sido nuestra principal fuente de información, con la única dificultad añadida de que el primer libro de actas se inicia el día 9 de febrero de 1814, cuando sabemos que las actividades de la Diputación se iniciaron el día 2 de setiembre de 1813. Así, entre estas dos fechas no tenemos constancia ni de los asistentes ni de los temas tratados. También hacemos notar las dificultades que nos ha supuesto la lectura de los dos primeros libros debido a su estado de deterioro, problema que ya detectó en el año 1875 el entonces presidente de la Diputación D. Miguel Alonso Pesquera, que en nota adjunta al primer libro nos dice que "en lo que se puede leer se ha transcrito fielmente el acta del día 14 de febrero de 1814, por ofrecer dificultades al leer el original".

Esta labor se ha completado con la lectura de los libros de actas del Consejo Provincial, durante el tiempo que estuvo vigente en la época isabelina y con los de la Comisión Provincial correspondientes al período del Sexenio, años en los que estas instituciones estuvieron en activo.

También hemos tenido acceso a los libros de actas del Ayuntamiento de Valladolid, custodiados en su Archivo Histórico Municipal, en las que se reflejan las relaciones, no siempre amistosas, entre Ayuntamiento y Diputación. Ha sido especialmente importante en los casos en que por ausencia de la correspondiente documentación en la Diputación, las actas municipales nos han ayudado con sus referencias a las actividades provinciales a la reconstrucción de las "lagunas" existentes. En este mismo Archivo hemos consultado los Boletines Oficiales de la Provincia desde el año de su creación de 1833.

En el Archivo de la Real Chancillería hemos podido conocer diversos documentos pertenecientes al Ayuntamiento de Valladolid y custodiados en el citado Archivo.

De la Gaceta de Madrid y de la "Colección de Reales Decretos y Órdenes mandadas publicar por las Cortes" hemos entresacado la abundante legislación producida en los años de referencia.

Finalmente en el Archivo Histórico Universitario hemos consultado las actividades escolares y la consecución de los grados académicos de los diferentes personajes que estudiaron en la Universidad vallisoletana y que tuvieron cierta relevancia política, ya sea como diputados, jefes políticos, intendentes o de empleados y ciudadanos que tuvieron relación con la Diputación.

A pesar de los inconvenientes encontrados, la información recabada apenas ha sido suficiente para conocer, en un primer momento, qué hace y qué dificultades pasa la Diputación en los primeros años de su existencia, o mejor dicho, entre el 2 de setiembre de 1813 y el 25 de junio de 1814. Éste fue un tiempo en el que apenas tuvo oportunidad de desarrollar su trabajo, entre otras razones por lo limitado de su vigencia y por lo limitado de su autonomía, y también por el necesario aprendizaje de los primeros diputados en los trabajos a realizar a favor de la provincia.

En el Trienio Liberal, ya se nota desde un principio una mayor disposición y dominio del trabajo, pero sobre todo se observa una mayor politización de la Diputación, con un esquema de actuación más radical y más liberal y con la aparición de unos diputados interesados en el control de la institución. Surgen los primeros destellos de control económico y político a nivel provincial, y la aparición "en escena", como diputado suplente a Cortes, del primer patriarca de una de las sagas más relevantes por su poder económico y político de la provincia, nos estamos refiriendo a Millán Alonso del Barrio, cabeza de la familia de los Alonso Pesquera.

A partir de 1835, con la re-instalación de forma definitiva de la Diputación, la información que aparece en los libros de actas mantiene una tendencia política 
próxima a las ideas conservadoras que proceden del gobierno central. A mi entender, se nota en las actividades de los diputados un cierto afán de control de la institución, y no en un sentido político, sino más bien en un sentido económico.

La Diputación es la institución perfecta para conocer las intenciones del Gobierno en la provincia, pues no es ningún secreto que el control y mando de la Diputación lo ejerce el jefe político de turno. Pero la información que reciben los diputados es buena para la toma de posiciones, especialmente en el tema de las actividades que generan beneficios económicos, entre los que destacan los proyectos de obras públicas, los proyectos agrícolas y sobre todo el tema de las tasaciones y valoraciones de las desamortizaciones de los bienes nacionales.

También, a partir de 1835, los cambios en la Diputación vienen dados por los acaecidos en el Gobierno de la Nación. Aunque el sistema de elecciones funciona de una manera más o menos correcta, con un sentido parcial, al tener sólo voto los electores con una determinada capacidad económica, es sistemático que ante un cambio de gobierno y sobre todo ante el cambio de partido gobernante, se produce también un cambio en sentido similar en la Diputación. Así vemos en un principio a un gobierno moderado, a continuación aparece el gobierno del trienio progresista de Espartero, otro segundo período moderado, el Bienio Progresista, un tercer período moderado y finalmente el Sexenio Revolucionario.

Estos cambios de gobierno provocan sistemáticamente cambios en la Diputación. Con el paso del tiempo, los partidos políticos se organizan y aparecen en la corporación, pero sobre todo son las élites familiares las que se organizan y controlan tanto a la institución como al partido político correspondiente a nivel provincial. A lo largo de estos años hay familias, como son los, Alonso Pesquera, Garzón, Serrano, Cantalapiedra, Pimentel, Arévalo, Pizarro-Cuadrillero, Reinoso, Cabeza de Vaca, etc., que están continuamente en los aledaños del poder, con independencia del partido político que gobierne, puesto que estos individuos son los que ejercen el control económico y social. Otra variante que se produce a lo largo de esos años es la sustitución de los diputados labradores por diputados licenciados y diputados burgueses, con la coincidencia de que todos ellos son grandes poseedores de tierra, y que al final del período también llegarán a dominar el sistema financiero de la provincia, es decir, son los grandes accionistas de bancos y cajas de ahorro.

La Diputación está consolidada y con el paso de los años se va perdiendo el excesivo control que sobre la institución venía ejerciendo el jefe político-gobernador. Los diputados están centrados en la vida política y económica de la provincia y están dejando constancia de su hacer en todas las actividades que son de su incumbencia, léase las obras públicas, las carreteras y los ferrocarriles, también la enseñanza y la beneficencia, así como los repartimientos de los impuestos y de las "quintas". Todo ello estuvo acompañado de una permanente penuria económica que sufría tanto la Diputación como la provincia. Un tema en el que no han tenido éxito las gestiones de los diputados es en el de las relaciones que mantienen con el Ayuntamiento de la capital. Esta institución, mucho más antigua, se ve relegada a un segundo término con el agravante de tener que admitir el control de la Diputación sobre su gestión económica a través de la presentación de las cuentas de gastos y de los presupuestos. Este problema no es bien digerido, en principio, por el Ayuntamiento, aunque tampoco ayudó la posición, algunas veces prepotente, de la Diputación.

En definitiva, aunque la información que se recibe a través de los libros de actas es siempre en un mismo sentido, es decir, desde el punto de vista de la Diputación, ello no ha sido obstáculo para llegar a conocer la institución e intentar plasmar la importancia que la Diputación tuvo en la vida política, económica, social y cultural de la provincia vallisoletana y la participación de los diputados como artífices o protagonistas de las mejoras conseguidas a lo largo de estos años. Una vez repasada la citada información, se tiene la sensación de que la Diputación ha sido una institución necesaria para la mejora de la provincia, aunque siempre queda la 
contrapartida de que la penuria económica fue el freno que impidió un mayor progreso.

A través de estas actas, hemos conocido: Las distintas sedes en las que la Diputación ha desarrollado sus trabajos. La formación y evolución de la provincia y de las diferentes Diputaciones que se sucedieron a lo largo de estos años, así como de los componentes de las mismas, tanto a nivel político como administrativo. Las diversas relaciones que en numerosas ocasiones mantuvieron con la Diputación tanto los Ayuntamientos de la provincia como el resto de Diputaciones del país, además de otros organismos con los que tiene contactos, como pueden ser el Ejército o la Universidad. Las actividades de la Diputación en las áreas que la fueron encomendadas a partir de los mandatos del gobierno y que fueron el tema principal de sus actuaciones y de su "razón de ser", entre las que pueden destacarse: Las obras públicas, con los informes sobre la construcción de carreteras, canales y ferrocarriles. Los plazos de ejecución de las obras y las dificultades de pago. Los impuestos con sus repartimientos y reclamaciones. El Ejército y sus sorteos, reemplazos y suministros. La Milicia Nacional. Los "facciosos". Sanidad y Beneficencia, con su transformación y progreso. Agricultura. Industria. Comercio. La Enseñanza y su generalización.

Además de todas estas actividades, las actas nos proporcionarán datos sobre los cambios que sufre la provincia a lo largo de estos años, tanto a nivel geográfico como demográfico, con una importancia especial a la información sobre la carestía de la vida por su incidencia en el mantenimiento de la paz social. Finalmente nos darán a conocer a los numerosos individuos que formaron parte de la institución y que fueron en definitiva los que la dieron lustre y prestigio en estos primeros años de su existencia.

En este último apartado sobre los diputados provinciales, una primera posibilidad es la de conocer el interés que tienen los potentados de la provincia en desempeñar el cargo de diputado, cuando era un cargo no remunerado y que obligaba a residir en la capital, particularmente a los diputados de los diferentes partidos judiciales de la provincia, durante como mínimo los noventa días al año en los que se celebraban sesión. Está claro que tienen que existir otros intereses, como pueden ser la proyección política o la mejora económica consustanciales al desempeño de la actividad provincial.

\section{6.- AGRADECIMIENTOS}

El capítulo de agradecimientos es siempre difícil de redactar, a causa del numeroso grupo de personas que me han ayudado. La colaboración prestada por todos los profesionales de los archivos ha sido muy importante, y no sólo desde un punto de vista profesional a través de su disposición en la investigación documental, sino también, y en muchos momentos muy necesarios, de ánimo y apoyo ante las dificultades para encontrar la información deseada.

Porque es difícil el enumerar a todas estas personas y sobre todo porque no me gustaría dejar "en el tintero" ninguno de sus nombres, quiero personalizar todo mi agradecimiento en la persona de César Otero, secretario general de la Diputación Provincial y fiel custodio de los libros de actas de la institución, así como a sus colaboradores, Esperanza y Chema, que me ayudaron y "sufrieron" mis numerosas peticiones durante todo el tiempo que investigué en la Diputación.

Tampoco puedo dejar de citar las ayudas y los consejos que Pedro Carasa Soto, catedrático de Historia Contemporánea de la Universidad de Valladolid, que como director de esta tesis, me ha proporcionado y sin cuya colaboración no habría sido posible el llevarla a buen término.

Finalmente, no puedo olvidar los sacrificios y preocupaciones de Carmen, mi mujer y de mis hijos, que siempre me han apoyado y me han animado para llevar a buen término este trabajo; a ellos mi amor y gratitud por su comprensión. 


\section{2.- LEGISLACIÓN SOBRE EL RÉGIMEN PROVINCIAL}

\section{1.-ANTECEDENTES}

Provincia y Diputación son dos conceptos, que aunque en principio aparezcan como independientes, a lo largo de este estudio se ven necesarios el uno para el otro y su unión conforma el nombre de una institución: La Diputación Provincial. Es un modelo creado por las Cortes de Cádiz, con la finalidad de modernizar las estructuras administrativas del país y sacarle del anquilosamiento en que se encontraba, como consecuencia de los rígidos planteamientos del Antiguo Régimen.

\subsection{1.-ANÁLISIS DE LA SITUACIÓN}

En los años previos a la llegada del constitucionalismo, el municipio era la institución tradicional en los niveles primarios de la administración, lo mismo a nivel económico que político, con una conexión directa con las directrices reales a través de los diferentes Consejos establecidos. También es cierto que con anterioridad a 1812 ya existían instituciones a las que podemos considerar precursoras de las Diputaciones.

Las Cortes de Cádiz, a partir de la Constitución, en su afán de modernizar el país, le dotan de una nueva institución: La Diputación provincial. Nace con la función de "intermediar entre el poder central y el pueblo", es decir, trasmitir las órdenes gubernamentales y por añadidura fiscalizar las actividades municipales. No podemos olvidar que, hasta estas fechas, son los Ayuntamientos los únicos organismos, que con una larga tradición histórica ordenaban y organizaban la vida de los ciudadanos.

El origen de esta nueva institución está claramente indicado en el título sexto de la citada Constitución de 1812, que en su artículo trescientos veinticinco nos señala que: "en cada provincia habrá una Diputación provincial, con la finalidad de promover su prosperidad".

Los diputados de Cádiz, ven la necesidad, al vertebrar un nuevo sistema político, de controlar y de centralizar la gestión política periférica, pero sobre todo y especialmente, sienten la necesidad de controlar las finanzas. También se dan cuenta de que, una vez desmanteladas las viejas instituciones del Antiguo Régimen, tienen necesidad de crear nuevas estructuras administrativas que faciliten la fluidez de las comunicaciones entre el municipio, que continúa siendo fundamental en el devenir de la vida ciudadana y el poder central. A partir de esta situación, iniciamos un recorrido sobre los acontecimientos legislativos e institucionales ocasionados a raíz de la puesta en marcha de las Diputaciones.

\subsection{2.- ORÍGENES DE LA PROVINCIA}

La palabra provincia es de origen romano "pro-victa" y nos indica en toda su extensión el territorio conquistado por Roma al exterior de sus fronteras ${ }^{14}$. Este territorio sufrió, con el paso del tiempo, modificaciones en su extensión, es decir, se fue subdividiendo y amoldando a áreas geográficas determinadas por ciertos límites naturales, como son los ríos o las montañas, y a cada "provincia" se la fue dotando de una serie de instituciones políticas y administrativas para su organización. En definitiva, los romanos organizaron administrativamente los territorios conquistados con cierta independencia de la metrópoli, aunque el poder político y militar permaneciera bajo el control de Roma.

Para Luis González Antón ${ }^{15}$, el término provincia aparece en la Corona de Castilla, en las Cortes de Toro de 1371, para designar a las cinco circunscripciones

14 CHUST, Manuel (Dir.) .Historia de la Diputación... ob. cit. "El término provincia quiere decir pro-victa, porque después de ser vencidos sus habitantes, los territorios conquistados se agregaban al Imperio Romano, como una unidad administrativa". Pág. 29.

15 ARTOLA, Miguel. Enciclopedia de Historia de España. Tomo V. Alianza Editorial. Madrid, 1991. Pág. 990. 
territoriales de carácter judicial y gobernadas por uno o dos alcaldes de provincia (son las de Castilla, León, Extremadura leonesa, Toledo y Andalucía) y se ha mantenido esta denominación hasta nuestros días.

\subsection{3.-ANTECEDENTES INTERNOS DE LAS DIPUTACIONES}

\section{Las Diputaciones Forales}

La más antigua y representativa de las Diputaciones forales es la del Reino de Navarra, ya que inicia sus actividades entre 1450 y 1550 , según la opinión de diversos historiadores que han estudiado esta institución ${ }^{16}$.

Esta Diputación nace con la finalidad de "representar y defender los intereses de los tres estados frente al poder real" 17 y también tiene la misión de "recaudar los servicios otorgados y velar por la defensa del Reino".

"La Diputación foral tenía vigencia en el tiempo que mediaba entre dos convocatorias a Cortes, con la finalidad de ejecutar los acuerdos de las mismas. De esta primera actividad, con el tiempo, pasó a representar al pueblo navarro ante el poder central, y si al principio tiene una menor importancia política y económica, en comparación con otras Diputaciones como las de Aragón y Cataluña, con el tiempo se fue afianzando. Cuando estas últimas desaparecen bajo el influjo de los "Derechos de Nueva Planta", la de Navarra, al igual que las de las Vascongadas, se afianzaron y fortalecieron en la defensa de los intereses de sus ciudadanos"18.

Finalmente, será en el año 1841 cuando nace la Diputación foral de Navarra, heredera de la Diputación del Reino y cuya vigencia continúa en la actualidad.

\section{Las Diputaciones de Asturias y del Reino de Galicia}

La Diputación de Asturias surge a partir de "las nuevas ordenanzas aprobadas en la Junta General del Principado de 19 de diciembre de 1594, tras recibir por gobernador al licenciado Duarte de Acuña" ${ }^{19}$, y su actividad se centra básicamente en la administración de los territorios y la provisión y elección de oficios municipales.

La Diputación General del Principado cesó en su configuración inicial en el año 1835, se reorganizó en base a las nuevas Diputaciones y se instaló de forma definitiva a partir del citado año.

En lo referente a la Diputación del Reino de Galicia, su nacimiento se puede fijar a partir del año 1480 con ocasión de "la pacificación del Reino de Galicia por los Reyes Católicos y el nombramiento de los representantes de las cinco provincias (Santiago, Betanzos, Lugo, Mondoñedo y Orense)" ${ }^{20}$.

Esta Junta tiene sobre todo un carácter representativo, ya que la administración está controlada y gobernada por el capitán general y el intendente del Reino de

16 SALCEDo IZU, Joaquín. La Diputación del Reino de Navarra. Ed. Universidad de Navarra. Pamplona, 1969. En su estudio sobre los orígenes de la Diputación de Navarra se refleja las opiniones de diferentes historiadores: Marichalar en su "Historia de la legislación y recitaciones del Derecho Civil en España" nos dice que "la noticia auténtica más antigua que aducen los escritos navarros acerca de la Diputación se remontan al año 1450, en que uno de los diputados era D. Pedro Veraiz, alcalde de Corte, y de esta circunstancia se tiene conocimiento por una carta que le escriben sus compañeros de Diputación, cuyo principio decía: Los diputados del Reino presentes en la villa de Ocit al honorable y discreto D. Pedro Veraiz, alcalde de Corte mayor y co-diputado nuestro...".García de Valdeavellano mantiene que "como delegación permanente de las Cortes, no se constituyó en Navarra hasta el año de 1501.Zuaznavar en su "Ensayo histórico-crítico sobre la legislación en Navarra" mantiene que "la Diputación tuvo su origen hacia el año 1530".Lo que sí está documentado y recuerda Salcedo Izu "es que la primera copia del acta de la Diputación se remonta al año $1576 "$

17 Ibídem. Pág. 10.

18 LACARRA, José María. Estructura Político-Administrativa de Navarra. Ed. Príncipe de Viana. Pamplona, 1963.

19 MUÑOZ del BUSTILlo ROMERO, Carmen. "Asturias: Cuerpo de Provincia" en Anuario de Historia del Derecho español, LXII, (1992) págs. 355-475.

20 GONZÁLEZ MARIÑAS, Pablo. Las Diputaciones provinciales... ob. cit. págs. 27-28. 
Galicia. Y en esta situación se mantendrá hasta que en los años de la invasión napoleónica, la reacción popular, al igual que sucedió a otras provincias, formó una Junta Suprema Revolucionaria que representó al Reino en las Cortes de Cádiz y actuó como puente hasta la formación de las nuevas Diputaciones provinciales.

\section{La Diputación permanente de las Cortes de Castilla}

Es una institución que nace en 1525 con la "exclusiva misión de administrar las rentas del encabezamiento de las tercias y alcabalas" ${ }^{21}$. En el año 1601 se le añade una nueva tarea, la de "administrar el Servicio de Millones" hasta que en el año 1694 fue absorbida por la Cámara de Millones. Esta transformación fue consecuencia de la política centralista del Reino, con el resultado de que, al igual que ocurre con las Cortes, dejan de ser instituciones castellanas con cierta autonomía, para convertirse en instituciones de ámbito nacional y dependencia real, aunque es verdad que durante el período de vigencia, la Diputación castellana se caracterizó por su "docilidad con la Monarquía”, ya que estuvo muy controlada por el Consejo Real.

La existencia de esta institución es puesta en duda por una serie de autores e historiadores, que trabajaron en la redacción de algunas de las constituciones del siglo XIX. Ríos Rosas en las discusiones sobre la aprobación de la Constitución de 1856 nos dice que "en Aragón, existió una Diputación permanente, análoga a la que queremos implantar. En Navarra existía otra institución similar, pero por lo que hace a Castilla, que el Sr. Olózaga ha presentado como ejemplo principal, es inexacto puesto que en Castilla no ha existido tal institución ni ninguna otra que se le parezca" ${ }^{22}$. Valera, también diputado en las Cortes Constituyentes de 1854-1856, expone que "según nuestros historiadores la Diputación permanente de las Cortes existió en los Reinos de Aragón, Valencia y Navarra, también de alguna manera en el principado de Asturias y en las Provincias Vascongadas, y aunque también aparece en Castilla, es de una forma difícil de deslindar sus facultades" ${ }^{\prime 23}$.

\subsection{4.- REFERENCIAS EXTERNAS DE LAS DIPUTACIONES \\ Los Departamentos y las Prefecturas}

La influencia francesa es innegable, tanto en lo referente a la administración como a la política, y en esta ocasión con mayor razón, ocasionada por el dominio de la Francia revolucionaria en un primer momento como por el posterior dominio militar de la Francia napoleónica. El departamento es la división administrativa francesa creada en 1789, y está regida por un prefecto. Para Ortego Gil es "el sistema de control periférico, utilizado por el centralista Estado francés, para el control y racionalización del territorio" 24 .

En España, por una parte José I desde el año 1808 y, por otra, los revolucionarios españoles opuestos al Rey intruso, proyectan cada uno por su lado dar al país un nuevo código fundamental que garantice el tránsito de un sistema rígido y obsoleto como es la administración del Antiguo Régimen, a un nuevo sistema de gobierno y de control tanto político como administrativo de los territorios ${ }^{25}$.

Es curioso que ambas fuerzas, que están encontradas en el campo político y en el militar, son afines y están cercanas en el campo administrativo y las dos se basan en las ideas que nacen de la Revolución Francesa de 1789 y las dos colaboran en el desmantelamiento de las instituciones del Antiguo Régimen. La coincidencia es

21 TOMÁS Y VALIENTE, Francisco. "La Diputación en las Cortes de Castilla” en Anuario de Historia del Derecho Español.n³2(1962), págs. 347-469.

22 LORCA SIERO, Antonio. Bases de la Constitución de 1856. Editorial Domo, Madrid, 1991. Toma como referencia el diario de Sesiones de las Cortes Constituyentes 1854-1856, pág. 3416. En referencia a la discusión sobre las Diputaciones permanentes, págs. 104-105.

23 LORCA SIERO, Antonio. Bases de la Constitución... ob. cit. pág. 105.

${ }^{24}$ ORTEGO GIL, Pedro. Evolución legislativa... ob. cit. págs. 40-93.

25 GONZÁLEZ MARIÑAS, Pablo. Las Diputaciones provinciales... ob. cit. pág. 43 y siguientes. 
notoria en el orden organizativo, partiendo del afán de cerrar el esquema polisinodial de los Consejos y creando nuevas y modernas instituciones administrativas.

José I, por decreto de 17 de abril de 1810, publicado en Sevilla, establece una completa organización administrativa que divide a la España peninsular en treinta y ocho prefecturas y ciento once subprefecturas ${ }^{26}$. Cada prefectura tenía tres subprefecturas, excepto Ciudad Real, Cuenca, Madrid y Teruel que tenían dos y Murcia que tenía cuatro. Pone al frente de cada una a un "prefecto" con amplias atribuciones administrativas y políticas, lo que le convierte en el hombre más poderoso de la circunscripción. Estas prefecturas tenían el nombre de las cuencas de los ríos que la bañan (al gusto revolucionario francés).

La división departamental no llegaría a ponerse en marcha, sobre todo a causa del estado de guerra en que se encuentra el país, y a la negativa a obedecer todas las órdenes que procedían de la administración francesa. No podemos olvidar que los constitucionalistas de 1812 hicieron un reparto similar y que el organizador en 1833 de la división territorial Javier de Burgos, era un fiel seguidor de los sistemas administrativos franceses.

\section{2.-LA LEGISLACIÓN GADITANA (1812-1814)}

\subsection{1.- LA CONSTITUCIÓN DE 1812}

\section{Planteamiento}

La Constitución de 1812, a la hora de legislar la organización y desarrollo de las actividades de las Diputaciones provinciales, teniendo en cuenta por un lado la actividad de las llamadas "Diputaciones históricas" y por otro la utilidad del ejemplo departamental procedente de la Revolución Francesa, plantea dos actuaciones muy definidas: Una de claro carácter administrativo, que convierte a la nueva institución en un organismo recaudador de impuestos. La otra de matiz político, consistente en establecer a través de la Diputación un canal de comunicación, o mejor dicho, un canal transmisor de las órdenes del poder central a través del jefe político, que actúa como presidente de la institución.

Concepción de Castro dice que "el sistema constitucional de 1812 consagra a la provincia como circunscripción electoral y dentro de ella, a las Diputaciones como eslabón entre los municipios y la política nacional" ${ }^{27}$. También mantiene que esta Constitución es la que "inaugura en España un régimen local, escalonado y homogéneo, que responde a determinados criterios básicos como son la representatividad ciudadana, la división de poderes, la racionalidad administrativa, creando instituciones locales y provinciales de origen electivo en todo el territorio: Diputaciones y Ayuntamientos" 28 .

Manuel Chust escribe que "algunos autores mantienen que las Diputaciones nacidas en Cádiz en 1812 son reflejo e influencia de la Revolución Francesa” y añade que "en realidad, no es sólo eso, sino que es algo más: la Revolución, tanto en Francia como en España, tenía el mismo objetivo de derrocar al feudalismo. En lo esencial es idéntico en ambos países"29.

En definitiva, el trabajo que se plantean en las Cortes de Cádiz tiene por finalidad organizar, en primer lugar, la división territorial de una forma más homogénea, como paso previo a la mejora de la actividad administrativa a partir de la Diputación provincial, y en segundo lugar, el de mantener un control, tanto de ese territorio, como de los Ayuntamientos y Diputaciones, a través de la figura del jefe político, representante del poder central y máxima autoridad provincial.

\footnotetext{
26 LOARCE GÓMEZ, José Luis. Historia de la Diputación... ob. cit. pág. 98.

${ }^{27}$ CASTRO, Concepción de. La Revolución ... ob. cit. pág. 95.

28 Ibidem. Pág. 57.

29 CHUST, Manuel (Dir.). Historia de la Diputación ... ob. cit. pág. 31.
} 


\section{Comisión legisladora}

Las Cortes de Cádiz de 1812, a causa de los avatares de la guerra, sufren una serie de dificultades "logísticas" para mantener la efectividad y eficacia de los trabajos legislativos. Fernández Almagro, en su estudio referido a los diputados electos, contabiliza un total de trescientos ocho diputados de los cuales sólo ciento ochenta y cuatro firman al pie del documento original de la Constitución ${ }^{30}$.

La comisión legisladora creada para la elaboración del proyecto de Constitución inicia sus trabajos el día 2 de marzo de 1811, con una sesión en la que acordaron para facilitar y agilizar la tarea el "tener presente para la elaboración del proyecto de Constitución de las memorias y proyectos elaborados con antelación". También se acordó que "se convidaría por la comisión a algunos sujetos instruidos que designase de fuera de ella y de las Cortes para ilustrarse en su conocimiento" 31.

El articulado referente a las Diputaciones provinciales fue aprobado, previa discusión plenaria. En el mismo se destaca que: El gobierno político de las provincias residirá en el jefe superior nombrado por el Rey, aunque se pretendió en el pleno añadir un complemento que abogaba por el nombramiento de dos adjuntos al jefe político, nombrados por la Diputación provincial, alegando como justificación que "la nación está habituada a que las provincias sean gobernadas por autoridades colectivas, elegidas por ellas y presididas por gobernadores de nombramiento real ${ }^{32}$, propuesta que fue rechazada.

En cada provincia habrá una Diputación llamada provincial, para promover su prosperidad, presidida por el jefe superior, que estará compuesta por el presidente, el intendente y siete individuos. No se legisló un mayor número de diputados ante el temor tanto al posible auge del federalismo como a la pérdida del poder de las Cortes $^{33}$.

La Diputación se renovará cada dos años por mitad, saliendo la primera vez el mayor número y la segunda el menor, y así sucesivamente. La elección de estos individuos se hará por los electores de partido, al otro día de haber nombrado los diputados de Cortes, "por el mismo orden con que éstos se nombran". Al mismo tiempo y en la misma forma se elegirán tres suplentes.

Para ser individuo de la Diputación provincial, se requiere ser ciudadano en el ejercicio de sus derechos, mayor de veinticinco años, natural o vecino de la provincia, con residencia a lo menos de siete años, y que tenga lo suficiente para mantenerse con decencia. Y no podrá serlo ninguno de los empleados de nombramiento del Rey. Para que una misma persona pueda ser elegida por segunda vez, deberá haber pasado a lo menos el tiempo de cuatro años, después de haber cesado en sus funciones.

Cuando el jefe superior de la provincia no pudiera presidir la Diputación, la presidirá el intendente, y en su defecto, el vocal que fuere primer nombrado.

La Diputación nombrará un secretario, dotado de los fondos públicos de la provincia y tendrá en cada año noventa días de sesiones.

30 GARÓFARO SÁCHEZ, Rafael. La Constitución gaditana de 1812. Ed. Diputación de Cádiz. Cádiz, 1996. Hace una referencia a la obra de Melchor Fernández Almagro "Orígenes del Régimen Constitucional en España" en lo que se refleja "el componente social de los constituyentes" indicando que se "contaba entre ellos a noventa y siete eclesiásticos, ocho títulos del Reino, treinta y siete militares, diez y seis catedráticos, sesenta abogados, cincuenta y cinco funcionarios, quince propietarios, nueve vicarios, cinco comerciantes, cuatro escritores y dos médicos. Total trescientos ocho diputados".

31 Actas de la Comisión de Constitución 1811-1813, recopiladas por María Cristina DIZ-LOIS. Acta del día 2 de marzo de 1811.

32 Ibídem. Acta del día 12 de enero de 1812.

33 ORTEGO GIL, Pedro. Evolución legislativa... ob. cit. A lo largo de estas páginas se refleja el temor de los diputados a Cortes de "que si se aumenta el número de diputados provinciales se estaba alimentando la forma federalista de Gobierno". También se dice que "se estaba discutiendo sobre el posible aspecto federalista de estas Corporaciones, y el recelo de las Cortes al ver su papel desfigurado”. Págs. 123 a 129. 
Uno de los artículos más importantes y trascendentes es el que fija el campo de actuaciones de la Diputación, y delimita este campo a las actividades económicas y administrativas, pero no se refleja en sus actuaciones la posibilidad de actuar en temas políticos. En el mismo, se detallan las áreas de gestión en los repartimientos de las contribuciones, los arbitrios, el control de las cuentas de los Ayuntamientos, las obras públicas, las comunicaciones, la educación de la juventud, cuidado de los establecimientos de beneficencia. En definitiva, "la finalidad de las Diputaciones era la de promover el fomento general de cada provincia, como auxiliares del gobierno".

Una vez aprobados por el pleno, el día 19 de marzo de 1812, las Cortes reunidas en la Iglesia de San Felipe Neri de Cádiz, aprobaron en sesión solemne la "Constitución Política de la Monarquía española".

\subsection{2.-LEGISLACIÓN COMPLEMENTARIA A LA CONSTITUCIÓN}

Aprobada la Constitución, y antes de que las Diputaciones se pongan en marcha, las Cortes completan y detallan su funcionamiento con la publicación de decretos y leyes que regulan las actividades de las nuevas instituciones provinciales.

\section{Decreto de 23 de mayo de 1812, sobre el establecimiento de las Diputacionesprovinciales en la Península y Ultramar}

Las Cortes generales y extraordinarias, con el objeto de facilitar la ejecución del artículo trescientos veinticinco de la Constitución, decretan "la instalación de Diputaciones provinciales, mientras no llega el caso de hacerse la conveniente división del territorio español en: Aragón, Asturias, Ávila, Burgos, Cataluña, Córdoba, Cuenca, Extremadura, Galicia, Granada, Guadalajara, Jaén, León, Madrid, La Mancha, Murcia, Navarra, Palencia, Vascongadas, Salamanca, Segovia, Sevilla, Soria, Toledo, Valencia, Valladolid, Zamora, Islas Baleares e Islas Canarias. Los individuos de las Diputaciones serán nombrados en las capitales de las provincias, siendo su número de siete".

Con la publicación de este decreto, no todas las provincias quedaron satisfechas al no disponer de Diputación y una de las que más se sintió ofendida y reclamó su derecho a tener Diputación provincial fue Cádiz, sede provisional de las Cortes, que solicitaba su separación de Sevilla, argumentando precisamente el protagonismo que tenía la ciudad en la actividad política del país. También en el archipiélago canario, la isla de Gran Canaria, reclamaba una Diputación separada de la isla de Tenerife. Todas estas reclamaciones no prosperaron, y el decreto se mantuvo en los términos aprobados.

\section{Orden de 15 de septiembre de 1812, sobre la formación de las Juntas Preparatorias para la elección de diputados}

Una vez aprobada la Constitución y el decreto de 23 de mayo, el siguiente paso para el establecimiento de las Diputaciones fue la convocatoria de elecciones, y para este fin se dictó la orden de 15 de septiembre de 1812, "Mandando formar las Juntas preparatorias para las elecciones de diputados a Cortes y diputados provinciales". A partir de esta orden, las provincias iniciaron las convocatorias de elecciones y, acto seguido, la formación de las Diputaciones.

\subsection{3.- INSTRUCCIÓN PARA EL GOBIERNO ECONÓMICO POLÍTICO DE LAS PROVINCIAS}

El día 23 de junio de 1813, la Regencia del Reino firma un real decreto sobre la "Instrucción para el Gobierno Económico-Político de las Provincias"34. En este

\footnotetext{
${ }^{34}$ Colección de Reales Decretos y Órdenes mandadas publicar por las Cortes en 1812. Imprenta Nacional, Madrid 1820-1823 (10 vol.) Tomo I. "Instrucción para el Gobierno Económico- Político de las Provincias". Real decreto también publicado en el suplemento de la Gaceta de la Regencia del sábado 24 de julio de 1813 , págs. 772 a 779
} 
documento se detallan las normas de actuación de los Ayuntamientos, Diputaciones y jefes políticos, de acuerdo con los artículos de la Constitución. Está compuesto por un total de setenta y ocho artículos divididos en tres capítulos. El capítulo primero trata sobre las obligaciones de los Ayuntamientos, el capítulo segundo es el dedicado a las Diputaciones y el tercero se refiere a los jefes políticos.

En el capítulo segundo se encuentra reflejado lo determinado por la Constitución, y a través de su redacción, se puede constatar, que tanto la comisión como el pleno de las Cortes con su aprobación han querido remarcar las dos características o parámetros en las que debía de desenvolverse las actividades de la Diputación: Promover la prosperidad y felicidad de los habitantes de la provincia, y quedar constancia de que la Diputación depende del gobierno a través del jefe político. "Así como los Ayuntamientos nada pueden ejecutar sin consulta y acuerdo de la Diputación, tampoco ésta podrá hacer nada sin consultar antes con el gobierno" 35.

\subsection{4.- EVOLUCIÓN LEGISLATIVA EN LA ÉPOCA GADITANA}

Los diputados constituyentes, aunque su intención es la de dar a la Constitución un cierto carácter centralista, también mantienen un deseo y afán de dotar a las provincias de una cierta autonomía, para la gestión de los asuntos que le correspondieran, especialmente de índole administrativa y económica. Se las permite controlar los repartimientos, los arbitrios, los pósitos, etc., todo ello con el límite que representa la figura del jefe superior político.

Pero la vida política nacional va modificando poco a poco la postura de las Cortes, y este planteamiento "tan liberal" va a tener una rectificación, con la aprobación por los mismos diputados de un proyecto, sobre la "Instrucción para el Gobierno Económico y Político de las Provincias". El decreto delimitaba sustancialmente las propuestas constitucionales concedidas a las Diputaciones, traspasando su poder de decisión y potenciando en consecuencia la figura del jefe político.

Es curioso que en el período que transcurre desde la promulgación de la Constitución hasta la aprobación de la Instrucción, los legisladores no han podido constatar que la supuesta autonomía que la Constitución concedía a las provincias, a través de las Diputaciones, haya ocasionado problemas y dificultades de gobierno, entre otras razones porque en junio de 1813, la mayoría de las Diputaciones no se habían constituido formalmente.

Esta actitud hace suponer que los diputados a Cortes, o se asustan del poder que se podía concentrar en las Diputaciones provinciales a partir de las posibilidades que las concedía la Constitución, o pensarían que las provincias no estaban lo suficientemente preparadas para gobernarse. Aunque en realidad lo que se produce es un grave fallo de la clase política dirigente, al no conceder un voto de confianza a favor de la capacidad de los pueblos para organizarse tanto política como económicamente, sin perder su cohesión con el gobierno central. El jefe político era la cabeza visible de ese afán por controlar y someter a las Diputaciones provinciales.

\section{3.- LA LEGISLACIÓN DEL TRIENIO LIBERAL (1820-1823)}

\subsection{1.- LA NUEVA PUESTA EN MARCHA}

El periodo absolutista iniciado en 1814 se puede dar por finalizado el día 1 de enero de 1820, con el levantamiento de Riego. Movimiento que en principio es de exclusivo carácter militar y que paradójicamente no llegó a triunfar en el ámbito castrense, y sí lo hizo y con éxito en el ámbito popular. Ello obligó a que Fernando VII simulara una conversión, de la noche a la mañana, hacia las ideas liberales, y llegara a prestar juramento de la Constitución de 1812 el día 9 de marzo, y el 14 del mismo mes "restableciera provisionalmente las Diputaciones de 1814". "Marchemos

35 ORTEGO GIL, Pedro. Evolución legislativa... ob. cit. Págs. 198-199. 
francamente y yo el primero por la senda Constitucional" ${ }^{36}$, es una frase que se ha hecho popular y que se puede considerar como el punto de partida de la segunda etapa constitucional española.

\section{Inicio de la actividad legislativa}

Después del 15 de junio de 1814, cuando se publica el decreto de supresión de las Diputaciones provinciales "como no necesarias" ${ }^{37}$, no se vuelve a tratar este tema hasta el 7 de marzo de 1820, a través de un decreto que restablece la Constitución de 1812, y de una circular de la Gobernación de la Península de 30 de marzo que restaura las Diputaciones. Además de estos decretos y para agilizar la puesta en marcha de las instituciones se acuerda que: "Al siguiente día de las elecciones de diputados a Cortes del 22 de mayo se procederá a la de individuos de las Diputaciones y mientras que se verifica la nueva elección y para que no padezca el servicio público, se reunirán provisionalmente a fin de entender en el despacho de los negocios más urgentes y perentorios, los vocales de las Diputaciones en el tiempo de su extinción en $1814 \ldots$ ". 38 .

Las elecciones para diputados a Cortes se celebran el 22 de mayo de 1820, e inician su tarea legislativa a partir del 9 de julio del mismo año. En temas relativos al desarrollo y funcionamiento de las Diputaciones provinciales, no tardaron en tratar, de acuerdo con las explicaciones enviadas por una serie de Diputaciones como las de León, Madrid, Vizcaya, Cataluña o Santander, sobre la modificación de la "Instrucción para el Gobierno de las Provincias" de 23 de junio de 1813.

La legislación sobre la administración provincial será objeto de discusión en el Trienio, pues las Diputaciones la consideraban como "una ley cerrada y encorsetada que no permitía a las corporaciones provinciales desarrollar todos los trabajos para los que habían sido creadas a partir de la Constitución doceañista, sobre todo por el papel predominante y decisorio del jefe político, que además era el presidente de la Diputación y era nombrado por el gobierno central ${ }^{39}$.

\subsection{2.- LOS PROYECTOS}

La actividad legislativa en los temas de la Diputación se centra especialmente en los proyectos para modificar la Instrucción de 23 de junio de 1813. En este sentido, hacemos notar la presentación de dos proyectos de muy diferente sentido, el primero de carácter progresista es el "Proyecto de Reforma de la Instrucción" presentado por las Cortes y el segundo es el "Proyecto de Reforma", de claro matiz conservador presentado por el Gobierno en 1822.

\subsection{3.- LEY DE 3 DE FEBRERO DE 1823 SOBRE "EL GOBIERNO ECONÓMICO- POLÍTICO DE LAS PROVINCIAS"}

$\mathrm{Ni}$ el proyecto de las Cortes de junio de 1821 sobre la organización provincial, ni el presentado por el gobierno en enero de 1822, tuvieron éxito a la hora de ser presentados en el Pleno. Ante esta disyuntiva, la comisión de Diputaciones redacta un nuevo proyecto el 29 de abril de 1822, que con el tiempo y la discusión en Cortes se convertirá en la ley de 3 de febrero de 1823 sobre "El Gobierno Económico-Político de las Provincias". Es una ley de carácter progresista que supera con creces a la todavía vigente Instrucción de 1813 y a los dos proyectos presentados en esta legislatura, aunque la comisión en su presentación admite que para su redacción se ha basado en el proyecto de las Cortes de junio de 1821, y en las consultas a las Diputaciones.

36 Colección de Reales Decretos y Órdenes... ob. cit. Tomo V.

37 Ibidem. Tomo I.

38 Ibidem. Tomo V.

${ }^{39}$ ORTEGO GIL, Pedro. Evolución legislativa... ob. cit. Relación de los diferentes proyectos legislativos de carácter provincial. Pág. 228 y sig. 


\section{Planteamiento}

El proyecto fue redactado por la comisión de Diputaciones de las Cortes, con la intención de preparar una ley que recogiera todas las carencias que la Instrucción de 1813 había planteado en su corta vigencia en el año 1813 y en los años que habían transcurrido del Trienio.

Como punto de partida se tomó tanto la Instrucción vigente como el proyecto de 1821, analizando las principales diferencias entre la ley y el proyecto, las dificultades encontradas y las soluciones propuestas, tanto por la comisión como por las Diputaciones.

En su estudio, la comisión constató que no estaba bien determinada la división de atribuciones entre la Diputación y el jefe político, y también que la Instrucción de 1813, había generado muchas disputas en su puesta en funcionamiento. Igualmente el proyecto de 1821 dejaba sin resolver algunos temas referentes a los Ayuntamientos.

A todos estos problemas, la comisión, a la hora de redactar su proyecto, tuvo en cuenta el buscar una serie de soluciones satisfactorias, que sirvieran especialmente para aclarar y mejorar las relaciones entre las tres principales instituciones de la provincia: Jefatura política - Diputación - Ayuntamiento.

\section{Desarrollo de la ley}

La discusión en Cortes del proyecto fue larga y exhaustiva, desde el 29 de abril de 1822 en que fue presentado, hasta el 3 de febrero de 1823 , en que fue aprobado como ley. El resultado fue considerado satisfactorio, especialmente por los diputados progresistas y por las Diputaciones, que veían satisfechas sus demandas y sus peticiones de autonomía, y valoraban como soluciones aceptables a la mayoría de dudas y cuestiones planteadas.

Si la Instrucción de 1813 estaba compuesta por setenta y ocho artículos divididos en tres capítulos, la "Ley de 3 de febrero de 1823" resulta una ley larga y detallada formada por cuatro capítulos y doscientos noventa y un artículos que trataban sobre los Ayuntamientos, las Diputaciones provinciales, los alcaldes y los jefes políticos.

\section{Escasa vigencia en el Trienio}

Una vez aprobada por las Cortes por decreto de 3 de febrero de 1823, y sancionada como ley con fecha 2 de marzo del mismo año, podemos ver que su efectividad en esta época es muy relativa, ya que apenas tuvo oportunidad de ponerse en funcionamiento, puesto que la situación política nacional estaba convulsionada por los continuos enfrentamientos entre los grupos liberales que controlaban las Cortes y los partidarios del Rey absolutista que bloqueaban y retrasaban la puesta en marcha de las leyes que emanaban del Parlamento.

Esta situación se agrava con la invasión del territorio nacional por las tropas de la Santa Alianza, "los cien mil hijos de San Luis", en abril de 1823, y culmina con la real orden de 1 de octubre del mismo año por el que se declaran "nulos y de ningún valor los actos del gobierno constitucional desde el 7 de marzo de 1820 al 1 de octubre de 1823". A partir del 1 de octubre queda anulada la Instrucción y también, por supuesto, las Diputaciones provinciales, por lo que la vigencia de esta ley se reduce a los ocho meses que transcurren desde febrero a septiembre de 1823 .

\section{Puesta en marcha en la época isabelina}

La muerte de Fernando VII en 1833 se corresponde con el fin de la "Década Ominosa" y el inicio de una nueva etapa de la política nacional. Su primer cambio está protagonizado por la puesta en marcha de una tímida reforma constituida por el decreto de 10 de abril de 1834, conocido con el nombre de "Estatuto Real". Continua a nivel administrativo en el año 1835 con el real decreto de 21 de septiembre por el que se re-instalaban las Diputaciones provinciales y que culminaría en agosto de 1836, con el restablecimiento de la Constitución de 1812 y de la ley de 3 de febrero de 1823 
sobre la "Instrucción para el Gobierno Económico-Político de las Provincias". Esta ley estuvo vigente hasta la publicación de la ley de 8 de enero de 1845, sobre la "Organización y Atribuciones de las Diputaciones Provinciales".

\section{Reimplantación en el Bienio Progresista}

Con el fin de la regencia de María Cristina y la llegada al poder de las fuerzas progresistas, capitaneadas por el general Espartero, se inicia una nueva etapa de vigencia de la Constitución que tendrá tanta duración como la que tiene el período progresista. En el caso de la ley "sobre el Gobierno Económico-Político de las Provincias" de 3 de febrero de 1823, su restablecimiento tiene lugar por decreto de 7 de agosto de 1854, hasta que el 16 de octubre de 1856, es sustituida por la ley de 8 de enero de 1845.A partir de este momento no volverá a estar vigente.

\section{4.-LA LEGISLACIÓN ISABELINA}

\subsection{1.- PROYECTOS Y LEYES EN LOS PRIMEROS AÑOS}

En el período de arranque de la época isabelina se produce una obligatoria y urgente actividad legislativa que pretende, por un lado retirar de la legalidad la legislación absolutista en vigor y, por otro, cubrir este vacío con una serie de leyes y decretos que posibiliten la normalidad en la actividad política nacional, hasta que las Cortes completen su trabajo legislativo.

No hay que olvidar que a partir de 1833 , con la muerte de Fernando VII, todas las leyes que se promulgan van encaminadas, tanto en su redacción como en su sentido político, hacia una nueva puesta en marcha de leyes liberales. Pretenden aproximarse al deseo de libertad expresado por los españoles y tienen como meta el igualar al espíritu de la Constitución de 1812 y de la "Instrucción para el Gobierno económico y político de las provincias" de 3 de febrero de 1823. Realmente estas dos leyes serán nuevamente puestas en vigor, pero mientras tanto, se legisla sobre temas y actividades que tienden a mejorar tanto el horizonte de libertad como la modernización de la administración, y en especial en su ámbito provincial. Entre estas destacan:

\section{Subdelegados de Fomento}

Es el primer paso para una nueva puesta en marcha de la administración provincial. Por real decreto de 23 de octubre de 1833, se creaba la figura del subdelegado de fomento, cuyo ámbito de actuación sería la provincia. En el año 1834 tomaría el nombre de gobernador civil y en 1836, con la puesta en marcha nuevamente de la ley de 3 de febrero de 1823, retomaría el nombre de jefe político.

A estos subdelegados se les concedía "la autoridad superior administrativa de la provincia", a diferencia de los jefes políticos que estaban considerados como la "superior autoridad política" y sus actividades englobaban las de los "ministerios" de Fomento e Interior en la provincia. Eran temas de su incumbencia las obras públicas, instrucción pública, beneficencia, fomento de la agricultura, de la industria y del comercio, policía, sanidad, seguridad, control de los Ayuntamientos, etc. En definitiva eran los representantes de la administración central en la provincia en unos años en los que la representación política apenas es ejercida.

\section{División territorial en provincias}

El día 30 de noviembre de 1833 se publica un real decreto sobre "La división territorial en provincias", redactado en tiempo record por el ministro de Fomento, Javier de Burgos, que trata de la división de la península en provincias. Está claro que se tomó como base los trabajos sobre la división territorial realizados por Felipe de Bauzá en el año 1822, y también que se vuelve a reconocer la necesidad de realizar una correcta división territorial para que se pudieran restablecer las administraciones provinciales a partir de las Diputaciones. 


\subsection{2.- EL ESTATUTO REAL}

Por real decreto de 10 de abril de 1834, se convocaban Cortes del Reino, decreto en el que se incluía una especie de carta constitucional, otorgada por la Reina Regente, y que tomó el nombre de Estatuto Real.

Era inevitable que a la muerte de Fernando VII se iniciaran, o mejor dicho, se fomentaran una serie de cambios en la forma de gobierno, cuyo punto de partida es el Estatuto. Los liberales favorables a la causa de Isabel II aspiraban al restablecimiento de la Constitución de 1812, reformada o sin reformar, aunque el gobierno pensó que el Estatuto era suficiente para conformar las ansias de libertad del pueblo. Lo cierto es que "el Estatuto fue considerado por unos como el principio del cambio en las ideas políticas al pasar de las ideas y tradiciones de la España del Antiguo Régimen a las de la España moderna, y por otros como el primer paso dado en el camino de las reformas ${ }^{40}$. Parece que esto último es lo que realmente sucedió.

Para Casimiro Martít1, el Estatuto Real "representa un intento de tender un puente para la reconciliación entre carlistas y liberales, que fue rechazado por los absolutistas y considerado insuficiente por los liberales, para modificar la organización social del Antiguo Régimen”. El Estatuto Real era, de principio, una norma otorgada por el poder real y no elaborada por los representantes populares y, además, reconocía un poder excesivo a la Corona y limitaba de forma considerable el número de participantes en las elecciones (para un total de 10.683.000 habitantes los votantes eran 16.026 , el $0,15 \%$ de la población $)^{42}$.

Miguel Artola ${ }^{43}$ dice que "el Estatuto es el símbolo de la transacción ofrecida por los isabelinos a los liberales, fórmula que estos últimos consideraron insuficiente, tanto por la influencia que se atribuye la Corona en la designación de representantes, como por el limitado número de los llamados a participar en las elecciones". Entendía que "el Estatuto satisfacía las aspiraciones de los liberales moderados" y para los progresistas "era sólo un primer paso en el proceso de democratización".

El Estatuto está formado por cincuenta artículos, divididos en cinco títulos y el preámbulo del decreto nos da detalles de sus intenciones ${ }^{44}$. La insatisfacción que generó el Estatuto a las aspiraciones legítimas de los españoles provocó su corta vigencia, ya que por real decreto de 13 de agosto de 1836 se mandó publicar la Constitución Política de 1812. "En el ínterin que reunida la nación en Cortes manifestare expresamente su voluntad, o diera otra Constitución conforme a las necesidades de la misma" 45 .

En definitiva, esta "carta otorgada" tuvo una vigencia de dos años y no se puede negar que sirvió como intermedio o "trampolín" para alcanzar mayores metas en el afán de progreso liberal del pueblo español.

\subsection{3.- NORMALIZACIÓN LEGISLATIVA}

En los años de vigencia del Estatuto Real que, como hemos repetido con anterioridad, es considerado como el primer paso de una tímida apertura política, las

40 MARTínez AlCUBILlA, Marcelo. Diccionario de Administración Española. Madrid, 1915. $6^{\mathrm{a}}$ Edición, Tomo IV. Constitución Política. El Estatuto Real (1834-1836). Pág. 276.

41 TUÑN DE LARA, Manuel (Dir.). Historia de España. (13 vol.). Tomo VIII. El Estatuto Real de 1834 por Casimiro Martí y Martí. Editorial Labor. Barcelona, 1997. Pág. 210.

42 Ibídem. Pág. 211.

43 ARTOLA, Miguel (Dir.). Historia de España... ob. cit. Pág. 65.

44 "Deseando restablecer en su fuerza y vigor las leyes fundamentales de la Monarquía, con el fin de que se lleve a cumplido efecto lo que sabiamente previenen para el caso en que ascienda al trono un monarca menor de edad; y ansiosa de labrar sobre un cimiento sólido y permanente la prosperidad y gloria de esta nación magnánima, he venido en mandar en nombre de mi excelsa hija Doña Isabel II, y después de haber oído el dictamen del Consejo del Gobierno y del de Ministros, que se guarde, cumpla y observe, promulgándose con la solemnidad debida, el precedente Estatuto Real, para la convocación de las Cortes del Reino". MARTÍNEZ ALCUBILLA, Marcelo. Diccionario... ob. cit., pág. 278.

45 Ibídem. Pág. 278. 
Cortes, continuaron con su afán de acelerar las reformas legislando y esforzándose por restablecer las leyes progresistas de la época del Trienio. Entre ellas destacamos las más significativas.

\section{Restablecimiento de las Diputaciones}

Una de las dificultades con que tropezaron los gobiernos en los primeros años de la época isabelina fue la falta de legislación sobre la administración provincial. No olvidemos que las Diputaciones fueron disueltas por real decreto de 1 de octubre de 1823. Y el Estatuto Real, como punto de partida del nuevo sistema de gobierno, no presenta en su articulado referencia alguna sobre el "Gobierno de las Provincias". Por eso se ponen en marcha nuevamente las Diputaciones provinciales, ya de un forma definitiva, a través del real decreto de 21 de septiembre de 1835 por el que se desarrolla "el modo de constituir y formar las Diputaciones provinciales".

\section{Restablecimiento de la Constitución de 1812}

En el año 1836, la efervescencia política promovida desde las filas progresistas, aceleran el final del Estatuto Real, que culminará en el mes de agosto, con el "Motín de la Granja" y el real decreto del día 13 por el que se "restablecía la Constitución de 1812". Esta restauración de la Constitución, ocasiona al mismo tiempo una vuelta a la legislación revolucionaria de las primeras épocas liberales. Se restablecen, la ley de imprenta de 1820, la ley de Ayuntamientos de 1812, la ley de Diputaciones de 1813, las milicias nacionales y las leyes desamortizadoras. Al mismo tiempo, se convocan Cortes Constituyentes para reformar la Constitución.

\section{Restablecimiento de la Ley de 3 de febrero de $\mathbf{1 8 2 3}$}

Como culminación a la restauración de leyes progresistas, con fecha 15 de octubre de 1836, se promulga una ley clarificadora, como indica su preámbulo: "Tiene el objeto de establecer un método claro y uniforme en el gobierno económico-político de las provincias, y que sus Diputaciones, jefes políticos y Ayuntamientos no tengan duda ni incertidumbre acerca de la esfera respectiva de sus facultades, cuya duda siempre redundará en perjuicio del servicio público y del interés de los pueblos".

El artículo primero de esta ley "restablece en su fuerza y vigor la ley de 3 de febrero de 1823 sobre el Gobierno Económico-Político de las Provincias".

\section{Aumento del número de diputados provinciales}

Este aumento es consecuencia del espíritu inquieto y renovador del que hacen gala las Cortes, del restablecimiento de la ley de 3 de febrero, y del deseo de modificar el número de diputados que había quedado plasmado en el real decreto de 21 de septiembre de 1835. Se presentó al pleno de las Cortes una solicitud demandando una ley que reflejara una ampliación del número de individuos en las Diputaciones provinciales de acuerdo con su población y su extensión, y también a la forma de proceder a su elección.

Con esta finalidad, con fecha 15 de enero de 1837, se aprueba la ley relativa "Al aumento de los individuos de las Diputaciones provinciales y cesación de las Juntas de Armamento y Defensa". Esta ley estaba formada por los cuatro artículos que a continuación se transcriben: Artículo primero. El número de diputados provinciales será igual al de partidos judiciales, siempre que éstos no bajen de siete. Artículo segundo. Se agregarían los individuos electos necesarios para completar esa proporción, manteniéndose los que fueran en sus cargos. Artículo tercero. La elección de los diputados que faltan, se hará por los electores que hubieran designado a los que lo fueran en aquel momento. Artículo cuarto. La Diputación continuará con el mismo método y distribución de sus sesiones. Se ordena el relevo en sus funciones de los individuos de la comisión de Armamento y Defensa. 


\subsection{4.- LA CONSTITUCIÓN DE 1837}

Las Cortes que salieron de las elecciones celebradas en el verano de 1836 , lo fueron con una mayoría progresista, aunque también se formaron con el carácter de constituyentes, pues era admitido de forma generalizada la necesidad de modificar y modernizar la vigente Constitución de 1812. En definitiva, se reconocía su provisionalidad. Una de las primeras actuaciones, una vez constituidas, fue la creación de una comisión encargada de redactar el nuevo texto constitucional. Estaba presidida por Argüelles y tenía como secretario a Olózaga.

Una de las principales preocupaciones con las que la comisión inició sus trabajos era la de "hacer una obra aceptable a todos los partidos" "46. Tenían interés en procurar eliminar las aristas más "exaltadas" de la Constitución de 1812 y presentar un texto más moderado, aunque para conseguirlo fuera con la condición de hacerlo menos detallista.

Parece un contrasentido que "la mayoría progresista que alcanzó el poder en 1836 sea la que redacte una Constitución conservadora que se encontraba a años luz de la original que reclamaban como fundamento de su ideario"47. Esta opinión es contestada por Casimiro Martí al indicar que "lo que preocupa a los progresistas es la búsqueda de una conciliación con los moderados, impuesta en parte por la necesidad de obtener una victoria bélica sobre las fuerzas absolutistas" ${ }^{48}$. Lo que sí parece una realidad es que los liberales, ya sean moderados o progresistas, y se verá a lo largo del siglo XIX, sólo estaban preocupados por alcanzar el poder olvidándose de sus ideales programáticos con tal de mantenerse.

\section{Desarrollo del proyecto}

Como hemos reflejado con anterioridad, la comisión dio pruebas de moderación y prudencia, consiguiendo de este modo una general aceptación al proyecto. En él se presentaban una serie de modificaciones y entre las más llamativas destacamos: La creación de una segunda cámara nombrada por la Corona, a partir de unas listas presentadas por los electores. Los ministros son designados por el Rey y tenían escaño en las Cortes. La Corona podía convocar y disolver las Cortes.

El establecimiento de las dos Cámaras tiene su precedente en el Estatuto Real, con la formación del Estamento de los Procuradores y el Estamento de los Próceres, este último de designación real. En el caso de la Constitución, el Rey nombraba a los senadores, a partir de una terna que le presentaban los electores.

En el caso del poder de veto concedido a la Corona, las discusiones fueron enconadas y los progresistas tuvieron que abandonar su idea de reflejar en el articulado "el poder soberano del pueblo" y, como dice Artola, "conservaron 1a soberanía nacional a costa de desplazarla al Preámbulo, con la frase de "siendo la voluntad de la Nación, en uso de su soberanía, revisar la Constitución Política promulgada en Cádiz..."

Para conseguir el equilibrio deseado, la comisión decidió redactar una Constitución generalista para cuyo fin "eliminaron del proyecto los preceptos o cuestiones que podían dejarse a la regulación más particular de leyes y reglamentos" 50 . La comisión había llegado a la conclusión de que, "una vez consolidado el sistema constitucional, no veía necesario amparar con la autoridad de la Constitución, la ley electoral, las disposiciones que regulan la función judicial o la administración

46 COLOMER VIADEL, Antonio. El Sistema Político de la Constitución española de 1837. Madrid, 1989.

47 ABAD, Juan José y TRIGO, Lorenzo. Historia de España. Club Internacional del libro. Tomo XV. Pág. 31.

48 TUÑN de LARA, Manuel (Dir.) Historia de España. ob. cit. Tomo VIII. Afianzamiento y despliegue del sistema liberal. Por Casimiro MARTI. Pág. 212.

49 ARTOLA, Miguel. Historia de España ... ob. cit. Tomo V, págs. 130-131.

${ }^{50}$ TOMÁS VILLARROYA, Joaquín. El Estatuto Real y la Constitución de 1837. Madrid. 1985. Págs. 47 y 48. 
territorial. Sin estas materias, el texto constitucional sería más breve y menos conflictivo el debate" ${ }^{51}$.

Como ejemplo de lo dicho con anterioridad tenemos el capítulo relativo a las Diputaciones provinciales y Ayuntamientos que en la Constitución de Cádiz estaba englobado en el título sexto y dividido en dos capítulos, dedicados respectivamente, uno a los Ayuntamientos y el otro a las Diputaciones provinciales, con un total entre los dos de veintinueve artículos. Mientras, en el proyecto para la Constitución presentado, que sería aprobado sin modificación, quedaba reducido a tres artículos agrupados en el título onceavo, con la denominación "De las Diputaciones provinciales y de los Ayuntamientos".

La comisión, que inició sus trabajos a partir de su nombramiento por las Cortes el día 5 de noviembre de 1836, presentó a las Cortes, el día 24 de febrero de 1837 su proyecto de Constitución. Los debates se inician el 13 de marzo y se dan por concluidos el día 22 de mayo y el día 18 de junio del mismo año fue promulgada solemnemente.

\section{Articulado}

La Constitución está formada por setenta y siete artículos más dos adicionales, repartidos en trece títulos. Respectivamente trataban de los españoles, de las Cortes, del Senado, del Congreso de los diputados, de la celebración y facultades de las Cortes, del Rey, de la sucesión de la Corona, de la menor edad del Rey y de la Regencia, de los ministros, del poder judicial, de las Diputaciones provinciales y de los Ayuntamientos, de las contribuciones, y de la fuerza militar nacional.

\section{Vigencia}

La Constitución de 1837 se mantuvo vigente desde el día 18 de junio, fecha de su promulgación, hasta el 23 de mayo de 1845, en cuyo día se aprobó una nueva Constitución. Su vigencia fue, por lo tanto, de ocho años, un tiempo muy corto al tratarse de una ley fundamental, escueta y con poco reglamento. Pero hay que reconocer que la efervescencia política de aquellos años obligaba a modificar constantemente los parámetros con que se medían las actividades políticas. Aunque en opinión de Miguel Artola, “esta Constitución gozó de una extraordinaria longevidad, dado que las sucesivas Constituciones, hasta la II República, no son más que la reproducción, sin apenas cambios, del texto del $37^{\prime, 52}$.

\section{Algunas conclusiones sobre la legislación del periodo}

Dada su redacción generalista, el proyecto de ley de la Constitución no tuvo muchas dificultades ni muchas discusiones para ser aprobado al estar de acuerdo la mayoría de las Cortes, con el borrador presentado por la comisión. Como hemos indicado antes, esta redacción presuponía que las Cortes tuvieran que legislar sobre las materias que no habían sido detalladas, como es por ejemplo, el funcionamiento de las Diputaciones provinciales. Según Posada, "la organización local y provincial es considerada como materia de ley ordinaria, salvo las breves indicaciones que se señalan en el texto" ${ }^{53}$.

Una consecuencia de este planteamiento es que a partir de 1837 y hasta 1845 , se ponen en marcha una serie de iniciativas legislativas que van conformando las instituciones estatales, entre ellas las Diputaciones y Ayuntamientos, de acuerdo con los posicionamientos establecidos en la Constitución. Hay que tener en cuenta que, durante todo este tiempo, continuará en vigor, en lo referente a las Diputaciones, la

51 ARTOLA, Miguel. Historia de España. ob. cit. Tomo V, pág. 130.

52 Ibídem. Pág. 130.

53 POSADA, Adolfo. Evolución legislativa del Régimen Local en España (1812-1909). Madrid, 1982. Pág. 157. 
ley del 3 de febrero de 1823, cuyo carácter progresista era causa de continuos roces entre los diputados de las diferentes tendencias políticas.

El temor de las Cortes, ante un exceso de autonomía de las Diputaciones que ya se mostró en la época de gestión de las primeras leyes en 1813, continúa vigente en estos años, como lo demuestran las discusiones que hubo en la comisión de la Constitución al decir que: "Estos cuerpos (las Diputaciones) son los instrumentos o medios para hacer cumplir las leyes, pero siempre bajo la responsabilidad del Poder ejecutivo" 54 . Esta inquietud se reflejará en las sucesivas leyes que se van aprobando, y también será la causa de la tardanza en aprobar la ley de 8 de enero de 1845, que será la que sustituya a la de 3 de febrero de 1823 .

\subsection{5.- LEYES COMPLEMENTARIAS SOBRE LAS DIPUTACIONES}

A falta de las puntualizaciones necesarias que no están marcadas en la Constitución, las Cortes legislan una serie de leyes que ayudan a que las Diputaciones puedan desarrollar su trabajo, que en principio continúa basándose en la ley de 3 de febrero de 1823, pero a la que los sucesivos gobiernos van poniendo cada vez más trabas al considerarla una ley demasiado progresista.

\section{Censo de Población de 1837}

Por real decreto de 29 de junio de 1837, se ordena la formación de un nuevo censo electoral. Es un primer paso necesario de actualización de los datos demográficos de todo el territorio ante las previsibles actuaciones electorales. Con este real decreto se fija a las Diputaciones provinciales, como las instituciones responsables del censo.

\section{Ley Electoral de 1837}

El 20 de julio de 1837 es aprobada y publicada una nueva ley electoral. Al poco tiempo de la aprobación de la Constitución, el gobierno continúa poniendo a punto y actualizando el sistema electoral. El dato más significativo que refleja la ley está referido al importante aumento del número de personas con derecho a voto. En el período 1834-1836, época del Estatuto Real, el número de votantes se correspondía con el $0,15 \%$ de la población, es decir 16.026 personas para una población de 10.683.000, y con esta nueva ley se pasa a un 2,2\% de población, lo que representa, para un mismo número de habitantes en el territorio un total de 235.026 individuos con derecho a voto.

\section{Libertad de expresión}

Por real decreto de 17 de agosto de 1837, se restablece la normativa legal vigente en el Trienio Liberal sobre el tema de libertad de expresión.

\section{Renovación de las Diputaciones provinciales}

Una reacción inmediata a la promulgación de la Constitución, en el tema específico que se refiere a las Diputaciones provinciales, fue el establecimiento de unas necesarias reglas de funcionamiento, como lo refleja la proposición de ley de 13 de septiembre de 1837 que se presenta a los pocos días de la aprobación de la Constitución ${ }^{55}$.

54 ORTEGO GIL, Pedro. Evolución legislativa ... ob. cit. Se recogen las opiniones de los componentes de la comisión, reflejadas en los Diarios de Sesiones Pág. 477.

55 "Disponiéndose por un artículo de la nueva Ley Fundamental la existencia de las Diputaciones provinciales, sin que se den reglas para su establecimiento y renovación, ni marquen sus atribuciones, y suponiendo que sus individuos deban ser nombrados por los mismos electores que en las próximas elecciones verifiquen la de diputados y propuesta de senadores para el nuevo Congreso, pido a las Cortes se sirvan acordar que la comisión de Ley Electoral forme y presente a la deliberación de las mismas un proyecto de ley que abrace todos los extremos necesarios que lleven al objeto que propongo, relativo a las Diputaciones" ORTEGO GIL, Pedro. Evolución legislativa ... ob. cit. Donde se recoge la petición a las Cortes del diputado Maura. Pág. 479. 
Esta ambiciosa petición no se consiguió plasmar en ley hasta el año 1845, y la comisión que se nombró para su estudio y desarrollo únicamente presentó un proyecto sobre "el modo de elegir las Diputaciones provinciales". La citada comisión admitía que: "El objeto de la ley como proyecto presentado se reducía a establecer un medio de renovar las Diputaciones provinciales, de modo que tengan el mismo origen que la representación nacional, además de conseguir el grande objeto de uniformar en cuanto sea posible la representación de las provincias con la nacional"

El proyecto de ley presentado para su discusión estaba formado por siete artículos. Entre los cambios que establecía esta ley, hay que destacar como uno de los más debatidos el artículo segundo en el que se pedía la renovación total de las Diputaciones en lugar de efectuarlo "por mitades" que era lo estipulado con anterioridad. Los detractores destacaban el riesgo de encontrarse con Diputaciones "inexpertas", problema que fue solucionado al permitir la "reelección" de los diputados vigentes. Otra de las novedades quedaba reflejada en el artículo cuarto, que permitía a las Diputaciones provinciales "subdividir los partidos en distritos para evitar que en los partidos de mucha extensión se perjudicase a los electores en hacerlos ir a las cabezas de ellos" ${ }^{, 57}$.

\section{Reelección de diputados}

Por ley de 28 de octubre de 1837 se establece que los diputados provinciales que sean reelegidos sin intervalo ninguno pueden renunciar al cargo. La comisión promotora de esta ley estimó que "son dignos de consideración los ciudadanos que abandonando por mucho tiempo sus intereses particulares han dedicado a promover los de su provincia; y para conciliarlo todo propone que las Cortes declaren que los diputados provinciales que sean reelegidos sin intervalo ninguno puedan renunciar a sus encargos". Aunque recuerda que, por regla general, estos cargos no son renunciables.

\section{El jefe político asume la Intendencia}

Por real decreto de 20 de diciembre de 1838, se establecen a través de siete artículos, una serie de modificaciones basadas en la desaparición de la figura del intendente y la absorción de sus funciones por el jefe político. En su artículo primero acuerda que "por ahora y sin perjuicio de lo que resuelvan las Cortes en la ley de presupuestos podrán servirse por una sola persona los gobiernos políticos y las intendencias civiles de las provincias".

En el resto del articulado se establece que: El número de plazas y funcionarios de las oficinas de Contabilidad quedan unidos a los gobiernos políticos. Los cesantes ocasionados por esta fusión tendrán prioridad a la hora de cubrir nuevas necesidades. Finalmente se remite a los ministros de Hacienda y Gobernación para llevar a cabo esta absorción.

Es un decreto claro y tajante y con posterioridad a su publicación no hay noticia sobre su derogación o posible modificación, pero la realidad nos dice que la norma que se postula en el mismo no se llevará a la práctica hasta el mes de enero de 1850, fecha de la supresión efectiva de los intendentes a través de la publicación de nuevos R.R.D.D. con fecha de 28 y 29 de diciembre de 1849 en los que "en sustitución de los jefes políticos y de los intendentes se vea una sola autoridad en la figura del gobernador de provincia. Es decir, los intendentes dejan de actuar realmente con fecha 1 de enero de 1850.

Con referencia a su incidencia en el marco de las actividades de la Diputación, vemos que con esta modificación desaparece el cargo de vicepresidente, asignado desde sus inicios al intendente. Con esta situación, ante la ausencia del jefe político,

56 Ibídem. Págs. 481-482.

57 Ibídem. En la que refleja las intervenciones en el Diario de Sesiones de las Cortes. Pág.486. 
será el secretario político el que asuma el cargo de jefe político interino, y como presidente interino de la Diputación ejercerá el diputado más antiguo.

\section{Aparición de la referencia a las Asociaciones obreras}

Por real decreto de 28 de febrero de 1839, se regula el establecimiento de las "Sociedades de Socorros Mutuos". Estas sociedades están consideradas como el embrión de las primeras asociaciones o sindicatos obreros, y aunque no tenían relación directa con las Diputaciones provinciales, sí que es un indicativo de la evolución política y social de estos años.

\section{Renovación de las Diputaciones}

Por la real orden de 24 de octubre de 1839 , se manda proceder a la renovación de las Diputaciones provinciales. En la exposición previa al articulado se justificaba esta convocatoria ante las lagunas y las dudas que se producían en la ley de 13 de septiembre de 1837, en especial sobre: La duración de las Diputaciones provinciales, la forma de renovación y el modo de hacer las elecciones ${ }^{58}$. Es una disposición que no modifica el funcionamiento de las Diputaciones y tampoco clarifica mucho "las lagunas" que justificaban su promulgación. La verdad es que sólo regula el periodo de elecciones. También es cierto que esta ley tuvo una corta vigencia, ya que al poco tiempo, el 18 de noviembre de 1839, se disolvió el Congreso y se convocaron nuevas elecciones a Cortes "lo que iba a acarrear problemas, perjuicios y entorpecimientos que pudieran derivarse de la concurrencia en la misma época de las operaciones electorales a Cortes y a Diputaciones provinciales" ${ }^{59}$.

Como consecuencia de estos acontecimientos, se promulgó otra real orden de 22 de noviembre de 1839 por el que la Reina Gobernadora "ha tenido a bien mandar que quede sin efecto la mencionada orden de 24 de octubre, continuando en el ejercicio de sus funciones los individuos que al tiempo que fue expedida componían las referidas Diputaciones provinciales, hasta que concluidas las elecciones de diputados a Cortes pueda procederse a la renovación de las indicadas corporaciones". A causa de esta medida quedó suspendida, que no anulada, esta citada ley de 24 de octubre y se suspendieron las elecciones y la toma de posesión de los nuevos diputados previsto para el día 1 de enero de $1840^{60}$.

\section{Nueva actualización de Diputaciones}

Por el decreto de la Regencia de 13 de octubre de 1840 "se manda proceder a la elección de individuos de las Diputaciones provinciales". Previamente, la aprobación por las Cortes del proyecto de ley de Ayuntamientos, que fue sancionado con fecha 14 de julio de 1840, suponía "un triunfo moderado en un ambiente progresista", y fue el detonante de un enfrentamiento político y un levantamiento popular de carácter progresista, que dio como resultado la pérdida de la regencia por la Reina María Cristina y el acceso al poder y a la regencia del general Espartero, cabeza visible del partido progresista.

De julio a septiembre de 1840 , se sucedieron una serie de manifestaciones de carácter progresista que culminaron con el inicio de una revuelta en la capital y la formación de Juntas Provisionales de Gobierno.

El día 13 de octubre, la Regencia Provisional, publicó un manifiesto en el que se resaltaba en lo concerniente al gobierno de las provincias lo siguiente: "La disolución de las actuales Cortes y la convocatoria de otras nuevas preveía la elección de Diputaciones provinciales, aun cuando se arrastrase la responsabilidad de no

58 Hay que tener en cuenta que las Diputaciones tenían una vigencia bianual. Se renovaban por mitad cada dos años, y la de este año de 1839 estaba vigente desde 1837 y todavía duraría hasta diciembre de 1840 .

59 Preámbulo a la R.O. de 22 de noviembre de 1839.

${ }^{60}$ No se celebraron elecciones a diputados provinciales hasta fines del año 1840 tomando posesión el 1 de enero de 1841, en tiempos de la Regencia de Espartero. 
hacerlo dentro del plazo marcado por la Constitución. La suspensión de la "Ley de Ayuntamientos", hasta que fuese revisada, apoyándonos para ello no solo en su inconstitucionalidad, sino en que sin la de Diputaciones provinciales, que ni aún a discutirse se empezó, no podían tener efecto alguno de sus disposiciones..." ${ }^{61}$.

El mismo día 13 de octubre se publicaron dos decretos de la Regencia, por el primero se suspendía la vigencia de la "Ley de Ayuntamientos" y por el segundo se mandaba proceder a la elección de nuevos diputados provinciales. Este último decreto, al igual que el que planteó la real orden de 24 de octubre de 1839, también fija las normas para efectuar nuevas elecciones, justificando su promulgación en la existencia de los mismos defectos y "lagunas" que se observaban, para el buen funcionamiento de la administración territorial, en la todavía vigente ley de 13 de septiembre de $1837^{62}$.

Había que tener en cuenta también la necesidad de adecuar las Diputaciones provinciales a la nueva situación política, en especial a buscar la fórmula de dar salida a la legitimidad de las Juntas Provisionales de Gobierno formadas en la mayoría de las provincias. Así se recogía en el preámbulo de la ley para "arreglar el estado en que en muchas provincias se encuentran estas Corporaciones a consecuencia de los últimos acontecimientos".

\subsection{6.-LEY MODERADA DE ORGANIZACIÓN Y ATRIBUCIONES DE LAS DIPUTACIONES PROVINCIALES DE 8 DE ENERO DE 1845}

Una vez aprobada la Constitución de 1837 , se observa en el ámbito político un interés, cada vez más intenso, de reformar la ley de 3 de febrero de 1823. Tanto moderados como progresistas, ven la necesidad del cambio, pero es el Partido Moderado el que va a intentar imponer sus ideas ante el predominio que mantiene en las Cortes: "Está claro que el Partido Moderado no aspira simplemente a reformar el régimen administrativo heredado del liberalismo, más bien su intención es la de legislar una ley que sustituya y modernice el texto de $1823^{\text {" }}$.

El problema se plantea por la dificultad de legislar ante la turbulenta vida política española a la que acompaña una cruenta guerra civil. Desde 1838 a 1845 se suceden una serie de cambios políticos que están acompañados con alteraciones de la vida ciudadana de carácter revolucionario que actúan como freno en las actividades legislativas. Como ejemplo claro tenemos a las leyes relativas a la administración provincial y municipal, "Ley de Ayuntamientos" y "Ley de Diputaciones". En estos años está vigente la ley de 3 de febrero de 1823, ley que es criticada tanto por moderados como por progresistas y que las Cortes mismas están interesadas en el estudio y aprobación de otra que la complemente, mejore o sustituya.

Este interés de las Cortes chocará con graves dificultades para alcanzar el éxito, ya que los diferentes proyectos que se presentan a lo largo de estos años no llegaron a transformarse en leyes vigentes, pero sí es cierto que sirvieron como referencia para la elaboración, discusión y aprobación el 8 de enero de 1845 de la "Ley de Organización y Atribuciones de las Diputaciones Provinciales".

Entre 1838 y 1845 se presentaron en las Cortes para su discusión: El proyecto de Diputaciones de 1838, preparado por Francisco Agustín Silvela, proyecto de carácter moderado que recoge con detalle las actividades provinciales y que es uno de los que más influencia tuvo en los posteriores proyectos que se presentaron hasta la aprobación de la "Ley de 8 de Enero de 1845." El proyecto de 1840, presentado por el gobierno, que en su preámbulo reconoce que sus fuentes y su referencia ha sido el

61 Firman el manifiesto el Duque de la Victoria, Joaquín María Ferrer, Álvaro Gómez de la Serna, Pedro Chacón, Manuel Cortina y Joaquín de Frías, en Valencia a 13 de octubre de 1840. Trascrito de Ortego Gil. Evolución legislativa ... ob. cit. pág. 560.

62 Presenta los mismos argumentos en que se basaron las Cortes para la aprobación de la ley de 24 de octubre de 1839, es decir: dudas sobre la duración de las Diputaciones, forma de renovación y modo de hacer las elecciones.

${ }^{63}$ CASTRO, Concepción de. La Revolución liberal... ob. cit. Pág. 155. 
realizado por Silvela. Los proyectos de Diputaciones de 1842, presentados en el periodo de la Regencia de Espartero, que se caracterizan por su claro matiz progresista "aunque estos proyectos se caracterizan por su espíritu liberal y bastante descentralizador y se hallan a medio camino entre la organización de 1823 y lo que el progresismo parecía dispuesto a aceptar en 1838 y 1840, bajo el gobierno de los moderados" $" 64$.

Junto a estos se presentaron los proyectos de ley correspondientes a los Ayuntamientos y jefes políticos, complementos obligatorios y necesarios para la ordenación administrativa provincial y que sufrirían la misma suerte al no ser aprobados en ninguna de las ocasiones.

\section{Puesta en marcha definitiva de la ley}

A lo largo de los años 1838 a 1842 , hemos conocido una serie de proyectos de leyes relativos a la organización de los Ayuntamientos, de las Diputaciones y de los gobiernos políticos. Será en el año 1843, pero sobre todo en 1844, coincidiendo con el fin del período progresista, cuando se agilice y finalmente se apruebe la ley. Durante el año 1843, es cierto que los gobiernos progresistas se mantienen en el poder y el general Espartero continúa como Regente, pero también es cierto que su poder se está tambaleando y su figura es cada vez más cuestionada. A lo largo del año se suceden diferentes gobiernos, que no son capaces de hacer frente, por una parte, a una opinión moderada cada vez más fuerte, y de otra parte a las continuas críticas que se generan en el seno del propio partido progresista.

Todo esto no es óbice para que el Regente esté convencido de la necesidad de organizar la administración provincial, como lo puso de manifiesto en el discurso de apertura de las Cortes efectuado el 3 de abril de 1843, discurso que fue contestado por las Cortes recordándole que: "Lo que importa es organizar unas leyes bien meditadas sobre Ayuntamientos, Diputaciones provinciales, milicia, instrucción pública, beneficencia, elecciones, etc. Sin que estos objetos estén bien arreglados, la Constitución, no puede obrar ni marchar y la libertad está falta de raíces y es una vana sombra del gobierno representativo" 65 .

Es cierto que el ejecutivo, que estaba convencido de la necesidad de mejorar la legislación provincial, a poco que se tranquiliza y controla la situación política, pone en marcha una serie de medidas a este fin. Una de ellas, es la publicación del decreto de la Regencia de 26 de agosto de 1843, por el que se mandaba proceder a la renovación de las Diputaciones provinciales justificándolo en que: "Las instancias hechas por la mayor parte de las Diputaciones provinciales para su renovación, la gravedad y cúmulo de negocios puestos a su cuidado y el cargo y azaroso período de tres años que llevan de existencia, sin que haya ley vigente que establezca su duración...”66.

Y es verdad que las Diputaciones se mantenían vigentes y sin cambios desde enero de 1841 y se mantendrán en sus puestos hasta octubre de este año de $1843^{67}$. Por el artículo primero de este decreto se ordenaba la celebración de elecciones para la renovación de las Diputaciones "para que pudieran tomar posesión de sus cargos el día 1 de noviembre".

El resto del articulado, con un total de diecisiete, está referido a las normas a respetar para la celebración de las elecciones. Hablan de la formación de distritos, de la ratificación de las listas electorales, de la normativa electoral, de los días de elecciones, del escrutinio y reclamaciones, de la elección de diputados y suplentes, de la comisión de examen de actas y su aprobación y de la comunicación de resultados al gobierno.

${ }^{64}$ Ibídem. Pág. 161.

${ }^{65}$ NIDO SEGALERVA, Juan del. Antología de las Cortes. 1840 a 1848. Madrid. 1910. Págs. 410 a 414.

${ }^{66}$ ORTEGO GIL, Pedro. Evolución legislativa ... ob. cit. Preámbulo del Decreto. Pág. 615.

67 Es el caso de la Diputación de Valladolid. También ocurre que la Diputación elegida en octubre de 1843, sólo durará dos meses, ya que el 1 de enero de 1844 se instala una nueva Diputación. 
En el transcurso del año 1844, con los moderados al frente del gobierno, se vuelve a hablar de la reforma administrativa y nuevamente se pone de manifiesto la ineludible modificación o sustitución de la ley de 3 de febrero de 1823. Será otra vez Francisco Agustín Silvela el político que más se preocupe por la reforma administrativa y el que publique sus ideas, con el afán de verlas plasmadas en las futuras leyes administrativas. En ella destaca tres puntos de partida: la centralización, la unidad y la uniformidad. Estas ideas van siendo apoyadas por una serie de políticos de ascendencia moderada como Javier de Burgos, que ven necesario el cambio y trabajan para conseguir la ansiada reforma administrativa.

Todas estas inquietudes se ven contestadas con la publicación el día 9 de octubre de 1844 de un real decreto en el que se dice: "Atendiendo a las razones que me ha hecho presentes mi Consejo de Ministros sobre la urgente necesidad de arreglar la legislación relativa a los Ayuntamientos, Diputaciones provinciales, gobiernos políticos y consejos de administración, he venido en autorizar al Ministerio de la Gobernación de la Península para que presente a las Cortes el adjunto proyecto de ley".

Este real decreto no quiere decir que el gobierno presente realmente un nuevo proyecto de organización provincial, sino que, en este caso lo que se solicita a las Cortes es la aprobación de un proyecto de "Ley de Autorización" para que el gobierno pueda fijar las atribuciones de las Diputaciones, de los Ayuntamientos, de los consejos y de los gobiernos políticos ${ }^{68}$.

Con esta medida las Cortes discutían y aprobaban el proyecto de "Ley de Autorización", es decir autorizaban al gobierno, pero no discutían ni tenían que aprobar los propios proyectos de organización, mucho más difíciles y complicados de aprobar, como hemos podido ver a lo largo de estos años.

El gobierno ya tenía preparados los proyectos de ley y sólo esperaba la aprobación por parte de las Cortes de la ley de autorización para ponerlas en marcha, como lo daba a entender en la exposición que acompaña al proyecto: "Convencido el gobierno de la necesidad de esta reforma, ha tiempo que se ocupa en prepararla, y sus trabajos se hallan en tal estado que con el acuerdo y autorización de las Cortes podría brevemente convertirse en leyes efectivas" $"$.

Se elige el camino de la ley de autorización porque, como reconoce el propio gobierno, "ninguno de los proyectos anteriores han podido conseguir su aprobación por los trámites largos y embarazosos de la discusión parlamentaria.... Esto prueba que en ciertas situaciones ofrece el método ordinario dificultades insuperables y que es fuerza buscar otro camino más breve y expedito" 70 .

El proyecto de ley de autorización se presenta el día 18 de octubre en primer lugar en el Senado, donde fue aprobado. Posteriormente pasó al Congreso de los Diputados donde igualmente fue aprobado aunque algunos diputados no eran partidarios de "dar carta blanca al gobierno". El Gobierno ya tenía "luz verde" para presentar las leyes correspondientes, que ya estaban preparadas, pues si la Reina firma la Ley de Autorización el día 1 de enero, el día 8 del mismo mes firmó las "Leyes de Organización y Atribuciones de los Ayuntamientos y de las Diputaciones".

\section{Articulado de la ley de 1845}

Como se ha repetido con anterioridad, esta ley está basada en los diferentes proyectos presentados en años anteriores, en especial los presentados por Silvela en

68 El proyecto de Ley de Autorización presentado dice literalmente: Artículo único. Se autoriza al gobierno para arreglar la legislación relativa a los Ayuntamientos, Diputaciones provinciales, Gobiernos políticos y Consejos provinciales de administración, poniendo desde luego en ejecución las medidas que al efecto adopte. Dando cuenta después a las Cortes. Madrid, 9 de octubre de 1844. El ministro de la Gobernación, Pedro José Pidal.

${ }^{69}$ ORTEGO GIL, Pedro. Evolución legislativa ... ob. cit. Declaración gubernamental que acompaña a la presentación del proyecto de Ley de Autorización. Págs. 642-643.

70 Ibídem. Pág. 643. 
1838, y por la comisión del Congreso en 1840. El día 8 de enero de 1845, Isabel II firmaba el real decreto por el que, "conformándome con el parecer de mi Consejo de Ministros, las Diputaciones provinciales se arreglan en su organización y atribuciones a las disposiciones contenidas en la siguiente Ley de Organización y Atribuciones de las Diputaciones Provinciales".

Esta ley estaba dividida en seis títulos y setenta y tres artículos, de carácter moderado y centralista. El título primero trata sobre la organización de las Diputaciones provinciales, y en su primer artículo vuelven el jefe político como presidente y el intendente como vicepresidente, de acuerdo con las tesis moderadas. El artículo quinto es el que se ha mantenido igual en todo los proyectos y ratifica que el cargo de diputado es honorífico, gratuito y obligatorio. Por último, destacamos el artículo sexto que vuelve a las tendencias moderadas de fijar la duración de la Diputación en cuatro años renovable a los dos años.

El título segundo especifica las cualidades necesarias para ser diputado provincial. Lo hace de forma muy similar a los proyectos presentados con anterioridad, en especial a los de los años 1838 y 1840 . A destacar el artículo séptimo apartado dos, en el que se fija el tener una renta determinada, condición que no figuraba en los proyectos anteriores, pero sí en la Ley Electoral donde se fijaba una cantidad determinada para ser elector. El resto de las condiciones y de los impedimentos de los diputados son similares.

El título tercero describe el modo de hacer las elecciones. Es un título largo y detallista, similar en extensión y en contenido a los proyectos presentados con anterioridad, en especial al proyecto de la comisión del Congreso presentado en el año 1838 y al proyecto de 1840, tanto en extensión como en articulado. Sabemos que el primer proyecto del año 1842 admite que es idéntico al de 1840, es decir, muy similar a todos los proyectos moderados. Especifica en el artículo veintiuno que no habrá lugar a casos de papeletas nulas, sino de nombres anulados cuando haya de más, y si hubiera de menos serían todos válidos. Asimismo, como está reflejado en los artículos treinta y dos, treinta y tres y treinta y cuatro, el Consejo Provincial, organismo de nueva creación, "entra en escena" como asesor del jefe político.

El título cuarto, que habla de las sesiones de las Diputaciones provinciales, pone de manifiesto que la Diputación provincial estará "a las órdenes" del jefe político, según se indica en su artículo cuarenta y nueve en el que queda bien especificado el único camino que puede tomar la Diputación: El "jefe político será el único conducto". Esta sumisión y "centralismo" se remataba en el artículo cincuenta que también ratifica al jefe político "como único a quien compete..." es decir, las Diputaciones quedaban sujetas a las decisiones que tomasen los jefes políticos, y desde luego anuladas en su autonomía. Lo único que esta ley no fija con detalle son los días de inicio de las reuniones, sólo detalla que serán dos y de veinte días de duración, y cuyo inicio determinará el gobierno. En definitiva, con este título se manifiesta de una forma clara el control del gobierno a través del jefe político y la sumisión en que se sitúa a las Diputaciones ante el poder central.

El título quinto especifica las atribuciones de las Diputaciones provinciales. El afán centralista y las maniobras para reducir la autonomía de las Diputaciones, así como su capacidad de toma de decisión, se vuelven a marcar en todos los artículos de este título. Toda actividad de la Diputación se ve limitada "conforme a lo que determinen las leyes y reglamentos". En conclusión, las Cortes con las leyes y el gobierno con los reglamentos, tenían la capacidad de reducir las facultades de las Diputaciones. Sus límites son claros, según el artículo cincuenta y ocho, al fijar que la Diputación no se podía exceder en lo estrictamente indicado, con lo que se acentuaba su carácter administrativo.

El título sexto concibe el presupuesto provincial de manera muy similar al que se presentó en el proyecto de ley de mayo de 1840. Mantiene en su artículo sesenta, primero del título, que los presupuestos los formará el jefe político, es decir, se sigue con la idea de centralizar y posteriormente la Diputación los discutirá y aprobará. 
La ley finaliza con el artículo setenta y dos por el que el gobierno dicta una serie de órdenes y reglamentos para adecuar las actividades de la Diputación a la nueva ley y con el artículo setenta y tres por el que quedaba, por fin, derogada la "Ley de 3 de Febrero de 1823".

En conclusión, con la aprobación de esta ley se da fin a la vigencia de las leyes doceañistas y se inicia un periodo de legislación moderada, salvo los dos años del Bienio Progresista (1854-56). Estará vigente hasta septiembre de 1863. Como características reseñables de esta ley podemos destacar el protagonismo que da a la figura del jefe político como "hombre fuerte" de la provincia, y la pérdida del poder ejecutivo de la Diputación, que pasa a ser un organismo colaborador del citado funcionario. Es decir, una ley centralista.

\section{Otras leyes moderadas complementarias}

Para adecuar el funcionamiento de las Diputaciones a la nueva normativa legal, el gobierno preparó y aprobó una serie de reales órdenes, necesarias para la puesta en marcha de la nueva ley. También aprobó, en un corto espacio de tiempo, las leyes relativas a la organización y atribuciones de los Ayuntamientos, de los Consejos provinciales y de los Gobiernos políticos.

\section{Ley de organización y atribuciones de los Ayuntamientos}

Esta es una de las leyes más discutida y que ocasionó una serie de enfrentamientos entre progresistas y moderados, discusión similar a la sucedida con la ley de Ayuntamientos de 1840 relatada con anterioridad, que fue la causa del abandono de la regencia por parte de María Cristina y de la llegada al poder de Espartero. El mismo día 8 de enero de 1845 en que es aprobada la ley de organización y atribuciones de la Diputación, también se aprobaba "que los Ayuntamientos de los pueblos se arreglen en su organización y atribuciones a las disposiciones contenidas en la siguiente Ley de Organizaciones y Atribuciones de los Ayuntamientos". Esta citada ley está constituida por ciento trece artículos distribuidos en siete títulos referidos respectivamente a la organización de los Ayuntamientos, al nombramiento de alcaldes y tenientes de alcalde, a la elección de los Ayuntamientos, a las sesiones de los mismos, a los Ayuntamientos actuales, a las atribuciones de los alcaldes y finalmente al presupuesto municipal.

Al igual que ocurre con la ley de Diputaciones, en esta de Ayuntamientos se confirma y ratifica el carácter centralista en que se desenvuelve la legislación que presentan los moderados.

Como característica de esta tendencia, tenemos el hecho de que los nombramientos de alcalde son de designación real "en todas las capitales y cabezas de partido judicial cuya población llegue a los dos mil vecinos. En los demás pueblos los nombrará el jefe político por delegación del Rey"71.

También es llamativo que, en contraposición con la anterior "Ley de 3 de febrero de 1823", en la que se acordaba que "siendo las Diputaciones provinciales la autoridad inmediata superior a los Ayuntamientos, ocurrirán estos a ellas en todos los negocios de sus atribuciones en que sea necesario" "72, ahora se dispone que todas las actividades municipales pasan a ser controladas y dirigidas por los Gobiernos políticos.

A lo largo del articulado de la ley, únicamente en dos ocasiones se hace referencia a las Diputaciones. Una en el artículo setenta y uno en el que "queda el gobierno autorizado para formar nuevos Ayuntamientos, oyendo a la Diputación provincial,..." Y otra en el artículo setenta y dos en el que se dice que "queda igualmente autorizado al gobierno para reunir dos o más Ayuntamientos y para

71 Artículo nueve de la Ley de 8 de enero de 1845.

72 Ver artículo ochenta y dos de la Ley de 3 de febrero de 1823. 
segregar pueblos de un Ayuntamiento y reunirlos a otro, oyendo también a la Diputación provincial...".

\section{Ley de "Organización y Atribuciones de los Consejos provinciales"}

El día 2 de abril de 1845, el gobierno acuerda que "los Consejos provinciales se establezcan y arreglen en su organización y atribuciones a las disposiciones contenidas en la siguiente Ley de Organización y Atribuciones de los Consejos Provinciales". ${ }^{73}$ Esta ley está dividida en cuatro títulos con un total de veinte artículos, que detallan su funcionamiento a partir de la organización, de las atribuciones, de las sesiones y de los procedimientos, y finalmente de las sentencias y de su apelación.

En el mes de enero, se habían publicado y puesto en marcha las leyes de Ayuntamientos y Diputaciones, que eran consideradas como los dos pilares básicos de la administración y ordenación a nivel municipal y a nivel provincial y a estas leyes se las añade la nueva ley de los Consejos provinciales, que nace con la finalidad de colaborar con el jefe político, con un carácter consultor y que restaba protagonismo y actividades a las Diputaciones provinciales.

Una serie de características llaman la atención en la configuración de este Consejo provincial. Está formado por tres a cinco individuos de designación Real. El jefe político es el presidente del Consejo. Los consejeros provinciales disfrutarán de sueldo, que será pagado de los fondos provinciales. Son cuerpos consultivos que además actuarán como tribunales administrativos. En conclusión, se trata de una nueva institución que nace bajo la presidencia y control del jefe político, con la finalidad de colaborar en el campo consultivo y en la resolución de los asuntos contenciosos. También absorberá actividades que con anterioridad estaban atribuidas a las Diputaciones provinciales.

\section{Ley para el Gobierno de las Provincias}

Dentro del esquema de la nueva legislación sobre la administración provincial, el mismo día 2 de abril de 1845 en que se publica la "Ley de Organización de los Consejos Provinciales", también se decide "que los Gobiernos políticos se arreglen en sus atribuciones a las disposiciones contenidas en la siguiente Ley para el Gobierno de las Provincias" 74 .

Con esta ley se completa la legislación que ordena los ámbitos municipales y provinciales. También en su contenido se confirma las intenciones gubernamentales de centralizar la gestión territorial a través de los jefes políticos. Se les otorga un control poco menos que exhaustivo, tanto de los municipios como de las Diputaciones, organismos que quedan reducidos a simples transmisores de órdenes que emanan del gobierno central y son recibidas a través del gobierno político.

Un recorrido por su articulado nos demuestra el amplio poder con que el gobierno reviste a la figura del jefe político, destacando la amplitud de las atribuciones que se conceden y de los poderes con que son investidos para hacer cumplir las citadas atribuciones.

Es una ley corta, aunque densa, que consta de once artículos, en los que se detallan las atribuciones de los jefes políticos y su supremacía en el mando de la provincia. Con la publicación de esta ley se cierra el circuito de leyes de talante conservador, puestas en marcha a lo largo del año 1845, y que como reconoce un contemporáneo: "En armonía esta ley con la municipal y la de Diputaciones provinciales, formaba su conjunto un sistema de exagerada centralización en extremo inconveniente, que condenó el mismo partido conservador en el preámbulo de un real decreto de febrero de $1853 \ldots$..,

73 Boletín Oficial de la Provincia de Valladolid (en lo sucesivo B.O.P.V). Real orden de 2 de abril de 1845, que se publica el día 19 de abril de 1845 .

74 B.O.P.V. no 47 de fecha 19 de abril de 1845.

75 MARTÍnEZ AlCUBILlA, Marcelo. Diccionario de Administración Española. IV Edición. Tomo V. Madrid, 1887. Pág. 235. 


\subsection{7.- LA CONSTITUCIÓN DE 1845}

La caída de Espartero y la llegada al poder de los moderados, con Narváez al frente del gobierno, propició el deseo de efectuar un cambio en la Constitución, ya sea legislando una nueva o reformando la vigente de 1837, a pesar del poco tiempo de vigencia que tenía. El interés por redactar un nuevo texto estaba en el afán de los nuevos gobernantes por equipar al país de una Constitución más moderada y de acuerdo con sus ideas políticas, es decir, como veremos más adelante: "el interés es el de redactar una Constitución de acuerdo con un determinado partido político".

\section{Las modificaciones constitucionales}

Para justificar el cambio, con referencia a la Constitución de 1837, el sector moderado se basaba en la dificultad que encontraban si querían gobernar respetando la legislación vigente y aducían que "la Constitución de 1837 se había mostrado poco apta para el gobierno, hecho por el que era necesario incumplirla frecuentemente" ${ }^{76}$.

Joaquín Tomás Villarroya mantiene que la Constitución de 1845 es presentada por sus redactores como una reforma alegando que "la remodelación de las instituciones constitucionales permitiría un mejor gobierno de la nación y una atención más profunda a sus necesidades"77. Aunque se puede hablar de reforma, simplemente porque se mantiene la misma estructura, las modificaciones que se realizan en la Constitución de 1837, hasta convertirse en la Constitución de 1845, son un claro exponente del recorte del poder a las Cortes, o mejor dicho, de la concentración del poder en manos de la Corona, en colaboración necesaria, con el gobierno de turno.

Los cambios introducidos más representativos son, la supresión de la referencia a la soberanía nacional, la decisión de que el Senado pase de ser elegido a partir de una terna a ser de designación real directamente, la supresión de la Milicia Nacional, y la vigencia de las Cortes por cinco años. Con estos cambios se pierde en su mayoría el sentido progresista que tenía la anterior Constitución ${ }^{78}$.

Otros autores resaltaban que la Constitución de 1845 establecía "un sistema político basado en el control total por la Corona, a través de su Consejo de Ministros, de los mecanismos reguladores de la acción política" ${ }^{79}$. Y los mismos autores ponen de manifiesto la importancia y el poder que se conseguía por parte de la Corona con la "la posibilidad de nombrar a todos los miembros de una Cámara, un medio eficaz de bloquear el poder político y también un método superior al veto" ${ }^{80}$.

Miguel Artola recoge como modificaciones importantes en el proyecto constitucional el abandono del juicio por jurados para los delitos de prensa, la eliminación de las ternas para la elección de senadores, y la desaparición de la referencia a la soberanía nacional. Mantiene que "la Constitución de 1845 no puede ser considerada como distinta de la anterior, desde el momento en que el sistema político que describe reproduce literalmente el texto anterior, sin otras modificaciones que las indicadas" ${ }^{81}$. Finalmente recuerda que "los cambios que no se hacen en la Constitución, se introducen en una serie de leyes orgánicas, hasta el punto de crear un

76 ESPADAS BURGOS, Manuel y URQUIJO GOITIA, José Ramón. Historia de España. Editorial Gredos. Tomo XI. Pág. 200 y siguientes.

77 TOMÁS VILLARROYA, Joaquín en Historia de España, dirigida por José María Jover Zamora. Tomo XXXIV. La Era Isabelina y el Sexenio Democrático. La Constitución de 1845. Pág. 199 y sig.

78 TUÑ́́N de LARA, Manuel (Dir.). Historia de España. ob. cit. Tomo VIII. Revolución Burguesa, oligarquía y constitucionalismo (1834-1923). Pág. 213 y sig.

79 ABAD, Juan José y TRIGO, Lorenzo. Historia de España. ob. cit. Tomo XV. Págs. 74-75.

80 Ibídem. Pág. 74, en la que hace referencia y resalta el poder que adquiría la Corona al tener el privilegio de nombrar a todos los componentes del Senado.

81 ARTOLA, Miguel. Historia de España. Ob. cit. Tomo V. pág. 187 y sig. 
régimen distinto bajo la misma ley fundamental" ${ }^{\$ 2}$. Lo que Artola quiere decir es que, aunque no considere que la Constitución sufra modificaciones importantes, que posiblemente sea así, lo que hace el legislador es acompañarla de una serie de leyes orgánicas que sí modifican realmente las instituciones políticas.

José Luis Comellas es del parecer que "la idea que prevaleció en un principio, fue la de reforma constitucional, más suave que la de elaborar una ley fundamental de nueva planta... porque no es lícito cambiar la Constitución de un país a gusto del partido dominante" ${ }^{83}$. Con esta frase "pone el dedo en la llaga" por los continuos errores que, a su juicio, cometen los políticos de la época al redactar leyes fundamentales con un claro sentido partidista y reseña a continuación las discusiones que se mantienen en los Plenos sobre la idoneidad de los cambios previstos por el gobierno, es decir, se critican los cambios por ser partidistas, pero se llega a aprobar la reforma.

Al respecto recoge a continuación la advertencia del diputado Posada que decía: "mientras la Constitución esté sujeta a continuas reformas, mientras esté expuesta a que cada mayoría modifique sus artículos según mejor le parezca, tened por seguro que no habrá paz en el país..." 84 .

En definitiva, la opinión de la mayoría de los historiadores sobre esta Constitución coincide en señalar que en líneas generales "es una copia de la Constitución de 1837" en la mayoría de su articulado, aunque es modificada de tal forma que recorta sensiblemente la tendencia progresista que se observaba en la anterior, y acaba siendo una Constitución conservadora hecha por un partido conservador.

Sin embargo, en el tema de las Diputaciones, no sufre variación repitiéndose de una forma literal los tres artículos del título noveno de la Constitución de 1837 (artículos sesenta y nueve, setenta y setenta y uno) en los tres artículos (setenta y dos, setenta y tres y setenta y cuatro) del título onceavo de la Constitución de 1845. Es lógico que recién aprobada la ley de 2 de abril de 1845, sobre el "Gobierno de las Provincias y sobre los Ayuntamientos", la Constitución se remita a esta ley para la ordenación provincial y municipal.

\section{Su promulgación y articulado}

Las discusiones sobre la conveniencia de reformar o de cambiar la Constitución no fueron obstáculo para que el gobierno presentara el proyecto del nuevo texto el 9 de octubre de 1844. Los debates se prolongaron por espacio de seis meses, hasta que finalmente, la nueva Constitución fue promulgada el 23 de mayo de 1845. En su redacción se mantienen los mismos trece títulos que la Constitución anterior y se modifica levemente el número de artículos que pasa de setenta y siete a ochenta. El título undécimo es el dedicado a las Diputaciones provinciales y los Ayuntamientos.

\section{Vigencia}

Esta Constitución se mantiene vigente desde su promulgación el día 23 de mayo de 1845, hasta el 5 de junio de 1869 , fecha en que es promulgada una nueva, ya situados en los días del Sexenio Revolucionario. También recordamos que entre los años 1854 a 1856, en el Bienio Progresista y con el general Espartero en el poder, esta Constitución estuvo suspendida, lo mismo que la ley de 2 de abril de 1845, sobre la "Organización de las Diputaciones", y en su lugar entraron en vigor la Constitución de 1812 y la ley de 3 de febrero de 1823 sobre el "Gobierno Económico y Político de las

82 Ibídem. Tienen el carácter de leyes orgánicas, complementarias de la Constitución: La ley electoral. Ley de Ayuntamientos y Diputaciones. Ley de Prensa. Ley de Administración. Ley de Orden público.

83 COMELlAS, José Luis. Los moderados en el poder (1844-1854) C.S.I.C. Madrid, 1970. Págs. 195 y sig.

84 Ibídem. Donde recoge la cita literal del acta del Consejo de fecha 31 de octubre de 1844. Pág. 167. 
Provincias". Es notorio, como nos recuerdan los políticos de la época, que durante el tiempo que permaneció vigente la Constitución no estuvo exenta de intentos de modificación y reforma, siempre en un sentido más conservador en consonancia con el gobierno en el poder.

Entre estos proyectos de modificación, destaca el presentado por Juan Bravo Murillo, jefe del gobierno en el año 1852, propuesta que no llegó a prosperar y que le costó el ministerio. Era un proyecto fiel al pensamiento de su creador y "se basaba en un robustecimiento de las atribuciones del poder legislativo y una reducción de las fuerzas del parlamentarismo" $" 85$.

\section{El acta adicional}

Con la vuelta al poder de los moderados, tras el paréntesis del Bienio Progresista, fue restablecida la Constitución de 1845 por real decreto de 15 de septiembre de 1856, aunque modificándola parcialmente al añadirla un "Acta Adicional" que se publica en la misma fecha ${ }^{86}$. A tener en cuenta que el primer acto del nuevo gobierno fue el de disolver y reorganizar las Diputaciones y Ayuntamientos.

En la exposición que acompaña al real decreto, el general O’Donnell presidente a la sazón del Consejo de Ministros, justifica el acta y hace un recorrido por las diferentes constituciones que han estado vigentes, además de la que recientemente se redactó en el Bienio y que no había sido promulgada. Considera que la Constitución no promulgada de 1856, sufrió una serie de aplazamientos "por el temor secreto acerca de la suerte de una obra que estaba señalada, aún antes de nacer con el triste sello que caracteriza a los seres enfermizos o abortivos... y no se puede aceptar como buena una Constitución que consigna principios de verdad problemática que en la práctica se prestan a aplicaciones desastrosas... y si a estas consideraciones se allegan los graves peligros de la cuestión religiosa, se comprenderá fácilmente el desacuerdo de aconsejar a V.M. la aceptación de este código". Continúa con la explicación por la que cree que no es conveniente el retorno a la Constitución de Cádiz de 1812 y está convencido de que esta citada Constitución "no llega las condiciones de satisfacer los deseos legítimos de los pueblos, ni se adapta al estado político" ${ }^{\$ 7}$.

Para Tomás Villarroya, la finalidad de la promulgación de esta acta se debe a que “el gobierno de O’Donnell tenía el propósito general y preferente de garantizar formal y eficazmente el cumplimiento de la Constitución de $1845^{88}$. Lo que quiere decir es que el interés de la modificación estaba relacionado con la posibilidad de respetar su contenido y cumplir todo su articulado.

La vigencia de esta acta adicional fue muy corta. Duró un mes, que fue el tiempo que O’Donnell estuvo al frente del gobierno, ya que la llegada de Narváez propició la derogación "porque el acta adicional altera y modifica la ley Constitucional del Estado en materias de la más grave importancia" " conservador del gobierno y al interés de Narváez de "borrar toda huella del Bienio y

COMELLAS, José Luis. Los moderados en el poder... ob. cit. Donde se destaca que "el punto más atacado y la medida más ruidosamente protestada era la referente a la celebración de sesiones a puerta cerrada, pues los políticos perderían su afán de protagonismo y el "hablar de cara a la galería". Págs. 315 y 316.

86 MARTÍNEZ ALCUBILlA, Marcelo. Diccionario de Administración... ob. cit. Se recoge el siguiente comentario: "sin llegar a promulgarse la anterior Constitución (en referencia a la Constitución Non Nata de 1856), ocurrieron los nuevos sucesos políticos que son harto conocidos, y el gobierno dictó un decreto (15 de septiembre de 1856) restableciendo la Constitución de 1845 y modificándola con el acta adicional que se inserta. En el preámbulo del decreto, decía el Ministerio a S.M. las razones que tenía para no optar por la Constitución de Cádiz, las que igualmente tenía para rechazar la de 1837 y las que le inclinaban por la de 1845, pero encontrándola también defectos, ideó para corregirlos el Acta Adicional. La vida de ésta fue tan escasa, que un mes no había transcurrido cuando se dejó sin efecto como vamos a ver".

87 Extracto de la exposición que dirige el Gobierno a la Reina, con los motivos que argumentan para recomendar la entrada en vigor de la Constitución de 1845 a la que se añade el acta adicional que se publica conjuntamente por real decreto de 15 de septiembre de 1856.

88 TOMÁS VILLARROYA, Joaquín. Historia de España. ob. cit. Tomo XXXIV. Pág. 297 y sig.

89 Ibídem. Extracto de la exposición elevada a la Reina por Narváez el 14 de octubre de 1856, justificando la derogación del acta adicional. Pág. 299. 
volver a la situación anterior a $1854 "{ }^{90}$. En consecuencia, el día 14 de octubre de 1856, se publicaba un real decreto por el que se dejaba sin efecto el acta adicional.

\section{Nueva reforma de la Constitución}

El mismo gobierno de Narváez, que derogó el acta adicional, preparó un proyecto de reforma constitucional, que, presentado en las Cortes en mayo de 1857, fue aprobado por la ley de 17 de julio de 1857. La reforma constitucional se centraba básicamente en dos temas: la composición del Senado y la redacción y aprobación de los reglamentos de la Cámara.

Como es norma en el Congreso, estas pretensiones de modificación fueron muy criticadas y contestadas tanto por el Senado como por el Congreso, en especial en el tema referente a las reformas del Senado, en el que, además de la figura de senador de designación real, se instituían las figuras del senador nato, que se concedía a los representantes más significativos de la Iglesia y del Estado, por ejemplo a los arzobispos. Y la senaduría hereditaria a favor de la aristocracia, que suscitó una serie de críticas y argumentos contra la pretensión de conceder derechos hereditarios a un grupo de senadores.

El que esta reforma de la Constitución se publicara como ley, no quiere decir que se pusiera en práctica, sino más bien la realidad nos dice que los dos temas objeto de la reforma no llegaron a promulgarse durante la vigencia de la citada ley, pues no se aprobaron las leyes que según el artículo veintiocho debían de establecer los reglamentos del Senado y del Congreso y tampoco se promulgó la ley, que según el artículo dieciocho debía de restablecer las vinculaciones para dar asistencia efectiva a la senaduría hereditaria.

\subsection{8.- NUEVA LEY UNIONISTA "PARA EL GOBIERNO Y ADMINISTRACIÓN DE LAS PROVINCIAS” DE 25 DE SEPTIEMBRE DE 1863}

Ley promulgada el día 25 de septiembre de 1863 , y que viene a sustituir a la hasta ahora vigente ley de 8 de enero de 1845 sobre "Organización y atribuciones de las Diputaciones Provinciales", ley para el "Gobierno de las Provincias" y ley sobre "Organización y Atribuciones de los Consejos Provinciales", leyes que fueron promulgadas en la misma fecha de 2 de abril de 1845 . Se mantiene en vigor y sin modificaciones la "Ley de Organización de Ayuntamientos" de 8 de enero de 1845 .

Y así como las leyes de 1845 tuvieron un amplio periodo de discusión antes de su aprobación por las Cortes, a pesar del deseo generalizado por parte de la mayoría de las fuerzas políticas de abandonar la ley de 3 de febrero de 1823, esta ley actual de 1863 pasó rápidamente el trámite parlamentario, ya que fue redactada y aprobada por la mayoría moderada. Resulta una ley más conservadora y centralizadora que su predecesora, a causa de la evolución gubernamental hacia unas ideas más inmovilistas y controladoras de las actividades políticas provinciales.

Para José Luis Comellas la actividad política a nivel provincial es clara "desde 1845, las Diputaciones provinciales y los cuerpos municipales nombrados desde Madrid, fueron poco más que herramientas del gobierno central" ". Y si las Diputaciones, desde 1845 estaban controladas por el poder central, está claro que a partir de la aprobación de esta nueva ley se acentúan las tendencias centralistas y conservadoras.

\section{Evolución legislativa}

Con referencia a la evolución legislativa de la administración provincial, vemos que también tiene su influencia la ideología del partido gobernante, y si seguimos la evolución de los gobiernos, vemos que la nueva "Ley para el Gobierno y

$90 \quad$ Ibídem. Pág. 300.

91 COMELLAS, José Luis (Coord.). Historia de España y América. Volumen XIV. "La España Liberal y Romántica. Ed. Rialp. Pág. 589. 
Administración de las Provincias" resulta de un carácter más conservador que su precedente de enero de 1845 , y lo mismo sucederá con la modificación que se hace en 1866 (la reforma de 1864 es mínima) que es fruto de la radicalización de los gobiernos, que se sitúan a la defensiva en un ambiente claramente revolucionario.

Es curioso, porque durante el Gobierno Largo de O'Donnell no se tenía por qué pensar en una legislación restrictiva, sobre todo cuando el propio O'Donnell intenta que en su gobierno participen fuerzas progresistas, a la vez que tanto el jefe del gobierno como Posada Herrera, su ministro de la Gobernación, tenían la intención de "acometer de nuevo la cuestión de la descentralización a través de nuevas leyes orgánicas menos restrictivas para los gobiernos provinciales y municipales" ${ }^{92}$.

A pesar de estas buenas intenciones, lo que sí es cierto es que la ley que se promulgó sobre la organización de provincias y municipios, justo después de la caída de su gobierno, resulta ser una ley más centralizadora y conservadora.

\section{Desarrollo de la ley}

Así como en el año 1845, para organizar la administración provincial, se hace a través de tres leyes, en el año de 1863, es una sola ley la que incluye la administración de la provincia, de los gobernadores provinciales, de las Diputaciones y de los Consejos provinciales.

Es una ley compuesta por cinco títulos y ciento dos artículos. El título primero trata del ámbito de aplicación de la ley, es decir, la provincia y el gobierno de la misma, a través del gobernador, desapareciendo la apelación de jefe político. También aparece la figura del subgobernador, en sustitución del jefe político subalterno.

El título segundo trata de los gobernadores de provincia, con una amplitud y detalle superior a la anterior legislación, y dejando claro desde el primer artículo que "El gobernador será la autoridad superior de la provincia en el orden administrativo y económico, y los representantes de los demás ministerios estarán a sus órdenes". Su nombramiento es a través de real decreto y a continuación se detallan sus atribuciones.

El título tercero es el referido a las Diputaciones provinciales y está dividido en cinco capítulos. Entre sus modificaciones más importantes, destaca la de "su gran dependencia del gobernador, que presidirá la Diputación cuando asista a sus sesiones, y será la persona que autorice todos los acuerdos y actividades de la Diputación, así como el de suspender sus sesiones". Sigue siendo de incumbencia de la Diputación discutir y votar el presupuesto provincial, efectuar el repartimiento de las contribuciones del Estado y fijar el cupo de cada pueblo en el reemplazo del ejército.

El título cuarto trata de los Consejos provinciales, de las cualidades que deben de tener los consejeros y de sus atribuciones. Es un largo título, compuesto de seis capítulos y treinta y seis artículos, en comparación con los veinte artículos que tenía en la anterior ley. Es un indicativo de la importancia que se da a los Consejos, en detrimento de las Diputaciones, aunque no se escapa a la dependencia de la figura del gobernador. la ley.

El título quinto trata de las disposiciones generales para el funcionamiento de

De acuerdo con lo que estipula esta citada ley, una vez aprobada, el gobierno aprobó el "Reglamento para el gobierno y administración de las provincias", el "Reglamento y atribuciones de los subgobernadores" y el "Reglamento sobre las actividades de los delegados territoriales".

\section{Las modificaciones de la ley}

En el año 1864, a escasos meses de su aprobación, ya se produce la primera modificación que tiene lugar el día 27 de abril, fecha en la que se publica las nuevas normas referentes a los nombramientos de los alcaldes y a las dietas y sueldos de los gobernadores de la provincia. 
El 21 de octubre de 1866, es aprobado por real decreto "un proyecto de ley reformando la legislación vigente sobre organización y atribuciones de los Ayuntamientos" y un segundo "proyecto de ley, reformando la vigente para el Gobierno y Administración de las provincias"93. Es la segunda modificación que recibe esta ley. En la exposición que acompaña al proyecto el ministro de la Gobernación González Bravo la justifica con la pretensión de atajar una evolución de la situación política donde se vislumbraban los afanes revolucionarios tanto de una parte importante de la clase política como de la población ${ }^{94}$.

Continúa en su exposición lamentándose de las facilidades que da la legislación vigente para que los municipios y Diputaciones formaran a su gusto el grupo de empleados y funcionarios ya que "la prerrogativa de elegir empleados desde seis mil reales de sueldo abajo, y la de proponer a otros de mayor remuneración que la ley habría concedido a las Diputaciones de provincia, la facilitaba el camino para completar el cuadro de subalternos. Había, pues, un estado movido por el genio de la insurrección dentro del estado legal" ${ }^{95}$.

Para evitar " estas facilidades” y arreglar la situación proponía la reforma de la ley, y además remataba la exposición con la petición de disolución de Ayuntamientos y Diputaciones, con una claridad que no deja dudas “... es preciso que los actuales Ayuntamientos, elegidos en una época de perturbación moral y política, nombrados bajo el influjo de temores, que cada día se desvanecen más, sean disueltos totalmente y reemplazados por municipalidades... que se limiten a los fines de la ley que regula su organización y fija sus atribuciones...Es asimismo indispensable para los fines de nuestro plan gubernativo, no sólo que se renueven por completo las Diputaciones de provincia, sino que su acción quede encerrada dentro de los límites que nunca debió traspasar..."

En conclusión, vemos un encasillamiento del gobierno y una "huida hacia adelante" para controlar la situación, lo que provoca un endurecimiento de la represión y de la radicalización política, ocasionada por el afán del poder central de controlar al máximo las instituciones provinciales y municipales.

Estas modificaciones afectan a un total de dieciséis artículos de la citada ley, y con la misma fecha se publican sendos reales decretos sobre la "Renovación total de todos los individuos de Ayuntamientos", y sobre la "Disolución de las actuales Diputaciones provinciales y la subsiguiente elección general de diputados provinciales y la instalación de las nuevas Diputaciones, con fecha $1^{\circ}$ de enero de 1867 en la Península e Islas Baleares y Canarias".

La vigencia de esta ley "para el Gobierno y Administración de las Provincias" incluida la última modificación, se dio por finalizada al mismo tiempo que finalizó el periodo isabelino. Si en septiembre de 1868, después de dos años de continuos levantamientos y "una subversión permanente", se produce el definitivo cambio de régimen con el inicio del Sexenio Revolucionario, en octubre del mismo año se aprueba una nueva "Ley Orgánica Provincial" que derogaba la ley de 25 de septiembre de 1863 junto a la modificación de 21 de octubre de 1866.

\subsection{9.- CONCLUSIONES}

Es llamativo, y no es la primera vez que queda reflejado en estas páginas y que volveremos a recalcar más adelante, el excesivo número de leyes relativas a la organización de la administración tanto a nivel nacional como provincial y municipal, que se legisla a lo largo del período isabelino. Dos son a nuestro entender las causas más principales de estos cambios. La primera es la necesidad de modificar toda la legislación correspondiente al Antiguo Régimen para adecuarla a las nuevas normas

93 B.O.P.V. $n^{\circ} 99$ de 24 de octubre de 1866. Con la copia del texto del Decreto publicado en la Gaceta de Madrid el día 22 de octubre de 1866.

94 B. O. P. V. no 99 con la "Exposición a S.M. que acompaña al proyecto de ley".

95 Ibidem.

96 Ibidem. 
liberales. La segunda está ocasionada por los continuos vaivenes provocados tanto por moderados como por progresistas, que en sus sucesivos períodos de hegemonía política propician continuos cambios en la legislación, lo que trastocan y dificultan el funcionamiento de la Diputación provincial.

Es importante el señalar que a lo largo de estos años se pone de manifiesto la existencia de dos diferentes puntos de vista sobre el modelo de gestión provincial y de gestión municipal. Por un lado tenemos el preconizado por los moderados que se inclinan por un sistema de corte provincialista que se apoya en la Diputación para mantener el control tanto desde un punto de vista político como administrativo de la provincia. Por otro lado, los progresistas se inclinan por el predominio de la gestión municipal de una forma más autónoma y sobre todo sin la fiscalización que el gobierno central ejercía a través de los gobernadores y sobre todo de las Diputaciones.

A estos dos diferentes modelos de gestión se unirá posteriormente el revolucionario federal que se pondrá en marcha a partir de 1868 y que trataremos en el siguiente capítulo.

Esta tensión que se produce en la legislación sobre los diferentes puntos de vista relacionados con el régimen local y provincial es tratada por Alejandro Nieto ${ }^{97}$, que en su obra contrapone la visión centralizadora de los moderados a la de los progresistas, más inclinados hacia la descentralización.

Los moderados pretendían mantener el control de las provincias a través de las Diputaciones y de los gobernadores, como instrumentos de las directrices del gobierno central haciendo un especial seguimiento de las actividades de los Ayuntamientos, en especial los de las capitales. En cambio los progresistas insistían en reforzar el sistema de gobierno municipal, basándose sobre todo en la posibilidad de la elección del alcalde por parte de los ediles electos y de esta forma progresar en la línea de la descentralización y autonomía del poder local frente a las injerencias de la nueva institución provincial, léase la Diputación, encargada de transmitir las órdenes del gobierno central. No podemos olvidar que en 1840, el tema de la elección de alcaldes en la "Ley Municipal" que se aprobó, fue el detonante de la salida de la regencia de María Cristina y la llegada al poder del general Espartero. Según el artículo cuarenta y cinco de la citada ley el gobierno se reserva el nombramiento del alcalde, con el previsible resultado de que un Ayuntamiento progresista tenga un alcalde moderado, nombrado por un gobierno moderado ${ }^{98}$. La consecuencia lógica de este problema es que en función de la mayoría se producen una serie de leyes y decretos municipales fuertes de los progresistas y débiles de los moderados y en contrapartida unas leyes provinciales fuertes de los moderados y débiles de los progresistas.

Esta tensión ente el municipalismo progresista y el provincialismo moderado es la que provoca este repetido vaivén legislativo tanto en las leyes locales como en las provinciales. Este problema también se traslada a otra serie de leyes como ocurre con la ley electoral, en la que a la hora de redactar su articulado se discuten diferentes puntos de vista, sobre todo en lo referente al número de electores y a la modificación de los distritos. Por una parte los moderados estaban interesados en restringir el censo electoral y en reforzar los distritos electorales con el consiguiente mayor control electoral por parte de la burguesía dominante, y por otra parte los progresistas estaban más preocupados en legislar un mayor número de electores a la vez que rehuían de los distritos, para que el control de las elecciones estuviera en la capital de la provincia, cuyos Ayuntamientos estaban controlados en su mayoría por los citados progresistas.

Con el paso de los años la tensión entre moderados y progresistas no pierde virulencia. Unos y otros se esfuerzan por mantener el control de los diferentes

\footnotetext{
${ }^{97}$ NIETO, Alejandro. Los primeros pasos del Estado constitucional. Ed. Ariel. Barcelona. 1996 ${ }^{98}$ Ibídem. Pág. 130
} 
organismos provinciales y municipales y siempre lo hacen a partir de la legislación, aunque también es verdad que los períodos progresistas son más cortos que los moderados con la consecuencia que la legislación moderada es más duradera. Una vez pasados los dos períodos progresistas protagonizados por el general Espartero, vemos que el resto de los años de la etapa isabelina está controlada por los centralistas gobiernos moderados, que se sirve de dos referentes para mantener el control del país: la Diputación provincial, principal órgano de control de los Ayuntamientos y el jefe político, vigilante de todo el entorno provincial y encargado de tomar la decisiones finales ${ }^{99}$.

Las leyes sobre Diputaciones y Ayuntamientos que se publicaron en el año 1845, suponen la confirmación del control por parte del gobierno, tanto del ámbito provincial como del municipal, a través de la Diputación. Los Ayuntamientos pierden parte de su autonomía, los alcaldes son nombrados por el gobierno, las Diputaciones ejercen el control administrativo y el gobernador ejerce el control político, y esta situación se mantendrá hasta el año 1868.

\section{5.- LA LEGISLACIÓN REVOLUCIONARIA}

\subsection{1.- INTRODUCCIÓN}

El Sexenio Revolucionario se inicia de modo similar al de otros cambios políticos que se producen en la España del siglo XIX. En un principio se trata de un pronunciamiento militar, dirigido por un "militar político" y apoyado por la burguesía. La gran diferencia es la de que en esta ocasión fueron secundados y acompañados por el proletariado, grupo social descontento y soliviantado porque es el que sufre las graves consecuencias de la crisis agrícola de la que deriva una crisis de alimentos, el encarecimiento de la vida y sus inevitables consecuencias de hambre y de paro.

A la crisis agraria se une la crisis financiera provocada por la pérdida del tejido industrial y la práctica bancarrota del Estado y la crisis política, motivada por el abandono del apoyo a la monarquía por la gran mayoría de la clase política.

A estas crisis, Fernández Segado ${ }^{100}$ añade una cuarta, "la crisis social" ocasionada por el fracaso de las leyes desamortizadoras que no consiguen establecer una nueva clase de campesinado medio y que han provocado el progresivo deterioro de la situación social del campesino. Dentro de esta serie de cambios destacamos los legislativos relacionados con la vida provincial y local y que se producen de una forma rápida. El 8 de octubre se forma el gobierno provisional presidido por Serrano, con Práxedes Mateo Sagasta como ministro de la Gobernación que rápidamente pone en marcha una serie de cambios legislativos de orden provincial. El día 13 de octubre se publica un decreto ley por el que se suprimen los Consejos provinciales. El día 21 del mismo mes otro nuevo decreto ley organiza las "Atribuciones de las Diputaciones Provinciales". El 9 de noviembre aparece un decreto "sobre el ejercicio del Sufragio Universal". Leyes que se completarán en junio de 1869 con la promulgación de la nueva Constitución, y posteriormente con las leyes orgánicas que la complementan. Es una época de efervescencia política y legislativa. Toda esta actividad legislativa está influenciada, sobre todo en los primeros momentos de la revolución por la grave situación social en la que se encontraba el país. Como muy bien lo refleja Rafael Serrano con referencia a Valladolid de la que nos dice que el Sexenio se abre paso en un contexto de pobreza, paro y carestía ${ }^{101}$.

Esta situación supuso un freno a las tentativas maximalistas de los legisladores en relación a las leyes que se tramitaron, y que aunque significaron un avance en

\footnotetext{
${ }^{99}$ CARASA SOTO, Pedro (Dir.). Diccionario biográfico de Alcaldes de Valladolid (1810-2010).Ed. Ayuntamiento de Valladolid. Valladolid. 2010. Págs. 34 y sig.

${ }^{100}$ FERNANDEZ SEGADO, Francisco. Las Constituciones históricas españolas. Ed. Cívitas. Madrid. 1986. Pág.267.

${ }^{101}$ SERRANO GARCIA, Rafael. El Sexenio revolucionario en Valladolid. Cuestiones sociales (18681874). Ed. Junta de Castilla y León. Valladolid. 1986. Pág. 75.
} 
algunos temas como los relativos a la libertad de prensa, a la ampliación del número de electores, y con referencia a las Diputaciones a una mayor libertad de acción, lo cierto es que tanto los gobiernos como las diferentes Cortes legislativas tuvieron un especial cuidado en legislar de una forma más bien conservadora para evitar el descontrol y la creación de falsas esperanzas de mejora en todos los niveles, tanto políticos como económicos y sociales.

Por estas causas, tanto el gobierno como las Cortes frenaron sus deseos de legislar en un mayor sentido progresista, y las leyes resultantes, en algunos casos fueron más conservadoras que lo deseado por progresistas y republicanos.

\subsection{2.- LEY DE ORGANIZACIÓN Y ATRIBUCIONES DE LAS DIPUTACIONES PROVINCIALES}

Esta ley rigió transitoriamente desde su fecha de publicación el 21 de octubre de 1868 hasta la puesta en vigor de la "Ley Orgánica Provincial" de 20 de agosto de 1870 , de acuerdo con lo prescrito en el artículo noventa y nueve de la reciente Constitución. Como hemos comentado con anterioridad, Sagasta como ministro de la Gobernación, puso en marcha esta ley a los pocos días de tomar posesión de su cargo con la clara intención de "descentralizar" la actividad política. Había que desahogar la presión que la anterior "Ley Provincial" de 1866 sometía a todas las actividades, tanto provinciales como municipales, a través del control a que eran sometidos por parte del gobernador de la provincia, al que la ley y el gobierno le concedían un gran protagonismo fiscalizador. También nos hemos referido a la anulación de los Consejos provinciales como otro paso más para la liberalización de la vida política provincial.

En definitiva, podemos considerar a esta nueva ley como representativa de un criterio intermedio entre las leyes precedentes de 1845 y 1863 con su característico matiz centralista y monopolizador del poder a través del gobernador, y la ley de 1870 , que junto a la de 3 de febrero de 1823, son las leyes provinciales verdaderamente descentralizadoras a juzgar por las numerosas facultades que el poder central delegaba en las Diputaciones y municipios.

Destacamos como novedad más importante de esta ley, la referida a que el nombramiento del vice-presidente de la institución se realiza por parte de los diputados electos y entre sus componentes, lo que comporta una mayor independencia de la Diputación a la hora de desarrollar sus actividades y en consecuencia una mayor autonomía. Sin embargo, esta descentralización y autonomía de las Diputaciones, no presupone necesariamente una mayor autonomía de los organismos municipales. La legislación sigue concediendo el control municipal a las Diputaciones, y aunque los municipios están regidos mayoritariamente por el partido progresista, las Diputaciones siguen controladas por la burguesía moderada, y al gobierno central, aunque de carácter progresista, le interesa mantener la situación de equilibrio entre el provincialismo moderado y el municipalismo progresista.

El articulado de esta "Ley Orgánica Provincial" está compuesta por ochenta y ocho artículos, repartidos en cinco títulos, a los que se añaden un artículo general y cuatro artículos transitorios.

El título primero está compuesto por un capítulo único, que trata sobre el "Territorio de la provincia y sus habitantes". Como novedad, aparece la división de la provincia en distritos electorales de 25.000 almas cada uno. Exige que cualquier modificación territorial "no podrá hacerse sin previo expediente en el que sean oídas las Diputaciones y Ayuntamientos interesados".

El título segundo trata sobre la "Administración de la provincia". Es el título más amplio de la ley, compuesto por seis capítulos y cuarenta y nueve artículos. Se legisla sobre las competencias de las Diputaciones, la organización y funciones de la corporación, sobre los secretarios provinciales y sobre los presupuestos provinciales. Sobresale en este título la aparición de la figura del vicepresidente, que es nombrado por la corporación de entre sus miembros, y que presidirá las sesiones de la Diputación cuando el gobernador de la provincia no asistiera. 
El título tercero en su capítulo único trata sobre "La dependencia jerárquica y responsabilidad de la Diputación, de los diputados y de los subalternos de la Diputación".

El título cuarto estipula el "Tratamiento, distintivos y sellos de las Diputaciones y de los diputados provinciales". Título que es de nueva creación y en el que se organiza el ceremonial de la Diputación y de los diputados.

El título quinto y último de la ley trata sobre el "Gobierno político de las provincias". En él se pueden destacar diferencias con las leyes anteriores al fijar que "el gobernador es el representante del gobierno en la provincia" a diferencia de las anteriores en las que se indicaba que "el gobernador es la autoridad superior de la provincia". La ley finaliza con un artículo general por el que "quedan derogadas todas las leyes y disposiciones anteriores que en cualquier forma contradigan la presente ley".

En definitiva, es una ley aperturista, descentralizadora y con tendencia al progresismo, pero también es una ley que desencanta a los que creían que la revolución iba a resolver todos los males que aquejaban al país. Por otra parte, la realidad nos dice que tanto el gobierno como las Cortes progresistas, no están por la labor de modificar su tendencia a la moderación en los temas legislativos, que las Diputaciones siguen controladas por la burguesía moderada y que los Ayuntamientos progresistas están centrando todos sus esfuerzos en mejorar la situación de sus vecinos en la lucha contra el paro y el hambre, y que lo tienen que hacer a partir de la penuria económica que sufren, agravada por la pérdida de los ingresos provenientes del abolido impuesto de consumos.

Toda esta situación se completa con la pérdida de la hegemonía que hasta estos años mantenía el gobernador, y que a partir de la publicación de esta ley, se desentiende de una forma efectiva de su presencia y de su influencia en la Diputación, y deja a este organismo provincial con una mayor libertad para gestionar todas sus actividades, lo que conlleva el control efectivo de los municipios.

\subsection{3.- DECRETO SOBRE EL EJERCICIO DEL SUFRAGIO UNIVERSAL DE 1868}

El decreto especial sobre el "Ejercicio del Sufragio Universal", según indicaba el artículo transitorio tercero de la Ley Orgánica Provincial, fue publicado el 9 de noviembre de 1868. Su finalidad no sólo se circunscribía a las elecciones para diputados provinciales sino que abarcaba, como es lógico, a todo tipo de elecciones tanto municipales, provinciales, como las de diputados a Cortes.

\section{Exposición y articulado}

En la exposición que acompaña al decreto, el ministro de la Gobernación, Práxedes Mateo Sagasta, justifica su promulgación invocando a la "soberanía nacional". Continúa desarrollando las ventajas de "un decreto tan indispensable como deseado". Justifica el mantenimiento de la edad de los electores en 25 años. Resalta que al incluir en un mismo decreto las elecciones de Ayuntamientos, Diputaciones provinciales y Cortes, facilita la práctica de las votaciones. Mantiene a la provincia como "unidad electoral", aunque la divide en demarcaciones electorales para paliar dos inconvenientes prácticos: "la privilegiada condición de los electores de provincias muy pobladas al tener derecho a elegir un mayor número de diputados que las provincias poco pobladas", y "el inconveniente de que estos electores de provincias muy pobladas tengan que acumular en su candidatura un número excesivo de nombres". Finaliza la exposición justificando la aplicación de una sanción penal severa para todos los atentados porque al efectuar una emisión libre del sufragio se reducen las precauciones.

El decreto está compuesto por seis capítulos divididos en ciento treinta y ocho artículos a los que se añade una disposición excepcional y tres disposiciones 
transitorias ${ }^{102}$. El capítulo primero, compuesto por veintiún artículos, trata de los electores, de los elegibles y de las incompatibilidades. El capítulo segundo, con cincuenta y tres artículos, es el más amplio y está referido a las elecciones municipales. El capítulo tercero está dedicado en veinte artículos al tema de las elecciones provinciales. El capítulo cuarto, constituido por treinta y siete artículos, está dedicado a las elecciones a Cortes. El capítulo quinto, con catorce artículos, está referido a la sanción penal y el capítulo sexto y último en cuatro artículos legisla sobre el orden en los colegios.

Este decreto es uno de los más esperados y deseados por los progresistas, pues basaban en él todas sus esperanzas para mantener y, en el mejor de los casos, ampliar la mayoría política de la que disfrutaban. Especialmente son las capas proletarias, que habían adquirido en muy poco tiempo un alto grado de politización, las que estarán más ilusionadas con la posibilidad de votar. La realidad va a ser que las Cortes, con mayoría progresista, van a seguir legislando de una forma muy limitada, corta y con un escaso espíritu revolucionario.

La aplicación de esta ley con la consiguiente ampliación del número de electores no va a tener repercusión en la formación de las Diputaciones, ya que éstas, como indicaremos con detalle más adelante, son las menos democráticas de todo el período estudiado, pues de las cinco diferentes Diputaciones que se suceden a lo largo del Sexenio, solamente en dos de ellas los diputados fueron elegidos a través de elecciones, ya que las tres restantes se establecieron a partir de "nombramientos superiores". Tanto en un caso como en otro su composición y control lo fueron con mayoría moderada.

\subsection{4.- LA CONSTITUCIÓN DE 1869}

Las Cortes Constituyentes del Sexenio iniciaron su andadura el 22 de febrero de 1869. El día 2 de marzo se nombra la comisión de Constitución, compuesta por quince miembros presididos por Salustiano Olózaga. El día 30 del mismo mes de marzo, el proyecto elaborado por la comisión, en muy breve espacio de tiempo, es leído en las Cortes, donde se inicia su discusión entre el 6 de abril y el 26 de mayo.

\section{Las Diputaciones en el texto constitucional}

El texto constitucional refleja las actividades provinciales y municipales a través del título séptimo, que consta de un solo artículo, el noventa y nueve.

Es posible que el rápido desarrollo que se prevé para la descentralización del régimen provincial, efectuado a través del decreto-ley de 21 de octubre de 1868 sobre "Organización y Atribuciones de las Diputaciones Provinciales", haya influido en la brevedad de este título, considerando como satisfactoria la resolución tomada por el gobierno.

De acuerdo con la redacción del citado artículo noventa y nueve, la organización de Diputaciones y Ayuntamientos se ajustarán a cinco principios: Gobierno de la provincia por la Diputación. Señalamiento de sesiones de carácter público. Publicación de cuentas y presupuestos. Intervención del Rey, o de las Cortes, en casos de extralimitación de funciones. Coordinación de los impuestos estatales y provinciales.

Vemos cómo por el primer principio se fija el carácter descentralizador al señalar "que el gobierno de la provincia se hará por su Corporación", y también observamos que el cuarto principio al invocar la intervención real, coarta en parte la descentralización del primero. De todas formas hay que reconocer que la atención que concede la Constitución de 1869 a las actividades provinciales y municipales es mínima, en términos comparativos, con la importancia que estas instituciones tienen en la vida cotidiana del país. 


\section{Aplicación de la Constitución y su articulado}

Con la promulgación el día 6 de junio de 1869 y la publicación en la Gaceta de Madrid $^{103}$ al siguiente día, se inicia la andadura de la nueva Constitución a pesar de lo complicada que estaba la vida política del país.

Puede que para hacer frente a esa complicación, y también para dar una mayor relevancia a la misma, y al mismo tiempo hacer resaltar el interés de su implantación y el respeto a su articulado, el ministro de la Gobernación, Sagasta, envió una circular a todos los gobernadores de provincia en la que hacía un canto a las excelencias de la Constitución. Iniciaba su carta instando al cumplimiento constitucional y a continuación ensalzaba la obra enmarcada dentro de la Revolución de 1868.

\section{Vigencia}

La Constitución, aunque fue en numerosas ocasiones infringida, se mantuvo vigente, tanto en los años de la regencia de Serrano, como durante el reinado de Amadeo I. Durante la República no llegó a derogarse, aunque sí se discutió sobre su artículo treinta y tres que establecía que la forma de Gobierno de la nación española es la Monarquía. En realidad no hay constancia de la modificación de ningún artículo aunque, como hemos repetido anteriormente, sí se infringió reiteradamente. En definitiva la Constitución de 1869 se mantuvo vigente hasta el 30 de junio de 1876, en que se promulgó una nueva Constitución, ya en el período de la Restauración.

\subsection{5.- LEY ELECTORAL DE 20 DE AGOSTO DE 1870}

El día 20 de agosto de 1870 fueron aprobadas por las Cortes tres nuevas leyes orgánicas, Ley Provincial, Ley Municipal, y también una nueva Ley Electoral, cumpliendo de esta forma con el mandato constitucional. Esta última ley es una continuación o complemento del decreto sobre el "Ejercicio del sufragio universal" publicado en noviembre de 1868. En ella se detallan las actividades y las formalidades a seguir en todos los actos electorales ${ }^{104}$.

El título primero trata de la problemática de los electores, elegibles, incapacidades, incompatibilidades y disposiciones generales. El título segundo trata sobre el procedimiento electoral de las elecciones municipales y provinciales, diputados a Cortes, compromisarios para senadores y senadores. En lo que se refiere al tema de las elecciones para diputados provinciales, a lo largo de sus quince artículos, nos marca las pautas para la celebración de las elecciones provinciales. El título tercero, trata sobre la sanción penal, las falsedades, coacciones, faltas en el cumplimiento de los deberes de los funcionarios, arbitrariedades y abusos y disposiciones comunes.

La duración de esta ley, cosa habitual en las leyes electorales, que cambian con mucha frecuencia, es realmente corta, puesto que el día 1 de enero de 1871 se publicará una nueva ley, complementaria de esta misma, y que se utilizará en las elecciones de diputados a Cortes de marzo de 1871 y abril y agosto de 1872. Finalmente una nueva ley electoral será aprobada el 11 de marzo de 1873 , que es la consecuencia de los cambios institucionales generados por la instauración de la República como nueva forma de Estado. Como dato más importante de esta nueva ley, tenemos en cuenta la ampliación del derecho a voto de todos los ciudadanos a partir de los veintiún años, lo que ocasionaba en consecuencia la ampliación del cuerpo electoral. publicado en la Gaceta de Madrid el día 7 de junio de 1869.

104 B.O.P.V. Nos. 146- 147 y 148 de los días $16-18$ y 20 de septiembre de 1870 , en los que se publica la Ley y de donde hemos tomado los datos. 


\subsection{6.- LEY ORGÁNICA PROVINCIAL DE 20 DE AGOSTO DE1870}

El día 20 de agosto de 1870 "las Cortes Constituyentes de la nación española, en uso de su soberanía decretan y sancionan la Ley Provincial" en cumplimiento de lo estipulado en el artículo noventa y nueve de la Constitución. Esta ley venía a sustituir a la publicada en octubre de 1868, y representa un paso adelante, de acuerdo con el espíritu constitucional, en el camino de descentralización de las actividades de las instituciones provinciales.

\section{Introducción y articulado}

El presidente del Consejo de Ministros, Ruiz Zorrilla, en su exposición enviada al regente de la Corona, anunciaba que las "leyes orgánicas ajustadas al espíritu del Código fundamental y encaminadas a evitar graves conflictos o manifestaciones perturbadoras, establecen la autonomía del municipio y de la provincia, normalizando sus relaciones y asegurando sus recursos..." ${ }^{105}$.

Como novedades de esta ley podemos destacar el aumento del número de diputados, en función del número de habitantes, teniendo cada provincia un mínimo de veinticinco, en lugar de los siete, para el caso de la provincia de Valladolid, que establecían las leyes anteriores. Aparece un nuevo organismo, la "Comisión Provincial", compuesta por cinco vocales que disfrutarán de sueldo. A diferencia del anterior Consejo provincial, estos vocales, estarán nombrados por la Diputación "de entre los individuos de su seno", y no por el gobernador de la provincia.

Esta "Ley Provincial" está compuesta por noventa y ocho artículos divididos en tres títulos ${ }^{106}$ referidos a las provincias, su territorio y habitantes, a la administración civil de las provincias y a la dependencia y responsabilidad de los diputados y agentes de la administración provincial.

Como conclusión, podemos decir que esta ley ratifica la línea de descentralización iniciada en el Sexenio. El gobernador, cuando asiste a las sesiones de la Diputación, preside la misma pero "sin voto". En ausencia del gobernador, la Diputación está presidida por el vicepresidente. Las decisiones de la Diputación se independizan en referencia a otras instituciones, ya sea el gobierno central ya sean los Ayuntamientos. Es competencia de la Diputación "la gestión, gobierno y dirección de los intereses particulares de la provincia". La Comisión provincial, órgano de nueva creación, compuesto por vocales de la Diputación, nace con la misión de "velar por el cumplimiento de los acuerdos de la Diputación" "resolver los asuntos que la sean encomendados" y preparar y estudiar previamente los expedientes a presentar en las sesiones de la Diputación. En definitiva es una forma de dar continuidad a la gestión provincial en tiempo de cierre de sesiones.

Con esta ley se cierra la legislación en materia provincial generada en el período del Sexenio Revolucionario, que mantendrá su vigencia durante este período y que será reformada y modificada en la época de la Restauración a través de la "Ley de Ordenación Provincial" promulgada el 16 de diciembre de 1876.

A partir de esta ley se estabiliza el funcionamiento de las Diputaciones. Es una ley que en opinión de Francisco Carantoña ${ }^{107}$, transforma la gestión de las Diputaciones con una serie de mejoras como son la autonomía administrativa, la ampliación de competencias, la elección del presidente y la creación de la Comisión provincial como órgano ejecutivo. En contrapartida a estas mejoras, la Diputación tiene que enfrentarse a graves dificultades para desarrollar su cometido como son las dificultades presupuestarias y económicas, los consabidos problemas de repartimientos de impuestos y sorteo de "quintos" a lo que hay que añadir en estos

105 B.O.P.V. Suplemento al no 121 del día 12 de agosto de 1870. Con la publicación de la Exposición al Regente.

106 B.O.P.V. no 128 y 129 de fecha 24 y 25 de agosto de 1870 .Con la publicación de esta Ley.

${ }^{107}$ CARANTOÑ A ALVAREZ, Francisco. Historia de la Diputación.... Ob. Cit. Págs. 121 y sig. 
años revolucionarios la penuria en la que están sumidos los Ayuntamientos y el levantamiento carlista.

Por otra parte, y según mantiene Rafael Serrano ${ }^{108}$, la pobreza el paro y el hambre ahondan el conflicto social y radicalizan la vida ciudadana, provocando un enfrentamiento entre el campesinado, más afín con la ideología carlista y el proletariado urbano, más politizado e inclinado a las tesis del progresismo republicano.

De todas formas, con estas leyes la Diputación se afianza en su trabajo, elude los debates políticos, reclama con mayor énfasis sus prerrogativas ante el gobierno y aunque sigue controlada por la mayoría moderada, sus relaciones con los Ayuntamientos, también en su mayoría regidos por los radicales progresistas, son más "amables" que lo fueron en los pasados años isabelinos, sobre todo porque tanto unos como otros, están más preocupados y tienen que buscar el apoyo mutuo para resolver sus respectivos problemas.

\subsection{7.- PROYECTO DE CONSTITUCIÓN FEDERAL DE 1873}

Con la abdicación de Amadeo I, las Cortes reunidas conjuntamente el 11 de febrero de 1873, proclaman por mayoría la República como forma de gobierno de la Nación. Este cambio presupone la convocatoria de elecciones generales a Cortes Constituyentes.

En la sesión inaugural de las nuevas Cortes celebrada el día uno de junio se tomó el acuerdo de nombrar una comisión parlamentaria encargada de redactar una nueva Constitución, que reflejara la nueva situación política del país. El 17 de julio se presenta al Pleno un proyecto de Constitución que según explicaron sus autores en la exposición preliminar "se ajustaba al patrón federal adoptado por la República".

\section{Articulado y características}

El proyecto presentado en las Cortes estaba formado por ciento diecisiete artículos repartidos entre diecisiete títulos y que en líneas generales mantiene el armazón de la Constitución de 1869, aunque acentúa la tendencia progresista.

Como características diferenciadoras destacan: La formación de un Estado Federal, constituido por un Estado Central y diez y siete Estados miembros, cada uno con su correspondiente Constitución. Un Parlamento bicameral integrado por el Congreso y el Senado. Un Tribunal Federal. Se consolida el establecimiento de la soberanía popular y el de la división de los poderes legislativo, ejecutivo y judicial. Se estipula la libertad de cultos y la separación de Iglesia y Estado.

\section{Conclusiones}

Este proyecto en opinión de Artola ${ }^{109}$ "no mereció más que dos intervenciones en tres días para no volver a tratarse de él". Para Tomás Villarroya ${ }^{110}$ "las Cortes no tuvieron ni posibilidad ni ganas de discutir el proyecto ante las dificultades que a nivel político, social y económico se sucedían a lo largo y ancho del territorio español". Martínez Alcubilla, abogado y administrativista, en aquellos años centraba su preocupación y su inquietud en que el proyecto fuese finalmente aprobado, pues en su opinión se oponía frontalmente a las ideas y sentimientos de una parte importante de la población.

Para Fernández Segado ${ }^{111}$, uno de los temas más importantes del proyecto es el referido a la organización territorial y a todos los cambios que este nuevo orden ocasiona. Destaca que la división federal del Estado en diecisiete regiones se

\footnotetext{
108 SERRANO GARCIA, Rafael. La Revolución de 1868 en Castilla y León. Ed. Universidad de Valladolid. Valladolid. 1992.

109 ARTOLA, Miguel. Historia de España.... Ob. cit. Tomo V. Pág. 365.

110 TOMAS VILLARROYA, Joaquín. Breve historia del constitucionalismo español. Ed. Centro de Estudios Constitucionales. Madrid. 1981. Págs. 98 a 101.

111 FERNÁNDEZ SEGADO, Francisco. Las Constituciones históricas..... Ob. cit. Págs. 343 y sig.
} 
corresponde básicamente con los antiguos reinos de la monarquía, a los que se añaden los Estados ultramarinos de Cuba y Puerto Rico. A todos ellos se les concede una gran autonomía económico-administrativa y la posibilidad de tener cada Estado su propia Constitución, con la única condición de que no se oponga a la Constitución del Estado Central.

Finalmente, y como dato relevante de la organización administrativa periférica, observamos que en este proyecto federal según se refleja en el artículo cuarenta y tres "los organismos políticos de la República son el Municipio, el Estado Regional y el Estado Federal o Nación". La importancia y preminencia que en el proyecto se da al municipio se completa en el artículo ciento seis en el que se refleja que "los municipios tienen una autonomía administrativa, económica y política".

En conclusión, el proyecto de Constitución Federal no hace mención a ninguna otra institución fuera del municipio, lo que nos da a entender que las Diputaciones provinciales no tenían cabida en la vida político-administrativa de la República. El progresismo radical consigue finalmente con este proyecto la hegemonía de la institución municipal como eje de la vida ciudadana, y la mejor forma de conseguirlo es eliminando a las otras instituciones que pudieran discutir o "hacer sombra" a los Ayuntamiento 


\section{3.- VIDA DE LA INSTITUCIÓN}

\section{1.-LA PROVINCIA DE VALLADOLID. EXTENSIÓN Y TERRITORIO}

La ordenación del territorio peninsular era una condición indispensable para poner en marcha los cambios que preconizaba la Constitución de Cádiz. Era necesario un cambio, no sólo en la legislación sino también en el ámbito de la organización territorial, para hacer posible el tránsito a las nuevas instituciones liberales y progresar en su asentamiento.

El Antiguo Régimen, a lo largo de su proceso histórico, había provocado tal diversidad territorial y tal complicación en los límites tanto municipales como provinciales y regionales, que hacían imposible el desarrollo normal y homogéneo de los nuevos órganos de gobierno, especialmente en el ámbito provincial, creados a partir de la nueva organización constitucional. Es por eso por lo que la Constitución ante las dificultades que ocasiona la división territorial, propone "hacer una división más conveniente del territorio español, luego que las circunstancias políticas lo permitan". Al mismo tiempo, los diputados buscaban una buena ordenación territorial, teniendo en cuenta una serie de parámetros como los de no mezclar habitantes con diversas leyes, costumbres o idiomas y la de mantener una equidistancia entre los pueblos de las nuevas provincias.

Los liberales son conscientes que para conseguir una buena organización administrativa es necesario en primer lugar una buena organización territorial, y tanto la una como la otra son igualmente necesarias para que la nueva institución encargada de controlar la provincia, es decir la Diputación, pueda desarrollar su trabajo en buenas condiciones, ya que a través de ella se debían de tramitar una serie de actividades y órdenes gubernamentales necesarias para el buen funcionamiento de la nueva administración nacional.

En definitiva, es necesaria una provincia homogénea y coherente en su extensión y dimensión para: Mejorar las comunicaciones, necesarias para conseguir y facilitar el movimiento de los habitantes entre los diferentes enclaves provinciales y para trasmitir de una forma eficaz las órdenes gubernamentales a través de la Diputación. Mejorar la gestión del cobro de impuestos a través de los repartimientos, atender a las reclamaciones y controlar los impagados. Mejorar la gestión militar de los repartimientos de los mozos destinados al ejército, con la atención a las reclamaciones y los siguientes envíos de los soldados a los cuarteles y al mismo tiempo apoyar y colaborar con el paso de las tropas por la provincia. Mejorar la gestión en los temas de demografía y estadística para tener a punto y al día con datos fiables los censos electorales.

Por todo ello es por lo que los liberales constitucionalistas, convencidos de la necesidad de mejorar el sistema político administrativo y social, se fijan como una de las primeras necesidades la de reordenar el territorio nacional en unidades administrativas provinciales con una nueva institución, la Diputación como entidad encargada de poner en marcha en su ámbito de influencia la nueva organización administrativa para satisfacer las necesidades del gobierno en materia de tipo fiscal, de tipo militar, de tipo estadístico y electoral y de tipo político

\subsection{1.- VALLADOLID EN EL ANTIGUO RÉGIMEN}

Las primeras divisiones de la España peninsular son el resultado de la división del país que efectúan los conquistadores romanos. Esta división prevalecerá en el período visigodo, pero desaparecerá con la llegada de los musulmanes. Será la Iglesia la que, una vez reconquistado el territorio a los árabes, inicie la reconstrucción de las antiguas provincias y las transforme en "provincias eclesiásticas"112.

112 MARTÍNEZ DIEZ, Gonzalo. "Génesis histórica de las provincias españolas". En Anuario de Historia del Derecho Español. N 51 (1981). Pág. 523. 
Sin embargo, la necesidad de la cobranza de impuestos, consolidará de alguna forma la división territorial y administrativa del país, partiendo por un lado de las antiguas divisiones históricas, y por otro del nuevo reparto de la propiedad territorial con ocasión de la reconquista. En el año 1590 se actualiza el Censo de Población para proceder al segundo reparto del Servicio de Millones. Este censo nos dice que el país está dividido en treinta y dos provincias y ocho distritos y entre ellas se encuentra "la provincia de Valladolid y el distrito de las Tierras del Conde de Benavente que incluía señoríos de Zamora, León, Valladolid y Orense"... ${ }^{113}$. Es una de las primeras referencias a Valladolid y a los territorios que la componían. Tomás González, cartógrafo de la época en sus "Normas para el repartimiento de 1590", nos detalla que las tierras del Conde de Benavente estaban formadas por "la Tierra y sacada de Benavente, Tierra de Mayorga, Tierra de Almanza, Tierra de Sanabria, Tierra de Portillo, y Tierra de Viana del Bollo". Las variantes más acusadas afectaban a la zona oeste por donde avanzaba la provincia hasta la comarca de Viana, ya en territorio de Galicia”.

A lo largo de los años que transcurren entre el censo de 1590 y el realizado por Floridablanca en los años 1785-89, la provincia de Valladolid, apenas modifica sus límite, manteniendo y consolidando sus enclaves de las Tierras de Viana del Bollo, Almanza, Mansilla y Palenzuela ${ }^{114}$.

El "Nomenclátor de Floridablanca" es uno de los más importantes estudios realizados sobre la división territorial del siglo XVIII. Floridablanca encargó el trabajo al archivero de la Secretaría de Estado, Francisco Javier de Santiago Palomares, que lo inició en 1785 a partir de la información transmitida por los intendentes del Estado, finalizando el estudio en 1789 (ver mapa $\mathrm{n}^{\circ}$ 2). En su prólogo se justifica su realización ${ }^{115}$. Ya con anterioridad, tanto el Gobierno como los más insignes hombres de la época, habían visto la necesidad de reordenar la administración territorial, de eliminar los numerosos enclaves de unas provincias en otras, de crear nuevas provincias por la excesiva extensión de algunas y de cambiar su capitalidad para así agilizar las comunicaciones periféricas.

Esta defectuosa distribución territorial también se refleja entre los políticos a través de la correspondencia entre ellos: "El Mapa General de la Península nos presenta cosas ridículas de unas provincias encajadas en otras, ángulos irregularcísimos por todas partes, capitales situadas en los extremos de sus partidos, intendencias extensísimas e intendencias muy pequeñas, obispados de cuatro leguas y obispados de setenta, tribunales cuya jurisdicción apenas se extiende fuera de los muros de la ciudad y tribunales que abarcan tres reinos, en fin todo aquello que trae consigo el desorden y la confusión..."116.

Al final del siglo XVIII, España está dividida en treinta y ocho provincias, entre ellas la de Valladolid, cuya extensión continúa integrada por "Las Tierras del Conde de Benavente" y los partidos judiciales de Almanza, Mansilla, Villalón, Palenzuela, Medina de Rioseco, Simancas, Torrelobatón, Tordesillas, Valladolid,

113 Ibídem. Pág. 533.

114 GARRIGÓS PICO, Eduardo. La economía española a fines del Antiguo Régimen. Alianza Universidad. Madrid. 1982 Reproducción del Mapa de la división territorial en el siglo XVI. Pág. 332. Ver mapa ${ }^{\circ} 1$.

115 "hallándose frecuentemente embarazado el Gobierno para dirigir sus órdenes y providencias a los muchos pueblos de la vasta monarquía española, por la pequeñez de unos, la identidad de otros, y la falta de una noticia exacta del partido y provincia a que pertenecía, resolvió S.M. a representación del Excmo. Sr. Conde de Floridablanca, Secretario de Estado y de Despacho, que se formase un Prontuario o Nomenclátor de los Pueblos de España sin omitir el más pequeño y extraviado, con expresión de sus jurisdicciones, partidos y provincias, a fin de que el vasallo más retirado y escondido no careciese del consuelo de ser conocido y auxiliado por su Rey y de sus cuidados paternales en caso de necesidad..." GARRIGÓS PICO, Eduardo. La economía ... ob. cit. Prólogo al Nomenclátor de Floridablanca. Pág. 37.

116 ARROYAL, León de. "Cartas político-económicas al Conde de Lerena” en Eduardo GARRIGÓS PICO “Organización territorial... ob. cit. Pág. 21. 
Portillo, Rueda del Almirante, Peñafiel, Medina del Campo, Olmedo, Puebla de Sanabria, Tierras del Conde de Benavente y Mayorga. En este censo no aparece el territorio de Viana del Bollo y la Mezquita "en la parte de Galicia", como perteneciente a la provincia, aunque en los repartimientos que se realizan en 1813 y en los días de constitución de las Diputaciones provinciales, sigue figurando como perteneciente a Valladolid (ver mapa $n^{\text {o }} 3$ ).

Como resumen del Nomenclátor, vemos que la provincia de Valladolid estaba formada por: dos ciudades, ciento setenta y cuatro villas, doscientos ochenta y ocho lugares, treinta y ocho aldeas, diecisiete granjas, once cotos redondos y ochenta y siete despoblados, con un total de 196.839 habitantes.

\subsection{2.- LA DIVISIÓN DEPARTAMENTAL}

La división provincial de España en los inicios del Siglo XIX "era arcaica e irracional en muchos aspectos, en la que reinaba la mayor desarmonía y desproporción entre las treinta y una provincias que se habían alcanzado en $1799 \ldots$ así Valladolid se extendía con sus enclaves hasta Almansa, Mansilla de las Mulas, Benavente, Puebla de Sanabria, Viana del Bollo y Palenzuela,... y esta situación obligó a la búsqueda de una división territorial con menos límites y proporciones más racionales" ${ }^{\prime 117}$.

El primer proyecto de nueva división territorial, será realizado en tiempo de la ocupación francesa. Es una de las primeras actuaciones de la nueva administración que se hizo "a imagen y semejanza" de la división administrativa establecida en el vecino país. La finalidad era la de organizar el país dividiéndole en unidades territoriales en las que se pudiera compaginar las actuaciones administrativas, judiciales y gubernativas.

Este proyecto, realizado por el canónigo y cartógrafo Juan Antonio Llorente, español al servicio del gobierno de José Napoleón I, presentaba la división de la península en treinta y ocho departamentos, y a cada departamento se le asignaba una Universidad, una Audiencia y una Diócesis.

Estos departamentos tenían una extensión regular entre todos ellos y en su mayoría se les denominaba, al gusto revolucionario francés, con una nomenclatura fluvial en referencia a las cuencas a las que pertenecían los territorios. Así el departamento del "Duero-Pisuerga", tenía su capital en Valladolid y estaba formado con territorios de Valladolid, Segovia y Burgos (de hecho la provincia de Segovia se integraba en el nuevo departamento).

El proyecto de Llorente fue aceptado por las autoridades francesas, con una serie de pequeñas modificaciones: Los departamentos tendrían la denominación de prefecturas. Se anulaba la denominación fluvial y se denominaba a las provincias con el nombre de la capital. Se dividían las prefecturas en subprefecturas.

De esta forma, por decreto de 17 de abril de 1810, que se publica en la Gaceta de Madrid el 4 de Mayo, el territorio español quedaba dividido en treinta y ocho prefecturas y ciento once subprefecturas. ${ }^{118}$ La prefectura de Valladolid tenía como subprefecturas a Valladolid, Segovia y Aranda de Duero.

Esta división prefectoral era "una obra artísticamente revolucionaria, puesto que se olvidaba de la historia anterior y sólo tenía como referencia su distribución equilibrada sobre el mapa... y su más destacada cualidad era la de ser realista, es decir no se tuvo en cuenta el pasado..."

117 MARTÍNEZ DIEZ, Gonzalo. “Génesis histórica ... ob. cit. Pág. 557.

118 MELÓN RUIZ DE GORDEJUELA, Amando. “El Mapa Prefectoral de España. 1810.” En Estudios Geográficos no 46 (1952). Pág. 387. Ver Mapa nº 4.

${ }^{119}$ Ibídem. Pág. 388 


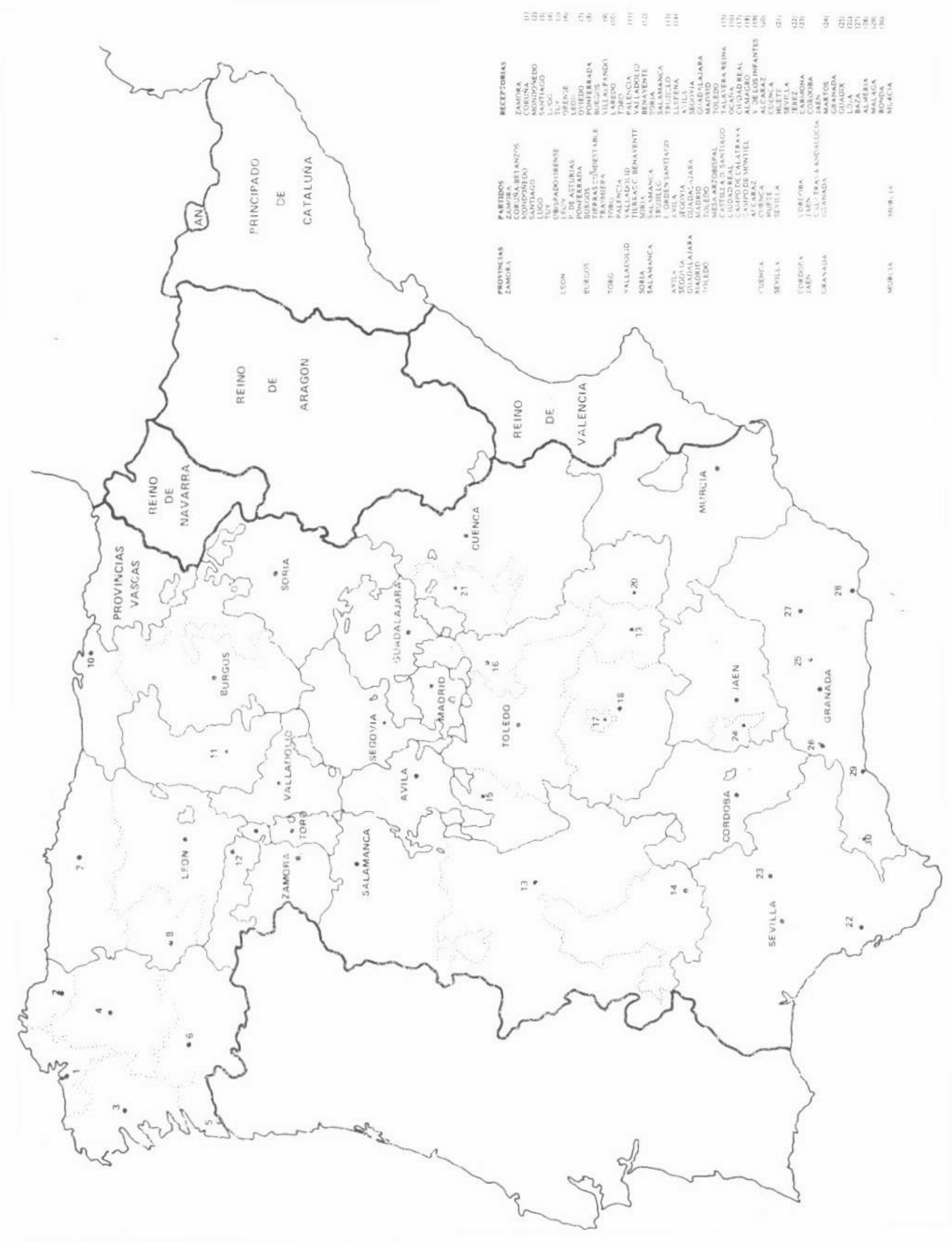

MAPA 1: España peninsular, siglo XVI. División administrativa según Tomás González. 


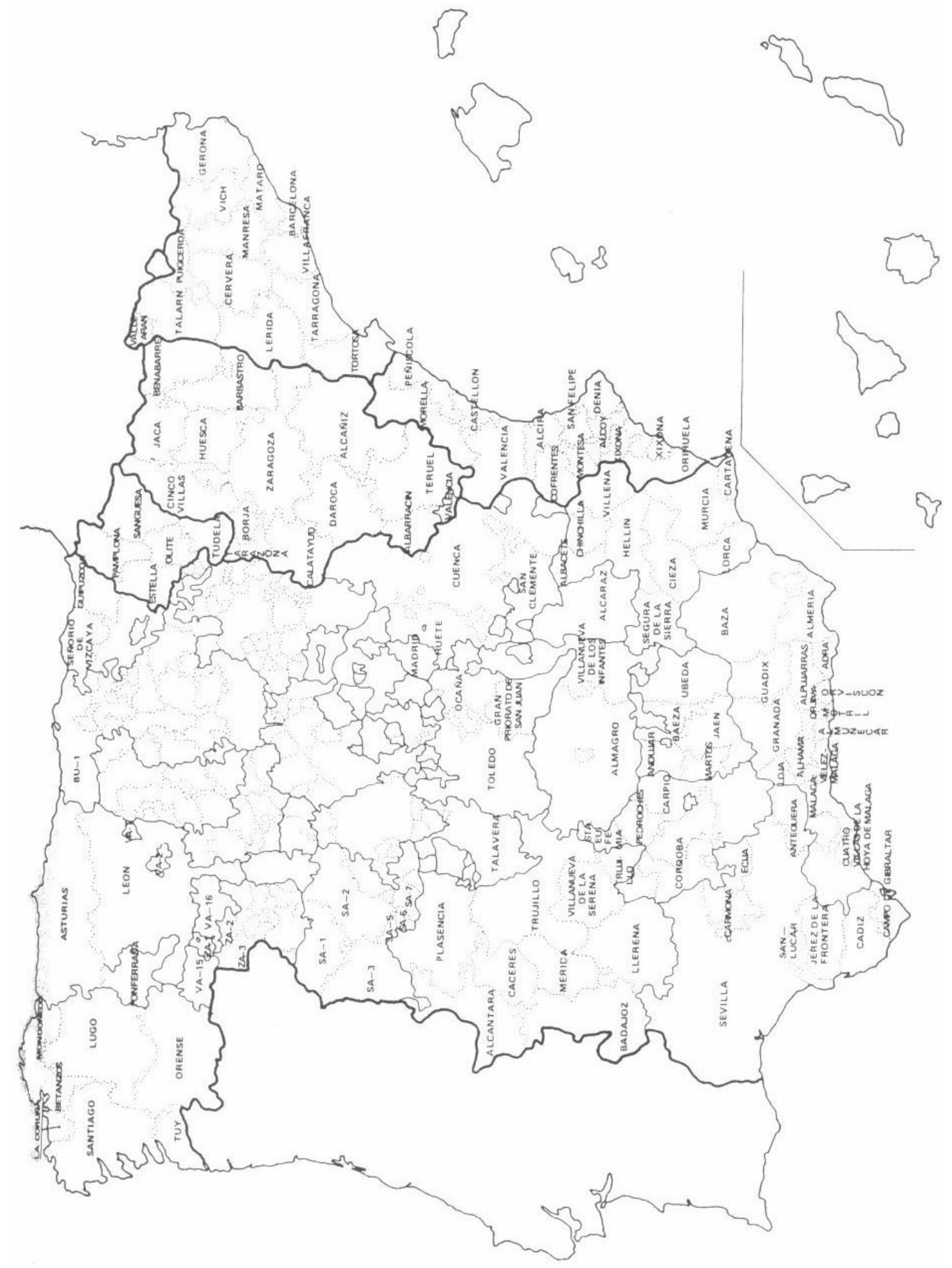

MAPA 2: España siglo XVIII, según el nomenclátor de Floridablanca. 


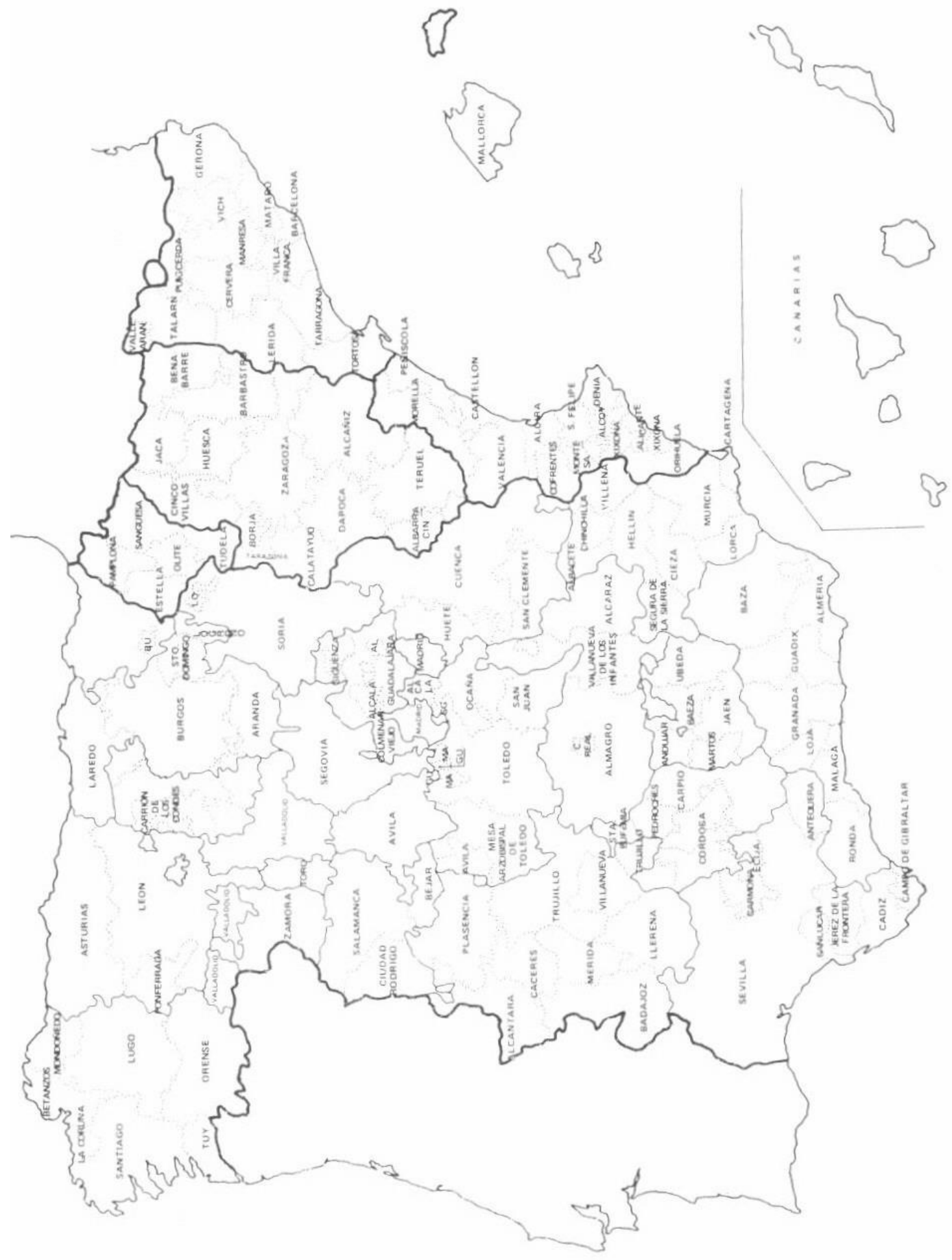

MAPA 3: España, siglo XVIII. División territorial y fiscal. Provincias y partidos. 
Y si desde un punto de vista histórico no se puede considerar una división "homogénea", desde un punto de vista geográfico y administrativo, hay que reconocer que el mapa resultante está formado por territorios de límites continuos y regulares, donde han desaparecido los numerosos enclaves característicos de las divisiones anteriores y en teoría son territorios mucho más ordenados y prácticos para lo que se pretendía, que era establecer un control efectivo de toda la península para mejorar la gestión administrativa y la de las comunicaciones a partir de un gobierno centralista.

La realidad nos demostró que esta división no tuvo un arraigo posterior y sólo existió "sobre el papel". Después de su publicación cayó en el olvido, sobre todo debido a la situación bélica en la que estaba sumergido el país y a la negativa de la mayoría de la población de aceptar iniciativas extranjeras, sobre todo si venían impuestas, aunque esto no es óbice para considerar esta división como el primer intento serio para la racionalización de la vida político-administrativa del país.

\subsection{3.- EL PROYECTO DE BAUZÁ DE 1813}

Las Cortes de Cádiz ya habían establecido el principio constitucional de que debía hacerse una nueva distribución del territorio, según quedaba reflejado en el artículo once, pero mientras no se hiciese la referida división y viendo las dificultades que surgían a la hora de poner en marcha las Diputaciones provinciales, las Cortes generales, en su primer paso y en espera de una solución definitiva, publicaron un real decreto con fecha 23 de mayo de 1812, por el que se dividía el territorio peninsular e islas adyacentes en treinta y una provincias "al objeto de facilitar la ejecución del artículo trescientos treinta y cinco de la Constitución y de que pueda verificarse, luego de que esta se publique, el útil establecimiento de las Diputaciones provinciales" ${ }^{120}$.

Las circunstancias bélicas retrasaron la puesta en marcha de la división territorial. Será en mayo de 1813, con la mayoría del territorio peninsular libre de las tropas francesas, cuando se vio que era llegada la hora de proceder a una división más conveniente del territorio español.

Las Cortes encargan a la Regencia la búsqueda de una solución para poner en marcha las ideas constitucionales ${ }^{121}$. El resultado de la petición de las Cortes es el oficio publicado por la Regencia el 24 de junio en el que: "La Regencia del Reino conminó al capitán de fragata D. Felipe de Bauzá para que se ocupara de la ejecución de lo expuesto por las Cortes, presentando la distribución de provincias que tuviera por más acertada, según sus conocimientos en la materia"122. Felipe de Bauzá presentó a la Regencia sus trabajos el 21 de septiembre del mismo año de 1813, y en la exposición que acompañaba al proyecto justificó las dificultades encontradas para la ejecución del

${ }^{120}$ Colección de Reales Decretos y Órdenes, mandados publicar por las Cortes en 1820. Imprenta Nacional. Madrid, 1820-23 (10 vol.) Tomo II.

121 "siendo de la mayor importancia para el buen gobierno del Estado que con la posible brevedad se lleve a efecto lo mandado en el artículo once de la Constitución, quieren las Cortes que la Regencia, reuniendo todos los datos y noticias que estime necesarios, presente el plan de la división política más conveniente del territorio de la península e islas adyacentes para proceder a su examen y aprobación" MARTINEZ DIEZ, Gonzalo. Génesis histórica ... ob. cit. Pág. 562, con la reseña del Diario de las Cortes Generales.

122 Felipe de Bauzá, nació en 1769. En el año 1813, cuando se le encargó por vez primera la división territorial de la península, era oficial de la Marina, con el grado de capitán de fragata y director del Depósito Hidrográfico en Madrid. Era un especialista en cartografía marítima, y en su carrera militar alcanzó el grado de capitán de navío. Miembro de la Real Academia de la Historia, trabajó en la elaboración del "Mapa General de España". Con la vuelta del absolutismo, en 1823, se exilió en Inglaterra, al ser condenado a muerte y confiscados todos sus bienes en 1826, por haber votado contra el Rey en las Cortes del Trienio. En su marcha a Inglaterra se llevó consigo gran parte de sus documentos, continuando con sus estudios y su investigación en Londres. Por sus conocimientos fue admitido en la "Royal Society" y recibió la orden de la Jarretera. En el año 1833, fue amnistiado por la propia gobernadora y cuando se disponía a regresar a España falleció. Fue enterrado en Westminster. Parte de sus trabajos volvieron a España, donde en la actualidad se encuentran en el Museo Naval de Madrid y otra parte quedó en Inglaterra, en posesión del British Museum 


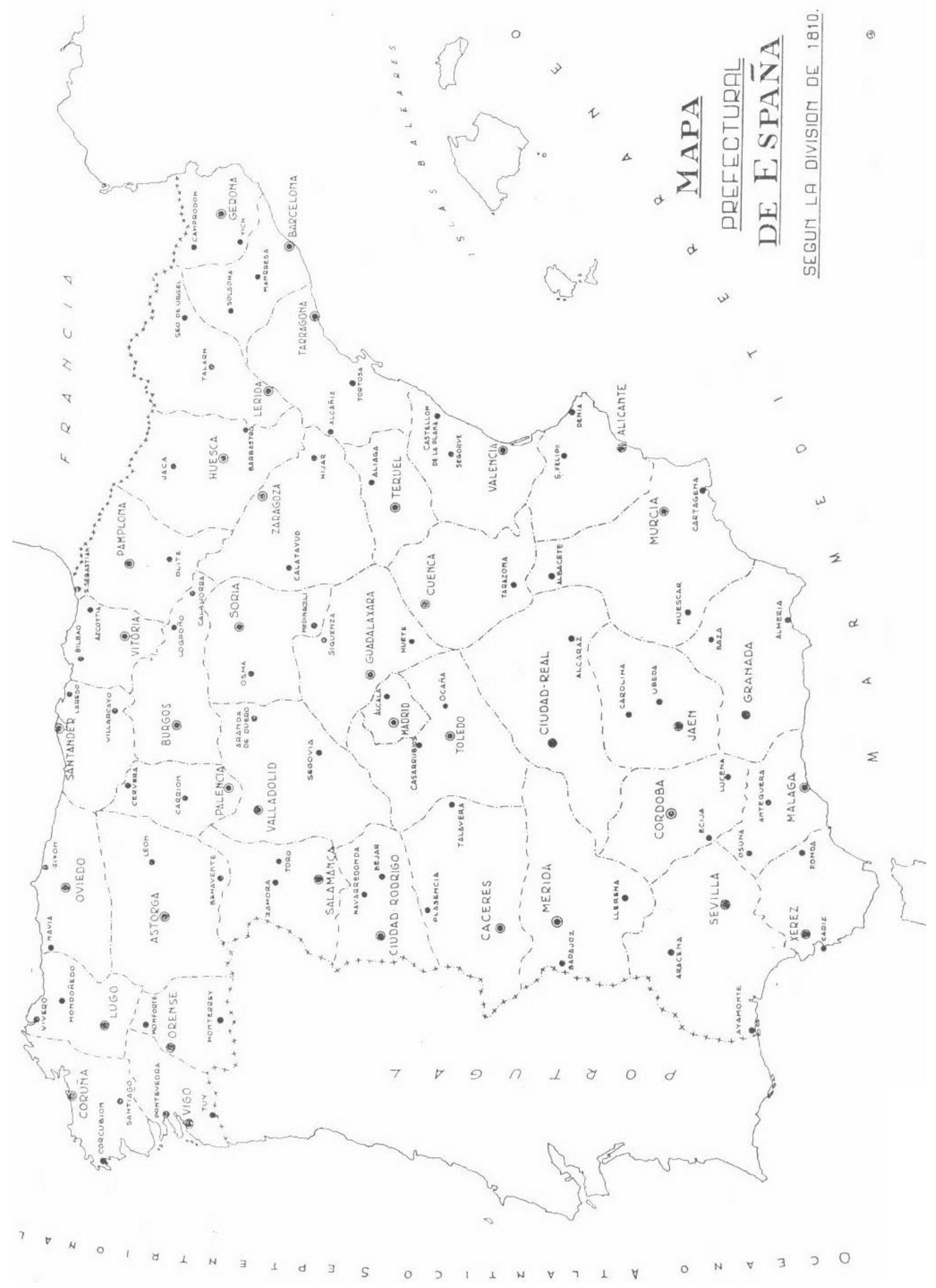

MAPA 4.- Cartograma del mapa prefectoral de España. 
encargo ${ }^{123}$. Como vemos, Bauzá se decide por hacer la división partiendo de la posición económica al considerar este parámetro como el más viable, pero también vemos que mantiene las líneas básicas de la división del Antiguo Régimen y en consecuencia la estructura y los límites de los Antiguos Reinos. Justifica esta suave modificación, en la poca fiabilidad que concede tanto a los datos sobre la riqueza del territorio como a los mapas de la época con los que trabajó para llevar a cabo su labor.

El proyecto presentado estaba constituido por la enumeración de las provincias, descripción de los límites, exposición de los criterios en que se ha basado para la realización del trabajo y un mapa, donde se refleja la división de la península en provincias (Ver Mapa 5). La división la realiza dividiendo el territorio en tres categorías de provincias. La de Valladolid está incluida en las de segunda categoría

En definitiva Bauzá presenta un proyecto formado por cuarenta y cuatro provincias y como característica de la nueva división podemos distinguir: Utiliza accidentes geográficos para establecer los límites de las nuevas provincias y mantiene la división histórica de los antiguos reinos. Fija los límites provinciales utilizando los límites de los términos municipales. Realiza la división en función de la extensión, riqueza y población, con predominio del sentido económico. Presenta modificaciones y reajustes de los límites para eliminar en lo posible los enclaves extra-territoriales.

Finalmente, el día 1 de mayo de 1814, es decir ocho meses después de que entregara al Secretario de Gobernación el expediente, pasó a las Cortes para su discusión, aunque le precedía un informe negativo del Consejo de Estado porque: "Lo hecho era tan incompleto y expuesto a tenerlo que variar, que le parecía al Consejo necesario que las Cortes diesen comisión a personas instruidas para la perfección de este plan y que de una vez se hiciese elevando no sólo el sistema político-económico, sino también el militar, eclesiástico y judicial y mientras tanto permanezcan las cosas en el mismo estado" ${ }^{124}$. Y no hubo tiempo para más, el proyecto quedó arrinconado ya que el 4 del mismo mes de mayo, Fernando VII firmaba su famoso decreto por el que declaraba nula la Constitución y todos los acuerdos tomados por las Cortes.

Por lo que respecta a los límites territoriales de la provincia de Valladolid, con la instalación de la Diputación provincial en 1813, se produce un interés entre los diputados que forman la institución por mejorar las comunicaciones entre la capital y los diferentes pueblos de la provincia "para hacer circular las órdenes". Ven rápidamente que el mayor inconveniente, a parte de la falta de buenos caminos, es la excesiva distancia que hay que cubrir para llegar a los partidos más alejados.

Hay que añadir también que las Cortes, además de la petición que hizo a Felipe de Bauzá para que efectuara la división del país en provincias, y para conocer con más detalle las necesidades y las inquietudes de los diferentes territorios, habían solicitado a los jefes políticos y a las Diputaciones provinciales, la opinión y el punto de vista de estas instituciones en relación con el trazado de los límites provinciales. Por eso no es de extrañar que el día 4 de Octubre de 1813, a los pocos días de la presentación del proyecto de Bauzá, y también al poco tiempo de haberse instalado, la Diputación de Valladolid, envía un Dictamen a la Regencia del Reino, sobre la situación de la provincia y el parecer de la institución sobre los límites provinciales.

123 “... hubiera deseado presentar a V.E. una sub-división más igual en extensión y población, pero ha sido imposible verificarlo por varias consideraciones, imposibles unas y otras dificilísimo de vencer. Las dos calidades de extensión y población son incompatibles, porque una legua cuadrada de ciertos distritos suele tener más población que muchas leguas de otros... y el resultado sería una monstruosidad porque dos territorios iguales en extensión darían uno triple o cuádruple población que otro...además como en el artículo once de la Constitución se habla en general de hacer una más conveniente división del territorio y esta puede ser civil, eclesiástica, militar y económica, me ha parecido tomar por base esta última..." CALERO AMOR, Antonio María. La división provincial de 1833. Bases y Antecedentes. Madrid. 1987. Págs. 113 y siguientes con la Exposición de Felipe de Bauzá al Secretario de Gobernación de la Península, adjuntando el Mapa y la División Territorial, según el acta de Sesiones del Congreso.

124 MARTínEZ DIEZ, Gonzalo. Génesis histórica... ob. cit. Pág. 563. Diario de sesiones de las Cortes. 
Este Dictamen trata, en primer lugar, sobre la pretensión del Partido de Viana del Bollo que solicitaba la declaración de su segregación absoluta de la provincia de Valladolid y su agregación a la de Orense, por razones de índole geográfica. Igualmente recoge los trabajos que inicia una comisión de "individuos" de la Diputación y de la Audiencia para la división de la provincia en partidos judiciales, y en la que se ponía de manifiesto "la monstruosa circunscripción de la provincia de Valladolid, señalando el modo de hacerla desaparecer... no siendo posible mejorar el trabajo remitido de la circunscripción interna de los diez partidos en que podría dividirse esta provincia y en que debieran de rendir los jueces de Primera Instancia, en tanto que no se circunscriba mejor la provincia misma, trabajo urgentísimo que debía de preceder al de la división de partidos y a todos los otros que hubieran de hacerse..." 125 .

Y no contenta la Diputación con organizar con este Dictamen la provincia de Valladolid, también hace referencia en el mismo a la división y fijación de límites territoriales en el resto de provincias de Castilla la Vieja y León "de un modo más natural y de más pronta ejecución porque los montes y los ríos son los que han de influir en estas divisiones..." 126.

El fin del período constitucional acabó con todos los proyectos presentados, y la provincia de Valladolid continuó con la "dislocación de las partes de su territorio". Aunque en la práctica el partido de Viana del Bollo pasó a depender de la provincia de Orense, su vinculación a Valladolid se mantuvo durante el Sexenio absolutista y en los principios del Trienio liberal, especialmente en los casos de hacer frente a los repartimientos de las contribuciones y a los sorteos de mozos para los remplazos del Ejército.

\subsection{4.- LOS LÍMITES PROVINCIALES EN EL TRIENIO El nuevo proyecto de Bauzá y Larramendi}

Con el inicio del nuevo período constitucional, se ponen en marcha las actividades parlamentarias, y las Cortes de nuevo sienten la necesidad de poner en práctica el artículo once de la Constitución, tarea necesaria para el buen funcionamiento de las instituciones constitucionales y en especial el de las Diputaciones provinciales, tema que recordamos quedó interrumpido en 1814 .

En junio de 1820, el Gobierno decidió crear una nueva comisión, y llamó a Felipe de Bauzá y le encargó nuevamente, en esta ocasión en colaboración con el intendente José Agustín de Larramendi, el trabajo de ordenación y repartición del territorio español. Es un trabajo desarrollado en un tiempo de nueve meses, y que está basado en el proyecto de División Territorial que realizó en 1813, estudio al que acompañó su nuevo "Mapa de la Península", para fijar con más precisión los límites. También se apoyó con los datos procedentes del último censo de población que se había realizado en 1818.

En marzo de 1821, Bauzá y Larramendi presentaron su proyecto al Gobierno, con una justificación de los motivos que la habían inclinado a hacer la división. Este segundo proyecto, más detallado y completo que el primero, destaca en comparación con el anterior por una serie de cambios como son: Se añaden siete nuevas provincias: Gerona, Zamora, Ávila (se separa de Segovia), Brihuega (actual provincia de Guadalajara), Valverde del Camino (actual Huelva), Albacete y Calatayud. Reduce las tres provincias vascas a una sola con capital en Vitoria. Suprime la provincia de Écija y deja de incluir en la lista a las Islas Canarias. La división del territorio es de cincuenta y dos provincias en lugar de las cuarenta y cuatro del proyecto de 1813 .

\footnotetext{
${ }^{125}$ Archivo de la Diputación Provincial de Valladolid (Secretaría General). Libro de actas (a partir de ahora A.D.P.V. Actas). Acta del 9 de mayo de 1820 con la "Exposición de la Regencia sobre límites provinciales y partidos judiciales" remitido el 4 de octubre de 1813 .

${ }^{126}$ A.D.P.V. Actas. Libro de actas del 9 de mayo de 1820.
} 


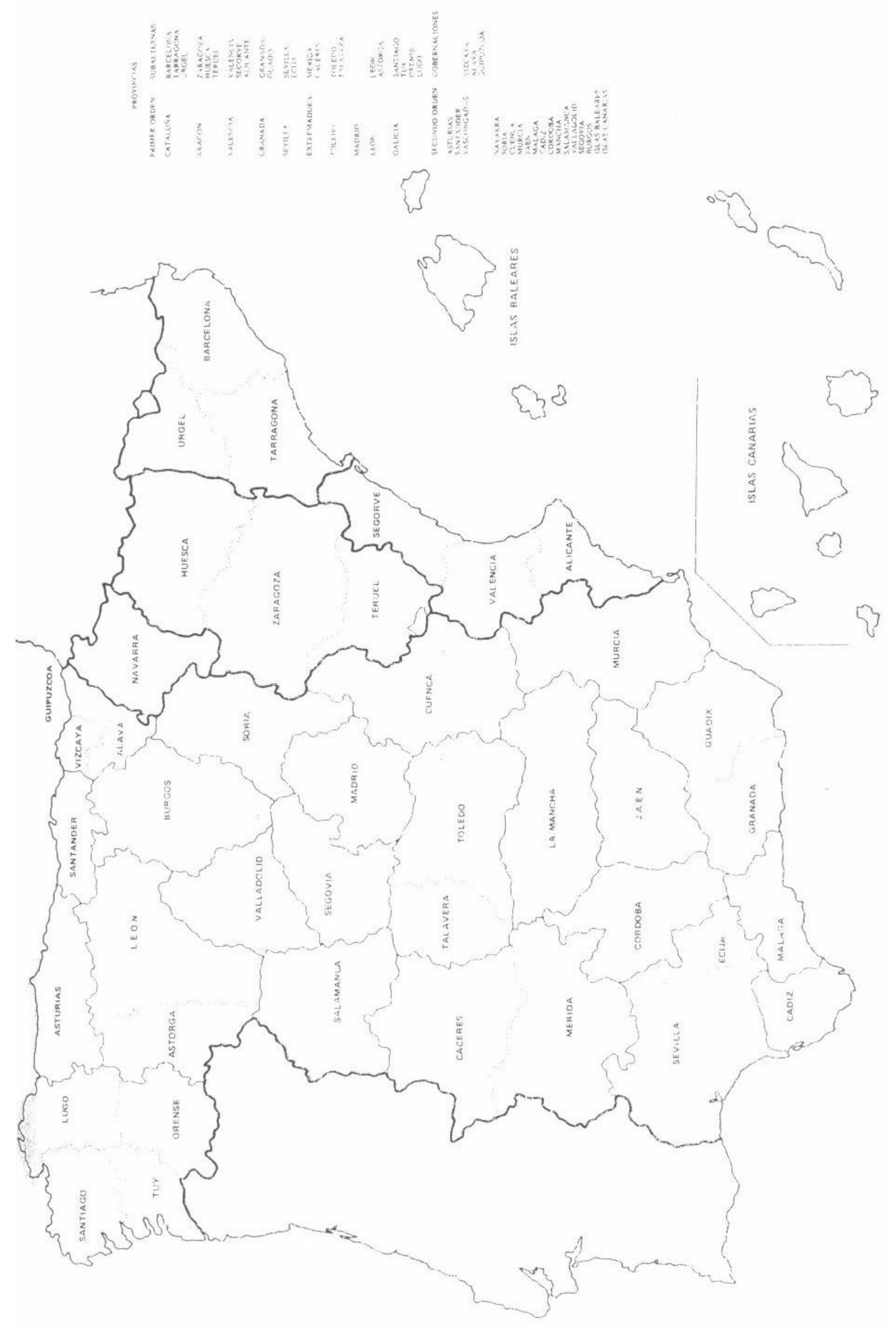

MAPA 5: Proyecto de provincias de Felipe de Bauza. 
Modifica la capitalidad de las provincias, por lo que Santiago, Tuy, Astorga y Guadix dejan de ser capital y en su lugar aparecen La Coruña, Pontevedra, Ponferrada y Baza.

El Gobierno pasó el proyecto a las Cortes para su discusión y aprobación, y éstas comenzaron su discusión a partir del 30 de septiembre de 1821. Las objeciones más importantes que las Cortes hicieron a este trabajo se referían fundamentalmente al coste económico que iba a tener para el Gobierno por el elevado número de provincias, teniendo en cuenta que cada provincia tendría un jefe político y una Diputación, con sus correspondientes funcionarios. También se formularon reclamaciones con respecto a la capitalidad de las provincias, a su denominación y a las quejas de los diputados sobre los nuevos límites. Los trabajos de las Cortes culminaron con la aprobación del proyecto y la publicación del decreto de 27 de enero de 1822 sobre la "División Provisional del Territorio Español".

Vemos que la mayor parte del "tiempo constitucional" transcurre entre la elaboración y el debate del proyecto, y una vez aprobado el decreto, las Diputaciones apenas tendrán tiempo para ponerlo en marcha, ya que tendrán que hacer frente a una serie de reclamaciones, litigios y quejas interprovinciales derivadas de las modificaciones territoriales.

Tampoco en esta ocasión se pudo conocer la bondad de la nueva división, ya que sólo tendrá vigencia hasta octubre de 1823, tiempo insuficiente para el asentamiento de los cambios y la resolución de las reclamaciones efectuadas por diferentes Diputaciones. El 1 de octubre Fernando VII firmaba el decreto declarando "nulos y de ningún valor todos los actos del Gobierno Constitucional...". En definitiva, volvíamos a la situación de 1820, es decir, continuamos sin tener una división provincial que sirva para organizar las funciones administrativas, económicas y políticas del país.

En el caso de la provincia de Valladolid en el año 1820 todavía no se había modificado la "monstruosa circunscripción de la provincia", según nos detallaba el informe de la Diputación de 4 de octubre de 1813 y el proyecto de Bauzá y Larramendi describía las deformidades de la provincia. Las Cortes, el 8 de noviembre de 1820, y a propuesta de la Diputación, en un acto previo e independiente de los trabajos desarrollados por la comisión de Bauzá y Larramendi, aprueba la división de la provincia, a efectos judiciales, en diez partidos: "Valladolid, Peñafiel, Medina del Campo, Olmedo, Tordesillas, Rioseco, Villalón, Puebla de Sanabria, Gradefes y Benavente" 127 .

Pero una cosa es el acto legislativo y otra muy diferente es el de admitir y acostumbrarse a la nueva situación y eso es lo que ocurre con los "repartimientos de las contribuciones así como con los sorteos para los reemplazos del ejército", que siguen considerando el territorio provincial formado con anterioridad. Así lo demuestra que en junio de 1821 se efectúa el repartimiento de trescientos un hombres para el reemplazo del ejército en el que se incluyen como partidos pertenecientes a la provincia de Valladolid a los de Viana del Bollo y Palenzuela.

De todas formas, a lo largo de 1821 se suceden una serie de consultas, comunicaciones y exposiciones de la Diputación, dirigidos tanto al gobierno central como a las Diputaciones limítrofes afectadas, manifestando sus puntos de vista con respecto a los posibles cambios y a las modificaciones que promueve, antes del conocimiento del proyecto de Bauzá y de sus posibles límites territoriales.

Como ejemplo tenemos las comunicaciones de la Diputación de Zamora reclamando que "los pueblos de Villar de Frades, Marzales, Torrecilla y Villalar,

\footnotetext{
127 "Valladolid se componía de 261 leguas cuadradas, 188.000 almas y 5.289 .081 pesos fuertes de riqueza. Sus partidos se hallan más hacia Galicia y otros enclavados en la provincia de León. En las inmediaciones de la capital apenas tenía superficie ni población. Era preciso corregirle estas deformidades y ninguna ciudad de Castilla puede disputarle ser cabeza de provincia, y así era necesario redondearla con un radio proporcionado como se ha hecho con parte de la extinguida provincia de Palencia, la de Toro, Segovia, Burgos y León." Colección de Reales Decretos y Órdenes mandados publicar...ob. cit. Tomo VIII.
} 
pertenecen a su provincia en función de la aprobación por las Cortes de la División de Partidos de la Provincia" ${ }^{128}$.

También es llamativa la reclamación de Palencia que hace saber a la Diputación de Valladolid que: "los once pueblos del Partido de Palenzuela ahora son de esa provincia" y "casi todo el Carrión, Valle del Cerrato y otros pueblos no distantes de Valladolid más de diez leguas, se han agregado a dicha provincia" ${ }^{129}$, noticia que resulta curiosa porque en realidad en el proyecto de Bauzá se contemplaba la desaparición de la provincia y el reparto de sus territorios entre las provincias limítrofes;.

La Diputación de Segovia, otra provincia con la que Valladolid tuvo litigios territoriales, no veía con buenos ojos las reclamaciones que la Diputación vallisoletana hacía sobre territorios que consideraba le correspondían como eran los pueblos de la "comunidad de Iscar", y sobre todo la reclamación sobre Cuellar y sus arrabales. La Diputación de Segovia presentó las alegaciones que consideró oportunas para aclarar la situación sobre los límites inter-provinciales.

La Diputación de Valladolid está preocupada por estas continuas actuaciones y reclamaciones de sus vecinos provinciales, pero sobre todo porque veía cómo se reducía su territorio provincial, en especial al conocer el dictamen de la comisión de las Cortes en las que se reflejaban los límites provinciales y los motivos justificativos de la división, por lo que acordó los perjuicios y la forma de resolverlos ${ }^{130}$. Después de esta exposición y del encargo que se hace al topógrafo Pedro García, y una vez cumplido el encargo por éste, la Diputación vuelve a presentar una nueva exposición a las Cortes extraordinarias y tras un largo y ampuloso elogio de las actividades legislativas, vuelve a pedir una reconsideración de los acuerdos de la comisión ${ }^{131}$.

Tiene razón la Diputación de Valladolid al quejarse de las conclusiones de la comisión, puesto que pierde una parte importante de su territorio, como son: el partido de Gradefes que pasa a la provincia de León y los de Puebla de Sanabria y Benavente que lo hacen a la provincia de Zamora, sin tener en cuenta el partido de Viana del Bollo y la Mezquita, que ya cedió en su tiempo a la provincia de Orense, y sin que quede compensado con otros territorios, pues apenas recibe unos pocos pueblos de las provincias de Ávila, Segovia y Burgos. Además como finalmente se mantiene la provincia de Palencia, la tiene que ceder el partido de Palenzuela, a la vez que tiene dificultades para integrar en Valladolid los pueblos que le pertenecen de esta provincia al negarse la Diputación palentina a reconocer los límites acordados por la comisión.

En definitiva el Decreto aprobado por las Cortes con los nuevos límites provinciales es asumido, no sin protestas, por la Diputación, lo que no es impedimento para seguir ocupándose a lo largo del año 1822 de la gestión de los importantes temas

128 “Exponer al Congreso los perjuicios que sufriría esta provincia de llevarse a efecto esta decisión, y para demostrarlo prácticamente, se encarga al profesor de Nobles Artes D. Pedro García, vecino de esta ciudad, la formación de un croquis o mapa compendioso topográfico de esta provincia y de los confines de las limítrofes en el que con diferentes fases se manifiesta la circunscripción actual de aquella, la que ha señalado la comisión y la que cree esta Diputación debe de quedar, cuyos límites se le manifestaron en el acto" ADPV. Actas. Libro de actas del 27 de junio de 1821 . Hacemos ver que la reclamación se hace en función del Dictamen presentado por la comisión y del proyecto de Bauzá, pero no se corresponde con el Decreto definitivo aprobado en enero de 1823.

129 ADPV. Actas. Libro de actas del día 30 de junio de 1821.

${ }^{130}$ ADPV. Actas. Libro de actas del día 27 de agosto de 1821. Pág. 371.

131 “que estas reflexiones (las que presenta la Diputación) conducen a demostrar que la comisión no ha acertado en la demarcación de esta provincia, porque si con razón la separó de sus lejanos límites al occidente y sin ella, de algunos pequeños pueblos al oriente, no supo surtirla por los demás puntos, por no oponerse a la idea de conservar todas las capitales y señaladamente la de Palencia... Bórrese, pues lo exige la general utilidad del mapa político de España la provincia de Palencia y distribúyase su territorio entre ésta y las de León, Santander y Burgos... y para mejor demostrar lo indicado, en el mapa topográfico adjunto que dentro de la fase encausada cierra la irregular circunscripción actual de la provincia, por la amarilla la señalada por la comisión y por la verde la que debe de tener consultando el interés particular y general de los pueblos..." ADPV. Actas. Libro de actas del 13 de septiembre de 1821. Pág. 418 a 420. 
del repartimiento de contribuciones y reemplazos del Ejército, para lo cual solicita a las Cortes el envío del censo de población que ha servido para los trabajos de la comisión, con el fin de realizar un reparto ajustado a la realidad. ${ }^{132}$. Para poner en ejecución lo más rápidamente posible el decreto, la Diputación de Valladolid se puso en contacto con las provincias limítrofes, solicitando la formación de una serie de comisiones con cada provincia para llegar a los acuerdos pertinentes en casos de litigios sobre la línea divisoria en función del documento oficial donde se detallan los límites de cada provincia ${ }^{133}$.

La Diputación también se comunica con los Ayuntamientos de los pueblos segregados para que se entiendan con sus nuevas Diputaciones ${ }^{134}$. Todas las provincias son reacias a desprenderse de los pueblos que pierden a causa de la "División Territorial" y por este motivo se produce una continua discusión entre las que reclaman los pueblos y las que tienen que cederlos. Lo cierto es que para Valladolid, la provincia que más inconvenientes le pone es la de Palencia, seguramente en "contestación" a la propuesta de la Diputación de Valladolid de "eliminar" la citada provincia. Desde el principio, Palencia se niega a entregar los pueblos que por la División se le concedía a Valladolid al mismo tiempo que reclamaba el control del partido de Palenzuela perteneciente con anterioridad a Valladolid. Las cosas llegaron a tal extremo que la Diputación de Valladolid dirigió una exposición a la Corona reclamando los territorios que la correspondían: "Vista por la Diputación, la resistencia de la provincia de Palencia para desprenderse de los pueblos agregados a este por la última división del territorio, se acordó dirigir a S.M. la siguiente representación" $" 135$.

También y en otro sentido, la Diputación Provincial de Valladolid recibe peticiones de pueblos que, o han pasado a otra provincia o están en los límites de la provincia y que solicitan ser agregados a la de Valladolid: "Mambrilla, Pedrosa, Boada, Quintanamanvirgo, Guzmán, Villavela, Olmedillo, Anguir y La Horra, solicitan ser incorporados a la provincia de Valladolid, mediante la gran distancia a que se hayan de Burgos y otros motivos que expresan"136.

Por lo que respecta a la provincia de Segovia, la Diputación de Valladolid acordó elevar al Gobierno una disposición en la que solicita el replanteamiento de los límites con la provincia segoviana en razón a que: "Vista la exposición hecha por la villa de Cuellar y otros diferentes pueblos pertenecientes a la provincia de Segovia, pretendiendo su agrupación a ésta por la mayor comodidad de hallarse a menor

132 "Necesitando esta Diputación, para dar cumplimiento al Decreto de Cortes relativo a la nueva circunscripción general de provincias y formar en esta el arreglo de partidos según las almas de los expresivos pueblos, tener a la vista el censo de población que sirvió de base y se consideró a cada uno de dichos pueblos en la operación, cuya noticia no será menos interesante y necesaria para distribuir con igualdad los cupos de hombres en la formación de la Milicia Nacional Activa y reemplazo del Ejército permanente. Se acordó pedir a las nuevas Cortes se la provea por su Secretaría de aquel documento, sin el cual está expuesta a padecer equivocaciones de mayor perjuicio en el desempeño de su encargo; y que a su tiempo se pidan a las provincias limítrofes de Ávila, Burgos, Segovia, Salamanca, León, Palencia y Zamora las noticias oportunas" ADPV. Actas. Libro de actas del día 22 de marzo de 1822. Pág. 83v.

${ }^{133}$ Al real decreto de 27 de enero de 1822, "sobre la División Provisional del Territorio Español”, le acompañaba un apéndice, sobre la demarcación de los límites de las diferentes provincias, y fue el que sirvió como documento de trabajo.

134،en virtud del decreto de las Cortes extraordinarias de 27 de enero último en que se prescribe la división del territorio español y por el que han quedado segregadas de esta provincia, las villas de Benavente, Puebla de Sanabria y Gradefes, con todos los pueblos de sus respectivos partidos, se acordó oficiar a los Ayuntamientos de las referidas villas advirtiéndoles que en adelante se entiendan, y sus respectivos pueblos, con la Diputación que por el mismo decreto han sido agregados y que se pasan a aquella corporación cuantos asuntos tienen pendientes en esta". ADPV. Actas. Libro de actas de 24 de mayo de 1822 . Pág. $164 \mathrm{v}$.

135 ADPV. Actas. Libro de actas del 4 de junio de 1822. Se refleja la "Representación a S.M." con la petición de que Palencia ceda los 34 pueblos que según el decreto de 27 de enero de 1822 , se debe de agregar a Valladolid "para alcanzar los 175.100 almas de población que se la determina".

136 ADPV. Actas. Libro de actas de 7 de junio de 1822. Pág. 197 v. 
distancia y mejor camino y de otras ventajas que les proporciona la necesidad de concurrir a esta capital por razón de sus producciones e industrias comercial y fabril..."137. La Diputación de Valladolid aprovecha la ocasión para reclamar al mismo tiempo los tres pueblos de Castrillo de Duero, Rábano y Canalejas que se han segregado de Valladolid y han pasado a Segovia.

Todo este cúmulo de reclamaciones no es exclusivo de la provincia de Valladolid, sino más bien es un problema general en toda la península, lo que obliga al Gobierno a publicar una real orden por la que se acuerda que las Diputaciones se entiendan ya con los pueblos comprendidos dentro de la línea de su demarcación, sin que se opongan a ello las provincias limítrofes, aunque los pueblos de que se trate hayan comprendido antes a ellas" 138 .

En conclusión, la provincia de Valladolid, con los límites aprobados en el decreto de 27 de enero de 1822, está formada básicamente por los anteriores territorios, disminuidos con el partido de Palenzuela que pasa a Palencia, los partidos de Mansilla y Rueda del Almirante que pasan a León y los partidos de Benavente y Sanabria que pasan a Zamora. La división en partidos judiciales queda de la siguiente forma: Valladolid, Medina del Campo, Olmedo, Tordesillas, Medina de Rioseco, Peñafiel, Valoria la Buena, Villalón, Mota del Marqués y Mayorga.

\subsection{5.- LA DIVISIÓN PROVINCIAL DE JAVIER DE BURGOS}

Con el fin del Trienio Liberal y el inicio de la Década Ominosa se produce nuevamente un parón en la evolución legislativa de tendencia liberal. Se vuelve al Gobierno absolutista y con él a las instituciones del Antiguo Régimen, y en materia de ordenación del territorio nos volvemos a encontrar como en 1814, es decir con una situación arcaica que entorpece el progreso y desarrollo de la vida administrativa. Esta situación de deterioro hace que una serie de políticos liberales propusieran reformas para mejorar y solucionar los problemas que el Gobierno absolutista no era capaz de arreglar.

Uno de estos políticos es Javier de Burgos ${ }^{139}$ que en el año 1826 y desde su residencia de París dirige a Fernando VII una Exposición donde analiza las causas de los males que aquejan al país y propone para su arreglo una serie de soluciones, entre las que destaca una profunda reforma en la administración civil del Estado, que contemplaba como necesaria y urgente la reforma de la división territorial. Estas propuestas no fueron aceptadas por el Rey, pero tampoco fueron olvidadas ya que al poco tiempo del fallecimiento del monarca, Javier de Burgos sería llamado a desempeñar una serie de tareas político-administrativas por la Reina Gobernadora.

Fernando VII, muere el 29 de septiembre de 1833 y el 21 de octubre la Reina Gobernadora le reclama para formar parte de su Gobierno, a través de un real decreto

${ }^{137}$ ADPV. Actas. Libro de actas del 7 de junio de 1822. Pág. 207 v.

${ }^{138}$ ADPV. Actas. Libro de actas del 17 de septiembre de 1822. Pág. 316, en la que se refleja la real orden de 5 de septiembre de 1822.

139 Javier de Burgos y Olmo, nació en Motril (Granada) en el año 1778. Estudió en el Colegio de San Cecilio de Granada y amplió sus estudios en Madrid en los ramos de Administración y Economía. En el año 1801, regresó a su ciudad natal para ejercer el cargo de regidor perpetuo y llevar la administración de sus propiedades. Durante los años de la invasión francesa desempeñó el cargo de sub-prefecto de Almería, después fue nombrado presidente de la Junta de Subsistencias de Granada de donde pasó a corregidor de la misma ciudad. En el año 1812, acusado de colaboracioni sta con los franceses, tuvo que abandonar su ciudad y marchó a Francia, donde continuó perfeccionando sus estudios administrativos. En 1817 regresó a España, instalándose en Madrid, donde ejerció el periodismo, llegando a ser director del Imparcial. En 1824 es encargado de gestionar el empréstito que solicitó el Gobierno en 1823 con los banqueros de París. Esta gestión le permitió conocer además la legislación francesa en materia de Administración Civil y también en estos años envió su famosa "Exposición" al Rey reflejando los males de la administración española. En 1827 regresó a España, se le concedió la Cruz de Carlos III y se le nombró miembro de las Juntas de Fomento y Aranceles del Consejo Supremo de Hacienda. En 1832 se retiró a sus posesiones de Granada donde permaneció hasta octubre de 1833, en que fue reclamado por la Reina Gobernadora para desempeñar el cargo de ministro de Fomento. También colaboró en la redacción del Estatuto Real. Murió en 1849. 
por el que se le nombra ministro de Fomento. En el mismo decreto la Reina Gobernadora "le encarga que se dedique antes de todo a plantear y proponerme, con acuerdo del Consejo de Ministros, la división civil del territorio español como base de la administración interior y medio para obtener los beneficios que meditaba hacer a sus pueblos..."140.

Los trabajos encomendados son realizados de una manera sorprendentemente rápida, y llama la atención de que a mediados de noviembre la propuesta de división provincial está pendiente del Consejo de Gobierno. El 30 de noviembre del mismo año de 1833 , es decir a los treinta y nueve días de recibir el encargo se dan por finalizados los trabajos, al publicarse el real decreto "mandando hacer la División Territorial de Provincias". Esta rapidez hace suponer que la división provincial de todo el territorio español realizada en tan corto espacio de tiempo, o estaba preparada de antemano o se utilizaron en su realización elementos anteriores ${ }^{141}$.

También es evidente que semejante trabajo no se puede hacer en tan poco tiempo si no se tenía ya un material abundante y elaborado, por muchos que fueran los colaboradores del ministro en esta tare ${ }^{142}$.

Pero la prueba de que la "División Provincial" de Burgos se apoyó en trabajos anteriores la tenemos en el mismo preámbulo del real decreto de 30 de noviembre, cuando la Reina Gobernadora dice que: "así lo habían verificado después de haber reconocido los prolijos trabajos hechos antes de ahora por varias comisiones y personas sobre tan importante materia" $" 143$.

Todas estas hipótesis, se refieren como es lógico, al aprovechamiento de los trabajos realizados en el Trienio por Bauzá y Larramendi, a los que se deben de añadir los documentos con las opiniones, comunicaciones y exposiciones que remitieron las Diputaciones provinciales, así como las reclamaciones que estas mismas instituciones hicieron al proyecto, a lo largo de los años 1822 y 1823.

No cabe duda de que Javier de Burgos conoció, estudió y se basó en los proyectos anteriores ante la similitud de las soluciones ${ }^{144}$, y eso no es inconveniente para reconocer la importancia de su trabajo, destacando unas características que Bauzá había obviado, como por ejemplo el respeto a los límites y la tradición histórica.

Estas opiniones, repetimos, no pretenden quitar méritos al trabajo realizado por Burgos, del que no podemos olvidar que es un especialista en organización administrativa, y también hay que recordar que la Reina-Gobernadora le eligió para el puesto, aparte de por su experiencia, por su planteamiento sobre la organización administrativa del país que hizo y quedó reflejado en la "Exposición a Fernando VII", analizando los males y proponiendo remedios. Es importante reconocer que la división territorial, aunque tenga puntos de contacto con los anteriores estudios, ha tenido que ser fruto de un profundo estudio de un tema tan problemático y discutido a lo largo de los últimos años.

Las diferencias más características entre el proyecto de Bauzá y el trabajo sobre la división territorial de Burgos son los siguientes: $1^{\circ}$. Las cincuenta y dos provincias del proyecto de 1823 quedan reducidas a cuarenta y nueve en la división de Burgos, al quedar suprimidas las provincias de Játiva, Calatayud y Villafranca del Bierzo. $2^{\circ}$. Se realizan cambios en alguna capitalidad, la de Chinchilla pasa a Albacete y la de Vigo a Pontevedra. $3^{\circ}$. Se hace una división por regiones: Andalucía, Aragón, Castilla la Vieja, Castilla la Nueva, Cataluña, Extremadura, Galicia, León, Murcia, Navarra, Valencia y Vascongadas. $4^{\circ}$. Los límites históricos de los antiguos reinos son

140 Decreto publicado en la Gaceta de Madrid el 22 de Octubre de 1833. Pág. 1.

${ }^{141}$ Opinión mantenida por Gonzalo MARTÍNEZ DIEZ, en Génesis Histórica ... ob. cit. Pág. 586.

${ }^{142}$ CALERO AMOR, Antonio María. La División Provincial... ob. cit. Pág. 43.

${ }^{143}$ Prólogo al Real Decreto de 30 de noviembre de 1833. En Colección de Reales Decretos publicados en el Nuevo Diccionario de Legislación de Aranzadi. Tomo XIX. Pág. 1254-1266.

${ }^{144}$ CALERO AMOR, Antonio María. La División Provincial... ob. cit. Pág. 44. Mantiene que la coincidencia de límites entre 1822 y 1833 es del $85-90 \%$ "después de haber cartografiado la división de 1822 sobre un mapa actual". 
respetados en todo el ámbito peninsular. $5^{\circ}$. Las variaciones más importantes son las realizadas en las provincias de Castilla, al ser éstas las más irregulares y las que más enclaves poseían. $6^{\circ}$. La denominación de la provincia se corresponde con el nombre de la capital excepto en cinco casos: Vizcaya, Guipúzcoa y Álava, Navarra y Canarias que tienen por capitales a Bilbao, San Sebastián, Vitoria, Pamplona y Las Palmas.

Independientemente de su origen o del grado de autoría que tenga la división provincial de Javier de Burgos, no podemos olvidar que su gran virtud ha sido que se ha mantenido prácticamente sin modificación hasta nuestros días. El mayor cambio que ha sufrido ha consistido en la división de Canarias en dos provincias: Gran Canaria y Tenerife, que se dividieron a partes iguales la extensión del archipiélago.

Es cierto que, como todos los cambios que se producen en los temas de límites y dominios, esta división no se salvó de las críticas y reclamaciones, en especial de las provincias que se consideraban perjudicadas, pero también es cierto que estas reclamaciones lo fueron en mucha menor medida que las que sufrieron los anteriores proyectos de 1813 y 1822 .

En conclusión, la división provincial fue aprobada por el Gobierno y aunque mantuvo el carácter de "provisional" al no pasar por las Cortes para su aprobación, fue puesta en marcha y siendo admitida por las instituciones provinciales, y dado su carácter general, también sirvió para que a partir de esta división se realizaran otras, como fueron las demarcaciones militares y las judiciales.

\section{La provincia de Valladolid. Su configuración definitiva a partir de 1833}

La provincia de Valladolid también en esta ocasión ve nuevamente recortados sus límites territoriales y no tiene un organismo representativo que pueda reclamar y argumentar a favor del mantenimiento de su integridad territorial, ya que la Diputación Provincial continua suspendida en sus funcionamiento y el jefe político, por un lado no tiene interés en enfrentarse al Gobierno que le nombró, y por otro lado no llega a conocer a fondo la problemática provincial debido al poco tiempo que suele permanecer al frente de la provincia.

Es un hecho cierto que la Diputación protestó ante el Gobierno en el año 1822 por "los perjuicios que le ocasionaba a la provincia la División de Bauzá", y eso es lo que hubiera ocurrido en el año 1833, es decir, tenía que haber protestado nuevamente en el año 1833, puesto que nuevamente la división territorial propuesta por Javier de Burgos, volvía a recortar la extensión provincial y eso es lo que hizo en 1835 a raíz del restablecimiento de las Diputaciones provinciales.

Al margen de las posibles reclamaciones de las provincias que se consideraban perjudicadas, vemos que es el Gobierno el que se encuentra con dificultades graves para poner en marcha y hacer cumplir el citado real decreto- Se ve obligado a "dar marcha atrás", si quiere mantener en funcionamiento, aunque sea "bajo mínimos" la actividades administrativas del país, sobre todo en tareas tan sencillas y que son las que marcan la vida tanto política como social del país, como son las referidas a los repartimientos de las contribuciones y a la celebración de los sorteos para los remplazos del ejército. Es el caso del real decreto de febrero de 1834: "ordenando un sorteo de 25.000 hombres para el Ejército, respetando el cupo de las antiguas provincias" $" 145$.

La necesidad de soldados ocasionada por la guerra civil, obliga al Gobierno a apoyarse en los límites anteriores, que ya estaban consolidados y reconocidos, y de esta forma evitar la confusión y las reclamaciones posteriores que iban a presentar la mayoría de las provincias a la hora de fijar los cupos provinciales para el repartimiento de los mozos.

Estos planteamientos y el mantenimiento parcial de la vigencia de anteriores divisiones provinciales no es obstáculo para que administrativamente el Gobierno

145 B.O.P.V. $\mathrm{n}^{\circ} 48$ de fecha 4 de marzo de 1834. Se publica el real decreto para el reemplazo del Ejército. 
continúe con su proceso de modernización provincial al establecer a través de un real decreto la división de la provincia de Valladolid en partidos judiciales ${ }^{146}$.

Esta división judicial se hace de acuerdo y tomando como punto de partida la división territorial de Javier de Burgos, aunque la aprobación de este decreto se vuelve a contradecir con la realidad a la hora de hablar de repartimientos de las contribuciones, ya que: "se acuerda hacer la distribución de la provincia en ocho partidos para el cobro de los arbitrios de Amortización"147. Distribución que se hace sin tener en cuenta la división de partidos realizada en 1834, y sobre todo que en la provincia de Valladolid vuelven a aparecer los partidos de Benavente y Sanabria: "con la tierra de Benavente compuesta por ciento veinte lugares poco considerables y Puebla de Sanabria con noventa y un lugares" ${ }^{148}$.

Estos vaivenes territoriales a que está sometida la provincia tienden a normalizarse y a centrarse en la "División Territorial" de 1833, cuando para dar cumplimiento al real decreto de 21 de septiembre de 1835 sobre el restablecimiento de las Diputaciones provinciales, el Gobierno Civil de la provincia de Valladolid, a este fin, acuerda: "la distribución de los pueblos de esta provincia que deben de reunirse para nombrar sus personas que han de concurrir respectivamente al pueblo central y a la cabeza de partido para la elección de diputado provincial suplente" ${ }^{149}$, aunque una serie de reales decretos aparecidos en el año 1836, vuelven a complicar la situación provincial al publicar la vigencia de la división de $1822^{150}$.

Esta comunicación no es exclusiva de la provincia de Valladolid, y aunque en la misma no se explican los motivos por los cuales se vuelve a poner en marcha la división de 1822, sí que se explican en otras comunicaciones remitidas a otras provincias, como queda patente en la siguiente real orden ${ }^{151}$. Estos vaivenes finalizan con la publicación el 23 de septiembre de una nueva real orden. ${ }^{152}$

${ }^{146}$ B.O.P.V. $n^{\circ} 44$ de 3 de junio de 1834 , donde se publica el real decreto de 21 de abril de 1834 "sobre la división del territorio español en partidos judiciales", en el que aparece para la provincia de Valladolid la formación de nueve partidos: Medina, Mota, Nava del Rey, Olmedo, Peñafiel, Rioseco, Valoria, Valladolid y Villalón, representando a un total de 274 pueblos, 47.493 vecinos y 184.642 habitantes.

${ }^{147}$ B.O.P.V. ${ }^{\circ} 64$ de 10 de agosto de 1835.

${ }^{148}$ Ibídem. Es curioso que en temas de repartimientos de contribuciones, se vuelve a considerar a Benavente y Puebla de Sanabria como territorios de la provincia de Valladolid. Lo mismo ocurre con el partido de Villalpando, que siendo de Zamora pasó a pertenecer a Valladolid a partir de la división de Bauzá de 1822 y que con la división de Javier de Burgos deja de pertenecer a Valladolid, pero que a nivel de partidos judiciales, sigue perteneciendo al ámbito de la provincia vallisoletana.

${ }^{149}$ B.O.P.V. $\mathrm{n}^{\text {0 }} 81$ de 8 de octubre de 1835, donde se relacionan los nueve partidos judiciales consolidados de la provincia de Valladolid y donde no se encuentran los territorios de Benavente y Puebla de Sanabria. Tampoco aparece en esta relación la comarca de Villalpando, ajustándose en este caso el ámbito provincial al acordado en la División Territorial de 1833.

150 "Se dio cuenta de la comunicación del jefe político, transcribiendo la real orden de 14 de septiembre de 1836 por la que manda S.M. que se restablezcan provisionalmente la demarcación de límites de esta provincia, aprobada por las Cortes en el decreto de división política del territorio español el 27 de enero de 1822. La Diputación se dio por enterada”. A.D.P.V. Actas. Comunicación aparecida en el libro de actas de fecha 5 de octubre de 1836. Pág. 167 v, aunque no se transcribe la R.O. de 14 de septiembre de 1836 .

151 "Enterada S.M. la Reina Gobernadora de lo que la Junta de Armamento y Defensa de esa provincia ha hecho presente acerca de los graves inconvenientes que resultan de la demarcación de límites que a la misma se asignaron por el real decreto de 30 de noviembre de 1833 , he tenido a bien resolver, atendiendo a la conveniencia pública, y conformándose con lo que dicha Junta ha propuesto, que sin perjuicio de las rectificaciones a que haya lugar en vista de los trabajos que presente la comisión mixta de división territorial, se restablezca provisionalmente la demarcación de límites de esa provincia aprobada por las Cortes en el decreto de división política del territorio español de 27 de enero de $1822 \ldots$.. Real orden de fecha 14 de septiembre de 1836, dirigida al jefe político de la provincia de Logroño, publicada en la Gaceta de Madrid el 22 de septiembre de 1836.

152 "Mandando activar la rectificación de la división territorial porque ha llegado felizmente la hora de hacer palpar a los pueblos los resultados positivos de una benéfica administración. S.M. la Reina Gobernadora desea emprender vigorosamente todas las reformas y mejoras que el tiempo señaló como precisas. Y una de las bases más esenciales para asentar estas mejoras es la acertada división 
Ni las críticas a la división territorial de 1833, ni la vuelta provisional a la división de 1822, ni el reconocimiento por parte del gobierno central de que Javier de Burgos realizó "una división rápida y sin todos los datos", influyeron en la provincia de Valladolid a efectos de una modificación de límites. Más bien, en este caso, el Gobierno ratificó todo lo hecho en 1833, a pesar de las diferentes reclamaciones que efectuaron los pueblos a través de la Diputación provincial. Son reclamaciones de pueblos que han pertenecido a Valladolid y no quieren cambiar de provincia y de pueblos limítrofes de otras provincias que solicitan pertenecer a Valladolid.

Es el caso de los pueblos de Villafranca de Duero y Cotanes que reclaman su pertenencia a la provincia de Valladolid, en lugar de a la de Zamora, provincia a la que pertenecen según el decreto de división territorial.

Estas reclamaciones territoriales generalmente vienen ocasionadas por la cercanía de los pueblos a los límites provinciales, y en muchos casos porque los vecinos de un pueblo tienen sus propiedades en zonas que han quedado en otra provincia, como es el caso de Iscar, pueblo situado al sur de la provincia y que reclama: "a los vecinos de otros pueblos con propiedades en Iscar para que paguen sus impuestos en Iscar y no lo hagan en la provincia de Segovia" ${ }^{153}$. Iscar es uno de los pocos territorios que son agregados a la provincia de Valladolid, procedente de la de Segovia, pero resulta que los pueblos cercanos de su influencia continúan perteneciendo a esta última provincia.

A lo largo del año 1836, continúan las reclamaciones y dudas de las Diputaciones sobre los límites territoriales, pero ya están canalizadas a través de las diferentes comisiones mixtas interprovinciales, creadas al efecto para estudiarlas y presentarlas a la aprobación de las Diputaciones interesadas, como lo recuerda la Diputación de Valladolid al solicitar que: "las comisiones mixtas formadas para la aclaración de las diferentes reclamaciones sobre la división territorial, trate al mismo tiempo las reclamaciones de los pueblos" ${ }^{154}$.

Los trabajos de las diferentes comisiones van progresando, aunque a veces sea de forma lenta, pero estos progresos se ven cuestionados por el Gobierno de la nación en cuanto tratamos, como hemos repetido anteriormente, de temas de repartimientos de contribuciones y de temas de reemplazos del ejército. Como ejemplo tenemos la consulta que la Diputación de Valladolid, y no nos olvidemos que estamos en 1836, hace: "para efectuar el repartimiento de los 4.200.000 reales de vellón, que corresponden a la provincia del repartimiento de los 200 millones, necesita conocer la riqueza de los partidos de Puebla de Sanabria y Benavente, y a tal fin se nombra a D. José Campesino en Benavente y a D. Alonso Rodríguez en Sanabria” ${ }^{155}$.

Vemos cómo en temas de recaudación se continúa con la división provincial anterior, y no sólo a 1833, sino también a 1822, es decir, nos remontamos a la división provincial existente en la época constitucional de 1812. Este planteamiento sobre el repartimiento de los 200 millones y los territorios afectados es admitido con normalidad, tanto por la Diputación de Zamora, que no pone ningún impedimento a que sea Valladolid la que se ocupe del repartimiento en territorios que son de su provincia, como por los pueblos afectados, cuando Benavente: "solicita reformar el repartimiento de los 4.200.000 reales, reformando el amillaramiento de los vicios que contenía" ${ }^{156}$.

Hacemos notar que la petición de reforma de Benavente, se realiza después de transcurrido más de un año del nombramiento de un comisionado para el estudio de su riqueza, con cuyos trabajos parece que el pueblo no ha quedado satisfecho, puesto que en febrero de 1838, continúa reclamando a la Diputación de Valladolid y ésta resuelve

territorial, por eso fue una de las primeras disposiciones tomadas..." B.O.P.V. N N $^{\circ} 19$ de 27 de septiembre de 1836, donde se publica la real orden.

153 A.D.P.V. Actas. Libro de actas de la sesión 69 de 10 de febrero de 1836.

154 A.D.P.V. Actas. Libro de actas. Sesión 90 de 10 de junio de 1836.

${ }^{155}$ A.D.P.V. Actas. Libro de actas. Sesión 112 del 19 de septiembre de 1836. Pág. 112.

${ }^{156}$ A.D.P.V. Actas. Libro de actas. Sesión 11 del 11 de enero de 1838. Pág. 40. 
que: "se deniega la solicitud de rebaja de la contribución correspondiente a la villa (de Benavente) en el repartimiento de los 200 millones" ${ }^{157}$. Y en el mismo mes, aparece otra reclamación, en esta ocasión correspondiente a los párrocos de Puebla de Sanabria, que se quejan y solicitan la devolución de las contribuciones.

Tenemos que admitir que todas estas reclamaciones son una excepción, ya que el empréstito de los 200 millones es un problema que se mantenía sin resolver, y al que se resistían los pueblos a contribuir a lo largo de los años. La realidad nos dice que los límites territoriales se van asumiendo y estabilizando a lo largo del año 1837. Las reclamaciones que se producen se centran especialmente en la fijación y discusión sobre los respectivos términos municipales, y en las peticiones para que no se reclamen pagos a los diferentes pueblos por las provincias a la que pertenecieron con anterioridad. Es el caso de Villafranca de Duero, que si con anterioridad reclamaba por su pertenencia a Valladolid y su afán por seguir perteneciendo a la misma provincia, ahora se queja: "por los límites con los pueblos de Toro y Tagarabuena" 158.

Lo mismo ocurre en los límites territoriales con Palencia, cuando el pueblo de Piñel de Arriba reclama a la Diputación de Valladolid: "el no tener que pagar al Ayuntamiento de Palencia el encabezamiento de niños expósitos"159.

Es una realidad que la mayoría de las reclamaciones sobre límites provinciales y ámbitos territoriales se refirieron a los territorios colindantes de las provincias de Zamora y Palencia. Con la primera de ellas, a causa de la gran extensión de territorios de las tierras de Benavente y Sanabria, además de Villalpando, que pasaron de Valladolid a Zamora. Como hemos visto con anterioridad, en temas especialmente contributivos seguían siendo controlados por Valladolid, lo que provocó las quejas del intendente de Zamora, interesado en controlar, ya en el año 1839: "el repartimiento de pueblos de la provincia de Zamora, que fueron de la provincia de Valladolid" ${ }^{160}$.

En el caso de Palencia, a pesar de que en esta división "se le devolvía" a la provincia palentina los territorios que habían pertenecido a Valladolid, como es el caso del partido de Palenzuela o de algunos términos del sur palentino, en el fondo se notaba el malestar de la Diputación de Palencia, ante la propuesta que realizó la Diputación vallisoletana en el año 1821, de solicitar la desaparición de la provincia de Palencia y el reparto de su territorio entre las provincias limítrofes ${ }^{161}$.

En definitiva, las provincias se van asentando, y los límites territoriales van siendo reconocidos por todas las Diputaciones. La provincia de Valladolid y sus instituciones aceptan las pérdidas de territorio que han sufrido a lo largo de las anteriores leyes sobre ordenación territorial. Lo mismo ocurre con esta nueva división de Javier de Burgos de 1833, que aunque no hay mucha diferencia con la realizada por Bauzá en 1822, sí es cierto que la provincia sigue perdiendo terreno. Se queda sin los territorios de Villalpando, que pasan a Zamora, los de Roa de Duero que pasan a Burgos, y la parte sur del Valle del Cerrato que pasa a la provincia de Palencia, territorios que en realidad no pertenecieron a Valladolid, salvo en el período comprendido entre 1822 y 1833 , es decir, fueron añadidos a la provincia de Valladolid en el proyecto de Bauzá, pero volvieron a pertenecer a su anterior provincia con el proyecto de Javier de Burgos.

\section{2.- LOS DIFÍCILES COMIENZOS DE LA DIPUTACIÓN}

El día 19 de marzo de 1812, las Cortes Constituyentes, reunidas en la Iglesia de San Felipe Neri de Cádiz, aprobaron el texto de la primera Constitución, con que se dotaba a la nación española. Una de las principales innovaciones que caracteriza a esta Carta Magna es la correspondiente a su título sexto, "Del Gobierno interior de la

${ }^{157}$ A.D.P.V. Actas. Libro de actas. Sesión 26 del 15 de febrero de 1838. Pág. 119.

${ }_{158}$ A.D.P.V. Actas. Libro de actas. Sesión 70 del 14 de noviembre de 1837. Pág. 162v.

159 A.D.P.V. Actas. Libro de actas. Sesión 67 del 31 de mayo de 1838. Pág. 17.

${ }^{160}$ A.D.P.V. Actas. Libro de actas. Sesión 148 de 30 de abril de 1839. Pág. 5.

161 A.D.P.V. Actas. Libro de actas del 13 de septiembre de 1821. Pág. 418v. 
Provincia y de los Pueblos", que en su capítulo primero trata sobre los Ayuntamientos y en el capítulo segundo desarrolla "El Gobierno Político de las Provincias y de las Diputaciones Provinciales". Se trata de la creación de la Diputación como institución provincial, y "como punto intermedio de comunicación entre el poder central y el poder local". En definitiva, lo que pretende es instaurar un organismo que sirva para transmitir y velar por el cumplimiento de las órdenes que el gobierno central pasa a los Ayuntamientos. Otra de las intenciones que los legisladores dan a la creación de la Diputación es la de fomentar el progreso en el ámbito provincial" ${ }^{162}$.

\subsection{1.- SITUACIÓN A ESCALA NACIONAL}

\section{Situación político-administrativa}

España en 1812 estaba sumida en una profunda crisis a nivel político, administrativo y especialmente bélico. La lucha contra los ejércitos franceses se extendía por toda la península y el país se encontraba dividido en dos bandos irreconciliables: los patriotas y los afrancesados.

Dentro de estos enfrentamientos, el único punto de vista que compartían, tanto el gobierno napoleónico de José I, como los diputados liberales que trabajaban en Cádiz, era la necesidad de erradicar las instituciones del Antiguo Régimen, y en su consecuencia, modernizar la vida del país. Unos se lo proponían a través de legislar "a imagen y semejanza de las instituciones francesas" y otros a partir de las ideas liberales que se desarrollaban en Cádiz y que quedarían plasmadas en la Constitución de 1812.

Los esfuerzos que se realizan por el gobierno josefino, tanto a nivel institucional, social o administrativo, en verdad no se vieron coronados por el éxito debido a las dificultades que surgían para ponerlos en marcha, a causa, por un lado, de los enfrentamientos bélicos, pero sobre todo por la negativa de la mayoría del país a colaborar con los invasores franceses.

Por "parte de Cádiz", tanto la desaparición de las instituciones del Antiguo Régimen, como la consolidación de los nuevos organismos previstos en la Constitución, no progresaban con la rapidez prevista por los liberales.

En realidad, en estos años, tenemos por un lado a "la España bajo la administración francesa", con su planteamiento administrativo viable y aceptable, pero que no cala en la ciudadanía, más interesada en fomentar el desorden civil para exasperar a los invasores y, por otro lado, tenemos el panorama de "la España liberal e independiente", que en lugar de aplicarse para desarrollar las propuesta establecidas en Cádiz, está inmersa en la lucha por mantenerse en el poder como "si de reinos de taifas se tratara" a través del establecimiento de Juntas de Gobierno a nivel regional, provincial y local fomentadas por un sinfín de "notables locales".

\section{Inicio de las actividades}

Tras la proclamación de la Constitución el 19 de marzo de 1812, con el consiguiente mandato de establecimiento de las Diputaciones provinciales a través del decreto de 23 de mayo del mismo año, se inicia por todo el territorio nacional una serie de actividades políticas, tendentes a la formación de las diferentes Diputaciones, que se llevarán a efecto en diferentes fechas y en diversas provincias.

De todas formas, la existencia de una serie de organizaciones provinciales, como eran las Juntas de Subsidio, Armamento y Defensa, o las Juntas Superiores o Juntas Provinciales, hizo que la instalación de las Diputaciones se hiciera de forma lenta.

${ }^{162}$ ANTA MUÑOZ, Antonio de. La Diputación Provincial de Valladolid (1813-1823). Aspectos institucionales. Año 2002. Pág. 7. Trabajo de investigación inédito. 
Una de las primeras en instalarse es la de Cataluña, considerada en la división territorial como una sola provincia, y que lo hace el 30 de noviembre de $1812^{163}$. La mayoría de las Diputaciones se instalan a lo largo del año 1813, como es el caso de Asturias que lo hará en los primeros días de marzo ${ }^{164}$, o la del Reino de Galicia, que estando también considerada como otra única provincia, con una clara división administrativa y sin graves preocupaciones por la posible ocupación francesa, no decide instalar su Diputación hasta el día 9 de marzo del citado año de 1813, fecha de su primera sesión celebrada en Santiago de Compostela, ciudad en la que al mismo tiempo se produce el cese de la Junta Suprema ${ }^{165}$.

Poco a poco y en todo territorio nacional, se van instalando las diferentes corporaciones. Murcia lo hará el 13 de abril, Ciudad Real el 30 de mayo, León el 30 de junio, Jaén el día 8 de agosto, Salamanca el 14 de agosto, al poco de quedar libre de tropas francesas, Palencia el 6 de septiembre, Toledo y la provincia de Extremadura lo harán el 9 de septiembre, Segovia el 1 de octubre. A lo largo del segundo semestre del año lo hacen la mayoría de las treinta y una provincias en que estaba dividido el país ${ }^{166}$.

\subsection{2.- SITUACIÓN A ESCALA PROVINCIAL}

$\mathrm{Si}$ a nivel nacional la instalación de las nuevas instituciones no fue una tarea fácil, en el escalón provincial, una serie de factores de índole política, social y económica entorpecen la puesta en marcha del nuevo organismo, agravado en el caso vallisoletano por la continua presencia de las tropas francesas en la ciudad, situación que impedía una normalización de la vida ciudadana.

\section{Situación política de Valladolid}

La provincia, desde un punto de vista político ${ }^{167}$, se encuentra dividida en dos grupos bien definidos: los afrancesados y los patriotas, y a su vez, éstos últimos estaban divididos en otros dos grupos: los serviles y los liberales, que si en su primer momento se unen para luchar contra los franceses, al final se convertirán en dos facciones irreconciliables. Esta situación puede ser considerada como "de auténtica guerra civil" motivada por una serie de acontecimientos como son: La ocupación francesa y sus continuas peticiones de alimentos, de equipamientos y de dinero, lo que provoca continuas quejas, lamentos y reclamaciones. El sentimiento patriótico, que reacciona de una manera tanto más exultante cuanto mayor es la presión a que se ve sometido por parte de los ocupantes. El persistente sentimiento conservador que desconfía de los cambios políticos, del mismo modo que desconfió de los cambios propuestos por los franceses. Ante esta situación, se produce en algunos sectores un acercamiento y aceptación de la filosofía liberal, como mal menor y preferible a la ocupación francesa, aunque la mayoría mantiene "las tradiciones ancestrales negadoras de cualquier cambio" $" 168$.

\section{Situación social vallisoletana}

La situación social es fruto de la enrevesada situación política, de la catastrófica situación económica y de la exigente situación militar.

${ }^{163}$ ORTEGO GIL, Pedro, Evolución legislativa.... ob. cit. En su página 225 nos indica la fecha de su instalación, citando la obra "Los orígenes de la Diputación de Barcelona".

${ }^{164}$ CARANTOÑA ÁLVAREZ, Francisco. La guerra de la Independencia en Asturias. Madrid. 1983, donde relata que la Diputación "se constituirá el día marcado por la Constitución, es decir, el día 1 de marzo de 1813".

165 GONZÁLEZ MARIÑAS, Pablo. Las Diputaciones Provinciales... ob. cit. Hace referencia a la sesión de instalación de la Diputación, celebrada el día 9 de marzo de 1813.

${ }^{166}$ Ibídem. Información de las diferentes comunicaciones que recibe la Diputación de Galicia, procedentes de otras provincias, anunciando su instalación. Págs. 67 y 68.

167 ANTA MUÑOZ, Antonio de. La Diputación... ob. cit. Pág. 18.

${ }^{168}$ ALMUIÑA FERNÁNDEZ, Celso. Historia de Valladolid. Valladolid en el Siglo XIX. Tomo VI. Pág. 110 y sig. 
No cabe duda de que el pueblo se ve agobiado por las diferentes situaciones en las que se ve inmerso, y una de las causas que provoca esta situación es la "hambruna" que se padece a lo largo y ancho de la provincia. Valladolid, desde el año 1803 en que se iniciaron las malas cosechas, no hace sino padecer hambre, y con el hambre aparece la miseria y la falta de trabajo, teniendo en cuenta la dependencia agrícola de la provincia. Las instituciones benéficas no son capaces de absorber el alto número de vagabundos y mendigos que pululan por los pueblos y por los campos ${ }^{169}$.

Además, como hemos relatado anteriormente, en los inicios de la vida constitucional, Valladolid sigue manteniendo una importante guarnición militar, lo que produce un continuo encarecimiento de los productos alimenticios. Ortega Rubio ${ }^{170}$, cronista de la ciudad, nos lo resalta cuando narra la carestía de los productos alimenticios.

\section{Situación económica provincial}

De los tres sectores básicos de la economía, a principios del siglo XIX, es sin duda la actividad agraria la más importante de la provincia con un $90 \%$ del valor de la riqueza de la provincia y con un $70 \%$ de la población dedicada a los trabajos agrícolas $^{171}$. Es una agricultura extensiva y de secano, con utilización del sistema de siembra de "año y vez", tras un año de siembra sigue otro año de barbecho, correspondiendo en consecuencia una producción de la cosecha cada dos años ${ }^{172}$.

En cuanto al comercio, solamente Valladolid, Rioseco y Medina mantienen una cierta actividad, destacando la capital como centro del comercio provincial, basado principalmente en la compra-venta de los productos agrícolas y sus derivados, así como en la compra de herramientas para la agricultura.

En el capítulo referente a la industria, no se puede hablar de la existencia de una industria de carácter moderno, sino más bien las fábricas existentes eran de tipo antiguo dedicadas en su mayor parte a la molinería, a textiles y cueros.

En conclusión, dos factores, que ya hemos repetido con anterioridad, intervienen en la angustiosa situación en que vive la provincia debido a las malas cosechas y la guerra. Estos factores que provocan la miseria son la carestía de la vida y la falta de trabajo, y como consecuencia de todo ello: el hambre.

\section{3.- LAS SEDES DE LA DIPUTACIÓN}

En estos primeros años de vida, los edificios donde la Diputación instaló sus oficinas, fueron tan provisionales como lo fue la vida de la propia Corporación y sólo será al final de este período estudiado cuando se vaya consolidando la Diputación como ente representativo de la provincia y al mismo tiempo, sus instalaciones serán más duraderas.

\subsection{1.- EL PALACIO REAL. PRIMERA SEDE EN 1813}

El día 2 de septiembre de 1813 se procedía a la celebración de la primera sesión de la Diputación Provincial de Valladolid. Es la "Sesión de Instalación". En realidad

169 MAZA ZORRILA, Elena. Valladolid: sus pobres y la respuesta institucional (1750-1900). Ed. Universidad de Valladolid. Secretariado de Publicaciones. Valladolid.1985.

170 "En estos días, las partidas de guerrillas interceptan los caminos y los pasos para la ciudad, sin permitir entrase pan ni comestible alguno; se carecía de casi todo y lo poco que había a excesivo precio. El pan a 11 y 12 reales, la cántara de vino a 60 reales, la de aceite a $200 \ldots$ las verduras sobre carísimas... y en fin todos los comestibles a unos precios tan subidos cual nunca se han oído ni visto. Sólo los vendedores de dichos géneros, cantineros y empleados franceses eran los que subsistían, los demás vecinos llenos de miseria...". ORTEGA RUBIO, Juan. Noticia de casos particulares ocurridos en la Ciudad de Valladolid. Año 1808 y siguientes. Imprenta de Hijos de Rodríguez. Valladolid, 1886. Págs. 192 y siguientes.

$171 \quad$ ANTA MUÑOZ, Antonio de. La Diputación ...ob. cit. Pág. 19.

172 MADOZ, Pascual. Diccionario Geográfico-Estadístico-Histórico de España y sus posesiones de Ultramar. Madrid. 1850. Tomo XV. Situación de la provincia de Valladolid en el siglo XIX. Introducción. 
no tenemos constancia del lugar donde se celebró esta sesión, aunque posiblemente y por lo revuelta que estaba la ciudad de Valladolid en esta época, con el abandono de la ciudad por las tropas francesas y la llegada de los ejércitos español e inglés, los diputados provinciales se reunirían en las "Casas Consistoriales", unos de los pocos edificios con salón de sesiones, que podían haber sido cedidos para esta ocasión por el Consistorio.

Los libros de actas de la Diputación vallisoletana no recogen la reseña de sus actividades hasta el día 9 de febrero de 1814, por lo que hasta esa fecha no conocemos el número de sesiones, ni los temas tratados, ni, por supuesto, el lugar donde se celebraron las citadas sesiones. Las primeras referencias que tenemos de las sesiones nos vienen a partir del citado 9 de febrero, donde queda constancia de que "la Diputación fue reunida en la casa-posada del Sr. jefe político..." ${ }^{173}$. Sin señalar donde residía el jefe político y sin tener certeza de la residencia, podemos aventurar que siendo el jefe político y presidente de la Diputación en este tiempo el mariscal de campo D. Antonio María Peón y Heredia, "General en Jefe de los Ejércitos de Castilla la Vieja", su vivienda estuviera situada en el Palacio Real, que desde el final de la Guerra de Independencia se había convertido en sede habitual de la Capitanía General de Castilla la Vieja.

En la siguiente sesión, con motivo de la celebración del aniversario de la Constitución, se comunica que "el señor jefe político, recibirá el día 19, aniversario de la Constitución, en su casa a las 11 de la mañana, a todas las autoridades y corporaciones y demás personas, y pasará enseguida a la Santa Iglesia Catedral, donde se celebrará solemne Tedeum" 174 . En este párrafo queda de manifiesto que el "recibir a todas las autoridades y jerarquías", presupone el tener un alojamiento amplio y preparado, lo que nos vuelve a inclinar a pensar en el Palacio Real.

Una última referencia a la sede de la Diputación nos dice que "en la ciudad de Valladolid, a treinta y un días del mes de mayo de mil ochocientos catorce, invitada la Diputación de esta provincia por el Sr. presidente gobernador militar y político de ella y estar reunida en su sala de sesiones..." ${ }^{175}$, nos informa de la existencia de una sede apropiada para la Institución.

En definitiva, sabemos que la Diputación tenía unas dependencias en donde celebrar sus sesiones e instalar la Secretaría y las oficinas correspondientes, pero no conocemos realmente el edificio donde estuvo instalada en los primeros mese s de su existencia. Sólo conoceremos con certeza que es el Palacio Real al iniciarse la nueva época de la Diputación en el año 1820. Será el 28 de abril, a los pocos días de su nueva instalación, cuando aparece reflejado en el libro de actas el acuerdo de los señores diputados al decir que "se acordó oficiar al conserje del Palacio para que franquee las oficinas que antes ocupó la Diputación" ${ }^{176}$. Es decir, en su primera época la Diputación provincial estuvo instalada en el Palacio Real, el edificio más representativo y el de mayor importancia de carácter civil existente en la ciudad ${ }^{177}$.

A partir del año 1800 el Palacio que apenas fue habitado desde que pasó a depender del Patrimonio Real, iniciará una nueva etapa de aprovechamiento de sus instalaciones para albergar a diferentes instituciones. Durante la invasión francesa fue

A.D.P.V. Actas. Libro de actas del día 9 de febrero de 1814. Primera anotación que aparece.

A.D.P.V. Actas. Libro de actas de la sesión del 18 de marzo de 1814.

A.D.P.V. Actas. Libro de actas del 31 de mayo de 1814

A.D.P.V. Actas. Libro de actas del 28 de abril de 1820.

RIVERA BLANCO, José Javier. El Palacio Real de Valladolid. 2a edición. Valladolid, 1981. Este Palacio fue construido en los años 1522 a 1526 por encargo de Francisco de los Cobos, primer marqués de Camarasa y secretario del Emperador Carlos I, casado con Doña María de Mendoza, hija de los condes de Rivadavia. Los planos son obra del arquitecto Luis de Vega. El edificio se construyó "en una propiedad adquirida en 1522 frente al Convento Dominico de San Pablo". En el año 1534, decidió ampliarlo, al convertirse en residencia del emperador durante su estancia en Valladolid. En el año 1600 el duque de Lerma compró "la casa principal del Sr. de los Cobos", a su sucesor y nieto, el tercer marqués de Camarasa, y se la vendió al año siguiente al Rey Felipe III "para establecer su residencia en Valladolid" dándole el título de Palacio Real. 
utilizado como Cuartel General de las tropas de ocupación y como alojamiento de Napoleón y de José I durante sus estancias en Valladolid. "Concluida la Guerra de la Independencia el palacio fue ocupado por el capitán general, José de Palafox, marqués de Lázaro y también presidente de la Real Chancillería. Se instaló en él el 13 de octubre de $1814 \ldots ., " 178$.

En octubre de 1814, la Diputación ya había sido disuelta a la vista del "real decreto de 15 del presente mes (junio), por el cual manda S.M. suprimir las Diputaciones provinciales... y que los papeles de sus Secretarías se pasen a las respectivas Contadurías de provincia" ${ }^{179}$. Como conclusión, podemos avanzar que la Diputación abandonó las habitaciones que había ocupado en el Palacio Real y que éste quedó ocupado por el ejército como sede de la Capitanía General de Castilla la Vieja.

\subsection{2.- EL PALACIO DE POLENTINOS EN EL TRIENIO LIBERAL 1820-1823}

El 21 de marzo de 1820 se vive en Valladolid una nueva andadura de la Diputación, y es tan urgente y provisional esta puesta en marcha que la primera sesión de la institución se celebra "en la posada-habitación del Sr. intendente, su presidente accidental en defecto del jefe superior" ${ }^{180}$. Las reuniones se suceden y la provisionalidad continúa, pues el día 10 de abril, en presencia por primera vez del recién nombrado jefe político y en consecuencia presidente de la Diputación, en las actas se puede ver que de nuevo está "reunida por convocatoria del Sr. jefe político en su casa-posada..." 181 .

La situación continúa en precario y la Diputación sigue sin tener salón de sesiones, ni secretario, ni local de oficinas en donde poder desarrollar el trabajo, hasta que el día 28 de abril, sobrepasado el mes de existencia y en su sesión número diecisiete, la Diputación acuerda, "oficiar al conserje del Palacio para que franquee las oficinas que antes ocupó la Diputación”. En la misma sesión, con la finalidad de equipar debidamente a su Secretaría y aprovechando la disolución del Tribunal de la Inquisición, "se acuerda oficiar al tesorero del Tribunal de la Inquisición, para la entrega de muebles del referido tribunal, para que sirvan para habilitar las oficinas que ha de ocupar la Diputación en el Palacio Real" ${ }^{182}$.

A través de estas anotaciones en las actas, la Diputación tiene la certeza de que va a volver a ocupar sus antiguas dependencias, y es lógico que así actúe para poder desarrollar el trabajo con cierta comodidad, y sobre todo para no tener que depender de asentamientos provisionales.

La sorpresa surge cuando al día siguiente, 29 de abril, queda reflejado en su libro de actas que "Visto el oficio del Sr. conserje del Palacio de esta ciudad perteneciente al Real Patrimonio, se acordó hacer una exposición a S.M. pidiendo habitación para el Sr. jefe superior y sus oficinas, con las de propios, sala de sesiones de la Diputación y demás oficinas necesarias para su Secretaría" "183. Y aunque los libros de actas no reproducen el oficio del conserje, está claro que su contestación fue negativa, que no iba a entregar las llaves sin un previo acuerdo y permiso del mayordomo del Patrimonio Real, y que tuvo que tener poderosas razones para proceder de esta manera.

RIVERA BLANCO, José Javier. El Palacio Real... ob. cit. pág. 85. Señala que "fue la primera estancia de alguna entidad que se produjo" y refleja que "con anterioridad el Palacio fue ocupado en los inmediatos días anteriores por la Diputación Provincial". A partir de esta fecha sí que es utilizado por los capitanes generales de Castilla la Vieja, como su residencia y la de sus oficinas militares. En 1854 pasa a ser sede de la Delegación de Hacienda de la provincia, en 1872 es la sede de la Chancillería y a partir de 1876 pasa a depender del Ministerio del Ejército, convirtiéndose en la sede de la Capitanía General de la $7^{\text {a }}$ Región Militar.

179 A.D.P.V. Actas. Libro de actas de la sesión del 25 de junio de 1814.

180 A.D.P.V. Actas. Libro de actas del día 21 de marzo de 1820.

181 A.D.P.V. Actas. Libro de actas del 10 de abril de 1820.

182 A.D.P.V. Actas. Libro de actas del 28 de abril de 1820.

183 A.D.P.V. Actas. Libro de actas del 29 de abril de 1820. 
Por otra parte, la Diputación, vista la negativa, desde luego inesperada, se dirige al administrador del Real Patrimonio, con el que llega a un acuerdo para firmar un contrato de arrendamiento de una parte de las instalaciones del Palacio, como queda reflejado en las actas ${ }^{184}$.

Pero la realidad era que el Palacio Real no estaba vacío, sino que estaba ocupado, y bien ocupado, por la Capitanía General del Ejército de Castilla la Vieja, y que el Sr. capitán general no estaba dispuesto a ceder el Palacio, aunque sea de una forma parcial, como lo hace ver en el oficio que remite a la Diputación ${ }^{185}$.

Parece ser que el capitán general lo tenía muy claro, aun sabiendo que el Rey había autorizado el contrato de arrendamiento y entre sus argumentos estaba el que el Palacio Real había sido sede de la Capitanía General desde el año 1814, año en que fue suprimida la Diputación. El Rey por su parte, una vez leída la exposición de Nicolás de Mahy, con su petición de permanecer en el Palacio y también la réplica de la Diputación, recordando que han firmado un contrato de arrendamiento, resuelve por real orden de 24 de junio que "se coloquen en el Palacio las oficinas del Sr. capitán general y las de la Diputación y su señor presidente, pagando aquél la parte de renta que le corresponda por el local que ocupe, y que entregará a la Diputación, pues que esta ha de entregar íntegros los 500 ducados en que se le arrendó" ${ }^{186}$.

A la Diputación provincial no le gustó la decisión salomónica del Rey y “acordó que no permitiéndosele el uso según y en los términos indicados en la real orden de 13 de mayo, en virtud de la cual se celebró un contrato solemne de arriendo entre la misma y el representante del Real Patrimonio, se aparta desde hoy del derecho que había adquirido..." 187 . Con esta decisión, la Diputación "hacía gala de su orgullo" al rechazar el arriendo, sobre todo porque el capitán general estaba decidido a ocupar la "habitación principal" y en realidad el edificio tenía la suficiente amplitud para permitir el acomodo de las dos instituciones. Ahora a la Corporación se la presentaba el problema de tener que buscar otro nuevo alojamiento, tanto para el jefe político como para las dependencias administrativas.

Aunque la Diputación había tomado la decisión de rescindir el contrato, siguió buscando apoyos a favor de los locales del Palacio, enviando un escrito, en esta ocasión a los diputados a Cortes por la provincia, explicándoles los pasos dados para hacerse con el arriendo del Palacio y rogándoles hicieran las gestiones oportunas en la corte y "se sirvan acercase a la Mayordomía Mayor de S.M. y procuren la pronta decisión de la última exposición enviada, atendidos los perjuicios que de otro modo podrán originarse, sobre el pago de la renta que se está incumpliendo" ${ }^{188}$.

184 “habiendo pasado la Diputación, juntamente con el Sr. jefe superior político, su presidente y el administrador del Real Patrimonio a ver y examinar el edificio del Palacio Real, con el fin de hacer el señalamiento, elección y división de las piezas que debían destinarse para las dos Secretarías, como también para la habitación del dicho Sr. jefe en virtud de la concesión que de aquel (el Palacio) hizo S.M. a la primera (la Diputación), por vía de arriendo, según real orden de 13 de mayo, comunicada en el particular por el Sr. mayordomo mayor y en consecuencia de haber ya otorgado la escritura, asegurando la renta anual convenida” A.D.P.V. Actas. Acta de la sesión del día 2 de junio de 1820.

185 "El Sr. comandante general interino de las Armas de esta provincia D. Nicolás Mahy, aunque informado de antemano de la suprema voluntad del Rey, manifestó sus intentos de conservar para su uso y del sucesor la más principal habitación del mismo Palacio, según la habían tenido y disfrutado sus antecesores y últimamente el Sr. conde de Montijo, sin que bastasen a convencerle las reflexiones que le hizo el referido señor jefe apoyado por los diputados provinciales y el precitado administrador del Real Patrimonio, relativa a que si por efecto de una especial gracia había permitido S.M. que habitaran el citado edificio los capitanes generales, siempre que lo hubiesen necesitado y ahora se lo había otorgado a esta Diputación, no era motivo para formar una competencia, respondiendo el Sr. comandante que lo tenía consultado a S.M” A.D.P.V. Actas. Libro de actas del 2 de junio de 1820 .

186 A.D.P.V. Actas. Libro de actas de 20 de julio de 1820, donde queda reflejado el acuerdo de S.M. transmitido a través del oficio del administrador del Real Patrimonio de Valladolid D. José de la Cuadra y Luzón.

187 A.D.P.V. Actas. Acuerdo reflejado en el acta del día 20 de julio de 1820.

188 A.D.P.V. Actas. Acuerdo tomado en la sesión del 7 de agosto de 1820. 
La contestación a estas gestiones no tardó en producirse de una manera clara y tajante a través de la "orden del Sr. mayordomo de S.M. fecha 23 del actual comunicada por D. José de la Cuadra Luzón, administrador en esta ciudad del Real Patrimonio, en oficio de hoy en que se tiene por anulada la escritura de arriendo del Real Patrimonio que otorgó a la Diputación, concediéndoselo todo al Excmo. Sr. capitán general" ${ }^{\prime 189}$.

A partir de estos momentos, la Diputación inicia la búsqueda de unos nuevos locales donde instalar sus oficinas, con una situación que nos llaman la atención y es que el general Nicolás Mahy había dejado la Capitanía General al haber sido destinado a la isla de Cuba. Para el cargo de capitán general es nombrado en primer lugar el general Tomás Moreno y Daoiz, el día 26 de junio de 1820 y posteriormente, el mariscal de campo Carlos Espinosa, el 28 de noviembre de 1820. Ambos actúan a la vez como capitanes generales y como jefes políticos de la provincia, y presidentes de su Diputación, esto quiere decir que una misma persona ocupa la jefatura de las tres instituciones, con lo que no debía de existir litigio entre ellas.

A la pregunta que nos podemos hacer sobre ¿dónde celebraba la Diputación sus sesiones?, nos la responde el administrador del Real Patrimonio, cuando remite un oficio a la Diputación "señalando que debe de pagar 1.500 reales anuales por renta de las piezas que ha ocupado en el Palacio Real" ${ }^{190}$. De esta forma, sabemos que desde junio el jefe político es el capitán general que habita en el Palacio y las oficinas de la Diputación y su salón de sesiones están ubicadas "en precario" en el mismo Palacio.

La Diputación, para resolver esta situación, "acordó dar comisión al Sr. Macho para que avocándose con S.E. le pida el término necesario para proporcionar otro edificio donde trasladar la Secretaría, conviniéndose en la renta por el alquiler de las piezas a ocupar" 191 .

Uno de los edificios por los cuales primero se interesa la Diputación, es el Colegio de Santa Cruz que conoce que está desocupado, y que tanto por su capacidad como por su situación lo considera "ideal para sus necesidades", y el comisionado Macho, el día 27 de agosto, al día siguiente de haberle encargado la búsqueda de nueva sede, envió una exposición al director del "Crédito Público", administrador en aquellos años del edificio, solicitando "el colegio de Santa Cruz para fijar en él la sala de sesiones y las oficinas de la Diputación"192. Al no tener contestación, a pesar del tiempo transcurrido en el mes de noviembre, la Diputación acordó "que se repita el oficio, exigiendo contestación afirmativa o negativamente, manifestando la extrañeza que ha causado la falta de resolución desde el 27 de agosto en que se hizo dicha exposición, repetida el 24 de septiembre, mucho más, cuando se está observando que los efectos del extinguido monasterio de Benedictinos de esta ciudad se están trasladando a dicho colegio, pudiendo subsistir en el local de donde se extraen" ${ }^{193}$. Como la decisión del director del "Crédito Público" sobre el colegio de Santa Cruz se alarga, la Diputación con fecha 29 de noviembre "acordó dar comisión al Sr. Pestaña para que con el secretario y oficial mayor proporcionen habitación cómoda para sala de sesiones y oficina de esta Diputación" ${ }^{194}$.

La búsqueda de un nuevo edificio para oficinas era en verdad urgente, pues se había perdido tiempo con las gestiones del colegio de Santa Cruz, y además, el administrador del Patrimonio Real no hacía más que reclamar que se desocuparan las oficinas del Palacio Real. Las gestiones que realiza el diputado Pestaña dan sus frutos, ya que a los pocos días, según se refleja en las actas del día 8 de diciembre ${ }^{195}$.

189 A.D.P.V. Actas. Libro de actas del día 26 de agosto de 1820

190 A.D.P.V. Actas. Libro de actas del 4 de diciembre de 1820.

191 A.D.P.V. Actas. Libro actas de 26 de agosto de 1820.

192 A.D.P.V. Actas. Libro de actas del día 27 de agosto de 1820.

193 A.D.P.V. Actas. Libro de actas del 18 de noviembre de 1820.

194 A.D.P.V. Actas. Libro de actas del 29 de noviembre de 1820.

195 "Habiendo visto, acompañado por el Sr. diputado Conde, secretario y vicesecretario, la casa perteneciente en la calle de la Cruz, al Sr. conde de Polentinos, y hallando que gozaba de la necesaria 
La Diputación no perdió el tiempo, deseando como estaba de encontrar una sede con la suficiente amplitud como para poder desarrollar todas sus actividades, sin olvidarnos de la necesidad que la había transmitido, de dejar los locales del Palacio Real. El día 8 se firmaban los contratos, el día 9 se realizaba la limpieza, traslado y colocación de muebles, y el día 10 se celebraba la primera sesión en el nuevo edificio del "Palacio del Conde de Polentinos"196. En esa misma sesión, vista la amplitud de la casa, se acuerda el aprovechamiento de los locales que quedan desocupados ${ }^{197}$.

Una vez que se han trasladado a los nuevos locales, la Diputación salda sus deudas con el Patrimonio Real, pagando los 750 reales que le reclaman por los locales que ocupó en el Palacio Real durante seis meses de junio a diciembre de 1820.

En el edificio del conde de Polentinos, se mantendrá la Diputación durante toda su vigencia en el Trienio, como nos recuerda el administrador del palacio a la hora de reclamar el pago convenido: "Exposición de Miguel Blázquez, administrador de las rentas del conde de Polentinos, reclamando el pago de las rentas de la casa que ocupa las oficinas de la Diputación" ${ }^{198}$.

De todos modos, la Corporación tiene un verdadero interés por conseguir el arrendamiento del Colegio de Santa Cruz, y no deja de reclamarlo de una forma continua a lo largo de los años 1821 y 1822. En la sesión que se celebra el 10 de marzo de 1822, se lamentan de la falta de noticias y se insiste en la petición: "Con motivo de no haber contestado los señores directores del Crédito Público a las diferentes exposiciones que les ha dirigido la Diputación con fechas de 27 de agosto, 24 de

capacidad, claridad y centralidad para los objetos indicados, aún sin ocupar las oficinas bajas destinadas a paneras del mismo dueño, otra habitación baja dada en inquilinato y otra alta de limosna a una criada antigua de la casa. ... Se trató de ajuste y renta con D. Miguel Blázquez, administrador de dicho señor, quedando convenida en la de 4.000 reales cada año bajo la condición que dicho administrador no había de poder alargar graciosamente ni por dinero, las tres referidas oficinas de panera y habitaciones ocupadas por él y otros cuando vacaren, sin dar antes noticia a la Diputación, por si la acomodare su arriendo para dejar independiente el edificio. Y aprobando como aprueba la Diputación cuanto han hecho sus señores individuos Pestaña y Conde, confiere a la misma comisión, el otorgamiento de la correspondiente escritura, obligando los fondos de la Diputación, y el vicesecretario, depositario de ellos, proceda al aseo, limpieza y estero de las piezas necesarias, trasladando la sala de sesiones, Secretaria y sus papeles" A.D.P.V. Actas. Acuerdo recogido en el libro de actas del 8 de diciembre de 1820 .

196 URREA, Jesús. Arquitectura y Nobleza. Casas y Palacios de Valladolid. Ayuntamiento de Valladolid. Valladolid, 1996. Nos describe los orígenes de la Casa-Palacio del conde de Polentinos, que se inicia en el año 1533, cuando siendo un corral propiedad de la Cofradía de Todos los Santos, fue arrendado al doctor Diego Buey, catedrático de Prima de Medicina en la Universidad, con el propósito de construir en él sus "casas principales". Esta casa sufrió con el tiempo varias modificaciones, y tuvo diferentes propietarios. En el año 1744, según Canessi "en el mismo lugar existe una casa propiedad de los Contreras". El Catastro de 1752, nos describe la casa "en la calle del Fuelle (hoy calle del Salvador) y dispone de cuarto bajo y principal, midiendo $28 \times 35$ varas (23’24x29’50 m.). Propiedad de Doña María de Contreras, hija de D. Jerónimo de Contreras Panio y Carvajal y de Doña María Ángeles Santisteban Onis Bañuelos, marqueses de Olivares de Duero, casada con D. Francisco José de Colmenares, conde de Polentinos, y allí vivió el matrimonio acompañado por ocho criados. Una vez disuelta la Diputación en 1823, y liberado el arrendamiento, el palacio pasó a ser residencia del general Blake, que falleció en el año 1827. Posteriorme nte, la casa fue vendida a los sucesores del general Longa, y a partir de estos momentos se la conoce como el Palacio de los Longa. La fecha de venta es dudosa, ya que según anuncio aparecido en el Boletín Oficial de la Provincia $n^{\circ} 53$ de 17 de abril de 1870 "por sentencia del juzgado de la audiencia de Valladolid es embargada la casa $n^{\circ} 3$ de la calle Salvador, propiedad de D. Felipe Colmenares y Contreras, conde de Polentinos y marqués de Olivares de Duero".

197 "Considerando la Diputación que el edificio que ha tomado en renta después de haber señalado y destinado las piezas principales para sala de sesiones, donde ya se ha celebrado la de este día, y colocación de Secretaría, Archivo y Contaduría de Propios, tiene otras interiores y bajas en que puede habitar el secretario y vice-secretario, como también el portero. Se acordó que pasen su habitación, distribuyéndolas según sus necesidades, con lo cual se conseguirá la más puntual asistencia a las horas de sesión y Secretaría, cuidado de ésta, custodia de sus papeles y efectos y sobre todo la comodidad pública en tener reunidos bajo un mismo techo las oficinas y primeros encargados de su cuidado y despacho" A.D.P.V. Actas. Libro de actas del día 10 de diciembre de 1820 .

198 A.D.P.V. Actas. Libro de actas del 23 de agosto de 1821. 
septiembre y 18 de noviembre de 1820 , relativas a que se sirviesen conceder en arriendo el edificio del extinguido colegio de Santa Cruz para colocar allí su sala de sesiones y oficinas, se acordó: Que se dirija la correspondiente exposición a S.M., haciendo la misma solicitud por el conducto del Ministerio de la Gobernación..." 199.

Esta última exposición al Monarca por medio del Ministerio de la Gobernación, tiene la misma respuesta que tuvieron los anteriores escritos: el silencio. Esto no es obstáculo para que la Diputación vuelva a tratar el tema de nuevo meses más tarde, en la sesión del 21 de agosto de 1822 en la que se vuelve a "acordar, que se haga la última exposición al gobierno, solicitando el uso del colegio de Santa Cruz para establecer las oficinas, extrañando que una provincia tan benemérita haya sido tan desatendida en este objeto, que ni aún contestación haya merecido a repetidas exposiciones que se citaron a la dirección del Crédito Público y al Gobierno" ${ }^{200}$.

Tampoco en esta última ocasión la Diputación tendrá contestación a su afán por fijar su residencia en el colegio de Santa Cruz. En el año 1823, por un lado ya se encuentra asentada en el Palacio de Polentinos, y por otro, la situación política tan enrarecida hace olvidar a los diputados provinciales su preocupación por el cambio y no volverán a reclamar, ni al "Crédito Público", ni al Gobierno, ni al Rey el alquiler del colegio, entre otras razones porque ya desde principios de año, la vida de la Diputación languidecía. Aunque oficialmente las Diputaciones no serán disueltas hasta primeros de octubre, la Diputación Provincial de Valladolid, dejó de tener sesiones ordinarias en febrero del citado año de 1823, y a partir de esa fecha sólo funcionan las comisiones de contribuciones y de reemplazos para el ejército.

\subsection{3.- ANEXOS AL PALACIO REAL EN EL AÑO 1835}

El día 22 de octubre de 1835, se celebra la sesión de instalación de la Diputación Provincial de Valladolid, "reunidos los señores que al margen se expresan en las Salas Consistoriales de esta ciudad en el día de la fecha..." 201.

De esta forma se inicia una nueva etapa en la vida de la Diputación, y en esta ocasión será la definitiva. Como en las dos veces anteriores el inicio de las actividades, se efectúa sin el tiempo suficiente como para poder celebrarlo en locales propios. En esta ocasión es el Ayuntamiento de la ciudad el que cede sus salones para celebrar la primera sesión. Dos días después se celebra una nueva sesión, y esta se hace "en la casa-posada del Sr. gobernador... y se acordó nombrar una comisión encargada de la búsqueda de enseres de la antigua Diputación..."202.

No sabemos "a ciencia cierta", dónde celebra sus sesiones la Diputación, pero conocemos que los diputados provinciales inician la búsqueda de unos locales en los que celebrar sus sesiones y organizar su Secretaría. Aprovechando la publicación de la real orden de enero de 1836, sobre la utilización y aprovechamiento de los conventos de las órdenes suprimidas, "consentía en trasladar sus oficinas en unión de las demás de la Real Hacienda y que el local que juzgaban más a propósito lo era el convento de San Benito el Real..."203. Estos deseos no se cumplieron, puesto que el capitán general no estaba de acuerdo en liberar el monasterio, que en aquellos años estaba siendo utilizado como cuartel.

En este estado, no tenemos certeza de dónde está ubicada la sede de la Diputación, sólo leemos "en la ciudad de Valladolid a siete de octubre de 1836, reunidos en la casa donde la Diputación celebra sus sesiones..." ${ }^{204}$. Es decir un año después del inicio de las actividades de la Diputación, no tenemos noticias fiables ni certeza de dónde está el local que acoge a los señores diputados. De lo que sí queda

\footnotetext{
199 A.D.P.V. Actas. Libro de actas del 10 de marzo de 1822.

200 A.D.P.V. Actas. Libro de actas del día 4 de agosto de 1822. Pág. 277.

201 A.D.P.V. Actas. Libro de actas del 22 de octubre de 1835.

202 A.D.P.V. Actas. Libro de actas del 24 de octubre de 1835.

203 A.D.P.V. Actas. Libro de actas del 1 de febrero de 1836.

204 A.D.P.V. Actas. Libro de actas del día 7 de octubre de 1836, en donde se refleja la sesión de instalación de la nueva Diputación celebrada el mismo día.
} 
constancia es del malestar de los diputados de las malas condiciones que tenía el local que utilizan para desarrollar su labor. Así lo hace ver el diputado Montero que en noviembre del mismo año 1836 "llamó la atención de la Diputación en razón de la imposibilidad de continuar en local tan estrecho como el que en la actualidad se ocupaba, y la necesidad de buscar otro más decoroso y de mayor disposición para recibir al público, y para que las oficinas, cuyos trabajos se aumentaban de día en día tuviesen el desahogo necesario, y también para que la corporación pudiese celebrar sus sesiones con la independencia y decoros debidos" 205 .

En conclusión, en este primer año de vigencia, la Diputación es seguro que no volvió a sus anteriores dependencias del Palacio de Polentinos, que como dijimos con anterioridad, estaba alquilado a la familia Blake. Sabemos que no ocupaban ese espacio porque el palacio era amplio y en el que estaban acomodados vemos cómo se quejaba el diputado Montero de "local tan estrecho". Tampoco es probable que estuviera en el Palacio Real, que ya sabemos que estaba ocupado por el Ejército y hemos visto que las relaciones de la Diputación con el Ejército no eran buenas. Sí es posible que ocupara, junto con las oficinas de la Real Hacienda, algunos de los locales anexos al Palacio Real, situados en la actual calle del León, donde posteriormente estuvieron situadas unas escuelas.

\subsection{4.- PALACIO DEL DUQUE DE OSUNA ENTRE 1836 Y 1845}

En la misma sesión del 6 de noviembre de 1836, en la que el diputado Montero se queja de la penosa situación en que se encuentran las dependencias de la Diputación: "El Sr. secretario comentó que a la sazón estaba vacante la casa de la plazuela de las Angustias, perteneciente al duque de Osuna. Se acordó que el Sr. diputado Serrano y el secretario pasasen en comisión a tratar del alquiler de dicha casa con el administrador, D. Liborio del Pino y se les autorizó para que hiciesen el ajuste en los términos que les pareciere y determinaran el pronto arreglo del local para trasladar inmediatamente las oficinas $" 206$.

A los pocos días de haberle comisionado, el Sr. Serrano presentó en el pleno del día 15 de noviembre de 1836 el acuerdo alcanzado, y la Diputación "acordó la aprobación de las condiciones de arriendo de la casa correspondiente al duque de Osuna sita en la plazuela de las Angustias" ${ }^{207}$. La Diputación aprobó estas condiciones

URREA, Jesús. Arquitectura y Nobleza... ob. cit. Pág. 247. El palacio de la calle de las Angustias, es conocido como palacio del Almirante de Castilla y al final de su existencia palacio del duque de Osuna. Edificio de "grandísimas dimensiones, situado frente a la iglesia de las Angustias, cuya fecha de edificación no se conoce, pero en el año 1426, ya estaba construido, y se cita como propiedad del Almirante de Castilla D. Alfonso Enríquez. Su arquitectura exterior es poco conocida y según el plano de Ventura Seco (1738) era un edificio de dos plantas y dos torres a los lados de la fachada principal. En el año 1605 se hicieron una serie de mejoras, entre ellas, "una obra nueva desde la iglesia del Hospital de San Cosme (actual iglesia del Rosarillo) hasta la torre antigua de la casa principal de dicho Sr. Almirante" para que "su excelencia y la familia de su casa pudiese oír misa”. En 1756, en el Catastro de Ensenada, el palacio pertenecía al Sr. conde de Benavente y tenía unas dimensiones de $104 \times 72$ varas $(86,3 \times 59.7 \mathrm{~m}$.) y un alquiler estimado en 1.800 reales. En el año 1836, a la muerte sin sucesión del conde de Benavente, el palacio pasó a pertenecer al duque de Osuna D. Pedro Téllez Girón, que fue quien se lo arrendó a la Diputación (en parte). En el año 1863, y ya en estado de gran deterioro, el edificio fue derribado y en parte de su solar se construyó el Teatro Calderón de la Barca.

${ }^{207}$ A .D.P.V. Actas. Libro de actas del día 15 de noviembre de 1836: $1^{\circ}$ El arriendo se toma por el tiempo que las oficinas de la Diputación permanezcan ejerciendo...2 ${ }^{\circ}$ Por razones de renta se pagarán 3.000 reales en cada año... $3^{\circ}$ Que para más seguridad de ambos contratos se han firmado y formado inventarios duplicados de vidrieras, puertas, llaves, picaportes...4 $4^{\circ}$ Que las obras de pura conveniencia que se ejecuten en la citada habitación serán por cuenta de la Diputación....5 Asimismo será cuenta de la Diputación la reposición de los pisos... $6^{\circ}$ Será asimismo cuenta de la Diputación cuidar por medio de su portero de abrir y cerrar las puertas principales. $7^{\circ} \ldots . .$. limpiar las $^{\circ}$ solanas y sobrados... $8^{\circ} \mathrm{En}$ el arriendo entra también el jardín y patio de entrada... $9^{\circ} \mathrm{Y}$ últimamente no se podrá subarrendar la citada habitación, sobrados, patios y jardines... 
de arrendamiento pactadas por el diputado Serrano y el administrador Pino, y también aprobó el traslado inmediato a las nuevas dependencias.

Era de tal envergadura la urgencia del traslado que los tres días siguientes a la sesión del acuerdo no se celebraron sesiones porque "todos los empleados de la Diputación estaban ocupados en efectuar el traslado". El día 19 de noviembre del año 1836, se celebró la sesión en el edificio del duque de Osuna, como nueva sede de la Diputación.

No había pasado un mes desde el inicio de las sesiones en la nueva sede, cuando la institución tiene que solicitar del administrador del duque de Osuna la ampliación del contrato de arrendamiento por la necesidad de nuevos locales al verse ampliada la Secretaría. El acuerdo se cierra con un aumento del precio de arrendamiento de 500 reales de más al año por el alquiler de otra habitación ${ }^{208}$. La habitación arrendada tiene que ser reparada "por el estado mismo en que se halla", lo que nos da idea de que la situación del edificio no es lo cuidada que esperaban los diputados. Es también curioso que la habitación alquilada comunica "a través de una galería cubierta" con el coro de la iglesia de San Cosme, aunque en el arrendamiento se especifica que no se permitirá el paso por la citada galería, a excepción de las personas que trabajan en la Diput ación.

En este local se mantuvo la institución hasta el año 1845 , ya que a raíz de la publicación de la ley de 8 de enero de 1845 "sobre Organización de Ayuntamientos y Diputaciones Provinciales" se produjeron una serie de cambios en la administración que modificaban las formas de actuar de las instituciones provinciales y locales. Así lo recordaba la circular de 19 de febrero de 1845 sobre "reunir en el mismo local el Gobierno político, Diputación y Consejo, acuartelando a la vez a la Guardia Civil".

En acuerdo con esta orden circular, en julio de 1845, el jefe político decide trasladar las oficinas de su Gobierno al palacio de Osuna. Pero no es posible el traslado de la Guardia Civil, por el que se inicia la búsqueda de un nuevo edificio para sede de todos los organismos políticos de la provincia. El 24 de septiembre del mismo año, las oficinas de la Diputación, abandonan el Palacio de Osuna, y se trasladan a la CasaPalacio del marqués de Villasante.

El abandono del Palacio de Osuna por la Diputación aceleró el deterioro del edificio, a lo que hay que añadir el poco interés de sus propietarios por mantenerlo y repararlo. Como nos relata Jesús Urrea, "el duque de Osuna vendió el Palacio en 1862 por 41.000 duros a D. Diego Morales, venta en la que se incluían todas las dependencias de las calles Rosario y Damas. Un año más tarde el edificio fue derribado y en su solar se edificó el Teatro Calderón".

\subsection{5.- PALACIO DEL MARQUÉS DE VILLASANTE EN 1845-1851}

A principios de 1845 , la publicación de la ley de 8 de enero, sobre la nueva organización de Ayuntamientos y Diputaciones, supone una pequeña revolución en la vida administrativa provincial. Uno de los cambios más significativos es el referente a la ubicación en un mismo edificio de todas las instituciones provinciales, es decir, Gobierno político, Diputación y Consejo provincial, a lo que había que añadir la Guardia Civil, de reciente creación. Se produjeron además otros cambios, no menos importantes, como son la supresión de la Secretaría de la Diputación, el paso de sus empleados al Gobierno político, y sobre todo, el control y el poder que se le concede al jefe político en todas las órdenes de la vida provincial. Estos cambios hacen que el jefe político inicie la búsqueda de un edificio capaz de cumplir con las exigencias de la ley, y en julio de 1845 se lo comunica a la Diputación ${ }^{209}$.

208 A.D.P.V. Actas. Libro de actas del 16 de diciembre de 1836, en el que queda reflejada la real orden de 24 de noviembre por la que "se suprimían las Contadurías de Propios y su personal y actividades pasan a depender de las Diputaciones".

209 "A consecuencia de la R.O. de 19 de febrero último, había hecho reconocer la Casa-Palacio del marqués de Villasante, con el fin de apurar sí podrían colocarse con comodidad y ventaja las dependencias de que la real orden hace mientes, pero que resultando del informe del arquitecto, los muchos gastos que tenían que invertirse para el arreglo de localidades de las mismas, y no 
En una primera tentativa, el jefe político rechaza el traslado al Palacio del marqués de Villasante y decide, por el contrario, el traslado de las oficinas del gobierno político al Palacio de Osuna, sede de la Diputación y como justificante para no hacer el traslado pone por excusa los costos de reparación y las duras condiciones de arrendamiento. Finalmente en septiembre del mismo año 1845 decide efectuar el traslado y a partir del mes de octubre, la Diputación pasa a desarrollar sus actividades al Palacio del marqués de Villasante, situación que confirma el estado de gastos, que reflejan "el pago de 2.916 reales al administrador del local que había ocupado la Diputación hasta fin de mes" 210.

El cambio no ha gustado mucho en la Diputación, que se ve compartiendo el Palacio de Villasante ${ }^{211}$, tanto con el Gobierno como con el Consejo provincial. Los señores diputados proponen un local propio en el que se puedan sentir más independientes. Tampoco el cambio ha servido para el total cumplimiento de la real orden de unificación de todas las instituciones, pues el cuartel de la Guardia Civil no se encuentra en el Palacio de Villasante, aunque está en un edificio lindero con el palacio, en el edificio del antiguo convento de San Diego ${ }^{212}$.

La Diputación Provincial, de acuerdo con la ley, sigue celebrando sus sesiones en las dependencias del Gobierno político. Así consta en la "sesión de instalación de la Diputación Provincial de Valladolid, celebrada en dicha ciudad el 15 de agosto de 1847, en el local de las sesiones de la Diputación sito en el Gobierno político" ${ }^{213}$. El estar bajo el control del jefe político, y sobre todo el no tener una sede propia no satisface a la Diputación, que por otro lado ve mermadas sus actividades en la misma proporción que aumentan los controles y actividades tanto del Gobierno provincial como del Consejo provincial. Esta incidencia se nota en los libros de actas, en donde apenas quedan reseñadas las actividades de la institución provincial.

Independientemente de todas estas vicisitudes, el Palacio de Villasante va a tener poca duración como sede compartida de la Diputación, ya que a finales de 1850 , un informe del gobernador de la provincia aboga por "la instalación en el edificio del colegio de San Gregorio de todas las oficinas del Estado y provinciales" ${ }^{214}$. Es el inicio del abandono del Palacio de Villasante, que no se hizo de forma inmediata ya que hasta finales de 1851 o principios de 1852, continuó siendo la sede de las instituciones provinciales.

pudiendo por otra parte admitir las condiciones que se le imponían por el dueño del indicado edificio, había determinado trasladarlas al que ocupaba la misma Diputación, por evitar el trastorno que ofrecía la mudanza de papeles de su archivo y de la economía que reportaba a la provincia en el pago de alquileres..." A.D.P.V. Actas. Libro de actas del día 19 de julio de 1845. La real orden de 19 de febrero a que hace referencia trata sobre "reunir en un mismo edificio al Gobierno político, Diputación, Consejo provincial y Guardia Civil".

210 A.D.P.V. Actas. Presentación de las cuentas provinciales por la Depositaría de Fondos, reflejado en el acta del día 29 de octubre de 1845.

211 URREA, Jesús. Arquitectura y Nobleza... ob. cit. Pág. 176. La Casa-Palacio del marqués de Villasante. La familia Villasante, es originaria de la zona de Espinosa de los Monteros. En el año 1460, un Villasante, pasa a residir a Rioseco en donde desarrolla una serie de actividades comerciales y adquiriendo "una importante fortuna" que invirtió en una serie de propiedades y entre ellas "diversas casas situadas detrás de las casas del Almirante" y en donde construyó sus "casas principales". El Catastro de Ensenada de 1756, indica que la casa pertenecía a D. Joaquín Teijeiro, señor de Villasante. En 1761, su nieto, Pedro de Alcántara Teijeiro, nombrado primer marqués de Villasante por Carlos III "residía en el palacio de la calle del Rosario". En el año 1825, el segundo marqués de Villasante trasladó su residencia a Madrid, siendo el inicio del abandono y deterioro del edificio, que en 1845 lindaba en un lado con casa de Rafael González Muñoz, y por otro con edificio donde estaba el cuartel de la Guardia Civil. En el año 1853 fue vendido a Félix Aldea, y en 1858 fue comprado por el Gobierno, que lo dedicó a residencia de los obispos, uso en el que continúa en la actualidad.

212 ORTEGA Y RUBIO, Juan. Noticia de casos particulares... ob. cit. Nos cuenta que "a finales de 1844 la Guardia Civil pasó a ocupar el convento de San Diego".

213 A.D.P.V. Actas. Libro de actas del 15 de agosto de 1847. Pág. 80.

214 A.D.P.V. Actas. Libro de actas del 16 de noviembre de 1850. 


\subsection{6.- COLEGIO DE SAN GREGORIO DESDE 1851 HASTA 1874}

El 5 de noviembre de 1850, toma posesión de su cargo de gobernador de la provincia, Ildefonso López de Alcaraz, y también en consecuencia presidente de la Diputación. El 16 del mismo mes presenta un informe en la sesión del día, con la propuesta de instalar todas las dependencias provinciales en el edificio de San Gregorio. "Y mostró las ventajas que con esta medida obtendría la provincia, manifestó la cantidad a que ascendían los gastos de las obras, con relación al presupuesto formado por el ingeniero-jefe del Distrito, y por último instó a la corporación a que votara la de 180.000 reales, que consideraba necesarios, a calidad de reembolso" ${ }^{215}$.

Los diputados provinciales se debieron de extrañar, por lo rápido con que el nuevo gobernador había estudiado la posibilidad de cambio de domicilio. Pero como también es cierto que no se encontraban a gusto en su actual emplazamiento, no debieron poner muchas trabas, y en la misma sesión de presentación del proyecto, la Diputación acordó adelantar, con un ligero recorte, el dinero necesario, aprobando 140.000 reales en lugar de los 180.000 solicitados, con una serie de condiciones ${ }^{216}$.

Al Sr. gobernador no le debieron de parecer mal las condiciones propuestas, ya que continuó con las gestiones del cambio y de adecuación de locales, gestiones que culminaron con la real orden de 30 de noviembre de 1850 "autorizando las obras del colegio de San Gregorio, con el fin de reunir las oficinas de Renta y Gobernación, aprobando el reintegro que adelanta la provincia, con el importe de los alquileres que en la actualidad se satisfacen por las mismas ${ }^{217}$.

La Diputación está satisfecha con la real orden y con el reembolso del dinero a través de los alquileres y espera realizar lo más pronto posible el traslado al colegio de San Gregorio ${ }^{218}$, una vez que se realicen las obras y de acuerdo con las peticiones formuladas, obras que se alargan en el tiempo y en la cuantía. Así lo demuestra el hecho de que a mediados de 1851 "se recibe un informe del ingeniero-jefe del Distrito, solicitando fondos para poder continuar las obras del colegio de San Gregorio, por el suplemento de tener que reparar los tejados. Se acordó destinar 40.000 reales en iguales condiciones que los 140.000 reales concedidos" 219 .

Las obras continuaron a lo largo del año 1851 , y es muy probable que a finales del citado año la Diputación haya trasladado sus actividades al nuevo edificio, ya que en las actas se anota que las reuniones de la institución se celebran "en la sala de sesiones de la Diputación", y además lo corrobora el "Acuerdo de solicitar al gobierno de S.M. cuadros y objetos del museo para adornar el salón de sesiones" ${ }^{220}$. En el año 1852 se continúan con los gastos para poner a punto las instalaciones, pero ya no son de reparaciones, sino de equipamiento de muebles en su mayoría, como lo reflejan las cuentas del presupuesto provincial, en las que se anota un gasto de " 2.175 reales,

215 A.D.P.V. Actas. Libro de actas del 16 de noviembre de 1850.

216 A.D.P.V. Actas. Libro de actas del 16 de noviembre de 1850: "1 ${ }^{\circ} \quad$ Que el reintegro por el Estado había de hacerse lo más pronto posible, y en el último caso por anualidades...2 ${ }^{\circ}$ Que para seguridad, se hipotecara especialmente el mismo edificio de San Gregorio... $3^{\circ}$ Que no pudiera obligarse a la provincia en adelantar mayor cantidad... $4^{\circ}$ Que había de hacerse un salón para los actos públicos de la Diputación y un cuarto de despacho para las sesiones ordinarias... $5^{\circ}$ Que se otorgase escritura públic a en la que se expresen estos extremos...".

217 A.D.P.V. Actas. Libro de actas del 2 de enero de 1851, donde se reproduce la real orden.

218 ARA GIL, Clementina Julia. Escultura Gótica en Valladolid y su provincia. Instituto Cultural Simancas. Ed. Diputación Provincial de Valladolid. Valladolid 1977. Pág. 227 y siguientes. El Colegio de San Gregorio, fue fundado en 1492 por el dominico Fray Alonso de Burgos y construido con planos de Guas, Colonia y Gil de Siloé, en terrenos cedidos por el convento de San Pablo. La finalidad es dual: una capilla funeraria para el fundador y un colegio para la formación de estudiantes. En su larga vida, el edificio sufrió numerosos cambios y reformas, tanto de modificación como de conservación. En 1810, sirvió de cuartel para las tropas de invasión francesas. En 1850, se reformó para adecuarlo como oficinas de la administración provincial. En 1884, se inicia una nueva reconstrucción del edificio y "cuando se emprendieron la obras, la ruina debía de ser tan inminente que hubo que desmontarlo todo y reconstruirlo de nuevo". En 1932, se adaptó para convertirlo en museo, utilidad en la que permanece hasta nuestros días.

219 A.D.P.V. Actas. Libro de actas del 5 de julio de 1851.

220 A.D.P.V. Actas. Libro de actas del 9 de noviembre de 1851. 
importe de los muebles para el salón del Consejo y Diputación en el nuevo edificio de San Gregorio"221. También en los presupuestos de 1852-53 se destinaron dos partidas de 25.000 reales para amueblar las salas de la Diputación y de 40.000 reales para obras en el colegio de San Gregorio ${ }^{222}$.

Todos estos gastos, por parte de la Diputación, se ven compensados con el abono por parte del gobierno a través de los Presupuestos Generales del Estado de los 207.122 reales y 8 maravedíes, importe de los gastos por las obras ejecutadas en el colegio de San Gregorio. La Diputación consideraba que esta resolución tan satisfactoria para sus intereses, se debía a las gestiones realizadas por el ministro de Fomento D. Mariano Miguel de Reynoso, ilustre vallisoletano, y en consecuencia "acordó dirigir a S.E. una atenta comunicación agradeciendo sus gestiones en bien de la provincia" 223 .

En los días siguientes el gobernador de la provincia presenta en la sesión de la Diputación "una relación de efectos comprados por importe de 28.725 reales, con destino a la sala de la Diputación ${ }^{224}$, cuya cuantía supone que el equipamiento del salón de sesiones tiene que ser espléndido, porque a partir de esta fecha no vuelven a aparecer en los libros de actas de la institución ninguna otra referencia de la sede de la Diputación, en especial en lo relativo a los gastos de equipamiento y de mantenimiento. En el año 1855 se puntualiza, para que no haya dudas, de dónde está ubicado que "el día 7 de marzo a las 10 de la mañana se dará principio al sorteo de noventa y cuatro soldados que deben de aportar los pueblos de la provincia... y el acto tendrá efecto en el salón de la citada corporación sito en el edificio que fue colegio de San Gregorio" 225 .

Una vez finalizado el Bienio Progresista, con los moderados nuevamente en el poder, los diputados de la primera Diputación nombrada en 1856 acuerdan "el nombramiento de una comisión para la inspección de todo lo que se refiere al mantenimiento y mejora de las dependencias del edificio" 226.

A partir de estos años, la Diputación empieza a ver una serie de inconvenientes en el edificio que estorbaban el buen desarrollo de su trabajo. Unas veces son los diputados y otras los empleados de la institución los que ponen de manifiesto su incomodidad y su precariedad. Es el caso del Sr. depositario de Fondos que pre senta una queja al Pleno "haciendo ver la inseguridad del local donde guarda la caja de caudales" 227 . Sus temores se ven confirmados cuando en junio de 1861, la Diputación abre un expediente por "el robo acaecido en la Depositaría el día 20 de mayo, por el que los ladrones horadaron el techo del cuarto del arca de Fondos y taladrada esta con un berbiquí se habían extraído 71.024 reales con 33 céntimos" 228.

Pero sobre todo lo que no agrada a la Diputación, y vuelve a incidir en el mismo problema, es el tener que compartir las dependencias tanto con el Gobierno de la provincia como con el Consejo provincial, que una vez anulado en la época del Bienio, vuelve a ser operativo. Como ejemplo tenemos el acta de toma de posesión de los nuevos diputados, que se celebra el 2 de diciembre de 1856 y que se realiza en el "despacho del Sr. gobernador". No se dice nada ni se sabe el motivo de por qué no se celebra en el salón de sesiones de la Diputación, o como ocurre en el año 1859 en que el gobernador "comunica sobre la conveniencia de instalar el alumbrado de gas en las oficinas del Gobierno y del Consejo provincial" 229 .

221 B.O.P.V. $\mathrm{n}^{\circ} 48$ de 15 de abril de 1852

222 B.O.P.V. n 74 de 17 de junio de 1852 .

223 A.D.P.V. Actas. Libro de actas del día 1 de abril de 1852.

224 A.D.P.V. Actas. Libro de actas del 22 de junio de 1852.

225 B.O.P.V. ${ }^{\circ} 27$ de 3 de marzo de 1855.

226 A.D.P.V. Actas. Libro de actas del 20 de agosto de 1856. Pág. 3 v.

227 A.D.P.V. Actas. Libro de actas del 23 de agosto de 1856.

228 A.D.P.V. Actas. Libro de actas del 12 de junio de 1861. En esta acta, la Diputación rectifica la cuantía del robo, ya que "una vez efectuado el arqueo del dinero", constató la falta de 27.524 reales y 33 céntimos.

229 A.D.P.V. Actas. Libro de actas del 1 de mayo de 1859. 
Comunicación que da a entender que el gobernador no tiene a la Diputación como una institución independiente como cualquiera de las otras que tienen su sede en el colegio de San Gregorio, aunque sí que la tiene en cuenta, cuando en la misma sesión en la que trata de la instalación del gas, solicita la aprobación de un gasto de 14.000 reales. Tal petición, aunque fue aprobada, no contó con el respaldo de la totalidad de los diputados, ya que hubo dos diputados, los Sres. Moyano y Salcedo que, con razón, votaron en contra al considerar que el edificio era de propiedad estatal y debería ser el Estado el que corriera con los gastos.

La Diputación, al poco tiempo, se volverá a quejar de que no tiene sala para sus sesiones, y recuerda que una de las condiciones y compromisos adquiridos por el gobernador, en los días que se realizó el cambio, fue el de poseer en exclusiva una sala de sesiones. En estos tiempos, la sala la tiene que compartir con el Consejo provincial y con una serie de comisiones de la provincia, como se refleja en la reclamación que hace al gobernador ${ }^{230}$.

Además de solicitar cierta independencia en el disfrute de las instalaciones de San Gregorio, para que sus actividades fueran más cómodas, la Diputación hace una propuesta para "nombrar a la capilla de San Gregorio como templo de la Diputación" para celebrar en él las funciones religiosas. "Y creían que ninguna más a propósito que la capilla del que fue colegio de San Gregorio, restaurada últimamente por el Sr. gobernador, que reúne la doble circunstancia de hallarse en el mismo edificio todas las oficinas civiles de la provincia" 231 . Fue aprobada la propuesta, a la que se añadió "la construcción de una espadaña en que poder colocar una campana proporcionada, para llamar a los fieles a los actos religiosos", y además también se autoriza el gasto de equipar a la capilla de "los efectos y ornamentos indispensables para poder conservar abierto el culto" a cuenta de los fondos de la Diputación.

La Diputación está preocupada por la capilla, pero también siente preocupación por el estado del edificio, especialmente de las habitaciones que ocupa y que comparte, como es el salón de sesiones ${ }^{232}$. A los pocos días de tomado el acuerdo, se aprobó el gasto de 30.000 reales para "las obras de reparación y decoración del salón de sesiones".

En el año 1863 se plantean nuevos cambios en la gestión de las instituciones provinciales, fruto de la nueva ley de 25 de septiembre. En lo tocante a la vida de las Diputaciones, su cambio más significativo se refiere a la aparición nuevamente de la figura de secretario de la Diputación a la que acompaña los funcionarios correspondientes que se hagan cargo de los trabajos administrativos de la Corporación. En consecuencia "esto obliga a habilitar el local que ha de ocupar la Secretaría y demás dependencias de la Diputación y Consejo provincial", y para tal fin se nombra una comisión de entre los diputados provinciales para evaluar las necesidades de espacio y para la compra de utensilios y muebles para equipar la Secretaría.

Es notorio que el edificio de San Gregorio se deteriora con el uso y con el paso del tiempo, lo que conduce a tener que realizar una serie de gastos para su mantenimiento, gastos que son en realidad los mínimos imprescindibles como se ve en

\footnotetext{
${ }^{230}$ A.D.P.V. Actas. Libro de actas del 20 de septiembre de 1860 "Relativa a la habitación en que debiera celebrar sus sesiones, teniendo muy presente que hasta aquí se veía precisada a usar la sala-despacho del Sr. gobernador, ocupada muchas veces por otras comisiones, reunidas al propio fin, y considerando que la necesidad y su propio decoro exigía que se le destinara local enteramente independiente con el indicado objeto y también para su reunión, en vez de hacerlo en las salas-oficinas como hasta ahora se verificaba y acordó oficiar al Sr. gobernador rogándole se sirviera habilitar uno de los departamentos del edificio con cargo su coste a la partida de imprevistos del presupuesto de este año".

231 A.D.P.V. Actas. Libro de actas del 5 de noviembre de 1861.

232 A.D.P.V. Actas. Libro de actas del 13 de marzo de 1862: "Teniendo también presente el estado de deterioro en que se encuentra el salón principal, donde la Diputación y el Consejo de la provincia celebran sus sesiones y convencida de la necesidad que existe de repararle... se acordó autorizar al Sr. gobernador en lo que alcanzasen sus facultades para hacer las obras que fueran precisas al objeto indicado".
} 
las actas de $1864^{233}$. Y esta actuación, en realidad una pequeña reparación, se cumplimenta en el año 1865 con la presentación de un "presupuesto para reparar el edificio del colegio de San Gregorio en las habitaciones que ocupa las oficinas del Gobierno de la provincia y las de carácter provincial" ${ }^{234}$.

En estos años el colegio de San Gregorio continúa siendo utilizado por todos los organismos provinciales. Entre los últimos que se integran en el edificio, con lo que supone la realización de obras para adecuar los diferentes locales, son la "Dirección de Cámaras Provinciales" y la "Comisión de Cuentas y Pósitos". Al mismo tiempo, continúan apareciendo en las actas de la Diputación anotaciones con partidas presupuestarias para la reparación del edificio y mantenerle en condiciones mínimas de utilización.

La vida provincial llega al mes de septiembre de 1868 con la Diputación en el colegio de San Gregorio y las turbulencias políticas ocasionadas por el fin del reinado de Isabel II y el inicio del Sexenio Revolucionario. Con el inicio de este período, se produce un gran cambio político a nivel nacional, que como es lógico conlleva un cambio en el Gobierno provincial y también en la Diputación que continúa y continuará ocupando y compartiendo el colegio con el resto de las instituciones provinciales y lo hará durante la mayor parte del período revolucionario. En el año 1869 nos lo recuerdan los diversos pagos que se apuntaban por parte de la Diputación y que se reseñan en sus libros de actas. En el caso de la capilla, a la cual, la institución presta mucha atención, "se autoriza el pago de 400 escudos para la capilla de San Gregorio, donde la Diputación tiene sus oficinas y celebra sus sesiones" ${ }^{235}$. También las habitaciones ocupadas por el Sr. gobernador se beneficiarán de las mejoras que se acuerdan en los Plenos, pues "se autoriza el equipamiento de la casa del gobernador

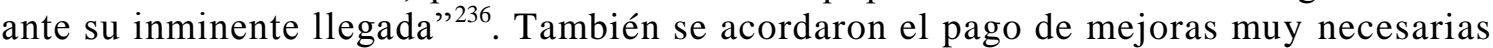
"en el escusado para el servicio de las oficinas de la Diputación, sitas en el colegio de San Gregorio" 237 .

Durante el año 1870, una serie de disposiciones y arreglos diversos nos recuerdan que la Diputación continúa sus trabajos en el mismo edificio, como es la "petición de arreglar jardines y patios del colegio de San Gregorio sede de la Diputación" $" 238$. A todo esto hay que añadir el especial cuidado en reparar la vivienda del Sr. gobernador, cosa que ocurre todos los años y que es debido al continuo cambio que se produce en las personas que ocupan el cargo de gobernador de la provincia, y que cada uno modifica la vivienda a su gusto, haciendo "obras en las habitaciones que el Sr. gobernador ocupa en el colegio de San Gregorio" 239 . En el año 1871, se vuelven a repetir las obras en la vivienda del gobernador, a lo que se añade la compra de muebles y otros objetos ${ }^{240}$. Este pago, viene precedido por un recordatorio justificativo del pago de estas facturas, que queda reflejado en el acta del 11 de julio del mismo año, en el que se aclara que "la Diputación utiliza el colegio de San Gregorio, propiedad del Estado, desde 1852, como salón de sesiones, Secretaría y Contaduría, a cambio de reparar el edificio" ${ }^{241}$.

A lo largo del año 1872, no se producen, ni se registran en los libros de actas ningún tipo de gastos por reparaciones a efectuar en el colegio, en este año sólo se

\footnotetext{
${ }^{233}$ A.D.P.V. Actas. Libro de actas del 27 de octubre de 1864: "atendiendo a la imperiosa necesidad de reparar los tejados del edificio del colegio de San Gregorio, en la parte que cubren las habitaciones ocupadas por la Diputación y sus dependencias, a fin de evitar los males que pudieran originar las lluvias, se acordó abonar con cargo a la partida de imprevistos del presupuesto provincial corriente los 294 reales a que ascendió la cuenta de gastos originados en el retejo de aquellas".

234 A.D.P.V. Actas. Libro de actas del 19 de noviembre de 1865.

235 A.D.P.V. Actas. Libro de actas del 29 de mayo de 1869.

236 A.D.P.V. Actas. Libro de actas del 8 de julio de 1869

237 A.D.P.V. Actas. Libro de actas del 21 de septiembre de 1869.

238 A.D.P.V. Actas. Libro de actas de 24 de febrero de 1870.

239 A.D.P.V. Actas. Libro de actas del 24 de marzo de 1870.

240 A.D.P.V. Actas. Libro de actas del 22 de julio de 1871.

241 A.D.P.V. Actas. Libro de actas de la comisión provincial de 11 de julio de 1871 .
} 
produce una "reclamación del Sr. gobernador, solicitando obras en las habitaciones que ocupa en el colegio de San Gregorio" ${ }^{242}$. Reclamación, a la que se añade una petición de reparación, justificando de cara al Pleno de la Diputación, el motivo por el que se debía de tener en cuenta la "petición de reparación del tejado de San Gregorio. Se pide que no se realice por ser un edificio propiedad del Estado. Se aprueba la propuesta ante la realidad de que la Diputación no paga alquiler por la utilización del colegio de San Gregorio" 243 .

El año 1873 viene marcado por los acontecimientos políticos nacionales, con la proclamación de la República. La vida de la Diputación está centrada en la preocupación por las guerras carlistas y los continuos sorteos para cubrir las necesidades del Ejército. Los señores diputados no se acuerdan de las reparaciones del edificio ni de la búsqueda de una nueva sede.

El año 1874 continúa con las mismas inquietudes que el año anterior, y la Diputación, con una mayor situación de control por parte del gobernador. Como claro exponente tenemos a la Diputación instalada el día 30 de mayo, que no es producto de elecciones, sino por nombramiento directo del Sr. gobernador. El motivo es que la vida provincial no sea lo efectiva que debiera ser, aunque sí que conocemos que las sesiones se siguen celebrando "en el salón de actos de la Diputación situado en el colegio de San Gregorio".

Una de las pocas referencias en este año a la situación de la sede de la Diputación nos la dejarán las discusiones para la aprobación de los presupuestos provinciales 1874-75 en los que se acuerda, después de una larga discusión aprobar "los capítulos séptimo y octavo, con la modificación de anular una partida de 125.000 pesetas para la compra de una casa-palacio para residencia de la Diputación y mantener 500 pesetas para el culto de la capilla de San Gregorio" ${ }^{244}$. Es un anuncio de cambio en el edificio a ocupar por la Diputación que continuará en los locales del colegio de San Gregorio, casi hasta el final del período del Sexenio. Como veremos más adelante, las gestiones para la adquisición de un edificio como sede de la institución se sucedieron con mayor o menor intensidad a lo largo de estos años y culminaron con éxito al finalizar el período.

\subsection{7.- EL PALACIO DE PIMENTEL A PARTIR DE 1874}

Bien es verdad que, como ha quedado reseñado con anterioridad, la residencia de la Diputación en la mayor parte del Sexenio Revolucionario estuvo situada en el colegio de San Gregorio. Pero también está demostrado que desde el principio del período, en el año 1869, los diputados provinciales trataron de buscar un nuevo edificio para el acomodo de los trabajos de la Diputación, aunque fueron en diferentes Diputaciones, diferentes diputados y diferentes años. Pero entre lo revuelta que anda la vida política nacional, con sus correspondientes repercusiones en la política provincial, y también con el problema añadido de la penuria económica en la que vivía la institución, fueron retrasando la decisión del cambio.

Los diputados provinciales en este período, es posible que vacilaran a la hora de invertir un dinero, que escaseaba o que no tenían, pero en todo momento y todos ellos coincidían en el interés por la adquisición del mismo edificio. Estaba situado cerca del colegio de San Gregorio y en un estado de habitabilidad y una amplitud que colmaba los deseos y las aspiraciones de los diputados provinciales, y lo consideraban como el edificio más idóneo como sede de la Diputación. Se trata de la Casa-Palacio de Pimentel, también conocida como el Palacio del conde de Rivadavia, situado en la Corredera de San Pablo ${ }^{245}$.

242 A.D.P.V. Actas. Libro de actas del 3 de diciembre de 1872.

243 A.D.P.V. Actas. Libro de actas del 5 de diciembre de 1872.

244 A.D.P.V. Actas. Libro de actas del 20 de junio de 1874.

245 URREA, Jesús. Arquitectura y Nobleza.... ob. cit. Pág. 137 y sig. "Palacio de Pimentel o del Conde de Rivadavia. Edificio construido en los primeros años del siglo XVI, perteneció en su origen a los marqueses de Astorga y condes de Trastámara. En el año 1506, juró en este palacio 
En el año 1869, la Diputación inicia las primeras actuaciones para efectuar el cambio, y lo justificaba por el interés de acomodar el Hospital Provincial en un edificio más amplio. En la sesión celebrada el día 1 de marzo, se da a conocer la propuesta de la casa palacio de la Plaza San Pablo ${ }^{246}$.

No era una mala operación para la Diputación, ya que acomodaba el Hospital Provincial en un edificio amplio, resolvía el problema del ruinoso Hospital de la Resurrección, y la institución se hacía con el Palacio Pimentel, aunque compartido en principio con el Gobierno de la provincia, y lo que es más interesante sin invertir dinero en la compra del edificio.

En el mes de septiembre de 1870, la nueva Diputación que se forma presenta un nuevo planteamiento para justificar la adquisición de un nuevo edificio, poniendo como excusa, la ocupación que tiene que soportar el edificio de San Gregorio, ante la presencia de las diferentes instituciones provinciales, y en la sesión que celebra el día 13, presenta una exposición, con una propuesta de cambio de sede, que queda recogida en las actas ${ }^{247}$. Por otro lado la Corporación no puede celebrar con comodidad sus sesiones, especialmente las secretas, porque no hay local apropiado.

En esta ocasión no mencionan el palacio de Pimentel, pero si tiene una nueva variante y es que tratan del alquiler de un edificio para sede de la Diputación únicamente, olvidándose de la exigencia de compartir espacio con las otras oficinas provinciales, cambio que es de suponer emana de la nueva "Ley Provincial". La comisión nombrada no hizo ninguna gestión que quedase plasmada en las actas de las sesiones, posiblemente debido a que a los cuatro meses se formó una nueva Diputación.

como príncipe heredero el futuro rey Carlos I. En el año 1517, es propiedad de Bernardino Pimentel, nieto del conde de Benavente. En el mismo año "en su estancia en Valladolid, el rey Carlos I, estuvo aposentado en el palacio de la Corredera de San Pablo". En el año 1527, nació en este palacio el que luego sería Felipe II, siendo su propietario el conde de Rivadavia, sin tener "noticia fiable" de cómo pasó la propiedad de Pimentel a Rivadavia. En 1752, según el Catastro de Ensenada, "la casa confrontaba con la plazuela de San Pablo, constaba de cuarto bajo, principal y cocheras, midiendo su fachada 60 x 56,5 varas y era propiedad del XIII conde de Rivadavia. En 1849 , la casa fue vendida por los marqueses de Camarasa y condes de Rivadavia en 80.000 reales al Exmo. Sr. Mariano Miguel de Reynoso, senador y comisario Regio de Agricultura. En 1874, el palacio fue adquirido por la Diputación provincial para hacerlo sede de la institución, a los herederos del Sr. Reynoso.

246 "Teniendo en cuenta que el edificio de San Gregorio, en el cual se hallan establecidas las oficinas del Gobierno y Diputación de esta provincia, reúne tanto por su situación geográfica, cuanto por su extensión y capacidad, todas las condiciones recomendables y precisas para destinarlas a hospital, y considerando así bien que el edificio de la Resurrección, destinado a Hospital Provincial de esta capital, no tiene capacidad bastante para contener el crecido número de enfermos pobres que acuden al mismo en demanda de asilo, la Diputación acordó: Solicitar por conducto del Sr. gobernador, la cesión en favor de la provincia, del edificio casa-palacio, sito en la plazuela de San Pablo ${ }^{\circ} 1$ de esta ciudad, y perteneciente al Patrimonio que fue de la Corona, para establecer en él las oficinas de la Diputación y del Gobierno, siendo por cuenta de esta corporación, los gastos que habrán de hacerse en su caso para la instalación de las expresadas oficinas y al mismo tiempo se pide autorización para destinar a Hospital Provincial el edificio de San Gregorio y en el cual están hoy establecidas las precitadas oficinas" A.D.P.V. Actas. Libro de actas del 1 de marzo de 1869. Según Urrea, la casa pertenecía a Mariano Miguel Reynoso, por compra al conde de Rivadavia en 1849. No hay constancia de que el palacio perteneciera al Patrimonio de la Corona.

247 A.D.P.V. Actas. Libro de actas del 13 de septiembre de 1870: "Diputación. Locales para oficinas. Varios señores diputados llamaron la atención por el estado ruinoso en que se encuentra uno de los locales de esta corporación, y la dificultad de sustituirle por otro por es tar ocupado todo el edificio con las dependencias de Gobernación. Hacienda y Fomento. Con tal motivo se hizo también observar por otro Sr. diputado que los locales en que se hayan establecidas las oficinas de esta Corporación son en extremo reducidas y en número tan insuficiente que no reúnen condiciones higiénicas, sin comentar que el despacho de los asuntos tenga lugar con la quietud, orden, atención y silencio que se hacen indispensables, por la circunstancia de la aglomeración del personal... En su vista se entró a discusión sobre la clase de obra a realizar, y considerando que las oficinas no pueden continuar en la forma en que están, mucho menos cuando empiece a funcionar la Diputación que se elija con arreglo a la nueva Ley Provincial, cuyo número de individuos ha de ser cuatro veces mayor que el que se compone en la actualidad. Se acordó el dar comisión a los Sres. Rábago y Guzmán para que busquen y contraten en arrendamiento un edificio donde puedan instalarse todas las dependencias de la corporación con la comodidad, desahogo y decencia convenientes". 
En el año 1871, en el mes de febrero, se forma una nueva Diputación, la tercera en el Sexenio, y en este año no se producirá ninguna gestión de compra o alquiler de edificio, ni tampoco reclamación alguna de los Sres. diputados, quejándose de la situación de los locales y de la falta de espacio, sobre todo si tenemos en cuenta que la nueva Diputación está formada por treinta y cinco diputados, en comparación con los nueve que componían la anterior. También es curioso que en este período no estén reflejados ningún tipo de gasto para el mantenimiento y reparación del edificio.

En el año de 1872, con la instalación de una nueva Diputación, vuelven a aparecer las intenciones de búsqueda de una nueva sede, cuando el Pleno de la misma, encarga a la Comisión Permanente la búsqueda de un edificio para albergar la nueva sede de la Diputación. Parece que las pesquisas de la comisión van por buen camino, pues el 22 de noviembre, aparece en el libro de actas una nota que dice: "acuerdo con la Sra. Lara para el arriendo de su casa, en la calle Angustias para oficina" ${ }^{248}$.

Y a la esperanza de un cambio presentado por esta breve nota, viene el desencanto que produce el acta del día siguiente con la opinión de la Comisión Permanente ${ }^{249}$.

Con la aprobación de este dictamen desaconsejando la compra o arrendamiento de un nuevo edificio, no se vuelve a tratar el tema del cambio. Lo que sí se vuelve a repetir es el interés de las diferentes personas que forman las distintas Diputaciones por tratar de la compra del mismo edificio, es decir, del Palacio de Pimentel, que en años pasados ha sido comprado por la familia Reynoso.

En el año 1874 , al final del año y al final de período, es cuando se produce la definitiva adquisición de un edificio como sede de la Diputación. Es el 10 de noviembre, cuando el diputado provincial, Eustaquio de la Torre, miembro de la Comisión Permanente, comunica a la Diputación la necesidad de adquirir el Palacio ${ }^{250}$.

Hacemos hincapié en que se vuelve a tratar del mismo edificio en que la Diputación puso la intención desde los inicios del período, allá por el año 1869, es decir, el Palacio de Pimentel o del conde de Rivadavia, y si en el año 1872, la Comisión Permanente consideraba "inadmisible las condiciones de arrendamiento", en 1874 el Pleno de la Diputación autorizaba a la Comisión para llegar a un acuerdo para la compra de la casa-palacio.

248 A.D.P.V. Actas. Libro de actas del 22 de noviembre de 1872. Es una anotación de dos líneas, sin aclarar quién es la propietaria, si ha habido acuerdo anterior o quién ha llegado al acuerdo de arrendamiento.

249 "Dictamen de la Comisión Permanente sobre el alquiler de una casa para oficinas de la Diputación. La Comisión Permanente, en cumplimiento de lo acordado por la Excma. Diputación Provincial, reservando a esta la resolución del traslado de las oficinas, opina que las ofertas hechas por el señor que se dice apoderado de los herederos de Dña. Dolores de Reynoso, no son admisibles bajo ningún concepto, y no habiendo antecedente alguno sobre el particular, entendiendo que no hay recursos sobrantes para crear nuevos gastos, no consideran urgente la adquisición de nuevos locales para la Diputación. Fue aprobado sin discusión” A.D.P.V. Actas. Libro de actas del 23 de noviembre de 1872.

250 "La necesidad de obtener un local a propósito donde establecer las oficinas, pues el que hoy ocupan no reúne ninguna circunstancia de capacidad, ni aun de decoro para las mismas. De capacidad, pues no hay suficiente desahogo en la sala de Negociado, separación entre ésta y la Contaduría ni sitio de ninguna clase para la Secretaría. De decoro, porque siendo el número de los Sres. diputados tan extenso, se carece de una sala de conferencias, de escritorios, de todo absolutamente que pueda aislar los centros de trabajo tan necesarios y de tan diversa índole en estas corporaciones. ... Suponiendo a los Sres. diputados perfectamente enterados de tales inconvenientes, la Comisión ha querido presentarles en este período algunos trabajos dirigidos a la adquisición del local por si así lo acordaban y al efecto propusieron al apoderado de los Herederos del Sr. Reynoso, si estaba en el ánimo de los mismo, la enajenación de la casa que les pertenece en la corredera de San Pablo, el cuál con comunicación de 30 del mes anterior pidió 90.000 pesetas, que comisionado el arquitecto provincial, ha dado un informe minucioso, tasándola en 65.000 pesetas. ... Puesto a votación de si es necesaria la adquisición de la casa-palacio para la Diputación, por unanimidad se acordó la necesidad de adquirirla para traslación de todas las dependencias, y autorizar a la Comisión Permanente para adquirir por compra el citado edificio, u otro que reúna circunstancias a propósito" A.D.P.V. Actas. Libro de actas del 10 de noviembre de 1874 . 
El acuerdo no se hizo esperar, pues si en la sesión del 10 de noviembre se concedía la autorización, en la sesión del 17 de diciembre, la Comisión comunicaba al Pleno la compra del edificio. ${ }^{251}$

Es una de las últimas actuaciones de la Diputación en el Sexenio, que como vemos, asegura la compra y justifica la operación, ya que está viendo que los acontecimientos políticos van en la dirección de nuevos cambios. También notamos que la operación se cerró por el precio que indicó el arquitecto provincial, es decir, 65.000 pesetas, en contra de las 90.000 pesetas que pedían los propietarios. Lo que sí es de resaltar el mérito y el acierto de la operación de la Diputación al efectuar la compra de la Casa-Palacio Pimentel, pues con los lógicos trabajos de reparaciones, modificaciones y transformaciones, siempre respetando su aspecto original, se ha mantenido hasta la actualidad como sede de la Diputación Provincial.

\section{4.- EVOLUCIÓN INSTITUCIONAL DE LA DIPUTACIÓN}

En estos primeros años de vida de la Diputación vallisoletana, tuvieron especial relevancia los nombramientos de los individuos que conformaron las sucesivas corporaciones, y que serían los encargados de desarrollar las actividades marcadas por los gobiernos de turno. En el caso de los jefes políticos-gobernadores, siempre lo fueron por nombramiento real, y en el caso de los diputados, unas veces lo fueron por decisión de las autoridades centrales, y en otras, que se corresponden con la mayoría de los casos, lo fueron a través de las correspondientes elecciones.

El jefe político es esencial durante las primeras corporaciones y destacaba sobre el resto de los componentes por el "plus" de autoridad y por el ejercicio de la presidencia que le reconocían las leyes. Era el encargado de trasmitir las órdenes del gobierno y de velar por el cumplimiento de las mismas. Con el paso del tiempo y la consolidación de la Diputación, esta hegemonía y autoridad fue diluyéndose y perdiendo "fuerza".

Los diputados provinciales fueron los auténticos protagonistas de cada una y todas las Diputaciones que se sucedieron a lo largo de estos años. Pusieron su esfuerzo, su dedicación y su tiempo, para satisfacer, o por lo menos intentarlo, las necesidades que acuciaban a la totalidad de las provincia.

Los secretarios que se sucedieron en el cargo, y los restantes funcionarios, junto con los componentes de las diversas comisiones que se formaron, tuvieron también su importancia y su mérito en la consecución y agilización de las gestiones para facilitar los trabajos encomendados. A todos ellos les acompañan también, diversos personajes que destacaron por su relevancia en la vida provincial, aunque no pertenecieron a la corporación.

Finalmente, todas estas Diputaciones, cada una en su época, en su estilo y con sus posibilidades trabajaron para desarrollar una serie de tareas, que en coincidencia con la situación política económica y social, estaban dirigidos a mejorar el nivel de bienestar de la población.

Entre el 2 de septiembre de 1813 y el 18 de marzo de 1875 , se sucedieron un total de veintiocho Diputaciones diferentes, divididas en: Una Diputación en los años

\footnotetext{
251 “Siendo una de las más principales entre las resoluciones tomadas por la Diputación provincial, en la última sesión periódica, la de llevar a cabo la adquisición por compra a los herederos de D. Mariano Miguel de Reynoso de la casa-palacio para establecer las oficinas de la Diputación, para llevar a efecto el contrato, previos los informes del arquitecto provincial, y varias conferencias con los expresados herederos, quedó definitivamente ajustada dicha casa, situada en esta capital, lindando con las calles de San Gregorio, corredera de San Pablo y otras notorias, en el precio de 13.000 duros, pagaderos en dos plazos, mitad al otorgamiento de la escritura y la otra mitad, al año de dicho otorgamiento, libre de toda carga, e intereses del $6 \%$ en el segundo plazo. ... Y para que llegado el plazo no se ofrezca dificultades a los que son o fueron vocales o representantes legítimos de la Diputación, una vez que se orillen las dificultades para formalizar el contrato, se acordó consignarlo a los efectos consiguientes" A.D.P.V. Actas. Libro de actas de la comisión permanente del 17 de dicie mbre de 1874.
} 
de la Constitución gaditana, tres Diputaciones durante el Trienio Liberal, diez y nueve Diputaciones en la época isabelina y cinco Diputaciones en el Sexenio Revolucionario.

\subsection{1.- LA PRIMERA DIPUTACIÓN Y LOS PRIMEROS DIPUTADOS}

\section{$1^{\text {a }}$ Diputación gaditana. Septiembre 1813 - Junio 1814}

\begin{tabular}{|c|c|c|c|c|}
\hline Nombre & Cargo & $\begin{array}{l}\text { Partido } \\
\text { judicial }\end{array}$ & $\begin{array}{c}\text { Permanencia en el } \\
\text { cargo }\end{array}$ & Sesiones \\
\hline Antonio María Peón y Heredia & $1^{\circ}$ Presidente & Jefe Político & Sep. 1813-Jun.1814 & 29 \\
\hline José Casimiro Lavalle & $2^{\circ}$ Presidente & Jefe Político & Junio 1814 & 2 \\
\hline José Rodríguez Camargo & Vice-presid. & Intendente & Sep. 1813-Jun 1814 & 47 \\
\hline Juan Andrés de Temes y Prado & Diputado & Valladolid & Sep. 1813-Jun 1814 & 31 \\
\hline José Pestaña & Diputado & Benavente & Sep. 1813-Jun 1814 & 35 \\
\hline Pedro Regalado Romero & Diputado & Valladolid & Sep. 1813-Jun 1814 & 41 \\
\hline José A. González Perotes & Diputado & Peñafiel & Sep. 1813-Jun 1814 & 6 \\
\hline Joaquín Argüello & Diputado & Rioseco & Sep. 1813-Jun 1814 & 17 \\
\hline Félix Prieto & Diputado & Gradefes & Sep. 1813-Jun 1814 & 23 \\
\hline Joaquín Maldonado & Diputado & Medina & Sep. 1813-Jun 1814 & 7 \\
\hline José Berdonces & Suplente & - & - & \\
\hline
\end{tabular}

Fin de la ocupación francesa

El día 19 de marzo de 1812, mientras las Cortes de Cádiz, aprobaban en una solemne sesión, celebrada en la iglesia de San Felipe Neri, la "Constitución Política de la Monarquía Española", en Valladolid, ocupada por las tropas francesas, ese mismo día se celebraba en la Santa Iglesia Catedral "un solemne Te Deum en honor del Rey José I, con los posteriores festejos en la ciudad patrocinados por el Ayuntamiento" 252.

Durante el resto del año 1812, la ciudad se ve inmersa en una serie de idas y venidas del ejército francés y en una consiguiente serie de entradas y salidas de las tropas españolas e inglesas. Estos acontecimientos hacen que, por un lado, mientras el resto de las ciudades libres del país se afanan por poner en marcha los cambios previstos en la Constitución y buen ejemplo de ello es la instalación de las Diputaciones provinciales de Cataluña, Asturias y Galicia, en Valladolid estos progresos se ven frenados por la presencia intermitente de las tropas de ocupación francesas, que impiden la proclamación de la Constitución y el arranque de las actividades de su Diputación provincial.

Este ir y venir de tropas provocan también una serie de peticiones tanto de las tropas francesas como de las españolas, referidas a exigencias de aprovisionamiento, mantenimiento, alojamiento y equipamiento de los soldados, además de las atenciones necesarias a los heridos de ambos bandos. Todas estas actuaciones quedan reflejadas en los libros de actas del Ayuntamiento de la capital, con las diversas reclamaciones que son presentadas por los vecinos al no poder hacer frente a los fuertes arbitrios a que son sometidos, por lo que aparte de expresar las quejas, anuncian el abandono de sus ocupaciones profesionales al no poder hacer frente a las contribuciones que se les exige $^{253}$.

\footnotetext{
${ }^{252}$ ORTEGA y RUBIO, Juan. Noticias de casos particulares... ob. cit. Págs. 177 y siguientes.

253 Archivo Histórico Municipal de Valladolid (en lo sucesivo A.H.M.V). Libro de actas $\mathrm{n}^{\circ} 1^{107}$, correspondientes a los años 1812 y 1814 (falta el año 1813) donde se recogen las quejas de comerciantes, alfareros, caldereros, sastres, escabecheros, tocineros, sombrereros, chocolateros, barberos, cirujanos, curtidores y aceiteros con solicitudes de pago de vales de suministro por aprovisionamiento a las tropas francesas, portuguesas, inglesas y españolas de aceite, velas, carbón, leña, sal, carne, pan, vajillas, ropa y alojamientos militares.
} 
El día 29 de julio del citado año 1812, en la reunión que se mantiene en el Ayuntamiento se toma el acuerdo de que, "en atención a la precipitada salida que ha hecho en la tarde de este día la tropa francesa, ha mandado se cierren las puertas reales de Santa Clara, a cuyo fin se pasa orden al alcalde y comisario del barrio para que ronden toda la noche y den parte al corregidor si advirtieran alguna novedad" ${ }^{254}$.

Y el resultado de esa precipitada salida lo tenemos reflejado el día 31, cuando el Ayuntamiento "dio orden para que oficiales y operarios de albañilería y carpintería concurran a la orden del arquitecto D. Pedro García para la reparación del Puente Mayor que rompieron ayer las tropas francesas" 255 .

El mismo día 31 de julio, entran en Valladolid las tropas españolas que son acogidas con gran alegría por el vecindario. Alegría que se va apagando cuando se dan cuenta de que las exigencias que presentan en temas de alojamientos, de suministros, de equipamientos y hasta de dinero en metálico no cesan y son similares a las francesas. Así vemos que la división del general Carlos España solicita para sus soldados "un equipamiento de 4.000 pares de zapatos y 4.000 camisas para su tropa lo que espera conseguir gracias al celo y patriotismo del Ayuntamiento" ${ }^{256}$.

El día 5 de agosto entra en Valladolid el general Santocildes, recién nombrado capitán general de Castilla la Vieja y jefe político de Valladolid. Una de sus primeras medidas fue la de destituir al corregidor cercano a los franceses, Pedro Pascasio Calvo y nombrar en su lugar a Juan Andrés de Temes, catedrático de la Universidad. También acordó "el día y modo en que debe de ejecutarse la solemne proclamación de la Constitución", acto que se fijó para el día 15, pero que no se pudo realizar por la entrada nuevamente en la ciudad del ejército francés al mando del general Clausel. Éste, como castigo, impuso a la ciudad una multa de 100.000 reales, y el Ayuntamiento, ante su falta de fondos, se vio obligado a confeccionar una relación de vecinos y cantidades a pagar por cada uno.

El día 7 de septiembre, entran de nuevo en la ciudad las tropas españolas e inglesas al mando de Lord Wellington, que volvió a dar la orden de "proclamar la Constitución", acto que se realizó al día siguiente, "formado el Ayuntamiento en las Casas Consistoriales y acompañado de personas de distinción, salió de ella con timbales y clarines y el Pendón Real que llevó el intendente-corregidor Dr. Temes, se hizo la publicación. Estaban colgados los balcones y en el principal, el retrato del Rey Fernando $7^{\circ}$. Se celebraron fiestas y manifestaciones de alegría" ${ }^{257}$.

Este mes de septiembre se caracteriza por una serie de ceses y nombramientos de personalidades políticas de índole provincial y local, y entre estos destaca el nombramiento de "Don Andrés Avelino Fernández, como corregidor de las Juntas de Subsistencia y demás servicios, de manera provisional, entre tanto que no se forme la Diputación provincial que manda establecer la Constitución" ${ }^{258}$. Es esta la primera referencia que se tiene en Valladolid sobre la posible instalación de la Diputación, intento que se ve frenado por la presencia de nuevo de tropas francesas "a las puertas de la ciudad". El día 28 de octubre la ciudad está sitiada y bombardeada, y ante el abandono de las tropas españolas, los franceses se apoderan nuevamente de la misma, con el resultado de la nueva destrucción parcial del Puente Mayor y nueva imposición de una multa, en esta ocasión de 600.000 reales, para cubrir las necesidades del ejército del general Reille.

En los inicios de 1813, las tropas francesas continúan en la ciudad y continúan exigiendo arbitrios y contribuciones a los ciudadanos. El día 19 de marzo, al igual que ocurrió en el año anterior, se celebra un "solemne Te Deum" en la catedral, con motivo de la onomástica del Rey José I. También se engalana la ciudad por el aviso de llegada del Rey, que se presenta el día 23 después de su definitiva salida de Madrid. Viene

\footnotetext{
${ }^{254}$ A.H.M.V.- Libro de actas $n^{\circ} 103$ del día 29 de julio de 1812.

${ }^{255}$ A.H.M.V.- Libro de actas 103 del 31 de julio de 1812 .

${ }^{256}$ A.H.M.V. Libro de actas $n^{\circ} 103$. Actas del día 5 de agosto de 1812.

${ }^{257}$ ORTEGA y RUBIO, Juan. Noticias de casos particulares... ob. cit. Pág. 203 y siguientes.

${ }^{258}$ A.H.M.V. Libro de actas $n^{\circ} 103$. Acta del día 26 de septiembre de 1812.
} 
acompañado por un gran número de personalidades que han abandonado igualmente la Corte y le acompañan en su retirada.

El Rey José permanece en Valladolid hasta el día 2 de junio del mismo año, fecha en que sale con dirección a la frontera francesa, siguiéndole el resto de tropas que abandonan definitivamente la ciudad el día 4. Entran a continuación las tropas españolas al mando del general Francisco Javier Castaños.

El día 21 de junio, se presenta el nuevo jefe superior político y capitán general de la provincia de Valladolid D. Antonio María Peón y Heredia, que como primera medida publicó un aviso "exhortando a la tranquilidad pública... y que todos los vecinos se esforzasen a contribuir con lo que pudieran para la subsistencia de la tropa" ${ }^{259}$.

\section{Instalación de la Diputación}

Sabemos por los cronistas de aquellos años que "las actividades democráticas" en la provincia de Valladolid se inician el día 28 de julio de 1813, con la presentación de los electores de las parroquias de la ciudad y de los pueblos de su partido, presentando las credenciales y aprobando los nombramientos ${ }^{260}$.

Igualmente el día 30, el Ayuntamiento, con un parecido ceremonial, eligió entre sus individuos, al diputado a Cortes que le correspondía por privilegio, siendo nombrado D. Pedro Lapuerta, regidor constitucional y relator de la Chancillería.

El día 12 de agosto continúan las elecciones, en este caso, para cubrir los puestos de cuatro diputados a las Cortes Extraordinarias, aunque estaban próximas a terminar. Resultaron elegidos José Adámez cura de la parroquia de Santiago de Valladolid, Evaristo Pérez de Castro diputado que fue en las Cortes Constituyentes de Cádiz y en la actualidad oficial mayor de la Secretaría de Estado, José Tomás Flórez vecino de Moral de la Reina, el Excmo. Sr. D. Félix Calleja virrey de Méjico y como suplente Tomás Moyano consejero de Castilla. Todos ellos naturales de esta provincia.

El día 24 de agosto, en las elecciones para diputados a Cortes ordinarias, fueron elegidos Gabriel Ugarte Alegría canónigo de la Catedral y doctor de la Universidad, Tomás Moyano, Alonso González y como suplente José Ramírez Cid.

También tenemos referencias de que, el día 30 de agosto de este año de 1813 , se celebraron elecciones a diputados provinciales, y que la Diputación se instaló y celebró su primera sesión el día 2 de septiembre de 1813, siendo presidida por D. Antonio María Peón y Heredia, mariscal de campo y jefe político de la provincia y siendo vicepresidente D. José Rodríguez de Camargo, intendente del Ejército y de la provincia, y estando presentes los diputados electos:

- D. Juan Andrés de Temes y Prado, catedrático de la Universidad.

- D. Joaquín Maldonado, vecino de Medina.

- D. Félix Prieto González, de Rueda del Almirante.

- D. José Pestaña, presbítero de Manganeses de la Polvorosa.

- D. Pedro Regalado Romero, relator de la Audiencia.

- D. José Antonio González Perotes, hacendado de Peñafiel.

- D. Joaquín Argüello, abogado de Valdenebro. Catedral.

Es elegido diputado provincial suplente D. José Berdonces, penitenciario de la

Esta instalación está contrastada documentalmente a partir de los libros de actas, y aunque la primera inscripción en el libro corresponde a la sesión celebrada el día 9 de febrero de 1814, en la sesión del 11 de marzo, coincidiendo con el inicio de

\footnotetext{
${ }^{259}$ ORTEGA y RUBIO, Juan. Noticias de casos particulares... ob. cit. pág. 233.

260، Este día, junto en las mismas Casas Consistoriales, a la hora de las 9, salieron todos para la iglesia Catedral, donde se celebró misa del Espíritu Santo por el Sr. obispo....Volvieron al Consistorio y a puerta abierta se hizo la elección de doce vocales. Estos se retiraron a conferenciar y después entraron, votaron y por mayor número de votos salió electo diputado de esta ciudad y partido D. Juan Antonio Gala, vecino de Castronuevo". ORTEGA Y RUBIO, Juan. Noticias de casos particulares... ob. cit. Págs. 237 y 238.
} 
las actividades queda reseñada “... la apertura de las nuevas sesiones del segundo año... desde su instalación verificada el día 2 de septiembre anterior..." 261 . También conocemos de su existencia y de sus actividades a través de sus relaciones con otras instituciones de la ciudad como es el Ayuntamiento, con el que se pone en contacto a través de un escrito fechado el 13 del mes de septiembre de 1813, es decir, a los diez días de su instalación en el que pone de manifiesto su preocupación por las comunicaciones y al mismo tiempo nos demuestra que ya ha nombrado secretario. La misiva nos dice que "para dar cumplimiento a las órdenes del Excmo. Sr. Duque de Ciudad Rodrigo, encargadas al ingeniero de su mando D. Jorge Wat, que se ha presentado en esta Diputación provincial con el arquitecto D. Pedro García comisionado por éste para el reconocimiento e informe de los puentes de Simancas, Villanueva, Quintanilla y Tudela, se necesita la orden que el mismo Sr. ingeniero inglés asegura haber entregado a Vds. a su arribo a esta ciudad. La Diputación ha acordado se oficie a Vds., como lo hago, al objeto de sin perder tiempo tenga la bondad de remitirlo a la Diputación que se halla reunida y a la espera. Dios guarde a V.S. muchos años. Valladolid a 13de septiembre de 1813. A, Capdevila. Secretario"262.

\section{Supresión de la Diputación}

El anuncio de Fernando VII de su intención de salir de Valençay con dirección a Perpignan y cruzar la frontera por la provincia de Gerona fue un motivo suficiente como para que Peón y Heredia, jefe político y presidente de la Diputación de Valladolid con fecha 30 de marzo de 1814, mandara "que en celebridad de tan fausta noticia se tengan regocijos públicos por tres días, publicándose la noticia para satisfacción del público" ${ }^{263}$. Pero lo que no se imaginaba el jefe político era que esa noticia iba a suponer el principio del fin de la vida de la Diputación en esta su primera etapa. Es más, el día 1 de abril, nuevamente, el jefe político pasó otro oficio comunicando que el Rey ya estaba en territorio español desde el día 24 de marzo ${ }^{264}$.

La entrada del Rey en el país es el inicio de una serie de enfrentamientos entre "liberales y serviles", es decir, detractores y partidarios del monarca. En Valladolid a partir del día 12 de mayo se producen una serie de enfrentamientos y "ocurrencias" en la ciudad. "Se quema la Constitución, se arranca la placa conmemorativa, se quitan a los alcaldes constitucionales y se reponen a los antiguos, el relator de la Audiencia en tiempos de la ocupación francesa, Vinuesa, un anciano de 80 años es ajusticiado, se detiene al decano de la Diputación Dr. Temes y se intenta desposeer de su mando al jefe político" 265 .

Estos tumultos se mantienen a lo largo de todo el mes de mayo, y durante este período la Diputación no mantiene sesiones, pero el Ayuntamiento sí se hace eco de una real orden ordenando "restablecer el orden y evitar los motivos o pretextos de las protestas, y siendo uno de ellos la lápida de la Constitución, se ordena retirarlas con prudencia y reserva por la noche, sin hacer mudanza de autoridades"266.

El jefe político, Sr. Peón y Heredia, a finales de mes, se traslada a Madrid para presentar el informe de las revueltas sucedidas en la capital, y aunque parece que los ánimos se van calmando, la Diputación se sorprende cuando en la reunión del día 8 de junio "se da lectura a dos oficios comunicados por el Sr. D. Antonio María Peón y Heredia, mariscal de campo de los Reales Ejércitos, y por el Sr. D. José Casimiro Lavalle, brigadier, comprensivos ambos del real decreto de 22 de mayo de S.M. (que

261 A.D.P.V. Actas. Libro de actas del día 11 de marzo de 1814.

262 A.H.M.V. Fondos de Chancillería. Caja 373, expediente 204. Oficio de la Diputación al Ayuntamiento.

263 A.D.P.V. Actas. Libro de actas del día 30 de marzo de 1814.

264 A.D.P.V. Actas. Libro de actas del día 1 de abril de 1814: "Y que en celebridad de esta noticia se había determinado por las Cortes se cante un solemne Te Deum en todas las iglesias de la monarquía en acción de gracias, lo que se había de verificar el día de mañana 2 en la iglesia Catedral con asistencia de todas las autoridades".

265 ORTEGA y RUBIO, Juan. Noticias de casos particulares...ob. cit. pág. 245.

266 A.H.M.V. Libro de actas $n^{\circ} 107$. Acta del día 26 de mayo de 1814. 
Dios guarde), dirigidos por el ministro de la Guerra, por el cual relevado el primero de la Comandancia Militar de Castilla la Vieja, se nombra y encarga al segundo. Posesionado ya en su ejercicio y correspondiendo a S.S. por este concepto la presidencia de la Diputación, fue reconocido por los individuos de ella y colocado en su asiento preminente" 267 .

A partir de este día los acontecimientos se suceden con rapidez, ya que el día 22 la Diputación tiene cierta información de que su disolución está próxima, y finalmente el día 25 se celebra la última sesión ${ }^{268}$.

Con esta acta, la Diputación da por cerrada la primera y breve etapa de su vida, sin tener, ni reflejar en sus escritos, la más mínima queja o contrariedad causada por las decisiones reales. Y tan llamativa como la sumisión de la Diputación es el radical cambio de opinión de los vecinos, que si en septiembre de 1813 aplaudía la llegada de la Constitución, en junio de 1814, rechazaba lo que aplaudía nueve meses antes. El pueblo, en este corto espacio de tiempo, ha visto que ni las Cortes ni las Diputaciones han sido lo efectivas que esperaban y ahora cambian de sentido y esperan que "el Deseado" les saque de su grave situación social y económica. En definitiva, confían en que las propuestas reales sean más eficaces que las liberales, y como relata Ortega y Rubio, "en la ciudad existen dos bandos llamados liberales y serviles, los primeros estaban por la Constitución y los segundos por el antiguo Gobierno... y la mayoría de los ciudadanos se inclinan por apoyar a los serviles y en consecuencia se producen una serie de ocurrencias contrarias a los liberales..." 269.

\section{Los primeros gestores de la Diputación}

Esta primera Diputación está vigente desde el día 2 de septiembre de 1813, día de su primera sesión de instalación, hasta el día 25 de junio de 1814, en cuya sesión se da lectura a la real orden de 15 del mismo mes, en la que se ordena la supresión de las Diputaciones y en consecuencia, el cese de sus actividades.

En este período se celebran cincuenta y dos sesiones entre los días 9 de febrero a 25 de junio de 1814. No hay constancia del número de sesiones realizadas entre el 2 de septiembre de 1813 y el 8 de febrero de 1814, por ausencia de datos reflejados en el libro de actas, cuya primera inscripción se corresponde con la citada sesión celebrada el día 9 de febrero.

En esta primera Diputación son elegidos siete diputados, que representan a los diferentes partidos judiciales existentes en la provincia, además de un diputado suplente.En el cuadro que se adjunta al inicio de este apartado, se reflejan los nombres de los presidentes, el vicepresidente y los diputados con referencia al partido judicial al que pertenecen, el tiempo de permanencia en el cargo y el número de sesiones a las que asistieron.

A la hora de elegir a los hombres de la nueva institución, los electores, aun siendo una provincia eminentemente agrícola, se decantaron por elegir sobre todo a "hombres de leyes", ya que entre los siete diputados más el suplente se encontraban un

267 A.D.P.V. Actas. Libro de actas del día 8 de junio de 1814

268 "Presidida por el comandante general Lavalle y siendo asistentes el intendente Camargo y los diputados Temes, Maldonado, Pestaña y Romero, firmando el acta el secretario Capdevila, se da lectura al real decreto de 15 del presente mes hecho saber a la Diputación en la sesión de este día por su presidente el Sr. brigadier comandante general de Castilla la Vieja, gobernador político de esta provincia D. Josep Casimiro de Lavalle, por el cual manda el Rey (que Dios guarde) suprimir las Diputaciones provinciales, como no necesarias y mediante el restablecimiento del Consejo Real, el cual está encargado por las leyes del conocimiento de algunos de los negocios encomendados a las Diputaciones y estar ya meditado el régimen que deberá observarse en los demás, mandando igualmente que los papeles de sus secretarías se pasen a las respectivas contadurías de provincia, se acuerda cesar y cerrar desde este mismo día sus sesiones, dando comisión a los Sres. diputados residentes en la ciudad D. Juan Andrés de Temes y D. Pedro Regalado Romero para que con el secretario D. Alejandro Capdevila, cuiden de que se incluyan los inventarios y se entreguen todos los papeles a la mayor brevedad a la Contaduría de la provincia..."A.D.P.V. Actas. Libro de actas del 25 de junio de 1814 .

269 ORTEGA y RUBIO, Juan. Noticias de casos particulares... ob. cit. pág. 252 y siguientes. 
catedrático, dos clérigos, dos abogados y tres hacendados, de los que dos de ellos también ejercían de abogados. Es decir, son todos representantes de la cultura, de los propietarios de la tierra y de los profesionales del derecho. Son individuos con capacidad económica y sin problemas para "tener lo suficiente para mantenerse con decencia", como exigía una de las condiciones para ser nombrado diputado.

\section{El personal de la Diputación}

En esta su primera etapa de funcionamiento la Diputación elige a un pequeño número de personas para hacer frente a las necesidades de la institución tanto a nivel administrativo como material. Son un grupo de cuatro funcionarios, todos ellos encuadrados en la Secretaría y encabezados por el secretario de la Diputación.

\section{Capdevila, Alejandro}

Es el primer secretario de la Diputación. Nació en Lerma, diócesis y provincia de Burgos, en el año 1766. Inició sus estudios superiores en la Universidad de Valladolid en el año 1779, fecha en la que solicitó su ingreso en la Facultad de Artes, "para oír facultad en esa Real Universidad"270. En el año 1813 es vecino de Peñafiel y al ser nombrado secretario de la Diputación, se traslada a vivir temporalmente a Valladolid.

Tiene a su cargo toda la gestión administrativa de la Diputación, aunque no tiene seguridad de su estabilidad en el empleo, como lo demuestra al remitir al Ayuntamiento de Valladolid el 7 de marzo de 1814, una misiva en la que "solicita al Ayuntamiento que como su existencia es temporal, pendiente de su aprobación o suspensión como secretario de la Diputación, por lo que no tiene seguridad de subsistencia, suplica que mientras no tenga el concepto de vecino no se le grave con el impuesto de alojamiento" 271 .

Esta preocupación por la estabilidad en el trabajo se confirma en el mes de junio del mismo año cuando se ordena la supresión de la Diputación y es encargado junto a los diputados Temes y Romero, como vecinos de la capital, de cerrar los libros, archivar los documentos y enviarlos a la Contaduría provincial. Vuelve a residir a Peñafiel donde ejerce de notario.

En el año 1820 es nuevamente reclamado por la Diputación, al ser puesta en vigencia, para hacerse cargo de la Secretaría. Se mantiene en el puesto desde el 21 de marzo, fecha en que se reanudan las actividades, hasta el 4 de mayo de 1823 , fecha en que de nuevo es disuelta la Diputación y se le vuelve a ordenar la entrega de toda la documentación de la Secretaría, esta vez, al "repostero" de las Casas Consistoriales.

En el año 1836 actúa como juez de Primera Instancia de Peñafiel y en escrito que dirige a la Diputación "solicita un certificado de los servicios realizados en la época constitucional como secretario de la Diputación" 272.

\section{González, Juan Nepomuceno}

Es nombrado en esta primera Diputación vicesecretario y depositario de Fondos, cargo que desempeña durante la vigencia de la misma. En el año 1820, es nuevamente llamado y ratificado como vicesecretario cargo, que desempeña hasta el año 1823, es decir, durante el período del Trienio Liberal.

En el año 1835, con la nueva puesta en marcha de la Diputación es nombrado oficial $1^{\circ}$ de la Secretaría. En el año 1836 es nombrado archivero de la Diputación, cargo al que accedió "previo examen", aunque su trabajo en este puesto no fue muy satisfactorio, en razón de las quejas que se plasman en las actas. Así vemos que en la sesión celebrada el 9 de noviembre de 1836, en el transcurso de las discusiones para la aprobación de la nueva plantilla de la Secretaría, el diputado Sr. Serrano comunica

\footnotetext{
270 Archivo Histórico Universitario de Valladolid (a partir de ahora A.H.U.V.A.) Caja 565.

271 A.D.P.V. Actas. Libro de actas del día 7 de marzo de 1814.

272 A.D.P.V. Actas. Libro de actas del día 8 de febrero de 1836
} 
que "en su inspección de la Secretaría hace ver los buenos rendimientos de los empleados, de lo que estaba satisfecho, excepto de D. Juan Nepomuceno González que había desempeñado la plaza de oficial $1^{\circ}$ y era completamente inútil para el desempeño de cualquier cargo, pidiendo se considerase que ya por su avanzada edad, ya por su poca actividad, se le cesase en el empleo de archivero con el que se le acababa de agraciar. El Pleno acordó ratificarle en la plaza de archivero dada su adhesión a la causa".

En el año 1837 solicitó abandonar la plaza de archivero y volver a su anterior puesto de oficial $1^{\circ}$ de la Secretaría, trabajo que desempeñó entre 1821 y 1823 . La Diputación acordó mantenerle en su actual puesto, a pesar de la negativa opinión que parte de los diputados tenían de él.

El 10 de julio de 1838, en la sesión que en ese día celebra la Diputación, se comunica "el fallecimiento de D. Juan Nepomuceno González, oficial $2^{\circ}$ archivero de la corporación"

\section{Caballero, Modesto}

Auxiliar de Secretaría, desarrolla su trabajo en esta primera Diputación de la Constitución, y no vuelve a aparecer como funcionario en los siguientes períodos ni del Trienio Liberal ni de la época isabelina.

\section{Cifuentes, Serafín}

Es nombrado y ejerce como portero de la institución, en el período en que ésta se encuentra vigente y, al igual que el auxiliar Caballero, no hay constancia de que vuelva a ser nombrado para el cargo en los siguientes períodos de funcionamiento de la Diputación.

\section{Personalidades provinciales en este período Ayuntamiento}

En septiembre de 1812, una vez que abandonan la ciudad las tropas francesas, el Intendente-Corregidor D. Andrés de Temes y Prado, que posteriormente será elegido diputado provincial, convoca elecciones municipales en las que resulta elegido alcalde Diego Antonio de Olmedilla y Escobedo, considerado como el primer alcalde constitucional, que toma posesión el 22 de septiembre de 1812 y permanece en el cargo hasta finales de 1813. El 21 de diciembre de 1813 es elegido alcalde Vicente Martín Gómez, que ejerce el cargo hasta el 4 de mayo de 1814, que deja el cargo con la llegada del Absolutismo ${ }^{273}$.

\section{Capitanía General}

En este corto período de tiempo, ya hemos reseñado que el capitán general de Castilla la Vieja, con sede en la capital, actúa igualmente como presidente de la Diputación de Valladolid, y en este caso son: El mariscal de campo Antonio María Peón y Heredia y el brigadier José Casimiro Lavalle.

\section{Diputados a Cortes}

El 12 de agosto de 1813 tiene lugar las elecciones para elegir a los cuatro diputados que le corresponden a Valladolid a las Cortes extraordinarias y resultaron elegidos José Adámez, Evaristo Pérez de Castro, José Tomás Flórez y Félix Calleja. El 24 del mismo mes se celebran elecciones para diputados a Cortes ordinarias, siendo elegidos Gabriel Ugarte Alegría, Tomás Moyano, Alonso González y José Ramírez ${ }^{274}$.

Obispado

Vicente José Soto Valcarce, es el obispo de la diócesis de Valladolid desde el año 1803 y continuará hasta 1818 .

\footnotetext{
${ }^{273}$ CARAS A SOTO, Pedro (Dir.). Diccionario Biográfico de Alcaldes de Valladolid (1810-2010).Ed. Ayuntamiento de Valladolid. Valladolid. 2010. Págs. 13 a 15.

${ }^{274}$ CARAS A SOTO, Pedro (Dir.). Diccionario biográfico de parlamentarios castellanos y leoneses. Ed. Universidad de Valladolid. Valladolid. 2011. Págs. 3 y sig.
} 


\section{Universidad}

Es rector de la Universidad, desde octubre de 1808, D. Santiago Linares y ejerce hasta octubre de 1813. Le sucede José García Nieto, que se mantiene hasta 1815.

\section{Trabajos y actividades desarrolladas}

Entre septiembre de 1813 y junio de 1814, los componentes de la nueva institución apenas tuvieron tiempo de tomar posesión de su cargo y de otras pocas actuaciones más. Es cierto que tenemos dificultades de conocer las actividades, debido sobre todo a que no tenemos noticias de lo realizado entre el 2 de septiembre de 1813 y el 14 de febrero de 1814, porque como hemos relatado con anterioridad, las inscripciones en los libros de actas no se inician hasta el mes de febrero de 1814.

Sí que tenemos constancia de que, en estos meses, la Diputación se dedicó con prioridad a realizar los repartimientos de las contribuciones y a reclamar los numerosos atrasos que sobre el mismo tema se produjeron. También se ocuparon de otros temas relacionados con la recién acabada Guerra de la Independencia: Al control de los "dispersos", es decir de los soldados que al finalizar la contienda abandonaron sus unidades y eran reclamados por el ejército. A atender las reclamaciones de los pueblos, obligados a efectuar el suministro a las numerosas tropas que estaban acampadas en los mismos. A gestionar la reparación de los diversos puentes y de los caminos de la provincia dañados durante la guerra y que dificultaban las comunicaciones.

\subsection{2.- LAS TRES DIPUTACIONES DEL TRIENIO 1820-23}

La publicación de la "Circular de la Gobernación de la Península" con fecha 30 de marzo de 1820, por la que se ordenaba el restablecimiento de las Diputaciones provinciales, es el punto de partida del reinicio de las actividades. Este nuevo período constitucional lo podemos dividir en tres etapas muy diferentes entre sí y que están enmarcadas cronológicamente por las tres diferentes Diputaciones que se suceden a lo largo del Trienio Liberal y que son:

La Diputación provisional. De marzo a Junio de 1820

La Diputación de la ilusión y esperanza. De junio de 1820 a febrero de 1822

La Diputación de la tensión y desencanto. De marzo de 1822 a febrero de 1823

\section{La Diputación Provisional. $1^{a}$ Diputación del Trienio. Marzo-Junio 1820}

La primera Diputación del Trienio es una Diputación provisional o "Diputación del Arranque", que actúa entre el 21 de marzo y el 5 de junio del año 1820 y está compuesta por un presidente, un vicepresidente y siete diputados. Celebró en este tiempo un total de treinta y cuatro sesiones y todos sus diputados proceden de la primera Diputación del período constitucional 1813-14, incluido José Berdonces, suplente en la Diputación constitucional y que sustituye al fallecido Pedro Regalado Romero.

$\quad$ Nombre
Luis del Águila
Pedro Domínguez Caballero
Juan Andrés de Temes y Prado
José Pestaña
José Antonio González Perotes
Joaquín Argüello
Félix Prieto
Joaquín Maldonado
José Berdonces

Partido
Judicial
Jefe Político
Intendente
Valladolid
Benavente
Peñafiel
Rioseco
Gradefes
Medina
Valladolid

$\begin{array}{cc}\begin{array}{c}\text { Permanencia en el } \\ \text { cargo }\end{array} & \text { Sesiones } \\ \text { Marzo-Junio1820 } & 29 \\ \text { Marzo-Junio1820 } & 25 \\ \text { Marzo-Junio1820 } & 32 \\ \text { Marzo-Junio1820 } & 25 \\ \text { Marzo-Junio1820 } & 8 \\ \text { Marzo-Junio1820 } & 23 \\ \text { Marzo-Junio1820 } & 22 \\ \text { Marzo-Junio1820 } & 11 \\ \text { Marzo-Junio1820 } & 19\end{array}$

Esta Diputación está caracterizada por la provisionalidad, la improvisación y por un cierto descontrol en la gestión de la provincia, situaciones que se reflejan desde el mismo día de la puesta en marcha de la institución. 
Así vemos cómo el intendente Pedro Domínguez Caballero, que con el título de presidente interino de una Diputación "non nata", el día 21 de marzo pasa un oficio a los diputados provinciales actuantes en los años 1813-14, por el que les convocaba a la sesión de instalación de la nueva Diputación (cuando el real decreto restableciendo las Diputaciones tiene fecha 30 de marzo). A la sesión acuden únicamente Juan Andrés de Temes y Joaquín Maldonado y en ella se acuerda cubrir una vacante y recoger la documentación ${ }^{275}$.

Estos acuerdos, en teoría, no debían de tener valor, al ser sólo tres los individuos que en esta sesión formaban la Diputación, cuando el "Reglamento de Funcionamiento de las Diputaciones", todavía en vigor, indica que "para poder constituirse en sesión es necesaria la presencia al menos de cinco individuos de la misma".

El que tiene prisa por presentarse es el nuevo jefe político y presidente que recién nombrado se presenta en la institución, el día 10 de abril, en la sesión a la que asisten el intendente Caballero, el decano Temes y el nuevo diputado Berdonces. El libro de actas nos lo dice ${ }^{276}$.

En el real decreto de restablecimiento de las Diputaciones de 30 de marzo, también se anunciaba la fecha de celebración de elecciones a diputados para el próximo 21 de mayo, lo que nos demuestra la provisionalidad anteriormente citada en las actividades de la Diputación, aunque esto no es obstáculo para que los diputados se preocupen por desarrollar su labor y solucionar en lo posible los problemas que se les presentan. La vigencia de esta Diputación, se extiende a lo largo de setenta y siete días en los cuales se celebran treinta y cuatro sesiones, un número amplio de sesiones pero necesario para intentar poner al día los expedientes atrasados.

El radical "cambio político" operado ha provocado que se crearan nuevas instituciones y organismos sin eliminar los existentes del período anterior, lo que obliga a la Diputación a recibir gran número de reclamaciones de quejas y de consultas. Un ejemplo curioso de esta situación es la que transmite el Ayuntamiento de Curiel $^{277}$. Lo mismo le ocurre a la propia Diputación que ve contestada su autoridad por instituciones similares que la precedieron o que se crearon eventualmente en los primeros días del cambio político y que se resisten a desaparecer. La Diputación no se atreve a enfrentarse a ellas y tiene que consultar con el Gobierno central la manera de proceder para solucionar el conflicto institucional. El caso se da en las reclamaciones de competencias de la "Junta de Gobierno Provisional, que fue creada a partir del 10 de marzo, por circunstancias que se creyó lo exigían así", y que a los pocos días se auto disolvió. Pero nuevamente y sin razón aparente volvió a ser puesta en marcha por los mismos individuos que la disolvieron, entre los que destacaba su presidente, el general Juan Martín "El Empecinado". La Diputación en exposición enviada a S.M., solicitaba una aclaración de competencias, argumentando que "ve marcadas en la Constitución y en los reglamentos y decretos que emanan de ella, las atribuciones de todas las

275 A.D.P.V. Actas. Libros de actas del día 21 de marzo de 1820: "Que por fallecimiento de D. Pedro Regalado Romero, individuo de esta corporación, corresponde ocupar su lugar al Sr. D. José Berdonces, canónigo de esta Santa Iglesia Catedral, primer suplente nombrado para este caso.... Que se recojan a la mayor brevedad los libros y papeles pertenecientes a esta Diputación enviados a su disolución, a la Contaduría de la provincia".

${ }_{276}^{27}$ "Reunida la Diputación en la casa-posada del Sr. D. Luis del Águila, jefe superior político por nombramiento de S.M. en consulta de la Junta Superior de Gobierno, en virtud de su invitación comunicada el día de ayer por mano del Sr. intendente y vicepresidente, en la cual manifiesta S.S. hallarse en posesión y ejercicio de sus atribuciones y que se apresuraba para darse a conocer en esta corporación, tanto por el honor nato de presidente, como por alternar con sus sabios e ilustres individuos en los trabajos comunes que ha de hacer la felicidad particular de la provincia..." A.D.P.V. Actas. Libro de actas del 10 de abril de 1820.

277 A.D.P.V. Actas. Libro de actas del 22 de marzo de 1820. "Esteban Sánchez, alcalde de Curiel por S.M., se queja del alcalde constitucional por haberle suspendido y negado el ejercicio de sus funciones". 
autoridades de la provincia para su gobierno interior en todos los ramos, y por lo mismo a primera vista parece no necesaria la Junta Provisional de Gobierno" ${ }^{278}$.

Las dificultades y enfrentamientos se enconan cuando el interlocutor es el Ayuntamiento de la capital. Éste no ve con agrado a la Diputación ya que le quita protagonismo y poder en el desarrollo de la política municipal, por lo que no duda en plantear en oficio enviado a la Diputación la disyuntiva de "a quien se debe de dirigir en los asuntos oficiales, si a la Junta Provisional del Empecinado o a la Diputación" 279.

Este período se cierra con la celebración de elecciones el día 22 de mayo y con la última sesión del ciclo, que tiene lugar el día 5 de junio, sesión en la que se da lectura a la "lista de los señores que en las elecciones de los días 21 y 22 de mayo salieron nombrados diputados a Cortes y diputados de la provincia" ${ }^{280}$.

\section{La $2^{a}$ Diputación del Trienio. De la ilusión y la esperanza. Junio 1820- Febrero 1822}

La segunda Diputación del Trienio, que podríamos denominar la Diputación de la Ilusión y de la Esperanza, fue gestionada por los cuatro presidentes que se suceden en este período. Durante su vigencia se celebraron un total de ciento setenta y tres sesiones. El número de diputados elegidos fue de ocho individuos y también fueron nombrados tres suplentes que no llegaron a ejercer.

$\quad$ Nombre
Luis del Águila
Tomás Moreno Daoiz
Carlos Espinosa
Pedro Clemente Ligués
Pedro Domínguez Caballero
J. Andrés de Temes y Prado
José Pestaña
J. Antonio González Perotes
Fernando Macho Soto
Juan A. Quijada Calderón
Alonso González Rodríguez
Santiago Conde Bravo
Tomás Ruiz Dávila
Luciano Salcedo
Francisco Antonio Mantilla
Toribio Valdés

Nombre

$\begin{array}{cc}\text { Cargo } & \text { PartidoJudicial } \\ 3^{\circ} \text { Presidente } & \text { Jefe Político } \\ 4^{\circ} \text { Presidente } & \text { Jefe Político } \\ 5^{\circ} \text { Presidente } & \text { Jefe Político } \\ 6^{\circ} \text { Presidente } & \text { Jefe Político } \\ \text { Vice-presidente } & \text { Intendente } \\ \text { Diputado } & \text { Valladolid } \\ \text { Diputado } & \text { Benavente } \\ \text { Diputado } & \text { Peñafiel } \\ \text { Diputado } & \text { Valladolid } \\ \text { Diputado } & \text { Mayorga } \\ \text { Diputado } & \text { Sanabria } \\ \text { Diputado } & \text { Cigales } \\ \text { Diputado } & \text { Olmedo } \\ \text { Dip. Suplente } & \text { Rioseco } \\ \text { Dip. Suplente } & \text { Almanza } \\ \text { Dip. Suplente } & \text { Pedraja Portillo }\end{array}$

$\begin{array}{cc}\begin{array}{c}\text { Permanencia en el } \\ \text { cargo }\end{array} & \text { Sesiones } \\ \text { Jun.1820- Nov.1820 } & 47 \\ \text { Nov. 1820-Dic. 1820 } & 3 \\ \text { Dic. 1820- Mar.1821 } & 6 \\ \text { Mar. 1821- Feb. 1822 } & 62 \\ \text { Jun. 1820- Feb. 1822 } & 51 \\ \text { Jun. 1820 } & 1 \\ \text { Jun. 1820-Feb.1822 } & 7 \\ \text { Jun. 1820-Feb. 1822 } & 61 \\ \text { Jun. 1820-Feb. 1822 } & 159 \\ \text { Jun. 1820-Feb. 1822 } & 106 \\ \text { Jun. 1820-Feb. 1822 } & 12 \\ \text { Jun. 1820-Feb. 1822 } & 159 \\ \text { Jun. 1820-Feb. 1822 } & 86 \\ \text { sin } & 0 \\ \text { sin } & 0 \\ \text { sin } & 0\end{array}$

Es la primera Diputación fruto de las elecciones, cuyos componentes se presentan con ganas de trabajar para alcanzar las metas de progreso previstas, pero con una clara filosofía de acatar sin discusión las directrices que reciben tanto del poder legislativo como del ejecutivo. El inicio de las actividades tiene lugar el día 7 de junio de 1820 , fecha en que se celebra la sesión de instalación, y se mantiene operativa hasta el 28 de febrero de 1822, aunque las sesiones finalizan el 13 de septiembre de 1821 .

Esta etapa se caracteriza por tres circunstancias. En primer lugar, por la estabilidad y continuidad de los diputados en contraste con los frecuentes cambios en la presidencia y con los consiguientes períodos de interinidad. En segundo lugar por el progresivo deterioro social que se constata a lo largo del período, a causa de la proliferación a lo largo y ancho de la provincia de numerosas partidas de "facciosos" y malhechores que dificultan la vida provincial. Y finalmente por las dificultades económicas y la miseria que se "enseñorea" de la provincia, como consecuencia de las malas cosechas.

La sesión de constitución de la Diputación y juramento de los siete diputados que la componen se celebra el día 7 de junio. Las sesiones de trabajo no se iniciarán

\footnotetext{
278 A.D.P.V. Actas. Libro de actas del día 26 de abril de 1820.

279 A.D.P.V. Actas. Libro de actas del día 27 de abril de 1820

280 A.D.P.V. Actas. Libro de actas del 5 de junio de 1820.
} 
hasta el 20 de julio y se darán por finalizadas en este primer año el día 15 de diciembre, fecha en la que se celebra la sesión número noventa. Este es el número máximo de sesiones que se pueden realizar en un año, según lo refleja la vigente "Instrucción para el Gobierno de las Provincias".

En este tiempo son numerosas las comunicaciones con otras Diputaciones provinciales en temas de "exaltación de la constitución", de peticiones de colaboración para reclamar a las Cortes "mejoras legislativas de progreso" y de "búsqueda de más altas cotas de libertad en la gestión de los trabajos encomendados". Otros temas prioritarios son los relacionados con la situación económica, en especial por las reclamaciones por falta de fondos de las arcas municipales, además de las propias arcas de la Diputación y en consecuencia, por los atrasos en la paga de los salarios, tanto de maestros que son la mayoría, como de los jueces y de funcionarios, lo mismo a nivel local provincial o nacional.

Entre octubre de 1820 y marzo de 1821 se produce un período de interinidad en la presidencia de la Diputación, al ser destinado el jefe político Luis del Águila de Valladolid a la jefatura política de La Mancha, según publicó el real decreto de 25 de octubre. Para cubrir esta baja, se hace cargo de la jefatura política, con carácter interino, el capitán general de Castilla La Vieja, en este caso Tomás Moreno y Daoiz, que ejerce únicamente desde el 21 de noviembre al 5 de diciembre. En esta fecha es sustituido en la Capitanía General por el mariscal de campo Carlos Espinosa, que ejerce con carácter interino, hasta el 20 de marzo de 1821. En esta fecha toma el mando como jefe político y presidente de la Diputación Pedro Clemente Ligués.

La llegada del nuevo presidente coincide con el inicio del segundo período de sesiones de la Diputación y con la presentación de un "Manifiesto a la Provincia" en el que se hace "un canto a la importancia del papel de la Diputación, como defensora de la ley y la propiedad y como interlocutora entre los ciudadanos y el Gobierno... excitando a todos los vecinos a cumplir con el deber de pagar los impuestos y hacer frente a los repartimientos... y sin olvidar que la verdadera riqueza de nuestra provincia se encierra en la tierra, en sus entrañas y en los frutos diversos y excelentes que concede con abundancia a los que no levantan la mano del cultivo, para que no lo destruyan los malvados ni les arruinen los ganaderos y pastores, enemigos del arbolado, de cercados y de cuanto les impide los pastos, aunque sean ajenos..."281."Manifiesto" que resulta un tanto sorprendente al ensalzar la riqueza agrícola y criticando a los ganaderos y pastores, cuya actividad la contrapone a la de los labradores.

Como premonición del enrarecimiento del ambiente social, se suceden una serie de enfrentamientos entre Diputación y Ayuntamiento, tema que no es novedoso pues se arrastra desde el nacimiento de las Diputaciones. En esta ocasión es debido a las continuas reclamaciones que se hace al Ayuntamiento porque no presenta las correspondientes cuentas de Propios. A ello hay que añadir la discusión sobre quién tiene el derecho a nombrar al coronel de la Milicia Nacional. Pero el enfrentamiento más curioso es el que mantiene la Diputación con el propio Gobierno Central a causa del nombramiento del contador de Propios de la provincia. El nombramiento corresponde al Gobierno, el cual comunica a la Diputación que ha sido nombrado para el cargo Juan Antonio Ribeiro Diez, que nada más llegar reclama un salario de 20.000 reales anuales, cuando la Diputación tiene asignado a este puesto la cantidad de 3.000 y no está dispuesta a pagar más dinero.

En el mes de julio de 1821, la Diputación se da cuenta de que ha consumido sesenta y tres sesiones y sólo la quedan veintiocho para completar el cupo de las noventa sesiones por período, y todavía la quedan de tratar los consiguientes repartimientos de los sorteos de quintos y de las contribuciones, además de tratar sobre el borrador de la "División Provisional del Territorio Peninsular", tema en el que la institución ya ha expresado su disconformidad. 
En el mes de agosto se consumen veintiuna sesiones en el tema del sorteo del remplazo del Ejército y se acuerda celebrar una sesión el 13 de septiembre, que sería la última, reservando seis para el mes de febrero que finalmente no se celebran. Por tanto en esta legislatura de los dos años de vigencia de la Diputación se celebraron ciento setenta y tres sesiones, disolviéndose el 28 de febrero de 1822.

\section{$3^{a}$ Diputación del Trienio. Diputación del desencanto. Marzo 1822 - Abril 1823}

La tercera y última Diputación del Trienio, que podríamos llamar "la del desencanto", inicia sus actividades el 1 de marzo de 1822 y finaliza el 27 de abril de 1823 , fecha en que es disuelta por la llegada de los absolutistas al poder. Durante este año pasan por la misma, tres presidentes, dos vicepresidentes y diez diputados.

\begin{tabular}{|c|c|c|}
\hline Nombre & Cargo & $\begin{array}{c}\text { Partido } \\
\text { Judicial }\end{array}$ \\
\hline Pedro Clemente Ligués & $6^{\circ}$ Presidente & Jefe Político \\
\hline José Fernández Queipo & $7^{\circ}$ Presidente & Jefe Político \\
\hline Antonio Buch & $8^{\circ}$ Presidente & Jefe Político \\
\hline P. Domínguez Caballero & Vice-Presid. & Intendente \\
\hline José de Goicoechea & Vice-Presid. & Intendente \\
\hline José Pestaña & Diputado & Benavente \\
\hline José A. González Perotes & Diputado & Peñafiel \\
\hline Fernando Macho Soto & Diputado & Valladolid \\
\hline Franc.Antonio Mantilla & Diputado & Almanza \\
\hline Isidro Torres & Diputado & Villalón \\
\hline Rafael Rodríguez & Diputado & Medina \\
\hline H. F. Cuadrillero Herce & Diputado & Rioseco \\
\hline José Galván & Diputado & Alaejos \\
\hline Juan Fernández González & Diputado & Villavelliz \\
\hline Bernardino de Haro & Diputado & Villalpando \\
\hline
\end{tabular}

$6^{\circ}$ Presidente

Vice-Presid.

Diputado

Diputado

$\quad \begin{aligned} & \text { Permanencia } \\ & \text { en el cargo }\end{aligned}$
Mar. 1822-Jun. 1822
Jul. 1822 -Sep. 1822
Oct. 1822 -Abr.1823
Mar. 1822-Jul. 1822
Ago. 1822-Abr.1823
Mar.1822-May.1822
Mar.1822-Abr. 1823
Mar.1822-Abr. 1823
Mar.1822-May. 1822
Mar.1822-Abr. 1823
Mar. 1822-Abr.1823
Mar. 1822-Abr. 1823
May. 1822-Abr.1823
May. 1822-Abr.1823
No toma posesión

Sesiones

10

21

94

15

113

0

63

125

10

112

144

57

57

62

0

El día 1 de marzo de 1822, bajo la presidencia del jefe superior político Pedro Clemente Ligués, se inician las sesiones de la nueva Diputación, con la toma de posesión y el correspondiente juramento de la Constitución por parte de los diputados recién elegidos. Se mantienen en sus puestos el "decano" Fernando Macho Soto y los "incombustibles" Pestaña y Perotes.

Este período está caracterizado por el descontento popular. Es un período de reclamaciones, de quejas, de lamentaciones por parte de los ciudadanos, y es a la vez un período en el que el Estado a través de la Diputación presiona al pueblo de una forma excesiva en su afán recaudador, tanto por el lado económico a través de los impuestos, como en el lado humano por los continuos reemplazos que se exigen para el Ejército.

La Diputación no cubrirá el período para el que fue elegida y prácticamente su vigencia tendrá un año de duración. Es un período que finalizará con un nuevo enfrentamiento social entre absolutistas y liberales. El conflicto es fruto, por una parte, de la cerrazón ideológica de los absolutistas y por otra parte de la incapacidad de los liberales de mejorar las cuotas de bienestar de los ciudadanos de este país. En este año de existencia, la Diputación celebró un gran número de sesiones, en total ciento cincuenta y siete, divididas entre las noventa sesiones que habitualmente celebra cada año y además sesenta y una sesiones que celebró la Junta de Reclutamiento y otras seis sesiones la Junta de Agravios.

Otra cuestión a la que se tuvo que enfrentar esta Diputación, es a la ordenación de la provincia y de la propia institución con motivo de la aprobación del decreto ley de 27 de enero de 1822 sobre la "División Provisional del Territorio Español". Esta ley tiene una gran incidencia, puesto que la provincia sufre una importante transformación y modificación de sus límites territoriales. En la Diputación y como consecuencia de estos cambios, también se producen la modificación de sus componentes. Así tenemos que: 
Francisco Antonio Mantilla, diputado por el partido de Almanza, pasa a pertenecer a la Diputación de León.

José Pestaña, diputado por Benavente, pasa a ejercer su cargo en la Diputación Provincial de Zamora.

José Galván, diputado por Alaejos y dependiente de Zamora, pasa a la jurisdicción de la Diputación de Valladolid.

Juan Fernández González, que ejercía como diputado por Villavelliz en Zamora, pasa a representar el partido de Mota del Marqués en la Diputación de Valladolid.

Bernardino de Haro, diputado por Villalpando, pasa igualmente de Zamora a Valladolid, pues este partido pasa a la provincia vallisoletana.

El problema que se le presenta a la Diputación vallisoletana es que han quedado dos plazas vacantes y son tres los nuevos diputados que se agregan en la nueva configuración. Este problema se soluciona ante la petición que formula Bernardino de Haro por "su absoluta imposibilidad (de ejercer como diputado) por el estado habitual de su salud, en cuya consideración ya había pedido su absoluta exoneración al Congreso nacional" 282 .

A partir del mes de mayo de 1822 , se inician una serie de cambios y alteraciones en la vida política, que son ejemplo de la inseguridad gubernamental y de la falta de confianza de las personas en el desarrollo de sus actividades políticas. Vemos que el jefe político deja el puesto al igual que el intendente y se nombra jefe político interino al intendente interino José de Goicoechea. Nada más hacerse cargo de la Presidencia de la Diputación, ésta "le invita a que tome las medidas más activas y eficaces para la persecución y exterminio de los muchos salteadores que andan en las inmediaciones de la capital y pueblos comarcanos, cometiendo notables excesos..." "283.

Durante el mes de junio se suspenden las sesiones y en la del 8 de julio se presenta el nuevo jefe político y presidente de la Diputación D. José Fernández Queipo. Los cambios gubernamentales se suceden con rapidez: En agosto se nombra un nuevo capitán general en la persona de D. Agustín Quiroga. En septiembre, vuelve a aparecer el intendente Goicoechea y se nombra capitán general a D. Francisco Dionisio Vives. En octubre, culminando estos cambios, se hace cargo de la jefatura política y presidencia de la Diputación D. Antonio Buch.

La última sesión que queda reflejada en el libro de actas se corresponde con el día 27 de febrero de 1823, con lo que se da por cerrada la vigencia de la Diputación provincial y del período del Trienio Liberal. Sin embargo, la corporación oficialmente se mantendrá en una teórica actividad hasta el 27 de abril, fecha en que quedará disuelta con la entrada de las tropas absolutistas en la ciudad, y que se completará con la entrada del ejército francés el 13 de mayo.

\section{Nueva suspensión en 1823}

A partir del día 1 de marzo de 1823, la Diputación provincial debería de haber iniciado las sesiones del nuevo año legislativo y aunque no cabe duda de que continúa en función lo hace de una forma precaria. Dada la situación política, social y militar, lo más seguro es que los diputados hayan regresado a sus lugares de origen, donde se mantendrán a la espera de los acontecimientos o se vislumbre una solución política. En la capital se mantienen con el jefe político los diputados residentes en la misma.

Las actividades de la Diputación las conocemos, sobre todo, a través de las referencias que quedan reflejadas en las actas del Ayuntamiento, referidas en su mayoría a las órdenes transmitidas por el jefe político. Así sabemos que a lo largo del mes de abril se precipitan los acontecimientos:

"Todas las joyas y alhajas de las iglesias y conventos serán trasladadas a las plazas fuertes para que no sean presa de la rapiña de los enemigos"

"La guarda de la pólvora se hará en el almacén de San Isidro"

282 A.D.P.V. Actas. Libro de actas del 23 de mayo de 1822

283 A.D.P.V. Actas. Libro de actas del 29 de mayo de 1822. 
"Se preparará un edificio fuerte para el caso de invasión de los facciosos"

"Se ordena la formación de un Ayuntamiento supletorio en la capital que reemplace a los que se ausentan de la capital por las actuales circunstancias, y que se forme en su mayoría por concejales de marzo de 1820 " 284.

Es curiosa esta noticia del "Ayuntamiento supletorio", en comparación con lo decidido para la Diputación. Es decir, al Ayuntamiento no se le cuestiona su existencia y se arbitra la forma de que continúe funcionando, pues se le considera una institución necesaria. Pero no ocurre lo mismo con la Diputación, que al ser considerada como una institución "genuinamente liberal", no se cambian los diputados, sino que simplemente se la suprime.

El día 24 de abril, ya se sabe en Valladolid que "los facciosos de O'Donell" ya están en Burgos. Ese mismo día entra en Valladolid la columna en retirada del general Juan Martín el Empecinado, al que acompañan individuos de las Diputaciones de Álava y Guipúzcoa. El día 25, el jefe político, Antonio Buch, abandona la ciudad con destino a Salamanca y Ciudad Rodrigo, dejando como presidente interino de la Diputación al intendente José de Goicoechea. El día 26 se retiran de la ciudad las tropas constitucionales del general Empecinado y al día siguiente entran las tropas absolutistas del brigadier Merino ${ }^{285}$.

El mismo día 17 de abril, el general O’Donell, envía un oficio al Ayuntamiento, en el que comunica su nombramiento, por parte de la "Junta Interina de Gobierno", como capitán general de Castilla la Vieja y presidente de la Real Chancillería, cargo que ya había desempeñado durante el Sexenio Absolutista. Su primera actuación fue la publicación de un bando en el que se ordenaba: "El restablecimiento de los alcaldes de marzo de 1820. El cese de todos los jefes políticos, alcaldes y jueces de Primera Instancia. La requisa del armamento y munición de la Milicia Nacional. El licenciamiento de los soldados del último reemplazo. La creación del cuerpo de Voluntarios Realistas".

Finalmente una noticia procedente del Ayuntamiento nos da detalle de la disolución de la Diputación provincial: "D. Isidro López de Arce, coronel retirado del Ejército de acuerdo con el informe del Sr. D. Hipólito Barcial, del Ayuntamiento, ha entregado todos los efectos que se expresan en la adjunta lista, que recibió del Sr. ex diputado provincial D. Fernando Macho Soto. Los efectos recogidos los ha depositado en las Casas Consistoriales y encarga la custodia al repostero Pedro de la Reguera" ${ }^{286}$.

El día 13 de mayo, se produce la entrada en la ciudad de las tropas francesas al mando del duque de Reggio. Finalmente el 27 de noviembre del mismo año 1823 se comunica al Ayuntamiento que "a la entrada de las tropas reales en la plaza de Ciudad Rodrigo, han apresado a D. Antonio Buch y D. Fausto Galiano, jefe político y secretario que fueron de esta capital..." 287 . Con esta noticia se cierra la reseña de los avatares de la Diputación provincial en la época del Trienio Liberal.

\section{La secretaría y su personal}

\section{Capdevila, Alejandro}

Secretario de la Diputación desde su instalación el 2 de septiembre de 1813, aparece nuevamente en la re-instalación celebrada el día 21 de marzo de 1820 , manteniéndose en el puesto durante las tres Diputaciones del Trienio, y entregando la documentación en el mes de mayo de 1823.

A.H.M.V. Libro de actas $n^{\circ} 113$, págs. 41, 45 y 71 de fecha 14,15 y 23 de abril de 1823 .

Empecinado y Merino fueron dos guerrilleros que lucharon juntos contra los franceses durante la Guerra de la Independencia y que ahora están enfrentados entre sí.

A.H.M.V. Libro de actas $n^{\circ} 113$, pág. 69. Fecha 4 de marzo de 1823

A.H.M.V. Libro de actas $n^{\circ} 113$, pág. 373 .Fecha 26 de diciembre de 1823. 


\section{Personal de la secretaría}

No hay constancia en los libros de actas de modificaciones en la composición del personal de la Secretaría, que sean diferentes a los que desempeñaron su labor durante el período de la Diputación de la Constitución 1813-14.

Así sabemos que el secretario de la Diputación Alejandro Capdevila, fue ratificado en su puesto, y lo mismo sabemos del vicesecretario, que también ejerció en el primer período, D. Juan Nepomuceno González y no hay razones para pensar en otros cambios por lo que se puede estimar que Modesto Caballero continúa como auxiliar y que Serafín Cifuentes, sigue ejerciendo de portero.

Es una realidad que con la ampliación de los trabajos encomendados, la Diputación, a petición de la Secretaría de Estado de la Gobernación de la Península, "fija el número de brazos necesarios en la Secretaría de la Diputación en los siguientes. Un secretario general con una dotación anual de 15.000 reales. Un oficial de primera con una dotación anual de 10.000 reales. Un oficial de segunda con una dotación anual de 8.000 reales. Un oficial de tercera con una dotación anual de 6.000 reales. Dos escribientes con una dotación anual de 3.300 reales cada uno. Un portero con una dotación anual de 2.920 reales" 288 . En consecuencia con estas nuevas necesidades, hay que pensar que el equipamiento de personal ha ido en aumento, aunque sólo tenemos constancia del nombramiento de José Vela como escribiente de la Secretaría.

\section{Otros personajes del período}

\section{O'Donell y Anethau, Carlos Manuel}

Capitán general de Castilla la Vieja entre los años 1818 a 1820 y entre 1823 a 1825. En el año 1818 fundó la Casa de Mendicidad o Beneficencia de Valladolid, y el mismo año, el 4 de diciembre es elegido académico de la Real Academia de la Purísima Concepción. Es un absolutista convencido y que por lo mismo es relevado de su mando con la llegada de los liberales en el Trienio. Abandona la ciudad, aunque deja a su familia en el convento de Santa Clara.

Al finalizar el Trienio vuelve a estar en primera línea al ser nombrado, con fecha 21 de abril de 1823, capitán general de Castilla la Vieja. En esa misma fecha entra con sus tropas en la ciudad de Burgos, y sin descanso se dirige a continuación sobre Valladolid, ante el temor de que el general Empecinado fuerce su entrada en el convento de las Clarisas y haga prisionera a su esposa. El 27 de abril entra en la ciudad $^{289}$. Se mantiene en el cargo de capitán general de Castilla la Vieja hasta el 8 de agosto de 1825, fecha en la que es nombrado para ocupar la Capitanía General de Valencia. El 23 de marzo de 1827, es nuevamente nombrado capitán general de Castilla la Vieja, manteniéndose en el puesto hasta su fallecimiento ocurrido en el año 1830. Durante todo el período de su mandato fue un "furibundo" perseguidor de los liberales.

\section{Alonso Rubio, Agustín \\ Más conocido como "El Rojo de Valderas", es el cabecilla de una "facción de malhechores" según unos, o de un "grupo de patriotas" según otros. Es decir, que para los liberales era un vulgar bandolero y asesino y para los absolutistas fue un héroe defensor del Rey.}

\footnotetext{
288 A.D.P.V. Actas. Libro de actas del día 8 de agosto de 1820.

289 Encabezamiento del bando publicado en la ciudad de Valladolid, el día 27 de abril de 1823: "Caballero Gran Cruz de la Real y Militar orden de San Hermenegildo y de la Francia del Lis de la Vendée. Condecorado con la medalla del Sufrimiento por la Patria y las medallas del $2^{\circ}$ y $5^{\circ}$ Ejércitos. Socio honorario de la Real Academia de San Carlos de Valencia, de la de Amigos del País de la misma ciudad y de las de Zamora, Valladolid, Palencia y Oviedo. Teniente general de los Reales Ejércitos. Gobernador y capitán general del Ejército y Reinos de Castilla la Vieja, León, Principado de Asturias y Costa de Santander; Inspector de sus Milicias Urbanas, presidente de la Real Chancillería de Valladolid, Juntas de Fortificación, Policía, Sanidad, etc., etc., etc.,...”.
} 
Actuó durante la mayor parte de vigencia del Trienio Liberal, por la zona de Tierra de Campos, hasta que en septiembre de 1822 las tropas del general Empecinado, en aquellos años gobernador militar de Zamora y empeñado en su persecución, sorprende al grueso de la partida en Villaornate, provincia de León, a la que derrota de forma completa y el "Rojo" es hecho prisionero. Trasladado a Valladolid se le condena a muerte, siendo "agarrotado" en los campos de San Isidro el 12 de febrero de 1823. Con la llegada de los absolutistas al poder en abril de 1823 fue rehabilitado por el Ayuntamiento de la ciudad y enterrado en la iglesia de San Andrés ${ }^{290}$.

\section{Autoridades}

\section{Ayuntamiento}

El Ayuntamiento de Valladolid en estos años del Trienio estuvo presidido por los siguientes alcaldes. Cesáreo Gardoqui Orueta toma posesión de la Alcaldía el 17 de abril de 1820. En enero de 1821, le sucede Pedro Pascasio Calvo Raso, que ejerce durante todo el año. En 1822 es alcalde Pedro Cuesta. En el año 1823 el alcalde fue Gil San Juan ${ }^{291}$.

\section{Capitanía General}

Los capitanes generales durante el Trienio Liberal fueron, en el año 1820 el teniente general conde de Montijo, el general Nicolás Mahy, el teniente general Tomás Moreno y Daoiz y el mariscal de campo Carlos Espinosa (estos dos últimos fueron también presidentes de la Diputación). En el año 1821 continúa como capitán general, el mariscal de campo Carlos Espinosa. En 1822 es nombrado capitán general el teniente general Agustín Quiroga, a los dos meses pasa la Capitanía al capitán general Francisco Dionisio Vives y a continuación el mariscal de campo Mariano Bresón, que se mantiene en el cargo hasta el final de período.

\section{Diputados a Cortes}

En las elecciones celebradas los días 21 y 22 de mayo del año 1820 resultaron elegidos: León Gil Muñoz, Francisco Ramonet Jaraba, José Remírez Gil y Gabriel Ugarte Alegría. En las celebradas en el año 1822 fueron nombrados diputados: Millán Alonso del Barrio, Vicente Cañas Portocarrero, Mateo Seoane Sobral y Álvaro María Ulloa y Cáceres (conde de Adanero) ${ }^{292}$.

\section{Obispado}

Durante el período del Trienio la sede episcopal de Valladolid se encuentra vacante hasta finales del año 1823 cuando es elegido obispo Juan Baltasar Toledano, que tomará posesión a principios de 1824 y permanecerá en el cargo hasta 1830.

\section{Universidad}

El Trienio se inicia siendo rector de la Universidad vallisoletana D. Joaquín Tarancón Manuel, nombrado en octubre de 1817 hasta diciembre de 1820. Le sucede Rafael Arche entre los años 1820 y 1822. Fernando Macho y Soto es el siguiente rector entre los años 1822 y 1825 .

\footnotetext{
${ }^{290}$ ORTEGA y RUBIO, Juan. Noticias de casos particulares... ob. cit. "El Ayuntamiento de la ciudad acordó honrar la memoria de este exaltado realista y al efecto, la noche del 12 de julio del mismo año 23, fue exhumado el cadáver y encerrado en dos cajas, una de plomo y otra de madera, se le expuso al público al día siguiente en la... A las siete de la tarde de ese mismo día se le trasladó procesionalmente... a la iglesia parroquial de San Andrés... y el cadáver fue sepultado en la capilla de San Antonio con una lápida que dice: "Aquí yace el héroe castellano D. Agustín Alonso Rubio, llamado y conocido vulgarmente por el Rojo de Valderas que por su ardiente amor por la Religión y por el Rey fue víctima el 12 de febrero de 1823. Su cuerpo fue trasladado del Campo de San Isidro a esta parroquia el 13 de julio del mismo año."

${ }^{291}$ CARASA SOTO, Pedro (Dir.). Diccionario biográfico de... ob. cit. Información de los alcaldes de la época. Págs. 13 a 15. En relación con la alcaldía del año 1823 la información procede de la Lista de los señores vecinos que han constituido sus Corporaciones municipales. Imp. E. Zapatero. Valladolid. 1901.

${ }^{292}$ CARAS A SOTO, Pedro (Dir.). Diccionario biográfico de parlamentarios ... ob. cit. Págs. 3 y sig.
} 


\section{Actuaciones más importantes de la Diputación en estos años}

Con la reactivación de las Diputaciones con su genuino carácter liberal, se vuelven a poner en marcha por parte de los hombres de la Diputación las principales inquietudes que caracterizaron a este período. Entre todas ellas destaca una de las más amplias, seguras y "antipáticas" de las tareas encomendadas a las nuevas corporaciones, y es la dedicada a los repartimientos de las contribuciones. Este trabajo se vio agravado al inicio del Trienio a causa de "la más miserable cosecha de granos" con que se presenta la temporada, lo que ocasiona un "enorme atraso en el pago de las contribuciones". Junto con este trabajo, el repartimiento de los quintos de la provincia, completan la mayor parte de la dedicación de los diputados.

Las actividades de obras públicas se reparten entre las de carácter local ante la petición del gobierno de "fomentar el trabajo de las obras de interés público para dar ocupación a los jornaleros", la petición de reanudación de la construcción del Canal de Castilla en su variante de "Canal de Campos" y la continuación de los trabajos de reparación de los puentes dañados, expedientes que se iniciaron durante la primera Diputación en el año 1814. En el tema de la beneficencia se inicia la tendencia de la Corporación a fiscalizar las actividades benéficas de la provincia y a dar los primeros pasos para su control.

Finalmente, la Diputación toma nota de los nombramientos de los maestros de "primeras letras" en la mayoría de los pueblos de la provincia y casi al mismo tiempo, empieza a reflejar en sus libros de actas las reclamaciones de los citados maestros por el atraso en el pago de sus salarios.

Todo esto, completado con los trabajos y discusiones producidos por la reordenación del territorio provincial, con los cambios de límites y con el traspaso de pueblos de una provincia a otra.

\subsection{3.- LAS TRES INICIALES DIPUTACIONES ISABELINAS 1835-1840}

El fallecimiento del rey Fernando VII, acaecido el 30 de septiembre de 1833, aparece como el punto de partida de una serie de medidas y de actividades políticas, lo que propicia "una vuelta a la normalidad", es decir, al fin del absolutismo y a la transformación, ciertamente lenta, de las estructuras del Estado para dar paso a una situación liberal, que alegra a muchos, pero que también a la que se opone otra parte importante de la sociedad.

Así vemos la aparición de instituciones liberales como la "Milicia Urbana", en contraposición con la desaparición de otras instituciones absolutistas como son los diferentes Consejos encargados del gobierno de la nación. El anuncio de la convocatoria a Cortes y la promulgación del Estatuto Real, tímido intento de apertura, son el ejemplo de la situación socio-política del país. En reacción a estas actividades aparecen a lo ancho y largo del territorio peninsular una serie de sublevaciones y la proliferación de "partidas realistas" o "partidas facciosas" que entorpecen la vida del país.

En el año 1834, a partir de actividades políticas y modificaciones legislativas se va conformando la liberalización de la encorsetada vida política: La convocatoria a Cortes generales ${ }^{293}$. El real decreto sobre la "División de las Provincias en Partidos Judiciales" 294 . El nombramiento de electores para las elecciones de procuradores a Cortes $^{295}$.

En 1835, se continúa con los "pequeños pasos liberalizadores" representados a nivel nacional con el nombramiento de Mendizábal como ministro de Hacienda y a nivel local y provincial con el nombramiento de Mariano Miguel de Reynoso como jefe de la Milicia Urbana de Valladolid (posteriormente será diputado a Cortes, senador y ministro).

\footnotetext{
${ }^{293}$ B.O.P.V. n ${ }^{\circ} 32$ de 22 de abril de 1834

${ }^{294}$ B.O.P.V. $n^{\circ} 44$ de 3 de junio de 1834

${ }^{295}$ B.O.P.V. n ${ }^{\text {o }} 50$ de 24 de junio de 1834
} 
Todos estos movimientos legislativos culminan con respecto a la política provincial con la publicación de la real orden de 21 de septiembre de 1835 , reproducida en el Boletín Oficial de la provincia de 29 de septiembre, que dicta "el restablecimiento provisional de las Diputaciones provinciales". Noticia complementada con las normas que se establecen para el nombramiento de los correspondientes electores, "que han de concurrir a la cabeza del partido para la elección de los diputados provinciales y sus suplentes" $" 296$.

Valladolid, el día 22 de octubre, celebra la sesión de instalación de la Diputación provincial, institución que a partir de este momento adquiere un carácter definitivo y que se mantiene hasta nuestros días.

En esta primera etapa isabelina, vemos la configuración de las tres primeras Diputaciones que transcurren entre el citado 22 de octubre de 1835 y el 31 de diciembre de 1840 .

La primera Diputación isabelina: "El arranque", que está vigente desde el 22 de octubre de 1835 al 5 de octubre de 1836.

La segunda Diputación isabelina, "según la Constitución de 1812", que se mantiene entre el 7 de octubre de 1836 al 24 de diciembre de 1837.

La tercera Diputación isabelina. "De la nueva Constitución de 1837", vigente entre el 26 de diciembre de 1837 y el 31 de diciembre de 1840.

\section{La $1^{\text {a }}$ Diputación isabelina. El arranque. Octubre de 1835-Octubre de 1836}

$\quad$ Nombre
José Antonio Ponzoá
Francisco Romo y Gamboa
Miguel Dordá
José Núñez de Arenas
Joaquín Copeiro del Villar
Marqués de Casa-Pizarro
Juan M. Fernández Vítores
Joaquín A. de Arguiello
Manuel Pérez
Casto María de la Rúa
José del Corral
Luis Gómez Villavedón
Gil Montalvo
Braulio Martín
Millán Alonso del Barrio
Joaquín Maldonado

$\begin{array}{cr}\text { Permanencia en el cargo } & \text { Sesiones } \\ \text { Oct. 1835 } & 4 \\ \text { Oct. 1835-Jun. } 1836 & 52 \\ \text { Jul. } 1836 & 2 \\ \text { Ago. 1836-Oct. } 1836 & 12 \\ \text { Oct. 1835-Dic. } 1835 & 48 \\ \text { Ene.1836-Oct. } 1836 & 9 \\ \text { Oct. 1835-Oct. } 1836 & 115 \\ \text { Oct. 1835-Oct. } 1836 & 98 \\ \text { Oct. 1835-Oct. } 1836 & 82 \\ \text { Oct. 1835-Oct. } 1836 & 88 \\ \text { Oct. 1835-Oct. } 1836 & 96 \\ \text { Oct. 1835-Oct. } 1836 & 97 \\ \text { Oct. 1835-Nov. } 183 & 8 \\ \text { Nov. 1835Oct.- } 1836 & 76 \\ \text { Oct.- 1835Oct. } 1836 & 92 \\ \text { Oct. 1835-Oct. } 1836 & 80\end{array}$

El día 22 de octubre de 1835, la Diputación provincial de Valladolid celebra su sesión de instalación, estando "reunidos los señores que al margen se relacionan, en las Salas Consistoriales de esta ciudad, en el día de la fecha, el Sr. gobernador civil, como presidente manifestó que hallándose en toda la provincia verificada la elección de diputados provinciales, y presentes siete de los nueve diputados electos se estaba en el caso de proceder a la instalación de la Diputación..." ${ }^{297}$.

Con esta simple fórmula se reiniciaban los trabajos de la Diputación, como si no hubieran estado interrumpidos en los años anteriores. A los pocos días, los diputados, deseosos de agradar a la provincia publicaban un "Manifiesto", en el que exponían sus intenciones y su buena voluntad, ya que "están convencidos de conocer los principales males que aquejan a la provincia y trabajarán para su destrucción". Destacan que uno de los males son los impuestos, y que van a actuar para "disminuir el peso de los tributos que agobia a los contribuyentes y sustituirlo por un sistema de

\footnotetext{
${ }^{296}$ B.O.P.V. $n^{\circ} 81$, en la que se publican las normas, de fecha 8 de octubre de 1835 .

297 A.D.P.V. Actas. Libro de actas del 22 de octubre de 1835, en el que se recogen los pormenores de la instalación.
} 
reparto aproximado a la exactitud" ${ }^{298}$. Son las buenas intenciones de una Diputación que todavía no está consolidada y que busca su sitio en la vida política provincial.

En conclusión, esta primera Diputación celebrará un total de ciento veintidós sesiones entre los días 22 de octubre de 1835 y 5 de octubre de 1836 . En todo este tiempo la Corporación estará formada por el presidente-jefe político, vicepresidenteintendente y nueve diputados provinciales en representación de los nueve partidos judiciales en que está dividida la provincia.

Todos los diputados se mantendrán en su puesto a lo largo de la corta legislatura, excepto el diputado por Medina D. Gil Montalvo que solicitó la "exacción de su cargo, a causa de un gran defecto físico-crónico, por su absoluta falta de oído", petición que le fue aceptada, y en su lugar se presentó el diputado suplente D. Braulio Martín. En esta Diputación se mantienen dos diputados que ya lo fueron en la "Primera Diputación Constitucional" de 1813: son Joaquín Antonio de Argüello, diputado por Rioseco, y Joaquín Maldonado, en representación de Olmedo y que con anterioridad lo fue por Medina. También aparece como diputado Millán Alonso del Barrio, el primero de una saga familiar que estará presente tanto en la política provincial como en la nacional.

La última sesión de esta Diputación se celebrará el 5 de octubre de 1836, fecha en la que se comunica que, "con motivo de estar convocados los diputados últimamente electos para instalar la Diputación en el día de mañana, se acordó cesar en el ejercicio de sus funciones".

\section{La $2^{\text {a }}$ Diputación isabelina. Con la Constitución de 1812. Octubre de 1836 - Diciembre de 1837}

$\quad$ Nombre
José Núñez Arenas
Joaquín Manuel de Alba
Antonio Porro López de Ulloa
Joaquín Copeiro del Villar
Pedro Sánchez Ocaña
Eusebio de la Fuente
Francisco Fernández Montero
Francisco Díez Serrano
Cesáreo Díaz
José Fernández
Venancio Camino
Facundo González
Juan Manuel Bergaz
Tadeo López Puga
Manuel de Alday

Cargo
$12^{\circ}$ Presidente
$13^{\circ}$ Presidente
Vice-Presid.
Vice-Presid.
Vice-Presid.
Diputado
Diputado
Diputado
Diputado
Diputado
Diputado
Diputado
Diputado
Diputado
Diputado

Partido
judicia
Jefe Político
Jefe Político
Intendente
Intendente
Intendente
Medina
Rioseco
Valladolid
Olmedo
Peñafiel
La Mota
Villalón
La Nava
Valoria
Valladolid

\section{Permanencia en el} cargo

Oct. 1836-Oct. 1837

Oct. 1837-Dic. 1837

Nov. 1836-May. 1837

Ene. 1837-May.1837

Jun. 1837-Dic. 1837

Oct. 1836-Dic. 1837

Oct. 1836-Dic. 1837

Oct. 1836-Dic. 1837

Oct. 1836-Dic. 1837

Oct. 1836-Dic. 1837

Oct. 1836-Dic. 1837

Oct. 1836-Dic. 1837

Oct. 1836-Mar. 1837

Mar. 1837-Dic. 1837

Mar. 1837-Dic. 1837

\section{Sesiones}

53

2

14

12

2

35

67

71

58

53

30

33

0

0

26

"Conforme a lo prevenido en la Constitución Política de la Monarquía, se estaba en el caso de proceder a la instalación de esta Corporación, en atención a hallarse reunida, en la casa donde la Diputación celebra sus sesiones, la mayor parte de los diputados electos que la componen". Con estas palabras del presidente, dichas en la sesión del 7 de octubre de 1836, se daba inicio a las actividades de la segunda Diputación isabelina. Como va siendo habitual, los presentes acuerdan publicar un "Manifiesto a la Provincia" en el que otra vez resaltan "los sacrificios que están dispuestos en hacer a favor de la provincia".

Aparte de las buenas intenciones, una de las principales preocupaciones al tomar posesión de sus cargos es la de conocer la situación económica en que se encuentra la institución, duda que les es aclarada rápidamente por el Sr. secretario al informar en la sesión del 12 de octubre que "en lo tocante a fondos, en caja no obraban

298 B.O.P.V. no 89 de 27 de octubre de 1835, en el que se publica íntegro el "Manifiesto a la provincia". 
más que veinte y ocho reales, y contando con el descubierto de la nómina de los empleados".

La Diputación, en el tiempo de su vigencia, entre el 7 de octubre de 1836 y el 25 de diciembre de 1837, celebra un total de setenta y dos sesiones, destacando en este tiempo la asiduidad del diputado por Valladolid Francisco Diez Serrano, que asistió a setenta y una de ellas. Entre octubre de 1836 y marzo de 1837 sólo están presentes en los plenos un máximo de siete diputados y será en la sesión del día 9 de marzo cuando se anuncie el nombramiento de dos nuevos diputados. El primero es Tadeo López Puga en representación del partido judicial de Valoria, que curiosamente no se presentará a ninguna sesión alegando "su enfermedad de reuma". El segundo es Manuel de Alday licenciado y alcalde $1^{\circ}$ constitucional de Valladolid, que es elegido en sustitución del diputado por Nava del Rey Juan Manuel Bergaz, que no se había presentado en la corporación y había solicitado su "exacción por la imposibilidad debida a una enfermedad crónica".

En la sesión del 16 de julio de 1837 y con la asistencia de los ocho diputados efectivos, por la ausencia de López Puga, para dar cumplimiento al real decreto de 15 de junio anterior, se toma el previsto juramento a todos los diputados y empleados "de hacer guardar la Constitución de la Monarquía Española sancionada por las Cortes Generales de 1837 ".

A partir del 20 de julio y hasta el 6 de octubre, la Diputación no se convocó, y entre el 16 de septiembre y el citado 6 de octubre "estuvo ausente de la ciudad por la entrada en la misma de las tropas de Zariategui", es decir, la ciudad estuvo ocupada por los carlistas.

La última sesión de esta Diputación se celebró el día 25 de diciembre de 1837, sesión en la que se dio cuenta del nombramiento de los nuevos diputados, y tomando acto seguido la palabra el Sr. presidente comunicó que "queda disuelta esta corporación, en cumplimiento del real decreto de 13 de septiembre y real orden circular de 6 de noviembre".

\section{La $3^{a}$ Diputación isabelina. Nueva Constitución. Diciembre 1837-Diciembre 1840}

Nombre
Joaquín Manuel de Alba
Matías Guerra
Pedro Sánchez Ocaña (1)
Jacinto Manrique
Ramón Ceruti
Juan Gutiérrez
Pedro Sánchez Ocaña (2)
Id (3)
Mariano Ruiz de Mendoza
Esteban Sayró
Felipe Sicilia
José A. González Perote
Manuel Martín Lozar
Pelayo Cabeza de Vaca
Miguel de las Moras
Atanasio Pérez Cantalapiedra
Manuel Llamas
Alejandro Nájera
Vicente Pimentel Bayón
Ildefonso García Casasola
Manuel de Velasco y Franco
Pedro Gómez Rozas
Francisco Blanco
Mariano Campesino

\begin{tabular}{|c|c|}
\hline Cargo & Partido judicial \\
\hline $13^{\circ}$ Presid. & Jefe Político \\
\hline $14^{\circ}$ Presid & Jefe Político \\
\hline $15^{\circ}$ Presid & Jefe Político \\
\hline $16^{\circ}$ Presid & Jefe Político \\
\hline $17^{\circ}$ Presid & Jefe Político \\
\hline $18^{\circ}$ Presid & Jefe Político \\
\hline $\begin{array}{c}\text { Vice-Pres. } \\
\text { Id. }\end{array}$ & $\begin{array}{c}\text { Intendente } \\
\text { Id. }\end{array}$ \\
\hline Vice-Pres. & Intendente \\
\hline Vice-Pres. & Intendente \\
\hline Vice-Pres. & Intendente \\
\hline Diputado & Peñafiel \\
\hline Diputado & Valladolid \\
\hline Diputado & La Mota \\
\hline Diputado & Valoria \\
\hline Diputado & Olmedo \\
\hline Diputado & Villalón \\
\hline Pres. Int. & Id. \\
\hline Diputado & Rioseco \\
\hline Diputado & Medina \\
\hline Diputado & Nava \\
\hline Diputado & Rioseco \\
\hline Diputado & Mota \\
\hline Diputado & Valoria \\
\hline Diputado & Valladolid \\
\hline
\end{tabular}

\begin{tabular}{|c|}
\hline Permanencia en el cargo \\
\hline Dic.1837-Nov.1838 \\
\hline Dic.1838-Ene. 1839 \\
\hline Ene.1839-Jun.1839 \\
\hline Jun.1839-Jun. 1840 \\
\hline Jul.1840-Ago. 1840 \\
\hline Sep. 1840 -Dic. 1840 \\
\hline Dic. 1837 - Dic. 1838 \\
\hline Dic. 1839 -Abr. 1840 \\
\hline Jul.1839- Nov.1839 \\
\hline Diciembre 1839 \\
\hline May.1840-Dic. 1840 \\
\hline Dic. 1837 -Dic. 1840 \\
\hline Dic. $1837-S e p .1840$ \\
\hline Dic. 1837-Mar.1840 \\
\hline Dic. $1837-S e p .1840$ \\
\hline Dic. 1837 -Dic. 1840 \\
\hline Dic 1837 -Sep. 1840 \\
\hline Nov.- Dic. 1840 \\
\hline Dic.1837-Dic.1839 \\
\hline Dic. $1837-D i c .1840$ \\
\hline Dic. 1837 -Dic. 1840 \\
\hline Oct.1840-Dic. 1840 \\
\hline Oct.1840-Dic. 1840 \\
\hline Oct.1840-Dic. 1840 \\
\hline Oct.1840-Dic. 1840 \\
\hline
\end{tabular}

Sesiones
83
2
47
48
1
2
108
20
13
4
8
216
183
182
133
197
149
5
69
86
50
3
5
1
5

Esta Diputación está caracterizada por su larga duración, sin precedentes en el corto período de existencia. Desde el 26 de diciembre de 1837 hasta el 31 de diciembre 
de 1840, son tres años, a lo largo de los cuales se celebran un extenso número de sesiones, alcanzando las doscientas veintitrés.

Otra característica a resaltar es la relativa a los numerosos cambios que se producen en la jefatura política y presidencia de la Diputación, con seis individuos en los tres años de duración, y en especial con tres jefes políticos que se suceden en el último trimestre del año 1840. Lo mismo sucede con los intendentes/vicepresidentes, con cuatro personajes diferentes en este período para un cargo, el de intendente, que es habitualmente de gran estabilidad.

La tercera característica que se refleja en este período está referida a los cambios de diputados que se producen al final del período, en coincidencia con la llegada de Espartero a la jefatura del Gobierno central. Así tenemos que los diputados Manuel Martín Lozar, de Valladolid y Miguel de las Moras, de Valoria, son destituidos y en su lugar se nombran diputados a Mariano Campesino por Valladolid y Francisco Blanco por Valoria ${ }^{299}$. También el diputado por La Mota del Marqués, Pelayo Cabeza de Vaca, abandona el cargo al ser elegido diputado a Cortes, y en su lugar se nombra a Pedro Gómez Rozas. Finalmente, por fallecimiento del diputado por Rioseco Alejandro Nájera, se nombra en su sustitución a Manuel de Velasco y Franco.

Como curiosidad podemos reseñar que de los nueve diputados electos, cinco de ellos, los de Peñafiel, Mota, Olmedo, Villalón y Valladolid, viven en la capital, y los cuatro restantes en sus respectivas cabezas de partido. Además, en esta Diputación vuelve a aparecer como diputado provincial por Peñafiel José Antonio González Perotes "el incombustible", que ya ejerció de diputado en los años 1813-14 y en el Trienio Liberal 1820-23.

En el año 1839, por real orden de 24 de octubre, "se mandaba renovar por mitad a las Diputaciones provinciales y establecer el orden que se debía de observar". En sorteo celebrado el 10 de noviembre correspondía cesar en el puesto a los Sres. Lozar, Vaca, González, Moras y Llamas. Nada más realizado el sorteo, fue anulada la real orden y prorrogado el período de vigencia de la Diputación. Será en la sesión del 25 de octubre de 1840, cuando se leerá "la orden de la Regencia Provisional del Reino del 13 de este mes, por la que se mandaba proceder a la renovación de las Diputaciones provinciales". Aunque no lo especificaba, la renovación era en su totalidad.

El 17 de diciembre de 1840, se celebrará la última sesión de la Diputación y en la misma se acordó "que todos los negocios pendientes se trasladen a la próxima corporación", que tomará el cargo a partir del día 1 de enero de 1841 .

\section{El vaivén de los presidentes y vice-presidentes}

En el apartado anterior hemos reseñado que una de las características de estos años es la del excesivo número de cambios que se producen en la jefatura política de la provincia. Estos cambios inciden en la buena marcha de las actividades de la Diputación, pues es inevitable que se "ralentice" la resolución de los problemas que se plantean en la institución, situación que se agrava cuando se ejerce la presidencia de una forma interina.

El vaivén en los nombramientos es tan grande que se producen situaciones extrañas, con nombramientos que no se ejecutan y ceses de individuos que no se han hecho con el cargo. Un ejemplo práctico lo tenemos, cuando en el libro de actas del día 24 de octubre de 1837 queda reseñada la real orden del día 10 del mismo mes, comunicando el cese del jefe político José Núñez Arenas y el nombramiento de nuevo jefe en la persona de Jerónimo Muñoz, que hasta entonces desempeñaba la jefatura política de Soria. El Sr. Muñoz no llegó a tomar posesión de su cargo, y a los dos meses el Boletín Oficial de la provincia del 12 de diciembre publica un real decreto por el que se nombra jefe político de la provincia a Joaquín Manuel de Alba "quedando

299 CARASA SOTO, Pedro (Dir.). Diccionario de Alcaldes....ob. cit. Con información sobre estos diputados que fueron alcaldes de Valladolid. Mariano Campesino ejerció en los años 1837-38, Pelayo Cabeza de Vaca durante 1842-43 y Manuel Martín Lozar lo fue en el año 1843. Págs. 299, 306 y 495. 
cesante Luis Puidullés últimamente nombrado". En definitiva, Jerónimo Muñoz es nombrado y no es cesado, aunque no se presenta ni ejerce como jefe político, y Luis Puidullés es cesado sin haber sido nombrado y sin ejercer cargo alguno en la provincia.

Entre los años 1835 y 1840 se suceden diez presidentes y siete vicepresidentes. En la primera Diputación que dura un año (desde octubre de 1835 a octubre de 1836), son tres presidentes y dos vicepresidentes los que pasan por la corporación. En la segunda Diputación, que también tiene una duración de un año (octubre 1836 a diciembre 1837), son dos los presidentes y dos los vicepresidentes que se suceden. Y en la tercera Diputación, entre enero 1838 y diciembre de 1840 , es decir en tres años, son cinco individuos los que pasan por la presidencia y tres los vicepresidentes.

\section{Todos los diputados de este período entre 1835 y 1840}

A lo largo de estas tres primeras Diputaciones de la época isabelina, que se suceden entre octubre de 1835 y diciembre de 1840, son treinta y tres los diputados que aparecen. Unos, Argüello, González, Perotes y Maldonado, son "viejos conocidos" de los años constitucionales 1813-14 y liberales 1820-23. Otros son nuevos en estos años, pero serán los primeros de una serie de "sagas familiares" que se mantendrán en la política provincial y en la nacional a lo largo de los años. Son los casos de Millán Alonso, de las Moras, de Martín Lozar, de Gómez Rojas, etc. Individuos que alternarán su presencia en la Diputación provincial con su presencia en el Congreso, en el Senado, o en el gobierno de la Nación, y sobre todo en los Ayuntamientos donde residen, labor política que habitualmente, será continuada por los hijos u otros familiares.

\section{La secretaría y el personal}

Con la nueva puesta en marcha de la Diputación provincial en octubre de 1835 , uno de los trabajos más importantes y más urgentes que se plantean es el de la organización administrativa, trabajo que se encomienda en la primera sesión a la "Comisión de Plantillas" recién nombrada.

El trabajo de la comisión se realiza de forma rápida, pues si el día 22 se le encarga la búsqueda de personal, el día 29, la Diputación aprueba: "El nombramiento de secretario y demás componentes de la Secretaría en los individuos que a continuación se relacionan: Secretario, José María Cano. Oficial $1^{\circ}$, Juan Nepomuceno González. Oficial 2º Julián Díez. Oficial $3^{\circ}$, Santiago Álvarez. Escribiente $1^{\circ}$, José Hernández. Escribiente $2^{\circ}$, Agustín González. Portero, Antonio Pinar".

De todos estos funcionarios, el único conocido con anterioridad es Juan Nepomuceno González, que ya ejercía de vicesecretario en la "Diputación Constitucional" 1813-14 y en las Diputaciones del Trienio Liberal 1820-23. A partir de la aprobación de estos nombramientos, en un relativamente corto espacio de tiempo, se suceden una serie de cambios y modificaciones de la plantilla de la Secretaría, tanto a causa de cambios por fallecimiento o renuncia como por ampliación motivada por el progresivo aumento de las actividades de la institución. En la sesión del 2 de noviembre, a los tres días de su nombramiento, la Diputación acepta la dimisión del escribiente $1^{\circ}$ José Hernández, nombrando en su lugar a Sixto Maroto y Salcedo. El 9 de agosto de 1836, la Diputación comunica que "por fallecimiento de Agustín González, queda vacante la plaza de escribiente $2^{\circ}$ y se acuerda su supresión y que los trabajos pasen al escribiente $1^{\circ}$ aumentando su dotación a 3.000 reales al año". El 22 de septiembre de 1836, un antiguo funcionario de la época del Trienio, José Vela, "solicita su ingreso en la Secretaría, trabajo que realizó en 1820-23", propuesta que en principio no fue aceptada, pero que será tenida en cuenta en la reorganización que tiene lugar en julio de 1837.

En la sesión del día 5 de octubre de 1836, última que celebra esta primera Diputación, el secretario de la misma presenta un informe sobre la situación y las 
necesidades de la Secretaría, haciendo ver la necesidad de aumentar el personal ${ }^{300}$. Petición que es aceptada por la nueva Diputación recién instalada, que en la sesión del 20 de octubre de 1836, aprueba el nombramiento del oficial $3^{\circ}$ de la Secretaría D. Santiago Álvarez, como Depositario de Fondos.

En la sesión del día 9 de noviembre del mismo año de 1836, el secretario José María Cano vuelve a presentar al Pleno de la Diputación un "nuevo proyecto de personal de la Secretaría de la Diputación Provincial", proyecto que se aprobó en la misma sesión con algunas modificaciones, centradas en la faceta económica, según quedó reflejado en el cuadro del libro de actas:

\section{Funcionarios}

José María Cano

Antonio $\mathrm{M}^{\mathrm{a}}$ Suárez

Julián Díez

Santiago Álvarez

Sixto Maroto

Juan Nepomuceno González

Manuel Domínguez

Miguel Álvarez

Vacante

Vacante

Antonio Pinar

Felipe Llera

Total coste anual

\section{Categoría}

Secretario
Oficial $1^{\circ}$
$1^{\circ}$ Oficial $2^{\circ}$
$2^{\circ}$ Oficial $2^{\circ}$
$3^{\circ}$ Oficial $2^{\circ}$
Archivero
Escribiente $1^{\circ}$
Escribiente $2^{\circ}$
Escribiente $3^{\circ}$
Escribiente $4^{\circ}$
Portero
Mozo de oficios

\section{Salario}

Actual

\begin{tabular}{l}
8.000 \\
5.000 \\
4.400 \\
4.000 \\
2.200 \\
3.000 \\
2.200 \\
2.200 \\
-- \\
-- \\
2.200 \\
360 \\
\hline 360
\end{tabular}

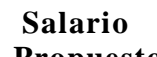

Propuesto

$$
\begin{array}{r}
14.000 \\
9.000 \\
8.000 \\
7.700 \\
6.000 \\
6.000 \\
4.000 \\
3.000 \\
2.600 \\
2.600 \\
2.600 \\
1.500 \\
\mathbf{6 7 . 0 0 0}
\end{array}
$$

Salario Aprobado

$$
\begin{gathered}
12.000 \\
6.600 \\
6.000 \\
5.500 \\
4.000 \\
4.000 \\
3.000 \\
3.000 \\
3.000 \\
--- \\
2.800 \\
500 \\
\mathbf{5 0 . 4 0 0}
\end{gathered}
$$

En resumen, rebaja los salarios propuestos, aunque los mejoran en relación con lo que cobraban con anterioridad y además no se cubren las plazas de los $3^{\circ}$ y $4^{\circ}$ escribientes.

En el año 1837 se producen nuevos cambios en la Secretaría, que se comunican en la sesión celebrada el 20 de abril, con el anuncio del fallecimiento del oficial $2^{\circ}$, Santiago Álvarez, baja que se cubre ascendiendo al oficial $3^{\circ}$ Sixto Maroto y nombrando nuevo oficial $3^{\circ}$ a Manuel Nieto Mazuelas. En el mes de mayo se nombra nuevo escribiente a Mariano Cano, ante la renuncia de Miguel Álvarez.

La situación real de la Secretaría y demás funcionarios de la Diputación nos lo confirma, cuando el día 16 de julio de este año 1837, se toma el juramento de la nueva Constitución a la totalidad de la plantilla, con la relación que queda reflejada en el libro de actas y que es la siguiente:

$\begin{array}{llll}\text {-Secretario: } & \text { José María Cano } & \text {-Subsecretario: } & \text { Antonio María Suárez } \\ \text { - Oficial } 1^{\circ}: & \text { Julián Diez } & \text { - Oficial } 2^{\circ}: & \text { Sixto Maroto y Salcedo } \\ \text { - Oficial } 3^{\circ}: & \text { Manuel Nieto } & \text { - Archivero: } & \text { Juan Nepomuceno González } \\ \text { - Escribiente } 1^{\circ}: \text { José Vela } & \text { - Escribiente } 2^{\circ}: & \begin{array}{l}\text { Manuel Domínguez } \\ \text { Antonio Pinar }\end{array} \\ \text { - Escribiente } 3^{\circ}: \text { Mariano Cano } & \text { - Portero: } & \\ \text { Empleados de la sección de Propios: } & & \\ \text { - Oficial } 1^{\circ}: & \text { Antonio de Poo } & \text { - Oficial 2o: } & \text { Deogracias Larraga } \\ \text { - Oficial } 3^{\circ}: & \text { Roque Soriano } & \text { - Auxiliar: } & \text { Antonio Alonso } \\ \text { - Auxiliar: } & \text { Manuel Díaz } & \text { - Auxiliar: } & \text { José Fernández Pellón } \\ \text { - Portero: } & \text { Andrés Brocos } & & \end{array}$

Esta plantilla se ve nuevamente modificada en octubre de este mismo año de $1837^{301}$. Los cambios se completan en el mes de diciembre, cuando por una parte "el

300 
Oficial $2^{\circ}$ Sr. Larraga es repuesto en su cargo" y por otra parte "se acuerda la supresión de la sección de Propios y sus empleados pasan a depender de la Secretaría". Se consuman estos cambios y organizan las categorías en la primera sesión que se celebra en el mes de enero de 1838. La colocación y la categoría quedan como sigue:

\begin{tabular}{ll} 
Secretario & José María Cano \\
\hline Oficial mayor y subsecretario & Antonio María Suárez \\
\hline $1^{\text {er }}$ oficial primero & Julián Diez \\
\hline $2^{\circ}$ oficial primero & Deogracias Larraga \\
\hline $1^{\text {er }}$ oficial segundo & Sixto Maroto \\
\hline $2^{\circ}$ oficial segundo & Roque Soriano \\
\hline $1^{\text {er }}$ oficial tercero & Manuel Nieto \\
\hline $2^{\circ}$ oficial tercero & Mariano Cano \\
\hline Archivo y Registro. Oficial $1^{\circ}$ & Antonio de Poo \\
\hline Archivo y Registro. Oficial $2^{\circ}$ & Juan Nepomuceno González \\
\hline $1^{\text {er }}$ escribiente & Manuel Domínguez \\
\hline $2^{\circ}$ escribiente & José Vela \\
\hline Portero & Antonio Pinar \\
\hline Mozo de oficio & Felipe Llera"302. \\
\hline
\end{tabular}

En julio del mismo año 1838, se anuncia el fallecimiento del archivero Juan Nepomuceno González y se nombra depositario de Fondos a José de Garaizabal "vecino y comerciante de la ciudad".

En el año 1839, el 16 de marzo el oficial $3^{\circ}$ Mariano Cano anuncia que "ha sido colocado en la Contaduría General de Gobernación, no pudiendo continuar en su actual empleo". La Diputación cubre la baja, contratando para el mismo puesto a Santiago Inés. También en el mismo mes de marzo del mismo año 1839, la Diputación comunica "la detención del portero y mozo de oficios de esta Corporación Felipe Llera por permitir el acceso al edificio a personas ajenas y a deshora" $" 303$.

Durante la mayor parte del año 1840, no se producen cambios en la Secretaría, manteniéndose activos todos los empleados. Dos noticias relacionadas con el funcionamiento administrativo se recogen en las actas. La primera se refleja en la sesión del día 20 de septiembre, en la que se anuncia el nombramiento de Manuel Nieto, oficial de la Secretaría como nuevo administrador del colegio de Santa Cruz, sin especificar si deja su puesto como funcionario. La segunda se refiere al anuncio de la "Junta Provisional del Gobierno de la Provincia", ya con Espartero y los progresistas en el poder, de la "separación de su destino del archivero de la Diputación D. Antonio de Poo", vacante que es cubierta por la Diputación al nombrar como nuevo archivero a D. Pedro Tomillo, "oficial del ejército retirado a causa de honrosas heridas en el campo de batalla. Se acuerda una dotación de 5.000 reales al año" ${ }^{304}$.

El destituido Antonio de Poo pasó a trabajar como representante en Valladolid de "una sociedad de gestión de asuntos en Madrid". En el año 1842 compró una finca de bienes desamortizados de 10 hectáreas en Valladolid por 22.120 reales.

\section{Cano Urquijo, José María}

Es vecino de Valladolid, ciudad en la que nació el 7 de diciembre de 1807. Sus padres eran Ángel Cano Muñoz, relator de la Chancillería y Teresa Urquijo Fernández.

Inicia sus estudios universitarios en noviembre de 1820, cuando a los 23 años solicita su ingreso en la Universidad de Valladolid, matriculándose en la Facultad de Leyes, Facultad en la que en junio de 1825 solicita ser examinado para optar al grado

\footnotetext{
haber permanecido en la ciudad durante la invasión de Zariategui, y lo mismo con el portero de la propia institución Andrés Brocos, no sólo por su permanencia, sino por haber entregado a la facción el uniforme y armamento de la Milicia Nacional” A.D.P.V. Actas. Libro de actas del 7 de octubre de 1837.

302 "Se acuerda que una vez extinguida la sección de Propios se integre todo su personal en la Secretaría de la Diputación, conservando a todos los empleados antiguos de la Secretaría con la adicción de los tres efectivos de Propios, quedando sin destino los auxiliares a los que la Diputación no está obligada a mantener, conservando los sueldos. A.D.P.V. Actas. Libro de actas del 2 de enero de 1838.

303 A.D.P.V. Actas. Libro de actas del 2 de marzo de 1839.

304 A.D.P.V. Actas. Libro de actas del 3 de noviembre de 1840.
} 
de bachiller en Leyes; y examinado el 11 de junio salió aprobado "némine discrepante". En el mes de junio de 1827, se presenta a los exámenes para alcanzar el grado de licenciado en Leyes, presentando los certificados de los cursos ganados, y es aprobado $^{305}$.

Se casa el 30 de marzo de 1833 con María Concepción Masas, hija de otro conocido jurista, con la que tuvo cinco hijos, uno de ellos Leopoldo, fue un conocido escritor vallisoletano del siglo XIX.

Ejerce la abogacía en Valladolid, actividad en la que destacó y ciudad en la que fue nombrado decano del Colegio de Abogados en el año 1849. ${ }^{306}$

También es un importante propietario tanto urbano como agrícola, ganadero e industrial.

Una de sus primeras actividades profesionales la desarrolla como secretario de la Diputación Provincial, cargo para el que es nombrado con fecha 29 de octubre de 1835, manteniéndose en el mismo hasta el mes de enero de 1845. En esta fecha, con ocasión de la aprobación de la "Ley Provincial" de 8 de enero, cesa en el cargo, al establecer la citada ley la desaparición del puesto de secretario de la Diputación. En el año 1841 , siendo secretario ya era considerado un potentado con " 2 criados y 8.000 reales en el amillaramiento" y en el año 1843 "compró una pequeña finca de bienes desamortizados, de una hectárea, de gran calidad y cerca de Valladolid por 10.520 reales" $" 307$.

En el año 1843 presenta en el Ayuntamiento una reclamación de agravio por tener que pagar 90 reales para la contribución de Culto y Clero, en concepto de abogado, cuando ya lo pagaba en concepto de secretario de la Diputación. A partir del año 1845, cuando abandona la Secretaría se dedica de lleno, a la abogacía y a los negocios en el ámbito provincial. Es miembro de la "Comisión Promotora del Ferrocarril Alar-Santander" y uno de los más importantes accionistas de la sociedad. En 1849 es el director de la Caja de Ahorros de Valladolid. En 1851 es el director del Monte de Piedad. En 1852 está considerado como el séptimo mayor contribuyente de la provincia. En 1855 aparece como el primer contribuyente del partido de Medina En el año 1860 es el decimotercer mayor contribuyente por "propiedad rural y pecuaria" con una renta de 8.679 reales. En 1861 es director de la Caja de Descuentos y el noveno mayor contribuyente de la provincia con 10.444 reales ${ }^{308}$.

En 1856, presenta una exposición a la Diputación Provincial, en la que se queja del comportamiento del Ayuntamiento de Villanueva de Duero, "como hacendado con casa abierta en Villanueva de Duero, solicita el derecho al disfrute de los pastos comunes como el resto de los vecinos del pueblo, haciendo notar que el Ayuntamiento no puede exigirle más de los 300 reales que generosamente dio en los años anteriores"309. En 1869 inicia una serie de litigios con el Ayuntamiento de Valladolid al considerarse perjudicado ante la decisión municipal de "expropiarle unos terrenos para construir una calle que comunique las calles de Constitución y Teresa Gil". Enfrentamientos que continúan en el año 1870 cuando por un lado "reclama el pago de las expropiaciones" y por otro el Ayuntamiento "inicia el expediente de expropiación de otra casa de su propiedad". El contencioso culmina en el año 1871 cuando el Ayuntamiento solicita a la Diputación "autorización para litigar contra José María Cano". En el año 1871 es el decimoséptimo mayor contribuyente provincial, "con propiedades en Villanueva de Duero" y una cuota de 2.901 pesetas de rentas.

\footnotetext{
305 A.H.U.V.A. Cajas 448 (doc. 211 a 218 ) y 565.

306 FERRERO MAESO, Concepción y BERZAL DE LA ROSA, Enrique. Historia del Colegio de Abogados de Valladolid. Ed. Ilustre Colegio de Abogados de Valladolid. Valladolid. 2008. Con información biográfica de este personaje.

307 RUEDA HERNANZ, Germán. La Desamortización de Mendizábal en Valladolid. 1836.43. Institución Cultural Simancas. Valladolid. 1980. Pág. 272.

${ }^{308}$ Datos procedentes del B.O.P.V. $\mathrm{n}^{\circ} 81$ de 8 de julio de $1849, \mathrm{n}^{\circ} 4$ de 9 de enero de $1851, \mathrm{n}^{\circ} 66$ de 2 de junio de $1855, \mathrm{n}^{\circ} 9$ de 20 de enero de 1860 y n $^{\circ} 157$ de 4 de octubre de 1861 . A.D.P.V. Actas. Libro de actas del día 12 de febrero de 1856.
} 
En política es de tendencia liberal progresista. En 1843 fue miembro de la Junta Provisional de Valladolid, al producirse la dimisión de Espartero. En 1853 es alcalde de la ciudad de Valladolid, cargo en el que continúa en el año 1854.En el año 1868, en los comienzos del Sexenio Revolucionario forma parte de la Junta Revolucionaria de Valladolid ${ }^{310}$.

Fallece en Valladolid el día 6 de noviembre de 1871.

\section{Autoridades y otros personajes Ayuntamiento}

El Ayuntamiento de la capital estuvo presidido por los siguientes alcaldes: En 1835, en las primeras elecciones constitucionales celebradas en octubre, es elegido Juan Manuel Fernández Vítores, que dimite a los pocos días al ser elegido diputado provincial. Es sustituido de forma interina por Vicente Landeta Cueto, que en las elecciones de diciembre sale elegido alcalde titular y ejerce el cargo hasta octubre de 1836. Diego Andrés de la Torre le sucede, pero en diciembre del mismo año, abandona el consistorio aquejado de una grave enfermedad.

Manuel Alday García es nombrado alcalde, en sustitución del anterior y ejerce hasta marzo de 1837, fecha en la que le sucede Mariano Campesino Hernando, que actúa hasta abril de 1838, excepto en los meses de septiembre y octubre de 1837 , tiempo en el que debido a la ocupación de la capital por las tropas de Zariategui, abandona la ciudad y para cubrir su ausencia es nombrada una Corporación provisional presidida por Andrés García Ureña.

En abril de 1838 se hace cargo de la alcaldía Higinio Melero Andrés hasta finales del mismo año. En 1839 es alcalde Domingo Blanco Salcedo. El año 1840 se inicia con la toma de posesión como alcalde de Mariano Miguel de Reynoso Abril, cargo que abandonó en febrero al ser nombrado diputado a Cortes y le sustituye entre febrero y septiembre Saturnino Gómez Escribano. En octubre de 1840 vuelve a ser elegido Mariano Campesino Hernando, que ejerce hasta diciembre de $1841^{311}$.

\section{Capitanía General}

Ocho capitanes generales de Castilla la Vieja se suceden en estos años: José Manso entre1834 y 1836. Antonio María Álvarez en 1836. Santiago Méndez Vigo en los años 1836 y 1837. Carlos Espinosa en1837 al igual que Manuel Lorenzo. Durante 1837 y parte de 1838 ejerce como Capitán general José Carratalá _ El resto del año 1838 actúa Luis Carandolet. Entre los años 1838 y 1840 ejerce el mando el capitán general Manuel de Latre

\section{Diputados a Cortes}

Diputados a Cortes entre 1835 y 1840 son: Manuel Alday García en 1836. Millán Alonso del Barrio en 1836, 1837,1839 y 1840. Manuel Álvarez García en 1836. Tomás Araujo Canedo en 1836. Pelayo Cabeza de Vaca en los años 1839 y 1840. Manuel Cantero San Vicente en 1836, 1837, 1839 y 1840. Eugenio Diez Pedreño en 1836. Valentín Llanos Gutierrez en 1836. Atanasio Pérez Cantalapiedra en 1839 y 1840. Luis Rodriguez Camaleño en 1837. Rafael Sanz Moreno en 1836. Mariano Miguel de Reynoso y Abril en 1837, 1839 y $1840^{312}$.

\section{Obispado}

El obispo de Valladolid en estos años es Juan Antonio Rivadeneira que ejerce desde el año 1830.

\section{Universidad}

La Universidad de Valladolid en el período 1835-1840 está regida por: Jerónimo Magaz, rector entre 1832-1836. Manuel Joaquín de Tarancón, entre 18361839 y Blas Pardo, rector entre 1839-1842.

\footnotetext{
${ }^{310}$ CARASA SOTO, Pedro. (Dir.) Diccionario biográfico de Alcaldes.... Ob. cit. Pág. 310.

${ }^{311}$.Ibidem. Págs. 13 a 15.

${ }^{312}$ CARASA SOTO, Pedro. (Dir.) Diccionario biográfico de parlamentarios.. Ob. cit. Págs. 3 y sig.
} 


\section{Secretaría del Gobierno Provincial}

Funcionarios del Gobierno político de la provincia son Joaquín Bernández, secretario en 1836, Luis Proyect en 1837 y Antonio Fernández de Córdoba y Golfín en 1838 (Procede de Cuenca y a los dos meses es nombrado jefe político de Zamora).

\section{Los Facciosos}

A lo largo del año 1837, una serie de facciones de carácter carlista arruinan y asolan los campos y pueblos de la provincia, sin apenas encontrar oposición del ejército. Destacamos los tres facciosos más influyentes.

Zariategui: Organizó una fuerza de 10 batallones y 200 caballos, que en octubre de 1837 entró en Valladolid, ante el abandono de su defensa por parte del ejército, lo que propició el cese fulminante del jefe político y del capitán general. Asoló toda la provincia exigiendo a los labradores de los pueblos por donde pasaba alimentos y dinero para el mantenimiento de su tropa.

Conde Negri: Jefe de otra partida de facciosos, estuvo a las puertas de Valladolid el 12 de abril de 1838, pero abandonó el intento de entrar ante la oposición de parte de los vecinos y tropas acuarteladas en el fuerte de San Benito.

Balmaseda: El más cruel de los cabecillas de estas facciones, que operó entre Quintanilla y Olmedo, y que destruyó en su totalidad el pueblo de Roa de Duero, cuyos vecinos se tuvieron que refugiar en el castillo de Peñafiel. En esta partida estuvo enrolado con la categoría militar de teniente coronel Santiago Lirio Burgoa, natural de Quintanilla y que en el año 1867 resultó elegido diputado a Cortes por Valladolid.

\section{Principales actividades desarrolladas}

A lo largo de estos años, una de las mayores preocupaciones de las tres Diputaciones está ocasionada por los perjuicios debidos a la proliferación de partidas carlistas, también llamadas "partidas facciosas". Éstas campan a lo largo y ancho de la provincia, sin que puedan ser neutralizadas por el ejército o la milicia, y llega a tal punto su dominio que se apoderan de la capital sin oposición.

En el tema de las obras públicas, destaca la terminación del Canal de Castilla en su ramal Sur que finaliza en Valladolid, y el inicio de la construcción de la carretera a Rioseco. El resto de actividades están referidas a las consabidas sesiones dedicadas a los repartimientos, tanto de contribuciones como de mozos para el ejército, con sus correspondientes reclamaciones. En el tema de la enseñanza, el comisionado de la Universidad, D. Claudio Moyano, solicita la ayuda de la corporación para evitar el cierre de la Universidad (Medicina) y recuerda que "para el bienestar de la provincia son necesarios dos importantes recursos: el Canal de Castilla y la Universidad".

A nivel nacional resalta en este tiempo la proclamación de la nueva Constitución de 1837 y el final de la Guerra Carlista.

\subsection{4.- LA DIPUTACIÓN DE LA REGENCIA DE ESPARTERO DE 1841 A 1843}

\section{Una Diputación progresista para un período progresista. $4^{\text {a }}$ de la época isabelina. Enero 1841-Octubre 1843}

El 9 de octubre de 1840, el general Espartero asume la presidencia del Gobierno y a los pocos días, el 12 del mismo mes, se hace cargo de la Regencia. Este cambio de gobierno tiene como consecuencia los anuncios de convocatoria de elecciones, tanto nacionales como provinciales y municipales y con el resultado, en este caso, de la formación de una nueva Diputación.

La Diputación celebra la sesión de instalación el 1 de enero de $1841^{313}$.La nueva Diputación, que se corresponde con la cuarta del período isabelino, se mantendrá

313 "En la ciudad de Valladolid a primero de enero de mil ochocientos cuarenta y uno, reunidos en el salón de sesiones de la Diputación provincial, en virtud de convocatoria del jefe político y bajo su presidencia, los señores al margen reseñados, quienes habían sido nombrados según decreto de la Regencia Provisional del Reino de trece de octubre próximo pasado..." A.D.P.V. Actas. Libro de actas del día 1 de enero de 1841 . 
operativa prácticamente el mismo tiempo que dura el protagonismo del general Espartero, es decir, desde el citado día 1 de en ero de 1841, hasta el 30 de octubre de 1843, fecha en la que se dan por finalizadas sus actividades, celebrándose en este período un total de doscientas treinta y ocho sesiones

\begin{tabular}{|c|c|c|c|c|}
\hline Nombre & Cargo & $\begin{array}{l}\text { Partido } \\
\text { Judicial }\end{array}$ & $\begin{array}{c}\text { Permanencia } \\
\text { en el cargo }\end{array}$ & Sesiones \\
\hline Juan Gutiérrez & $18^{\circ}$ Presi & Jefe Político & Ene.1841-Dic. 1841 & 51 \\
\hline Julián Sánchez Gata & $19^{\circ}$ Presi & Jefe Político & Sep.1842-Dic. 1842 & 15 \\
\hline Luis Sagasti & $20^{\circ}$ Presi & Jefe Político & Ene.1843-Feb. 1843 & 11 \\
\hline Manuel Llamas & $21^{\circ}$ Presi & Jefe Político & Mar. 1843-Jun. 1843 & 16 \\
\hline Juan Ruiz Cermeño & $22^{\circ}$ Presi & Jefe Político & Jul.1843-Ago.1843 & 11 \\
\hline Benigno Quirós y Contreras & $23^{\circ}$ Presi & Jefe Político & Sep. 1843 & 3 \\
\hline Diego Manuel de Mosquera & $24^{\circ}$ Presi & Jefe Político & Oct. 1843 & 1 \\
\hline Marqués de Casa Pizarro & Vice-Pres. & Intendente & Ene.1841-Dic. 1841 & 9 \\
\hline Lorenzo Perabeles & Vice-Pres. & Intendente & Ene. 1842-Ago. 1842 & 2 \\
\hline Ramón Barbaza & Vice-Pres. & Intendente & Sept. 1842-Dic. 1842 & 2 \\
\hline Felipe Sicilia & Vice-Pres. & Intendente & Ene. 1843 -Feb. 1843 & 9 \\
\hline Juan Buznego & Vice-Pres. & Intendente & Mar.1843-Oct. 1843 & 18 \\
\hline Cristóbal Magdaleno Fernández & Diputado & Valladolid & Ene. $1841-F e b .1841$ & 10 \\
\hline Faustino Alderete & Diputado & Valladolid & Jun.1841-Oct.1843 & 156 \\
\hline Baltasar González & Diputado & Nava del Rey & Ene.1841-Oct. 1843 & 185 \\
\hline Agustín de Represa & Diputado & Rioseco & Ene.1841-Oct. 1843 & 168 \\
\hline Andrés Alonso García & Diputado & Peñafiel & Ene. 1841-Jul. 1843 & 131 \\
\hline Atanasio Pérez Cantalapiedra & Diputado & Medina & Ene.1841-Mar. 1841 & 22 \\
\hline Pedro Paulino Cantalapiedra & Diputado & Medina & Jun .1841-Oct. 1843 & 115 \\
\hline Juan Manuel Arévalo & Diputado & Olmedo & Ene. 1841-Oct. 1843 & 188 \\
\hline Manuel Gusano & Diputado & Villalón & Ene.1841Jul. 1843 & 189 \\
\hline Manuel López Puga & Diputado & Valoria & Ene. 1841 Oct. 1843 & 116 \\
\hline Francisco Rodríguez Rubio & Diputado & La Mota & Ene. 1841 -Oct. 1843 & 139 \\
\hline
\end{tabular}

.Como características más señaladas de esta Diputación podemos destacar el carácter progresista de la mayoría de sus componentes, las numerosas peticiones que se reciben en la Diputación procedentes del Gobierno central para conocer "la conducta moral y política" de gran número de ciudadanos que habitualmente destacaban por su carácter conservador, y los numerosos cambios que se producen en las personas de jefes políticos e intendentes, que alternan con otros períodos de interinidad, temas que ya hemos resaltado también en anteriores Diputaciones.

\section{Abundan los cambios en la presidencia}

Volvemos a destacar en este capítulo los numerosos cambios que se producen en la jefatura política provincial, que como es natural inciden en la presidencia de la Diputación. En lo referente al cargo de jefe político-presidente hay que destacar los siguientes cambios. En el período de vigencia de esta Diputación entre enero 1841 y octubre 1843 se suceden siete jefes políticos-presidentes. Durante todo el año 1841 se mantiene Juan Gutiérrez como presidente. Entre enero y septiembre de 1842, está vacante la titularidad de la presidencia y el vicepresidente-intendente, sólo preside dos sesiones, con lo cual la presidencia la ejercen los diputados Baltasar González y Juan Manuel Arévalo. En el año 1843, entre enero y octubre se suceden en el cargo cinco jefes políticos-presidentes diferentes. En el caso de los intendentesvicepresidentes, es también llamativo los numerosos cambios, sobre todo porque el cargo de intendente, por su profesionalidad, suele ser más técnico que político, y en definitiva más estable. En estos tres años se suceden cinco intendentes, resaltando la escasa asistencia de los mismos a las sesiones de la Corporación.

\section{Los diputados provinciales}

La estabilidad es la tónica dominante de esta Diputación, que a lo largo de sus casi tres años de vigencia apenas sufre modificaciones en sus componentes. Al principio de la legislatura se producen dos cambios motivados por causas "de fuerza 
mayor" y al final de la misma se producen dos ceses de diputados "por causas políticas".

En principio, en la sesión de instalación celebrada el citado 1 de enero de 1841 se ponen reparos al nombramiento de tres diputados. Manuel López Puga diputado electo por el partido de Valoria no es admitido al no presentar el acta de nombramiento expedido por la Junta de Escrutinio. Será admitido en febrero, una vez acreditado su nombramiento. Pedro Fernández de Velasco diputado electo por Peñafiel es rechazado su nombramiento por ser promotor fiscal, incompatible por ley con el cargo de diputado. En nuevas elecciones es elegido y aprobado el nombramiento de Andrés Alonso García. Francisco Rodríguez Rubio es diputado electo por el partido de Mota del Marqués, aunque su acta es rechazada por las denuncias de "irregularidades en las elecciones de Tordesillas". La Diputación ordena nuevas elecciones en las que sale electo Julián Maestro, pero ante las reclamaciones presentadas por el Sr. Rubio, se anulan las segundas elecciones y se ratifica el nombramiento de Francisco Rodríguez Rubio.

Dos cambios de diputados se producen en los primeros meses de 1841. Atanasio Pérez Cantalapiedra, diputado por Medina, presenta la dimisión en el mes de marzo al ser elegido diputado a Cortes por la provincia. Después de nuevas elecciones es elegido Pedro Paulino Cantalapiedra que toma posesión en el mes de junio. Cristóbal Magdaleno Fernández, diputado por Valladolid, fallece en el mes de mayo y en su lugar es elegido nuevo diputado Faustino Alderete, que toma posesión de su cargo en el mes de julio.

Al final del período, tras la dimisión de Espartero al frente del Gobierno central, la Junta Provisional del Gobierno de la Provincia recién nombrada, suspende en sus funciones, con fecha 30 de julio de 1843, a Andrés Alonso García diputado por Peñafiel, y a Manuel Gusano diputado por Villalón. Durante los meses de agosto, septiembre y octubre, la Diputación actúa con dos diputados de menos, puesto que los dos cesados no son reemplazados.

\section{Los funcionarios de la Secretaría La Secretaría}

Los cambios que se producen en la Diputación, y sobre todo los cambios políticos y militares, provocados por la llegada a la Regencia de la nación del general Espartero, no influyen ni en el funcionamiento administrativo de la Secretaría ni tampoco en su composición. En una de las primeras sesiones que celebra la Diputación son aprobados los presupuestos de gastos, en los que vienen reflejados los "nuevos salarios de los funcionarios", salarios que son similares a los aprobados en el año 1836. Así quedan los sueldos, expresados en reales: Secretario 12.000. Subsecretario 6.600. Oficial $1^{\circ}$ 6.400. Oficial $2^{\circ}$ 6.000. Oficial $3^{\circ}$ 5.500. Oficial 4. 5.000. Oficial $5^{\circ}$ 4.400. Archivero 5.000. Escribiente $1^{\circ} 3.300$. Escribiente $2^{\circ} 3.000$. Escribiente $3^{\circ}$ 3.000. Portero 2.800.Mozo de oficio 600.

En la primera sesión de la Diputación celebrada el 1 de enero de 1841, el escribiente Miguel Francisco de las Moras presenta la dimisión al no estar conforme con el trabajo, dimisión que es aceptada y no se repone la baja. En la sesión del 26 de febrero, el secretario informa sobre la supresión de la plaza de apoderado, nombrando al oficial Manuel Nieto para asumir el cargo "sin mayor retribución". El 14 de abril de 1841 el archivero Pedro Tomillo presenta la dimisión "por virtud de la promoción al destino de administrador de Rentas del partido de Peñafiel, por calificación de la Junta de jefes de Hacienda del distrito". En el mes de diciembre de 1842, el oficial $3^{\circ}$ Sixto Maroto es nombrado nuevo depositario de Fondos de la Corporación y ya no se vuelven a producir más cambios en la composición de la Secretaría hasta el final de vigencia de la Diputación.

En lo que respecta a noticias importantes en el funcionamiento de la Secretaría, la primera es el cambio en el sistema de financiación, tanto en lo referente al pago de salario como a los gastos de material de oficina. Este cambio está reflejado en las actas 
de la sesión celebrada el 6 de mayo de 1841, con la explicación por parte del presidente del nuevo sistema, que había sido acordado conjuntamente con el secretario. Así lo expresó el presidente: "Que era llegado el caso de que la Diputación arreglase definitivamente la Secretaría, determinando los gastos que habían de ser objeto de los presupuestos, contando con el compromiso del secretario de que la cantidad de 105.100 reales en que montaban los sueldos y gastos presupuestados, podía ser economizada en 5.100 reales si se permitía la distribución a la manera que el secretario considerase oportuna". La Diputación aprobó el acuerdo de entregar los 100.000 reales al Sr. secretario y éste se encargaba de todos los gastos, redactándose un contrato con las condiciones que debían de regir al respecto" ${ }^{314}$. Este acuerdo resultó satisfactorio por las dos partes, ya que al siguiente año de 1842, se renovó el acuerdo, manteniendo la misma cantidad de 100.000 reales por todo el año.

La segunda noticia que llamó la atención fue la relativa al pago de una cierta cantidad de dinero al portero de la corporación, sin ningún tipo de justificación y con la sospecha de pagar algún favor que no se comprobó, pero lo cierto es que en la sesión del 2 de mayo de 1841"comparecieron los individuos de Matapozuelos que en el año 1840 hicieron un libramiento de 70 reales al portero de la Diputación". Y aunque estos individuos afirman que lo hicieron de buena fe y sin intención de ofender a la Corporación, esta acordó multarles con 20 ducados, que se destinarían al vestuario de la Milicia Nacional.

La tercera noticia a destacar es la publicación del "Manifiesto a la Provincia", que presentó el secretario en la sesión del 16 de febrero de 1843, con ocasión de la celebración de elecciones de diputados a Cortes, en el que se hacía mención especial a "la importancia de elegir bien sin tener en cuenta intereses y banderas. Hombres elegidos que tengan la firmeza de: Mantener las Leyes Fundamentales de 1839. Mantener el trono de la inocente Isabel. Mantener la Regencia del invicto Duque". En definitiva, una proclama política en defensa del Gobierno de Espartero.

\section{Autoridades y otros relevantes políticos provinciales}

$\mathrm{Si}$ al principio de este capítulo ya hemos dejado constancia del numeroso grupo de jefes políticos e intendentes que se suceden durante este corto período de tiempo, no podemos dejar de reflejar en este apartado los numerosos individuos que se suceden en otros organismos del Estado, tanto militares como civiles.

\section{Ayuntamiento}

Durante estos años ocupan la alcaldía vallisoletana cuatro conocidos ex diputados provinciales. Mariano Campesino en 1841. Pelayo Cabeza de Vaca en 1842. En 1843 Manuel Martín Lozar ejerció en el mes de enero, y presentó la dimisión al resultar elegido diputado provincial. En su lugar es promovido a la alcaldía Atanasio Pérez Cantalapiedra, que ejerce hasta finales del citado año ${ }^{315}$.

\section{Capitanía General}

En la Capitanía General de Castilla la Vieja, se producen continuos relevos a su frente, ya sean titulares o interinos. La relación es la siguiente: José Carratalá es nombrado capitán general en noviembre de 1840. Atanasio Alesón actúa de capitán general interino entre enero y junio de 1841. Mariano Ricafort es nombrado capitán general entre julio y septiembre de 1841. Felipe Rivero, es capitán general

314 A.D.P.V. Actas. Libro de actas del 6 de mayo de 1841, con la redacción completa del contrato firmado, que resumimos a continuación: $1^{\circ}$.- Los 100.000 reales se recaudarán en base a un repartimiento en la provincia. $2^{\circ}$.- El secretario entregará una fianza. $3^{\circ}$.- La Diputación entregará los fondos mensualmente, previo pago de los salarios. $4^{\circ}$. - El secretario se hace cargo de los gastos de material de oficina, alumbrado y calefacción. $5^{\circ}$.- El secretario se hace cargo de los gastos extraordinarios de sorteos, veredas y propios. $6^{\circ}$. No será responsabilidad del secretario la reposición de muebles. $7^{\circ}$.- La Diputación acordará la forma de cubrir el artículo anterior. $8^{\circ}$. - Los pagos se harán por el mismo orden de contabilidad establecido. $9^{\circ}$. - Los atrasos que se adeuden por la Diputación se satisfarán a través de los descubiertos de los pueblos. $10^{\circ}$.- La Diputación continuará nombrando a los funcionarios y cesándoles si ha lugar con arreglo a sus facultades.

${ }^{315}$ CARAS A SOTO, Pedro (Dir.). Diccionario biográfico de alcaldes.... Ob. cit. Págs. 13 a 15. 
entre octubre y diciembre de1841. Atanasio Alesón, vuelve a ser nombrado capitán general, esta vez titular y se mantiene entre enero de 1842 y mayo de 1843 . Santos San Miguel ejerce de capitán general en junio de 1843. Miguel Seniosain es nombrado capitán general por la Junta Provisional del Gobierno de la Provincia del 1 al 4 de julio de 1843. Francisco Javier Aspiroz es también nombrado por la misma Junta entre el 4 de julio al 8 de agosto de 1843. José Manso es nombrado por real orden de 8 de agosto de 1843 y se mantiene hasta agosto de 1845 .

\section{Diputados a Cortes}

A lo largo de estos años son elegidos diputados a Cortes por la provincia de Valladolid los siguientes señores: En el año 1841: Pelayo Cabeza de Vaca, Manuel Cantero San Vicente, León Gil Muñoz, Miguel Herrero López y Atanasio Pérez Cantalapiedra. En 1843 son: Epifanio Esteban Díaz, Pedro Nicanor González Puertas, Atanasio Pérez Cantalapiedra, Luis Sagasti García-Herreros y Juan Antonio Seoane Bayón. Son senadores en este período los vallisoletanos Manuel Joaquín Tarancón, Miguel López de Baños Monsalve, Juan Pasalodos y Roldán y Vicente Gil Muñoz ${ }^{316}$.

Obispado

Recordamos así mismo que Juan Antonio Rivadeneira continúa ejerciendo como obispo de Valladolid.

\section{Universidad}

El rector de la Universidad es Blas Pardo desde 1839 hasta 1842. Antonio María del Valle es nombrado el 10 de junio de 1842 hasta octubre de 1843.

\section{Secretaría del Gobierno provincial}

Los secretarios del Gobierno político de la provincia son Pedro Nicanor González, que asume la jefatura interina en febrero de 1842, Domingo Saavedra, que actúa de jefe político en julio de 1842, y José María Rebollo que es nombrado secretario el 22 de agosto de 1843.

\section{Otros personajes}

El marqués de Remisa sigue con intereses económicos en la región, al actuar como director del Canal de Castilla y presidente del Consejo de Administración del ferrocarril Alar-Santander.

La Junta Provisional del Gobierno de la Provincia, que se hace cargo de la dirección política de la misma en el tiempo que media entre la dimisión de Espartero y la formación de un nuevo Gobierno (1 de julio a 19 de agosto de 1843), está formada por los siguientes señores: Presidente, Miguel Seniosain, Mariscal de Campo. Vicepresidente, Francisco Agustín Silvela, Magistrado. Vocales, Claudio Moyano Samaniego, Faustino Alderete, Pelayo Cabeza de Vaca, Gregorio Barahona y Pedro Ochotorena. Como secretario actúa José María Cano Urquiza.

\section{Actividades más importantes en esta Diputación}

A lo largo de estos tres años progresistas, en el plano político se consolida el estado liberal con dos soportes principales: La Milicia Nacional y los Ayuntamientos. Son dos instituciones que apoyan sin fisuras al liberalismo y que en el caso de Valladolid serán los motores de su transformación y modernización ${ }^{317}$.

Los diputados a Cortes vallisoletanos en estos años tienen especial relevancia en la defensa de los intereses tanto provinciales como locales, como son los casos de la permanencia de la Universidad, institución que se sentía amenazada por el cierre, o en la petición de conventos desamortizados por parte del Ayuntamiento de la Capital, interesado en los mismos para efectuar una mejor urbanización de la ciudad.

En el tema de las obras públicas se inician las contrataciones de las carreteras que comunicarían Valladolid con León por un lado y con Salamanca por otro. Sin

\footnotetext{
${ }^{316}$ CARAS A SOTO. Pedro (Dir.). Diccionario biográfico de parlamentarios.... ob. cit. Págs. 3 y sig. ${ }^{317}$ LUENGO SANCHEZ, Jorge. El nacimiento de una ciudad progresista. Valladolid... ob. cit. Estudia las relaciones entre estas instituciones. Además, nos informa sobre las incidencias ocurridas con la caída de la torre de la Catedral.
} 
embargo, la finalización de las obras se prolongaría durante largos años, por la falta de recursos para el pago a los contratistas, a lo que a su vez, había que añadir a la negativa de los pueblos a hacer frente a los arbitrios necesarios para su financiación, alegando que deberían ser carreteras nacionales y en consecuencia su coste debería de correr a costa del Estado. No les falta razón al presentar como ejemplo la que se está construyendo entre Medina y Tordesillas como parte de la carretera que une Madrid con La Coruña y financiada por cuenta del Estado.

En lo relativo a la enseñanza, se continúa con la construcción de escuelas y las reclamaciones de los maestros por atrasos en el pago de los salarios. Valladolid estrena Escuela Normal. Y en el caso de la beneficencia, se produce un enfrentamiento con el Cabildo catedralicio por el nombramiento de administrador de la Casa de Beneficencia, competencia que es reclamada por las dos instituciones ${ }^{318}$.

\subsection{5.-LAS CINCO DIPUTACIONES MODERADAS. AÑOS 1844 A 1854}

El fin de la Regencia progresista de Espartero da paso al predominio de los conservadores en las instituciones políticas, tanto a nivel nacional como provincial y local. En el caso de las Diputaciones, la consecuencia inmediata es la de dar por finalizadas las actividades de la última Diputación elegida en el período progresista y proceder a la elección de nuevos diputados, de carácter moderado.

Entre los años 1844 y 1854 , en la Corporación provincial vallisoletana, se suceden cinco diferentes Diputaciones, que se corresponden de la quinta a la novena del período isabelino. Mantienen una duración regular, de acuerdo con lo estipulado en la legislación vigente, que oscila entre los dos y tres años, excepto la última, que resulta anormalmente corta, únicamente cuatro meses, a causa de los acontecimientos políticos ocasionados por una nueva llegada de los progresistas al gobierno. En este período se suceden una serie de cambios legislativos que condicionan el funcionamiento de la Diputación, y traen como consecuencia una pérdida de competencias y de actividades.

Las dos leyes más interesantes que se promulgan, referidas a las Diputaciones, propician una importante modificación en la gestión de la institución. Se trata de la "Ley de Diputaciones Provinciales", de 8 de enero de 1845, que independientemente de los cambios que se producen en el funcionamiento de las corporaciones, destaca porque incorpora en su articulado una mayor dependencia de la Diputación a la autoridad del jefe político como rasgo esencial. También se promulga la "Ley de Consejos Provinciales", de 2 de abril de 1845, que presupone la creación de un nuevo organismo, independiente de la Diputación y bajo la autoridad del jefe político. Se detallan su organización, sus atribuciones y sus actividades, que inciden en la Diputación, puesto que una parte importante de su gestión es sobre áreas que con anterioridad estaban encomendadas a la Corporación provincial. En cuanto a su gestión, desaparece prácticamente la Secretaría de la Diputación, con el cese del secretario y el traslado de los funcionarios a otros organismos y oficinas de la Jefatura política, al igual que los trabajos de la Secretaría. En los períodos de funcionamiento de la Diputación, la corporación nombra, de entre los diputados, a un secretario y un vicesecretario, que se encargan de la gestión documental. Y por otra parte, a partir de 1850, aparece y se refuerza la figura de gobernador de la provincia, que asume las competencias de los jefes políticos y la de los intendentes. De esta forma, desaparece de la Diputación la figura del vicepresidente, que era ejercida por el intendente, ocupando la presidencia el Sr. gobernador, y ante su ausencia y con carácter interino preside el vicepresidente del Consejo Provincial o en su ausencia, el diputado decano.

A continuación se reflejan, los cuadros de las cinco Diputaciones, con su duración, las sesiones celebradas y los individuos que las formaron.

${ }^{318}$ MAZA ZORRILLA, Elena. Valladolid y sus pobres.... Ob. cit. 
5ªputación isabelina. "La más larga". Noviembre 1843 - Julio 1847

\begin{tabular}{|c|c|c|c|c|}
\hline Nombre & Cargo & $\begin{array}{l}\text { Partido } \\
\text { judicial }\end{array}$ & $\begin{array}{c}\text { Permanencia } \\
\text { en el cargo }\end{array}$ & Sesiones \\
\hline Diego Manuel de Mosquera & $24^{\circ}$ Presid. & Jefe Político & Nov. 1843-Dic.1843 & 30 \\
\hline Laureano de Arrieta & $25^{\circ}$ Presid. & Jefe Político & Ene.1844-Mar. 1846 & 155 \\
\hline José Fernández Enciso & $26^{\circ}$ Presid. & Jefe Político & Abr.1846-Ago. 1846 & 7 \\
\hline José María del Campo & $27^{\circ}$ Presid. & Jefe Político & Sep.1846-Feb. 1847 & 5 \\
\hline Mariano Herrero Prieto & $28^{\circ}$ Presid. & Jefe Político & Mar. 1847-Jul 1847 & 12 \\
\hline Juan Buznego & Vice-Pres. & Intendente & Nov. 1843-Dic. 1843 & 2 \\
\hline Manuel de Villaverde & Vice- Pres. & Intendente & Feb. 1843-Jul. 1847 & 70 \\
\hline Manuel Gusano & Diputado & Villalón & Nov.1843 -Jul. 1847 & 199 \\
\hline Tomás de Rueda Lorenzo & Diputado & Olmedo & Nov.1843-Jul.1847 & 161 \\
\hline Antonio Santana Santos & Diputado & Nava & Nov.1843-Jul. 1847 & 215 \\
\hline Dionisio Nieto & Diputado & Valladolid & Nov.1843-Jul. 1847 & 173 \\
\hline Dionisio Enríquez & Diputado & Rioseco & Nov.1843-Jul.1847 & 143 \\
\hline Manuel Fernández Montealegre & Diputado & Medina & Nov.1843-Jul.1847 & 153 \\
\hline Manuel Quintero Rodríguez & Diputado & Valoria & Nov.1843-Jul. 1847 & 180 \\
\hline Mariano de la Mata Jaques & Diputado & Mota & Nov.1843-Jul.1847 & 129 \\
\hline Millán Alonso Del Barrio & Diputado & Peñafiel & Nov.1843-Dic.1846 & 147 \\
\hline
\end{tabular}

El día 1 de noviembre de 1843, el jefe político de la provincia, Diego Manuel de Mosquera, recién nombrado a raíz del cambio político, convoca en el salón de sesiones de la Diputación al intendente Juan Buznego y a los nueve diputados recientemente elegidos. Todos los diputados electos son nuevos en la política y en la Diputación, excepto el diputado por Villalón, Manuel Gusano, que ejerció el cargo en la Diputación progresista, y que fue cesado al final de la misma, y también el diputado por Peñafiel, Millán Alonso del Barrio, que ejerció como diputado en el año 1835, en la recién instaurada Diputación, la primera de la época isabelina.

En la sesión de instalación y con la pertinente ceremonia de juramento del cargo y toma de posesión, se produjeron dos reclamaciones sobre los nombramientos que prácticamente se solventaron a lo largo de la misma sesión. La primera procede del partido de La Mota del Marqués, en el que además del diputado elegido, Mariano de la Mata Jaques, se presenta también Fernando Cabezudo, "que había tomado asiento con los demás señores diputados y que reclamaba que era él el elegido, aunque después de revisadas las actas que se encontraban en manos del jefe político, se confirmó que el diputado electo era el Sr. Mata "por lo que el Sr. Cabezudo se retiró del salón, dejando sobre la mesa varios documentos en apoyo de sus derechos". La segunda reclamación la presentan varios electores del pueblo de Alaejos, que pedían la nulidad de la elección de Antonio Santana Santos, diputado por Nava del Rey, y defendían el nombramiento de Silvestre González, basando su reclamación en el hecho de que "al citado Antonio Santana Santos se le habían adjudicado varias papeletas rellenadas a favor de Antonio Santana, que era otro vecino de Alaejos"; también argumentaban que "en el cuarto día de elecciones Silvestre había recibido cincuenta votos y sólo le habían contabilizado treinta y dos". Puesta a votación esta reclamación fue desechada por mayoría de votos.

Esta Diputación, la más larga del período, estuvo vigente desde el 1 de noviembre de 1843 hasta el 30 de julio de 1847, celebrando en todo este tiempo un total de doscientas cuarenta sesiones.

El 15 de agosto de 1847, se inician los trabajos de la nueva Diputación, la sexta que se forma en la época isabelina. La "sesión de instalación se celebra en el local de las sesiones de la Diputación, sito en el Gobierno Político, presentes los señores diputados citados al margen y presidiendo el acta el jefe político de la provincia D. Mariano Herrero, se dio lectura a la real orden de 30 de junio pasado, por la que S.M. manda renovar la totalidad de las Diputaciones 


\section{$6^{a}$ Diputación isabelina. Con poco trabajo. Agosto 1847 - Marzo 1850}

\author{
Nombre \\ Mariano Herrero Prieto \\ Manuel de la Cuesta Cossío \\ Anselmo Merino \\ Rafael de Navascues \\ Juan Perales \\ José Rafael Guerra \\ Joaquín Aguilar \\ José Muñoz de San Pedro \\ Ramón Sardina \\ Manuel Villaverde \\ Miguel de Dueñas \\ Benito Díez del Río \\ Laureano Girón \\ Gabino Madrueño \\ Domingo Garzón San Juan \\ Nemesio López \\ Felipe Cabrejas de la Plaza \\ Bernardo Samaniego \\ José Luis Prieto
}

$\begin{array}{ll}\text { Cargo } & \begin{array}{l}\text { Partido } \\ \text { judicial }\end{array} \\ 28^{\circ} \text { Presi } & \begin{array}{l}\text { Jefe Político } \\ \text { Jefe Político }\end{array} \\ \text { 29 Presi } & \text { Vice. Consejo } \\ \text { Presi Int. } & \text { Jefe Político } \\ 30^{\circ} \text { Presi } & \text { Jefe Político } \\ 31^{\circ} \text { Presi } & \text { Gobernador } \\ 32^{\circ} \text { Presi } & \text { Intendente } \\ \text { Vice-Presi } & \text { Intendente } \\ \text { Vice-Presi } & \text { Intendente } \\ \text { Vice-Presi } & \text { Intendente } \\ \text { Vice-Presi } & \text { Medina } \\ \text { Diputado } & \text { Nava } \\ \text { Diputado } & \text { Rioseco } \\ \text { Diputado } & \text { Valoria } \\ \text { Diputado } & \text { Villalón } \\ \text { Diputado } & \text { Peñafiel } \\ \text { Diputado } & \text { Olmedo } \\ \text { Diputado } & \text { Mota } \\ \text { Diputado } & \text { Valladolid } \\ \text { Diputado } & \\ \end{array}$

$\begin{array}{lr}\begin{array}{l}\text { Permanencia } \\ \text { en el cargo }\end{array} & \text { Sesiones } \\ \text { Ago. 1847-Feb.1848 } & 12 \\ \text { Mar. 1848-Ene. 1849 } & 24 \\ \text { Febrero 1849 } & 2 \\ \text { Mar. 1849-Ago. 1849 } & 3 \\ \text { Sept. 1849-Dic. } 1849 & 5 \\ \text { Ene. 1850-Mar. } 1850 & 0 \\ \text { Ago. 1847-Sept. } 1847 & 1 \\ \text { Oct. 1847-Abr. } 1848 & 0 \\ \text { Mayo 1848 } & 0 \\ \text { Jun. 1848-Dic. 1849 } & 5 \\ \text { Ago. 1847-Mar. } 1850 & 37 \\ \text { Ago. 1847-Mar. } 1850 & 11 \\ \text { Ago. 1847-Mar. } 1850 & 41 \\ \text { Ago. 1847-Jun. } 1849 & 35 \\ \text { Ago. 1847-Mar. } 1850 & 23 \\ \text { Ago. 1847-Mar. } 1850 & 38 \\ \text { Sept. 1847-Mar. } 1850 & 30 \\ \text { Oct. 1847- Mar. } 1850 & 11 \\ \text { Mar. 1848-Mar. } 1850 & 34\end{array}$

Los diputados que forman esta Diputación son todos nuevos y todos prestan el juramento y toman posesión de su cargo, sin presentarse reclamación alguna. El único diputado que no se presenta a la toma de posesión es el electo por Valladolid, Eugenio Díez, y que tampoco lo hace en las siguientes sesiones. Ante su prolongada ausencia, el 21 de diciembre de este año de 1847 en la sesión que celebra la Diputación, el jefe político comunica que "habiendo decidido de acuerdo con el Consejo provincial que D. Eugenio Díez, electo diputado provincial por el partido de esta Capital, no tiene las cualidades que para este cargo exige la ley de 8 de enero de 1845 y no habiendo reclamado dicho señor dentro del término marcado en la real orden de 29 de agosto último, fue acordado que se proceda a nuevas elecciones en el partido de esta capital los días 29,30 y 31 del actual".

Celebradas las citadas elecciones, resultó elegido diputado D. José Luis Prieto, que tomó posesión del cargo en la sesión celebrada el 12 de marzo de 1848 . Se da así por completada la composición de la Diputación, que en realidad no tiene agobios para cubrir los trabajos encomendados, ya que, como hemos dicho, la existencia del Consejo provincial deja a la Diputación sin apenas competencias. Fruto de esta carga de trabajo son las cuarenta y cinco sesiones que se celebran desde agosto de 1847 hasta marzo de 1850. La mayoría de estas sesiones se dedicaron a tratar los temas de la construcción de las carreteras a través de la provincia y al estudio y aprobación de los presupuestos.

\section{$7^{a}$ Diputación isabelina. Una Diputación con poca actividad. Abril 1850-Marzo 1852}

El día 3 de abril de 1850, se inician las actividades de la nueva Diputación, la séptima del período isabelino, que se mantendrá vigente hasta el 30 de marzo de 1852. En este período de dos años se mantiene la tendencia iniciada en los años anteriores de celebrar un escaso número de sesiones, en consonancia con la poca carga de trabajo que se mantiene en la Diputación.

En los apartados anteriores está reflejado el comentario de que la existencia del Consejo provincial y las actividades que desarrolla tienen una relación directa con las que celebra la Diputación. Como dato comparativo tenemos que en este período 1850 1852, la Diputación celebra un total de treinta y dos sesiones, y el Consejo, en el mismo tiempo, se reúne en ciento noventa y una ocasiones. También el tipo de asuntos a tratar está en consonancia con las actuaciones de los dos organismos. Trata la Diputación preferentemente sobre los temas de presupuestos y comunicaciones 
(ferrocarriles y carreteras). Por su parte, el Consejo Provincial trata asuntos que con anterioridad eran desarrollados por la Corporación, como son los de quintos, Ayuntamientos, pósitos, propios, sanidad, justicia, enseñanza, arbitrios, etc.

Nombre

José Rafael Guerra

Id.

Anselmo Merino

Francisco de la Valette

Ildefonso López Alcaraz

Miguel María Fuentes

Miguel de Dueñas

Mariano Lino Reynoso

Norberto Sanz

Ignacio Arévalo

Nemesio López

Laureano Girón

Miguel de las Moras

José Luis Prieto

Domingo Garzón San Juan

$\begin{array}{cl}\text { Cargo } & \begin{array}{c}\text { Partido } \\ \text { judicial } \\ \text { 32 }\end{array} \\ \text { Id. } & \begin{array}{c}\text { Idesid. } \\ \text { Id. }\end{array} \\ \text { Interino } & \text { Vice.Consejo } \\ \text { Interino } & \text { Gob. Militar } \\ \text { 33 } 3^{\circ} \text { Presid. } & \text { Gobernador } \\ \text { No ejerce } & \text { Gobernador } \\ \text { Diputado } & \text { Medina } \\ \text { Diputado } & \text { Nava } \\ \text { Diputado } & \text { Olmedo } \\ \text { Diputado } & \text { Mota } \\ \text { Diputado } & \text { Peñafiel } \\ \text { Diputado } & \text { Rioseco } \\ \text { Diputado } & \text { Valoria } \\ \text { Diputado } & \text { Valladolid } \\ \text { Diputado } & \text { Valladolid }\end{array}$

Permanencia
en el cargo

Sesiones

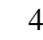

15

1

14

26

21

2

29

17

25

32

11

Como detalle de las sesiones celebradas, en el libro de actas están reflejadas las siguientes: En el año 1850 se celebran doce sesiones; cuatro en el mes de abril, seis en octubre y dos en noviembre. En 1851, son dieciséis las sesiones celebradas repartidas entre los meses de enero, marzo, abril, mayo, julio, septiembre y noviembre, con una media de dos a tres sesiones por mes. En 1852 son cuatro las sesiones realizadas: una en enero y tres en el mes de febrero.

\section{$8^{a}$ Diputación isabelina. Continúa la atonía en la Diputación. Abril 1852 - Marzo 1854}

Nombre

José Rafael Guerra

Pedro Bardaji

Francisco del Busto

Francisco Lara

Nemesio López

Miguel de las Moras

Ignacio Arévalo

Mariano Lino Reynoso

Norberto Sanz

Luis García Pizarro

Miguel de Dueñas

Ángel Pastor

Cargo
$32^{\circ}$ Presid.
$34^{\circ}$ Presid.
$35^{\circ}$ Presid.
Diputado
Diputado
Diputado
Diputado
Diputado
Diputado
Diputado
Diputado
Diputado

$\begin{array}{lr}\begin{array}{c}\text { Permanencia } \\ \text { en el cargo }\end{array} & \text { Sesiones } \\ \text { Abr.1852-Ene. 1853 } & 10 \\ \text { Febr. 1853 } & 1 \\ \text { Mar. 1853-Mar.1854 } & 12 \\ \text { Abr. 1852-Mar.1854 } & 19 \\ \text { Abr.1852-Mar. 1854 } & 20 \\ \text { Abr.1852-Mar.1854 } & 16 \\ \text { Abr.1852-Mar.1854 } & 1 \\ \text { Abr.1852-Mar. 1854 } & 16 \\ \text { Abr.1852-Mar. 1854 } & 11 \\ \text { Abr.1852-Mar.1854 } & 14 \\ \text { Abr.1852-Mar. 1854 } & 7 \\ \text { Abr.1852-Mar.1854 } & 14\end{array}$

Sesiones

10

Gobernador

Gobernador

Gobernador

Valladolid

Peñafiel

Valoria

Mota

Nava

Olmedo

Rioseco

Medina

Villalón

Inicia sus actividades esta octava Diputación isabelina con la presencia de tres nuevos diputados, Francisco Lara, Luis García Pizarro y Ángel Pastor, pues el cuarto al que tocaba renovar, el diputado por Peñafiel Nemesio López, resultó reelegido. Su vigencia se extiende entre el mes de abril de 1852 y se mantiene hasta finales de marzo de 1854 , con una actividad similar a las anteriores Diputaciones. En estos dos años la corporación celebra únicamente veintitrés sesiones, dedicadas en la mayoría de los casos a tratar sobre presupuestos. Sobresale el tema de las comunicaciones, en especial el gran auge que toman las construcciones de los diferentes ferrocarriles que se proyectan a lo ancho y largo de la provincia, sin olvidarse de las "eternas" obras de las carreteras.

De las veintitrés sesiones, diez se celebran en el año 1852: cuatro en abril, dos en mayo y una en junio, julio, septiembre y noviembre. Nueve en el año 1853: tres en abril, una en mayo, dos en junio y dos en noviembre. Y cuatro sesiones en el año 1854: una en enero, dos en febrero y una en marzo. 


\section{$9^{a}$ Diputación isabelina. Última y más corta de la época moderada. Abril - Junio 1854}

$\quad$ Nombre
Francisco del Busto
Francisco Lara
Nemesio López
Miguel de las Moras
Baltasar Maldonado
Manuel Martín Ortiz
Serapio Tamariz
José Moyano
Luis García Pizarro
Ángel Pastor

\begin{tabular}{|c|c|}
\hline Cargo & $\begin{array}{l}\text { Partido } \\
\text { judicial }\end{array}$ \\
\hline $35^{\circ}$ Presid. & Gobernador \\
\hline Diputado & Valladolid \\
\hline Diputado & Peñafiel \\
\hline Diputado & Valoria \\
\hline Diputado & Medina \\
\hline Diputado & Olmedo \\
\hline Diputado & Mota \\
\hline Diputado & Nava \\
\hline Diputado & Rioseco \\
\hline Diputado & Villalón \\
\hline
\end{tabular}

El arranque de esta novena Diputación isabelina no indica ningún tipo de incidencia, como queda reflejado en el acta de instalación: "En Valladolid a 1 de abril de 1854, reunidos en el salón de sesiones los señores que se expresan al margen, se leyó por el Sr. gobernador de la provincia el real decreto de 21 de enero último... y en su virtud se declaró instalada. Acto seguido prestan juramento los nuevos diputados Baltasar Maldonado, Manuel Martín Ortiz, José Moyano y Serapio Tamariz".

De esta forma iniciaba la Diputación sus trabajos, sin saber que su vigencia iba a ser muy corta. En tiempo, puesto que su duración se limita a los meses de abril a julio de 1854 y en sesiones, ya que efectuará únicamente dos sesiones en el mes de abril, la primera es la sesión de instalación y la segunda se dedicará a aprobar las cuentas del año 1853 y otras dos en el mes de mayo, dedicadas ambas a la presentación, discusión y aprobación de los presupuestos del próximo año 1855.

La Diputación, no se vuelve a reunir, aunque se mantiene vigente hasta el 24 de julio. En esta fecha la recién formada Junta Provisional del Gobierno de la provincia de Valladolid, acuerda y decreta lo siguiente:

-Artículo primero. Se suprimen sin excepción los derechos de puertas.

-Artículo segundo. La Junta de acuerdo con el Ayuntamiento, acordará los medios necesarios para suplir los productos que percibía por dichos conceptos.

-Artículo tercero. Se suprime el Consejo provincial.

-Artículo cuarto. Se restablece la Diputación provincial, conforme a la ley de 3 de febrero de 1823, con los individuos que próximamente nombrará la Junta.

Es el fin de esta Diputación y también el fin de la Década Moderada.

\section{De jefes políticos a gobernadores. Desaparición de los intendentes}

La modificación del cambio de nombre de los representantes del poder central no presupone el cambio de su actividad, ni por supuesto una modificación del control que ejerce en la Diputación. Ya se llame jefe político o gobernador, las funciones del poder central siguen siendo las de controlar todo tipo de actividad provincial. Con anterioridad a este cambio de denominación, se produce la aparición de otra figura política intermedia, el jefe político subalterno, "con la misión de colaborar con el jefe político de la provincia, haciéndose cargo de un distrito provincial".

En el caso de la provincia de Valladolid, por real decreto de 1 de diciembre de 1847, se nombra jefe político subalterno del distrito de Rioseco a Manuel Osorio, que ejerce el cargo hasta 11 de noviembre de 1848, fecha en la que por un nuevo decreto se nombra para el mismo cargo a Francisco García Moreno. Pero esta modalidad dura poco tiempo, ya que en el Boletín Oficial de la provincia del día 2 de octubre de 1849, se publica un real decreto "por el que se suprimen los jefes políticos de distrito, pasando estos a ser alcaldes corregidores". Finalmente, al poco tiempo de la publicación de esta supresión se publican unos reales decretos con fecha 28 y 29 de diciembre de 1849 , en el que se comunica que "en sustitución de los jefes políticos e intendentes, se crea una sola autoridad civil en cada provincia con la denominación de 
gobernador de provincia". En definitiva, los gobernadores asumen las responsabilidades políticas de los jefes políticos y de los intendentes, y éstos últimos se centran en su trabajo como delegados del Ministerio de Hacienda.

En lo que respecta a los nombramientos, también en este período se producen una serie de comunicados, anunciando diferentes nombramientos de jefes políticos y gobernadores, que en realidad no llegan a materializarse. Así tenemos la comunicación de Pedro Galvir, jefe político de Badajoz, que hace al Consejo provincial y que este organismo reseña en sus actas del día 22 de febrero de 1848 "anunciando su nombramiento como jefe político de Valladolid". Nombramiento que no es confirmado y del que no se vuelve a tener noticias. Otro nombramiento que sí es publicado es el del real decreto de 14 de junio de 1850, en el que se anuncia "el nombramiento de gobernador de la provincia de Valladolid a Alejandro Castro, intendente de Barcelona". En este caso, aunque la noticia está avalada por un real decreto, el nombramiento no llegó a materializarse, ni tampoco se publicó ninguna rectificación. Lo mismo ocurre con el nombramiento de gobernador de la provincia de D. Miguel María Fuentes, que es nombrado por real decreto de 7 de marzo de 1851, toma posesión el día 20 y el 12 de abril es cesado, sin haber presidido ninguna sesión de la Diputación.

\section{Los diputados provinciales de la época moderada}

Cinco Diputaciones se suceden a lo largo de estos años, entre noviembre de 1843 y julio de 1854, todas ellas de mayoría moderada, con algunas excepciones de carácter progresista. Durante estos años un total de veintinueve diputados se suceden en representación de los nueve partidos judiciales que conforman la provincia. De ellos tres ya pertenecieron a Diputaciones anteriores y también estarán presentes en Diputaciones posteriores. Otros quince individuos repetirán cargo, tanto en las diferentes Diputaciones de la Década Moderada, como en las del resto del período isabelino, aunque ninguno ejercerá en los años del Sexenio. Por fin, once serán los diputados que sólo estarán presentes en una legislatura y no volverán a presentarse. Otro dato a tener en cuenta es que de los veintinueve citados diputados que se suceden a lo largo de estas legislaturas, diecinueve de ellos han cursado estudios universitarios, en su mayoría en la Facultad de Leyes. Todos estos diputados al igual que los que han ejercido en etapas anteriores, como igualmente los que ejerzan en los años próximos serán objeto de una breve biografía en capítulo posterior.

\section{Sin Secretaría y con Consejo. Los avatares de la Secretaría Secretaría}

En la Diputación, que coincide con el inicio de la Década Moderada, la Secretaría mantiene las mismas funciones y el mismo sistema de funcionamiento que se llevaba en las legislaturas anteriores. Siguiendo la misma pauta, el secretario de la corporación con fecha 7 de noviembre de 1843, presenta al Pleno un informe sobre las actividades y trabajos de la Secretaría.

El 30 de octubre de 1844, la comisión encargada de formar el presupuesto provincial y el presupuesto de la Secretaría, presenta una propuesta en la que se modifica el personal, así como los sueldos y gastos de funcionamiento para el año 1845. La propuesta, que fue aprobada, definía la configuración de la Secretaría en la siguiente forma:

Secretario: José María Cano, con un salario de 10.000 reales

Oficial $1^{\circ}$ : Julián Díez, con un salario de 6.000 reales

$1^{\text {er }}$ oficial $2^{\circ}$ : Manuel Nieto, con un salario de 5.000 reales

$2^{\circ}$ oficial $2^{\circ}$ : Sixto Maroto y Salcedo, con un salario de 5.000 reales

$3^{\text {er }}$ oficial $2^{\circ}$ : Deogracias Larraga, con un salario de 5.000 reales

Portero: Manuel Domínguez, con un salario de 2.000 reales

Mozo de oficio: Vicente Herrero, con un salario de 500 reales

Con esta reorganización quedaban cesantes los oficiales y escribientes Roque

Soriano, Santiago Inés y José Vela, y ante la grave situación económica en que se 
encontraban estos individuos, el diputado por Peñafiel Millán Alonso del Barrio presentó en la Diputación una moción en la que resaltaba "La deplorable situación en que quedan estos individuos. Propone que se les señale una jubilación de 5 reales diarios en consideración a su edad septuagenaria. Propuesta aprobada por el Pleno" 319.

Finalmente, para gastos de la Secretaría, se recuerda que durante los años anteriores de 1841-42-43, se habían presupuestado 100.000 reales al año, pero que en 1845 se presupuestaba 71.500 reales, con una rebaja de 28.500 , en razón de la reducción de los gastos de personal.

Con fecha 30 de enero de 1845 se publica la ley de 8 de enero sobre "Organización de Ayuntamientos y Diputaciones" en la que se reflejan los radicales cambios que afectan a la Secretaría y que provocan cierta paralización de sus actividades al saber que van a ser suprimidas. El Gobierno, para cortar estos problemas, publica el 18 de enero una real orden "mandando continuar a los empleados de la Secretaría de la Diputación, bajo la dependencia del jefe político".

A partir del mes de agosto de 1845, se inicia el desmantelamiento administrativo, al pasar el secretario José María Cano a la Secretaría del Consejo provincial, organismo de reciente creación manteniendo en unos meses las actividades de la Diputación.

En septiembre, se dispone por real decreto del día 8 "que la Secretaría del gobierno político de esta provincia se aumente con dos oficiales con destino a los trabajos del Consejo de la misma, cuyos sueldos han de pagarse de los fondos de la misma. Un oficial $1^{\circ}$ con 8.000 reales y un oficial $2^{\circ}$ con 7.000 reales, siendo nombrados Julián Díez y Manuel Nieto, oficiales de la Secretaría de la Diputación”.

En octubre del repetido año 1845, se consuma la desaparición, cuando en la sesión celebrada el día 30 se registró la intervención del jefe político, quien dijo que "estando verificada la traslación del archivo de la Diputación al nuevo local que había elegido y estando cumplidos los demás extremos que sobre el particular habían acordado en la sesión del 24 de septiembre último, quedaba extinguida de hecho la Secretaría desde el día inmediato y por lo mismo estaba la Diputación en el caso de proceder al nombramiento del diputado que había de ejercer las funciones de secretario con arreglo a lo previsto en la Ley de Ayuntamiento y Diputaciones de 8 de enero de 1845". La Diputación, en el mismo día 30 de octubre, nombró secretario al diputado Dionisio Nieto y vicesecretario al también diputado Manuel Gusano.

A partir de esta fecha, la Diputación ha quedado sin funcionarios, pero para liquidar una serie de asuntos pendientes, en el mes de noviembre, se nombra funcionarios auxiliares a Sixto Maroto y Deogracias Larraga con un salario de 3.000 reales anuales, cantidad muy inferior a la que cobraban en la Secretaría. Maroto continuaba siendo el depositario de Fondos de la Diputación, aunque por poco tiempo, puesto que en diciembre renunció a las plazas de depositario y auxiliar, asumiendo Larraga estas funciones, además de ser nombrado depositario de Fondos de la Escuela Normal. Por otro lado, Santiago Inés, uno de los funcionarios cesantes, es nombrado escribiente del Consejo provincial y José Vela, otro de los cesantes, se queja de que le han anulado la pensión acordada de 5 reales al día. Finalmente, la Diputación rechaza la petición de Felipe Redondo de cubrir la vacante dejada por Sixto Maroto.

Deogracias Larraga en el año 1852 aparece como administrador del duque de Osuna y en el año 1855, como tal administrador, presenta un contencioso en la Diputación contra el Ayuntamiento de Vega de Valdetronco por una deuda de 74.258 reales procedentes de rentas atrasadas.

A lo largo de estos años se producen los siguientes nombramientos de los diputados que realizarán las tareas de secretarios y vicesecretarios:

En 1846. Febrero: Secretario Manuel Gusano y vicesecretario Mariano de Mata. Julio: Secretario, Mariano de Mata y vicesecretario, Antonio Santana Santos. Octubre: 
Secretario, Manuel Gusano y vicesecretario, Manuel Quintero. Diciembre: Secretario, Manuel Quintero y vicesecretario, Tomás de Rueda.

En el año 1847. Marzo: Secretario, Manuel Quintero y vicesecretario, Tomás de Rueda. Mayo: Secretario Dionisio Enríquez y vicesecretario Manuel Quintero. Agosto: El día 15 se procede a la instalación de la nueva Diputación y al nombramiento de los nuevos cargos: Secretario, Nemesio López y vicesecretario, Gabino Madrueño.

En el año 1848. Marzo: Secretario, Gabino Madrueño y vicesecretario, José Luis Prieto. Septiembre: Secretario, José Luis Prieto y vicesecretario, Nemesio López.

Año 1849. Enero: Secretario, Nemesio López y vicesecretario, Gabino Madrueño. Febrero: Secretario, Gabino Madrueño y vicesecretario, Nemesio López. Octubre: Secretario, Nemesio López y vicesecretario, José Luis Prieto.

Año 1850. Con la instalación de la nueva Diputación en el mes de abril, se nombra como secretario a Mariano Lino Reynoso y vicesecretario a Norberto Sanz, nombramientos que se mantienen a lo largo del año.

El año 1851. Marzo: Secretario, Mariano Lino Reynoso y vicesecretario, Norberto Sanz. Julio: Secretario, Miguel de las Moras y vicesecretario, Norberto Sanz. Noviembre: Secretario, Mariano Lino Reynoso y vicesecretario, Norberto Sanz.

En el año 1852, con la llegada de la nueva Diputación, instalada el 1 de abril, se nombra secretario a Mariano Lino Reynoso y vicesecretario a Luis García Pizarro, que se mantienen en el cargo durante todo el año.

El año 1853, se inicia con los mismos diputados, es decir, secretario, Mariano Lino Reynoso y vicesecretario, Luis García Pizarro. Noviembre: Secretario, Luis García Pizarro y vicesecretario, Nemesio López.

Año 1854. Se mantienen los mismos diputados en los primeros meses, hasta que en abril se procede a la instalación de la nueva Diputación, en la que se nombra como secretario a José Moyano y vicesecretario a Manuel Martín Ortiz, que se mantienen en los puestos hasta julio del mismo año, en que se disuelve la Diputación. Entonces se inicia un nuevo ciclo a partir del Bienio Progresista, época en la que se volverá a poner en marcha nuevamente la Secretaría de la Diputación.

\section{El Consejo provincial}

En el Boletín Oficial de la Provincia de Valladolid del 19 de abril de 1845, se publica la ley de 3 de abril sobre "Organización y Atribuciones de los Consejos provinciales", entidad de nueva creación a la que se le encomiendan una serie de actividades, que en su mayoría estaban gestionadas por las Diputaciones provinciales. Sus atribuciones abarcaban las siguientes áreas: Tribunal administrativo, repartimientos, contratos, y obras públicas.

También se reflejaba la composición de los Consejos, que estarían formados por el jefe político como presidente y tres vocales con sueldo. Esta paga oscilará entre los 8.000 y 12.000 reales anuales, cantidad importante y que contrastaba con el tratamiento a los diputados provinciales, que no tenían ningún tipo de remuneración.

Las actividades del Consejo provincial de Valladolid se inician el día 29 de julio de 1845, dando detalles de su composición en el acta de la sesión de instalación ${ }^{320}$. En el mes de agosto, por real orden del día 4, se nombra vicepresidente a Manuel Martín Lozar y entre los meses de septiembre a diciembre, parte de los funcionarios de la Diputación pasan a desempeñar los trabajos del Consejo provincial.

\footnotetext{
320 “En la ciudad de Valladolid y sala de despacho del jefe político de la provincia a 29 de julio de 1845 y hora de las 11 de la mañana, reunidos los Sres. Laureano Arrieta, jefe superior político, Manuel Martín Lozar, Salvador María de los Ríos, Anselmo Merino y Ricardo Díaz de Rueda, nombrados por real orden del 14 del corriente vocales propietarios para componer el Consejo, y José Francés de Alaiza, nombrado también consejero súper-numerario, con el objeto de construir e instalar el referido Consejo provincial, no habiendo asistido el otro consejero súper-numerario Saturnino Gómez Escribano, por haber hecho dimisión,... y después de leída las leyes y reales órdenes concernidas, se procedió por el Sr. presidente a tomar juramento a los señores consejeros y se declaró constituido el Consejo, del que como secretario certifico. Firmado: José María Cano”.
} 
Como es lógico, el Consejo, al desarrollar sus trabajos, resta importancia a las actividades de la Diputación, que ve cómo las cuestiones más relevantes son trasferidas de un organismo al otro.

En su primer año de actividad, 1845, el Consejo celebra veinticinco sesiones en las que trata sobre temas electorales, obras públicas, aprobación de presupuestos municipales, temas judiciales, etc. Durante el año 1846, se mantienen los mismos consejeros, que celebran a lo largo del año un total de ciento dos sesiones, en las que tratan temas de presupuestos municipales, propios, repartimientos, distritos electorales, beneficencia, arbitrios, instrucción pública, sanidad. En el año 1847, se celebran ciento treinta y dos sesiones y se repiten los temas a tratar, es decir, quintas, repartimientos, sanidad, beneficencia, instrucción pública, elecciones, presupuestos, etc.

En el año 1848, por real orden publicada el 22 de marzo, se comunica la renuncia del vicepresidente Manuel Martín Lozar, y su baja se cubre, nombrando vicepresidente a Anselmo Merino y vocal a José Francés de Alaiza. Con estos cambios, el Consejo queda formado por Anselmo Merino como vicepresidente y los vocales Salvador María de los Ríos, Ricardo Díaz de Rueda y José Francés de Alaiza. Con esta composición celebran ciento treinta y seis sesiones con los mismos temas relacionados en años anteriores.

En febrero de 1849 se nombra secretario del Consejo a Antonio Carrión y se celebran a lo largo del año ciento diecisiete sesiones con los habituales temas a tratar. En 1850, no hay modificaciones en la composición del Consejo, y este celebra ochenta y siete sesiones. En 1851, se completa el Consejo con el nombramiento de vocales supernumerarios en las personas de Donato Basanta y Castor Ibáñez de Aldecoa y se celebran en este año noventa y seis sesiones.

En el año 1852, se producen una serie de cambios, que se inician el día 2 de enero con la dimisión de los vocales Ricardo Díaz de Rueda y Salvador Ma de los Ríos, pasando los supernumerarios a vocales propietarios. Queda el Consejo con la siguiente composición: Vicepresidente, Anselmo Merino. Vocales, José Francés de Alaiza, Donato Basanta, y Castor Ibáñez de Aldecoa. Vocales supernumerarios, Vicente Álvarez Cossìo y Manuel López Puga. En el mes de abril dimite Castor Ibáñez de Aldecoa y toma asiento en su lugar Manuel López Puga. Como supernumerario se nombra a José María Mendigutía. En este año se celebran ochenta y cuatro sesiones. En el año 1853, continúan los mismos consejeros y a lo largo del año se celebran ochenta $\mathrm{y}$ seis sesiones.

En el año 1854 y hasta la supresión del Consejo, decretada por la Junta Provisional del Gobierno de la Provincia, con fecha 26 de julio, se celebran cincuenta sesiones, y en la fecha de la supresión el Consejo estaba formado así: Vicepresidente, Anselmo Merino. Vocales, José Francés de Alaiza, Donato Basanta y Vicente Álvarez de Cossío. Secretario, Antonio Carrión.

\section{Autoridades y otras personalidades Ayuntamiento}

El año 1844 se estrena con la elección de alcalde en la persona de Saturnino Gómez Escribano. En marzo es elegido Mariano Miguel de Reynoso y Abril, que presenta la dimisión en el mes de octubre al ser elegido diputado a Cortes. El 21 de octubre de 1844 se nombra alcalde a Juan Manuel Fernández Vítores, que se mantiene en el cargo hasta diciembre de 1845. En 1846 y 1847 es Nemesio López Redondo el que ejerce la alcaldía vallisoletana.

En el año 1848 Gregorio Barahona es elegido alcalde, aunque su permanencia en el cargo se ciñe únicamente al mes de enero. Manuel Fernández Camaró le sucede y ejerce entre los meses de febrero y junio y finalmente José Oller Menacho es elegido alcalde y se mantiene en el cargo desde julio de 1848 hasta julio de 1849.

En julio de 1849 es Manuel de las Heras el que se hace cargo de la alcaldía hasta abril de 1850 y le sustituye hasta final de año José Torres Casado. En el año 1851, José María Palarea Soto es alcalde durante el mes de enero, José Antonio Altuna 
desde febrero hasta octubre y Calixto Fernández de la Torre se mantiene en el cargo el resto de 1851, todo el año 1852 y hasta junio de 1853. José María Cano Urquijo toma posesión el día 27 de junio de 1853 y deja la alcaldía en octubre de $1854{ }^{321}$.

\section{Capitanía General}

La Capitanía General de Castilla La Vieja mantiene en estos años sus habituales cambios en la figura de capitán general, aunque a menudo son personajes que se repiten y que ya han ejercido el cargo con anterioridad. Así tenemos a: José Manso, capitán general entre agosto de 1843 y agosto de 1845. Jacobo María de Espinosa, Barón de Solar de Espinosa ejerce entre agosto de 1845 y agosto de 1846. Manuel Pavia y Laci, entre agosto de 1846 y febrero de 1847. Manuel de la Concha, entre marzo y septiembre de 1847. Felipe Rivero, actúa entre octubre de 1847 y abril de 1853. Ramón Bohorquez, entre mayo y septiembre de 1853. José María Laviña entre octubre de 1853 y julio de 1854 .

\section{Diputados a Cortes y Senadores}

Como diputados a Cortes resultan elegidos en las elecciones de Septiembre de 1843: Manuel Alday Garcia, Millán Alonso del Barrio, Manuel Cantero San Vicente, Epifanio Esteban Díaz, Pedro Nicanor González Puertas y Miguel Herrero López. En las elecciones de diciembre de 1846: Millán Alonso del Barrio, Joaquín Belloso Melgar, Román García Fernández y Luis Sagasti García-Herreros. En los comicios de agosto de 1850: Millán Alonso Barrio, Ángel Juan Álvarez Osorio, Ignacio Arévalo Miera, Joaquín Belloso Melgar y Benito Fernández Maquieira.

En las elecciones del mes de mayo de 1851, repiten los mismos diputados que resultaron elegidos en el año 1850. En el año 1853, en las últimas elecciones de este período, celebradas en el mes de febrero, son diputados: Millán Alonso del Barrio, Lorenzo Arrazola García, Benito Fernández Maquieira y Mariano Herrero Ceruelo. Senadores por la provincia son: Manuel Joaquín Tarancón y Vicente Pimentel Bayón ${ }^{322}$. Obispado

Juan Antonio Rivadeneira continúa al frente del Obispado de la Diócesis desde el año 1830 y en consecuencia con su cargo es senador del Reino. Además, ostenta el título de prior de Junquera de Ambía y el cargo de auditor de la Rota. Está en posesión de la Gran Cruz de Isabel La Católica.

\section{Universidad}

La Universidad, en estos años, está regida por: Claudio Moyano Samaniego entre 1843 y 1845 . En el año 1845 , el jefe político de la provincia D. Laureano de Arrieta, es nombrado rector accidental, actuando también como tal rector el secretario del gobierno José González Eusebio, cuando ejerce la jefatura política interinamente. Vuelve a ser nombrado rector Claudio Moyano Samaniego, desde 1846 hasta 1850, año en el que cesó al ser nombrado rector de la Universidad Central. Le sucede Manuel de la Cuesta y Cossío, que ejerce desde 1850 hasta 1863.

\section{Delegados de Hacienda}

Con la desaparición del cargo de intendente, aparecen en su lugar los administradores de Rentas, que a partir de enero de 1850 son: Eustaquio García, Manuel Palacios y Villalba y Manuel Ruiz del Portal, individuos que se suceden en el cargo hasta 1853, en que por real decreto de 12 de mayo se crea en su lugar la figura de delegado de Hacienda, siendo nombrado para este cargo a Francisco Lavinay.

\section{Otros personajes}

Uno de los ciudadanos más inquieto y preocupado por la situación de la provincia es Benito Fernández Maquieira, agricultor y propietario, de tendencia progresista. Fue elegido diputado a Cortes en 1850 y tuvo una destacada actuación en defensa de la imposición de aranceles a la importación de cereales y del mantenimiento de las exportaciones de grano a Puerto Rico, que habían sido suprimidas. En 1852,

${ }^{321}$ CARASA SOTO, Pedro (Dir.). Diccionario biográfico de Alcaldes... Ob. cit. Págs. 13 a 15. ${ }^{322}$ CARASA SOTO, Pedro (Dir.). Diccionario biográfico de parlamentarios.... ob. cit. Págs. 3 y sig. 
visitó, a título privado, la Exposición Internacional de Londres donde compró un arado que regaló a la provincia. Ejerció como director general del Tesoro.

En otro orden de cosas y como dato curioso, tenemos que el duque de Medinaceli, con motivo de la desamortización del convento de San Pablo, el 6 de febrero de 1844, reclamó a la Diputación setenta y cinco cuadros que había donado al convento. Ante la negativa de la Diputación y tras varias controversias, el asunto se zanjó cuando por real orden de 20 de octubre de 1844 "se ordena entregar al Sr. duque de Medinaceli, varios retratos de pontífices que están en el Museo y que proceden del convento de San Pablo".

\section{Trabajos más relevantes en estos años}

Con la llegada del Consejo provincial, los trabajos de la Diputación quedan minorados, y centrados sobre todo en la elaboración y aprobación de los presupuestos provinciales, presupuestos que habitualmente son deficitarios, por lo que la Diputación está obligada a solicitar la autorización superior para equilibrarlos a través de arbitrios.

A pesar de estas limitaciones, en el tema de las obras públicas no podemos de dejar de resaltar la importancia del desarrollo de los proyectos de ferrocarriles, en especial la línea de Alar-Santander, como remate al establecimiento de una vía de comunicación con la costa a través del Canal de Castilla hasta Alar y a partir del citado Alar y hasta Santander construyendo una vía férrea. Otro de los proyectos más interesantes que estudia la Corporación, conjuntamente con otras Diputaciones del norte de España, es la creación del ferrocarril entre Bilbao, Valladolid y Madrid, que posteriormente se convertiría en la línea del Norte entre Irún y Madrid pasando por Valladolid. En las comunicaciones por carretera, continúan a lo largo de estos años la construcción de las carreteras que desde Valladolid comunicarían con León y Salamanca, atrasadas por problemas económicos.

Otras actividades desarrolladas por la Diputación están referidas a la modernización de la agricultura, a la petición de aranceles para proteger la producción triguera de la provincia, a la unificación de los numerosos establecimientos benéficos de la provincia y al progresivo control que la corporación está tomando en los mismos.

\subsection{6.-DOS DIPUTACIONES PROGRESISTAS. BIENIO 1854-56}

La nueva llegada del general Espartero al poder tiene como consecuencia un cambio político que se corresponde con la aparición de un nuevo Gobierno de carácter progresista, en sustitución de los defenestrados moderados.

Este cambio, a nivel nacional, tiene su repercusión a escala provincial, con la formación de una nueva Diputación, lo que conlleva el cambio de los diputados que representaban a la provincia. Como es habitual en estos cambios y en estos años, el gobernador de la provincia abandona sus funciones y se hace cargo del gobierno la recién creada "Junta Provisional del Gobierno de la Provincia", institución encargada de dirigir las actividades provinciales, hasta que se estabiliza la situación política nacional, se forma nuevo Gobierno central, y éste a su vez nombra un nuevo gobernador civil. Éste, en una de sus primeras medidas, tendrá que organizar el funcionamiento de la Diputación, y de acuerdo con las instrucciones recibidas tendrá que ratificar los nombramientos hechos por la Junta Provisional, o en su defecto proceder a un nuevo nombramiento, o a la convocatoria de elecciones para cubrir los puestos de diputados provinciales.

Con este planteamiento, vemos que el inicio del Bienio Progresista produce el nombramiento de una nueva Diputación, además de otros dos cambios importantes que inciden en el funcionamiento de la institución. En primer lugar, la supresión del Consejo provincial, con lo que la Diputación se vuelve a hacer cargo de todos los asuntos que a nivel provincial, en los últimos años habían estado gestionados por el Consejo $^{323}$, y en segundo lugar, la puesta en marcha de la Secretaría de la Diputación,

323 Como ejemplo de la amplitud de los temas que trata la Diputación y su diferencia con la época de existencia del Consejo, tenemos que el libro de actas de la Diputación $\mathrm{n}^{\circ} 12$ se corresponde con la 
con la correspondiente asunción de actividades que con anterioridad estaban a cargo de la Secretaría del Gobierno Civil y de los diputados que ejercían como secretarios. La consecuencia de la nueva puesta en marcha de la Secretaría es la de efectuar la contratación del personal funcionario.

\section{La 10 ${ }^{a}$ Diputación isabelina. Progresista y provisional. Julio-Agosto 185}

\begin{tabular}{|c|c|c|}
\hline Nombre & Cargo & $\begin{array}{l}\text { Partido } \\
\text { judicial }\end{array}$ \\
\hline Miguel Álvarez & $36^{\circ}$ Presid. & Gobernador \\
\hline Juan José Santander & Diputado & Medina \\
\hline Miguel de las Moras & Diputado & Valoria \\
\hline Santiago Quiroga Martínez & Diputado & Valladolid \\
\hline Andrés Alonso García & Diputado & Peñafiel \\
\hline Manuel Gusano & Diputado & Villalón \\
\hline Serapio Tamariz & Diputado & Mota \\
\hline Ventura García Escobar & Diputado & Rioseco \\
\hline Manuel Martín Ortiz & Diputado & Olmedo \\
\hline Genaro Santander & Diputado & Nava \\
\hline
\end{tabular}

Permanencia
en el cargo
Jul. 1854-Ago. 1854
Jul. 1854-Ago. 1854
Jul.1854-Ago. 1854
Jul. 1854-Ago. 1854
Jul. 1854-Ago. 1854
Jul.1854-Ago. 1854
Jul. 1854-Ago. 1854
Jul.1854-Ago. 1854
Jul. 1854-Ago. 1854
Agosto 1854

Sesiones

Esta primera "Diputación Progresista", décima de la época isabelina, es nombrada por la "Junta Provisional del Gobierno de la Provincia", que a su vez y con anterioridad, había cesado a la anterior.

Su carácter provisional está reflejado principalmente en su duración, ya que inicia sus actividades el día 30 de julio de 1854, y es disuelta el 15 de agosto del mismo año. Si la Junta Provisional es el organismo que la nombró, es también el mismo organismo que la disuelve. En conclusión, es una Diputación provisional de quince días de duración y en la que se celebran quince sesiones.

El libro de actas nos da detalles de su nombramiento, de su provisionalidad y de las primeras decisiones que toma la Junta y de las que se hace eco la Diputación. Así lo dice en la sesión de instalación del 30 de julio ${ }^{324}$. También publicó el 1 de agosto un "Manifiesto a la Provincia", en el que se hacía un llamamiento, solicitando la confianza de los habitantes de la provincia, prometiendo por parte de la institución "el trabajar por la libertad, justicia y moralidad para conseguir que la nueva etapa sea próspera y beneficiosa a toda la provincia".

\section{La 11 ${ }^{a}$ Diputación isabelina. Progresista con diputados progresistas. Agosto1854. Agosto 1856}

Esta Diputación cubre prácticamente todo el período del Bienio. Se inician las actividades con la sesión de instalación, que se celebra el día 17 de agosto de 1854, en

la que se explica el nombramiento de los diputados. Así nos dice que, "en virtud de convocatoria dada al efecto por el Sr. gobernador civil, a los señores diputados reseñados al margen, a los que se le dio posesión de su cargo, con arreglo al real decreto de 7 de agosto por el que se ordena convocar a los diputados que lo eran en el

trascripción de las actas de las sesiones que la corporación celebra entre los años 1846 a 1854 , periodo de ocho años en el que está vigente el Consejo Provincial, y el libro de actas $n^{\circ} 13$, se refiere únicamente a los asuntos tratados por la Diputación entre los años 1854-1856, es decir, en el período progresista de dos años, en el que está suspendido el Consejo provincial.

324 "En la ciudad de Valladolid, a 30 de julio de 1854, reunidos a las doce del día, previa convocatoria al efecto, en la sala donde la Diputación provincial celebra sus sesiones, los señores reseñados al margen, se leyó el decreto de la Junta de Gobierno de fecha 24 del actual, inserto en el Boletín Oficial de la provincia número 89, por el que se acuerda lo siguiente: Se suprime el Consejo provincial. Se restablece la Diputación con arreglo a la ley de 3 de febrero de 1823. Se nombra secretario interino a D. Juan Nepomuceno Altolaguirre, que lo es del Gobierno de la provincia. A continuación, recibido el juramento de los señores diputados, se nombró una Comisión compuesta por los Sres. presidente, Quiroga, Alonso y Tamariz, para que en nombre de la Diputación felicite a la Junta Provisional de Gobierno, por el acierto y tino con que ha dirigido la provincia, desde el 15 del actual, fecha de inicio del feliz alzamiento...". 
año 43... Por el partido de Rioseco se nombró a Ventura García Escobar, como medida de consecuencia y utilidad pública, a fin de que el partido de Rioseco no careciese de representante, ya que por el indicado partido se hallaba en el caso excepcional de haber muerto los cuatro señores diputados que le habían representado en los años 1840-41-42 y 43. El diputado por Valoria, Miguel de las Moras fue elegido por ser el diputado de 1840 y por las circunstancias particulares del diputado de 1843 Manuel López Puga".

Nombre

Miguel Álvarez

Nicolás María Rivero

Manuel Gusano

Bernardo Iglesias

Domingo Saavedra

Patricio Azcárate

Juan Diego Pérez

Ignacio Méndez Vigo

Baldomero Menéndez

Carlos Iñigo y Anciso

Francisco Castillón

Juan Manuel Arévalo

Ildefonso García Casasola

Isidoro Mariano Cafranga

Francisco Rodríguez Rubio

Andrés Alonso García

Manuel Gusano

Domingo Garzón San Juan

Faustino Alderete

Miguel de las Moras

Juan Antonio de las Moras

Ventura García Escobar

Benito Moreno

Pedro Paulino Cantalapiedra

\begin{tabular}{cl} 
Cargo & $\begin{array}{l}\text { Partido } \\
\text { judicial }\end{array}$ \\
$36^{\circ}$ Presid. & Gobernador \\
$37^{\circ}$ Presid. & Gobernador \\
$38^{\circ}$ Presid. & Gobernador \\
$39^{\circ}$ Presid. & Gobernador \\
$40^{\circ}$ Presid. & Gobernador \\
--- & Gobernador \\
Secretario & Gobierno \\
Secretario & Gobierno \\
Secretario & Gobierno \\
Secretario & Gobierno \\
--- & Gob. Milit. \\
Diputado & Olmedo \\
Diputado & Nava \\
Diputado & Nava \\
Diputado & Mota \\
Diputado & Peñafiel \\
Diputado & Villalón \\
Diputado & Villalón \\
Diputado & Valladolid \\
Diputado & Valoria \\
Diputado & Valoria \\
Diputado & Rioseco \\
Diputado & Rioseco \\
Diputado & Medina \\
\hline
\end{tabular}

$\begin{array}{lr}\begin{array}{l}\text { Permanencia } \\ \text { en el cargo }\end{array} & \text { Sesiones } \\ \text { Agosto 1854 } & 2 \\ \text { Ago. 1854-Oct.1854 } & 20 \\ \text { Ene. 1855-Ago.1855 } & 45 \\ \text { Sep. 1855-May.1856 } & 28 \\ \text { May. 1856-Jun.1856 } & --- \\ \text { Julio 1856 } & -- \\ \text { Agosto 1855 } & 16 \\ \text { Agosto 1855 } & -- \\ \text { Ene. 1856-Mar.1856 } & 6 \\ & -- \\ \text { Agosto 1856 } & -- \\ \text { Ago. 1854-Ago.1856 } & 72 \\ \text { Agosto 1854 } & 1 \\ \text { Sep.1854-Ago. 1856 } & 88 \\ \text { Ago. 1854-Ago.1856 } & 102 \\ \text { Ago.1854-Ago.1856 } & 94 \\ \text { Ago. 1854-Dic.1854 } & 21 \\ \text { Ene.1855-Ago.1856 } & 47 \\ \text { Ago. 1854-Ago.1856 } & 130 \\ \text { Ago.1854 } & 3 \\ \text { Sep.1854-Ago.1856 } & 90 \\ \text { Agosto 1854 } & 2 \\ \text { Sep.1854-Ago. 1856 } & 93 \\ \text { Ago.1854-Ago.1856 } & 21 \\ & \end{array}$

En la sesión del 18 de agosto se vuelve a recordar a todos los ciudadanos que la Diputación está empeñada en trabajar por el afianzamiento de la moralidad y a cambio solicita de los pueblos que les sigua prestando su colaboración y sacrificio. En conclusión, esta Diputación se mantiene operativa entre agosto de 1854 y agosto de 1856 , celebrando en este tiempo un total de ciento cuarenta y ocho sesiones.

\section{Presidentes y gobernadores}

El real decreto de 20 de agosto de 1854 establece una importante modificación en el funcionamiento de la Diputación, detallando que "ante la ausencia del go bernador civil, el gobierno interino estará mandado por el secretario del Gobierno Civil y la presidencia de la Diputación lo será por el diputado decano".

Con anterioridad a la publicación de este decreto, el individuo que presidía la Diputación era en principio el intendente-vicepresidente y con posterioridad, a la desaparición de la figura del intendente, era el vicepresidente del Consejo provincial al que correspondía la presidencia. A partir de este momento, ni los gobernadores interinos ni los secretarios del gobierno presidirán las sesiones de la Diputación, aunque en el caso de los secretarios, asistían a las sesiones.

A continuación reseñamos los diferentes gobernadores, tanto titulares como interinos, que han regido los destinos de la provincia en estos dos años. Vuelven a ser llamativos los numerosos cambios que se producen, signo de la inestabilidad política que se vivió en el Bienio Progresista.

Así tenemos: Cinco gobernadores civiles, que además ejercieron el cargo de presidentes de la Diputación. Fueron: Miguel Álvarez, Nicolás María Rivero, Manuel Gusano, Bernardo Iglesias y Domingo Saavedra. Un gobernador civil que no llegó a tomar posesión de la presidencia de la Diputación: Patricio de Azcárate. Cuatro secretarios del Gobierno que ejercieron de gobernadores interinos, que asistieron a 
varias sesiones pero no las presidieron: Juan Diego Pérez, Ignacio Méndez Vigo, Baldomero Menéndez y Carlos Iñigo y Anciso. Finalmente, y cerrando el período, un gobernador militar, que, en virtud del estado de guerra declarado en la provincia, fue nombrado gobernador civil por el capitán general de Castilla la Vieja, aunque ni presidió ni asistió a ninguna sesión de la Diputación: Francisco Castillón.

\section{Los diputados provinciales}

La condición de nombrar diputados "a los que lo fueron en 1843", según ordenaba la real orden de 7 de agosto de 1854, hace que en este período aparezcan pocos diputados nuevos, teniendo también en cuenta que, tanto en la corta Diputación provisional como en la segunda y definitiva de este período, los diputados no resultaron elegidos a través de elecciones sino que lo fueron por nombramiento directo de la autoridades gubernativas. En definitiva, en el Bienio Progresista, desarrollan su trabajo en la Diputación un total de dieciocho diputados, de los cuales seis son nombrados por vez primera.

\section{La nueva Secretaría}

El 30 de julio de 1854, fecha de la instalación de la décima Diputación, primera del período Progresista, uno de los primeros acuerdos que se tomaron es el de "nombrar secretario interino de la Diputación al secretario del Gobierno de la provincia D. Juan Nepomuceno Altolaguirre".

En la segunda sesión, que se celebra en la tarde del mismo día 30 de julio, se trata: "Como asunto urgente a despachar por la Diputación se toma nota de la necesidad de fijar el número de empleados de la Secretaría, acordando nombrar a los Sres. Gusano, Escobar y Tamariz para que formen la plantilla, teniendo presentes los servicios de los aspirantes, su capacidad y las demás buenas prendas de moralidad y afección a la causa nacional proclamada".

La comisión es rápida en el estudio y toma de decisiones porque en la sesión del día siguiente, 1 de agosto, "se aprueba la plantilla de la Secretaría, acordada por la comisión con sus correspondientes salarios:

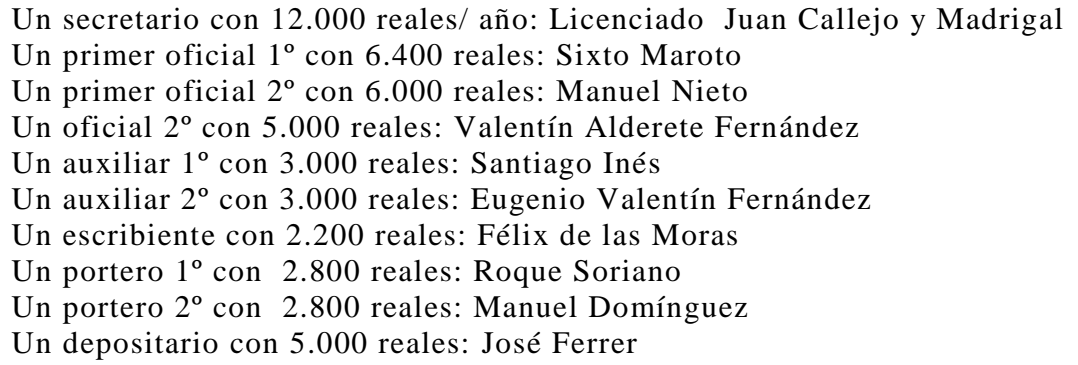

En la misma sesión se amplió la plantilla, al acordar "emplear a Tomás Dávila como oficial $3^{\circ}$ con 4.000 reales al año y a Julián Diez como auxiliar con 3.000 reales al año". Al día siguiente, 2 de agosto, se da posesión y se toma juramento al nuevo secretario: el licenciado Juan Callejo y Madrigal.

El 22 de diciembre de 1854 , se vuelve a ampliar la plantilla al contratar un nuevo oficial $2^{\circ}$ en la persona de Simón Sáez, con un salario de 5.500 reales al año. En el mes de enero de 1855, se acuerda formar una comisión para estudiar nuevamente la plantilla de la Secretaría y adecuarla a las necesidades de la corporación. La comisión formada por Benito Moreno, Juan Antonio de las Moras y Pedro Paulino Cantalapiedra, presentan en la sesión del 15 de enero, la nueva plantilla de funcionarios de la Secretaría, que queda y se aprueba de la siguiente forma: 
Oficial $4^{\circ}$ : Valentín Alderete Fernández

Auxiliar $1^{\circ}$ : Santiago Inés

Auxiliar $2^{\circ}$ : Eugenio Valentín Fernández

Auxiliar $3^{\circ}$ : Félix de las Moras

Portero $1^{\circ}$ : Roque Soriano

Portero $2^{\circ}$ : Manuel Domínguez

Depositario: José Ferrer
4.000 reales al año

3.300 reales al año

3.000 reales al año

2.200 reales al año

3.000 reales al año

2.800 reales al año

2.800 reales al año

En la sesión del día 18 se nombra a Sixto Maroto como interventor de Fondos.

\section{Autoridades y otros personajes}

La llegada del Bienio Progresista tiene como consecuencia una serie de cambios en las personalidades políticas dirigentes, como es el caso del cambio de los diputados provinciales, la desaparición del Consejo provincial y también la formación de otras entidades o corporaciones de carácter político.

\section{Ayuntamiento}

José María Cano Urquijo ejerce la alcaldía desde el año 1853 y la deja en octubre de 1854, fecha en la que toma posesión del cargo Santiago Quiroga Martínez, que venía de ser diputado provincial en agosto del mismo año y permanecerá como alcalde hasta 1856 , es decir, durante todo el período progresista ${ }^{325}$.

\section{Capitanía General}

En la Capitanía General de Castilla la Vieja, como hemos reflejado, es nombrado capitán general el 18 de julio de 1854, el mariscal de campo Atanasio Alesón, aunque con una duración efímera en el cargo, pues el 28 de agosto del mismo año es nombrado nuevo capitán general en la persona del teniente general Joaquín Armero y Peñaranda, que se mantendrá en el cargo hasta el año 1858, y tendrá su protagonismo en la provincia, al declarar el estado de guerra en julio de 1856, con motivo del "Motín del Pan", y al mismo tiempo por nombrar en estos días como gobernador civil de la provincia al general gobernador militar Francisco Castillón.

\section{Diputados a Cortes}

Los diputados a Cortes elegidos en 1854 fueron Atanasio Pérez Cantalapiedra con 6.440 votos, José Güell y Renté con 6.239 votos, Juan Antonio Seoane con 6.146 votos, Pedro Calvo Asensio con 4.887 votos y Antonio Santana Santos con 3.302 votos. Pérez Cantalapiedra y Santana Santos fueron diputados provinciales ${ }^{326}$.

\section{Obispado}

En estos dos años de duración del Bienio Juan Antonio Rivadeneira continúa como obispo de la ciudad.

\section{Universidad}

Manuel de la Cuesta y Cossío continúa como rector de la Universidad durante estos años.

\section{Otros personajes}

El 18 de julio de 1854, fecha de inicio del Bienio, se forma la Junta Provisional del Gobierno de la Provincia, compuesta por los siguientes individuos: Presidente, Agustín Nogueras. Vicepresidente, Atanasio Alesón (capitán general).Vocales, José Francés de Alaiza, Vicente Álvarez Cossío y Donato Basanta. El presidente no es conocido. El vicepresidente es el capitán general nombrado en ese mismo día y los tres vocales lo eran del extinto Consejo provincial.

Faustino Ruiz es el delegado de Hacienda. Nacional.

José Pérez Delgado es brigadier de los Ejércitos y subinspector de la Milicia

Esteban Remolar, médico afincado en Medina, es una continua fuente de noticias por sus reclamaciones y sus rarezas: "Nació en el año 1806. Estudió medicina en Madrid. Vecino de Medina donde ejerció la medicina, con gran prestigio como médico y erudito. Compró dos conventos y dos casas en Medina, procedentes de bienes

${ }^{325}$ CARAS A SOTO, Pedro (Dir.). Diccionario biográfico de Alcaldes ... ob. cit. Págs. 13 a 15.

${ }^{326}$ CARASA SOTO, Pedro (Dir.). Diccionario biográfico de parlamentario ... ob. cit. Pág. 3 y sig. 
desamortizados por los que pagó 270.000 reales. También compró 195 hectáreas de terreno en Tierra de Medina y Tierra de Pinares por 122.000 reales. Raro en sus costumbres, dispuso en su testamento que cuando le creyeran muerto le decapitaran, lo que se hizo en 1870 "327. En el año 1845 , se le abre causa por abandono de su profesión de médico. En 1855, reclama para ser repuesto en su trabajo de médico, y en el mi smo año la Diputación y la Junta de Sanidad le agradecen el socorro llevado a cabo en Rodilana, pueblo atacado por la epidemia de cólera (para más información sobre este personaje ver el tema de Sanidad y Beneficencia).

\section{Trabajos más importantes realizados en este período}

La disolución del Consejo provincial vuelve a dar a la Diputación todo el protagonismo en el desarrollo de los trabajos provinciales, aunque los problemas de la carestía de la vida, las malas cosechas y las graves dificultades económicas por las que atraviesan tanto el país como la provincia, harán que los progresos se ralenticen sobremanera.

Los repartimientos tanto de contribuciones como de soldados, además de sus correspondientes sesiones de reclamaciones, cubren más del $50 \%$ de las ocupaciones de la Corporación, y el resto se dedican al tema de los presupuestos y sobre todo a tratar por todos los medios posibles sobre la terminación de las carreteras que desde Valladolid conducen a León y a Salamanca y que todavía se encuentran en construcción, a pesar de que sus trabajos se iniciaron en el año 1841. En lo relativo a obras públicas, en el año 1855 se aprueba el proyecto relativo a la línea del ferrocarril que una las ciudades de Valladolid y Vigo. Con relación al ferrocarril del Norte, ya se trabaja en las obras entre Valladolid y Miranda, a la vez que se estudia la forma de financiarlo, a través de los ingresos por la venta de los Bienes Nacionales, además de convocar a los "Sres. capitalistas y comerciantes de la ciudad" para pedirles su colaboración.

Uno de los acontecimientos más importantes que sucede en estos años es el descontento social. Las malas cosechas y el alto precio de los cereales tienen inquieta a la Diputación que ya en el año 1855 remite una "Exposición a S.M." en la que expone una serie de medidas para "prevenir y remediar la calamidad pública por la subida considerable del precio de los cereales" 328 .

En 1856 se mantiene la preocupación por el deterioro de la situación social, más agravada si cabe, por una desaforada presión contributiva y una inestable situación política, lo que llevará a la población a protagonizar una agitación social sin precedentes que desembocará el 24 de junio con una serie de graves incidentes en Valladolid, Rioseco y Palencia, conocidos como el "Motín del Pan". El desencadenante en Valladolid de este estallido social es debido a la puntual falta de pan en las panaderías de la capital, lo que provoca una protesta multitudinaria y una violenta agresión a las autoridades y a sus bienes.

Para José Daniel Reboredo Olivenza ${ }^{329}$ tres son las causas principales que provocaron este conflicto. En primer lugar, un problema de subsistencias agravado por una escasa capacidad adquisitiva, un acaparamiento y especulación de granos, una carencia de mercados y una falta de fluidez en las comunicaciones. En segundo lugar está la aparición de la "conciencia social" en la clase trabajadora favorecida por la llegada a Castilla de las llamadas "ideas socialistas". En tercer lugar se refiere a cierto tipo de manejos políticos entre los que destaca los provenientes de una creciente ideología republicana que supo infundir "la fobia de los amotinados hacia las fábricas

\footnotetext{
327 RUEDA HERNANZ, Germán. La Desamortización... ob. cit. pág. 306.

328 A.D.P.V. Actas. Libro de actas del 25 de octubre de 1855. Las medidas solicitadas son: Prohibir la exportación de trigo. Permitir el acopio de granos. Obligar a los almacenistas a surtir a la población. Fijar un precio especial a las "clases menesterosas".

${ }^{329}$ REBOREDO OLIVENZA, José Daniel. "El motín del pan en 1856 en Castilla la Vieja”, en Pablo MARTÍNEZ (et al.). Crisis demográfica y tensiones sociales en la Castilla del siglo XIX. Universidad de Valladolid. Valladolid. 1987. Págs. 121 y sig.
} 
de harina" a las que consideraban las culpables de la carestía y fue el blanco preferente de las protestas y actos vandálicos de los descontentos.

\subsection{7.- VUELTA A LA DIPUTACIÓN CONSERVADORA: LAS OCHO} DIPUTACIONES DEL “PERÍODO GRIS” (1856-1868)

El progresismo ha salido del gobierno y de las instituciones, y volvemos a la monotonía conservadora, dominada a nivel nacional por el denominado "Gobierno largo de O'Donell". En lo referente a la Diputación y a la gestión de los temas provinciales, es adecuada la denominación de "Período Gris" y es que, en realidad, es un período anodino y sin alicientes, en el que el protagonismo de la gestión provincial vuelve a recaer en el Consejo Provincial.

Entre los años 1856 y 1868, se suceden ocho Diputaciones que podemos agrupar en tres tipos. Las tres primeras, las Diputaciones duodécima, decimotercera y decimocuarta de la época isabelina, están formadas por los nueve diputados provinciales habituales, que representan a los nueve partidos judiciales en que está dividida la provincia. A destacar los cambios en la ideología de los diputados, consecuencia del cambio político.

Las dos siguientes Diputaciones, las decimoquinta y decimosexta de la citada época isabelina, tienen como particularidad el que están formadas por diez diputados, es decir uno más que las anteriores, como consecuencia de la división de la capital en dos distritos judiciales, debido al crecimiento que experimenta la ciudad. Estos dos distritos son denominados Audiencia y Plaza.

Finalmente en las tres últimas Diputaciones isabelinas, decimoséptima, decimoctava y decimonovena, vuelven a modificarse el número de diputados, al pasar de diez a once representantes provinciales, por formarse el nuevo partido de Tordesillas y mantenerse el de La Mota del Marqués. Al final del período, en junio de 1867, desaparecen los partidos de Valoria y La Mota, aunque se mantienen los diputados.

El cambio lógico y previsto que se produce con la llegada de los conservadores es el de la vuelta a la vigencia de la "Ley de Diputaciones de 8 de enero de 1845 ", lo que conlleva de nuevo dos importantes cambios en la Diputación: El restablecimiento de las actividades del Consejo provincial y la desaparición de la Secretaría y su control por el Gobierno Civil. Con esta situación, a la Diputación sólo la quedan como actividades principales en las que centra sus esfuerzos: La formación de los presupuestos provinciales, endémicamente deficitarios, y el fomento de las vías de comunicación, con especial atención a los proyectos ferroviarios.

\section{Tres primeras Diputaciones conservadoras. Agosto 1856- Marzo 1858}

El fin del progresismo trae como consecuencia la formación de unas Diputaciones de un claro matiz conservador y este es el caso de estas tres primeras, la duodécima, decimotercera y decimocuarta de la época isabelina. La primera de ellas tiene como característica que no procede de ningún tipo de elección, sino que sus miembros son nombrados por el capitán general de Castilla la Vieja, como queda reflejado en el libro de actas ${ }^{330}$. Las dos siguientes Diputaciones se forman con pocos cambios, pero manteniendo el carácter conservador, y también manteniendo el número habitual de nueve diputados en representación de los nueve partidos judiciales.

A continuación están reflejados los cuadros de estas tres Diputaciones con todos sus componentes, el partido al que representan y el número de sesiones a las que asisten, además de los correspondientes gobernadores civiles a los que corresponde la presidencia de la corporación.

330 A.D.P.V. Actas. Libro de actas del 19 de agosto de 1956. "Previa convocatoria hecha por el Sr. D. Antonio Méndez Vigo, gobernador de la provincia a los Sres.... a quienes el Excmo. Sr. capitán general del Distrito ha nombrado en uso de las facultades que le concede la real orden de 26 de julio pasado...". 


\section{$12^{a}$ Diputación isabelina. Agosto- Noviembre 1856}

Inicia sus actividades el 19 de agosto de 1856 hasta el 30 de noviembre del mismo año. En este período celebra un total de cincuenta y tres sesiones.

\section{Nombre}

Antonio Méndez Vigo

Francisco del Busto

Genaro Santander

Vicente Pimentel Bayón

Joaquín López de Tejada y

Navia (M. de Gallegos).

Pedro A. de Tordesillas

y Villagómez (C.de Patilla)

Miguel Herrero López

José Serrano Foronda

Laureano Melero

Cándido Moyano Zamora

Francisco $\mathrm{M}^{\mathrm{a}}$ de Blas Ramírez

\begin{tabular}{|c|c|}
\hline Cargo & $\begin{array}{c}\text { Partido } \\
\text { judicial }\end{array}$ \\
\hline $41^{\circ}$ Presid. & Gobernador \\
\hline $42^{\circ}$ Presid. & Gobernador \\
\hline Diputado & Nava del R \\
\hline Diputado & Medina \\
\hline Diputado & Mota \\
\hline Diputado & Olmedo \\
\hline Diputado & Valladolid \\
\hline Diputado & Rioseco \\
\hline Diputado & Villalón \\
\hline Diputado & Peñafiel \\
\hline Diputado & Valoria \\
\hline
\end{tabular}

$\begin{array}{lr}\quad \begin{array}{c}\text { Permanencia } \\ \text { en el cargo }\end{array} & \text { Sesiones } \\ \text { Ago. 1856-Nov.1856 } & 5 \\ \text { Noviembre 1856 } & 0 \\ \text { Ago. 1856-Nov.1856 } & 48 \\ \text { Ago.1856-Nov.1856 } & 40 \\ & \\ \text { Ago. 1856-Nov.1856 } & 31 \\ & \\ \text { Ago. 1856-Nov.1856 } & 31 \\ \text { Ago. 1856-Nov.1856 } & 51 \\ \text { Ago.1856-Nov.1856 } & 35 \\ \text { Ago.1856-Nov.1856 } & 31 \\ \text { Ago. 1856-Nov.1856 } & 31 \\ \text { Ago. 1856-Nov.1856 } & 26\end{array}$

\section{$13^{\text {a }}$ Diputación isabelina. Diciembre 1856 - Junio 1858}

Se instala el día 2 de diciembre de 1856, terminando sus actividades el 17 de julio de 1858 , con veintisiete sesiones.

\begin{tabular}{|c|c|c|}
\hline Nombre & Cargo & $\begin{array}{l}\text { Partido } \\
\text { judicial }\end{array}$ \\
\hline Francisco del Busto & $42^{\circ}$ Presid. & Gobernador \\
\hline Clemente Linares & $43^{\circ}$ Presid. & Gobernador \\
\hline Vicente Pimentel Bayón & Diputado & Medina \\
\hline Miguel de las Moras Ortega & Diputado & Valoria \\
\hline José Moyano Sánchez & Diputado & Nava \\
\hline Ángel Pastor & Diputado & Villalón \\
\hline José Pizarro Diez & Diputado & Rioseco \\
\hline Calixto Fernández Torre & Diputado & Valladolid \\
\hline Isidro Álvarez de Casas & Diputado & Peñafiel \\
\hline \multicolumn{3}{|l|}{ Pedro A. de Tordesillas y } \\
\hline Villagómez (C. de Patilla) & Diputado & Olmedo \\
\hline Diez & Diputado & La Mota \\
\hline
\end{tabular}

$\begin{array}{lr}\begin{array}{l}\text { Permanencia } \\ \text { en el cargo }\end{array} & \text { Sesiones } \\ \text { Dic.1856-Nov.1857 } & 16 \\ \text { Dic.1857-Jun.1858 } & 11 \\ \text { Dic.1856-Jun.1858 } & 5 \\ \text { Dic.1856-Jun. 1858 } & 26 \\ \text { Dic.1856-Jun. 1858 } & 26 \\ \text { Dic.1856-Jun. 1858 } & 19 \\ \text { Dic.1856-Jun. 1858 } & 15 \\ \text { Dic. 1856-Jun. 1858 } & 24 \\ \text { Dic. 1856-Jun. 1858 } & 19 \\ & \\ \text { Dic. 1856-Jun. 1858 } & 6 \\ \text { May.1858Jun. 1858 } & 3\end{array}$

\section{$14^{\text {a }}$ Diputación isabelina. Julio 1858 - Marzo 1860}

Se pone en marcha el 18 de julio de 1858 y da por finalizada la legislatura el 30 de marzo de 1860 , siendo de cuarenta el número de sesiones que se celebran.

Nombre
Clemente Linares
Castor Ibáñez de Aldecoa
Cayetano Bonafós
Miguel de las Moras Ortega
José Moyano Sánchez
Calixto Fernández de la Torre
Isidro Álvarez de Casas
Felipe Cabrejas de la Plaza
Toribio Valbuena
Sebastián Diez Salcedo
Isidoro Ternero Garrido
Francisco López Flores

\begin{tabular}{|c|c|}
\hline Cargo & $\begin{array}{l}\text { Partido } \\
\text { judicial }\end{array}$ \\
\hline $43^{\circ}$ Presid. & Gobernador \\
\hline $44^{\circ}$ Presid. & $\begin{array}{l}\text { Gobernador } \\
\text { Gobernador }\end{array}$ \\
\hline Diputado & Valoria \\
\hline Diputado & Nava \\
\hline Diputado & Valladolid \\
\hline Diputado & Peñafiel \\
\hline Diputado & Olmedo \\
\hline Diputado & Villalón \\
\hline Diputado & Rioseco \\
\hline Diputado & Tordesillas \\
\hline Diputado & Medina \\
\hline
\end{tabular}

Permanencia
en el cargo
Jul. 1858-Nov.1858
Mar. 1859-Mar. 1860
Ene.1859-Febr. 1859
Jul.1858-Mar. 1860
Jul. 1858-Mar. 1860
Jul.1858-Mar. 1860
Jul. 1858-Mar. 1860
Jul.1858-Mar. 1860
Jul.1858-Mar. 1860
Jul.1858-Mar. 1860
Jul.1858-Mar. 1860
Jul.1858-Mar. 1860

Sesiones

\section{Dos Diputaciones con pocas sesiones. Abril 1860- Diciembre 1863}

Estas dos Diputaciones tienen pocas características que resaltar y entre ellas la más importante es la de la ampliación del número de diputados que pasa de nueve a 
diez, con ocasión de la división de la capital en dos partidos judiciales, que toman la denominación de Valladolid-Plaza y Valladolid-Audiencia ${ }^{331}$. Otra característica es la del escaso número de sesiones que se celebran en este período, dedicadas principalmente al estudio y aprobación de los presupuestos provinciales y al fomento de las comunicaciones, basadas principalmente en la construcción de líneas ferroviarias.

Son sesiones largas y dedicadas en especial a la discusión para conseguir cuadrar a través de arbitrios los déficits presupuestarios y a buscar la forma de financiar la construcción de las nuevas líneas ferroviarias. A continuación quedan reseñados los cuadros de las dos Diputaciones con todos los componentes de las mismas, así como su presencia en las actividades de la institución.

\section{$15^{\text {a }}$ Diputación isabelina. Abril 1860 - Marzo 1862}

Comienza sus actividades el 1 de abril de 1860 y se dan por finalizadas el 30 de marzo de 1862 y celebran un total de treinta y una sesiones.

\begin{tabular}{lllll}
\multicolumn{1}{c}{ Nombre } & Cargo & $\begin{array}{l}\text { Partido } \\
\text { judicial }\end{array}$ & $\begin{array}{c}\text { Permanencia } \\
\text { en el cargo }\end{array}$ & Sesiones \\
Castor Ibáñez de Aldecoa & $44^{\circ}$ Presid. & $\begin{array}{l}\text { Gobernador } \\
\text { Abr. 1860-Mar. 1862 }\end{array}$ & 30 \\
Calixto Fernández Torre & Diputado & Valladolid Aud. & Abr. 1860-Mar. 1862 & 26 \\
Francisco López Flores & Diputado & Medina & Abr. 1860-Mar. 1862 & 26 \\
Isidro Álvarez de Casas & Diputado & Peñafiel & Abr. 1860-Mar. 1862 & 16 \\
Sebastián Diez Salcedo & Diputado & Rioseco & Abr. 1860-Mar. 1862 & 16 \\
Felipe Cabrejas de la Plaza & Diputado & Olmedo & Abr. 1860-Mar. 1862 & 15 \\
Eduardo Ruiz Merino & Diputado & Valladolid Plaza & Abr. 1860-Mar. 1862 & 28 \\
Vicente Delgado Rico & Diputado & Nava & Abr. 1860-Mar. 1862 & 22 \\
Ramón María Nava & Diputado & Tordesillas & Abr. 1860-Mar. 1862 & 30 \\
Agustín Bendito Carrillo & Diputado & Valoria & Abr. 1860-Mar. 1862 & 31 \\
Manuel Daniel & Diputado & Villalón & Nov. 1860-Mar.1862 & 22
\end{tabular}

$16^{a}$ Diputación isabelina. Abril 1862- Diciembre 1863

Está vigente entre el 1 de abril de 1862 y el 31 de diciembre de 1863, con veintidós sesiones a lo largo de la legislatura.

$\quad$ Nombre
Castor Ibáñez de Aldecoa
Rufo de Negro
Toribio Rubio Campos
Antonio Hurtado
Francisco López Flores
Sebastián Diez Salcedo
Eduardo Ruiz Merino
Ramón María Nava
Agustín Bendito Carrillo
Manuel Daniel
Vicente Delgado Rico
Fernando Cabeza de Vaca
Pedro A. Pimentel Arévalo
Eusebio Alonso Pesquera

Partido
judicial
Gobernador
Gobernador
Gobernador
Gobernador
Medina
Rioseco
Valladolid Plaza
Tordesillas
Valoria
Villalón
Nava
Valladolid Aud.
Olmedo
Peñafiel

$\begin{array}{lc}\begin{array}{c}\text { Permanencia } \\ \text { en el cargo }\end{array} & \text { Sesiones } \\ \text { Abr. 1862-Ene. 1863 } & 10 \\ \text { Feb. 1863-Mar. 1863 } & --- \\ \text { Abr. 1863-Ago. 1863 } & 3 \\ \text { Sep. 1863-Dic. 1863 } & --- \\ \text { Abr.1862-Dic. 1863 } & 16 \\ \text { Abr.1862-Dic. 1863 } & 16 \\ \text { Abr.1862-Dic. 1863 } & 20 \\ \text { Abr.1862-Dic. } 1863 & 22 \\ \text { Abr.1862-Dic. } 1863 & 17 \\ \text { Abr.1862-Dic. } 1863 & 14 \\ \text { Abr.1862-Dic. } 1863 & 9 \\ \text { Abr.1862-Dic. } 1863 & 20 \\ \text { Abr.1862-Dic. } 1863 & 22 \\ \text { Abr.1862-Dic. } 1863 & 19\end{array}$

\section{Las últimas Diputaciones isabelinas. Enero 1864- Septiembre 1868}

La creación de un nuevo partido judicial, el de La Mota del Marqués, manteniendo el de Tordesillas, provoca el aumento de un diputado, pasando el Pleno de la Diputación de tener diez a once diputados. Por otro lado, con esta decisión finalizan las "luchas" que Tordesillas y Mota han mantenido a lo largo de la historia provincial por ser cabezas de partido judicial. Bien es verdad que este aumento dura poco tiempo, pues al final del periodo isabelino, en junio de 1867, desaparecen los 
partidos de La Mota y el de Valoria, aunque se mantienen en el cargo los diputados elegidos.

En este tiempo también se produce un importante cambio legislativo, con la "puesta en marcha" de la ley de 25 de septiembre de 1863 sobre "El Gobierno y Administración de las Provincias". Uno de los cambios más significativos es el referido a que la Diputación nombra al presidente de la institución en sus períodos de sesiones, aunque si está presente el gobernador, éste preside las sesiones.

Finalmente un hecho llamativo se produce durante la decimoséptima Diputación, ya que en sus dos años de vigencia, pasan por el gobierno civil de la provincia seis gobernadores-presidentes de la Diputación, más un gobernador que no llega a estar presente en las sesiones de la corporación provincial, y también dos secretarios del gobierno, que actúan como gobernadores interinos y que como tal asisten a varias sesiones de la Diputación.

A continuación están reflejados los cuadros de estas tres últimas Diputaciones, que se suceden entre enero de 1864 y septiembre de 1868.

\section{$17^{\text {a }}$ Diputación isabelina. Enero 1864 - Diciembre 1865}

Transcurre a partir del 1 de enero de 1864 y finaliza el 31 de diciembre de 1865 , celebrando un total de cuarenta y nueve sesiones en los dos años de vigencia.

Nombre

Antonio Hurtado

Bartolomé Hermida

Vicente Lozana

Ángel María Dacarrete

José de la Fuente Alcántara

José Gallostra y Frau

Manuel Ureña

Ramón de Mazón y Valcárcel

Eugenio Rubi

Francisco López Flores

Eduardo Ruiz Merino

Pedro A. Pimentel Arévalo

Eusebio Alonso Pesquera

Isidro Álvarez Casas

Agustín Álvarez Vicente

Bernardo Real Alonso

Pedro Regalado de las Moras

Luis Alonso Martín

Carlos Palmero Olea

Tomás Villanueva

Vicente Delgado Rico Id.

Juan de Mata Zorita Alonso

$\begin{array}{cl}\text { Cargo } & \begin{array}{c}\text { Partido } \\ \text { judicial }\end{array} \\ \text { Gobernador } \\ 46^{\circ} \text { Presid. } & \begin{array}{l}\text { Gobernador } \\ \text { Gobernador }\end{array} \\ \text {--- } & \text { Gobernador } \\ 48^{\circ} \text { Presid. } & \text { Gobernador } \\ 49^{\circ} \text { Presid. } & \text { Gobernador } \\ 50^{\circ} \text { Presid. } & \text { Gobernador } \\ \text {--- } & \text { Interino } \\ \text { Secr. Gobierno } & \text { Interino } \\ \text { Secr. Gobierno } & \text { Medina } \\ \text { Diputado } & \text { Valladolid Plaza } \\ \text { Diputado } & \text { Olmedo } \\ \text { Diputado } & \text { Peñafiel } \\ \text { Diputado } & \text { Peñafiel } \\ \text { Diputado } & \text { Rioseco } \\ \text { Diputado } & \text { Mota } \\ \text { Diputado } & \text { Valoria } \\ \text { Diputado } & \text { Tordesillas } \\ \text { Diputado } & \text { Villalón } \\ \text { Diputado } & \text { Valladolid Aud. } \\ \text { Diputado } & \text { Nava } \\ \text { Diputado } & \text { Id. } \\ \text { Id. } & \text { Nava } \\ \text { Diputado } & \end{array}$

\begin{tabular}{lr}
\multicolumn{1}{l}{$\begin{array}{c}\text { Permanencia } \\
\text { en el cargo }\end{array}$} & Sesiones \\
Ene. 1864-Abr. 1864 & 7 \\
May. 1864-Jun. 1864 & 1 \\
Ago.1864-Sept. 1864 & 0 \\
Oct. 1864-Ene. 1865 & 7 \\
Mar. 1865Jun. 1865 & 3 \\
Jul. 1865-Dic. 1865 & 9 \\
Junio 1865 & 0 \\
Julio1864 & 1 \\
Febrero 1865 & 0 \\
Ene. 1864-Dic.1865 & 42 \\
Ene.1864-Dic. 1865 & 38 \\
Ene. 1864-Dic.1865 & 46 \\
Ene. 1864-Abr.1865 & 31 \\
May.1865-Dic.1865 & 4 \\
Ene. 1864-Dic.1865 & 45 \\
Ene. 1864-Dic.1865 & 46 \\
Ene.1864-Dic.1865 & 44 \\
Ene.1864-Dic. 1865 & 43 \\
Ene.1864-Dic. 1865 & 31 \\
Ene.1864-Dic. 1865 & 48 \\
Ene-Abr 1864 & 20 \\
Ene-Dic 1865 & 0 \\
May.1864-Dic.1864 & 3
\end{tabular}

$18^{a}$ Diputación isabelina. Enero- Diciembre 1866

Esta Diputación está vigente entre el 1 de enero y el 31 de diciembre del año 1866. Un año en el que se producen diez y ocho sesiones.

\author{
Nombre \\ José Gallostra y Frau \\ Manuel Somoza y Cambero \\ Mariano Herrero Prieto \\ Eduardo Ruiz Merino \\ Francisco López Flores \\ Pedro A. Pimentel Arévalo \\ Tomás Villanueva \\ Bernardo Real Alonso \\ Pedro Regalado de las Moras \\ Luis Alonso Martín
}

\begin{tabular}{|c|c|}
\hline Cargo & $\begin{array}{l}\text { Partido } \\
\text { judicial }\end{array}$ \\
\hline $50^{\circ}$ Presid. & Gobernador \\
\hline & Gobernador \\
\hline $51^{\circ}$ Presid. & Gobernador \\
\hline Diputado & Vallad. Plaza \\
\hline Diputado & Medina \\
\hline Diputado & Olmedo \\
\hline Diputado & Vall. Audiencia. \\
\hline Diputado & Mota \\
\hline Diputado & Valoria \\
\hline Diputado & Tordesillas \\
\hline
\end{tabular}

Permanencia en el cargo

Ene. 1866-Abr. $1866 \quad 9$

Abr.1866-Jul. $1866 \quad 0$

Ago. 1866-Dic. 1866

Ene.1866-Dic. $1866 \quad 18$

Ene. 1866-Dic. $1866 \quad 13$

Ene.1866-Dic. $1866 \quad 15$

Ene. 1866-Dic. $1866 \quad 16$

Ene. 1866-Dic.1866 14

Ene.1866-Dic. $1866 \quad 16$

Ene. 1866-Dic. $1866 \quad 18$ 
Agustín Álvarez Vicente

Isidro Álvarez Casas

Juan Francos

Hermenegildo Burgos Pérez

$\begin{array}{ll}\text { Diputado } & \text { Rioseco } \\ \text { Diputado } & \text { Peñafiel } \\ \text { Diputado } & \text { Villalón } \\ \text { Diputado } & \text { Nava }\end{array}$

Ene.1866-Dic. 1866

Ene. 1866-Dic. 1866

Ene.1866-Dic. 1866

Ene. 1866-Dic. 1866
17

9

18

14

\section{$19^{a}$ Diputación isabelina. Enero 1867 - Septiembre 1868}

Última Diputación del período isabelino que inicia sus actividades el 1 de enero de 1867 finalizando las mismas el 20 de septiembre de 1868, después de celebrar cincuenta y dos sesiones.

\begin{tabular}{|c|c|c|}
\hline Nombre & Cargo & $\begin{array}{c}\text { Partido } \\
\text { judicial }\end{array}$ \\
\hline Mariano Herrero Prieto & $51^{\circ}$ Presid. & Gobernador \\
\hline Manuel Ureña & $52^{\circ}$ Presid. & Gobernador \\
\hline Vicente Álvarez Cossío & --- & Gob. Interino \\
\hline Donato Basanta & Diputado & Olmedo \\
\hline Eduardo Ruiz Merino & Diputado & Valladolid Plaza \\
\hline Tomás Villanueva & Diputado & Valladolid Aud. \\
\hline Vicente Pizarro Cuadrillero & Diputado & Rioseco \\
\hline Luis Alonso Martín & Diputado & Tordesillas \\
\hline Justo de Prado Martínez & Diputado & Villalón \\
\hline Pascasio García Galán & Diputado & Nava \\
\hline Francisco Jofre de Villegas & Diputado & Mota \\
\hline Celestino Dueñas Rodríguez & Diputado & Medina \\
\hline Agustín Bendito Carrillo & Diputado & Valoria \\
\hline Rafael Espinosa Rico & Diputado & Peñafiel \\
\hline
\end{tabular}

$\begin{array}{lr}\begin{array}{l}\text { Permanencia } \\ \text { en el cargo }\end{array} & \text { Sesiones } \\ \text { Ene.1867-May. } 1867 & 4 \\ \text { Jun.1867-Ago. } 1868 & 34 \\ \text { Septiembre } 1868 & 2 \\ \text { Ene.1867-Sept. 1868 } & 42 \\ \text { Ene.1867-Sept. } 1868 & 49 \\ \text { Ene.1867-Sept.1868 } & 47 \\ \text { Ene.1867-Sept. 1868 } & 45 \\ \text { Ene.1867-Sept. } 1868 & 51 \\ \text { Ene.1867-Sept. } 1868 & 48 \\ \text { Ene. 1867-Sept.1868 } & 44 \\ \text { Ene.1867-Sept.1868 } & 13 \\ \text { Ene.1867-Sept. } 1868 & 43 \\ \text { Ene. 1867-Sept.1868 } & 32 \\ \text { May.1868-Sept.1868 } & 12\end{array}$

\section{Los gobernadores - presidentes}

A lo largo de estos años que cubren las últimas Diputaciones de la época isabelina, en relación con los gobernadores y su presencia al frente de la provincia, se producen dos periodos bien diferenciados entre sí. El primero transcurre entre los años 1856 y 1863, en coincidencia con la estabilidad del gobierno central y con la vigencia de cinco Diputaciones diferentes. Destaca por la "extraordinaria permanencia" de los gobernadores en su puesto, en contraposición con la rapidez con que aparecían y desparecían del cargo en épocas anteriores. Entre agosto de 1856 y diciembre de 1863 , son sólo seis los gobernadores que se suceden en el cargo, destacando a Francisco del Busto y Clemente Linares, con un año de permanencia cada uno de ellos. Pero sobre todo es Castor Ibáñez de Aldecoa el gobernador que se mantiene en el cargo durante tres años y nueve meses.

Un segundo período comprendido entre febrero de 1863 y septiembre de 1868 se caracteriza por la provisionalidad de los gobernadores, la proliferación de gobernadores interinos, puesto en el que actúan tanto los secretarios del Gobierno Civil, como los vicepresidentes del Consejo provincial. El ejemplo más claro lo tenemos durante la vigencia de la decimoséptima Diputación entre enero de 1864 y diciembre de 1865. Es decir, en dos años se produce un auténtico aluvión de cambios, nombramientos, ceses, interinidades con un total de nueve individuos que se suceden a lo largo de este tiempo, y que de alguna forma intentaban representar a la provincia. Destaca entre todos ellos Manuel Ureña, que toma posesión el 25 de junio de 1865 y es cesado el 28 del mismo mes y año, es decir, tres días de permanencia en el cargo.

La gestión de los gobernadores, como presidentes de la Diputación, también sufrirá modificaciones en estos años, con ocasión de los cambios legislativos que se producen. Éstos se inician con la finalización del Bienio Progresista y la puesta en vigor nuevamente de la "Ley del 8 de enero de 1845", con la que se vuelve al sistema en el que, en ausencia del gobernador, es gobernador interino el secretario del Gobierno Civil, pero como presidente de la Diputación lo es el vicepresidente del Consejo Provincial. Así lo recordaba una circular del gobierno publicada en el Boletín Oficial de la provincia el 21 de octubre de 1856 al anunciar "que con el restablecimiento de la ley de 8 de enero de 1845, los gobernadores deben de tener presente el aumento de sus atribuciones". 
Esta situación se modifica a partir del 1 de enero de 1864, fecha con la que se inicia la aplicación de la ley de 25 de septiembre de 1863 sobre "El gobierno y administración de la provincia", en la que, "de acuerdo con los artículos treinta y siete, cuarenta y siete y cincuenta y cuatro de la citada ley se nombra presidente durante esta reunión al Sr. diputado Francisco López Flores...”. A partir de esta fecha, el presidente de la Diputación es nombrado de entre los miembros de la misma, y por un período determinado, aunque al poco tiempo el gobierno recuerda con la real orden de 13 de febrero de 1864 que "el gobernador, cuando asista a las sesiones de la Diputación, ejercerá la presidencia y tendrá voz y voto".

En definitiva, la Diputación nombra al presidente de la reunión, pero el que sigue ejerciendo la autoridad es el gobernador. Lo que sí ocurre es que el citado gobernador deja de asistir a la mayoría de las sesiones, aunque en casos de controversia o de enfrentamientos, es el que hace prevalecer su autoridad.

En realidad, una vez finalizado el Bienio con su legislación más progresista y con mayor autonomía, se vuelve a la vigencia de la ley de 8 de enero de 1845 y en consecuencia se vuelve a un mayor control y centralización de las actividades de la institución y al mismo tiempo a una mayor dependencia del gobierno central, y aunque en 1863 se produce un nuevo cambio legislativo al aprobarse la nueva ley "para el Gobierno y Administración de las Provincias de 25 de septiembre", resulta una ley tan conservadora y centralista como la anterior y en la que el gobernador sigue manteniendo su control y autoridad sobre la provincia por delegación del poder central, aunque se quiera "disimular" con el nombramiento del presidente en cada reunión. El gobernador siempre tiene la capacidad y el poder de decisión con independencia de lo que la Diputación haya acordado.

\section{Los diputados provinciales}

En este "período gris" con el que se cierra la época isabelina, un total de cuarenta y cinco diputados se suceden en la gestión de las ocho diferentes Diputaciones que trascurren entre 1856 y 1868.

Como datos estadísticos se destaca que seis diputados ejercieron en Diputaciones anteriores, cinco repetirán en las Diputaciones del Sexenio, diecinueve ejercerán en una sola legislatura y veintiséis diputados repetirán escaño en varias legislaturas.

\section{La Secretaría de la Diputación}

El inicio del nuevo período conservador isabelino, en lo que respecta a la Diputación se producen los dos cambios característicos que vienen marcados por la nueva puesta en marcha de la ley de 8 de enero de 1845 . Por una parte, la disolución de la Secretaría de la Diputación, y por otra la nueva puesta en marcha del Consejo provincial.

Una vez finalizado el período progresista, la nueva Diputación que se forma el día 19 de agosto de 1856, en su sesión de instalación, toma el acuerdo de "destituir al anterior secretario Juan Callejo y Madrigal y nombrar nuevo secretario de la Diputación, aprobando el nombramiento de Francisco Martínez Mondelo"332. Acuerdo que se completa a los dos días de este nombramiento, con la reorganización de la Secretaría y la aprobación de los nuevos salarios, para el año en curso de 1856. Así queda reflejado en las actas ${ }^{333}$.

\footnotetext{
332 A.D.P.V. Actas. Libro de actas del día 19 de agosto de 1856.

333 “Acuerdo de la supresión de la plaza de oficial $3^{\circ}$, cuyo propietario es Valentín Alderete. También se acuerda el cese de los empleados Simón Sáez y Tomás Dávila. La Secretaría, con los correspondientes salarios anuales queda compuesta de la siguiente forma: Secretario: Francisco Martínez Mondelo. Salario 12.000 reales. Oficial $1^{\circ}$ : Bernabé Merino, salario 7.000 reales. Oficial $2^{\circ}$ : Sixto Maroto, salario 6.000 reales. Oficial $3^{\circ}$ : Eugenio Valentín, salario 4.000 reales. Oficial $4^{\circ}$ : Dionisio Mota, salario 4.000 reales. Depositario: José Ferrer, salario 9.000 reales. Auxiliar: Santiago Inés, salario 3.000 reales. Escribiente $1^{\circ}$ : Félix Moras, salario 2.500 reales. Escribiente $2^{\circ}$ : Simón Sáez, salario 2.500 reales.
} 
En esta relación se refleja el contrasentido de que después de anunciar el cese de los oficiales Sáez y Dávila, aparecen en el cuadro de componentes como escribientes aunque en el cuadro de distribución de tareas que se publica a fin de mes estos dos individuos no aparecen en el organigrama de la Secretaría.

En la sesión que se celebra el 30 de agosto, la Diputación aprueba el reparto de actividades de los componentes de la Secretaría, quedando de la siguiente forma:

Francisco Martínez Mondelo, al frente de la Secretaría es el responsable de los Negociados de Régimen Interior, Personal, Material, Actas, Contencioso administrativo, Autorización para procesar, Competencias y Elecciones.

Bernabé Merino, oficial $1^{\circ}$, lleva los departamentos de Presupuestos provinciales Policía Urbana y Rural, Reemplazos del Ejército y la Reserva, Caminos vecinales y carreteras, Obras públicas y Agricultura.

Sixto Maroto, oficial $2^{\circ}$, se encarga de los temas de Ayuntamientos, Incidencias, Milicia Nacional, Propios, Comunes, Subsistencias, Montes, Pósitos y Archivo.

Eugenio Valentín, oficial $3^{\circ}$, es el responsable de los negociados de Suministros, Presos pobres, Presupuestos y cuentas municipales, Contribuciones y Arbitrios.

Dionisio Mota, oficial 4º lleva los asuntos de Beneficencia, Estadística, Bagajes y alojamientos, Instrucción primaria y División territorial.

Santiago Inés, auxiliar administrativo, es el responsable de mantener la colección de Gacetas y el Boletín Oficial.

Félix Moras, escribiente $1^{\circ}$, es el auxiliar del secretario.

Alejandro Nion, escribiente $2^{\circ}$, es el encargado del Índice general

Bibiano Jiménez, escribiente $3^{\circ}$, lleva la correspondencia y su distribución. franqueo.

Anacleto Valverde, escribiente $4^{\circ}$, lleva la correspondencia, su cierre y

Estos tres últimos escribientes son de nuevo nombramiento, a los que se les señala un salario anual de $2.000,1.800$ y 1.200 reales respectivamente.

$\mathrm{Si}$ a finales del mes de agosto se da por finalizada la reorganización de la Secretaría, a principios de septiembre del mismo año 1856 , se inician una serie de cambios que afectan en especial al secretario. El día 7 del citado mes, deja de firmar las actas y a partir del día 12 es el oficial $1^{\circ}$ Bernabé Merino, el que firma como secretario interino. Se aclara la situación a los dos días siguientes, cuando en la sesión de la Diputación se da a conocer el "Manifiesto del secretario Sr. Martínez Mondelo, en el que anuncia que habiendo sido agraciado por S.M. con la Secretaría del Gobierno de la provincia de Burgos, e instado por su jefe para que se presente inmediatamente a posesionarse de dicho destino, le es tan indispensable como sensible el separarse de la Diputación" ${ }^{334}$. En el mismo mes de septiembre se nombra nuevo escribiente en la persona de Norberto Rodríguez, en reemplazo de Alejandro Nion, que anteriormente había renunciado a la plaza.

En el mes de octubre, la Diputación no había iniciado las gestiones para cubrir la plaza vacante de Secretaría, cuando por real decreto se restablece la ley de 8 de enero de 1845, lo que lleva consigo la supresión de las actividades de la Secretaría de la Diputación. Ésta, en la sesión del día 21, "acuerda, según lo resuelto en la real orden de 18 del actual, la supresión de la Secretaría de esta corporación y el nombramiento del oficial Bernabé Fernández Villegas para encargarse del archivo y papeles de la misma, poniéndose de acuerdo con el oficial designado al efecto Eugenio Valentín" ${ }^{335}$.

Escribiente $3^{\circ}$ : Tomás Dávila, salario 2.500 reales. Portero mayor: Roque Soriano, salario 3.000 reales.Portero $2^{\circ}$ : Manuel Domínguez, salario 2.800 reales". A.D.P.V. Actas. Libro de actas del 21 de agosto de 1856 .

334 A.D.P.V. Actas. Libro de actas del 14 de septiembre de 1856. El secretario Francisco Martínez Mondelo en 1862 será nombrado secretario del Gobierno de Valencia y en 1863, se le nombra gobernador civil de Pontevedra.

335 A.D.P.V. Actas. Libro de actas del 21 de octubre de 1856. 
A partir de este momento, y de acuerdo con lo establecido en la repetida ley de 8 de enero, se inician los nombramientos de secretario y vicesecretario de la Diputación, de entre los diputados de la corporación. Así tenemos que en la sesión de instalación de la nueva Diputación que tiene lugar el 2 de diciembre de 1856 se nombran secretario a José Moyano Sánchez y vice-secretario a Calixto Fernández de la Torre. El 26 de junio de 1857 se ratifica como secretario a José Moyano Sánchez y se nombra vicesecretario a Miguel de las Moras.

El 18 de julio de 1858 , se celebra la sesión de instalación de la nueva Diputación, y se procede a los correspondientes nombramientos que recaen en los siguientes diputados: Secretario José Moyano Sánchez y vicesecretario Sebastián Diez Salcedo. En este mismo año, Julián Diez, que fue oficial $4^{\circ}$ de la Secretaría de la Diputación y que pasó posteriormente a trabajar en el Consejo provincial, "solicita una pensión por su incapacidad para trabajar, con treinta y cuatro años de servicio al Estado, dieciseis de ellos en la Secretaría de la Diputación y con sesenta y cuatro años de edad. Se acuerda ayudarle con una pensión de 6 reales diarios" ${ }^{336}$.

En mayo de 1859, con ocasión del inicio de la "Primera Reunión del año", se ratifica el nombramiento de José Moyano Sánchez como secretario y se nombra vicesecretario al diputado Isidoro Ternero Garrido. En el año 1860, en la sesión de instalación de la decimoquinta Diputación isabelina celebrada el día 1 de abril se nombran secretario a Eduardo Ruiz Merino y vicesecretario a Ramón María de Nava, nombramientos que se mantienen durante toda la legislatura. El 1 de abril de 1862 se celebra la sesión de instalación de la decimosexta Diputación nombrando en el transcurso de la misma al secretario Eusebio Alonso Pesquera y al vicesecretario Fernando Cabeza de Vaca.

A partir de 1864 se vuelve a modificar el funcionamiento de la Diputación y de acuerdo con la ley recientemente aprobada de 25 de septiembre de 1863 "Sobre el Gobierno y Administración de las Provincias", en la sesión de instalación de la decimoséptima Diputación isabelina que se celebra el 1 de enero de 1864: "De acuerdo con los artículos treinta y siete, cuarenta y siete y cincuenta y cuatro de la citada ley, se nombra presidente de la Corporación a D. Francisco López Flores y representante de la provincia a D. Eusebio Alonso Pesquera. Se nombra secretario interino a D. Manuel Nieto" ${ }^{337}$.

Con la nueva ley se restablece la Secretaría de la Diputación, y con el fin de dotar a la Corporación de un secretario titular, en la sesión del 3 de enero del repetido año 1864, se acuerda presentar al gobierno una terna para que se efectúe el correspondiente nombramiento, terna que está formada por los siguientes candidatos: Joaquín Martínez Chantrero, licenciado en Jurisprudencia y oficial del Cuerpo de Administración Civil desde 1857, secretario del Consejo provincial. José Ferreras, licenciado en Derecho Civil y Canónico y en Derecho Administrativo, oficial $3^{\circ}$ del Consejo de la Provincia. César Alba García, doctor en Derecho Civil y Canónico, abogado del Colegio de esta Audiencia. Promotor fiscal sustituto del Juzgado de esta capital.

El 20 de enero se confirma el nombramiento de secretario en la persona de Joaquín Martínez Chantrero, que al mismo tiempo mantiene el puesto de secretario del Consejo provincial. La Diputación una vez que toma posesión el secretario, no publica como era habitual con anterioridad, la composición, categoría y salario de los funcionarios de la Secretaría. Únicamente se reflejan en las actas los cambios que se producen. Así tenemos que el 20 de enero de 1864 se nombra auxiliar de Secretaría a Manuel Nieto, además de archivero, y José Ferrer es el nuevo depositario de la Diputación. El 23 de enero de 1864 se nombra portero a Eleuterio Morales en sustitución del fallecido Roque Soriano. El 8 de abril de 1864 se cesa a José Ferreras como oficial $3^{\circ}$ por enfermedad y se nombra a Natalio Real Bazaco en su puesto con el

336 A.D.P.V. Actas. Libro de actas del 15 de octubre de 1858.

337 A.D.P.V. Actas. Libro de actas del 1 de enero de 1864. 
sueldo de 6.000 reales al año. El 10 de mayo de 1864 se nombra oficial $1^{\circ}$ a Severino Rojas y oficial $2^{\circ}$ a Norberto Rodríguez. El 12 de abril de 1866 José Ferrer renuncia a su cargo de depositario por tener 76 años de edad y se le señala una pensión de 400 escudos al año. El 30 de mayo de 1866 se nombra depositario a D. Fidel Serrano.

Esta configuración de la Secretaría vuelve a ser modificada por real orden de 21 de octubre de 1866, por la que "se modifica la ley de 25 de septiembre de 1863 , y se vuelve parcialmente a lo dispuesto en la ley de 8 de enero de 1845 , en lo que respecta al funcionamiento de la Secretaría de la Diputación". En definitiva, vuelve a desaparecer la Secretaría de la Diputación y reaparece la figura del diputado-secretario. En la sesión de instalación de la decimonovena y última Diputación isabelina celebrada el 1 de enero de 1867 se procede al nombramiento de secretario a Francisco María Jofre de Villegas y Villar. El 6 de julio de 1867 se nombra secretario al diputado Luis Alonso Martín, y el 20 de septiembre de 1868, en la última sesión de la Diputación se nombra secretario a Eduardo Ruiz Merino.

\section{El Consejo provincial}

El Consejo provincial, que estuvo suprimido en el período del Bienio Progresista, vuelve nuevamente a la actividad, como nos demuestra el acta de instalación ${ }^{338}$ :

El 4 de noviembre de 1856, se constituye el Consejo titular, iniciando las actividades en el mismo día con los siguientes consejeros: Vicepresidente Vicente Pimentel Bayón y consejeros Cándido Moyano Zamora, Francisco María de Blas y Pedro Galván. Secretario Matías Nieto.

El anterior vicepresidente, Anselmo Merino, no asistió a pesar de haber sido convocado, porque presentó previamente la dimisión. Y el recién nombrado vicepresidente Vicente Pimentel cesa en el cargo a los pocos días de su nombramiento, ya que el 18 de noviembre del mismo año 1856 se presenta y toma posesión del cargo el nuevo vicepresidente D. José Francés de Alaiza.

En el año 1857, por real orden de 21 de abril, son nombrados consejeros supernumerarios Francisco Caracciolo Bayón y Vicente Diez, presentándose en el Consejo en la sesión del día 5 de mayo. A lo largo de este año, en la Secretaría se suceden dos nuevos secretarios; en enero firma Félix de Figueroa y Betón y en junio es titular Fabián Gil. Finalmente en el mes de diciembre se nombra nuevo consejero a Vicente Álvarez Cossío en sustitución de Pedro Galván.

En el año 1858 se producen nuevos cambios en la Vicepresidencia, ya que el vicepresidente Francés de Alaiza es nombrado secretario del Gobierno Civil de Toledo, quedando el Consejo formado de la siguiente manera: vicepresidente Cándido Moyano Zamora y consejeros Francisco María de Blas, Vicente Álvarez Cossío y Ángel de la Riva Espiga. Secretario Antonio Carrión.

\footnotetext{
338 "En Valladolid a 24 de octubre de 1856, reunidos en el despacho del Sr. gobernador de la provincia a las 11 de la mañana Vicente Pimentel y Francisco de Blas, consejeros interinos nombrados con arreglo a la disposición $4^{\mathrm{a}}$ de la real orden circular del 18 del corriente, para la más pronta ejecución del real decreto de 16 del mismo, por el cual se restablece en toda su fuerza y vigor el sistema administrativo creado en virtud de la ley de 8 de enero de 1845. El Sr. gobernador manifestó: Que tan pronto como recibió la Gaceta Oficial del día 17, había oficiado a la Excma. Diputación provincial, trasladándola el decreto y autorizándola a que siguiese conociendo en los asuntos urgentes, que como el de quintas, no admite dilación, de forma interina. Que en cumplimiento de la real orden citada había nombrado el día 20 consejeros provinciales interinos a Vicente Pimentel, Marqués de Gallegos, Conde de Patilla, Cándido Moyano y Francisco María de Blas, ausentes de la capital, después de haber estado reunidos sin descanso, desde la instalación de la Diputación el 19 de agosto próximo pasado. Que había resuelto instalar el Consejo, aunque no se hubieren reunido la mayoría de consejeros, autorizando a los dos consejeros presentes con ayuda del secretario a entrar en el ejercicio de sus funciones. Que se habilita como secretario interino al oficial $1^{\circ}$ Bernabé Merino. Previo el juramento requerido se dio por instalado el Consejo".
} 
En el año 1859 se nombra nuevo secretario en la persona de Joaquín Martínez Chantrero, que se mantendrá en el cargo hasta marzo de 1868. El Consejo se mantiene con los mismos componentes hasta el año 1861, año en el que abandona la Vicepresidencia Cándido Moyano Zamora y es nombrado para sustituirle Francisco María de Blas, completando el Consejo con el nombramiento de Inocencio García como nuevo consejero.

La aprobación de la ley de 25 de septiembre de 1863 "sobre el Gobierno y Administración de las Provincias" modifica la composición del Consejo provincial. En enero de 1864, con la puesta en marcha de la citada ley, se inician las actividades con la siguiente configuración: Presidente Francisco María de Blas, vicepresidente Vicente Álvarez Cossío, consejeros Ángel de la Riva Espiga e Inocencio García. Secretario Joaquín Martínez Chantrero.

Este Consejo mantiene los mismos componentes, hasta el 2 de febrero de 1866 fecha en la que se da lectura a la real orden de 26 de diciembre de 1865 por la que "Se declaran cesantes a los vocales del Consejo Francisco María de Blas y Ángel de la Riva". Para cubrir las vacantes se presentan como candidato Francisco Caracciolo Bayón, que es consejero supernumerario, y también se presentan para cubrir las vacantes los consejeros recientemente destituidos Francisco María de Blas y Ángel de la Riva. Ante esta ocurrencia, "el gobernador dice no tener nada que objetar sobre la candidatura del Sr. Caracciolo, pero en cuanto a los otros dos señores, manifiesta que fueron cesados por haber faltado a sus deberes como funcionarios" 339 .

En la sesión extraordinaria del 1 de marzo se nombra nuevo consejero a Ignacio Martín Casado y se ratifica a Ángel de la Riva Espiga. El Consejo queda formado por el presidente Vicente Álvarez Cossío, los consejeros Ángel de la Riva Espiga, Inocencio García e Ignacio Martín Casado. Secretario, Joaquín Martínez Chantrero. Como consejeros supernumerarios son nombrados Santiago Prieto y Eladio Chacel, ratificados por la real orden de 24 de marzo de 1866.

En el mes de marzo de 1868, abandona la Secretaría el Sr. Chantrero, siendo nombrado secretario accidental Ricardo Belloch. El Consejo provincial celebra la última sesión de esta época isabelina el 25 de septiembre de 1868 , sesión a la que asisten Inocencio García, que firma como presidente accidental e Ignacio Martín Casado, que son los dos únicos consejeros que han asistido a las ocho sesiones que se celebran en septiembre.

El Consejo provincial, en esta su segunda época isabelina, que transcurre entre los años 1856 a 1868, mantiene una gran actividad, en detrimento de la Diputación. Sus actividades están referidas a temas de: quintas, beneficencia, propios, Ayuntamientos, presupuestos, sanidad, censos, pósitos, reclamaciones, elecciones municipales, justicia, instrucción pública, etc. Es decir, son temas que, como hemos comentado con anterioridad, eran tratados por la Diputación.

Otro dato curioso es el alto número de sesiones que realiza, superiores, desde luego, a las que mantiene la Diputación. A lo largo de los años, se celebran: En 1856, a partir del 24 de octubre se celebran treinta y cinco sesiones. En 1857, ciento treinta y una sesiones. En 1858, doscientas ocho sesiones. En 1859, setenta y nueve sesiones. En 1860, setenta y seis sesiones. En 1861, ochenta y tres sesiones. En 1862, ochenta sesiones. En 1863, ciento treinta y siete sesiones. En 1864, noventa y seis sesiones. En 1865, ciento siete sesiones. En 1866, ciento veintinueve sesiones. En 1867, ciento sesenta y seis sesiones. En 1868 hasta el 25 de septiembre que se celebra la última son ciento treinta y siete. 


\section{Autoridades y otros personajes Ayuntamiento}

El día 1 de julio de 1856 es nombrado alcalde Valentín Llanos Gutiérrez, y el 15 de noviembre del mismo año llega a la Alcaldía Eduardo Ruiz Merino ejerciendo el cargo hasta marzo de 1857. Posteriormente será elegido diputado provincial.

En marzo de 1857 es elegido Antonio Florencio de Vildósola Landecho y ejerce el cargo hasta diciembre de 1858. En enero de 1859 es elegido alcalde Nemesio López Redondo y se mantiene en el puesto hasta finales de 1860. A principios de 1861 es elegido Juan Sigler Ceballos y continúa hasta mayo de 1862. Le sucede Manuel de Ureña Cádenes que se mantiene en el cargo desde el mes de junio de 1862 hasta julio de 1863. Antonio Medina Canales se hace con el puesto desde el mes de septiembre hasta febrero de 1864 .

A lo largo de 1864 son tres las personalidades que se suceden en la Alcaldía. Calixto Varela Montes durante febrero y marzo, Juan María Villar de la Torre de abril a octubre y Juan López Bustamante entre octubre y noviembre de 1865.

Faustino Allande Valledor inicia su mandato en diciembre de 1865 y se mantiene en el cargo hasta julio de 1866. Le sucede Eugenio Caballero, que ejerce el mandato más largo del período al permanecer en el cargo desde agosto de 1866 hasta septiembre de 1868 , con lo que se da por finalizada la época isabelina ${ }^{340}$.

\section{Capitanía General}

Continúan los cambios en la Capitanía, aunque en este período se percibe una mayor estabilidad y permanencia en el puesto de los diferentes capitanes generales. Así tenemos que de 1854 a 1857 ejerce Joaquín Armero y Peñaranda. En 1858 son José Campuzano y Herrera y Cayetano Urbina y Daoiz. En 1859 José Martínez Tenaquero que se mantiene hasta 1862. En 1863 José de Orozco y Zúñiga. En 1864 Eduardo Fernández de San Román. En 1865 Francisco Serrano Bedoya. En 1866 José de Orozco y Zúñiga. En 1867 Francisco de Paula Garrido y Enrile. En 1868 Francisco Parreño y Lobato de la Calle.

\section{Diputados a Cortes}

En 1857 son electos: Gaspar Cuadrillero Otero de Tejada, Pedro Moyano, Conde de Patilla, Benito Fernández Maquieira y Millán Alonso del Barrio.

En 1858: Miguel Zorrilla, Conde de Patilla, Enrique O’Donell, Pedro Salaverría y Antonio Méndez Vigo.

En 1860: Claudio Moyano Samaniego, Miguel Zorrilla, Atanasio Pérez Cantalapiedra, José María Orense y Pedro Calvo Asensio.

En 1863: Antonio Méndez Vigo, Mariano Lino Reynoso, Cándido Pimentel, Conde de Patilla y Carlos O'Donell.

En 1864: Mariano Lino Reynoso, Conde de Patilla, Antonio Méndez Vigo, Miguel de las Moras y Carlos O'Donell.

En 1867: Claudio Moyano Samaniego, Eusebio Fernández de Velasco, Santiago Lirio, Domingo Jesus Francos y José Moyano Sánchez.

Son senadores: Millán Alonso del Barrio, Ángel Juan Álvarez Osorio, Miguel López de Baños Monsalve y Antonio Méndez Vigo Santamarina ${ }^{341}$.

\section{Obispado}

Juan Antonio de Rivadeneira continúa como Obispo de Valladolid, desde 1830, fecha de su nombramiento, hasta 1856, año en el que fallece. En el año 1857 la Diócesis pasa a ser Arzobispal, por lo que D. Luis de la Lastra y Cuesta, toma posesión como primer Arzobispo de Valladolid. Ejerce el cargo hasta 1863.

El 20 de enero de 1864, la Diputación da lectura a la comunicación de "D. Juan de la Cruz Ignacio Moreno y Maisonave, recientemente nombrado Arzobispo de Valladolid, comunica su entrada a la ciudad y se presenta como Prelado Doméstico de S.S., Señor de Junquera de Ambía, Caballero de la R.O. de Carlos III, senador

${ }^{340}$ CARAS A SOTO, Pedro (/Dir.). Diccionario biográfico de Alcaldes... ob. cit. Págs. 13 a 15. ${ }^{341}$ CARAS A SOTO, Pedro (Dir.). Diccionario biográfico de parlamentarios.... Ob. cit. Págs. 3 y sig. 
vitalicio, del Consejo de S.M. etc. etc.”. El 10 de abril de 1868 se le impone el Birrete Cardenalicio.

\section{Universidad}

Es rector desde 1850 hasta 1863 Manuel de la Cuesta y Cossío. Entre 1863 y 1869 ejerce como rector Atanasio Pérez Cantalapiedra.

\section{Delegación de Hacienda}

En estos años se suceden al frente de la Delegación los siguientes señores. En 1856 y 1857 Cayetano de Acuña. En los años 1858 y 1859 Esteban Morales. Entre 1860 y 1864 Justo González Romero. En 1865 José María Undabeitia. Desde 1866 a 1868 ejerce el cargo Juan José Egozcue.

\section{Otros personajes}

En este período son numerosos los individuos que aparecen en la vida política, comercial e industrial de la provincia. De entre todos ellos destacamos a los que, aunque no pertenecieron a la Diputación, ejercieron una gran influencia en las decisiones y actividades de la provincia, en especial en el ámbito de la política provincial y nacional, de la economía y en la mejora de las estructuras provinciales. Son: Vicente Álvarez Cossío, José Francés de Alaiza, Claudio Moyano Samaniego y Mariano Miguel de Reynoso y Abril.

\section{Álvarez Cossío, Vicente}

Por real orden de 22 de enero de 1852 es nombrado vocal-consejero del Consejo provincial de Valladolid. Es su primera toma de contacto con la provincia. Se mantiene en el puesto hasta el 26 de julio de 1854 , fecha en la que se produce la disolución del Consejo, a la llegada del Bienio Progresista.

El 24 de octubre de 1856, inicia nuevamente su andadura el Consejo y en la sesión que celebra el 1 de diciembre de 1857 "se presenta y presta juramento el nuevo consejero Vicente Álvarez”. Cargo que desempeñará hasta el 12 de julio de 1864, fecha en la que es nombrado vicepresidente. En septiembre de 1865 es presidente interino y en junio de 1866 es presidente titular.

En virtud de ese cargo, actúa como gobernador interino y presidente de la Diputación, ante la ausencia del titular, como ocurre en 1867 que "como gobernador interino, ante la ausencia del gobernador titular Sr. Ureña, cede el mando de la provincia al capitán general al establecer el estado de guerra en toda la provincia". del titular.

En septiembre de 1868 preside las sesiones de la Diputación, ante la ausencia

\section{Francés de Alaiza, José}

José Severino Francés Enríquez de Alaiza nació el 22 de febrero de 1815 en Puebla de los Andes, en América. Es hijo de José Francés, teniente coronel del Ejército, destacado en las colonias americanas.

En el año 1827 es feligrés de la parroquia de San Martín de Valladolid. "El 13 de octubre de 1827, solicita el ingreso en la Universidad de Valladolid, matriculándose en la Facultad de Leyes. En 1834 solicita ser examinado para alcanzar el grado de bachiller en Jurisprudencia y examinado el 6 de junio salió aprobado némine discrepante" ${ }^{342}$.

En el año 1843 es juez de Primera Instancia en Valladolid y en 1844 es el director de la Sociedad General de Socorros Mutuos, empresa editora de "El Correo de Castilla", periódico que se publica en 1854 y 1855 , del que es administrador y redactor.

En la sesión de instalación del Consejo provincial, celebrada el 29 de julio de 1845, es nombrado consejero supernumerario, y en 1848 por real orden de 22 de marzo, se le nombra consejero titular, actuando como tal hasta el 26 de junio de 1854, fecha en la que el Consejo provincial es suprimido.

342 A.H.U.V.A. Cajas 458 (doc. 271 a 277) y 567. 
Con la vuelta a la actividad del Consejo en octubre de 1856, vuelve a ser nombrado consejero y vicepresidente el 18 de noviembre del mismo año, cargo que mantiene hasta el 24 de agosto del repetido 1858, fecha en la que inicia su actividad como secretario del Gobierno Civil de Toledo. En 1863 es gobernador civil de Canarias, en 1864 lo es de Guadalajara y de Alicante. En 1866 vuelve a Toledo como gobernador civil.

\section{Moyano Samaniego, Claudio}

Nació en Bóveda de Toro, provincia de Zamora, el 30 de octubre de 1809. "Inicia sus estudios universitarios en la Universidad de Salamanca, en 1824, matriculándose en la Facultad de Filosofía. En 1827, solicita ser examinado para alcanzar el grado de bachiller en Filosofía. Entró a examen el 8 de noviembre y salió aprobado. El mismo año 1827, se matriculó en la Facultad de Leyes de la misma Universidad, donde alcanzó el grado de bachiller en Jurisprudencia en el año 1830. El 24 de febrero de 1833 solicita incorporarse a la Universidad de Valladolid presentando los certificados de los cursos probados en la Universidad de Salamanca. Se matricula en la Facultad de Leyes. El 14 de junio de 1833, solicita ser examinado para alcanzar el grado de licenciado en Jurisprudencia, y presentado a examen salió aprobado. El 24 de septiembre de 1833 en solicitud al Sr. rector de la Universidad expone que habiendo recibido el grado de licenciado solicita el grado de doctor. Se le fijan días para recibirlo" ${ }^{343}$. En 1834, recién acabada la carrera ingresó en el Colegio de Abogados de Valladolid. En el año 1835, se ofrece para dar clases en la Facultad de Geografía de la Universidad de Valladolid, prestando su apoyo además, para evitar el cierre de la institución. Se casó en Valladolid con Juana Nieto.

En 1836 es capitán de la Milicia Nacional. En este mismo año ejerce en la Universidad como catedrático de Derecho Romano. En 1837 ingresa como académico en la Real Academia de Nobles Artes de la Purísima Concepción, siendo nombrado en 1839 vocal de la Comisión Artística. En el año 1841, es nombrado alcalde $2^{\circ}$ de Valladolid, siendo en este mismo año, comisionado por la Universidad para defender nuevamente la permanencia de la institución ante el riesgo de ser clausurada por el Gobierno.

En 1843, ante la caída del gobierno de Espartero, es nombrado vocal de la Junta Provisional del Gobierno de la Provincia. En este mismo año es nombrado rector de la Universidad de Valladolid, cargo en el que permanece hasta el año 1850.

Es diputado a Cortes en representación de Toro, Zamora y Valladolid, en la mayoría de las legislaturas que se suceden entre los años 1843 a 1876 . Está afiliado al partido moderado, en el que llegó a desempeñar la jefatura del mismo.

En el año 1850 es nombrado rector de la Universidad Central (Madrid). En 1853 es nombrado ministro de Fomento, nombramiento que se volvió a repetir en 1856 con el Gobierno de Narváez y en 1864, en el Gabinete de Arrazola. En 1857, ejerciendo como ministro de Instrucción Pública, presentó y las Cortes aprobaron la Ley de Instrucción Pública, conocida como "Ley Moyano". En 1862, preside, en Valladolid, la "Junta General de Distribución del Crédito de las Inundaciones". En 1866 es nombrado vocal del Consejo de Instrucción Pública. En 1881 es senador del Reino ${ }^{344}$. Falleció en Madrid el día 7 de marzo de 1890.

\section{Reynoso y Abril, Mariano Miguel de}

Es una de las figuras más importantes del Valladolid del siglo XIX tanto en el ámbito provincial como en el nacional. Sobresale en múltiples facetas culturales, comerciales industriales y políticas. Nace en Valladolid el 8 de mayo de 1799, hijo de Mariano Reynoso y de Lucía Abril. Su hermano mayor, José María se casó con Josefa Oscáriz y tuvieron tres hijos Mariano Lino diputado y senador, Manuel, senador y

343 A.H.U.V.A. Cajas 458 (doc. 1 y 2), 504 (doc. 113 a 116), 573 y 669-71.

${ }^{344}$ CARASA SOTO, Pedro (Dir.). Diccionario biográfico de parlamentarios ... ob. cit. pág. 874 
Rafael, magistrado. Su hermana Adelaida se casó con Francisco Lara, diputado provincial y tuvieron cuatro hijos, su hija María del Socorro se casó con Cástor Ibáñez de Aldecoa, gobernador civil de la provincia y su otra hija Josefa se casó con Luis García Pizarro, diputado provincial. En el año 1814 estudia geografía y matemáticas en la Real Academia de Matemáticas y Nobles Artes de la Purísima Concepción institución en la que posteriormente ejerció como profesor de matemáticas. En 1823, con el fin del Trienio Liberal, se retira al pueblo de Sedano, en el norte de Burgos, a causa de sus ideas liberales.

El 27 de agosto de 1832 se casó con Dolores Salgado Viana, perteneciente a la nobleza gallega, con la que no tuvo hijos. Se instala en Valladolid y se afilia al partido moderado. En 1835 es el jefe de la Milicia Urbana de Valladolid, con el grado de comandante, siendo nombrado subinspector de la misma en 1837.

Entre los años 1837 y 1848 destaca como comprador de bienes desamortizados. “Compró 530 hectáreas en las comarcas de Tierra de Medina y Campiña del Pisuerga, y especialmente en esta segunda comarca, adquirió la finca de Arroyo de la Encomienda, que procede de la Orden de San Juan de Jerusalén. Por estas propiedades llegó a pagar 934.000 reales. También su familia llegó a comprar 1.065 hectáreas, seis casas, dos molinos y seis fincas urbanas por un importe total de 4.867.000 reales, parte de ellas a través de su testaferro y compañero político Juan Manuel Fernández Vítores" ${ }^{345}$. En 1849 compra el Palacio de Pimentel al Marqués de Camarasa y posteriormente sus herederos se lo venderán a la Diputación.

Es elegido diputado a Cortes por Valladolid entre los años 1836 a 1847 . En el año 1848 el Boletín Oficial de la provincia publica un anuncio del gobierno en el que "se ordena la elección de un diputado a Cortes por el distrito de La Mota del Marqués, por haber sido nombrado senador D. Mariano Miguel de Reynoso" 346 . Es elegido alcalde de Valladolid en enero de 1840, pero a los dos meses abandona la Alcaldía al ganar las elecciones para diputado a Cortes. Vuelve a ser nombrado alcalde en enero der 1844 pero vuelve a dejar el cargo en octubre del mismo año al volver a ser elegido diputado a Cortes ${ }^{347}$. En 1848 es consejero real de Agricultura, Industria y Comercio, siendo nombrado en 1851 inspector general de Agricultura. Llega a ministro de Fomento entre 1851 y 1852. En estos años al frente del ministerio, se preocupó de conseguir mejoras técnicas aplicadas a la agricultura, como fueron las mejoras de las semillas y el perfeccionamiento de la maquinaria agrícola. En el año 1855, ya retirado de la actividad política nacional, se centró en las actividades industriales y agrícolas en la provincia, al montar en sus propiedades de Arroyo y La Flecha dos fábricas de harina. Es miembro de la "Comisión Promotora del Ferrocarril Alar-Santander", y, aunque propietario de grandes fincas, no está catalogado como agricultor sino como industrial y propietario.

Es uno de los mayores contribuyentes de la provincia. "En 1855 era el segundo mayor contribuyente con 6.885 reales de renta. En 1860 es el séptimo con 11.640 reales y en 1861 el décimo con 10.444 reales". Ejerce como director de la Sociedad de Seguros Mutuos y de la Caja de Ahorros de Valladolid. Pertenece al Liceo Artístico y Literario y a la Sociedad Económica de Amigos del País.

Es tío de Mariano Lino de Reynoso y Oscariz, que continuó la carrera política de su tío y que ejerció como diputado provincial en los años 1850 a 1854, diputado a Cortes en tre 1863 y 1865 , gobernador civil en enero de 1875 y senador en la época de la Restauración.

Falleció en Valladolid el 23 de abril de 1863.

346 CARASA SOTO, Pedro (Dir.). Diccionario biográfico de parlamentarios... Ob. cit. Pág. 872. B.O.P.V. de fecha 18 de diciembre de 1848 .

${ }^{347}$ CARASA SOTO, Pedro (Dir.). Diccionario biográfico de Alcaldes... ob. cit. págs.554 y sig. 


\section{Actividades más importantes en este período}

Este período está enmarcado por un lado con el final del Bienio Progresista y sus problemas y dificultades ocasionados por la carestía de la vida y el descontento social que condujeron a los hechos violentos conocidos con el nombre del "motín del pan", y por otro lado, con el inicio del Sexenio Revolucionario, período en el que tomarán protagonismo los profundos cambios sociales y políticos. Entre estos dos movimientos sociales, es decir entre 1856 y 1868, dos acontecimientos marcarán la vida de la provincia. Por un lado asistimos a un gran desarrollo industrial liderado por una naciente industria harinera, a lo que siguió por otro lado, una grave crisis financiera provocada por el alto índice de endeudamiento a causa de las grandes inversiones realizadas, que no fueron lo rentables que de ellas se esperaban.

En el tema industrial destaca la construcción de numerosas fábricas de harina, especialmente a orillas del canal de Castilla, vía de transporte y comunicación primordial para la exportación harinera a través del ferrocarril Alar-Santander y del puerto de esta ciudad. Especialmente entre 1856 y 1863 se produce una gran transformación de los viejos molinos harineros en flamantes fábricas de harina, cuyo número prácticamente se duplicó en estos años, lógicamente no sólo en número de fábricas sino también en la capacidad de molturación. La provincia evoluciona de una forma positiva que se traduce en el progreso de la agricultura lo que se corresponde con una mayor producción de granos, acompañado por una mayor producción de harinas y con una legislación favorable que favorece la libre exportación de los productos agrícolas y la prohibición de importación de cereales del extranjero, con el resultado de un aumento de la exportación y la masiva salida de granos de la provincia $^{348}$.

Como consecuencia del auge de la industria harinera y en la mayoría de los casos protagonizados por los mismos propietarios, surgen otras series de industrias que se asentaron en la provincia como la algodonera, la textil o la siderúrgica, esta última con la especialización en la fabricación de aperos de labranza y en maquinaria para la repetida industria harinera.

El segundo acontecimiento importante sucedido en estos años es el de la crisis financiera representada por las dificultades económicas en las que se encontraba la línea del ferrocarril Alar-Santander y la quiebra del Banco de Valladolid, hechos que provocaron una cascada de suspensiones de pagos y quiebras de numerosos harineros y comerciantes entre los años 1864 y 1866, y que también arrastró a otra serie de industrias.

Entre los más destacados se halla Antonio Ortiz Vega, que a principios de los años sesenta es el mayor contribuyente de la provincia, tanto en la contribución industrial como en el subsidio, y del que se comunica "el embargo de veinte casas en Alar del Rey con un almacén en el Canal, tres casas en Valladolid y tres fábricas de harina en La Flecha y Palencia". Otros comerciantes e industriales afectados son: Juan Antonio Fernández Mantilla, Cipriano Herrero de la Cruz, José María Iztueta, Salcedo Núñez y Cía, Ciriaco de la Cámara, Sociedad Industrial Castellana, Eloy Lecanda, Francisco Miguel Perillán, Sebastián Ruiz Salcedo, Tomás Alfaro, Bernardo Monclús, Zamacoa y Cía, Juan Fernández Rico, Gutiérrez Calderón, etc, etc.

Esta crisis acabó con el esplendor de la industria harinera y con la oportunidad de hacer de Valladolid un centro industrial y comercial de primer orden. La especulación financiera, el afán de enriquecimiento rápido y la falta de solidez económica, arruinó las posibilidades de progreso y desarrollo provincial ${ }^{349}$

También es de destacar la mejora de las comunicaciones con la terminación de una serie de carreteras como las que unían a la capital con las ciudades de Salamanca y

\footnotetext{
348 MORENO LÁZARO, Javier. Los empresarios harineros castellanos (1765-1913). Ed. Universidad de Valladolid. Valladolid. 1999. Detalla las actividades harineras del eje Valladolid-Palencia-Santander y las consecuencias de la crisis.

${ }^{349}$ Ibídem. Información sobre los escándalos financieros y la quiebra del banco de Valladolid. Pág.115.
} 
León, que finalmente se pusieron en marcha en estos años. Se fomenta la construcción de una serie de carreteras provinciales con la finalidad de facilitar los intercambios entre los pueblos de la provincia. Es especialmente importante, sobre todo por la mejora que supuso en las comunicaciones, la construcción de las vías férreas que comunicaban a Valladolid tanto con Madrid como con el norte del país, en especial con Irún y sobre todo con Santander, puerto por el que salen la mayoría de la producción agraria que se produce en la Meseta y que va destinada a la exportación. Un hito importante en la mejora y progreso ciudadano es el del inicio de los trabajos para la construcción del "Canal del Duero", vía de agua destinada a garantizar el aprovisionamiento de aguas a la ciudad.

Otra actividad a resaltar es la de la propaganda y fomento de la Exposición Agrícola de Londres con la intención de conocer los progresos en materia agrícola para mejorar los sistemas de producción de la provincia. A este fin se organiza un viaje subvencionado por la Diputación.

Por lo demás, la Diputación, con la vuelta del Consejo provincial, vuelve a centrar sus trabajos en la aprobación de los presupuestos, en la modernización de la sanidad y la beneficencia a partir de la creación del hospital provincial y la unificación de los diversos establecimientos benéficos, que comporta una mejora en la atención de los habitantes de la provincia.

En la enseñanza conviene destacar los progresos en la generalización de la enseñanza primaria en la mayoría de los pueblos de la provincia, aunque con sus correspondientes dificultades a la hora de pagar a los maestros, el buen funcionamiento del Instituto de Segunda Enseñanza, en la ciudad, así como las Escuelas Normales. Por otro lado, vemos cómo la Universidad se consolida con un aumento del número de alumnos 350

\subsection{8.- LAS CINCO DIPUTACIONES DEL SEXENIO. 1868-1874}

Como acabamos de relatar, la quiebra industrial y financiera deja a Valladolid, capital y provincia, sumida en una profunda crisis, agravada por la sequía que sufre el campo en estos años y que tiene como consecuencia la pérdida de la cosecha y el descontento social. Este es el panorama con el que se recibe al Sexenio.

Estamos ante el inicio de una época cambiante y revolucionaria, que desde un punto de vista social, se inicia con una población apagada, hambrienta y desmoralizada, y aunque parezca un contrasentido, también satisfecha por ver el final de la monarquía y por la esperanza de conocer tiempos mejores. Esta satisfacción ciudadana queda de manifiesto a través de las numerosas manifestaciones que se celebran en apoyo de la Revolución y en el aumento de la militancia de los partidos progresistas y en especial del partido republicano.

Por otra parte, desde un punto de vista institucional, los Ayuntamientos son las instituciones que asumen desde un primer momento los postulados revolucionarios y apoyan sin fisuras a las Juntas Revolucionarias que se forman en las poblaciones más importantes. Al Ayuntamiento de Valladolid le faltó tiempo para hacer suyas las reclamaciones de los promotores de ls Revolución en lo concerniente a la abolición del impuesto de consumos y a la supresión de las quintas.

Finalmente, desde un punto de vistas político, con relación a su incidencia en la Diputación, se producen una serie de cambios en la institución provincial, en su funcionamiento, en sus relaciones con el gobernador, en el aumento de su autonomía, en un aumento de las actividades ${ }^{351}$.

Si el 20 de septiembre de 1868 se celebra la última sesión de la Diputación isabelina, el 14 de octubre del mismo año, da comienzo a sus actividades, no una nueva Diputación, sino la "Comisión Especial de la Junta Revolucionaria Provincial",

${ }^{350}$ PALOMARES IBAÑEZ, Jesús María (Dir.). Historia de la Universidad.... Ob. cit.

${ }^{351}$ SERRANO GARCÍA, Rafael. El Sexenio Revolucionario en Valladolid. Cuestiones sociales (1868 1874). Ed. Junta de Castilla y León. Valladolid. 1986. 
entidad que desde el 1 de octubre se considera la máxima autoridad provincial y que convoca, sin ningún tipo de elecciones, a una serie de representantes de los partidos judiciales de la provincia ${ }^{352}$.

Es la única reunión que celebra esta "Comisión Especial", con la finalidad de aparentar normalidad y dar continuidad a los trabajos pendientes, hasta que el 21 de octubre se forma la primera Diputación del Sexenio.

A lo largo de estos años, se producirán una serie de cambios legislativos que tendrán su repercusión en el funcionamiento de la Diputación. El primer cambio se produce a través de un decreto de la Junta Revolucionaria por el que se suprime las actividades del Consejo provincial y se vuelve a poner en marcha la Secretaría de la Diputación.

El segundo cambio se produce el 21 de octubre de 1868, con la aprobación de la ley sobre la "Organización y Atribuciones de las Diputaciones Provinciales". Esta norma oficializa la puesta en marcha de las Secretarías de la Diputación con sus correspondientes funcionarios y sobre todo, el nombramiento por parte de la Diputación del presidente en la persona de uno de los diputados que forman la corporación. En consecuencia, se produce una pérdida de representatividad del gobernador.

El tercer cambio es la promulgación de la "Ley Electoral" de 20 de agosto de 1870, que modifica el número de diputados que forman el Pleno de la Diputación. Pasan de tener un representante por partido judicial a tenerlo por cada distrito. La provincia de Valladolid está formada por treinta y cinco distritos, con lo cual, se pasa de once a treinta y cinco diputados.

El cuarto cambio de importancia para el funcionamiento de la Diputación está motivado por la aprobación el 20 de agosto de 1870 de una nueva "Ley de Organización Provincial". La ley contempla la aparición de un nuevo organismo la "Comisión Provincial" también llamada "Comisión Permanente", que está formada por cinco diputados, entre los que se nombra un vicepresidente y que tendrán como misión "vigilar la exacta ejecución de los acuerdos de la Diputación y la preparación de todos los asuntos de que ésta haya de ocuparse".

Otra importante modificación es la de la potenciación de la figura de presidente de la Diputación, con un mayor poder ejecutivo y con el mantenimiento testimonial del gobernador "que presidirá las sesiones cuando asista, sin voto".

\section{$1^{\text {a }}$ Diputación del Sexenio. Nombrados. Octubre 1868 - Octubre 1869}

La Primera Diputación del Sexenio Revolucionario inicia sus actividades el 21 de octubre de 1868. Estuvo en principio presidida por el gobernador civil interino D. Genaro Santander y formada por los representantes de los once partidos judiciales, que conforman la provincia "nombrados por la Junta Revolucionaria de la capital". Destaca como una de sus características la de que, además de los diputados titulares, son elegidos también otros tantos diputados suplentes, aunque la novedad más importante está dada por el nombramiento, en su primera sesión, del presidente de la Diputación entre los diputados titulares. Así tenemos que, en esta primera Diputación, ejerce como el quincuagésimo tercer presidente de la misma a lo largo de su historia el diputado de Tordesillas D. Francisco Rodríguez Rubio. En el mes de noviembre los once diputados con que se inicia la legislatura quedan reducidos a nueve al desaparecer los partidos judiciales de La Mota y Valoria, y los pueblos que lo formaban repartidos entre Tordesillas y Rioseco en el primero de los caso y entre Peñafiel y Valladolid en el segundo.

352 “En Valladolid, a 14 de octubre de 1868, se reúnen en una de las salas del Gobierno de esta provincia los Sres. Lucas Guerra, individuo de la Junta Revolucionaria de esta capital, en representación de los partidos a que esta da nombre, Manuel de la Cruz Alonso en representación del partido de Medina de Rioseco, Niceto Sanz en la de Olmedo, Mariano Capdevila en la de Peñafiel y Juan de Mata Zorita en la de Tordesillas...”A.D.P.V. Actas. Libro de actas del 14 de octubre de 1868 . 
Esta Diputación finaliza sus trabajos el 17 de octubre de 1869 , celebrando en su período de vigencia noventa y ocho sesiones.

\begin{tabular}{l}
\multicolumn{1}{c}{ Nombre } \\
Genaro Santander \\
Manuel Somoza Cambero \\
José Pascasio de Escoriaza \\
José Gómez Diez \\
Juan de Mata Zorita Alonso \\
Francisco Rodríguez Rubio \\
Manuel Cruz Alonso Martín \\
Joaquín García Escobar \\
Mariano Capdevila Pedrero \\
José García Serrano \\
Lucas Guerra Franco \\
Valentín Rodríguez \\
Teodoro Rodríguez Monroy \\
Lázaro Diez Quijada \\
Niceto Sanz \\
Juan Gualberto Ayllón \\
Eusebio Escudero \\
Francisco Calvo Asensio \\
Pedro Romero \\
Ignacio de Aspes Álvarez \\
Pedro Criado \\
Máximo Clemente Herrero \\
Ulpiano Muñoz Zapata \\
Claudio Santana Santana
\end{tabular}

$\begin{array}{cc}\text { Cargo } & \text { Partido judicial } \\ \text { G. Interino } & --- \\ \text { Gobernador } & --- \\ \text { Gobernador } & --- \\ \text { Gobernador } & --- \\ \text { Diputado } & \text { Tordesillas } \\ \text { 53 Presid. } & \text { Tordesillas } \\ \text { Diputado } & \text { Rioseco } \\ \text { Suplente } & \text { Rioseco } \\ \text { Diputado } & \text { Peñafiel } \\ \text { Suplente } & \text { Peñafiel } \\ \text { Diputado } & \text { Valladolid Plaza } \\ \text { Suplente } & \text { Valladolid Plaza } \\ \text { Diputado } & \text { Valladolid Aud. } \\ \text { Suplente } & \text { Valladolid Aud. } \\ \text { Diputado } & \text { Olmedo } \\ \text { Suplente } & \text { Olmedo } \\ \text { Diputado } & \text { Valoria } \\ \text { Diputado } & \text { La Mota } \\ \text { Diputado } & \text { Medina } \\ \text { Suplente } & \text { Medina } \\ \text { Diputado } & \text { Villalón } \\ \text { Suplente } & \text { Villalón } \\ \text { Diputado } & \text { Nava } \\ \text { Suplente } & \text { Nava } \\ & \end{array}$

$\begin{array}{cr}\text { Permanencia en el cargo } & \text { Sesiones } \\ \text { Octubre } 1868 & 1 \\ \text { Nov. } 1868 \text {-Feb. } 1869 & 11 \\ \text { Feb. } 1869 \text {-May. } 1869 & 27 \\ \text { Jun. 1869-Oct. } 1869 & 2 \\ \text { Octubre } 1868 & 1 \\ \text { Oct. } 1868 \text {-Oct. } 1869 & 87 \\ \text { Oct. } 1868 \text {-Oct. } 1869 & 70 \\ \text {--- } & -- \\ \text { Oct. } 1868 \text {-Oct. } 1869 & 66 \\ \text {--- } & -- \\ \text { Oct. } 1868 \text {-Dic. } 1868 & 11 \\ \text { Ene. } 1869 \text {-Oct. } 1869 & 57 \\ \text { Oct. } 1868 \text {-Nov. } 1868 & 12 \\ \text { Dic. } 1868 \text {-Oct. } 1869 & 48 \\ \text { Oct. } 1868 \text {-Mar. } 1869 & 27 \\ \text { Mar. } 1869 \text {-Oct. } 1869 & 38 \\ \text { Oct. } 1868 \text {-Nov. } 1868 & 10 \\ \text { Octubre } 1868 & 1 \\ \text { Oct. } 1868 \text {-Oct. } 1869 & 49 \\ \text { Febrero } 1869 & 7 \\ \text { Oct. 1868-Nov. } 1868 & 5 \\ \text { Nov.1868-Oct. } 1869 & 60 \\ \text { Oct. } 1868 \text {-Oct. } 1869 & 44 \\ \text {--- } & --\end{array}$

\section{$2^{a}$ Diputación del Sexenio. Sin elecciones. Octubre 1869 - Febrero 1871}

La Segunda Diputación del Sexenio inicia sus actividades con la sesión de instalación celebrada el 18 de octubre de 1869, "en la que se reunieron a las doce de la mañana en el salón donde celebra sus sesiones la Excma. Diputación y bajo la presidencia de José Gómez Diez, gobernador de la provincia, los señores diputados reseñados al margen, conforme con las instrucciones del Excmo. Sr. capitán general del Distrito, revestido hoy de amplias y extraordinarias facultades por hallarse declarado el territorio en estado de guerra, y que ha nombrado con fecha 11 del corriente mes...".

Esta Diputación está compuesta por los nueve diputados titulares, en representación de los nueve partidos judiciales, y sin nombramiento de los suplentes. En la primera sesión es confirmado como presidente Francisco Rodríguez Rubio, diputado por Tordesillas. Se mantiene activo hasta el 16 de febrero de 1871, celebrando en su tiempo de vigencia un total de ciento veintisiete sesiones.

$\quad$ Nombre
José Gómez Diez
Eduardo de Loma Santos
José Gallostra y Frau
Francisco Rodríguez Rubio
Juan Antonio Rábago
José Gardoqui Fernández
Telesforo Reoyo Pérez
Máximo Clemente Herrero
Félix Alonso García
Liborio Guzmán
Ignacio Aspes Álvarez
Tomás López Morales

Cargo
Gobernador
Gobernador
Gobernador
$53^{\circ}$ Presid.
Diputado
Diputado
Diputado
Diputado
Diputado
Diputado
Diputado
Diputado

Partido judicial

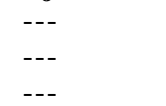

Tordesillas

Valladolid Aud.

Valladolid Plaza

Rioseco

Villalón

Peñafiel

Nava

Medina

Olmedo

$\begin{array}{cc}\text { Permanencia en el cargo } & \text { Sesiones } \\ \text { Oct. } 1869 \text {-Feb. } 1870 & 3 \\ \text { Mar. } 1870 \text {-Feb. } 1871 & 21 \\ \text { Febrero } 1871 & --- \\ \text { Oct. } 1869 \text {-Feb. } 1871 & 124 \\ \text { Oct. } 1869 \text {-Feb. } 1871 & 105 \\ \text { Oct. } 1869 \text {-Feb. } 1871 & 51 \\ \text { Oct. } 1869 \text {-Feb. } 1871 & 104 \\ \text { Oct. } 1869 \text {-Feb. } 1871 & 104 \\ \text { Oct. } 1869 \text {-Feb. } 1871 & 100 \\ \text { Oct. } 1869 \text {-Feb. } 1871 & 86 \\ \text { Oct. } 1869-\text { Feb. } 1871 & 119 \\ \text { Oct. } 1869-\text { Feb. } 1871 & 118\end{array}$

\section{$3^{\text {a }}$ Diputación del Sexenio. Muchos y con elecciones. Febrero 1871 - Octubre 1872}

La Tercera Diputación de este período y primera en la que los diputados no son nombrados, sino que son el resultado de las elecciones que se celebraron los días 1, 2 y 3 de febrero de 1871. "Quedó constituida bajo la presidencia del Sr. gobernador, el día 17 de febrero de 1871, en el salón de sesiones de la Diputación". 
Las novedades más importantes que se producen en esta Diputación son el resultado de la entrada en vigor de la "Ley Electoral" y de la "Ley Provincial", ambas aprobadas el 20 de agosto de 1870. Las más importantes son: El incremento del número de diputados elegidos, que asciende a treinta y cinco personas, tantas como son los distritos en que está dividida la provincia. La puesta en marcha de la nueva institución denominada Comisión Provincial o Comisión Permanente, que inicia su andadura a partir del 28 de febrero de 1871. El nombramiento de presidente y vicepresidente de la Diputación.

\begin{tabular}{|c|c|c|c|c|}
\hline Nombre & Cargo & Distrito & $\begin{array}{c}\text { Permanencia en el } \\
\text { cargo }\end{array}$ & Sesion \\
\hline José Gallostra y Frau & Gobernador & --- & Feb.-Mar. 71 & 1 \\
\hline Primitivo Seriña & Gobernador & --- & Abr.-Ago. 71 & 2 \\
\hline Pedro Oller y Cánovas & Gobernador & --- & Nov. 71-Jun. 72 & 8 \\
\hline Vicente Lobit & Gobernador & --- & Sep.-Oct. 71 & \\
\hline Id. & Id. & --- & Jun.-Oct. 72 & \\
\hline \multicolumn{5}{|l|}{ Valladolid } \\
\hline Anselmo Allue Allue & Vicepresd. & S. Miguel & Feb. 71-Oct. 72 & 56 \\
\hline Ángel Rodríguez Villamandos & Diputado & Catedral & Feb. 71-Oct. 72 & \\
\hline José Muro López & Diputado & S. Andrés & Feb. 71-Jul. 71 & 10 \\
\hline Remigio Ocejo Bringas & Diputado & S. Andrés & Ago.71-Oct. 72 & 12 \\
\hline Demetrio Gutiérrez Cañas & Diputado & S. Martín & Feb 71-Oct. 72 & - \\
\hline Miguel Ibáñez Martín & Diputado & S. Pedro & Feb 71-Oct. 72 & 67 \\
\hline Mariano Lozano Villanueva & Diputado & Salvador & Feb. 71-Feb. 72 & 3 \\
\hline Laureano Álvarez López & Diputado & Santiago & Feb 71 - Oct. 72 & 39 \\
\hline Manuel Gutiérrez Barquín & Diputado & S. Nicolás & Feb 71-Oct. 72 & 51 \\
\hline Quirino Marquina & Diputado & Mucientes & Feb 71-Oct. 72 & 49 \\
\hline Juan Antonio de las Moras & Diputado & Valoria & Feb 71-Oct. 72 & 53 \\
\hline \multicolumn{5}{|l|}{ Medina } \\
\hline Sebastián Fernández Miranda & Diputado & Rueda & Feb. $71-$ Abr. 72 & 55 \\
\hline Felipe Arévalo Miera & Diputado & Carpio & Feb. 71-Oct. 72 & \\
\hline Pedro Montalvo & Diputado & Medina & Feb. 71-Oct. 72 & 44 \\
\hline \multicolumn{5}{|l|}{ Rioseco } \\
\hline José Manuel Cuadrillero Nájera & Diputado & Palazuelos & Feb. 71-Oct. 72 & 46 \\
\hline Telesforo Reoyo Pérez & Diputado & Rioseco & Feb. 71 & \\
\hline Manuel de Cruz Alonso Martín & Diputado & Rioseco & Mar. 71-Oct. 72 & J. \\
\hline Benito Moreno & Diputado & Villabrágima & Feb. 71-Oct. 72 & 6. \\
\hline Andrés Domínguez de la Mata & Diputado & Villar de Frades & Feb. 71-Oct. 72 & 50 \\
\hline \multicolumn{5}{|l|}{ Peñafiel } \\
\hline Félix Alonso García & $54^{\circ}$ Presid. & Campaspero & Feb. 71-Oct. 72 & 6 \\
\hline Felipe Tablares Maldonado & Diputado & Encinas & Feb. 71-Oct. 72 & 5 \\
\hline Eustaquio de la Torre Mínguez & Diputado & Peñafiel & Feb. 71-Oct. 72 & 5 \\
\hline Miguel Alonso Pesquera & Diputado & Quintanilla & Feb. 71-Oct. 72 & \\
\hline \multicolumn{5}{|l|}{ Olmedo } \\
\hline Francisco Martín Torés & Diputado & Olmedo & Feb. 71-Oct. 72 & 2 \\
\hline Julián Pérez Cantalapiedra & Diputado & Matapozuelos & Feb. 71-Oct. 72 & 29 \\
\hline Pablo Valdés & Diputado & Portillo & Feb. 71-Oct. 72 & 50 \\
\hline Miguel Velasco Neira & Diputado & Mojados & Feb. 71-Oct. 72 & 52 \\
\hline \multicolumn{5}{|l|}{ Mota } \\
\hline Marcelino Diez Bueno & Diputado & Tordesillas & Feb. 71-Oct. 72 & 22 \\
\hline Fernando María Arévalo Miera & Diputado & Torrelobatón & Feb. 71-Oct. 72 & \\
\hline Pablo Pinilla García & Diputado & Mota & Feb. 71-Oct. 72 & 55 \\
\hline \multicolumn{5}{|l|}{ Villalón } \\
\hline Ángel de la Riva Espiga & Diputado & Villalón & Feb.-May. 71 & 10 \\
\hline Manuel González García & Diputado & Villalón & May. 71-Oct. 72 & 26 \\
\hline Patricio Torres López & Diputado & Mayorga & Feb. 71-Oct. 72 & 42 \\
\hline Máximo Clemente Herrero & Diputado & Cuenca $\mathrm{C}$. & Feb. 71-Oct. 72 & 44 \\
\hline Laureano Melero & Diputado & Villavicencio & Feb. 71-Oct. 72 & 37 \\
\hline \multicolumn{5}{|l|}{ Nava } \\
\hline Claudio Santana Santana & Diputado & Alaejos & Feb. 71-Oct. 72 & 49 \\
\hline Antonio Martín Vargas & Diputado & Castronuño & Feb. 71-Oct. 72 & 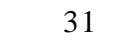 \\
\hline Mariano Osorio Casasola & Diputado & Nava & Feb. 71-Oct. 72 & 3 \\
\hline
\end{tabular}

En la sesión de instalación se nombra presidente al diputado Félix Alonso García, que se convierte en el quincuagésimo cuarto presidente de la corporación, y como 
vicepresidente a Juan Antonio de las Moras. La Diputación finaliza su legislatura el 31 de octubre de 1872, celebrando en este tiempo setenta sesiones.

\section{$4^{\text {a }}$ Diputación del Sexenio. Con elecciones y República. Noviembre 1872 - Mayo 1874}

La Cuarta Diputación, junto con la anterior, son las únicas en este período en las que los diputados son el resultado de unas elecciones. En este caso se celebraron entre los días 10 a 13 de septiembre de 1872. Sus actividades se inician el 2 de noviembre de 1872 de forma interina, hasta que el 7 del mismo mes, una vez aprobadas las actas de los diputados se procedió al nombramiento del quincuagésimo quinto presidente en la persona de Laureano Álvarez López, diputado por Valladolid y como vicepresidente a Manuel de la Cruz Alonso Martín, elegido diputado por el distrito de Rioseco.

Las actividades de la Diputación se dan por finalizadas en la sesión del día 11 de mayo de 1874 , por el gobernador ${ }^{353}$, habiendo celebrado cuarenta y dos sesiones.

Nombre

Vicente Lobit

José González-Alegre Álvarez

Ramón Lafarga

Cándido González Gutiérrez

Rafael de Adán y Castillejo

Agustín Vic. Teijón Rodríguez

Donato González Andrés

Ambrosio de Villava

Valladolid

Anselmo Allue Allue

José Mozo

Luis Antona Semolinos

Eladio Quintero Martínez

Juan Antonio Rábago

Benigno Villalba

Miguel Ibáñez Martín

Eusebio Burgueño

Laureano Álvarez López

Juan Bautista Teijón

Manuel Gutiérrez Barquín

Jerónimo Conde Camazón

Fidel Recio del Castillo

Juan Antonio de las Moras

\section{Medina}

Galo Olivares

Toribio Bayón Cano

Pedro Montalvo

Rioseco

José M. Cuadrillero Nájera

Fed. Lorenzo Cacho Frontaura

Manuel de Cruz Alonso Martín

Venancio Izquierdo

Ángel de la Riva Espiga

Andrés Domínguez de la Mata

Faustino de la Rua

Peñafiel

Eustaquio de la Torre Mínguez

Luis Alonso Burgueño
Cargo

\section{Distrito}

Gobernador
Gobernador
Gobernador
Gobernador
Gobernador
Interino
Interino
Gobernador

Diputado

Diputado

Diputado

Diputado

Diputado

Diputado

Diputado

Diputado

$55^{\circ}$ Presiden.

Diputado

Diputado

Diputado

Diputado

Diputado

Diputado

Diputado

Diputado

Diputado

Diputado

Vicepresid.

Diputado

Diputado

Diputado

Diputado

Diputado

Diputado
---
--
---
---
---
---
---

S. Miguel

S. Miguel

Catedral

S. Andrés

S. Andrés

S. Martín

S. Pedro

Salvador

Santiago

Santiago

S. Nicolás

S. Nicolás

Mucientes

Valoria

Medina

Rueda

Carpio

Palazuelos

Palazuelos

Rioseco

Villabrágima

Villabrágima

Villardefrades

Villardefrades

Peñafiel

Peñafiel

Permanencia en el cargo

Sesiones

Nov. 72-Feb. 73

Mar.-May. 73

Jun.-Dic. 73

Ene. 74

Feb. 74

Feb. 74

Mar.-Abr. 74

May. 74

Nov. 72-Feb. 74

Mar.-May. 74

Nov. 72-May. 74

Nov. 72-Feb. 74

Mar.-May. 74

Nov. 72-May. 74

Nov. 72-May. 74

Nov. 72-May. 74

Nov. 72-May. 73

Jun. 73-May. 74

Nov. 72-Feb. 74

Mar.-May. 74

Nov. 72-May. 74

Nov. 72-May. 74

Nov. 72-May. 74

Nov. 72-May. 74

Nov. 72-May. 74

Nov. 72-May. 74

May. 74

Nov. 72-May. 74

Nov. 72-May. 74

May. 74

Nov. 72-May. 74

May. 74

Nov. 72-May. 74

May. 74
4

2

2

$-\cdot$

$--$

$---$

$---$

24

5

38

27

6

38

31

35

23

3

26

2

16

33

36

26

20

23

1

39

39

0

10

1

25

1

${ }^{353}$ A.D.P.V. Actas. Libro de actas del 11 de mayo de 1874. Dice el libro de actas, "abierta la sesión se dio lectura a un oficio del Sr. gobernador, participando que en uso de las facultades que le concede la circular del Poder Ejecutivo de la República de 5 de febrero, ha tenido a bien, relevar del cargo de

diputados provinciales a los señores...Y en cumplimiento de orden superior ha tenido a bien, suspender hasta nueva orden las sesiones de la Diputación...". 
Félix Alonso García

Felipe Tablares Maldonado

Miguel Alonso Pesquera

Eugenio Martín García

Olmedo

Francisco Martín Torés

Francisco García Duque

Segundo Cantalapiedra Maestro

Pablo Valdés

Miguel Velasco Neira

Mota

Marcelino Diez Bueno

Fernando Arévalo Miera

Pablo Pinilla

Villalón

Manuel González García

Francisco Reoyo

Francisco Calderón Mantilla

Máximo Clemente Herrero

Laureano Melero

Nava

Mariano Osorio Casasola

Pedro Álvarez Guerra

Claudio Santana Santana

Mariano Gavilán de Gavilán

$\begin{array}{lllr}\text { Diputado } & \text { Campaspero } & \text { Nov. 72-May. 74 } & 24 \\ \text { Diputado } & \text { Encinas } & \text { Nov. 72-May. 74 } & 34 \\ \text { Diputado } & \text { Quintanilla } & \text { Nov. 72-May. 74 } & 39 \\ \text { Diputado } & \text { Quintanilla } & \text { May. 74 } & 1 \\ & & & \\ \text { Diputado } & \text { Olmedo } & \text { Nov. 72-May. 74 } & 4 \\ \text { Diputado } & \text { Olmedo } & \text { May. 74 } & 1 \\ \text { Diputado } & \text { Matapozuelos } & \text { Nov. 72-May. 74 } & 36 \\ \text { Diputado } & \text { Portillo } & \text { Nov. 72-May. 74 } & 31 \\ \text { Diputado } & \text { Mojados } & \text { Nov. 72-May. 74 } & 16 \\ & & & \\ \text { Diputado } & \text { Tordesillas } & \text { Nov. 72-May. 73 } & 24 \\ \text { Diputado } & \text { Torrelobatón } & \text { Nov. 72-May. 74 } & 18 \\ \text { Diputado } & \text { Mota } & \text { Nov. 72-May. 74 } & 33 \\ & & & \\ \text { Diputado } & \text { Villalón } & \text { Nov. 72-May. 74 } & 11 \\ \text { Diputado } & \text { Villalón } & \text { May. 74 } & 1 \\ \text { Diputado } & \text { Mayorga } & \text { Nov. 72-May. 74 } & 30 \\ \text { Diputado } & \text { Cuenca C. } & \text { Nov. 72-May. 74 } & 5 \\ \text { Diputado } & \text { Villavicencio } & \text { Nov. 72-May. 74 } & 0 \\ & & & \\ \text { Diputado } & \text { Nava } & \text { Nov. 72-Feb. 74 } & 7 \\ \text { Diputado } & \text { Nava } & \text { Mar.-May. 74 } \\ \text { Diputado } & \text { Alaejos } & \text { Nov. 72-May. 74 } & 18 \\ \text { Diputado } & \text { Castronuño } & \text { Nov. 72-May. 74 } & 34\end{array}$

\section{5 a . Diputación del Sexenio. Fin del período. Junio 1874-Marzo 1875}

La quinta y última Diputación del Sexenio se inicia el día 30 de mayo de 1874. "Reunidos en el salón de sesiones de la Diputación los Sres. diputados que figuran al margen, convocados por la circular del Sr. gobernador de esta provincia, inserta en el Boletín Oficial del 28 del corriente...". En la sesión del citado día, es nombrado el quincuagésimo sexto presidente al diputado Telesforo Reoyo Pérez, diputado por Rioseco y vicepresidente a Miguel Velasco Neira, diputado por Olmedo.

En la sesión del día 11 de enero de 1875, el Pleno de la Diputación recoge en el libro de actas "el fausto suceso de la proclamación del Rey D. Alfonso XII". La finalización del Sexenio no provocó la disolución de la Corporación, sino que ésta continuó con sus trabajos y con todos sus diputados, a excepción de cuatro ceses que se produjeron en enero, hasta el 18 de marzo de 1875. Al día siguiente iniciaría sus actividades la "Primera Diputación de la Restauración". En todo este tiempo de vigencia sólo se celebraron dieciocho sesiones.

\begin{tabular}{|c|c|c|c|c|}
\hline Nombre & Cargo & Distrito & $\begin{array}{c}\text { Permanencia en el } \\
\text { cargo }\end{array}$ & Sesione \\
\hline Ambrosio de Villava & Gobernador & --- & Jun.-Dic. 74 & 1 \\
\hline Mariano Lino Reinoso & Gobernador & --- & Ene.-Feb. 75 & 1 \\
\hline Bartolomé Romero Leal & Gobernador & --- & Mar. 75 & 0 \\
\hline \multicolumn{5}{|l|}{ Valladolid } \\
\hline José Mozo & Diputado & S. Miguel & Jun. 74-Mar. 75 & 15 \\
\hline Luis Antona Semolinos & Diputado & Catedral & Jun.-Dic. 74 & 15 \\
\hline Enrique Castilla Lanuza & Diputado & Catedral & Ene.-Mar. 75 & 1 \\
\hline Juan Antonio Rábago & Diputado & S. Andrés & Jun 74-Mar. 75 & 14 \\
\hline Gaspar Villarias Ruiz & Diputado & S. Martín & Jun 74-Mar. 75 & 17 \\
\hline Miguel Ibáñez Martín & Diputado & S. Pedro & Jun.-Dic. 74 & 1 \\
\hline Manuel Fernández Rico & Diputado & S. Pedro & Ene.-Mar. 75 & 1 \\
\hline Eusebio Burgueño & Diputado & Salvador & Jun. 74-Mar. 75 & 16 \\
\hline Pedro Antonio Pimentel & Diputado & Santiago & Jun. 74-Mar. 75 & 13 \\
\hline Fernando Miranda González & Diputado & S. Nicolás & Jun. 74-Mar. 75 & 16 \\
\hline Juan Antonio Moras & Diputado & Valoria & Jun. 74-Mar. 75 & 6 \\
\hline Fidel Recio del Castillo & Diputado & Mucientes & Jun. 74-Mar. 75 & 13 \\
\hline \multicolumn{5}{|l|}{ Medina } \\
\hline Paulino Flores & Diputado & Medina & Jun. 74-Mar. 75 & 3 \\
\hline Francisco Macho Mesones & Diputado & Rueda & Jun. 74-Mar. 75 & 7 \\
\hline Pedro Montalvo & Diputado & Carpio & Jun. 74 & 1 \\
\hline Francisco López Flores & Diputado & Carpio & Nov. 74-Mar. 75 & 7 \\
\hline
\end{tabular}




\begin{tabular}{|c|c|c|c|c|}
\hline Telesforo Reoyo Pérez & $\begin{array}{l}56^{\circ} \\
\text { Presiden. }\end{array}$ & Rioseco & Jun. 74-Mar. 75 & 14 \\
\hline J. Manuel Cuadrillero Nájera & Diputado & Palazuelos & Jun. 74-Mar. 75 & 13 \\
\hline Venancio Izquierdo & Diputado & Villabrágima & Jun. 74-Mar. 75 & 15 \\
\hline Andrés Domínguez Mata & Diputado & Villar de Frades & Jun. 74-Mar. 75 & 10 \\
\hline \multicolumn{5}{|l|}{ Peñafiel } \\
\hline Eustaquio Torre Mínguez & Diputado & Peñafiel & Jun. 74-Mar. 75 & 13 \\
\hline Domingo Fernández Velasco & Diputado & Campaspero & Jun. 74-Mar. 75 & \\
\hline Felipe Tablares Maldonado & Diputado & Encinas & Jun. 74-Mar. 75 & \\
\hline Miguel Alonso Pesquera & Diputado & Quintanilla & Jun. 74-Mar. 75 & 12 \\
\hline \multicolumn{5}{|l|}{ Tordesillas } \\
\hline Marcelino Diez Bueno & Diputado & Tordesillas & Jun.-Dic. 74 & \\
\hline Pedro Gómez Rozas Reinero & Diputado & Tordesillas & Ene.-Mar. 75 & \\
\hline Fernando Arévalo Miera & Diputado & Torrelobatón & Jun 74-Mar. 75 & \\
\hline Andrés Fernández Fernández & Diputado & Tiedra & Jun 74-Mar. 75 & 1 \\
\hline \multicolumn{5}{|l|}{ Villalón } \\
\hline Ángel de la Riva Espiga & Diputado & Villalón & Jun 74-Mar. 75 & 14 \\
\hline Francisco Calderón Mantilla & Diputado & Mayorga & Jun 74-Mar. 75 & \\
\hline Eduardo López & Diputado & Cuenca C. & Jun 74-Mar. 75 & 1 \\
\hline Laureano Melero & Diputado & Villavicencio & Jun 74-Mar. 75 & \\
\hline \multicolumn{5}{|l|}{ Nava } \\
\hline Pedro Álvarez Guerra & Diputado & Nava & Jun 74-Mar. 75 & \\
\hline Fructuoso Pérez Minayo & Diputado & Alaejos & Jun 74-Mar. 75 & \\
\hline Mariano Gavilán Gavilán & Diputado & Castronuño & Jun 74-Mar. 75 & \\
\hline \multicolumn{5}{|l|}{ Olmedo } \\
\hline Francisco Martín Torés & Diputado & Olmedo & Jun 74-Mar. 75 & \\
\hline Segundo Cantalapiedra & Diputado & Matapozuelos & Jun.-Dic. 74 & \\
\hline \multicolumn{4}{|l|}{ Maestro } & \\
\hline Federico Botella & Diputado & Matapozuelos & Ene.-Mar. 75 & \\
\hline Pablo Valdés & Diputado & Portillo & Jun. 74-Mar. 75 & \\
\hline Miguel Velasco Neira & Vicepresid. & Mojados & Jun. 74-Mar. 75 & \\
\hline
\end{tabular}

\section{Los gobernadores y secretarios del Sexenio}

La figura del gobernador como el más importante individuo de la Diputación y vigilante por cuenta del Gobierno para conocer y dirigir las actividades de la Corporación va perdiendo fuerza a partir de la llegada del Sexenio y sus cambios legislativos. La pérdida de hegemonía del gobernador se inicia con la promulgación de la ley de "Organización y Atribuciones de las Diputaciones Provinciales" de 21 de octubre de 1868, ya que entre su articulado destaca:

La aparición de la figura del vicepresidente de la Diputación, que es nombrado por la propia Corporación y que preside las sesiones "en ausencia del gobernador", ausencia que cada vez es más frecuente.

El gobernador pasa de ser "la autoridad superior de la provincia" a ser "el representante del Gobierno en la provincia".

La ausencia del gobernador es cubierta por el vicepresidente de la Diputación.

Esta tendencia del gobernador a desentenderse de los problemas y actividades de la Diputación se acentúa con la "Ley Orgánica Provincial" del 20 de agosto de 1870, en la que sobresalen algunas novedades importantes, como son:

La Diputación nombra a un presidente de entre sus miembros.

El gobernador preside la Diputación "sin voto" cuando asista a las sesiones.

La ausencia del gobernador es cubierta de nuevo por el secretario del Gobierno, excepto en la Presidencia de la Diputación y de la Comisión Permanentel.

Un ejemplo de esta pérdida de representatividad y de influencia, se puede ver en la evolución de las sesiones de la Diputación que son presididas por el gobernador. Las Diputaciones que transcurren entre los años 1856 a 1868 y que son las Diputaciones duodécima a decimonovena de la época isabelina, se realizan un total de doscientas noventa y dos sesiones, de las que ciento noventa son presididas por el gobernador, es decir el $65,1 \%$. En el Sexenio, en cambio, la presidencia del gobernador es menor. En la primera Diputación el gobernador preside cuarenta y una de las noventa y ocho sesiones, el 41,84\%. En la segunda Diputación el gobernador 
preside veinticuatro de ciento veintisiete sesiones, el 18,90\%. En la tercera Diputación sólo preside once de setenta sesiones, es decir, el 15,71\%. En la cuarta Diputación son ocho de cuarenta y dos sesiones, el 19,04\%. En la quinta y última Diputación el gobernador preside dos de treinta y cinco, el 5,71\%. En el total del Sexenio el gobernador preside ochenta y seis de las trescientas setenta y dos sesiones que se celebran, lo que representa el $23,11 \%$.

Otro dato significativo de su pérdida de interés por la Diputación y su Presidencia son las frecuentes disculpas y justificaciones de las ausencias. Así tenemos que Primitivo Seriñá no se presenta en la Diputación, aunque remite una comunicación en la que "se ofrece a la Corporación". También Pedro Oller y Cánovas que se presenta "abre la sesión y expone que los asuntos del servicio le obligan con sentimiento a dejar la Presidencia y ausentarse". El gobernador González-Alegre se presenta en la sesión de la Diputación y sin tomar la presidencia "se retira para atender los asuntos que le están encomendados". Finalmente el gobernador Ambrosio de Villava convoca a la Diputación para la sesión de instalación, no se presenta a la misma y en su lugar se lee un comunicado "lamentando el no poder estar presente por impedírselo asuntos urgentes del servicio".

En conclusión, a partir del Sexenio, los gobernadores civiles dejan de ser considerados como presidentes de la Diputación, aunque se mantenga la formalidad de que "presiden las sesiones cuando asisten a las mismas", según lo establece la "Ley electoral" de 20 de agosto de 1870.

\section{Los diputados revolucionarios}

El cambio que se produce a nivel legislativo hace que el número de diputados en este período aumente de una forma espectacular, sobre todo a partir de la tercera Diputación. Ésta se forma, de acuerdo con la nueva "Ley Provincial" de 20 de agosto de 1870, con tantos diputados como distritos en los que está dividida la provincia. Es decir que de nueve diputados que forman las dos primeras Diputaciones del Sexenio pasamos a treinta y cinco, número con el que se forman las siguientes.

Entre octubre de 1868 y marzo de 1875 , pasan por la institución un total de noventa y cuatro diputados diferentes, repartidos entre las cinco Diputaciones, aunque el total de diputados que ejercieron entre todas ellas asciende a ciento cincuenta y cuatro, que se distribuyen de la siguiente forma. En la primera Diputación son nombrados veinte diputados entre titulares y suplentes, aunque algunos de estos últimos no llegaron a ejercer. En la segunda Diputación son nombrados únicamente nueve diputados, debido a que no se nombran suplentes y a que desaparecen en la división provincial dos partidos judiciales: Valoria y La Mota. La tercera Diputación está formada por un total de treinta y ocho diputados, de los que treinta y cinco se corresponden con los respectivos distritos electorales en que está dividida la provincia y los tres restantes son nuevos diputados elegidos en sustitución de los titulares, por diferentes motivos. En la cuarta Diputación son cuarenta y siete los diputados que ejercen en la legislatura, los treinta y cinco titulares que la inician, más otros doce, que en una ocasión son cinco y en otra son siete, que son nombrados, tras el cese de otros tantos, por el capitán general en febrero y mayo de 1874. En la quinta Diputación, la última del período, son cuarenta los diputados que actúan, y que se corresponden con los treinta y cinco que se nombran por los distritos más cinco que son nombrados en enero de 1875 , por el cese previo de los titulares, ya en el inicio de la Restauración.

Otro dato de interés sobre los noventa y cuatro individuos que ejercieron a lo largo del Sexenio, se refiere a su presencia en las diferentes legislaturas. Así tenemos que cincuenta y seis diputados ejercieron en una sola legislatura, diez y siete diputados lo fueron en dos Diputaciones, veinte diputados ejercieron en tres diferentes Diputaciones y un solo diputado estuvo presente en cuatro Diputaciones. Ninguno repitió en las cinco Diputaciones y siete de ellos únicamente habían sido diputados en el período isabelino. 


\section{La Secretaría de la Diputación}

Las nuevas autoridades revolucionarias tienen prisa en poner nuevamente en marcha la Secretaría de la Diputación y equiparla de funcionarios. Previamente a la instalación de la nueva Diputación, se forma la Comisión Especial de la Junta Revolucionaria de Valladolid, que se constituye en su sesión del día 14 de octubre de $1868^{354}$. El día 22 de octubre, ya recién instalada la primera Diputación del Sexenio, se vuelve a tratar el tema de la Secretaría, en esta ocasión para efectuar el nombramiento del secretario. ${ }^{355}$.

El establecimiento definitivo de la Secretaría se formaliza en la quinta sesión que celebra la Diputación el 23 de octubre, en la que, "de acuerdo con la ley de 21 del actual se procede al nombramiento de empleados de la Secretaría de la Diputación, ante la necesidad urgente de despachar los asuntos de la Corporación y se acuerda formar la siguiente plantilla" 356 . Se aprobó en la misma sesión un gasto de 2.400 escudos para material de escritorio. Esta plantilla se modifica en el mes de diciembre del mismo año 1868, con otros nombramientos ${ }^{357}$. En la sesión del 29 de mayo de 1869 , se vuelve a modificar la composición de la Secretaría tanto en el número de empleados, el escalafón y en el salario, quedando establecida de la siguiente forma ${ }^{358}$.

Con esta composición finalizan las actividades de la primera Diputación del Sexenio en octubre de 1869, aunque por poco tiempo. Nada más comenzar los trabajos de la nueva Corporación, en la sesión del día 3 de diciembre de 1869 , el diputado Liborio Guzmán, comisionado por el Pleno de la Diputación para "adecuar la plantilla

En ese acto "vieron reconocida la necesidad de tener empleados a su inmediato servicio que se ocuparan en preparar los negocios de la competencia de la Comisión y ejecutar los acuerdos que se tomasen por la misma con vista de su resultado y se acordó nombrar a Manuel Nieto Mazuelas, reponiéndole a la vez en el cargo de archivero provincial que venía desempeñando con el haber anual de mil escudos, a Manuel Rodríguez Morán, con el carácter de oficial a sueldo de 700 escudos anuales, a Joaquín Clavero Millán, con el de escribiente y sueldo de 400 escudos y para portero a Francisco Rodríguez, cesante del mismo cargo con anterioridad, con el de 300 escudos también anuales" A.D.P.V. Actas. Libro de actas del 14 de octubre de 1868, correspondiente a la Comisión Especial.

355 Entonces la Diputación "considera que es de indispensable necesidad contar con una persona de reconocida capacidad, con el carácter de secretario, que se encargue de despachar todos los negocios que sean competencia de la misma, y reuniendo todas las cualidades Juan Callejo Madrigal, secretario que fue de la Corporación en los años 1854-1856, con la circunstancia especial, además, de su decidida afección a la revolución nacional últimamente realizada, se acuerda por unanimidad nombrarle para el citado cargo..." A.D.P.V. Actas. Libro de actas del 22 de octubre de 1868.

${ }^{356}$ Secretario: Juan Callejo Madrigal con 1.600 escudos anuales. Vicesecretario y archivero: Manuel Nieto Mazuelas, con 1.000 escudos anuales. Oficial $1^{\circ}$ : Eduardo Marín del Castillo, con 1.000 escudos anuales. Oficial $2^{\circ}$ : Miguel Martínez Sagarmínaga, con 700 escudos anuales. Oficial $3^{\circ}$ : Agapito Cantalapiedra Hernández, con 700 escudos anuales. Oficial $4^{\circ}$ : Manuel Rodríguez Morán, con 700 escudos anuales. Oficial 5º: Tomás Dávila Amengual, con 600 escudos anuales. Escribientes: Pedro Fuentes Colino, con 400 escudos de sueldo. Pedro Asensio Quiroga, con 400 escudos de sueldo. Joaquín Clavero, con 400 escudos de sueldo anual. José Pérez Feijoo, con 400 escudos de sueldo anual. Porteros: Fernando Bravo, con 300 escudos de sueldo anual. Santiago Ceballos, con 300 escudos de sueldo anual. Depositario: Fidel Serrano, con 900 escudos de sueldo anual.

357 Simón Martín es nombrado nuevo oficial de la Secretaría encargado de los trabajos de Beneficencia, al quedar suprimida la Junta y asumir la Diputación la responsabilidad de sus actividades. Miguel Martínez Sagarmínaga abandona la Secretaría al ser nombrado administrador del Hospital. Agapito Cantalapiedra pasa de oficial $3^{\circ}$ a oficial $2^{\circ}$, Manuel Rodríguez Morán pasa de oficial $4^{\circ}$ a oficial $3^{\circ}$, Tomás Dávila pasa de oficial $5^{\circ}$ a oficial $4^{\circ}$ y Joaquín Clavero pasa a oficial $5^{\circ}$.

358 Secretario. Juan Callejo y Madrigal, con un salario anual de 2.000 escudos. $1 \stackrel{\text { er }}{\text { Oficial }}$ $1^{\circ}$.vicesecretario y contable: Eduardo Marín del Castillo, con 1.400 escudos. $2^{\circ}$ Oficial $1^{\circ}$ y depositario: Fidel Serrano, con 1.200 escudos. $3^{\circ}$ Oficial $1^{\circ}$ y archivero: Manuel Nieto Mazuelas, con 1.000 escudos. $1^{\text {er }}$ Oficial $2^{\circ}$ Manuel Rodríguez Morán, con 800 escudos. $2^{\circ}$ Oficial $2^{\circ}$ Simón Martín Herrero, con 800 escudos. $1^{\text {er }}$ Oficial $3^{\circ}$ Agapito Cantalapiedra, con 700 escudos. $2^{\circ}$ Oficial $3^{\circ}$ Tomás Dávila Amengual, con 700 escudos. Oficial $4^{\circ}$ Joaquín Clavero Millán, con 600 escudos. Auxiliares temporeros: Casto Marcos con 500 escudos, Eladio Gutiérrez con 500 escudos, Esteban Higuera con 400 escudos, José Pérez Feijoo con 400 escudos, Pedro Fuentes Colino con 400 escudos, Pedro Asensio Quiroga con 400 escudos, Pedro Fromerta con 400 escudos, Porteros: Fernando Bravo con 300 escudos y Santiago Ceballos con 300 escudos. 
a las necesidades reales de la Secretaría", presenta un dictamen: "Declarando cesantes a todos los empleados de la Secretaría, que cobran sueldo, a excepción del secretario, continuando como interinos, hasta que se realice una nueva plantilla de empleados y se nombren definitivamente en la primera sesión ordinaria del año. Se aprueba el dictamen por cinco votos contra cuatro".

El problema es que no se conforma una nueva plantilla y que la situación de interinidad no favorece el trabajo de la Secretaría con el aumento de los expedientes pendientes. Lo que provoca un aumento de las necesidades de empleados, lo contrario de lo que se pretendía en el dictamen del diputado Guzmán, por eso en la sesión del 19 de enero de 1870 queda reflejado que "vistas las dificultades que ocasiona el acuerdo de la Diputación del 3 de diciembre último, de declarar interinos a los empleados de la Secretaría, se acuerda: Confirmar en sus puestos a todos los empleados, y también se acuerda ampliar la plantilla con nuevos nombramientos" ${ }^{359}$.

Con esta plantilla finalizan las actividades de la segunda Diputación en febrero de 1871, y con el agradecimiento que hace el pleno de la Diputación al escribiente Leopoldo Vitini, "por los trabajos de realización del cuadro estadístico de todos los diputados desde 1813 hasta la fecha".

La plantilla queda estabilizada, pero a partir de enero de 1870 es con la persona del secretario con la que se inician una serie de acuerdos de cambio y de anulación de los acuerdos, que no tienen otra consecuencia que la interinidad que se produce a lo largo del año. El problema se inicia cuando en la sesión del 15 de enero de 1870 "se acuerda nombrar nuevo secretario en la persona de Joaquín Farias y Merino, con un sueldo de 2.000 escudos al año, y mientras se le provee del título continúa el actual secretario, Juan Callejo y Madrigal" A partir de esta fecha, el secretario Callejo no vuelve a firmar las actas y lo hace en su lugar como secretario interino, el vicesecretario Eduardo Marín de Castillo.

Como información complementaria, se sabe que el nuevo secretario Farias procede de la Diputación de Logroño, y el secretario de Valladolid Juan Callejo, es nombrado secretario de la Diputación de Logroño. Con estas premisas, la Diputación de Valladolid, en sesión celebrada el 20 de febrero de 1870 trata dos temas de Secretaría: a) Conceder a instancia de Joaquín Farias y Merino, licencia de un mes para recuperar la salud. b) Conceder la instancia presentada por Joaquín Farias y Merino, secretario de la Diputación de Logroño, en solicitud de permuta de los puestos. La Diputación de Valladolid acepta la propuesta y ratifica el nombramiento de Callejo como secretario, aunque en el mes de abril sigue actuando como secretario interino Marín del Castillo. El problema vuelve a aparecer cuando, finalmente el 26 de abril de 1870, Callejo toma posesión de la Secretaría de la Diputación de Valladolid. Pero al día siguiente, es Farias el que solicita la anulación del acuerdo de permuta, declarando la Diputación la nulidad del acuerdo el día 1 de mayo. A pesar de todas estas variaciones, acuerdos y desacuerdos, el 26 de Mayo de 1870 vuelve a aparecer ya de forma definitiva la figura de Callejo como secretario de la Diputación de Valladolid.

Las actividades de la tercera Diputación del Sexenio se inician en febrero de 1871 , sin cambios en la plantilla de funcionarios, aunque con la novedad de que, de acuerdo con la "Ley Provincial" de 20 de agosto de 1870, según el artículo veintiocho "la Diputación una vez constituida definitivamente, elegirá entre sus componentes a

$3593^{\text {er }}$ Oficial $2^{\circ}$ : Manuel Maté, con sueldo de 800 escudos anuales. $2^{\circ}$ Oficial $4^{\circ}$ : Sabas Conde, con sueldo de 600 escudos anuales. Escribientes: Eduardo Gutiérrez, con sueldo de 400 escudos anuales. Julián Mañueco, con sueldo de 400 escudos anuales. Gregorio Barragán, con sueldo de 400 escudos anuales. Leopoldo Vitini, con sueldo de 400 escudos anuales. Además, se cesa al auxiliar temporero Eladio Gutiérrez y se nombra en su lugar con carácter permanente a José Martínez Martínez. Se confirma como permanente al auxiliar Casto Marcos Tarrero. Se declara cesante al escribiente José Pérez Feijoo y se nombra en su lugar a Eustaquio Chico. Se cesa a Pedro Asensio Quiroga y se nombra a Julio Urrutia. 
dos secretarios para todas las sesiones...", sin cuestionar la figura del secretario de la Diputación, y que serán los responsables de verificar y firmar las actas. Así, a lo largo de esta legislatura actúan como secretarios en los diferentes períodos ordinarios y extraordinarios los siguientes diputados: Mariano Osorio, Marcelino Diez Bueno, Antonio Martín Vargas, Miguel Alonso Pesquera y Demetrio Gutiérrez Cañas. Por lo que respecta al colectivo de funcionarios de la Secretaría, en esta legislatura se producen dos cambios. En primer lugar, la renuncia del depositario Fidel Serrano, al ser nombrado auxiliar de Hacienda, y en consecuencia, en segundo lugar el nombramiento en sustitución del anterior de Julián Termens Cambronero. Completan estos cambios con la nueva configuración de la plantilla que se efectúa en el mes de julio de $1871^{360}$.

A partir del 2 de noviembre de 1872, fecha en que se inicia la cuarta Diputación del Sexenio, se nombran diputados secretarios con carácter interino a Marcelino Diez Bueno y a Segundo Cantalapiedra. Se reconoce el día 5 del citado mes a los titulares en las personas de Benigno Villalba y Miguel Ibáñez Martín manteniéndose sin cambios a lo largo de la legislatura. Lo mismo sucede con los funcionarios de la Secretaría, ya que entre noviembre de 1872 y mayo de 1874 no se produce ningún cambio en la composición de la plantilla.

La quinta Diputación inicia sus actividades el 30 de mayo de 1874, nombrando en el mismo día como secretarios titulares a los diputados Francisco Martín Torés y Fernando Miranda, que actúan como tales hasta el final de la legislatura en marzo de 1875.En las actas no están reflejados cambios en la plantilla, aunque en la sesión del 7 de noviembre de 1874 se estudia "la petición de los escribientes Jacinto Sánchez y Nicanor Sanz para que se les nivele el sueldo al de los demás de su clase". Sin tener constancia con anterioridad de la referencia de la contratación de estos nuevos funcionarios, ya que en su última plantilla conocida de la Secretaría no figuran estos nombres.

\section{Otras instituciones}

El cambio político lleva aparejado un cambio, tanto de las instituciones, como de los individuos que las dirigen, y el Sexenio Revolucionario es un claro ejemplo de ello.

\section{La Junta Revolucionaria}

El gobernador civil titular en septiembre de 1868 es el primero que sufre las consecuencias del cambio político, al ser destituido y encarcelado. En su lugar toma el mando de la provincia la Junta Revolucionaria Provincial, organismo que se crea para evitar un vacío de poder en el ámbito provincial. El 1 de octubre de 1868, tiene lugar la formación de la Junta, constituida por los siguientes señores: Genaro Santander, Liborio Guzmán, Eulogio Eraso Cartagena, Lucas Guerra, Remigio Calleja, José María Cano, Eugenio Alau, Eusebio de la Fuente, Manuel Gutiérrez Barquín, Laureano Álvarez, Francisco Goñi, Pablo de la Llana, Ángel Bellogin, Andrés Cea y Francisco Gospedal Muñoz

Se nombra presidente a Genaro Santander, que también asume el cargo de gobernador interino, y secretario a Laureano Álvarez. De los quince miembros de la Junta, siete han sido o serán nombrados diputados provinciales, uno es catedrático y los restantes son industriales y comerciantes. El 14 de octubre se amplía la Junta

\footnotetext{
360 "Estudiadas las modificaciones realizadas por la Comisión provincial, se acuerda confirmar en los cargos de: secretario Juan Callejo y Madrigal, contador Eduardo Marín del Castillo, tesorero Julián Termens Cambronero, archivero Manuel Nieto Mazuelas, oficial de Administración Tomás Dávila Amengual, oficial de Fomento Francisco Arranz, oficial de Beneficencia Joaquín Clavero Millán, oficial de Cuentas Agapito Cantalapiedra, encargado del Registro Casto Marcos, auxiliares Eduardo

Gutiérrez y Gregorio Barragán, escribientes Eustaquio Chico, Leopoldo Vitini, Julio Urrutia y Julián Mañueco. Porteros Santiago Ceballos y Fernando Bravo. Con esta reorganización se declaran cesantes a seis funcionarios".
} 
Revolucionaria Provincial, al incorporarse otros representantes de los partidos judiciales como son: Miguel Fernández Gallego, Manuel de la Cruz Alonso, Mariano Capdevila, Pedro Romero, Nicomedes Ruiz, Isidoro Valentín, Niceto Sanz, y Máximo Alonso.

Esta Junta actúa en el ámbito provincial, en representación del Gobierno Civil, y entre las funciones que se arroga está el nombramiento de los diputados provinciales que forman la primera Diputación del Sexenio. Su actividad se mantiene hasta el 30 de octubre, es decir, tiene un mes de actividad. En ese día, por un decreto del Gobierno central, "se ordena la disolución de las Juntas Revolucionarias".

\section{La Comisión Provincial}

El Consejo Provincial, institución de apoyo a la Diputación, que ha venido funcionando a lo largo de la mayor parte de la era isabelina, es disuelto por la Junta Revolucionaria de Valladolid, en el mismo día en que es constituida. Dicha suspensión será ratificada por el Gobierno central en comunicación publicada en el Boletín Oficial del 28 de abril de 1869, "haciendo valer la suspensión de los Consejos provinciales y el cese de todos su funcionarios".

Durante toda la legislatura de la primera Diputación, octubre de 1868 a octubre de 18 69, no funciona ningún organismo de colaboración. En la sesión de instalación de la segunda Diputación, que se celebra el 18 de octubre de 1869, el Pleno de la Diputación acuerda "la elección de la Comisión Permanente, en la cual se delegan las facultades para el examen y preparación de los negocios, recayendo en los Sres. Rodríguez Rubio, Rábago y Aspes”. Es la primera referencia a un nuevo organismo que ayude y colabore con la Diputación en la resolución de los expedientes, con el inconveniente de que este organismo no tiene reflejo de su actividad en las actas, es decir, no se puede asegurar que esté funcionando y resolviendo los asuntos provinciales que se le hayan podido encargar, aunque es una institución previa a la creación de la Comisión provincial.

La Comisión provincial es creada a través de la "Ley Orgánica Provincial” de 20 de agosto de 1870, que en su artículo cincuenta y siete dice que "la Diputación en su primera sesión ordinaria de cada año elegirá a los individuos que hayan de formar la Comisión provincial". En materia de competencias, la citada ley atribuye a la Comisión "la vigilancia de la exacta ejecución de los acuerdos, resoluciones de incidencias, reclamaciones y revisión de acuerdos". En definitiva, es el nuevo organismo colaborador de la Diputación, que sustituye al Consejo provincial de la época isabelina, y que tuvo como precedente a la Comisión Permanente durante 1870 , y que a diferencia del Consejo provincial y con similitud a la Comisión Permanente, está formado por diputados provinciales nombrados por la propia institución.

La Comisión provincial ${ }^{361}$ inicia sus actividades el 25 de febrero de 1871 , a los pocos días del arranque de la tercera Diputación del Sexenio. En febrero de 1872, se procede a la renovación parcial de los miembros de la Comisión, que queda formada por el vicepresidente Juan Antonio de las Moras y los vocales Laureano Álvarez López, Andrés Domínguez de la Mata, Eustaquio de la Torre Mínguez y Miguel Velasco Neira.

A lo largo de la vigencia de esta tercera Diputación entre febrero de 1871 y octubre de 1872 , se celebran un total de ciento setenta y seis sesiones en las que se

\footnotetext{
361 Los libros de actas llevan el título de Comisión Provincial, aunque en las actas tanto de las sesiones de la Diputación como las del Consejo, se escribe indistintamente Comisión Provincial y Comisión Permanente. "En la ciudad de Valladolid a 25 de febrero de 1871, bajo la presidencia del Sr. gobernador, se reunieron los Sres. Fernando Arévalo Miera, Sebastián Fernández Miranda, Miguel Ibáñez Martín, Eustaquio de la Torre Mínguez y Andrés Domínguez de la Mata, diputados provinciales elegidos en la sesión de día 23 del actual, individuos de la Comisión Permanente, el Sr. gobernador dio por instalada dicha Comisión, acordando acto seguido a proceder a la elección de vicepresidente, lo que recayó por unanimidad en D. Fernando Arévalo Miera, que aceptó y tomó posesión. Como secretario actúa el de la Diputación D. Juan Callejo y Madrigal”
} 
tratan numerosos temas sobre Beneficencia, Sanidad, Enseñanza, Aprovechamientos forestales, Ayuntamientos, Propios, Precios medios, Obras públicas, Arbitrios, Impuestos y Repartimientos. Pero sobre todo destaca el número de sesiones dedicadas a las quintas, tanto en la faceta de reclutamiento como en la de reclamaciones.

La cuarta Diputación del Sexenio inicia sus actividades el 2 de noviembre de 1872, y la reinstalación de la Comisión provincial tiene lugar el 13 del mismo mes y año, con la toma de posesión de los vocales nombrados. Figuran el vicepresidente Juan Antonio de las Moras y los vocales Miguel Velasco Neira, Pablo Pinilla, Galo Olivares y Manuel Gutiérrez Barquín, que dimite en abril de 1874, al ser nombrado gobernador civil de Pontevedra, y es sustituido por Segundo Cantalapiedra.

En abril de 1873, la Comisión presenta al Pleno de la Diputación una memoria de sus actividades, y entre las que destaca que "entre el 7 de diciembre de 1872 y el 10 de marzo de 1873 se han celebrado cincuenta y una sesiones con mil setenta y seis temas tratados y acordados". Como resumen de las actividades de esta legislatura, entre noviembre de 1872 y mayo de 1874 , se celebraron ciento cuarenta y cuatro sesiones, en las que se repiten los temas de la legislatura anterior y en las que vuelve a destacar el alto número de sesiones dedicadas a los quintos, ya sea por los reclutamientos como por las reclamaciones.

Finalmente, en la quinta y última Diputación del Sexenio, la Comisión provincial inicia sus actividades el 31 de mayo de 1874, sesión a la que se elige al vicepresidente Eustaquio de la Torre Mínguez y a los vocales Gaspar Villarías, Marcelino Diez Bueno, Andrés Domínguez de la Mata y Pedro Montalvo. Éste último fallece a los pocos días de tomar posesión, y es sustituido por el diputado Pedro Álvarez Guerra. También como novedad en esta legislatura son nombrados vocales suplentes a los diputados Eduardo López, Luis Alonso Burgueño, Pablo Valdés, Fructuoso Pérez Minayo y Felipe Tablares Maldonado

En enero de 1875, ya con la Restauración en marcha, Pedro Gómez de Rozas Reynero, sustituye a Marcelino Diez Bueno. En esta legislatura, entre junio de 1874 y marzo de 1875 , se celebran ciento veinte y cinco sesiones, y vuelven a sobresalir las dedicadas a quintas, que entre las sesenta y seis sesiones que se celebran de junio a noviembre, son algo más del $50 \%$ del total de las actividades de la Comisión.

\section{Autoridades y otras personalidades}

En las diversas instituciones, tanto de carácter regional, provincial o local, tienen lugar los siguientes nombramientos:

\section{Ayuntamiento}

Cándido González Gutiérrez es nombrado alcalde el 4 de octubre de 1868 por la Junta Revolucionaria y permanece en el cargo hasta fin de año. Le sucede Emiliano Tarazona Barragán, que tomo posesión en el mes de enero de 1869 hasta el mes septiembre del mismo año. José del Olmo Palomera ejerce sólo en el mes de octubre de 1869 y Liborio Guzmán Lucas en los meses de noviembre y diciembre del repetido 1869. Blas Dulce Álvarez se mantiene en la Alcaldía durante los años 1870 y 1871.

Mariano Barrasa Díez es alcalde en 1872, hasta julio de 1874, con un paréntesis entre los meses de septiembre y diciembre de 1873, en los que estuvo al frente del Ayuntamiento republicano Manuel Pérez -Terán Yenes. José del Olmo Palomera vuelve a ejercer de alcalde entre julio de 1874 y abril de $1875^{362}$.

\section{Capitanía General}

En este período la Capitanía General vuelve a ser uno de los destinos más inestables entre todas las instituciones de nivel nacional. Ejercen este cargo: En 1868 José Martínez Tenaquero. En 1869 Ramón Gómez Pulido y Francisco de Paula Garrido. En 1871 Mauricio Socias del Jaguar, Juan de Acosta y Muñoz y Gabriel Baldrich y Palau. En 1873 Domingo Ripoll y Gimeno. En 1874 Eulogio González Iscar, Mariano Álvarez de Bohorquez (Duque de Gor) Agustín de Burgos y Llamas y

\footnotetext{
362 CARASA SOTO, Pedro (Dir.). Diccionario Biográfico de Alcaldes ... ob. cit. Págs. 13 a 15
} 
José de la Gándara y Navarro. En 1875 Rafael Acedo y Rico-Amat (Conde de la Cañada).

\section{Diputados a Cortes}

En escrutinio celebrado en el salón de sesiones de la Diputación el 30 de enero de 1869, se descubrieron los siguientes resultados: Atanasio Pérez Cantalapiedra con 16.366 votos, Sabino Herrero Olea con 15.893 votos, Carlos O'Donell. Duque de Tetuán, con 15.852 votos. Antonio Méndez Vigo con 14.242 votos y Gaspar Núñez de Arce con 12.612 votos.

En las elecciones celebradas en el mes de marzo de 1871, resultaron elegidos Sabino Herero Olea, Juan Muñoz Vargas, José Muro López-Salgado, Toribio Valbuena Rodríguez y Atanasio Pérez Cantalapiedra.

A lo largo del año 1872 se celebraron dos elecciones. En las del mes de abril, resultaron elegidos Manuel Cantero San Vicente, Sebastián Fernández Miranda, Miguel Herrero López, José Muro López-Salgado y Cándido Pimentel Arévalo. En las celebradas en el mes de agosto salen diputados Liborio Guzmán Lucas, Miguel Herero López, Sabino Herero Olea, José Lagunero Guijarro, Benito Moreno Redondo y Pedro Perotes Vargas.

En el mes de mayo de 1873 se celebran las últimas elecciones correspondientes a este período revolucionario. En las mismas resultan diputados Laureano Álvarez López, Benito Romero, José Muro López-Salgado, Pedro Romero Peláez, Esteban Samaniego Muñoz y Toribio Valbuena Rodríguez ${ }^{363}$.

Obispado

Continúa como Arzobispo de Valladolid, a lo largo de todo el período del Sexenio, el Cardenal Juan de la Cruz Ignacio Moreno y Maisonave. A partir de 1875 deja la sede vallisoletana al ser nombrado Cardenal-Arzobispo de Toledo.

\section{Universidad}

Atanasio Pérez Cantalapiedra ejerce como rector hasta el 1 de febrero de 1869, al ser nombrado diputado a Cortes. Andrés de la Órden le sucede a partir de julio de 1869 hasta octubre de 1870. Eugenio Alau y Comas lo es entre 1870 a 1872 y José María Frías a partir de 1872 hasta 1879.

\section{Delegados de Hacienda}

Es una actividad que habitualmente ha sido estable, pero que en el Sexenio resulta con numerosos cambios. En estos años tenemos a:

Eugenio Rodríguez del Olmo, nombrado el 16 de octubre de 1868. Teodomiro Collazo, el 19 de noviembre de 1868. Francisco de Sales Ordóñez el 27 de enero de 1871. Perfecto Arnaez el 17 de noviembre de 1871. Emilio García Moré, el 11 de julio de 1872. Manuel López Fariñas, el 9 de enero de 1873. José Pérez Valdés, el15 de abril de 1873. Bricio M. Caramés, el 26 de febrero de 1874. José Nebot, el 23 de junio de 1874.

\section{Actividades de la Corporación en el Sexenio}

A lo largo de estos seis años, la Diputación se consolida y afianza sus actuaciones. Aunque sean años tan difíciles como los anteriores, las actividades se van normalizando y se aceptan como parte importante y necesaria para el desarrollo de la provincia.

Como puntos importantes a destacar, tenemos en primer lugar los cambios en la gestión de la institución propiciados por la puesta en marcha de una legislación más abierta, que coincide con una mayor autonomía de la Diputación y que sobre todo la exime de la tutela del gobernador. Es importante esta medida, que se mantendrá en el futuro, de autonomía institucional, es decir, que la Diputación trata sobre un tema, lo discute y lo aprueba o rechaza en función de su decisión democrática y no tiene que estar pendiente de la última palabra del gobernador. Hemos señalado en estas páginas como "un lunar democrático" el que tres de las cinco Diputaciones fueron nombradas

\footnotetext{
${ }^{363}$ CARAS A SOTO, Pedro (Dir.). Diccionario biográfico de parlamentarios...ob cit. Págs. 3 y sig.
} 
y no elegidas, más bien, a causa de las turbulencias políticas que de las injerencias del gobierno en la vida provincial.

En segundo lugar es interesante conocer la importancia de la Comisión Permanente en apoyo del trabajo de la Diputación. Comisión que está formada por cinco diputados provinciales, es decir los nombra la Diputación de entre sus miembros, y que se dedican a preparar, estudiar y presentar en los Plenos, los trabajos que deben de ser evaluados y aprobados si procede por el propio Pleno.

En tercer lugar y como trabajos a destacar en este período anotamos: Las ayudas a la sequía que en los inicios del Sexenio asolan los campos castellanos. La creación de la Granja-Escuela. Los trabajos que se organizan para la celebración de las numerosas elecciones municipales en todos los pueblos de la provincia. Los trabajos de mejora de la sanidad y de la beneficencia. Las numerosas sesiones dedicadas a la elaboración de los presupuestos. El sorteo de los quintos que le corresponden a la provincia, con las consiguientes sesiones para "oír las reclamaciones". Todo ello enmarcado en un ambiente más político de lo que habitualmente se reflejaba en anteriores Diputaciones. También los trabajos de construcción de ferrocarriles y carreteras, los repartimientos, la enseñanza, en definitiva, todas las actividades que son asumidas por la Corporación, son vistas con agrado por los habitantes de la provincia, que admiten como beneficiosos los trabajos que a través de la misma se llevan a cabo.

En definitiva, si algo destaca en estos años es la proliferación de las actividades de índole política. Ya hemos reflejado con anterioridad el que la ciudadanía está más politizada, que dentro de un ambiente progresista destaca el republicanismo de la población, que la puesta en marcha del sufragio universal es un aliciente añadido y por el que los ciudadanos habitualmente excluidos de las elecciones se sientan "importantes" a la hora de ejercer el derecho de voto.

Por otra parte, y retomando la tendencia política de los diputados podemos observar que la burguesía no ha perdido el control de la Diputación, tanto en las legislaturas de nombramiento como en las de elecciones. En las relaciones de diputados podemos ver a los representantes de las familias más poderosas de la provincia. Los Alonso Pesquera, Pimentel, Miranda, de las Moras, Arévalo, López Flórez, etc., etc., son un ejemplo de la presencia en la institución de la burguesía harinera, industrial y propietaria, a pesar de las dificultades por las que han pasado en los últimos años de crisis ${ }^{364}$

\section{5.- ÍNDICE ONOMÁSTICO DE FUNCIONARIOS Y PERSONALIDADES}

\section{FUNCIONARIOS}

A

Alba García, César

Alonso, Antonio

Álvarez, Miguel

Arranz, Francisco

B

Barragán, Gregorio

Brocos, Andrés

C

Caballero, Modesto

Cano Urquijo, José María

Cantalapiedra Hernández. A

Ceballos, Santiago

Cifuentes, Serafín

Conde, Sabas

D

Dávila Amengual, Tomás

Alderete Fernández, Valentín

Altolaguirre, J. Nepomuceno

Álvarez, Santiago

Asensio Quiroga, Pedro

Bravo, Fernando

Callejo y Madrigal, Juan

Cano, Mariano

Capdevila, Alejandro

Chico, Eustaquio

Clavero Millán, Joaquín

Díaz, Manuel

${ }^{364}$ SERRANO GARCÍA, Rafael. La revolución de 1868 en Castilla y León. Ed. Universidad de Valladolid. Valladolid. 1992. 
Diez, Julián

Farias y Merino, Joaquín

Fernández Villegas, Bernabé

Ferreras, José

Fuentes Colino, Pedro

G

González, Agustín

Gutiérrez, Eduardo

H-I-J

Hernández, José

Higuera, Esteban

Jiménez, Bibiano

L-LL

Larraga, Deogracias

M

Mañueco, Julián

Marín del Castillo, Eduardo

Martín Herrero, Simón

Martínez Chantrero, Joaquín

Martínez Sagarmínaga, Miguel

Merino, Bernabé

Moras, Félix de las

Mota, Dionisio

$\mathbf{N}$

Nieto Mazuelas, Manuel

O-P

Pérez Feijoo, José

Poo, Antonio de

R

Real Bazaco, Natalio

Rodríguez, Francisco

Rodríguez Morán, Manuel

$\mathbf{S}$

Sáez, Simón

Sanz, Nicanor

Soriano, Roque

T-U

Termens Cambronero, Julio

Urrutia, Julio

V

Valentín Fernández, Eugenio

Vela, José

\section{PERSONALIDADES}

A

Acedo y Rico-Amat, Rafael

Acuña, Cayetano

Alau y Comas, Eugenio

Alfaro, Tomás

Alonso, Máximo

Altuna, José Antonio

Álvarez Bohórquez, Mariano

Álvarez García, Manuel

Álvarez Osorio, Ángel Juan

Armero y Peñaranda Joaquín

Arrazola García, Lorenzo

B

Baldrich y Palau, Gabriel

Barahona, Gregorio

Barrasa, Mariano

Bellogín, Ángel

Bernárdez, Joaquín

Bohórquez, Ramón

Burgos y Llamas, Agustín

Domínguez, Manuel

Fernández Pellón, José

Ferrer, José

Fromerta, Pedro

González, Juan Nepomuceno

Gutiérrez, Eladio

Herrero, Vicente

Inés, Santiago

Llera, Felipe

Marcos Tarrero, Casto

Maroto y Salcedo, Sixto

Martínez Martínez, José

Martínez Mondelo, Francisco

Mate, Manuel

Morales, Eleuterio

Moras, Miguel Francisco de las

Nión, Alejandro

Pinar, Antonio

Redondo, Felipe

Rodríguez, Norberto

Rojas, Severino

Sánchez, Jacinto

Serrano, Fidel

Suárez, Antonio María

Tomillo, Pedro

Valverde, Anacleto

Vitini, Leopoldo

ACTIVIDAD

Capitán General

Hacienda Pública

Rector

Comerciante

Junta Revolución

Alcalde

Capitán General

Diputado Cortes

Diputado Cortes

Capitán General

Diputado Cortes

Capitán General

Alcalde

Alcalde

Junta Revolución

Secretario Gob.

Capitán General

Capitán General
Acosta y Muñoz, Juan

Adámez, José

Alesón, Atanasio

Allande Valledor, Faustino

Alonso Rubio, Agustín

Álvarez, Antonio María

Álvarez Cossío, Vicente

Andrés de la Torre, Diego

Araujo Canedo, Tomás

Arnáez, Perfecto

Aspíroz, Francisco Javier

Balmaseda

Barcial, Hipólito

Belloch, Ricardo

Belloso Melgar, Joaquín

Blanco Salcedo, Domingo

Bresón, Mariano

\section{ACTIVIDAD}

Capitán General Diputado Cortes Capitán General

Alcalde

Faccioso

Capitán General

Consejero

Alcalde

Diputado Cortes

Hacien. Pública

C. General

Faccioso

Funcionario M.

Secretario

Diputado Cortes

Alcalde

Capitán General 
C

Caballero, Eugeni

Calvo Asensio, Pedro

Calleja, Remigio

Cámara, Ciriaco

Cantero San Vicente, Manuel

Caraciolo Bayón, Francisco

Carandolet, Luis de

Carrión, Antonio

Castillón, Francisco

Cea, Andrés

Claussel

Concha, Manuel dela

Cuesta, Pedro

D

Díaz de Rueda, Ricardo

Díez Pedreño, Eugenio

E

Egozcue, Juan José

España, Carlos

Espinosa, Jacobo

F

Fernández Andrés, Avelino

Fdez. de Córdoba, A.

Fernández Mantilla, Juan A.

Fernández Rico, Juan

Fernández Velasco, Eusebio

Figueroa y Betón, Félix de

Francés de Alaíza, José

Frías, José María

G

Galiano, Faustino

Galván, Pedro

Garaizabal, José de

García, Eustaquio

García, Pedro

García Moré, Emilio

García Ureña, Andrés

Guerra, Lucas

Gil Muñoz, León

Gómez Escribano, Saturnino

González Gutierrez, Cándido

González Iscar, Eulogio

González Silvestre

Gospedal Muñoz, Francisco

Gutierrez Calderón

H-I

Heras, Manuel de las

Herrero Olea, Sabino

L

Lagunero Guijarro, José

Lapuerta, Pedro

Latre, Manuel

Laviña, José María

Lirio, Santiago

Llanos Gutiérrez, Valentín

López de Baños Monsalve M.

López Fariñas, Manuel

Lorenzo, Manuel

M

Magaz, Jerónimo

Mahy, Nicolás

Martín Casado, Ignacio

Martín Gómez, Vicente

Medina Canales, Antonio

Melero Andrés, Higinio

Mendigutía, José María
Alcalde

Diputado Cortes

Junta Revolución

Comerciante

Diputado Cortes

Consejero

Capitán General

Secretario Gob.

Gob. Militar

Junta Revol.

General

Capitán General

Alcalde

Consejero

Diputado Cortes

Hacienda Pública

General

Capitán General

Corregidor

Secretario Gob.

Comerciante

Industrial Har.

Diputado Cortes

Secretario

Consejero

Rector

Secret, Gob.

Consejero

Comerciante

Contador Rentas

Arquitecto

Hacienda Públ.

Alcalde

Junta Revolución

Diputado Cortes

Alcalde

Alcalde

Capitán General

Candidato Dip.

Junta Revolución

Industrial Harinero

Alcalde

Periodista

Diputado Cortes

Regidor

Capitán General

Capitán General

Diputado Cortes

Diputado Cortes

Diputado Cortes

Hacienda Pública

Capitán General

Rector

Capitán General

Consejero

Alcalde

Alcalde

Alcalde

Consejero
Cabezudo, Fernando

Candidato

Calvo Raso, Pedro Pascasio Alcalde

Calleja, Félix

Diput.Corte

Campuzano Herrera, José

Cañas Portocarrero, V.

Caramés, Bricio, M.

Carratalá, José

Castaños, Francisco Javier

Castro, Alejandro

Chacel, Eladio

Collazo, Teodomiro

Cuadrillero, Gaspar

C.General

Dip.Cortes

Hacienda

C. General

C. General

Intendente

Consejero

Hacienda

Diput. Cortes

Díez, Vicente

Dulce Álvarez, Blas

Consejero

Alcalde

Eraso Cartagena, Eulogio

Espartero, Baldomero

Junta Revol.

General

Esteban Díez, Epifanio

Diputado Cortes

Fernández Camaró, Manuel Alcalde

Fernández Gallego, Miguel Junta Revoluc

Fdez .Maquieira, Benito Dip. Cortes

Fdez. San Román, Eduardo General

Fernández Velasco, Pedro Promotor Fiscal

Flórez, José Tomás

Francos, Domingo Jesús

Diputado Cortes

Diputado Cortes

Galvir, Pedro

Jefe Político

Gándara y Navarro, José

Gardoqui Orueta, Cesáreo

García, Inocencio

C. General

Alcalde

Consejero

García Fernández, Román Diputado Cortes

García Moreno, Francisco Jefe Subalt.

Garrido y Enrile, F. de Paula General

Gil, Fabián Secretario

Gil Muñoz, Vicente Diputado Cortes

Gómez Pulido, Ramón Capitán General

González Puertas, Pedro N. Diputa Cortes

González Romero, Justo Haciend Pública

Goñi, Francisco

Güel y Renté, José

J. Revolución

Diput. Cortes.

Herrero de la Cruz, Cipriano Comerciante

Iztueta, José María

Comerciante

Landeta Cueto, Vicente

Alcalde

Lastra y Cuesta, Luis de la

Lavinay, Francisco

Lecanda Eloy

Llana, Pablo de la

López de Arce, Isidro

López Bustamante, Juan

López Redondo, Nemesio

Hacienda

Comerciante

Junta Revolució

Coronel

Alcalde

Alcalde

Maestro, Julián

Manso López, José

Martín Empecinado, Juan

Martínez Tenaquero, José

Medinaceli, Duque

Méndez Vigo, Santiag

Merino, Anselmo
Candidato Dip.

Capitán General

General

Capitán General

Aristócrata

Capitán General

Consejero 
Monclús, Bernardo

Morales, Esteban

Moyano, Pedro

Moyano Samaniego, Claudio

Muñoz Vargas, Juan

$\mathbf{N}$

Nebot, José

Nieto, Matías

Núñez de Arce, Gaspar

Ochotorena, Pedro

O'Donell, Carlos

Olmo, José del

Ordoñez Palomera, Francisco

Orozco y Zúñiga, José

Osorio, Manuel

Olmedilla y Escobedo, Diego A.

P-Q

Palacios y Villalba, Manuel

Pardo, Blas

Pasalodos y Roldán, Juan

Pérez de Castro, Evaristo

Pérez-Terán Yenes, Manuel

Perillán, Francisco Miguel

Pimentel Arévalo, Cándido

Prieto, Santiago

Quiroga, Agustín

Ramonet Jaraba, Francisco

Reggio, Duque de

Reguera, Pedro

Remisa, Marqués de

Reynoso Abril, Mariano Miguel

Ricafort, Mariano

Ripoll y Gimeno, Domingo

Rivero, Felipe

Rodríguez del Olmo, Eugenio

Ruiz, Faustino

Ruiz Salcedo, Sebastián

S

Saavedra, Domingo

Salcedo Nuñez y Cia

Sanchez Esteban

San Miguel, Santos

Sanz Moreno, Rafael

Seoane Bayón, Juan Antonio

Serrano Bedoya, Francisco

Silvela, Francisco Agustín

Soto Valcarce, Vicente José

T

Tarancón, Manuel Joaquín de

Toledano, Juan Baltasar

U

Ugarte Alegría, Gabriel

Undabeitia, José María

Ureña Cadenes, Manuel

V-W

Valentín, Isidro

Valledor, Faustino

Vildósola, A. Florencio de

Villar de la Torre, Juan M.

Wat, Jorge

$\mathbf{Z}$

Zariategui

Zamacoa y Cia.
Comerciante

Hacienda

Diputado Cortes

Diputado Cortes

Diputado Cortes

Hacienda Pública

Secretario Gob.

Diputado Cortes

Alcalde

Diputado Cortes

Alcalde

Hacienda Pública

Capitán General

Jefe Subalterno

Alcalde

Contador Rentas

Rector

Diputado Cortes

Diputado Cortes

Alcalde

Periodista

Diputado Cortes

Consejero

Capitán General

Diputado Cortes

Militar

Repostero Ayto.

Banquero

Ministro-Alcalde

Capitán General

Capitán General

Capitán General

Hacienda Pública

Hacienda Pública

Comerciante

Secretario Gob.

Comeerciante

Alcalde Curiel

Capitán General

Diputado Cortes

Diputado Cortes

Capitán General

Diputado Cortes

Obispo

Rector- Senador

Obispo

Diputado Cortes

Hacienda Pública

Alcalde

Junta Revolución

Alcalde

Alcalde

Alcalde

Ingeniero

Faccioso

Comerciante
Montijo, Conde de

Capitán General

Moreno Maisonave, Ignacio Obispo

Moyano, Tomás

Diputado Cortes

Muñoz, Gerónimo

Jefe Político

Negri, Conde de

Faccioso

Nogueras, Agustín

Político

O'Donell y Anethau, Carlos General

O'Donell, Enrique

Oller Menacho, José

Diputado Cortes

Alcalde

Orense, José María

Diputado Cortes

Ortiz Vega, Antonio

Comerciante

Osuna, Duque de

Aristócrata

Palarea Soto, José María

Parreño y Lobato, F.

Pavía y Lacy, Manuel

Pérez Delgado, José

Pérez Valdés, José

Perotes Vargas, Pedro

Proyect, Luis

Puidullés, Luis

Alcalde

Capitán General

Capitán General

Milicia Nacional

Hacienda

Diputado Cortes

Secretario Gob.

Jefe Político

Rebollo, José María

Reille

Secretario Gob.

Remírez Gil, José

Remolar, Esteban

General

Diputado Cortes

Médico

Ribeiro Díez, Juan Antonio Contador Propios

Ríos, Salvador M. de los Consejero

Rivadeneira, Juan Antonio Obispo

Rodríguez Camaleño, Luis Diputado Cortes.

Romero, Benito

Diputado Cortes

Ruiz del Portal, Manuel Contador Rentas

Ruiz, Nicomedes

Jun. Revolución

Salaverría, Pedro

Diputado Cortes

Samaniego Muñoz, Esteban Diputado Cortes

San Juan, Gil

Alcalde

Santocildes

General

Seniosain, Miguel

Seoane Sobral, Mateo

Sigler Ceballos, Juan

C. General

Diputado Cortes

Alcalde

Socias del Jaguar, Mauricio Capitán General

Tarazona Barragán, EmilianoAlcalde

Torres Casado, José Alcalde

Ulloa y Cáceres, Álvaro

Diputado Cortes

Urbina y Daoiz, Cayetano

Capitán General

Valle, Antonio María

Rector

Varela, Calixto

Alcalde

Vives, Francisco Dionisio

Vinuesa

Wellington, Lord

Capitán General

Relator Aud.

General

Zorrilla, Miguel

Diputado Cortes 


\section{4.-ACTIVIDADES DE LA DIPUTACIÓN}

\section{1.-FUNCIONES GENERALES Y AUTORIDAD POLÍTICA}

Las Diputaciones provinciales nacen al amparo de la Constitución de 1812, y de su articulado se deducen las funciones que deben de desarrollar. Así como el artículo trescientos veinticinco señala que las Diputaciones "nacen para promover la prosperidad de la provincia", en el artículo trescientos treinta y cinco, nos detalla cuáles son las actividades encomendadas. Nos habla de los repartimientos, tan to de las contribuciones como de los mozos destinados a los ejércitos, de los Ayuntamientos y la administración de sus bienes, de las comunicaciones y obras públicas, de la educación, de la beneficencia y sanidad, en fin de todo lo que es tendente a mejorar la vida de los habitantes de la provincia. Este encargo se mantendrá a lo largo de su existencia, o cuanto menos, hasta la llegada de la Restauración, que es el espacio cronológico que analizamos.

\subsubsection{FUNCIÓN EN LA ÉPOCA CONSTITUCIONAL GADITANA. 1813-1814}

En este período inicial de la vida de la Diputación, que viene precedido de una cruenta guerra contra los franceses, las Diputaciones en general y la de Valladolid en particular, se encuentran con que las funciones que recoge la Constitución y que posteriormente detalla la "Instrucción para el Gobierno Económico-Político de las Provincias" ${ }^{365}$, son amplias y pretenciosas. Especialmente porque dicen lo que tienen que hacer, pero no las proveen de los medios necesarios. Es decir, el mayor problema con que se encuentra la Diputación no está en poner en marcha las obras públicas provinciales que considere más necesarias, o la promoción y el fomento de la enseñanza, o el mantenimiento con dignidad de los centros benéficos y asistenciales, por poner ejemplos claros, sino que, sobre todo, el problema radica en la falta de previsión económica para poder desarrollar todas esas actividades. Particularmente en una época que destaca por la penuria y la pobreza de unos pueblos que llevan muchos años siendo esquilmados, en un principio lo fueron por las tropas invasoras francesas, posteriormente lo serán por las exigencias y necesidades de los ejércitos nacionales y sus aliados, y finalmente en todo tiempo por el Erario Público. Éste imponía una presión recaudatoria sin miramientos, que sólo se preocupaba de aumentar los ingresos y que era incapaz de ordenar las cuentas, reducir los gastos, o cuando menos, equilibrar los gastos con los ingresos.

Por esta razón, a lo largo de esta corta etapa de vigencia de la Diputación, su actividad nos viene centrada, en primer lugar, por la preocupación básica de realizar los repartimientos de las contribuciones, lo que llevaba aparejada su recaudación, ya sea de buen grado o a la fuerza, y en segundo lugar necesitaba dar contestación e intentar solucionar las numerosas reclamaciones que la citada contribución generaba, así como los recursos, quejas y agravios comparativos que recibían.

El primer año de vigencia de la Corporación, ésta tiene que tratar un gran número de expedientes, para lo cual no estaba preparada. Ello ocasiona su acumulación, tanto por el gran número de reclamaciones, que constituían la mayoría de los expedientes, como por las peticiones de los habitantes de la provincia, que habían depositado en la Diputación sus esperanzas para la resolución de todos los problemas que les aquejaban. El libro de actas nos lo refleja de una forma clara ${ }^{366}$.

365 Ley publicada con fecha 23 de junio de 1813.

366 "De acuerdo con lo estipulado en la Constitución, se inician las sesiones del segundo año en la ciudad de Valladolid a los once días del mes de marzo de mil ochocientos catorce... ...y habiéndose reunido para la apertura de las nuevas sesiones del segundo año, fue presentado por el secretario del libro de actas, un extracto firmado de ellas y un estado general clasificado de los diferentes asuntos, acabados y pendientes, que pasaban de cuatro mil cuatrocientos, con otro estado particular relativo a los presos..."A.D.P.V. Actas. Libro de actas correspondiente al día 11 de marzo de 1814. 
Desde el 2 de septiembre de 1813 al 10 de marzo de 1814, cuatro mil cuatrocientos asuntos "acabados y pendientes" son excesivos para un período tan corto de tiempo. Como hemos apuntado anteriormente, en su mayoría son asuntos que corresponden a recursos sobre reintegros de cantidades por suministros a las tropas, quejas por no poder ejercer el "libre comercio", de reciente legislación, reclamaciones sobre repartimientos, agravios comparativos, situación de "dispersos" (individuos enrolados en el ejército y en la guerrilla que abandonaron la milicia al fin de la guerra), etc.

Si en el primer año de vigencia, la Diputación tuvo sesiones entre septiembre y diciembre de 1813, el segundo año también está enmarcado en un período corto de tiempo, desde marzo a junio de 1814. En este tiempo se repiten los afanes de la Diputación para resolver unos problemas que también se repiten y que están, en la mayoría de los casos, ocasionados por la penuria económica, la escasez de las cosechas y el escaso desarrollo comercial e industrial en que está sumida la provincia.

\subsubsection{ACTIVIDADES EN EL TRIENIO LIBERAL. 1820-1823}

En el tiempo de vigencia de la Diputación, coincidente con el período del Trienio Liberal y nuevamente de acuerdo con el mandato de la Constitución, la Corporación provincial se preocupó de solucionar, o al menos intentarlo, los problemas que afectaban a la provincia. Será al final del período, con la aprobación de dos nuevas leyes relativas a la organización provincial, las que marcarán el camino para el desarrollo de la política provincial y el asentamiento de la Diputación.

La primera fue la "Ley de "División Provisional del Territorio Español", aprobada por decreto del 27 de enero de 1822, que facilitará la ordenación provincial tanto en el número de pueblos como en los límites de las diferentes provincias" ${ }^{367}$. La segunda fue la "Ley de 3 de Febrero de 1823 sobre el Gobierno Económico-Político de las Provincias", que trataba sobre la organización de las Diputaciones, con un mayor carácter liberal y con un desarrollo más amplio y detallado que el expuesto en la Constitución de 1812. Repetía las mismas competencias, es decir, sobre contribuciones con sus repartimientos y sus reclamaciones, sobre Ayuntamientos y el control de arbitrios, propios y pósitos, sobre reemplazos y milicias con sus repartimientos y reclamaciones correspondientes, sobre presupuestos, sobre obras públicas, sobre beneficencia y sanidad, sobre instrucción pública, sobre censo y estadística, sobre fomento de la riqueza de la agricultura y del comercio" ${ }^{368}$. Como vemos por sus fechas de aprobación, estas dos leyes, apenas tuvieron vigencia en este período, y por lo mismo no llegarán a tener influencia en las actividades de la Diputación.

Los trabajos que desarrolla la Diputación se vuelven a repetir de una manera similar a los efectuados en la primera época. Nuevamente se centran en gran número de expedientes sobre los repartimientos que se realizan, tanto en el tema contributivo como en el de levas para el ejército, y sus correspondientes reclamaciones, a lo que hay que añadir los relativos a la petición de todo tipo de ayudas.

En el año 1820 se celebraron ciento veintitrés sesiones, en las que se trataron mil quinientos noventa y cuatro expedientes, a los que tenemos que sumar otros doscientos veinte expedientes que despachó el Sr. jefe político en los días en que la Diputación no celebró sesiones. En el año 1821 fueron noventa las sesiones celebradas, aunque aumentó el número de expedientes tratados, que llegaron a mil setecientos ochenta y nueve. En el año 1822 se volvieron a celebrar las noventa sesiones que mandaba el reglamento, a las que se añadieron sesenta y una sesiones celebradas por la Junta de Reemplazos para el Ejército y seis sesiones exclusivas

\footnotetext{
367 Ley publicada a partir de los trabajos realizados por Bauzá y Larramendi, con el detalle de los límites provinciales y el número de pueblos que corresponden a cada provincia. Ver en capítulo $3^{\circ}$ "La provincia de Valladolid. Extensión y territorio".

368 Ver en capítulo $2^{\circ}$ : La legislación en el Trienio Liberal (1820-1823),
} 
correspondientes a las Juntas de Agravios de los repartimientos de la contribución, es decir, un total de ciento cincuenta y siete sesiones que trataron tres mil ciento treinta y dos expedientes.

En el siguiente cuadro adjuntamos un resumen de los asuntos tratados en este período.

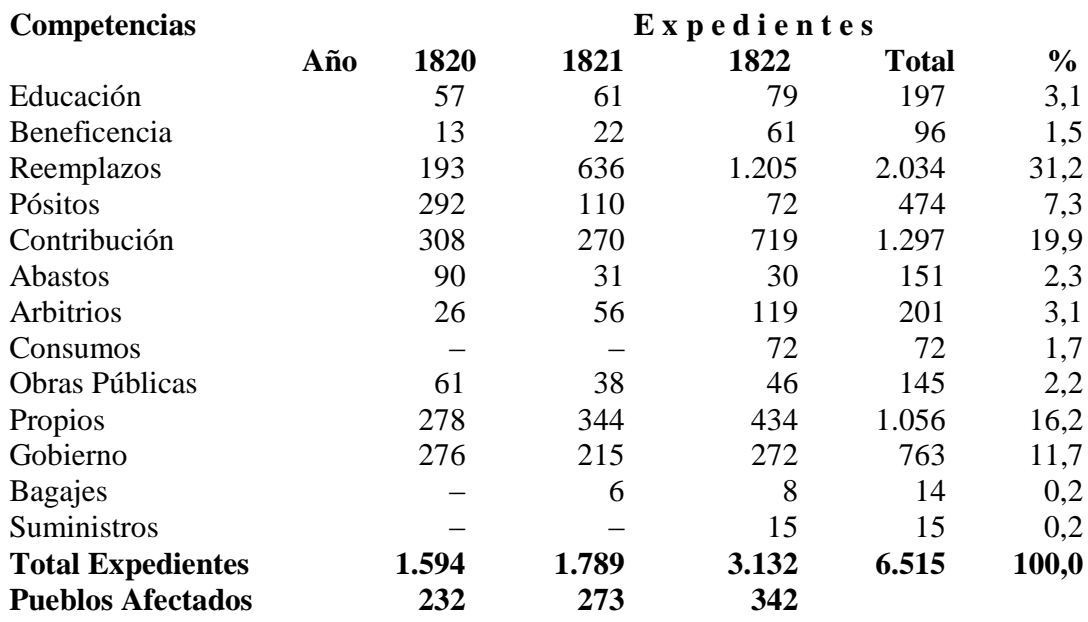

Como podemos observar, el tema de los reemplazos del Ejército es el que más expedientes genera, tanto por lo que concierne a las convocatorias de los "quintos", como por las abundantes reclamaciones que suscitan.

Otro problema en el que abundan los expedientes es el relativo a las contribuciones, por la insatisfacción en los repartimientos y por las numerosas reclamaciones y quejas que provocan. Otros asuntos muy solicitados vemos que son el de Propios, con sus expedientes sobre arriendos y aprovechamientos, y el de Pósitos, instituciones cuya finalidad social es la de ayuda a través de préstamos de sus fondos de granos y de dinero en los años de crisis y de dificultades por la pérdida de cosechas. Es lo que ocurre en el año 1820, con motivo de las continuas peticiones de reparto de granos, con el fin de paliar los efectos negativos de una mala cosecha ${ }^{369}$.

\subsubsection{ACTUACIONES EN LA ÉPOCA ISABELINA. 1835-1868}

La Diputación vuelve a iniciar sus actividades, y en esta ocasión será de una forma definitiva, a través del real decreto de 21 de septiembre de 1835 , que reafirmaba el papel de la Diputación como "protectora de los intereses de los pueblos de la provincia". A tal fin, y como un primer paso para fijar sus competencias, las Cortes Generales restablecen tanto la Constitución de 1812 como la ley de 3 de febrero de 1823 "sobre el Gobierno Económico-Político de las Provincias". Es un primer paso para que las Diputaciones puedan iniciar sus andaduras, con un marco legal reconocido y un conocimiento de sus atribuciones y sus competencias. En este período isabelino, que se enmarca entre los años 1835 y 1868 , la vida de la Diputación se tiene que ajustar, por un lado, a las modificaciones que supone la legislatura, y por otro, a la importancia que con el paso del tiempo se va concediendo a las diferentes competencias que son de su incumbencia. Repasemos brevemente su evolución.

a.- Respecto a la legislación, vemos que las Diputaciones arrancan con las mismas leyes con las que se cerró la etapa del Trienio Liberal ${ }^{370}$ y que se mantendrán vigentes hasta el año 1845, año en que se aprueba la ley de 8 de enero sobre "Organización y Atribuciones de las Diputaciones Provinciales". Esta ley se

${ }^{369}$ CARASA SOTO, Pedro. "Los pósitos en la España del siglo XIX", en Investigaciones históricas $n^{\circ} 4$ (1983). Págs. 247-304.

370 Constitución de 1812 y ley de 3 de febrero de 1823. 
caracteriza por el control y hegemonía en el ámbito de la institución provincial ejercido por el jefe político como representante directo del gobierno, en detrimento de las Diputaciones que sufren una pérdida de autoridad a la hora de desarrollar sus competencias. La creación de un nuevo organismo, "El Consejo Provincial", que nace a través de la ley de 2 de abril de 1845 y cuyo presidente es el jefe político, restará protagonismo y trabajo a las Diputaciones que verán cómo parte de sus competencias le son sustraídas de su ámbito de influencia.

Estas leyes estarán vigentes hasta el año 1863, excepto en los años 1854-56, que se corresponden con el Bienio Progresista, período en el que se restablecerán nuevamente las leyes orgánicas vigentes con anterioridad como la "Ley sobre el gobierno económico político de las Provincias" de 3 de febrero de 1823, la Ley de Imprenta de 1837 o el Reglamento de la Milicia Nacional de 1822.

El 25 de septiembre de 1863, se promulga una nueva ley "Para el Gobierno y Administración de las Provincias" que sustituye a la ley de 1845, que legisla sobre las Diputaciones, sobre los Consejos provinciales y sobre los gobernadores. Es una ley continuista, que no modifica de forma llamativa las actividades de las Diputaciones ni su dependencia del poder central a través de los gobernadores de la provincia. Esta ley será modificada parcialmente en 1866 y estará vigente hasta el año 1868, en que será derogada en consonancia con el fin de la época isabelina y el comienzo del Sexenio Revolucionario.

b.- Respecto a las competencias, se mantienen las mismas que se ejercieron en las etapas anteriores y en esta ocasión repartiendo la responsabilidad y el trabajo con los nuevos Consejos provinciales. Como actuaciones y asuntos relevantes podemos destacar:

$1^{\circ}$. Obras Públicas. Con la prioridad del desarrollo de las comunicaciones, en las que destacamos tres grandes proyectos que se hacen realidad a lo largo de estos años: El Canal de Castilla, el ferrocarril y las carreteras nacionales, provinciales y locales.

$2^{\circ}$. Enseñanza. Con el desarrollo de la instrucción pública y su extensión a lo largo y ancho de la provincia, en el que destacan la creación del Instituto de Enseñanza Media y la ampliación y potenciación de los estudios universitarios

$3^{\circ}$. Agricultura. Sobresalen la promoción de ferias y mercados, la mejora y difusión de técnicas agrícolas y la creación de una "Escuela de Agricultura".

$4^{\circ}$. Ejército. Son continuas las peticiones de reemplazo, tanto para el Ejército como para la Milicia Nacional. Esta es una de las actividades en las que se emplea más tiempo, tanto por parte de la Diputación como por el Consejo, ya que los dos organismos tenían diferentes atribuciones en esta materia.

$5^{\circ}$. Contribuciones. Son básicos sus repartimientos y en consecuencia las numerosas reclamaciones que se producen.

$6^{\circ}$. Sanidad y Beneficencia. Se produce un lento proceso de provincialización y control de las numerosas instituciones benéficas, que se van transformando y unificando hasta alcanzar una visible mejora en su actividad. Con referencia especial a la Sanidad, en estos años se inician actuaciones específicas para prever y minimizar los peligros epidémicos.

$7^{\circ}$. Presupuestos provinciales. Es uno de los capítulos que más actividad generará en esta época y que se caracteriza por una constante: "su continuo déficit". Este déficit está causado principalmente por dos actuaciones: la morosidad de los Ayuntamientos de la provincia y el abultado gasto no ajustado a lo previsto. Esta situación provoca una serie de rectificaciones y de nuevos repartimientos para intentar su equilibrio.

En definitiva, nos encontramos ante una época marcada por el asentamiento de la institución y un continuo trabajo tendente a mejorar la vida de los ciudadanos. Tal intención se verá frenada con harta frecuencia ante la escasa capacidad económica que padece la Diputación y que no le permite resolver los problemas que se le plantean. 
Durante esta época isabelina son diecinueve las diferentes Diputaciones que tratan, todas ellas, de mejorar las condiciones de vida de los habitantes de la provincia. La duración es muy irregular ya que oscila entre los dos y tres meses a los dos y tres años, en función de las incidencias de la política a nivel nacional. Un recorrido rápido a lo largo de estos años nos hace ver las actividades que más destacan y los trabajos y preocupaciones de los diputados provinciales.

\section{Reinicio de las actividades en los años 1835-1840}

En este período de organización y puesta a punto de las corporaciones, son tres las Diputaciones que se encargan de desarrollar los trabajos que les incumben. La primera Diputación se mantiene efectiva entre octubre de 1835 y octubre de 1836, con ciento veintidós sesiones en las que se tratan novecientos trece expedientes. La segunda Diputación cubre los trabajos entre octubre de 1836 y diciembre de 1837 con setenta y dos sesiones celebradas y ochocientos tres expedientes resueltos. La tercera Diputación tiene una amplia duración que va desde diciembre de 1837 a diciembre de 1840. Son tres años de vida con doscientas veintitrés sesiones y un total de cinco mil ochenta y cuatro expedientes.

Con el paso del tiempo, las actividades de la Corporación se van ampliando y esto se deduce del gran número de expedientes que son tratados en la última Diputación. El motivo de este aumento hay que buscarlo en la utilización del sistema de trabajo por comisiones, es decir, éstas tratan los asuntos independientemente y al pleno de la Diputación ya llegan resueltos prácticamente y sólo hay que tramitar su aprobación.

Las comisiones nombradas eran las de Ayuntamientos, Obras Públicas, Interior, Guerra, Instrucción Pública, Beneficencia, Agricultura, Industria y Comercio, División Territorial, Diezmos y Alhajas, Enajenación de Conventos Suprimidos y Requisa de Caballos y Bagajes. En la tercera Diputación se mantienen un total de trescientas treinta y una reuniones de las diferentes comisiones, distribuidas de la siguiente forma:

La Comisión de Ayuntamientos celebra ciento diez reuniones, la Comisión de Contribuciones noventa y una, la Comisión de Guerra setenta y ocho sesiones, veintidós de ellas dedicadas a reclamaciones, la Comisión de Instrucción Pública se reúne quince veces, la Comisión de Interior efectúa doce reuniones y la de Obras Públicas registra diez. Hay que añadir además quince sesiones de otras comisiones. Destacan los numerosos expedientes y reuniones de la comisión de Ayuntamientos, que tratan de una forma excepcional el tema de las listas electorales. Ocasiona gran cantidad de reclamaciones sobre inclusiones y exclusiones en las mismas. También abundan los expedientes referentes a temas de "Bienes de Propios" y a "Pósitos".

Otra Comisión que celebra gran número de reuniones y en consecuencia gran número de expedientes es la de Contribuciones, que trata sobre los repartimientos de la totalidad de los pueblos de la provincia y, en contrapartida, las numerosas reclamaciones en disconformidad con los repartos. La Comisión de Guerra es de las más activas y resuelve los expedientes de reemplazos, sorteos, reclamaciones y suministros a las tropas.

\section{Desde un punto de vista progresista en los años 1841-1843}

La cuarta Diputación se mantiene vigente a lo largo de los años 1841-43, período que coincide con la presidencia en el gobierno del general Espartero. Los cambios de Diputación no obstan para que se continúen tratando los mismos temas. Listas electorales, contribuciones y reemplazos representan la mayoría de las actividades.

Se celebran doscientas treinta y ocho sesiones en las que se tratan cinco mil cuatrocientos setenta expedientes. En 1841 son dos mil ciento ochenta y nueve expedientes de los que quinientos cuatro se dedican a reclamaciones de quintos y doscientos diecisiete de listas electorales. En 1842 son mil quinientos veinte 
expedientes de los que trescientos treinta y cuatro son reclamaciones de quintos. En 1843 se despachan mil setecientos sesenta y un expedientes de los que setecientos setenta y seis son reclamaciones de listas electorales. En el siguiente cuadro se reflejan los expedientes tratados a lo largo de estas primeras Diputaciones.

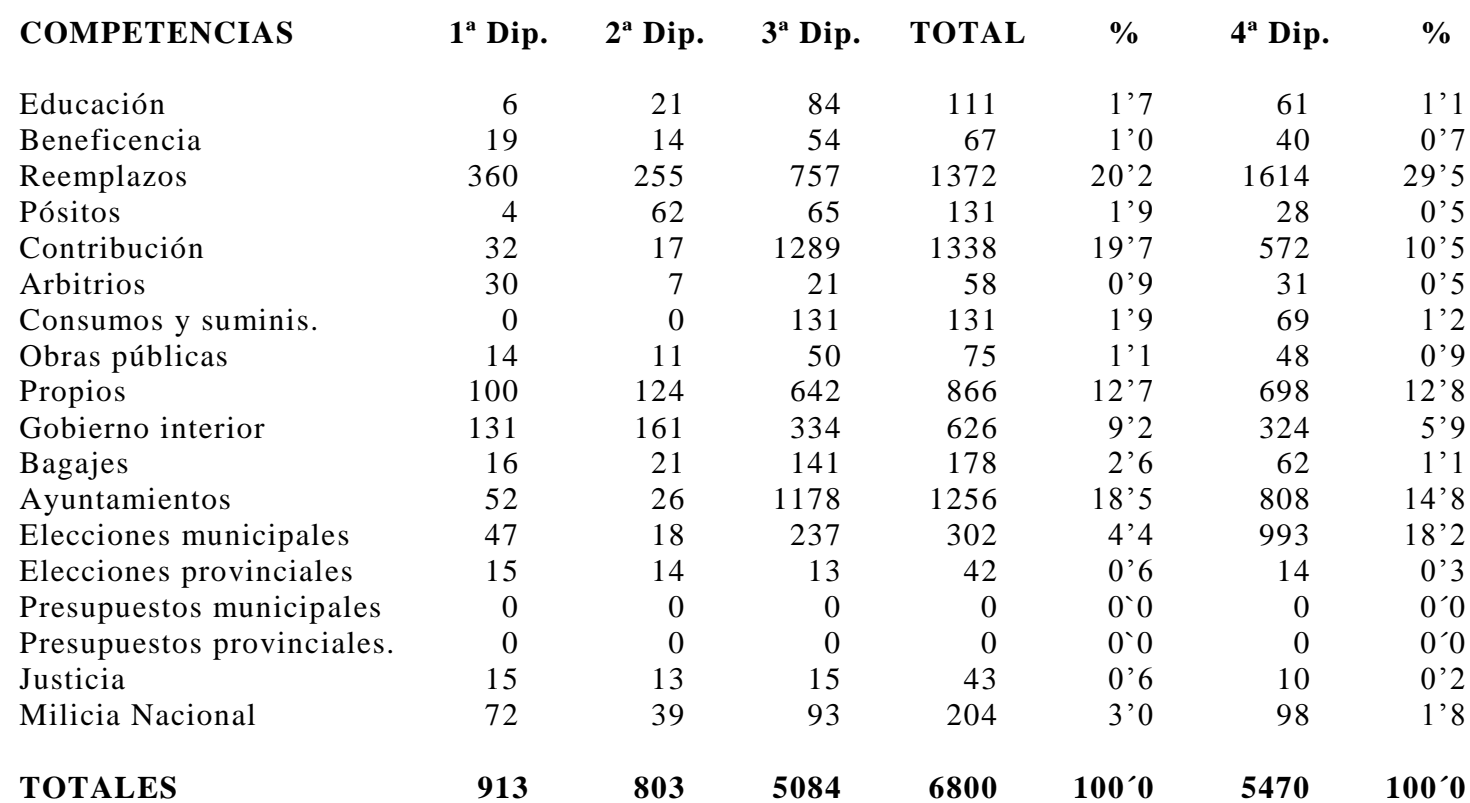

En las tres primeras Diputaciones que se suceden entre los años 1835 y 1840 destacan los expedientes correspondientes a los reemplazos de los mozos para el Ejército y a las reclamaciones que acompañan y que junto a los repartimientos de las contribuciones son los dos más importantes trabajos que se realizan sobre el resto de actividades. Son asimismo las dos actividades que generan una gran repulsa por parte de los ciudadanos y que los diputados asumen como una de sus obligaciones. Según vemos en el cuadro adjunto, estas dos actividades suponen el $40 \%$ del total de la corporación. Otros asuntos que pudieran ser más importantes para la provincia, como las obras públicas, en especial las relativas a las vías de comunicación, la educación y la beneficencia, que son tres capítulos con cuya mejora se daría satisfacción a la ciudadanía, vemos que solamente representan el 2’7\% de la actividad institucional. En este desfase se echan en falta las posibles quejas que deberían de haber presentado los diputados ante la autoridad del jefe político, pidiendo el fomento de las actuaciones que supusieran una mejora para el bienestar ciudadano.

Por lo que respecta a la cuarta Diputación que se sucede entre 1841 y 1843 , destacamos su composición progresista, de la que se podía esperar una actuación más social, pero la realidad nos presentó una decepción de los habitantes de la provincia. De la actuación de esta Diputación no se desprende nada especial, más bien se repiten los mismos parámetros porcentuales de las anteriores Diputaciones, es decir, exceso de expedientes de reemplazos y de contribuciones, y escasez en los temas que podían suponer un progreso provincial.

\section{Período moderado y pérdida de actividad en los años 1844-1854}

En estos años se suceden un total de seis Diputaciones, con parecidas actividades y diferentes duraciones. La quinta Diputación, que se mantiene desde noviembre de 1843 hasta julio de 1847, siendo la Diputación que más dura a lo largo del período isabelino, celebra un total de doscientas cuarenta sesiones. En el transcurso de esta Diputación se pone en marcha la nueva "Ley de Organización y Atribuciones de las Diputaciones" en enero de 1845. La ley contempla la creación de un nuevo organismo provincial, "El Consejo Provincial", que inicia su andadura en julio de 1845 y que asumirá la mayoría de las actividades de la Diputación. 
Si dividimos esta legislatura en dos partes, vemos que en la primera parte, es decir, antes de la puesta en marcha del Consejo provincial, que se extiende entre noviembre de 1843 y junio de 1845 , con veinte meses, la Diputación celebra ciento cincuenta y ocho sesiones en las que se tratan dos mil trescientos dos expedientes. En la segunda parte, entre julio de 1845 y julio de 1847, durante veinticinco meses, la Diputación celebra ochenta y dos sesiones en las que trata únicamente trescientos veintinueve expedientes. En este mismo período, la Comisión provincial tiene doscientas veintinueve sesiones en las que tratan mil seiscientos cincuenta y dos expedientes, que están claramente precisados en los libros de actas, pero que son los que se detraen de las actividades de la Diputación.

En el cómputo de este período se tratan los temas habituales, entre los que destacan los trescientos setenta y nueve expedientes de reclamaciones sobre las listas electorales y mil novecientos treinta y ocho expedientes que se tratan en veinte sesiones monográficas sobre reclamaciones en el sorteo de mozos para el reemplazo del ejército. El Consejo Provincial trata con prioridad temas de Ayuntamientos, como son los bienes de propios, pósitos, elecciones municipales, presupuestos municipales, y además se ocupa de asuntos de beneficencia, suministros a la tropa, bagajes, contribuciones y sus reclamaciones, etc.

La sexta Diputación inicia sus trabajos en agosto de 1847 hasta marzo de 1850 y celebra en estos días un total de cuarenta y cinco sesiones. En el mismo tiempo, el Consejo provincial trata asuntos provinciales a lo largo de doscientas cuatro sesiones. Es una demostración del auge que toma el Consejo en detrimento de la Diputación. En sus cuarenta y cinco sesiones, la Diputación trata ciento ochenta y seis expedientes, en su mayoría de carácter institucional, como es el estudio y puesta en marcha de diferentes reales órdenes, como por ejemplo el establecimiento de puestos públicos en diferentes pueblos, o las rebajas en los repartimientos de la contribución que solicitan varios pueblos afectados por la malas cosechas $\mathrm{y}$, sobre todo, la discusión $\mathrm{y}$ aprobación de los presupuestos provinciales. El Consejo provincial en sus doscientas cuatro sesiones trata mil seiscientos setenta y un expedientes, con los habituales temas de reemplazos y sus reclamaciones. Destacan las ochocientos noventa y ocho reclamaciones de los quintos que consumen catorce sesiones completas en abril de 1848 , cuarenta y seis sesiones en octubre y noviembre del mismo año y treinta y nueve sesiones en marzo y abril de 1849.

La séptima Diputación transcurre entre abril de 1850 y marzo de 1852, tiempo en el que se celebran treinta y dos sesiones de la Diputación y ciento noventa y dos en el Consejo. La Diputación trata ciento tres expedientes, centrados principalmente en el estudio y aprobación de los presupuestos provinciales y en el tema de obras públicas. En este sentido, se preocupan por agilizar las obras de las carreteras a León y a Salamanca, que se hallan en construcción, y las obras del ferrocarril, en especial en el recorrido Alar-Santander y en la línea del Norte. El Consejo provincial trata setecientos diecisiete expedientes con los habituales temas de sorteos, sanidad, Ayuntamientos, propios, cuentas municipales. Vuelven a destacar en agosto de 1851 las veintinueve sesiones para oír las cuatrocientas sesenta y dos reclamaciones de los quintos sorteados.

La octava Diputación celebra veintitrés sesiones entre abril de 1852 y marzo de 1854 siendo ciento cincuenta y dos las que celebra el Consejo provincial. Como vemos, la Diputación cada vez efectúa menos sesiones y trata de menos temas. En este período se centra en la discusión y aprobación de los presupuestos provinciales y también en el seguimiento de las obras del ferrocarril del Norte, así como en su financiación, con un total de setenta y un expedientes tratados. Por su parte, en el mismo tiempo, el Consejo, en seiscientos cuarenta y tres expedientes, trata de elecciones municipales, de propios, de pósitos, de sanidad y sorteos. Destacan nuevamente las treinta y dos sesiones que se celebran en julio y agosto de 1852 y veintiséis sesiones en junio de 1853, todas ellas monográficas y dedicadas a oír las 
reclamaciones de los quintos, con quinientas catorce protestas, lo que representa el $80 \%$ del trabajo.

La novena Diputación es última de este período y experimenta una corta duración, ya que inicia sus actividades en abril y cierra en julio de 1854. En total, cuatro meses en los que se celebran cuatro sesiones. En la primera aprueba las actas de diputados, la segunda está dedicada a las cuentas del año 1853, la tercera a tratar de ferrocarriles y en la cuarta se presentan los presupuestos de 1855. En este tiempo, el Consejo provincial celebra cuarenta y cuatro sesiones, todas ellas para tratar, en trescientos veintiún expedientes, sobre los sorteos de los reemplazos y las reclamaciones que presentan los mozos. El 19 de julio se celebra la última sesión del Consejo, que será suprimido por real orden de 24 de julio de 1854. Es el fin de la Década Moderada.

A continuación resumimos los expedientes tratados por las cinco Diputaciones que se suceden a lo largo de estos años. La columna $\mathrm{D}$ está referida a los expedientes tratados por la Diputación y la $\mathrm{C}$ a los del Consejo provincial.

Competencias
Educación
Beneficencia
Reemplazos
Pósitos
Contribución
Arbitrios
Consumos y suministros
Obras públicas
Propios
Gobierno interior
Bagajes
Ayuntamientos
Elecciones municipales
Elecciones provinciales
Presupuestos municipales
Presupuestos provinciales
Justicia
Milicia Nacional
TOTALES

\begin{tabular}{rrrr}
\multicolumn{2}{c}{$\mathbf{5}^{\mathbf{a}} \mathbf{D I P}$} & \multicolumn{2}{c}{$\mathbf{6}^{\mathbf{a}} \mathbf{D I P}$} \\
2 & \multicolumn{1}{c}{$\mathbf{C}$} & \multicolumn{1}{c}{$\mathbf{D}$} & \multicolumn{1}{c}{$\mathbf{C}$} \\
28 & 7 & 9 & 3 \\
22 & 25 & 8 & 26 \\
1103 & 835 & 51 & 898 \\
19 & 8 & 0 & 5 \\
275 & 32 & 7 & 2 \\
29 & 23 & 5 & 19 \\
44 & 9 & 35 & 8 \\
59 & 29 & 21 & 15 \\
96 & 128 & 0 & 71 \\
141 & 14 & 8 & 6 \\
46 & 5 & 0 & 4 \\
360 & 50 & 22 & 36 \\
65 & 314 & 0 & 545 \\
11 & 0 & 14 & 0 \\
2 & 164 & 1 & 23 \\
16 & 0 & 5 & 0 \\
6 & 9 & 0 & 10 \\
9 & 0 & 0 & 0 \\
$\mathbf{2 3 3 1}$ & $\mathbf{1 6 5 2}$ & $\mathbf{1 8 6}$ & $\mathbf{1 6 7 1}$
\end{tabular}

$\begin{array}{rr}\mathbf{7}^{\mathbf{a}} \mathbf{D I P} \\ \mathbf{D} & \mathbf{C} \\ 8 & \\ 10 & 18 \\ 4 & 46 \\ 0 & \\ 4 & 10 \\ 0 & 13 \\ 0 & \\ 25 & 2 \\ 2 & 4 \\ 14 & \\ 0 & \\ 16 & 49 \\ 0 & 3 \\ 13 & \\ 0 & 3 \\ 7 & \\ 10 & \\ 0 & \\ \mathbf{1 0 3} & \mathbf{7 1}\end{array}$

\begin{tabular}{rrrrr}
\multicolumn{2}{c}{$\mathbf{8}^{\mathbf{a}} \mathbf{D I P}$} & \multicolumn{2}{c}{$\mathbf{9}^{\mathbf{a}} \mathbf{D I P}$} & \\
$\mathbf{D}$ & $\mathbf{C}$ & \multicolumn{1}{c}{$\mathbf{D}$} & $\mathbf{C}$ & Total \\
4 & 2 & 1 & 0 & 67 \\
4 & 9 & 0 & 0 & 123 \\
11 & 514 & 1 & 321 & 4200 \\
0 & 1 & 0 & 0 & 36 \\
4 & 3 & 0 & 0 & 337 \\
1 & 5 & 0 & 0 & 95 \\
0 & 1 & 0 & 0 & 101 \\
12 & 9 & 7 & 0 & 197 \\
0 & 23 & 0 & 3 & 372 \\
9 & 9 & 0 & 3 & 213 \\
1 & 0 & 0 & 0 & 58 \\
8 & 17 & 0 & 1 & 559 \\
0 & 21 & 0 & 0 & 977 \\
9 & 0 & 13 & 0 & 60 \\
0 & 17 & 0 & 1 & 239 \\
8 & 0 & 3 & 0 & 39 \\
12 & 0 & 0 & 47 & 47 \\
0 & 0 & 0 & 0 & 9 \\
$\mathbf{7 1}$ & $\mathbf{6 4 3}$ & $\mathbf{2 5}$ & $\mathbf{3 3 0}$ & $\mathbf{7 7 2 9}$
\end{tabular}

\section{La Diputación vuelve a asumir todas las actividades en los años 1854-1856}

El inicio del Bienio Progresista presupone la disolución de la Diputación y del Consejo, y el nombramiento de una nueva Diputación. Esta nueva institución, con carácter de emergencia y sin mediar elecciones, se hará cargo de todas las actividades provinciales con carácter exclusivo, puesto que los consejos provinciales no actuarán en estos años y vuelve a estar vigente la ley de 23 de febrero de 1823.

Tenemos que recordar que son nombrados diputados en la primera legislatura progresista los mismos hombres que dirigieron la institución en 1841-43, es decir, vuelven los diputados del primer ciclo progresista. Con esta nueva situación, desde un punto de vista político, se producen una serie de cambios legislativos que inciden en el funcionamiento de la Diputación, como son la vuelta de las leyes vigentes en los años progresistas de 1820-23 y 1841-43. Esta situación nos lleva a tener una Diputación más libre y con más autonomía. Desde un punto de vista institucional, la supresión del Consejo y la puesta en marcha nuevamente de la Secretaría permite a los diputados retomar en toda su amplitud los trabajos en la gestión de las actividades institucionales, incidiendo en los temas de enseñanza, sanidad y beneficencia.

La décima Diputación tiene una duración corta y efímera, vigente en los meses de julio y agosto de 1854, en los que celebra quince sesiones. Se centran sobre todo en organizar la nueva forma de trabajo con la eliminación del Consejo y la creación de nuevo de la Secretaría de la Diputación. Vuelve a asumir y decidir sobre todas las actividades y en este corto tiempo aprueba sesenta y tres expedientes, entre los que 
destaca la aprobación de los presupuestos provinciales que quedaron pendientes de la Diputación anterior.

La undécima Diputación es la que cubre todo el Bienio, ya que se extiende desde agosto de 1854 hasta julio de 1856. En este período celebra ciento cuarenta y ocho sesiones en las que se tratan un total de mil cuatrocientos veintitrés expedientes, sobresaliendo entre todos ellos los trescientos setenta y siete relativos a las reclamaciones por inclusión y exclusión de las listas electorales presentadas tanto por los Ayuntamientos como por los particulares. Destacan también las doscientas veintiuna reclamaciones presentadas a los sorteos de los reemplazos del Ejército, realizados en este período. El resto de expedientes se reparte entre las habituales actividades de la Diputación, entre los que sobresale el tema de propios por la extraordinaria petición de arriendos y venta de sus bienes y además la gran petición de tala de árboles que solicitan muchos pueblos, lo que nos quiere dar a entender de las dificultades de los habitantes a causa de las malas cosechas.

\author{
COMPETENCIAS \\ Educación \\ Beneficencia \\ Reemplazos \\ Pósitos \\ Contribución \\ Arbitrios \\ Consumos y suministros \\ Obras públicas \\ Propios \\ Gobierno interior \\ Bagajes \\ Ayuntamientos \\ Elecciones municipales \\ Elecciones provinciales \\ Presupuestos municipales \\ Presupuestos provinciales \\ Justicia \\ Milicia Nacional \\ TOTALES
}

$\mathbf{1 0}^{\mathbf{a}} \mathbf{D I P}$
1
1
4
0
0
1
0
1
10
9
0
31
3
0
0
1
0
1
$\mathbf{6 3}$

$\mathbf{1 1}^{\mathbf{a}} \mathbf{D I P}$
25
89
217
25
20
42
14
64
303
63
8
191
152
9
118
8
14
61
$\mathbf{1 4 2 3}$

\begin{tabular}{|c|c|}
\hline TOTAL & $\%$ \\
\hline 26 & $1^{\prime} 7$ \\
\hline 90 & $6^{\prime} 1$ \\
\hline 221 & $14^{\prime} 9$ \\
\hline 25 & $1 ' 7$ \\
\hline 20 & $1 ' 3$ \\
\hline 43 & $2 ’ 9$ \\
\hline 14 & $1^{\prime} 0$ \\
\hline 65 & $4^{\prime} 4$ \\
\hline 313 & $21 ' 1$ \\
\hline 72 & 4'8 \\
\hline 8 & 0,5 \\
\hline 222 & $14^{\prime} 9$ \\
\hline 155 & $10^{\prime} 4$ \\
\hline 9 & $0^{\prime} 6$ \\
\hline 118 & 7'9 \\
\hline 9 & $0^{\prime} 6$ \\
\hline 14 & $1^{\prime} 0$ \\
\hline 62 & $4^{\prime} 2$ \\
\hline 1486 & $100^{\prime} 0$ \\
\hline
\end{tabular}

El Bienio Progresista, en el ámbito nacional, está dedicado a la discusión política y a los intentos de cambio hacia una sociedad más progresista y más participativa en las tareas comunales. Por lo que respecta a la Diputación, ésta se forma con los mismos individuos que ejercieron en los años 1841-43. La verdad es que si en aquellos años no aportaron nada especial a la provincia en temas relativos al progresismo, difícilmente lo harán en estos años, a pesar de las mejoras en las áreas de comunicaciones educación y sanidad. El "motín del pan" de junio de 1856 es una manifestación del fallo de los políticos progresistas en trabajar por la mejora de la situación social y por el progreso del nivel económico. Los políticos se enfrascaron en la discusión de la filosofía política y se olvidaron de dar la adecuada respuesta a las necesidades de la provincia.

\section{Inicios con poca actividad y final revuelto en los años 1856-1868}

En el ámbito nacional, es la época del gobierno moderado de la Unión Liberal, conocido con el sobrenombre de "Gobierno Largo". No ocurre lo mismo con las Diputaciones, pues en este período se suceden ocho Diputaciones diferentes, que continúan con los trabajos habituales y conocidos. También ocurre que vuelve nuevamente a estar operativa la ley de 8 enero de 1845, con lo cual también funciona de nuevo el Consejo provincial.

Con estos planteamientos, la Diputación se centra en debatir asuntos específicos de carácter político y de puesta en marcha de los mandatos del gobierno central. Asimismo se dedican a la elaboración y aprobación de los presupuestos provinciales, además de los grandes problemas de esta época, las comunicaciones, en 
especial carreteras y ferrocarriles. El Consejo provincial centran su trabajo en los sorteos de mozos para el ejército y sus reclamaciones, elecciones y presupuestos municipales, además del control de Ayuntamientos y sus bienes de propios y pósitos.

La duodécima Diputación transcurre entre agosto y noviembre de 1856, tiene una corta duración, pero con un alto número de sesiones, en total cincuenta y tres, en las cuales diecisiete se dedican a la comisión de quintos y sus reclamaciones. También se vuelve a trabajar con el sistema de comisiones. Las que se forman en esta Diputación son las de Gobierno Interior, Presupuestos, Contribuciones, Subsistencias, Milicias, Propios, Pósitos, Obras Públicas, Policía urbana, Sanidad e Instrucción Pública, que tratan un total de ochocientas ochenta y un expedientes. El 25 de octubre, se vuelve a poner en marcha el Consejo provincial, que celebra veinticinco sesiones, todas ellas dedicadas a quintas y a presupuestos provinciales.

La decimotercera Diputación se extiende desde diciembre de 1856 a junio de 1858 , celebra en este año y medio, veintisiete sesiones, con un cortísimo número de ciento veintidós expedientes. En ellos se trata especialmente sobre el presupuesto provincial que consume cinco sesiones, el sorteo de los quintos que ocupa tres sesiones y las obras públicas, que son tratadas en dos sesiones. Ayuntamientos y repartimientos son otras actividades que se tratan en los plenos de la Diputación. El Consejo provincial celebra ciento noventa y dos sesiones, con mil seiscientos cincuenta y siete expedientes, especialmente dedicados al tema de las quintas con seiscientos ochenta y dos expedientes de reclamaciones, que se tratan en el año 1857 , y cuatrocientos setenta y cuatro en la primera mitad de 1858 .

La decimocuarta Diputación desarrolla sus trabajos desde julio de 1858 hasta marzo de 1860, tiempo en el que se celebran cuarenta sesiones en las que se tratan ciento cincuenta y cuatro expedientes, en su mayoría referentes a los presupuestos provinciales, a las comunicaciones, al problema de los ferrocarriles que es tratado en exclusiva en cuatro sesiones, a la agricultura con la Feria Agrícola, a la guerra de África y a las quintas. En el mismo período el Consejo celebra doscientas sesenta y cuatro sesiones con mil quinientos ochenta y ocho expedientes y temas de quintos, de los que se ocupa en veinticuatro sesiones, listas electorales con doce sesiones, elecciones municipales que ocupan diez sesiones, y además se ocupan de Ayuntamientos, propios, enseñanza, etc.

La decimoquinta Diputación se mantiene entre abril de 1860 y marzo de 1862 , tiempo en el que celebra treinta y una sesiones, en las que se ocupa de doscientos cincuenta y ocho expedientes relativos a las peticiones de otros tantos pueblos solicitando la exclusión de sus bienes de propios de la desamortización de bienes públicos, decretada por el Gobierno. También se aprueban ciento setenta y seis expedientes, principalmente referidos a ferrocarriles, presupuestos provinciales, ayudas para la guerra de África, desamortizaciones, etc. El Consejo celebra ciento cuarenta y ocho sesiones en las que tratan sobre quintas, con seiscientas cincuenta y dos reclamaciones, cuentas y elecciones municipales, pósitos y propios, con un total de ochocientos cincuenta y cinco expedientes.

La decimosexta Diputación es operativa desde abril de 1862 a diciembre de 1863, tiempo en el que celebra veintidós sesiones, con ciento siete expedientes tratados, relativos a bienes desamortizados, presupuestos provinciales, obras públicas, agricultura con la Exposición Agrícola de Londres, instrucción pública, bagajes, etc. En este mismo período, el Consejo provincial celebra ciento noventa y nueve sesiones, con mil ciento setentay cuatro expedientes sobre reclamaciones de quintos, con novecientos veintiocho, elecciones municipales, policía urbana, Ayuntamientos, etc.

La decimoséptima Diputación está vigente desde enero de 1864 a diciembre de 1865, y en estos dos años mantiene cuarenta y nueve sesiones en las que se tratan doscientos cuatro expedientes referentes en su mayoría a presupuestos provinciales, obras públicas, beneficencia y contribuciones. El Consejo celebra doscientas dos sesiones con setecientos doce expedientes, entre los que destacan los de quintas con seiscientos diez reclamaciones, cantidad que representa el $30 \%$ de trabajo que 
desarrolla el Consejo en el año 1864, siendo similar al año 1865 en el que se tratan cuatrocientas noventa reclamaciones. Como detalle anecdótico, resaltamos que estas reclamaciones ocupan en el libro de actas del Consejo un total de cincuenta y trés páginas de las ciento noventa y seis que cubren todo el año, es decir, el $26 \%$ del libro.

La decimoctava Diputación, con una duración de un año, entre enero y diciembre de 1866, tiempo en el que se celebran dieciocho sesiones con ciento dos expedientes tratados relativos a presupuestos provinciales, beneficencia, obras públicas, instrucción pública y elecciones. El Consejo provincial celebra ciento veintinueve sesiones en las que resuelve asuntos de Ayuntamientos (pósitos, propios, elecciones municipales) y sobre todo el tema de quintas y sus reclamaciones con cuatrocientos cuarenta y cuatro expedientes, sobre un total de setecientos treinta y nueve tratados.

La decimonovena Diputación, última de la época isabelina, se extiende entre enero de 1867 y septiembre de 1868, tiempo en el que celebra cincuenta y dos sesiones con trescientos cuarenta expedientes, sobre obras públicas, beneficencia, gobierno interior, presupuestos provinciales, instrucción pública, Guardia rural, bagajes y en la formación de distritos electorales, actividad que ocupa setenta expedientes. El Consejo celebra trescientas dos sesiones, con mil doscientos ochenta y nueve expedientes, referentes a elecciones municipales, Ayuntamientos, sanidad, beneficencia, propios, pósitos y quintas con trescientas una reclamaciones en 1867 y cuatrocientas cuarenta y dos en el año 1868.

A lo largo de estos años del "período gris" con el que finalizará la época isabelina, la Corporación ha trabajado para que estén en marcha los ferrocarriles, progrese la educación, se modernice y se transforme la beneficencia, aunque los mozos continúan con sus reclamaciones para evitar su ingreso en el Ejército y los ciudadanos asumen el pago de las contribuciones y centran sus energías en alcanzar el "grado de elector". Esta idílica situación, sin embargo, se verá lastrada al final del período por una grave crisis financiera que provoca el estancamiento de la agricultura y de la industria relacionada con el campo, puntos básicos del progreso provincial. Los diputados están enredados en el debate político, pero no parece que dediquen su esfuerzo y su influencia a la que es primordial y razón de ser de la existencia de la Diputación: mejorar el bienestar ciudadano.

Como queda reflejado en el cuadro siguiente, se vuelven a repartir las actividades provinciales entre la Diputación y el Consejo (la columna D se refiere a la Diputación y la columna $\mathrm{C}$ al Consejo). Con dos datos que llaman la atención: El primero se refiere al número de expedientes tramitados en el apartado de Reemplazos con seis mil ochocientos ochenta y ocho, lo que representa el $60,5 \%$ del total de expedientes. El segundo se refiere al número de expedientes que trata la Diputación ( 2.344 y el $\left.20{ }^{\prime} 5 \%\right)$ en comparación con los del Consejo (9.041 con el 79'5 \%).

LEGISLATURA
COMPETENCIAS
Educación
Beneficencia
Reemplazos
Pósitos
Contribución
Arbitrios
Consumos y Sumin.
Obras públicas
Propios
Gobierno Interior
Bagajes
Ayuntamientos
Elecciones munic.
Elecciones provin.
Presupuestos munic.
Presupuestos prov.

\begin{tabular}{rrr}
\multicolumn{2}{c}{$\mathbf{1 2}^{\mathbf{a}} \mathbf{D}$} & \multicolumn{2}{c}{$\mathbf{1 3}^{\mathbf{a}} \mathbf{D}$} & $\mathbf{D}$ \\
5 & 0 & 10 \\
14 & 1 & 26 \\
552 & 15 & 8 \\
16 & 0 & 0 \\
13 & 0 & 4 \\
15 & 0 & 0 \\
8 & 1 & 10 \\
25 & 0 & 10 \\
93 & 2 & 0 \\
28 & 5 & 14 \\
2 & 0 & 3 \\
32 & 2 & 6 \\
4 & 0 & 3 \\
9 & 0 & 11 \\
49 & 2 & 2 \\
5 & 0 & 15
\end{tabular}

\begin{tabular}{rrr}
${ }^{\mathbf{C}} \mathbf{C}$ & \multicolumn{2}{c}{$\mathbf{1 4}^{\mathbf{a}} \mathbf{D}$} \\
4 & 13 & \multicolumn{1}{c}{$\mathbf{C}$} \\
9 & 14 & 11 \\
1126 & 9 & 1291 \\
1 & 0 & 2 \\
28 & 14 & 19 \\
5 & 3 & 3 \\
15 & 9 & 11 \\
6 & 16 & 14 \\
46 & 2 & 49 \\
12 & 22 & 36 \\
3 & 0 & \\
30 & 25 & 42 \\
290 & 1 & 38 \\
0 & 12 & 0 \\
52 & 0 & 32 \\
0 & 11 & 0
\end{tabular}

\begin{tabular}{rrrr}
\multicolumn{1}{c}{$\mathbf{1 5}^{\mathbf{a}} \mathbf{D}$} & \multicolumn{2}{c}{$\mathbf{1 6}^{\mathbf{a}} \mathbf{D}$} \\
24 & 23 & 11 & \multicolumn{1}{c}{$\mathbf{D}$} \\
9 & 7 & 2 & 10 \\
6 & 652 & 4 & 928 \\
0 & 1 & 0 & 7 \\
281 & 9 & 0 & 11 \\
5 & 3 & 2 & 3 \\
12 & 3 & 17 & 6 \\
26 & 12 & 18 & 18 \\
0 & 26 & 1 & 25 \\
27 & 17 & 13 & 55 \\
5 & 0 & 4 & 0 \\
12 & 31 & 12 & 25 \\
2 & 19 & 3 & 11 \\
9 & 0 & 10 & 0 \\
0 & 46 & 0 & 39 \\
11 & 0 & 7 & 0
\end{tabular}




\begin{tabular}{|c|c|c|c|c|c|c|c|c|}
\hline Justicia & 11 & 2 & & 3 & 30 & 5 & 27 & 34 \\
\hline Milicia Nacional & 0 & 0 & & 0 & 0 & 0 & 0 & 0 \\
\hline TOTAL ES & 881 & 122 & 16 & 154 & 1586 & 434 & $\begin{array}{r}110 \\
7\end{array}$ & $\begin{array}{r}117 \\
4\end{array}$ \\
\hline LEGISLATURA & \multicolumn{2}{|c|}{$17^{\mathrm{a}} \mathrm{D}$} & \multicolumn{2}{|c|}{$18^{\mathrm{a} D}$} & \multicolumn{2}{|c|}{$19^{\mathrm{a}} \mathrm{D}$} & \multirow{2}{*}{ TOTAL } & \\
\hline COMPETENCIAS & D & $\mathbf{C}$ & D & $\mathbf{C}$ & D & $\mathbf{C}$ & & $\%$ \\
\hline Educación & 18 & 1 & 11 & 1 & 17 & 3 & 128 & $1 ' 1$ \\
\hline Beneficencia & 15 & 10 & 6 & 23 & 20 & 26 & 203 & $1 ' 8$ \\
\hline Reemplazos & 4 & 1100 & 2 & 444 & 4 & 743 & 6888 & $60{ }^{\prime} 5$ \\
\hline Pósitos & 0 & 25 & 1 & 7 & 0 & 19 & 79 & 0,7 \\
\hline Contribución & 7 & 6 & 8 & 8 & 9 & 30 & 447 & 3,9 \\
\hline Arbitrios & 5 & 5 & 1 & 6 & 1 & 6 & 63 & 0,5 \\
\hline Consumos y Sumin. & 23 & 3 & 9 & 4 & 17 & 7 & 155 & $1 ' 4$ \\
\hline Obras públicas & 31 & 28 & 8 & 27 & 54 & 59 & 352 & $3{ }^{\prime} 1$ \\
\hline Propios & 0 & 35 & 0 & 52 & 2 & 83 & 416 & 3,6 \\
\hline Gobierno Interior & 35 & 56 & 18 & 37 & 56 & 95 & 526 & $4^{\prime} 6$ \\
\hline Bagajes & 5 & 1 & 0 & 1 & 6 & 3 & 35 & $0{ }^{\prime} 3$ \\
\hline Ayuntamientos & 16 & 54 & 7 & 36 & 21 & 81 & 432 & 3,8 \\
\hline Elecciones munic. & 10 & 295 & 4 & 19 & 101 & 17 & 817 & $7 \cdot 2$ \\
\hline Elecciones provin. & 12 & 3 & 14 & 2 & 17 & 0 & 99 & 099 \\
\hline Presupuestos munic. & 0 & 61 & 1 & 42 & 1 & 83 & 410 & 3,6 \\
\hline Presupuestos prov. & 19 & 0 & 10 & 0 & 10 & 0 & 88 & $0 ’ 7$ \\
\hline Justicia & 4 & 28 & 2 & 30 & 4 & 34 & 247 & $2{ }^{\prime} 1$ \\
\hline Milicia Nacional & 0 & 0 & 0 & 0 & 0 & 0 & 0 & $0^{\prime} 0$ \\
\hline TOTALES & 204 & 1712 & 102 & 739 & 340 & 1289 & 11385 & $100{ }^{\prime} 0$ \\
\hline
\end{tabular}

\subsubsection{ACTUACIONES EN EL SEXENIO REVOLUCIONARIO. AÑOS 1868 A 1874}

Las Diputaciones provinciales en el Sexenio evolucionan en el mismo sentido progresista en el que evoluciona la política general del país. Con fecha 21 de octubre de 1868, al poco tiempo de iniciado este período, se promulga la "Ley de Organización y Atribuciones de las Diputaciones Provinciales". Su rapidez en redactarla y aprobarla es similar al interés por trasladar al ámbito provincial las tendencias progresistas que se extienden a lo largo del país. Es una ley que da más autonomía a las Diputaciones a la hora de gestionar las actividades provinciales y a la que se devuelve la totalidad de la gestión provincial al eliminar los Consejos provinciales.

La legislación en este período, en el tema dedicado a la gestión provincial, se completará con la "Ley Provincial" aprobada el 20 de agosto de 1870 y que sustituye a la de 1868. Es una ley que marca el punto máximo de autonomía y descentralización de las Diputaciones y que éstas no disfrutaban desde su creación en 1812.

La Diputación deja de depender del gobernador y todos los asuntos y actividades con las que trata "son de su exclusiva competencia". Los diputados pasan a ser treinta y cinco en lugar de nueve, de acuerdo con el número de distritos en los que se divide la provincia. El presidente no es el gobernador, sino que es nombrado de entre todos los diputados al inicio de los períodos de sesiones.

Si la ley de octubre de 1868 anula las actividades de los Consejos provinciales, la ley de agosto de 1870 crea una Comisión provincial o Comisión permanente, formada por cinco diputados provinciales, con la finalidad de agilizar los trabajos de la Diputación y dar continuidad a sus actividades en el tiempo en que la institución no celebra sesiones.

En este período de tiempo se suceden un total de cinco Diputaciones, que gestionarán las habituales actividades que vienen desarrollando desde su creación, destacando los asuntos de repartimiento de contribuciones, sorteo de mozos para los reemplazos del ejército, el control de los Ayuntamientos y de sus bienes de propios y sus pósitos, los presupuestos provinciales y el fomento de las obras públicas, en especial ferrocarriles y carreteras. 
La primera Diputación del Sexenio está vigente desde octubre de 1868 a octubre de 1869. En este año celebra un total de noventa y ocho sesiones en las que se estudian mil cuatrocientos cuarenta y séis expedientes, que tratan, en especial, sobre elecciones, cuentas y presupuestos municipales y reclamaciones de quintos. Destaca el gran número de expedientes solicitando ayudas para paliar los efectos de la sequía y también la venta y arriendo de propios para mejorar la situación del campesinado afectado por las pérdidas de cosechas. Otros problemas tratados son los correspondientes a los presupuestos provinciales, su elaboración y aprobación, complementados con presupuestos adicionales tendentes a equilibrar los déficits.

La segunda Diputación del Sexenio se extiende entre octubre de 1869 y enero de 1871. Celebran un amplio número de sesiones, ciento veintisiete, en las que tratan dos mil seiscientos ochenta y ocho expedientes, entre los que destacan los relativos a los Ayuntamientos, con mil ciento noventa y un expedientes sobre presupuestos, aprobación de gastos y las numerosas peticiones de ayuda, así como los arriendos y ventas de propios y el reparto del grano de los pósitos, todo ello con la finalidad de paliar los efectos de la sequía y de las malas cosechas. Las reclamaciones de los quintos con setecientos sesenta y cinco expedientes continúan siendo muy importantes. Los expedientes se completan con temas de contribuciones, presupuestos provinciales, obras públicas, beneficencia, bagajes, instrucción pública, con trescientos setenta y un expedientes, que completan el total.

La tercera Diputación del Sexenio es la que estrena la nueva Ley de ordenación provincial, con la ampliación a treinta y cinco diputados y la puesta en marcha de la Comisión provincial, lo que hace que los plenos de la Diputación pierdan una parte importante de su carga de trabajo y se traslade a la citada Comisión. La vigencia de esta Diputación va desde febrero de 1871 a octubre de 1872 , tiempo en el que se realizan setenta sesiones con doscientos cinco expedientes, en especial sobre presupuestos provinciales, obras públicas, beneficencia, enseñanza y bagajes. La Comisión permanente celebra ciento sesenta y ocho sesiones, con mil ochocientos seis expedientes, con asuntos sobre contribuciones, reemplazos y Ayuntamientos con sus correspondientes reclamaciones.

La cuarta Diputación del Sexenio está vigente desde noviembre de 1872 hasta marzo de 1874, tiempo en el que celebra cuarenta y dos sesiones con ciento cuarenta y nueve expedientes relativos a gobierno interior, obras públicas, presupuestos provinciales y beneficencia. La Comisión permanente celebró ciento setenta y seis sesiones con tres mil ochocientos ochenta y siete expedientes sobre Ayuntamientos, bagajes, beneficencia y propios. Destaca la petición de aprovechamiento forestal y, sobre todo, las reclamaciones de los reemplazos con dos mil ochocientos cincuenta y ocho expedientes presentados en los tres reemplazos que se realizan durante estos años (demasiados reemplazos y peticiones de mozos en época de malas cosechas).

La quinta Diputación del Sexenio inicia su andadura en mayo de 1874 y está vigente hasta marzo de 1875, fecha en que es disuelta. En este período sólo celebra diecisiete sesiones en las que los diputados se centran básicamente en la formación y aprobación de los presupuestos provinciales, la ultimación de cuentas y temas de gobierno interior como son las solicitudes de dimisión y las peticiones de cese de ciertos diputados ante la agitación política que precede a la Restauración. Es pequeño el número de expedientes tratados, en total noventa y cuatro. La Comisión trabaja sobre dos mil ochocientos ochenta y cuatro expedientes en ciento treinta y cinco sesiones con los habituales asuntos "de marcha corriente" entre los que sobresale el de reclamaciones de quintos con mil ochocientos cincuenta expedientes en 1874 y setecientos sesenta y cinco en 1875 . Es la respuesta y la protesta de la población ante las continuas peticiones de reemplazos por parte del Gobierno. El resto de temas son los de Ayuntamientos, contribuciones, beneficencia, sanidad y obras públicas.

En el cuadro adjunto se resumen los diferentes expedientes tratados tanto por la Diputación (D) como por la Comisión(C), en estos años. 


\begin{tabular}{|c|c|c|c|c|c|c|c|c|c|c|}
\hline \multirow[b]{2}{*}{ Competencias } & \multirow{2}{*}{$\begin{array}{r}1^{\text {a }} \text { Dip. } \\
\text { D }\end{array}$} & \multirow{2}{*}{$\begin{array}{c}\text { 2 }^{\mathbf{a}} \text { Dip. } \\
\text { D }\end{array}$} & \multicolumn{2}{|c|}{$3^{\text {a }}$ Dip. } & \multicolumn{2}{|c|}{$4^{\text {a Dip. }}$} & \multicolumn{2}{|c|}{$5^{\mathrm{a}}$ Dip. } & \multirow[b]{2}{*}{ TOTAL } & \multirow[b]{2}{*}{$\%$} \\
\hline & & & D & $\mathbf{C}$ & D & $\mathbf{C}$ & D & $\mathbf{C}$ & & \\
\hline Educación & 27 & 37 & 17 & 16 & 13 & 25 & 4 & 17 & 151 & $1 ' 1$ \\
\hline Beneficencia & 44 & 36 & 38 & 65 & 19 & 86 & 8 & 30 & 326 & 2,5 \\
\hline Reemplazos & 408 & 765 & 2 & 550 & 3 & 2858 & 0 & 2615 & 7201 & $54 ’ 7$ \\
\hline Pósitos & 5 & 15 & 0 & 1 & 0 & 1 & 0 & 4 & 26 & $0 ’ 2$ \\
\hline Contribución & 114 & 175 & 2 & 47 & 6 & 11 & 4 & 25 & 384 & $2 ' 9$ \\
\hline Arbitrios & 47 & 46 & 3 & 17 & 0 & 10 & 0 & 20 & 143 & 1 '1 \\
\hline Consumos y sum. & 5 & 12 & 0 & 23 & 0 & 28 & 0 & 11 & 79 & $0 ’ 6$ \\
\hline Obras públicas & 58 & 77 & 17 & 51 & 17 & 75 & 2 & 39 & 336 & 2 ' 6 \\
\hline Propios & 283 & 955 & 10 & 638 & 0 & 628 & 0 & 44 & 2558 & $19 ’ 4$ \\
\hline Gobierno interior & 49 & 57 & 45 & 28 & 35 & 23 & 25 & 23 & 285 & $2 ’ 2$ \\
\hline Bagajes & 5 & 28 & 3 & 12 & 0 & 9 & 0 & 17 & 74 & $0 ’ 6$ \\
\hline Ayuntamientos & 106 & 228 & 10 & 54 & 8 & 61 & 3 & 17 & 487 & $3{ }^{\prime} 7$ \\
\hline Elecc. Municip & 132 & 10 & 0 & 272 & 0 & 7 & 0 & 1 & 422 & $3{ }^{\prime} 2$ \\
\hline Elecc provinciales & 10 & 9 & 36 & 0 & 27 & 0 & 36 & 0 & 118 & $0{ }^{\prime} 9$ \\
\hline Presup Munic & 120 & 221 & 2 & 10 & 1 & 46 & 0 & 17 & 417 & $3{ }^{\prime} 2$ \\
\hline Presup. Provinc & 6 & 5 & 19 & 17 & 18 & 12 & 11 & 6 & 94 & $0{ }^{\prime} 7$ \\
\hline Justicia & 27 & 12 & 1 & 5 & 2 & 7 & 1 & 3 & 58 & $0 ’ 4$ \\
\hline Milicia Nacional & 0 & 0 & 0 & 0 & 0 & 0 & 0 & 0 & 0 & $0{ }^{\prime} 0$ \\
\hline TOTALES & 1446 & 2688 & 205 & 1806 & 149 & 3887 & 94 & 2884 & 13159 & 100 \\
\hline
\end{tabular}

Los años del Sexenio, representan una mayor independencia de la Diputación con respecto al gobierno, al desaparecer la figura del presidente/gobernador y al ser la propia Diputación la que nombra al presidente de entre todos los diputados. Este cambio representa un gran progreso para la vida de la institución por lo que supone la toma de decisiones con una menor intervención del poder político provincial y central.

Este es un tiempo revuelto, revolucionario, politizado y republicano, en el que la Diputación comparte sus actividades con la Comisión permanente, con la relativa ventaja de que los componentes de esta segunda institución son diputados nombrados por la primera. Los expedientes que se tratan son similares a los de otros años. Se repiten los correspondientes a los de reemplazos y se sigue sin tener referencias sobre la agricultura, que siendo la actividad más importante de la provincia, apenas tiene cabida en los trabajos provinciales, excepto cuando hay que quejarse por las malas cosechas o por las dificultades de exportación de los trigos.

\subsection{OBRAS PÚBLICAS}

El siglo XIX, para la provincia vallisoletana, es una época de progreso en el problema de las comunicaciones por dos razones poderosas. En primer lugar por su retraso que hace que toda mejora, por pequeña que sea, suponga un importante avance para la red provincial, sobre todo teniendo en cuenta que su orografía, por su situación en plena meseta, no ofrece grandes dificultades para el desarrollo y construcción de carreteras y caminos. En el inicio del siglo las comunicaciones de Valladolid con el resto del país son prácticamente nulas o mejor dicho: son comunicaciones precarias que en su mayoría están compuestas por "caminos de herradura". Esta situación hace difícil el transporte de los productos agrícolas, base de la economía provincial, ya que unas buenas comunicaciones supondrán al mismo tiempo la mejora y el progreso en la agricultura y en el comercio.

En segundo lugar, el progreso tecnológico hace que cambien las preferencias a las que deba dedicarse la Diputación. Si en los primeros años de vigencia de la institución el objetivo prioritario es la mejora de las carreteras y caminos vecinales, posteriormente será el Canal de Castilla, la obra más importante que se realiza en la región, con gran repercusión en su agricultura y economía y finalmente será a mediados del siglo la formidable expansión del ferrocarril, que se convertirá en la vía de comunicación más importante tanto a nivel nacional, como regional y provincial, y 
gracias a este medio se fomentará el progreso provincial en sus dos facetas más importantes y ya repetidas: la agricultura y el comercio.

\subsection{1.- CARRETERAS Y CAMINOS VECINALES}

\section{Restaurar los destrozos de la guerra sobre los puentes}

La primera preocupación que se hace ver en los plenos de la Diputación de Valladolid, en los inicios de su actividad y referidas a las obras públicas, es la de restablecer las comunicaciones y reparar las escasas vías y caminos vecinales. El motivo no es otro que el de tener que subsanar los estragos ocasionados en los años de la invasión francesa, a causa de la ocupación de la provincia en principio por los ejércitos franceses, y posteriormente por los ejércitos nacionales y sus aliados ingleses y portugueses.

Una forma clásica de frenar los avances del enemigo fue la de entorpecer su marcha destruyendo las vías de comunicación y dentro de estas vías, los puntos estratégicos y más castigados fueron los puentes. Por eso no es de extrañar que una de las primeras anotaciones que aparecen en los libros de actas esté referida a la "presentación de las cuentas de gastos de reparación de los puentes de Simancas, Villanueva de Duero y Quintanilla de Abajo en el año próximo anterior y el de Valdestillas en el 1812, presentada por su director D. Pedro García, arquitecto de esta ciudad, cuyo importe fue de treinta y seis mil setecientos reales y treinta y dos maravedíes...Se acordó su aprobación y librar la expresada cantidad a favor de dicho señor arquitecto..." 371 .

Además del interés de la corporación por arreglar las comunicaciones en beneficio de todos los ciudadanos, también son los comerciantes e industriales los que hacen las gestiones necesarias para restablecer las comunicaciones y de esta forma mantener sus actividades. Es el caso de la comunicación del intendente de Rentas a la Diputación sobre "el informe del administrador general subalterno de Peñafiel, comunicándole de haberse destruido el puente provisional de madera sobre las aguas del Duero"372. Ante esta noticia, la Diputación inicia el expediente para actuar, solicitando los datos necesarios de los daños, las causas y los costes de reparación. Pero los molineros de Peñafiel, que son los principales afectados por ser el puente el único acceso posible a sus molinos, a los pocos días presentan una propuesta por la que se comprometen "a reconstruirlo de su cargo si les proporcionan 16 ó 20 vigas y de 80 a 100 travesaños" ${ }^{373}$. Propuesta que fue aceptada por la Diputación que encargó al alcalde de Peñafiel la vigilancia de las obras y a su vez, los molineros al mismo tiempo que reparan el puente, mantienen la actividad de sus negocios.

La Diputación está dispuesta a mejorar las comunicaciones y a gastarse el poco dinero del presupuesto a este fin, pero no está dispuesta a atender reclamaciones sobre reparaciones accesorias a particulares ${ }^{374}$.

En la capital tampoco se libran de los trabajos para restablecer las comunicaciones, y en un principio tiene que ser el Ayuntamiento, al no estar todavía constituida la Diputación, el responsable de la reparación y así el día 31 de marzo de 1812, el alcalde "dio orden para que oficiales y operarios de albañilería y carpintería concurran a la orden del arquitecto D. Pedro García para la reparación del Puente Mayor que rompieron ayer las tropas francesas" ${ }^{375}$. Y en el año 1814, el Ayuntamiento

A.P V Actas Libro de actas del 18 de marzo de 1814

A.D.P.V. Actas. Libro de actas del 11 de mayo de 1814. "Micaela de Ventosa, pide que se la repare la venta que a corta distancia de la villa de Ventosa, servía en la carretera de Valladolid a Salamanca para el descanso de trajineros y transeúntes, a lo que se opone el alcalde de la villa, que dice que la venta debe de ser demolida por ser albergue de personal sospechoso y de mal vivir".

375 A.H.M.V. Libro de actas municipal del 31 de marzo de 1812. 
de la ciudad "propone a la Diputación la reparación del puente sobre el Esgueva en la calle Labradores con el importe de la venta de un pequeño terreno baldío" ${ }^{376}$. Poco más pudo hacer la Diputación, al ser suprimida al poco tiempo, pues celebró su última sesión el 25 de junio de 1814.

En el año 1820, con la Diputación nuevamente restablecida, la situación de las obras públicas no había mejorado, pues se mantenían las mismas dificultades de comunicación tanto entre los diferentes pueblos de la provincia como entre las diferentes ciudades de la región y la Diputación continuaba con la incapacidad económica para fomentarlas. El gobierno también es consciente de la falta de infraestructuras, reconoce su penuria económica y además sabe de la mala situación económica y agrícola del país a causa de las malas cosechas, por lo que "excita el celo de las Diputaciones a que en el desempeño de sus funciones promuevan todas las obras públicas que consideren útiles en sus territorios respectivos para proporcionar ocupación y trabajo a los jornaleros y a cuyo efecto propondrán los arbitrios que tengan por conveniente para cubrir estos gastos" ${ }^{377}$.

El gobierno, como vemos, pide ayuda a las Diputaciones para que fomenten las obras, den trabajo y además las financien a través de arbitrios e impuestos provinciales. A su vez, las Diputaciones siguen pidiendo ayuda al gobierno para mantener mínimamente operativas las escasas vías provinciales, al mismo tiempo que tienen que hacer frente a las numerosas peticiones de reparación y reconstrucción de los puentes de la provincia, muchos de ellos pendientes desde los años de la Guerra de la Independencia, como lo recuerda la petición del pueblo de Rueda del Almirante que sigue reclamando "reparar el puente arruinado por el general Blake" ${ }^{378}$. Aunque más curiosa es la situación del puente de Puente Duero, cuya reparación reclaman los vecinos "por el ruinoso y peligroso estado del puente y la urgente necesidad de su reparación". A la vista de esta reclamación, la Diputación "oficia al administrador de Correos, ya que el referido puente pertenece a la Dirección de Correos y Caminos" "379.

A todo este aluvión de peticiones, tenemos que añadir las de otras Diputaciones reclamando la parte proporcional de los diferentes trabajos que se realizan en las provincias limítrofes, como es el caso de Segovia, con las obras del puente de Pedraza de la Sierra, por lo que reclama a diferentes pueblos de esta provincia "el importe de 598.419 reales y 26 maravedíes, según el expediente de su referencia examinado y aprobado por el Supremo Consejo de Castilla con los cupos correspondientes a los respectivos pueblos contribuyentes" 380 .

A todas estas peticiones se suma la que realiza la ciudad de Toro, que reclama a Valladolid la cantidad de 48.855 reales por las obras del puente de la ciudad, al mismo tiempo que comunica y se lamenta de que no tiene dinero para pagar las obras del puente de Rioseco, cantidad que le reclama la Diputación. Las obras de "las calzadas y puentes de Rioseco" son una de las actuaciones más ambiciosas de la provincia, obras que van a quedar inconclusas debido a la falta de dinero. Esto produjo un importante perjuicio económico en la zona, que había puesto sus esperanzas en su remate, lo que suponía una buena vía de comunicación y de salida de los productos de "Tierra de Campos". La Diputación, en el examen de las cuentas presentadas por el depositario de las obras Felipe Rubio y de las que presenta Evaristo Lamas, recaudador de los arbitrios cargados a los pueblos de la provincia con destino a estas obras, "está convencida de la imposibilidad de continuar las obras y de pagar al arquitecto Martín de Meane los 170.000 y más reales que resultan en su favor, según

376 A.D.P.V. Actas. Libro de actas del 26 de marzo y 29 de abril de 1814.

377 Colección de Reales Decretos y Órdenes...ob. cit. Tomo VI. Real orden de fecha 19 de septiembre de 1820

378 A.D.P.V. Actas. Libro de actas del 20 de mayo de 1821

379 A.D.P.V. Actas. Libro de actas de los días 3 y 24 de mayo de 1820

380 A.D.P.V. Actas. Libro de actas del 6 de mayo de 1820. 
la tasación de obras y materiales, sin un auxilio de dinero por el gobierno de la cantidad señalada en el presupuesto general" ${ }^{381}$.

La Diputación, en su afán por llevar a buen término la obra, remite una "Exposición a S.M." haciendo historia de las vicisitudes de la misma, y solicitando ayuda para conseguir su remate ${ }^{382}$. La Diputación se lamenta de su mala situación económica, lo que no la permite el realizar una serie de trabajos pendientes, como son los diversos puentes de la provincia, que no acaban de repararse, o que se hace en unas condiciones tan mínimas que al poco tiempo vuelven a estar intransitables. En los libros de actas se reflejan las peticiones de Valladolid, Tordesillas, Almanza, Simancas, Castrogonzalo, Cabezón, Valdestillas, Puente Duero, Tudela, Quintanilla de Abajo y Peñafiel, completando la relación con la petición de reconstrucción de "otros volados e inutilizados en la pasada guerra".

Además de las citadas reparaciones de los puentes, a finales de 1822, está en el ánimo de la Corporación el abrir una carretera que desde Benavente comunique con las zonas de Sanabria y Viana del Bollo hasta alcanzar Santiago y Galicia, a través de la "Portilla de la Canda", para lo cual inicia los expedientes correspondientes. La interrupción de sus actividades pone freno a los trabajos de mejora de las comunicaciones.

\section{Atención a las carreteras interiores y exteriores de la provincia}

No es probable que en el período de la Década Ominosa se mejorase la situación en lo referente a las vías de comunicación, puesto que con la vuelta a las actividades de la Diputación, se vuelven a tratar los mismos problemas y las mismas inquietudes que se plantearon en la época del Trienio. La corporación provincial sigue preocupada por la falta y el deterioro de sus carreteras provinciales, sobre todo cuando por real orden de 24 de febrero de 1836 se ordenaba "un repartimiento de 83.000 reales de los fondos de pósitos, con objeto de rehabilitar los caminos que desde Palencia conducen a las costas cantábricas" ${ }^{, 83}$. Este planteamiento no es del agrado de la Diputación, que en su "Exposición a S.M.", solicita que ese dinero se destine a pagar la construcción de la carretera de Valladolid a Olmedo, "con lo que se conseguiría mejorar las comunicaciones y facilitar el transporte de tropas que se dirigen hacia el norte" ${ }^{384}$. Nótese la subordinación del plan de carreteras a las necesidades militares más inmediatas.

En el año 1839 se estudió una propuesta del diputado provincial por Mota del Marqués, Pelayo Cabeza de Vaca, con la finalidad de mejorar la carretera que desde

381 A.D.P.V. Actas. Libro de actas del 7 de julio de 1821.

382 "En el año pasado de 1775, cuando la ciudad de Medina de Rioseco, comprendida en esta provincia, contaba con sobrantes de mucha consideración de los fondos de sus propios y arbitrios, proyectó la construcción de pontones y calzadas a las salidas principales de ella con dirección a distintos puntos... y levantado los planos y establecido el coste en 1.041 .929 reales y 7 maravedíes, prometiendo pagar dicha ciudad la mitad, confiada en las pingües rentas... Como variaran después las circunstancias y los caudales se destinaron a otros objetos el expediente quedó paralizado... En el año 1817 se prepara todo lo necesario para el remate de las obras por la cantidad de 639.500 reales, pero por el estado miserable en que se encontraba la ciudad a causa de la pasada guerra no se pudo cumplir con lo prometido... Una vez instalada la Diputación en el año próximo pasado, el arquitecto se quejó de la falta de pago de las obras [...] y no hallando otro medio que el de ocurrir a V.M., a la que suplica se sirva expedir su real orden para que de los 19 millones considerados en el presupuesto con destino a carreteras del Rey, se ponga a disposición de esta Diputación 670.000 reales, con lo que después de pagado el arquitecto se concluyan las obras, tan útiles y necesarias al paso y carretera general a Galicia, Asturias y otros puntos interesantes de continuo tránsito". A.D.P.V. Actas. Exposición al Rey, remitida por la Diputación y reflejada literalmente en el acta del día 7 de julio de 1821.

383 A.D.P.V. Actas. Libro de actas del 23 de marzo de 1836, en el que se transcribe el real decreto.

384 Petición que es denegada, confirmando el Gobierno su interés por mejorar el camino desde Palencia a Herrera de Pisuerga, según se publica en el Boletín Oficial de la Provincia no 88 de 19 de julio de 1836. Posteriormente y con fecha 30 de abril de 1839 se aprueba por R.O. la construcción de la carretera Valladolid-Olmedo, con la financiación de los 83.000 reales de los fondos de los pósitos, cantidad que es considerada como inexistente por la Diputación, "pues la situación de los pósitos era apurada por los continuos repartimientos que había sufrido el año anterior". 
Simancas llegaba a Tordesillas, "manifestando las considerables ventajas que habría de resultar a la provincia la recomposición del camino de Simancas a Tordesillas, dando salida por él, a sus frutos, todos los pueblos del sudoeste de la provincia" ${ }^{" 385}$.Entre tanto, la carretera de Valladolid a Rioseco sigue dando problemas tanto de construcción como de presentación y situación de las cuentas, ya que el depositario de fondos, reclama al administrador de la obra "la justificación del pago de 78.000 reales, o en su caso la devolución de dicha cantidad" "386.

Además de la financiación de las carreteras de la provincia, la Diputación tiene que hacer frente a la parte proporcional de los gastos de las carreteras que pasan por la provincia. Así lo recuerda la real orden de 30 de diciembre de 1839, que trata sobre el trazado y construcción de la carretera de Zamora a Villacastín, en la que se pide la emisión de los arbitrios necesarios para su financiación.

En el período comprendido en los años 1840-41 apenas se refleja actividad en el fomento de las carreteras por parte de la Diputación, y solamente será la Diputación de León, interesada en el remate de las comunicaciones con Asturias, la que solicite a la Diputación de Valladolid la reunión de una comisión de ambas para tratar el tema.

Una carretera que sí tiene importancia, pero que sufrirá una serie de retrasos y aplazamientos, es la que comunica con Salamanca, continuando el trazado desde Tordesillas. El día 13 de septiembre de 1841, se acuerda crear una comisión al respecto y financiar los trabajos a través de los arbitrios correspondientes. Por otra parte, continúan los trabajos de la carretera general Madrid-Galicia entre las poblaciones de Sanchidrián, Medina y Tordesillas, pero que al ser carretera nacional, está financiada en su totalidad por el Estado y no tiene incidencia en la Diputación.

A partir del año 1842, se progresa en los proyectos de Valladolid-Mayorga y Valladolid-Salamanca, siendo presentados el 16 de marzo, por el ingeniero Antonio Arrieta, director de las obras ${ }^{387}$. En la misma sesión en que se anuncia el remate de las obras, también se presenta una relación de arbitrios, con lo que se cubriría el coste de estas obras. Son treinta y cuatro arbitrios que van desde los consumos habituales de cualquier ciudadano hasta los suntuarios y de lujo, que sólo se pueden permitir un limitado número de personas. La cantidad que se impone oscila entre un maravedí que se cobra por cántaro de vino hasta 100 reales por cada coche de lujo o por cada función pública. Estos arbitrios son protestados por la mayoría de los pueblos a través del diputado Sr. Cantalapiedra ${ }^{388}$. En la subasta celebrada el día 24 de junio, sólo se cubrieron los siete primeros trozos de la carretera de Mayorga a los contratistas Manuel Ormaeche de Munquía y Ramón Romillo de Carriedo en el Valle de Mena por la cantidad de 1.524.300 reales. La subasta de la carretera de Parada de Rubiales quedó desierta. Se convocó una nueva subasta para el 20 de septiembre en la que no hubo postores para cubrir los trabajos y además los contratistas de Mayorga rechazaron las exigencias de la fianza impuesta y se retiraron de la puja.

385 A.D.P.V. Actas. Libro de actas del 16 de mayo de 1839.

386 A.D.P.V. Actas. Libro de actas del 8 de junio de 1839.

"Esta Diputación ha creído conveniente proceder al remate de los once trozos en que se ha dividido la longitud total de la carretera hasta el puente de Mayorga, y de los quince en que del propio modo está subdividida la línea hasta Parada de Rubiales en Salamanca... El remate de las dos líneas de carreteras se celebrará el día 24 de junio en la sala de sesiones de esta Corporación, debiendo tener entendido que las 20.390 varas de longitud que componen los once trozos hasta el puente de Mayorga están presupuestadas en 4.764.920 reales, en que se incluye la explanación, firme, alcantarillado y pontones y que las 101.535 varas de longitud de los quince trozos hasta Parada de Rubiales se han valorado en los mismos términos en 4.594.345 reales..."A.D.P.V. Actas. Libro de actas del 3 de mayo de 1842. Es una trascripción literal en la que discrepamos de los números que están reseñados. La distancia que habla de Valladolid a Mayorga indica 20.390 varas ( 1 vara $=0,836$ metros) por lo que indica que la distancia es de 17,045 kilómetros cuando la realidad está en 70 kilómetros. La segunda discrepancia está en el precio ya que resulta más cara una carretera de 20.390 varas que otra de 101.535 , siendo similares las dificultades orográficas.

388 "solicitan suspender las obras de las carreteras de Mayorga y Parada de Rubiales por cuatro años, para dar un respiro a los pueblos de la provincia porque hoy en día están agobiados". A.D.P.V. Actas. Libro de actas del 9 de junio de 1842. Con el acuerdo por el que se rechaza la petición de Cantalapiedra. 
Una nueva subasta se convocó para el 1 de diciembre del mismo año 1842 , en la que sólo se presentaron los dos contratistas anteriores de los siete tramos de Mayorga, a los que se les concedió la contrata sin las exigencias anteriores. El 15 de diciembre se volvió a convocar nueva subasta. En esta ocasión se aprobó la concesión de cinco tramos de Valladolid a Parada de Rubiales por 1.603.235 reales a los mismos contratistas Ormaeche y Romillo a los que se habían adjudicado parte de la carretera de Mayorga. Se vuelve a convocar subasta el 7 de enero de 1843 y el 25 del mismo mes en el que se aprueba la contratación de tres nuevos tramos de la carretera de Rubiales a Isidro del Campo de Reinosa, Ramón Fernández y Eusebio Rodríguez de Valladolid y Adrián Micieces de Alaejos.

El día 20 de febrero, en sesión extraordinaria se procedió a la aprobación de un "repartimiento de 10.323.265 reales a que asciende el importe total de los presupuestos de las carreteras de Mayorga y Parada de Rubiales, con inclusión del interés del $5 \%$ que han devengado las cantidades que se anticipan por los contratistas" ${ }^{389}$. Pero como es habitual en estos casos, la mayoría de los pueblos rechazaron el repartimiento realizado. En principio, sólo lo aprobaron cincuenta pueblos de los doscientos setenta y dos que componen la provincia, todos ellos directamente interesados en la construcción de la carretera, pero que posteriormente también rechazaron los arbitrios. Ante esta situación la Diputación convoca a los comisionados de los pueblos a una nueva reunión para tratar de llegar a un acuerdo sobre la financiación. Se inician estos nuevos contactos el 10 de julio de 1843, con los pueblos del partido de Valoria, "que se quejan de la pobreza de sus pueblos y de la imposibilidad de hacer frente a los cupos y lo rechazan por unanimidad" ${ }^{390}$. De la misma forma se expresaron la totalidad de los comisionados de los pueblos del resto de los partidos, es decir, de Olmedo, Alaejos, Medina, Peñafiel, La Mota, Rioseco, Villalón y Valladolid, y todos ellos rechazaron los arbitrios.

La situación se complica cuando los contratistas que ya han comenzado la construcción de las carreteras "sin haber cobrado un céntimo", reclaman el pago de la obra realizada más los intereses. En una reunión con la Diputación se acordó "que el pago de los trabajos de los quince trozos contratados se hará por trimestres. Las obras de 1843 se pagarán por su importe, sin intereses y a partir de 1844 se pagará un rédito de $5 \%$ de la obra adelantada" ${ }^{391}$. La Diputación ve otra posibilidad de financiación cuando, a través de un informe del diputado por Alaejos D. Baltasar González, se entera "del préstamo solicitado por el Gobierno a D. José de Salamanca por un importe de 400 millones para la construcción de carreteras nacionales" ${ }^{392}$. Ante esta noticia, el Pleno de la Corporación acuerda solicitar que las carreteras de León y Salamanca sean de carácter nacional y en consecuencia, financiadas por el Gobierno, y al mismo tiempo se le pide que se haga cargo de las escrituras firmadas por los contratistas. Es una posibilidad de construir las carreteras sin gravar la economía de la provincia. Se nombra a los diputados González y Puga para ocuparse de las gestiones necesarias para llevar el asunto a buen término a través de una "exposición al Gobierno" y hacer "el desplazamiento a la Corte en comisión" para tratar el tema.

Las gestiones tienen un éxito relativo, pues "por real orden de 9 de noviembre de 1843, se aprueba la declaración de carretera general la proyectada entre Valladolid y León, con las obras a cargo de la Nación, aunque la provincia debe de costear la cuarta parte y la carretera de Valladolid a Parada de Rubiales, con los arbitrios ya concedidos" ${ }^{\prime 393}$.

Esta solución, aunque en un principio fue aprobada por la Diputación, no impidió que parte de los diputados se quejaran del "agravio que se les hacía" y se

\footnotetext{
389 A.D.P.V. Actas. Libro de actas del 20 de febrero de 1843, con detalle del importe de los arbitrios para cada pueblo de la provincia.

390 A.D.P.V. Actas. Libro de actas del 10 de julio de 1843.

391 A.D.P.V. Actas. Libro de actas del 31 de julio de 1843.

392 A.D.P.V. Actas. Libro de actas del 6 de septiembre de 1843.

393 A.D.P.V. Actas. Libro de actas del 17 de noviembre de 1843, donde se publica la real orden.
} 
presentó una exposición redactada por los diputados Alonso y Montealegre ${ }^{394}$. La Diputación acordó presentar esta "exposición" al Gobierno, al que también llegaban las reclamaciones de los contratistas que seguían trabajando sin recibir pago alguno. El Ministerio de Gobernación de la Península ante esta situación acuerda que la Diputación pague una buena parte ${ }^{395}$. En definitiva, la Diputación no consigue solucionar y agilizar el tema de las carreteras, pues han pasado los años 1842, 1843 y parte de 1844 y los problemas de financiación continúan. El Gobierno pide a la Diputación que cobre los arbitrios y ésta sigue reclamando al Gobierno que se las declare carreteras nacionales. Al mismo tiempo, se trabaja en el modo de hacer efectivos los arbitrios ya concedidos, para pagar las obras y es que las actuaciones tanto del Gobierno como de la Diputación son muy cambiantes. En julio de 1844 se publica una real orden "eximiendo a la provincia del pago de la cuarta parte de los gastos con que tenía que contribuir para la construcción de la carretera de Valladolid a León y se apliquen a la de Salamanca los arbitrios concedidos con este objeto" ${ }^{396}$.

Es una forma salomónica de zanjar el problema, "el Estado paga una carretera y la provincia paga la otra", pero los problemas no se solucionan, entre otras cosas, porque la Diputación de Valladolid no tiene dinero ni de dónde sacarlo y además le surgen más gastos, motivados por la ansiada visita de la reina, lo que obliga al jefe político Laureano de Arrieta a enviar un oficio a la Diputación en julio de 1845 en la que solicita que "atendiendo a la urgente necesidad de que se ponga transitable el nuevo camino de esta capital a Simancas de manera que desaparezcan los continuos e inminentes riesgos que en el día ofrece su tránsito, pido a la Diputación se ejecuten las obras y reparaciones que el ingeniero jefe de Caminos señale como necesarios" ${ }^{397 .}$.

Las dificultades en estas carreteras, tanto de construcción como de financiación continúan, pero eso no es inconveniente para iniciar las gestiones tendentes a construir una nueva carretera desde Valladolid a Calatayud. Para ello se procede al nombramiento de una comisión que se encargue del estudio de viabilidad y sobre todo de financiación ${ }^{398}$. En este último sentido, el jefe político pasa un informe al Gobierno "sobre la conveniencia de extender hasta Salamanca la carretera proyectada desde Zaragoza a Valladolid y Zamora, solicitando del Gobierno que la carretera se construya en dirección a Salamanca en lugar de Zamora" ${ }^{399}$.

En el año 1847, se publica la real orden de 21 de enero "por la que se aplican 5.500 .000 reales a la carretera de Valladolid a Calatayud" "400. La Diputación, en consecuencia, propone la adopción de arbitrios para la financiación de la carretera, cobrar seis reales en fanega de sal y el pontazgo de los puentes de Simancas y Tudela. Además tiene que discutir el trazado, puesto que parte de los diputados, encabezados por el representante de Valoria, Sr. Quintero, se hacen eco de la petición de los pueblos del valle del Esgueva "para que la carretera de Aragón pase por su valle en lugar de por Tudela y Peñafiel", a lo que la Diputación contesta remitiéndose a la comisión formada, para que sea ésta la que decida por dónde debe de pasar la

394 “sobre que las dos líneas de caminos son notoriamente de la clase de generales y por consiguiente de cuenta de la nación... y no es razonable la real orden de 9 de noviembre, por la que se tenía que pagar por parte de la provincia la cuarta parte de la carretera de Mayorga y la totalidad de la de Parada de Rubiales, ya que la miseria pública y el lastimoso estado de los pueblos pagando las contribuciones ordinarias a duras penas presentaban la más absoluta posibilidad de hacer sacrifico alguno" A.D.P.V. Actas. Libro de actas del 6 de febrero de 1844.

395 "enterada S.M., ha tenido a bien resolver que la Diputación abone a los citados contratistas la totalidad de las obras que hubieren ejecutado del camino provincial de Valladolid a Parada de Rubiales, y las hechas en la carretera de León hasta el 9 de noviembre del año último, en que fue declarada carretera general aplicando a estos pagos los arbitrios propuestos por la misma Corporación..." A.D.P.V. Actas. Libro de actas de 25 de mayo de 1844.

396 B.O.P.V. n ${ }^{\circ} 90$ de fecha 27 de julio de 1844.

397 A.D.P.V. Actas. Libro de actas del 16 de julio de 1845. En ella, algunos diputados hacen ver que "la visita real no es razón para comprometer a los pueblos en unos gastos que no podían soportar".

398 A.D.P.V. Actas. Libro de actas del 24 de junio de 1847.

399 A.D.P.V. Actas. Libro de actas del 7 de julio de 1846.

400 B.O.P.V. n ${ }^{\circ} 12$. Real orden publicada en el Boletín del 28 de enero de 1847. 
carretera. Y la comisión hace ver "que en los primeros años de este siglo se acordó la dirección por el camino de Tudela y Peñafiel, que los puentes de estos dos pueblos ya están construidos, que el camino hasta Peñafiel ya está hecho y sólo es necesario ensancharlo y no son necesarias las expropiaciones, y que el camino del valle de Esgueva sería totalmente nuevo"401.

Entre tantos inconvenientes, aparece una buena noticia en el Boletín Oficial de la Provincia, anunciando el 20 de mayo de 1847 "la autorización para transitar por la carretera de Valladolid a León por Mayorga, al estar ya concluida".

En el año 1848 sigue en su fase de construcción la carretera de Salamanca y en el mismo año se inician las obras de la carretera de Calatayud, que por una "comunicación de la Dirección General de Obras Públicas" es declarada "gran carretera transversal", lo que supone que la mitad de sus gastos serán pagados con fondos del Estado. El proyecto de esta carretera asciende a 4.735.800 reales, tal como fue aprobado por real orden de 10 de enero de 1847. De esa cantidad, se destinan un millón a invertir en el año 1848 en "las obras de los puentes de Tudela y Peñafiel y el trozo de Valladolid a Tudela. La Diputación hace cuentas y ve que el montante que tiene que desembolsar asciende a 2,5 millones de reales, y como única salida tiene que hacerlo a través de los arbitrios: Pontazgo del puente de Tudela y el $8 \%$ de recargo en las especies de consumo ${ }^{402}$.

En el año 1849, se inician los trámites para la construcción de una nueva carretera que una las ciudades de Valladolid y Segovia, y ya en los inicios se pide un informe al ingeniero de caminos por parte del jefe político de Valladolid, "porque no está de acuerdo con el trazado proyectado por la Diputación de Segovia" "403.

En el año 1851 se inician los trabajos para la construcción de la carretera de Valladolid a Zamora, "con un coste para la provincia de Valladolid de dos millones de reales, y que el $50 \%$ corresponde al Estado por ser carretera mixta. Se hace ver que el camino hasta Tordesillas está intransitable y que la carretera será beneficiosa para la provincia. Se acuerda solicitar al Gobierno el inicio de las obras" ${ }^{404}$. La solicitud tiene éxito, pues se corrobora a través de la real orden de 23 de enero de 1852 , en la que se comunica que "es aprobado el remate celebrado en Madrid para ejecutar las obras de la carretera transversal de Valladolid a Zamora, en la parte de Valladolid a favor de Domingo Benito y Guillén por la cantidad de 2.628.043 reales".

La carretera que sigue teniendo dificultades para su realización es la repetida de Valladolid a Salamanca, aunque se suceden las aprobaciones por parte del Gobierno. A lo largo del año 1852, en principio por real orden de 15 de abril de 1852, "se aprueba el proyecto de construcción de la carretera entre Parada de Rubiales y Tordesillas por 3.586.650 reales, con cargo a los fondos del Estado". Esta se complementa con otra real orden de 3 de mayo de 1852 "sobre el proyecto de carretera de Salamanca a Parada de Rubiales por un importe de 1.954 .488 reales" 405 .

En los sucesivos presupuestos de los años 1853 y 1854, se siguen incluyendo cantidades para el pago a los contratistas de las carreteras. Pero una cosa es presupuestar y otra muy distinta el pago de los trabajos, pues como se refleja en los de 1853: "El rechazo de los presupuestos por el Gobierno, obliga a negociar el déficit de 549.958 reales con cargo a la eliminación de los pagos de las carreteras y el acuerdo con los constructores para que continúen las obras con la condición de abonar el $6 \%$ de interés por las obras hechas y no pagadas".

En el año 1854, continúa la Diputación con sus dificultades económicas y con "una situación tan caótica ante el considerable déficit de 2,5 millones de reale s que resulta del presupuesto provincial del año corriente, que no tiene otra solución que aplazar el pago de la deuda que arrastra con los contratistas de las carreteras de

401 A.D.P.V. Actas. Libro de actas del 23 de junio de 1847.

402 A.D.P.V. Actas. Libro de actas del 23 de octubre de 1847.

403 A.D.P.V. Actas. Libro de actas del 14 de junio de 1849.

404 A.D.P.V. Actas. Libro de actas del 7 de noviembre de 1851.

405 A.D.P.V. Actas. Libro de actas del 27 de mayo de 1852. 
Calatayud y Zamora que ascienden a 512.810 reales que debe a Pedro Martín Sanz y 1.007.506 que son a favor de Domingo Benito y Guillén" ${ }^{406}$. Estos aplazamientos no agradan a los contratistas, pues continúan invirtiendo su dinero, pero no reciben nada de las arcas de la Diputación, que no tiene más remedio que reconocer "que no tiene capacidad económica para mantener tantas obras y que además tiene a la provincia muy gravada en años de penuria y grave falta de cosechas".

En el año 1855, la carretera de Segovia sigue en fase de proyecto, y la Dirección General de Carreteras pasa un oficio a la Diputación para que "tome una decisión sobre el trazado de la carretera Valladolid-Segovia por Carbonero, camino que tiene 1,5 leguas menos que por Santa María de Nieva, que tiene como dificultad la construcción de un puente nuevo" ${ }^{407}$. El ingeniero de obras públicas opta por Carbonero y, aunque la Diputación se inclina por Santa María de Nieva, la real orden de 2 de marzo de 1856 "aprueba la construcción de la carretera de Segovia a Valladolid por Carbonero, con un presupuesto de 4.854.964 reales".

El año 1856 es un año de revueltas, de motines, y de hambre en el ámbito provincial. Para paliar estas dificultades, con ocasión de la toma de posesión de una nueva Diputación, los diputados "examinaron muy detenidamente el expediente general de caminos vecinales instruido en Secretaría con arreglo a las supremas

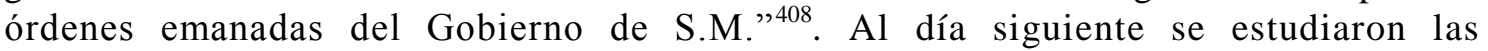
realizaciones de una serie de caminos vecinales, con la finalidad principal de mejorar la situación económica de los jornaleros. La financiación se realizará a través de los bienes de propios o de arbitrios de las poblaciones directamente interesadas. Las obras acordadas son las siguientes:

\section{Caminos de Primer y Segundo Orden}

Se atendieron obras, en este sentido, de caminos de primer orden entre Rioseco y Villalón, vía en la que ya hay realizados algunos tramos. También entre Rioseco y Villalpando por Villafrechós, entre Rioseco y Toro por Villardefrades. Asimismo se aborda la construcción de un camino desde Rábago por Peñafiel, Villaco y Villafuerte a la estación del ferrocarril de Dueñas. Se realizan obras en el camino que desde Valladolid pasa por Renedo, Castronuevo, Villarmentero y Villanueva de los Infantes hasta Encinas para enlazar todos estos pueblos con la carretera de Madrid (camino de valle de Esgueva). Igualmente se realiza un camino que comunica Medina del Campo y Fuentesauco por Nava del Rey y Alaejos.

Referente a los caminos de segundo orden, se abordan los de Valladolid a Vega de Valdetronco por Torrelobatón, los de Cigales y Corcos a Quintanilla de Trigueros, los de Rueda por La Seca a Matapozuelos para empalmar con el ferrocarril. Se hacen obras entre Pesquera y Canillas por Piñel de Arriba y Piñel de Abajo, entre Peñafiel y Canalejas, entre Tudela y Cuellar por Montemayor, entre Medina del Campo y Olmedo, entre Mojados y Valdestillas a la estación del ferrocarril y entre Valladolid y Montealegre por Fuensaldaña ${ }^{409}$.

En el año 1858 se sigue progresando en la construcción de los caminos vecinales y al mismo tiempo se proyectan otros nuevos de carácter interprovincial, como son los de Peñafiel con Cevico de la Torre (Palencia), Becilla de Valderaduey con Villada (Palencia) y Tordesillas con Olmedo.

\footnotetext{
406 A.D.P.V. Actas. Libro de actas del 16 de julio de 1854

407 A.D.P.V. Actas. Libro de actas del 3 de julio de 1855.

408 “... y considerando que es un negocio vital para las localidades que representan, porque se roza con la grave queja de subsistencias y hasta con la de orden público, pues que de su resolución han de reportar grandes beneficios (a los) menesterosos, asegurando en lo posible un jornal para atender a sus necesidades en el próximo invierno, acordó oír el dictamen facultativo del Sr. ingeniero del distrito D. Antonio López y en presencia de él celebrar otra sesión el día de mañana" A.D.P.V. Actas. Libro de actas del 2 de diciembre de 1856.

409 A.D.P.V. Actas. Libro de actas del 3 de diciembre de 1856.
} 
Pero los caminos vecinales se deterioran con facilidad y la necesidad de mantenerlos transitables obliga a la Diputación a "nombrar una comisión para estudiar el asunto y proponer soluciones". Todos los inconvenientes se centran en la dificultad para obtener los fondos necesarios para la reparación. Como posible solución, "se invitó a la sesión a Mr. Georgeri, ingeniero del Ferrocarril del Norte, a causa de la buena disposición de la compañía en auxiliar a la provincia. La Diputación acordó facilitar al citado ingeniero los documentos relativos a la reparación de caminos para que propusiera los auxilios que podía dar a la provincia" ${ }^{410}$. El ingeniero Georgeri presentó su "Plan de Caminos" y un "Pliego de Condiciones", según el cual "la Compañía realizará los trabajos por cuenta de la provincia. ... Al reembolso de su coste se añadirá una octava parte por gastos generales. ... Los caminos a construir son: Mota-Valladolid; Nava del Rey-Alaejos; Rueda-Pozaldez; Mojados-Valdestillas; Cubillas-Cabezón" 411 . En verdad, no era una propuesta beneficiosa para la provincia, sino más bien era una respuesta interesante para la Compañía del Norte. Lo cierto es que la Diputación no contestó al proyecto de Georgeri, aunque continuó fomentando la construcción de caminos sin aclarar en ningún momento el modo de financiarlos.

Será con ocasión de la publicación de la real orden de 24 de diciembre de 1862 por la que se pide "la formación de un Plan de Caminos, con cargo a los fondos de la provincia", cuando la Diputación acuerde la construcción de nuevos caminos. Son caminos que completan la red establecida en el año 1856 y que enlazan entre sí los principales pueblos de la provincia y también con diferentes carreteras generales: Bolaños-Villada. Villalón-Izague. Rioseco-Urones. Valladolid-Casasola. Valladolid -Cubillas. Alaejos-Nava del Rey. Rueda-Olmedo. Puente Blanca-Iscar. TudelaCampaspero. Pesquera-Encinas. Renedo-Castrillo.

En la sesión plenaria que celebra la Diputación en enero de 1865 , se vuelve a insistir en la importancia de los caminos vecinales y en la necesidad de rematar su construcción. Lo mismo sucede con las carreteras en vías de terminación, como son los trayectos Valladolid - Calatayud, Valladolid - Zamora, Valladolid - Salamanca y Valladolid - Segovia. Carreteras que en su mayoría están prácticamente terminadas, o se rematarán entre los años 1865-1868, pero que continúan con los inconvenientes de su falta de pago y en consecuencia de las continuas reclamaciones de los contratistas.

A partir de 1868, nuevas dificultades económicas a causa de la pérdida de la cosecha, motivada por la sequía, hace que se vuelvan a activar la construcción de obras públicas, con la intención ya repetida en ocasiones anteriores y que se reflejan en los libros de actas de "dar trabajo a los jornaleros". Esto hace que se presenten una serie de proyectos, unos de nueva creación y otros pendientes de años anteriores. Son Rioseco-Palencia, Rioseco-Villada, Villafranca de Duero-Padilla, Villalón-Palencia, Castrodeza-Mota, Rioseco-Tordesillas, Olmedo-Matapozuelos, Peñafiel-Sepúlveda, Alaejos-Nava de la Libertad, Peñafiel-Segovia, Valladolid-Villabañez y La Seca a carretera La Coruña. Y con estos proyectos continuaron los trabajos de mejora de las vías de comunicación de la provincia, sin que surgieran nuevos proyectos o nuevas construcciones hasta finales de 1874.

Como resumen a este apartado dedicado a las carreteras, un hipotético mapa de la provincia en estos años nos mostraría la gran cantidad de obras realizadas o en vías de realización. En este punto hay que destacar el gran esfuerzo que realiza la Diputación para equipar a la provincia con una red viaria que facilite el transporte y las comunicaciones entre todos los pueblos. Es la finalidad de las numerosas realizaciones de caminos vecinales de primero y de segundo orden. Vemos como las "cabezas de partido" se comunican entre sí, y con los pueblos de su influencia, sin olvidar su conexión con la capital.

En este mismo sentido, otra importante actuación en este ámbito, es la de la articulación de una serie de carreteras que con el punto de partida en Valladolid, se

410 A.D.P.V. Actas. Libro de actas del 15 de abril de 1862

411 A.D.P.V. Actas. Libro de actas del 8 de mayo de 1862. 
dirigen hacia las capitales del entorno regional, como con Salamanca, Zamora, León, Segovia, que complementan a las ya existentes carreteras de Burgos y de Palencia, con cuya construcción se potencia la situación estratégica de Valladolid como cabecera de la región castellana, que se complementa con la conexión a Madrid y con la realización del "eje transversal", que enlaza las capitales de Galicia y Aragón, a través de la capital castellana. Esta gran actividad viaria, tiene a la Diputación como a su más firme defensora y promotora, que se responsabiliza de la gestión de las obras y carga con una parte importante de su coste.

\subsubsection{EL CANAL DE CASTILLA}

Es la más importante obra de ingeniería que se realiza a lo largo del siglo XIX en las provincias de Palencia y Valladolid. Formaba parte de un ambicioso proyecto de canales que comprendía también las provincias de León y de Segovia y con una conexión con el río Duero en la provincia de Zamora, además de la pretensión de unir el Canal de Castilla con el Canal Imperial de Aragón. Todas estas intenciones pronto se vieron recortadas tanto por su dificultad técnica como por su dificultad económica. Para la provincia de Valladolid estaba claro que la finalidad principal del canal era la de acercar la producción agrícola castellana a los puertos del Cantábrico.

La historia de la construcción del canal se inicia en el año 1751, a partir del interés del Marqués de la Ensenada en el progreso de las comunicaciones fluviales, quien encarga a Antonio de Ulloa y al ingeniero francés Carlos Lemaur, que "inicien los estudios tendentes a conseguir la comunicación de la zona castellana de Tierra de Campos con el puerto de Santander" ${ }^{\prime 12}$.

El ingeniero Lemaur elabora un borrador al que denomina "Proyecto General de Canales de Castilla", en el que se contempla la construcción de una vía fluvial dividida en tres canales: Canal del Norte, desde Alar del Rey hasta Calahorra de Ribas. Canal de Campos, desde Calahorra de Ribas a Rioseco. Canal del Sur, desde El Serrón a Valladolid. Además preveía un canal que comunicaría Alar del Rey con la costa Cantábrica, lo que completaría una parte del proyecto. Asimismo un canal de comunicación y riego desde Segovia a Valladolid. Y finalmente contemplaba un canal de riego y comunicación desde Rioseco al río Duero en Zamora.

Las obras se inician en el año 1753, con la construcción de un tramo del Canal de Campos, y sufrirían una primera parada en el año 1757. En estos cinco años se construyó "el trozo que se inicia en Calahorra de Ribas y llegaba hasta Paredes de Navas". Se volvieron a retomar las obras en el año 1759 y continuaron hasta 1804 . En esta ocasión se reiniciaron en el Canal del Norte y se construyó la totalidad del Canal desde Alar del Rey hasta Calahorra de Ribas y también un trozo del Canal del Sur, desde el Serrón hasta Villamuriel de Cerrato. Parte de estas obras se ejecutaron bajo la dirección del ingeniero Juan de Holmar, por jubilación de Carlos Lemaur.

En el año 1804, se volvieron a suspender las obras, tanto por causas políticas como por causas económicas. En este período que transcurre desde el inicio de obras en 1753 hasta la parada de 1804, el ritmo de las mismas fue bastante lento, pues se construyó un total de 2.836 varas por año ${ }^{413}$, lo que representa 2.361 metros anuales. Hay que valorar que además del trazado del Canal, se construyeron una serie de exclusas para regular el caudal, además de puentes, muelles y almacenes.

En la primera etapa de vigencia de la Diputación que discurre entre los años 1813 y 1814, no se hace referencia alguna a las obras del Canal, entre otras razones porque las citadas obras están paralizadas, y continuarán en esa situación hasta el año 1820. Es a principios del citado año, con la nueva puesta en marcha de la Diputación, cuando por ésta se retoma el interés por el Canal y la finalización de las obras. En una de las primeras sesiones "se acordó invitar a las Diputaciones Provinciales de Castilla,

${ }^{412}$ HELGUERA QUIJADA, J, GARCÍA TAPIA, N. y MOLINERO HERNANDO, F. El Canal de Castilla. Ed. Junta de Castilla y León. Valladolid. 1990.

413 Una vara equivale a 0,836 metros. 
acerca de la continuación del Canal de Campos, manifestando las grandes ventajas que podrá acarrear al país, a fin de que diputados individuos de su seno concurran el día 12 de mayo al punto céntrico de Palencia a conferenciar sobre el objeto" ${ }^{414}$. Las contestaciones de las Diputaciones de Zamora, Salamanca, Segovia y León fueron positivas y aceptaron la reunión. La Diputación de Valladolid acordó comisionar al diputado Berdonces.

En este período de vigencia de la Diputación, en el Trienio Liberal, las referencias al remate de las obras del Canal serán numerosas y predominarán sobre el resto de las obras públicas. En verdad sólo fueron referencias, porque curiosamente en estos tres años no se reiniciaron las obras, pero sí que se movilizaron las Diputaciones interesadas para conseguir el remate del Canal.

El Gobierno Central, por su parte, también muestra interés por acabar las obras, como queda demostrado a través de los presupuestos generales para el año 1821 que, aprobados por real decreto de 8 de noviembre de 1820, fijaban un capítulo para Caminos y Canales con un importe de doce millones de reales. Entre las diferentes obras presupuestadas, vemos varias obras de la provincia como son el camino de Burgos a Valladolid y las reparaciones de los puentes de Valdestillas y Castrogonzalo. Al final del capítulo se refiere al Canal de Castilla: "Para la continuación del de Castilla en concepto de obra nueva, se aplica todo el sobrante, que después de satisfechas las mismas que quedan expresadas, resulte hasta doce millones de reales, que para los objetos citados se pone a disposición del Ministerio de Gobernación de la Península"415.

Si de los doce millones presupuestados descontamos el importe del resto de las obras, que ascienden a 8.897.716 reales, vemos que para el Canal de Castilla resta una cantidad de 3.102.284 reales, es decir, el 25,85\% del total presupuestado. Porcentaje indicativo de la importancia que concede el gobierno a la citada obra. Sin embargo, a pesar de las buenas intenciones, ese dinero no llegó a su destino, las obras del Canal, ya que estas no se reanudaron, aunque sí se gastaron ciertas cantidades en la conservación de la obra ya realizada.

En el siguiente año de 1821, el Gobierno sigue con el interés de las obras, pero también reconoce que sus dificultades económicas no le permitirán dedicar fondos al Canal, por lo que invita a las Diputaciones y a los particulares a financiar las obras a través de una real orden, ${ }^{416}$ en la que queda reflejado el interés del gobierno por las obras, pero también el reconocimiento de su imposibilidad de dedicarle una mínima cantidad de dinero. De acuerdo con esta real orden, las Diputaciones se reúnen y tratan de poner en marcha las obras, cosa que agrada al gobierno. "S.M. ha visto con mucho agrado y satisfacción la exposición de la Junta de diputados provinciales reunidos en Palencia para tratar de la continuación del Canal de Castilla y excita el

\footnotetext{
414 A.D.P.V. Actas. Libro de actas del 21 de abril de 1820.

415 Colección de Reales Decretos y Órdenes... ob. cit. Tomo VI. Real decreto de 8 de noviembre de 1820.

416 “La real orden adjunta enterará a V.S. que las obras públicas que se tienen por más necesarias y que conviene emprender y seguir con más tesón son las del Canal de Campos. Reconocida muy generalmente esta necesidad, se creyó que los particulares y autoridades de Castilla las promovería mancomunándose y finalizando algunas propuestas. Esto aún no se ha verificado, y convencido el Gobierno de ser este el medio más eficaz y acaso el único de dar a las cosechas de Castilla la extracción y valor que necesitan.... Como por otra parte el estado de la nación no permite anticipar los fondos necesarios para esta empresa, conviene que V.S. se entiendan con las Diputaciones Provinciales de Burgos, Santander, León, Palencia y Zamora y promuevan por todos los medios posibles la formación por acciones o de otro modo, de una compañía o empresa que se quiera encargar de la continuación de estas obras con la obligación de concluirlas en un tiempo determinado. A este fin se la concederán todas ventajas y seguridades... y el Gobierno facilitará los ingenieros que dirigirán las obras por cuenta de la compañía". Colección de Reales Decretos y Órdenes... ob. cit. Tomo VI. Real orden de fecha 14 de agosto de 1821, sobre el Canal de Campos (doc. 152).
} 
celo de los individuos de dicha Junta para llevar a cabo las obras"417. Pero la Diputación de Valladolid no está de acuerdo con las conclusiones de la Junta y en su oficio remitido al resto de participantes les hace ver "que los medios que se han propuesto para continuar el Canal de Castilla, y principalmente el de repartir cuatro millones y medio de reales entre las seis provincias de la demarcación, por la pobreza en que están constituidas, no son suficientes, y menos si el gobierno no hace efectivas las cantidades señaladas en los presupuestos generales en los dos años anteriores y sucesivos...". Continúa en el mismo oficio presentando una posible solución de financiación: “...que para este último objeto, opina, sería oportuno destinar los descubiertos de la contribución que con cualquier motivo tengan todos los pueblos de las seis provincias y por los años desde 1814 hasta el 1820, ambos inclusive" ${ }^{418}$.

Esta propuesta también es enviada a los diputados a Cortes de las citadas provincias para que la conozcan y apoyen. Mientras los diputados trataban el tema, el gobierno, aun sabiendo la imposibilidad económica de realizar otro nuevo canal, "manda formar cinco secciones compuestas de ingenieros de caminos y canales, para que cada una, en el terreno que se le designe, se emplee en hacer los reconocimientos y demás trabajos que se señalan dirigidos a adquirir las noticias y datos necesarios a fin de llevar a efecto la prolongación y unión de los Canales de Castilla y Aragón..." 419 . Tema al que la Diputación "acuerda unir al expediente del Canal de Castilla" pero que no tiene en cuenta al ver que las dificultades para la continuación del Canal de Castilla son cada vez mayores, en temas económicos, y no piensa en su prolongación hacia las tierras de Aragón.

Las esperanzas de reiniciar las obras aumentan cuando las Cortes, aceptando la propuesta de la Diputación de Valladolid, el 29 de junio de 1822, aprueban un decreto, ratificado por la real orden de 29 de julio del mismo año, acordando que "de los atrasos correspondientes a las contribuciones territoriales y de consumo de los años 1820 y 21, que deban los pueblos de esta provincia y los de Zamora, Burgos, Santander, León, Salamanca, Palencia, Ávila y Segovia, se destine la cantidad que corresponda al Canal de Castilla en los presupuestos de dichos dos años" ${ }^{420}$.

Ante esta nueva situación, la Diputación de Valladolid, se pone en contacto con el intendente de Rentas, a fin de conocer las cantidades "en descubierto" que tienen los pueblos de la provincia, a la vez que le enviaba copia del citado decreto para posteriormente poder disponer del dinero. El citado intendente contesta rápido a la Diputación, diciendo que no tiene inconveniente en remitirle la relación que solicitaba con los descubiertos, pero que no estaba dispuesto a ceder ningún tipo de recaudación, "porque el Ministerio de Hacienda no me ha comunicado ninguna orden para cesar en esa recaudación". Esta contestación obliga a la Diputación a dirigirse al jefe político para que reclame al Gobierno "la necesidad de que se comunique por el Ministerio correspondiente dicha orden a los Sres. intendentes. Que todos los atrasos que se recauden se destinen a las obras del Canal de Castilla. Que fije el gobierno los sitios y obras por donde se ha de dar principio a las del Canal de Castilla..." ${ }^{421}$.

Mientras tanto, las obras están paradas, aunque es necesario efectuar labores de mantenimiento y conservación en los tramos ya realizados, por eso el juez conservador del Canal pasa un oficio a la Diputación en el que detallaba "las maderas necesarias para el Canal Nacional de Castilla" ${ }^{422}$. Para cumplir con las necesidades planteadas, la Diputación propone a los pueblos que tengan pinares de su propiedad

417 A.D.P.V. Actas. Libro de actas del 4 de marzo de 1822 en la que se muestra la real orden junto al oficio del presidente de la Diputación de Palencia, comunicando la reunión de la Junta de Diputados.

418 A.D.P.V. Actas. Libro de actas del 10 de marzo de 1822.

419 A.D.P.V. Actas. Libro de actas del 1 de junio de 1822.

420 A.D.P.V. Actas. Libro de actas del 3 de septiembre de 1822.

421 A.D.P.V. Actas. Libro de actas del 4 de octubre de 1822.

422 A.D.P.V. Actas. Libro de actas del 27 de septiembre de 1822. 
que provean del citado material al encargado de la conservación, previa tasación y pago.

Con respecto a la recaudación, la Diputación ha reclamado al intendente y ha pedido al jefe político que se aclare con el Gobierno y como no tiene noticias positivas ni de uno ni de otro, acuerda dirigirse a los pueblos reclamando directamente "los descubiertos" "223. Ante este oficio, la contestación del intendente es inmediata, pues al día siguiente envía un oficio a los pueblos, a los que amenaza con "actuar con apremio a los que ingresen sus descubiertos en la Depositaría de la Diputación”. La Diputación no hace mucho caso de las amenazas, ya que está más preocupada por plantear y dar inicio a las obras, tiene confianza en que se ingresarán importantes cantidades en la Depositaría y por eso remite una "exposición" al gobierno en la que pide reactiven las obras ${ }^{424}$. Esas cantidades parece que finalmente van a llegar y a facilitar la terminación de las obras, pues el día 11 de enero de 1823 se publica una real orden, en la que se convoca a una reunión de la Junta de Diputaciones en la ciudad de Palencia con el fin de "tratar de la continuación de las obras del canal". Se fija la fecha para el 20 de febrero, y es nombrado para representar a Valladolid el diputado Isidro de la Torre. Días antes de esta reunión, en la Diputación se recibe un oficio del jefe político de la provincia, "anunciando la remisión de una libranza, expedida a cargo del Tesoro de la Hacienda Pública de esta provincia, de dos millones trescientos setenta y cuatro mil trescientos cincuenta y seis reales, que se han de endosar y entregar a la Diputación"

Cuando parecía inminente el inicio de las obras, vino una nueva suspensión de la Diputación. También de una forma incomprensible, se anuló la reanudación de las obras motivadas por un cambio político, que en buena lógica no debería de incidir en estos hechos. Lo cierto es que con la finalización del Trienio y la entrada en una época absolutista, los gobiernos vuelven a olvidarse del Canal. Esta actuación demuestra en realidad que fueron las Diputaciones las instituciones que más lucharon por rematar las obras, pero que no tuvieron la oportunidad ni el tiempo necesario para alcanzar la meta propuesta.

En el año 1831, cercano ya el final de la Década Ominosa, se reanudaron las obras y lo hicieron en el Canal del Sur, bajo la dirección del ingeniero Epifanio Esteban, que partiendo desde Dueñas, llegaría a desembocar en el río Pisuerga en Valladolid, dándose por terminada la obra en el año $1835^{426}$. Previamente al inicio de los trabajos, se procedió a la privatización del conjunto de canales, creándose la "Compañía del Canal de Castilla", empresa que financió las obras y responsable tanto de la finalización de los canales, como de su explotación comercial e industrial a través del transporte y el alquiler de los molinos y almacenes construidos a lo largo de su curso.

En el año 1835, recién instalada nuevamente la Diputación, las obras que quedaban pendientes eran las del Canal de Campos, desde Paredes de Nava hasta Medina de Rioseco. En esta época se realiza un balance de los costes de construcción

423 "Viendo la Diputación sin efecto los recomendables objetos que determina el decreto de Cortes de 29 de junio último, que destina todos los descubiertos de la contribución territorial y de consumos de 1820 y 21 para la continuación de las obras del Canal de Castilla, sin embargo de las repetidas invitaciones hechas al efecto al Sr. intendente, se acordó: Que se imprima y circule dicho decreto a los pueblos, advirtiéndoles no pongan los descubiertos en que se hallan por dicho concepto en la Tesorería de Provincia, y que lo hagan a la mayor brevedad en la Depositaría de la misma Diputación". A.D.P.V. Actas. Libro de actas del 13 de noviembre de 1822.

424 "se designen los trabajos y obras más necesarias del Canal de Castilla para dar principio a ellas, tan luego como ingrese en la Depositaría los atrasos de contribuciones que le están concedidas para dicho fin por el decreto de las Cortes del 29 de junio anterior, manifestando que a su entender es sin duda la más necesaria a la utilidad común la continuación de dicho Canal desde Dueñas hasta su desagüe al río Pisuerga, cuyo trozo de 5 a 6 leguas ofrece más facilidad en su ejecución..."A.D.P.V. Actas. Libro de actas del 19 de noviembre de 1822.

425 A.D.P.V. Actas. Libro de actas del 18 de febrero de 1823.

426 B.O.P.V. $\mathrm{n}^{\circ} 23$ del 21 de marzo de 1835, en el que se publica "el fin de las obras del ramal del Canal de Castilla que finaliza en Valladolid". 
del canal, recogidos por Helguera Quijada ${ }^{427}$ y que ascendían a las siguientes cantidades:

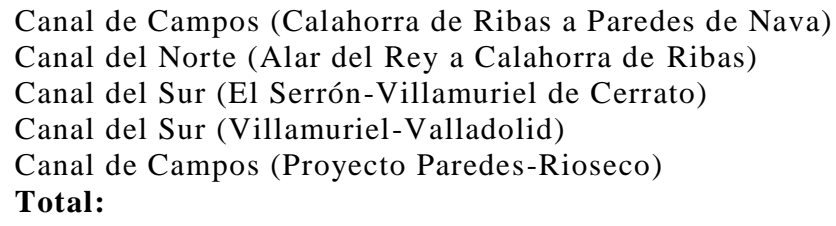

En conclusión, con la llegada de la Diputación, la única obra pendiente es el remate del Canal de Campos. En la primera toma de contacto, tanto con el gobierno central como con la Compañía del Canal, quedó aclarado que el tramo previsto en principio de Alar del Rey a Reinosa no se realizaría porque no era ni técnicamente viable ni económicamente rentable, con lo que la idea inicial de comunicación con la costa cantábrica quedaba incompleta.

Una vez rematado el Canal del Sur, con la llegada a Valladolid, se iniciaron las obras del Canal de Campos desde Paredes a Rioseco. Pero al poco tiempo se paralizaron nuevamente a causa de las dificultades económicas y de las causadas en la región por la "guerra carlista". A pesar de todo, estos inconvenientes no son obstáculo para que las actividades del canal desde Valladolid a Alar se inicien, anunciándolo a través del Boletín Oficial de la Provincia, con detalle de recorridos y precios:

"Distancia Valladolid-Alar: 28 leguas.

Carga de las barcas: 500-600 fanegas de trigo.1.700-2.000 arrobas de harina.

Precio: 1 maravedí por arroba y legua. 4 maravedíes por fanega y legua. La vuelta a mitad de precio" 428 .

Entre 1835 y 1842, las obras apenas avanzan, lo que provoca una queja del diputado por Rioseco D. Alejandro Nájera que se dirige a la Diputación "penetrado de las ventajas que ha de resultar a esta provincia de la continuación del ramal del Canal de Castilla, trazado hasta la ciudad de Rioseco, y teniendo noticias de haberse contratado aquella línea, ruega a la Diputación se sirva excitar el celo del Gobierno de S.M. para que dando un impulso a la referida contrata tenga efecto la obra indicada" 429 .

Interesa rematar las obras y también los trabajos de conservación y de reparación, sobre todo porque los defectos en la construcción perjudican a otras personas, como es el caso del barrio de San Bartolomé de Valladolid que solicita, de acuerdo con los técnicos, "sangrar las aguas desde la inclusa treinta y nueve para evitar las inundaciones de San Bartolomé" 430 .

A partir de 1842, se reanudan las obras del Canal de Campos y no pararán hasta su terminación en el año 1849, el día 9 de noviembre, de acuerdo con la notificación del Ayuntamiento de Rioseco informando: "que en este día han llegado las aguas al muelle del Ramal de Campos". A partir de esta fecha, se puede considerar que el Canal hasta Alar está operativo en los dos ramales y que su actividad es creciente y también rentable, y lo será hasta la llegada de su gran competidor, el ferrocarril. Como idea del tráfico del canal tenemos el cálculo que se hace en 1865, año en el que nos dice que "sólo desde Rioseco se exportaban por el Canal de Castilla de tres y media a cuatro millones de fanegas de trigo, sin contar las muchísimas arrobas de harina" 431 .

Una vez concluidas las obras, la Diputación no vuelve a tratar el tema del Canal de Castilla, salvo en esporádicas noticias, como es el comunicado del Marqués

HELGUERA QUIJADA, Juan y otros El Canal de Castilla ob. cit.

B.O.P.V. Boletín de fecha 24 de diciembre de 1836, donde se publica el anuncio de la Compañía del Canal, informando de su puesta en funcionamiento.

A.D.P.V. Actas. Libro de actas del 20 de diciembre de 1838.

A.D.P.V. Actas. Libro de actas del 4 de julio de 1836.

A.D.P.V. Actas. Libo de actas del 11 de enero de 1865. 
de Remisa, director general de la Compañía del Canal de Castilla, anunciando "el traslado de las oficinas de Palencia a Valladolid" ${ }^{432}$.

Nuevamente la Diputación, en este tema del Canal de Castilla, ha demostrado un gran interés en el seguimiento y remate de las obras, aunque a diferencia de su gestión de carreteras, en este caso se ha mantenido al margen de los problemas de financiación. Es importante resaltar su esfuerzo y preocupación en pedir, reclamar, solicitar, en definitiva intentar por todos los medios que no se olvide nadie de las obras e involucrar a todas las personalidades de la provincia para que el gobierno mantenga el interés por la conclusión de los trabajos.

Hay que destacar que este interés demostrado, ha dado a la Diputación vallisoletana un papel de protagonista entre el resto de instituciones de la región, teniendo la iniciativa en el curso de las diversas reuniones mantenidas con el resto de Diputaciones afectadas por esta construcción animando a los comisionados y pidiendo su apoyo para llevar a buen fin el remate de las obras.

Esta preocupación también se mantiene a partir de la puesta en funcionamiento del tráfico por el Canal, y se centra en el fomento del transporte de granos, así como en la implantación de fábricas de harina en sus orillas.

\subsubsection{EL FERROCARRIL}

La primera referencia en las actas de la Diputación de Valladolid, sobre las posibilidades del ferrocarril y su paso por la provincia, aparece el día 14 de abril de 1845, día en que la Diputación recibe en audiencia a D. José Miguel Arrieta Mascarna, comisionado por la Diputación General de Bilbao para tratar el tema del ferrocarril de Bilbao a Madrid y a la vez tratar del tema de reparto de los gastos preliminares del estudio. La Diputación "aprueba la cooperación y se acuerda fijar una reunión con el Ayuntamiento para tratar el tema conjuntamente con el comisionado Arrieta" ${ }^{433}$.

Al día siguiente, 15 de abril, en el salón de actos de la Diputación y bajo la presidencia del jefe político, Laureano de Arrieta, se reúnen conjuntamente Diputación y Ayuntamiento, con el comisionado de Bilbao, José Miguel Arrieta, y se plantea por una parte el interés de la provincia y de la capital, y por otra las grandes ventajas que ocasionaría a la provincia el paso del ferrocarril. El comisionado habló "de la favorable acogida de Álava y Burgos y solicitó la colaboración de Valladolid, acordando contribuir a los gastos previos estimados en 300.000 reales a repartir entre todas las provincias concurridas. Se aprueba la participación de Valladolid con el $12 \%$ de los gastos, aportando la Diputación dos tercios y el tercio restante el Ayuntamiento" $" 434$.

Se nombra una comisión formada por el diputado Quintero, el alcalde Fernández Vítores y el procurador síndico Merino, que inicia sus trabajos de forma inmediata y que no tarda en remitir un oficio a la Diputación "reclamando la cantidad comprometida por la provincia para gastos preliminares de estudios y planos" ${ }^{435}$. La Diputación, consecuente con su compromiso, aprobó en los presupuestos provinciales para el año 1846 "el abono de 10.000 reales para lo que pueda causarse en el levantamiento de planos en el ferrocarril de Bilbao a Madrid, a cuyo objeto se comprometió la Diputación" ${ }^{436}$.

El afán por la construcción de ferrocarriles se extiende por toda la península, y a la Diputación provincial de Valladolid, que trabajó para la puesta en marcha del ferrocarril Bilbao-Madrid, la sorprende la publicación de una real orden "autorizando

432 A.D.P.V. Actas. Libro de actas del 15 de julio de 1841.

433 A.D.P.V. Actas. Libro de actas del 14 de abril de 1845.

434 A.D.P.V. Actas. Libro de actas del 15 de abril de 1845.

435 A.D.P.V. Actas. Libro de actas de 29 de octubre de 1845, fecha en la que se refleja el acuerdo de "remitir los 16.000 reales ofrecidos".

436 A.D.P.V. Actas. Libro de actas del 5 de diciembre de 1845. 
a Lorenzo Flores Calderón la ejecución de un camino de hierro de Valladolid a Zaragoza" 437 .

No hay más propuestas en los siguientes años, hasta que en 1850 , en el acta de toma de posesión de la nueva Diputación, se da lectura a una comunicación de D. Mariano Miguel de Reynoso en la cual "invita a la Excma. Diputación Provincial a que con su respetable ejemplo contribuya al aumento de la suscripción pública para llevar a efecto el ferrocarril de Alar a Santander" ${ }^{438}$. Aunque es una línea que no "toca" en la provincia vallisoletana, sí que tiene importancia para el desarrollo económico y agrícola de la misma, por ser la solución lógica y la continuidad logística del Canal de Castilla hasta las costas del Cantábrico, ante la imposibilidad ya manifestada, de continuar el canal a través de la cordillera cantábrica. La Diputación acuerda "la inversión a nombre de la provincia de trescientas acciones de la sociedad para la construcción del ferrocarril de Alar a Santander, a pesar de la penuria en que se encuentran las arcas provinciales y al mismo tiempo solicita que se excite a los Ayuntamientos de la provincia para seguir el ejemplo de la Corporación" "439. Esta petición desemboca en una real orden de 20 de agosto en la que se autoriza "la venta de bienes de propios en los pueblos para invertirlos en atender al ferrocarril de Isabel II (Alar-Santander)".

Indudablemente, la prioridad entre las varias líneas de ferrocarril para la provincia es la de Irún-Madrid y también lo es para la Compañía del Norte, cuyo Consejo de Administración invita a la Diputación a seguir colaborando económicamente. A este fin, el 26 de septiembre de 1851 "se reúnen en el cuartodespacho del Sr. gobernador, los Sres. diputados con el Sr. gobernador y los Sres. Pablo Ramón Aurrecoechea y Gabriel Ma Orbegozo, comisionados por la Diputación de Vizcaya, Ayuntamiento y Junta de Comercio de Bilbao, para tratar sobre el tema del ferrocarril Irún-Madrid, y sobre los beneficios que reportaría a Castilla. Solicitan una garantía del 3\% para los capitales que entren en la empresa, en el caso de que el gobierno no cumpliera los compromisos contraídos, y al mismo tiempo estiman una inversión de 200 millones de reales. La Diputación acordó ofrecer las garantías que se pedían" 440 .

A los pocos días el Consejo de Administración convoca a una reunión, el 1 de diciembre en Burgos, de las Diputaciones interesadas para tratar de la puesta en marcha del proyecto. Por parte de Valladolid asiste el diputado provincial Mariano Lino de Reynoso. A la citada reunión asisten representantes de Vizcaya, Álava, Burgos, Logroño y Valladolid, en la que se acuerda solicitar al Gobierno su colaboración en la construcción del ferrocarril, a lo que éste contesta con una real orden de 29 de marzo de 1852, en la que solicita la formalización del acuerdo suscrito en la reunión de Burgos y al mismo tiempo comunica que la cuantía de la garantía a cubrir por el Estado será del 1,5\%, por lo que el resto de Diputaciones tendrán que cubrir el $1,5 \%$ restante ${ }^{441}$.

Las que llevan buen ritmo son las obras del ferrocarril Alar-Santander, a pesar de las dificultades orográficas sobre todo en el tramo de Reinosa, ya que en el mismo año 1852 la Diputación refleja "la manifestación realizada por los Sres. diputados que asistieron en Santander a la inauguración del ferrocarril de Isabel II, por el distinguido

437 B.O.P.V. $n^{\circ} 106$ de fecha 4 de septiembre de 1845, con la publicación de la real orden.

438 A.D.P.V. Actas. Libro de actas del 3 de abril de 1850. Mariano Miguel de Reynoso es Comisario Regio de Agricultura y ex-diputado a Cortes.

439 A.D.P.V. Actas. Libro de actas del 12 de abril de 1850

440 A.D.P.V. Actas. Libro de actas del 26 de septiembre de 1851.

441 A.D.P.V. Actas. Libro de actas del 1 de febrero de 1852. Con la reseña literal de los acuerdos alcanzados. También se refleja el encargo que se da al comisionado Reynoso, para que trate de la adhesión del acuerdo de la Diputación Provincial de Palencia, que no había asistido a la reunión y había demostrado poco interés en colaborar en la construcción del ferrocarril. 
recibimiento, en especial por el ministro de Fomento. Se acordó agradecer las atenciones de la Diputación y ciudad de Santander" ${ }^{\text {"42 }}$.

Esta inauguración, reflejada literalmente en las actas, hay que ponerla en duda, especialmente por la reseña que aparece en el año 1855, con ocasión de la Junta de Accionistas del Ferrocarril de Isabel II, reunida el 23 de junio en la ciudad de Santander, en la que se tomaron los siguientes acuerdos: "Renovación de cuatro miembros del Consejo de Administración. Pronta terminación de la sección $3^{\text {a }}$ : AlarReinosa. Inicio de los trabajos de la sección $1^{\text {a }}$ : Santander-Caldas. Rescisión del contrato al contratista Mr. Mould" ${ }^{\text {"433 }}$. En definitiva, no está claro si lo que el ministro de Fomento inauguró en 1852 fue el inicio de las obras o la puesta en marcha del servicio. Pero sí es cierto que a partir de 1855 no vuelve a aparecer ninguna reseña sobre el ferrocarril de Isabel II en las actas de la Diputación, salvo alguna petición de permiso de los pueblos para la venta de propios y adquirir acciones del ferrocarril. Aparecen posteriores intentos de la Diputación en épocas de penuria económica, interesada en vender las trescientas acciones del ferrocarril que se compraron en 1850 en los inicios de su construcción.

Por otra parte, el ferrocarril Irún-Madrid sigue en su fase de proyecto, siendo apoyado y fomentado por el Gobierno, que a través de la real orden de 9 de mayo de 1852, hace ver la importancia de esta línea y al mismo tiempo pide a la Corporación provincial que decida "qué parte del interés del 6\% estaría dispuesta a asumir". La Diputación contestó con el acuerdo de que "auxiliaría con la mitad del déficit que resulte entre los rendimientos del ferrocarril y el $6 \%$ del interés ofrecido por el gobierno" 444 . Al poco tiempo, el gobierno por real decreto de 4 de julio de 1852, dispone que "la construcción del ferrocarril Madrid-Irún pase por Valladolid y Palencia" "45. La Diputación, una vez conocida esta propuesta, envió una exposición al gobierno en la que daba las gracias por este acuerdo y, al mismo tiempo, solicitaba que el ferrocarril pasase también por Ávila, según decisión tomada en Peñaranda de Bracamonte por comisionados de Madrid, Ávila, Segovia, Valladolid y Salamanca.

La fiebre del ferrocarril, en estos años de mediados de siglo, está en su apogeo y continuamente surgen proyectos y propuestas de nuevas líneas, como se refleja en la comunicación de la Dirección General de Obras Públicas, sobre "el proyecto que partiendo del ferrocarril Madrid-Irún, en Valladolid, venga a desembocar en el puerto de La Coruña" 446 . Al poco tiempo se publica una real orden, por la que "accediendo a una exposición de D. Eduardo Chao, se ha dignado autorizarle, con arreglo al artículo cuarenta y cinco de la Ley de Ferrocarriles, para verificar los estudios de una línea que partiendo de Valladolid venga a desembocar en el puerto de Vigo..." ${ }^{447}$. Asimismo se concede "autorización a D. Enrique Wisley, en nombre de Focks, Henderson y Cía. de Londres, para practicar los estudios del ferrocarril Madrid-Irún por Valladolid" 448.

Pero la actuación más importante es la reunión que se celebra en el salón de sesiones de la Diputación, a la que asisten bajo la presidencia del gobernador de la provincia, el pleno de la Diputación, los diputados a Cortes por la provincia y el alcalde y procuradores del Ayuntamiento, para tratar del "importantísimo negocio de llevar a cabo la línea del ferrocarril del Norte, no debiendo retrasarse su construcción porque va a suponer un gran progreso para las provincias del Norte y Poniente, que

442 A.D.P.V. Actas. Libro de actas del 14 de mayo de 1852. La inauguración del ferrocarril fue presidida por Mariano Miguel de Reynoso, a la sazón ministro de Fomento (ex -diputado a Cortes por Valladolid) en la que hace ver su "importancia por el auge que tendrá el Canal de Castilla, al quedar completada la comunicación con la Tierra de Campos para dar salida a los productos castellanos".

443 A.D.P.V. Actas. Libro de actas del 2 de julio de 1855.

444 A.D.P.V. Actas. Acuerdo reflejado en el libro de actas del 27 de mayo de 1852.

445 A.D.P.V. Actas. Libro de actas del 8 de julio de 1852.

446 A.D.P.V. Actas. Libro de actas del 7 de julio de 1855

447 B.O.P.V. $n^{\circ} 100$ del 21 de agosto de 1855. En este mismo Boletín se reproduce la Ley de Ferrocarriles.

448 B.O.P.V. n ${ }^{\circ} 93$ de fecha 4 de agosto de 1855. 
entrarán en comunicación con el resto de Europa". El único obstáculo que tienen las provincias interesadas es la de encontrar bases para garantizar el pago a los empresarios (según se vio en la reunión de 16 de Diciembre de 1851 en Burgos). La desamortización de la propiedad, decretada por las Cortes Constituyentes, abriendo un campo baratísimo a tan colosales empresas, removió todos los obstáculos.

Vistas estas posibilidades la Diputación acordó los cinco puntos siguientes: $1^{\circ}$ Que se excite el celo patriótico de las provincias más directamente interesadas en esta construcción. $2^{\circ}$ Que a fin de no retrasar el inicio de las obras y mientras se resuelve el litigio entre Ávila y Segovia, se disponga lo necesario para iniciar las obras de Valladolid a Miranda. $3^{\circ}$ Que estando próxima la venta de los bienes de propios acordada por la ley de $1^{\circ}$ de mayo del presente año, y debiendo optar los Ayuntamientos por el empleo que han de hacer a su producto, se destine la mitad de éste a la construcción de la mencionada vía, reservando la otra mitad para las atenciones municipales. Habiendo de representarse este producto en los "Títulos de $3 \%$ intransferibles" que dará el gobierno en pago de los bienes enajenados, ha creído la Diputación que será suficiente que depositen estas provincias la mitad del papel que por aquel concepto reciban, para que, ofreciéndolo como garantía a cualquier empresa constructora, pueda levantar el capital para esta obra. $4^{\circ}$ Según los informes del Ayuntamiento, asciende a 80 millones de reales la tercera parte del capital con que habrán de contribuir las provincias para la realización del ferrocarril íntegro desde Madrid a Irún, cuya suma, en juicio de la Diputación, obtiene el premio del $7 \%$ de rédito y $3 \%$ de amortización, con sólo el depósito de la mitad del papel. Esta operación de crédito tan conocida consiste en depositar la parte de papel de la venta indicada por treinta y tres años, al cabo de los cuales volverá a poder de los respectivos pueblos empezando entonces a utilizarse de su rédito. $5^{\circ}$ Respecto de los pueblos que no tienen propios contribuirán con una cuota determinada que se invertirá en la compra de papel al 13\%, el cual volverá a los pueblos a los treinta y tres años. Estos son los medios que ha escogido la Diputación para llevar a cabo la obra, y esta propuesta se pasa a las Diputaciones interesadas para que manifiesten si están de acuerdo. A la vez se pide a los diputados a Cortes que "usen de su influencia para que por medio de una ley se dé curso a un proyecto que cambiará el aspecto de la provincia"449. A partir de la aprobación de estos acuerdos, la actividad sobre el ferrocarril se acelera, pues si la reunión se celebró en el mes de septiembre de 1855 , en octubre "la Diputación aprueba la subasta de los trescientos ochenta y cinco lotes de propios de Nava del Rey por valor de 2.253.581 reales" 450 .

En el mes de noviembre se recibe una comunicación de "D. Enrique Wisley, representante de Focks, Henderson y Cía. de Londres, interesado en la subasta de la línea de ferrocarril de Valladolid a Burgos" ${ }^{451}$. En el mismo mes, el gobernador de la provincia pasa una comunicación a la Diputación a la que acompaña una real orden del Ministerio de Fomento pidiéndola que: "arbitre los medios de abonar la tercera parte de la subvención concedida por la ley de 14 del corriente para la ejecución del ferrocarril de Valladolid a Burgos, a razón de 1.300.000 reales la legua, evaluándoles en proporción de los comprendidos en el territorio de esta provincia" ${ }^{452}$.

A esta comunicación, la Diputación contesta dándose por enterada con el siguiente cálculo: "el trayecto de la línea férrea de esta capital hasta el límite de su territorio en dirección a Burgos es de cuatro leguas, en cuya proporción asciende la tercera parte con que debe de intervenir a 1.733 .333 reales y un tercio, suma que pondrá a disposición del gobierno con la oportunidad que reclamen las circunstancias de las obras y con arreglo a la ley" "453. Además, en su afán por aplazar los trámites,

449 A.D.P.V. Actas. Libro de actas del 29 de septiembre de 1855. Trascripción literal de los acuerdos.

450 A.D.P.V. Actas. Libro de actas del 5 de octubre de 1855. Nava del Rey tiene abund antes bienes de propios, situación que no es general entre los pueblos de la provincia.

451 A.D.P.V. Actas. Libro de actas del 21 de noviembre de 1855.

452 A.D.P.V. Actas. Libro de actas del 26 de noviembre de 1855.

453 A.D.P.V. Actas. Contestación de la Diputación en la misma acta del 26 de noviembre de 1855. 
convoca para el día siguiente de esta sesión a una reunión extraordinaria "a los Sres. capitalistas y comerciantes que a continuación se expresan" ${ }^{454}$. En la reunión del 27 de noviembre, convocada con gran interés y expectación por parte de la Diputación, quedó rápidamente aclarado que los capitalistas y comerciantes no estaban dispuestos a cooperar en la financiación del ferrocarril: "La línea de Valladolid a Burgos no ofrece interés", según José Ortiz Alegre. "Debe de ser la provincia la que haga frente al coste", según José $M^{a}$ Fernández-Vítores. "Los esfuerzos deben de dirigirse a la línea Valladolid-Madrid", a criterio de Juan Fernández Rico. Ante esta situación, la Diputación no tiene más remedio que pensar en "echar mano de los arbitrios más fáciles y menos gravosos" para la financiación. No obstante, se acordó de formar una comisión para estudiar las ventajas que conllevaría la instalación de la vía férrea.

La que no descansa es la empresa Focks, Henderson y Cía., que el 30 de noviembre presenta una propuesta de suscripción de treinta millones de reales para la "Empresa de Construcción del Ferrocarril de Valladolid a Burgos". En respuesta, la Diputación acuerda acudir a la suscripción con cuatro millones de reales procedentes de los bienes provinciales de la Beneficencia.

A primeros del año 1856, las Diputaciones de Valladolid y Burgos, en una reunión que celebran el 9 de febrero para activar la construcción del tramo comprendido entre las dos ciudades, acuerdan "presentarse en comisión en la Corte" para tratar de agilizar su construcción. Ello sucede a pesar de que la Diputación de Palencia, también incluida en el proyecto, no muestra mucho interés en su aprobación, aunque esto no impide que se "excite a la comisión enviada a Madrid y que se les confiera amplias facultades para que en nombre de la provincia rematen si es preciso y hagan los contratos que crean más beneficiosos a lo mismo, con el fin de conseguir que la línea férrea se construya prontamente" ${ }^{455}$. Esta comisión tiene su éxito, pues en el Boletín Oficial de la provincia del 23 de febrero se publica un manifiesto de la Diputación anunciando "la adjudicación de la subasta del ferrocarril del Norte a favor de Crédito Mobiliario, por 506.400 reales la legua" ${ }^{456}$. Una vez aprobada la subasta en febrero, el inicio de las obras parece inminente, y durante el mes de marzo se celebran una serie de reuniones de la comisión nombrada por la Diputación, Sres. Arévalo, Alderete y Moras y la del Ayuntamiento, Sres. Sierra, Revenga y Semprún. El objetivo era organizar fiestas para su celebración ${ }^{457}$. La Diputación cifra el coste de estos

454 A.D.P.V. Libro de actas del 26 de noviembre de 1855, con la relación de los capitalistas y comerciantes: Juan Fernández Rico, Pedro Pombo, Toribio Lecanda, José Fernández, Juan Sigler, Semprún Hnos., Millán Alonso del Barrio, José Ortiz, Mariano Miguel de Reynoso, José Ma Iztueta, Cipriano Alonso, Julián Revenga, Francisco Campo, J. $\mathbf{M}^{\mathrm{a}}$. Fernández Vítores, José Fernández Sierra y Benito Martínez Jover.

455 A.D.P.V. Actas. Libro de actas del día 12 de febrero de 1856. Comisión de la Diputación de Valladolid formada por los Sres. Alonso, Moras y Cafranga, que en principio tuvieron una reunión con la comisión de la Diputación de Burgos y después se desplazaron a Madrid.

456 B.O.P.V. n ${ }^{\circ} 24$ de fecha 23 de febrero de 1856. En este anuncio figura como beneficiario "Crédito Mobiliario" y desaparece la compañía Focks, Henderson y Cía. También llama la atención las diferencias del precio: en un principio se tomó el precio de la legua en 1.300 .000 reales, en el año 1855 , y en el momento de firmar el contrato se hace a 506.400 reales, un $65,78 \%$ más barato.

457 "El programa de las funciones públicas que han de solemnizar la venida del Sr. presidente del Consejo de Ministros, Duque de la Victoria, para el acto importantísimo de la inauguración de las obras de la $2^{\text {a }}$ sección de la línea del ferrocarril del Norte que da principio en esta capital y termina en Burgos. Inauguración prevista para el día 24 de abril de 1856.

Las bases generales del programa de funciones son las siguientes: $1^{\circ}$.- La Diputación, de acuerdo con el subinspector de la Milicia Nacional de la provincia, invitará a estas fuerzas ciudadanas para que se cubra la carrera que ha de traer al Duque desde el límite de la provincia hasta la Capital. $2^{\circ}$. - La Diputación se trasladará a la villa de Olmedo para recibir a tan digno personaje... $3^{\circ}$. - El Ayuntamiento de la capital saldrá al punto más a propósito para el recibimiento. $4^{\circ}$. - Una vez instalado el Duque en la capital, en el Palacio de Capitanía General... se levantarán dos tiendas de campaña para el acto con preparación de vinos generosos, pastas y otras cosas a propósito. 5º.- Antes y después de la inauguración, para solaz del público se establecerán bailes y circularán gigantones, iluminación y fuegos. $6^{\circ}$.- Se preparará una corrida de toros. $7^{\circ}$.- Se dispondrá de función de teatro. $8^{\circ}$.- Se arreglará un banquete al que asistirán las comisiones". A.D.P.V. Actas. Libro de actas del 7 de marzo de 1856. 
festejos en 40.000 reales, gastos que compartirá con el Ayuntamiento. Llegado el mes de abril, el día 22 en el Boletín Oficial de la provincia, se anuncia que "para inaugurar el ferrocarril del Norte, el jueves 24 llegará a esta capital el Duque de la Victoria" ${ }^{458}$.

Esta es la última noticia que tenemos de los festejos programados, pues la Diputación no tiene más sesiones, y los acontecimientos políticos que se desarrollan en estas fechas, con la dimisión posterior de Espartero y la disolución de la Diputación, hace que no quede constancia de los actos celebrados con motivo de la inauguración de las obras.

Otro acontecimiento que resalta la importancia del ferrocarril, tanto para la ciudad como para la provincia, es la visita que realiza la reina Isabel II en el mes de julio de 1856, con la finalidad de inaugurar el puente Príncipe Alfonso y dejar constancia con su presencia de que el desarrollo y progreso de Valladolid pasa por el desarrollo y progreso del ferrocarril. En esta visita, la Diputación apenas tuvo participación pues el protagonismo de la visita lo asumió el Crédito Mobiliario, sociedad promotora de las obras y de los talleres ferroviarios ${ }^{459}$

La Diputación de Segovia, que también está interesada en que el ferrocarril pase por su ciudad, en comunicación con la de Valladolid, "solicita su cooperación para construir una línea férrea que desde Segovia empalme en Valladolid con la línea del Norte" ${ }^{460}$. Petición que repite al poco tiempo, adjuntando el proyecto y la forma de financiación de las obras. Ya a finales del año 1856, se anuncia el inicio de las obras entre Valladolid y Viana de Cega, a la vez que "para fomentar el trabajo" aparece la construcción de una serie de caminos hacia las estaciones de ferrocarril de Dueñas y Valdestillas. Lo que nos indica que la marcha de los trabajos iba a buen ritmo, tanto en sentido Burgos como en sentido Madrid.

Otro nuevo proyecto de ferrocarril se presenta en la Diputación, y en esta ocasión es por parte de la Diputación de Salamanca que "presenta un proyecto para la construcción de un ramal del ferrocarril desde Salamanca a Medina del Campo y solicita se la informe con qué cantidad podría contribuir al efecto por parte de esta provincia de Valladolid". La Diputación de Valladolid envió una contestación rápida y consecuente, manifestando "que estaba convencida de los beneficios de esta obra, pero que en la actualidad los compromisos de pagar las enormes sumas que adeudaba a los contratistas de las carreteras de Calatayud y Zamora, la imposibilitaban el hacer oferta alguna, pues todos los recursos permitidos por la ley no alcanzaba a cubrir el déficit del presupuesto" 461 .

Mejor fortuna tiene el proyecto del ferrocarril de Zamora, al recibir la Diputación un expediente en el que se incluye la real orden de 30 de marzo de 1857 "para la ejecución del ferrocarril de Zamora que enlazará con el ferrocarril del Norte en Valdestillas" "462. Este ferrocarril, finalmente, no enlazará en Valdestillas, sino que partirá desde Medina del Campo. A partir del año 1861 se iniciarán los trámites de expropiación de terrenos. Tal actividad se ve entorpecida por los inconvenientes que surgen a causa de las numerosas reclamaciones que se presentan, como la de José Félix de Ortúzar que solicita "la modificación del trazado del ferrocarril, por atravesar parte del terreno denominado Casa-Palacio de Falces" ${ }^{463}$.

Las obras del ferrocarril del Norte son las que se desarrollan con una buena regularidad, pues en el año 1857 se inician las obras en Medina del Campo. A pesar de ello, la Diputación impaciente por ver terminadas las obras envía "una exposición a S.M. solicitando ayuda a la empresa del ferrocarril del Norte, en especial por medio de

458 B.O.P.V. n ${ }^{\circ} 49$ de fecha 22 de abril de 1856.

459 CARASA SOTO, Pedro. La reina en la Ciudad (Usos de la Historia en la visita de Isabel II a Valladolid, 1858). Ed. Ayuntamiento de Valladolid. Valladolid. 2007.

460 A.D.P.V. Actas. Libro de actas del 12 de marzo de 1856.

461 A.D.P.V. Actas. Libro de actas del 4 de noviembre de 1857 .

462 A.D.P.V. Actas. Libro de actas del 9 de diciembre de 1857.

463 A.D.P.V. Actas. Libro de actas del 16 de agosto de 1857. 
los bienes de propios para que pudieran terminar las obras del ferrocarril" ${ }^{464}$. Al poco tiempo, autoriza "un contrato privado entre el Crédito Mobiliario Español y la Comunidad de Villa y Tierra de Cuellar, para que el primero construya un trozo de la carretera de Cuellar a Tudela para empalmar con la de Calatayud, a cambio de 100.000 traviesas para el ferrocarril del Norte, procedentes de los pinares comunitarios" 465 .

El periódico vallisoletano El Norte de Castilla informa con abundantes detalles del progreso de las obras ferroviarias. Ente las diversas noticias destaca la publicada el 16 de junio de 1860, sobre la llegada de la primera locomotora a Valladolid. El 1 de agosto comunica la realización del primer viaje entre Valladolid y Venta de Baños. El 15 de septiembre, sobre el primer viaje desde Valladolid a Medina del Campo, y el 25 de noviembre entre Valladolid y Burgos. Todos en el año 1860. El 4 de marzo de 1863 se efectúa el primer viaje entre Valladolid y Madrid. También refleja noticias sobre las actividades de los ferrocarriles, los problemas de su construcción, los enlaces con las estaciones y las diferentes y variadas peticiones que se hacen. Como ejemplo tenemos la "exposición del Ayuntamiento de Valladolid dando cuenta del traslado de las oficinas del ferrocarril a Madrid y solicitando ayuda para que no se saquen de Valladolid los talleres del ferrocarril. Se acordó enviar una comisión a Madrid para gestionar la presencia del ferrocarril en la capital" ${ }^{466}$. Esta es una reclamación que se realiza con la preocupación de mantener en la ciudad la más importante, en aquellos años, actividad industrial. ${ }^{467}$

En el año 1866, el ferrocarril, ya es un medio habitual de transporte, como lo demuestra la noticia de que "la Compañía del Norte, reclama a esta Diputación 343 escudos, importe del tren especial para ir a Arévalo a esperar a S.M." ${ }^{468}$.

En el año 1865, la Dirección General de Ferrocarriles presenta un anteproyecto a la Diputación del "Plan General de Ferrocarriles" y ésta contesta con un informe sobre las líneas que a su parecer son las más interesantes para la provincia. Los datos más significativos del mismo informe se detallan a continuación. "1 ${ }^{\circ}$ Las líneas designadas, en construcción o en proyecto, son las más interesantes para la provincia. Es muy conveniente la línea Valladolid-Calatayud, por Almazán, y sería conveniente prolongarla hasta Astorga por Rioseco, con lo que se comunicaría Galicia con Aragón. Se debe de suprimir la línea Salamanca-Zamora al estar funcionando la de MedinaZamora y en construcción la de Medina-Salamanca. $2^{\circ}$ Propuesta de nuevas líneas: Medina del Campo-Astorga por Tordesillas y Benavente. La ventaja de esta línea es que atraviesa en su totalidad terreno llano. $3^{\circ}$ Facilitarían estas nuevas líneas los movimientos de los productos agrícolas de la región: vino, trigo, harina, etc. $4^{\circ}$ Los jornales de los braceros y los costes de los transportes son baratos en la provincia, "siendo un jornal ordinario de 5 a 6 reales". $5^{\circ}$ Las principales zonas de la provincia, Tierras de Medina, Mota, Tordesillas y Rioseco, quedarían comunicadas entre sí y con el resto de regiones"

Pocas más incidencias se anotan en las actas. Las últimas que aparecen son las del año 1867, en que se inicia el estudio del expediente de la línea de Valladolid a Ariza. En el año 1868 se inicia su construcción, y en 1872 "la Sociedad del Ferrocarril Valladolid-Ariza, solicita el apoyo de la Diputación" ${ }^{470}$. Es la última reseña correspondiente al año 1872, relativa a los ferrocarriles en el período del Sexenio Revolucionario.

\footnotetext{
464 A.D.P.V. Actas. Libro de actas del 18 de julio de 1858

465 A.D.P.V. Actas. Libro de actas del 15 de octubre de 1858.

466 A.D.P.V. Actas. Libro de actas del 1 de abril de 1864.

${ }^{467}$ CARASA SOTO, Pedro (Coord.) La Ciudad y el Tren. Talleres y Ferroviarios en Valladolid (18561936). Ayuntamiento de Valladolid. Valladolid. 2003. CARASA SOTO, Pedro. Ciento cincuenta años del ferrocarril en la ciudad de Valladolid. Ed. Ayuntamiento de Valladolid. Valladolid. 2006.

468 A.D.P.V. Actas. Libro de actas del 12 de abril de 1866.

469 A.D.P.V. Actas. Libro de actas de la sesión plenaria del 11 de enero de 1865.

470 A.D.P.V. Actas. Libro de actas del 19 de abril de 1872.
} 


\subsubsection{OTRAS OBRAS PÚBLICAS}

Hasta el año 1820 no se inicia en los pueblos de la provincia una tímida mejora de las infraestructuras de carácter local. A partir de estos años, a causa de las dificultades económicas que sufre la provincia por las malas cosechas y el consiguiente problema de paro en los jornaleros, es cuando la Diputación, en un intento por paliar esta situación, alienta a los pueblos al fomento de sus obras locales. Les anima a reparar y construir caminos vecinales, fuentes públicas, Casas Consistoriales, escuelas, cárceles, pósitos, etc. Obras que en su mayoría son sufragadas con el producto de los arrendamientos de los bienes de propios o a través de impuestos al consumo o por arbitrios.

"Reparar la calzada para mantener a los jornaleros pobres" 471 es una de las numerosas anotaciones en los libros de actas de la Diputación, que en este caso está referido a una solicitud del pueblo de Villabrágima. Las pequeñas obras se suceden a lo largo de la provincia, en su mayoría promovidas por los Ayuntamientos, que solicitan las obras, presentan los presupuestos, piden el dinero y pagan a los jornaleros. Así tenemos:

-Quintanilla de Abajo, solicita reparar el puente y la calzada.

-Simancas quiere reparar el puente "dañado por los ingleses".

-Villaverde de Medina solicita reparar la fuente pública "por ser la única del pueblo y tiene peligro de infestarse".

-Valladolid necesita ampliar la cárcel "por las muchas entradas que diariamente hay y apenas caben ya los presos en el calabozo".

-Manzanal de Abajo solicita reparar el puente "cortando los árboles necesarios".

-Villalón solicita permiso para edificar la escuela, casa de estudios, cárcel y pósito, "por 114.000 reales a través de la venta de los edificios que ocupan en la actualidad".

-Olivares de Duero solicita "vender veintidós fanegas de grano para pagar el arreglo de la fuente".

-Boecillo solicita "emplear caudales de propios para la compostura de varios pantanos".

-Cevico de la Torre solicita la construcción del cementerio.

- Valdestillas pide autorización para reparar la iglesia.

-Villalba de Adaja solicita la reparación del puente "por lo fácil y poco costoso que resultaría”.

-La Seca solicita licencia para reparar la Casa Consistorial, panera, caminos, calles y calzadas "pues todo está en muy mal estado".

En el año 1822, como el paro de los jornaleros continuaba siendo un grave problema, el Gobierno, en su afán de fomentar el trabajo y paliar el paro y al mismo tiempo mejorar la salubridad ciudadana, por real orden de 5 de septiembre "encarga a las Diputaciones que promuevan por todos los medios a su alcance la construcción de cementerios" ${ }^{472}$. En consecuencia, la Diputación lo comunicó a los diferentes pueblos, animándoles a realizar estos trabajos y acordar la forma de pago.

En el año 1835, la Diputación inicia nuevamente su andadura, y los pueblos vuelven a pedir y reclamar de la Corporación las ayudas necesarias para mejorar sus instalaciones. Así tenemos que en 1837:

-Portillo reclama reparar un trozo de calzada.

-Castrodeza solicita reparar la Casa Consistorial.

-Bolaños pide reparar el Camino Real.

-Megeces solicita reparar el puente.

- Valladolid pide ayuda para reparar la Casa Consistorial.

-Simancas sigue pidiendo reparar el puente.

-Pedrosa del Rey solicita reparar la fuente pública.

-Cuenca de Campos, pide reparar el acueducto.

471 A.D.P.V. Actas. Libro de actas del 5 de abril de 1821.

472 A.D.P.V. Actas. Libro de actas del 14 de septiembre de 1822. 
En el año 1838, se siguen presentando expedientes de reparaciones, de pequeñas obras públicas:

-La comisión de Obras Públicas acuerda reparar los puentes de Gradefes, Megeces, Renedo y Siete Iglesias y la carretera Valladolid-Rioseco, el camino de Tordesillas a Rioseco, la carretera de Rueda a Madrid y una legua del camino a Simancas.

-Cuenca de Campos pide la reparación de la fuente pública.

-Quintanilla de Abajo pide construir "una panera”.

-La comisión de Obras acuerda construir "la Casa de la Cebada" de Valladolid y "el puente encarnado" sobre el Esgueva.

-La Diputación acuerda "contratar una barca, hasta reparar el puente de Boecillo"

-Castrobol solicita construir un puente de madera.

En el año 1839, el día 24 de enero, el jefe político "recuerda la real orden sobre obligaciones de los pueblos de ejecutar trescientas veinticinco varas a la entrada y salida de las carreteras principales" así como la real orden de 18 de enero "sobre recursos para la construcción de caminos". El 23 de mayo, se presenta en la Diputación el expediente para reparar el puente de Villalba de Adaja y la torre de la Colegiata de Medina.

En el año 1840, con ocasión de la división de la provincia en distritos electorales, se hace ver en la Diputación la mala situación de los caminos que comunican entre sí a los diferentes pueblos: "la distancia de Pozaldez a Olmedo es de tres cuartos de legua de pésimo camino y los caminos que de Matapozuelos y Valdestillas conducen a Olmedo son casi intransitables y en esta estación inseguros..."473. Situación que el diputado por Olmedo denuncia y reclama su reparación, por ser responsabilidad de la institución.

Durante el período 1840-43, apenas aparecen peticiones de reparaciones en los pueblos, y no es porque estén completamente equipados, sino porque han cubierto su cupo de gastos y no están dispuestos a realizar más obras gravando las economías vecinales, ya de por sí bastante castigadas. Esto no impide que surjan de vez en cuando solicitudes de reparación y mantenimiento. Así quedan registradas las siguientes obras:

- Ventosa de la Cuesta solicita un arbitrio para reparar el cementerio.

-Moral de la Reina vende unos terrenos, en 20.000 reales para realizar varias obras.

-Villalba de Adaja solicita reparar el puente "pues no pueden pasar los carros".

-Valladolid pide la reparación del "Camino de la Cárcel".

-Becilla solicitó la reparación del cementerio.

En el año 1844, la Diputación, para organizar y agilizar las peticiones de los pueblos, crea una comisión formada por los diputados Gusano y Montealegre para "estudiar las peticiones de los pueblos sobre la construcción y reparación de puentes y edificios vecinales" $" 474$.

Una obra que es acogida con interés en la Diputación, tanto por su importancia como obra pública, como también por la mejora de la sanidad en los pueblos, es el saneamiento y encauzamiento del río Esgueva en todo su recorrido por la provincia y que fue declarada de "utilidad pública". Siguiendo este ejemplo, Medina del Campo consiguió el mismo tratamiento para el río Zapardiel a su paso por la villa.

En los años 1845 a 1854 , los goteos de las obras continúan en los diferentes pueblos de la provincia:

-Valdestillas repara su puente e interrumpe el paso por el mismo durante quince días, lo que obliga a los usuarios a desviarse por Villanueva de Duero.

- Valladolid solicita la construcción de un camino que le comunique con los pueblos del valle de Esgueva.

-Se aprueba la construcción de un nuevo puente en Valladolid por 666.049 reales.

473 A.D.P.V. Actas. Libro de actas del 8 de enero de 1840.

474 A.D.P.V. Actas. Libro de actas del 30 de noviembre de 1844. 
-Villalón y Rioseco piden ayuda a los fondos provinciales para rematar el camino que están construyendo entre los dos pueblos.

Los años "progresistas" de 1854-56 coinciden con la llegada de unos años de sequía, de malas cosechas y de hambre, y nuevamente los pueblos iniciarán una serie de reclamaciones de obras y solicitudes de ayuda "para abrir trabajo a la clase obrera o braceros del campo en la próxima estación de invierno, con la mira de que puedan proporcionarse el precioso alimento" ${ }^{\prime 47}$. De acuerdo con estas peticiones, la Diputación acuerda contribuir con fondos provinciales al remate de las obras del camino de Villalón a Rioseco, aportando 18.000 reales para Villalón y 13.000 reales para Rioseco, completando su ayuda con 9.000 reales para construir caminos en el valle de Esgueva. Además acuerda: "Reparar la escuela de Villanubla, la casa del maestro de Esguevillas, los puentes y pontones de Peñafiel, la Casa Consistorial de Laguna, la fuente de Quintanilla de Trigueros, el puente de Simancas, la escuela de Villardefrades, la caseta de la Guardia Civil de Zaratán, el puente de Aniago, el camino de Castronuevo y la cárcel de Valladolid".

Desde los años 1856 a 1868, la provincia está inmersa en su afán de construcción de vías férreas, y apenas se concede importancia a estos trabajos locales, que no dejan constancia en las actas de la Diputación. Así y todo, siguen apareciendo peticiones de trabajos a nivel local: En Valladolid, en el año 1858, se recoge la publicación de una real orden de 20 de agosto "sobre la necesidad de terminar el Puente Colgante, obra iniciada en 1852". San Pedro de Latarce solicita reparar el camino a Villalpando. Gatón de Campos pide que se le repare el puente.

En el año 1863, se presenta un interesante expediente en la Diputación, promovido por D. León Alejo, con el proyecto para construir un canal de riego del Duero, "que tomando las aguas del Duero en Villabañez llegue a Valladolid, para consumo de agua potable. Se acordó evacuar un informe favorable, con la obligación de terminar las obras en tres años y canalizar el agua hasta el centro de la capital" ${ }^{476}$.

En 1868 se vuelven a solicitar una serie de trabajos, en esta ocasión de canalización de los ríos Sequillo, Zapardiel, Esgueva y Valderaduey, con la finalidad ya consabida y repetida en años anteriores de "dar trabajo a los jornaleros", a consecuencia de la gran sequía que sufre el país.

Entre los años 1867 y 1875 , una serie de trabajos y obras se suceden en los diferentes pueblos de la provincia: Obras diversas en Moral, Castronuevo, Ciguñuela, Langayo, Torrelobatón, Fresno, Mojados, Esguevillas, Berrueces, Cigales, Bolaños, Tordesillas, Portillo, Tiedra y Mota. Reparaciones de caminos en Villabañez, Esguevillas, Fompedraza, Becilla, Castrodeza, Villada, Rioseco, Villalba del Alcor, Matapozuelos, Zaratán, Serrada, Bamba, Olmedo y Mota. Casas consistoriales en Villaverde, Mojados, Olmos de Esgueva, Monasterio, Trigueros, Fuente-Olmedo, Muriel, Villafrechos y Torrelobatón. Construcción de fuentes en Montealegre, Tordesillas, Villalba del Alcor, Fresno, Torrescárcela y Esguevillas. Reparación de puentes en Nava de la Libertad, Puente Duero, Boecillo, Quintanilla de Abajo y Valdestillas. Encauzamiento del río Sequillo en Tamariz y Villanueva de S. Mancio. Caminos vecinales en Villalba del Alcor, Villanueva de Duero, Mucientes, Esguevillas, Villavicencio, Ceinos y Becilla. También el nombramiento de peones camineros, numerosos en estos años, es otra oportunidad de trabajo a los jornaleros.

En resumen, la provincia de Valladolid, al final del período estudiado, se ha estabilizado en un número de doscientos treinta y siete pueblos, de los cuales a lo largo de estos años ciento treinta y seis son los que han solicitado ayudas a la Diputación para realizar mejoras en su entorno y al mismo tiempo paliar las dificultades en la que se encuentran los vecinos sin trabajo, lo que representa el $57^{\prime} 4 \%$ de la totalidad de los pueblos. De este número de pueblos setenta se han dedicado a la

475 A.D.P.V. Actas. Libro de actas del 5 de octubre de 1855 , en la que se recoge la solicitud del Ayuntamiento de Villalón, preocupado por la situación de sus vecinos.

476 A.D.P.V. Actas. Libro de actas del 31 de enero de 1863. 
reparación y mejora de las calzadas y puentes, cincuenta y siete han mejorado los edificios municipales, en especial, casas consistoriales, escuelas y fuentes y nueve han dedicado sus esfuerzos y su dinero a la canalización de los ríos que pasan por los aledaños de la población.

\section{3.- LA DIPUTACIÓN COMO GESTORA DE IMPUESTOS}

La Diputación es una institución creada, a través de la Constitución de 1812, para actuar como puente o conexión entre el gobierno central y los habitantes de las diferentes provincias. El gobierno nombra a la Diputación "su agente intermediario" en la gestión de una serie de actividades difíciles de controlar "desde la Corte". Los impuestos son una de las actividades citadas, la más importante y también una de las más difíciles de llevar a buen término. Es una actividad "antipática", puesto que, aunque la mayoría de los habitantes están sujetos al pago de los impuestos, las dificultades económicas y la penuria en la que está sumida la provincia hacen que el pago de las contribuciones sea rechazado sistemáticamente por los vecinos. No comprenden que tengan que pagar, cuando lo que ganan no les garantiza su supervivencia. Se niegan a pagar y el gobierno les obliga y les presiona a través de la Diputación.

\subsection{1.- LOS IMPUESTOS A PARTIR DE LA CONSTITUCIÓN DE 1812}

El día 13 de septiembre de 1813 se establecía en Cádiz el "Nuevo Plan de Contribuciones Públicas", ley que suprimía los impuestos de rentas provinciales y rentas estancadas y los sustituía por "una contribución única proporcional a través de un repartimiento de la riqueza de los individuos". La finalidad era la de recaudar más y que el reparto y presión fiscal fuera más justo y equitativo. Por esta ley también se eliminaba "el medio diezmo" que cobraba el Estado, pero no se tocaban las rentas de la Iglesia.

Estas buenas intenciones no fueron tan eficaces como se pensó en un principio y la nueva contribución en realidad resultó ser más gravosa, especialmente en la provincia vallisoletana y para los campesinos, como demuestran las numerosas quejas que se reciben a través de la Diputación. El motivo es que los nuevos impuestos se pagaban en metálico y la mayor parte de los impuestos eliminados se satisfacían en especie. Los labradores tropiezan con grandes dificultades para la venta de sus excedentes por falta de canales de comercialización y por dificultades en el transporte, lo que provoca, por un lado, el abuso de los comerciantes de granos y por otro, la falta de liquidez de los labradores para pagar los impuestos.

La Diputación, cuando pretende cobrar las contribuciones, se ve inmersa en una serie de continuas reclamaciones realizadas por pueblos y vecinos contra los repartimientos. Esta actividad ocupa la mayor parte de la gestión de los diputados y al mismo tiempo hace impopular a la institución. El cobro está tan complicado y tan atrasado que obliga a la Diputación, en el año 1814, a exigir a todos los pueblos que "en el plazo de dos meses, todos y cada uno de los pueblos se presenten en la Contaduría para liquidar las cuentas de los municipios, y no sólo del último año, sino también de los atrasos pendientes desde el año $1808^{\text {" }}$ "77.

Esta petición no consigue otra cosa que aumentar los oficios de reclamaciones, de agravios comparativos o de lamentos por no poder hacer frente a las deudas. Además la Diputación tiene que ayudar a cobrar a otras Diputaciones e instituciones de otras provincias. Así lo refleja el oficio de la Diputación de Palencia que "solicita se auxilie a los comisionados que envía a pueblos de esta provincia y Obispado de aquella, con objeto de liquidar el alcance de rentas de la Iglesia y recoger el importe 
de los descubiertos en que se hallan, para destinarlos al socorro de las necesidades de los ejércitos" $"$ "478.

Es tal la importancia de los descubiertos que el intendente de Rentas envió un oficio a la Diputación, haciéndola ver la importancia "en que resulta el descubierto de 326.000 y más reales contra los pueblos de La Nava del Rey, Pollos, Sieteiglesias y Cigales por el tercio fin de diciembre y los meses de enero y febrero de la contribución directa, y el desprecio con que han mirado las medidas suaves que propuso esta Diputación..." ${ }^{479}$. Como ejemplo también tenemos la reclamación del Ayuntamiento de Benavente que se queja de que "no tiene Casa Consistorial, con el agravio de que se le cargaba un quinto del total de impuestos del partido". Pero lo que no dice es que, consultada la Intendencia sobre el asunto, informó "que dicha villa no ha pagado nada del cargo de contribución directa ni en los últimos meses del año anterior ni en los tres de este año ya vencido" $" 480$.

De este estado de morosidad no se escapa tampoco el Ayuntamiento de la capital, pues el diputado comisionado José Pestaña informa acerca del estado de cuentas y, a la vista del informe presentado, "se acordó que el Ayuntamiento de la capital debe de ser ejemplo para el resto de pueblos de la provincia" ${ }^{481}$.

Las quejas, reclamaciones y recursos de agravios son continuas a lo largo de la legislatura, y a veces tan justas que la Diputación accede a las solicitudes, como es el caso del pueblo de Berrueces que, ante sus reclamaciones y lamentos por la mala cosecha habida, "se acordó descontar a la villa de Berrueces una quinta parte de la contribución, contando desde el 1 de septiembre" ${ }^{482}$.

Todas estas reclamaciones y protestas provocan atrasos y negativas en el pago de los impuestos y en consecuencia una serie de dificultades económicas en los compromisos que la Hacienda Pública tiene adquiridos. Así lo refleja la exposición del tesorero provincial de Hacienda"sobre la falta absoluta de caudal en su Tesorería para auxiliar con una paga, acordada por el Sr. intendente a los dieciséis oficiales prisioneros fugados de Francia y que por orden del general en jefe se tienen que presentar en sus destinos y están desnudos y sin nada para emprender la marcha..." "483. El mismo intendente se queja de lo atrasada que se encuentra la recaudación de la contribución directa y de la resistencia de los pueblos a hacerla efectiva. Esta falta de liquidez es tan evidente que hasta el propio jefe político se queja a la Intendencia porque "es indispensable el pago de los gastos de la Secretaría del Gobierno y sueldo de los empleados del mes de marzo, y al no tener fondos la Tesorería, estos gastos se pueden pagar del $5 \%$ adicional de la contribución directa" ${ }^{484}$.

En resumen, es tal el desorden en este asunto de contribuciones y repartimientos, que la Diputación para poder realizar los cobros tiene que pedir ayuda al Ejército para que envíe tropas que acompañen a los comisionados encargados de los citados cobros, para evitar los daños y agresiones por parte de los "normalmente sumisos" contribuyentes. Las protestas y enfrentamientos se agudizan cuando los comisionados pretenden el cobro de otros tipos de impuestos "más antipáticos si cabe" como son los correspondientes a los obispados o los restos de impuestos "señoriales".

478 A.D.P.V. Actas. Libro de actas del 8 de junio de 1814.

479 A.D.P.V. Actas. Libro de actas del 11 de marzo de 1814

480 A.D.P.V. Actas. Libro de actas del 20 de abril de 1814.

481 Se decide que, dentro del plazo perentorio del segundo día, pague no sólo lo adeudado por razón de la contribución directa, sino también cuantos atrasos hubiera debido de recibir de las anteriores contribuciones... en la inteligencia de que esta Diputación no puede alcanzar el por qué al citado Ayuntamiento se le dispensa tanta morosidad en el pago de su débitos, cuando los demás Ayuntamientos de las cabezas de partido y pueblos, a pesar de sus respectivas reclamaciones, acaso más fundadas que las de aquel, han estado y están en su insolvencia, sufriendo los más costosos apremios militares..."A.D.P.V. Actas. Libro de actas del 23 de marzo de 1814.

482 A.D.P.V. Actas. Libro de actas del 30 de marzo de 1814.

483 A.D.P.V. Actas. Libro de actas del 4 de mayo de 1814.

484 A.D.P.V. Actas. Libro de actas del 29 de abril de 1814. 
Para colmo de la presión fiscal ejercida por el gobierno central, el día 8 de junio de 1814, en vísperas de la disolución de la Diputación, se lee en la sesión ordinaria una real orden del 31 de mayo por la que, "enterado S.M. de los apuros de fondos en que se halla el Real Erario, para atender a sus más urgentes obligaciones, manda reunir de esta provincia la suma de 300.000 reales de vellón remitiéndolos a la Tesorería General a la mayor brevedad ${ }^{485}$.

Es decir, el cometido principal de la Diputación en esta época, en materia de impuestos, ha sido el de recaudar fondos, enfrentarse a los vecinos y habitantes de la provincia, obedecer y pedir a sus conciudadanos que obedezcan. "Espera la Diputación que los dóciles castellanos viejos (vean) las necesidades del Real Erario (y) se esmeren en pagar sus respectivas contribuciones... Es forzoso confiar en los desvelos y protección del Soberano y entregarse ciegamente a la obediencia de su Real Voluntad"486. La Diputación, sabiendo el próximo fin de sus actividades, no hace ni amago de resistencia, simplemente acepta con docilidad los planteamientos "supremos" y esa docilidad que exhibe ante las exigencias reales o gubernamentales es la misma docilidad que pide a los habitantes de la provincia.

\subsection{2.- LOS IMPUESTOS EN EL TRIENIO LIBERAL. 1820-1823}

En esta nueva etapa de la Diputación, los impuestos y su repartimiento se perfilan nuevamente como una de las áreas más importantes dentro de sus actividades. Está claro que repercute en todos los pueblos porque todos están sujetos al pago de impuestos. También es cierto que las dificultades económicas y la penuria en que está sumida la provincia hacen de esta actividad una de las más controvertidas y de las que encuentran un mayor rechazo social. El apartado económico es el que genera un mayor trabajo en la Diputación y en todo el período del Trienio Liberal, los expedientes tratados entre contribuciones, arbitrios y consumos, suponen el $24,1 \%$ del total.

\section{Las contribuciones de carácter nacional}

En un primer momento, las Cortes legislan y simplifican los impuestos, aboliendo la diversidad de los mismos, cuyo origen se remonta al Antiguo Régimen, y los reúne en tres principales tipos de contribuciones: Territorial, de Consumos y Urbana.

El sistema de reparto contributivo se ajusta a un esquema que se mantiene a lo largo de estos años. En primer lugar, el gobierno fija la cuantía de los impuestos y realiza el reparto por provincias en función de su riqueza y su población. Son dos parámetros muy difíciles de fijar y muy discutidos. Especialmente la Diputación de Valladolid reclama continuamente, por un lado al gobierno para que le remita las estadísticas por las que se basa para fijar el número de habitantes y los baremos que utiliza para calcular la riqueza de la provincia. Por otro lado, reclama insistentemente a los Ayuntamientos que remitan a la Diputación "los cuadernos de riqueza", es decir, la relación de los rendimientos agrarios del pueblo y "los cuadernos de estadística", para conocer el número real de habitantes. A veces, las informaciones sobre estos sistemas de control son tan antiguas, que es lógico que las provincias reclamen contra lo que consideran bases incorrectas para fijar los impuestos. Como veremos más adelante, en Valladolid en el año 1821, los impuestos se reparten con arreglo a la población y riqueza del año 1818.

En segundo lugar, la Intendencia hace el reparto de la cantidad global asignada a la provincia, dividiéndola entre todos los pueblos, con los parámetros de riqueza y población que los diferentes Ayuntamientos han transmitido a la Diputación. Estos repartimientos tienen que ser aprobados con el visto bueno de la Diputación.

485 A.D.P.V. Actas. Libro de actas del 8 de junio de 1814.

486 A.D.P.V. Actas. Libro de actas del 17 de junio de 1814. Extracto de la proclama del jefe superior político, José Casimiro Lavalle, dirigida a la provincia. 
En tercer lugar, como último paso, los pueblos, una vez recibidos los repartimientos correspondientes a cada uno, hacen su derrama interna dividiendo el montante que les ha correspondido entre todos los vecinos en función de su riqueza.

Todos estos movimientos generan una serie "de reclamaciones encadenadas". De la Diputación al gobierno de la Nación, "quejándose de la cuantía que les ha correspondido en comparación con otras provincias" y recuerda al mismo tiempo "la miseria que existe en la provincia". Protestas de los pueblos con respecto a la Diputación, a la que ofician quejándose de "agravios comparativos" con referencia a otros pueblos. Demandas de los particulares, que también envían sus quejas a la Diputación lamentándose del repartimiento hecho por el Ayuntamiento.

Este circuito de reclamaciones se cierra con las que recibe la Diputación y que proceden del gobierno. Vienen motivadas porque ni la Diputación, ni los pueblos, ni sus vecinos han cumplido con su obligación, unos la de cobrar y otros la de pagar. En este sentido es especialmente llamativo lo ocurrido en el año 1820, con un oficio de la Secretaría de Hacienda en el que se dice que "enterado S.M. del enorme atraso en el pago de la contribución general perteneciente a los años 1818 y 1819 y que influyendo en ello la maliciosa idea, formada por los pueblos, de que por el nuevo feliz sistema, quedan libres de pago de contribuciones, para evitar los graves males que puede acarrear este error si no se ataja, quiere S.M. que la Diputación procure ilustrar a los pueblos sobre el particular..."487. La Diputación, ante este aviso, tuvo que recordar a los pueblos que tenían que pagar las contribuciones atrasadas, porque no se iban a perdonar.

El año 1820 es difícil y complicado en el tema recaudatorio, pues además de los referidos atrasos de los años 1818 y 1819, la mala cosecha de este año dificulta el pago de los impuestos. Este problema obliga, por un lado, a repartir trigo de los pósitos para poder sembrar, y por otro lado, fuerza a las Cortes a aprobar un real decreto por el que "se perdona una parte de las contribuciones a los pueblos que satisfagan los dos tercios de ella en la época que se expresa".

Por parte de la Diputación, y ante las numerosas peticiones que recibe de los pueblos solicitando "el perdón de las contribuciones a causa de la "mala cosecha", se toma el acuerdo de oficiar al resto de las Diputaciones de Castilla la Vieja "para que sirvan representar al Gobierno la común esterilidad del presente año, con el objeto de que se minore la contribución" ${ }^{488}$. La Diputación de Valladolid remite una exposición a las Cortes pidiendo comprensión ${ }^{489}$.

Las Cortes aceptan parcialmente las peticiones de la Diputación, aprobando un real decreto por el que "se rebaja un tercio de la contribución en los dos plazos que quedan pendientes".

Con respecto al año 1821, que en teoría debía de ser un año sin problemas y con una cosecha aceptable, no deja de tener dificultades para el cobro de los impuestos, como indica el oficio del secretario de Estado y Despacho de la

487 A.D.P.V. Actas. Libro de actas del 6 de mayo de 1820, donde queda reflejado el oficio remitido por la Secretaría de Hacienda de fecha 21 de abril.

488 A.D.P.V. Actas. Libro de actas del 8 de agosto de 1820.

$489 \quad$ "que así como se considera obligada a ser activa y eficaz en velar sobre que sus conciudadanos no sean omisos en pagar las contribuciones que deben levantar para sostener las cargas del Estado, tampoco puede desentenderse de elevar al Congreso todas las consideraciones oportunas cuando se hallan imposibilitados de allanarlas por faltar los productos que constituyen su riqueza. Es bien notorio que lo principal de esta provincia es el ramo agricultor, pero también lo es que este año ha sido tanta la esterilidad de los frutos, que no se ha verificado producto alguno...Esta Diputación solicita del Congreso Augusto... que se indemnice de las contribuciones, que no pueden cubrir sin recurrir a la venta de sus propiedades. Así lo espera..."A.D.P.V. Actas. Libro de actas del 10 de agosto de 1820, en el que se refleja la exposición a las Cortes de la Diputación "sobre minorar el cupo de las contribuciones" 
Gobernación de la Península99. También llama la atención el oficio enviado por el secretario del Despacho de Hacienda ${ }^{491}$.

Los dos últimos años, ya sean por unas causas, ya sean por otras, han sido complicados en la economía, pero el año 1822 no es mejor, pues a una mayor presión fiscal en economías maltrechas, se añade en este año un grave problema de inseguridad ciudadana y de descontento, o mejor dicho, de desencanto con los resultados del gobierno liberal. Ello provoca una efervescencia social, al irse dando cuenta los habitantes de la provincia que la Diputación no les resuelve los problemas, sino más bien lo contrario, al ser la "cabeza visible" del poder central en los asuntos tan ingratos y complicados como los impuestos. El enfrentamiento entre la Diputación y el gobierno se ve complicado en este año por la disputa con el Ministerio de Hacienda, sobre los atrasos de las contribuciones de 1820 y 1821. Aunque el decreto de las Cortes de 29 de junio de 1822 se los concedía a la Diputación "para reanudar las obras del Canal", sin embargo la Tesorería de Hacienda no está de acuerdo ni reconoce la forma y modo de poner en práctica dicho decreto.

En definitiva, lo que resulta evidente es que a lo largo de estos tres años son continuas las reclamaciones de los vecinos, los "toques de atención" del gobierno reclamando agilidad en el cobro de las contribuciones y las peticiones de la institución provincial al gobierno y a las Cortes para que se rebaje la cuantía de los impuestos, pues la presión fiscal que sufre "es mucho mayor que la de otras provincias en términos comparativos de riqueza, pues el precio de los productos es superior... y la diferencia con otras provincias es enorme. Los vinos de toda la costa de Cataluña y de Andalucía se venden al triple que el de esta provincia y los granos al doble, resultando por tanto su riqueza superior..."

En el cuadro adjunto reflejamos el resumen de las contribuciones que se cargaron a la provincia durante el Trienio Liberal.

$\begin{array}{lccccc}\text { Año } & \text { Territorial } & \text { Consumo } & \text { Urbana } & \text { Total } & \text { Habitantes } \\ 1820 & 3.304 .975 & --- & 530.476 & 3.835 .451 & 168.862 \\ 1821 & 2.681 .657 & 2.059 .687 & -- & 4.741 .344 & 164.389 \\ 1822 & 3.165 .247 & 1.937 .047 & 183.309 & 5.285 .603 & 184.275\end{array}$

El dato de los habitantes correspondientes al año 1820 se ha recogido del decreto de "División Provisional de la Provincia", en el que se refleja una población de 37.525 vecinos por 4'5 habitantes por vecino, con una cuantía de impuestos de 22 '7 reales por habitante y año. Los habitantes del año 1821 se tomaron por la administración de las cifras del padrón realizado en el año 1818, y se calcularon 36.531 vecinos, multiplicado por el coeficiente de 4'5 habitantes por vecino, correspondiendo a cada habitante una cuantía de $28^{\prime} 8$ reales por impuestos. Los habitantes del año 1822 son los provenientes de la nueva ley de "División Provisional del Territorio Español" y son el resultado de multiplicar por el coeficiente de 4'5 a los

\footnotetext{
$490 \quad$ En ella comunica "que siendo de la mayor necesidad el activar las liquidaciones de los pueblos desde el año 1808 a 1819 para cumplir con lo mandado por las Cortes... S.M. ha tenido a bien resolver que se den las órdenes oportunas a fin de que los gefes (sic) políticos y las Diputaciones provinciales exciten el zelo (sic) de aquellos (pueblos) para que presenten los documentos y realicen la liquidación" Colección de Reales Decretos y Órdenes... ob. cit. Gobierno Político de la provincia de Valladolid. Doc. 114 de fecha 13 de abril de 1821.

491 En él se lamenta que "en lugar de recibir la Tesorería General auxilio de caudales de las provincias, por ser las obligaciones de las Cortes muy superiores a los medios que proporcionan para llenarlas, se experimenta por el contrario que las reclaman las provincias de la Tesorería como hace V.S. en oficio del 22 del corriente... Es asombroso el atraso de contribuciones que tienen las provincias de Castilla y es por lo mismo inútil que se reclamen auxilios pecuniarios mientras haya semejantes atrasos..." Colección de Reales Decretos y Órdenes... ob. cit. Intendencia de la Provincia de Valladolid. Doc. 128 de fecha 29 de julio de 1821.

492 A.D.P.V. Actas. Libro de actas del 15 de septiembre de 1822. Con la exposición remitida a las Cortes, solicitando la reducción de la contribución.
} 
40.950 censados, y la correspondencia en impuestos asciende a $28^{\prime} 7$ reales por habitante.

\section{Los arbitrios provinciales y locales}

Así como el Estado se apoya en las contribuciones para cubrir sus necesidades, los municipios para cubrir sus gastos lo hacen a través de la imposición de arbitrios. En la mayoría de los pueblos, los gastos municipales se cubrían en su mayoría con las rentas procedentes de los bienes de propios, basados en la venta y arrendamiento de pastos, eras, montes, molinos, etc. Otro sistema implantado en estos años es el referido al arrendamiento de los llamados "artículos de consumo". El decreto de las Cortes de 25 de junio de 1821 autorizaba a las Diputaciones "el consentir que los pueblos graven con impuestos a los géneros de consumo, cuando falten otros medios menos gravosos para cubrir sus gastos municipales, entendiendo como artículos de consumo al vino, vinagre, aguardientes con licores, aceite y carne" ${ }^{493}$. Cuando los pueblos no conseguían cubrir sus presupuestos con estos ingresos, tenían que recurrir al repartimiento de arbitrios entre todos los vecinos. Este sistema también es utilizado para cubrir los gastos extraordinarios, casi siempre referidos a la construcción y mejora de los diversos servicios municipales, como la casa consistorial, la fuente pública, los caminos vecinales, cementerios, escuelas, cárceles, etc., así como el pago de los salarios de maestros y empleados.

\section{Propuesta de abolición de impuestos}

Una de las principales propagandas que hicieron los liberales fue la de la abolición de determinados impuestos, y entre ellos, uno de los más antipáticos para los ciudadanos era el "derecho de puertas", impuesto que fue abolido al inicio de la época liberal. Pero tuvo que ser repuesto al poco tiempo, ante el problema que se ocasionaba a los Ayuntamientos, que perdían una parte importante de sus ingresos y que no eran sustituidos por otros, por lo que la economía municipal se resentía.

Otro impuesto del que se hizo también bandera de la reducción fiscal fue el diezmo. Sí fue rebajado, pero tuvo su impacto negativo en los contribuyentes al tener que abonarlo en metálico en lugar de en especie, lo que ocasionaba serios problemas de liquidez, especialmente a los labradores.

La eliminación de los variados tipos impositivos que gravaban a la ciudadanía hay que tomarla como positiva, pero no porque se redujeran la cuantía de lo que debía de pagar cada individuo, sino que suponía una clarificación del régimen impositivo, especialmente para la administración de Hacienda.

\subsection{3.- LOS IMPUESTOS EN LA ÉPOCA ISABELINA. 1835-1868}

Las Diputaciones se implantan en el país de una forma definitiva a partir del año 1835 , pero eso no quiere decir que los habitantes de la provincia no siguieran sufriendo con los impuestos a lo largo de la Década Ominosa, como lo seguirían haciendo en la época isabelina.

Si nos remontamos al año 1833, vemos que en el Boletín Oficial de la provincia, que inicia su publicación en este mismo año, ya se publican diferentes noticias que nos hablan de impuestos y de los problemas que tiene la Hacienda Pública para hacerlos efectivos. Como ejemplos tenemos diferentes reales órdenes aprobando solicitudes de rebajas de Contribución, también una curiosa real orden publicada el 20 de agosto en el Boletín Oficial informando sobre la forma de combatir los fraudes en los procesos recaudatorios, o las más habituales reales órdenes reclamando unas veces y exigiendo otras el pago de las contribuciones atrasadas.

El 22 de octubre de 1835, se celebra la "sesión de instalación" de forma definitiva de la Diputación Provincial de Valladolid, sesión en la que se dio posesión

493 A.D.P.V. Actas. Libro de actas del 16 de marzo de 1822, es el que se reseña la exposición a las Cortes, pidiendo aclaraciones al citado decreto de 25 de junio de 1821 . 
del cargo a los diputados. Además se redactó una "alocución dirigida a la provincia", poniendo de manifiesto la preocupación de la corporación por las contribuciones y su justo reparto. En ella subrayan que "será su primer cuidado disminuir el peso con que la desnivelación en la exacción de tributos agobia a los contribuyentes y buscar un sistema de repartimiento aproximado a la exactitud"

Los planteamientos que hace la Diputación no se han modificado, sus preocupaciones en materia económica siguen siendo las mismas y la situación de la provincia, según queda reflejado en la alocución, tampoco ha mejorado. Así que a 10 largo de este período isabelino veremos que la gestión de los impuestos, su cobro, la atención de las numerosas reclamaciones y los atrasos serán una de las mayores ocupaciones y preocupaciones con que se enfrentará la Diputación. Sin olvidarnos de las penurias económicas que atravesará la provincia ante la falta de liquidez de la institución provincial, reflejada en los continuos déficits de sus presupuestos.

En un intento por mejorar la economía de la provincia, la Diputación envía una exposición a la Reina pidiendo soluciones ${ }^{495}$. Un problema adicional en estos primeros meses de funcionamiento se presenta a la hora de cubrir los gastos que origina la Diputación. No dispone de dinero ni tiene el gobierno previsión en sus presupuestos, lo que obliga a publicar una real orden con nuevos repartimientos ${ }^{496}$. Ante la aprobación de este decreto, el diputado por Peñafiel, Millán Alonso, advirtió al Pleno que "los pueblos se iban a quejar amargamente", porque además de la presión de las contribuciones estatales, aparecía un nuevo impuesto promovido precisamente por la corporación y recuerda que en sus inicios ésta prometió mejorar la presión fiscal.

A partir del año 1836, la Diputación inicia sus actividades con los repartimientos de los impuestos a través de una comisión que se nombra de "individuos de la institución". Su misión es la de unificar el repartimiento realizado por la Intendencia de Rentas de la provincia y modificarlo en los términos que crea conveniente. Aunque, como la primera comisión nombrada reconoce, la falta de información sobre las propiedades y riqueza de los habitantes de la provincia hace difícil ser "justo" en el reparto de los impuestos.

Este problema se hace patente cuando la provincia publica su lista de mayores contribuyentes, para fijar qué ciudadanos tienen derecho a ejercer el voto tanto en las elecciones a diputados nacionales como provinciales. El 17 de junio de 1836 se hace pública la primera lista de "mayores contribuyentes en las que se reflejan los ochocientos dos electores de la provincia con derecho a voto por tener renta superior a 440 reales. Al igual que cualquier otro repartimiento, esta lista genera una serie de reclamaciones de personas que dicen tener derecho y "se han quedado fuera" y también de los que piden su exclusión por otras diversas causas.

Las contribuciones estatales siguen generando protestas, aunque finalmente son asumidas con resignación por los contribuyentes Pero los que "levantan ampollas" son los repartimientos extraordinarios, como ocurre con el real decreto 30 de agosto de 1836, que aprueba "un adelanto de 200 millones reembolsables... correspondiendo a la provincia de Valladolid la cantidad de 4.200 .000 reales" ${ }^{497}$. Repartimientos que se producen con demasiada frecuencia, en unos años en que la guerra civil ocasiona una serie de gastos que tienen como últimos pagadores a los contribuyentes, como ocurre con el pueblo de Peñafiel que, "solicita autorización para repartir 36.390 reales,

494 B.O.P.V. $\mathrm{n}^{\text {o }} 89$ de fecha 27 de octubre de 1835, donde se publica el "Manifiesto dirigido a la Provincia".

495 "que se alivien a los pueblos de Castilla las pesadas cargas que les agobian y aniquilan y que los errores y desaciertos de las últimas administraciones redujeron casi a la miseria" A.D.P.V. Actas. Libro de actas del 4 de noviembre de 1835. Pág. 110, con la trascripción literal de la "Exposición a S.M. la Reina".

496 "autorizando a las Diputaciones provinciales para que hagan un repartimiento en la cantidad de 30.000 reales para cubrir sus gastos más precisos y urgentes... en tanto se aprueban los presupuestos de gastos provinciales" A.D.P.V. Actas. Libro de actas del 7 de marzo de 1836. A.D.P.V. Actas. Libro de actas del 15 de septiembre de 1836, con la copia del decreto. 
recaudados por los facciosos" ${ }^{498}$. Esta presión fiscal se completa con el repartimiento extraordinario de 300.000 reales que se autoriza a la Diputación provincial ${ }^{499}$.

Ante este cúmulo de peticiones, no es de extrañar que se presente una queja en la Diputación proveniente del Sr. intendente ante "la lentitud en la recaudación de los 4.200.000 reales" $"$ "500. Queja a la que la Diputación contesta pidiendo a la Intendencia una relación de morosos, a la vez que se pide a la Depositaría de Fondos de la Diputación "ver lo que han producido los arbitrios impuestos e ingresados en esta Depositaría para el pago de los 200 millones y tener una cuenta de lo ingresado, notificar a los Ayuntamientos las deudas de dichos arbitrios y conocer la situación de los fondos de los pósitos"

La situación económica del país en estos años no puede estar más revuelta, pues el Gobierno central pide un adelanto de 200 millones, la Diputación necesita 300.000 reales para su desenvolvimiento y los pueblos tienen que pagar las "requisas de las facciones". Además llega el ejército, que por boca del capitán general de Castilla la Vieja "solicita a la corporación que cooperase todo lo posible a fin de que se sirviese facilitarle de 4 a 5.000 duros para atender las necesidades del Ejército de este distrito" $" 502$. La Diputación, una vez conocida la cuantía de los fondos en la Depositaría que ascienden a 42.684 reales, acordó prestar al ejército "en calidad de reintegro" la cantidad de 38.000 reales.

Las quejas de los habitantes de la provincia continúan ante la insistente petición de dinero en efectivo y de suministros exigidos, tanto por los grupos "de facciosos" como por parte del ejército. Ante este problema, la Diputación manifiesta "la triste situación de la provincia por las continuas exacciones y por el modo con que se hacían, especialmente por las tropas, que abusaban pidiendo suministros y se negaban a entregar los bonos correspondientes, no pudiendo actuar a través de la vía administrativa por estar la provincia en estado de guerra" ${ }^{503}$.

Los pueblos, mientras tanto, intentan arreglar sus dificultades a través de sus bienes, como por ejemplo Megeces, que tiene que "solicitar la corta de árboles de propios" si quiere pagar sus impuestos, o Portillo, que reclama al Ejéercito "el pago del suministro de 15.000 raciones de pan, carne, vino y cebada" y también Nava del Rey reclama 8.000 reales "entregados a la facción de Zariategui". En definitiva, todo son reclamaciones y todos son pagos, y para colmo, una serie de contribuyentes se lamentan "de no poder pagar los impuestos, pues la Intendencia no les admiten los billetes del Tesoro" ${ }^{\text {504 }}$. El tema se consultó por la Intendencia con el Ministerio de Hacienda, que decidió "no permitir el pago con Bonos del Tesoro, a causa de la penuria de fondos, al igual que no admitir billetes de los prestamistas Gaviria, Lafont, Guandamino, Perú, Casals y Remisa y sólo admitir billetes del Tesoro del adelanto de los 200 millones" $" 505$.

Para completar la carga fiscal del año 1837, aparece el impuesto de los diezmos, con la petición de la Intendencia de Rentas a la Diputación, para "que se le informara en razón de si la contribución del Diezmo del año último se había o no recaudado puntualmente" ${ }^{206}$. Además, se discutía si este impuesto debía de ser pagado en metálico o en frutos. Acabamos el año con el real decreto de autorización "a la

499 "para atender los gastos de defensa de la capital y cubrir las necesidades del equipo de milicianos nacionales movilizado" A.D.P.V. Actas. Libro de actas del 12 de diciembre de 1836.

500 A.D.P.V. Actas. Libro de actas del 5 de febrero de 1837.

501 A.D.P.V. Actas. Libro de actas del 16 de marzo de 1837.

502 A.D.P.V. Actas. Comunicación reflejada en el libro de actas del 14 de junio de 1837. La traducción de "duros" a reales, se toma por equivalencia de 1 duro $=20$ reales, con lo que la petición en reales asciende a la cantidad de 80.000 a 100.000 reales.

503 A.D.P.V. Actas. Libro de actas del 11 de noviembre de 1837.

504 A.D.P.V. Actas. Libro de actas del 4 de enero de 1838.

505 A.D.P.V. Actas. Libro de actas del 16 de enero de 1838.

506 A.D.P.V. Actas. Libro de actas del 8 de febrero de 1838.
} 
Diputación para hacer un repartimiento de 300.000 reales con la finalidad de cubrir los gastos provinciales" ${ }^{\text {507 }}$.

En estos primeros años de la época isabelina y también de la vida de la Diputación, se suceden una serie de contribuciones extraordinarias, a lo que sigue otra serie de quejas y reclamaciones ante las obligaciones que acarrean el pago de los impuestos. Entre todos estos años, es el de 1838 el que destaca por el continuo "goteo" de impuestos que se producen.

La primera exigencia corresponde al Ejército, con una nueva comunicación del capitán general en el mes de marzo, en la que "hacía notar el estado crítico en que se hallaba la Pagaduría Militar, careciendo hasta de lo más preciso... y reclamando hasta la cantidad de 10 a 12 mil duros, que tendrían su reintegro por repartimientos y ventas de baldíos" ${ }^{\$ 08}$. Ante esta petición, la Diputación, a través de la comisión de contribuciones, pidió a los capitalistas de la provincia su colaboración para cubrir la cantidad reclamada por el Ejército aunque sin gran éxito pues "la comisión encargada de la suscripción de los 8.000 duros, a pesar de las excitaciones hechas a los capitalistas, no había podido reunir más que la insignificante cantidad de 50.000 y pico de reales" $" 509$. El poco éxito se puede explicar porque, con anterioridad en el mes de febrero, el intendente de Rentas había comunicado una nueva contribución "para tener a disposición del Gobierno 9.000 duros mensuales para cubrir el desembolso de 10 millones de reales del Banco Nacional de San Fernando, la Diputación acordó reclamar la presencia de los alcaldes para convencerles de hacer frente a este nuevo impuesto" 510 .

La presión fiscal continúa, cuando en el mes de junio, la comisión de contribuciones advierte de que "a fin de ir reuniendo los datos precisos para hacer el repartimiento de la contribución extraordinaria de Guerra, se pide al intendente una nota con los bienes nacionales enajenados en la provincia" ${ }^{511}$.

En realidad, todo el año 1838 es una sucesión de peticiones de impuestos, de repartimientos, y las actas de la Diputación están llenas de reclamaciones y de quejas. En todas las sesiones celebradas aparece la comisión de contribuciones con el tratamiento de una serie de expedientes que abarca prácticamente a toda la provincia. Especialmente en los días posteriores a la aparición y publicación de los repartimientos efectuados para cubrir los impuestos, y sobre todo los extraordinarios, como ocurre a lo largo del mes de julio con la "Contribución extraordinaria de Guerra". En la primera sesión del mes se leyó el real decreto de 30 de junio de 1838 por el que se manda repartir y exigir la contribución extraordinaria de guerra decretada por la ley de 3 de noviembre de 1837 en la cantidad de 603.986.284 reales. Para la provincia de Valladolid se fija la siguiente contribución: 6.881.101 reales de vellón sobre riqueza territorial y pecuaria; 400.000 reales de vellón sobre riqueza industrial y comercial; 2.597 .755 reales de vellón sobre consumo de aguardiente, licores, sal y tabaco. Enterada la Diputación, acordó que para que en esta provincia tuviera cumplido efecto el repartimiento de los cargos que por esta ley se le habían señalado, se convocara sin demora a todos los diputados para que el día 14 se presenten para ocuparse de los indicados trabajos" ${ }^{512}$.

En la reunión del día 14, se encargó a la comisión de contribuciones, para que junto a "otros señores asociados representantes del comercio e industria de la provincia trabajaren para realizar un justo repartimiento" ${ }^{513}$. La comisión trabajó

513 A.D.P.V. Actas. Libro de actas del 14 de julio de 1838. Los "individuos asociados" que forman parte de la comisión son: Por el comercio: Gregorio Becerra de Valladolid, Tomás Diez de la Guardia, de Medina y Francisco Semprún de Rioseco. Por la industria material: Millán Alonso, de 
rápidamente pues el 20 de julio presentó al Pleno de la Diputación las "Bases para hacer las distribuciones de la contribución extraordinaria de guerra, teniendo en cuenta la dificultad por la falta de estadística" ${ }^{514}$. Una vez discutida la propuesta, se aprobaron tanto las bases como los repartimientos realizados sobre dichas bases y se publicaron el 14 de agosto de 1838 con la relación completa de todos los pueblos de la provincia y la cantidad que correspondía a cada uno, cantidad que oscilaban entre los 1.615.742 reales que tenía que repartir la capital y los 784 reales imputados a la Granja de Quiñones.

A partir de esta publicación, se produce una nueva "cascada" de reclamaciones, de peticiones y de quejas con referencia al nuevo repartimiento destacando entre tod as la presentada por el Ayuntamiento de la capital. Éste fue recibido "en audiencia" y presentó su disconformidad por la cuantía que le había correspondido en el reparto. Tanto las protestas como los retrasos en el pago se generalizan, lo que obliga a la Diputación a remitir una circular a todos los pueblos "reclamando el pago de los impuestos atrasados a través de bienes de propios, cartas de pago canceladas, caballos

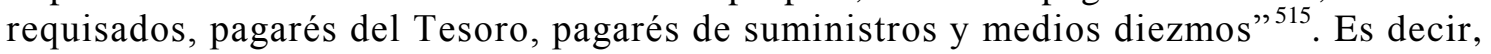
todo se admite con tal de cobrar los impuestos.

La mala situación económica, agravada por los gastos de la guerra, la padece la mayoría de la población, y no se salvan ni los conventos de religiosas, que se ven obligadas a solicitar ayuda a la Diputación ${ }^{516}$.También es curioso el problema generado en el pueblo de Oteruelo, con la pregunta del intendente, sobre "a quién exigir el cupo de contribuciones si ha quedado despoblado" ${ }^{517}$.

Con la finalidad de evitar de una forma parcial las reclamaciones, la Diputación formó una comisión para actualizar los "encabezamientos" y de esta forma repartir más justamente los impuestos. Pero a los pocos días de su funcionamiento, pasó un informe en el que se resaltaban las dificultades ${ }^{518}$. El problema era evidente; nadie tenía interés en decir la verdad para de esta forma pagar lo menos posible. Es decir, los propietarios y capitalistas estaban interesados en ocultar sus bienes para eludir los impuestos y al no tener la Diputación un sistema de fiscalización no podía hacer un repartimiento correcto en función de la riqueza de cada habitante. Mientras tanto, se almacenaban los expedientes y se demoraba el pago de los impuestos. Este problema llegó a ser tan acuciante que la Diputación "acordó autorizar al Sr. presidente y a los miembros de la comisión de contribuciones para que vieran y determinaran diariamente todos los repartimientos, quejas de agravios y demás negocios. La absoluta falta de fondos y la ninguna esperanza de que ingresaran cantidades bastantes para sufragar las atenciones que pesaban sobre la corporación, la ponían en el compromiso de adoptar recursos para salir de estas

Quintanilla y Toribio Valdés de la Pedraja de Portillo y por la industria intelectual, Valeriano Rodríguez de Torrelobatón.

$5141^{\circ}$. La contribución de consumos se repartirá en todos los pueblos de la provincia tomando por tipo los encabezos de rentas provinciales. En la capital se hará por los derechos de puertas del año $1837.2^{\circ}$. La contribución territorial e industrial se distribuirá tomando por base las cuotas de la contribución de paja y utensilios. $3^{\circ}$. Se tendrá en cuenta los aumentos de la propiedad particular por efecto de la compra de bienes nacionales" A.D.P.V. Actas. Libro de actas del 20 de julio de 1838.

${ }^{515}$ B.O.P.V. Boletín del 12 de marzo de 1839.

516 "sobre la situación desesperada en que se hallan, por no cumplirse la promesa de satisfacción de ayudas señaladas por las Cortes, a lo que el Sr. intendente manifestó la imposibilidad de cumplirlo por la absoluta falta de fondos y la decisión del Gobierno de dedicar los fondos de Tesorería sólo a cubrir las necesidades del Ejército" B.O.P.V. Boletín del 8 de noviembre de 1839.

517 B.O.P.V. Boletín del 27 de febrero de 1840

518 "cada día encontraba mayores obstáculos para aspirar a una base justa y capaz por sí sola de demostrar la verdadera riqueza de los pueblos, que ni la formación de nuevos amillaramientos ni las relaciones que se pidieran a los Ayuntamientos y particulares eran suficientes a este objeto... y no acertando el camino a elegir se acordó activar los trabajos de estadística". A.D.P.V. Actas. Libro de actas del 13 de marzo de 1840. 
dificultades. Se acordó reclamar de apremio los atrasos en los repartimientos de los años 1837,38 y $39 . . . " 519$.

La Diputación no había acabado de reclamar los atrasos cuando una nueva contribución extraordinaria se presenta amparada en el real decreto de 30 de julio de 1840, que se publica en el Boletín Oficial de la provincia "ordenando llevar a efecto la Contribución Extraordinaria de Guerra de 180 millones de reales, correspondiendo a la provincia 2.375.303 reales por la contribución territorial y pecuaria, y 700.000 reales por contribución comercial e industrial" ${ }^{520}$. En consecuencia, la Diputación, "al tener que ocuparse de un negocio de la mayor importancia como era el repartimiento del cupo designado a la provincia de la Extraordinaria de Guerra..., acordó nombrar una comisión compuesta por los Sres. Cantalapiedra, Campesino y Rozas, para que propongan las bases sobre las que habría que girar el repartimiento..." ${ }^{521}$. Esta comisión apenas pudo iniciar sus trabajos, pues la Diputación fue disuelta. Aunque esto no es obstáculo para que el Sr. intendente reclame a la nueva Diputación "la pronta recaudación de la contribución extraordinaria de guerra, lamentando la apatía con que procedían S.S. en este tema, a la vez que solicita a la corporación que verifique los repartimientos, pues en caso contrario lo haría la sección de Rentas" ${ }^{522}$. Ante la urgencia presentada por el Sr. intendente, la Diputación nombra la comisión de contribuciones. A los pocos días se presenta el repartimiento que es aprobado por el Pleno de la Diputación el día 14 de febrero, el correspondiente a la Riqueza Territorial y Pecuaria, y el 1 de marzo el repartimiento sobre la Riqueza Comercial e Industrial.

A partir del año 1841 la Diputación tiene que hacer frente a la recaudación de otro impuesto, que no es nuevo, sino que aparece por vez primera como responsabilidad de la Diputación el realizar su repartimiento. Nos estamos refiriendo al impuesto de "Culto y Clero" 523 . Acompaña a este repartimiento una relación presentada por la Secretaría, detallando la cantidad que corresponde a cada uno de los doscientos ochenta y cinco pueblos de que se compone la provincia. Señala por un lado el cupo correspondiente a la riqueza territorial cuyo total es de 1.030 .740 y por otro el que corresponde a la riqueza industrial y comercial con un total de 257.685 reales. Como ejemplo de la cuantía de este repartimiento, tomamos el de la capital que asciende a 106.092 reales sobre la riqueza industrial y comercial. Lo que representa un porcentaje del $41,1 \%$ del total y el correspondiente a la riqueza territorial asciende a 163.491 reales, lo que supone el 16,1\% del total provincial. En este año, como con los anteriores, no aparecen los repartimientos de las contribuciones ordinarias; es posible que esos impuestos sean controlados directamente por la Intendencia de Rentas.

A finales de 1842 aparece nuevamente una circular del gobierno, señalando el cupo de la contribución de Culto y Clero correspondiente a Valladolid, con una cuantía de 1.224.280 reales computables a la riqueza territorial y 224.000 reales computables a la riqueza industrial y comercial, lo que supone un total de 1.448.280 reales $^{524}$. Aprobado el repartimiento, se publica con detalle la relación con el importe correspondiente a cada pueblo. Si tomamos en comparación con el repartimiento del año anterior de la capital, vemos que en esta ocasión tiene que pagar 92.224 reales correspondientes a la riqueza industrial y comercial (el 41,1\%) y 196.281 reales correspondientes a la riqueza territorial (el 16,1\%). Es decir, aunque las cantidades finales son diferentes, se repiten los porcentajes porque se repiten las bases que han

519 A.D.P.V. Actas. Libros de actas correspondientes al 28 de marzo y al 3 de noviembre de 1840.

520 B.O.P.V. ${ }^{\circ} 139$ de 19 de noviembre de 1840 .

521 A.D.P.V. Actas. Libro de actas del 30 de noviembre de 1840.

522 A.D.P.V. Actas. Libro de actas del 26 de enero de 1841.

523 En la sesión de 25 de septiembre aparece "un repartimiento de 1.288 .425 reales de vellón para cubrir las necesidades del culto y clero... y que este repartimiento se haga por la misma base que se adoptó para el anterior repartimiento de la contribución extraordinaria de guerra de los 180 millones" A.D.P.V. Actas. Libro de actas del 25 de septiembre de 1841.

524 B.O.P.V. $n^{\circ} 144$ de 1 de diciembre de 1842 en el que se publica la circular de S.A. el Regente del Reino de fecha 18 de septiembre de 1842. 
servido para su cálculo. Pero esto no es obstáculo para que se inicie de nuevo el "rosario" de reclamaciones y peticiones de exacción. Como ejemplo mostramos la reclamación del secretario de la Diputación, D. José María Cano, que se queja "por tener que pagar por la contribución al Culto y Clero 90 reales en concepto de abogado, cuando pagó en concepto de secretario de la Diputación"

En el año 1843, la Diputación no tiene referencias de repartimientos generados por contribuciones estatales. Pero sí aprueba y efectúa "un repartimiento de 10.323.365 reales para cubrir los costos de las carreteras de León y Salamanca" 526. Impuesto y repartimiento que fue muy protestado por la población, dispuesta a sufrir los impuestos ordinarios, pero a la que no la gustaban los extraordinarios. Además, este repartimiento sobrepasaba su capacidad de pago, y no dejaron de recriminar a la Diputación por lo que consideraban: "una injusticia el tener que pagar unas carreteras que consideraban nacionales". En las audiencias sucesivas que tuvieron en la Diputación, la totalidad de los pueblos se negaron a admitir este repartimiento.

El año 1844, se inicia con un nuevo repartimiento correspondiente a la contribución de Culto y Clero, según ordena la real orden de 5 de marzo, y detallando para la provincia de Valladolid una cantidad de 1.288.425, idéntica a la presentada para el año 1842. A los pocos días, el intendente de Rentas pasa a la Diputación una notificación "reclamando a la Diputación el ingreso de 255.527 reales por la contribución extra de guerra de los 600 millones correspondientes a los descubiertos de varios pueblos" ${ }^{, 527}$.

La Diputación, en una actitud extraña para ella por su habitual obediencia a las directrices del gobierno, no entrega el dinero de la Extraordinaria de los 600 millones, porque no los puede cobrar a los pueblos. Ni hace el repartimiento de la contribución de Culto y Clero, lo que obliga al gobierno a publicar una real orden el 5 de noviembre, advirtiendo "que si las Diputaciones no ejecutan los repartimientos de Culto y Clero y el de Paja y Utensilios, lo hagan los intendentes al igual que los encabezamientos de rentas provinciales" ${ }^{528}$. Esta notificación tiene una rápida contestación por parte de la Diputación. En el mes de diciembre presenta y aprueba los repartimientos de la contribución de Paja y Utensilios, nuevo impuesto o nueva denominación que se reparte por primera y única vez. Además presenta el repartimiento de la contribución de Culto y Clero. Y para solucionar las urgencias que provocan estos trabajos en la Diputación se presenta una moción del diputado por Peñafiel D. Millán Alonso, en la que solicita mayor rapidez ${ }^{529}$. En definitiva, lo que pide el diputado es que la comisión de contribuciones trabaje un mayor número de días para tener todos los expedientes estudiados y ser aprobados en los días que se celebre pleno de la Diputación.

En el año 1845, se inicia un nuevo sistema de contribuciones estatales, cuya responsabilidad de repartimiento es concedida a las Diputaciones. Por real decreto de 1 de agosto "se aprueba el repartimiento de 300 millones, impuesto por la Ley de Presupuestos sobre el producto líquido de los Bienes Inmuebles, de Cultivo y Ganadería..., siendo el cupo señalado a esta provincia (de Valladolid) el de 5.758.000 reales..." 530 . Como es habitual, la Diputación nombra una comisión para que proceda al referido repartimiento, para lo cual toman las mismas bases que se utilizaron para

525 A.H.M.V. Libro de Actas n ${ }^{\circ} 128$ del Ayuntamiento de Valladolid de 11 de febrero de 1843.

526 A.D.P.V. Actas. Libro de actas del 20 de febrero de 1843.

527 A.D.P.V. Actas. Libro de actas de 19 de mayo de 1844. Es significativo el atraso en el cobro, pues esta contribución se inició por R.O. de 3 de noviembre de 1837.

528 A.D.P.V. Actas. Libro de actas del 26 de noviembre de 1847.

529 "que en atención a los embarazos que sufre la recaudación de las contribuciones generales por la falta de aprobación de los repartimientos y de la resolución de las reclamaciones que proceden de los mismos, cuyas circunstancias hacen imposible las cuotas señaladas a los pueblos y a los contribuyentes, continúe la Diputación conociendo interinamente de estos negocios en tanto que el Gobierno de S.M .determine lo que crea conveniente" A.D.P.V. Actas. Moción presentada en la sesión del 14 de febrero de 1845.

530 A.D.P.V. Actas. Libro de actas del 11 de agosto de 1845. 
las contribuciones de Culto y Clero, impuesto que no vuelve a aparecer. Este nuevo impuesto es protestado "por agravio comparativo" por la mayoría de los diputados provinciales, como manifiestan en su exposición los Sres. Rueda, Montealegre y Gusano ${ }^{531}$.

Independientemente de la reclamación al Gobierno sobre lo injustos que son para la provincia los nuevos impuestos, la Diputación tiene que acatar las leyes y presenta un repartimiento que una vez aprobado es publicado en el Boletín Oficial de la Provincia ${ }^{532}$. Ante el gran número de protestas que se suceden, la Diputación "acuerda nombrar una comisión para que teniendo presente los puntos que la sugiera su ilustración, redacte el proyecto de una exposición relativa a los inconvenientes del sistema tributario" ${ }^{533}$. La Diputación pues, ante el aumento de la presión recaudatoria para unas economías débiles, tiene que hacer frente a muchas quejas y reclamaciones, entre las que abundan las efectuadas "por abuso en el cobro de contribuciones" y "por el cobro de la contribución de Inmuebles". En otros casos son personas conocidas, como "Millán Alonso e Hipólito Gómez de Palacios, dueños de Retuerta, que se quejan de la contribución de Inmuebles".

Pero la mayor dificultad para que los impuestos sean equitativos, como reconoce la comisión nombrada para fijar "las bases", estriba en la poca fiabilidad de los datos que se manejan, tanto por las autoridades locales, provinciales y nacionales, "porque los pueblos desfiguran su riqueza en los amillaramientos". Esto hace suponer que nadie dice la verdad ni conoce la verdadera riqueza de la provincia.

El año 1846, una vez pasado el descontento general provocado por los nuevos impuestos, no ofrece grandes novedades. Se aprueban y se reparten las contribuciones de Inmuebles, Cultivo y Ganadería, divididas en dos semestres. El primero asciende a 2.399 .000 reales y el segundo a 2.240.000. La cantidad era inferior en 1.119.000 reales al repartimiento del año anterior, lo que prueba la justicia de las reclamaciones tanto de los ciudadanos como de la Diputación.

Para el año 1847, el Sr. intendente de Rentas comunicó que "ejecutado por esta Intendencia de Rentas el repartimiento de los 4.480 .000 reales señalados a la provincia por la contribución de Inmuebles, Cultivo y Ganadería en el General de 250 millones para el año 1847, lo paso a manos de V.S. para que se sirva darle su conformidad.... ${ }^{534}$. La cantidad de 4.639 .000 reales, que correspondió al año 1846, se repite en el mismo repartimiento de contribución de Inmuebles, Cultivo y Ganadería, correspondiente al año 1848 y que "afectó a los 278 pueblos de la provincia" 535. En este año, además de esta contribución, la Diputación tiene que hacer su repartimiento de 379.432 reales, "con objeto de cubrir el déficit de los presupuestos provinciales" ${ }^{536}$. Presupuestos que hasta estas fechas no aparecen en las actas de la Diputación, pero que a partir de estos años aparecerán sistemáticamente. Y se reflejarán con dos actuaciones, ambas gravosas para la provincia, un repartimiento de los presupuestos y a los pocos meses un nuevo repartimiento para cubrir el déficit y el "presupuesto supletorio". La presión fiscal del año 1848 se completa con la aparición de un real

531 “considerando que en la contribución Extraordinaria de Guerra de los 600 millones, hubo provincias con más cupo que esta, y en la actualidad, respecto a la de Inmuebles, sucede lo contrario, por lo que desean saber las causas del cambio y del daño gravísimo a la provincia, y solicitan al gobierno de S.M. la rebaja del cupo, compatible con la riqueza de la provincia. Se aprobó el envío de una exposición al gobierno haciéndose extensiva al nuevo sistema tributario" A.D.P.V. Actas. Moción de los diputados citados y acuerdo del pleno en la sesión del día 16 de agosto de 1845 .

532 B.O.P.V. $\mathrm{n}^{\circ} 117$ de fecha 30 de septiembre de 1845 , en la que se publica "el repartimiento de los 2.879.000 reales, mitad del cupo que le correspondió a la provincia en la contribución de Inmuebles, Cultivo y Ganadería”, con la relación de lo que corresponde a cada uno de los 275 pueblos de la provincia.

533 A.D.P.V. Actas. Acuerdo tomado en la sesión celebrada el 3 de diciembre de 1845. La comisión estaba compuesta por los Sres. Alonso, Santana y Gusano.

534 A.D.P.V. Actas. Libro de actas del 11 de diciembre de 1846.

535 B.O.P.V. $\mathrm{n}^{\circ} 145$ de fecha 4 de diciembre de 1847.

536 B.O.P.V. n ${ }^{\circ} 146$ de fecha 7 de diciembre de 1847. 
decreto "sobre cobranza de un anticipo forzoso de 100 millones. De esta cantidad le corresponde a Valladolid 1.700 .000 reales", "el repartimiento de esta cantidad se realiza entre los 1529 mayores contribuyentes" $" 537$.

El año 1849, se inicia con la presentación y aprobación de los presupuestos provinciales que aparecen en las actas, sin detallar las partidas de gastos e ingresos. Pero sí se señala que tienen que hacer frente a un déficit de 879.943 reales, a través de repartimientos y de recargos en las contribuciones normales. La contribución de Inmuebles, Cultivo y Ganadería se aprueba con su correspondiente repartimiento, cuyo total asciende a la cantidad de 4.480 .000 reales, cantidad que también correspondió en el año 1847. El año se remata con una contribución extraordinaria y su "repartimiento de 896.000 reales de vellón que corresponden a la provincia por el aumento de 50 millones de la contribución Territorial" 538 .

Los impuestos correspondientes al año 1850, referidos a la contribución de Inmuebles, Cultivo y Ganadería, ascienden a la cantidad de 5.391.209 reales. Cantidad que supera en casi un millón a la que correspondió en el año anterior. Tras ser aprobados, apenas se presentaron reclamaciones o agravios "por entender la Diputación, que los amillaramientos han sido realizados por los respectivos pueblos y

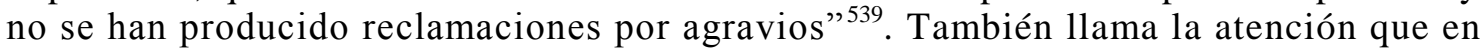
este año se presenten y aprueben unos presupuestos provinciales con un déficit mínimo de 11.722 reales, resultado de presentar unos ingresos de 1.226 .981 y unos gastos de 1.237.703.

En el año económico de 1851, aparece nuevamente el "Impuesto de Culto y Clero", con un importe de 2.592.558 reales, y sobre cuya cantidad se prepara el correspondiente repartimiento. La contribución de Inmuebles, Cultivo y Ganadería, asciende a la cantidad de 5.406.000 reales. El presupuesto provincial se cierra con la aprobación de unos ingresos de 1.555.901 reales y unos gastos de 1.491.399, resultando un superávit de 64.502 reales. Como dato a tener en cuenta, resaltamos que es la primera y única vez que las cuentas se presentan y aprueban con superávit.

Para el año 1852 se presentan unas cuentas provinciales con un déficit de 315.987 reales, y la comisión de contribuciones no especifica la forma de cubrir el citado déficit. Igualmente por la Intendencia de Rentas se presenta el repartimiento de la contribución de Inmuebles, Cultivo y Ganadería, con una cantidad idéntica al año anterior, es decir, 5.406.000 reales.

El año 1853 presenta unos presupuestos provinciales con unos ingresos que ascienden a 929.364 reales y unos gastos de 1.319.934 reales, resultando un déficit de 290.570 reales. Para equilibrar los presupuestos, la Diputación solicita al gobierno autorización para recargar en un $8 \%$ la contribución Territorial. La contribución de Inmuebles, Cultivo y Ganadería asciende a 5.437.000 reales, cantidad que según la Intendencia de Rentas está basada en los datos obtenidos por el amillaramiento de la provincia, que está cifrado en 52.282.984 reales, cifra que aparece por vez primera como justificativa de la contribución.

Estos son unos años tranquilos, si nos referimos a la ausencia de contribuciones extraordinarias, situación que no se da desde el año 1849. Lo que redunda en la tranquilidad de la provincia a nivel impositivo, y de la Diputación, al reducir su carga de trabajo tanto de repartimientos como de reclamaciones. Suponemos que también es debido a una bonanza de la situación económica del país. Ejemplo de esta situación es la transformación de la Deuda que mantiene la provincia con la Hacienda Pública, como pone de manifiesto la "Comisión Central de Liquidación de Débitos", que "reclama a la provincia de Valladolid 1.600.000 reales de vellón de atrasos de la Contribución Extraordinaria de Guerra, contribuciones

537 B.O.P.V. no 78 y 81 de 29 de junio y 6 de julio de 1848 .

538 B.O.P.V. $n^{\circ} 89$ de 26 de julio de 1849.

539 A.D.P.V. Actas. Libro de actas del 27 de octubre de 1849. 
civiles, y subsidios" ${ }^{540}$. Ante esta situación, el diputado a Cortes por Valladolid, Benito Fernández Maquieira, "se ofrece para tratar de minorar en lo posible la citada cantidad, gestión en la que emplearía las influencias de todos sus amigos" ${ }^{541}$. Este ofrecimiento se realizó en la audiencia que le concedió la Diputación el 8 de febrero de 1852. En verdad que los resultados fueron rápidos y satisfactorios, pues el 14 de mayo del mismo año, se leía en el Pleno de la Diputación una comunicación del referido diputado a Cortes en la que anuncia el resultado ${ }^{542}$. En conclusión, una deuda de 1,6 millones se transforma en un pago efectivo de 70.000 reales, "pago que se realizó a través de siete cartas de pago expedidas por la Tesorería el 16 de junio de $1852^{\prime \prime 543 . ~}$

Para el año 1854 se presentan unas cuentas provinciales con un gran desfase entre los ingresos de 529.449 reales y los gastos de 1.711 .464 , lo que genera un déficit que asciende a 1.182 .015 reales. "Utilizando todos los recargos permitidos por la ley, sólo se cubrirían 935.347 y por el resto de 246.668 reales, se solicita autorización del gobierno para efectuar un nuevo recargo en la contribución Territorial" ${ }^{544}$. Además de esos repartimientos extraordinarios para equilibrar los presupuestos, y ante la negativa del gobierno a la petición de nuevos recargos, a la Diputación no le queda otra solución que aplazar el pago de los débitos que mantiene con los diferentes contratistas de las carreteras de Zaragoza y de Zamora. Los desastres económicos de la Diputación no acaban con esta deuda, pues en marzo de este año de 1854 tiene que presentar un nuevo "presupuesto adicional" que presenta un déficit de 716.658 reales. Viene motivado especialmente por los trabajos extraordinarios de las carreteras y ferrocarriles, y para solucionar el problema no tienen otra salida que añadir más recargos ${ }^{545}$.

Los impuestos correspondientes al año 1855 se inician con la presentación en el mes de mayo de 1854 de unos presupuestos provinciales con unos gastos que están igualados con los ingresos en 1.423 .602 reales. Pero como para equilibrarlos han tenido que gravar los impuestos estatales, en cantidad superior a la permitida por el gobierno, la Diputación, en solicitud enviada, "ruega al gobierno de S.M la aprobación por este año de los recargos que propone la comisión, aunque excedan del $8 \%$ y $10 \%$, teniendo en cuenta las circunstancias extraordinarias en que se halla la provincia" ${ }^{, 46}$. En vísperas del año 1855 se había aprobado el repartimiento de 5.437.000 reales correspondiente a la contribución de Inmuebles, Cultivo y Ganadería, de acuerdo con la real orden de 15 de septiembre y "la comisión de contribuciones, una vez dada su conformidad a este repartimiento procedió a añadir a esta cantidad el recargo correspondiente de los déficits presupuestarios de la provincia, lo que dio

540 A.D.P.V. Actas. Libro de actas del 8 de febrero de 1852.

541 A.D.P.V. Actas. Libro de actas del 8 de febrero de 1852. Uno de los amigos que destaca es el ministro de Fomento y ex-diputado a Cortes Mariano Miguel de Reynoso.

542 "S.M. se ha dignado condonar tres cuartas partes de 1.280.499 reales a que quedó reducida la deuda de 1.600 .000 por contribuciones atrasadas, y mandar que los 320.125 reales de la cuarta parte restante se pagara en títulos de la Deuda diferida del 3\%, que hallándose sobre el $22 \%$ del valor nominal, quedaría completamente libre la provincia con el desembolso de 70.000 reales" .A.D.P.V. Actas. Libro de actas del 14 de mayo de 1852.

543 A.D.P.V. Actas. Libro de actas del 22 de junio de 1852.

544 A.D.P.V. Actas. Libro de actas del 14 de junio de 1853.

545 “teniendo en cuenta que ya están gravadas al máximo la contribución Territorial, el subsidio y los consumos, la corporación propone como únicos recursos el recargo del 4\% sobre la riqueza territorial y pecuaria de la provincia que rendirá 217.812 reales y un $2 \%$ sobre la matrícula del Subsidio y del Comercio que producirá 21.000 reales... y, para el resto, se pide autorización para aplazar el pago el mayor número de años las partidas del capítulo $4^{\circ}$ del presupuesto ordinario..." A.D.P.V. Actas. Libro de actas de 8 de marzo de 1854. El capítulo $4^{\circ}$, es el referido a las Obras Públicas, en el que destacan los cargos a pagar a los contratistas de las carreteras de Zamora y Calatayud.

546 A.D.P.V. Actas. Libro de actas del 17 de mayo de 1854. Se refleja el acuerdo de gravar la contribución Territorial en un $14 \%$ en lugar del $10 \%$ autorizado y la contribución Industrial y Comercial en un $12 \%$ en lugar del $8 \%$ que autorizó el Gobierno. 
como resultado un repartimiento que asciende a un total de 6.568 .418 reales" ${ }^{547}$. A lo largo de 1855, la provincia tenía que hacer frente a dos nuevos recargos. El primero se corresponde con la presentación de un presupuesto adicional por parte de la Diputación y el correspondiente repartimiento para cubrir el déficit resultante y que asciende a 488.500 reales. El supuesto recargo corresponde a una comisión extraordinaria de 230 millones de billetes del Tesoro, correspondiendo a Valladolid la cantidad de 3.939.000 reales "a repartir entre los mayores contribuyentes de la provincia”.

Las contribuciones correspondientes al año 1856 han sido reflejadas en las actas correspondientes de una forma muy parca. En lo referente a los presupuestos provinciales, no aparece cantidad alguna. Sí se hace "especial referencia a los créditos de los empresarios de las carreteras en los presupuestos provinciales y se acordó una liquidación general de los atrasos junto a los pagos a efectuar en el año corriente" Por lo que respecta a las contribuciones estatales, por la real orden de 9 de noviembre, se convoca a las Diputaciones para que "se ocupen preferentemente de la derrama de 300 millones de la contribución territorial para el año $1856 \ldots$, resultando para la provincia de Valladolid una cuantía de 5.432.000 reales, correspondientes a los Bienes Inmuebles, Cultivo y Ganadería" ${ }^{549}$.

En lo correspondiente al año 1857, en un intento por mejorar los presupuestos, se formó, recién iniciado el año, una comisión compuesta por los Sres. Alonso, Moreno y Cafranga, que constatan y proponen que, "haciéndose cargo la Diputación del considerable déficit de 2.5 millones de reales que resultaba del presupuesto provincial para el año corriente, de la dificultad de cubrirle, aunque se apelase a todos los recursos ordinarios y extraordinarios..., se propone y se acordó enajenar el título de 300 acciones de 2.000 reales del ferrocarril de Alar a Santander..."550. Y aunque tuvieron buena voluntad, la comisión presentó y el Pleno aprobó los presupuestos con un déficit de 836.923 reales. También se aprobó el repartimiento correspondiente a la contribución de Inmuebles, Cultivo y Ganadería, presentado por la Administración de la Hacienda Pública y que ascendía a la cantidad de 6.343.167 reales.

El presupuesto provincial correspondiente al año 1858 se inicia en junio del año anterior, aprobándose en el mes de noviembre con las siguientes cifras: Ingresos 516.381; Gastos 1.508.076; Déficit 991.695 reales. La aprobación tuvo lugar sin especificar el sistema a utilizar para cubrir el déficit, y esta situación se agravó cuando en el mes de mayo se aprobó un presupuesto adicional con 563.151 reales de déficit. En lo referente a los impuestos estatales, se procedió al repartimiento de 6.343.167 reales por contribución de Inmuebles, Cultivo y Ganadería. A lo que hubo de añadir una contribución extra-ordinaria de 50 millones aprobada por ley de 25 de marzo de 1858 lo que representó un repartimiento adicional a la provincia de Valladolid de 1.250.976 reales. Es tónica habitual en estos años la continua aparición de presupuestos adicionales y repartimientos extraordinarios, lo que complica el dominio sobre la situación real de la economía y la cantidad que los ciudadanos de la provincia tienen que dedicar a los impuestos.

El presupuesto provincial de 1859 se presenta para su discusión en septiembre de 1858 , en la sesión celebrada el día 12 , donde se reflejan una serie de modificaciones, pero no se indican las cifras definitivas ni se deja constancia de su aprobación. Lo que sí quedó reflejado es el presupuesto adicional con resultados muy equilibrados, pues recoge unos ingresos de 958.634 reales y tiene previstos unos gastos de 975.119 reales, con un mínimo déficit de 16.485 reales. En lo concerniente a la contribución de Inmuebles, Cultivo y Ganadería, la Diputación aprueba el repartimiento de 7.594 .145 reales correspondientes a la provincia.

A.D.P.V. Actas. Libro de actas del 15 de febrero de 1855.

549 A.D.P.V. Actas. Libro de actas del 20 de noviembre de 1855.

550 A.D.P.V. Actas. Libro de actas del 24 de febrero de 1857. 
Para el año 1860 la Diputación presenta y aprueba unos presupuestos provinciales "habituales" con unos ingresos de 590.503 reales, unos gastos de 1.825 .639 y con un déficit resultante de 1.235 .136 reales. El déficit será absorbido a través de la imposición de una serie de arbitrios en las contribuciones Territorial, Industrial y de Consumos ${ }^{551}$. Para el mismo año, la Diputación aprueba el repartimiento de 7.657 .590 reales en concepto de contribución de Inmuebles, Cultivo y Ganadería, que es presentado por la Hacienda Pública.

En el año 1861, los presupuestos provinciales presentan unos gastos de 1.868.163 y unos ingresos de 685.163 reales, con el resultado de un déficit de 1.163 .000 reales, que como es habitual serán equilibrados con recargos en las contribuciones Territorial, Industrial y de Comercio. Como detalle fuera de lo normal, en este año no se produce el presupuesto adicional. Con referencia a la contribución de Inmuebles, Cultivo y Ganadería, se presenta un repartimiento de 7.657.590 de reales, cantidad idéntica a la repartida en el año anterior. Para colmo de desgracias, además de las penurias económicas que sufre la Diputación, se produce en este año un robo en la Depositaría provincial ${ }^{552}$.

Los presupuestos de 1862 de carácter provincial presentan unas cifras de ingresos de 673.555 y unos gastos de 2.138 .720 con un déficit que asciende a 1.465.165, para cubrirlo se aprueban una serie de arbitrios y recargos sobre los impuestos nacionales. Estos presupuestos son complementados con el presupuesto adicional presentado en el mes de mayo formado por unos ingresos de $1.069 .529 \mathrm{y}$ unos gastos de 965.226 reales con un superávit de 104.303 reales. Con respecto a los impuestos nacionales, se presentan los repartimientos para la contribución Territorial de Inmuebles, Cultivo y Ganadería con una cantidad global de 7.657 .590 reales, cantidad idéntica a la del año anterior.

Para el año 1863, se vuelve a repetir la cantidad que se repartió en los años anteriores, sobre la contribución de Inmuebles, Cultivos y Ganadería, es decir, la de 7.657.590 reales. Los presupuestos provinciales, que según las actas "son formados por el Sr. gobernador", recogen unas cifras de ingresos de 807.906 y gastos de 2.703.620 con un déficit de 1.895 .714 reales, presupuesto que será equilibrado con la habitual forma de gravar con arbitrios y porcentajes en los diferentes impuestos de carácter nacional. En mayo de este año, se presentan unos presupuestos adicionales, que tienen la virtud y la rareza de cuadrar sus cifras, pues tanto los ingresos como los gastos se fijan en 1.007.473 reales. En junio del mismo 1863, por real decreto se modifican el principio y fin del año económico, iniciándose a partir del 1 de julio y dándose por terminado el 30 de junio del año siguiente. Para este nuevo período económico 1863-64, la contribución de Inmuebles, Cultivo y Ganadería, vuelve a repetir el repartimiento de 7.657.590, apuntándolo como es lógico a los presupuestos aprobados en enero de 1863, es decir, el repartimiento se realizará sobre el $50 \%$ de la cantidad para cubrir el primer semestre del año 1864. Con respecto a los presupuestos provinciales, la Diputación presenta para el nuevo año económico un presupuesto formado por ingresos: 865.021; gastos: 3.257 .267 con un déficit resultante de 2.392.246 reales, aprobándose al mismo tiempo las propuestas de arbitrios para cubrir el déficit.

Para el año económico 1864-65, se presentan unos presupuestos provinciales compuestos por unos ingresos de 979.913, gastos de 3.204.274 y un déficit de 2.224.361 reales, aprobándose igualmente el correspondiente sistema para cubrir el déficit a través de recargos en los impuestos. El déficit como vemos de año en año va

551 A.D.P.V. Actas. Libro de actas del 8 de junio de 1859.

552 "Expediente del robo acaecido en la Depositaria el día 20 de mayo, por el que los ladrones horadaron el techo del cuarto del arca de fondos, y taladrada esta con un berbiquí se habían extraído 71.024 reales con 33 céntimos" A.D.P.V. Actas. Libro de actas del 12 de junio de 1861 . A través del relato de los hechos, la Diputación admite unas pérdidas de sus fondos de 27.524,33 reales y el resto hasta los 71.024,33 reales robados, son 7.500 reales pertenecientes al depositario y 36.000 reales depositados en la caja por D. Ángel Chamoso. 
en aumento, aunque este año nos sorprende el presupuesto adicional al presentar unas cifras de ingresos de 3.164.674, gastos de 300.250 y un superávit de 2.634.361. Este sobrante, según la Diputación, se destinará a la construcción de caminos vecinales, sin especificar en detalle de dónde proceden tan abultados ingresos. Con respecto al repartimiento de la contribución de Inmuebles, Cultivo y Ganadería en este período 1864-65, se aprueba por la cantidad de 7.702.135 reales, basado en la riqueza provincial de 58.873 .338 reales. En este año se produce un repartimiento adicional de 583.568 reales, que le corresponden a la provincia por recargo de un repartimiento extraordinario de 30 millones, según real decreto de 25 de junio de 1864 .

Una novedad en el año económico 1865-66 es el cambio de moneda, desapareciendo el real y en su lugar las cuentas se presentan en escudos ${ }^{553}$. El presupuesto provincial asciende a 101.156 de ingresos, 397.650 de gastos, con un déficit de 296.494 escudos, que se cubren con arbitrios extraordinarios. Estos presupuestos se complementan con los adicionales que vuelven a ser extraños, pues presentan más cifras de ingresos de 351.133, gastos de 148.694 y superávit de 202.439 escudos. Con el nuevo período económico se presenta un repartimiento de la contribución de Inmuebles, Cultivo y Ganadería por la cantidad de 830.114 escudos.

El año económico 1866-67, presenta un presupuesto provincial de 110.851 en ingresos, 408.316 en gastos y déficit de 297.465, que será "enjugado" a través de arbitrios. Con la novedad que en este año no se presenta presupuesto adicional. El repartimiento en este mismo período de la contribución de Inmuebles, Cultivo y Ganadería, repite la misma cifra que el año anterior de 830.114 escudos.

El presupuesto provincial para el período 1867-68 se aprueba con las cantidades de 135.839 de ingresos, 413.548 de gastos y un déficit de 277.709 escudos. En este período tampoco aparece presupuesto adicional, y el déficit es cubierto a través de arbitrios sobre la contribución ${ }^{554}$. La contribución sobre Inmuebles, Cultivo y Ganadería, vuelve a repetir su repartimiento que asciende a 830.114 escudos.

Para el período 1868-69, último año de esta época, se mantiene la misma tónica de un alto déficit, amortizado con recargos. Sigue la ausencia de presupuesto adicional. Los presupuestos provinciales se aprueban con unos ingresos de 155.042 escudos, gastos de 419.541 escudos y déficit de 264.499 escudos. El repartimiento de la contribución de Inmuebles, Cultivo y Ganadería asciende a 913.125 escudos.

A lo largo de estos años hemos podido evaluar la continua subida de los impuestos de nivel estatal. Vemos cómo la contribución de Inmuebles, Cultivo y Ganadería, impuesto que se inició en el año 1845, con un montante, traducido a escudos, de 575.800 en el repartimiento de aquel año a los 913.125 escudos que representó el repartimiento de este último año. En estos veinticuatro años, la presión fiscal subió el $63,1 \%$.

Por otra parte, hemos visto cómo los presupuestos provinciales han evolucionado en función de las necesidades de la Diputación y han tenido que hacer frente a los gastos para mantener su actividad a través de gravar con recargos los impuestos estatales.

Como resumen de las actividades contributivas en estos años de la época isabelina, adjunto presentamos un cuadro con la evolución de los impuestos de carácter nacional, reflejados en reales de vellón, unidad monetaria de curso legal en los años citados. Los años 1837, 1839 y 1843 no están reseñados por falta de información en las actas de la Diputación.

553 El cambio de unidad monetaria de real a escudo, se publicó en la Gaceta de Madrid n ${ }^{\circ} 139$ del día 18 de mayo de 1864, aunque no se tuvo en cuenta hasta el inicio de este año económico. La unidad es de 1 escudo $=10$ reales y la presión fiscal es similar.

554 La cuantía del porcentaje a gravar en los arbitrios en todos estos años se mantiene en los siguientes parámetros: 5\% de recargo sobre la contribución de Inmuebles, Cultivo y Ganadería. 10\% de recargo sobre la contribución Industrial y de Comercio. $45 \%$ de recargo sobre el subsidio de Consumo en todos los pueblos. 
A partir del año 1865, la unidad monetaria pasa del real de vellón al escudo y para dar una visión de continuidad al cuadro, durante los últimos cuatro años hemos pasado las cifras presupuestadas en escudos a reales.

\section{Cuadro con la evolución de los impuestos de carácter nacional}

\begin{tabular}{|c|c|c|c|}
\hline AÑ̃ & $\begin{array}{l}\text { Contribución } \\
\text { Extraordinaria }\end{array}$ & $\begin{array}{c}\text { Contribución de } \\
\text { Culto y Clero }\end{array}$ & $\begin{array}{l}\text { Contribución de Inm } \\
\text { Cultivo y Ganad }\end{array}$ \\
\hline 1836 & 4.200 .000 & & \\
\hline 1838 & 9.878 .856 & & \\
\hline 1840 & 3.075 .303 & & \\
\hline 1841 & & 1.288 .425 & \\
\hline 1842 & & 1.448 .280 & \\
\hline 1844 & & 1.288 .425 & \\
\hline 1845 & & & 5.758 .000 \\
\hline 1846 & & & 4.639 .000 \\
\hline 1847 & & & 4.480 .000 \\
\hline 1848 & 1.700 .000 & & 4.639 .000 \\
\hline 1849 & 896.000 & & 4.480 .000 \\
\hline 1850 & & & 5.391 .209 \\
\hline 1851 & & 2.592 .558 & 5.406 .000 \\
\hline 1852 & & & 5.406 .000 \\
\hline 1853 & & & 5.437 .000 \\
\hline 1854 & & & 5.445 .300 \\
\hline 1855 & 3.939 .000 & & 5.437 .000 \\
\hline 1856 & & & 5.432 .000 \\
\hline 1857 & & & 6.343 .167 \\
\hline 1858 & 1.250 .976 & & 6.343 .167 \\
\hline 1859 & & & 7.594 .145 \\
\hline 1860 & & & 7.657 .590 \\
\hline 1861 & & & 7.657 .590 \\
\hline 1862 & & & 7.657 .590 \\
\hline 1863 & & & 7.657 .590 \\
\hline $1863-64$ & & & 7.657 .590 \\
\hline $1864-65$ & & & 7.702 .135 \\
\hline $1865-66$ & & & 8.301 .140 \\
\hline $1866-67$ & & & 8.301 .140 \\
\hline $1867-68$ & & & 8.301 .140 \\
\hline $1868-69$ & & & 9.131 .250 \\
\hline
\end{tabular}

Como dato comparativo, la Diputación de León en el año 1843 y con un número de habitantes similar a la de Valladolid, pasó unos repartimientos de la contribución de Inmuebles, Cultivo y Ganadería por un importe de 5.839.000 reales, cifra similar a la de Valladolid.

Durante los primeros años de funcionamiento de la Diputación, no hay constancia en las actas de la presentación y aprobación de presupuestos en el Pleno correspondiente. Únicamente están reflejadas las autorizaciones para repartir entre los pueblos de la provincia un mínimo de dinero necesario para cubrir los gastos más urgentes, práctica utilizada por la mayoría de las Diputaciones. Así vemos que en el año 1843 Guadalajara presenta un repartimiento de 181.154 reales con el fin de cubrir los gastos de funcionamiento previstos, y lo mismo ocurre con Segovia que reparte 177.915 y Ciudad Real 105.503 reales de vellón.

Otro dato significativo es que la incidencia en la menor recaudación y en el mayor número de reclamaciones, así como del envío de comisionados para activar los cobros, coinciden como es natural con los años de crisis económica ocasionados por las malas cosechas. 
Con referencia a los presupuestos provinciales en el siguiente cuadro quedan reflejadas las cuentas provinciales presupuestas a lo largo del período isabelino.

\begin{tabular}{|c|c|c|c|c|}
\hline AÑO & INGRESOS & GASTOS & DEFICIT & SUPERAVIT \\
\hline 1848 & - & - & 379.433 & - \\
\hline 1849 & - & - & 879.943 & - \\
\hline 1850 & 1.226 .981 & 1.237 .703 & 11.722 & - \\
\hline 1851 & 1.555 .901 & 1.491 .399 & - & 64.502 \\
\hline 1852 & - & - & 315.987 & - \\
\hline 1853 & 929.364 & 1.319 .934 & 290.570 & - \\
\hline 1854 & 529.449 & 1.711 .464 & 1.182 .015 & - \\
\hline Adicional & - & - & 716.658 & - \\
\hline 1855 & 1.432 .602 & 1.423 .602 & - & - \\
\hline Adicional & - & - & 488.500 & - \\
\hline 1856 & - & - & 1.161 .418 & - \\
\hline 1857 & - & - & 836.923 & - \\
\hline 1858 & 516.381 & 1.508 .076 & 991.695 & - \\
\hline Adicional & - & - & 563.151 & - \\
\hline 1859 & 958.634 & 975.119 & 16.485 & - \\
\hline 1860 & 590.503 & 1.825 .639 & 1.235 .136 & - \\
\hline 1861 & 685.163 & 1.868 .163 & 1.163 .000 & - \\
\hline 1862 & 673.555 & 2.138 .720 & 1.465 .165 & - \\
\hline Adicional & 1.069 .529 & 965.226 & - & 104.303 \\
\hline 1863 & 807.906 & 2.703 .620 & 1.895 .714 & - \\
\hline Adicional & 1.007 .473 & 1.007 .473 & - & - \\
\hline $1863-64$ & 865.021 & 3.254 .267 & 2.392 .246 & - \\
\hline $1864-65$ & 979.913 & 3.204 .274 & 2.224 .361 & - \\
\hline Adicional & 3.164 .674 & 300.250 & - & 2.634 .361 \\
\hline $1865-66$ & 1.011 .560 & 3.976 .500 & 2.964 .940 & - \\
\hline Adicional & 3.511 .330 & 1.486 .940 & - & 2.024 .390 \\
\hline $1866-67$ & 1.108 .510 & 4.083 .160 & 2.974 .650 & - \\
\hline $1867-68$ & 1.358 .390 & 4.135 .480 & 2.777 .090 & - \\
\hline $1868-69$ & 1.550 .420 & 4.195 .410 & 2.644 .990 & - \\
\hline Adicional & 5.425 .550 & 7.029 .920 & 1.604 .330 & - \\
\hline
\end{tabular}

Como indicábamos con anterioridad a este cuadro, los presupuestos en él reflejados se corresponden con lo presupuestado, pero por supuesto que no con lo recaudado, ya que, dada la miseria en la que se desenvuelve la provincia, podemos calcular un cumplimiento de la recaudación que oscila entre el $40 \%$ y el $50 \%$, cantidad similar a la estimada por Pastrana Morilla en su estudio sobre esta misma Diputación en los años posteriores a la Restauración.

Finalmente, y como queda demostrado en el citado cuadro, las cuentas provinciales son un desastre de fiabilidad, de cumplimiento y de orden presupuestario, pues es inconcebible los grandes desfases entre los ingresos y los gastos y los continuos déficits originados a lo largo de estos años fruto de unas cuentas poco 
fiables, con grandes fallos en las previsiones de ingresos y con un grave descontrol de los gastos.

\subsection{4.- LOS IMPUESTOS EN EL SEXENIO. 1868-1874}

La llegada de una nueva forma de Gobierno fue recibida en principio con grandes esperanzas por parte de la población, sobre todo teniendo en cuenta que el período isabelino, en materia de impuestos y su recaudación, fue un completo desastre. También es cierto que esas "grandes esperanzas" se desvanecieron de una forma rápida, pues tenemos que reconocer que el año 1868, "a caballo" entre los dos períodos, no se puede considerar para la provincia de Valladolid como un año bueno, económicamente hablando. Más bien todo lo contrario pues nos encontramos con un año marcado por la sequía y la consiguiente pérdida de la cosecha, lo que conlleva como hemos repetido hasta la saciedad hambre, miseria y desesperación para los vallisoletanos.

Esta preocupación se hace patente con las iniciales actuaciones de la primera Diputación del Sexenio, que continúa con interés los trabajos para sacar adelante las ayudas que se habían iniciado en la anterior corporación. Éstas consistían en la suscripción de un empréstito de 600.000 escudos, con la previa autorización del gobierno, a través de una subasta pública para cubrir esa cantidad. Subasta que resultó un fracaso, pues en las dos ocasiones que se procedió a licitar el empréstito, sólo se consolidó una propuesta de compra de 6.000 escudos. Lógico fracaso teniendo en cuenta la situación económica y la dependencia de la mayoría de los habitantes de los resultados agrícolas.

Ante esta situación, la Diputación busca otras soluciones, y acuerda "reactivar la solicitud de un empréstito de 1,5 millones de escudos para atender las necesidades de la provincia y de su agricultura" ${ }^{555}$. Además en una exposición dirigida al gobierno, se acuerda que se estudie y se remedie ${ }^{556}$. En realidad, en la provincia no hay otra cosa que sequía y miseria y desde luego lo que no hay es dinero para cubrir las subastas del empréstito, y lo poco que se dispone se utiliza para pagar los impuestos.

A la que no la cuadran las cuentas es a la Diputación, ya que la comisión nombrada por la nueva corporación, para aprobar las cuentas provinciales, detecta "la existencia en la Caja provincial de 74.000 escudos en billetes del que fue Banco de Valladolid, correspondientes a las cuentas del año económico 1867-68. Se acuerda pedir responsabilidades al depositario de aquel año y a la Diputación existente puesto que este dinero no tiene valor" $"$ "557.

En el nuevo período político, la Diputación, para cubrir sus necesidades aprueba unos presupuestos adicionales presentados en el segundo semestre de 1869. Contemplan unos ingresos de 542.554 escudos y unos gastos de 702.992 escudos, con un déficit resultante de 160.433 escudos. Con la diferencia de que en esta ocasión y dados los problemas económicos que padece la provincia, acuerda que "para cubrir este déficit se propone la enajenación de 1594 Bonos del Tesoro que suscribió la Diputación" 558 . También a lo largo de este primer semestre de 1869, la Diputación acuerda conceder una serie de ayudas a diferentes pueblos "para paliar los efectos de

\footnotetext{
555 Boletín Oficial de la Junta Revolucionaria de Valladolid (a partir de ahora B.O.J.R.V.), Publicado en el $\mathrm{n}^{\circ} 16$ de fecha 16 de octubre de 1868 .

556،Que se estudie la grave situación de la provincia motivada por la pérdida de la cosecha a causa de la sequía y la necesidad de dar trabajo a los jornaleros y suministrar grano a los agricultores para la siembra y pedir al Ministerio de Hacienda provea a la provincia del grano necesario para la siembra, o en su defecto la cantidad en metálico equivalente para su compra y pedir al ministro de Fomento el realizar obras públicas para paliar el paro de los obreros. Como garantía de todo esto, se ofrece el $80 \%$ de las láminas de los bienes de Propios, los bienes del Común de los pueblos y el valor de las fincas nacionales desamortizadas". A.D.P.V. Actas. Libro de actas del 22 de octubre de 1868.

557 A.D.P.V. Actas. Libro de actas del 11 de diciembre de 1868.

558 A.D.P.V. Actas. Libro de actas del 4 de febrero de 1869.
} 
la sequía", ayudas basadas en la reducción o demora en el pago de las contribuciones y también autorizando la venta del patrimonio municipal.

El año económico 1869-70 se inicia aprobando el repartimiento de la contribución de Inmuebles, Cultivo y Ganadería, que repite la cantidad del año anterior y que asciende a 913.125 escudos. Por otro lado la Diputación, presenta y apruebe unos presupuestos provinciales, en la misma línea que los años anteriores, es decir, con un abultado déficit. Las cifras son las siguientes: ingresos 253.314, gastos 543.603 y déficit de 290.289 escudos. En esta ocasión no se detalla la forma de repartir el déficit para equilibrar las cuentas, pero sí se acuerda, en vista de la situación de la provincia "conceder el perdón de la contribución por pérdida de la cosecha del año 1869 a un total de ciento veinte pueblos de la provincia" ${ }^{559}$.

Los presupuestos del año 1870-71 se presentan con la novedad de la aparición de la nueva unidad monetaria, "la peseta", puesta en vigor recientemente y a la que se da una equivalencia de 1 peseta $=0,40$ escudos. Los presupuestos provinciales se acuerdan con unos ingresos de 382.285 pesetas, gastos de 1.273 .814 pesetas, con un déficit resultante de 891.529 pesetas. La cantidad se repartirá entre todos los pueblos de la provincia con base a un incremento en los repartimientos de la contribución Territorial y los subsidios. Nuevamente en enero de 1871 se presentan y aprueban unos presupuestos adicionales que están formados por unos ingresos de 1.139.494 pesetas, gastos por 589.599 pesetas, con un superávit de 549.895 pesetas. El dinero se utilizará para disminuir la deuda que la Diputación mantiene con los contratistas de las carreteras y ferrocarriles. La contribución de Inmuebles, Cultivo y Ganadería está cifrada en 2.864 .365 pesetas, cantidad de la que se presenta y aprueba el repartimiento para la provincia.

La situación económica no mejora, pues en los libros de actas se suceden una serie de peticiones de aplazamiento de los impuestos, peticiones de perdón de los mismos y las consabidas reclamaciones. Esta situación llega al extremo de que "los comisionados de apremio se quejan porque no consiguen realizar ningún cobro de las cuotas correspondientes a los gastos provinciales y no cobran ni las dietas" ${ }^{560}$.

Para el año económico 1871-72, se aprueban los presupuestos provinciales en la siguiente cuantía: ingresos 494.704, gastos 993.867, con un déficit resultante de 499.153 pesetas. El déficit se repercutió en los cupos de contribución de la provincia "entre los 237 pueblos con cantidades que oscilan entre los 88.652 pesetas que corresponden a Valladolid y las 125 pesetas a Fompedraza". A esta ley se añaden el presupuesto adicional que se aprueba con unos ingresos de 1.573 .710 pesetas, gastos de 477.692 y un superávit resultante de 1.096.018 pesetas. La contribución de Inmuebles, Cultivo y Ganadería, hace un repartimiento de 2.866 .926 pesetas.

El año 1872-73 continúa con el mismo sistema de aprobación de presupuestos provinciales, con déficit y presupuestos adicionales con superávit, sin tener referencia ni explicación del porqué de estos presupuestos tan contradictorios. Para los primeros tenemos ingresos de 411.325, gastos de 1.002.374, déficit de 591.049 pesetas. Para los segundos: ingresos de 1.528.644, gastos de 261.155, superávit de 1.267 .489 pesetas. Por contribución de Inmuebles, Cultivo y Ganadería, se aprueban unos repartimientos de 2.868.845 pesetas, cantidad similar a la de años anteriores.

En el año 1873-74 se presentan unos presupuestos provinciales, con unos ingresos de 422.727 , gastos de 983.426 y déficit de 560.699 pesetas y en el segundo trimestre se presentan unos presupuestos adicionales con unos ingresos de 1.360.763,

559 A.D.P.V. Actas. Libro de actas del 26 de febrero 1870. Está reflejado el detalle de todas las cantidades y todos los pueblos beneficiados. Las cantidades oscilan entre los 13.000 escudos perdonados a Rioseco y los 500 a Arroyo. Junto a este acta, aparece en hoja separada un "oficio del Gobierno Civil de Valladolid, no 1769 de fecha 25 de agosto de 1891, en el que "se reclama por la Delegación de Hacienda a la Diputación provincial la cantidad de 1.278.816 pesetas, importe de los perdones que concedió a 229 pueblos de la provincia por las calamidades que sufrió durante el año económico 1870-71".

560 A.D.P.V. Actas. Libro de actas del 27 de noviembre de 1870. 
gastos de 449.063 y un superávit de 911.700 pesetas. El planteamiento del año anterior se vuelve a repetir. En el mismo período se presenta un repartimiento por contribución de Inmuebles, Cultivo y Ganadería por importe de 3.187.691 pesetas.

En este período aparece una contribución extraordinaria, ordenada a través de la ley de 25 de agosto de 1873 , y un empréstito de 175 millones a repartir entre todas las provincias, correspondiendo a la de Valladolid la cantidad de 3.523 .190 pesetas, que se tendrá que distribuir entre todos los pueblos de la provincia. Ante esta petición la Diputación solicita al gobierno "que admita el pago de la parte correspondiente a la provincia, con el valor de las láminas por los bienes vendidos por los pueblos, ya que es el único medio de poder cubrir el cupo, dada la penuria económica en que se encuentra la provincia" $" 561$.

Ya al final del período, en el año económico 1874-75, se presentan y aprueban los presupuestos provinciales con ingresos de 411.493, gastos 868.828 resultando un déficit de 457.335, por el que se hace un repartimiento a toda la provincia. El presupuesto adicional, si lo hubo, ya que no lo hemos verificado por estar fuera del período estudiado, es de suponer que presentará las características de años anteriores, presentando un superávit, dedicado al pago de las numerosas deudas a los contratistas. El repartimiento correspondiente a la contribución de Inmuebles, Cultivo y Ganadería, es de 3.456.367 pesetas, cantidad que como podemos comprobar es ascendente, en la cuantía, a lo largo del período.

Con estas cantidades finaliza la relación de impuestos que sufren los vallisoletanos a lo largo del Sexenio, época que se inició con grandes esperanzas en materia económica, pero que acabó con penuria, con pobreza, con desencanto y con un poco más de miseria. Esta situación no fue mejorada por la Diputación, que como es habitual también se dedicó a ser fiel a las consignas del poder central. Acató y obedeció sin rechistar las decisiones de los diferentes gobiernos, tanto de la Monarquía como de la República, olvidándose de que una de las finalidades de su creación era la de "mejorar la vida de la provincia".

En los siguientes cuadros resumimos la actividad económica de la Diputación en materia de impuestos y de presupuestos a lo largo del Sexenio Revolucionario.

$\begin{array}{ccc}\text { AñNO } & \begin{array}{c}\text { CONTRIBUCIONES ESTATALES } \\ \text { Contribución } \\ \text { Extraordinaria }\end{array} & \begin{array}{c}\text { Contribución de Inmuebles } \\ \text { Cultivo y Ganadería }\end{array} \\ 1869-70 & & 2.282 .812 \\ 1870-71 & & 2.864 .365 \\ 1871-72 & & 2.866 .926 \\ 1872-73 & 3.523 .190 & 2.868 .845 \\ 1873-74 & & 3.187 .691 \\ 1874-75 & & 3.456 .367\end{array}$

Como vemos, la evolución de la presión fiscal entre los años 1869 y 1875, asciende al 66'04\% entre los 2'28 millones del año 69 y los 3'45 del 75.

Otro dato a tener en cuenta es la de la unidad monetaria, la peseta, con la que se confeccionan los presupuestos a partir del año 1870, unidad en la que están reflejadas la totalidad de las cantidades de estos cuadros.

Como podemos ver a continuación, los presupuestos provinciales durante este período se comportan de una forma similar a los que se realizan en la época isabelina. Continúan con sus excesivos déficits, lo que dificulta un desarrollo normal de las actividades de la Diputación y lo único que se consigue al presentar unas cifras tan dispares y de una forma tan constante es crear falsas expectativas y un mayor entorpecimiento de las actividades provinciales. 
PRESUPUESTOS PROVINCIALES

\begin{tabular}{l}
\multicolumn{1}{|c|}{$\mathbf{N} \mathbf{0}$} \\
$1869-70$ \\
$1870-71$ \\
Adicional \\
$1871-72$ \\
Adicional \\
$1872-73$ \\
Adicional \\
$1873-74$ \\
Adicional \\
$1874-75$
\end{tabular}

INGRESOS
633.285
385.285
1.139 .494
494.704
1.573 .710
411.322
1.528 .644
422.727
1.360 .763
411.493

GASTOS
1.359 .007
1.273 .814
589.599
993.867
477.692
1.002 .374
261.155
983.426
449.063
868.828

DÉFICIT
725.722
891.529
0
499.153
0
591.049
0
560.699
0
457.335

SUPERAVIT
0
0
549.895
0
1.096 .018
0
1.267 .489
0
911.700
0

Como datos comparativos, vemos que la Diputación de León en el año fiscal 1873-74 presenta unos presupuestos equilibrados de ingresos y gastos que ascienden a 566.597 pesetas y Ciudad Real presenta un déficit de 13.817 pesetas al fijar un presupuesto con unos ingresos de 724.451 y unos gastos que ascienden a 748.269 pesetas, ambas ciudades con unos presupuestos más equilibrados que los de Valladolid.

A lo largo de todos estos años hemos hecho una revisión de los impuestos, su cuantía y su repercusión en la economía ciudadana y hemos llegado a la conclusión de la antipatía y animadversión que han generado.

Sin embargo, hay un impuesto del que no hemos hablado, y que no está reflejado en estas páginas y era el que producía una mayor contestación por parte de la ciudadanía, el más odiado y el más criticado por todos. Nos referimos al impuesto de consumos, un impuesto de carácter municipal que gravaba todos los productos que se introducían en la ciudad. Este impuesto, y su abolición fue utilizado como bandera reivindicativa de los líderes revolucionarios y en consecuencia fue suprimido de una forma temporal en los períodos progresistas del Bienio y el Sexenio.

En Valladolid y durante el Sexenio, la presión popular hizo que el impuesto de consumos fuera abolido en los eufóricos primeros días de la Revolución, en octubre de 1868, aunque el Ayuntamiento muy pronto se dio cuenta de que sin los ingresos procedentes de los consumos no podía subsistir. El gobierno de la Nación, conocedor de los problemas municipales, creó en su sustitución el impuesto personal, decisión que no agradó a los contribuyentes y al mismo tiempo no solucionó el problema de la financiación municipal. Ante esta situación, el impuesto se repuso en junio de 1870. Con la proclamación de la Primera República, en febrero de 1873, se pidió nuevamente su abolición, pero en esta ocasión el Ayuntamiento vallisoletano mantuvo vigente el impuesto con la promesa de estudiar su supresión a la hora de redactar los presupuestos del próximo año ${ }^{562}$.

\section{4.- EJÉRCITO Y MILICIA}

La Diputación provincial es una institución político-administrativa de carácter netamente civil, que en principio no tiene ninguna actividad compartida con la administración militar, como se refleja muy claramente en la Constitución de 1812, punto de partida de sus actividades. En su artículo trescientos treinta y cinco nos da detalle de las actividades encomendadas a las Diputaciones, entre las que curiosamente no aparece ninguna relacionada con el Ejército. Esto no es obstáculo para que, ya en sus inicios, se dedique de alguna forma a la gestión de ciertos trabajos relacionados con la Milicia, como por ejemplo, a la legalización de los soldados "dispersos", ciudadanos que al final de la guerra, habían abandonado sus unidades sin la autorización correspondiente.

\footnotetext{
${ }^{562}$ SERRANO GARCIA, Rafael. El sexenio revolucionario en .... Ob. cit. Págs. 131 y sig.
} 
Durante el Trienio Liberal, la Diputación ya se encarga de los repartimientos de los "mozos", de los sorteos y del posterior envío de los "quintos" a sus respectivos destinos militares, y será al final de este período, a partir de la publicación de la ley de 3 de febrero de 1823 sobre "El Gobierno Económico-Político de la Provincia", cuando se asignen a la Diputación competencias que tiene que compartir con la autoridad militar. El artículo noventa y tres la encarga de la organización de los reemplazos del Ejército y su repartimiento y la resolución de dudas y quejas de los Ayuntamientos y particulares y por el artículo noventa y cuatro se hace cargo de la formación y puesta en marcha de la Milicia Nacional Local, su organización, instrucción y armamento. Esta Milicia representa una actividad "para-militar" con una cierta responsabilidad por parte de la institución.

Ya en la época isabelina, de acuerdo con la legislación, se normaliza la colaboración de las Diputaciones con el estamento militar en una serie de trabajos. Destacan los repartimientos de los reemplazos, los sorteos de los "quintos", la entrega de los mozos en "caja" y la atención a las reclamaciones. Éstas, en gran número, se originan al solicitar los afectados la "exención" tanto en el sorteo como en la incorporación al ejército, a través de alegaciones por enfermedad, por defecto físico, por imposibilidad o por agravio.

Por eso no es de extrañar el que los repartimientos de los reemplazos del Ejército sean, junto a los repartimientos de las contribuciones, los temas por un lado más "antipáticos" de cara a la población y por otro lado los temas que más se tratan en las sesiones y que más trabajo dan, tanto a las comisiones que se forman para su resolución como a los plenos de la Diputación. Otras actividades también relacionadas con el ejército, como son los suministros y bagajes, constituían una fuente de protestas de los pueblos que los consideraban abusivos y contrarios a sus intereses. En otra vertiente, los enfrentamientos con las "partidas facciosas", también ocasionan múltiples perjuicios económicos a la provincia, tanto por los movimientos de tropas, como por las exigencias de los sublevados, en los pueblos por donde pasan.

\subsection{1.- EL EJÉRCITO Y LA DIPUTACIÓN, FRENTE A FRENTE}

En los años que la Diputación inicia sus actividades, 1813-1814, la provincia, como el país en general, están "familiarizados" con el ejército a través de los continuos movimientos de tropas que ocasiona la guerra contra los franceses. Como consecuencia lógica se asume la preeminencia de la autoridad militar sobre la civil, situación que se pone de reflejo en Valladolid, sede de la Capitanía General de Castilla La Vieja. A esta situación añadimos la circunstancia de que el jefe político, y por lo tanto presidente de la Diputación, ejerce al mismo tiempo el cargo de capitán general de la Región.

Una de las consecuencias de la Guerra de la Independencia es el estado de penuria del Ejército, que se ve en la necesidad de pedir ayuda a la institución provincial para hacer frente a las dificultades de todo tipo que tiene planteadas, en especial las económicas, aunque también pide ayuda a sus propios mandos militares, como queda de relieve ante la lectura que se hace en el pleno de la Diputación sobre la "resolución de S.M. las Cortes de 22 de abril de 1814, excitando con premio a los jefes militares, a que se establezcan Depósitos de Beneficencia para los militares estropeados en la guerra" ${ }^{, 63}$. En el plano económico, es llamativa la petición verbal que hace a la Diputación el coronel del Regimiento de Caballería del Infante, ante la orden que ha recibido de desplazarse de Valladolid, "haciendo saber que no tiene recursos para poner en marcha el regimiento. La Diputación acordó abonar la paga del mes de marzo, pero como no tenía fondos en la Tesorería se echa mano de los granos que puede haber en la administración de Rioseco"564. Como vemos, la situación

563 A.D.P.V. Actas. Libro de actas del 6 de mayo de 1814.

564 A.D.P.V. Actas. Libro de actas del 22 de junio de 1814. 
económica no es buena ni agradable y no sólo para el Ejército sino tampoco para la Diputación.

Los años del Trienio son sobre todo unos años de organización del Ejército a través de los trabajos de las Cortes. La legislación se inicia el 9 de junio de 1821 con la publicación del real decreto sobre la "Ley Constitutiva del Ejército", con la finalidad de organizar la institución militar y se completa el 28 de febrero de 1822 , fecha en la que se publica la real orden de "División del territorio peninsular en trece distritos militares $"$ " Por lo que respecta a las relaciones Ejército-Diputación, en este período se oficializan los trabajos de remplazos del Ejército a través de la Diputación, lo que hace que se eliminen los enfrentamientos y dificultades de entendimiento entre las dos instituciones, situación que se ve facilitada por el carácter liberal que se imprime en este período sobre todo al Ejército. Como sabemos, el período de vigencia de las instituciones liberales se termina en el año 1823, con el fin del Trienio y el inicio de la Década Ominosa.

En el año 1835, con la vuelta a la actividad de la Diputación, se vuelve a reflejar en sus libros de actas sus relaciones, no siempre amistosas con el Ejército. Empeoran en especial cuando el Ejército entorpece las actividades de la provincia, como ocurre en el mismo año de 1835, cuando la normalización de la Diputación coincide con los levantamientos realistas y carlistas en el norte del país, situación que se deteriora por la escasa disciplina del Ejército y la falta de estabilidad de los frentes de guerra que ocasionaban una extensión de las zonas en conflicto y una inestabilidad en el dominio de las acciones bélicas ${ }^{566}$. Este hecho vuelve a convertir a la provincia en el camino natural de paso de las tropas en sus movimientos hacia las zonas de conflicto con los inconvenientes que ello ocasiona. Por eso la Diputación se ve obligada a "enviar una queja al capitán general por los excesos que cometen la Guardia Nacional y las tropas en la provincia" ${ }^{567}$. A lo que el capitán general contesta con el anuncio de más complicaciones, al "comunicar el paso por la provincia de la División Portuguesa en dirección a Burgos"

Un tema que siempre fue causa de enfrentamientos es el de los acuartelamientos, especialmente en la capital. Se resuelve, de forma indirecta, gracias a la desamortización, como demuestra la comunicación del capitán general al intendente al anunciarle "haber ocupado muchos conventos, antes y después de la exclaustración, para ocuparlos con tropas y hacer de ellos almacenes... y que por la situación de la capital entre la Corte y el teatro de la guerra, expone debe de conservarse para cuartel el monasterio de San Benito y el de San Pablo y San Francisco, ínterin dure la guerra" ${ }^{569}$. Esta solución es parcial y ocasiona un largo enfrentamiento, que durará varios años, entre Ejército y Diputación, por los costes de la fortificación de la ciudad, en especial del "fuerte de San Benito", sobre todo conociendo las dificultades económicas por las que atraviesan las dos instituciones.

La situación de guerra civil en que está sumido el país obliga al Ejército a solicitar ayudas continuas a la Diputación. En el año 1837 se suceden una serie de peticiones del capitán general "solicitando la cooperación de la corporación para que facilitase de cuatro a cinco mil duros para poder atender las necesidades del Ejército en este Distrito... El Ejército del Norte reclama a la provincia una provisión de dos mil fanegas de cebada..Se reclaman recursos para las obras del fuerte de San Benito" 570 .

\footnotetext{
565 El Distrito $\mathrm{n}^{\circ}$ 3, está compuesto por las provincias de Oviedo, León, Salamanca, Zamora, Ávila y Valladolid y su capital se fija en Valladolid.

${ }^{566}$ Para conocer los avatares de la guerra carlista ver TANSKI, Joseph. El informe Tanski y la guerra civil carlista de 1833-1840. Ed. Ministerio de Defensa. Madrid. 2011.

567 A.D.P.V. Actas. Libro de actas del 9 de noviembre de 1835.

568 A.D.P.V. Actas. Libro de actas del 14 de noviembre de 1835.

569 A.D.P.V. Actas. Libro de actas del 12 de marzo de 1836.

570 A.D.P.V. Actas. Libro de actas del 14 de junio y 11 de noviembre de 1837 .
} 
Como es habitual, la Diputación se queja de "las continuas exacciones y exigencias de las tropas", pero sobre todo, ve por un lado que el Ejército va y viene al norte y por otro ve que una parte de la provincia está dominada por la facción de Zariategui. Éste llegó a entrar en la capital y allí se mantuvo entre los meses de julio y septiembre de 1837, sin que el Ejército hiciera nada por evitarlo o por defender la ciudad. Esta invasión provoca por un lado la destitución del capitán general Carlos Espinosa y por otro obliga a rematar las obras del fuerte de San Benito. La controversia Ejército-Diputación no está en la fortificación de San Benito, en lo que están las dos de acuerdo, sino en saber quién es el que tiene que pagar los gastos. Está claro que el Ejército "no tiene un duro" y que la Diputación no está mejor, aunque finalmente asuma el coste. Reacciona rápidamente el capitán general, que una vez acordado el que "los gastos de fortificación correrán a cargo de la Diputación, reclama el pago de los sueldos de las brigadas de presidiarios del canal que trabajan en las obras de fortificación" $" 571$.

El año 1838, es un año duro para el Ejército, que continua pidiendo "50 caballos para completar la fuerza de cuatro escuadrones de Caballería de Cuerpos Francos, según la real orden de 19 de enero de 1838", y además "la construcción de 562 ollas de rancho según el modelo remitido, procurando que su construcción se hiciera a la mayor brevedad posible" ${ }^{, 572}$. Todas estas peticiones se realizan en el mes de febrero, pero en el mes de marzo "el jefe político notificó a la Diputación que el día anterior, había tenido una reunión en la casa-habitación del Sr. Capitán General, compuesta por las autoridades administrativas... y personas notables... para hacer presente el estado crítico en que se hallaba la pagaduría militar, careciendo hasta de lo más preciso para atender la subsistencia del Ejército, ... solicitando de la corporación procurase facilitar por cualquier medio algunos fondos para asistir al Ejército. Ante esta situación la Diputación acordó reclamar a los capitalistas una cantidad de diez a doce mil duros, que serían reintegrados por repartimientos y a través de la venta de baldíos". Pero la convocatoria fue un completo fracaso porque, "a pesar de las excitaciones hechas a los capitalistas, la comisión nombrada, no había podido reunir más que la insignificante cantidad de cincuenta mil y pico de reales" ${ }^{573}$.

El fracaso de esta gestión de la Diputación se le comunica al capitán general, pero éste es reiterativo y, ante la necesidad tan urgente de dinero, envía una nueva comunicación a la institución en la que se lamenta "hallarse en el mayor apuro por falta de recursos y siendo su deber el precaver de las fatales consecuencias a que pudiera dar lugar la desatención de las obligaciones militares de la plaza ruega proporcione a la Pagaduría Militar las cantidades que para cubrir lo estrictamente

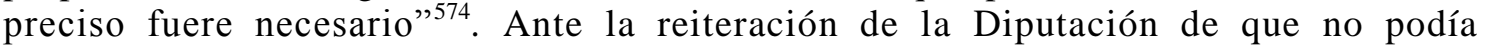
ayudar porque no tenía fondos ni posibilidad de conseguirlos, el capitán general a través del intendente militar amenaza diciendo que "se apoderaría por la fuerza de todos los caudales que se ingresaran en la Tesorería" 575 .

Esto es un ejemplo de la difícil situación por la que atraviesa el Ejército, que no sabe, por un lado, cómo derrotar a los carlistas y, por otro, cómo mantener "sin dinero" los numerosos gastos que ocasiona la guerra ${ }^{576}$. El caso del capitán general del Tercer Distrito en Valladolid no es excepcional, ya que el gobierno se ve obligado, para evitar un grave desabastecimiento del Ejército, a publicar una real orden de fecha 23 de febrero de 1839 "fijando los suministros por esta provincia en el mes de febrero para los Ejércitos del Norte en 278.690 raciones de pan y 26.487 de pienso. La

571 A.D.P.V. Actas. Libro de actas del 13 de enero de 1838.

572 A.D.P.V. Actas. Libro de actas del 15 y 22 de febrero de 1838.

573 A.D.P.V. Actas. Libro de actas del 18 y 21 de marzo de 1838.

574 A.D.P.V. Actas. Libro de actas del 3 de agosto de 1838.

575 A.D.P.V. Actas. Libro de actas del 1 de septiembre de 1838.

${ }^{576}$ Este tema de la situación del Ejército y sus relaciones con las autoridades civiles están detallad as en PAYNE, Stanley G. Ejército y sociedad en la España liberal (1808-1936) Ed. Akal. Madrid. 1977 y en TANSKI, Joseph. La guerra civil carlista ... ob. cit. Págs. 123 y sig. 
Diputación acordó garantizar a los contratistas el pago del importe de los suministros y para lo cual se realiza un repartimiento a la provincia a cuenta de las contribuciones ordinarias" $" 577$.

Aparte de los aprovisionamientos, el tema de las fortificaciones sigue siendo otro de los enfrentamientos con el Ejército, sobre todo porque al final es la Diputación la que se tiene que hacer cargo de los gastos que se ocasionan. Así ocurre con Peñafiel y la fortificación de su castillo, que pasa por dificultades ante los atrasos en el pago de los trabajos por parte de la Intendencia Militar, y también con el fuerte de San Benito que sigue dando problemas y gastos. Lo reconoce el "informe del jefe político sobre la existencia en el fuerte de San Benito de un considerable almacén de pólvora que, aunque custodiado con el debido esmero, todavía ofrecía peligro en la estación actual por la falta de un pararrayos, con el riesgo ante una posible tormenta del estío y con el consiguiente peligro para la población. La Diputación acordó colocar un pararrayos..."

El Convenio de Vergara, firmado entre Espartero y Maroto, pone fin a la Guerra Carlista y también a los enfrentamientos entre la Diputación y la Capitanía General por la presencia masiva de unidades del Ejército por toda la provincia. Aunque las exigencias del Ejército sean excesivas y la Diputación y los ciudadanos se quejen, lo cierto es que no les agrada el poder perder una parte de la guarnición militar ubicada en la ciudad. De esa manera lo hace saber "el presidente de la Diputación ante la noticia de que el Ayuntamiento constitucional de Burgos había pedido al Gobierno de S.M. la gracia de que se estableciera en aquella ciudad el "quinto departamento de Artillería", y que como si se llegase a conceder, Valladolid tenía que sufrir considerables daños, solicita que se representare al Gobierno en solicitud de que no se retocase la orden a virtud de la cual se mandó fijar en esta capital el referido Departamento" ${ }^{579}$.

La llegada al poder del Duque de la Victoria tranquiliza las relaciones de la Diputación con el Ejército, entre otras causas porque el fin de la guerra acaba con los movimientos de las tropas. En las actas de la institución provincial no aparecen referencias al Ejército, con excepción de las habituales sesiones dedicadas a los reemplazos con el consiguiente repartimiento y entrega de los mozos al Ejército, además de las reclamaciones que se hacen por este concepto.

Todavía en el año 1842, se mantiene la controversia sobre el pago de los gastos de la fortificación de San Benito, situación en la que se involucra el Ayuntamiento de la capital, al que la Diputación se queja de "que está desmontando el fuerte y utilizando el material, y se acordó ordenar al Ayuntamiento que parase la demolición" ${ }^{580}$. Parece que no hay otro motivo de enfrentamiento, puesto que los años pasan y no hay otras noticias al respecto de las relaciones entre las dos instituciones. Tenemos que alcanzar el año 1854 para oír hablar nuevamente del fuerte de San Benito, cuando la Diputación comunica "el acuerdo con el capitán general para desmontar el fuerte de San Benito a costa de la Diputación, haciendo suyos los materiales" $" 581$.

De todas formas, las relaciones Capitanía-Diputación, son el fruto del enfrentamiento por la primacía en la representación de la vida ciudadana. Es decir, es una "lucha" entre el poder militar y el poder político de carácter provincial por ver quién es el hegemónico. Aunque también es cierto que los continuos cambios en la persona del capitán general no ayudan a consolidar las relaciones personales con el jefe político-presidente de la Diputación. Una prueba de la animosidad entre los

577 A.D.P.V. Actas. Libro de actas del 2 de marzo de 1839. Con anterioridad a esta real orden, a finales del año 1838 el capitán general reclamó a la provincia un suministro de 300.000 raciones de pan y 150.000 raciones de pienso.

578 A.D.P.V. Actas. Libro de actas del día 23 de mayo de 1839.

579 A.D.P.V. Actas. Libro de actas del 23 de noviembre de 1839.

580 A.D.P.V. Actas. Libro de actas del 26 de octubre de 1842.

581 A.D.P.V. Actas. Libro de actas del 30 de octubre de 1854. 
representantes de la Diputación y el capitán general nos aparecerá, avanzado el período isabelino, en el año 1865, cuando la Diputación refleja en su libro de actas otro conflicto ${ }^{582}$. Con el paso del tiempo y cerca ya el fin del período isabelino, la situación política se va deteriorando y el Ejército se vuelve a erigir en el árbitro de la situación, en especial a partir de agosto de 1867, fecha en la que el Gobierno "declara a la provincia en estado de guerra, y el gobernador resigna el mando de la parte política en el Sr. capitán general" ${ }^{583}$. Situación que desembocará en septiembre de 1868, cuando el capitán general ordena la concentración de las tropas en la capital, como preludio del inicio del Sexenio Revolucionario. En este período la vida política predomina sobre la militar, lo que hace que el Ejército no tenga relación con la Diputación, excepto como ya hemos apuntado en lo relativo a las operaciones para los alistamientos y los ingresos de los mozos en las filas militares.

\subsection{2.- REEMPLAZOS. LOS "MOZOS” CONTRA EL EJÉRCITO}

La gestión de los remplazos es la actividad más importante que tiene que desarrollar la Diputación, conjuntamente con el Ejército. Es un trabajo que está dividido en dos partes muy bien diferenciadas. Por una parte, el repartimiento de los mozos que corresponde a cada pueblo en función del número de jóvenes convocados y también del número de habitantes de cada pueblo. Por otro lado, la solución de los expedientes de reclamaciones y alegaciones que presentan los mozos en su afán de evitar ser enviados al ejército.

En los años 1813-14, recién formada la Diputación y recién acabada la guerra contra los franceses, la institución provincial, más que hacer los trabajos de repartimiento, lo que tiene que hacer es en un principio conocer la situación provincial. Debe saber el número de habitantes y conocer y controlar a los numerosos mozos que vuelven a sus casas, sin saber a ciencia cierta si están licenciados o si han abandonado sus unidades sin permiso, lo que les convierte en prófugos.

En este período, la Diputación recibe numerosas comunicaciones de individuos, que solicitan "que no se les declare dispersos". Su situación en el Ejército no estaba muy clara, al haber "servido" como soldado tanto en regimientos regulares como también en las numerosas unidades guerrilleras, que fueron disueltas al finalizar la guerra y sus componentes enviados a casa sin ningún tipo de formalismo. Un ejemplo claro de esta situación y de su desconocimiento, tanto por parte del gobierno como del propio Ejército, es el de la convocatoria de un reemplazo y su correspondiente repartimiento que no llegó a celebrarse en principio a nivel provincial, "al considerar la Diputación que hallándose cubierto el cupo de hombres señalados a la provincia con dispersos, se mandó suspender la quinta". Y también a nivel nacional con la publicación de una orden de la Regencia acordando que "con motivo de haberse asegurado que existía en el Reino una fuerza armada excesiva de 150.000 hombres, la quinta no era necesaria"584.

Con la llegada del Trienio y la vuelta a la actividad de la Diputación, se normaliza la situación y los reemplazos se efectúan regularmente en función de las necesidades del Ejército. Esta actividad conlleva una excesiva carga de trabajo que se traduce en numerosas sesiones para celebrar los repartimientos, los sorteos de "décimas" y "quebrados" y oír las reclamaciones que presentan un gran número de mozos, como ocurre en el año 1822 en que la Junta Supletoria de Reemplazos celebra

\footnotetext{
${ }^{582}$ A.D.P.V. Actas. Libro de actas del 19 de noviembre de 1865. "Protocolo: Comunicación del capitán general invitando al Besamanos por el Santo de S.M. y habiéndose manifestado por el Sr. presidente de la Corporación, D. Eduardo Ruiz Merino, que la autoridad militar no comunicó a los actos públicos y fiestas de carácter civil la Diputación acordó no asistir al citado acto de Corte, y para que nadie pensara que era un acto contra la Reina acordó que el gobernador transmitiera a S.M. los respetos de la Diputación".

583 B.O.P.V. $n^{\circ} 351$ de fecha 18 de agosto de 1867.

584 A.D.P.V. Actas. Libro de actas correspondiente a los días 14 de febrero y 29 de abril de 1814.
} 
sesenta y una sesiones en los meses de diciembre de 1822 y enero y febrero de 1823 para resolver los quinientos siete expedientes que se presentaron.

En los años del Trienio se celebraron tres repartimientos: El primero, en mayo de 1821 , fecha en la que se convoca un reemplazo de 16.595 soldados de los cuales corresponde a la provincia de Valladolid 301 mozos "en función de los 187.390 habitantes en que se estima su población". El segundo, en junio de 1822, cuando se ordena un reemplazo de 7.983 soldados, de los que corresponden a Valladolid 124 en base a 175.100 habitantes. El tercero, en octubre de 1822, con el reemplazo de 29.973 hombres, y se señalan para la provincia de Valladolid 467 mozos por los 175.100 habitantes. En el mes de febrero de 1823 se vuelve a solicitar un nuevo reemplazo de 29.973 soldados y a la provincia de Valladolid 467 mozos, cantidad idéntica al último reemplazo efectuado. La petición se hace en vista de la situación política "para poner en pie de guerra al Ejército", pero este reemplazo no llegó a celebrarse por la venida del absolutismo, período que no presupone la desaparición de los reemplazos y sí su gestión por la Diputación al ser suspendidas sus actividades.

Consecuencia lógica de los reemplazos, los sorteos y los repartimientos que se realizan, son las reclamaciones. Reclamaciones por agravios, peticiones y excusas para evitar ser enviados al Ejército. Son numerosos los mozos que piden ser librados del envío al Ejército por una variada gama de enfermedades y defectos físicos. Entre todos ellos sobresale los "cortos de talla" y los "estrechos de pecho", defectos posiblemente relacionados con la miseria y hambre que reinan en la provincia. También encontramos a cojos, mancos, herniados, tuertos y un largo etc. Otro numeroso grupo alega una especial situación familiar que les daría el derecho a qued ar exentos como son "el hijo único de viuda pobre" "el hijo de padre sexagenario" y "el tener otro hermano en el Ejército".

Otra parte de los mozos, los más pudientes, presentan un sustituto "pagado para eludir su ingreso en filas" y hay otros que pretenden librarse a base de mentiras y "cacicadas". Así ocurre con "el malicioso procedimiento de no incluir en el alistamiento y sorteo del pueblo de Corrales, al alcalde Bonifacio Bombín, siendo como es viudo y sin hijos, pues aun cuando hubiera tenido yunta de labrar, que no tenía, debió ser comprendido. Se aprobó apercibirle seriamente con la privación de ejercer el honroso cargo y multarle con 100 ducados..." 585 .

Finalmente, hay ocasiones en que las reclamaciones se hacen por el conjunto de los mozos, con el fin de expresar la protesta por la más que previsible incorporación al Ejército, como es el caso de Cuenca de Campos que "ante la insolencia y el alboroto de los mozos en el acto de dar principio a la ejecución del sorteo, el Ayuntamiento solicitó el auxilio de una fuerza armada de veinte hombres para mantener la tranquilidad" $" 586$.

Además de tener que enfrentarse a las reclamaciones de los ciudadanos, la Diputación se ve en la necesidad de reclamar, ella misma, al Ejército, ante la situación de abandono y miseria que sufren los soldados. Ésta se refleja en la queja que envía al jefe de la Caja de Reclutas porque "habiendo tenido noticias la Diputación de que en el Hospital Militar de esta capital han fallecido un gran número de quintos procedentes del sorteo del año próximo pasado y también de la absoluta desnudez con que han estado desde su ingreso en caja...se acordó pedir al comandante general del Distrito información de los mozos y regimientos de destino y cuántos enfermos, curados y muertos han resultado y la causa que lo han motivado" 587.

La llegada de la época isabelina es el punto de partida para la normalización de las actividades de la Diputación y, entre ellas, cómo no, están los remplazos. Si la Diputación inicia sus actividades el 22 de octubre de 1835 , el 28 del mismo mes comienza los trabajos en función del real decreto de 24 de octubre "sobre el 
reclutamiento de 100.000 soldados de 18 a 40 años, correspondiendo a la provincia de Valladolid 1.528 hombres,... no debiendo considerase exentos a los faltos de talla" ${ }^{" 588}$. El ingreso de los mozos se realiza el mes de noviembre entre los días 13 y 30 y entre las dos fechas se publica un real decreto de fecha 20 de noviembre "declarando libres del servicio ordinario del Ejército y Milicia a los que habiendo tocado la suerte de soldados, entreguen un caballo de buen servicio y 1.000 reales de vellón" ${ }^{589}$.

Con los repartimientos llegan también las reclamaciones y prácticamente antes de celebrarse los sorteos, ya se empiezan a recibir las primeras de ellas, correspondientes a los individuos que "se quejan por la inclusión indebida en las listas de mozos". Es curioso que, en este primer sorteo y a tenor de las 779 reclamaciones recibidas, se pone de manifiesto el que hay un gran número de mozos que son declarados inútiles, ya sea porque es verdad o también porque algunos mozos se lesionan para evitar ser "enrolados en el ejército". Estas prevenciones son puestas de manifiesto por la Diputación en su comunicación al capitán general "ante la numerosa lista de inútiles remitida por S.E., esta Diputación presume que la inutilidad de los quintos en cuestión, había sido adquirida después de hecha la entrega por esta Diputación y que se ofrecía a reemplazar los inútiles por defecto físico, salvo los que hubieren adquirido su inutilidad en el depósito y los que mal aconsejados, hubieren fomentado los males que alegaron y los que maliciosamente se mutilan... por lo que ruega a S.E. envíe a estos mozos para sufrir un nuevo reconocimiento..."

En el año 1836 se procede a un nuevo reemplazo al publicarse la real orden de 26 de agosto "llamando al servicio de las armas a 50.000 hombres, de los que corresponden a Valladolid 770"591. Ante esta petición, la Diputación reclama al Gobierno "la exención del sorteo de los nacionales movilizados por su labor contra los facciosos que habían invadido Castilla, en especial ante la facción de Basilio" ${ }^{592}$. Petición que es denegada. Llama la atención de este reemplazo el que curiosamente es bajo el número de reclamaciones, sólo 303 y apenas las hay por agravios o por inutilidad, aunque sí se producen deserciones. Lo que hace que el capitán general reclame a la Diputación "la captura de los desertores".

El año 1837 es un año atípico, puesto que a nivel nacional no se produce la petición de reemplazo para el Ejército, pero a nivel provincial, el estado de guerra decretado en la provincia por el capitán general provoca un "llamamiento a las armas de todos los mozos de 16 a 40 años".

El año 1838 se inicia convocando un reemplazo, a través de una real orden de 20 de febrero, "ordenando efectuar una quinta de 40.000 hombres y la Diputación acordó realizar la distribución de los 624 hombres que correspondían a esta provincia, tomando como base la distribución realizada en 1835 con la quinta de los 100.000 hombres" ${ }^{~ 593}$. Una vez realizado el sorteo, se inicia el período de reclamaciones, con un total de 320 expedientes que afectan a 140 pueblos de la provincia. Entre las peticiones de inutilidad destacan las de "corto de talla", "hijo de viuda pobre", "padre sexagenario", es decir, las habituales, aunque hay veces que sorprenden las enfermedades que alegan como por ejemplo "por fatuo" o "por no distinguir entre ovejas y corderos".

En el año 1839 se convoca el reemplazo anulado a finales de 1838, por real orden de 10 de enero, "ordenando una nueva quinta de 40.000 hombres, correspondiendo a la provincia de Valladolid 630 mozos, presentando el repartimiento el día 28 y acordando celebrar los sorteos de décimas los días 30 y 31 de octubre sobre "la recluta de 100.000 soldados...".

589 B.O.P.V. n 101 de fecha 24 de noviembre de 1835 .

590 A.D.P.V. Actas. Libro de actas del 21 de enero de 1836.

591 B.O.P.V. n ${ }^{\circ} 110$ de 6 de septiembre de 1836.

592 A.D.P.V. Actas. Libro de actas de 16 de septiembre de 1836

593 A.D.P.V. Actas. Libro de actas del 3 de marzo de 1838. 
del mismo mes" 594 . La entrega de "los quintos en caja" se realiza a partir del 14 de febrero para lo cual, la Diputación manda "disponer de un local en la misma forma que el año anterior, disponer de 2 ordenanzas carabineros para mantener el orden y nombrar un sargento tallador y facultativos" ${ }^{~ 595}$. Una vez realizado el sorteo, la Diputación trata las 293 reclamaciones pertenecientes a 139 pueblos, en las que sigue destacando las habituales de otros años, a las que hay que añadir las denuncias y procesamiento de los prófugos.

El año 1840 parece que iba a ser uno de los "raros" años en los que no se convocaría un reemplazo para el Ejército. Pero aunque tarde sí que se realizó, "por decreto del Regente de 31 de agosto de 1841 se ordena hacer un reemplazo de 50.000 hombres por lo correspondiente al año 1840, correspondiendo a la provincia de Valladolid un total de 394 mozos, de los cuales 237 serán para el Ejército y 157 para la Milicia"596. Es decir, el Ejército no perdona el reemplazo de 1840, sino que lo atrasa a septiembre de 1841. Las audiencias públicas para oír las reclamaciones se celebran del 12 al 22 de noviembre, tratando 254 expedientes que corresponden a 134 pueblos de la provincia. En esta ocasión la "nueva" reclamación que se presenta es la de "pedir la nueva talla de otro mozo que con anterioridad ha sido declarado corto".

No se habían terminado de solucionar las reclamaciones de 1840 cuando se vuelve a convocar un nuevo reemplazo, en esta ocasión del año 1841. El día 10 de noviembre "se inicia el sorteo de fracciones resultantes del repartimiento de la quinta de 394 hombres para el Ejército y Reserva del presente año...". Se inician los trabajos del nuevo sorteo de décimas el 11 de noviembre y las reclamaciones se inician el 4 de diciembre con diez sesiones que afectan a 145 pueblos con un total de 273 expedientes, dando por finalizados los trabajos el día $14, " 597$.

En el año 1842, antes de convocarse un nuevo reemplazo, aparece en el Boletín Oficial de la Provincia una serie de anuncios ofreciendo la posibilidad de librarse del Ejército. El sistema propuesto era contratar un sustituto a cambio de cierta cantidad de dinero, una parte a fondo perdido si no resulta elegido y si es elegido se fijará la cantidad definitiva entre las dos partes ${ }^{598}$. El reemplazo del año es publicado en el mes de septiembre "ordenando un repartimiento de 394 soldados señalados a esta provincia para el reemplazo de 25.000 hombres, decretado por las Cortes el día 1 de agosto, correspondiendo al alistamiento del presente año" ${ }^{\text {599 }}$. Lo que llama la atención de estas cifras es que el total para el país es de 25.000 hombres y para la provincia 394, y en el pasado año el total del país era de 50.000 hombres y sin embargo para la provincia fue de 394. Es decir, a la mitad de reemplazo a nivel nacional no se produce ninguna reducción a nivel provincial. La Diputación no refleja en sus actas ningún tipo de reclamación o de protesta. Se procede al sorteo de "fracciones y décimas" y a continuación se inician las sesiones públicas para resolver las reclamaciones de 323 expedientes de 190 pueblos, destacando en gran número "la presentación de sustituto".

En 1843, en el mes de septiembre, la Diputación toma nota de la comunicación del jefe político, "dando cuenta del decreto del Gobierno de 17 de agosto, mandando verificar un reemplazo de 25.000 hombres para el ordinario del Ejército, cogiendo un

594 B.O.P.V. $\mathrm{n}^{\circ} 16$ de 5 de febrero de 1839, con la publicación de la lista completa de los mozos sorteados.

595 A.D.P.V. Actas. Libro de actas del 13 de febrero de 1839.

596 A.D.P.V. Actas. Libro de actas de 13 de septiembre de 1841

597 A.D.P.V. Actas. Libro de actas del 10 de noviembre y 14 de diciembre de 1841 .

598 B.O.P.V. ANUNCIO.- Aviso para la suscripción a la quinta que debe de celebrarse en el presente año. Se admiten suscripciones y contratos para reemplazar en la suerte de soldado a los que les toque en la próxima quinta, antes de celebrados los sorteos. La suscripción será de 500 reales que se pagarán anticipados y perderá si sale libre el suscriptor, y si soldado, le servirá de abono y en parte de pago de la cantidad en que convenga con la empresa. Lo podrá verificar el que lo guste por una cantidad convencional que no excederá de 2.500 reales, a todo riesgo, por cuya suma, si le tocase la suerte de soldado se le pondrá el sustituto o sustitutos que necesite, y de salir libre lo perderá, quedando en beneficio de la empresa. Publicado el 3 de marzo de 1842.

599 A.D.P.V. Actas. Libro de actas del 14 de septiembre de 1842. 
cupo a la provincia de 394 hombres, 157 al Ejército y 237 a la Reserva". La Diputación "acuerda cumplir con lo dispuesto en la real orden de 31 de agosto de 1841, e iniciar el repartimiento de los 394 hombres de acuerdo con el padrón de 17 de septiembre de 1842 "600. El 13 de noviembre se envía "a la Caja Militar el contingente de quintos" y con anterioridad la Diputación había resuelto las 380 reclamaciones que presentan 137 pueblos, entre los que destacan como viene siendo habitual "los cortos de talla", "hijos de viuda pobre", "hijos de padre sexagenario", "tener un hermano en el ejército" y sobre todo "presentación de sustituto".

En el año 1844, por real decreto de 26 de abril "se ordena una quinta de 50.000 hombres para el reemplazo ordinario del Ejército, correspondiendo a la provincia de Valladolid 788 quintos". Presentado y aprobado el repartimiento se completa el calendario para realizar los sorteos, la entrega a la "caja militar" y oír las reclamaciones de los mozos en 621 expedientes correspondientes a 227 pueblos, cantidad muy elevada y que es debido a los problemas que ocasionan las condiciones para cubrir las sustituciones. Es expresiva la denuncia del diputado Quintero al avisar "que todos estaban enterados de lo difícil que era en este año de poner un sustituto, recordando que era el gobierno el que había cerrado la puerta a la sustitución, privando a los que tenían la desgracia de salir soldados de una facultad que les dispensaba la ley..." 601 . En definitiva "es una desgracia salir soldado", y además se aumenta el número de reclamaciones al no poder presentar sustitutos. Estas reclamaciones se repiten como en años anteriores, peticiones de talla a los interesados y a otros mozos, pobres, ancianos, sordos, tiñosos, con brazos rotos, prófugos, etc, etc.

Para el año 1845, se ordenará el reemplazo con un año de retraso, según la real orden de 4 de octubre de 1846, por la que "se ordena una quinta de 25.000 hombres para el reemplazo del Ejército permanente, correspondiente al alistamiento del año 1845 , con 394 soldados señalados a esa provincia" ${ }^{602}$. Los sorteos de "décimas y fracciones" se realizan los días 8 y 9 de noviembre. Las reclamaciones, que a partir de este año son responsabilidad del recientemente creado Consejo provincial, ascienden a un total de 308, de las que no conocemos los pueblos afectados.

El reemplazo del año 1846 se inicia el 1 de junio de 1847, con la publicación de la real orden del 16 de mayo, "por la que el gobierno de S.M. ordena un reemplazo de 25.000 hombres, correspondientes al alistamiento de 1846 y practicado el repartimiento por la Secretaría de los 394 hombres que corresponden a la provincia, se aprobó y se acordó celebrar el día 4 a las 7 de la mañana el sorteo de fracciones y el sábado 5 a la misma hora el de décimas" ${ }^{603}$. El Consejo provincial, inicia las audiencias públicas para oír las reclamaciones de los mozos a partir del día 25 con 317 expedientes tratados.

El reemplazo de 1847 se inicia con la publicación de la ley de 28 de enero de 1848 "ordenando el reemplazo de 25.000 hombres, correspondientes al año 1847 , con 394 soldados señalados a esta provincia" ${ }^{604}$. Los días 17 y 18 de marzo se celebran los sorteos de "fracciones y décimas" y las audiencias para oír las reclamaciones de los mozos, a través del Consejo provincial, se inician el 5 de abril, con un total de 354 reclamaciones.

El reemplazo del año 1848 se pone en marcha en la sesión extraordinaria de la Diputación, celebrada el día 14 de septiembre, en la que "se lee la real orden de 30 de agosto por la que se llama al servicio de las armas por el tiempo de siete años a 25.000 hombres del alistamiento de este año. A esta provincia le corresponden 394 soldados" ${ }^{\prime 605}$. Una vez sorteados los mozos, se inician las audiencias públicas para tratar sobre las 389 reclamaciones. Con el paso de los años se va observando una

600 A.D.P.V. Actas. Libro de actas del 6 de septiembre de 1843.

601 A.D.P.V. Actas. Libro de actas del 7 y 17 de mayo de 1844.

602 B.O.P.V. $\mathrm{n}^{\circ} 130$ de 27 de octubre de 1846 y n $^{\circ} 137$ de 12 de noviembre de 1846.

603 A.D.P.V. Actas. Libro de actas del día 1 de junio de 1847.

604 A.D.P.V. Actas. Libro de actas del 12 de marzo de 1848 y B.O.P.V. no 36 de 23 de marzo de 1848.

605 A.D.P.V. Actas. Libro de actas del día 14 de septiembre de 1848. 
mayor dedicación a este tema, al ser mayor el número de reclamaciones y de sesiones para resolver los agravios.

Las sesiones de la Diputación del año 1849 se inician el día 16 de enero, con la lectura del real decreto de 5 de diciembre anterior por el que "se llama al servicio de las armas a 25.000 hombres del alistamiento de 1849 , de los que tocan a esta provincia 394 soldados. Se acuerda hacer el sorteo por el empadronamiento de $1848^{" 006}$. En la misma sesión se acuerda celebrar los sorteos de fracciones y décimas los días 19 y 20 del mismo mes de enero. Las 401 reclamaciones y peticiones de "exacción" se celebran por el Consejo a lo largo de los meses de febrero, marzo y abril con un total de 59 sesiones.

El reemplazo correspondiente al año 1850 no iniciará los trabajos de repartimiento hasta el día 1 de julio de 1851. En esa fecha la Diputación, "declarada abierta la sesión se da lectura al real decreto de 20 de junio último por el cual se dispone se proceda a distribuir entre los pueblos los 394 soldados que han correspondido en el reemplazo de 25.000 hombres" ${ }^{607}$. Las sesiones públicas para "oír las 333 reclamaciones" se celebran a lo largo del mes de agosto, con un total de 28 sesiones.

Las llamadas a los reemplazos del Ejército siguen haciéndose con gran retraso, ya que el reemplazo de 1851 se hace coincidiendo con la apertura de sesiones de la nueva Diputación, sesión que se celebra el 1 de abril de 1852. En dicha sesión "se dio cuenta del real decreto de 6 de marzo, último por el cual se llamaba al servicio de las armas a 10.000 hombres, correspondientes al alistamiento del año 1851. También se aprobó el repartimiento practicado por la Secretaría entre los pueblos de la provincia de los 146 soldados que a la misma corresponden fijándose el día 3 para realizar el sorteo de décimas" ${ }^{608}$. Las audiencias para "oír las 140 reclamaciones" se realizan en septiembre de 1852.

El reemplazo correspondiente al año 1852 no se realiza. Como hemos observado en el reemplazo del año anterior, la petición de soldados ha sido únicamente de 10.000 hombres, señal de que el Ejército no tenía necesidad de más soldados.

En el año 1853, en sesión extraordinaria celebrada por la Diputación el día 8 de abril, "se da lectura al real decreto de 30 de marzo por el cual se dispone la distribución entre los pueblos de la provincia de los 315 soldados que han correspondido en el reemplazo de 25.000 hombres del año actual. Se acuerda señalar el día 11 a las 8 de la mañana para el sorteo de 98 soldados que corresponden a las 980 décimas" ${ }^{\circ}$. Aprobado el sorteo, se inicia una nueva modalidad, que ya vimos en el último reemplazo. Se trataba de iniciar el ingreso en caja, durante un número de días y presumiblemente, en estos días se tratan las 254 reclamaciones de los mozos que van a ingresar. En esta ocasión el ingreso en caja se inicia el 15 de junio y finaliza el 30 de julio ${ }^{610}$.

El año 1854 se inicia con la publicación del real decreto de 3 de enero "llamando al servicio de las armas, por el tiempo de ocho años a 25.000 hombres, correspondientes al alistamiento y sorteo actual, correspondiendo a esta provincia 317 soldados" $"$. El sorteo de décimas se realiza el 4 de febrero y el 15 de mayo se inician las audiencias para oír las 248 reclamaciones.

\footnotetext{
606 A.D.P.V. Actas. Libro de actas del 16 de enero de 1849.

607 A.D.P.V. Actas. Libro de actas del 1 de julio de 1851.

608 A.D.P.V. Actas. Libro de actas del día 1 de abril de 1852.

609 A.D.P.V. Actas. Libro de actas del día 8 de abril de 1853.

610 Como dato curioso, señalamos que las actas del Consejo provincial correspondientes al año 1853, ocupan un total de 94 páginas, de las cuales 66 se refieren a los "sorteos de quintos" "entrados en caja" y "reclamaciones" es decir el $70,2 \%$ de los asuntos tratados, aunque no se especifica los detalles de lo tratado.

611 B.O.P.V. n ${ }^{\circ} 6$ de 14 de enero de 1854. A.D.P.V. Actas. Libro de Actas del 1 de febrero de 1854.
} 
El repartimiento correspondiente al año 1855 se inicia en la sesión de la Diputación del día 12 de febrero con la "lectura de la comunicación del Ministerio de la Gobernación del 8 del actual, anunciando el servicio de las armas por el tiempo de ocho años a 25.000 hombres del alistamiento de este año, con 320 soldados que corresponden a la provincia entre un total de 1765 mozos que han entrado en el sorteo y real decreto de igual fecha informando de los días en que deben practicarse las operaciones" ${ }^{\prime 12}$. Se fijan los días 10 a 19 de abril para la entrega de los quintos en caja, siendo la entrega de cada día para un partido judicial y de esta forma evitar las aglomeraciones.

La llegada del Bienio Progresista conlleva una serie de cambios tanto políticos como administrativos. En nuestro caso, la modificación más importante es que la Diputación vuelve a asumir todas las gestiones relativas a los reemplazos, al ser disuelto el Consejo, y se vuelven a reflejar en las actas las sesiones públicas correspondientes para tratar los expedientes sobre agravios y reclamaciones que se presentan. Estas sesiones tienen lugar durante los días 10 a 20 de abril, con 209 expedientes correspondientes a 115 pueblos. Entre las reclamaciones más frecuentes vuelven a aparecer los cortos de talla, los hijos de viuda pobre, los hijos de padre sexagenario, los que tienen otro hermano en el ejército.

En el año 1856 se produce el llamamiento de dos reemplazos, uno para el Ejército y el otro para la Milicia Nacional. Para el primero de ellos, la Diputación convoca una sesión el día 7 de marzo para "ocuparse S.S., de acuerdo con la Ley de Reemplazos de 26 de enero, del repartimiento de 162 soldados por 1.346 mozos sorteados en 1855, que han correspondido a la provincia en el reemplazo de 16.000 hombres del alistamiento y sorteo actual de $1856^{\text {" }} 613$.

El segundo reemplazo del año se produce en el mes de julio "ordenando el alistamiento en la provincia de 304 soldados para la Milicia Nacional del total de 30.000 hombres"614. Sin otra comunicación se acuerda la entrega de quintos a partir del 25 de septiembre, fecha en que también se inician las audiencias públicas para resolver los expedientes de reclamaciones, con veintitrés sesiones en las que se tratan 463 expedientes correspondientes a 198 pueblos. Muchos expedientes y muchos pueblos para equipar una milicia que en años anteriores tenían el ingreso restringido.

También en el año 1857 se efectúan dos reemplazos, el primero se convoca por real decreto de 25 de abril, "por el que se llama al servicio de las armas para el reemplazo del Ejército Activo a 50.000 hombres al sorteo y lista de este año" ${ }^{615}$. De acuerdo con este reemplazo, le corresponde a la provincia de Valladolid el efectuar un repartimiento de 811 soldados. El segundo reemplazo se realiza a partir del real decreto de 14 de diciembre "llamando al servicio de las Armas a 30.000 hombres con destino a los Cuerpos de Milicia Nacional. A la provincia de Valladolid le corresponden 386 soldados en función de los 1.329 mozos sorteados en 1856". Sigue siendo curiosa la petición de reemplazos para la Milicia, cuando la actuación de este cuerpo es mínima y puede decirse que en la práctica está "disuelta y extinguida", según el real decreto publicado en el Boletín Oficial de la Provincia de fecha 26 de agosto de 1856. Lo corrobora la modificación que se produce cuando el día 31 de diciembre, una vez celebrado el sorteo, se dice que "el repartimiento de los 386 hombres es para el Ejército de la Reserva" ${ }^{616}$.

Por lo que respecta a las correspondientes reclamaciones, en este año de 1857, funcionando de nuevo el Consejo provincial, es a este organismo al que le compete la tramitación de los 682 expedientes con las habituales reclamaciones de corto de talla,

612 A.D.P.V. Actas. Libro de actas del 12 de febrero de 1855. B.O.P.V. Boletín del 13 de marzo de 1855.

613 A.D.P.V. Actas. Libro de actas del 7 de marzo de 1856.

614 B.O.P.V. $n^{\circ} 89$ de fecha 24 de julio de 1856.

615 B.O.P.V. $n^{\circ} 69$ del 30 de abril de 1857.

616 A.D.P.V. Actas. Libro de actas de 17 de diciembre de 1857. B.O.P.V. N 204 de 31 de diciembre de 1857. 
hijo de viuda pobre, hijo de padre sexagenario, hermano en el ejército, etc., etc. Para el repartimiento del mes de diciembre, las sesiones para "oír las reclamaciones" se efectúan en dieciseis sesiones y 333 expedientes.

El 22 de marzo de 1858 se reúne la Diputación en sesión extraordinaria, "convocada por el Sr. gobernador para tratar el tema del repartimiento de 366 soldados, señalados a esta provincia de los 25.000 pedidos por real orden de 15 de mayo, con destino al Ejército Activo. Se procede al reparto entre los pueblos de la provincia, con arreglo a los 1.865 mozos sorteados en 1857, señalando el día 30 para celebrar el sorteo"617. Una vez celebrado el sorteo se procedió a comunicar a los pueblos las fechas de "entrega en caja" y se iniciaron las sesiones públicas para tratar de las reclamaciones recibidas, que tienen lugar en el mes de julio en catorce sesiones, en las que se "oyeron" 309 expedientes.

Para el año 1859, se convoca un remplazo a través del real decreto de 1 de mayo, "por el que se llama al servicio de las armas a 25.000 hombres para el año actual con destino al reemplazo del Ejército Activo. A esta provincia la corresponde un cupo de 379 soldados de acuerdo a los 1.949 mozos sorteados en abril de 1858 "618. Las reclamaciones se tramitan por el Consejo, resolviendo un total de 263 expedientes.

El reemplazo del año 1860 se convoca por la ley de 2 de noviembre de 1859 , "llamando al servicio de las armas para 1860 a 50.000 hombres, petición adelantada a causa de la guerra de África". Se completa con la real orden de 3 de diciembre, "por la que se dispone la reunión de la Diputación, con el fin de practicar el repartimiento del cupo correspondiente al reemplazo de 50.000 hombres, correspondiendo a Valladolid 737 mozos por los 2.002 sorteados en el año 1859" "619. Los 660 expedientes de reclamaciones se estudiaron durante los meses de enero y febrero.

El día 1 de enero de 1861, en la sesión que celebra la Diputación "se da lectura a la ley de 15 de diciembre por la que se llama al servicio de las armas a 35.000 hombres correspondientes al actual año de 1861. A Valladolid le corresponden 579 por 2.181 mozos sorteados en el año 1860 " ${ }^{20}$. El sorteo de "décimas" se celebró el 5 de enero, el día 10 se publicaron las listas definitivas y las 522 reclamaciones correspondientes a este reemplazo se vieron en el Consejo provincial.

En la sesión del 13 de marzo de 1862, en el salón de sesiones de la Diputación, "se dio cuenta de la ley de 1 del actual, por el que se llama al servicio de las armas a 35.000 hombres del alistamiento y sorteo del año corriente, y al mismo tiempo se dio lectura a la real orden de 2 de marzo por la que se señala a esta provincia 534 soldados e igualmente se acordó fijar la fecha de sorteo para el 19 de marzo" ${ }^{621}$. Tanto el sorteo como los repartimientos son publicados en el Boletín Oficial de la Provincia del día 23 de marzo y las audiencias públicas para "oír las reclamaciones" se celebran en el Consejo en las que se da solución a 453 expedientes.

Para el año 1863, en la sesión de la Diputación del 2 de marzo, "se da lectura a la ley de 17 de febrero último por el cual se llama al servicio de las armas a 35.000 hombres del alistamiento y sorteo del año corriente de 1863. También se da lectura a la real orden de 8 de febrero que señala a esta provincia 513 soldados por 2.122 mozos sorteados en el año 1861"622. Se fija la fecha de 5 de marzo para el sorteo de "décimas". Las 471 reclamaciones son vistas en audiencia pública por el Consejo provincial, a lo que hay que añadir cinco sesiones más dedicadas a la presentación y aceptación de sustitutos.

A.D.P.V. Actas. Libro de actas del día 22 de mayo de 1858 .

618 A.D.P.V. Actas. Libro de actas del 7 de mayo de 1859.

619 B.O.P.V. n 175 de 13 de noviembre de 1859. A.D.P.V. Actas. Libro de actas del 12 de diciembre de 1859 .

620 A.D.P.V. Actas. Libro de actas del día 1 de enero de 1861.

621 A.D.P.V. Actas. Libro de actas del 13 de marzo de 1862.

622 A.D.P.V. Actas. Libro de actas del 2 de marzo de 1863. 
El repartimiento de quintos correspondiente al Reemplazo de 1864 se aprueba en la sesión que la Diputación celebra el día 1 de abril, "de acuerdo con la ley de 18 de marzo, por la que se aprueba un reemplazo de 35.000 hombres del alistamiento de 1864, correspondiendo a la provincia 517 soldados en función de los 2.139 mozos sorteados en el año $1863 "$ "623. Se fija el sorteo de décimas para el 6 de abril. En el mes de mayo se celebran en el Consejo las audiencias públicas para tratar las reclamaciones de 545 expedientes.

En el año 1865, por real orden de 19 de mayo, se convoca "un repartimiento de 35.000 hombres para el ejército activo y la reserva, correspondientes al sorteo de 1865 y a tal efecto la Diputación celebra sesión extraordinaria para efectuar el repartimiento de los 557 soldados que han correspondido a la provincia por los 2.315 mozos sorteados en $1864 " 624$. Las audiencias públicas para oír las reclamaciones se celebran en doce sesiones y 498 expedientes.

En la sesión extraordinaria que celebra la Diputación el 28 de mayo de 1866, "se trata sobre el repartimiento de 457 soldados señalados a la provincia, correspondientes a los 30.000 hombres convocados para el alistamiento y sorteo del año 1866 y de acuerdo con la real orden de convocatoria, se cubrirán en primer lugar los soldados necesarios para completar las armas especiales de Caballería e Infantería entre mozos de 20 a 21 años. El resto hasta los 30.000 ingresará en los Cuerpos de la Reserva, destinando cada soldado al batallón provincial que le corresponda" ${ }^{625}$. En la misma sesión se acuerda celebrar el sorteo de "décimas" y posteriormente resolver 392 reclamaciones.

El Boletín Oficial de la Provincia del 2 de julio de 1867 hace público "el llamamiento a filas de 40.000 hombres para el alistamiento y sorteo de este año. A Valladolid le corresponden 662 hombres por los 2.389 mozos sorteados en el presente año"626. El repartimiento correspondiente a este reemplazo se trata en la sesión que celebra la Diputación el día 6 de julio. El Consejo tratará sobre 549 reclamaciones.

En el año 1868, se convoca un nuevo reemplazo correspondiente al mismo año, de 40.000 hombres, de los cuales le corresponden a la provincia de Valladolid 665 soldados por los 2.369 hombres sorteados en 1.867. La Diputación inicia los trabajos correspondientes en la sesión celebrada el día 29 de febrero, "con el resumen del repartimiento de los 665 hombres señalados a esta provincia del alistamiento y sorteo del año actual, por virtud de la Ley de 26 de junio último y hallándolo conforme se aprobó y se señaló para el sorteo de soldados por razón de décimas el 5 de marzo próximo" 627 . Las 580 reclamaciones se tratan en el Consejo provincial, en veintiocho sesiones públicas.

Iniciado el Sexenio Revolucionario, se convoca un nuevo reemplazo para el Ejército correspondiente al año 1869, a través del decreto del Gobierno del 26 de marzo. A la convocatoria habitual, en este caso de 25.000 hombres de los cuales corresponden a la provincia de Valladolid 421 en función de los 2.281 mozos sorteados en 1868, se le añaden una serie de condiciones peculiares al proponer que "este llamamiento se puede cubrir con mozos de 20 a 30 años, con mozos de 30 a 40 años que hayan sido soldados y se alisten voluntarios ó con 600 escudos" ${ }^{628}$. La Diputación en la sesión que convoca para tratar sobre el repartimiento de este reemplazo, da lectura y trata sobre "la ley de 26 de marzo y la intención de que la Diputación pueda llenar el cupo de mozos que le corresponde con voluntarios o en metálico, y está dispuesta a evitar que los pueblos se vean precisados a cubrir el contingente con el tercer medio que indica la ley" ${ }^{629}$. Es decir, la Diputación no quiere

623 A.D.P.V. Actas. Libro de actas del día 1 de abril de 1864.

624 A.D.P.V. Actas. Libro de actas del 26 de mayo de 1865.

625 A.D.P.V. Actas. Libro de actas del 28 de mayo de 1866.

626 B.O.P.V. $n^{\circ} 312$ de fecha 2 de julio de 1867.

627 A.D.P.V. Actas. Libro de actas del 29 de febrero de 1868.

628 B.O.P.V. $n^{\circ} 70$ correspondiente al 30 de marzo de 1869.

629 A.D.P.V. Actas. Libro de actas del día 5 de abril de 1869. 
que los "mozos de 20 a 30 años" vayan al Ejército y espera y desea que aparezcan voluntarios. En último caso estaría dispuesta, sobre el papel y en principio, a arbitrar los medios necesarios para cubrir los costes de no enviar los mozos y abonar 6.000 reales por cada recluta que no encuentre un voluntario y con esta última finalidad anuncia la subasta de un empréstito de 240.000 escudos "acordando fijar el 15 de junio para la subasta de acciones del crédito de quintos. También admite voluntarios para cubrir el cupo de mozos de reemplazo, por 50 escudos al ingresar y 300 escudos al año de presencia, o por 400 milésimas (de escudo) al día durante cuatro años de servicio activo" ${ }^{630}$.

Además de estas acciones, tendentes a cubrir el reemplazo con voluntarios o con dinero, la Diputación envía una circular a todos los pueblos animándoles a cubrir las plazas que le correspondan a cada uno con voluntarios "para que ni un solo hijo de la provincia vaya al servicio de las armas contra su voluntad" ${ }^{631}$. Pero la realidad se impone y la penuria y la falta de entusiasmo por el Ejército se reflejan en las actas al ver que "de los 421 soldados correspondientes a la provincia, sólo se han presentado 18 voluntarios y no se habían presentado licitadores a la subasta de los 240.000 escudos. La Diputación admite la imposibilidad de cumplir con su deseo al no tener ni voluntarios ni dinero, y en consecuencia acuerda fijar las fechas para la entrega de quintos por parte de los pueblos entre los días 27 de julio a 1 de agosto" ${ }^{632}$. Las reclamaciones correspondientes a este reemplazo, ante la desaparición del Consejo, son atendidas por la Diputación provincial, que ve 280 expedientes, con las habituales reclamaciones referidas a la talla, situación familiar y enfermedades varias como "padecer del estómago", "tener varices" o "incapacidad mental". Otras más curiosas o llamativas son "padecer de los órganos genitales" o "retracción en el flexor del dedo meñique de la mano derecha".

El reemplazo de 1870 convoca al servicio de las armas a 40.000 hombres y la Diputación en sesión extraordinaria, "acuerda fijar el 15 de mayo para efectuar las operaciones de repartimiento de los 683 soldados que le corresponden por los 2.545 mozos sorteados en 1869 de un total de 40.000 hombres. También acordó fijar el sorteo de décimas el 10 de junio y la publicación de los resultados en el Boletín Oficial de la Provincia del 12 del mismo mes" ${ }^{633}$. Este año no hubo ningún tipo de intención por parte de la Diputación ni de hacer un llamamiento para la presentación de voluntarios, ni tampoco se hizo propaganda para liberar a los mozos del Ejército a través de dinero, pues se sabía que en la provincia no había "ni voluntarios ni dinero". Las reclamaciones "se ven en audiencia pública de la Diputación" en catorce sesiones en las que se tratan 609 expedientes, con las habituales peticiones de "inutilidad" y además otras curiosas como "tener tiña", "ser tartamudo", "padecer de pulmón, asma y hernia" ó "tener caries en mandíbula inferior" por la que es declarado inútil.

Para el año 1871, se ordena un reemplazo y se efectúa el repartimiento correspondiente en sesión extraordinaria de la Diputación, "dando lectura a la real orden de 9 de julio por la que se llama al servicio de las armas a 35.000 hombres. El cupo señalado a la provincia en relación con los 2.656 mozos sorteados es de 640 soldados. A cada mozo le corresponden 2 décimas y 41 milésimas y después de aplicar esta fracción a los de cada pueblo se leyó y aprobó la distribución realizada" ${ }^{634}$. Para solucionar el tema de las reclamaciones, se ocupa la Comisión provincial, institución creada en ese mismo año, que se tratan 516 expedientes de reclamaciones y 139 de sustituciones.

En el año 1872, se convoca un reemplazo de 40.000 hombres, realizándose por la Diputación el repartimiento correspondiente, "por el que ha correspondido a la

\footnotetext{
630 A.D.P.V. Actas. Libro de actas del día 1 de mayo de 1869.

631 B.O.P.V. n ${ }^{\circ} 122$ correspondiente al 5 de Junio de 1869.

632 A.D.P.V. Actas. Libro de actas del 18 de julio de 1869.

633 A.D.P.V. Actas. Libro de actas del 10 de junio de 1870

634 A.D.P.V. Actas. Libro de actas del 19 de julio de 1871 .
} 
provincia 676 soldados por los 2.380 mozos sorteados en este año"635. Las reclamaciones se ven en la Comisión provincial con 479 expedientes de reclamación, 143 de redención y 54 de sustitución.

En el año 1873, el Boletín Oficial de la Provincia publica una circular en la que "el gobernador interino D. Ramón Lafarga, convoca a la Diputación para el día 29 de agosto, de acuerdo con el artículo treinta y ocho de la Ley Provincial de 20 de agosto de 1870, para llevar a efecto la movilización de 80.000 hombres y hacer la distribución del cupo que corresponde a cada pueblo. En Valladolid de 2.208 mozos alistados, sirven de base para fijar el cupo de 1.452 hombres" ${ }^{636}$. En la sesión extraordinaria convocada con anterioridad a realizar las labores de repartimiento se lee una queja del diputado Alonso Pesquera, "por el agravio que supone el que del repartimiento de los 80.000 hombres en todo el país, hayan quedado libres de él cuatro provincias: Canarias, Álava, Guipúzcoa y Vizcaya" ${ }^{637}$. El sorteo de décimas y la lista del repartimiento definitivo se efectúan el 4 de septiembre y las reclamaciones correspondientes, que ascienden a 891 expedientes, se ven y se tratan entre septiembre y octubre en veinticuatro "audiencias públicas".

En el mes de enero de 1874, con la situación política muy complicada, se publica un decreto "llamando a filas a todos los mozos de la reserva" ${ }^{638}$ y en el mes de mayo un nuevo decreto del presidente de la República amplía el número de mozos a ingresar en el Ejército, "llamando a las armas a todos los mozos que el 31 de diciembre último hubieran tenido 19 años cumplidos" ${ }^{639}$. Con estos planteamientos no es necesario el hacer repartimientos ni sorteos de mozos, pues se convoca en principio a todos los mozos de la reserva y posteriormente a todos los de 19 años cumplidos. Aunque tampoco la Diputación refleja en sus actas la fecha del ingreso de los mozos en Caja, por lo que el Ministerio de la Gobernación fija el 16 de junio como plazo máximo de presentación de los reclutas. Unos días antes de la finalización del plazo de presentación, nuevamente el Ministerio de la Gobernación envía una comunicación a las provincias en las que hace notar que "el ingreso en caja ha ido por lo general con regularidad, pero es considerable el número de los mozos declarados soldados que no se han presentado por lo que se decreta que se prolonga hasta el día 20 del actual el plazo para presentarse. Los mozos que no se presenten serán declarados prófugos. Se reclamará a los mozos o a sus padres 5.000 pesetas. Los insolventes sufrirán prisión ordinaria de un día por cada medio duro de deuda" ${ }^{640}$. Decreto que según parece no dio mucho resultado pues el Gobierno tiene que prorrogar el plazo de presentación hasta el 30 de junio.

La situación política se sigue deteriorando y las sublevaciones en diferentes zonas de la península se siguen extendiendo. El Gobierno en un nuevo decreto "ordena la formación de 80 nuevos batallones con 125.000 hombres para la reserva extraordinaria. A Valladolid le corresponden 2.101 mozos por 28.556 varones de 22 a 35 años, según el censo de $1860 "$ "641.

Estas convocatorias no se reflejan en las actas de la Diputación, es decir, no se tratan en las sesiones ni los repartimientos ni los sorteos, pero sí es cierto que se efectúan por las "numerosísimas" reclamaciones que se reciben en la Comisión porovincial a lo largo del año, así tenemos: En febrero 326 expedientes, en marzo 79, en junio, 660, en agosto 440, en septiembre 474. En resumen, un excesivo número de reclamaciones que se corresponden al mismo tiempo con un excesivo número de mozos reclamados por el Ejército en el último año de vigencia del Sexenio Revolucionario.

\footnotetext{
635 A.D.P.V. Actas. Libro de actas del 20 de noviembre de 1872.

636 B.O.P.V. $n^{\circ} 128$ correspondiente al día 28 de agosto de 1873.

637 A.D.P.V. Actas. Libro de actas del 29 de agosto de 1873.

638 B.O.P.V. Boletín del 11 de enero de 1874

639 B.O.P.V. Boletín del 5 de mayo de 1874.

640 B.O.P.V. Número extraordinario del 10 de junio de 1874

641 B.O.P.V. n 109 del 21 de julio de 1874.
} 
A continuación presentamos unos cuadros en los que se reflejan, a lo largo de todo el período estudiado, los reemplazos llevados a efecto, los mozos afectados, el número total de reclamaciones y un detalle sobre las reclamaciones más usuales. También hacemos notar que el incremento de las reclamaciones está en relación directa con las dificultades por las que atraviesa la provincia, es decir, a mayor penuria más reclamaciones. Otro factor importante del rechazo al ingreso en el Ejército es el concerniente a la necesidad de mano de obra en el campo, mano de obra formada sobre todo por los hijos de los campesinos y si son jornaleros y tiene familia a su cargo el ingreso "en filas" supone el hambre para la familia.

RESUMEN DE REEMPLAZOS Y RECLAMACIONES

\begin{tabular}{|c|c|c|c|c|c|c|c|c|c|c|}
\hline Año & 1821 & 1822 & 1835 & 1836 & 838 & 839 & 1840 & 1841 & 1842 & 1843 \\
\hline $\mathrm{N}^{\circ}$ de mozos & 301 & 589 & 1528 & 770 & 624 & 630 & 394 & 394 & 394 & 394 \\
\hline Reclamaciones & 379 & 507 & 779 & 303 & 320 & 293 & 254 & 273 & 323 & 380 \\
\hline \multicolumn{11}{|l|}{ Tipo de Reclamación } \\
\hline Error en sorteo & 0 & 0 & 21 & 9 & 9 & 0 & 2 & 0 & 10 & 5 \\
\hline Diversos & 0 & 63 & 74 & 55 & 34 & 34 & 19 & 22 & 18 & 20 \\
\hline Corto de talla & 61 & 74 & 137 & 57 & 100 & 00 & 140 & 192 & 175 & 178 \\
\hline Hijo de viuda pobre & 14 & 52 & 74 & 65 & 46 & 46 & 32 & 16 & 14 & 21 \\
\hline Hijo de sexagenario & 10 & 35 & 36 & 20 & 15 & 15 & 12 & 10 & 6 & 5 \\
\hline Hermano en Ejército & 15 & 10 & 29 & 43 & 37 & 37 & 16 & 5 & 16 & 9 \\
\hline Inútil-enfermo & 105 & 107 & 143 & 34 & 43 & 43 & 29 & 28 & 14 & 11 \\
\hline Situación familiar & 144 & 55 & 93 & 15 & & 7 & 2 & 0 & 6 & 8 \\
\hline Sustitutos & 13 & 76 & 104 & 17 & & 6 & 0 & 64 & 12 & 1 \\
\hline Prófugos & 17 & 35 & 68 & 5 & 5 & 8 & 2 & 0 & 0 & 2 \\
\hline Año & 1844 & 1845 & 1846 & 1847 & 1848 & 1849 & 1850 & 1851 & 1853 & 1854 \\
\hline $\mathrm{N}^{\mathrm{o}}$ de mozos & 788 & 394 & 394 & 394 & 394 & 394 & 394 & 146 & 315 & 317 \\
\hline Reclamaciones & 621 & 308 & 317 & 354 & 389 & 401 & 333 & 140 & 254 & 248 \\
\hline \multicolumn{11}{|l|}{ Tipo de Reclamación } \\
\hline Corto de talla & 362 & 143 & 121 & 157 & 134 & 151 & 148 & 61 & 93 & 81 \\
\hline Hijo de viuda pobre & 40 & 17 & 23 & 12 & 19 & 28 & 15 & 11 & 21 & 17 \\
\hline Hijo de sexagenario & 28 & 7 & 9 & 11 & 11 & 9 & 13 & 5 & 7 & 12 \\
\hline Hermano en Ejército & 18 & 14 & 8 & 15 & 17 & 19 & 12 & 4 & 3 & 9 \\
\hline Inútil-Enfermo & 28 & 34 & 41 & 40 & 53 & 82 & 47 & 43 & 61 & 74 \\
\hline Situación Familiar & 8 & 10 & 13 & 15 & 12 & 19 & 7 & 7 & 11 & 13 \\
\hline Error en sorteo & 26 & 7 & 12 & 19 & 12 & 3 & 7 & 2 & 5 & 3 \\
\hline Diversos & 43 & 15 & 34 & 21 & 41 & 14 & 34 & 7 & 21 & 11 \\
\hline Sustitutos & 63 & 54 & 47 & 53 & 72 & 59 & 41 & 0 & 31 & 19 \\
\hline Prófugos & 5 & 7 & 9 & 11 & 18 & 17 & 9 & 0 & 2 & 9 \\
\hline A $\tilde{\mathbf{n o}}$ & 1855 & 1856 & 1857 & 1858 & 1859 & 1860 & 1861 & 1862 & 1863 & 1864 \\
\hline $\mathrm{N}^{\mathrm{o}}$ de mozos & 320 & 466 & 1197 & 366 & 379 & 737 & 579 & 534 & 519 & 517 \\
\hline Reclamaciones & 209 & 463 & 1015 & 309 & 263 & 660 & 522 & 453 & 471 & 545 \\
\hline \multicolumn{11}{|l|}{ Tipo de Reclamación } \\
\hline Corto de talla & 120 & 95 & 214 & 141 & 97 & 179 & 189 & 141 & 153 & 147 \\
\hline Hijo de viuda pobre & 23 & 40 & 72 & 16 & 19 & 64 & 34 & 29 & 41 & 30 \\
\hline Hijo de sexagenario & 21 & 35 & 49 & 11 & 8 & 49 & 27 & 25 & 36 & 31 \\
\hline Hermano en Ejército & 3 & 4 & 27 & 13 & 11 & 23 & 12 & 19 & 15 & 22 \\
\hline Inútil-Enfermo & 19 & 143 & 297 & 31 & 58 & 193 & 109 & 93 & 117 & 131 \\
\hline Situación Familiar & 5 & 12 & 39 & 15 & 13 & 15 & 27 & 13 & 36 & 50 \\
\hline Error en sorteo & 14 & 41 & 13 & 6 & 2 & 19 & 9 & 18 & 12 & 15 \\
\hline Diversos & 4 & 68 & 83 & 14 & 27 & 41 & 47 & 69 & 5 & 51 \\
\hline Sustitutos & 0 & 22 & 189 & 53 & 23 & 61 & 56 & 40 & 53 & 59 \\
\hline Prófugos & 0 & 3 & 32 & 9 & 5 & 16 & 12 & 6 & 3 & 9 \\
\hline Año & 1865 & 1866 & 1867 & 1868 & 1869 & 1870 & 1871 & 1872 & 1873 & 1874 \\
\hline $\mathrm{N}^{\mathrm{o}}$ de mozos & 557 & 457 & 662 & 665 & 421 & 683 & 640 & 676 & 145 & 2101 \\
\hline Reclamaciones & 498 & 392 & 549 & 580 & 280 & 609 & 655 & 676 & 891 & 1979 \\
\hline
\end{tabular}


Tipo de Reclamación

Corto de talla

Hijo de viuda pobre

Hijo de sexagenario

Hermano en Ejército

Inútil-Enfermo

Situación Familiar

Error en sorteo

Diversos

Sustitutos

Prófugos

$\begin{array}{llllllllll}161 & 103 & 179 & 142 & 43 & 65 & 133 & 112 & 207 & 492 \\ 33 & 21 & 38 & 53 & 25 & 48 & 47 & 51 & 33 & 79 \\ 20 & 15 & 27 & 19 & 29 & 56 & 41 & 31 & 40 & 74 \\ 12 & 17 & 12 & 39 & 16 & 37 & 53 & 59 & 41 & 190 \\ 129 & 103 & 141 & 173 & 61 & 125 & 148 & 121 & 271 & 597 \\ 19 & 41 & 20 & 17 & 10 & 18 & 21 & 47 & 30 & 83 \\ 11 & 7 & 3 & 12 & 3 & 47 & 19 & 12 & 10 & 37 \\ 54 & 20 & 72 & 20 & 16 & 15 & 23 & 19 & 91 & 125 \\ 47 & 62 & 51 & 93 & 68 & 184 & 139 & 197 & 149 & 253 \\ 12 & 3 & 6 & 12 & 9 & 14 & 31 & 27 & 19 & 49\end{array}$

\subsection{3.- SUMINISTROS Y BAGAJES}

A principios de este capítulo nos hemos referido a la desorganización existente en el Ejército en los años 1812-14, que coincide con el final de la invasión francesa y también con la entrada en funcionamiento de las Diputaciones. A esta institución la llegan en sus primeros días de existencia una serie de reclamaciones procedentes de la mayoría de los pueblos, reclamaciones que se pasan al Ejército, en las que se lamentan por los inconvenientes que sufren ante la presencia de las numerosas tropas que circulan por la provincia.

Estas tropas generan una serie de exigencias, de problemas y de gastos que tienen que ser satisfechos por los vecinos. Aunque posteriormente estos reclaman a la Diputación el pago de los servicios realizados, no están conformes con la situación, entre otras cosas porque tienen que adelantar el dinero o la mercancía y luego tardan mucho tiempo en recuperarlo, lo que les provoca una serie de dificultades, en especial por la crítica situación económica en que se encuentra la provincia.

Es tal la importancia de este problema y la reticencia de los pueblos a colaborar en el suministro, que las Cortes aprueban un decreto por el que se ordenaba a la Diputación "que se abonen a los pueblos los suministros que se hagan a las tropas portuguesas, una mitad en dinero en efectivo y la otra mitad en cuantía de sus respectivas contribuciones" ${ }^{642}$. En otras ocasiones, es la propia Diputación la que tiene que organizar los suministros para evitar abusos y dificultades en los aprovisionamientos. Así ocurre con el acuerdo que se toma ante las reclamaciones que hacen los pueblos de las merindades del Tera ${ }^{643}$. En el caso de la capital, las quejas se centran en la obligación de alojar a los oficiales durante un excesivo número de días.

Con la llegada del Trienio Liberal y la vuelta a la actividad de la Diputación, ésta se vuelve a hacer cargo y a tratar de resolver los problemas de transportes, de suministros y de alojamientos, que genera el Ejército en la provincia. Son obligaciones que pesan sobre los ciudadanos sin tener a cambio ninguna ventaja o satisfacción, ya que el cobro de los suministros sigue siendo una tarea "harto difícil de conseguir". En estos años, además aparecen nuevas exigencias de los militares, como es la "requisa de caballos" para el equipamiento del Ejército. Este es un trabajo encargado a la Diputación y que resulta "antipático" a los labradores, pues no tienen los animales para su recreo, sino por necesidades de trabajo y no admiten de buen grado la requisa. Además la Diputación tiene que adelantar los dineros para el pago de los animales.

Ya en la época isabelina, en febrero de 1837, se presenta en la Diputación el "Reglamento de Bagajes y Suministros", redactado con la finalidad de fijar y organizar los derechos y las obligaciones tanto del Ejército como de los ciudadanos. Pretenden conseguir un buen servicio con respecto a estos temas, en especial el

642 A.D.P.V. Actas. Libro de actas del día 3 de marzo de 1814

643 "Acordando que las tropas en tránsito a Galicia que vayan de Benavente a Puebla, o las que vuelvan de Galicia, se racionen en estos dos puntos o cabezas de partido sin exigir cosa alguna en los pueblos de la vereda, a cuyo efecto se han fijado los correspondientes almacenes e igualmente se acordó oficiar al comandante general y jefe político de esta provincia para que las tropas en tránsito se racionen en Benavente y Puebla de Sanabria" A.D.P.V. Actas. Libro de actas del día 1 de abril de 1814. Recordamos que en estos años tanto Benavente como Puebla de Sanabria pertenecían a la provincia de Valladolid. 
referido a los bagajes, ya que es siempre motivo de discusión la obligación de poner a disposición del Ejército tanto animales como carromatos para el traslado de la tropa y del material correspondiente. Además de otros trabajos que surgen y que los pueblos reclaman, como sucede con la petición y reclamación de San Miguel del Pino, que "solicita al Ayuntamiento que se le exima al pueblo de la obligación de aportar carros y caballerías para el servicio de fortificación de la capital" "644.

Son unos años de enfrentamientos bélicos en las provincias del norte del país y el Ejército en su continuo ir y venir por la provincia continua generando enfrentamientos y roces en su trato con los pueblos ${ }^{645}$. Sin duda, las dificultades del Ejército para equipar y alimentar a los soldados se ven agravadas por la desconfianza de los proveedores habituales ante la falta de pago de sus servicios. Esto hace que el intendente militar del Ejército de Castilla la Vieja envíe a finales de 1837 un oficio a la Diputación manifestando la exigencia de ayudas ${ }^{646}$. La Diputación, en cumplimiento de lo dispuesto, celebró sesiones extraordinarias los días 1 y 2 de enero de 1838 . Se procedió a la subasta de los suministros solicitados con la condición de que el pago se hiciera por la Hacienda Militar "que debía de satisfacer religiosamente el importe del valor de los artículos con el primer ingreso correspondiente a la consignación del mes de diciembre próximo pasado" ${ }^{647}$.

Pero la situación está tan revuelta que todos los pueblos se quejan de la presión a que están sometidos. Así lo pone de manifiesto Joaquín Maldonado, ex diputado provincial y comisionado de Suministros y Bagajes de Olmedo en exposición remitida a la Diputación, en la que destacaba "los graves apuros en que se veía la comisión por falta de fondos para hacer los suministros que diariamente se le reclamaban y a la dificultad de que los pueblos de Pozaldez y Ataquines se negaban a satisfacer los cupos que les habían cabido en el repartimiento" ${ }^{648}$.

Ante esta situación de continuos abusos por un lado y negativas a colaborar por el otro, la Diputación aprobó un "Reglamento para el Servicio de Bagajes y Suministros de la Provincia" redactado por la comisión formada en 1837 y presentado en 1838. Estaba constituido por cuatro capítulos y veintinueve artículos, en los que se reflejaban los derechos y obligaciones sobre este tema. En el capítulo primero, en cinco artículos, se trata sobre el servicio de bagajes. El servicio de bagajes es una carga general que comprende a todos los contribuyentes de la provincia .La Diputación repartirá entre los pueblos los fondos que se necesiten. Los Ayuntamientos harán la distribución del cupo correspondiente, que será entregado al depositario provincial y expuesto al público para que puedan presentar las reclamaciones pertinentes.El capítulo segundo, dividido en siete artículos está referido a la retribución. Se fijan la cuantía de los servicios de bagajes, especificando la retribución por la dificultad del camino. Se fijan los precios de los retenes, de los pueblos cabeza de cantón. Se fija el sistema administrativo de acreditar el servicio y la forma de cobrar al término del mismo. Se fija la acreditación de los pueblos que no hacen un servicio regular. El capítulo tercero, de cinco capítulos, está referido a los encargados

644 A.D.P.V. Actas. Libro de actas del día 6 de mayo de 1837. Reclamación que fue rechazada puesto que la ley especificaba "que todos los agricultores de 5 leguas a la redonda tenían la obligación de aportar su ayuda a las obras".

645 “Abusando al pedir suministros y negándose a entregar los bonos correspondientes, no pudiendo (la Diputación) ejercer actuaciones por estar declarada la provincia en estado de guerra...y quejándose al capitán general por hacer una requisitoria, sin autorización del Gobierno, de 18 caballos para el Regimiento de Húsares" A.D.P.V. Actas. Libro de actas del 16 de noviembre de 1837.

646 "que no habiendo acudido postores a la subasta que había celebrado para proporcionar 222,5 arrobas de tocino, 118 de bacalao, 256 arrobas de arroz y 240 de aceite, con el objeto de proveer al fuerte de San Benito de esta capital y completar el número de 60.000 raciones, según orden del capitán general, se veía en la previsión de reunir a la Diputación para que por los medios que estime convenientes dispusiera la reunión de los referidos pedidos... garantizando el pago del total importe de los mismos..." A.D.P.V. Actas. Libro de actas del 31 de diciembre de 1837. A.D.P.V. Actas. Libro de actas del día 1 de enero de 1838 .

648 A.D.P.V. Actas. Libro de actas del 16 de enero de 1838. 
del régimen y buen orden del servicio. Habrá una comisión en cada cantón presidida por el alcalde y formada por cuatro individuos, que serán elegidos anualmente, con atribuciones para el buen funcionamiento de los bagajes. El depositario provincial será el encargado de pagar los servicios realizados. El capítulo cuarto, con once artículos, trata acerca del suministro de raciones. El suministro de raciones será una carga municipal a la que están obligados todos los ciudadanos. Las comisiones de bagajes tendrán intervención en la administración de los suministros, y las mismas comisiones cuidarán de que se reintegren a los pueblos el importe de los suministros, aun cuando sea un suministro accidental por algún pueblo que no sea punto de etapa. Se especifican las obligaciones de los almacenistas, la responsabilidad de los Ayuntamientos y de las comisiones. Se especifican la responsabilidad de las comisiones y de los alcaldes. La Diputación resolverá en caso de dudas y reclamaciones.

A lo largo del mes de enero de 1838, se aprobó el reglamento, se acordó su publicación y se aprobaron igualmente "los puntos de etapa y pueblos agregados a cada cantón, además de la división de la provincia en diecinueve cantones ${ }^{649}$. El reglamento detalla la forma de efectuar los bagajes y de repartir los suministros, pero no contenta a los pueblos porque tienen que continuar soportando las numerosas peticiones y además sufrir el atraso en el abono de los servicios, como queda patente por la queja de los pueblos "por el frecuente tránsito de tropas por los diferentes pueblos de la provincia y la continua demanda de suministros" ${ }^{650}$. También el Ayuntamiento de la capital se queja porque el comisario de Guerra "reclamaba del Ayuntamiento 3.200 raciones de carne y vino para el suministro de las tropas que acaban de 1legar" $" 651$.

Los servicios de bagajes y de suministros a la tropa tienen una mayor demanda entre los años 1837 y 1840, especialmente motivado por las guerras en el norte del país. Entre 1840 y 1845 aparecen con una menor continuidad, ya que los movimientos de tropas por la provincia prácticamente se han paralizado. Se reseñan en las actas esporádicamente algunas reclamaciones por atraso en los pagos de suministros y también quejas entre cantones por falta de colaboración. A partir del año 1845, con la creación del Consejo provincial, una serie de actividades realizadas por la Diputación pasan a ser gestionadas por el citado Consejo de acuerdo con la real orden publicada en el Boletín Oficial de la Provincia. Entre ellas las relacionadas con los bagajes y los suministros, "para que los Consejos provinciales sustituyan a las Diputaciones en la liquidación de los suministros hechos por los pueblos, de conformidad con el informe emitido por el intendente general militar..." ${ }^{, 652}$. También para facilitar tanto el suministro como el pago, el gobierno acuerda unificar en cada provincia los precios de los suministros a la tropa, y la Diputación "acordó nombrar una comisión formada por los diputados Rueda y Montealegre para fijar los precios de los suministros a la tropa" ${ }^{653}$. A partir del año 1847 , se acordará mes por mes los precios que se fijan para los suministros ${ }^{654}$.

Pocas anotaciones aparecen en los libros de actas sobre las actividades y servicios de bagajes y suministros, tanto en los años en que se mantienen activos los Consejos, como en los años en que es suspendida su actividad. Parece que a partir del año 1860 , la Diputación vuelve a tomar este tema entre sus cometidos habituales al ver que, "de acuerdo con la real orden de 7 de marzo, declarando el servicio de bagajes

A.D.P.V. Actas. Libro de actas del 25 de enero de 1838, con la trascripción literal del Reglamento reseñado y de los acuerdos adoptados.

650 A.D.P.V. Actas. Libro de actas del día 15 de mayo de 1838.

651 A.D.P.V. Actas. Libro de actas del 5 de junio de 1838.

652 B.O.P.V. n 42 de fecha 7 de abril de 1846.

653 A.D.P.V. Actas. Libro de actas del 16 de marzo de 1846.

654 Los precios medios de los suministros a las tropas correspondientes a los años 1847 a 1874 , están mensualmente reflejados, tanto en los libros de actas como en los boletines oficiales de la provincia. 
gasto obligatorio de la provincia, la Diputación para conocer las condiciones y monto de la subasta pidió a las cabezas de cantones información de caballerías y carros utilizados en los años 1855-1859, acordando nombrar una comisión para estudiar las condiciones de remate" ${ }^{\prime 655}$. La Diputación estaba interesada en subastar el servicio, ya que era "un gasto provincial" y así evitar esta servidumbre a los pueblos. Pero esta idea no se plasmó en realidad al no aparecer licitadores interesados en hacerse cargo del servicio, tanto por escasez de dinero y también porque en la provincia no había ninguna "empresa" con capacidad suficiente para hacerse cargo de esta contrata. Por lo que se acordó que "al quedar desierta la subasta del servicio de bagajes en los trece cantones de la provincia, este servicio se seguirá prestando por los vecinos que pasarán las papeletas del servicio para que sean abonadas por la Diputación" ${ }^{656}$.

En el año 1863, la Corporación es consciente de que la proliferación de líneas férreas es un aliciente para unificar los servicios de bagajes y que sea precisamente por este medio por el que se hagan los transportes, tanto de tropas como de suministros. Por eso acordó pasar un informe al gobierno y, en espera del resultado de la consulta, fijó los siguientes precios de bagajes: Carro con 2 caballerías y 1 legua de servicio a 4'50 reales. Por cada caballería mayor se cobrará 1'50 reales. Por cada caballería menor el precio se incrementará en 1 real. Por cada caballería que lleve cada carro que exceda de dos: 1'50 reales.

A lo largo de los años 1863 a 1867 se continúa sacando a subasta el servicio de bagajes, pero también se repite, en todos estos años, el quedar desierta la subasta por falta de licitaciones. También los suministros se mantienen estables, pero en el año 1868, año especial de hambre y revolución para mantener cierta tranquilidad en los pueblos, el capitán general ordena que, "con el fin de acarrear el menor gravamen posible, con los movimientos de las tropas, a los pueblos de este distrito, cuya situación es en la actualidad tan tensa por la pérdida de la cosecha, se ordena a las tropas se aprovisionen de sus raciones en los puestos de partida para evitar el hacerlo en los pueblos del tránsito..." ${ }^{, 657}$.

En el año 1869 se vuelve a convocar subasta para el servicio de bagajes, "a celebrar el 28 de mayo bajo el tipo de 5.000 escudos la provincia a repartir entre los correspondientes cantones: Alaejos, 277 escudos. Vecilla, 320 escudos. Olmedo, 133 escudos. Portillo, 23 escudos. Cabezón, 254 escudos. Medina, 396 escudos. Simancas, 254 escudos. Tordesillas, 980 escudos. Fresno, 7 escudos. Rioseco, 327 escudos. Valladolid, 884 escudos. Mojados, 248 escudos. La Mota, 368 escudos. Villalón, 133 escudos. Villanubla, 396 escudos" ${ }^{\prime 658}$.

La Diputación, no obstante, sigue interesada en utilizar el ferrocarril, para lo que se pone en contacto con las Diputaciones de Palencia, Burgos, León y Santander, para fomentar este sistema. Finalmente parece que esta iniciativa tiene éxito a partir del año 1871, en el que la Diputación "abona al ferrocarril el transporte de los presos carlistas" ${ }^{\prime 659}$.

\subsection{4.- DE LA MILICIA NACIONAL A LA GUARDIA CIVIL}

La Milicia Nacional es un cuerpo armado que tiene su origen en la Constitución de 1812, que en su título octavo, capítulo segundo, trata de la formación de las Milicias. Sus actividades y cometidos serán detallados en el "Reglamento de la Milicia Nacional", publicado en abril de 1814 con la finalidad de: "Mantener la tranquilidad pública. Perseguir y aprehender a los malhechores y desertores. Escoltar las conducciones de presos y caudales públicos. Defender los hogares y término del pueblo, de los enemigos de la seguridad y tranquilidad". En síntesis y como recogía el apartado de "juramento de los milicianos", pretendía "la defensa de la Religión

655 A.D.P.V. Actas. Libro de actas del 16 de abril de 1860.

656 B.O.P.V. no 148 del 19 de septiembre de 1861 .

${ }^{657}$ B.O.P.V. n ${ }^{\circ} 161$ del 15 de julio de 1868.

658 A.D.P.V. Actas. Libro de actas del 25 de mayo de 1869.

659 A.D.P.V. Actas. Libro de actas del 14 de noviembre de 1871. 
Católica, Apostólica y Romana, la conservación del orden interior del pueblo, guardar y hacer guardar la Constitución, ser fieles al Rey, obedecer a los jefes y defender la bandera nacional..." ${ }^{660}$. En conclusión, se trata de un cuerpo armado, de carácter local, formado por los vecinos del pueblo, con la finalidad de pacificar los territorios, una vez acabada la guerra contra los franceses. Debía combatir a los bandidos y a las partidas de "facciosos" y desertores que se enseñoreaban del país y hacían inseguros e intransitables los caminos. ${ }^{661}$

Esta institución no se pondrá en funcionamiento en el "período constitucional" (1812-1814), por lo que la Diputación tampoco tiene que hacer frente a su organización en la parte que la corresponde. Será con los inicios del Trienio Liberal cuando con fecha 31 de agosto de 1820, se publica el real decreto de las Cortes con el nuevo "Reglamento de la Milicia Nacional", con algunas modificaciones con respecto al anterior, pero en el que las actividades básicas de su cometido se mantenían, es decir, el mantenimiento del orden público y la persecución de desertores y malhechores.

La Diputación, como institución provincial, asume una serie de actividades relacionadas con las Milicias, su organización, sus actividades y su financiación. Su trabajo se centra principalmente en: Atender las reclamaciones de los ciudadanos en todos los asuntos relacionados con la Milicia. Determinar qué individuos tienen derecho y quiénes tienen la obligación de ser milicianos. Vigilar la recaudación de las cuotas de los "exceptuados", obligados por librarse de la Milicia a pagar una cuota de 5 reales al día. Verificar la correcta utilización de los fondos y su inversión en la compra de armamento, material y uniformes. Presentar una terna, entre la que se nombrará al subinspector provincial.

El día 4 de mayo de 1821, se publica un "Reglamento adicional de la Milicia", que completa el anterior y organiza diferentes batallones de milicianos. En este nuevo reglamento se fija con detalle un tema que dio origen a una serie de aclaraciones y exposiciones presentadas por numerosas Diputaciones, y es el de "los individuos que por su actividad están exentos de participar en la Milicia". A este respecto, la Diputación de Valladolid envió una amplísima exposición al Gobierno sobre "la exacción de los jornaleros y lo que debíamos de entender por jornalero" ${ }^{662}$. Los jornaleros, los "clérigos in sacris" y los funcionarios eran parte de los individuos que no tenían obligación de incorporarse a la Milicia, aparte de los que abonaban los 5 reales diarios y los que eran rechazados por defecto físico, siendo realmente un importante grupo de personas. Pero además había otra forma de librarse, como es la practicada por el vizconde de Valoria que en exposición dirigida a la Diputación "solicita su exacción por ser hipocondríaco, y hace la oferta de 3.000 reales a favor de la Milicia Nacional. La Diputación acordó su exacción y que se le den las gracias por el donativo" "663.

Las actividades de la Milicia, así como sus reclamaciones a la Diputación en solicitud de mejoras y ampliación de sus miembros, se van incrementando a lo largo de los años del Trienio, a la vez que se va enrareciendo la atmósfera política y se va deteriorando la situación económica. La consecuencia directa es el aumento de los descontentos y la proliferación de malhechores y desertores. Una muestra de esta situación es la petición por parte del gobierno de un reemplazo extraordinario,

660 Ver el Reglamento de la Milicia Nacional publicado en la Gaceta de Madrid el día 18 de abril de 1814. Pág. 498 y sig.

661 PEREZ GARZÓN, Sisinio. Milicia Nacional y Revolución burguesa. Ed. C.S.I.C. Madrid. 1978.

Obra en la que hace un estudio completo sobre la evolución de la Milicia Nacional y su influencia en las actividades ciudadanas a lo largo de su existencia. Jorge LUENGO, en El nacimiento de una ciudad progresista... ob. cit., nos hace un interesante análisis de esta institución en Valladolid.

662 A.D.P.V. Actas. Libro de actas del 26 de octubre de 1820, donde se refleja íntegramente la exposición enviada a S.M. con el parecer de la Diputación sobre la definición de "jornalero". También aparece otra exposición enviada el día 16 del mismo día de octubre sobre "la explicación de la voz de "funcionario público" y su derecho a ser exento del servicio de la Milicia Nacional.

663 A.D.P.V. Actas. Libro de actas del 15 de diciembre de 1820. 
convocado en el año 1823, "en la cuantía de 1.313 hombres para completar los batallones de la Milicia Activa que corresponden a la provincia de Valladolid", cuando habitualmente los repartimientos que corresponden a la provincia no alcanzan el $50 \%$ de esa cifra.

La Milicia Nacional es disuelta con la llegada del período absolutista y en su lugar se crea la Asociación de Voluntarios Realistas, con objetivos similares a los estipulados para la Milicia, que volverá a su actividad una vez concluida la Década Ominosa. Será en el período isabelino cuando la Milicia tenga su mayor actividad. En esta nueva etapa la Milicia reaparece con el calificativo de "urbana", con un curioso matiz burgués, al exigir una serie de requisitos de índole económica para poder ingresar en la misma.

El primer jefe de la Milicia Urbana de Valladolid es D. Mariano Miguel de Reynoso, que posteriormente será diputado a Cortes, senador y ministro de Fomento. Al ponerse nuevamente en marcha la Diputación, recupera entre sus funciones el control sobre las actividades de la Milicia, que al poco tiempo de su nueva instalación pasa a denominarse Guardia Nacional ${ }^{664}$ con la misma finalidad, es decir, mantener el orden y luchar contra las bandas de forajidos y facciosos.

La verdad es que tienen una gran labor que hacer, pues la situación social no ha mejorado y el desorden es muy grande a lo largo de la provincia ya que proliferaron ladrones y bandidos. La Guardia tenía que hacer frente a las numerosas "partidas" de realistas o carlistas, situación que obliga al gobierno a publicar una real orden el 14 de febrero de 1836, "encargando a las Capitanías Generales formen noticia detallada de las fuerzas de la Guardia Nacional". La Diputación provincial, a petición del capitán general, le comunica la cuantía de las fuerzas en la provincia ${ }^{665}$.

El año 1836 finaliza con un nuevo cambio del nombre, pues por real orden de 3 de septiembre "se restablece el nombre de Milicia Nacional". Se la organiza en brigadas, batallones y compañías, y tras este cambio se efectúan una serie de nombramientos de jefes de la Milicia en numerosos pueblos de la provincia. Culmina con el nombramiento de subinspector de la Milicia Nacional en la provincia a petición del inspector general. A tal efecto "en sesión extraordinaria de la Diputación con los jefes de la Milicia de Valladolid se presentó una terna para que el inspector general nombre al subinspector provincial. Se designan a estos tres sujetos: Mariano Miguel de Reynoso, comandante del batallón de la Milicia Nacional de Valladolid. Francisco de Lara, comandante del escuadrón de la Milicia Nacional de Valladolid. Esteban Salvador Garrán, propietario y oficial de la Milicia Nacional" ${ }^{666}$. Fue elegido subinspector el comandante de la Milicia de Valladolid, Mariano Miguel de Reynoso.

La Diputación, responsable en parte de su buen funcionamiento, es desde luego la receptora de todas las quejas que tanto la Milicia como los vecinos la transmiten. Los vecinos porque no se sienten protegidos y los milicianos porque no se sienten respaldados ni apoyados por las autoridades, sobre todo en lo relativo al equipamiento y a su mantenimiento económico, lo que lleva al inspector de la Milicia a proponer "que sean los pueblos los que sufraguen sus respectivas fuerzas de milicianos" con la colaboración de la Diputación. La idea no convence al gobierno que recuerda por medio de un real decreto que "es atribución de las Diputaciones, los fondos que se

664 Real decreto publicado en el Boletín Oficial de la Provincia el 10 de octubre de 1835.

665 Destaca que "el total de efectivos de la Guardia Nacional era de 14.434 guardias, que entre ellos había algunos que fueron realistas y muchos en los que no concurren las circunstancias que requiere la ley ni gozaban de buena opinión, que en algunos pueblos no había quien enseñare a cuidar y manejar las armas y que en otros, todos los labradores salían a cultivar los campos y quedaba el pueblo con sólo mujeres... además de tener en cuenta que se necesitaban para equipar a la Guardia Nacional 9.367 armamentos, por lo que pedía a S.E. 1o solicitara al Gobierno de S.M...." A.D.P.V. Actas. Libro de actas del 11 de marzo de 1836.

666 A.D.P.V. Actas. Libro de actas del 24 de septiembre de 1836. 
recauden del impuesto de 5 a 50 reales sobre los que no prestan el servicio a la Milicia Nacional" $" 667$

La Milicia Nacional no es capaz de combatir a las partidas de "facciosos". Así lo demuestra la invasión de la capital por la partida de Zariategui, que fue ocupada sin haber encontrado oposición por parte de los milicianos y que tuvo como consecuencia la destitución de su cargo del subinspector Sr. Reynoso. Posteriormente a estos acontecimientos un grupo de treinta y seis guardias nacionales se queja a la Diputación "manifestando que en virtud de orden de los comandantes de sus compañías se hallaban presos en las Salas Consistoriales sin haberles manifestado oficialmente el motivo, aunque suponían fuese por no haber asistido a la formación el día que estuvo a la vista de esta capital la facción de Negri y por cuya razón se les trataba de formar causa por un Consejo de Guerra..." $" 668$. Y es que tanto las partidas de Zariategui como la de Negri controlaban prácticamente toda la provincia, sin encontrar resistencia a sus movimientos.

En el año 1839, figura como subinspector de la Milicia Nacional D. Francisco Osorio, que nombra comandante del segundo batallón de la ciudad a D. Pelayo Cabeza de Vaca, catedrático de la Universidad y ex-diputado provincial. En el mes de agosto de este año se celebra una sesión extraordinaria conjunta entre Diputación, Ayuntamiento de la capital y el subinspector de la Milicia con la finalidad de mejorar "el orden y la disciplina en el cuerpo ${ }^{669}$.

En el año 1841, el inspector general de la Milicia Nacional, en oficio remitido a la Diputación, "solicita se le envíe una terna para nombrar al subinspector de la provincia y en el pleno de la Diputación, se acordó por unanimidad hacer la propuesta, colocando en primer lugar al que lo era en la actualidad Francisco Osorio, en segundo a José María Manglano, $2^{\circ}$ comandante del batallón de esta capital y en tercero a Esteban Salvador Garrán, capitán de carabineros del mismo..." ${ }^{670}$. Fue ratificado en el cargo de subinspector Francisco Osorio, según circular del Boletín Oficial de la Provincia de 27 de febrero, quien al poco tiempo de ser confirmado en su puesto, se presentó en la Diputación "para dar a conocer el estado por cuerpos de la fuerza de la Milicia Nacional de la provincia, con el número de fusiles que tenía y que le faltaban"671. Los mandos de la Milicia siguen empeñados en hacer una selección muy rigurosa de milicianos y en evitar la entrada de individuos que no reúnan determinadas condiciones sociales y económicas, pues como bien refleja Sisinio Pérez Garzón, "la Milicia Nacional es una institución que nace por interés de la burguesía y para defender a la burguesía"672. El problema estriba en que no se pueden controlar a todos los componentes, sobre todo cuando el gobierno ordena un reemplazo en el mismo año de 1841 de 50.000 hombres, destinando parte de estos efectivos a cubrir las vacantes de la Milicia. En otras ocasiones, las dificultades de funcionamiento de la Milicia están ocasionadas por la penuria económica, como ocurre con la decisión del Ayuntamiento de Rioseco que en oficio se queja a la Diputación ${ }^{673}$.

667 B.O.P.V. n $^{\circ} 87$ de 22 de julio de 1837 , donde se publica el real decreto.

668 A.D.P.V. Actas. Libro de actas del 7 de mayo de 1838.

669 "Y se abrió una discusión acerca de los medios que podían servir a propósito para restablecer el orden y la disciplina en la Milicia. El Sr. subinspector hizo diferentes observaciones para ilustrar a la Junta de las causas que motivaron la desorganización de la fuerza y manifestó la necesidad de que se reorganizara disolviendo el batallón. Manifestó que una de las causas es la arbitrariedad con que se había procedido a excluir e incluir en la Milicia por personas no autorizadas a sujetos a quienes no correspondía por ley...Se acordó aprobar la propuesta de suspender la elección de oficiales ínterin se reorganiza el cuerpo" A.D.P.V. Actas. Libro de actas del 25 de agosto de 1839.

670 A.D.P.V. Actas. Libro de actas del 10 de enero de 1841.

671 "Al mismo tiempo, consulta con el Pleno la forma de costear los 3.446 fusiles y 4.259 cartucheras que faltaban para completar el equipo y los medios para excluir del alistamiento a los que no debían de estar" A.D.P.V. Actas. Libro de actas del 3 de mayo de 1841.

672 PÉREZ GARZÓN, Juan Sisinio. Milicia Nacional y revolución burguesa. ob. cit..

673 "se lamenta de los graves males que ha de ocasionar a la Milicia de la ciudad, la rebaja que V.E. se ha servido hacer en la retribución de 5 a 50 reales de los sujetos que no pertenecen a esta clase... y decidiendo disolver la Milicia por la falta de reintegro debido a la rebaja de 5 a 50 ". La decisión 
A principios del año 1842, en el mes de enero, es nombrado subinspector de la Milicia Nacional José María Manglano. Una de sus preocupaciones es la de equipar debidamente a los milicianos, consiguiendo que a finales del mismo año la Diputación comprometa y autorice "la confección de 160 uniformes y 100 correajes para la Milicia Nacional de la capital por un importe de 35.640 reales" ${ }^{674}$. El año 1843 se inicia con la confirmación en el cargo del subinspector provincial José María Manglano y con la controversia con el alcalde de Valladolid, Sr. Martín Lozar, de reciente nombramiento. La Diputación le pide que sea "exonerado del cargo" por ser asesor de la Milicia Nacional con carácter de "fuero militar", pero una vez tratada la discusión en el Pleno, se acordó ratificarle como alcalde.

A finales del mismo año de 1843, coincidiendo con el final del gobierno de Espartero y la entrada de los moderados en el poder, se publica un real decreto de fecha 18 de diciembre "sobre la supresión de la Inspección y Subinspecciones de la Milicia Nacional"675. Medida que se completa con el bando publicado por el capitán general de Castilla la Vieja, el día 3 de febrero de 1844, "disolviendo la Milicia

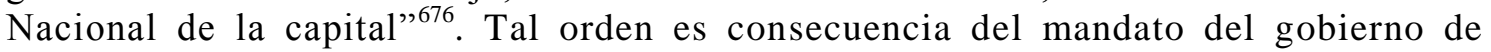
"desarmar la Milicia Nacional de todos los pueblos que pasasen de 300 vecinos", actuación motivada para evitar que se repitiesen "los sucesos de Alicante y Cartagena". Aunque es más verosímil la opinión de Pérez Garzón cuando dic e que "la Milicia Nacional es disuelta por los moderados, porque la consideraban un peligro para la emergente burguesía y su propiedad privada proveniente de la desamortización" "677.

La Milicia Nacional vallisoletana fue una de los principales protagonistas del pronunciamiento de 1840 conjuntamente con las fuerzas progresistas de la ciudad, por ese motivo y por las estrechas relaciones entre milicianos y progresistas es por el que su disolución no es bien recibida en Valladolid, ciudad que destaca por el entendimiento entre Ayuntamiento y Milicia y por la tendencia progresista de que hacen gala las dos instituciones. La llegada de los moderados al poder y el apoyo del Ejército facilita su disolución sin más graves incidentes que alguna protesta ciudadana ${ }^{678}$.

Con esta rara situación de la Milicia Nacional desarmada y disuelta, se producen dos noticias que inciden directamente en su futuro. La primera es la publicación de un real decreto "creando un cuerpo especial de fuerzas armadas, denominado Guardia Civil"679. Este cuerpo quita importancia y protagonismo a la Milicia Nacional y acabará sustituyéndola, pues su campo de actuación y su finalidad son los mismos que los de la Milicia, teniendo en cuenta también que este nuevo cuerpo no depende de la Diputación, sino que tiene un carácter similar al militar. La segunda noticia es contradictoria con lo dicho con anterioridad, ya que se trata de la "convocatoria de una quinta de 50.000 hombres, correspondiendo a Valladolid 788, de los que 563 son para el Ejército y 221 para la Milicia" ${ }^{680}$. Convocatoria que se hace con posterioridad a la orden de creación de la Guardia Civil, y que se puede considerar como necesidad de destinar los 221 hombres a la Milicia de los pueblos con menos de "300 vecinos", que son los que todavía mantienen vigente la institución.

ocasionó las protestas del batallón y la Diputación, dando la razón a los componentes de la Milicia, “desautorizó al Ayuntamiento de Rioseco y acordó remitir al juez de primera instancia la exposición enviada por el Ayuntamiento y el testimonio de los milicianos... enviando copia al Gobierno" A.D.P.V. Actas. Libro de actas del 16 de septiembre de 1841.

674 A.D.P.V. Actas. Libro de actas del 16 de diciembre de 1842.

675 A.D.P.V. Actas. Libro de actas del 21 de diciembre de 1843.

676 A.D.P.V. Actas. Libro de actas del 5 de febrero de 1844.

677 PÉREZ GARZÓN, Juan Sisinio. Milicia Nacional... ob.cit.

${ }^{678}$ LUENGO SANCHEZ, Jorge. El nacimiento de una ciudad....ob. cit. Pág. 39 y sig.

679 B.O.P.V.Boletín del día 18 de abril de 1844. LÓPEZ GARRIDO, Diego, hace un estudio detallado de la evolución del Instituto Armado en los primeros años de su existencia en su obra La Guardia Civil y los orígenes del Estado centralista. Alianza Editorial. Madrid. 2004.

680 B.O.P.V. Boletín del día 16 de mayo de 1844. 
A partir del año 1844, la situación de la Milicia Nacional es incierta y sus actividades son prácticamente nulas. Esta situación se mantiene hasta el año 1854, es decir, en todo el período de la Década Moderada. Con el inicio del Bienio Progresista, la Milicia Nacional vuelve a dar señales de vida y si en 1844 se habló de disolución, en este año de 1854 se habla de re-instalación y a través de dos reales decretos "se nombra inspector general de la Milicia Nacional a Evaristo San Miguel y subinspector de la Milicia Nacional de la provincia de Valladolid al brigadier José Pérez Delgado" ${ }^{\prime 61}$. Una vez tomado posesión de su cargo el subinspector provincial, solicita audiencia a la Diputación provincial "para tratar el tema de la petición del Ayuntamiento de Valladolid de formar una compañía de Artillería, indicando el Sr.Pérez Delgado que la Milicia Nacional se considera como el sostén de las instituciones liberales, pero no está de acuerdo en formar una compañía de Artillería, por necesidad de que los artilleros sean altos y robustos y no es el caso de los alistados en Valladolid y además no está probada su lealtad política" ${ }^{682}$.

En definitiva, las actividades de la Milicia Nacional se reanudan al mismo tiempo que la Diputación vuelve a controlar sus actividades y también a cubrir sus necesidades. Tema este complicado por la penuria de las instituciones, como delata la consulta del Ayuntamiento de Valladolid "sobre la forma de pagar 500 cartucheras para la Milicia Nacional y el gasto de su Banda de Tambores"683. También en el tema de la "lealtad política" es causa de enfrentamientos y peticiones, tanto de ingreso en la Milicia como de peticiones de expulsión de los "individuos que no reúnan las condiciones exigidas por el reglamento". Un caso así ocurre en la ciudad de Rioseco que a propuesta del diputado provincial del partido Benito Moreno "se acuerda eliminar de la Milicia Nacional de Rioseco a cuarenta y cuatro individuos que no merecían confianza" ${ }^{684}$. Ante la negativa del Ayuntamiento a cumplir con lo ordenado, "la Diputación acuerda rogar al gobernador de la provincia para que con una comisión de la Diputación formada por los Sres. Moreno y De las Moras, junto con el subinspector de la Milicia Nacional, pase a la ciudad de Rioseco y haga efectiva la eliminación de los cuarenta y cuatro individuos y proceder a continuación a la reorganización completa del batallón para impedir que se relaje el principio de autoridad indispensable para el gobierno y bienestar de los pueblos" ${ }^{685}$.

Pero con el final del Bienio, también se vislumbra el final de la Milicia, que en estos dos años mantiene su actividad gracias al equipamiento que se hace de milicianos a través de los reemplazos del Ejército, distribuyendo los mozos sorteados en función de las respectivas necesidades. Como ejemplo tenemos la convocatoria que se realiza en el año 1856, cuando se solicita para la Milicia Nacional de Valladolid un total de 304 mozos, celebrando en el mes de agosto "el sorteo de Décimas de 105 soldados de la Milicia Provincial", actuación que no será muy importante, puesto que a los "tres" días de este sorteo se da a conocer una real orden "ordenando el desarme de la Milicia Nacional" ${ }^{686}$. Hay que tener en cuenta que este no es un desarme parcial, como ocurrió en el año 1844, que se desarmó a la Milicia en función de los vecinos de cada pueblo, sino que es total. Esta orden es ratificada a finales del mismo mes de agosto, con la publicación de un real decreto, "disolviendo y extinguiendo definitivamente la Milicia Nacional" ${ }^{687}$.

Pero, aunque sobre el papel la Milicia está formalmente disuelta, la Diputación sigue tratando los casos y las reclamaciones de diferentes mozos destinados en este cuerpo a lo largo del mes de agosto. El día 23 se trata un expediente sobre litigios de un mozo en la lista de Alaejos y Nava. El día 25 se trata un expediente de competencias de San

\footnotetext{
681 B.O.P.V. Boletín de los días 19 y 21 de septiembre de 1854, con la publicación de los R.R.D.D.

682 A.D.P.V. Actas. Libro de actas del 9 de septiembre de 1854.

683 A.D.P.V. Actas. Libro de actas del 11 de octubre de 1854.

684 A.D.P.V. Actas. Libro de actas del día 2 de marzo de 1855

685 A.D.P.V. Actas. Libro de actas del 12 de abril de 1855.

686 B.O.P.V. no 94 de fecha 5 de agosto de 1856.

687 A.D.P.V. Actas. Libro de actas del día 25 de septiembre de 1856
} 
Vicente. El día 26 la Diputación nombra al Marqués de Gallegos como su representante en la Junta de Distrito de la Milicia Nacional. El día 28 se fijan los días de entrega de quintos. Todas estas actuaciones culminan el día 25 de septiembre en el que en audiencia pública la Diputación "da inicio a las operaciones de admisión de quintos del alistamiento y sorteo del presente año para el reemplazo de Milicias provinciales $"$ "688.

Es esta la última referencia que aparece en las actas de la Diputación, relacionada con la Milicia Nacional o Provincial. Es cierto que en el año 1857 se vuelve a convocar un reemplazo, correspondiendo a Valladolid 386 soldados "con destino a los cuerpos de Milicia provincial", aunque al poco tiempo de este anuncio se aclara que "los 386 hombres son para el Ejército de la Reserva". A partir del año 1857, la Diputación no vuelve a tratar temas de Milicia Nacional.

Será a finales del período isabelino cuando aparece un nuevo cuerpo policial que tiene visos de ser el sustituto de la Milicia, es la "Guardia Rural", institución fomentada por los agricultores en defensa de sus propiedades. La Diputación en estos años apenas nos indica nada al respecto, salvo en raras ocasiones, en las que aparecen en sus actas notas sobre autorizaciones para el nombramiento de guardias rurales en diversos pueblos de la provincia. Esta es una información mínima de la realidad que se corresponde con la existencia de una Guardería Rural, que en el año 1861 estaba formada por 17.224 guardias, cuando la Guardia Civil estaba compuesta por menos de 13.000 hombres ${ }^{689}$. La Diputación, con cierto retraso, reclama su instalación en abril de 1867 , al tener necesidad de cubrir el vacío de autoridad en el que se encuentra la provincia ${ }^{690}$, aunque no se tienen informes de "movimientos de bandoleros y facciones", parece cierto que los caminos de la provincia siguen siendo inseguros, por lo que acuerda, ratificado por el gobierno por real orden de 12 de julio de 1867, "Fijar la plantilla interina y el salario de la Guardia Rural para la provincia de Valladolid en: Un jefe con un salario de 80 escudos al mes. Dos subjefes con un salario de 40 escudos al mes. Un sargento con un salario de 30 escudos al mes. Dos cabos con un salario de 277 escudos anuales. Sesenta guardias con un salario de 700 milésimas de escudo al día" ${ }^{691}$. Ante las numerosas consultas y reclamaciones que el gobierno recibe por parte de las Diputaciones, aclara por real orden de 31 de agosto de 1867 que "el coste del mantenimiento y de los uniformes de la Guardia Rural debe de ser sufragado con fondos de la provincia, porque será la que reciba los beneficios" ${ }^{692}$.

En el año 1868 la Diputación amplía de una manera ostensible la plantilla de la Guardia Rural, fijándola en "Un comandante, tres capitanes, tres tenientes, tres alféreces, seis sargentos, treinta cabos y trescientos guardias". Aprueba igualmente para este año un presupuesto para la Guardia que ascendía a 102.659 escudos al año. A lo largo del año 1868, continúan en las actas de la Diputación, las referencias a la Guardia Rural y a los gastos de su funcionamiento, es decir, todo lo referente a su equipamiento, sus salarios, la construcción de casas-cuarteles. En definitiva, se trata de una serie de gastos que se ponen en "tela de juicio" ante la falta de resultados que se conseguían con este Cuerpo. En la Diputación "se reciben quejas de los malos resultados de la Guardia Rural y muchos pueblos han tenido que restablecer sus guardias, lo cual visto por la Diputación, acordó dirigirse al gobierno alertando de la situación" $" 693$. Aunque al gobierno no le dio tiempo a reaccionar, con el fin de la época isabelina y llegada del Sexenio Revolucionario, el nuevo gobierno en una de sus primeras actuaciones y por decreto provisional de 21 de octubre de 1868 , "ordena la

A.D.P.V. Actas. Libro de actas del día 25 de septiembre de 1856. LOPEZ GARRIDO, Diego. La Guardia civil.... Ob. cit. Págs. 150-151.

"Habiéndose publicado la Ley y Reglamento de la Guardia Rural, se pide al gobierno de S.M. se introduzca en la provincia esta nueva Guardia". A.D.P.V. Actas. Libro de actas del día 25 de abril de 1867.

A.D.P.V. Actas. Libro de actas del 20 de julio de 1867.

A.D.P.V. Actas. Libro de actas del 25 de septiembre de 1867.

A.D.P.V. Actas. Libro de actas del día 18 de julio de 1868. 
extinción de la Guardia Rural" y aunque el citado decreto no lo menciona, la verdadera causa de su disolución se encuentra en la consolidación de la Guardia Civil como única institución encargada de la seguridad interior del país ${ }^{694}$.

Durante el Sexenio, la Diputación no tiene conocimiento de actividades de ningún cuerpo dedicado al mantenimiento del orden tanto en los pueblos como por los caminos. Lo que nos hace pensar que, por un lado, no son necesarios y, por otro lado, la Guardia Civil, ya asentada en el país, cubre todas las necesidades de orden y vigilancia. Sin embargo, por inercia o por necesidades del presupuesto, en el año 1871 aparece una reclamación a la Diputación a través de una consulta "sobre por qué se grava a los pueblos con recargos para la Guardia Rural cuando ésta está extinguida" ${ }^{695}$.

\subsection{5.- LOS "FACCIOSOS". RENEGADOS SOCIALES Y POLÍTICOS}

El reinicio de la vida constitucional, tanto en 1820 como en 1833 , se ve entorpecida por las actividades de las "partidas", que se dividen en dos tipos muy diferentes en su origen, aunque ambas coincidan en los resultados. Las partidas de bandoleros son el producto de la miseria y la falta de trabajo y están compuestas en su mayoría por bandidos, malhechores, desertores y contrabandistas, sin olvidarnos como mantiene López Garrido" ${ }^{696}$ "de los campesinos empobrecidos a causa de la desamortización y enajenación desenfrenada de bienes de propios y baldíos, como principales participantes del bandidaje" Se aprovechan de la situación de descontrol que tiene el país y se unen con la finalidad de expoliar y robar todo lo que encuentran al paso, atracando a los caminantes y asaltando a los pueblos. Su periodo de máxima actividad se centra en los años del Trienio Liberal.

Las partidas de facciosos están formadas por los descontentos políticos de la vida constitucional, es decir por realistas y carlistas. Facciosos a los que la Diputación provincial de Valladolid en una de sus primeras sesiones les define como "toda persona contraria al régimen constitucional que se une a otras personas formando partidas o cuadrillas con la finalidad de entorpecer la vida de los ciudadanos e impedir el desarrollo de una manera natural de las actividades comerciales, industriales y agrícolas" ${ }^{697}$. Estas partidas tienen un carácter político-militar, pero las consecuencias de su actuación son similares a la de los bandoleros, esto es, perturbar la vida social, la paz y el orden en el territorio de su actuación. Estas cuadrillas tienen su período de máxima actividad en los inicios de la época isabelina, coincidiendo con la "Primera Guerra Carlista" (1833-1840), aunque la actividad de algunos grupos se mantiene latente a lo largo de los años "isabelinos".

La provincia de Valladolid sufre como es natural el acoso de estas partidas. En primer lugar las de bandoleros, que como hemos dicho están centradas en los años del Trienio, y que a pesar del gran despliegue de soldados y milicianos, controlan la mayoría de la provincia copiando las tácticas guerrilleras. La situación es tan grave que en 1822, el jefe político pide a la Diputación que incite a los pueblos a prepararse contra ellas ${ }^{698}$.

Entre las más famosas partidas de bandoleros en la época del Trienio tenemos la de Agustín Alonso Rubio, más conocido como "El Rojo de Valderas", que actuó por

\footnotetext{
${ }^{694}$ LOPEZ GARRIDO, Diego. La Guardia Civil... ob. cit. Págs. 147-159.

695 A.D.P.V. Actas. Libro de actas del 12 de diciembre de 1871.

${ }^{696}$ LOPEZ GARRIDO, Diego. La Guardia Civil... ob. cit. Pág.51. Un estudio sobre el bandolerismo lo tenemos en PASTOR PETIT, Domingo. El bandolerismo en España. Barcelona. 1979.

697 A.D.P.V. Actas. Libro de actas del 15 de septiembre de 1820.

698،que faculte a los pueblos para que de sus propios o arbitrios, o por repartimientos, pudiesen contribuir a la formación y pago de sueldos de una fuerza armada de 60 milicianos voluntarios de infantería y 30 de caballería para que persigan constantemente dentro de la provincia a los facciosos, turbadores del orden público, ladrones, malhechores y contrabandistas con 6 reales diarios cada individuo de infantería y 9 el de caballería, 15 cada uno de sus tres comandantes y 20 el principal. Se acordó dirigir a los pueblos un impreso con lo oficiado por el Sr. jefe político, persuadiendo de las ventajas que esta propuesta resultaría a la provincia en las actuales circunstancias" A.D.P.V. Actas. Libro de actas del 21 de septiembre de 1822.
} 
el norte de la Tierra de Campos. Partida que fue derrotada por las tropas del general Empecinado, a la sazón gobernador militar de Zamora, y su cabecilla "El Rojo" fue ajusticiado en Valladolid. En un principio fue enterrado en "el páramo de San Isidro", pero con la llegada del absolutismo, fue llevado procesionalmente y enterrado con honores militares en la iglesia de San Andrés de la capital (ver su biografía en capítulo $3^{\circ}$ en el tema que trata sobre las Diputaciones del Trienio).

Otra de las partidas "tristemente populares" es la de Pedro González, apodado "El Periquito", que actuó por la provincia durante los años 1820 y 21 , y que a finales de 1822 se entregó a las autoridades. La Diputación provincial "solicitó el indulto del "Periquito" y sus compañeros al presentarse con armas y caballos, amparados en el real decreto de 11 de noviembre, que determina que los facciosos que se entreguen voluntariamente, sin delitos de sangre, serán enviados al Ejército por el plazo de 6 años" ${ }^{\prime 999}$.

El fin de la "Década Ominosa" y la llegada al poder de los liberales produjeron el descontento de los absolutistas y en consecuencia la aparición de "partidas realistas", que combaten con las armas la vuelta a la legalidad constitucional. Resaltan en el entorno castellano y en el año 1833 "los levantamientos realistas en Segovia y Zamora y la lucha contra la facción del Cura Merino en los Montes de Oca"700. "El Cura Merino", famoso guerrillero que luchó contra los franceses, y furibundo absolutista, había conseguido rehacer su partida. En el año 1836, la Diputación advierte que "hacía pocos días que habían transitado por algunos pueblos de la provincia, con fuerzas a las que los pueblos pequeños no hubieran podido resistir y las armas hubieran caído en poder de aquellos, como sucedió en Coca y en Quintanilla de Abajo..."701.

Una nueva partida se está formando en la provincia y son los llamados "Rebeldes de D. Basilio". Partida que en poco tiempo consigue reunir un buen número de hombres, cosa que preocupa al capitán general de Castilla la Vieja. Para evitar ese poder de convocatoria emite un bando "sobre la forma de concentrar a los mozos de 16 a 40 años para evitar que vayan con los facciosos" "702.

La partida más importante y numerosa es la "facción de Zariategui". Se "enseñoreó" de la provincia, se apoderó de la capital en el verano del año 1837, y realizó continuas "requisas" en diferentes pueblos para asegurar su suministro. Su influencia fue tan amplia y sus correrías tan audaces, que obligó al capitán general a publicar un bando en el Boletín Oficial Extraordinario de la Provincia "asegurando a la ciudad que la plaza de Valladolid no va a ser abandonada a los facciosos de Zariategui" ${ }^{703}$. Pero mientras el capitán general decía que la capital no sería abandonada y el subinspector de la Milicia Nacional ordenaba la defensa de la ciudad, lo cierto es que ninguno de los dos cumplió. En los meses de julio, agosto y septiembre, la capital estuvo ocupada por las fuerzas de Zariategui, como lo refleja la Diputación al reanudar sus sesiones en el mes de octubre, en el que "convoca sesión extraordinaria para tratar el tema de las elecciones de senadores y diputados a Cortes, que no habían podido tener efecto en tiempo oportuno, por haber sido ocupada la capital y algunos pueblos de la provincia por la facción de Zariategui" ${ }^{704}$. Las consecuencias de esta ocupación son la destitución del capitán general Carlos Espinosa, y el expediente abierto por la Diputación al oficial $2^{\circ}$ Deogracias Larraga "por haber permanecido en la capital durante la permanencia de la facción de Zariategui, dando pruebas de desafección" ${ }^{705}$.

\footnotetext{
699 A.D.P.V. Actas. Libro de actas del 13 de diciembre de 1822.

700 B.O.P.V. $n^{\circ} 41$ de 30 de noviembre de 1833.

701 A.D.P.V. Actas. Libro de actas del 11 de marzo de 1836.

702 B.O.P.V. n 97 correspondiente al día 9 de agosto de 1836.

703 B.O.P.V. Boletín Extraordinario del día 8 de agosto de 1837.

${ }^{704}$ A.D.P.V. Actas. Libro de actas del 6 de octubre de 1837.

705 A.D.P.V. Actas. Libro de actas del 7 de octubre de 1837.
} 
Durante el fin del año 1837 y principios de 1838, continúan los peligros de invasión de la capital y pueblos importantes. Sobre todo por las noticias alarmantes que se producen sobre la presencia en el pueblo palentino de Torquemada de una importante fuerza "carlista" formada por unos diez batallones. También por la formación de una nueva facción en la provincia, la del "Conde Negri", que estuvo merodeando por los alrededores de la capital y que según el cronista Ortega y Rubio "se aproximó a Valladolid, esperando tener la misma acogida que la de Zariategui, pero no fue así y tuvo que salir de las cercanías de la ciudad" "N06. Negri se retira con sus hombres hacia el sur de la provincia, y en el mes de junio la "facción" es "batida" en Piedrahita por las tropas del general Espartero.

Una nueva facción, la de "Balmaseda", procedente de la provincia de Burgos, acampa en las cercanías de Olmedo, con la consiguiente alarma de la población.

En el mes de septiembre de 1838, el capitán general declara el estado de guerra en la provincia ante las alarmantes noticias de la llegada de la partida del Cura Merino. Era una de las más numerosas que merodeaban por la región, estaba compuesta de 300 hombres y 200 caballos, ante cuya fuerza la provincia no disponía de los hombres armados necesarios para hacerles frente. Visto el peligro de ocupación de la capital, la Diputación suspende sus sesiones el 7 de septiembre y señala a la ciudad de Zamora como el destino de los diputados y donde tenían que presentarse si la facción entraba en Valladolid.

Con la firma del armisticio entre los generales Espartero y Maroto, se da por concluida la "Guerra Civil" y en consecuencia la actividad "facciosa" decae. Aunque lo que antes era una partida militar se transforme en partida de bandoleros, como ocurre con la facción de Balmaseda que opera en la zona de Peñafiel. De esto se hace eco la Diputación en su sesión extraordinaria de Junio de 1840, donde se lee un informe del jefe político ${ }^{707}$.

Otro tema relacionado con las partidas y que se mantiene a lo largo de los años es el de las reclamaciones por los suministros entregados o requisados a la fuerza, cuando las diferentes partidas se han apoderado de los pueblos y de los bienes que en ellos se encontraban. Así en el año 1841 aparecen una serie de reclamaciones de vecinos de Olmedo solicitando el pago de los suministros que tuvieron que dar a la facción de Balmaseda. Igualmente reclamaron los que hicieron por otros varios pueblos los facciosos de Zariategui. Las reclamaciones se alargan con los años y en 1845 aparece: "la aprobación de los arbitrios propuestos por la Diputación provincial para liquidar los suministros hechos por varios vecinos (de la capital) a la facción de Zariategui por importe de 166.136 reales" ${ }^{\text {"708 }}$.

La tranquilidad con respecto a las partidas es prácticamente total en toda la península a partir de estos años. Únicamente pequeñas noticias salpican la monotonía de la vida social de la provincia, como es el levantamiento en el año 1860 "de una partida facciosa en Aranda, compuesta por 25 ó 30 hombres que se levantan proclamando Rey a Carlos VI" ${ }^{709}$. Partida que no llega a penetrar en la provincia, pero que inquieta a la Diputación por la proximidad a Peñafiel y porque casi simultáneamente se producen otra serie de levantamientos de poca importancia en la zona del Maestrazgo. A la vez coincide con la guerra de Marruecos.

ORTEGA Y RUBIO, Juan. Historia de Valladolid. H. de H. Gutiérrez. Valladolid 1881. Relato de los sucesos acaecidos el 12 de abril y el intento de ocupación de la capital por la facción de Negri. "Dando cuenta de los partes recibido desde Peñafiel y el valle de Esgueva, sobre la facción capitaneada por el feroz Balmaseda que se había situado en la zona de la Ribera próxima a la provincia. Roa y Nava de Roa habían sido destruidas y sus habitantes refugiados en Peñafiel .Lamenta que la partida de Balmaseda no hallase resistencia por la absoluta falta de fuerza militar en el Distrito, lo que hacía recelar si llevaría su intento a invadir la capital, igualmente exenta de elementos de resistencia" A.D.P.V. Actas. Libro de actas de la sesión extraordinaria del 4 de junio de 1840 .

709 B.O.P.V. n 52 correspondiente al 5 de abril de 1860 . 
En el año 1867, ya a finales del período isabelino, con ocasión de la efervescencia política, la inestabilidad constitucional y los problemas del hambre a causa de la pérdida de las cosechas, se produce, como reacción de la grave situación social, la reactivación de una serie de partidas por la provincia que el gobernador civil de la época las bautizó con el nombre de "latro-facciosas".

Con el inicio del Sexenio, la situación de tranquilidad social se deteriora, lo que obliga al gobernador a enviar una circular a los pueblos "previniendo a los alcaldes a fin de exterminar las partidas de facciosos y malhechores que existen en varias provincias y que pueden invadir ésta" ${ }^{, 710}$. En Valladolid, ante la situación de la provincia, el capitán general declara el estado de guerra, anunciando al mismo tiempo que "la partida republicana que salió de la capital el día 8 es alcanzada en los Montes Torozos, atacada y dispersada"711. En el año 1872, nuevamente el gobernador se ve obligado a advertir "del levantamiento de partidas en la provincia de tipo carlista, entre las que destaca una partida de 120 a 140 hombres en Piña de Esgueva dando vivas a Carlos VII, facción que fue dispersada por la Guardia Civil de Corcos"712. Termina el mismo año, con la aparición en Puente Duero de una partida facciosa de cincuenta hombres "de carácter republicano y carlista", actividad que prolifera hasta la proclamación de la República.

\section{5.- SANIDAD Y BENEFICENCIA}

La Diputación provincial de Valladolid, cuando inicia su andadura en los años 1813-1814, recién finalizada la Guerra de la Independencia, se encuentra por un lado con el desconocimiento por parte de la institución de los temas sanitarios y por otro lado, también se topa con numerosas instituciones benéficas, con muchos años de existencia y muy controladas tanto por los Ayuntamientos, por la Iglesia y por numerosas "fundaciones pías" de carácter benéfico-asistencial. Con esta situación la Diputación recibe el encargo de la Constitución, a través de su artículo trescientos treinta y cinco, de "cuidar de que los establecimientos piadosos y de beneficencia lleven sus respectivos objetos..."

Dispuesta a cumplir con lo estipulado, la Diputación inicia sus trabajos centrándose en comenzar por un control y conocimiento de los numerosos establecimientos benéficos extendidos a lo largo y ancho de la provincia. Pretende que por un lado conozcan y acaten las normas procedentes del gobierno y por otro lado les sirva de interlocutor en las peticiones que puedan hacer estos centros. La gran dificultad que encuentra en estos primeros tiempos es la falta de colaboración de las instituciones que controlan los centros de beneficencia, celosas de su independencia y autonomía y no dispuestas a ceder el control y la gestión de los establecimientos y sobre todo el de su gestión económica.

Con el paso de los años y ya en plena época isabelina se van modificando las "intenciones" tanto de los gobiernos, como de las Diputaciones. De una idea primera de control de las actividades benéficas se irá pasando a un control de la sanidad y de la beneficencia, es decir, no se limitan las actividades, sino que lo que de verdad interesa es controlar las instituciones. Lo interesante en estos momentos, como señaló el Pfr. Carasa ${ }^{713}$, es el paso del encargo asistencial desde la iniciativa de la Iglesia al protagonismo de las autoridades locales. Este tránsito se realizó mediante dos fenómenos de intervención sobre la gestión y sobre el patrimonio de estas instituciones benéficas. La intervención en la gestión benéfica estuvo apetecida primero por los Ayuntamientos, en un conocido proceso de municipalización de los establecimientos benéficos, que promovieron los progresistas en la ley de beneficencia

\footnotetext{
710 B.O.P.V. $n^{\circ} 156$ de fecha 25 de julio de 1869.

711 B.O.P.V. $n^{\circ} 202$ de fecha 15 de octubre de 1869.

712 B.O.P.V. $n^{\circ} 63$ de fecha 25 de abril de 1872.

713 CARAS A SOTO, Pedro. Pauperismo y Revolución... ob. cit. pág. 448 y siguientes. ID El sistema hospitalario español en el siglo XIX. De la beneficencia al sistema sanitario actual. Valladolid, 1985
} 
de 1822, con el ánimo de concentrar en las ciudades las instituciones asistenciales en manos de sus Ayuntamientos, o mejor, de sus Juntas Municipales de Beneficencia. Después pretendieron la gestión de las instituciones de beneficencia los moderados, que en la ley de 1849 establecieron la provincialización de las mismas, dejándolas principalmente en manos de las Diputaciones, o con mayor propiedad a cargo de las Juntas Provinciales de Beneficencia, con la doble idea de centralizar más la administración de la beneficencia y de orientarla a socorrer a los necesitados rurales de la provincia que estaban inmigrando en las capitales. Se establece así la a veces áspera pugna entre Ayuntamientos y Diputaciones por el control administrativo y económico de la beneficencia municipal o urbana y la provincial o rural. A nosotros nos corresponde en este trabajo centrarnos en la provincialización de la beneficencia que llevan a cabo las Diputaciones. El otro gran proceso de control sobre las instituciones benéficas consistió en la desamortización de 1855 , por la que sus patrimonios se convirtieron en títulos de la deuda a disposición de Ayuntamientos y Diputaciones para organizar sus respectivas beneficencias municipales y provinciales.

Esta trayectoria está aplicada a Valladolid por Elena Maza Zorrilla ${ }^{714}$ cuando en su estudio sobre la beneficencia recuerda que las instituciones benéficas en la época moderna eran la base de la asistencia social y al mismo tiempo eran instituciones consolidadas y con un gran poder económico y social. Con el paso de los años iniciaron un lento proceso de pérdida de poder en paralelo con lo que les sucede al resto de instituciones del Antiguo Régimen. Con la llegada del siglo XIX y del liberalismo se acentúa esta pérdida pasando de ser fuertes en lo económico y en lo social a pasar a depender de los presupuestos públicos. Es en este tiempo cuando la Diputación inicia su intervención en estas instituciones, por un lado como garante de la continuidad de las actividades benéficas y por otro como pretendiente a tomar el control tanto asistencial como económico de las mismas.

Según había escrito Pedro Carasa, el cambio más característico de estos años en relación con la beneficencia "no fue la revolución del sistema asistencial, sino el cambio de las fuerzas sociales que lo controlaron y organizaron". La mayoría de las instituciones benéficas pasaron de un ámbito de propiedad particular eclesiástica y religiosa a una situación de gestión pública en manos de Ayuntamiento y Diputaciones, siguiendo unas etapas que se caracterizaron por la municipalización, la provincialización y la desamortización.

\subsection{1.- SANIDAD: DE LA INICIATIVA ECLESIÁSTICA A LA BENEFICENCIA PROVINCIAL}

En los años 1813-1814 la sanidad está basada aún en los escasos recursos caritativos y en los remedios religiosos que practicaban en las parroquias, fundaciones, cofradías, hospitales y obras pías, y en algunos pueblos y ciudades en la presencia de un cirujano o médico para atender las necesidades de sus vecinos. En contrapartida, estos cirujanos y médicos reciben un salario, habitualmente repartido entre "metálico y en especie", que pocas veces es satisfecho con puntualidad. Ante estos problemas, la Diputación es la institución encargada de velar por el cumplimiento de las obligaciones de los médicos y sobre todo, y es lo que más falla, del pago de los emolumentos comprometidos por los Ayuntamientos.

Son numerosos los expedientes presentados por médicos y cirujanos "reclamando el pago de sus salarios". Las actas de la Diputación en esta su primera etapa, que apenas reflejan tres meses de actividades, tienen abundantes referencias a los problemas médicos. En sus primeras anotaciones leemos que "el cirujano de Villabrágima, Juan Espinosa, pasa una exposición reclamando aumento de salario y pago de atrasos". También "el médico de Tudela reclama sus salarios", y no son sólo los individuos los que reclaman, también sabemos que "la Asociación de Medicina

\footnotetext{
${ }^{714}$ MAZA ZORRILLA, Elena. Valladolid: sus pobres y la respuesta.... Ob. cit.
} 
reclama al Ayuntamiento de la capital los salarios del Dr. Maisonave, médico y cirujano" 715 .

En la época del Trienio Liberal, la sanidad sigue siendo casi exclusivamente una relación de reclamaciones de médicos y cirujanos, sin otras mayores preocupaciones sanitarias. Aparecen constantes referencias: "El médico cirujano de Rioseco solicita el pago de 10 meses de atrasos". "Puebla de Sanabria se queja del abandono de la sanidad pública y también de la instrucción, por falta de medios para pagar al médico, al cirujano y al maestro". "En Simancas el médico reclama 1.833 reales de atrasos". "El médico de Matapozuelos reclama los salarios atrasados de 1819 y 1820". "El Ayuntamiento de Villalón propone arbitrios para pagar al médico". "La Diputación trata de expedientes de pagos atrasados a los médicos de Cigales, Benavente, Pozaldez, Tudela de Duero y Tordesillas". "El Hospital de Santa María de la Piedad de Benavente, reclama el dinero de los suministros hechos a los franceses en los años 1810,1811 y $1812 \% 716$. A lo largo del año 1822, continúan las reclamaciones, y en este caso de cantidades más importantes, como si los médicos reclamantes no hubieran cobrado sus salarios durante todo el período. Así tenemos que: El cirujano de Medina reclama 10.000 y más reales por el pago de sus salarios atrasados". "Los médicos titulares de Medina piden 2.000 reales que se les adeudan por atrasos". "El Ayuntamiento de Simancas, acuerda el arriendo de saca de corambre y haza de las bodegas para pagar al médico, al cirujano y al maestro". "El médico de Villanueva de los Caballeros pide se le paguen los atrasos". "El cirujano de Boecillo reclama 3.000 reales de dotación". "El médico de Medina reclama 7.100 reales de salarios adeudados". "En Tordesillas, el médico reclama 2.500 reales"717. Las reseñas referentes a la sanidad se completan con la publicación de una real orden de fecha 5 de agosto de 1822 por la que, "se concede al Ayuntamiento de Peñafiel, el convento de los frailes franciscanos para reunir en él lo dos hospitales de la villa"718.

La sanidad en la época isabelina sigue con los mismos problemas, curiosamente todos centrados en su índole económica y ninguno referido a inquietude $\mathrm{s}$ sanitarias. La Diputación, con su nueva puesta en marcha, recoge desde un principio los habituales expedientes de reclamaciones, la mayoría de ellos presentados por los médicos con peticiones económicas. Los Ayuntamientos contratan a los médicos pero no les pagan lo convenido y además, con la misma facilidad que son contratados pueden ser despedidos. Todo eso es motivo de reclamaciones y de quejas que se reflejan en las actas. Ante la mediación de la Diputación hay Ayuntamientos como el de Tudela de Duero que en su contestación se remiten a que "reclamen su expulsión a la justicia".

En los años 1836 y sucesivos, con un funcionamiento normal de la Diputación, la mayoría de expedientes que se presentan en la institución están relacionados con los consabidos problemas económicos, con continuas controversias entre vecinos por los nombramientos de médicos y cirujanos y con la disconformidad de los profesionales de la medicina. Así vemos reflejado en el año 1836 que "el Ayuntamiento de Matapozuelos acusa a la falta de fondos para mantener al cirujano, pero los vecinos a los pocos días provocan un alboroto por el nombramiento de un médico". "El médico de Bercero se queja porque el Ayuntamiento le hace dimitir". "Los vecinos de Becilla de Valderaduey piden el cese del médico". "Los vecinos de Olmedo se quejan por tener que pagar un repartimiento para mantener al médico". "Los vecinos de Torrelobatón piden que se readmita al cirujano despedido".

En el año 1837, continúan las diferencias entre médicos, vecinos y Ayuntamientos. "El Ayuntamiento de Torrelobatón no autoriza al cirujano Liborio del Pino a trasladarse a Tordesillas". "Cincuenta y tres vecinos de Santa Eufemia

715 A.D.P.V. Actas. Reseñas en los libros de actas de febrero, abril y junio de 1814

716 A.D.P.V. Actas. Libros de actas del 27 de octubre de 1820 y 17 de marzo y 5 de junio de 1821 .

717 A.D.P.V. Actas. Libro de actas de marzo a agosto de 1822 .

718 A.D.P.V. Actas. Libro de actas del 14 de septiembre de 1822. 
reclaman al alcalde por contratar un cirujano sin autorización". "El Ayuntamiento de Tamariz recuerda al cirujano que no está exento del pago de contribución". "El Ayuntamiento de Castromonte recuerda a sus vecinos que todos tienen que colaborar en la paga del salario del médico-cirujano".

El año 1838 se inicia con los expedientes de reclamaciones, similares a los de años anteriores, es decir, por un lado "los médicos siguen reclamando el pago de sus salarios" como ocurre en los pueblos de Tordesillas y Pozaldez, y por otro "los vecinos rechazan el nombramiento del médico", como ocurre en Cuenca de Campos. Otros dos asuntos llaman la atención de la Diputación. "El hospital de Tordesillas se queja por la obligación que tiene de prestar alojamiento a las tropas". "La Academia de Medicina y Cirugía del distrito de Castilla y León presenta un oficio de queja, lamentándose de los abusos introducidos en algunos pueblos de fiar la curación de los enfermos a cirujanos romancistas y curanderos" $" 719$.

Durante el año 1839 se suceden las reclamaciones en términos similares a los años anteriores. "Se autoriza al Ayuntamiento de Peñafiel a contratar un médico con el salario de 9.000 reales anuales". "El Ayuntamiento de Tordesillas solicita autorización para vender un terreno de propios para pagar al médico". "El Ayuntamiento de Portillo presenta un repartimiento para pagar al cirujano". "El cirujano de Pedrosa del Rey reclama sus salarios".

A lo largo del año 1840, en contraposición de años anteriores en los que se sucedían una serie de reclamaciones de médicos en diferentes pueblos, las actas de la Diputación sólo reflejan el contencioso que mantiene el Ayuntamiento de Tordesillas con el médico Dr. Gavilán. Este doctor reclama una serie de atrasos de sus salarios y, aunque el Ayuntamiento durante el año anterior vendió unos terrenos para pagar las deudas del médico, éste sigue reclamando, a través de una exposición a la Diputación. Una vez estudiados por el pleno los argumentos presentados, "ordena a los concejales de Tordesillas se presenten a la barra el día 4 de febrero para tratar el tema de las deudas al médico Dr. Gavilán" "720. El día 4 de febrero, el libro de actas refleja las actuaciones y los acuerdos. "El Sr. presidente avisó sobre la presencia del Ayuntamiento de Tordesillas y mandó que se presentase el alcalde Ramón de Guzmán para resolver el contencioso con el médico Pedro Gavilán. El Sr. presidente le recriminó por el desacato al no solucionar el problema. El alcalde echó la culpa al Ayuntamiento anterior y no dio soluciones para reparar el desacato. El alcalde no da satisfacción y no entiende porque es sordo. Se mandó pasar, entonces, al regidor Bedoya y como con sus explicaciones no satisfizo a la corporación, se acordó: Que el jefe político procediera con todo rigor contra el Ayuntamiento" "721. Pero el procedimiento del jefe político no debió de ser muy severo, puesto que nos encontramos con que en el año 1842, aparece de nuevo una exposición del Dr. Gavilán "reclamando los atrasos desde el año 1840 de su sueldo de médico".

Entre los años 1841 y 1845 , se produce un acusado descenso de las reclamaciones de los médicos y en todos estos años apenas vemos algunas reclamaciones: "El cirujano de Viana de Cega reclama los salarios atrasados", "el cirujano de Esguevillas solicita 200 reales al año por atender a los pobres", "el cirujano de Valladolid, Sabino Ara, reclama la plaza de cirujano del Hospital General, ya que el cirujano nombrado Julián Sacristán es cirujano romancista", "el Ayuntamiento de Valdestillas solicita utilizar los fondos de sus propios para pagar al médico", "el profesor de medicina operatoria de Tordehumos reclama su salario", "el Ayuntamiento de Torrecilla presenta un repartimiento para pagar al médico", "el médico de Valdestillas reclama el pago de sus salarios", "el médico de Mota del Marqués reclama su salario". 
El año 1843 es el que destaca por una serie de reclamaciones y enfrentamientos entre el Ayuntamiento de Medina y el médico de aquella villa, el Dr. Esteban Remolar. Las discusiones se inician el 11 de enero cuando "el médico de Medina, Dr. Remolar, se queja porque el Ayuntamiento le quiere modificar el contrato". Cuestión en la que el Ayuntamiento no le hizo caso, y en represalia el Dr. Remolar "se mete en política" al solicitar en reclamación cursada a la Diputación que "se anulen las elecciones en Medina, salvo en las parroquias de Santo Tomé y La Colegiata". Esta reclamación se efectúa en el mes de febrero, y en el mes de marzo "el médico Esteban Remolar se queja de que ha sido destituido por el Ayuntamiento, por culpa de varios concejales resentidos. Se acuerda que se dirija al Tribunal de Justicia si no está de acuerdo. Al mismo tiempo, la Diputación decide citar al alcalde de Medina y al Dr. Remolar para poder llegar a un acuerdo" "722.

Como contestación a esta petición de reunión, el Dr. Remolar en exposición que remite a la Diputación, reitera "la solicitud de mi reposición, dudando del beneficio de la mediación de la Diputación". Al margen de la desconfianza del médico, la reunión se celebró en Medina. El Sr. Alderete, diputado provincial y comisionado por la institución, solicitó al Ayuntamiento la reposición del médico, pero el pleno no aceptó la petición de la Diputación. El Dr. Remolar, en vista del poco éxito de la reunión, reclamó a la Junta Suprema de Sanidad del Reino, la cual envió una comunicación a la Diputación "informando de la exposición enviada por D. Esteban Remolar, médico de Medina, quejándose del Ayuntamiento por haberle separado de la plaza de médico titular y pidiendo su reposición" ${ }^{723}$. A lo largo de su vida profesional continuará, con sus reclamaciones, puesto que está claro que no llegó en ningún momento a tener buenas relaciones con los diferentes Ayuntamientos. Así en el año 1845, el Ayuntamiento denuncia al Dr. Remolar "por falta en el abandono de su profesión", y llegaron al año 1854 en la que el Dr. Remolar presenta un expediente a la Diputación "reclamando su reposición en el trabajo del que fue despedido en 1843". Reclamación que vuelve a repetir en el año 1855 (breve biografía en el capítulo $3^{\circ}$, en el epígrafe que trata sobre la $15^{\text {a }}$ Diputación isabelina en 1854-56).

A partir del año 1846, con la puesta en marcha del Consejo provincial, todos los asuntos concernientes a la Sanidad son traspasados desde la Diputación a este nuevo organismo. Con lo cual desaparecen de las actas de la Diputación las referencias a la sanidad, y en esta situación se mantendrá al margen de la Diputación, hasta el año 1854, que con la llegada del Bienio Progresista y la desaparición del Consejo provincial, vuelven a aparecer en las actas los problemas habituales de los médicos. Ahora serán mucho más numerosas que las veintisiete referencias que aparecieron relacionadas con la sanidad entre los años 1845-1854.

En el año 1854 leemos que: "el médico de Pollos reclama sus salarios atrasados", "el cirujano de Santovenia reclama el pago del salario de 1854", "El Ayuntamiento de Mota del Marqués acuerda imponer un arbitrio de un real en cántaro de vino para pagar al médico", "el Ayuntamiento de La Pedraja solicita un repartimiento de 1.000 reales para pagar al médico", "los vecinos de Villamarciel se quejan porque el cirujano ha dejado el pueblo sin cumplir el contrato".

El año 1855 es un año abundante en reclamaciones a causa de los atrasos en el pago de los salarios en Alcazarén, Pozal de Gallinas, Pollos, Villafrechós, Castroponce, Villalón, Cigales, y San Román de Hornija. En Cigales "se aprueba la destitución del médico y se convoca la vacante". En Palazuelo de Vedija "se anula el nombramiento de médico". En Villalón "el médico reclama los honorarios de una autopsia". En Pesquera "el cirujano se queja por tener que atender a los pobres". En Villagarcía "se aprueba el nombramiento de facultativo". En Iscar "se anuncia la vacante de médico con 6.000 reales al año". También son características de este año las numerosas contrataciones que hacen diferentes pueblos, como Muriel de Zapardiel,

722 A.D.P.V. Actas. Libro de actas del 12 de marzo de 1843.

723 A.D.P.V. Actas. Libro de actas del día 11 de junio de 1843. 
Castromonte, Carpio, Aldeamayor y Rodilana. Igualmente son numerosas las reclamaciones que efectúan médicos y cirujanos, solicitando aumento de salario "por atender a pacientes pobres" como ocurre en Muriel, Zaratán y en Valdenebro de los Valles. Pero lo más preocupante es el acuerdo del Ayuntamiento de San Román de Hornija, que "aprueba la creación de la plaza de médico con 7.000 reales anuales para asistir a todos los vecinos ante la crítica situación de invasión del cólera morbo en los pueblos limítrofes"

Durante el año 1856, continúa la presentación de expedientes en la Diputación con las consiguientes reclamaciones, tanto de médicos que no cobran como de Ayuntamientos interesados en pagar a los médicos. Así tenemos que en Zaratán, Villagarcía, Melgar de Arriba, Geria, Rueda, Melgar de Abajo y Pozal de Gallinas, sus respectivos médicos reclaman el pago de los atrasos, y de otra parte, los Ayuntamientos de Boecillo, Ceinos, Peñafiel, Villardefrades y Rueda presentan solicitudes para contratar nuevos médicos.

Otro de los problemas que surgen en este año es el de las diversas reclamaciones de médicos ante la obligación de atender a los pobres, considerando que es poca la ayuda que reciben. En esta situación reclaman médicos de Bamba, Medina, Rodilana y Herrín. Finalmente en otros pueblos los médicos se quejan "porque apenas son pagados por los trabajos extraordinarios del cólera morbo". Esto ocurre en Rueda y en Pollos.

A partir del año 1857 , con la puesta nuevamente en funcionamiento del Consejo provincial, la Diputación vuelve a perder protagonismo en el tratamiento de los temas de sanidad y es este organismo el que nuevamente vuelve a tratar sobre los mismos. Son contadas las ocasiones en que la Diputación tiene que resolver. "En 1857 el Ayuntamiento de Pedrajas de San Esteban aprueba la contratación de un médico". "En 1858 la Diputación aprueba el nombramiento de médico en Villanueva de las Torres, Castromonte, Santovenia y Fuente el Sol”. "El Ayuntamiento de San Román de la Hornija presenta un expediente para la creación de una plaza de médico-cirujano, titular de la villa dotada con 8.000 reales anuales a pagar con las rentas de los pastos comuniegos". "En 1859 se presentan expedientes para proveerse de una plaza de cirujano en los pueblos de Cogeces, Villamuriel, Lomoviejo, Palazuelo, Peñaflor, Villabrágima, Villacid, Piñel de Abajo y Morales de Campos". "La Junta Provincial de Sanidad promueve un expediente para adoptar medidas para vacunar el ganado y las personas del mal de la viruela, y por su parte la Diputación acuerda consignar 10.000 reales para adquirir pus varicoso" "725.

En el periodo de vigencia del Consejo, entre los años 1857 a 1868, éste trata en sus reuniones habituales un total de cincuenta y siete expedientes, realmente muy inferiores a lo que habitualmente trataba la Diputación. El mismo planteamiento se presenta en el periodo del Sexenio Revolucionario, pues entre 1869 y 1874 se tratan cincuenta y ocho expedientes relativos a la sanidad provincial, en la Comisión permanente. Los plenos de la Diputación tratan en prioridad temas de beneficencia que en muchas ocasiones se mezclan con los de sanidad.

\subsection{2.- LAS EPIDEMIAS, EL AZOTE DE LA POBLACIÓN}

En una época en que aún no se conocían los medios elementales de higiene tanto privada como pública, los peligros de epidemia y los contagios eran bastante frecuentes, y sobre todo ocasionaban una mortalidad extraordinaria. El temor a la epidemia, aunque el foco de la misma estuviera lejano, era suficiente para preocupar a la población, como ocurrió en el año 1820, año en que recién instalada la Junta de Sanidad, en reunión urgente que celebra el día 13 de junio "se leyó la orden de S.M., con motivo del contagio que se sospecha padecerse en el pueblo de Son Servera en la isla de Mallorca". Aunque Mallorca está lejos, es una isla y no hay certeza de la

724 A.D.P.V. Actas. Libro de actas del 2 de julio de 1855.

725 A.D.P.V. Actas. Libro de actas del 22 de febrero de 1859. 
existencia de la epidemia, el temor al "cólera morbo" es muy grande, por lo que la Junta de Sanidad tomó una serie de acuerdos para "precaver los males que ocasionaría la propagación del contagio anunciado". Nuevamente en el mes de septiembre del mismo año 1820, es decir a los tres meses, ya no es en la isla, sino que es en la península y el gobierno vuelve a publicar otra real orden "para que se tomen las medidas oportunas al efecto de impedir la entrada en Cádiz y Jerez por haberse manifestado la reproducción de la epidemia de años anteriores". Estas medidas al parecer surten efecto, pues la epidemia ha podido ser controlada, aunque el gobierno mantiene su prevención al recordar en marzo de 1821 "que se informe al gobierno si en la provincia hay conventos de San Juan de Dios para que se les aplique las medidas que se han tomado con el de Cádiz”. Lo cual indica que el foco de la epidemia era el convento de Cádiz. En Valladolid para evitar cualquier problema se ha cerrado el convento de S. Juan de Dios, convento que continuaba cerrado en el año 1822, lo que motiva la reclamación del prior a la Diputación.

Una nueva epidemia de "cólera morbo" se extiende por la provincia en el año 1833 y sus inicios están referenciados en el recién estrenado Boletín Oficial de la Provincia que nos da noticias sobre la epidemia de cólera morbo que se está extendiendo por la provincia e informa sobre las medidas a adoptar para evitar su propagación, entre las que destaca la conveniencia de la construcción de cementerios a las afueras de las poblaciones, aparte de otros remedios curiosos como el de "la bondad de los ladrillos de sal piedra para la curación del cólera morbo" $" 726$.

En el año 1834 la epidemia alcanza su apogeo pero como señala Pablo Marcos Martínez ${ }^{727}$, hasta el mes de junio no se ponen en marcha las primeras medidas preventivas y relata que el retraso viene motivado por la defectuosa administración, el afán de ocultar la magnitud del drama y la creencia de que al no reconocer la existencia del contagio, se podían mitigar sus efectos.

Los temas de la construcción de cementerios en las afueras, la construcción del alcantarillado, la prohibición de los enterramientos en las iglesias y la prohibición de los funerales "de cuerpo presente" son actuaciones beneficiosas para erradicar la epidemia. Pero no son rápidas, los cementerios y el alcantarillado por su coste y los enterramientos y funerales por costumbre, por lo que la Junta de Sanidad recuerda en un bando que se publica y se reparte por toda la provincia lo importante que resulta el respetar una serie de medidas higiénicas básicas para controlar la epidemia, destacando la higiene y el aseo personal, la higiene en los alimentos, la limpieza de las calles y la recogida de basura. Otras medidas complementarias son las que toma el Ayuntamiento de la capital, que "acuerda la suspensión de las ferias para evitar la propagación del cólera", medidas que se complementan con las peticiones de ayuda económica para progresar en el fomento de la higiene.

La Diputación conoce los problemas de la epidemia a través de una serie de expedientes que reclaman su atención y que tiene que estudiar, relacionados con el tema, como es el proyecto de un alumno de la Facultad de Medicina, que presenta un estudio sobre un método eficaz para precaver y curar el cólera. Existieron además otros expedientes más prosaicos como ocurre con los presentados por los médicos de Tordesillas, que reclaman el pago de los trabajos realizados en 1834, con ocasión de la epidemia de cólera morbo sufrida por la citada villa ${ }^{728}$. También la Diputación sabe que ni la Junta de Sanidad ni los médicos pueden luchar contra la epidemia si no se mejoran las condiciones higiénicas de la población y estas medidas pasan por modificar las costumbres ciudadanas a través de la educación y de la inversión económica. En el año 1840, se produce nuevamente alarma de epidemia, y la población es alertada a través de una circular que se publica en el Boletín Oficial de la

726 B.O.P.V. $n^{\circ} 28$ de fecha 15 de octubre de 1833.

${ }^{727}$ MARCOS MARTÍNEZ, Pablo. Crisis demográfica y tensiones sociales en la Castilla del siglo XIX. Ed. Universidad de Valladolid. Valladolid. 1987.

728 A.D.P.V. Actas. Libro de actas del 19 de junio de 1836. 
Provincia "sobre la adopción de medidas pertinentes, para evitar la propagación de la viruela aparecida en la Mota del Marqués"729.

En los años 1854 y 1855 , se inicia una nueva epidemia de cólera morbo y lo avisa el Boletín Oficial de la Provincia cuando con fecha 31 de agosto de 1854, publica una real orden "sobre preocupación y aviso de invasión de la epidemia de cólera morbo". Alarma que se confirma cuando el día 2 de enero de 1855 se publican en el mismo periódico oficial las reglas de actuación para evitar el contagio del cólera morbo. Parece que las "reglas" hacen su efecto, pues en marzo del mismo año, "el gobierno comunica la total desaparición del cólera morbo, y para evitar una nueva reproducción como ocurrió en 1834, el gobierno ha previsto las medidas higiénicas necesarias para evitarlo" ${ }^{730}$. Información que parece muy optimista cuando en el mes de agosto, "ante la aparición de una nueva epidemia de cólera morbo se ordena se tomen las medidas oportunas y necesarias para prevenir su extensión".

Y continuando con esta epidemia, que a veces aparece y otras veces está dominada, la Diputación reseña en su libro de actas tres noticias relacionadas con el tema, vistas en el mes de septiembre: "La Diputación provincial agradece a D. Esteban Remolar, médico de Medina, el socorro llevado a cabo en Rodilana, terriblemente atacado por la epidemia reinante". "Enterada la Diputación de la liquidación ventilada por las oficinas del Sr. gobernador, designando los honorarios devengados por los facultativos de medicina en la asistencia a varios pueblos atacados por el cólera morbo, acordó: Devolver para nueva liquidación deduciendo los gastos de manutención y carruaje, y que practicada, se abonen de estos fondos y reparta a los pueblos invadidos, con deducción de lo que resulte justamente aplicado a los fondos de la provincia". "Se lee en el Pleno de la Diputación el manifiesto publicado por el Sr. gobernador, en el que se asegura que ante la celebración de las fiestas de la capital declara solemnemente que no reina el cólera en Valladolid y no hay razón para suspender la próxima feria". Pero el propio gobernador que aseguraba que en Valladolid no reinaba el cólera, anunciaba en el mes de octubre "la situación aflictiva de varios pueblos de la provincia por invasión del cólera morbo". Situación que se confirma con una serie de expedientes promovidos por diversos pueblos ocasionados por la lucha contra la epidemia. "El Ayuntamiento de Peñafiel gratifica a los médicos por los servicios extraordinarios durante la invasión del cólera morbo con 6.670 reales". Igualmente en los pueblos de Portillo, Pozal de Gallinas, Nava del Rey, Pollos y Ceinos, los distintos Ayuntamientos premian y gratifican a sus médicos por "los esfuerzos realizados para erradicar el cólera morbo". En Tudela de Duero, el médico "reclama los gastos de alojamiento de los facultativos que se alojaron en su casa durante la invasión del cólera morbo y además un premio por los servicios extraordinarios". A principios de 1856, la epidemia se considera controlada.

Tras unos años de tranquilidad, una nueva amenaza de epidemia de cólera morbo, surge en el año 1865, lo que propicia una reunión urgente del Pleno de la Diputación para tratar del tema ${ }^{731}$. Esta convocatoria se hace en octubre de 1865 y en abril de 1866 todavía continúa el riesgo de epidemia, por lo que la Academia Médico Quirúrgica, publica una instrucción para prevenir la invasión del cólera morbo. Esta es la última noticia que hace referencia a la epidemia, lo que hace suponer que a partir de esta fecha está controlada, no volviendo a aparecer ninguna otra incidencia epidemiológica en lo que resta del período isabelino. del cólera morbo asiático y de que de llegar desgraciadamente este caso, pudieran los pueblos tener recursos auxiliares cuando los suyos propios no basten a satisfacer las atenciones que origine la epidemia. En consecuencia la Diputación acordó transferir de la partida de impuestos los 50.000 escudos destinados al Instituto Provincial de Segunda Enseñanza al capítulo de Calamidades Públicas y nombrar una comisión compuesta por los diputados residentes en la capital para hacer la distribución de los mencionados fondos" A.D.P.V. Actas. Libro de actas del 22 de octubre de 1865. 
Durante la vigencia del Sexenio no se registran asuntos relativos a episodios sanitarios ni epidémicos, con la excepción de la petición a la Diputación, por parte de la Junta de Sanidad, solicitando "se tomen medidas para evitar la extensión del tifus que se encuentra extendido por las provincias de Burgos, Palencia, Zamora, Salamanca, Zaragoza y Madrid"732. Aunque no resulta de gravedad en la provincia, el Ayuntamiento de Tordehumos advierte sobre casos de tifus entre sus vecinos, pero no se propagaron más allá de este pueblo.

\subsection{3.- BENEFICENCIA. CONTROL PROVINCIAL DE POBRES Y RECURSOS}

En el año 1813, cuando la Diputación provincial inicia su andadura, en la provincia abundaban toda una serie de establecimientos benéficos, hospitales, asilos, casas de misericordia, de niños expósitos, etc. Instituciones con una larga y dilatada historia, con diferentes orígenes y finalidades, pero con un mismo denominador común: todas ellas estaban dirigidas y controladas por organismos de carácter religioso, ya sean obispados, órdenes religiosas, obras pías y en último caso por los Ayuntamientos respectivos. Como ejemplo tenemos que "el director de la Casa de Misericordia y Expósitos de esta ciudad expone al Ayuntamiento que los Agustinos Calzados reclaman al Establecimiento como patrono de las obras pías de Fabio Nelli la cantidad de 13.044 reales de vellón procedentes del complemento de misas" ${ }^{733}$. La misión que tiene la Diputación sobre los establecimientos benéficos provinciales, a fin de cumplir con uno de los trabajos que tiene encomendados en este ámbito, no es la de controlar a los centros y sí la de velar por la buena gestión de los citados establecimientos.

En el año 1820, recién iniciada la segunda etapa de funcionamiento, la Diputación en su afán por seguir conociendo las actividades benéficas, aprueba el realizar una visita por una comisión nombrada a tal fin, a los establecimientos benéficos establecidos en la capital. Tal intención es contestada rápidamente por el obispado, el cual comunica "la resistencia a la visita acordada por la Diputación a los Hospitales Generales y de Esgueva". Los hospitales están funcionando bajo la tutela del obispado y no es de su agrado que la Diputación interfiera en su gestión. Pe ro ésta insiste en sus pretensiones, "reiterando la visita a los hospitales que son instituciones a las que la Diputación tiene la potestad de vigilar" ${ }^{\text {734 }}$.

Para evitar estas discusiones, que no son exclusivas de esta provincia, el gobierno con el fin de "reordenar las actividades benéficas", por real decreto de 27 de diciembre de 1821 aprueba la creación de las "Juntas Municipales de Beneficencia". Detalla en su artículo dieciseis la relación que debe de existir entre la citada Junta y los organismos públicos competentes: "Estas Juntas se entenderán en todo directa y exclusivamente con los Ayuntamientos respectivos, y sólo en el caso de tener que reclamar de agravio contra ellos, podrá dirigirse en derechura a las Diputaciones provinciales, las cuales en todo lo relativo al ramo de beneficencia se entenderán con el Ministerio de la Gobernación de la Península" $" 735$.

Es el primer paso del gobierno en la línea de mejorar la gestión de la beneficencia, a través de la "provincialización de las instituciones benéficas". Otro objetivo es canalizar las ayudas a través de las citadas Juntas de Beneficencia, actuación que se complementa con un nuevo real decreto "relativo a que por el Ministerio de Gracia y Justicia se insista a los R.R. Obispos y demás Prelados a que hagan conocer a sus diocesanos lo muy conveniente que sería que las limosnas que se

B.O.P.V. no 58 de fecha 13 de marzo de 1869 .

733 A.D.P.V. Actas. Libro de actas del día 1 de abril de 1814. Sobre la Casa de Misericordia en Valladolid ver PALOMARES IBAÑEZ, José María. La asistencia social en Valladolid. El Hospicio de Pobres y la Real Casa de Misericordia (1724-1847). Ed. Diputación Provincial de Valladolid. Valladolid. 1975.

734 A.D.P.V. Actas. Libro de actas de los días 12 y 18 de abril de 1820 .

735 Colección de Reales Decretos y Órdenes... ob. cit. Tomo VII. R.D. de 27 de diciembre de 1821. 
acostumbran a distribuir a los pordioseros se entreguen en adelante a las respectivas Juntas de Beneficencia, instaladas en virtud de la circular de 30 de julio último" ${ }^{736}$.

Este es un decreto de "buenas intenciones", pues es conocido que las Casas de Beneficencia tienen graves dificultades para mantener sus actividades desde un punto de vista económico. Las ayudas son escasas para la cantidad de pordioseros, desheredados, ancianos, expósitos, enfermos y muchas otras personas que no tienen trabajo y necesitan de la caridad pública para subsistir. Por su parte, las instituciones oficiales, es decir, Ayuntamientos y Diputaciones, no tienen capacidad para mantenerlos a pesar de las recomendaciones del gobierno de "que de los fondos de propios, se suministre lo necesario a los establecimientos de beneficencia para su conservación". Aunque como muy bien dice Elena Maza, "el Gobierno está interesado en acabar con la autonomía administrativa de las instituciones benéficas y a que la organización y cuidado de estos establecimientos pasen a ser controlados por los poderes públicos"737.

En línea con estos propósitos de puesta en manos de las autoridades locales, al final del Trienio la Diputación actúa ante una serie de peticiones, cursadas a través de la Junta de Beneficencia, en las que numerosas mujeres de milicianos, a causa de la larga estancia de sus maridos en la Milicia solicitan ayuda, "pues no disponen de medios de subsistencia y se acuerda que los Ayuntamientos ayuden a estas mujeres con un real y medio al día" ${ }^{\text {738 }}$.

Reclamaciones que se repiten a lo largo del año 1822, ante la penuria que sufre la provincia y ante la situación de desamparo en que continúan las mujeres de los milicianos. Son habituales las peticiones como "la solicitud de María del Olmo, vecina de esta ciudad y esposa de Roque Gallardo, cabo $1^{\circ}$ del batallón de Milicia Activa de la provincia pidiendo se la socorra de los fondos públicos para atender a su subsistencia y la de un niño de corta edad, con que se halla y se acordó pasarlo al Ayuntamiento para que socorriese a la interesada con lo que crea conveniente" 739 .

El problema está centrado en que la Junta de Beneficencia ${ }^{740}$ no tiene capacidad económica para resolver todos los problemas que se la presentan. Únicamente puede dedicarse a actuar de interlocutora entre la Diputación y las instituciones benéficas, pero sin capacidad de decisión. El gobierno, consciente de esta difícil situación, busca la forma de ayudar a los centros asistenciales y como ejemplo tenemos el caso de Palencia, en el que a través de una real orden "se manda hacer saber a todos los jefes políticos que será del agrado de S.M. que los hospitales, hospicios y demás casas de beneficencia socorridas por la Hacienda Nacional, se provean de las mantas que se fabrican en la Casa de Misericordia de la ciudad de Palencia"741.

El fin del período liberal representa igualmente el fin de esta segunda etapa de vigencia de la Diputación. Como consecuencia, los centros benéficos vuelven a estar bajo el control de las órdenes religiosas, de los cabildos y de las numerosas obras pías encargadas de su regencia. En el año 1835, en que se retoman las actividades provinciales a cargo de la Diputación, también se vuelve a tomar contacto con los problemas de la beneficencia y a reclamar su derecho a fiscalizar las actividades de

736 A.D.P.V. Actas. Libro de actas del 13 de septiembre de 1821.

737 MAZA ZORRILLA, Elena. Valladolid, sus pobres....ob. cit. Pág. 222.

738 A.D.P.V. Actas. Libro de actas del 19 de agosto de 1822.

739 A.D.P.V. Actas. Libro de actas del 2 de septiembre de 1822

740 La Junta de Beneficencia, inició sus trabajos a partir del 8 de agosto del año 1821, según el libro de actas del 27 de agosto: "en que se celebra la primera junta en la posada del jefe superior, su presidente nato estando formada por D. Fernando Macho Soto, representante de la Diputación D. Baltasar Hermoso y Daza y D. Nicanor Ibáñez por el Ayuntamiento de la capital, D. José Cabeza de Vaca y D. Gabriel Semprún como vecinos ilustrados y los profesores de Medicina y Cirugía D. Ildefonso Navarro y D. Lucas Dueñas".

741 A.D.P.V. Actas. Libro de actas del 22 de agosto de 1821. 
los establecimientos benéficos. Así lo hacía ver el diputado Sr. Sanz, diciendo que los Ayuntamientos deben dar cuenta de la beneficencia a la Diputación ${ }^{742}$.

El principal problema estriba en que los fondos de que disponían los centros de beneficencia en muchas ocasiones no eran suficientes para cubrir las necesidades de los acogidos con las consiguientes dificultades que esta situación provocaba. Con el paso de los años, de todas formas, se observa una tendencia a controlar, por parte de la Diputación, los establecimientos benéficos, ya sea los dependientes de la Iglesia o de otro tipo de fundaciones de carácter privado. Tan pronto como comienza la Década Moderada, se intensifica el proceso de provincialización. Es tal la proliferación de establecimientos, que en el año 1845, el jefe político envía a la Diputación una comunicación "solicitando un listado de todos los establecimientos benéficos de la provincia con la finalidad de clarificar y conocer la situación de la beneficencia provincial". En consecuencia con esta tendencia, la Junta de Beneficencia en el año 1849 "presenta un proyecto de estatuto de la Junta Provincial de Beneficencia, con la propuesta de unificar las Casas de Maternidad, Expósitos y Misericordia, bajo la denominación de Hospicio Provincial de Valladolid".

La preocupación por las mejoras en la beneficencia continúa con el paso de los años, aunque en la mayoría de los casos esta preocupación no se traduce en mejora real de los beneficiarios, situación que se agrava en el año 1855, con la desamortización de Madoz, ley que provoca una pérdida real de capital en todos los centros benéficos vallisoletanos que ven como sus bienes rústicos se han transformado en Papel del Estado, cuyo valor y rentabilidad se va perdiendo con el paso de los años ${ }^{743}$. En este contexto tenemos las comunicaciones que se mantienen entre la Dirección General de Beneficencia y la Diputación, en las que la primera se dirige a la segunda y pregunta que: "con cuánto podía contribuir la provincia para la construcción y reparación de los establecimientos benéficos provinciales". A lo que la Diputación acordó responder "comprometiéndose a destinar a mejoras de las instalaciones provinciales, lo mismo que destine el gobierno supremo, durante un período de cuatro años siempre que no exceda de 100.000 reales". La contestación del gobierno viene a través de la R. O. de 30 de octubre, en la que "se concede una subvención de 360.000 reales para la reparación de los centros de beneficencia de la provincia, con la condición de que la Diputación invierta el doble de esa cantidad en la citada reparación",744.

En estos años era habitual la donación de bienes, hecha en testamento por diversos benefactores. Pero también era habitual que la Diputación verificase la veracidad y cuantía de las donaciones. Como ejemplo tenemos que, ante la petición de la Junta de Beneficencia, la Corporación rechazó la donación de D. Ignacio Grijalba, "porque dicho señor no tiene bienes para cubrir el legado".

Con la llegada del Sexenio Revolucionario, en la sesión del 20 de marzo del año 1869, "se aprueba el reglamento de funcionamiento de la Sección de Beneficencia una vez que ha pasado a ser controlada por la Diputación". Para alcanzar un mejor funcionamiento de la beneficencia, la Diputación elige de entre sus miembros a una comisión para el estudio y control de las actividades benéficas, que llega a la conclusión de que la mejora de la actividad de los establecimientos pasa por dotarles de fondos económicos. Por ello recomienda a la Diputación que "acuerde la enajenación de Bonos del Tesoro hasta 4.000 escudos". Y además, como las cuentas de los diferentes establecimientos benéficos no estaban muy claras, la Corporación

742 “que el abandono en que estaban los establecimientos de beneficencia exigía que la Diputación acordase medidas para corregir los abusos y la más principal era la de pedir las cuentas de las incursiones de caudales, por lo que convenía circular en el Boletín Oficial de la Provincia la responsabilidad de los Ayuntamientos en el cumplimiento del art. 35 de la Ley de Beneficencia, que establece la obligación de remitir a la Diputación las cuentas de los establecimientos benéficos". A.D.P.V. Actas. Libro de actas del 26 de junio de 1838.

${ }^{743}$ MAZA ZORRILLA, Elena. Valladolid: sus pobres y.... ob. cit. Págs. 320 y sig.

744 A.D.P.V. Actas. Libro de actas del 3 de abril y 4 de diciembre de 1860. 
reclama los balances económicos a los patronos de las mismas. Y "ante su negativa a entregar los valores de la Beneficencia, pone el asunto en manos de los abogados"745. Acto seguido se nombra a un nuevo comisionado en la persona de Ignacio María Bueno, con la finalidad "de conocer el estado de los censos, las hipotecas y los deudores de los establecimientos benéficos provinciales, es decir Hospitales y Hospicio y se acuerda como pago, el abono de una comisión entre el 3 y el $12 \%$ según los años de descubierto"746.

El problema de la Diputación es que ignora la cuantía de los bienes y de los deudores de estas instituciones. Si el nombramiento de este nuevo apoderado se celebró en agosto de 1870, ya en febrero de 1871, el citado Sr. Bueno presenta a la Diputación un resumen de la situación económico-administrativa de las instituciones benéficas, sin especificar cifras ni nombres. Esta actividad se remata en el año 1873, con la "puesta al día de los créditos y bonos que posee la Beneficencia Provincial, investigada por D. Ignacio María Bueno" "747. Esta información se completa a los pocos días con la publicación de la "Memoria presentada por el Sr. Bueno sobre la considerable suma que representan los créditos y la existencia de los títulos para demandar las deudas". En este caso, la Diputación tampoco da detalles de la cuantía de los créditos ni de los beneficiarios, pero sí está conforme con el trabajo realizado, aprobar la memoria y conceder "un premio de 500 pesetas al Sr. Bueno por su inestimable labor". A la vez, para completar el trabajo, la Diputación también acordó el nombramiento de abogados para reclamar las deudas a través de la Justicia ${ }^{748}$. Aunque las deudas a la beneficencia sean grandes, está claro que se tardará en cobrar. Mientras tanto, la situación económica de los establecimientos benéficos pasa por graves dificultades, como reflejan las actas del año 1872, con la petición "de un aprovisionador de la beneficencia que solicita la rescisión del contrato". Petición que es debida, como es lógico, a que no se le paga las provisiones desde hace tiempo y, aunque la Diputación tiene en cuenta a los centros en sus presupuestos, a la hora de la verdad, nunca llega a cumplir con lo propuesto en los mismos.

En conclusión, vemos que la beneficencia, a lo largo de su recorrido entre los años 1813 a 1874 , se va transformando y modernizando, con tendencia a mejorar y a dar una mayor satisfacción a los usuarios, ya sean pobres, huérfanos o enfermos, con dos cambios fundamentales. Se coloca en manos de las autoridades locales y se da preponderancia a la gestión provincial. Dentro del cómputo de establecimientos benéficos hay tres que destacan tanto por su historia, como por las ayudas que prestan a una sociedad, que en estos años se encontraba muy desprotegida socialmente hablando. Estas son la Casa de Niños Expósitos, que se transformará en Hospicio Provincial, el Hospital de la Resurrección, que pasaría a denominarse Hospital Provincial, y el Hospital de Inocentes Dementes, que sería posteriormente el Manicomio Provincial ${ }^{749}$.

\section{La Casa de Niños Expósitos}

Los primeros pasos del Hospicio vallisoletano se inician en el año 1724, bajo los auspicios del duque de Hijar que para tal fin cedió la propiedad de su palacio situado en la actual plaza de Las Brígidas, con la presentación de un memorial al rey Felipe V "para recoger a cerca de mil vecinos pobres" ".50 1752 toma el nombre de Real Casa de Misericordia, aunque siempre se le conoció con el nombre genérico de

745 A.D.P.V. Actas. Libro de actas del 7 de julio de 1870.

746 A.D.P.V. Actas. Libro de actas del 31 de agosto de 1870.

747 A.D.P.V. Actas. Libro de actas del 11 de marzo de 1873.

748 La Diputación nombra abogado a D. Eladio Quintero y procurador a D. Benigno Villalba, a mbos individuos eran diputados provinciales en los años 1872 a 1874.

749 MAZA ZORRILLA, Elena. Valladolid y sus pobres...ob. cit., con un estudio completo sobre los centros asistenciales en Valladolid, su evolución y su modernización.

${ }^{750}$ Para una mayor información sobre la historia del Hospicio ver PALOMARES IBAÑEZ, Jesús María, La asistencia social en Valladolid. El Hospicio de Pobres y la Real Casa de Misericordia (1724-1847). Ed. Diputación de Valladolid. Valladolid. 1975 
Hospicio. En el año 1813 con el inicio de las actividades de la Diputación, en el Hospicio convivían tres instituciones, la Casa de Misericordia, el Asilo de Niños Expósitos y la Maternidad, que compartían el mismo edificio, la misma administración y las mismas dificultades económicas. Una de las primeras referencias que se reflejan en los libros de actas en su primer año señala que "el director de la Casa de Niños Expósitos presenta las cuentas a la Diputación haciendo ver los atrasos que le adeuda la Hacienda Pública de 46.954 reales y 35 maravedís, lo que entorpece su economía" 751 .

Es, sin duda, el problema económico el mayor con que se encuentran los establecimientos de beneficencia y a los cuales no se puede sustraer la Diputación. Si en 1814 se hace eco de las dificultades del Hospicio a causa de los "atrasos de la Hacienda Pública", en 1821 se tiene que enfrentar a más dificultades al no cobrar un arbitrio que habitualmente le pagaban los cosecheros de vino. El director de la "Casa de Niños Expósitos" envía un oficio a la Diputación "reclamando el pago del arbitrio de dos maravedís que le pagaban desde tiempo, por cada cántaro de vino con que deben de contribuir los pueblos cosecheros de la provincia con arreglo al real decreto de 26 de enero de 1818, pero que hallándose embarazada su cobranza, y sien do uno de los principales recursos con que se sostiene el establecimiento, pide se tomen las providencias más eficaces"752. Ante la reclamación, la Diputación indaga el motivo por el que se ha dejado de pagar el arbitrio, impuesto en su día por el Consejo de Castilla, y resultó que con la llegada del Trienio Liberal había sido abolido. Durante el año 1821, la Casa de Niños Expósitos sigue reclamando el pago del arbitrio de "dos maravedís por cántaro de vino", pues para el director se considera necesario para el mantenimiento del establecimiento. En el año 1822 continúa la controversia sobre el pago del arbitrio, aunque en este caso, el gobierno había intervenido incrementando esa cantidad en los impuestos corrientes. Sin embargo, es cierto que el Hospicio no recibía el dinero, lo que obligaba al director a recordar a la Diputación esta situación $^{753}$. La Diputación, tan escasa de fondos como el Hospicio, envió una "exposición al Soberano Congreso", solicitando una aclaración y una salida para conseguir la financiación necesaria a la Casa de Expósitos.

La llegada de la Década Ominosa y la consiguiente desaparición de la Diputación no son óbice para que el Hospicio en esta época siguiera teniendo dificultades económicas. También en estos años se produce el traslado al palacio de los condes de Benavente, situado en la Plaza de San Nicolás, edificio en el que se mantendrá hasta su desaparición en 1974.

Nada más reiniciada su andadura en 1835, la Diputación solicita al administrador del Hospicio "un informe sobre su situación económica". En estos años se vuelve a reproducir la controversia del arbitrio "de los dos maravedís por cántaro de vino". Por un lado el diputado Pimentel, en exposición enviada a la Diputación en enero de 1838, "solicita la abolición por ser desigual, de la carga de dos maravedís por cántaro de vino, por parte de los cosecheros", por otro lado, el administrador de la Casa de Expósitos D. Manuel de Alevesque reclama "cuatro maravedís por cántaro de vino, al no tener fondos para hacer frente a todas las necesidades" y finalmente la comisión de Beneficencia solicitará "que el impuesto de dos reales por cántaro de vino para el sostenimiento de los niños expósitos, se hiciera por todos los contribuyentes". Este asunto continuará a lo largo de los años, con periódicas reclamaciones del director de la Casa ante sus dificultades económicas y también con las quejas de los pueblos por tener que pagar este arbitrio. No será resuelto este problema hasta el año

751 A.D.P.V. Actas. Libro de actas del 1 de abril de 1814.

752 A.D.P.V. Actas. Libro de actas del 28 de octubre de 1820.

753 "que habiendo comunicado a los pueblos la liquidación efectuada por la Contaduría de Rentas del importe quinqueniado con que debían asistir a la misma en subrogación de los dos maravedís por cántaro de vino, se negaban a hacerlo, por cuyo motivo imposibilitaba el cubrir sus atenciones, pidiendo a la Diputación que proveyera del oportuno remedio" A.D.P.V. Actas. Libro de actas del 16 de marzo de 1822. 
1847, época en la que se inician una serie de modificaciones que permitirán regularizar las cuentas del Hospicio.

Desde este momento se refuerza la provincialización aún más. En primer lugar, se pasa una exposición al gobierno "para conocer si la Casa de Niños Expósitos tiene carácter provincial" ya que en caso afirmativo pasaría a ser controlada por la institución. En segundo lugar, se acuerda el incluir en los presupuestos de la Diputación de 1848 una partida destinada al mantenimiento de la beneficencia, con una serie de recomendaciones de mejora, como es la de que "se considera mezquina la suma de ochenta y ocho reales por retribución anual a los enterradores de los expósitos fallecidos, y justos los cuatrocientos trece reales al cura de S. Nicolás por los bautizos y ciento cuarenta al sacristán". Y también se considera interesante y se recomienda una visita a la Casa para conocer su estado, pero sobre todo para solucionar, tanto la financiación de la institución como la controversia con los cosecheros de vino de la provincia: "Se acordó suprimir el arbitrio de 86.475 reales y 11 maravedís correspondientes a los dos maravedís por cántaro de vino, e incorporar a los presupuestos el importe de dicho arbitrio"754. En tercer lugar, la estabilización de la Casa de Niños Expósitos pasa por el proyecto que se presenta en la Diputación el 25 de noviembre de 1849 con la propuesta de "unificar las Casas de Maternidad, Expósitos y Misericordia, bajo la denominación de Hospicio Provincial de Valladolid", proyecto que fue aprobado por el Pleno.

La Diputación, al aceptar el control del Hospicio, admite por un lado las reclamaciones de los funcionarios del mismo, es decir, médicos, empleados, administrativos, etc., solicitando aumento de salarios y por otro lado, inicia los movimientos necesarios para equilibrar las cuentas, una vez controladas y viendo el desfase entre gastos e ingresos. Como ejemplo tenemos que, en los presupuestos de 1849 , se reflejan unos ingresos de 27.236 reales y unos gastos de 168.652 reales,

Durante los años siguientes se reclamarán ingresos y se realizarán ventas. En el año 1847 "se aprueba el corte de árboles propiedad de la Casa de Expósitos para ayudar a su mantenimiento", "se reclama al Ayuntamiento de Valladolid 96.169 reales de réditos de su censo desde el año 1823" y "se solicita instalar una hijuela de la Casa en Tordesillas para evitar el envío de huérfanos a la Casa-Hospicio de Toro". En el año 1848 "se acuerda acceder al aumento de la dotación en cincuenta ducados a los médicos de la Casa de Misericordia, Niños Expósitos y Maternidad". Aunque la mejor forma de equilibrar los presupuestos es la de vender las numerosas propiedades que posee el Hospicio. Para ello, en 1849 "se venden a censo reservativo unas viñas en la cuesta de San Cristóbal pertenecientes a la Casa de Misericordia, con la condición de fijar un rédito del $3 \%$ y que sólo se dan a censo las 78 obradas que se fijan por el agrimensor y se salva el derecho de disponer del resto hasta las 130 higüadas y 26 estadales de que hablan los antiguos apeos". En el año 1850 y para hacer frente a unos gastos de 232.625 reales, se acuerda la venta de "una finca en San Miguel del Pino, una viña en Fuensaldaña, una vivienda en el Atrio de Santiago, una tierra, propiedad del Hospicio, a censo, y la Dehesa de Porres, que se vende a censo". En el año 1851, se siguen reseñando una serie de ventas de diferentes propiedades. "Venta de una escribanía, gravada por un censo. Venta de una casa propiedad del Hospicio. Venta de dos solares en la calle Olleros, pertenecientes al Hospicio. Mariano Miguel de Reynoso compra a censo reservativo terrenos en Arroyo propiedad del Hospicio. Venta de una casa en la calle La Parra, a censo reservativo". En el año 1852 continúan las ventas, y se estiman en los presupuestos del siguiente año económico "unos ingresos de 185.100 reales procedentes de la venta de terrenos del Hospicio". En los libros de actas se refleja en este año la venta a D. Apolinar Oliva, a censo reservativo, de las casas 9 y 11 de la calle Prado, 10 y 16 de la calle Obispo y 6 de la calle Boariza, pertenecientes al Hospicio". La venta a Manuel Monedero de la casa de la

754 A.D.P.V. Actas. Libro de actas del 23 de octubre de 1847. 
calle de San Martín ${ }^{\circ} 5$, calle Parra $n^{\circ} 9$ y el solar de la calle Del Medio, propiedad del Hospicio.

El Hospicio, además de vender, también recibe donaciones, de acuerdo con lo reflejado en las $\operatorname{actas}^{755}$. En el año 1853, la Diputación autoriza la venta, a censo reservativo, de otras diez casas propiedad del Hospicio. Parece que son las últimas que se venden, pues no vuelven a aparecer más anuncios, aunque el dinero ingresado no ha sido suficiente para mejorar la situación del Hospicio y el director se queja a la Diputación "del lamentable estado de la Casa-Hospicio de la provincia y la urgente necesidad de prestar auxilio a los expósitos, muchos ya muertos y todos expuestos a morir por falta de alimento. La Diputación acordó librar 32.277 reales, con lo que se cubrían las necesidades hasta fin de septiembre" ${ }^{756}$ A partir del año 1854, la Diputación, proyecta mejoras y ayudas al Hospicio al pagar la mensualidad a las amas lactantes del Hospicio y destinar 10.000 reales para obras en el edificio. En este mismo año se nombra administrador a D. Félix González Santana. En el año 1855 se acuerda librar 20.000 reales al Hospicio, la subida salarial a los médicos y a la vez se decide abonar al Hospicio 30.000 reales. En el año 1856, se nombra médico del Hospicio a Deogracias Fernández. En el año 1858, se acuerda aumentar la dotación del capellán y se le conceden 6.000 reales al año, con 283 misas. Se aprueba una nueva plantilla de médicos con un médico con 5.000 reales año, otro médico con 3.000 reales año y un cirujano con 2.000 reales año. En el año 1861 se acuerda conceder aumento de salario: El director pasa de 6.000 a 8.000 reales. El administrador de 4.200 a 6.200 reales. El médico pasa de 3.000 a 6.000 reales, todo ello teniendo en cuenta el elevado precio que habían tomado los artículos de primera necesidad.

En el año 1865, la Diputación, en su memoria anual dirigida al gobierno, en el capítulo de la Beneficencia destaca la dedicación de mayores recursos en el presupuesto. En el año 1866 la Diputación aprobó "adquirir la maquinaria para instalar una imprenta en el Hospicio" como nueva fuente de ingresos. Ocasión que aprovechó el director de la Casa para solicitar de la institución"la impresión de todos los documentos de la Diputación".

Con la llegada del Sexenio en el año 1868, se produce el nombramiento de administrador del Hospicio en la persona de Miguel Martínez Sagarmínaga, que con anterioridad desempeñaba el cargo de oficial $2^{\circ}$ en la Secretaría de la Diputación "con 4.000 escudos de sueldo anual". Disfrutó por poco tiempo del cargo, pues con fecha 14 de abril de 1869 "se anuncia la muerte del administrador del Hospicio Miguel Martínez Sagarmínaga y se nombra nuevo administrador a Luis Navarro". Persona que tampoco durará mucho en el cargo, pues a finales del mismo año 1869, la Diputación acuerda "cesar en su cargo al administrador del Hospicio y nombrar en sustitución a Remigio Capilla Aguilar". Este cese era consecuencia del dictamen de la comisión de Beneficencia en el que "se lamenta de la mala y deplorable situación en que se encuentra el Hospicio" "757. Haciendo hincapié en el mismo informe, no sólo lo referente al edificio y las ruinosas instalaciones que ocupan, sino sobre todo a la grave situación de los hospicianos; hace un relato "del lamentable estado en que se encuentran los asilados en el Hospicio por la falta de prendas de abrigo". Ante esta

755 "Expediente de donación al Hospicio Provincial por Norberto Mediavilla de una casa en la calle La Huerta tasada en 25.846 reales, otra en la Plazuela de San Pedro de 50.338 reales, otra en la Plaza Mayor de 50.284 reales y la propiedad del oficio de portero de la Real Chancillería y 53.800 reales dados a préstamo al 6\%. A descontar un censo sobre la casa de la calle La Huerta de 4.836 reales, un capital duplo sobre la casa de la Plazuela de San Pedro a favor de la Capellanía de la parroquia por 44.000 reales, una carga a favor del Estado sobre la casa de la Plaza Mayor de 3.175 reales. En resumen: Bienes 182.274. Bajas 56.624. Líquido adjudicado 125.650 reales. También es baja el oficio de portero legado por Mediavilla a su ama Francisca Martínez por los días de su vida y 4 reales diarios de la renta de la Plaza Mayor, por los días de su vida y los 72 reales por 12 misas". A.D.P.V. Actas. Libro de actas del día 15 de febrero de 1853.

${ }^{756}$ A.D.P.V. Actas. Libro de actas del 2 de septiembre de 1854.

757 A.D.P.V. Actas. Libro de actas del 1 de diciembre de 1869. 
situación la Diputación toma el acuerdo de "convocar a los comerciantes para que surtan de paños" ${ }^{, 758}$.

El verdadero problema está en la falta de fondos para que el Hospicio y los hospicianos tengan cubiertas sus necesidades mínimas, y no era un problema de administración sino que el administrador tenga algo que administrar. En este sentido, se van moviendo y ampliando las actividades de la institución, pues si ya está en funcionamiento la imprenta, en estos días se aprueba la instalación de un taller de tejidos, en el que además de cubrir las necesidades propias, puedan trabajar para el exterior generando unos beneficios de los que están tan necesitados los asilados. Para dirigir el taller, se nombra maestro-tejedor a Pedro González Benito. En esta misma línea, otra propuesta, que en este caso no llegará a materializarse, es establecer "una fábrica de cajas de cerillas". Lo que sí funciona con regularidad es la banda de música, que en el mes de febrero de 1870 "solicita permiso para tocar por la calle".

Paralelo al aumento de las actividades "industriales", también aumenta el número de asilados que pretenden realizar estudios. En 1870 se trata sobre "la solicitud de un hospiciano para ser matriculado en el Instituto de Segunda Enseñanza y la petición de la Dirección del Hospicio para subvencionar a un hospiciano para que pueda realizar la carrera de Magisterio y a otro para pagarle el título de bachiller" ${ }^{759}$. Actuaciones de mejora de la enseñanza que se complementan con la solicitud pasada por el director del Hospicio el 12 de noviembre de 1874, para "instalar en el Hospicio una escuela de párvulos, con el fin de mejorar el nivel de los niños asilados".

La forma ideal de mantener ocupados a los hospicianos es con el trabajo o con el estudio. Como hemos visto y la Diputación recordará más tarde, los asilados pasan hambre y pasan frío y, si además están desocupados, no es de extrañar que tengan enfrentamientos entre sí o lo que es peor, con otras personas como "la agresión a palos de un celador por dieciocho internos del Hospicio". Para evitar estos incidentes, la comisión de Beneficencia propone "visitar los establecimientos y establecer normas de funcionamiento para evitar los abusos que se suceden en los mismos, en es pecial en el Hospicio Provincial" ${ }^{, 760}$. Otra de las preocupaciones que surgen en estos años del Sexenio es la referente a la dotación del personal facultativo y sus reclamaciones, básicamente económicas. También en estos años se producen peticiones de nombramientos y cambios de médicos, que son cuestionados en diferentes intervenciones de los diputados, lo que ocasiona atrasos y demoras que entorpecen la normal actividad del Hospicio.

Como noticia interesante en el año 1872, tenemos la comunicación del depositario provincial, Fidel Serrano, anunciando el cobro de 135.000 reales de las cuentas pendientes del Hospicio, que en su día gestionó el comisionado Ignacio María Bueno. Esto anima al director de la institución a "convocar un concurso entre sastres para equipar de trajes a los asilados, admitir en el Hospicio a todos los niños huérfanos pobres en estado de lactancia y acopiar ropa, calzado y alimentos para los asilados" $" 761$.

\section{El Hospital Provincial}

La Casa de Expósitos era un establecimiento prácticamente único para toda la provincia de Valladolid, ubicado en la capital. Lo mismo se puede decir del Hospital de Dementes, que no sólo acogía a enfermos de la provincia sino que también a los que provenían de las provincias limítrofes. Pero esto no ocurría en lo referente a los hospitales, pues la existencia de estos establecimientos repartidos por toda la provincia es muy numerosa y la mayoría de ellos tutelados por instituciones religiosas ya sean conventos, cabildos u obras pías.

758 A.D.P.V. Actas. Libro de actas del 2 de enero de 1870.

759 A.D.P.V. Actas. Libro de actas de 26 de febrero de 1870 y 14 de diciembre de 1871 .

760 A.D.P.V. Actas. Libro de actas del 3 de mayo de 1871.

761 A.D.P.V. Actas. Libro de actas del 14 de diciembre de 1871. 
A principios del siglo XIX, dos eran los más importantes hospitales situados en la capital: el viejo Hospital de Santa María de Esgueva ${ }^{762}$, el más antiguo de los hospitales provinciales, ya que fue fundado por el Conde Pedro Ansúrez entre los años 1073 y 1109 para lo cual donó su palacio, con la condición de "dedicarlo al cuidado de los pobres y enfermos de la ciudad". Tenía una capacidad de ochenta camas. Por real orden de 3 de octubre de 1851 es declarado Hospital Municipal y todos sus bienes pasaron a ser controlados por la Junta Municipal de Beneficencia. Estuvo activo hasta el año 1932, en la que se dio por finalizada su actividad. El otro hospital de la ciudad, el más importante y amplio, es el Hospital de la Resurrección, también llamado Hospital General, que se encontraba situado en la plaza de Zorrilla, en los terrenos donde en la actualidad se levanta la "casa Mantilla" equipadas con trescientas camas. Fue fundado en el año 1553, ante el interés del Ayuntamiento que regaló los terrenos. En el año 1886, ya con la denominación de Hospital Provincial, pasa a instalarse en el nuevo edificio del Prado de la Magdalena, con una capacidad de trescientas sesenta camas. Con la inauguración de este edificio, se llega a un acuerdo con la Universidad, para facilitar las prácticas a alumnos de la Facultad de Medicina.

La Diputación en el inicio de sus actividades trata de asumir el control de estos hospitales y esta actuación la ocasionaría frecuentes enfrentamientos con los regidores hospitalarios, celosos de su autonomía tanto económica como asistencial. Estos problemas ya se reflejaban en las actas del año 1820 , con ocasión de la pretendida visita de la Comisión de Beneficencia a los hospitales de la Resurrección y Esgueva, en la capital. Tal acción fue rechazada por parte del gobernador del Obispado, pues estos dos hospitales eran gestionados parcialmente por el Cabildo y no "era de su agrado" ninguna visita de inspección. Esta actitud no frena la actividad de la Diputación que necesita conocer tanto el número como la utilidad de estos centros benéfico-sanitarios. También quiere verificar la veracidad de las numerosas peticiones de ayuda. Entre ellas, "el director del Hospital San Juan Bautista de Benavente, Antonio Ceballos, se queja del deplorable estado y mala asistencia en que se halla dicho hospital. El Ayuntamiento de Simancas solicita ayuda ante el mal estado del hospital de la villa. El diputado Sr. González Perote presenta un listado con los hospitales y centros de beneficencia de Rioseco, Tamariz de Campos y Villafrechós. El Ayuntamiento de Peñaflor de Hornija reclama al ecónomo 2.100 reales de los fondos del hospital. El Ayuntamiento de Corcos reclama al párroco las cuentas del hospital"

En referencia a la situación hospitalaria de la capital, surgen los recurrentes conflictos entre Ayuntamiento y Diputación en torno a la cuestión benéfica. En el año de 1822, "el Ayuntamiento solicita agregar a sus centros benéficos el edificio, huerta y corrales del suprimido convento de Trinitarios Calzados. Pero la Diputación, visto el edificio carente de las comodidades necesarias que exigen un gasto extraordinario, acordó que no era viable la adjudicación de dicho edificio. Pero excita el celo del Ayuntamiento a que promueva la traslación de los tres hospitales generales de la Resurrección, el de Esgueva y el de San Juan de Dios al Monasterio de Prado, que ofrece capacidad para la reunión de los enfermos de los tres y la ventaja de que administrados sus fondos por una mano, resultaría mucha economía y además el sobrante de aquellos locales podría destinarse al Asilo de Beneficencia..." ${ }^{764}$. Es la primera vez que la Diputación plantea el unificar los tres hospitales de la capital, para lo que se apoya en ofrecer uno de los numerosos conventos libres que existían en la ciudad. Tal intención se perdió con la disolución de la Diputación al finalizar el Trienio Liberal.

762 TIEDRA, José de. El Hospital de Santa María de Esgueva de Valladolid. Imprenta Casa Martín Valladolid. 1937.

${ }^{763}$ MAZA ZORRILLA, Elena. La sociedad en la segunda mitad del siglo XIX. En V.V.A.A. Valladolid en el siglo XIX. Tomo VI de Historia de Valladolid. Ateneo, 1985.

764 A.D.P.V. Actas Libro de actas del 28 de marzo de 1822. 
El período absolutista transcurrió sin resolver el problema de la precaria situación económica, y en el año 1835, cuando nuevamente se activa la Diputación, ésta recibe numerosas peticiones de ayuda para mantener el funcionamiento de los hospitales. Pero la situación era tan caótica, que el gobierno central "en un intento de reordenar la situación" publicó una real orden en el año 1839 "mandando que las Diputaciones atiendan el pago de los facultativos de los centros benéficos" 765 . Pero el conflicto sobre beneficencia entre Ayuntamiento y Diputación prosigue. En estos años los hospitales de la capital estaban en tan grave estado de deterioro económico que el Hospital de Santa María de Esgueva "solicita a la Diputación permiso para vender cuatro casas con el fin de cubrir sus gastos más urgentes". El Ayuntamiento de Valladolid, administrador de los hospitales, se olvida de la oferta de la Diputación hecha en 1822 de reunir los tres hospitales en un mismo edificio para abaratar y mejorar la gestión económica. Por el contrario, se dedica a enfrentarse a la comisión de Beneficencia, y con motivo del nombramiento de capellanes "rechaza el nombramiento de la Junta de Beneficencia, pues considera de su incumbencia el nombramiento de capellán en el Hospital General de la Resurrección" 766.

El problema es que ninguna de las dos instituciones está dispuesta a ceder sus competencias y el afán por controlar los hospitales no les permite trabajar por el bien de los enfermos, además se pone de manifiesto la resistencia de ambas a la hora de decidir la fusión de los diferentes centros. Finalmente, al igual de lo que pasó con el Hospicio, unificado y "provincializado", en el año 1849 y por la misma ley de 20 de junio se reorganiza la asistencia sanitaria en Valladolid y el "Hospital de la Resurrección" pasa a denominarse "Hospital Provincial". Al mismo tiempo, se "municipaliza" el Hospital de Esgueva y con ello desaparecen ciertas controversias por el dominio de los hospitales. Esta reorganización de los hospitales no quiere decir que los regidores estuvieran de acuerdo con la citada ley, prueba de ello es que en el año 1866 todavía se discuta sobre la municipalización del Hospital de Esgueva y la provincialización del Hospital de la Resurrección, situación que tiene que ser confirmada por la "R.O. de 27 de noviembre de 1866, por la que se declara Hospital Provincial al Hospital de la Resurrección" ${ }^{767}$.

Una vez tomado el control del hospital, y en esta ocasión de forma definitiva, la Diputación presenta un "presupuesto adicional" en el que incluye las partidas necesarias para su funcionamiento. "Gastos 15.262,197 escudos. Ingresos 2.713,004 escudos". ${ }^{768}$. En la misma sesión que se aprobaron las modificaciones, se confirmó

\footnotetext{
765 B.O.P.V. $\mathrm{n}^{\mathrm{o}} 110$ de fecha 12 de septiembre de 1839.

766 A.D.P.V. Actas. Libro de actas del 9 de marzo de 1844.

767 “La Diputación el 4 de enero de 1867 aprueba un informe emitido por la comisión de Beneficencia, que está formada por los diputados Basanta, Moreno, Alonso y Pizarro, acerca de los medios que conviene adoptar para la ejecución de la real orden de 27 de noviembre último, en que se declara provincial el Hospital de la Resurrección de esta capital, y después de discutido el asunto, la Diputación acordó de conformidad en todas sus partes por lo propuesto por dichos señores comisionados: $1^{\circ}$. Que ante todo se nombrase por quien corresponda, el personal que en el informe se dice, incautándose la provincia del edificio, el cual deberá inscribirse en el Registro de la Propiedad, previas las formalidades de la ley. $2^{\circ}$. Que se forme un doble y minucioso inventario de todo, con presencia si lo creyeran necesario de los Sres. Basanta, Moreno, Alonso y Pizarro, a quienes se nombra de esta comisión. $3^{\circ}$. Que verificado todo, funcione el establecimiento por cuenta de la provincia, formándose al respecto el presupuesto y "Reglamento Interior" para su servicio" A.D.P.V. Actas. Libro de actas del 4 de enero de 1867.

768 Con la intención de disminuir los gastos se aprueban una serie de modificaciones, como: "reducir el sueldo del médico de 700 a 500 escudos, suprimir 333,400 escudos por sueldo de farmacéutico y pago de recetas, suprimir 97,333 escudos por sueldo de practicante, suprimir la farmacia, suprimir 146 escudos de dotación de un capellán, suprimir 500 escudos por gastos de medicinas, reducir de 300 a 200 escudos la partida de conservación y reducir de 3.000 a 1.000 escudos la de imprevistos" A.D.P.V. Actas. Libro de actas del 22 de marzo de 1867.
} 
también el presupuesto del año económico 1867-68, con unos números que siguen marcando un sentido deficitario. ${ }^{769}$.

Con la llegada del Sexenio, el Hospital Provincial mantiene una actividad condicionada por las dificultades económicas, ya que una cosa es presupuestar unos ingresos y otra muy diferente es la de proveer realmente de fondos a la institución. La Diputación en este sentido no es coherente, pues si en el año 1868 una de sus primeras actuaciones, cuando se hizo cargo del hospital, fue la de "suprimir la botica" con el fin de reducir gastos y equilibrar el presupuesto, a primeros de 1869 acuerda "crear la botica del Hospital General de la Resurrección".

En el mes de mayo del mismo año 1869 se nombra administrador a Antonio Saavedra, farmacéutico a Antonio Villar y capellán a Vicente Silva. En la sesión del día 19 de junio "un estudiante de la Facultad de Medicina solicita su remuneración por los trabajos como practicante en el Hospital Provincial de la Resurrección". Porque una cosa es hacer prácticas bajo el control de los profesores y otra muy diferente es la de trabajar y no recibir paga de ninguna clase. Aunque del coste de las clases prácticas se queja el diputado Sr. Guzmán, preocupado por las dificultades económicas que atraviesa el Hospital y ante la gran afluencia de pobres que se presentan y que entorpecen la atención al resto de enfermos.

El enfrentamiento con la Facultad de Medicina se inicia cuando se conoce "la comunicación de Andrés de la Orden, renunciando al cargo de director facultativo del Hospital Provincial de la Resurrección de esta ciudad, que como decano de la Facultad de Medicina desempeña por haber sido nombrado rector de la Universidad literaria de la misma"770. Para cubrir esta baja, la Diputación, de acuerdo con la costumbre, nombra director del Hospital al decano de Medicina. Nuevamente el diputado Sr. Guzmán se queja de la preponderancia de la Facultad de Medicina, de que "las clases prácticas de medicina son caras" y del "gran número de enfermos pobres que no pagan". Por ello hace la siguiente propuesta a la Diputación: "Fijar un número de enfermos para las clases prácticas. El resto de enfermos pobres que sean atendidos por la Beneficencia. Nombrar como director del Centro a un médico de la Beneficencia en lugar de al decano de Medicina" 771 .

La Universidad está de acuerdo con este planteamiento, y al mismo tiempo comunica que "sólo puede atender a 100 enfermos". Pero los que no están de acuerdo con la gestión y el coste del hospital es una parte importante de los diputados provinciales, que en la sesión dedicada a la aprobación de los presupuestos provinciales, "se quejan de que las instituciones benéficas por ser provinciales deben de ser mantenidas y subvencionadas por la Diputación. "El Hospital no debía de ser provincial, debiendo ser también mantenido por el Ayuntamiento". Aunque también se oyeron voces a favor, como la propuesta del Sr. Miranda, diputado por Medina ofreciendo a la Diputación "el Hospital de Medina, como Hospital Provincial y General de la Provincia". O la del Sr. Alonso Pesquera, diputado por Peñafiel, que "como representante de once miserables pueblos abogo por mantener la beneficencia en el Hospital de la Resurrección después de 314 años de existencia". O la solución propuesta por el Sr. Moras, diputado por Valladolid, que pide "mantener al Hospital de la Resurrección como Provincial y que atienda a los enfermos que envíen los Ayuntamientos que serán los que paguen las estancias y a los transeúntes que lo pague la Diputación" ${ }^{772}$. Esta última propuesta, aunque no está recogida en el acta, es la que se debió de aprobar, pues si esta discusión transcurrió en la sesión del 1 de mayo de

769 "Gastos de 32.178 escudos - Ingresos de 12.139 escudos". Así pues, el "flamante Hospital Provincial", además de deficitario, está ruinoso y no puede funcionar correctamente, por lo que la Diputación, al poco tiempo "reclama al gobernador sobre el lamentable estado en que se encuentra el Hospital de la Resurrección, declarado provincial, por lo que se resiente la atención de los enfermos" A.D.P.V. Actas. Libro de actas del 25 de abril de 1867.

770 A.D.P.V. Actas. Libro de actas del 19 de octubre de 1869.

771 A.D.P.V. Actas. Libro de actas del 22 de noviembre de 1869.

772 A.D.P.V. Actas. Libro de actas del día 1 de mayo de 1871. 
1871, en el mes de diciembre del mismo año, "la administración del hospital tiene dificultades para cobrar a los Ayuntamientos las estancias de sus enfermos, llegado al extremo de amenazar con no admitir más enfermos si no se realiza el pago de las deudas anteriores"773. La Diputación para mediar en esta controversia, por un lado exigió a los Ayuntamientos que pagaran las deudas con el hospital, pero por otra parte pidió al hospital que no negara la entrada en el mismo a ningún enfermo.

Es verdad que el hospital tiene dificultades económicas, y también lo es que la Diputación no puede hacer frente a todos los gastos, pero también es cierto que los Ayuntamientos padecían tantas o mayores dificultades que el hospital en temas económicos. Porque si estas reclamaciones se realizan en el año 1871, en el año 1874, con ocasión de la discusión presupuestaria del año económico 1874-75, "se reclaman las deudas que los Ayuntamientos tienen con el Hospital de la Resurrección por estancias, deuda que asciende a 199.085 pesetas". Además se propone por parte de los diputados "la devolución del hospital al Ayuntamiento de Valladolid, para que lo administre por cuenta propia, como lo ha hecho por espacio de más de tres siglos sin interrupción desde 1553 a 1867, ya que los enfermos de la capital forman la casi totalidad del hospital". En realidad, es el Ayuntamiento de Valladolid el que debe prácticamente la totalidad de lo reclamado por el hospital y se niega a pagar la deuda, por lo que la Diputación tomó el acuerdo de "ceder el Hospital de la Resurrección al Ayuntamiento, siempre que se cumplan las condiciones de "zanjar definitivamente la cuestión de las deudas, entregar el hospital con todos los bienes que tenía en 1867 , compromiso del Ayuntamiento para mantener todos los servicios y hacerse cargo de todas la mejoras y gastos" ${ }^{, 74}$. Finalmente, el hospital se mantendrá a cargo de la Diputación, que por otro lado, ya en aquellos años, iniciaba los trabajos de construcción de un nuevo edificio, amplio y moderno al que se trasladarían desde el viejo Hospital de la Resurrección.

\section{El Hospital de Inocentes Dementes}

El Hospital de Inocentes-Dementes es, junto al Hospicio y al Hospital Provincial, una de las instituciones de beneficencia más representativas y con muchos años de existencia. Fue fundado en el año 1489 por Sancho Velázquez de Cuellar y se instaló en una vivienda propiedad del fundador situada en la antigua calle de Orates, hoy de Cánovas del Castillo ${ }^{775}$.

Este hospital, a diferencia de los otros dos centros benéficos, acogía a enfermos de las provincias limítrofes, como se refleja en los libros de actas en la primera referencia al Hospital de Inocentes y lo atestigua un oficio enviado por su administrador al jefe político de Zamora en el año $1820^{776}$. La llegada de la Diputación, tanto en el período 1813-14 como en los años 1820-23, no perturba la marcha habitual del Hospital. En estos años la Corporación provincial no hace otra función que la de velar por el buen funcionamiento de la institución, sin olvidarse de que el control y los nombramientos de los órganos rectores era un privilegio que mantenía el cabildo catedralicio.

En la época isabelina, el hospital continúa manteniendo su actividad de atender a los dementes. La Diputación, de acuerdo con las órdenes del gobierno, ha nombrado de entre sus miembros una Comisión de Beneficencia que en el año 1840 "remite un oficio avisando de la muerte del administrador de la Casa de Inocentes-Dementes,

\footnotetext{
773 A.D.P.V. Actas. Libro de actas del 14 de diciembre de 1871.

774 A.D.P.V. Actas. Libro de actas del 22 de junio de 1874

775 GONZALEZ GARCÍA-VALLADOLID, Casimiro. Valladolid, sus recuerdos y sus grandezas. Imprenta de H. Rodríguez. Valladolid. 1894. Tomo I, pág. 462. Cr. E.MAZA, Valladolid y sus pobres... 776 "en contestación del Sr. Agustín Cabello, administrador del Hospital de Inocentes de esta ciudad ofreciendo hacer cuanto sea posible por condescender a los piadosos sentimientos del Sr. jefe político superior de la provincia de Zamora, sin embargo de que por no haberse pagado los propios de dicha ciudad, la cantidad anual señalada, había perdido el derecho de admisión de sus dementes" A.D.P.V. Actas. Libro de actas del 29 de abril de 1820.
} 
comunicando al mismo tiempo, que nombra como administrador interino a D. José Berdonces, hasta que la Diputación nombre al definitivo" "777. En el año 1841, el nombramiento seguía siendo interino, porque al interés de la Comisión de Beneficencia de ser la responsable del nombramiento se oponía al Cabildo de la Santa Iglesia Catedral, que solicita a la Diputación "se le mantenga el derecho de elegir administrador del Hospital de Inocentes-Dementes, del cual le había privado la Junta de Gobierno de esta provincia"778. En la Diputación se inicia una discusión de estas posturas: por un lado el diputado Sr. González mantenía la postura de que era el Cabildo Catedralicio el organismo que tenía la facultad del nombramiento y que había sido ratificado por la Diputación en la sesión del 2 de mayo de 1840. Por otro lado el diputado Sr. Cantalapiedra defendía el derecho de la Junta de Beneficencia (a la cual pertenecía) a presentar el candidato que considerase más adecuado según lo especificaba el propio Reglamento de la Junta de Beneficencia. Ante estas posiciones tan divergentes, una vez debatido el asunto en el Pleno de la Diputación, el jefe político pasó el correspondiente informe al gobierno que zanjó el tema a través de una "Orden de la Regencia Provisional del Reino por la que se nombra administrador del Hospital de Inocentes-Dementes de Valladolid a D. Víctor Lasa Barrasa" ${ }^{779}$.

La demanda de ingresos en el hospital es alta, y en la mayoría de los casos son los Ayuntamientos los que colaboran económicamente con el pago de ciertas cantidades para que el hospital atienda a los vecinos sin posibilidades económicas. En 1842 es el pueblo de La Seca el que "aprueba la ayuda para mantener en el hospital a un vecino". En 1843 es el Ayuntamiento de Arroyo el que "solicita ayuda para mantener a un demente sin recursos". En 1846, la Junta de Beneficencia acuerda enviar un enfermo a Zaragoza "porque allí admiten a todos y porque el hospital de Valladolid tiene dificultades para mantener la demanda de enfermos".

En el año 1847 la Diputación inicia los trámites para modificar la situación del hospital y darle carácter provincial, pues sería "la mejor forma de poder prestarle ayuda". Dichos trámites finalizan con la publicación en el año 1848 de la real orden de 11 de mayo por la que "se declara establecimiento provincial a la Casa-Hospital de Dementes de Valladolid". Es el primer hospital de la ciudad que adquiere el carácter de provincial, y a partir de este momento es la Diputación la que rige los destinos de esta institución. Como primera medida, se estudia el expediente "de las obras del edificio destinado a Hospital de Inocentes" de acuerdo con lo estipulado en lareal orden de 20 de julio de 1848. Se aprueba "que para rematar las obras se propone la venta del edificio donde se encuentra actualmente el Hospital" ${ }^{780}$. En el año 1849 y en la sesión que se celebra el día 21 de enero, se sigue hablando no sólo de las obras del hospital, sino que la comisión nombrada para gestionar las obras informa a la Diputación sobre otros planteamientos diferentes.

Así la comisión propone, en primer lugar, examinar el estado del actual edificio y el del edificio titulado "Palacio de la Casa del Cordón", adquirido para trasladar el hospital ${ }^{781}$. En segundo lugar, constata que el hospital actual es de

777 A.D.P.V. Actas. Libro de actas del 13 de mayo de 1840. José Berdonces es canónigo de la Catedral y fue diputado provincial en 1820 .

778 A.D.P.V. Actas. Libro de actas del 14 de diciembre de 1840

779 A.D.P.V. Actas. Libro de actas del 23 de febrero de 1841.

780 A.D.P.V. Actas. Libro de actas del 18 de octubre de 1848.

781 Palacio de la Casa del Cordón, en URREA FERNÁNDEZ, Jesús. Arquitectura y Nobleza ... ob. cit. Pág. 243, en la que nos relata la historia del Palacio- Casa del Marqués de Águilafuente o Casa del Cordón. Palacio construido por el obispo de Palencia D. Pedro de Castilla en 1461, toma el nombre de Águilafuente, cuando una descendiente se casa con el Duque de Béjar, señor de Águilafuente, y se denominó "del Cordón” por tener un cordón de San Francisco esculpido en la puerta de entrada. El día 1 de mayo de 1847 D. Ángel María Carvajal Fernández de Córdoba, Duque de Abrantes y Linares y Marqués de Águilafuente llegó a un acuerdo con el Ayuntamiento para redimir y cancelar un censo de 150.000 reales de capital que en 1779 había impuesto un antecesor suyo a favor del Hospital de Dementes de Valladolid entregando en compensación la Casa del Cordón, $\mathrm{n}^{\circ} 12$ de la calle de Herradores (hoy Alonso Pesquera)... Las obras de adecuación duraron hasta 1850, año en 
reducidas dimensiones y no admite más de veintiocho enfermos y la demanda de pacientes de la provincia más los de otras provincias asciende a ciento veinte y con la gran demanda para ingresar enfermos, está en una grave situación de penuria de terreno. En tercer lugar, para paliar el problema ya se han trasladado provisionalmente a la Casa del Cordón parte de los enfermos. Es un palacio situado en una zona amplia de la ciudad con una huerta próxima. Finalmente, la comisión solicita al jefe político autorización para trasladar el hospital al Palacio del Cordón y al mismo tiempo, autorizar el coste de reparación con cargo a los presupuestos provinciales y además en ejercer la venta del viejo hospital y otras casas que tiene en la ciudad". La propuesta de la comisión fue aprobada y se solicitó autorización del jefe político para efectuar el traslado. Se hace de forma rápida, pues el 25 de noviembre del mismo año 1849 se acuerda en el Pleno de la Diputación "sacar a pública subasta la venta del edificio del Hospital de Dementes, en la calle Orates".

En el año 1850, la Diputación se enfrenta a la Iglesia, situación que ya se había repetido con anterioridad con otros hospitales de la ciudad "al reclamar el Cabildo Catedralicio el patronato del Hospital de Dementes"782. Señal de que el obispo seguía teniendo gran influencia en los temas benéficos que afectaban a la ciudad. A falta de otras noticias más interesantes en el año 1851, el director del hospital reclama a la Diputación: "la mesa de billar, perteneciente a la provincia, que se hallaba abandonada, para su servicio en el establecimiento". Mesa que había desaparecido a causa del traslado.

La vida del hospital continúa su curso sin grandes altibajos y a diferencia del Hospicio y del Hospital de la Resurrección, sin grandes agobios económicos. Las noticias más llamativas que se suceden en los libros de actas, están relacionadas con el personal y con las obras de mejora de las instalaciones. En 1855, se aprueba un aumento de salario de los médicos. En 1856, se nombra director médico del hospital a D. Lucas Guerra. En 1858, La Diputación aprueba el equipamiento del hospital propuesto por la Junta Provincial de Beneficencia con tres médicos a 6.000-5.500 y 5.000 reales año, un médico agregado para enfermedades ordinarias con 3.000 reales, un cirujano con 2.200 reales año. En 1860 la administración del hospital solicita aumento de sueldo y se permite al director pasar de 5.500 a 8.000 reales año, al administrador de 5.400 a 7.300 reales año, al secretario de 4.000 a 5.800 reales año. En 1861, "con el fin de mantener el hospital en buenas condiciones, la Diputación acuerda aportar 60.000 reales para la reparación de la Casa de Dementes, mejorando los baños y la galería de la sección de mujeres" ${ }^{\text {"783. }}$. El acuerdo es refrendado por la real orden de 31 de mayo, en la que se aprueba además una subvención del gobierno de 55.454 reales, que se utilizó para "la compra de un corral para la ampliación del Hospital de Dementes".

En 1864, "se aprueban las siguientes obras en el hospital: construir una casa de baños, un local para enfermos sucios y un dormitorio y sala de mujeres, todo ello tasado en 11.302 reales". En 1865 "como resultado de las visitas que se han hecho al establecimiento, se ha encontrado en buen orden para la admisión de orates y se reconoce un trato a las acogidas hasta cariñoso por parte de los empleados y dependientes del establecimiento". En 1866, la Diputación aprueba "la compra a D. Millán Alonso de dos casas en la calle de Herradores $n^{\circ} 9$ y 11 para ampliar el Hospital de Dementes por 84.580 reales, teniendo en cuenta las necesidades en que se encontraba el establecimiento para facilitar comodidad al crecido número de enfermos que en él se albergaban"784.

Con la llegada del Sexenio en el año 1868, el director del hospital, D. Lucas Guerra, adquiere cierto protagonismo político al tomar posesión como presidente de la

que se trasladó el Manicomio desde su antigua casa de la calle de los Orates (hoy Cánovas del Castillo).

782 A.D.P.V. Actas. Libro de actas del 7 de octubre de 1850.

783 A.D.P.V. Actas. Libro de actas del día 4 de mayo de 1861.

784 A.D.P.V. Actas. Libro de actas del día 3 de enero de 1866. 
Junta Revolucionaria de la Capital. Posteriormente será nombrado diputado provincial, cargo del que presentará la dimisión por incompatibilidad con su cargo de director del hospital. Pero "la Diputación rechaza su dimisión al no considerar que el sueldo de director del Hospital de Dementes procede del Estado, y por lo tanto no puede acogerse al decreto de 12 de noviembre que expresa que no pueden ejercer cargo oficial alguno los que reciban sueldo del Estado o de la provincia" ${ }^{785}$. Aunque, según las actas la dimisión no es aceptada, el Dr. Lucas Guerra sigue de director del hospital y no vuelve a ejercer como diputado.

En el año 1869 , con el fin de hacer frente a las necesidades económicas de la institución, la Diputación autoriza la venta de Bonos del Tesoro propiedad del hospital. En el mes de diciembre del mismo año, el director pide autorización para celebrar la fiesta de la institución el "día de los inocentes". Fecha en la que aprovecha el discurso del acto patronal para reclamar de la Diputación más atención y sobre todo más ayuda económica, para mantener las instalaciones. Recuerda que una de las formas para salir de las dificultades económicas es la de "activar la recaudación de las deudas", tema en el que la Diputación es consciente de la dificultad "dada la situación de penuria en la que se encuentra la provincia". En el año 1870, independientemente de que el hospital pasa por dificultades económicas, continúa pidiendo a la Diputación permiso para ampliar sus dependencias. En el mes de enero el director "solicita autorización para comprar terrenos con el fin de ampliar el Hospital". En el mes de abril, la Diputación "acuerda comprar una casa para ampliación del Hospital de Dementes". Pero hasta que se compre la casa y se arregle para instalar en ella los enfermos, se tiene que conformar con "la instalación de una cocina económica".

El hospital necesita con urgencia llevar a cabo su ampliación, pues ha de habilitar un local provisional para "alojar en él a las mujeres". Además, de acuerdo con la orden circular de 27 de julio de 1870, "los dementes pobres podrán ser enviados a Valladolid en el caso de las provincias cercanas que no cuenten con locales al efecto". Pero las gestiones administrativas de la compra van muy lentas, y no será hasta finales del año 1871, coincidiendo con el nombramiento como nuevo administrador del hospital en la persona de Mariano Vázquez de Prada, cuando la Diputación comunica "la compra de una casa en la calle de La Merced para la ampliación del Manicomio Provincial, con el que linda" ${ }^{786}$. En el año 1872, el director Lucas Guerra sigue de director facultativo del Centro y a la vez es nombrado también director económico del mismo. En esa situación se llega a los años de la Restauración

\section{Conclusiones}

Si hacemos un pequeño repaso a las vicisitudes benéficas que ocurren en la provincia y que hemos relatado en las páginas precedentes, podemos constatar en primer lugar que tanto la sanidad como la beneficencia en los años previos a este estudio, desarrollan unas actividades primarias y están fuertemente controladas por la Iglesia y los Municipios. En segundo lugar, los liberales inician una promoción y mejora de estas dos actividades en defensa del bienestar ciudadano. En tercer lugar, el inicio del control de los establecimientos por la Diputación es el punto de partida de la mejora asistencial y del progreso en las actuaciones sanitarias y benéficas, ya sea por los trabajos y desvelos de la institución o por la propia progresión de los establecimientos en los años de bonanza económica. En cuarto lugar, es verificable que la desamortización de Madoz corta de raíz la autonomía económica de los centros benéficos al eliminarle sus vías de financiación. Por último, la provincialización, palabra del profesor Carasa, de la beneficencia, reaviva el secular enfrentamiento entre Diputación y Ayuntamiento, empeñadas ambas instituciones en controlar todas y cada una de las numerosa obras benéficas, los Ayuntamientos porque eran los que

785 A.D.P.V. Actas. Libro de actas del 24 de noviembre de 1868.

786 A.D.P.V. Actas. Libro de actas del 13 de noviembre de 1871, en el que se utiliza por vez primera el nombre de Manicomio. 
con anterioridad gestionaban las actividades y las Diputaciones porque en función del mandato gubernamental, luchaban por su dominio. También en este campo se mantiene la pugna entre el progresismo municipal y el conservadurismo provincial. Enfrentamiento que en esta materia se amplía al Cabildo, a la Universidad y a un numeroso grupo de Fundaciones y Obras Pías, que no ven con buenos ojos las pretensiones de las Diputaciones de controlar las Instituciones que desde tiempo inmemorial son regidas por estas diferentes asociaciones. Enfrentamiento que es ocasionado por la indefinición de competencias y de recursos entre los propietarios de los centros benéficos y la Diputación, aspirante a manejarlos.

\section{6.- AGRICULTURA}

La agricultura es la actividad más importante que se desarrolla en la provincia, en estos años de referencia, pues de este sector económico viven la gran mayoría de sus habitantes. Entre los años 1813 y 1874 se producen una serie de cambios importantes en el desarrollo agrícola, cambios que están protagonizados en unos casos por las malas cosechas con los resultados de hambre y miseria, en otros casos son cambios causados por las desamortizaciones tanto de Mendizábal como de Madoz, que provocan importantes modificaciones de la propiedad de la tierra, en el primer caso beneficiando a los grandes propietarios y en el segundo a los pequeños y medianos labradores y finalmente hay otros casos de progreso que están propiciados por las buenas cosechas, la mejora de las comunicaciones, con especial referencia al Canal de Castilla y el interés demostrado por una serie de personalidades vallisoletanas que se preocuparon por hacer progresar la agricultura ${ }^{787}$. Ante este panorama es lógico pensar en que la Diputación fuera la promotora de todos los esfuerzos necesarios para mantener una progresión positiva en la actividad agrícola. Al ser la principal fuente de riqueza, debía de ser en consecuencia su principal preocupación, para que el fomento y mejora de esta actividad redundara en la mejora del bienestar provincial.

La realidad nos demuestra que la Diputación no está en condiciones ni tiene capacidad técnica ni económica para hacer una labor de progreso. En los casos de dificultades se dedica a contemplar impotente la miseria de la agricultura y a lamentarse de las desgracias que se suceden en el campo, ya sea a causa de la sequía, de las inundaciones, de las heladas, de los incendios, de las epidemias, etc. En los casos de progreso, contempla con satisfacción el desarrollo positivo y ofrece su colaboración. Hay que tener en cuenta que la mayoría de los diputados provinciales son propietarios agrícolas o relacionados de alguna forma con la agricultura, la ganadería o actividades indirectas dependientes de las mismas.

Como en el resto de las competencias de la Diputación, dividiremos en cuatro períodos la evolución de su acción agrícola a lo largo de estos años. Primero en 1813$\underline{1814}$, en los inicios de la vida constitucional. Son los primeros meses de actividad de la Diputación, con las dificultades creadas por el fin de la ocupación francesa y el corto tiempo de vigencia de la Diputación. Segundo, entre 1820 y 1823 en el período del Trienio Liberal. Caracterizado por el afán de progreso y la desgracia de las malas cosechas, a lo que hay que añadir el entorpecimiento de la actividad constitucional generado por el absolutismo real. Tercero, en los años comprendidos entre $1835 \mathrm{y}$ $\underline{1868}$, en la época isabelina. Período en el que se inicia una preocupación por parte de los organismos públicos por la mejora de la agricultura y de las técnicas agrícolas. El cuarto período abarca los años de $\underline{1869 \text { a } 1874}$, con la agricultura del Sexenio. Años

${ }^{787}$ YUN CASALILLA, Bartolomé (Coor.). Estudios sobre capitalismo agrario, crédito e industria en Castilla (siglos XIX y XX) Ed. Junta de Castilla y León. Valladolid 1991. DIEZ ESPINOSA, José Ramón. "Agricultura, industria y comercio en la segunda mitad del siglo XIX" en Celso ALMUIÑA (Coord.). Valladolid en el siglo XIX. Ed. Ateneo de Valladolid. Valladolid. 1985. 
de una gran actividad política y que en los temas agrícolas se centran en la búsqueda de mejoras técnicas y en la enseñanza especializada de cultivos.

\subsection{1.- LA AGRICULTURA EN LOS PRIMEROS AÑOS DE VIDA DE LA DIPUTACIÓN, 1813-1814}

La Diputación provincial ya tiene bastante en los años de inicio de su actividad con intentar mantener los trabajos principales que la han sido encomendados por el gobierno, léase repartimiento de contribuciones y de reemplazos del Ejército. No tenía posibilidades de preocuparse de la agricultura, que como hemos reflejado con anterioridad es una actividad de importancia capital para el mantenimiento económico de la provincia y que sirve también para el desarrollo de otras actividades tanto comerciales como industriales. En estos años, además, los agricultores tienen que hacer el esfuerzo añadido de recomponer la situación agraria y rehacer en muchos casos las instalaciones y viviendas que han quedado muy deterioradas a causa de la ocupación francesa.

Por otra parte, la vida de la Diputación es tan corta que apenas tiene tiempo de preocuparse por la situación agrícola. Desde septiembre de 1813 a junio de 1814, tiempo de vigencia institucional, no podemos pedirla que, en este breve período trate de mejorar la agricultura. Por otro lado, los agricultores mantienen la monotonía del "esperar y rezar", es decir, sembrar, esperar, rezar para que la cosecha sea buena y si no, lamentarse de que la cosecha ha sido mala. En definitiva no hay ninguna referencia a la agricultura en los libros de actas de este período, a excepción de las solicitudes de reclamación que remiten los agricultores a la Diputación, en solicitud de pago, para resarcirse de las entregas de productos agrícolas que se han efectuado a las tropas, tanto francesas de ocupación como nacionales de liberación.

\subsection{2.- LA AGRICULTURA EN EL TRIENIO LIBERAL, 1820-1823}

La llegada del Trienio activa en la Diputación la inquietud por la agricultura y sus mejoras, pero desgraciadamente los inicios de las actividades de la Diputación coinciden con los resultados de un desastroso año agrícola. La mala cosecha obliga en las primeras sesiones a solicitar a las Cortes una rebaja de los impuestos, ya que, "son poquísimos los labradores que después de satisfacer sus rentas, diezmos y demás gabelas, les sobra lo preciso para cubrir la próxima sementera, y aún la anterior son en crecido número los que no la han recolectado" 788 . Será habitual que la Diputación haga de intermediaria ante el gobierno central para remediar todas las desgracias que se abaten sobre los agricultores.

Unas veces es el alza de precios, en el caso de malas cosechas, ante la dificultad de importar el grano de otras provincias y en el caso contrario, de buenas cosechas, la situación es más deplorable al producirse un "envilecimiento" de los precios. En todos los casos, siempre con un resultado negativo para el agricultor que está habituado a "llorar a la administración para que le rebaje los impuestos y rezar al cielo para que el tiempo le acompañe".

Retomando la situación catastrófica con que nos encontramos en el año 1820, a causa de la pérdida de la cosecha, la mayoría de los pueblos de la provincia, en especial los situados en la Tierra de Campos, a la hora de iniciar una nueva sementera, solicitan ayuda de grano, procedente de los pósitos, para poder sembrar. Se ven apoyados por el real decreto de 18 de octubre "alusivo al socorro de los labradores que por inutilidad de la cosecha última carecen de grano para cubrir sus barbechos". A esta ayuda le acompaña la exposición que la Diputación envía al Congreso solicitando una rebaja en los cupos de la contribución ${ }^{789}$.

788

789

"Al estar sus conciudadanos imposibilitados de pagar la contribución por la falta del producto que constituye su riqueza $[\ldots]$ lo principal de esta provincia es el ramo agricultor, pero el presente año ha sido de una gran esterilidad de los frutos [...] unos labradores no han cogido la simiente que derramaron, y los más afortunados no han arribado a duplicarlas[...] y los precios de los granos 
El año 1821 no es un año de sobresaltos, lo que hace suponer que la cosecha entra dentro de unos términos razonables. La Diputación remite un oficio a los Ayuntamientos de Medina, Olmedo, Peñafiel, Tordesillas, Rioseco y Valladolid, para que "reclamen a los pueblos las devoluciones de los granos que entregaron a préstamo los respectivos pósitos" ${ }^{\text {790. }}$. Pero, curiosamente y según parece, los pueblos o no se han recuperado del desastre del año anterior porque les cuesta trabajo devolver el grano prestado, o se pensaban que no iban a tener que devolverlo. Lo cierto es que la Diputación recibe un aluvión de peticiones solicitando "una moratoria en las devoluciones por no tener posibilidades".

En lo referente a las cosechas y su evolución, después de la desastrosa cosecha de 1920 y de la menos mala de 1921, en la que el agricultor no devuelve el préstamo de grano, parece que el gobierno va tomando con cierta lógica y prevención la evolución de las cosechas, y antes de la de 1822, quiere conocer como está en realidad la situación del campo con vistas a la futura cosecha. A través de una real orden de 12 de marzo, pide que "se informe de las esperanzas que promete la próxima cosecha, para estimar si hay que hacer variación en las leyes prohibicionistas de la introducción de granos". La Diputación por su parte contesta a esta pregunta informando de que "no se conoce falta de aguas ni el campo las necesita, vista a primeros de marzo, que los campos ofrecen abundancia y que aún sin la cosecha la provincia tiene sobrante para surtir a la nación, sin recibir los granos del extranjero"791, con lo cual la Diputación esta diciendo que la cosecha de 1821 fue realmente buena.

La situación agríola tiene dos polos, ya que si en el año 1820 el problema fue debido a la desastrosa cosecha, en el año 1822 y de acuerdo con las previsiones, se produce una situación diametralmente opuesta, con una cosecha excepcional, aunque tanto en un año como en otro desemboca en un resultado negativo para la agricultura. En 1822, la Diputación recoje las lamentaciones de los agricultores al decir que "está obligada a parecer ingrata con el cielo, que derramando abundantes frutos hacen más costoso su beneficio para que se pudran por falta de salida"792.

Otra vez la falta de comunicaciones y de canales de comercialización hace que un año de buena cosecha y posibilidades de recuperación de la maltrecha economía campesina se torne en lamentable. Los labradores no saben qué hacer con sus cosechas y se ven abocados a trabajar para recoger los frutos, para luego perderlos ante la imposibilidad de venderlos. Nuevamente es la Diputación la encargada de transmitir a "la superioridad" las amarguras por las que pasa la agricultura provincial. ${ }^{793}$.

Una noticia que es acogida con gran alegría por parte de la Diputación es la propuesta que en este año de 1822 hace la Dirección General de Estudios de establecer en Valladolid una "Escuela Especial de Agricultura Experimental". La propuesta es contestada rápidamente por la Corporación provincial, "recomendando el pronto establecimiento de la Escuela Especial de Agricultores designada a esta ciudad por el artículo sesenta y uno del Reglamento General de Instrucción Pública"794. La

siguen en el envilecimiento de los años de mayor abundancia por la falta de circulación a Galicia, León y Portugal[...] solicitando que se les indemnice de las contribuciones pertenecientes a este tramo, que no pueden cubrir sin vender los terrenos de su propiedad" A.D.P.V. Actas. Libro de actas del 11 de agosto de 1820, en la que se inserta la trascripción literal de la exposición enviada a las Cortes.

790 A.D.P.V. Actas. Libro de actas del 13 de septiembre de 1821. Cfr. P.CARASA, Los pósitos en España en el siglo XIX”, en Investigaciones Históricas, 4 (1983) 254-304.

791 A.D.P.V. Actas. Libro de actas del 22 de marzo de 1822.

792 A.D.P.V. Actas. Libro de actas correspondientes al 12 de agosto de 1822

793 En exposición dirigida al Rey: "Convencida la Diputación Provincial de Valladolid de que los habitantes de ella con sus abundantes cosechas, están sumidos en el abatimiento y último estado de indigencia por la imposibilidad de dar salida a sus frutos y consiguiente envilecimiento o nulidad de los precios, recuerda a S.M. la anterior idea de la Diputación Provincial de Zamora para que se sirva promover la extracción de dichos frutos por las Juntas de La Hinojosa y Fregeneda, por medio de un tratado con la Corte de Portugal...” A.D.P.V. Actas. Libro de actas del 13 de diciembre de 1822.

${ }_{794}$ A.D.P.V. Actas. Libro de actas del 22 de marzo de 1822. 
Diputación, consciente de la importancia del proyecto y deseosa de su puesta en marcha, propone a la Sociedad de Amigos del País, el trabajar conjuntamente para llevar a cabo su realización, para lo cual, ofrece los terrenos necesarios para el desarrollo de los trabajos y estudios agrícolas a través de la citada Escuela.

Siguiendo con su preocupación por la mejora de la agricultura, el Gobierno publica una R. O. en fecha 31 de mayo de 1822, ordenando que "las Diputaciones manifiesten al Gobierno las obras nuevas o convenientes para aumentar los riegos y beneficiar en grande la agricultura". La Diputación acordó oficiar a todos los Ayuntamientos trasmitiéndoles esta real orden y pidiéndoles que dijeran lo que necesitaban. También la Diputación se preocupa por el estado de la Escuela Experimental que se habría proyectado, dirigiéndose con fecha 28 de noviembre del mismo año 1822 al Director General de Estudios, interesándose por su situación.

Finalmente en el año 1823, como resumen de su actividad, la Diputación transmite al jefe político un "Pliego Anual", en el que se resalta sobre la agricultura algo referente al Canal de Campos y a la Escuela Especial de Agricultura ${ }^{795}$. Con estas buenas intenciones, la Diputación dio por finalizadas las actividades en materia agrícola en el año 1823, siendo ésta una de sus últimas actuaciones al ser suspendidas su vigencia a la llegada de la Década Ominosa. Pero no queda constancia de que estas buenas intenciones y proyectos se llevaran a buen término.

\subsubsection{LA AGRICULTURA EN LA ERA ISABELINA: 1835-1868}

Una vez iniciada su actividad institucional en 1835, la Diputación no refleja en sus libros de actas actividad alguna en el tema agrícola. No se habla de la Escuela Experimental porque no está en marcha. Tampoco se dice nada sobre el Canal de Castilla, obra que sigue parada. Apenas hay tierras de regadío y los campos vallisoletanos no conocen la maquinaria agrícola, a excepción del arado romano y poco más. La novedad en estos años está centrada en la desamortización de los bienes eclesiásticos promovida por el ministro Mendizábal, bienes que en su gran mayoría son comprados por grandes propietarios y que perjudican gravemente a los arrendatarios, en su mayoría campesinos y pequeños agricultores, que pierden el arriendo o se ven obligados a trabajar en peores condiciones. ${ }^{796}$. Lo único que se trata en la Diputación relativo a la agricultura son las continuas peticiones de los pueblos en relación con sus bienes de propios, solicitando el arriendo, el aprovechamiento y sobre todo la venta y siempre acuciados por la necesidad de dinero.

Las ayudas económicas a la agricultura en épocas anteriores al siglo XIX estaban representadas por la existencia de los pósitos, controlados y gestionados en la mayoría de los casos por los Ayuntamientos aunque también los hay de carácter particular. La función primordial del pósito era la de prestar a los labradores el grano necesario para la siembra, en los años en los que las cosechas no han sido buenas y para que la falta de medios no haga imposible la siembra. Además del grano, los pósitos también disponían de dinero en metálico, aunque los préstamos en efectivo no eran habituales ${ }^{797}$.

\footnotetext{
795 “Que en punto a los riegos y mejora de la agricultura no se han prestado los pueblos a dar las noticias respectivas, aunque son bien notorias sus necesidades y que lo que influirá de un modo visible será la continuación del Canal de Campos... Que para facilitar la extracción de productos de esta provincia se utilice la salida de Portugal contratando con la Corte de este Reino... Que para llevar a efecto el establecimiento de la Escuela Especial de Agricultura Experimental, es opinión de la Diputación la gran utilidad de un establecimiento para lo cual concede un terreno que perteneció al Monasterio de San Benito con más de 200 obradas de vega, llano y ladera..." A.D.P.V. Actas. Libro de actas del 18 de febrero de 1823.

${ }^{796}$ DIEZ ESPINOSA, José Ramón. “Agricultura, industria...” ob. cit. Págs. 317-350. En Celso ALMUIÑA Valladolid en el siglo XIX Sobre la desamortización ver RUEDA HERNANZ, Germán La desamortización de Mendizábal en Valladolid (1836-1853). Ed. Cátedra. Madrid. 1986.

${ }^{797}$ CARASA SOTO, Pedro. "El crédito popular en Valladolid en el Siglo XIX", en V.V.A.A., La Comisión de Reformas Sociales y la condición obrera en Valladolid. Universidad de Valladolid. Valladolid. 1985. CARASA SOTO, Pedro (1991), El crédito agrícola en España durante la
} 
Una gran realidad en el campo vallisoletano, repetida hasta la saciedad, está centrada en la crisis económica y para paliar las dificultades que se presentan, los labradores tiene que acudir a los créditos no sólo a través de los pósitos, sino que cuando estas instituciones inician su decadencia en los primeros años del siglo XIX y no aparecen otras entidades de crédito, al agricultor no le queda otro remedio que ponerse en manos de la usura. Un práctica que en palabras del profesor Carasa es "una de las lacras más notables y menos conocidas de la agricultura castellana" y que provoca una grave pérdida que incide en la producción agrícola y en el consumo al desviar parte de la riqueza que genera la tierra a manos extrañas que no invierten en el campo.

Hasta el año 1841, la Diputación no refleja en sus actas cuestión alguna con respecto a la agricultura. Este año se plantea un tema interesante tanto desde un punto de vista económico como agrícola, como es la circular que se lee en la sesión del 14 de diciembre en la que se "interesa por la creación de Bancos de Labradores". Tal circular está motivada por una orden de S.A. el Regente, "por la que se excita a las autoridades para la formación de Bancos de Labradores". Una petición o deseo gubernamental que resulta curiosa, pues es difícil que los labradores, inmersos en sus endémicas dificultades económicas, sean capaces de formar un banco. La pérdida de importancia de los pósitos y la proliferación de los intermediarios usureros fomentan la creación, en el mismo año de 1841, de la Caja de Ahorros Provincial. Ésta en un principio se inclina por la actividad urbana, pero pronto se da cuenta de que el dinero está en el campo y en los agricultores, a la vez que es aprovechada por éstos para eludir la práctica usurera al mismo tiempo que fomentan el ahorro. Posteriormente se produce una eclosión de bancos y sociedades financieras dedicadas al crédito agrícola interesadas en conceder los préstamos a los agricultores y al mismo tiempo acostumbrarle a depositar sus excedentes monetarios en las citadas instituciones. Entre 1857 y 1864 florecen numerosos bancos y cajas que la crisis de 1864 se encargará de truncar.

Otra noticia que aparece regular y periódicamente es la preocupación del Ministerio de Agricultura por luchar contra la plaga de langosta que aparece invariablemente todos los años, causando graves daños en las cosechas. "En el año 1841 se dictan medidas para exterminar la langosta..."." "En el año 1844 se publican normas de actuaciones a tener en cuenta, para luchar contra la plaga de langosta". "En el año 1845 se vuelve a recordar las medidas para la lucha contra la langosta". "En el año 1847 la Sociedad Económica Matritense envía una comunicación con los medios que se pueden poner en práctica para la extinción de la langosta".

El año 1848 es el punto de partida de una serie de actuaciones de la Diputación en el camino de la modernización de la agricultura. Por R. O. del 7 de abril "se efectúa la instalación de la Junta de Agricultura, formada por: Presidente, Manuel de la Cuesta, jefe político. Vicepresidente, Mariano Miguel de Reynoso de Valladolid. Secretario, Juan Manuel Prieto de Villalón. Vocales, Manuel de la Concha de Rioseco, José Fernández de Peñafiel, Vicente Pimentel de Medina, Jacobo Santander de La Nava del Rey, Juan Fernández Vítores de La Mota del Marqués, Manuel López Puga de Valoria y José González Tascón de Olmedo". Uno de los más destacados componentes de esta Junta, el vicepresidente Mariano Miguel de Reynoso, será nombrado Comisario Regio para la Inspección de la Agricultura, según el real decreto de 6 de octubre del mismo año 1848. Puesto en el que desarrollará una labor en pro de la agricultura, y en este sentido envía una comunicación a la Diputación en la que "solicita un informe sobre el fomento de la agricultura"798. En contestación a esta petición, la Comisión de Agricultura de la Diputación remite un dictamen sobre el asunto en el que destaca a priori que es muy difícil presentar un dictamen sobre la

Restauración, entre la usura y el control social. En: YUN CASALILLA, Bartolomé (Coord.): Estudios sobre capitalismo agrario, crédito e industria... Ob. cit. págs. 289-343.

798 A.D.P.V. Actas. Libro de actas del 16 de enero de 1849. 
agricultura ${ }^{799}$. La primera condición del dictamen, "producir más a menos coste", no va acompañado de una explicación sobre la forma de conseguirlo, pero sí la ofrece para la segunda condición,"dotar al mercado de granos de medios de transporte", tema en el que la comisión se extiende en la forma de realizar las obras de mejora del transporte. Indica que se deben de hacer a través de empresas particulares, que se dé prioridad a los capitalistas de la región, que para devolver los capitales adelantados se ceda el aprovechamiento de las obras a las empresas que han realizado el trabajo, sin hacer una concesión perpetua, que el Canal de Castilla es muy importante como vía de comunicación, pero se deben de ampliar el número de barcazas. Finalmente, la comisión recomendó al Comisario Regio el procurar por parte del gobierno evitar en lo posible "el contrabando de granos", única forma que según la comisión frenaba la caída de los precios de la producción cerealista provincial.

Para una provincia donde, como hemos dicho, la agricultura es la base de la economía, la Diputación apenas trata en sus libros de actas ningún tema agrícola en el tiempo que transcurre entre los años 1850 a 1855. Por un lado, en el año 1850 la Diputación no se hace eco de la celebración de la $1^{\text {a }}$ Exposición de "Productos de Agricultura, Industria y Artes", que tuvo lugar en la ciudad y que a ciencia cierta no fue organizada por la institución. Únicamente se da publicidad en el Boletín Oficial de la Provincia de un R. D. en el que se informa de la "Creación de una Escuela de Agricultura en Aranjuez" ${ }^{800}$. Ante este anuncio, la Diputación no reacciona y no se acuerda de que en el lejano año de 1822, el gobierno a través de la Dirección General de Agricultura, había puesto una escuela similar en Valladolid. Lo único que tiene en cuenta, como si fuera la solución de los problemas del campo agrario provincial, es "convocar una plaza para estudiar en la Escuela Central de Agricultura" ${ }^{801}$.

En el año 1855, el problema está centrado en la desastrosa y calamitosa situación en que se encuentra la agricultura provincial, motivada por la pérdida de la cosecha lo que provoca por un lado "una calamidad pública por falta de trabajo", y por otro lado "la subida considerable del precio de los cereales".

En el año 1856, en una de sus primeras sesiones, la Diputación "acuerda elegir a Ricardo Rubio como alumno de la Escuela Central de Agricultura con una beca de 3.000 reales año hasta que acabe la carrera". Pero en marzo del mismo año, "el pensionado Ricardo Rubio dice que no ha podido matricularse en la Escuela de Agricultura por no estar funcionando y que lo ha hecho en la Escuela de Ingenieros Agrónomos. La Diputación aprueba la decisión y aumenta la dotación a 4.000 reales" ${ }^{\prime 02}$. Este becario continuará con sus estudios y en el año 1859, cuando se solicita una beca para la Escuela de Agricultura la Diputación contestará que está cubierta la plaza desde el año 1855.

En el mismo año de 1859, la preocupación por mejorar la agricultura en la provincia se plasma en la propuesta del gobernador civil Cástor Ibáñez de Aldecoa a la Diputación de "celebrar en la capital una Exposición Agrícola y Mercantil de las provincias de Castilla, considerando que era una oportunidad interesante para conocer los avances técnicos, los frutos extraños y los progresos de la agricultura. Con una estimación de coste de 204.000 reales, según el presupuesto que acompaña" ${ }^{803}$. Previamente a su presentación, el gobernador había contactado con un importante grupo de comerciantes, industriales y harineros de la provincia para darles a conocer la idea y recabar su ayuda y colaboración, cosa que consiguió. Ante esta propuesta, todos los diputados estuvieron de acuerdo en apoyarla, pero también todos expresaron

799 "Los progresos tienen que estar encuadrados en dos condiciones principales: Producir más con menos costo. Dotar al comercio de granos, de medios económicos de transporte. La primera condición se conseguirá a través de estimular a los agricultores y la segunda a través de la ayuda del Estado" A.D.P.V. Actas. Libro de actas del 25 de enero de 1849. B.O.P.V. no 117 de fecha 29 de septiembre de 1855

801 A.D.P.V. Actas. Libro de actas del 24 de octubre de 1855.

802 A.D.P.V. Actas. Libro de actas del 15 de marzo de 1856.

803 A.D.P.V. Actas. Libro de actas del 9 de abril de1859. 
su preocupación por la dificultad de reunir los 204.000 reales de coste. No obstante, acabaron aprobando una contribución de 123.000 reales y a la vez se nombró una comisión que se preocupara de fijar el lugar más idóneo para instalarla, así como su organización. Entre abril y septiembre tuvieron lugar los trabajos de organización y montaje de la Exposición, que se realizó en los terrenos destinados a levantar la Estación del Ferrocarril del Norte. Se dio una gran importancia a su carácter regional y se cuidaron sobremanera el envío de invitaciones a las diferentes provincias de Castilla y de León. En el programa enviado se daba importancia a la finalidad de la Exposición, esto es, a promover el crecimiento económico, a fomentar la agricultura, la ganadería y la industria y a potenciar el comercio entre las diferentes provincias. La Exposición abrirá sus puertas el día 20 de septiembre de 1859 con una duración de 10 días y estuvo coronada por el éxito, como lo demuestra el que debido a la gran afluencia de expositores obligaron a la organización a ampliar las instalaciones para dar cabida a todos. Destacaba la presencia de industriales harineros, textiles, de curtidos, metalúrgicos, sin olvidarnos en especial de los agricultores y ganaderos como protagonistas de la Exposición.

El gobernador una vez finalizada la Feria comunica a la Diputación "el éxito de la Exposición Castellana y el detalle de los gastos realizados para ponerla en marcha, haciendo notar que se ha rebasado lo presupuestado ante la importancia que ha tenido y el aumento de las galerías destinadas a la industria, la ganadería, la agricultura y las bellas artes. La Diputación aprobó los gastos ocasionados por la ampliación" ${ }^{804}$. En la misma sesión, participó a los diputados que se habían concedido 598 premios a los expositores más interesantes, en las tres áreas en las que había estado dividida, es decir, en agricultura, ganadería e industria y bellas artes. Destacaron los premios a la industria de material agrícola, a la industria textil, a diferentes tipos de cereales, legumbres y vinos, cuya entrega solemne se realizó el 13 de mayo de $1860^{805}$.

En el mismo año de 1859, la Diputación, preocupada por la situación agrícola, remitió un escrito de contestación a la Dirección General de Aduanas y Aranceles, solicitando medidas restrictivas en la comercialización de productos agrarios. ${ }^{806}$. En definitiva plantea unas peticiones claramente proteccionistas de la agricultura provincial.

A partir del año 1860, los pueblos plantean igualmente unas medidas proteccionistas de sus bienes. Pues es notorio que una de las riquezas de los pueblos de la provincia están centradas en la "propiedad de las tierras de propios", y se muestran contra la pretensión del gobierno de "desamortizar los bienes de propios o del común". Por lo que solicitan a la Diputación "se excluyan de la venta diferentes fincas pertenecientes a los propios de los pueblos solicitantes, como comprendidos en las leyes de 1 de mayo de 1855 y 11 de julio de 1856 ". La petición es admitida por la Diputación que "evacuó al Gobierno Central" los pertinentes informes favorables a las peticiones de los pueblos. A lo largo del mes de abril se procedió al tratamiento de

804 A.D.P.V. Actas. Libro de actas del 12 de noviembre de 1859.

${ }^{805}$ Una información detallada sobre este evento en SERRANO GARCÍA, Rafael. "La Exposición castellana de 1859", en Altares, revista de Historia Contemporánea, 1 (2006), págs.149-166.

806 Solicita "la prohibición de importación de cereales del extranjero, porque la principal fuente de riqueza de la provincia es la feracidad del suelo y el fomento de la agricultura y el resto de los elementos de riqueza están subordinados a la producción agrícola. La Diputación recuerda que el deber del Gobierno de S.M. es el de procurar por todos los medios el amparo y protección de la agricultura. Que es necesaria la libre exportación y la absoluta prohibición de importación de productos agrícolas, armonizando en casos determinados esta propuesta en vistas de la escasez. Que el precio medio del trigo en la provincia durante los años 1849 a 53 fue de 25 reales la fanega, con un precio mínimo de 21 y máximo de 33 reales. El morcajo a 18 reales, el centeno a 13, la cebada a 13, los garbanzos a 70 y las muelas, titos y lentejas a 30 reales la fanega. Que en el año 1847 el trigo alcanzó los 45 reales y en 1855 los 80 reales la fanega, y en este año se importaron 14.000 fanegas de trigo inferior, con mayor coste que el nacional. Que el precio del trigo para evitar la carestía y permitir una importación limitada y de control se estima entre 55 y 60 reales la fanega" A.D.P.V. Actas. Libro de actas del 2 de mayo de 1859. 
ciento setenta y cuatro expedientes, correspondientes a otros tantos pueblos, todos ellos pidiendo la "exclusión de la venta de propios". Como ejemplo tenemos la petición que hace Villavicencio de los Caballeros ${ }^{807}$. A estas peticiones del mes de abril se suman cuarenta y siete expedientes tramitados en el mes de mayo, lo que hace un total de doscientos veintiún pueblos que se niegan a vender sus propiedades, lo que representa el $81,5 \%$ de los pueblos de la provincia. Ello obliga a la Diputación a dirigir una "exposición" a la Reina solicitando "que se declare que todos los bienes de aprovechamiento común se exceptúen de la desamortización".

Es llamativo que la Diputación sólo trate un tema determinado a lo largo del año y en este caso es el tema de las fincas desamortizadas, sin abordar otros tratamientos de temas agrícolas. Esto ocurre en el año 1860, y durante el siguiente año 1861, no aparece ningún tipo de información. Sólo conocemos el anuncio que se publica en el Boletín Oficial de la Provincia, sobre la instalación en la capital de la "Compañía Aseguradora de Ganados y Cosechas Hispano-Portuguesa". Es reflejo del interés que van tomando los agricultores en un tema tan poco conocido y admitido por los labradores como es el seguro de las cosechas y el ganado. El presidente provincial de esta aseguradora es el ex-diputado provincial D. José Moyano.

El año 1862 se caracteriza por la propaganda que se está haciendo sobre la "Exposición de Londres", que mantendrá sus actividades a lo largo de la mayor parte del año. La Diputación anima a "industriales, ganaderos y labradores a conocer los progresos que se presentan en la citada exposición", evento que tendrá lugar entre los meses de mayo a septiembre de este año de 1862. En este sentido, la Diputación también acordó “comisionar a D. Juan Fernández Rico, propietario de esta ciudad y socio de la fábrica de fundición, a D. Tomás Villanueva, labrador y ganadero de la capital, y a D. Laureano Melero, ganadero y labrador de Villavicencio de los Caballeros, a asistir a la Exposición, siendo los propios comisionados los que señalen la época más conveniente. El tiempo de permanencia será de cuarenta días. Se abonará a cada comisionado 8.000 reales para ayuda de gastos. La comisión podrá comprar los objetos y ganados que crea conveniente. La cantidad máxima de compra será de 66.000 reales. La comisión hará una reseña del viaje" 808 .

En el mes de septiembre, la Diputación recibe la memoria de los comisionados $^{809}$, dio su conformidad a las compras realizadas, acordó enviar una comunicación para agradecer las atenciones recibidas por parte de los granjeros ingleses y fijó las fechas para realizar los diferentes ensayos ${ }^{810}$. Una vez repartidas todas las semillas, y viendo la Diputación que tenían necesidad de más semillas, puesto que la petición había sido más amplia que la calculada, acordó "autorizar al Sr. gobernador a comprar en Londres 50 fanegas de avena de la que se recolectaba en

807 “excluir de la venta los prados que pertenecían a este pueblo, porque ahora y en todo tiempo, habían sido de aprovechamiento común y gratuito y eran indispensables para el pasto del ganado de labor y que sin ellos no podrían sin gran quebranto subsistir los labradores de este pueblo..." A.D.P.V. Actas. Libro de actas del 17 de abril de 1860 .

808 A.D.P.V. Actas. Libro de actas del 8 de mayo de 1862.

809 En ella explican "los objetos de industria y agricultura presentados, información detallada de los sistemas de cultivo, relación de la compra de arados por ser mejores que los de Castilla y relación de la compra de semillas. Las compras son las siguientes: 100 fanegas de trigo de Australia. 50 fanegas de trigo de Canadá. 50 fanegas de trigo de Danzink. 50 fanegas de avena. 50 fanegas de trébol de flor encarnada. 10 fanegas de heno. Una máquina para limpiar y trillar (empleo de 3 caballos) y una máquina para cortar paja (movida por fuerza animal)" A.D.P.V. Actas. Libro de actas del 28 de septiembre de 1862 .

810 El programa para noviembre era, "estando prevista la llegada de las semillas compradas, fijar los precios y la forma de reparto. Se acordó hacer el reparto entre los labradores más cuidadosos y entusiastas. No dar más de cuatro fanegas de trigo y menos de dos. No dar más de dos celemines de trébol o heno y menos de uno. Pagar por fanega de trigo 44 reales y por celemín de heno o trébol 5 reales. No ceder a otros labradores la simiente recibida. Informar a los alcaldes de las condiciones de las tierras a sembrar. No mezclar la simiente con otras. Dar cuenta al alcalde del partido del resultado de la cosecha. Remitir por los alcaldes un listado con el reparto de simiente efectuado" A.D.P.V. Actas. Libro de actas del 18 de noviembre de 1862. 
aquel país, y repartirla entre los labradores más a propósito y a precios módicos" ${ }^{811}$. Y continuando con su preocupación por mejorar los resultados agrícolas, declara su disposición a introducir los avances ${ }^{812}$. Esta preocupación por la mejora de la agricultura continúa reflejándose en las actas de la Diputación, aunque es verdad que de forma esporádica. En el año 1864 vuelve a reclamar del gobierno "la creación de una Escuela de Agricultura en la ciudad". En el año 1865, se publica un anuncio "animando a los agricultores a comprar una máquina sembradora, ideada por Pedro Martínez López". También en este año, se recuerda la importancia de "la industria vinícola, pidiendo la contratación de un práctico en el arte de la vinificación". En el año 1866, en un continuo afán por la Escuela de Agricultura, se aprueba una partida de 10.000 escudos "para la creación de un campo de aplicaciones prácticas de agricultura", a la vez que se solicita del Ayuntamiento de la capital "la cesión del Prado de la Magdalena para instalar en él un vivero". En 1867 se presenta por parte de su creador Policarpo Gante "una máquina para exprimir la uva sin necesidad de lagar" y también la Diputación acuerda "reparar las máquinas agrícolas compradas en la Exposición de Londres".

Finalmente el año 1868 es un año realmente desastroso en el capítulo de la agricultura, pues ya en el mes de marzo, cunde la preocupación entre los agricultores al presentarse un expediente relativo a la "aparición de la epidemia de langosta en Mayorga". La Diputación, aprueba, en primer lugar, la adopción de las medidas necesarias para luchar contra la plaga y evitar su extensión por el resto de la provincia, y en segundo lugar la provisión de 6.000 reales, que se dedicarán a la paga de los salarios a los jornaleros dedicados a "la recogida de la langosta". A mediados del año, en Mayorga no se ha podido controlar la plaga, y se certifica "la pérdida total de la cosecha de cereales debido a la constante sequía... lo que explica las peticiones de numerosos pueblos de los partidos de Rioseco, Tordesillas, Valladolid y Villalón, de elevar al Gobierno de S.M. una solicitud de perdón de la contribución y la entrega de los granos necesarios para poder efectuar la siembra" "813. La situación es tan grave, tanto para la agricultura como para la ganadería, que "las provincias vascongadas se ofrecen para que el ganado de Castilla pueda pastar en los montes de aquellas provincias". En otro sentido, la Diputación "ante la grave situación que atraviesa la provincia, acuerda suspender su participación en las ferias de la capital”. En la última sesión que celebra la Diputación, en la época isabelina, el día 20 de septiembre de 1868, queda constancia de que en Mayorga se continúa luchando contra la langosta. Y en el resto de la provincia, en especial la Tierra de Campos, se sigue luchando contra el hambre y la miseria provocada por la continua sequía que asola los campos.

\subsubsection{LA AGRICULTURA EN EL SEXENIO, 1868- 1874}

Los principales temas que trata la Diputación con referencia a la agricultura a lo largo del Sexenio se centran en los problemas que ocasionan las malas cosechas que se obtienen a lo largo de estos años. También está presente el afán de la Diputación por crear una Escuela de Agricultura en la provincia.

En el año 1868, en los inicios del Sexenio, la Diputación vuelve a tratar y a encontrarse con los mismos problemas que se sufrieron en la anterior etapa, y en la primera sesión que celebra la nueva Diputación recientemente constituida se estudiaron algunas soluciones. "Los medios de auxiliar a los labradores de esta

811 A.D.P.V. Actas. Libro de actas del 5 de enero de 1863.

812 "dispuesta como se halla la Diputación a introducir en la provincia todas las mejoras y adelantos que se fueran conociendo o que ofrezcan posibilidades de buen resultado ya en el ramo de agricultura, ya en el de industria o ya en otro cualquiera, y deseando en consecuencia hacer las pruebas convenientes con el alforfón o trigo sarracénico en las diferentes clases de terreno de la provincia, acordó: autorizar al Sr. gobernador para que se encargase de la compra de 50 fanegas de esta semilla, con el fin de repartirla entre los agricultores que se creyese más a propósito a 44 reales fanega en la misma forma que se había verificado con el de Australia y las simientes de heno y trébol" A.D.P.V. Actas. Libro de actas del 31 de enero de 1863.

813 A.D.P.V. Actas. Libro de actas del día 2 de julio de 1868. 
provincia para que pudieran hacer la siembra de cereales en el año actual... y teniendo en mente la situación aflictiva en que se encontraba la provincia por consecuencia de la pérdida de las cosechas, se acordó: Dirigirse al Sr. ministro de Hacienda, rogándole se sirviera poner a disposición de la Diputación el número de fanegas de grano necesarias para la siembra..." 814 .

Esta situación de penuria y de malas cosechas se repite en los dos años siguientes. A principios del año 1871, la Diputación "ante las dificultades de cobrar los repartimientos a los pueblos, víctimas en los tres últimos años de la pérdida de sus cosechas, solicita del gobierno el perdón de las contribuciones, y para cubrir la falta de recaudación, solicita levantar un empréstito de 750.000 pesetas" ${ }^{\text {" }} 15$. Está visto que la pérdida de las cosechas presupone el no tener que utilizar maquinaria, lo que hace que "la comisión de Agricultura de la Diputación pide a esta que investigue donde se encuentra la maquinaria comprada en $1863 " 816$.

El segundo tema sobre agricultura que se trata en la Diputación es el de la creación de la Escuela de Agricultura. Se comenzó a hablar de ello en el año 1822 y todavía continúa sin plasmarse en una realidad, aunque en el año 1868, por real decreto de 20 de noviembre, "se ordena la creación de una Granja-Escuela". Ante esta noticia, la Diputación, creyendo en su rápida implantación, inicia los trámites y nombra una comisión con la finalidad de poner en práctica el proyecto. Pero a mediados de 1869 la Corporación sigue hablando de la "propuesta de creación de una Escuela Teórico-Práctica de la Agricultura, como motor del progreso de la agricultura castellana, pues el retraso de su agricultura se debe a la falta de formación y a la falta de capitales. Se acuerda pedir ayuda al Ayuntamiento de la capital para que ceda el Convento de Santa Ana y la Huerta del Rey para situar la escuela" ${ }^{817}$. Llegando el año 1873, con el tema de la Granja-Escuela todavía en estudio, la Diputación estudia una nueva propuesta de "creación de una Granja Modelo para el estudio y fomento de la agricultura en la finca del Santuario de Matallana en Villalba del Alcor" ${ }^{\text {"18. Las }}$ dificultades económicas y los desfases presupuestarios tienen como consecuencia, la anulación de la habilitación de un crédito para la creación de la tan repetida GranjaEscuela de Agricultura.

\section{7.- INDUSTRIA Y COMERCIO.}

En honor a la verdad, este es un capítulo que se podía suprimir perfectamente de la relación de actividades protagonizadas por la Diputación sin que se echara en falta. Esto no quiere decir que tanto la industria, en especial la harinera, como el comercio, también importante el relacionado con la agricultura no tuvieran una destacada actividad y fueran los motores del progreso provincial. Pero es difícil pergeñar unas cuantas líneas relatando las actividades que, lideradas por la Diputación, se producen en la provincia en todo lo relacionado con la industria y el comercio. Es verdad que en los primeros años de su existencia la Diputación refleja de una forma clara a través de la Exposición que envía al gobierno, el 15 de septiembre de 1820: "Haciendo presente el miserable cuadro en que se encuentra esta provincia... que desde 1808 a 1813 fue el continuo teatro de terribles desastres, quiebras y extorsiones ocasionadas por la guerra... Grano y vino son las únicas riquezas de que depende la subsistencia de la provincia... y sólo esta capital y Rioseco tienen un miserable comercio y no hay en toda la provincia una fábrica de consideración...Los vinos de toda la costa catalana y de Andalucía se venden siempre a una triple estimación a los de esta provincia, y los granos doble cuando menos..." Es el mensaje que se transmite desde la Diputación relativo al estado de la industria y

814 A.D.P.V. Actas. Libro de actas del 21 de octubre de 1868.

815 A.D.P.V. Actas. Libro de actas de 4 de enero de 1871.

816 A.D.P.V. Actas. Libro de actas del 26 de febrero de 1871.

817 A.D.P.V. Actas. Libro de actas del 31 de agosto de 1869.

818 A.D.P.V. Actas. Libro de actas del 22 de abril de 1873.

819 A.D.P.V. Actas. Libro de actas del día 15 de septiembre de 1820. 
comercio de la provincia y es el punto de partida para conocer la "triste situación de la provincia" en el ámbito económico.

En lo que respecta al comercio, ya la Cortes Constituyentes se hacían eco para conseguir el fomento de actividades recomendando "remover los obstáculos y trabas que se opongan a la mejora y progreso de la industria y el comercio". En realidad son los Ayuntamientos los que están interesados en controlar el comercio como fuente de financiación de los gastos municipales. Interés al que se contrapone el deseo de los comerciantes por conseguir la "libertad de comercio" reclamada desde el año 1814, como hace "un vecino de Portillo que reclama para que no se le impida el libre comercio". Vuelve a ser reclamada en el año 1820, cuando "los carniceros de Valladolid exigen libertad de comercio". Apenas se consigue en 1834, en la época isabelina, a través de un real decreto en el que "se ordena el fomento de la libertad de venta y circulación de los artículos de comer, beber y arder".

Con respecto a la industria, hasta el año 1841, la Diputación no recoge noticia alguna referente a esta materia. Es en abril de este año cuando se refleja "la queja del fabricante de estameñas de Valladolid por el aumento de los impuestos". También el propietario y diputado provincial por Peñafiel, Millán Alonso, es un conocido y casi único industrial de la provincia con una fábrica de papel en Sardón de Duero. En el año 1842 presenta un expediente en la Diputación "sobre la limpieza, tanto por su parte como por parte del Ayuntamiento de Traspinedo, del arroyo y nuevo cauce que conducen las aguas de su fábrica de Sardón, de acuerdo con las escrituras otorgadas en 1825 y $1840 "$ ".

En el año 1844, el diputado a Cortes por la provincia, Lorenzo Arrazola, comunica a la Diputación "el envío de una exposición al gobierno sobre la declaración libre de derechos de las harinas españolas hacia la isla de Cuba". Es la demostración de que la fabricación de harina ya se ha convertido en la más importante actividad industrial de la provincia. En especial, a raíz de la finalización de las obras del Canal de Castilla, vía de comunicación que se ha convertido en la más importante vía de salida hacia el puerto de Santander de la producción harinera de la provincia. A partir de estos años, tanto la Diputación de Valladolid como la de Santander fomentan la mejora de las comunicaciones entre Alar y Santander, a la vez que solicitan la protección del gobierno para impedir la importación de granos de otros países, tanto a la península como a la isla de Cuba, principal destino de los granos castellanos.

A partir de los años 50, la progresión de la agricultura fomenta la progresión de la industria y el comercio relacionado con la misma. En el año 1850, la celebración de la "Primera Exposición de productos de agricultura, industria y arte" es el inicio del progreso en los ámbitos comercial e industrial. En 1859 están consolidadas las actividades mercantiles e industriales, como lo demuestra el éxito alcanzado por la "Exposición Agrícola y Mercantil" que se celebra en los terrenos de la futura estación del ferrocarril del Norte. Acompañando a la marcha positiva de estas citadas actividades agrícolas, mercantiles e industriales, también florecen en Valladolid las actividades financieras que lideradas por el Banco de Valladolid, formarán el más importante grupo financiero regional y el tercero nacional por detrás de Madrid y Barcelona ${ }^{820}$.

Esta marcha positiva se tuerce en el año 1864 , cuando se produce una crisis en una serie de establecimientos comerciales e industriales, complementados con las dificultades económicas que se producen en la capital, especialmente ocasionadas por la quiebra del Banco de Valladolid, o mejor dicho, la quiebra del banco es la causa de las quiebras comerciales. Así tenemos en el año 1865, la publicación con fecha 26 de enero de la noticia sobre la decisión de que "el Tribunal de Comercio declara la

\footnotetext{
${ }^{820}$ DIEZ ESPINOSA, José Ramón. "Agricultura, industria y comercio” en ALMUIÑA FERNANDEZ, Celso Valladolid en el siglo XIX... ob. cit. Págs. 332 y sig. Tema también estudiado por SERRANO

GARCÍA, Rafael "La quiebra de un modelo expansivo. Las crisis financiera y agrícola en Castilla (1864-68)" en YUN CASALILLA, Bartolomé. Estudio sobre el capitalismo agrario ....ob. cit. Págs.77.
} 
quiebra de Antonio Ortiz Vega y de Juan Antonio Fernández Mantilla". No hay que olvidar que Ortiz Vega es uno de los hombres más ricos de la provincia, con propiedades tanto industriales, comerciales y también agrícolas. En los días siguientes, el mismo Tribunal declara la quiebra de los conocidos "propietarios y comerciantes Eloy Lecanda, Francisco Miguel Perillán, Sebastián Diez Salcedo, Cipriano Merino de la Mora, José María Iztueta, Salcedo y Núñez, Tomás Alfaro, Ciriaco de la Cámara, Bernardo Monclús". En definitiva, los más importantes comerciantes que con anterioridad se quejaban de la falta de vías de comunicación para "exportar los frutos de la provincia", ahora echan la culpa de sus problemas a la ampliación de las comunicaciones a través de nuevas carreteras y nuevo ferrocarril que facilitan la entrada de productos de importación a los que no sabe hacer frente el comercio de la provincia y siguen suspirando por que el Gobierno "eliminase los aranceles a la exportación e impusiese aranceles a la importación".

Fiel reflejo de la situación de la industria y el comercio es la situación de las entidades de crédito en la provincia, que tampoco fueron capaces de activar la economía. Como muestra de los avatares de los bancos en la provincia, tomamos como ejemplo el Banco de Valladolid, por su importancia en la época del inicio de sus actividades, por su corta vida y por los perjuicios que ocasionó al comercio e industria provincial.

La vida del Banco de Valladolid se inicia en el año 1857, en el que por real decreto "se autoriza la creación del Banco de Valladolid a los siguientes señores: Benito Martínez Jover, Miguel de Polaco, Toribio Lecanda, Salvador Feliciano Pérez y Juan Fernández Rico". Sus fundadores son miembros de la élite harinera castellana y también en su mayoría promotores y accionistas de los ferrocarriles, en especial del "Ferrocarril de Isabel II" y el de la "Compañía del Norte" ${ }^{821}$. Inicia sus actividades el 31 de julio del mismo año firmando como administrador Antonio Méndez Vigo y como secretario Castor Ibáñez de Aldecoa, ambos individuos son antiguos gobernadores de la provincia. Sus actividades se mantienen aparentemente normales, aunque un tema preocupante era el de que los principales clientes eran a su vez sus principales accionistas, que viendo la marcha positiva de la entidad, o en prevención de posibles dificultades fomentan la creación de nuevas entidades financieras. Así aparecen en 1862 el Crédito Castellano y en 1864, en vísperas de la quiebra la Unión Castellana y la Sociedad de Crédito Industrial Agrícola y Mercantil.

En el año 1865, la Diputación recibe un informe sobre "la situación en que se encuentra este Banco, con más de un millón de billetes del banco con una gran depreciación y el perjuicio que ocasionaba a la ciudad. Se nombra una comisión para tratar de ayudar al banco en la Corte, con el diputado a Cortes Mariano Lino Reynoso" "822. La comisión no consiguió su objetivo, porque a principios de 1867, la Diputación recibe una notificación "del juez de Primera Instancia de Valladolid, comunicando la formación de causa criminal por estafa contra el Banco de Valladolid" ${ }^{\prime 23}$. Fueron finalmente suspendidas sus actividades con fecha 17 de agosto de 1867 , lo que da fin a 10 años de actividad.

En conclusión, el Banco de Valladolid cierra sus puertas con el convencimiento de haber sido estafados tanto los inversores como los clientes por los componentes de su Consejo de Administración formados por "la flor y nata" de la burguesía harinera e industrial, que utilizaron al banco para sanear sus capitales ante la escasa rentabilidad de sus inversiones en los ferrocarriles. Este cierre repercute en el resto de entidades financieras de la ciudad que también se ven abocadas a la quiebra. ${ }^{824}$

MORENO LÁZARO, Javier. Los empresarios harineros castellanos .... Ob. cit. y B.O.P.V. n 71 de fecha 3 de mayo de 1857.

822 A.D.P.V. Actas. Libro de actas del 22 de julio de 1865.

823 A.D.P.V. Actas. Libro de actas del día 1 de enero de 1867.

TORTELLÁ CASARES, Gabriel. Los orígenes del capitalismo en España. Ed. Tecnos. Madrid. 1982. Págs. 77-128. 
Los directivos del banco fueron procesados, y para escándalo de la ciudadanía, el proceso judicial estuvo estancado a lo largo de los años para que finalmente los encausados, léase los Pombo, Fernández Rico, Reynoso, Polanco, Lecanda, no llegaron a ser, no sólo condenados, sino ni siquiera juzgados. ${ }^{825}$

Ante todos estos movimientos especulativos, la Diputación no entra en la búsqueda de soluciones o en la reconducción de las maniobras perjudiciales para los clientes del banco. Es posible de que no se entere del problema o no quiera intervenir dada la importancia de los promotores encausados. Inicia una investigación cuando en la toma de posesión de los diputados elegidos en la Primera Diputación del Sexenio, al hacer el recuento en la caja provincial aparecen 74.000 escudos en billetes del Banco de Valladolid reflejados en los inventarios recientemente realizados, por lo que la Diputación pide explicaciones a los diputados existentes en esos años puesto que ese dinero carece de valor. A partir del año 1870 , se inicia un expediente para conocer la procedencia de ese dinero y de la responsabilidad del depositario provincial del año 1868, D. José Ferrer. La Diputación no puede ocultar "la gravedad que envuelve la existencia en caja del papel del Banco de Valladolid, en respetable suma, sin explicarse su procedencia y no pudiendo consentir tal desfalco acordó exigir las responsabilidades a los funcionarios que intervinieron en el cambio de billetes, suspendiendo hasta que se aclare por la comisión formada, la pensión del anterior depositario D. José Ferrer". ${ }^{826}$ Para solucionar el problema, la Diputación nombra una comisión para que estudie y determine la procedencia de los billetes y la responsabilidad de su entrada en la caja de la Depositaría. Para aclararlo plantea una serie de preguntas sobre fecha de ingreso de los billetes, motivo y concepto del ingreso, persona que hizo el ingreso, autoridad que lo autorizó, situación del Banco de Valladolid, fecha de salida de los billetes y paradero actual" ${ }^{827}$. La comisión, después de una serie de indagaciones, presentó a la Diputación las conclusiones a las que había llegado y entre ellas destaca que el depositario de los años 1867-68, D. José Ferrer "no tuvo en absoluto una actuación sospechosa". ${ }^{828}$.

En definitiva, ya en el año 1861, los billetes estaban en la Caja y lo curioso es que no se hubiera actuado con anterioridad en el momento de la quiebra del Banco. Lo que hace sospechar que en la Diputación no se tenía conciencia del dinero que tenía el depositario, como tampoco se comprende bien la reacción de la Corporación de "enajenar en pública subasta 5.000 duros en billetes del Banco de Valladolid al tipo mínimo del 20\%”. Es decir, en principio reconoce que estos billetes no están en circulación y no tienen valor y pretende subastarlos, aunque sea al $20 \%$ de su valor. La intención no tendrá éxito, pues en el año 1874 se publica en el Boletín Oficial de la Provincia un anuncio de "subasta para la venta de billetes del Banco de Valladolid por valor nominal de 186.650 pesetas, presentada por la Diputación Provincial a celebrar el 23 del presente mes de abril" ${ }^{829}$. La subasta nuevamente quedó desierta, y con posterioridad la Diputación no reflejó otra iniciativa para enajenar estos billetes.

Como resumen a esta actuación, la Diputación que habitualmente está "sin un duro", tiene desde el año 1861 "30.000 y pico de duros del Banco de Valladolid". No hace ninguna gestión con ese dinero y, lo que es peor, no tiene constancia de su

Detalles técnicos sobre la especulación y bancarrota financiera en PÉREZ GARCÍA, María del Pilar. La bancarrota de un banco emisor: El Banco de Valladolid. Ed. Instituto de Contabilidad y Auditoría de Cuentas. Madrid. 1991.

826 A.D.P.V. Actas. Libro de actas del 1 de diciembre de 1870.

827 A.D.P.V. Actas. Libro de actas del 18 de abril de 1871.

${ }^{828}$ En el dictamen se destaca: “ $1^{\circ}$.Ya en el año 1861, con motivo del robo de la Caja de la Depositaría, en el acta que se levantó de las existencias en caja se habla de 30.000 y pico de duros del Banco de Valladolid. $2^{\circ}$. Es notoria la honradez del Sr. Ferrer. $3^{\circ}$. Se dieron órdenes para admitir el valor nominal en las arcas del Estado en 1861. $4^{\circ}$. El ingreso en caja era porque era una moneda de circulación corriente en Valladolid y que procedía del cobro de impuestos. 5 . Que su ingreso tuvo que ser autorizado por el Sr. gobernador. $6^{\circ}$. Que la situación del Banco de Valladolid fue satisfactoria hasta el año 1865" A.D.P.V. Actas. Libro de actas del 15 de diciembre de 1871.

829 B.O.P.V. Boletín del día 12 de abril de 1874. 
existencia en Caja. Únicamente cuando el Banco ha quebrado y sus billetes no tienen ningún valor, es cuando inicia una serie de investigaciones para no sacar nada en limpio. En esta ocasión y en este tema, la Diputación no estuvo a la altura de las circunstancias, no colaboró, no alertó de los riesgos del Banco, no aportó nada positivo y en realidad lo que ocurrió es que resultó timada como otros muchos clientes $\mathrm{y}$ accionistas en la quiebra fraudulenta del Banco.

\section{8.- ENSEÑANZA}

El artículo ciento treinta y uno de la Constitución de 1812 determina cómo una de las facultades de las Cortes, es la de "establecer el plan de enseñanza pública en toda la monarquía...". Con lo que quiere hacer notar la preocupación de los diputados de Cádiz y la importancia que dan a la promoción de la enseñanza como base y punto de partida para el progreso del país. Esta importancia se da sobre todo a "las primeras letras", es decir, a la alfabetización del país, pues es conocido que siendo famosas sus universidades y muy conocidas por su prestigio, sus habitantes son analfabetos en su gran mayoría.

En el Trienio Liberal, como medio para la mejora de la alfabetización, se publica en junio de 1821 el "Reglamento General de la Instrucción Pública". En él se detalla y articula "las bases generales de la Enseñanza Pública", resaltando entre sus artículos "la gratuidad de la enseñanza". El reglamento divide la enseñanza en tres categorías: "La primera es la general y básica que se dará a la infancia en escuelas de primeras letras. La segunda enseñanza comprende conocimientos que constituyen la civilización general de la nación. Esta enseñanza se proporcionará en establecimientos que se dará el nombre de universidades de provincia. La tercera enseñanza comprende estudios que habilitan para ejercer alguna profesión particular y se dará en cátedras agregadas a las universidades". El "Reglamento" se completa con "la Organización de Escuelas Especiales", "la Universidad Central", "los Catedráticos", "la Dirección General de Estudios" y "la Financiación".

Ya en la época isabelina, la generalización de la enseñanza a todos los niveles produce una gran necesidad de maestros y también de edificios en donde instalar las escuelas. Los maestros se fueron formando a partir de la creación de las Escuelas Normales, y para escuelas se aprovecharon los numerosos conventos desamortizados y también cualquier otro local disponible, ya fuera la cárcel o el pósito y que fueron habilitados para la enseñanza. Lo que no se consiguió fue una financiación racional de los gastos de enseñanza y durante toda la época estudiada se arrastrará un continuo déficit en los costes de escolarización, con las consiguientes reclamaciones de los afectados, es decir, de los maestros ${ }^{830}$.

\subsection{1.- LAS PRIMERAS LETRAS. INICIO DE LA ALFABETIZACIÓN}

Si el artículo ciento treinta y uno encargaba a los diputados en Cortes el establecimiento del "Plan General de Enseñanza Pública", el artículo trescientos veintiuno determina que "estará a cargo de los Ayuntamientos el cuidar de todas las escuelas de primeras letras y de los demás establecimientos de educación que se paguen de los fondos del común". Y además encarga a las Diputaciones Provinciales que "promuevan la educación de la juventud... y velen por el cumplimiento de lo prevenido a los Ayuntamientos acerca del establecimiento de escuelas de primeras letras".

Es una constante y una preocupación de los legisladores el fomento de los estudios a partir de las escuelas primarias o escuelas de "primeras letras". También es una preocupación de las instituciones tanto locales como provinciales el establecer y

\footnotetext{
${ }^{830}$ Para conocer en detalle la evolución educativa en el siglo XIX consultamos: RUIZ BERRIO, Julio. Política escolar en España en el siglo XIX (1808-1833). C.S.I.C. Madrid. 1970. MARTÍN JIMENEZ, Ignacio. La educación Primaria y Secundaria en la provincia de Valladolid (1857-1875). Ed.

Diputación de Valladolid. Valladolid. 2008. M.E.C. Historia de la educación en España. De las Cortes de Cádiz a la Revolución de 1868. Servicio de Publicaciones MEC. Madrid. 1979.
} 
mantener las escuelas. Es cierto que en estos años, tanto los Ayuntamientos como la Diputación, tienen dificultades en cumplir con las leyes, pues los Ayuntamientos no tienen dinero, ni escuelas, ni maestros y tienen dificultades para poner en marcha la enseñanza. La Diputación no puede ayudar a los Ayuntamientos, porque también está escasa de fondos y no hace otra cosa que recriminarles por la incapacidad de llevar a cabo la formación educativa de los niños.

Con este planteamiento es normal que la Diputación reciba las peticiones y quejas de maestros y las transmita a los Ayuntamientos, conminándoles a cumplir con lo mandado en la Constitución. Así vemos que en el año 1814 "Clemente Reoyo, solicita ser nombrado maestro de primeras letras, y una casa donde ubicar la escuela". "Andrés Hernández reclama el pago de salarios atrasados". "Prudencio Hernández, de Valladolid, dice que no puede continuar dando clases si no recibe el salario estipulado". "José Martín presenta un recurso para que se le examine como maestro de primeras letras" $" 831$.

Después del paréntesis absolutista, las Cortes del Trienio vuelven a buscar con gran interés la alfabetización del país, como punto de partida para la mejora de la vida. Prueba de ello, es el citado "Reglamento General de Instrucción Pública" que se difunde a través del real decreto de 29 de junio de 1821 .

Estas buenas intenciones chocan, como es habitual en este país y en estos años, con la dificultad de falta de medios económicos para implantar y desarrollar lo legislado en el antedicho real decreto. La Diputación de Valladolid anima a los Ayuntamientos a que, de acuerdo con la ley, doten al pueblo de escuelas y de maestros. La buena voluntad e interés de los Ayuntamientos hace que habiliten para escuela cualquier casa o local libre, aunque no reúna unas mínimas condiciones para impartir las clases. Con los maestros, surge la dificultad de que una vez contratados, los Ayuntamientos se encuentran sin dinero para pagar sus salarios.

En su búsqueda por facilitar y mejorar la enseñanza, la Diputación se hace eco de las innovaciones en la materia y ensaya en algunas escuelas "el Sistema Lancasteriano de Enseñanza". Este sistema, importado de Inglaterra, trata sobre "el establecimiento de una metodología consistente en que son los propios alumnos, los que una vez iniciados en la enseñanza básica, son los encargados de transmitir sus conocimientos a sus compañeros" ${ }^{832}$. Sistema que no llegó a ponerse en marcha y que en las provincias donde se implantó resultó un fracaso.

A lo largo del Trienio Liberal son curiosas las continuas noticias que se registran en la Diputación relativas a las reclamaciones de pueblos y de maestros con referencia a la enseñanza de las primeras letras. En el año 1820, los libros de actas registran numerosos expedientes ${ }^{833}$. En el año 1821 continúan llegando a la Diputación

${ }^{831}$ A.D.P.V. Actas. Libro de actas de los días 4 de febrero, 23 de marzo y 9 de mayo de 1814 . A.H.M.V. Libro de actas del 8 de enero de 1814 .

832 Este método se ensayó en la provincia de Valencia en marzo de 1821, donde se instaló la "primera escuela lancasteriana", con una duración efímera.

833 Rodilana: El maestro de primeras letras solicita el pago de sus sueldos. Boecillo: Se nombra al maestro con un salario de 4 reales diarios. Cervillego: El maestro reclama una casa para poder dar clases. Palazuelo de Vedija: El maestro reclama sus salarios. Benavente: Se concede el título de maestro de primeras letras a Juan Ferrer. Francisco Durán solicita ser examinado como maestro. Se nombra a un maestro de primeras letras. San Llorente: Se nombra maestro de primeras letras. Un vecino pide permiso para ejercer el oficio de maestro de primeras letras. Villalón: El maestro de primeras letras reclama del Ayuntamiento le abone la cantidad de 1.883 reales de salarios vencidos, y le provea de ejemplares de la Constitución y del catecismo político. Torrelobatón: El maestro de primeras letras solicita el pago de su consignación. Rioseco: El preceptor de Latinidad pide el pago de sueldos atrasados. Valdestillas: Toribio García solicita ser examinado para maestro de primeras letras. La Nava del Rey: El Ayuntamiento decide aumentar la dotación del maestro. Geria: El maestro pide se le aumente la dotación de 1.040 reales al año. Villanueva de los Infantes: El Ayuntamiento nombra al maestro. Villalba del Alcor: El maestro de primeras letras pide a la Diputación que obligue a todos los que tengan hijos los envíe a la escuela. Valladolid: Agustín García solicita abrir una escuela. Clemente Reoyo, maestro más antiguo de primeras letras de esta ciudad, solicita un local para establecer su escuela en cualquiera de los edificios pertenecientes a las temporalidades de los Jesuitas. El Ayuntamiento acuerda pagar los salarios de los maestros de Primeras Letras que antes pagaba la Sociedad de Amigos del País. Rafael 
un gran número de expedientes relacionados con la enseñanza de las primeras letras. Vemos una relación de pueblos con diversas reclamaciones ${ }^{834}$.

Durante el año 1822, se mantienen las reclamaciones en materia de enseñanza pero ya con un claro matiz económico, porque la mayoría de los expedientes tratados son debidos a peticiones de pago de salarios atrasados o de aumento de los salarios ${ }^{835}$.

Independientemente de toda esta serie de problemas, también es verdad que la dedicación y buen hacer de los maestros está fuera de toda duda. Así lo demuestra el oficio de la Dirección General de Estudios que, con fecha 22 de abril de 1822, "encarga a la Diputación se manifieste al maestro de primeras letras de Rioseco D. Ángel Escudero, haber merecido la aprobación de la Dirección General el método que sigue, y que la Diputación se sirva proteger su escuela, promover el pago de atrasos de sueldos y premiarle con alguna gratificación. La Diputación acordó que se le den las gracias por su método, celo y esfuerzos en la enseñanza y que se dé cuenta en otra sesión lo concerniente en cuanto a gratificación" $" 836$.

En el año 1823, los acontecimientos políticos nacionales centran la atención de la Diputación. Pero continúan las reclamaciones centradas principalmente en los

Rivera solicita ser examinado para maestro. Gabriel de la Anunciación, presbítero regular de los Carmelitas Descalzos del Convento de Extramuros, expone que habiendo solicitado ser secularizado y determinado su pase a la enseñanza de la facultad, pide se le examine para maestro de primeras letras.

${ }^{834}$ Tordehumos: El maestro de primeras letras pide la aprobación del título, y al poco tiempo se queja de que ha sido sustituido y el Ayuntamiento nombra nuevo maestro. Villalón: El maestro Manuel Martínez de Poza envía una exposición manifestando que el Ayuntamiento no le ha provisto del Catecismo Político y de ejemplares de la Constitución que reclamó hace meses. También se queja de que no le han pagado el sueldo estipulado de 200 ducados anuales. Pide que se haga un repartimiento para cubrir sus deudas. Tudela: El maestro de primeras letras solicita el nombramiento y al mismo tiempo aumento del sueldo de 2.000 reales en vez de 1.790. Valladolid: Se nombra a dos maestros de primeras letras, y también los maestros solicitan se les pague el medio año vencido de las rentas de las casas donde tie nen establecidas las escuelas. Almanza: Los maestros piden el pago de los atrasos a través del juez. Puebla de Sanabria: el maestro reclama el pago de los sueldos atrasados y el Ayuntamiento tiene que alquilar el piso para pagarle. Piden la aprobación del título de maestro de primeras letras en los pueblos de Castrillo Tejeriego, Aldeamayor de San Martín y Ciguñuela. Reclaman aumento de sueldo los maestros de Cabezón, Rueda, Villalba del Alcor, Corrales y Nava del rey (3 reales diarios). Reclaman el pago de salarios atrasados en Quintanilla de Abajo, Benavente, Cervillego de la Cruz, Pozaldez y Nava del Rey. Matapozuelos: El maestro de primeras letras se queja porque no quiere que nombren a otro maestro en el pueblo. Ciguñuela: El maestro solicita estudiar con el libro de Torcuato Torio de la Riva. Aguilar de Campos: El maestro se queja de que "un agricultor inculto ha abierto una escuela". Villanueva de los Infantes: El Ayuntamiento acuerda pagar al maestro los 400 ducados al año con los fondos de propios.

${ }^{835}$ Reclaman el pago de los salarios atrasados los maestros de los siguientes pueblos: Villanueva de los Caballeros, Medina del Campo, Cabezón, Corrales, Torrelobatón, Robladillo, Palacios de Campos, Mojados, Valdestillas, Villanueva de los Infantes, Esguevillas, Rioseco y Pollos. Solicitan aumento de sueldo los maestros de los pueblos de: Quintanilla de Arriba, Rodilana (pide 1.500 reales), Villafer (pide aumento de 1.500 a 1.700), Geria, Castronuño y Valdearcos. Solicitan ser examinados para acceder al título de maestros de primeras letras vecinos de: Mayorga, Valdestillas, Valdenebro, Peñafiel, Villanubla, Pedrosa de Duero, Tordehumos y Valladolid. Palacios de Campos: El maestro reclama por ser despedido. Otero de Sanabria: Solicita nombrar otro maestro. Aguilar de Campos: Se concede para escuela la casa prioral de los Benedictinos de Carrión, pero el alcalde no la considera buena y pide la panera del pósito. San Vicente del Palacio: El maestro se niega a ir a examinarse para el título a Valladolid. Cabezón: El maestro se queja a la Diputación "porque el alcalde le ha obligado junto al alguacil a darle las llaves de la escuela para colocar en ella dos pesos". Valdestillas: El maestro Tomás Hernández, pide que se le paguen los atrasos de los fondos de propios. Villafuerte: El maestro pide que no se permita la enseñanza a otro, por no tener título. Villanueva de los Infantes: El maestro pide arreglar la escuela a través de arbitrios. Castrejón: El maestro se queja a la Diputación porque el Ayuntamiento ha nombrado maestro al regidor decano, sacristán y colector de granos. Villanubla: Francisco Pérez solicita ser examinado para maestro de primeras letras. Se le convoca para el día 18 para ser examinado por los maestros Clemente Reoyo y José Redondo en presencia del diputado Sr. Macho. Rioseco: El Ayuntamiento pide el edificio del suprimido Hospital de San Juan de Dios para escuela. Torrelobatón: Se aprueba un repartimiento para pagar al maestro. Nava del Rey: El Ayuntamiento acuerda dotar al pueblo de otra escuela aprobando un repartimiento.

836 A.D.P.V. Actas. Libro de actas del 7 de mayo de 1822. 
atrasos en el pago de salarios. En el "Resumen Anual" que presenta la Corporación al jefe político, se pone así de manifiesto ${ }^{837}$.

Es esta la última noticia sobre la enseñanza que quedó reseñada en los libros de actas en el tiempo del Trienio Liberal. Ya en la época isabelina, continúa la preocupación del gobierno por el fomento de la enseñanza. Como primera medida, para conocer la situación, y aún antes de poner en marcha nuevamente a las Diputaciones, un real decreto ordena "hacer un inventario de todas las escuelas y maestros de primeras letras de los que están dotados los pueblos". Actuación que se completa con la publicación de una "Instrucción para el Régimen y Gobierno de las Escuelas de Primeras Letras", y con un nuevo R. D. por el que se ordena "abolir los azotes en las escuelas" $" 838$.

Los pueblos, dentro de sus limitadas posibilidades, se preocupan por el buen funcionamiento de sus escuelas. Así lo demuestra el Ayuntamiento de Tamaríz de Campos que publica en el Boletín Oficial de la Provincia un anuncio en el que enjuicia la grave situación de la enseñanza ${ }^{839}$. En realidad, los problemas económicos continúan, tanto los relativos a la financiación de los maestros, como los correspondientes a la construcción de escuelas, independientemente del período político que se viva, ya sea en el período liberal, en el absolutista o en el isabelino. En el año 1836, ya con la Diputación en marcha, el problema más grave que se detecta es el de "falta de maestros de primeras letras". De ahí que la recién creada "Comisión de Instrucción Pública" solicite del gobierno que "prepare el Reglamento para poder examinar de acuerdo con las directrices del Ministerio de Instrucción Pública a los pretendientes a maestros de primeras letras". A lo largo de este año, se destacan algunas reclamaciones, como la de Castromonte, donde se pide que las rentas del hospital se destinen a mantener la escuela, o la de Palacios de Campos, en donde el maestro se queja de que las rentas de la capellanía se las queda el cura, o la de San Cebrián de Mazote, donde un exclaustrado solicita ser nombrado maestro de primeras letras. Finalmente, para beneficiar y fomentar la instalación de escuelas y su mejor financiación una real orden de fecha 22 de noviembre decreta que "los bienes de fundaciones de escuelas están exentos del 15\%" "840.

En el año 1837, maestros y Ayuntamientos siguen con sus expedientes de reclamaciones de salarios y de fondos para la habilitación de escuelas ${ }^{841}$. Al finalizar el año, y para mejorar el número de maestros y evitar que éstos tengan que dejar

837 "El deplorable estado de la primera educación por falta de escuelas en muchos pueblos de la provincia, falta de dotación de los maestros y proponiendo como medidas a adoptar para proporcionar la buena educación de la juventud, que se destine a la competente dotación de los maestros, entre otros fondos, los productos de fundaciones piadosas que puedan tener esta aplicación, como lo han solicitado a esta Diputación numerosos pueblos de la provincia..." A.D.P.V. Actas. Libro de actas del 18 de febrero de 1823.

838 B.O.P.V. no 80 de 18 de octubre de 1834.

839 "Anuncio: Vacante la escuela de primeras letras de la villa de Tamaríz, siendo su consignación 64 fanegas de trigo, 36 que pagan diversas fundaciones y las 28 restantes por repartimiento de vecinos y 200 reales en dinero cobrado de propios" B.O.P.V. n 96 de 12 de noviembre de 1835.

840 A.D.P.V. Actas. Libro de actas del 12 de diciembre de 1836.

${ }^{841}$ Palacios de Campos: El maestro solicita aumento de salario. Herrín de Campos: El maestro reclama 1.000 reales de atrasos. Aguilar de Campos: El maestro solicita ser exento de devolver 24 fanegas de trigo al pósito. Mota del Marqués: El maestro se queja del Ayuntamiento. Quintanilla de Trigueros: Los vecinos se quejan porque el Ayuntamiento quiere echar al maestro. Benafarces: El Ayuntamiento pide que el sueldo del maestro se pague de los beneficios de obras pías. Laguna: El Ayuntamiento despide al maestro porque no tiene título. Villanueva de Duero: El maestro reclama su salario. Valdestillas: El maestro reclama 7.800 reales de deuda. Castromonte: Los vecinos piden que se venda el hospital para pagar el sueldo del maestro. Valladolid: Un maestro reclama 7.500 reales de deuda. El Ayuntamiento pide que las extinguidas escuelas de la Compañía de Jesús vuelvan a funcionar pagadas por la Caja de Amortización. Pozal de Gallinas: Una maestra solicita ser elegida para la enseñanza de las niñas "por ser repugnante y abiertamente opuesto a las buenas costumbres la confusión en un mismo local de jóvenes de ambos sexos". 
temporalmente el trabajo, el Gobierno publica una R.O. "por la que los maestros de primeras letras están exentos de servicio a la Milicia Nacional" $" 842$.

El año 1838 se caracteriza por el gran número de reclamaciones protagonizadas por los maestros en petición del pago de los salarios atrasados ${ }^{843}$, Son un total de veintisiete pueblos de la provincia, el $10 \%$. Se hace la observación de que en varios de estos pueblos, las reclamaciones son tantas como el número de maestros que ejercen en cada uno de ellos. Así tenemos que en Rioseco y Villabañez se presentan tres reclamaciones de atrasos y en Castromonte, Portillo y Villardefrades son dos los expedientes que se presentan.

Otros varios expedientes nos hacen ver las dificultades por las que atraviesa la enseñanza, siempre pendiente de su financiación. Surgen además otros numerosos y variados problemas que en la mayoría de los casos no afectan directamente ni a los métodos de enseñanza ni a la calidad de la misma. Así tenemos otra serie de reclamaciones ${ }^{844}$.

En los años 1839 y 1840, apenas se registran expedientes de reclamaciones relativas a la enseñanza, en curioso contraste con los numerosos que fueron los correspondientes al año 1838. En estos dos años sólo aparecen cinco referencias ${ }^{845}$. En el año 1841, reaparecen las diferentes reclamaciones tanto de Ayuntamientos como de maestros $^{846}$. En el año 1842, continúan las dificultades para cubrir los costes de la enseñanza, aunque los pueblos "se las van ingeniando" para encontrar los fondos necesarios con que cubrir los gastos de las escuelas y los salarios de los maestros ${ }^{847}$.

842 B.O.P.V. n ${ }^{\circ} 137$ de 30 de noviembre de 1837.

${ }^{843}$ Así tenemos expedientes relativos a los pueblos de Mota del Marqués, Villabrágima, Rioseco, Laguna, Quintanilla de Trigueros, Viana de Cega, Tamariz, Tordehumos, Torrecilla de la Orden, Portillo, Cabezón, Villardefrades, Mojados, Villabañez, Boecillo, Fuensaldaña, Corcos del Valle, Valdestillas, Curiel, Ciguñuela, Castromembibre, Villagarcía, Langayo, Castromonte, S. Salvador, S. Vicente de Palacio y Nava del Rey.

${ }^{844}$ Villamuriel: El Ayuntamiento presenta una exposición a la Diputación en la que expone que dado el fallecimiento de Luis Aguado, canónigo de Palencia, que testó a favor de una escuela en Villamuriel, pide se reclame a la Justicia el cumplimiento testamentario Tordehumos: Se pide que el pueblo sea dotado de otra escuela. Castrillo de Duero: Se reclaman los daños causados a la escuela "por alborotos populares". Viana de Cega: El Ayuntamiento comunica que no puede pagar 250 reales que adeuda al maestro por salarios. Curiel: El maestro pide que "no se le desaloje de su destino". Valladolid: Un maestro solicita ser repuesto en su cargo del que había sido desposeído por el diputado Sr. Lozar. Un vecino solicita el título de maestro de primeras letras. Villalón: El maestro se queja del trato que recibe del Ayuntamiento. Velliza: El maestro solicita ser repuesto en su cargo. Villanueva de S. Mancio: Se solicita dotar a la escuela de los bienes de una Capellanía. Tamariz: El Ayuntamiento pide a yudar a la escuela con "una obra pía". Torrecilla de la Torre: Se busca un local adecuado para la instalación de la escuela. Villavellid: Un presbítero exclaustrado solicita ser maestro de primeras letras. Encinas: El Ayuntamiento expedienta al maestro "por sus malos antecedentes políticos".

845 "Se publica en el Boletín Oficial de la Provincia del 2 de mayo de 1839, el Reglamento de Escuelas Públicas de Instrucción Primaria". "El Ayuntamiento de Castromembibre solicita a la Diputación, en expediente de fecha 1 de octubre de 1839, "autorización para dotar a la escuela de 9 fanegas de pan cocido, que antes se daba a los pobres". "El Ayuntamiento de Rioseco, reclama el certificado de pago de salarios atrasados a los maestros". "El Boletín Oficial de la Provincia (13 de marzo de 1840) convoca exámenes para maestros de primeras letras". "El Ayuntamiento de Mojados anuncia la vacante de una plaza de maestro".

${ }_{846}$ Así tenemos constancia de que en Velilla: Se aprueban arbitrios para la dotación de la escuela. Valbuena de Duero: El Ayuntamiento solicita "agregar a la dotación del maestro de primeras letras los productos de una obra pía”. Melgar de Arriba: Se solicita la cesión de una panera del estado para escuela. Renedo: El maestro solicita aumento del salario. Medina del Campo: El maestro reclama el pago de atrasos. Canillas: Para pagar al maestro el Ayuntamiento tiene que "añadir una obra pía". Matapozuelos: El maestro reclama el pago de los atrasos. Cabezón: El Ayuntamiento solicita autorización para vender sus terrenos de propios para pagar 1.100 reales al maestro. La Cistérniga: El Ayuntamiento pide ayuda a Valladolid para pagar al maestro. Ataquines: El maestro Juan González Mendoza, reclama atrasos. Fresno: El alcalde avisa que no puede pagar la deuda del maestro.

${ }^{847}$ Así tenemos: Simancas pide aumentar la dotación de la escuela con obras pías. Los Ayuntamientos de Geria, Castromonte y Rodilana acuerdan hacer repartimientos para pagar a los maestros. En La Pedraja se acuerda dedicar a la escuela las rentas del despoblado de Cardiel. El maestro dePesquera de Duero reclama el salario. En Cabezón se aprueba el nombramiento del maestro de primeras letras con un salario de 1.100 reales al año. Traspinedo, Moraleja de las Panaderas y Gatón de Campos acuerdan 
Como dato curioso, vemos que no sólo son los maestros los que sufren la falta de dinero, cosa que también ocurre con los médicos, los jueces y hasta con los curas, como ocurre con "el Ayuntamiento de Pozal de Gallinas que acuerda contratar al cura más barato para decir la misa de la fiesta" ${ }^{848}$. El año 1843 no supone ninguna sorpresa en lo relativo a la enseñanza, y se continúa con los mismos problemas ${ }^{849}$.

A lo largo del año 1844 apenas aparecen reclamaciones o expedientes relativos a la enseñanza. Únicamente son dos las referencias: Fuente Olmedo solicita autorización para gravar 4 maravedís en fanega de pan para dotar al maestro de primeras letras. Rioseco solicita la anulación de una de las dos plazas de maestro de primera educación. En el año 1845, no aparece ninguna referencia en el tema de reclamaciones. En temas de enseñanza, el año se inicia con un discurso del jefe político pronunciado el día 9 de enero con ocasión "del acto de instalación de la Sociedad Vallisoletana para el establecimiento de escuelas de párvulos". Y se completa con el anuncio que aparece en el Boletín Oficial de la Provincia del día 8 de mayo, avisando de que, "ante el éxito de la primera escuela de párvulos situada en el antiguo monasterio de los Premostratenses, se acuerda iniciar las actividades de una segunda escuela en el antiguo convento de San Diego, frente a la plaza de Los Leones y que se inaugurará el próximo día 13, San Pedro Regalado". El año finaliza con la preocupación por mejorar la enseñanza primaria, que poco a poco va calando en la sociedad. Prueba de ello es la propuesta de la Comisión Provincial de Enseñanza, alentando a los pueblos a aumentar los presupuestos destinados a la enseñanza para "dotar de menaje a las escuelas, proveer la enseñanza de niños pobres y dotar de premios a los alumnos" $" 850$.

A partir del año 1846, con la puesta en marcha del Consejo provincial, organismo complementario y paralelo a la Diputación, los temas de enseñanza pasan a depender del citado Consejo. La Diputación deja de registrar en sus actas las incidencias escolares, aunque tampoco el Consejo, refleja en sus libros actividades de enseñanza entre los años 1846-1854, tiempo de vigencia. Sólo se registran diez expedientes, aunque el Boletín Oficial de la Provincia nos recuerda que siguen existiendo dificultades económicas al publicar el 6 de noviembre de 1851 una circular del gobierno "exigiendo el pago de atrasos a los maestros".

En el año 1854, con la llegada del Bienio Progresista, por parte del gobierno se decreta la suspensión de actividades del Consejo provincial. Lo que hace que la Diputación retome nuevamente los asuntos relativos a la enseñanza, y vemos nuevamente reflejadas en las actas los expedientes correspondientes a esta materia. Así vemos que "se aprueban en Rubí de Bracamonte las obras de reparación de la escuela", "Villagarcía pide que se repare su escuela, aprobándose una inversión de 3.000 reales en la obra", "Berrueces acuerda un repartimiento de 3.000 reales para reparar la escuela".

Durante el año 1855, continúan las peticiones de reparación de las escuelas y prácticamente desaparecen las reclamaciones de pago de salarios atrasados. Las

pagar el sueldo de los maestros con los fondos de propios. En Castroponce se acuerda instalar la escuela en la panera. En Valladolid se efectúan los exámenes públicos de Instrucción Primaria, presididos por el presidente de la comisión de Instrucción Pública, el diputado provincial D. Manuel Gusano.

848 A.D.P.V. Actas. Libro de actas del 10 de junio de 1842.

${ }^{849}$ En las actas están reflejados: Olivares de Duero, Simancas, Melgar de Abajo y Bolaños, pueblos en los que los respectivos maestros reclaman el pago de los salarios atrasados. En Peñaflor de Hornija el maestro reclama 449 reales de deuda. En Torrelobatón "no hacen caso" de las reclamaciones que hace el maestro para que le paguen el salario de todo el año. Los poblados de Villaverde, Carrioncillo y Dueñas de Medina aprueban la creación de una escuela a instalar en Villaverde. Castrillo de Duero aprueba la dotación de un maestro. Villalba del Alcor acuerda subir el salario al maestro a 2.800 reales al año. Torrelobatón acuerda pagar al maestro 300 ducados año. En Urones el maestro dimite y solicita la plaza de secretario. Roales aprueba un repartimiento para reparar la escuela. Olmedo acuerda manten er la escuela con el importe de unos foros. Valdenebro acuerda pagar la escuela con la venta de una obra pía. Casasola de Arión vende unas rentas para pagar la escuela. En Iscar. El maestro pide que se le aumente el salario a 1.650 reales-año.

850 B.O.P.V. $\mathrm{n}^{\circ} 113$ de fecha 20 de septiembre de 1845 
peticiones que se reciben en la Diputación, son las siguientes: "Quintanilla de Trigueros, La Unión de Campos, Barcial de la Loma, Boecillo, Ceinos de Campos, Nava del Rey, Bustillo de Chaves, Villahamete y Tordesillas, inician expedientes para aprobar obras de ampliación y construcción de escuelas". Se completa el año con la petición de la Diputación al gobierno para que acuerde que "la Instrucción Primaria sea obligatoria en ambos sexos".

En el año 1856, vuelven a desaparecer las referencias a la enseñanza en las actas de la Diputación. Como testimonio, sólo se registra que "los maestros de Becilla de Valderaduey reclaman el salario del último trimestre".

Con la finalización del período del Bienio Progresista y la llegada de los moderados al poder, se pone en funcionamiento nuevamente el Consejo provincial, lo que supone un traspaso de competencias. La Diputación vuelve a quedar vacía de responsabilidad en la enseñanza, pero en contraste tampoco el Consejo trata expedientes en la materia. Una noticia interesante se produce en el año 1858, con la publicación por Marcelino Sánchez Raña del Nomenclátor alfabético de la provincia de Valladolid con expresión de las escuelas que hay en la misma ${ }^{851}$ en la que nos detalla la existencia de 425 escuelas con 15.719 alumnos y 7.843 alumnas. Como datos más reseñables en el tiempo que transcurre entre 1856 y 1868 podemos señalar algunas solicitudes ${ }^{852}$.

Un dato a tener en cuenta y que nos llama la atención es la pérdida de información por parte de la Diputación de los temas de enseñanza. Si analizamos el comportamiento de la institución en esta materia, vemos que su preocupación por la vida escolar es muy grande en los primeros años de vigencia de la Diputación. También observamos que desde los años 1857 a 1868, es decir prácticamente doce años, no hay referencias a la educación en prácticamente todo el período. Esto nos puede llevar a la conclusión, posiblemente errónea, de la pérdida de interés por la enseñanza por parte de la institución provincial, porque lo que no podemos creer es que la enseñanza transcurra plácidamente y sin problemas a lo largo de estos años. También es posible que el Consejo provincial o la Comisión de Enseñanza efectúen una labor tan eficiente que no necesite la intervención de la Diputación, cosa dudosa de creer.

Con la llegada del nuevo período político "del Sexenio", con su consecuente desaparición del Consejo provincial, vuelve nuevamente a quedar reflejado en las actas los problemas e inquietudes de todos los implicados en el tema, léase maestros y Ayuntamientos. A finales del año 1868, una vez tranquilizada la vida política, y disueltas las Juntas Revolucionarias Provinciales, la Diputación tiene que hacer frente a una serie de maestros de la provincia que, "separados de sus trabajos por la Junta Revolucionaria, reclaman el ser repuestos en sus empleos". El año 1869 no es precisamente un año fácil en la vida provincial, ya que la sequía y la pérdida de las cosechas van complicando un camino lleno de dificultades, y de esto no se puede librar la enseñanza. De esta forma vemos los expedientes más repetidos en esta materia ${ }^{853}$. Aunque donde se da cuenta de las dificultades, en especial económicas, por

\footnotetext{
${ }^{851}$ Información tomada de MARTÍN JIMENEZ, Ignacio. La educación primaria.. ob. cit. págs.179-196. 852 1857. Publicación de la Ley de Instrucción Pública, promovida por Claudio Moyano, con fecha 9 de septiembre. 1858. El Ayuntamiento de Villabrágima solicita una subvención para construir una escuela presupuestada en 77.000 reales. 1859-1860. El Consejo Provincial trata cinco expedientes relativos a la enseñanza. 1861. Aprobación de una subvención de 28.706 reales a Mota del Marqués para la construcción de una escuela. 1862-63-64. El Consejo provincial trata cuatro expedientes escolares: Carpio solicita una subvención para la escuela y casa del maestro. Valladolid, solicita 50.000 reales para escuelas. Bamba, presenta un expediente para construir una escuela. Herrín de Campos, solicita ayuda para construir una casa para el maestro. 1865. Se aprueban dos expedientes para construir dos escuelas en Castrejón y en Tiedra. 1866. Mota del Marqués aprueba la venta de títulos para construir una escuela. 1867. Berceruelo presenta expediente para construir una escuela. 1868. Tamariz de Campos, solicita reparar la escuela.

853 "Reclamación del pago de sueldos atrasados "solicitados por los maestros de Vega de Río Ponce, Becilla, San Pelayo, Pozaldez, San Pablo, Arroyo, La Mota del Marqués y Ciguñuela" "El maestro de
} 
las que pasa la enseñanza es en la propia Comisión de Enseñanza, que se ve obligada a "suprimir la plaza de escribiente, en vista de la situación angustiosa en que se encuentra la provincia, y además se obliga a hacer un presupuesto de gastos en todas las economías posibles" ${ }^{854}$. .

A partir del año 1871, inicia su funcionamiento la Comisión provincial, que se hace cargo de los expedientes relativos a la enseñanza. Nuevamente la Diputación vuelve a quedar sin atribuciones en la materia y sin reseñas en las actas. Aunque lo más grave es que la Comisión tampoco refleja actividad interesante en materia escolar. En los años 1871 a 1874 se reflejan en sus actas muy pocas actividades sobre esta materia y sin explicar de qué trata cada expediente. Sólo podemos conocer su número y así está reflejado que en 1871 se trataron once expedientes de enseñanza, en 1872 fueron nueve, en 1873 se trataron catorce expedientes y en 1874 se trataron otros catorce expedientes.

\subsection{2.- LA ENSEÑANZA MEDIA. LENTA CONSOLIDACIÓN}

Dos instituciones escolares son las más representativas y las que más preocupan a la Diputación en su afán de cubrir las necesidades de la provincia, en el nivel de la enseñanza media, a lo largo del siglo XIX. Son la Escuela Normal, como formadora de maestros de las primeras letras, que iniciará el curso en el año 1845 (en Valladolid), y el Instituto de Enseñanza Media o Instituto de Segunda Enseñanza, encargado de dar una formación escolar intermedia entre las primeras letras y la Universidad, y que se pondrá en marcha en la capital a partir del año 1848.

Otra institución de enseñanza que ya funcionaba con anterioridad a estas dos es la "Academia de Nobles y Bellas Artes de la Purísima Concepción", enmarcada también en la enseñanza media y dedicada a la formación de sus alumnos en un ámbito artístico y técnico. Esta institución fue fundada por un grupo de próceres vallisoletanos el 28 de octubre de 1779 con el nombre de Academia de Matemáticas, Geometría y Dibujo y con la finalidad, determinada en sus estatutos, de promover y fomentar el conocimiento de las nobles artes mediante la enseñanza de las matemáticas y el dibujo, además de velar por la observancia de los cánones artísticos en la arquitectura, pintura y escultura ${ }^{855}$. En los primeros años de su vida padeció una serie de dificultades al no disponer de recursos económicos propios y tener que llevar a cabo el sostenimiento del profesorado a través de aportaciones voluntarias. En el año 1813, recién instalada la Diputación, la Academia comunica su establecimiento en la calle Teresa Gil, y en el Trienio Liberal, aparecen referencias a las ocupaciones de la Academia cuando se la encomienda efectuar los "exámenes de agrimensores".

Con ocasión de las sucesivas desamortizaciones de conventos, la Academia fue haciéndose cargo de numerosas obras de arte procedentes de los conventos y de las iglesias cerradas. Durante años, aparte de la enseñanza, se dedicó a clasificar, ordenar y cuidar de las numerosas obras de arte, que iba colocando y almacenando en los locales del Colegio de Santa Cruz, edificio en el que finalmente se instalará el Museo Provincial en el año 1840. También se preocupó de mantener y ordenar libros y documentos procedentes de los citados conventos clausurados. En el año 1849, por real decreto de 31 de octubre, se acordaba la disolución de la Real Academia de Nobles Artes y en su lugar se constituyó la Academia Provincial de Bellas Artes, que

Pozal de Gallinas se queja porque el Ayuntamiento le ha rebajado el sueldo" "El maestro de Quintanilla de Abajo, se queja porque el Ayuntamiento no le ha renovado en su puesto" "Se nombran nuevos maestros en Arroyo y Carpio"

${ }^{854}$ En el año 1870 siguen reclamando el pago de los jornales atrasados los maestros de Vill anubla, Vega de Valdetronco, Bamba, San Román de Hornija y Muriel. A lo que se añade el maestro de Pozaldez, que preocupado por el paro, "establece una academia para instruir a la clase obrera" A.D.P.V. Actas. Libro de actas del 23 de febrero de 1870.

${ }^{855}$ PRIETO CANTERO, Amalia. Historia de la Real Academia de Nobles y Bellas Artes de la Purísima Concepción de Valladolid. Inst. Cultural Simancas. Valladolid. 1983. 
continuó con los trabajos del cuidado y conservación de Museo y la impartición de clases de pintura, escultura y arquitectura.

La Escuela Normal surge de la necesidad de formar a los maestros de Primeras Letras, cuando al mismo tiempo se fomenta la Enseñanza Primaria. Esta necesidad ya había sido observada con anterioridad, en especial por las Órdenes religiosas dedicadas a la enseñanza, que establecieron escuelas especiales de formación para sus religiosos. Oficialmente hasta la publicación del real decreto de 4 de agosto de 1836 no se legaliza la creación de Escuelas Normales en España, "cada provincia podrá sostener por si sola o reunida con otra, a juicio de las Diputaciones Provinciales, un Escuela Normal..." 856.

En el inicio del período isabelino, la Diputación recién instalada tiene noticias del funcionamiento a partir del año 1837 de una Escuela Normal en Madrid, cuando por R.O. se le comunica "el nombramiento de los alumnos que van a asistir a la Escuela normal" ${ }^{\prime 57}$. Dan a entender, aunque no se especifica, que los alumnos asistentes son uno por cada provincia, ya que la Diputación "aprueba el ingreso en la Escuela Normal de D. Simón Aranda". Con la llegada del gobierno de Espartero se fomenta la ampliación del número de Escuelas Normales, al publicar una real orden "mandando establecer una Escuela Normal de instrucción primaria en cada provincia" ${ }^{858}$. La real orden tiene fecha del año 1840 , pero no se hará efectiva hasta el año 1842, cuando se inicia la instalación de otras escuelas. El 15 de enero de 1841, el gobierno reclama a la Diputación el pago del último semestre de los alumnos de la Escuela Normal de Madrid, petición que es ratificada por el director de la citada Escuela que en nota enviada a la Diputación "reclama 3.000 reales por los alumnos del segundo semestre" $" 859$, señal inequívoca de que son varios los alumnos asistentes.

El Ayuntamiento de la capital, interesado como la Diputación por agilizar la creación de la Escuela Normal, presenta y aprueba en sesión del 13 de diciembre de 1841 "emplear 40.000 reales del fondo de propios para invertirlos en la compra del Convento de Premostratenses y adecuarlo para ser utilizado como Escuela Normal". La Diputación está convencida que será más rentable, el establecer una escuela en la capital que enviar los alumnos a estudiar a Madrid. En el año 1842, estos alumnos "piden licencia para permanecer en la Corte después del mes de marzo en que concluyen los estudios para reconocer algunos establecimientos de educación" $" 860$.

La Diputación en el año 1842 inicia los preparativos para la apertura de la escuela, a través de una comisión formada por los diputados Represa y Gusano "para estudiar la creación de la Escuela Normal", a la vez que concede una ayuda "para la compra de libros". En el año 1843 "la Comisión de Instrucción Pública, comunica el presupuesto de gastos para el establecimiento de la Escuela Normal, que asciende a 25.200 reales, cantidad que se aprueba repartir entre todos los pueblos" $\$ 61$.

El 30 de septiembre de 1843, se comunica a la Diputación la habilitación de un local del Convento de Premonstratense "para escuela de educación primaria", anexo a la futura Escuela Normal. Ésta continúa sin entrar en funcionamiento, ya que en diciembre del mismo año, la comisión de Enseñanza continúa evaluando sus costes, que para el año 1844, los fija en 17.400 reales. De todas formas, el pleno de la Diputación, aprueba la instalación y el pago de los costes, a la vez que "excita al Ayuntamiento de la capital a que contribuya con una mayor cantidad". La petición es contestada por el Ayuntamiento con "el inicio de las obras en el Convento Premonstratense para el establecimiento de la Escuela Normal" ${ }^{862}$.

${ }^{856}$ ARIAS MARTINEZ, Benito (Coord.). De Escuela Normal a Facultad de Educación. 150 años de innovaciones educativas en Valladolid. Universidad de Valladolid. Valladolid. 1998.

${ }^{857}$ A.D.P.V. Actas. Libro de actas del 4 de junio de 1837.

858 B.O.P.V. $n^{\circ} 156$ de fecha 26 de diciembre de 1840 .

859 A.D.P.V. Actas. Libro de actas del 2 de mayo de 1841.

860 A.D.P.V. Actas. Libro de actas del 20 de enero de 1842

861 A.D.P.V. Actas. Libro de actas de 14 de marzo de 1843

862 A.D.P.V. Actas. Libro de actas del 20 de diciembre de 1844 
En el año 1844, aparece en las actas la primera referencia al Instituto de Segunda Enseñanza, con ocasión de la publicación de la R.O. de 3 de noviembre "sobre la instalación en la capital de un Instituto de Segunda Enseñanza". La noticia es recogida por la Diputación, pero de la que no hace referencia a su implantación, sobre todo porque está pendiente de la puesta en marcha de la Escuela Normal. También está en trámite la aprobación de los presupuestos de funcionamiento que son estimados por la Comisión de Enseñanza en la cantidad de 13.508 reales, de los cuales considera la Diputación que le corresponden hacer frente a 7.653 reales, y el resto deben ser asumidos por el Ayuntamiento. Finalmente, las actas de la Diputación reflejan que "con fecha 30 de marzo de 1845 se abrió la Escuela Normal" ${ }^{863}$, fecha realmente tardía "pues en la fecha de la inauguración ya funcionaban cuarenta y dos Escuelas Normales de las cuarenta y nueve provincias de que constaba el país". Con la finalidad de fomentar la formación de maestros, el jefe político propuso "que se envíe un alumno de cada partido judicial a la Escuela Normal". Son convocadas las plazas correspondientes por la Diputación, a la vez que se preparan los presupuestos del primer curso ${ }^{864}$. La Diputación completa su actuación, subvencionando con cinco reales al día para ayudar al mantenimiento de los alumnos, y a la vez nombra depositario de los fondos de la Escuela al funcionario Deogracias Larraga. En los presupuestos del año 1848 figura una partida para gastos de la Escuela Normal que ascienden a 21.900 reales ${ }^{865}$. Además, se destina una partida de 2.300 reales "para libros y material".

El Instituto de Segunda Enseñanza ${ }^{866}$ está prácticamente olvidado desde la publicación del real decreto de instalación publicado en 1844 , ya que no ha iniciado su actividad. En el año 1845 se vuelve a tratar sobre el tema, al aprobar por otro R.D. de 4 de septiembre su "agregación a la Universidad de Valladolid". Con fecha de 8 de julio de 1847 la Diputación acuerda que "Este Instituto debe de ser mantenido por la Universidad". Se puntualiza que el Estado sólo se encargará de su mantenimiento "si la provincia colabora con alguna cantidad". Acto seguido, la Diputación acuerda presupuestar 40.000 reales e iniciar los trámites para buscar el edificio idóneo donde instalar el Instituto.

En el mes de abril de 1848, en comunicación enviada a la Diputación por Juan Antonio Rábago, anuncia que: "como propietario de la Hospedería del Colegio de Santa Cruz, ofrezco dicho edificio para su utilización como Instituto de Segunda Enseñanza". En el mes de septiembre del mismo año 1848, el diputado Sr. López, presenta un informe al Pleno de la institución ${ }^{867}$. El Instituto inicia sus actividades en

\footnotetext{
863 A.D.P.V. Actas. Libro de actas del 8 de abril de 1845.
}

864 "Se dio cuenta de una comunicación del presidente de la comisión de Instrucción, incluyendo el presupuesto de gastos e ingresos de la Escuela Normal que deben de servir para el curso que dará principio el día 1 de septiembre próximo y acaba en agosto de 1846. Igualmente se comunican la relación de los alumnos para la escuela elegidos por los diferentes partidos judiciales. Son los siguientes: de Rioseco Elías Domínguez, de Villabrágima.De Villalón Remigio Sánchez, de Melgar de Arriba. De Medina Juan Martín, de Rodilana. De Valoria Jorge Díez, de Tamariz. De Olmedo Hermenegildo Rueda, de Ramiro. De Valladolid Buenaventura Varela De. Peñafiel Luis Mariscal. De Nava del Rey Antolín Monroy de Morales de Nava. De Mota del Marqués Dionisio Mata Caminero". A.D.P.V. Actas. Libro de actas del 18 de julio de 1845.

${ }^{865}$ Se reparten de la siguiente forma: Director, 7.000 reales. Vicedirector, 5.000 reales. Capellán, 1.500 reales. Portero, 1.100 reales Cuatro alumnos pensionistas, 7.300 reales. TOTAL, 21.900 reales A.D.P.V. Actas. Libro de actas del 23 de octubre de 1847.

${ }^{866}$ Este tema relativo al Instituto de Segunda enseñanza de Valladolid es tratado en detalle en: CARAS A SOTO, Pedro (Coord.). La Enseñanza Secundaria y el Instituto Zorrilla. Ed. Instituto Zorrilla. Valladolid. 2009. SAN MIGUEL BENITO, María Begoña. El Instituto de Segunda Enseñanza de Valladolid desde su establecimiento hasta 1930. Memoria de Licenciatura inédita en Historia Contemporánea. Universidad de Valladolid. V.V.A.A. Los LXXV años del Instituto Zorrilla de Valladolid. 1907-1982. Ed. Ayuntamiento de Valladolid. Valladolid. 1986.

867 "Sobre la situación de los trabajos para dotar a la ciudad de un edificio para Instituto de Segunda Enseñanza, anejo a la Universidad literaria, comunica que la hospedería de Santa Cruz fue adquirida por el Sr. Rábago, procedente de bienes nacionales y que traspasa la carta de pago a la provincia por la 
el curso escolar 1848-49, y en los presupuestos correspondientes al año 1849, se aprueban las correspondientes partidas para el mantenimiento tanto del Instituto como de la Escuela Normal. "Instituto de Segunda Enseñanza: ingresos 3.300 reales, gastos 40.000 reales. Escuela Normal: ingresos 8.370 reales, gastos 26.600 reales"

La Diputación, consciente de su precaria situación económica, propone el traspaso del Instituto a la Universidad Literaria, sobre todo porque, a principios del año 1849 , se lee en la sesión de la Diputación "La comunicación del Sr. Juan Antonio Rábago, reclamando el pago de los 30.000 reales en que se fijó la venta de la Hospedería de Santa Cruz" ${ }^{868}$. Porque en realidad la Diputación no ha pagado los 6.000 reales acordados y Cuenca de Campos sigue debiendo los censos al Sr. Rábago en lugar de al Colegio de Santa Cruz. Finalmente por R.O de 10 de julio de 1850 se acuerda que "el Colegio de Santa Cruz pase a depender de la Universidad de Valladolid". El 27 del mes de noviembre, el rector Manuel de la Cuesta "en sesión conjunta con los diputados provinciales Nemesio López y José Luis Prieto como testigos, se hace cargo de los edificios enseres y pertenencias del Colegio y pasaron a continuación a la Hospedería de Santa Cruz, destinada a Instituto Provincial, para cuyo uso exclusivo había entregado la provincia a la Universidad y también hicieron entrega del edificio al Rector" ${ }^{\prime 899}$. El hecho positivo es que el Instituto ha iniciado sus cursos y es a partir de este año cuando se mantienen en funcionamiento permanente la Academia de Bellas Artes, la Escuela Normal y el Instituto de Segunda Enseñanza.

En el año 1852 el gobierno, a través de una real orden promueve la creación de una "Escuela de Sordo-Mudos y Ciegos", para lo cual pide cooperación a la Diputación que, además de concederla, solicita que una de las escuelas previstas se instale en la capital.

En estos años, como viene siendo habitual, la Diputación se debate entre sus deseos de mejorar la enseñanza y las dificultades que encuentra debido a la penuria económica por la que atraviesa. Así aparecen una serie de incapacidades económicas en otros asuntos relativos a la enseñanza. "La Academia de Bellas Artes solicita autorización para contratar un nuevo profesor de dibujo, pero es desechado por la Diputación por falta de fondos" ${ }^{870}$. "La comisión de Instrucción Primaria solicita crear una Escuela Normal de Maestras y la Diputación, aunque considera su creación de gran utilidad, pero no teniendo fondos para cubrir las necesidades acuerda remitir el expediente al Sr. gobernador para que proporcione otros recursos" 871 . "La Diputación advierte al rector de la Universidad que no puede mantener la Biblioteca de Santa Cruz por penuria económica". "Se solicita la creación de las Cátedras de Agricultura y de Comercio, añadidas al Instituto, si el gobierno asume sus costes" ${ }^{\$ 72}$.

En el año 1859, la Escuela Normal de Maestras ya está en funcionamiento, aunque el día 4 de mayo, el director de Instrucción Pública pregunta a la Diputación "si está dispuesta a pagar 19.500 reales para mantener la Escuela Normal de Maestras". Siendo su contestación afirmativa, la sigue preocupando el coste de mantenimiento de las Escuelas y del Instituto, por lo que continúa con la búsqueda de la manera de disminuir los costes, sobre todo, ante la negativa del gobierno a seguir manteniendo parte de los gastos del Instituto. Por eso "abre un expediente y pasa una consulta al gobierno sobre si la provincia debería hacer frente a todos los gastos del

cantidad de 30.000 reales, de los que se paga 6.000 reales en metálico y 24.000 reales, con censos que Cuenca de Campos debe al Colegio de Santa Cruz. Se aprueba la compra acordada por la comisión y se destinan 10.000 reales para la reparación y retejo del edificio y al mismo tiempo se acuerda adecentar los alrededores de la Hospedería y Museo de Santa Cruz".

868 A.D.P.V. Actas. Libro de actas del 30 de marzo de 1849

${ }^{869}$ ALCOCER MARTINEZ, Mariano. Historia de la Universidad de Valladolid. Imprenta Castellana. Valladolid. 1922

870 A.D.P.V. Actas. Libro de actas del 17 de mayo de 1854.

871 A.D.P.V. Actas. Libro de actas del 9 de diciembre de 1857

872 A.D.P.V. Actas. Libro de actas del 15 de octubre de 1858. 
Instituto o continuar pagando los 40.000 reales, como lo venía haciendo desde $1845, " 873$

En el pasado año de 1852, se empezó a hablar de la creación de una "Escuela de Sordo-Mudos y Ciegos". Ya estamos en 1860 y la Escuela no está formada y parece que el gobierno se ha olvidado del tema. Pero el rector de la Universidad rescata la idea y propone a la Diputación "la creación de un Colegio de Sordo-Mudos en el Distrito Universitario, y aceptando la propuesta acuerda informar a los gobernadores de las provincias del distrito para que se informen de su conveniencia" ${ }^{874}$. Aunque en la misma comunicación el rector recuerda a la Diputación "que adeuda 112.000 reales por el sostenimiento del Instituto de Segunda Enseñanza". Ante esta reclamación, la Diputación acordó nombrar una comisión para estudiar la conveniencia de reparar el edificio de la Hospedería de Santa Cruz o la búsqueda de un nuevo edificio más amplio. La comisión a finales del año 1860, presenta sus conclusiones a la Diputación con dos soluciones: "Solicitar la cesión del Colegio de Santa Cruz para el Instituto, trasladando el Museo a otro edificio, o la construcción de un nuevo edificio para Instituto de Segunda Enseñanza" 875 .

En el año 1861, la Diputación aún no ha decidido la nueva ubicación del Instituto, y el gobierno sigue reclamando los 112.800 reales que le adeuda por los gastos de mantenimiento del edificio. La Diputación pretende finiquitar la deuda con el anuncio de que "estando próxima la construcción de un nuevo edificio, el dinero reclamado se debía de destinar al auxilio de las nuevas obras". Esta decisión de construir un nuevo edificio está basada en las conclusiones a que ha llegado la comisión que estudia el proyecto de la nueva ubicación del instituto ${ }^{876}$.

A partir del año 1862 las actuaciones de la Diputación con respecto a la enseñanza están centradas en los temas económicos. Preocupa sobre todo el futuro del edificio del Instituto, que todavía no tiene una firme decisión sobre su construcción. "Por real orden de 12 de febrero de 1862, se interesa sobre la activación de la construcción del edificio para Instituto de Segunda Enseñanza, aplazando hasta entonces la condonación de la deuda de 112.800 reales" ${ }^{877}$. "El director del Instituto de Segunda Enseñanza reclama material científico para los laboratorios, informando al mismo tiempo del ruinoso estado en que se encuentra el edificio, y que no se podía estar en él por mucho tiempo".

Tampoco la Escuela de Sordo-Mudos tiene su sede asegurada en la capital, pues "por real orden de 8 de enero de 1862, se acuerda la creación del Colegio de Sordo-Mudos en Burgos, hasta que se construya el edificio de Valladolid" 878 . Las Escuelas Normales siguen generando gastos, "para reparación de las Escuelas Normales, la Diputación acuerda el pago de 5.000 reales para la de Maestros y 2.432 para la de Maestras”

Pero lo que sigue preocupando a la Diputación, en el año 1863, es la incertidumbre sobre el nuevo edificio del Instituto. "Considerando que los trámites con el Real Patrimonio para acceder a los terrenos de los Dominicos y además el

873 A.D.P.V. Actas. Libro de actas del 18 de julio de 1859.

874 A.D.P.V. Actas. Libro de actas del 14 de febrero de 1860.

875 A.D.P.V. Actas. Libro de actas del 4 de diciembre de 1860.

${ }^{876}$ El informe trata "Sobre las gestiones con el duque de Pastrana, dueño de la Casa-Palacio de la Corredera de San Pablo, y después con empleados del Real Patrimonio, respecto del terreno que ocupó el Convento de los Dominicos de la ciudad, y tomando en cuenta las ventajas de este terreno que fue Convento de San Pablo, toda vez que por su extensión podía construirse un Edificio-Instituto, se recomendaba la decisión de solicitar de S.M. la cesión del mismo con todos los corrales adyacentes. Se acordó aprobar la propuesta y suspender los acuerdos con el duque de Pastrana" A.D.P.V. Actas. Libro de actas del 24 de diciembre de 1861. La Casa-Palacio de la Corredera de San Pablo es conocida como el Palacio de Villena, fue mandado construir por el Marqués de Villena, pasando posteriormente a la casa ducal de Frías y Pastrana. En el año 1876 fue adquirida por el marqués de Casa Pombo y en 1899 por el marqués de Alonso Pesquera. Posteriormente fue la sede del Gobierno Civil.

877 A.D.P.V. Actas. Libro de actas del 14 de abril de 1862.

878 A.D.P.V. Actas. Libro de actas del 13 de marzo de 1862. 
tiempo de ejecución de planos y obras no permitiría ponerlo en servicio para el próximo año y teniendo en cuenta las dificultades de encontrar un edificio para sustituirle, se acordó solicitar del gobierno de S.M. el edificio del Colegio de Santa Cruz, actual Museo y Academia de Bellas Artes" ${ }^{879}$. La Diputación, por un lado, sigue estando interesada en conseguir el Colegio de Santa Cruz, que en la época del Trienio lo solicitó para su sede y que posteriormente lo requiere para cubrir cualquier necesidad que se le presente. Por otro lado, no ve mucho interés en el gobierno, que por real orden de 30 de junio de 1863 "aprueba los presupuestos del año económico 1863-64, manteniendo en suspenso la partida de 500.000 reales para el Instituto, hasta que no lo apruebe el gobierno de S.M" ${ }^{\not 880}$. La situación se complica en el año 1864, al publicarse una nueva R. O. de fecha 16 de abril "por la que se deniega el presupuesto de 500.000 reales destinado al Instituto de Segunda Enseñanza". Con lo cual la Diputación estudia las cuatro posibilidades que tiene para solucionar el problema: $1^{\circ}$. Reparar el edificio que ocupa actualmente el Instituto en la Hospedería del Colegio de Santa Cruz. $2^{\circ}$. Solicitar del Patrimonio Real el Colegio de Santa Cruz. $3^{\circ}$. Trasladarse al palacio del duque de Pastrana, situado en la Corredera de San Pablo. $4^{\circ}$. Construir un edificio nuevo en los terrenos de San Pablo, frente al Palacio Real.

En la memoria anual que envía al gobierno, la Diputación se lamenta de las dificultades que encuentra para la mejora del nivel de enseñanza, y sobre todo para conseguir un nuevo edificio para Instituto. En la citada memoria, lamenta no ver cumplida la prioridad de la Diputación ${ }^{881}$.

La Diputación, preocupada por el Instituto, se "ha olvidado" de las Escuelas Normales, y se lo recuerda el Ayuntamiento, cuando, a principios del año 1866, envía un oficio notificando "la próxima ruina que amenaza el edificio que fue Convento de San Diego y particularmente los locales y galerías que ocupa el Colegio Normal de Maestras" $\$ 82$. Con la intención de solucionar el problema la Diputación nombra una comisión y mientras tanto espera la decisión del Gobierno sobre el solar de San Pablo. La solución finalmente llegará con la publicación de la R. O. de 12 de noviembre de 1866 "por la que se autoriza la venta del terreno del Convento de los Dominicos de Valladolid para construir el Instituto de Segunda Enseñanza"883. Definitivamente, no será hasta septiembre de 1867 cuando la Diputación "acordó la compra del solar de San Pablo, con las medidas de 20.808 metros de superficie y tasado en 14.358 escudos, libres de cargas" ${ }^{884}$. Pero el afán y la fijación de la Diputación por el Colegio de Santa Cruz, hace que se complique la situación, cuando "estudia la posibilidad de instalar el Instituto de Segunda Enseñanza en el Colegio de Santa Cruz y pasar Museo y Biblioteca al edificio a construir en el solar de San Pablo" ${ }^{\$ 5}$

879 A.D.P.V. Actas. Libro de actas del 15 de abril de 1863.
880 A.D.P.V. Actas. Libro de actas del día 2 de enero de 1864.

881 "El esfuerzo presupuestario de importancia para las obras de ampliación y decoración de las Escuelas Normales de Maestros y Maestras y también para el Instituto de Segunda Enseñanza. Si el nuevo Edificio-Instituto que se ha propuesto construir con todas las condiciones que puedan apetecerse para la más esmerada educación intelectual y física de la juventud no se halla ya en vías de ejecución debido es a causas muy superiores a los esfuerzos que se ha empleado para conseguirlo. Hace tres años que la Diputación solicitó de S.M. la cesión con las condiciones que estimase justas del terreno que ocupó el Convento de Dominicos de esta capital, perteneciente al patrimonio, y si bien por real orden de 12 de febrero de 1862 se accedía a sus deseos, no haciéndose mérito alguno en ella, de si en lo que se decía solar de San Pablo, se hallaba comprendida la parte de fachada que mira al Palacio Real, fue necesario pedir aclaraciones que no han podido obtenerse del Excmo. Sr. Administrador General por las dificultades graves que parece ha encontrado en ello. La Diputación repetirá sus gestiones y si no pudiese conseguir el citado terreno tal como le ha menester, procurará dar impulso al proyecto que tiene concebido sobre el edificio que actualmente sirve para el Instituto" A.D.P.V. Actas. Libro de actas del 11 de enero de 1865 .

882 A.D.P.V. Actas. Libro de actas del 1 de enero de 1866.

883 A.D.P.V. Actas. Libro de actas del 2 de enero de 1867.

884 A.D.P.V. Actas. Libro de actas del 5 de septiembre de 1867.

885 A.D.P.V. Actas. Libro de actas del 4 de diciembre de 1867. 
No es este el único cambio o petición de cambio, ya que hay nuevas propuestas a finales del año 1868, y de la época isabelina. Estando la provincia regida por la Junta Provincial Revolucionaria, organismo que se ha hecho con el control de la Diputación, refleja el libro de actas un acuerdo por el que "el Palacio Real pasará a ser sede del Instituto y el edificio del Instituto pasa a ser Cuartel de Voluntarios de la Libertad" $"$. Sin especificar qué edificio del Instituto pasa a ser cuartel, si el viejo de la Hospedería de Santa Cruz o el nuevo de San Pablo. Como es sabido, no había sido construido en tan poco espacio de tiempo (desde septiembre de 1867 que se compró el solar a octubre de 1868 en que se inicia el Sexenio Revolucionario). La realidad nos dice que el nuevo instituto de Enseñanza Media, con el nombre de José Zorrilla, se inauguró en el año $1908 .^{887}$

Normalizada la situación política y en plena vigencia de los gobiernos progresistas del Sexenio, la Diputación continúa con su labor de favorecer la enseñanza y remite al Instituto una información recibida "Sobre un método de enseñanza para el Instituto de Segunda Enseñanza". Las Escuelas Normales de Maestros y Maestras continúan con su "normal" actividad entre las que se anota con fecha 4 de febrero de 1869, "el nombramiento de Dña. Juana Lombraña como nueva directora de la Escuela Normal de Maestras". Finalmente, es la Academia de Bellas Artes la que solicita la ampliación de sus actividades presentando un proyecto "para establecer nuevas clases de enseñanza". A lo que contesta la Diputación, conforme con lo proyectado, con la aprobación "del funcionamiento en la Academia de Bellas Artes de las nuevas clases de maestros de obras, aparejadores y agrimensores". La Academia en agradecimiento por el interés de la Diputación, regala un cuadro a la Corporación, obra del Sr. Jadraque, pintor de la Escuela de Bellas Artes y becado en Roma por la Diputación desde años atrás.

\subsection{3.- LA UNIVERSIDAD. DIFICULTADES DE SUPERVIVENCIA}

Una de las instituciones más antigua y prestigiosa de Valladolid. Fundada en el año 1241 por Alfonso VIII, para unos historiadores como consecuencia del traslado del Estudio General de Palencia, y para otros por fundación real y directa. En 1292 se consolida su mantenimiento gracias a las rentas otorgadas por Sancho IV. En 1417 la fue concedida la Facultad de Teología y en 1517 es declarada Universidad Mayor del Reino, junto con Salamanca y Alcalá, ampliando sus estudios con las Facultades de Leyes y Medicina. Durante los siglos XVII y XVIII se contagia de la general postración del país. ${ }^{888}$ En los primeros años del siglo XIX (1808-1814) pasa por una de sus peores crisis. Se refleja en el escaso número de alumnos que cursan sus estudios en las diferentes facultades. No se puede olvidar que una de las principales causas que motivan esta escasez es la guerra que se mantiene contra las tropas francesas, y otra de las causas es la, tantas veces repetida, penuria económica. Las enseñanzas que se imparten en estos años, repartidas entre las diferentes Facultades con el porcentaje correspondiente, son: Teología con cincuenta y cuatro alumnos y 35'3\%. Leyes tiene cuarenta y cinco alumnos y 29'4\%. Cánones cuenta con cuarenta y cuatro alumnos y $28,8 \%$. Medicina sólo con nueve alumnos y el 5'9\% y Artes y Filosofía un alumno y 0 ' $6 \%{ }^{889}$.

A pesar de las dificultades, no deja de ser una institución con una importante aportación en la vida de la ciudad, tanto en sentido social, político o militar. En estos

886 Boletín Oficial de la Junta Revolucionaria $n^{\circ} 22$ de fecha 22 de octubre de 1868.

887 Para más información sobre el Instituto y la Enseñanza Media, ver en CARASA SOTO, Pedro (Coord.). La Enseñanza Secundaria y el Instituto... ob. cit. También en V.V.A.A. Los LXXV años del Instituto... ob. cit. y en la tesis doctoral de SANZ, Federico. La segunda enseñanza oficial en el siglo XIX. Valladolid.1981.

${ }^{888}$ PALOMARES IBAÑEZ, Jesús María (Coord.). Historia de la Universidad... ob. cit.

889 PALOMARES IBÁÑEZ, Jesús María (Coord.). Historia de la Universidad... ob. cit. Datos obtenidos del estudio realizado por DIEZ ÁLVAREZ, Wenceslao, sobre los alumnos que cursan sus estudios en la institución (vol. $2^{\text {a }}$ pág. 415-416). 
años destacamos "la actuación de los estudiantes en la batalla de Cabezón, contra las tropas francesas", "el mantenimiento de la actividad académica en los años de ocupación de la ciudad por los franceses", "el aire de liberalismo que llena la Universidad con la llegada del período constitucional". Una vez acabada la guerra, la Universidad vuelve a tomar su pulso normal, pero las secuelas del conflicto siguen vigentes y el rector de la institución mantiene cierto temor a que se produzca su desaparición. Así lo expone en el oficio que remite al presidente de la Diputación, advirtiéndole de que "tiene noticias de que se ha presentado un Plan de Instrucción Pública en las Cortes, en el que no se haya comprendido esta Universidad y siendo un tema tan interesante para la provincia le avisa para que tome las medidas oportunas" $" 890$.

Puede que esta decisión esté motivada por la constatación por parte del gobierno del escaso número de alumnos que en este año de 1814 están matriculados en la Universidad y que asciende a ciento cincuenta y tres. Pero lo más seguro es que esa situación no sea sólo de la Universidad vallisoletana, sino que otra serie de universidades se encuentren en parecida situación. El gobierno lo que en realidad pretende es reducir el número de universidades y quiere que pasen de veintidós a once en toda la península. Finalmente se mantendrá la de Valladolid a la que se añadirán los estudiantes procedentes de las suspendidas universidades de Ávila y Burgo de Osma.

Desde 1814 a 1820, con la Diputación suspendida, la Universidad continúa con normalidad su vida académica, que sigue estando marcada por la escasez de alumnos. La situación continúa a partir de 1820 , ya que con la vuelta a la "normalidad constitucional", vuelven a aparecer noticias preocupantes sobre la continuidad de la Universidad. Inquieta también la consiguiente existencia de un proyecto de ley que contempla la suspensión de la institución vallisoletana. La Diputación, ante estas noticias tan alarmistas, envía una exposición a las Cortes en la que se muestra "deseosa de no omitir cuanto pueda contribuir a promover la prosperidad de la provincia... se dirige al augusto Congreso para manifestar su oposición al proyecto de trasladar la Universidad Mayor, establecida desde tiempos muy remotos en esta capital y que la debe en gran parte su celebridad y nombradía..." Extendiéndose en el escrito con la descripción de los beneficios que reporta a la ciudad, la facilidad de dar carreras a los vecinos y el auge del comercio. Remata su exposición diciendo que “...no puede menos que considerar la remoción de la Universidad como una medida violenta y no se advierten una urgente necesidad y evidentes motivos de conveniencia pública, y su traslado supondría un perjuicio irreparable a la ciudad, pues es una capital donde se ha establecido gran número de artesanos y comerciantes en proporción a la gran concurrencia de escolares" ${ }^{\$ 891}$. Este anuncio de disolución o traslado no se lleva a efecto, pero lo cierto es que la Universidad no tiene una gran actividad. En el año 1822 se vuelven a repetir las "amenazas" y la Universidad vuelve a reclamar el apoyo de la Diputación. En este caso es la Facultad de Medicina, cuyos "enseñantes de medicina solicitan el apoyo de la Diputación para que la Escuela de Medicina no sea trasladada de la ciudad" 892

Las dificultades de la Universidad no son sólo políticas o de supervivencia, sino que también las tiene económicas. Está interesado el rector en defender en "las Cortes" la existencia de la Universidad, y oficia a la Diputación manifestado que, "con motivo de estar privada de la casi única renta con que consiste su dotación, se halla sin fondos para anticipar al comisionado por dicha Corporación para ir a la Corte, los gastos del viaje" $"$. Ante esta petición económica, la Diputación contesta "a vuelta de

890 A.D.P.V. Actas. Libro de actas del día 22 de abril de 1814.

891 A.D.P.V. Actas. Libro de actas del 21 de octubre de 1820. Con la exposición literal enviada a las Cortes, en la que además se resalta que la ciudad: "ya ha sufrido una grave pérdida con la conversión de la Chancillería en Audiencia y la minoración de la guarnición militar"

893 A.D.P.V. Actas. Libro de actas del 19 de agosto de 1822. 
correo" que no tiene fondos para hacer frente a esos gastos. Sí hace caso a los estudiantes de Medicina, que no le piden dinero, sino sólo apoyo a sus pretensiones. "Acordó enviar al gobierno un oficio en apoyo de los estudiantes de Medicina en su petición a la Dirección General de Estudios para que no tengan que trasladarse a otra Escuela Especial establecida por el gobierno"894.

La Década Ominosa ha pasado y la normalización de la vida política con la llegada de la época isabelina se refleja en el nuevo y definitivo arranque de la Diputación en 1835 y en el interés del gobierno, recogido a través de una real orden, para que "las Universidades continúen abiertas", y poco tiempo después, con un nuevo interés por demostrar un principio de política liberal, publicaba otro real decreto por el que "se deroga el uso del traje talar a los estudiantes".

Un grave problema se le presenta a la Universidad con motivo de la ley de 24 de julio de 1837, por el que se suprimían las contribuciones de diezmos y primicias, lo que suponía un importante prejuicio económico para la institución al ser despojada de la mayoría de sus rentas. Como dato significativo, tenemos que las rentas de la Universidad en el curso académico 1834-35 ascendieron a 1.068.776 reales de rentas y matrículas, alcanzando las rentas el $90 \%$ de esta cantidad ${ }^{895}$.

Pero la vida de la Universidad vallisoletana, al igual que ocurrió en el período constitucional de 1813-14 o en el período liberal de 1820 a 1823 , sigue sin estar afianzada y continúa dependiendo de la voluntad o el capricho de los gobiernos de turno. Ante los nuevos rumores de cierre de la institución, una comisión del Claustro Universitario es recibida en la Diputación, con propuestas para fortalecer la vida universitaria, y cómo no, también su economía, agregando a la Universidad el colegio de Santa Cruz ${ }^{896}$. La Diputación, como es habitual en ella, "acordó tomar en consideración la propuesta y comunicar su decisión". Parece claro que la Diputación, por un lado, está interesada desde los inicios de su actividad en hacerse con el colegio de Santa Cruz. No lo ha conseguido porque es patrimonio del Estado, pero resulta raro que consiga la cesión a la Universidad. Y por otro lado, en estos años ya se comenzaba a hablar del Instituto de Segunda Enseñanza y del interés de la Diputación por situarlo en Santa Cruz. No podemos olvidar tampoco que la Diputación no estaba dispuesta a ceder las rentas del colegio "de forma gratuita", aunque finalmente el colegio de Santa Cruz pasaría en efecto a la Universidad en el año 1850.

En el año 1843, la Universidad vuelve a sentir el peligro del cierre y sus representantes, D. Claudio Moyano y los doctores López y Sánchez Ocaña, visitan en primer lugar el Ayuntamiento "solicitando el apoyo de la Corporación para que la Universidad se mantenga abierta" $" 897$. A continuación son recibidos en audiencia por el pleno de la Diputación, "En la misma, los comisionados solicitan que en la próxima reforma de la Enseñanza no se suprima la Facultad de Medicina de Valladolid... y al mismo tiempo solicitan la creación de una Comisión Diputación-AyuntamientoClaustro, para tratar el tema. Por la Diputación se nombra a los Sres. Gusano y Puga" ${ }^{\text {"98 }}$. El problema se centra en que cada vez que el gobierno habla de nuevos

894 A.D.P.V. Actas. Libro de actas del 26 de noviembre de 1822.

${ }^{895}$ ALCOCER MARTINEZ, Mariano. Historia de la Universidad...ob.cit. En la que nos da cuenta de la dotación a la Universidad en el año 1347, por el rey Alfonso XI, de una renta anual de 20.000 maravedíes provenientes de los arciprestazgos de Portillo y Cevico de la Torre.

896 “el Sr. presidente D. Claudio Moyano Samaniego felicita a la Diputación por sus trabajos y añadió que para aumentar el bienestar, la provincia contaba con dos recursos: el Canal de Castilla y la Universidad. Las ventajas del primero aún no habían comenzado y las del segundo por desgracia no parecían ser duraderas por el anunciado arreglo de las universidades. La decadencia de fondos para mantener la Universidad hacía presagiar su traslado a otra parte de un momento a otro. La solución se encuentra en aumentar las rentas de la Universidad, en la actualidad reducidas al importe de las matrículas. Excitando a la Diputación, por estar en sus manos el proveer este recurso, ya que el colegio de Santa Cruz disponía de rentas, que si no bastantes para cubrir las cargas todas de la Universidad, lo eran al menos para hacerlo de la mayor parte. Por ello solicitaba la agregación del colegio a la Universidad" A.D.P.V. Actas. Libro de actas del 27 de enero de 1838.

897 A.H.M.V. Libro de actas 128 de 14 de febrero de 1843.

898 A.D.P.V. Actas. Libro de actas del 15 de febrero de 1843. 
planes de enseñanza, la Universidad de Valladolid teme por su cierre o por la pérdida de alguna de sus Facultades. Señal de que no tienen una actividad que satisfaga al gobierno central. Para asegurar de todas formas el éxito en lo posible "la comisión acordó ir a la Corte y reclamar la ayuda del diputado D. Juan Antonio Seoane" ${ }^{899}$. A los pocos días de estos acuerdos, el Ayuntamiento de la capital recibe una "comunicación de D. Atanasio Pérez Cantalapiedra y de D. Luis Sagasti, desde Madrid, asegurando la continuidad de la Academia de Medicina en Valladolid" 900.

Todo esto ha ocurrido a lo largo del año 1843, y la tranquilidad de la Universidad por la garantía de su funcionamiento se mantiene hasta el año 1845. En el mes de julio de este año se repite la situación del recibimiento en el Pleno de la Diputación, de una comisión del Claustro Universitario en el que solicita su apoyo para evitar la suspensión ${ }^{901}$. Esas previsiones de supresión parece que esta vez van en serio pues en septiembre del mismo año 1845, en una nueva audiencia que les concede la Diputación, los comisionados Antonio María del Valle y Benito Sangrador comunican "que en el nuevo plan de enseñanza recibido se suprimía el Colegio de Medicina”. La Diputación oída la comisión, acordó ante el perjuicio que ello ocasionaba pasar a la Corte en comisión de Diputación, Ayuntamiento y Claustro para tratar de evitar el cierre de la Facultad de Medicina. También se acordó oficiar a los diputados a Cortes por la provincia para que cooperaran en la consecución de lo deseado $^{902}$. Todas estas preocupaciones y trabajos por mantener la Facultad de Medicina no consiguieron su objetivo pues "según el Plan Pidal de 1845 se suprimió oficialmente la Facultad de Medicina de Valladolid y esta especialidad sólo se impartía en cinco de las diez universidades existentes. La medicina se vuelve a implantar en 1857, con la Ley Moyano" 903.

En el año 1850, por real orden de 10 de julio, se acuerda la cesión del colegio de Santa Cruz a la Universidad y el 27 de noviembre del citado año en reunión conjunta del rector Manuel de la Cuesta con los diputados provinciales, Nemesio López y José Luis Prieto, se hizo la entrega tanto del colegio, sede del Museo Provincial, como de la Hospedería, utilizada como Instituto de Enseñanza Media.

Durante el curso 1850-51 son ya 500 los alumnos que estudian en las diferentes Facultades: Derecho tiene 394 alumnos, el 80\%. Teología está en 88 alumnos, el 16\%. Filosofía con 12 alumnos, el 2\% y Medicina 10 alumnos, el 2\%. Durante el año 1851 se deja de impartir clases de Teología, ya que según el Concordato firmado con la Santa Sede "la Teología se impartirá en los Seminarios Conciliares". En 1854 el Claustro de la Universidad solicita a través de la Diputación "el restablecimiento de la Cátedra de Teología en la Universidad Literaria de Valladolid" 904.

899 A.D.P.V. Actas. Libro de actas del 14 de marzo de 1843.

900 A.H.M.V. Libro de actas de fecha 22 de abril de 1843.

901 "Que habiendo conocimiento (el Claustro) de la novedad que el gobierno intentaba hacer en algunas de las Facultades que en ella se enseñaban, pues que según las noticias que habían adquirido, existía el proyecto de suprimir la de Teología y Medicina, habiendo acordado acudir a S.M. manifestando la utilidad y ventajas que representaba a las provincias de Castilla la Vieja la permanencia de todos los ramos de instrucción posibles, y poniendo de manifiesto los gravísimos perjuicios que se ocasionaban con la supresión... y esperaba que la Diputación apoyase la continuidad de todas las Facultades..." A.D.P.V. Actas. Libro de actas del 18 de julio de 1845.

902 A.D.P.V. Actas. Libro de actas del 28 de septiembre de 1845.

903 MARTÍN GONZÁLEZ, Juan José y TORREMOCHA HERNANDEZ, Margarita. La Universidad de Valladolid. Ed. Universidad de Valladolid. Valladolid. 1997. Informa sobre los avatares de la Facultad. Ver págs. 139-140. Cierre del que queda constancia en PALOMARES IBAÑEZ, Jesús María. La Universidad de Valladolid... ob. cit. págs. 560 y 563. Finalmente en SINOVA, Germán (Coord.).VI Centenario de la Facultad de Medicina de Valladolid. Ed. Junta de Castilla y León. Valladolid. 2006 nos informa en su pág. 182, que "en 1857 la Ley Moyano reinstauró la Facultad de Medicina, la cual al no tener edificio propio, se instaló en el Hospital de la Resurrección".

904 A.D.P.V. Actas. Libro de actas del 11 de octubre de 1854. Esta reseña literal en las Actas se contradice con las noticias del cierre de la Facultad de Medicina. Es posible que ocurra algo parecido al cierre ocurrido en 1804, época en la que se suspendieron las clases pero no los exámenes. 
Aparece una laguna de información universitaria en la Diputación, que sigue su marcha sin noticias hasta el año 1866. Entonces, como es habitual en situaciones anteriores, reaparece nuevamente un hipotético peligro de cierre de la institución académica, al leerse en el Pleno "un dictamen del Sr. Merino, que junto con el Sr. Reynoso, han tratado de convencer al gobierno de S.M. para que se conserve la Universidad Literaria de Valladolid"905, a lo que la Diputación responde enviando una comisión formada por los diputados Basanta y Pizarro, con el fin de "gestionar cerca del Gobierno de S.M. el que se conserve la Universidad Literaria" "906. Además se remiten en el mismo sentido de defensa de la Universidad varias cartas a una serie de personajes relacionados con la provincia y residentes en Madrid. Se envían misivas de intercesión a: "Sr. Duque de Valencia, D. Lorenzo Arrazola, D. Claudio Moyano, Sr. Arzobispo de Valladolid, D. Millán Alonso, Sr. Marqués del Duero, Sr. Marqués de Valderas, Sr. Duque de Gor, Sr. Conde de Puñoenrostro, D. Genaro Catalina, D. Santiago Lirio, D. Eusebio Fernández de Velasco, Sr. Marqués de Caballero, D. Domingo Jesús Franco, D. Pedro Moyano y D. Antonio Méndez Vigo". Con este numeroso envío, parece que la Diputación conjura el cierre de la Universidad, que a estas alturas de la época isabelina sigue siendo el único tema de comunicación Diputación-Universidad. También será la última comunicación que oficialmente tendrán las dos instituciones, que no volverán a tener relaciones hasta la lleg ada del Sexenio Revolucionario.

Una de las primeras actividades del gobierno en el mismo período político del Sexenio es la publicación de un decreto de la Regencia por el que "se crea la Facultad de Teología de la Universidad de Valladolid". Facultad que dejó de impartir estudios en el año 1851, en 1854 se volvió a solicitar su apertura, pero que hasta abril de 1869 no vuelve a entrar en funcionamiento. Parece ser que este año 1869 es un buen año para la Universidad, pues "el 3 de abril de 1869 se aprueba la inclusión en la Universidad del Doctorado de Medicina, con el equipamiento de dos catedráticos"; "el 31 de agosto de 1869, se aprueba la instalación de unas nuevas Facultades: La Facultad de Filosofía y Letras y la Facultad de Ciencias". Con estas nuevas incorporaciones se potencia la situación de la Universidad y se posibilita la ampliación del número de alumnos. A finales del año, el recién nombrado rector de la Universidad y antiguo decano de Medicina tiene que "preparar la relación de profesores del Doctorado de Medicina, de los certificados académicos y de los respectivos sueldos asignados" ${ }^{907}$ y además tiene que hacer frente otra vez al peligro de cierre de la Universidad, pues tiene noticias "fundadas de que el gobierno de Su Alteza el Regente ha propuesto a las Cortes la supresión de la Universidad Literaria de esta ciudad" 908 .

Parece habitual que, en los momentos de cambio de la vida política nacional, los gobiernos de turno cuestionan la continuidad de la Universidad vallisoletana, con la consiguiente preocupación de la Diputación. Pero también es posible que sea la propia Universidad la que no vea con claridad su futuro o desconfíe de sus propias capacidades. En este caso puede que sea así, puesto que a los pocos días, "el presidente del Consejo de Ministros apoya la continuidad de la Universidad de Valladolid", según certifica el telegrama enviado al Rectorado y a la Diputación.

En el año 1870, se inicia el curso en la Facultad de Filosofía, en el mes de octubre, abriéndose la matrícula "hasta el grado de doctor". El equipamiento de profesores, en el inicio de sus actividades, estaba formado de la siguiente forma:

Cuadro de catedráticos de la Facultad de Filosofía y Letras
$\begin{array}{ll}\text { Literatura Latina } & \text { Dr. José Pardo Fernández. } \\ \text { Historia Universal } & \text { Dr. Gregorio Martínez }\end{array}$

905 A.D.P.V. Actas. Libro de actas del 5 de agosto de 1866.

906 A.D.P.V. Actas. Libro de actas del 6 de julio de 1867.

907 A.D.P.V. Actas. Libro de actas del 23 de octubre de 1869.

908 A.D.P.V. Actas. Libro de actas del 20 de noviembre de 1869. 
Historia de España

Estudios críticos de los griegos

Lengua Hebrea

Lengua Árabe

Estética

Historia de la Filosofía

\author{
Dr. José Muro López \\ Lic. Vicente Polo \\ Lic. Francisco Herrero \\ Lic. Manuel Angulo \\ Lic. Rafael Cano \\ Dr. Gregorio Martínez
}

Llama la atención en esta primera lista de catedráticos el nombramiento de José Muro López como catedrático de Historia de España, cuando en noviembre del año anterior de 1869 , la propia Universidad comunicaba "la separación de su cargo de catedrático de Metafísica al Dr. D. José Muro López"909.

Pocas novedades más nos ofrece la Diputación de sus relaciones con la Universidad. Únicamente se recoge en el año 1871 el nombramiento de rector a D. Eugenio Alau y vice-rector a D. José María Frías. En el año 1872, se comunica el nombramiento de rector a favor de D. José María Frías que se mantiene en el cargo hasta el año 1879. No se tienen más noticias en el período que finaliza con el Sexenio Revolucionario.

\section{9.- CONCLUSIONES.}

Desde 1813, inicio de las actividades de la Diputación, hasta 1874, fecha límite del período estudiado, la provincia de Valladolid experimenta un gran cambio, una evolución positiva, una modificación de sus hábitos y desde luego, una importante transformación en sus habitantes. En estos años la Diputación inicia sus actividades enfocadas al cumplimiento de una de las premisas por las que fue creada: "trabajar por el progreso de la provincia". Es arriesgado admitir que el progreso de la provincia sea debido a la actuación exclusiva de la institución provincial, aunque sí que se puede decir que una parte del progreso es debido a los esfuerzos que parten de la Diputación, teniendo en cuenta que los informes y referencias sobre las que nos basamos son las actas de provinciales, lo que nos inclina a enjuiciar estas actividades bajo un punto de vista parcial.

Como punto de partida, la Diputación es innegable que inicia su andadura en los tres diferentes períodos en los que se dividió, $1813-14,1820-23$ y a partir de 1835 , con un gran interés y gran ilusión por parte de los diputados provinciales deseosos de trabajar por la provincia. Aunque también hemos visto cómo mantenían una "obediencia excesiva" hacia el jefe natural y designado, es decir, el jefe político y hacia las directrices gubernamentales. Esta sumisión a los mandatos del gobierno se mantiene en la mayor parte del período, ya que el cambio hacia una cierta autonomía y una mayor iniciativa en las actuaciones de los diputados no se alcanzará hasta los años del Sexenio, época en la que la Diputación disfrutará de más independencia en el desarrollo de sus actividades.

También tenemos que dividir las actuaciones de la Diputación en dos vertientes. La primera es la de las actividades que le son impuestas por el Gobierno y que tienen que ser realizadas de forma obligatoria. Nos referimos a los repartimientos, tanto de impuestos como de mozos para el Ejército. Son dos obligaciones que no pueden ser discutidas ni cuestionadas y que además no generan riqueza ni satisfacciones y que solamente dan trabajo y reclamaciones. La segunda vertiente es la de las actividades en las cuales la diputación tiene una mayor autonomía y que son susceptibles de reportar riqueza y beneficios a la ciudadanía. Son los trabajos de mejora y ampliación de las comunicaciones, de mejora de la sanidad y la beneficencia, de progreso en la agricultura, en la industria y el comercio y de la generalización de la enseñanza. En definitiva son las actividades cuya mejora es indicativa del progreso de la provincia y que dan satisfacción cuando se consiguen las cotas previstas, a la vez que son un acicate para la mejora de la gestión y del progreso de los ciudadanos que son los interesados en conseguir un buen nivel de vida. 
Con referencia a los impuestos ya hemos indicado con anterioridad que a la hora de llevar a cabo repartimientos de impuestos, está claro que la Diputación actúa como una simple transmisora de las intenciones, deseos y órdenes de la superioridad a través del intendente. Es un trabajo ingrato, y de una gran dedicación, ya que la misión de la Diputación es la de cobrar los impuestos, ya sea de una forma voluntaria por parte de los contribuyentes, o en caso contrario a través del envío de comisionados encargados de cobrar por la fuerza. Lo único que puede hacer en beneficio de la provincia es solicitar demoras y perdones de las deudas en los tiempos de crisis y de dificultades graves, pero en líneas generales no tiene más remedio que acatar y cumplir con las obligaciones contributivas. Por otra parte, también la Diputación es generadora de impuestos que se producen por sus gastos de funcionamiento y que tienen que ser cubiertos con el gravamen de arbitrios complementarios a las contribuciones estatales. Es una de las actividades de las que la Diputación no se siente satisfecha y no la suele considerar de una forma positiva. Aunque sea una actividad obligatoria, antipática y poco agradable, hay que reconocer que el papel de la institución para formar hábito de pagar impuestos sin la amenaza de los comisionados es la mejor labor que ha podido hacer en este tema. El contribuyente es anárquico y desobediente y la Diputación, poco a poco, habitúa a los ciudadanos a pagar los impuestos.

En líneas generales, su trabajo en la época gaditana se centró en rebajar Las cotas de morosidad que presentaban los contribuyentes sin olvidar la gestión de los expedientes de reclamaciones. En el Trienio Liberal reinicia el trabajo de convencer a los ciudadanos de que deben de pagar los impuestos, y a la vez se hace ver como defensora de los contribuyentes en los años de malas cosechas solicitando la rebaja de impuestos o en otro caso, conseguir el aplazamiento del pago o el presentar las correspondientes reclamaciones. A esta situación de pago de impuestos estatales hay que añadir los correspondientes arbitrios provinciales necesarios para el funcionamiento de la institución y cubrir sus necesidades económicas. En la época isabelina, se estabilizan los impuestos, los ciudadanos protestan pero pagan y la Diputación vigila para que los contribuyentes paguen y el gobierno afloje su presión contributiva. En este último punto falla el gobierno pues somete a la población a una serie de contribuciones extraordinarias para hacer frente a los gastos de la guerra carlista, a las crecientes necesidades del país, a la guerra de África, a lo que hay que añadir los impuestos provinciales, también crecientes, generados por los gastos de construcción de las numerosa vías de comunicación. En el Sexenio ya se puede constatar que aunque la presión contributiva es fuerte y la economía no es buena, debido a las malas cosechas de los primeros años, la recaudación de impuestos se realiza de una forma "tranquila" y con menos protestas y menos reclamaciones, fruto de la mayor educación ciudadana y de la persistente preocupación de la Diputación.

Con respecto al Ejército y la Milicia, la otra actividad obligatoria, la Diputación dedica el $50 \%$ de sus trabajos, al remplazo de los mozos y a su ingreso en las filas del Ejército. Como todo trabajo que procede de órdenes del gobierno, es cumplido fielmente por la Diputación, entre otras razones porque no la queda más remedio. En contra de este buen hacer, está la antipatía de los "mozos" hacia su ingreso en filas y las argucias que presentan para evitarlo, ya que una parte importante de la economía familiar estaba basada en el trabajo de estos jóvenes, considerados como la más importante y necesaria mano de obra agrícola. Junto con los impuestos, esta actividad hace que la Diputación sea vista con antipatía por parte de los habitantes de la provincia. Por otra parte, sus relaciones con el Ejército no fueron ni muy cordiales ni muy fluidas, porque como ocurría con el Ayuntamiento de la capital, eran instituciones que luchaban cada una por su lado para conseguir cierta hegemonía en el ámbito provincial.

En resumen podemos fijar que tres son los problemas que enfrentan a Ejército y Diputación: La penuria económica, los remplazos de los mozos y la servidumbre de suministros y bagajes. La penuria económica, que sufren tanto el uno como la otra, 
aunque en este caso y en los años que nos ocupan es el Ejército el que continuamente está solicitando ayudas a la Diputación. La guerra contra los franceses, la guerra carlista y la guerra de África son tres acontecimientos que generan grandes gastos, además de los necesarios y normales de los acuartelamientos. Para cubrir estos gastos la Capitanía General de Valladolid se está dirigiendo continuamente a la Diputación en petición de ayuda. Los remplazos es el segundo de los problemas y aunque la Diputación, como hemos comentado con anterioridad, cumple escrupulosamente con los mandatos de "las llamadas a filas", no deja de darse cuenta que al cubrir las necesidades militares se produce un problema en las necesidades agrícolas, industriales y comerciales de la provincia al verse privados, y por muchos años, de la juventud para desarrollar los trabajos, siendo en definitiva una actividad que la da mucho trabajo y la quita el colectivo más importante de la provincia. Finalmente, los bagajes y suministros son otra imposición, que incide en la renta de los ciudadanos al tener que servir y ceder al Ejército sus cosechas, sus ganados, sus carruajes y sus viviendas, siempre con la promesa de que serán debidamente pagados y siempre con la realidad de hacerlo por poco dinero y tarde. Como colofón no podemos dejar de citar el trabajo de la Diputación en el desarrollo y mantenimiento de la Milicia Nacional, que aunque de carácter municipal, estuvo tutelada por la institución provincial, y también el esfuerzo que tuvo que hacer en defensa de los ciudadanos en el caso de los numerosos desmanes ocasionados por las partidas de bandoleros, facinerosos y facciosos, haciendo frente a los gastos ocasionados por estas partidas.

Las Obras Públicas es el capítulo al que más se dedicó la Diputación y se centró en el desarrollo de tres diferentes tipos de vías de comunicación: carreteras, Canal de Castilla y ferrocarriles. En estos años asistimos a una importante mejora de las comunicaciones, cuya escasez fue siempre objeto de continuas quejas por parte de los habitantes de la provincia, vías por las que se iniciará el gran despegue económico e industrial de la provincia y llegará a tener su mayor esplendor a mediados del siglo.

En el tema de carreteras dio una gran importancia y resultó beneficioso para la provincia el fomento de las vías y caminos provinciales con una gran mejora de las comunicaciones entre pueblos cercanos lo que facilitaba las relaciones y el intercambio entre ellos, no obstante, la Diputación centró todos sus esfuerzos en la construcción de una serie de carreteras que convirtieron a Valladolid en el centro geográfico de dos ejes de comunicaciones; el primero, de norte a sur, era el que comunicaba a Madrid con la frontera francesa a través de esta ciudad; el segundo, de este a oeste, nos comunicaba con las provincias de León, Salamanca, Zamora por un lado y Zaragoza por otro, sin olvidar la conexión con Segovia. La Diputación estuvo preocupada por su construcción, pero no fue capaz de agilizar su "puesta en marcha", perdió mucho tiempo en llevarlas a buen término y además sufrió ante la falta de dotación económica y trasladó una parte importante de su coste a cargo de la provincia, lo que supuso una pesada hipoteca en las arcas provinciales.

Con respecto al Canal de Castilla, obra financiada en su totalidad por el gobierno, la Diputación procuró en todo momento agilizar su construcción porque estaba segura de la importancia de la misma como vía de exportación de la producción agrícola castellana. Además era consciente de que los labradores estaban muy interesados en esta obra, ya que basaban su progreso en esta vía, cosa que resultó cierta, tanto en el sentido de la agilización del transporte como en el fomento de la industria harinera. Es una obra que excede de lo provincial pero que será fundamental para convertir a Valladolid en el centro de la producción cerealista y en el centro de transformación de los productos agrarios.

Por último, en el tema de los ferrocarriles, tercer elemento del conjunto de infraestructuras, la Diputación estuvo interesada desde el principio en su construcción, aunque la operación la resultó muy cara, ya que no llegó a amortizar el dinero invertido y se endeudó demasiado con el agravante de que el déficit resultante fue amortizado por todos los habitantes. En la primera línea en la que estuvo interesada es la del ferrocarril Alar-Santander o de Isabel II, importante por completar la 
circulación entre el centro productor agrícola e industrial castellano y Santander como puerto de embarque. En este tema estuvo muy presionada por la burguesía de los negocios, por los industriales y comerciantes vallisoletanos, interesados en su construcción, si bien es verdad que también invirtieron sus ahorros en su financiación. La segunda línea a la que más esfuerzo dedicó es a la que enlazaba Madrid con los puertos del Cantábrico y con la frontera francesa o Compañía del Norte, empresa de la que fue una de las promotoras, aunque posteriormente y debido a su coste, cedió el protagonismo a las grandes financieras internacionales. Sin olvidar otras líneas que no fueron tan trascendentales pero si necesarias como el Ferrocarril de Ariza, que comunicaba Valladolid con Aragón, Cataluña y la costa mediterránea.

Muy importante también fueron una serie de obras de carácter municipal como fueron los cementerios, las casas consistoriales, las fuentes, escuelas, etc., es decir, una serie de pequeñas obras locales que facilitaban la vida de los vecinos. En definitiva, en las obras públicas, la Diputación estuvo al tanto de su construcción, su progreso y su mejora, pero siempre lastrada por su escasa capacidad económica.

Sanidad y Beneficencia es otro de los capítulos, en realidad como en la mayoría de las otras actividades institucionales, en los que la provincia es deficitaria y a la Diputación la corresponde el trabajo, en principio, de normalizar la situación, para posteriormente iniciar la modernización de las instituciones sanitarias y benéficas de la provincia. Esta tesitura la obliga a enfrentarse a la Iglesia y a los Ayuntamientos, propietarios y patronos de las diferentes instituciones, además de tener que hacer frente a los problemas generados por la desamortización al descapitalizar la mayoría de las asociaciones benéficas.

Con respecto a la Sanidad, en principio actúa como una receptora de quejas tanto de los profesionales de la medicina, en la mayoría de los casos, como de los Ayuntamientos ante el incumplimiento por parte de unos y de otros de sus obligaciones contractuales, entre las que destacan las de falta y retraso en el pago de los salarios. Su actividad en pro de la mejora sanitaria siempre se produce con cierta demora, aunque el paso de los años y la insistencia de la Diputación, tanto ante los responsables municipales como a los profesionales de la medicina, hace que los pueblos se sientan más receptivos a la hora de tratar con los médicos y más responsable a la hora de cumplir con sus obligaciones de pagar sus honorarios. Es el inicio de la progresión positiva de la sanidad, tanto en atención por parte del médico como por parte del paciente. Ejemplo de esta mejora lo tenemos reflejado en el caso epidémico, ya que al principio de estos años no se preveía con anterioridad la llegada de una epidemia, es decir, no se actuaba con prevención, sino que sólo se preocupaban de la situación cuando la enfermedad ya se ha apoderado de la provincia y en muchos casos con graves consecuencias, lo que les hacía ir por detrás de los acontecimientos. Con el paso de los años y con las mejoras que se legislan en el saneamiento de los pueblos, la construcción de nuevos cementerios, el inicio del alcantarillado, la mejoría de la higiene y de la atención sanitaria, hace que las epidemias estén más controladas y disminuya la mortalidad entre la población cuando se ve afectada.

En lo referente a la Beneficencia la Diputación se encuentra con prácticamente la totalidad de las instituciones benéficas bajo el control eclesial y municipal y a partir de esta situación tiene que iniciar una fuerte transformación tanto en la atención de los necesitados, como en el trabajo de conseguir que este control, poco a poco, pase a manos laicas y provinciales, situación que provoca enfrentamientos con el Ayuntamiento o con la Iglesia. Se va imponiendo la provincialización, de una forma progresiva, de los hospitales y centros benéficos que gestionados por la Diputación atienden las demandas tanto rurales como ciudadanas. Estas instituciones van mejorando tanto en instalaciones como en atenciones sanitarias, a pesar de las dificultades económicas de la Diputación, que interfieren en la marcha y en el desarrollo de los trabajos de los profesionales de la medicina. La penuria en los presupuestos se traduce en precariedad en la atención benéfica y hospitalaria. De todas 
formas, la mejora asistencial de los centros benéficos en estos años es una realidad que tiene que ver con el progreso de la higiene y la medicina, aunque seriamente dificultada por los problemas que surgieron con la descapitalización de las instituciones. Las tensiones entre municipalización y provincialización tampoco permitieron resultados eficaces, limitados por cuestiones de rivalidad administrativa y por falta de financiación. Al final se nota la mano de la modernización en la mayoría de las instituciones, con un mayor control provincial, una mejor organización y una racionalización del número de instituciones. A todas estas mejoras no las puede acompañar la económica, pues las instituciones benéficas son pobres y la Diputación también.

En cuanto a la agricultura, era la actividad base de la economía provincial alrededor de la que se situaban el resto de los sectores productivos, tanto los relacionados con el comercio como con los de carácter industrial. Este era un tema bien conocido por la Diputación, pues la mayoría de los diputados era propietarios agrícolas, lo que contrasta con la escasa preocupación que muestran a la hora de promocionar su desarrollo, pero hay que reseñar que la evolución agrícola fue pareja con la de otras actividades, como fueron las comunicaciones, la industria, la sanidad o la enseñanza. Es decir, a lo largo de los años se va notando una actuación positiva en estas áreas. Las cosechas marcan la pauta del comportamien to provincial, es decir, una buena cosecha supone un desahogo en la economía campesina y es un acicate para el resto de actividades que se mueven alrededor del "agro". Por el contrario, un año agrícola malo presupone dificultades en el comportamiento económico en todo el ámbito provincial.

La Diputación, en esta área y en los primeros años del siglo XIX, tiene que luchar contra dos dificultades, la primera es la de reorganizar la agricultura una vez acabada la guerra de la independencia, guerra que ha dejado los campos asolados y con los campesinos dedicados a luchar contra los franceses y la segunda está ocasionada por las sucesivas malas cosechas que arruinan al campo y a los campesinos. Por ese motivo la Diputación se dedica a mantener una defensa de la agricultura, basada en la petición de ayudas, tanto de las semillas necesarias para la siembra como de rebaja de los impuestos, sin entrar en la búsqueda de mejoras en las diferentes escalas de la producción agrícola, como podían ser las mejoras en las semillas, en los regadíos, en los "aperos de labranza", en los sistemas de siembra, etc. Con la llegada de la era isabelina el campo sigue sufriendo con los problemas que le genera la guerra carlista, pero poco a poco se va estabilizando la situación, las cosechas están siendo productivas, la Diputación sigue trabajando en defensa del mantenimiento de aranceles a la importación, las comunicaciones mejoran a la vez que lo hace el comercio de granos, se nota la gran ayuda del Canal de Castilla como vía principal de salida de los productos agrícolas, y eso se traduce en la celebración de la Primera Exposición de productos de agricultura, industria y artes, celebrada en el año 1850 , y continúa en el año 1859 , con la celebración y el consiguiente éxito de la Exposición Agrícola Castellana. La Diputación inicia el camino de la mejora de la agricultura, con el fomento de los nuevos cultivos, nuevas herramientas, propuestas de visita a la Exposición de Londres y una mayor preocupación por la comercialización y la defensa de los productos del campo. Se esforzó también en la solicitud del mantenimiento de aranceles y en la vigilancia de los flujos de importación y exportación, todo ello acompañado por el auge de la economía centrada en la industria harinera. Estos años, llamados el "Reino de Ceres" por otros historiadores, refleja un panorama que ilusiona a la provincia hasta 1864, años que fueron de una gran bonanza en las cosechas. A partir de 1865, la sequía dará al traste con todas las ilusiones en este apartado de la agricultura a lo que se sumará el "crack" de las entidades financieras, acompañadas por las dificultades del comercio y de la industria vallisoletana, que afectaron de manera importante a la Diputación misma. Todos estos problemas que también se sufrieron en algunos años del Sexenio, no deben de 
estropear la marcha positiva de la agricultura, cuya evolución en el sentido de progreso fue el acicate para el resto de las actividades provinciales.

En referencia a la industria y comercio, aunque eran actividades muy ligadas a la agricultura, en ellas la Diputación no tiene una actuación notoria. De la única manera que consigue beneficiarlas es mediante el desarrollo de las comunicaciones, el fomento de la agricultura y la mejora en las áreas sociales como la enseñanza o la sanidad. La industria harinera es la gran apuesta de la burguesía castellana para progresar, y el Canal de Castilla es el eje a lo largo del cual se sitúan la mayoría de las fábricas. El comercio de granos progresa al mismo tiempo que se desarrolla la industria harinera y su gestión comercial sobrepasa los límites provinciales. Otras importantes industrias son las dedicadas al textil y a la industria metalúrgica relacionada con la maquinaria harinera y los aperos de labranza. De todas formas, la red comercial e industrial de la provincia estuvo influida de una forma negativa por las dificultades financieras y económicas que surgieron a partir de 1864, con ocasión de la crisis del Banco de Valladolid y de otras instituciones financieras provinciales. La crisis arrastró en su caída a un considerable número de comerciantes y produjo la consiguiente pérdida de la pujanza comercial e industrial. En este contexto, la Diputación fue una mera espectadora.

En el inicio de sus actividades la Diputación se encuentra con que la enseñanza es la menos desarrollada de todas ellas y excepto en el caso de la Universidad, apenas existían centros educativos, la mayoría de ellos situados en la capital. Por este motivo es importante resaltar los esfuerzos de la Diputación con referencia a la enseñanza en sus tres grandes apartados de primeras letras, enseñanza media y Universidad. Mantiene una preocupación por el fomento de la alfabetización, lleva un lento progreso en la implantación de la enseñanza media y una constante preocupación por la supervivencia de la Universidad.

En el caso de las primeras letras se pone de manifiesto la penuria económica de los Ayuntamientos, incapaces de mantener una escuela de lo más rudimentaria y el salario de un maestro y como consecuencia vemos que la Diputación, a la que tampoco la sobran "los dineros" tiene que hacer frente a las peticiones de los Ayuntamientos y a las reclamaciones de los maestros, unos solicitando ayudas para poner en marcha las escuelas y otros reclamando ayudas para cobrar los salarios. Este es el panorama de la enseñanza en los primeros años, situación que poco a poco va cambiando y con el paso de los años disminuyen las reclamaciones salariales y la preocupación de los Ayuntamientos por mejorar las escuelas se mantienen, lo que nos demuestra una concienciación de la necesidad de la enseñanza y la colaboración y ayuda de la Diputación fue importante para alcanzar esta tendencia de alfabetización. Con respecto a la enseñanza media, la segunda gran preocupación de la Diputación, la falta de dinero condiciona el funcionamiento del Instituto y su mantenimiento, a lo que hay que añadir la menor incidencia que tiene sobre la población y el menor número de alumnos interesados en los estudios medios hace que se retrase la apertura del Instituto e igualmente se retrasa la construcción de un nuevo edificio para impartir estas enseñanzas. Finalmente, con respecto a la Universidad, la Diputación, en un área en la que no tiene responsabilidad, ni en sentido académico ni en sentido económico, actúa en todo momento de una forma positiva, ofreciendo su ayuda y colaboración en los momentos en los que es requerida. Es una realidad que la institución es más efectiva cuando menos obligaciones económicas tiene que desarrollar y además, en el caso universitario, fue importante su influencia ante personalidades del gobierno y de las Cortes a través de la gestión de antiguos diputados que ejercen tanto como diputados a Cortes o como ministros y altos funcionarios gubernamentales.

En definitiva, en el tema de la enseñanza, que también se puede extrapolar al resto de las actividades provinciales, la Diputación no presenta unos resultados espectaculares, pero hay que reconocer que la evolución positiva que se observa en la provincia, en parte se puede adjudicar a su gestión y a su intervención. La virtud de la Diputación es que cumple al pie de la letra las directrices gubernamentales y actúa 
de forma eficaz cuando el trabajo no requiere inversión económica. En definitiva, su trabajo y su rendimiento están influidos, en primer lugar, por las interferencias de los jefes políticos-gobernadores, más preocupados por obedecer y contentar al gobierno que por trabajar, en su calidad de presidentes de la Diputación. En segundo lugar, por la obediencia de los diputados provinciales, ya fueran progresistas o moderados, que no se enfrentan a la voluntad gubernamental. El tercer factor que le afecta es la penuria de la economía provincial tantas veces repetida a lo largo de estas páginas, que tiene una gran importancia y representó el mayor freno al progreso y expansión de todas las actividades provinciales y en consecuencia del trabajo de la Diputación.

En conclusión, la Diputación trabajó en la mejora social y estuvo limitada en la mejora económica de la provincia, y en su descargo hay que constatar que su evolución fue similar a la del resto del país. 


\section{5.- ELITES PROVINCIALES EN TORNO A LA DIPUTACIÓN}

Para una mejor ordenación del tiempo, de las actividades y de los personajes, en un primer apartado hacemos un recorrido de la vida de la Diputación, es decir, desde septiembre de 1813, hasta el final del período estudiado que se fija en el mes de marzo de 1875, en siete divisiones que coinciden con el sistema político dominante en el país, en función de los presidentes-gobernadores que dirigieron la institución. En un segundo apartado nos referimos a los vicepresidentes- intendentes, En un tercer apartado del capítulo, aparecen un índice onomástico y alfabético de todas las personalidades que ejercieron como presidentes y vicepresidentes de la Diputación en todos estos años y un breve resumen biográfico de los mismos

Con respecto a la gestión de los diputados provinciales, igualmente ordenamos su tiempo, sus actividades y sus personajes en otros tres apartados, el primero relacionado con la vida de la Diputación, el segundo se centra en un índice alfabético de los diputados y en el tercero hacemos una relación de sus biografías.

\section{1.- PRESIDENTES DE LA DIPUTACIÓN: JEFES POLÍTICOS- GOBERNADORES Y ASIMILADOS}

La Constitución de 1812 establece que la autoridad que presida la Diputación debe de ser el jefe político nombrado por el gobierno del momento. Esta decisión se traslada a la legislación que se sucede a lo largo de estos años y que se mantiene hasta la llegada del Sexenio. A partir del 20 de febrero de 1871 es cuando los gobernadores dejan de ser al mismo tiempo presidentes de las instituciones provinciales. Este sistema provoca en las Diputaciones dos incidencias que marcan el desarrollo de sus actividades. La primera es que, lógicamente, los jefes políticos son afines al color político de los gobiernos por los que han sido nombrados. La segunda es que, debido a la inestabilidad política de todo este período, al frente de las Diputaciones y de los gobiernos políticos se suceden un excesivo número de personalidades, lo que provoca una pérdida de eficacia en el trabajo de la institución.

\subsection{1.-EN LA PRIMERA ÉPOCA LIBERAL: $1813-14$ y 1820-23}

Estos años se caracterizan por el hecho de que, en su mayoría, los presidentes de la Diputación a la vez que jefes políticos de la provincia, son capitanes generales de Castilla la Vieja y por lo general, son militares de ideología liberal. Antonio María Peón y Heredia, tiene el honor de ser el primer presidente de la Diputación, ya que ejercía de capitán general en las fechas en que se puso en marcha. Casimiro Lavalle le sucedió en vísperas del cese de actividades en este primer período y en el corto período en el que ejercieron se centraron en la organización de la Diputación, la ordenación de la provincia tras la guerra y hacer frente a los primeros escarceos absolutistas que le costaron el puesto al presidente Peón.

En los tres años del Trienio son seis los personajes que se suceden al frente de la Diputación, Luis del Águila es el que inicia la serie, al que le siguen los jefes políticos interinos, Tomás Moreno Daoiz y Carlos Espinosa, ambos militares. Este último volverá a ser nombrado capitán general en 1837, con el dudoso comportamiento de que abandonó la ciudad ante la amenaza de invasión del faccioso Zariategui. A continuación aparece Pedro Clemente Ligues, el primer presidente y jefe político que no es militar y el primero que tiene experiencia política, pues ejerció este cargo con anterioridad. José Fernández Queipo le sucede y Antonio Buch cierra la lista cuando sin haber sido destituido tiene que abandonar la ciudad ante la llegada de las tropas absolutistas. En estos dos períodos en los que la Diputación está en 
funcionamiento durante cuarenta y cinco meses, desde septiembre de 1813 hasta junio de 1814 y desde marzo de 1820 hasta febrero de 1823, la presidencia es ejercida por ocho jefes políticos, dos de ellos con carácter interino, con el resultado de una media de 5'6 meses de permanencia en el cargo, siendo José Casimiro Lavalle el que menos tiempo duró con sólo un mes de presidencia y Pedro Clemente Ligues como el más duradero ya que permaneció durante diez y seis meses, lo que representa un tercio de los dos períodos.

La búsqueda de sede para la institución, las gestiones para agilizar la construcción del Canal de Castilla, la organización de la Milicia Nacional, los problemas de hambre y miseria ocasionados por las malas cosechas, las quejas ante los proyectos de la reordenación de las provincias que perjudican la extensión de la de Valladolid y los consiguientes repartimientos de contribuciones y de "quintos", son todas ellas las principales actividades que se suceden a lo largo de estos años.

\subsection{2.- GOBENADORES Y PRESIDENTES EN LAS REGENCIAS (1835-40)}

En octubre de 1835 se inicia la tercera y definitiva etapa en la existencia de la Diputación y en estos años de las Regencias se estrena como primer presidente de la institución José Antonio Ponzoá, que ejercía el cargo de gobernador de la provincia. Le suceden Francisco Romo y Gamboa y Miguel Dordá. Con José Núñez Arenas se vuelve a tomar el nombre de jefe político en lugar de gobernador y es el presidente que tuvo el dudoso honor de abandonar la ciudad ante la amenaza de invasión del rebelde Zariategui y por el que fue destituido. Joaquín Manuel de Alba y Matías Guerra son los siguientes presidentes, a los que les sigue Pedro Sánchez Ocaña, que ejerció en primer lugar como intendente y vicepresidente para ser posteriormente nombrado presidente. Jacinto Manrique, Ramón Ceruti y Juan Gutiérrez cierran esta larga lista en este corto tiempo.

Desde octubre de 1835 hasta diciembre de 1840, principio y fin de esta etapa transcurren un total de sesenta y tres meses, tiempo en el que pasan por la presidencia de la Diputación diez personalidades, lo que representa una media de 6'3 meses por cada presidente con Miguel Dordá como el que menos tiempo estuvo en la presidencia, un mes nada más, y José Núñez Arenas es el más duradero manteniendo la presidencia durante quince meses.

Las actividades en estos años están marcadas por la guerra carlista y el saqueo de la provincia por las tropas del faccioso Zariategui. El continuo paso de tropas por la provincia no mejora la situación de la guerra y no impide que Zariategui siga actuando sin problemas, a lo que hay que añadir las continuas servidumbres de las tropas, traducidas en los servicios de bagajes, suministros y alojamientos obligatorios. Las peticiones de ayuda económica que solicita el capitán general, los sorteos de los remplazos para el Ejército y las reclamaciones al Ministerio de Fomento por la nueva división provincial, gravemente perjudicial para la provincia, son los temas más destacados en estos años, a los que hay que añadir la puesta en marcha parcial del Canal de Castilla, la organización y atención a los servicios de enseñanza de las primeras letras, atender a las reclamaciones procedentes de la sanidad y los trabajos para la recaudación de las contribuciones.

\subsection{3.-LOS PRESIDENTES DEL TRIENIO ESPARTERISTA: 1841-43}

En este período llama la atención el que se mantenga la misma Diputación de carácter progresista, y sin embargo sean numerosos los jefes políticos que desfilan por la presidencia de la institución. Parece un contrasentido que ante la estabilidad del gobierno central se produzca la inestabilidad en la Jefatura Política de la provincia. Juan Gutiérrez, presidente de la anterior Diputación, continúa todo el año 1841 y durante su mandato se produce la caída de la torre de la Catedral. Le sucede el intendente Lorenzo Perabeles, que curiosamente ejerce, aunque sea de interino, más tiempo que el resto de presidentes que se suceden en este período, y que tuvo una serie de enfrentamientos con algunos diputados por haber suspendido de sus funciones al 
alcalde de Valladolid por no obedecerle. Julián Sánchez Gata es el siguiente presidente que toma posesión en octubre de 1842 y hasta octubre de 1843 continúa una serie de nombramientos, con una duración mínima, de Luis Sagasti García-Herrero, que será posteriormente diputado a Cortes por Valladolid, Manuel Llamas, diputado provincial con anterioridad, Juan Ruiz Cermeño, que ocupa el cargo de jefe político con carácter interino, político veterano y diputado a Cortes, Benigno de Quirós y Contreras, que es presidente durante un mes escaso y Diego Manuel de Mosquera, que continuará ejerciendo el cargo en la siguiente legislatura pasado el tiempo de la Regencia de Espartero. En resumen, una Diputación que dura desde enero de 1841 a octubre de 1843, es decir, treinta y cuatro meses con ocho presidentes, lo que supone una permanencia media de cuatro meses cada uno, con Juan Gutiérrez como el más constante con once meses y Diego Manuel de Mosquera el más breve ya que permanece el último medio mes.

En estos tres años escasos de vigencia de esta Diputación, los ocho presidentes tienen como máxima preocupación dar curso a las numerosas peticiones que se reciben del gobierno central para que informe sobre "la conducta moral y política" de un gran número de ciudadanos. Una novedad en el funcionamiento de la Diputación es la aparición de la figura del "diputado semanero" con la finalidad de tratar los temas con más rapidez y mantener en marcha la gestión de los asuntos en el tiempo en que no se celebren sesiones. Otras ocupaciones de la Diputación están centradas en la formación de las nuevas listas electorales y además en la celebración de elecciones municipales. El interés por mejorar todos los aspectos de la Milicia Nacional es evidente en estos años, con la ratificación de D. Francisco Osorio como subinspector y las diferentes gestiones para equipar y mejorar los equipamientos milicianos. Varios pueblos de la provincia siguen reclamando el pago de los suministros que tuvieron que dar a las facciones de Balmaseda y Zariategui en años anteriores. El remate de las obras del Canal de Campos, la activación de las obras de las carreteras de León y Salamanca con la consiguiente negativa de los comisionados de los diferentes partidos judiciales para aprobar los arbitrios necesarios para su construcción y las consabidas sesiones de sorteos y reclamaciones de mozos para el Ejército completan los trabajos de esta legislatura progresista.

\subsection{4.- LOS JEFES POLÍTICOS-GOBERNADORES EN LA DÉCADA MODERADA: 1844-54}

A lo largo de la Década Moderada pasaron por el Gobierno político de la provincia un total de diez y seis personalidades entre titulares e interinos, repartidos entre las cinco legislaturas que se suceden en estos años. Su duración fue irregular, en función del buen hacer en el cargo o de los "caprichos" del ministro de la Gobernación de turno. La presidencia se inicia con Diego Manuel de Mosquera que ya actuaba como presidente de la Diputación durante la anterior legislatura, al que le suceden Laureano de Arrieta, José Fernández Enciso, José María del Campo y Mariano Herrero-Ceruelo Prieto, que será posteriormente elegido diputado a Cortes por el partido de Medina, además de Manuel Martín Lozar que actuó como presidente en virtud de su cargo de vice-presidente del Consejo provincial. Todos estos personajes durante la primera legislatura de este período, la más larga del mismo. Manuel de la Cuesta y Cossío es el primer presidente de la segunda legislatura al que le suceden Anselmo Merino, Rafael Navascués, Juan Perales que es el último presidente que ostenta el cargo de jefe político y José Rafael Guerra que es el primer gobernador en hacerse cargo de la presidencia de la Diputación a la vez que absorbe también la Intendencia de la provincia y en consecuencia desaparece el cargo de vicepresidente de la Diputación. Este último presidente continúa en la siguiente legislatura, con Anselmo Merino en calidad de gobernador interino por ser vicepresidente del Consejo provincial y Francisco Lavalette, que ejerce como gobernador militar y que accede al cargo de gobernador interino a la vez que presidente, completando el período con el nombramiento de Ildefonso López Alcaraz. En la siguiente Diputación, además de 
repetir José Rafael Guerra, son presidentes Pedro Bardaji y Francisco del Busto que continuará como presidente en la última legislatura de este período. Desde noviembre de 1843 a junio de 1854 transcurren un total de diez años y ocho meses, es decir ciento veintiocho meses que divididos entre los diez y seis presidentes resultan a una media de ocho meses por presidente. Esta duración que oscila entre los dos años que se mantuvo en el cargo Laureano de Arrieta y los veintidós días que disfrutó Miguel María Fuentes. En el índice biográfico y cronológico, se relacionan todos los responsables que ejercieron en este período, con el nombre de jefe político hasta finales de 1849 , y a partir de enero de 1850 , con el nombre de gobernador y que, a su vez, ejercieron como presidentes de la Diputación.

Las audiencias públicas para "oír las reclamaciones de los quintos", la proclamación de "mayoría de edad" de Isabel II, la declaración de "carretera general" a la carretera de León y las reclamaciones de los constructores de la carretera de Salamanca son los asuntos más importantes de la presidencia de Mosquera. El presidente Arrieta estrena el cargo con un enfrentamiento con los diputados progresistas a cuenta de la aprobación de la Ley de Ayuntamientos de 1840 y con la declaración conjunta con el capitán general, del estado de excepción en la capital para facilitar el desarme de la Milicia Nacional. De todas formas en su largo tiempo de permanencia en el puesto se realizaron otros trabajos como las interminables audiencias públicas para atender las reclamaciones de los sorteos de soldados, de las contribuciones y de las listas electorales y la formación de los presupuestos provinciales, también fue constituido el Consejo provincial y se iniciaron las conversaciones para poner en marcha las obras del ferrocarril. Con la puesta en marcha del Consejo, la Diputación pierde parte importante se sus actividades que quedan centradas principalmente en la gestión de las obras públicas y en la confección de los presupuestos provinciales.

\subsection{5.- ABUNDANTES GOBERNADORES EN EL BIENIO PROGRESISTA: 1854-} 56

Al igual que aconteció en el período progresista del general Espartero entre los años 1841 y 1843 , en este "bienio progresista" nos encontramos con una situación similar en referencia a la estabilidad de la Diputación por una parte, y a la inestabilidad y poca duración en el cargo de los gobernadores de la provincia por otra. En lo referente a la Diputación, tenemos la instalación "urgente" de una legislatura provisional, con una duración de quince días, y a continuación una definitiva que se mantiene en funcionamiento el resto del período progresista, es decir dos años. Por lo que respecta a los gobernadores, vuelven a ser llamativos los numerosos cambios y nombramientos de los diferentes personajes que pasan por el Gobierno político y en consecuencia por la Presidencia de la Diputación. En el transcurso de estos dos años, se suceden en el cargo seis gobernadores titulares y a la vez presidentes de la Diputación. Uno no llegó a tomar posesión de la Presidencia de la Diputación, tres secretarios del Gobierno ejercieron como gobernadores interinos y asistieron a las sesiones de la Diputación, aunque no las presidieron. Finalmente, un gobernador militar, actuó al mismo tiempo como gobernador civil de la provincia, pero tampoco llegó a ejercer como presidente de la Diputación. En definitiva, un "baile" de nombramientos, un excesivo número de personajes y, en consecuencia, poca efectividad en el trabajo a desarrollar. Sólo una característica les unía a todos ellos, excepto al gobernador militar, y era su pertenencia a ideologías progresistas, antimonárquicas o republicanas. Miguel Álvarez es el presidente de la Diputación que inicia las actividades del Bienio Progresista nombrado por la Junta Provisional de Gobierno de la Provincia y que es sustituido al poco tiempo por Nicolás María Rivero con un tiempo también breve en el cargo. Juan Diego Pérez es secretario del Gobierno que ante la ausencia del titular desempeña el cargo de gobernador interino y que al mismo tiempo ejerce como presidente de la Diputación y cede el puesto a Manuel Gusano cuando es nombrado gobernador titular. Todas estas personalidades se 
suceden entre julio y diciembre del mismo año 1854. En el año 1855 ejercen como presidente de la Diputación Ignacio Méndez Vigo Santamarina en calidad de gobernador interino al ser secretario del Gobierno y Bernardo Iglesias. En 1856 se estrena con la Presidencia el gobernador interino Baldomero Menéndez y los titulares Domingo Saavedra y Patricio Azcárate, rematando este período con la Presidencia de un gobernador militar, Francisco Castillón, que toma el mando al ser declarado el estado de guerra en la provincia. En total diez diferentes presidentes se suceden en estos veinticuatro meses con el resultado más corto de permanencia media en el cargo que se limita a 2'4 meses por cada presidente, con Bernardo Iglesias como el más constante al durar diez meses e Ignacio Méndez Vigo Santamarina y Patricio Azcárate que ejercen durante medio mes, sin olvidar que Miguel Álvarez y Nicolás María Rivero ejercen durante un mes.

En estos dos años de vigencia del Bienio y con la poca estabilidad de los presidentes, pocas actividades pueden ser reseñadas aunque las más llamativas son las de disolución del Consejo provincial y la puesta en marcha de nuevo de la Milicia Nacional y la entrada en funcionamiento de la Secretaría provincial. Con respecto a las propuestas extraordinarias destacan, las reuniones con otras Diputaciones y empresas interesadas en la construcción del ferrocarril del Norte, la creación de la Sociedad del Ferrocarril de Isabel II y la suscripción promovida por la Diputación para la adquisición de un palacio para residencia del Duque de la Victoria. En las actividades habituales se reseñan la preocupación por la extensión de la epidemia del cólera-morbo, la petición del uso de los cereales almacenados en los pósitos para paliar la miseria y el hambre debido a las malas cosechas como asimismo se autoriza la tala y aprovechamiento de los montes comunales para el mismo fin. Estas medidas no consiguieron su propósito lo que provocó los tumultos conocidos con el nombre de "los motines del pan".

\subsection{6.-LOS GOBERNADORES-PRESIDENTES EN LA UNIÓN LIBERAL: 1856-68}

En consonancia con la estabilidad gubernamental propiciada por el "Gobierno Largo de O'Donell", también los gobernadores se mantienen en sus puestos un período de tiempo más largo de lo habitual. Como ejemplo tenemos a Castor Ibáñez de Aldecoa, que se mantiene en el cargo un tiempo record de tres años y nueve meses. Tenemos la contrapartida en la segunda mitad de estos años, cuando la permanencia y estabilidad de los gobernadores se ve afectada por la consecuente inestabilidad de los gobiernos y el enrarecimiento del clima político y social, que finalizará con la llegada del "Sexenio Revolucionario". El modelo de este período nos lo da el gobernador Manuel Ureña, con una permanencia en el cargo de tres días, en los que no llegó a tomar posesión de la presidencia de la Diputación. Esto trae como consecuencia la proliferación de los gobernadores interinos en la figura del secretario del Gobierno Civil, pero no ejercen la Presidencia de la Diputación, ya que por ley en estos años le corresponde al vicepresidente del Consejo provincial. También es de destacar la pérdida de importancia de la figura del gobernador al frente de la Diputación. Esta situación se verá clarificada a partir de la publicación de la ley sobre "El Gobierno y Administración de la Provincia" de 25 de septiembre de 1863, en la que se legisla que el nombramiento del presidente de la institución será realizado por los diputados provinciales, de entre los miembros de la Corporación, con la puntualización de que "cuando el gobernador asista a las sesiones, ejercerá la presidencia y tendrá voz y voto".

A continuación queda reflejada la relación de los gobernadores de la provincia que ejercieron su mando en la misma y también se relaciona a los secretarios del Gobierno, que en su mayoría actuaron como gobernadores en casos de interinidad. La relación se inicia con Antonio Méndez-Vigo Santamarina al que sucede Francisco del Busto, que ya ejerció como presidente en los años 1852 a 1854. Matías Torres Estelá es secretario del Gobierno y ejerce de presidente hasta la toma de posesión de Clemente Linares al que sigue Cayetano Bonafós, presidente de corta duración, todo 
lo contrario del siguiente que es Cástor Ibáñez de Aldecoa y Usabel, que como hemos reseñado con anterioridad es el presidente de la Diputación que más tiempo se mantiene en el cargo en todos estos años en los que le sustituye en las ausencias como gobernador interino y presidente el secretario del Gobierno Antonio del Castillo. En 1863, Rufo de Negro es titular, Ramón de Mazón y Valcárcel es interino y Toribio Rubio Campos y Antonio Hurtado son titulares. En 1864 son titulares Bartolomé Hermida, Vicente Lozana y Ángel María Dacarrete. En 1866 Eugenio Rubí ejerce interinamente en espera de la toma de posesión del titular José de la Fuente Alcántara, al que le sucede José Gallostra y Frau. En 1866 es gobernador interino Bernardo Sierra y titulares Manuel Somoza y Cambero y Mariano Herrero-Ceruelo Prieto. Manuel Ureña y Cádenes después de su breve paso de tres días por el Gobierno Civil, vuelve en 1867 como gobernador y presidente de la Diputación y durante su mandato $\mathrm{y}$ en sus ausencias ejercieron el gobierno interino los secretarios Rafael Trillo Figueroa y Manuel González Marino y la presidencia de la Diputación Vicente Álvarez Cossío como vicepresidente del Consejo provincial.

En total dieciséis gobernadores titulares y ocho interinos son veinticuatro personalidades que fueron presidentes en un período de doce años y tres meses, es decir ciento cuarenta y siete meses, lo que resulta una media de 6' 1 meses por cada presidente, repitiendo que Cástor Ibáñez de Aldecoa y Usabel es el más duradero con cuarenta y cinco meses y dejando aparte la corta presencia de Ureña como gobernador tenemos a los diversos secretarios que ejercieron por pocos días ante las ausencias de los titulares.

Estos doce años de predominio conservador, en otro capítulo de este estudio hemos bautizado como "el período gris" en referencia a la monotonía que se plasma en los libros de actas de la Diputación cuando trata sus asuntos, y que contrastan con la alegría que emana de la sociedad ante los progresos que se suceden en la provincia encabezados y liderados por el espectacular desarrollo de las comunicaciones y el no menos importante crecimiento de la industria harinera que son los motores, junto con el lento progreso de la agricultura, de la buena marcha y el crecimiento económico de la provincia. Esta alegría está poco reflejada en la Diputación, que está sobrepasada por la hegemonía del Consejo provincial. En estos años la institución trabaja en la formación de los presupuestos y la creación de arbitrios para equilibrarlos, en la disolución definitiva de la Milicia Nacional, en los trabajos de repartimientos de soldados y de contribuciones, en la puesta en marcha de la Exposición Agrícola y Mercantil, en impulsar una suscripción de ayuda para cubrir los gastos de la guerra de África, en los expedientes promovidos por doscientos treinta y ocho pueblos de la provincia, el $88 \% 1 \%$ del total, solicitando la exclusión de venta como bienes desamortizados de las fincas del común de propiedad municipal, en el robo en la Depositaría provincial, en el envío de una comisión provincial a la Exposición Universal de Londres, en el fomento del Plan de Caminos provinciales, gestiones para la construcción del edificio para Instituto de Enseñanza Media y para la Escuela Normal y en la declaración de Provincial al Hospital de la Resurrección,

Al final de estos años, entre la quiebra financiera que sufren las entidades bancarias de la provincia y que se inicia con la quiebra del Banco de Valladolid y a la que acompañan otra serie de quiebras y suspensiones de pagos de numerosos e importantes comerciantes, conjuntamente con las malas cosechas, hacen que la sensación de pobreza y de tristeza se extienda por toda la provincia.

\subsection{7.- GOBERNADORES PROGRESISTAS DEL SEXENIO: 1868 -74}

Quince gobernadores y nueve secretarios del Gobierno se suceden a lo largo de estos seis años que conforman el período revolucionario al frente de la provincia. Etapa en la que se constata la pérdida de la presidencia de la Diputación por parte de los gobernadores, aunque no se pierde la influencia de los mismos en lo que respecta a la gestión de los asuntos provinciales. Es cierto que los responsables políticos no presiden habitualmente las sesiones de la Corporación, y si lo hacen es para abrir la 
sesión y retirarse "por exigencias de los asuntos del servicio". Como es lógico, una característica que une a la mayoría de estos personajes, es su ideología progresista. También llama la atención en estos años los numerosos cambios que se producen en la Secretaría del Gobierno Civil, un empleo que en años anteriores había tenido un mayor carácter administrativo, lo que propiciaba su larga duración y que en el Sexenio, al tener un mayor carácter político, al ser por ley el sustituto del gobernador, sufre parecidos vaivenes en su estabilidad en el cargo. Sobre todo resalta que, al cambio de gobernador, automáticamente se produce un cambio en el secretario.

Por orden cronológico la relación de gobernadores se inicia con Genaro Santander, que fue diputado provincial y es presidente de la Junta Revolucionaria y gobernador interino, al que le sigue Manuel Somoza y Cambero, que ejerció como gobernador y presidente de la Diputación en 1866 y José Pascasio de Escoriaza. José Gómez Díez es nombrado gobernador y a su cese ocupa su puesto Eduardo de la Loma Santos que deja en el cargo con carácter de interino al secretario del Gobierno Abdón de Paz. En el año 1871 se suceden en el cargo José Gallostra y Frau, que fue también presidente de la Diputación, a la vez que gobernador en 1865, Primitivo Seriñá, Vicente Lobit y Pedro Oller y Cánovas, en cuyo mandato es sustituido en ocasiones por el secretario Enrique Fernández, que dimite con la nueva llegada de Vicente Lobit, cuyo secretario Eugenio Reguera actuará en sus ausencias como gobernador interino. José González-Alegre y Álvarez es el primer gobernador que preside la Diputación en el período republicano, al que le sustituye en sus ausencias el secretario Ramón Lafarga. A continuación es nombrado titular Cándido González Gutiérrez, al que le suple en ocasiones el secretario Agustín Víctor Teijón y Rodríguez, a los que sucede como titular Rafael Adán y Castillejo que junto con el secretario del Gobierno, Donato González Andrés, ejercen la presidencia en las sesiones a las que asisten. Finalmente son gobernadores Ambrosio de Villava como titular, Rafael González Liquinano como interino, Mariano Lino de Reynoso y Oscáriz y Bartolomé Romero Leal como titulares. Estas veinticuatro personalidades ejercen como gobernadores en los setenta y ocho meses del Sexenio lo que nos da una presencia media en el cargo de 3'3 meses, con una oscilación de doce meses de estancia de Eduardo de la Loma y medio mes que dura Cándido González Gutiérrez, sin tener en cuenta los días que ejercen los secretarios del Gobierno.

Hay que resaltar que todos estos personajes presiden la Diputación en las sesiones a las que asisten, pero los presidentes efectivos de la institución y que son nombrados de entre los diputados electos son Francisco Rodriguez Rubio durante la primera y segunda Diputaciones, Félix Alonso García lo es en la tercera Diputación, Laureano Álvarez López es presidente en la cuarta y Telesforo Reoyo es elegido para la quinta y última Diputación del Sexenio.

A lo largo de estos seis años, la Diputación vuelve a retomar en toda su amplitud las actividades provinciales al desaparecer el Consejo provincial y aunque se implanta la Comisión provincial, esta está formada por parte de los diputados titulares y se dedica a la preparación de los asuntos para su discusión en los plenos. Elecciones municipales, ayudas a la sequía, presupuestos municipales y presupuestos y arbitrios provinciales, formación del censo provincial con fines electorales, repartimientos de mozos y repartimientos de contribuciones con sus correspondientes y respectivas reclamaciones, solicitud de realización de bagajes por el ferrocarril, arrendamientos de bienes de propios, recepción, pagos y presupuestos de carreteras provinciales, gestiones para la adquisición del Palacio de Pimentel como sede de la Diputación, son parte de las actividades que realiza la Diputación, amén de las continuas peticiones sobre sanidad beneficencia y enseñanza.

\section{2.-VICEPRESIDENTES DE LA DIPUTACIÓN E INTENDENTES DE LA PROVINCIA}

Además de nombrar al presidente de la Diputación en la persona del jefe político, el gobierno especialmente en los primeros años de existencia de las 
Diputaciones, ve necesario el nombramiento de los vicepresidentes, en la figura del intendente de la provincia, por la necesidad de controlar y de acentuar el cobro de los impuestos. Las "arcas del Estado", después de un período de guerra y de crisis, estaban exhaustas, por lo que era necesario asegurarse los cobros. Para ello, no duda en colocar al intendente, que en un principio lo era también del ejército, para asegurar y dar importancia a una de las principales actividades que debían de ser controladas.

Una vez que se estabilizó la existencia de las Diputaciones y se modernizaron las estructuras estatales, a partir de las leyes legislativas puestas en marcha en el año 1845, la figura del intendente se fue transformando hacia la forma de delegado de Hacienda. Con ello su figura y su presencia en la Corporación fue amortizada y sus responsabilidades en la misma fueron asumidas por el gobernador. De esta forma, estos vicepresidentes-intendentes se mantuvieron en activo entre los años 1813 y 1849, tiempo dividido en dos períodos bien determinados. El primero de ellos transcurre durante los primeros años de vigencia de las Diputaciones, es decir, entre los años 1813-14 y 1820-23, y el segundo período está enmarcado entre los años 1835 y 1849. A partir de esta fecha el vicepresidente de la Corporación "será nombrado por la Diputación de entre sus miembros".

El 2 de septiembre de 1813, inicio de las actividades institucionales, José Rodríguez Camargo es intendente del Ejército y de la provincia y en consecuencia es el primer vicepresidente de la Diputación, cargo en el que se mantendrá hasta el fin de vigencia de esta etapa en junio de 1814. Con el inicio del Trienio Liberal y la nueva puesta en marcha de la Diputación, Pedro Domínguez Caballero intendente de la provincia es nombrado vicepresidente de la Diputación a partir de su nueva instalación en marzo de 1820 y ejercer hasta mayo de 1822 en el que es sustituido por José de Goicoechea, que actúa hasta la disolución de la institución en mayo de 1823. A partir de la época isabelina y con el arranque definitivo de la Diputación, Joaquín Copeiro del Villar como intendente interino ocupa el cargo de vicepresidente, cargo en el que se mantiene hasta la llegada del titular Rafael García-Pizarro y Zaldúa de Gambeo, al que le sucede Antonio Porro López de Ulloa y posteriormente Pedro Sánchez Ocaña, que actuando como vicepresidente será nombrado jefe político, por lo que actúa al mismo tiempo como presidente y vicepresidente. Mariano Ruiz de Mendoza, intendente interino es el siguiente vicepresidente al que le suceden Esteban Sayró, Felipe Sicilia y Lorenzo Perabeles, que a la vez que asume la intendencia ejerce como presidente, ante la ausencia del titular, Ramón Barbaza y Juan Buznego, todos ellos ejercen entre 1839 y 1843 . En estos primeros años isabelinos son frecuentes los cambios en la Intendencia, a pesar de ser una profesión estabilizada por su especialización. Manuel de Villaverde, Joaquín Aguilar, José Muñoz de San Pedro y Ramón Sardina son los últimos vicepresidentes intendentes que ejercen desde enero de 1844 a diciembre de 1849 , fecha en la que desaparece la figura de intendente.

\section{3.- ÍNDICE ONOMÁSTICO DE GOBERNADORES E INTENDENTES. TITULARES, INTERINOS Y ASIMILADOS}

A continuación se relacionan las diferentes personalidades que han ocupado cargos en la Diputación, como presidentes y vicepresidentes con los datos relativos al cargo oficial para el que fueron nombrados, el tiempo que ejercieron en la Diputación, reflejado en meses, y a las diferentes Diputaciones a las que asistieron. Éstas quedan señaladas con los indicativos C para la Diputación Constitucional Gaditana (18131814), $\mathrm{T}$ para las tres Diputaciones del Trienio (1820-1823), Y para las diecinueve Diputaciones isabelinas (1835-1868) y S para las cinco Diputaciones del Sexenio (1868-1874).

\begin{tabular}{llcc}
\multicolumn{1}{c}{ NOMBRE } & \multicolumn{1}{c}{ ACTIVIDAD } & MESES / CARGO & LEGISLATURA \\
A & & & \\
Adán y Castillejo, Rafael & Gobernador & 7 & $4 \mathrm{~S}$ \\
Águila, Luis del & Jefe político & 3 & $1 \mathrm{~T}$ \\
Aguilar, Joaquín & Intendente & $6 \mathrm{Y}$
\end{tabular}


Alba, Joaquín Manuel de Álvarez, Miguel

Álvarez Cossío, Vicente

Arrieta, Laureano de

Azcárate, Patricio

Barbaza, Ramón de

Bardaji, Pedro

Bonafós, Cayetano

Buch, Antonio

Busto, Francisco del (1)

Busto, Francisco del (2)

Buznego, Juan

C

Campo, José María del

Castillo, Antonio del

Castillón, Francisco

Ceruti, Ramón

Copeiro del Villar, Joaquín

Cuesta y Cossío, Manuel de la

D

Dacarrete, Ángel María

Diego Pérez, Juan

Domínguez Caballero, Pedro

Dordá Miguel

E

Escoriaza, José Pascasio de Espinosa, Carlos

F

Fernández, Enrique

Fernández Enciso, José

Fernández Queipo, José

Fuente Alcántara, José de la

Fuentes, Miguel María

G

Gallostra y Frau, José (1)

Gallostra y Frau, José (2)

García Pizarro y Zaldúa de Gambeo

Rafael (Marqués de Casa Pizarro)

Goicoechea, José de

Gómez Díez, José

González-Alegre y Álvarez, José

González Andrés, Donato

González Gutiérrez, Cándido

González Liquinano, Rafael

González Marino, Manuel

Guerra, José Rafael

Guerra, Matías

Gusano, Manuel

Gutiérrez, Juan

H

Hermida, Bartolomé

Herrero Ceruelo Prieto, Mariano (1)

Herrero Ceruelo Prieto, Mariano (2)

Hurtado, Antonio

I

Ibáñez de Aldecoa y Usabel, Cástor

Iglesias, Bernardo

Íñigo y Anciso, Carlos

L

Lafarga, Ramón

Lavalette, Francisco de

Lavalle, José Casimiro

Ligués, Pedro Clemente

Linares, Clemente

Llamas, Manuel

Lobit, Vicente
Jefe político

Gobernador

Gob. Interino

Jefe político

Gobernador

Intendente

Gobernador

Gobernador

Jefe político

Gobernador

Gobernador

Intendente

Jefe político

Secretario Gob.

Gob. Interino

Jefe político

Intendente inter.

Jefe político

Gobernador

Secretario, Gob

Intendente

Jefe político

Gobernador

Jefe polít. inter.

Secretario Gob.

Jefe político

Jefe político

Gobernador

Gobernador

Gobernador

Gobernador

Intendente

Intendente

Gobernador

Gobernador

Secretario Gob.

Gobernador

Secretario Gob.

Secretario Gob.

Gobernador

Jefe político

Gobernador

Jefe político

Gobernador

Jefe político

Gobernador

Gobernador

Gobernador

Gobernador

Secretario Gob.

Secretario Gob.

Gobernador inter.

Jefe político

Jefe político

Gobernador

Jefe político

Gobernador

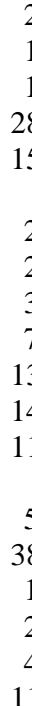

$10 \mathrm{Y}-11 \mathrm{Y}$

$19 \mathrm{Y}$

$5 \mathrm{Y}$

$11 \mathrm{Y}$

$4 \mathrm{Y}$

$8 Y$

$14 \mathrm{Y}$

$3 \mathrm{~T}$

$8 Y-9 Y$

$12 \mathrm{Y}-13 \mathrm{Y}$

$4 \mathrm{Y}-5 \mathrm{Y}$

$5 \mathrm{Y}$

$14 \mathrm{Y}-15 \mathrm{Y}-16 \mathrm{Y}$

$11 \mathrm{Y}$

$3 \mathrm{Y}$

$1 \mathrm{Y}$

$6 \mathrm{Y}$

$17 \mathrm{Y}$

$11 \mathrm{Y}$

1T-2T-3T

$1 \mathrm{Y}$

$1 \mathrm{~S}$

$2 \mathrm{~T}$

$3 \mathrm{~S}$

$5 \mathrm{Y}$

$3 \mathrm{~T}$

$17 \mathrm{Y}$

7Y

17Y-18Y

$3 \mathrm{~S}$

$1 Y$

$3 \mathrm{~T}$

$2 \mathrm{~S}$

$4 \mathrm{~S}$

$4 \mathrm{~S}$

$4 \mathrm{~S}$

$5 \mathrm{~S}$

18Y-19Y-1S

6Y-7Y-8Y

$3 \mathrm{Y}$

$11 \mathrm{Y}$

$3 Y-4 Y$

$17 \mathrm{Y}$

$5 \mathrm{Y}-6 \mathrm{Y}$

18Y-19Y

$17 \mathrm{Y}$

14Y-15Y-16Y

$11 \mathrm{Y}$

$11 \mathrm{Y}$

$4 \mathrm{~S}$

$7 \mathrm{Y}$

$1 \mathrm{C}$

2T

13Y-14Y

$4 \mathrm{Y}$

2S-3S 
Loma y Santos, Eduardo de la López Alcaraz, Ildefonso

Lozana, Vicente

M

Manrique, Jacinto

Martín Lozar, Manuel

Mazón y Valcárcel, Ramón de

Méndez-Vigo Santamarina, Antonio

Méndez-Vigo Santamarina, Ignacio

Menéndez, Baldomero

Merino, Anselmo

Moreno y Daoiz, Tomás

Mosquera, Diego Manuel de

Muñoz de San Pedro, José

$\mathbf{N}$

Navascués, Rafael

Negro, Rufo de

Núñez Arenas, José

O

Oller y Cánovas, Pedro

P Q

Paz, Abdón de

Peón y Heredia, Antonio $\mathrm{M}^{\mathrm{a}}$

Perabeles, Lorenzo

Perales, Juan

Ponzoá, José Antonio

Porro López Ulloa, Antonio

Quirós y Contreras, Benigno

$\mathbf{R}$

Reguera, Eugenio

Reynoso Oscariz, Mariano Lino

Rivero, Nicolás María

Rodríguez Camargo, José

Romero Leal, Bartolomé

Romo y Gamboa, Francisco

Rubí, Eugenio

Rubio Campos, Toribio

Ruiz Cermeño, Juan

Ruiz de Mendoza, Mariano

S

Saavedra, Domingo

Sagasti García-Herreros, Luis

Sánchez Gata, Julián

Sánchez Ocaña, Pedro (1)

Sanchez Ocaña, Pedro (2)

Santander Genaro

Sardina, Ramón

Sayró, Esteban

Seriñá, Primitivo

Sicilia, Felipe

Sierra, Bernardo

Somoza y Cambero, Manuel

T

Teijón y Rodríguez, Agustín Víctor

Torres Estelá, Matías

Trillo y Figueroa, Rafael

$\mathbf{U}$

Ureña y Cádenes, Manuel de

V

Villarías Ruiz, Gaspar

Villava, Ambrosio de

Villaverde, Manuel de
Gobernador

Gobernador

Gobernador

$7 \mathrm{Y}$

$17 \mathrm{Y}$

Jefe político

Jefe político inter.

$3 \mathrm{Y}$

$5 \mathrm{Y}$

16Y-17Y

$12 \mathrm{Y}$

$11 \mathrm{Y}$

$11 \mathrm{Y}$

$6 \mathrm{Y}$

$2 \mathrm{~T}$

$4 \mathrm{Y}-5 \mathrm{Y}$

$6 \mathrm{Y}$

$6 \mathrm{Y}$

$16 \mathrm{Y}$

$1 \mathrm{Y}-2 \mathrm{Y}$

Gobernador

Jefe político

Gobernador

Secretario Gob.

Jefe político

Intendente

Jefe político

Jefe político

Intendente

Jefe político

Secretario Gob.

Gobernador

Gobernador

Intendente

Gobernador

Jefe político

Secretario Gob.

Gobernador

Jefe político

Contador Rentas

Gobernador

Jefe político

Jefe político

Intendente

Jefe político

Gobernador inter.

Intendente

Intendente

Gobernador

Intendente

Secretario Gob.

Gobernador

Secretario Gob.

Secretario Gob.

Secretario Gob.

Gobernador

Secretario Gob.

Gobernador

Intendente
$3 \mathrm{~S}$

3

9

$3 \mathrm{~S}$

$1 \mathrm{C}$

$4 \mathrm{Y}$

$6 \mathrm{Y}$

$1 \mathrm{Y}$

$2 \mathrm{Y}$

$4 \mathrm{Y}$

$4 \mathrm{~S}$

$5 \mathrm{~S}$

$11 \mathrm{Y}$

$1 \mathrm{C}$

$5 \mathrm{~S}$

$1 \mathrm{Y}$

$17 \mathrm{Y}$

$16 \mathrm{Y}$

$4 \mathrm{Y}$

$3 \mathrm{Y}$

11Y

$4 \mathrm{Y}$

$4 Y$

2Y-3Y

$3 \mathrm{Y}$

$1 \mathrm{~S}$

$6 \mathrm{Y}$

$3 Y$

$3 \mathrm{~S}$

$3 \mathrm{Y}$

17Y-18Y

18Y-1S

4S

12Y-13Y-14Y

17Y-19Y

19Y

1S-2S

$5 \mathrm{~S}$

5Y-6Y-7Y

En total y a lo largo de todos estos años pasan por la Diputación setenta y siete gobernadores y diecinueve secretarios del Gobierno, es decir noventa y seis 
presidentes, tanto titulares como interinos de la Diputación, aunque algunos de ellos no llegaron a ejercer o no llegaban a tomar posesión como tales, en especial en los últimos años en los que se nombraba presidente a uno de los diputados electos, aunque como hemos repetido cuando el gobernador se presentaba, presidía. De todos ellos, cuarenta ejercían o siguieron ejerciendo la actividad política, veintidós pertenecían a la Administración, nueve eran militares, otros nueve se dedicaban a la política como diputados y de dieciséis se ignora sus actividades. Con respecto a los intendentes, son diecisiete los que ejercieron como vicepresidentes, que hicieron carrera en la Administración y que tres fueron militares.

De todos ellos, a continuación describimos una breve reseña biográfica.

\section{Adán y Castillejo, Rafael}

[Presidente de 5-II-1874 a 19-II-1874]

En el Boletín extraordinario de la provincia del 5 de febrero de 1874, anuncia que "en el día de hoy, me he encargado del Gobierno de la provincia, que el Poder Ejecutivo de la República se ha dignado confiarme por decreto del 31 del pasado mes". Acto seguido, y como viene siendo habitual en estos días, hace público un "Manifiesto a la Provincia" en la que resalta la grave situación social por la que atraviesa tanto la provincia como el país y hace votos por "sostener con energía el orden social para que tanto la industria como el comercio y la propiedad agrícola gocen de la tranquilidad pública necesaria para su desarrollo". En definitiva, es un discurso ampuloso y lleno de grandes y buenas intenciones, pero que no tendrá opción a desarrollar. A los quince días, es decir, el 19 del mismo mes, es cesado sin llegar a presidir ninguna sesión de la Diputación, y cede el mando de la provincia al secretario del Gobierno, Donato González Andrés, que actuará como interino hasta el mes de mayo del mismo año 1874.

\section{Águila, Luis del}

[Presidente de 10-IV-1820 a 25-X-1820]

Brigadier de los Ejércitos Nacionales. Comendador de la Real y Distinguida Orden Americana de Doña María Isabel La Católica. Comendador Militar de la Orden de San Fernando. Es nombrado jefe superior político de la provincia de Valladolid por real decreto de 30 de marzo de 1820, y toma posesión de su cargo de tercer presidente de la Diputación en la sesión del 10 de abril, manteniéndose en el puesto hasta el 25 de octubre del mismo año de 1820 , en que por otro real decreto de S.M. es nombrado jefe político de la provincia de La Mancha. Como presidente de la Diputación asiste a un total de setenta y seis sesiones.

\section{Aguilar, Joaquín}

[Vicepresidente de 16-X-1847 a 28-X-1847]

Por real decreto de 18 de junio de 1847, se anuncia el nombramiento de Joaquín Aguilar como nuevo intendente de la provincia, procediendo del mismo cargo en la provincia de Almería. Toma posesión de su cargo de vicepresidente de la Diputación, en la sesión que se celebra el día 16 de octubre, siendo esta la única sesión a la que asiste, pues en la siguiente, que se celebra el 22 de octubre, se presenta y actúa como vicepresidente con carácter interino el contador de Rentas D. Eustaquio García. Por real decreto de 28 de octubre de 1847 se le comunica el cese de su cargo.

\section{Alba, Joaquín Manuel de \\ [Presidente de 12-XII-1837 a 3-XI-1838]}

Es coronel de Infantería y gobernador militar del "Fuerte de San Benito" de Valladolid, cuando es nombrado jefe político de la provincia, por real decreto publicado en el Boletín Oficial $\mathrm{n}^{\circ} 142$ de fecha 12 de diciembre de 1837. En la sesión que celebra la Diputación ese mismo día, se presenta, presta juramento y toma posesión de la Presidencia como décimo tercer presidente, asistiendo a las dos últimas sesiones que se celebran en esta legislatura. El 26 de diciembre del mismo año 1837, 
preside la sesión de instalación de la nueva Diputación y se mantiene en el puesto la mayor parte del año 1838, tiempo en el que asiste a ochenta y tres sesiones.

En octubre de 1838, "por real orden de S.M., se le concede licencia por un mes para que pase a la Corte a restablecer su salud", pero ya no vuelve a Valladolid. El 3 de noviembre por real orden del mismo año es nombrado jefe político de Zaragoza, dejando al frente de la Jefatura de Valladolid de forma interina al secretario del Gobierno Luis Proyect. En el año 1859 es nombrado administrador de Rentas de la isla de Cuba y primer jefe de sección de la Dirección General de Ultramar ${ }^{910}$. En el año 1860, es nombrado intendente general del Ejército y Hacienda de Puerto Rico, cargo en el que se mantiene hasta el año 1866 , en que es cesado ${ }^{911}$.

\section{Álvarez, Miguel \\ [Presidente de 18-VII-1854 a 24-VIII-1854]}

Es nombrado gobernador civil de la provincia, por decreto de la Junta Provisional del Gobierno de la Provincia, de fecha 18 de julio de 1854, tomando posesión de su cargo en el mismo día. El 30 de julio preside la sesión de instalación de la nueva Diputación, y asiste y preside las quince sesiones que se celebraron hasta el día 14 de agosto, fecha en que es disuelta. El 17 de agosto del mismo año 1854 preside la sesión de instalación de la nueva Diputación y asiste a la sesión del día siguiente, que sería su última presidencia, pues el 24 de agosto envía a la Diputación un "manifiesto de despedida" comunicando su cese. Es el trigésimo sexto presidente de la Diputación, que permanece en el cargo un mes.

\section{Álvarez Cossío, Vicente \\ [Presidente interino de 1-VIII-1867 a 15-VIII-1867]}

En el año 1867 ejerce como presidente del Consejo provincial y en correspondencia a su cargo actúa como gobernador interino en las ausencias del titular. El 1 de agosto de 1867, se hace cargo del puesto y además, de la presidencia interina de la Diputación hasta que el día 15 de mismo mes "resigna el mando" en el capitán general al declararse el estado de guerra en la provincia.

\section{Arrieta, Laureano de \\ [Presidente de 3-I-1844 a 23 IV- 1846]}

Con categoría de "Secretario de S.M. con ejercicio de decretos..." es nombrado jefe político de la provincia de Valladolid, por real decreto de 3 de enero de 1844. Toma posesión de su cargo el día 12 del mismo mes y se convierte en el vigésimo quinto presidente de la Diputación. Como tal publica en su acto de investidura un "Manifiesto a la provincia" animando a la participación y el progreso a todos los habitantes de la misma. A los pocos días de iniciarse en el cargo, en la sesión del 30 de enero mantiene un enfrentamiento con parte de los diputados como consecuencia de las discusiones para la aprobación de la Ley de Ayuntamientos de 1840 y aplazada la votación para el 5 de febrero sólo se presentaron los diputados Alonso, Quintero, Rueda y Montealegre. El mismo día 5, de acuerdo y conjuntamente con el capitán general, declara el estado de excepción en la capital con la finalidad de "desarmar" a la Milicia Nacional. Estado que se levantó al día siguiente. El 29 de julio de 1845 preside el acto de instalación del Consejo provincial, tomando el juramento a los vocales electos. El 1 de noviembre de 1845 preside como rector accidental la apertura del curso de la Universidad. Por real decreto de 23 de abril de 1846, se le comunica su cese como jefe político de Valladolid y en el mismo decreto se le comunica el nombramiento de magistrado de la Audiencia de Pamplona. En el tiempo que ejerció como presidente de la Diputación, el más extenso del período, se mantuvo en el

910 B.O.P.V. $n^{\circ} 105$ de fecha 12 de julio de 1859.

911 B.O.P.V. $\mathrm{n}^{\circ} 197$ de 16 de diciembre de 1860 , en el que se publica el nombramiento. B.O.P.V. $\mathrm{n}^{\circ} 90$ de 13 de octubre de 1866 , en el que se publica el cese. 
ejercicio del cargo dos años y cuatro meses, asistiendo a un total de ciento cincuenta y cinco sesiones.

\section{Azcárate, Patricio}

[Presidente de 2-VII-1856 a 18-VII-1856]

Es un gobernador civil que apenas tuvo tiempo de ejercer el cargo. Tomó posesión el mismo día 2 de julio de 1856, fecha en la que se publica su nombramiento. Procede de la provincia de Vizcaya. Su presencia al frente de los destinos de la provincia es muy breve, y se reduce a los días transcurridos entre el 2 y el 18 de julio.

En este corto período de tiempo, la Diputación está suspendida en sus funciones, la provincia está declarada en estado de guerra, y a nivel nacional se producen cambios, con la dimisión de Espartero y la formación de un Gobierno moderado presidido por O’Donell. El gobernador Azcárate en estos quince días no hace otra cosa que tomar posesión y anunciar su cese, que se comunica el 18 de julio, al mismo tiempo que vuelve a ser nombrado gobernador de Vizcaya.

\section{Barbaza, Ramón}

[Vicepresidente de 3-IX-1842 a 3-XII-1842]

Es teniente coronel retirado de Infantería. El 3 de septiembre de 1842 publica en el Boletín Oficial de la Provincia una comunicación anunciando su nombramiento como intendente de la provincia, y como tal asiste a dos sesiones de la Diputación, hasta que en el mes de diciembre abandona el cargo.

\section{Bardaji, Pedro}

[Presidente de 15-I-1853 a 8-III-1853]

En el año 1852 ejerce como gobernador de la provincia de Burgos. En el año 1853, por real decreto, publicado en el Boletín Oficial de la Provincia del día 11 de enero, "se nombra gobernador de la provincia de Valladolid a D. Pedro Bardají, procedente del Gobierno de Burgos". Toma posesión el 15 de enero y se mantiene en el puesto hasta el 8 de marzo. En este tiempo preside una sesión de la Diputación, con una situación curiosa, ya que ejerce su cargo en el tiempo que transcurre entre el 15 de enero, fecha del cese del gobernador anterior Sr. Del Busto y su posterior nuevo nombramiento, que tiene lugar el 11 de marzo. Es el trigésimo cuarto presidente de la Diputación.

\section{Bonafós, Cayetano}

[Presidente de 27-XI-1858 a 20-II-1859]

Por real decreto de 27 de noviembre de 1858, es nombrado gobernador civil de Valladolid, tomando posesión del cargo el día 21 de diciembre. Su presencia al frente del Gobierno provincial es muy corta, pues el 20 de febrero de 1859, el Boletín Oficial de la Provincia publica un comunicado anunciando su despedida. No llegó a tomar posesión de la presidencia de la Diputación, al tener ésta suspendidas las sesiones en este tiempo. El mismo real decreto que notificaba su cese en Valladolid comunicaba su nombramiento como gobernador de la provincia de Valencia. El 26 de agosto de 1860 , se publica su nombramiento como gobernador de Granada, a la que pasa desde Valencia, y permanece en ese puesto hasta que el 17 de marzo de 1861 anuncia su renuncia al mismo por haber sido elegido diputado a Cortes. Por real decreto que se publica en el Boletín Oficial el 27 de febrero de 1863, es nombrado gobernador civil de Sevilla, cargo en el que dura poco tiempo, pues el 18 de mayo del mismo año cesa en Sevilla y es nombrado gobernador de Zaragoza. En el año 1866 es designado gobernador de Barcelona, tomando posesión el 13 de julio y permaneciendo en el cargo hasta el 8 de septiembre de 1867, fecha en la que se publica su nombramiento como jefe de la Sección de Orden Público del Ministerio de la Gobernación, "cesando en el Gobierno de Barcelona". El último destino conocido es el de director de Política del Ministerio de la Gobernación, cargo en el que es declarado cesante el 13 de octubre de 1868 . 


\section{Buch, Antonio}

[Presidente de 5-X-1822 a 24-IV-11823]

Es natural del lugar de Orán, perteneciente a la diócesis de Toledo. Estudió en la Facultad de Artes de la Universidad de Valladolid ${ }^{912}$. El primer cargo que desempeña es el de jefe político de la provincia de Zamora, en el que estuvo desde el 13 de marzo al 30 de septiembre de 1822. El día 5 de octubre, en la sesión que celebra la Diputación, se presentó y prestó juramento como nuevo jefe político. Es el octavo presidente de la Diputación, la cual presidió en noventa y cuatro sesiones entre el 5 de octubre de 1822 y el 22 de febrero de 1823 , fecha en que se celebra la última sesión. Continuó al frente de la Diputación hasta el día 24 de abril, en que ante la llegada de las tropas absolutistas del general O'Donell abandona la ciudad en dirección a Salamanca y Ciudad Rodrigo. La última noticia que tenemos de Buch es la de su detención en Ciudad Rodrigo, a la entrada de los absolutistas en la ciudad, en el mes de noviembre de 1823, junto al secretario del Gobierno político, Justo Galiano.

\section{Busto, Francisco del}

[Presidente de 7-XII-1852 a11-I-1853, de 4-III-1853 a 18-VII-1854 y de 31-X-1856 a 7-XII-1857]

En el año 1848 aparece como jefe político de la provincia de Burgos, según publica el Boletín oficial de la provincia del 1 de abril de 1848. En el año 1850, por real decreto de 15 de enero, es nombrado gobernador de la provincia de Logroño. En el año 1852, el 7 de diciembre, es nombrado gobernador de la provincia de Valladolid, tomando posesión de su cargo el día 30 del mismo mes. Con fecha 11 de enero de 1853 se publica un real decreto por el que se le cesa, y se le vuelve a nombrar gobernador de Burgos. Nuevamente el 4 de marzo del mismo año 1853, vuelve a ser nombrado gobernador de Valladolid, tomando posesión como trigésimo quinto presidente de la Diputación en la sesión que se celebra el 8 de abril. A partir de esta fecha asiste y preside las doce sesiones que se celebran hasta el final de la legislatura, que tiene lugar el 8 de marzo de 1854.

Continua al frente del Gobierno y de la nueva Diputación que se instala el 1 de abril de 1854, asistiendo a las cuatro sesiones que se celebran hasta el final de su vigencia. Acaba el 18 de julio, fecha en la que la Junta Provisional del Gobierno de la Provincia acuerda su destitución y, de esta forma, se inicia el Bienio Progresista. Una vez finalizado el período del Bienio, el 31 de octubre de 1856, es nuevamente nombrado gobernador de Valladolid, tomando posesión del cargo el día 11 de noviembre. El día 2 de diciembre de 1856, fecha en que inicia sus actividades la nueva Diputación, preside sus sesiones como el cuadragésimo segundo presidente de la misma. Se mantiene en el cargo hasta diciembre de 1857, tiempo en el que asiste a dieciséis de las veintisiete sesiones que se celebran. El 7 de diciembre de 1857 es nombrado gobernador de la provincia de Pontevedra. En febrero de 1858 cesa como gobernador de Pontevedra, y pasa a ejercer el mismo cargo en la provincia de Cádiz, manteniéndose en este puesto hasta el mes de julio del mismo año, en que es cesado.

\section{Buznego, Juan}

[Vicepresidente de 14-II-1843 a 5-I-1844, Presidente interino el X-1843]

El día 14 de febrero de 1843 se presenta en la Diputación para tomar posesión de su cargo de vicepresidente, al haber sido nombrado intendente de la provincia. Hasta el final de la legislatura, el 30 de octubre de 1843, asiste a dieciocho sesiones de la Diputación, ejerciendo como presidente de la misma durante el mes de octubre, ante la ausencia del titular. El día 1 de noviembre del mismo año 1843 asiste a la instalación de la nueva Diputación, manteniéndose en el cargo y asistiendo a seis

912 A.H.U.V.A. Caja 564. Con los certificados de los estudios realizados, en los que figura el lugar de Orán como perteneciente a la provincia de Lugo: "En el curso 1794-95 asiste a la Cátedra de Lógica dada por el profesor Gil_Carranza y a la Cátedra de Elementos Matemáticos dada por el profesor M. Hernando Eraso". 
sesiones. El 30 de enero de 1844 envía un oficio a la Diputación en el que comunica "que por decreto de 5 de enero próximo pasado, se le declara cesante de la Intendencia de Rentas y, hasta la llegada de su sucesor, deja el cargo de forma interina al contador de Rentas D. Francisco González de Alberu”. En este período asiste a dos sesiones.

\section{Campo, José María del}

[Presidente de 15-VIII-1846 a 10-III-1847]

En el año 1846 ejerce como jefe político de Granada, cuando por real decreto de 15 de agosto es nombrado para el mismo cargo en la provincia de Valladolid. Toma posesión, como vigesimoséptimo presidente de la Diputación el día 1 de octubre. Asiste únicamente a cinco sesiones, pues su permanencia en el cargo es muy breve. El 27 de febrero de 1847 anuncia la "concesión por parte de S.M. de una licencia de dos meses para pasar a la Corte". Situación que habitualmente supone que el cambio está cerca, lo cual se ratifica con el real decreto de 10 de marzo, por el que "cesa en el cargo de la provincia de Valladolid y se le nombra jefe político de la provincia de Sevilla". El 5 de enero de 1850 se le nombra gobernador de la provincia de Málaga, y el 14 de noviembre de 1857 es nombrado gobernador de la provincia de Badajoz.

\section{Castillo, Antonio del}

[Secretario de Gobierno de 14-II-1860 a 3-III-1863]

Toma posesión del cargo de secretario del Gobierno de Valladolid, el 14 de febrero de 1860. El 10 de agosto del mismo año 1860, ante la ausencia del gobernador Ibáñez de Aldecoa, ejerce como gobernador interino, hasta el 11 de septiembre. Vuelve a ejercer como tal gobernador interino en junio y septiembre de 1862 y en febrero de 1863. Permanece en el cargo hasta el 3 de marzo de 1863, fecha en la que se publica su cese.

\section{Castillón, Francisco}

[Gobernador militar-Presidente interino de 18-VII-1856 a 14-VIII-1856]

Desde febrero de 1852 ejerce el cargo de gobernador militar de Valladolid. Lo continuaba ejerciendo en el mes de julio de 1856, cuando al declararse el estado de guerra en toda la provincia, el capitán general Joaquín Armero y Peñaranda le ordena "hacerse cargo del Gobierno interino de la provincia, mientras llega el nuevo gobernador civil D. Antonio Méndez Vigo". Se trata de un período de una gran efervescencia social y política y que en Valladolid coincide con la revuelta del "motín del pan", la dimisión del gobernador Azcárate, y la ausencia de la autoridad provincial.

Su mando como gobernador de la provincia se extiende entre el 18 de julio y el 14 de agosto, y durante este tiempo, en que la Diputación está disuelta, demuestra su carácter militar y autoritario. Así queda reseñado en sus advertencias a la provincia ante el impago de las contribuciones o el nombramiento de la nueva Diputación. "Encargado hoy del Gobierno Civil de la provincia, a la vez que del Militar de la misma, he visto con desagrado no pocas quejas por conducto de la Delegación de Hacienda de los encargados de la recaudación de contribuciones... y no toleraré la menor falta y trataré como enemigos a los alcaldes que entorpezcan y a los contribuyentes que no hagan efectivas sus contribuciones. Valladolid a 23 de julio de 1856. Firmado Francisco Castillón" $"$.

También se encarga de los nombramientos de la Diputación, de acuerdo con su superior. "Por el Excmo. Sr. capitán general se me comunica la siguiente orden: Atendiendo a la necesidad de las Corporaciones Populares y en uso de las facultades extraordinarias de que me hallo revestido, he dispuesto, previo acuerdo con V.E., la designación de las personas en que habrá de renovarse la citada Corporación. Valladolid a 11 de agosto de 1856. Fdo. Francisco Castillón" $" 114$. 


\section{Ceruti, Ramón}

[Presidente de 3-VII-1840 a 10-IX-1840]

La misma real orden de 3 de julio de 1840 que establecía el cese de Jacinto Manrique anunciaba asimismo el nombramiento de nuevo jefe político de la provincia de Valladolid en la persona de D. Ramón Ceruti, que desempeñaba el mismo cargo en la provincia de Huelva. Se presenta en la sesión que celebra la Diputación el 13 de agosto, en la que juró la Constitución y tomó posesión de su cargo como decimoséptimo presidente de la institución. En la misma sesión leyó un "manifiesto" en el que daba detalles de todas las acciones que pensaba realizar para el bien de la provincia, especialmente en obras públicas, "con el impulso a las carreteras de Olmedo y Tordesillas". No tuvo más oportunidades, puesto que fue a la única sesión que asistió, ya que el 10 de septiembre, es decir, en menos de un mes, es destituido por la "Junta Provisional del Gobierno de la Provincia".

\section{Copeiro del Villar, Joaquín}

[Vicepresidente de 22-X-1835 a 1-I-1836. Interino en 1837]

Joaquín Copeiro del Villar y García de Alcaraz. Caballero de la Orden de

Carlos III. Maestrante de la Real Caballería de Ronda. Teniente coronel de la Milicia. De la Sociedad de Amigos del País de Sevilla. Contador de Rentas de la provincia de Valladolid, ejerce como intendente interino a partir de julio de 1835 , fecha de la jubilación del intendente titular Pedro Domínguez Caballero. En la sesión de instalación de la Diputación el 22 de octubre de 1835 se presenta y ocupa el cargo de vicepresidente de la institución. Se mantiene en el mismo hasta enero de 1836, fecha en la que deja el cargo al intendente titular. En este período asiste a cuarenta y ocho sesiones de la Diputación, tanto como vicepresidente, como también de presidente en funciones, al no asistir el jefe político. A lo largo del año 1837 continúa ejerciendo como contador de Rentas de la provincia, aunque sigue asumiendo el cargo de intendente interino ante las ausencias del titular. En consecuencia, asiste a las sesiones de la Diputación como vicepresidente. En el transcurso de la segunda Diputación isabelina, de octubre del 36 a diciembre del 37, asiste a doce sesiones de la Diputación, tanto como intendente interino cuanto como jefe político interino.

A principios del año 1839 es nombrado académico de la "Real Academia de Bellas Artes y Matemáticas de la Purísima Concepción de Valladolid". En el mes de agosto del mismo año 1839 cesa en el cargo de contador de la provincia, coincidiendo con el cese del intendente Sánchez Ocaña. En el año 1850 es ascendido a la categoría de intendente de primera clase y nombrado vocal de la "Junta de Calificación de Derechos de Clases Pasivas" $" 915$.

\section{Cuesta y Cossío, Manuel de la}

\section{[Presidente de 3-III-1848 a 31-I-1849]}

Natural de Tudanca, en la provincia de Santander, lugar donde nació en el año 1803. Inició sus estudios en el Seminario de Burgos, en el que realizó cursos de Lógica, Metafísica y Filosofía Moral. El 23 de noviembre de 1818 solicita el ingreso en la Universidad de Valladolid, donde inició los estudios en su Facultad de Leyes, en la que consiguió alcanzar el grado de bachiller en Leyes, en examen celebrado el 22 de junio de 1826. Continuó los estudios en la misma Facultad hasta alcanzar el grado de bachiller en Cánones, con fecha 3 de junio de 1830. En el año 1831 ingresó en el Colegio de Abogados de Valladolid, trasladándose a continuación a su pueblo de Tudanca, donde ejerció la abogacía. Se casó con Antonia de Arenal y Ponte. En el año 1836 es nombrado "Individuo de la Real Sociedad Cantábrica"916.

Su carrera política se inicia en el año 1835, cuando es nombrado diputado provincial de Santander, en la recién creada institución, por el partido judicial de 
Cabuérniga, cargo que desempeñó hasta agosto de 1836, fecha en la que se disolvió la Diputación. En el año 1837 es nuevamente elegido diputado provincial por el mismo partido, desempeñando el cargo hasta abril de 1840. El 7 de abril de 1840, de acuerdo con el real decreto de la misma fecha, es nombrado jefe político de la provincia de Zamora, manteniéndose en el puesto hasta el 1 de septiembre del mismo año, fecha en la que es cesado al hacer frente al pronunciamiento de las tropas partidarias del general Espartero.

Por real decreto de 20 de diciembre de 1843, es nombrado jefe político de la provincia de Logroño, donde implantó la Ley de Ayuntamientos y "actuó de forma rápida en el desarme de la Milicia Nacional". "Contribuyó a los primero ensayos de la Industria Sedera de la provincia" y "su comportamiento fue decisivo en la extinción de la partida levantada por el cabecilla Zurbano". Por real decreto de 27 de enero de 1845 "se le concede la Cruz supernumeraria de la Real y Distinguida Orden de Carlos III, para recompensar el celo, lealtad e inteligencia que había mostrado en el desempeño de su destino". Se mantiene en el cargo hasta el mes de mayo de 1845.

En la legislatura del año 1844, es nombrado diputado a Cortes por la provincia de Santander, "continuando en la legislatura de 1845 y en las dos del año 1846 ". Por real decreto de 14 de mayo de 1845 es nombrado jefe político de Vizcaya, provincia de la que también fue nombrado intendente. En este período puso en marcha el Consejo provincial y presidió las Juntas Generales, y se mantuvo en el cargo hasta el mes de abril de 1847 fecha en la que "cesó en ambos destinos por el mal estado de su salud, quebrantada en el servicio público".

En el año 1848, por real decreto de 3 de marzo, es nombrado jefe político de la provincia de Valladolid. Toma posesión de su cargo de vigésimo noveno presidente de la Diputación, en la sesión que se celebra el 12 del mismo mes de marzo, y presidió sus sesiones en veinticuatro plenos de la Corporación. En este tiempo es nombrado presidente de la Junta de Agricultura de la provincia. Se mantiene en el cargo hasta enero de 1849. Por real decreto de 31 de enero de 1849, es nombrado jefe político de la provincia de La Coruña, en la que trabajó eficazmente en la mejora y bienestar de los pueblos de esa provincia, aunque tuvo que cesar en el cargo porque "nuevamente volvió a resentirse gravemente su salud, y dejó el gobierno de la provincia el 31 de diciembre de 1849". A partir de esta fecha, abandonó la actividad política, aunque continuó en el ejercicio del servicio público. El 1 de mayo de 1850 , es nombrado rector de la Universidad Literaria de Valladolid, ciudad que ya no abandonaría y en la que se consolidó al ser nombrado "auxiliar de esta Audiencia, como abogado de ella, para sustituir a los magistrados en sus ausencias y enfermedades". Se mantuvo en ambos cargos hasta su fallecimiento, ocurrido el 31 de agosto de $1863^{917}$.

\section{Dacarrete, Ángel María}

[Presidente de 23 -IX-1864 a 15-II-1865]

El 23 de septiembre de 1864 se publica el real decreto de su nombramiento como gobernador de Valladolid, cesando en el cargo que desempeñaba con anterioridad de oficial del Ministerio de la Gobernación El día 5 de octubre, en la sesión que celebra la Diputación, toma posesión como el cuadragésimo octavo presidente de la misma, y en correspondencia con su cargo preside siete sesiones de la Corporación. Se mantiene en el cargo hasta el 15 de febrero de 1865, fecha en la que sin ningún aviso previo, deja de asistir a las sesiones, haciéndolo en su lugar el secretario del Gobierno Eugenio Rubí que también ejerce como gobernador interino. En el Boletín Oficial de la Provincia del 18 de julio de 1866, se anuncia su nombramiento como jefe de Administración de segunda clase, hasta que el 13 de ene ro

917 A.H.U.V.A. Caja 347. Resumen de los méritos y circunstancias relativas a D. Manuel de la Cuesta y Cossío, de fecha 11 de mayo de 1861. Notificación del fallecimiento del Sr. rector de la Universidad de Valladolid y detalle de los gastos ocasionados por su funeral celebrado el día 5 de septiembre de 1863 . 
de 1867, en el mismo periódico, se anuncia "la dimisión de Ángel María Dacarrete del cargo de jefe de Administración de segunda, por el mal estado de su salud".

\section{Domínguez Caballero, Pedro}

[Vicepresidente de 21-III-1820 a 15-IX-1822]

"Del Consejo de S.M. su secretario en ejercicio de decretos. Caballero pensionado de la Real y Distinguida Orden Española de Carlos III. Individuo de la Sociedad de Amigos del País de Córdoba Lucena y Baeza. Intendente del Ejército Nacional de Castilla la Vieja y de la provincia de Valladolid". Estos son los "méritos" que presenta el intendente, cuyo nacimiento situamos en la provincia de Córdoba. De sus primeras noticias sabemos que en el año 1819 ya ejercía como intendente de la provincia de Valladolid, y en consecuencia se considera el vicepresidente de la Diputación a partir del real decreto de su nueva instalación. El 21 de marzo de 1820 convoca a los antiguos diputados y celebra la sesión de instalación en ausencia del presidente jefe político.

Se mantiene en el cargo de vicepresidente de la Diputación en la mayor parte del Trienio, hasta el mes de septiembre de 1822, asistiendo en estos años a un total de noventa y una sesiones. Coincidiendo con el inicio de la "década ominosa", vuelve a ser nombrado intendente de la provincia de Valladolid. Entre 1824 y 1828 fue corregidor del Ayuntamiento y en este período "actuó con vigor contra los liberales". El día 15 de mayo de 1827 es nombrado individuo de la "Real Academia de Matemáticas y Nobles Artes de la Purísima Concepción". Continúa de intendente de la provincia durante todo el período absolutista, cargo en el que se mantiene hasta el año 1835, en que, con motivo de la nueva instalación de la Diputación Provincial, deja el cargo en el que es sustituido interinamente por el contador Joaquín Copeiro del Villar. En el año 1837, "traslada su domicilio a la Corte".

\section{Dordá, Miguel}

[Presidente de 18-VI-1836 a 9-IX-1836]

Es nombrado gobernador civil de la provincia de Valladolid, por real orden que se publica en el Boletín Oficial de la Provincia $\mathrm{n}^{\circ}$ 75, de fecha 18 de junio de 1836. Procede del mismo cargo ejercido en la provincia de León, toma posesión como undécimo presidente de la Diputación el día 6 de julio del mismo año de 1836. Apenas tiene tiempo de iniciar las actividades al frente de la institución, su gestión se limita a presidir dos sesiones, ya que es cesado en el cargo en el mes de septiembre, con apenas tres meses de permanencia en la Presidencia de la Diputación.

\section{Escoriaza, José Pascasio de}

[Presidente de 10-II-1869 a 31-V-1869]

Por decreto del gobierno provisional de 10 de febrero de 1869 , se le nombra gobernador civil de la provincia de Valladolid, y toma posesión del cargo el día 22 del citado mes. Durante el tiempo que ejerce como gobernador, asiste y preside las veintisiete sesiones que celebra la Diputación en este tiempo. El 31 de mayo de 1869 comunica a la Diputación "que en el día de hoy ceso en el cargo de gobernador de la provincia por haber sido trasladado a la de Barcelona. De conformidad con el artículo ochenta de la Ley Orgánica Provincial de 21 de octubre de 1868, queda encargado del mando interino de la provincia D. Francisco Rodríguez Rubio, vicepresidente de la Diputación" $"$.

\section{Espinosa, Carlos}

[Presidente interino de 3-XII-1820 a 28-XII-1822]

Mariscal de campo de los Ejércitos, es nombrado capitán general de Castilla la Vieja por real orden de 28 de noviembre de 1820, tomando posesión de su cargo el 3 de diciembre, y al mismo tiempo se hace cargo con carácter de interino de la Jefatura 
Política de Valladolid y al mismo tiempo de la Presidencia de la Diputación. Actúa como quinto presidente hasta el 20 de marzo de 1821, asistiendo en este tiempo a un total de seis sesiones. En la Capitanía General de Castilla la Vieja se mantiene en el cargo hasta el día 28 de diciembre de 1822. En 1837 vuelve a hacerse cargo de la Capitanía General, por nombramiento publicado en el Boletín Oficial de la Provincia $\mathrm{n}^{\mathrm{o}} 107$ de 5 de julio, tomando posesión de su cargo el 28 de agosto. En el mes de septiembre del mismo año 1837 tiene que hacer frente al peligro de invasión de la capital por parte de la "facción de Zariategui". Su comportamiento no es muy correcto, puesto que al igual que el jefe político Arenas, abandonan la ciudad ante la proximidad de las tropas rebeldes, que entran sin dificultades en la capital ante el abandono de los defensores. El 17 de octubre es destituido y en diciembre del mismo año de 1837, la Diputación Provincial redacta un informe "pedido por el fiscal de la causa mandada formar al general D. Carlos Espinosa, para la averiguación de su conducta militar en esta capital y provincia los días 15,16 y 17 de septiembre último".

\section{Fernández, Enrique}

[Gobernador interino 3-XI-1871 a 18-VI-1872]

En el mes de noviembre de 1871 aparece como secretario del Gobierno Civil de Valladolid, coincidiendo con la toma de posesión del gobernador titular Sr. Oller. Ante las repetidas ausencias del titular, ejerce como gobernador interino en diciembre de 1871 y en febrero, abril y mayo de 1872. En junio de 1872, ante la llegada del nuevo gobernador Vicente Lobit, es cesado.

\section{Fernández Enciso, José}

[Presidente de 26-III-1846 a 15-VIII-1846]

Según se publica en el Boletín Oficial de la Provincia de Valladolid, de fecha 28 de julio de 1846, es "abogado de los Tribunales Nacionales y Comendador de la Orden de Isabel la Católica”. En enero de 1846 ejerce como jefe político de tercera clase en comisión, en la provincia de Barcelona. Por real decreto de 26 de marzo de 1846 es nombrado jefe político de Valladolid, tomando posesión del cargo, y también el de presidente de la Diputación, en la sesión que se celebra el 25 de abril del mismo año. Es el vigesimosexto presidente. Se mantiene en activo durante un breve tiempo, ya que el 15 de agosto se publica una real orden por la que se le traslada con el mismo empleo a la provincia de Córdoba. En su tiempo de permanencia en Valladolid presidió los actos de la Diputación en siete ocasiones. Estando ya en su destino de Córdoba, envió un comunicado a la Diputación de Valladolid "presentando las cuentas desde el día 22 de abril, fecha de su toma de posesión, hasta el día en que cesó en el cargo" ${ }^{919}$. De la Jefatura Política de Córdoba pasó a ejercer el cargo de jefe superior de Policía de Madrid. Por real decreto de 15 de enero de 1850 es nombrado gobernador de la provincia de La Coruña.

\section{Fernández Queipo, José}

[Presidente de 8-VII-1822 a 4-X-1822]

El día 8 de julio de 1822 , en la sesión de reapertura de la Diputación, se presenta como nuevo jefe superior político y séptimo presidente de la Diputación provincial. Se mantiene en el cargo por un corto espacio de tiempo, pues el 4 de octubre abandona la Presidencia habiendo asistido en este tiempo a un total de veintiuna sesiones.

\section{Fuente Alcántara, José de la}

[Presidente de 22-II-1865 a 20-VI-1865]

Por real decreto de 22 de febrero de 1865, es nombrado gobernador de la provincia de Valladolid, tomando posesión de su cargo el 14 de marzo. En la primera reunión ordinaria de 1865 que celebra la Diputación el 18 de abril, se presenta, toma 
posesión como el cuadragésimo noveno presidente de la institución y preside la sesión que se celebra el citado día. La presidirá en otras dos ocasiones más, en el corto período de tiempo que permanece en activo en su cargo provincial. El 20 de junio del mismo año 1865 publica en el Boletín Oficial una circular anunciando que "en este día ceso en el mando del Gobierno de la provincia en virtud de lo dispuesto por el real decreto de 15 del corriente, en el que S.M. se ha dignado trasladarme al de la provincia de Granada, quedando encargado interinamente del gobierno el secretario D. Eugenio Rubí”.

\section{Fuentes, Miguel María}

[Presidente de 7-III-1851 a 12 -IV-1851]

En el año 1850 ejerce como gobernador de la provincia de Toledo. Es jefe de Administración de primera clase. Por real decreto de 7 de marzo de 1851 es nombrado gobernador de la provincia de Valladolid, tomando posesión del cargo el 20 de marzo, siendo cesado en el cargo por otro decreto de 12 de abril. En este corto período de tiempo, 22 días, no llega a tener relación alguna con la Diputación, en un tiempo en que no había sesiones, por lo cual no se le tiene en cuenta como presidente de la institución. En el año 1861, aparece como contador general de la Deuda Pública.

\section{Gallostra y Frau, José}

[Presidente de 7-VII.1865 a 15-IV-1866 y 9-II-1871 a 8-IV-1871]

Nació en Peralta (Navarra), el 23 de abril de 1833. Licenciado en Derecho por la Universidad de Madrid. Funcionario con la categoría de Ordenador de Pagos del Ministerio de la Gobernación. Afiliado políticamente al partido unionista.

A través de las informaciones procedentes de los Boletines Oficiales, se conocen las ciudades a las que fue destinado como gobernador. El 18 de octubre de 1861 se publica su nombramiento como gobernador civil de la provincia de Salamanca. El 2 de mayo de 1862 se anuncia su cese en Salamanca y el nombramiento como gobernador de Albacete. El 5 de junio de 1863 se anuncia su traslado a la provincia de Alicante y el 7 de octubre del mismo año se publica su cese en Alicante y su traslado a la provincia de Burgos. En el año 1864 ejerce como gobernador civil de la provincia de Murcia hasta el 25 de septiembre en que es trasladado desde Murcia al Gobierno Civil de Vizcaya. El 7 de julio de 1865 toma posesión de su cargo de gobernador civil de la provincia de Valladolid "que S.M. La Reina se ha dignado confiarme por real decreto de 28 de junio pasado". El 22 de julio preside la sesión de la Diputación, convirtiéndose en el quincuagésimo presidente de la misma y asiste y preside, a partir de esta fecha, las nueve sesiones que celebra la Diputación en lo que resta de legislatura, que finaliza el 31 de diciembre de 1865. El 1 de enero de 1866 preside la sesión de instalación de la nueva Diputación, de forma que es el único gobernador que en todos estos años ha asistido a todas las sesiones que ha celebrado la Diputación durante su mandato.

El 15 de abril de 1866 el Boletín Oficial de la Provincia, comunica que "habiendo sido nombrado Ordenador General de Pagos del Ministerio de la Gobernación por real decreto de 11 de abril, ceso en el mando de esta provincia, quedando encargado del gobierno de la misma el secretario D. Bernardo Sierra, con arreglo al artículo noveno de la Ley de 25 de septiembre de 1863 ”. Se mantiene en el Ministerio de la Gobernación poco tiempo, pues el 18 de julio del mismo 1866 se publica su dimisión como "Ordenador General de Pagos". Vuelve a la actividad política en la época del Sexenio Revolucionario, a través del decreto de la Presidencia del Consejo de Ministros de 9 de febrero de 1871 por el que, "atendiendo a las circunstancias que concurren en D. José Gallostra y Frau, Ordenador General de Pagos, cesante, del Ministerio de la Gobernación, vengo en nombrarle gobernador civil de la provincia de Valladolid". Toma posesión de su cargo el 14 del mismo mes y año y el 17 preside la sesión de instalación de la nueva Diputación Provincial, siendo a la única sesión a la que asiste. El 24 del mismo mes de febrero de 1871 preside la 
primera sesión de la recién creada Comisión provincial o Comisión permanente, órgano de apoyo a la Diputación creado por la Ley de Organización Provincial de 20 de agosto de 1870. El 26 de marzo de 1871 se ausenta con licencia, dejando como gobernador interino al secretario interino y no vuelve a su puesto, ya que por decreto de S.A. el Regente de 8 de abril "es cesado en su cargo de gobernador". En las elecciones de 1871, es elegido diputado a Cortes por Palencia. En 1872 se presenta y es elegido por Puerto Rico. En 1873 es diputado a Cortes por Almadén (Ciudad Real). En la Restauración continúa con su actividad política al presentarse y ser elegido senador por Valladolid en las elecciones celebradas en los años 1879 y 1881, con la característica de ser uno de los escasos "cuneros" presentados y elegidos en la provincia. Es ministro de Hacienda en los años 1883-84 ${ }^{920}$. Falleció en Madrid el 14 de febrero de 1888 .

García-Pizarro y Zaldúa de Gambeo, Rafael. Marqués de Casa Pizarro [Vicepresidente de 1-I-1836 a 1-X-1836. Presidente interino de XII-1840 a 31-I-1842]

Rafael García-Pizarro y Zaldúa de Gambeo, marqués de Casa-Pizarro, vizconde de la Nueva Orán es Caballero del hábito de Santiago, Comendador de la Real Orden Americana de Isabel La Católica y socio de número de la "Sociedad de Amigos del País de Toledo".

En el mes de enero de 1836 toma posesión de su cargo de subdelegado de Rentas y Loterías e intendente de la provincia de Valladolid. A la vez toma posesión en el mismo mes de la vicepresidencia de la Diputación. Se mantiene en el cargo hasta el mes de octubre, asistiendo en este tiempo a nueve sesiones. Coincidiendo con la instalación de una nueva Diputación, en octubre de 1836, deja la Intendencia de Valladolid, al haber sido nombrado intendente de la provincia de Ávila. En el mes de diciembre de 1840 vuelve nuevamente a ser nombrado intendente en la provincia de Valladolid, manteniéndose en el cargo hasta el mes de enero de 1842. Asiste en este tiempo a ocho sesiones de la Diputación, la mayoría de ellas como presidente interino por ausencia del titular. En el mes de febrero de 1842 comunica su traslado como intendente a la provincia de Oviedo. En abril de 1866 aparece en el Boletín Oficial de la Provincia el anuncio de su nombramiento como gobernador civil de Segovia.

\section{Guerra, José Rafael}

[Presidente de 15-I-1850 a 19-VI-1950 y 12-IV-1851 a 7-XII-1852]

El 29 de diciembre de 1849 se publica el real decreto de su nombramiento como gobernador de la provincia de Valladolid, procedente de la Jefatura Política de Zaragoza. Es la primera personalidad que ostenta el nombre de gobernador.

Toma posesión de su cargo el 15 de enero de 1850, y preside la sesión de instalación de la nueva Diputación, como trigésimo segundo presidente de la misma, en la sesión del 3 de abril. Ejerce el cargo, por un corto espacio de tiempo, hasta el 19 de junio del mismo año, período en el que asiste a cuatro sesiones de la Corporación. El 19 de junio de 1850, es nombrado gobernador de la provincia de La Coruña, en virtud del real decreto emitido el mismo día. El 12 de abril de 1851, es nombrado nuevamente gobernador de la provincia de Valladolid, tomando posesión del cargo de presidente de la Diputación en la sesión que se celebra el 30 del mismo mes. Se mantiene en el cargo hasta diciembre de 1852, asistiendo en ese segundo periodo a veinticinco sesiones de las dos Diputaciones que presidió. El día 7 de diciembre de 1852 es nombrado gobernador de Badajoz.

\section{Guerra, Matías}

[Presidente de 9-XII-1838 a 22-I-1839]

Es nombrado jefe político de la provincia de Valladolid por real decreto de 24 de noviembre de 1838. Procede del mismo cargo en la provincia de Alicante. El día 9

\footnotetext{
${ }^{920}$ CARASA SOTO, Pedro (Dir.). Diccionario Biográfico de parlamentarios ... ob. cit. pág. 391
} 
de diciembre toma posesión, comunicando a la Diputación en el mismo día "haberme encargado del mando de la provincia". El día 11 de diciembre, en la sesión que celebra la Diputación, se presenta, presta juramento y toma posesión como decimocuarto presidente de la institución, siendo su presencia al frente de la misma muy breve. Asiste únicamente a dos sesiones, ya que el día 22 de enero de 1839 el Boletín Oficial publica la real orden por la que "se cesa en la Jefatura Política de la provincia al Sr. D. Matías Guerra".

Goicoechea, José de

[Vicepresidente el 23-V-1822 a 30-V-1822 y de 1-IX.1822 a 24-IV-1823]

Es natural de la villa de Bilbao, perteneciente a la diócesis de Calahorra. Inició sus estudios superiores en la Universidad de Oñate en la que estudió Filosofía Moral durante el curso 1787-88, al curso siguiente pasó a la Universidad de Zaragoza, donde estudió $1^{\circ}$ de Leyes, y volvió a Oñate en el curso 1789-90 donde se matriculó de $2^{\circ}$ de Leyes. En el año 1790 solicita su ingreso en la Universidad de Valladolid, en la que continúa sus estudios de leyes. El 30 de mayo de 1792 "solicita le sea concedido el grado de bachiller en Leyes por parte de la Facultad de Leyes de la Universidad de Valladolid ${ }^{921}$.

En el mes de mayo de 1822, es nombrado intendente de la provincia de Valladolid, siendo presentado en la sesión del día 23 , en la que además actúa como presidente interino, ante la ausencia del titular. No vuelve a presentarse en la Diputación y en el mismo mes pasa un oficio, despidiéndose de los diputados "por haber sido trasladado a la Intendencia de Mallorca". Vuelve a aparecer como intendente de Valladolid en septiembre de 1822 y se mantendrá en el puesto has ta la llegada de los absolutistas. El 24 de abril de 1823 se queda al mando de la Jefatura Política y la Presidencia de la Diputación, con carácter interino al abandonar la ciudad el titular Sr. Buch. En este período asiste a un total de ciento trece sesiones. En el mes de mayo de 1823, ya con la Diputación disuelta, anuncia su marcha a Madrid.

\section{Gómez Díez, José}

[Presidente de 24-V-1869 a 16-III-1870]

Natural de Palencia, ciudad en la que nació en el año 1831. "En el año 1845 solicitó el ingreso en la Universidad de Valladolid, matriculándose en su Facultad de Filosofía, donde cursó estudios entre 1845 y 1849. El 27 de junio de 1849 solicitó ser examinado para alcanzar el grado de bachiller en Filosofía, acompañando los certificados de los cursos probados. Examinado los días 30 de junio y 4 de julio resultó aprobado por tres votos contra dos" ${ }^{222}$.

El 24 de mayo de 1869, por decreto del presidente del Poder Ejecutivo, es nombrado gobernador civil de la provincia de Valladolid, tomando posesión del cargo el 10 de julio del mismo año, manteniendo el mando y asistiendo y presidiendo dos sesiones de la Diputación hasta el 10 de octubre de 1869, día en el que "resigna el poder en el capitán general, al declararse el estado de guerra en todo el distrito". La cesión del poder al capitán general no supone su cese, sino que prácticamente está a las órdenes de la autoridad militar. Conforme a esta situación, el 18 de octubre preside la sesión de instalación de la nueva Diputación "de acuerdo con la comunicación pasada por el Sr. capitán general, por continuar declarado el territorio en estado de guerra". El 19 de diciembre del mismo año 1869 vuelve a tomar la total responsabilidad y mando de la provincia al levantarse el citado estado de guerra, al mismo tiempo que el Regente del Reino, "en premio a sus desvelos a favor de la provincia, le concede la Gran Cruz de Isabel la Católica"923. A lo largo de esta

921 A.H.U.V.A. Caja 434, con los expedientes de los cursos aprobados en la Facultad de Leyes: Decretales, Instituciones Canónicas y Quinario de Leyes. Se le concede el grado de licenciado en Leyes.

922 A.H.U.V.A. Caja 508 (doc. 356-360).

923 A.D.P.V. Actas. Libro de actas del 20 de octubre de 1869. 
Diputación sólo ha presidido la sesión de instalación, y vuelve a presidir la sesión del 5 de marzo de 1870. En ella anuncia que, de acuerdo con el decreto del 2 de marzo, se le admitía su dimisión, aunque un telegrama que se lee en el mismo día y procedente del ministro de la Gobernación "le ordena mantenerse en el cargo hasta nuevo aviso". Este aviso se hará efectivo el 16 de marzo al publicarse en el Boletín Oficial la comunicación "del cese del gobernador y la toma de posesión del nuevo propietario".

Durante su mandato como gobernador de la provincia actúan como secretarios del Gobierno Gaspar Villarías Ruiz hasta el 11 de enero de 1870, fecha en la que se anuncia su traslado al mismo cargo en Oviedo, y a partir de esa fecha lo hará Joaquín Félix Barbeito, nombrado al efecto por orden ministerial de 18 de diciembre de 1869, y se mantendrá en el puesto hasta el 27 de marzo del mismo año.

\section{González-Alegre y Álvarez, José}

[Presidente de 8-III-1873 a $234-\mathrm{V}-1873$ ]

"Libertad, Orden y Justicia es el lema de la República, y el ideal de mis creencias" son las primeras palabras que pronuncia en el acto de toma de posesión del cargo de gobernador de la provincia de Valladolid, que se celebra el día 8 de marzo de 1873. Por ellas se adivina su pertenencia al partido republicano. El día 11 se presenta en la Diputación, preside la sesión, y en su discurso se presenta "como delegado del Poder Ejecutivo de la República, ofrezco mi apoyo a la Diputación para sostener los principios de esta forma de gobierno proclamada por la Asamblea Nacional" "924. La parte central de la alocución es una petición de ayuda a la Diputación para mantener el orden público, apelando "al republicanismo del pueblo vallisoletano". Finalizado el discurso y sin entrar en el orden del día, "se retiró para atender los asuntos que le están encomendados". Vuelve a la Diputación en una segunda ocasión el 29 de mayo de 1873, en la que anuncia su despedida "por haber sido nombrado diputado a Cortes. Agradece las atenciones recibidas y recuerda que sus padres murieron en Valladolid y tiene parientes en la ciudad".

\section{González Andrés, Donato}

\section{[Presidente interino de 20-II-1874 a 30-V-1874]}

El 20 de febrero de 1874 hace público un comunicado en el que anuncia que "en el día de hoy he tomado posesión del cargo de secretario del Gobierno Civil de esta provincia, y de gobernador interino de la misma por ausencia del propietario" $" 925$. Como gobernador interino convoca a la Diputación, para celebrar sesión extraordinaria el 9 de marzo, para tratar el tema de presupuestos. A esta sesión no se presenta, pero en ella se da lectura a una comunicación del capitán general, en la que "en uso de las facultades extraordinarias de que me hallo investido anuncio el nombramiento de nuevos diputados". El 27 de abril, comunica nuevamente a la Diputación su decisión de suspender la sesión prevista para el 11 de mayo. A la vez anuncia el cese de siete diputados y el consiguiente nombramiento de otros nuevos para cubrir las bajas. Acuerda el mismo día 11 la finalización de la legislatura. Cesa en sus funciones el 30 de mayo, con la presentación del gobernador titular, Ambrosio de Villava y del nuevo secretario Rafael González Liquinano.

\section{González Gutiérrez, Cándido}

[Presidente de 5-I-1874 a 31-I-1874]

Nace en Ciguñuela (Valladolid) el 10 de marzo de 1820, hijo de Gaspar y de Paula. Estudió en la Facultad de Derecho de la Universidad de Valladolid, recibiendo el título de licenciado en Jurisprudencia. Ingresó en el Colegio de Abogados de Valladolid en 1846. El 24 de mayo de 1855 se casó con Isabel Hickmann.

En política fue un destacado progresista que trabajó por el triunfo de la revolución de 1868, y una vez que ésta triunfó, la Junta Revolucionaria le eligió como

924 A.D.P.V. Actas. Libro de actas del 11 de marzo de 1873.

925 B.O.P.V. ${ }^{\circ} 28$ de fecha 22 de febrero de 1874. 
nuevo alcalde, cargo en el que permaneció tres meses en los que trabajó por mejorar la institución, de acuerdo con sus ideales revolucionarios, e intentar encauzar la precaria situación económica del Ayuntamiento. En 1871 fue candidato en las elecciones a diputado provincial ${ }^{926}$.

El 5 de enero de 1874, el capitán general de Castilla la Vieja, Eulogio González, publica el siguiente bando dirigido a Cándido González Gutiérrez: "en virtud de las facultades que me confiere el Poder Ejecutivo de la República, queda V.S. nombrado por la presente disposición gobernador civil de la provincia. Valladolid, 5 de enero de 1874. Firmado: Eulogio González. Este nombramiento se completa con la toma de posesión celebrada el día 11 del citado enero. También realiza una "Proclama a los habitantes de Valladolid" en la que informa que desea mantener el orden público ${ }^{927}$. Estas buenas intenciones del recién nombrado gobernador, duran poco tiempo, veinte días, pues el 31 de enero es cesado en su cargo según decreto del Gobierno de la República.

Con la llegada de la Restauración siguió con sus inquietudes políticas y colaboró en el arranque del partido socialista. En 1906 fue proclamado presidente del partido liberal, pero no volvió a ocupar ningún otro cargo oficial. Falleció en Valladolid el 19 de abril de 1915.

\section{González Liquinano, Rafael}

\section{[Secretario de Gobierno de 25-V-1874 a 4-I-1875]}

El 30 de mayo de 1874 aparece como secretario del Gobierno Civil, coincidiendo con el nombramiento del nuevo gobernador Ambrosio de Villava con el que se mantiene en el puesto el mismo tiempo que el gobernador, al que suple en sus ausencias como gobernador interino en los meses de octubre de 1874 y enero de 1875 . En este último mes convoca a la Diputación el día 8: "siendo de urgente necesidad la reunión del Pleno de la Diputación de esta provincia para adoptar los acuerdos y resoluciones que procedan con motivo del cambio político últimamente realizado a consecuencia de la proclamación como Rey de España a D. Alfonso XII ruego a V.S. se sirva asistir a la reunión extraordinaria a celebrar el día 11 del presente mes". Siendo su última actuación, tanto como secretario como gobernador interino, pues la sesión del día 11 está presidida por el gobernador titular Mariano Lino de Reynoso y Oscáriz.

\section{González Marino, Manuel}

\section{[Secretario del Gobierno de 30-VII-1867 a 30-XII-1868]}

Al cese del anterior secretario Bernardo Sierra, le sucede por corto tiempo Rafael Trillo Figueroa, hasta que por real orden de 30 de julio de 1867 es nombrado nuevo secretario del Gobierno Civil de Valladolid Manuel González Marino, cargo en el que permanece hasta el mes de diciembre de 1868. En septiembre de 1867 ejerce como gobernador interino ante la ausencia del titular Manuel Ureña Cádenes.

\section{Gusano, Manuel}

[Presidente de 26-XII-1854 a 9-VIII-1855]

Ejerció el cargo de diputado provincial en la cuarta Diputación isabelina entre los años 1842 y 1843. Continuó como tal diputado en la quinta Diputación que transcurre entre 1843 a 1847 , en ambas legislaturas representando al partido de Villalón. En el año 1854 es nombrado nuevamente diputado provincial por Villalón en las novena y décima Diputación. Dejó el cargo al poco tiempo de iniciarse las

${ }^{926}$ CARAS A SOTO, Pedro (Dir.). Diccionario biográfico de Alcaldes .... ob. cit. pág. 405.

927 “el Excmo. Sr. capitán general ha tenido a bien nombrarme nuestro gobernador civil, atendiendo, si es posible decirlo, más al cariño fraternal que me profesa, que a las condiciones que en mí concurren, para desempeñar un puesto tan importante en las circunstancias actuales. Con el objeto de corresponder dignamente a su confianza y a la del Gobierno de la República, estoy resuelto a sostener el orden público, suprema necesidad en estos momentos críticos...”.B.O.P.V. Boletín extraordinario del día 11 de enero de 1874 
actividades de esta última, al ser nombrado gobernador civil de la provincia y en consecuencia trigésimo octavo presidente de la Diputación. Su mandato se extiende entre el 26 de diciembre de 1854 y el 9 de agosto de 1855 . Ver más información biográfica en el apartado correspondiente a los diputados provinciales.

\section{Gutiérrez, Juan}

[Presidente de 11-XI-1840 a 7-XII-1841]

Por real decreto de 11 de noviembre de 1840, la Regencia Provisional del Reino le nombra jefe político de la provincia de Valladolid, procedente de la provincia de Lérida donde desempeñaba el mismo cargo. En la sesión que celebra la Diputación el 14 de diciembre se presenta, presta juramento y toma posesión de su cargo como decimoctavo presidente de la Corporación, asistiendo en esta legislatura a las dos últimas sesiones. En enero de 1841, preside la instalación de la nueva Diputación, de carácter progresista, que se corresponde a nivel nacional con la Regencia del general Espartero. Se mantiene al frente de la misma hasta el mes de diciembre, cuando el día 7 se publica en el Boletín Oficial de la Provincia su nombramiento como jefe político de Barcelona. La noticia se completó con la comunicación, hecha el 14 de diciembre, en la que se explicaba que, "por decreto de 6 del mes anterior, había sido trasladado al Gobierno Político de Barcelona, y manifestaba el profundo sentimiento que le causaba el separarse de los individuos de esta Corporación, con cuya amistad se había honrado...". En su tiempo de estancia en Valladolid asistió a cincuenta y una sesiones de la Diputación. En el año 1854 se publica su nombramiento como gobernador de La Coruña. No hay noticias de su tiempo de estancia en Barcelona, ni tampoco de su posible destino en otras provincias.

\section{Hermida, Bartolomé}

[Presidente de 6-IV-1864 a 2-VI-1864]

El Norte de Castilla del 7 de julio de 1858 publica una serie de noticias políticas, entre las que destaca el cese de Bartolomé Hermida como gobernador de la provincia de Granada. También se hace eco de que, "a pesar de los numerosos cambios políticos que se producen en esta época, sólo diez de los gobernadores nombrados son de ideas progresistas". En febrero de 1864 es nombrado gobernador civil de la provincia de Zaragoza, cargo en el que está por un corto tiempo, puesto que por real decreto de 6 de abril del mismo año es nombrado para el mismo empleo en Valladolid. El 19 de abril toma posesión de su destino y en la misma fecha publica una circular "A los habitantes de la provincia" en la que anuncia sus intenciones ${ }^{928}$.

A partir de esta fecha mantiene una gran actividad, publicando circulares y exigiendo a todos los pueblos el cumplimiento de sus obligaciones. El 10 de mayo, con ocasión de la apertura de la reunión extraordinaria de la Diputación, preside sus sesiones como el cuadragésimo séptimo presidente de la misma desde su creación. En una de sus circulares y conociendo su próximo relevo y los frecuentes cambios en los gobiernos provinciales, advirtió que "sucede de ordinario que cuando hay cambio de autoridades, se cree que las providencias dictadas y aún no ejecutadas por el saliente quedan como en suspenso, ínterin el entrante no las confirme. Esto es una equivocación, la autoridad es siempre la misma y la variación de la persona no afecta. Entiéndase y cúmplase lo acordado".

El día 2 de junio ha dejado el mando de la provincia en manos del secretario, Ramón de Mazón y Valcárcel y no se producen más noticias hasta el recuerdo póstumo que se hace en la sesión de la Diputación del 5 de octubre de 1864, en la que "se acuerda abonar 465 reales de gastos por motivos de haber depositado en la capilla

928 “S.M. La Reina se ha dignado honrarme con su confianza, encargándome del Gobierno Político y Administrativo de esta hermosa y siempre leal provincia. No esperéis de mi, pomposos ofrecimientos, no soy hombre de programas. Mi programa es mi deber y mi más claro y ardiente deseo llenarlo tan cumplidamente como conviene a nuestro bienestar y tranquilidad. Justicia y fomento fueron siempre las bases principales de mi administración y lo serán aquí....”. 
provincial de San Gregorio los restos mortales del Ilmo. Sr. gobernador D. Bartolomé Hermida".

\section{Herrero Ceruelo Prieto, Mariano}

[Presidente de 10-III-1847 a 9-III-1848 y 6-VIII-1866 a 26-IV-1867]

Natural de Palencia, ciudad en la que nació el 9 de noviembre de 1796, hijo de Matías Herrero Prieto, nacido en la localidad de Villafrades de Campos, y de María Jacinta Ceruelo. Su padre ejerció la abogacía en Valladolid y posteriormente pasó por varios cargos de la Administración. Mariano Herrero Ceruelo cursó estudios en la Facultad de Derecho de la Universidad de Valladolid, donde obtuvo el grado de bachiller en Leyes en el año 1818. Se casó en Béjar, ciudad de la que era Corregidor, el 20 el junio de 1825, con Micaela Sánchez Ocaña y López de Ontiveros, sobrina de Pedro Sánchez Ocaña, que fue jefe político e intendente de Valladolid entre 1837 y 1840. El matrimonio tuvo cinco hijos.

Continuó su carrera en la Administración, ejerciendo el cargo de fiscal del crimen en Valencia y comisario regio en Murcia, y una vez finalizado el régimen absolutista de Fernando VII, y a pesar de sus servicios en estos años, pasó como oidor a la Audiencia de Valladolid, y posteriormente a la de La Coruña. En política es conocido como un convencido absolutista. En el año 1840 es nombrado jefe político interino en León, aunque no llegó a ejercer el cargo al ser destituido por las nuevas autoridades progresistas. Entre 1844 y 1846 ejerce como jefe político en varias provincias, hasta que con fecha 10 de marzo de 1847, se publica un real decreto por el que se le nombra jefe político de Valladolid. Se comunica en el mismo decreto su cese en el mismo cargo que hasta la fecha desempeñaba en la provincia de Salamanca. Tomo posesión como el vigésimo octavo presidente de la Diputación, en la sesión que se celebra el día 3 de abril, asistiendo como tal a las doce sesiones que se celebran en el final de esta legislatura. El día 15 de agosto del mismo año 1847 preside la sesión de instalación de la nueva Diputación, tomando el juramento a los nuevos diputados. Se mantiene al frente de la Jefatura Política y de la Presidencia de la Diputación hasta el día 9 de marzo de 1848. En esta fecha se publica en el Boletín Oficial de la Provincia una "Circular del Gobierno Político" en la que se comunica que, "habiéndose dignado S.M. (q.D.g.) nombrarme inspector del Cuerpo de Administración Civil y debiendo cesar en el mando civil de la provincia, se ha hecho cargo del mismo D. Manuel de la Cuesta...". En el tiempo en que ejerció la Presidencia de la Diputación en esta legislatura, asistió a las doce sesiones celebradas. En el año 1849, según refleja el Libro de Actas del 21 de enero, la Diputación "acuerda devolver 1.900 reales a D. Mariano Herrero, que había adelantado en su época de jefe político".

Mantuvo su vinculación con la provincia de Valladolid, como lo demuestra su elección de diputado a Cortes por el partido de Medina, en las elecciones celebradas en mayo de 1851 y en febrero de 1853. En 1853 es nombrado gobernador civil de Santander ${ }^{929}$. Durante la vigencia del Bienio Progresista, está cesante en sus trabajos con la Administración. En el año 1858, el Boletín Oficial de la Provincia de fecha 16 de febrero comunica su nombramiento como jefe de Administración del Ministerio de la Gobernación. En el año 1866, por real decreto publicado en el Boletín Oficial de 17 de julio "se nombra gobernador civil de la provincia de Valladolid a D. Mariano Herrero, director general de Administración Local del Ministerio de la Gobernación".

En la sesión de la Diputación que se celebra el 6 de agosto se presenta nuevamente y toma posesión, como el quincuagésimo primer presidente de la Corporación, asistiendo como tal a cuatro sesiones. Comunica en la última, celebrada el 24 de octubre del mismo año 1866, el decreto del Ministerio de la Gobernación "ordenando disolver las Diputaciones provinciales, y proceder a la elección de todos sus miembros en los días 25-26 y 27 de noviembre de 1866”. El 1 de enero de 1867

\footnotetext{
${ }^{929}$ CARASA SOTO, Pedro (Dir.). Diccionario biográfico de parlamentarios.... ob. cit. pág. 531.
} 
preside la sesión de instalación de la recién nombrada Diputación, encabezando las cuatro sesiones que se celebran en el mes. En la sesión del 21 de marzo se recibe en la Diputación una comunicación del gobernador, anunciando su dimisión. Se confirma posteriormente en el Boletín Oficial de la Provincia del día 26 de mayo, al publicar el real decreto por el que "S.M. acepta la dimisión del gobernador de Valladolid por motivos de salud".

Finalmente, y ya en los comienzos del Sexenio Revolucionario, el 12 de octubre de 1868, el Boletín Oficial de la Junta Revolucionaria de Valladolid publica un decreto en el que se hace ver que, "considerando los antecedentes políticos de D. Mariano Herrero Ceruelo Prieto, gobernador que fue de esta provincia, se le declara privado de todos sus derechos activos y pasivos, excluyéndole de la misma como empleado cesante". Fallece en Madrid el 18 de marzo de 1875.

\section{Hurtado, Antonio}

[Presidente de 16-VIII-1863 a 6-IV-1864]

Es nombrado gobernador civil de la provincia de Valladolid por real orden de 16 de agosto de 1863 y toma posesión de su cargo el 3 de septiembre. El día 1 de enero de 1864 preside la instalación de la nueva Diputación Provincial, como cuadragésimo sexto presidente de la misma. Aunque de acuerdo con la ley de 25 de septiembre de 1863 "la Diputación nombrará un presidente de entre sus miembros para las diferentes reuniones que se celebran", el gobernador mantiene su voz, su voto y la Presidencia cuando asiste a las sesiones. Estará al frente del Gobierno Civil hasta el 6 de abril de 1864 y en este período presidirá las sesiones de la Diputación en siete ocasiones. Por real decreto del citado 6 de abril es cesado como gobernador de Valladolid y se le nombra para el mismo cargo en la provincia de Cádiz.

\section{Ibáñez de Aldecoa y Usabel, Cástor} [Presidente de 15-II-1859 a 28-I-1863]

Nacido en Bilbao el 28 de marzo de 1822, hijo de José Antonio Ibáñez de Aldecoa, de Lequeitio y de Casilda de Usabel, de Bilbao. "Fue bautizado el mismo día de su nacimiento por el cirujano Añíbarro, por ocurrir en peligro de muerte" 930 . "Inició sus estudios en el Colegio de Humanidades de Bilbao y en la Universidad de Oñate. En el año 1841 solicitó su ingreso en la Universidad de Valladolid matriculándose en la Facultad de Leyes. En 1845 presenta la solicitud para ser examinado del grado de bachiller en Jurisprudencia y celebrado el examen el 5 de julio fue aprobado. En 1847 solicita ser examinado para alcanzar el grado de licenciado en Jurisprudencia, presentando los expedientes de los cursos probados. Examinado el 28 de mayo para el ejercicio teórico y el 1 de junio para el práctico, es aprobado por unanimidad" ${ }^{931}$.

Acabados sus estudios, establece su residencia en Valladolid, ciudad en la que desarrolla sus actividades profesionales y en la que se casó con María del Socorro Lara, sobrina de Mariano Miguel de Reynoso. En el año 1857, el Boletín Oficial de la Provincia del día 3 de mayo publica la autorización para la creación del Banco de Valladolid, entidad de la que es nombrado secretario. En febrero de 1875 se le nombra presidente de la Junta Provincial de Agricultura, Industria y Comercio de Valladolid.

Su actividad política la inicia en el año 1851, cuando en el mes de abril es nombrado consejero supernumerario del Consejo provincial de Valladolid, cargo del que dimite en abril de 1852. En el año 1858 es nombrado gobernador civil de Palencia, tomando posesión el 4 de julio y permaneciendo en el cargo hasta el 15 de febrero de 1859, fecha en la que según el Boletín Oficial de la Provincia es nombrado gobernador civil de Valladolid. En la sesión que celebra la Diputación el 8 de abril de 1859, toma posesión como cuadragésimo cuarto presidente de la institución, asistiendo a partir de ese momento a todas las sesiones que se celebran, en total veintiséis,

${ }^{930}$ A.H.U.V.A. Caja 673 (doc. 13).

931 A.H.U.V.A. Caja 471 (doc. 71 a 76). 
aunque la Diputación había celebrado con anterioridad catorce sesiones. El 1 de abril de 1860 preside la sesión de instalación de la decimoquinta Diputación del período isabelino y nada más iniciada esta legislatura publica un "manifiesto a la provincia" en el que advierte "del levantamiento en Aranda de una partida de facciosos formada por 25 a 30 hombres que proclaman rey a Carlos VI" ${ }^{932}$. Se mantiene en el cargo durante toda la legislatura, que se prolonga hasta el 30 de marzo de 1862, asistiendo a treinta de las sesiones que se celebran, faltando sólo a una. El 1 de abril de 1862 vuelve a presidir la sesión de instalación de la decimosexta Diputación, y continúa ejerciendo como tal presidente hasta el mes de enero de 1863, asistiendo en este tiempo a once sesiones. Como gobernador de Valladolid y presidente de su Diputación, es el individuo que más ha durado en el cargo, en todo el tiempo estudiado, de la institución con una permanencia de tres años y nueve meses. Por real decreto de 28 de enero de 1863 se le comunica "que es cesado en el cargo de gobernador de la provincia de Valladolid, y es nombrado para el mismo cargo en la provincia de Granada". Continúa su carrera política como gobernador de diferentes provincias, así tenemos que el 18 de marzo de 1863 cesa en Granada y es nombrado para el mismo cargo en Valencia, y de Valencia, al poco tiempo pasa a La Coruña. Aunque el 4 de febrero de 1864 anuncia su dimisión como gobernador de La Coruña "por motivos de salud", lo cierto es que vuelve a ser nombrado gobernador de Valencia. El 13 de julio de 1866 comunic a su cese como gobernador civil de Valencia, posiblemente su último cargo político pues a lo largo del Sexenio no se le conoce ningún destino.

\section{Iglesias, Bernardo}

[Presidente de 9-VIII-1855 a 29-V-1856]

Por real decreto de 9 de agosto de 1855 es nombrado gobernador civil de la provincia de Valladolid, "cesando en el mismo cargo en la provincia de Córdoba". Toma posesión del cargo el día 21 y en su primera actuación, publica un "Manifiesto a la Provincia" en el que "solicita la colaboración de los Sres. diputados para trabajar a favor de la provincia y mejorar la situación de sus habitantes... Ante la celebración de las fiestas de la capital, declaró solemnemente "que no reina el cólera en Valladolid y no hay razón para suspender las próximas ferias..." ${ }^{933}$. El 12 de diciembre del mismo año 1855 , comunica a la Diputación "que debiendo de salir en este día a tomar parte de las Cortes Constituyentes, de las que soy diputado por León, queda encargado durante mi ausencia del Gobierno de la provincia, en la parte civil, el secretario del gobierno D. Baldomero Menéndez, y en la económica, el administrador de Hacienda D. Faustino Ruiz". En marzo de 1856 vuelve a hacerse cargo del Gobierno y de la Diputación, presidiendo las tres sesiones finales de esta última corporación, que cierra el mes de abril su ciclo de sesiones y que ya deja de celebrarse, pues en agosto queda disuelta. En este tiempo, como trigésimo noveno presidente de la Diputación asiste a veintiocho sesiones. Continúa al frente del Gobierno Civil, hasta el 29 de mayo, día en el que publica un comunicado en el Boletín Oficial de la Provincia en el que "agradece las atenciones recibidas en los nueve meses que ha estado al mando del Gobierno de la provincia, y anuncia que Su Majestad ha tenido a bien nombrarle gobernador civil de Valencia".

\section{Iñigo y Anciso, Carlos}

[Secretario de Gobierno de 6-VI-1856 a 5-II-1857]

Es nombrado secretario del Gobierno Civil en junio de 1856, según publica el Boletín Oficial de la Provincia $\mathrm{n}^{\circ} 68$ de 6 de junio, en los últimos días del Bienio. Ejerce como gobernador interino en los inicios del nuevo período moderado, durante 
el mandato del gobernador Antonio Méndez Vigo y Santamarina, entre julio y octubre de 1856. Se mantiene en el cargo de secretario hasta febrero de 1857.

\section{Lafarga, Ramón}

[Secretario Gobierno de 1-III-1873 a 28-VIII-1873 y Presidente de 28-VIII-1873 a 4-I-1874]

En el mes de marzo de 1873 es nombrado secretario del Gobierno Civil de Valladolid, y en función del cargo en el mes de mayo, "por orden del Sr. gobernador, envía a la Guardia Civil para auxiliar a los recaudadores de impuestos". Al cesar el gobernador titular Sr. González-Alegre, toma el mando de la provincia como gobernador interino el 29 de mayo de 1873, ejerciendo la interinidad hasta finales del mes de agosto, solicitando en este tiempo y en varias ocasiones a la población "que se mantenga la tranquilidad".

El 28 de agosto del citado 1873 publica en el Boletín Oficial un comunicado "A los habitantes de la provincia", en el que anuncia que "en el día de hoy me he hecho cargo en propiedad del Gobierno de esta provincia para el que he sido nombrado por decreto del Gobierno de la República de 26 del actual y cuyo cargo he venido desempeñando accidentalmente, merced a la eficaz cooperación que todos me habéis prestado... y faltaría al más sagrado deber si no os diera por ello las más expresivas gracias... En mi corta interinidad he intentado resolver las cuestiones de orden público... Defensor ardiente de la República y observador sincero de las Leyes, a ellas ajustaré mi conducta y por nada faltaré a su cumplimiento" 934 . Como gobernador titular asiste y preside las dos sesiones que la Diputación celebra los últimos días de agosto, la del día 29 para comunicar su nombramiento y la del día 30, en la que acepta "el ofrecimiento de los voluntarios de Valladolid para acudir a donde les manden con el fin de batir a los facciosos, y siendo de cuenta del Gobierno el equipamiento del armamento y la manutención".

La Diputación no vuelve a reunirse hasta marzo de 1874, y el Gobierno en septiembre de 1873 suspende las garantías constitucionales. La medida comporta que la mayor parte de las atribuciones del gobernador pasen al capitán general, y en esa situación se mantiene hasta que es cesado el 4 de enero de 1874 , tanto de su cargo de gobernador como el de secretario del Gobierno, pues simultaneaba ambos cargos desde su nombramiento como máxima autoridad de la provincia.

\section{Lavalette, Francisco de}

[Gobernador militar. Presidente de 9-VIII-1850 a 15-XI-1850]

Mariscal de Campo de los Ejércitos Nacionales, en el mes de agosto de 1847 aparece como general gobernador militar de la plaza de Valladolid. En agosto de 1850 continúa en el mismo cargo, y con fecha del día 9 toma posesión del cargo de gobernador interino. Como tal preside la sesión de la Diputación que se celebra el día 6 de octubre del mismo año, siendo la única vez que lo hace. El 15 de noviembre de 1850 deja el cargo de gobernador interino, aunque continúa como gobernador militar hasta marzo de 1852 .

\section{Lavalle, José Casimiro}

\section{[Presidente de 22-V-1814 a 25-VI-1814]}

Brigadier de los Reales Ejércitos, es nombrado por real decreto de 22 de mayo de 1814, comandante militar y jefe político de Valladolid. El día 8 de junio toma posesión de su cargo como segundo presidente de la Diputación provincial, permaneciendo en este puesto hasta el día 25 del mismo mes, en cuya sesión se da lectura al real decreto del 15 de junio, por el que "queda suprimida la Diputación".

No hay constancia de su permanencia en la Comandancia Militar o en la Jefatura Política durante el período absolutista. Tampoco hay opinión sobre su actividad al frente de la Diputación, puesto que se limitó a asistir a dos sesiones, la 
primera corresponde a su toma de posesión y la segunda para firmar el acta de disolución.

\section{Ligués, Pedro Clemente}

[Presidente de 20-III-1821 a 22-IV-1822]

Toma posesión de su cargo de jefe político y sexto presidente de la Diputación en la sesión celebrada el 20 de marzo de 1821. Con anterioridad ejerció el mismo cargo en la Jefatura Política de Navarra. Es el primer jefe político que no es militar y por lo tanto no ejerce de capitán general de Castilla la Vieja. Permanece en el cargo durante toda esta segunda legislatura del Trienio, hasta el mes de marzo de 1822, fecha final del período de sesiones y de legislatura, asistiendo a un total de setenta y dos sesiones. En la fecha de apertura de la Diputación, en su tercera legislatura en marzo de 1822 , continúa de jefe político, por lo que preside la sesión de apertura, y sigue ejerciendo como presidente hasta junio del citado año, presidiendo la institución en diez ocasiones. En el mes de mayo se ausenta de la ciudad, y deja como gobernador y presidente interino al intendente y vicepresidente José de Goicoechea.

\section{Linares de la Roza, Clemente}

\section{[Presidente de 1-XII-1857 a 28-XI-1858]}

Natural de Villarcayo (Burgos), ciudad en la que nació en noviembre de 1817, de familia acomodada, que a consecuencia de la guerra carlista, tuvieron que abandonar el pueblo y establecerse en Burgos, ciudad en la que Clemente inició su carrera administrativa. Es conocido por su ideología liberal.

En el año 1834 es oficial 3º del Gobierno Civil de Burgos. En 1839 es oficial $1^{\circ}$ del Gobierno civil de Almería y en 1845 alcanza el puesto de Secretario en el mismo. En 1846 pasa a ejercer el mismo cargo en el Gobierno civil de Burgos y en 1854 es nombrado gobernador civil de Palencia. Durante el Bienio, por sus ideas contrarias al progresismo, se retira de la actividad política ${ }^{935}$. En 1856 es nombrado gobernador civil de Burgos, según publica el Boletín Oficial de la Provincia, el día 7 de octubre de 1856. El día 1 de diciembre de 1857 toma posesión como gobernador de Valladolid, asistiendo el día 9 del mismo mes a la sesión de la Diputación, en la que tomó posesión como el presidente cuadragésimo tercero de la misma. Asiste y preside las once sesiones a las que asistió de las veintisiete que se celebraron en la legislatura, hasta junio de 1858. Continúa como gobernador y presidente de la Diputación, tomando el juramento a los nuevos diputados de la decimocuarta Diputación en la sesión de instalación que se celebra el 18 de julio de 1858 .

El 28 de noviembre del citado año comunica su despedida y encarga el mando interino de la provincia al vicepresidente del Consejo provincial Cándido Moyano Zamora. En el tiempo que ejerció asistió a diez sesiones de las cuarenta que celebró la Diputación a lo largo de la legislatura. El motivo por el que deja el cargo es el real decreto de 29 de octubre de 1858 , por el que es nombrado $2^{\circ}$ jefe de la Dirección General de Propiedades y Derechos del Estado, del Ministerio de la Gobernación. En 1859 es elegido diputado a Cortes por el distrito de Medina de Pomar en la provincia de Burgos. El 4 de noviembre de 1859 el Ministerio de la Gobernación a través de un real decreto comunica "que habiendo fallecido D. Clemente Linares, diputado a Cortes por Medina de Pomar, se ordena proceder a nueva elección".

\section{Llamas Gómez, Manuel \\ [Presidente de 17-II-1843 a 24-VI-1843]}

Es nombrado jefe político de la provincia con fecha 17 de febrero de 1843, toma posesión como vigésimo primer presidente de la Diputación en la sesión del 19 del mismo mes y año y se mantiene hasta el 24 de junio del citado 1843 , fecha en la que es destituido por la Junta Provisional de Gobierno a raíz del fin de la Regencia de

${ }^{935}$ CARASA SOTO, Pedro. (Dir.). Diccionario biográfico de parlamentarios ... ob. cit. pág. 580 
Espartero. Con anterioridad había ejercido de diputado provincial elegido en el mes de diciembre de 1837 hasta diciembre de 1840. Ya en este período actuó como presidente interino en ausencia del titular. En 1841 es diputado a Cortes por Valladolid. Ver su biografía en el capítulo de diputados provinciales.

\section{Lobit, Vicente}

[Presidente de 31-VIII-1871 a 19-X-1871 y 18-VI-1872 a 21-II-1873]

El Boletín Oficial de la Provincia del 31 de agosto de 1871 publica el decreto de la Presidencia del 26 del mismo mes por el que, "de acuerdo con el Consejo de Ministros, vengo en nombrar gobernador civil de la provincia de Valladolid a D. Vicente Lobit, que desempeñaba igual cargo en la de Toledo". Toma posesión del cargo el 7 de septiembre. Pero apenas tiene tiempo de iniciar sus trabajos, pues el 19 de octubre de 1871 anuncia que "en este día resigno el mando de este Gobierno en el secretario del mismo D. Abdón de Paz, según así me lo ordena el Sr. ministro de la Gobernación. Durante los cuarenta y cuatro días que desempeñé mi cargo no recibí más que pruebas de afecto y consideración. A todos, mi sincera gratitud" ${ }^{936}$. En este corto espacio de tiempo, no asiste a ninguna sesión de la Diputación. Destaca por su clara tendencia progresista.

Vuelve a aparecer como gobernador civil de Valladolid, a través de un decreto de la Presidencia del Gobierno de 18 de junio de 1872, por el que "vengo en nombrar gobernador de la provincia de Valladolid a D. Vicente Lobit, que ha desempeñado el cargo en varias provincias. Firmado: Ruiz Zorrilla". Toma nuevamente posesión del cargo el día 21, y publica un "Manifiesto a la provincia" en la que explica que "vuelvo con las mismas ideas que tenía en el tiempo anterior que goberné la provincia.... Al mismo tiempo, me alegro de que el Partido Progresista Democrático Radical ocupe el Gobierno" "937. En los primeros meses de este su segundo mandato, no asiste a las actividades de la Diputación, y será el 2 de noviembre de 1872 cuando presida por vez primera la sesión de instalación de la nueva Diputación, la cuarta del período revolucionario. Asiste además a otras tres sesiones que se celebraron en el citado mes de noviembre. También preside la instalación de la Comisión provincial. No vuelve a estar presente en las sesiones de la Diputación. Únicamente tiene contacto con la Corporación a través de un comunicado, en el que "reclama a la Diputación para que realice las obras necesarias para mejorar las habitaciones que ocupa en el colegio de San Gregorio" ${ }^{938}$. El 21 de febrero de 1873, a través de una circular, comunica "a los habitantes de Valladolid: Hoy ceso en el mando de la provincia. Al separarme de vosotros no llevo el más leve remordimiento de haber faltado a nadie... y llevo una grata memoria de las Corporaciones provincial y municipal. Me aparto con sentimiento, pero me cabe la satisfacción de conocer a la persona que me remplaza. En Madrid ó en donde la suerte me lleve, tendréis un amigo" ${ }^{939}$. Le sustituye con carácter interino el secretario del Gobierno Eugenio Reguera.

\section{Loma y Santos, Eduardo de la}

[Presidente de 16-III-1870 a 9-II-1971]

El 16 de marzo de 1870 toma posesión como gobernador civil de Valladolid, cargo para el que había sido nombrado por decreto de 2 de marzo de 1870. Se mantiene en el cargo hasta febrero de 1871, asistiendo en este tiempo a veintiuna sesiones de la Diputación "como presidente sin voto". Por decreto de la Presidencia del Consejo de Ministros de 9 de febrero de 1871 "se le nombra gobernador civil de Zaragoza, cesando en el mismo cargo que desempeña en Valladolid". Durante su presidencia le acompaña como secretario del Gobierno Antonio María de Ron nombrado por "orden de S.A. el Regente" de fecha 27 de marzo de 1870 y cesado en enero de 1871 .

936 B.O.P.V. ${ }^{\circ} 165$ del 20 de octubre de 1871.

937 B.O.P.V. Boletín del 21 de junio de 1872.

938 A.D.P.V. Actas. Libro de actas del 3 de diciembre de 1872.

939 B.O.P.V. n ${ }^{\circ} 29$ de 23 de febrero de 1873. 


\section{López Alcaraz, Ildefonso}

[Presidente de 15-XI-1850 a 7-III-1851]

El día 15 de noviembre de 1850 se presenta en la Diputación y presta juramento como el trigésimo tercer presidente de la institución. En la misma sesión comunica su nombramiento como gobernador de la provincia, de acuerdo con el real decreto de 20 de septiembre. Ejerce el cargo hasta el mes de marzo de 1851, asistiendo en este tiempo a cuatro sesiones de la Diputación. Por real decreto de 7 de marzo de 1851 es nombrado gobernador de la provincia de Toledo. Continúa su carrera política presidiendo diferentes Gobiernos provinciales, teniendo noticias de que en el año 1856 ejerce como gobernador de Tarragona y el 14 de noviembre de 1857 es destinado como gobernador a Huelva.

\section{Lozana, Vicente}

[Presidente de 11-VIII-1864 a 23 IX-1864]

"En el día de hoy y previas formalidades de la ley, me he encargado del gobierno de esta provincia, que me fue concedido por S.M. la Reina (q. D. g.), por real decreto de fecha 26 de julio último..." Esta nota circular en el Boletín Oficial de la Provincia del 11 de agosto de 1864 era la noticia de su llegada como gobernador de Valladolid, procedente de desempeñar el mismo cargo en la provincia de Guadalajara. Su estancia en Valladolid, al igual que ocurrió con los inmediatos antecesores, es corta y poco efectiva, porque a los dos meses de su nombramiento, "por real decreto de 23 de septiembre de 1864, se le declara cesante en el mando del Gobierno de Valladolid". En este tiempo no llegó a tomar posesión de la Presidencia de la Diputación, aunque sí llegó a presidir la reunión extraordinaria del Consejo provincial celebrada el 9 de septiembre. En el año 1866 aparece su nombramiento como gobernador civil de la provincia de Burgos.

\section{Manrique, Jacinto}

[Presidente de 18-VI-1839 a 3-VII-1840]

El 18 de junio de 1839 envía desde Madrid una comunicación a la Diputación "dando parte de haber merecido de la bondad de S.M. el nombramiento de jefe político de la provincia de Valladolid, trasladándose para desempeñarlo a la mayor brevedad". Se presenta y toma posesión en la sesión extraordinaria que se celebra el 24 del mismo mes de junio, convirtiéndose en el decimosexto presidente de la Diputación. En años anteriores ya había desempeñado cargos políticos en otras provincias. En los años del Trienio, al final del período, ejerció el cargo de jefe político de la provincia de Zamora entre septiembre de 1822 y abril de 1823 , fecha esta última en la que se disolvió la Diputación. En el año 1838 y hasta su nombramiento para Valladolid, ejerció la Jefatura Política de la provincia de Cádiz. Se mantiene en Valladolid hasta el 3 de julio de 1840 fecha en la que "S.M. le manda cesar en el Gobierno de la provincia". En este año como presidente de la Diputación asistió a cuarenta y ocho sesiones.

\section{Martín Lozar, Manuel}

[Presidente interino de 5-III-1847 a 10-III-1847]

Ejerció de presidente interino de la Diputación durante cinco sesiones celebradas entre el 5 y el 10 de marzo de 1847, en virtud de su cargo de vicepresidente del Consejo Provincial. Con anterioridad fue diputado provincial entre diciembre de 1837 y diciembre de 1840. También es alcalde de Valladolid en enero de 1843. Ver su biografía en el capítulo de diputados provinciales. 


\section{Mazón y Valcárcel, Ramón de}

[Secretario de Gobierno de 3-III-1863 a 11-VIII-1864. Presidente interino de 21-VI-1863 a 30VII-1863 y de 19-VII-1864 a 11-VIII-1864]

Es nombrado secretario del Gobierno de Valladolid por real orden que se publica el 3 de marzo de 1863 en el Boletín Oficial de la Provincia. Procede de Guadalajara, ciudad en la que desempeñaba el mismo cargo. En el mismo mes de su toma de posesión actúa como gobernador interino, al cesar el titular Rufo de Negro. El 21 de junio vuelve a ejercer como presidente interino al ausentarse el titular, Toribio Rubio Campos, hasta finales de julio A lo largo del año 1864 sigue ejerciendo como secretario, asumiendo el gobierno de la provincia de forma "accidental" ante los numerosos cambios y ausencias de los gobernadores titulares. De esta forma ejerce en los meses de mayo y junio. El 19 de julio del mismo año 1864 anuncia en el Boletín Oficial que "desde este día y con autorización superior, quedo encargado del mando de esta provincia con el carácter de gobernador interino, toda vez que he cesado de serlo accidental, como secretario del Gobierno. Lo que inserto en este periódico oficial para su mayor publicidad". Continúa ejerciendo como gobernador interino hasta el 11 de agosto, fecha en que es relevado de su cargo a la llegada del nuevo gobernador Sr. Lozana. En este tiempo de interinidad llegó a presidir la Diputación en una única sesión. También dejó de ejercer como secretario del gobierno. De la Secretaría de Valladolid pasó a ejercer como alcalde de Barcelona hasta el 27 de julio del año 1866 en que "cesa en su cargo de alcalde de Barcelona".

\section{Méndez Vigo Santamarina, Antonio}

\section{[Presidente de 18-VII-1856 a 23-X-1856]}

Nacido en Oviedo el 9 de agosto de 1817, hijo de Pedro y de María Teresa, pertenecientes a una noble y conocida familia asturiana. Su abuelo fue catedrático en la Universidad de Oviedo y su padre fue militar. Otro de sus hermanos, Ignacio, ejerció como secretario del Gobierno Político de Valladolid. Se casó en dos ocasiones, la primera el 4 de enero de 1845 con Modesta Fernández Cuevas, que falleció el 19 de octubre de 1853, y la segunda el 4 de noviembre de 1856 con Carmen Núñez-Arenas Bravo, teniendo cuatro hijos con cada una de sus esposas.

Su vida empresarial está basada en la explotación del gran patrimonio familiar formado por numerosas fincas agrícolas, destacando la de Colloto, en el municipio de Siero. También se dedicó a otros negocios empresariales, centrados en el ferrocarril, llegando a ser el secretario del Consejo de Administración de la Compañía del Norte.

$\mathrm{Su}$ actividad política se inicia en el año 1843, cuando se afilia al grupo progresista de Oviedo, siendo elegido diputado provincial y diputado a Cortes. En el año 1854 vuelve a salir como diputado a Cortes por Oviedo. En el año 1856 rompe con el partido progresista, y es nombrado gobernador de la provincia de Valladolid, por real decreto de 18 de julio de 1856, publicado por el gobierno moderado del general O’Donell. Toma posesión del cargo el 14 de agosto del mismo año. El 19 de agosto preside la sesión de instalación de la nueva Diputación, manteniéndose en el cargo como el cuadragésimo primer presidente de la misma, durante los tres meses que dura la legislatura, asistiendo y presidiendo cinco sesiones de las cincuenta y tres que se celebran. Por real decreto de 23 de octubre de 1856, es aceptada la dimisión que hace de su cargo.

En julio de 1857 es nombrado administrador del recién creado Banco de Valladolid. En julio de 1858 es designado gobernador civil de Valencia, renunciando a su cargo en febrero de 1859, al ser elegido diputado a Cortes por la provincia de Valladolid. En abril de 1860 continúa como diputado a Cortes por Valladolid y comunica y entrega a la Diputación Provincial un donativo de 5.000 reales para la suscripción abierta en la provincia para "Ayuda a los muertos y heridos de la Guerra de África" de parte del Sr. Vizconde de la Trinidad, de Oporto. Continua como representante de la provincia en las Cortes, en sucesivas elecciones, y en diciembre de 
1865, al ser nuevamente elegido tanto por Rioseco como por Avilés, opta por representar a esta segunda población.

En el año 1866 ejerce como gobernador civil de Barcelona, cargo del que es cesado, según informa la Gaceta el 13 de julio del mismo año. En 1869 da un giro más conservador a su ideario político. Es elegido nuevamente diputado a Cortes por Valladolid en las elecciones celebradas en el mes de febrero, y en el año 1870 vuelve a las Cortes como diputado por Asturias. En el año 1871 es derrotado en las elecciones para las Cortes por el distrito de Medina de Rioseco. Tras esta derrota, consiguió ser nombrado senador por la provincia de Oviedo y, desde este nuevo cargo, atacó al gobernador de Valladolid, José Gallostra, perteneciente al partido unionista, por las ilegalidades cometidas en las elecciones que le valieron la derrota ${ }^{940}$. Falleció en Madrid, el 8 de abril de 1872.

\section{Méndez Vigo Santamarina, Ignacio}

Presidente interino de 9-VIII-1855 a 21-VIII-1855]

Hijo de Pedro y de María Teresa, distinguida familia residente en Asturias, es hermano de Antonio, que fue gobernador civil de Valladolid en agosto y septiembre de 1856. Gracias a la influencia familiar tanto por parte de su padre como de su hermano inicia una larga carrera tanto administrativo como política a través de las secretarias de Gobierno y de diversos gobiernos civiles. La comienza en enero de 1855 cuando, con la llegada de Manuel Gusano al gobierno de la provincia, es nombrado secretario del mismo en sustitución de Juan Diego Pérez. El 9 de agosto del mismo año, al cese del gobernador Gusano, es nombrado gobernador interino de la provincia, cargo que ejerce durante unos días, ya que el 21 del mismo mes, toma posesión el nuevo gobernador Iglesias. En este tiempo no asiste a ninguna sesión de la Diputación.

En octubre de 1855, abandona la Secretaría del Gobierno, y pasa a ejercer el cargo de gobernador civil a través de diferentes nombramientos. Así tenemos que en 1856 es gobernador civil en Ávila. En 1857 pasa como gobernador a Córdoba. En 1858 es nombrado gobernador de Zaragoza. En 1860 pasa de Zaragoza a Cádiz. En 1862 cesa en Cádiz y pasa de gobernador a Granada. En el mismo año 1862 vuelve a ser nombrado gobernador de Zaragoza. En 1863 es aceptada su dimisión y no se le conocen nuevos destinos ${ }^{941}$.

\section{Menéndez, Baldomero}

[Presidente interino 12-XII-1855 a 30-III-1856]

Ejerce como secretario del Gobierno Civil de Valladolid a partir de octubre de 1855. El 12 de diciembre, ante la ausencia del gobernador titular Bernardo Iglesias, se hace cargo del Gobierno Civil, con carácter interino y ejerce como tal hasta finales de marzo de 1856, fecha de vuelta del titular. En su tiempo de interinidad asiste a seis sesiones de las que celebra la Diputación, aunque no las preside. En junio del mismo año 1856 deja la Secretaría del Gobierno, y no se le conocen otros destinos hasta que en 1866 es nombrado gobernador civil de Guadalajara (B.O.P.V. ${ }^{\circ} 14$ de 17 de julio) y en 1868 pasa como gobernador a Cáceres (B.O.J.R.V. no 19 del 19 de octubre).

\section{Merino, Anselmo}

[Presidente interino de 21-VII-1849 a 22-VIII-1849. De 14-V-1850 a 17-VIII-1850. De 1-III-1851 a 20-III-1851]

Es natural de Villafranca-Montes de Oca, en la provincia de Burgos. "Estudió durante 3 años en el Seminario de Burgos. Ingresó en la Universidad de Valladolid en el año 1829 en la Facultad de Derecho. El 30 de abril de 1835, solicitó ser examinado

940 CARAS A SOTO, Pedro (Dir.). Diccionario biográfico de parlamentarios ... ob. cit. pág. 685. ${ }^{941}$ B.O.P.V. no 122 de 9 de octubre de $1856 . \mathrm{n}^{\circ} 181$ de 20 de noviembre de $1857 . \mathrm{n}^{\circ} 105$ de 4 de julio de 1858. $\mathrm{n}^{\circ} 40$ de 15 de marzo de 1860. R.D. de 7 de marzo de 1862 . B.O.P.V. $\mathrm{n}^{\circ} 180$ de 18 de noviembre de 1862. R.D. de 17 de marzo de 1863. Boletines y Decretos en los que se anuncian los sucesivos cambios. 
para alcanzar el grado de bachiller en Leyes acompañando certificado de los cursos probados entre 1829 y 1835 . Fue aprobado "némine discrepante". El 27 de agosto de 1838, solicita ser examinado para el grado de licenciado en Leyes, fue examinado y aprobado" ${ }^{942}$. Ejerce como abogado en la ciudad de Valladolid.

Inicia su carrera política en el Consejo provincial, el 29 de julio de 1845, fecha en la que es constituido y del que es nombrado consejero. El 15 de abril de 1848 es nombrado vicepresidente del Consejo y, de acuerdo con la ley de 8 de enero de 1845 , es el sustituto con carácter interino del jefe político en sus ausencias, y en consecuencia con esta citada ley ejerce de jefe político interino y como tal preside la Diputación. Lo hizo desde el 21 de julio hasta el 22 de agosto de 1849 "por indisposición del jefe político Sr. Navascués", preside una sesión de la Diputación. Después desde el 14 de mayo hasta el 17 de agosto de 1850, fecha en la que toma posesión el nuevo gobernador interino, preside dos sesiones. Desde el 1 al 20 de marzo de 1851, ejerce nuevamente el cargo con interinidad. Su carrera política finaliza como vicepresidente del Consejo provincial, el día 26 de julio de 1854, fecha en la que es suprimido el referido Consejo por decreto de la Junta Provisional del Gobierno de la Provincia. No se vuelven a tener datos de su actividad política, aunque profesionalmente continúa ejerciendo como abogado, inscrito en el Colegio de Valladolid.

\section{Moreno Daoiz, Tomás}

\section{[Presidente interino de 25-X-1820 a 3-XII-1820]}

Teniente general del Ejército, el 26 de junio de 1820, es nombrado capitán general de Castilla la Vieja. Al quedar vacante la Jefatura Política de Valladolid el 25 de octubre, en la misma fecha es nombrado jefe político interino. Al mismo tiempo ostenta la presidencia interina de la Diputación, cargo en el que se mantiene hasta el 3 de diciembre del mismo año en que es sustituido tanto en la Capitanía General como en la Jefatura Política y Presidencia de la Diputación. Es el cuarto presidente que actúa en un tiempo muy corto, asistiendo únicamente a tres sesiones de la Diputación.

\section{Mosquera, Diego Manuel de \\ [Presidente de 26-IX-1843 a 6-I-1844]}

Es nombrado jefe político y en consecuencia vigésimo cuarto presidente de la Diputación, por decreto del gobierno de 26 de septiembre de 1843. En la sesión del 18 de octubre, se presenta y toma posesión de la Presidencia de la Diputación, siendo la única sesión a la que asiste en esta legislatura, pues la misma finaliza el 30 del mismo mes. El día 1 de noviembre de 1843, preside el acto de instalación de la nueva Diputación, presidencia que mantiene en las treinta sesiones a las que asiste durante los meses de noviembre y diciembre. Al poco tiempo de haber presidido la instalación de la nueva Diputación, mantiene una controversia con el alcalde de Valladolid, Sr. Gómez Escribano, "sobre quién debe de descubrir el retrato de Isabel II, tirando del cordón" ${ }^{943}$. Mosquera propone que se hiciera conjuntamente, a lo que el alcalde se negó e impuso su criterio de ser "él mismo el que tirara del cordón". El día 6 de enero de 1844 se publica un real decreto por el que se le relevaba de su cargo.

\section{Muñoz de San Pedro, José}

[Vicepresidente de 27-IX-1847 a 10-V-1848]

Por real decreto de 27 de septiembre de 1847, es nombrado nuevo intendente de la provincia de Valladolid, toma posesión de su cargo el 28 de octubre y se mantiene en el cargo hasta el mes de mayo de 1848, en que por otro real decreto del día 10, se notifica su cese. No llegó a asistir a ninguna sesión de la Diputación ya que esta no celebró ninguna desde octubre de 1847 hasta marzo de 1848 y en las sesiones 
del mes de abril, no hizo acto de presencia, por lo que llegó a tomar posesión del cargo de vicepresidente, aunque si trabajó en los temas de contribuciones y arbitrios.

\section{Navascués, Rafael}

[Presidente de 1-II-1849 a 25-VIII-1849]

Por real decreto de 1 de febrero de 1849 "Su Majestad se ha servido resolver que D. Rafael de Navascués, jefe político de Toledo, pase a desempeñar el mismo cargo en la provincia de Valladolid". Toma posesión de su cargo como jefe político el 17 de marzo, y se presenta por vez primera para presidir la Diputación provincial como su trigésimo presidente, el 12 de mayo del mismo año. Su presencia al frente de la provincia es muy corta, asistiendo únicamente a tres sesiones, hasta que en agosto del repetido año 1849 por real decreto del día 25, "es cesado en su cargo". No se conocen otras noticias sobre su actividad, tanto profesional como política.

\section{Negro, Rufo de}

[Presidente de 27-I-1863 a 22-III-1863]

Por real decreto de 27 de enero de 1863, es nombrado gobernador de la provincia de Valladolid. Procede del mismo cargo en la provincia de Guadalajara.

El 15 de febrero del mismo año el Boletín Oficial de la Provincia anuncia que "en el día de hoy he tomado posesión del Gobierno de esta provincia, que S.M. la Reina (Q.D.G.) se dignó confiarme por real decreto de 27 de enero último. Lo que publico en este periódico oficial para conocimiento de la provincia". Y sin apenas tiempo para leer el anuncio de su toma de posesión, el 22 de marzo del mismo 1863, el Boletín Oficial comunica que: "por R. D. de 18 del corriente S.M. La Reina se ha dignado declararme cesante. Acatando con el mayor respeto la voluntad de nuestra Augusta Soberana, entrego el mando en este día al Sr. secretario del Gobierno. Un gran infortunio doméstico que afligió mi corazón a los pocos días de llegar a esta capital, y el corto tiempo que he tenido el mando a mi cargo no me han permitido dejar en esta provincia recuerdo alguno de mi transitoria administración. Séame permitido al ausentarme consignar mis ardientes deseos de prosperidad $\mathrm{y}$ engrandecimiento de esta rica y noble provincia, y mi gratitud a todos los que me han consolado en mis amarguras y auxiliado en el ejercicio de mis funciones". En este corto espacio de tiempo y, aunque se celebran varias sesiones, no se presenta ni tiene contacto con la Diputación, y es el diputado decano Manuel Daniel el que actúa de presidente, y el secretario del Gobierno que se hace cargo de la interinidad es Ramón de Mazón.

\section{Núñez Arenas, José}

\section{[Presidente de 10-IX-1836 a 15-X-1837]}

El día 10 de septiembre de 1836, se presenta como nuevo jefe político de la provincia, tomando el cargo en la sesión de la Diputación celebrada el mismo día. Toma posesión como el duodécimo presidente de la institución y asistiendo a las doce sesiones que se celebran hasta el final de la primera legislatura. El día 7 de octubre del mismo año de 1836 preside la sesión de instalación de la nueva Diputación, en la que se presenta como "Benemérito de la patria. Teniente coronel del Real Cuerpo de Artillería. Condecorado con varias Cruces por méritos de guerra. De la Real Sociedad Económica Matritense. Socio de número de la de Requena y jefe político de Valladolid, etc.". En el mes de julio de 1837 y en sesión extraordinaria del pleno de la Diputación, procede a la toma del juramento de la "Constitución de la Monarquía Española, sancionada por las Cortes en 1837" a la totalidad de diputados y funcionarios de la Diputación.

En el mes de octubre de 1837, habiendo asistido a cincuenta y tres sesiones, es cesado en sus funciones, "por haber abandonado la ciudad el 18 de septiembre ante la 
amenaza de invasión por parte de la facción enemiga de Zariategui" "944. En febrero de 1838, la Diputación vigente en esa fecha le reclama la cantidad de 8.000 reales "que le prestó el Ayuntamiento de Medina para el mantenimiento de los presos pobres, y no entregó el recibo de resguardo" 945 .

\section{Oller y Cánovas, Pedro}

[Presidente de 25-X-1871 a 18-VI-1872]

Ejerce como gobernador de la provincia de Valladolid entre octubre de 1871 y junio de 1872, período de tiempo en el que sucede en el mando a Vicente Lobit en 1871 y se lo vuelve a entregar en 1872. Por decreto de 25 de octubre de 1871, es nombrado gobernador de la provincia, tomando posesión del cargo el 3 de noviembre. El 6 de noviembre se presenta en la Diputación, presidiendo la sesión del citado día. Durante su ejercicio como gobernador preside y asiste a ocho sesiones de la corporación. La mayoría de las veces que se presenta, su actuación, según recogen las actas, se reduce a "abrir la sesión y exponer que los asuntos del servicio le obligaban con sentimiento a dejar la Presidencia y ausentarse".

En diciembre de 1871 y en febrero 1872 , en sendas ausencias de su puesto, cede el mando interino al secretario del Gobierno D. Enrique Fernández. Lo más relevante que acaeció en el tiempo que estuvo al frente del Gobierno fue su enfrentamiento a los componentes de la Diputación, al considerar éstos que "el gobernador invadía sus actividades y sus derechos". Estos enfrentamientos culminaron en la sesión del 19 de abril de 1872, cuando los diputados recriminaron al gobernador su interferencia en el nombramiento del diputado D. Benito Moreno, para cubrir una baja en la Comisión Provincial. "Al pedir la palabra el Sr. Barquín, el Sr. gobernador le preguntó que para qué. El Sr. Barquín le contestó que cuando se la concediese lo sabría. El Sr. gobernador no le autorizó a hablar y levantó la sesión" "946. A los dos días de este enfrentamiento, es decir el 21 de abril, anuncia "su ausencia de la provincia, cediendo el mando al secretario Sr. Fernández". No vuelve a su puesto, que se quedará sin cubrir y bajo la presidencia interina del secretario del Gobierno Enrique Fernández, hasta que se publica el decreto de 18 de junio de 1872, por el cual el Consejo de Ministros "admite la dimisión del cargo de gobernador de la provincia de Valladolid, que ha presentado D. Pedro Oller y Cánovas, y nombrando nuevo gobernador en la persona de D. Vicente Lobit".

\section{Paz, Abdón de}

[Presidente interino de 9 a 14-II-1871 y 30-III-1871 a 20-IV-1871]

Por real orden de 23 de enero de 1871, es nombrado secretario del Gobierno Civil de Valladolid. En febrero del mismo año, ante el cese del gobernador titular, Eduardo de la Loma, ejerce como gobernador interino, y en virtud de ese ejercicio convoca a los diputados electos de la tercera Diputación del Sexenio, para la sesión de instalación que se celebra el día 17. El 14 de febrero, entrega el mando al gobernador titular recién nombrado Sr. Gallostra y Frau. El 26 de marzo del mismo año 1871, vuelve a hacerse cargo del gobierno de forma interina "al ausentarse el gobernador titular". Pero al ser él mismo autorizado a ausentarse por "Real Licencia", aparece como secretario interino y también como gobernador interino, el oficial $1^{\circ}$ de la Secretaría Alfredo de Gómez Zaragoza. Reintegrado a su puesto el 30 de marzo, continúa ejerciendo el mando interino hasta el 20 de abril, fecha en la que se persona el nuevo gobernador Sr. Seriñá. En agosto vuelve a ejercer como interino ante la ausencia del nuevo gobernador, y lo mismo sucede en los meses de septiembre y octubre, ante los sucesivos cambios que se producen. En el mes de noviembre, con la llegada del nuevo gobernador Oller y Cánovas, cesa en sus funciones. 


\section{Peón y Heredia, Antonio María \\ [Presidente de 2-IX-1813 a 8-VI-1814]}

El 21 de junio de 1813, siendo mariscal de campo de los Reales Ejércitos, se presenta en Valladolid al ser nombrado comandante general y jefe superior político de la provincia. Ejerce como primer presidente de la Diputación a partir de la sesión de instalación celebrada el día 2 de septiembre del mismo año de 1813. Fue fundador y director de "La Gaceta de Valladolid", periódico que inicia su publicación en 1813 "en fecha posterior al 4 de junio", que es el momento del abandono de la ciudad por parte de las tropas de ocupación francesas. Se estima que dejó de publicarse al final del período constitucional, aproximadamente en junio de 1814, cuando se produce su relevo al frente de la Jefatura Política de la provincia. Es un periódico de corte liberal ${ }^{947}$. Durante su permanencia en Valladolid, es nombrado "Académico honorario y protector de la Real Academia de Matemáticas y Nobles Artes de Valladolid”948. En las postrimerías de su mandato, entre los días 12 y 14 de mayo de 1814, tiene que hacer frente a una serie de oscuras acusaciones que le costaron el puesto ${ }^{949}$.

El día 8 de junio de 1814, es relevado de sus cargos de comandante militar y jefe político de la provincia, y en consecuencia cesa como presidente de la Diputación. En su período de presidente asiste a veintinueve sesiones de la Diputación.

\section{Perabeles, Lorenzo}

[Vicepresidente de 15-II-1842 a 3-IX-1842]

Es intendente del Ejército e "Individuo de la Sociedad Económica de Amigos del País de Ávila y Oviedo". El día 15 de febrero de 1842 anuncia su toma de posesión como intendente de la provincia, comunicando al mismo tiempo el ejercicio en el cargo de jefe político interino. El 12 de marzo, en la sesión que celebra la Diputación, "entró el intendente, jefe político interino y habiendo ocupado la silla de Presidencia manifestó los buenos deseos... para cooperar al buen éxito de los trabajos...". Entre sus primeras actuaciones realizadas el mismo día, estuvo la de decidir el cese del alcalde $1^{\circ}$ de Valladolid, Pelayo Cabeza de Vaca "por no obedecerle". La decisión fue votada en contra por el pleno de la Diputación pero no fue aceptada por la Presidencia argumentando que por ley "los jefes políticos están facultados para suspender a los alcaldes nombrados por el pueblo". Por ello se pidió la mediación del capitán general de la Región. Con fecha 15 de marzo se leyó en la Diputación un comunicado en el que “... después de la conversación con el general Martín Iriarte, pasó la competente orden al Sr. D. Pelayo Cabeza de Vaca... para que ejerza las funciones como alcalde $1^{\circ}$ constitucional, según le correspondan...". Son las dos únicas sesiones a las que asiste en la Diputación y no tendrán más noticias de él hasta que, con fecha 22 de junio del mismo año 1842, comunica que "teniendo que ausentarse de la provincia por asuntos del servicio, quedaba encargado del Gobierno Político el secretario Domingo

947 ESTRADA, Julio y TRAPOTE, María del Carmen. "Sobre la prensa periódica en Palencia y Valladolid durante la Guerra de la Independencia". Separata 63 de la publicación Tello Téllez de Meneses, Palencia, 1992. Estos autores mantienen la tesis de la existencia de 2 periódicos en Valladolid, con el nombre de "La Gaceta". El primero es "La Gaceta de la 6 a provincia" que se editó en el año 1810, de carácter afrancesado, y dirigida por Antonio de la Peña, y que dejó de publicarse a partir de la salida de los franceses, y cuyo fin coincide con el inicio de la publicación de "La Gaceta de Valladolid" de Peón y Heredia.

948 A.H.U.V.A. Libro 560, folio 50. Registro Principal con los nombres de todos los individuos pertenecientes a la Real Academia de la Purísima Concepción.

949 "Debido a las ocurrencias de algunos pocos facciosos de la ciudad... insinuándole que le habían cesado en sus funciones de comandante general y también en la de presidente de la Diputación y que el mando militar se había traspasado al Sr. Conde de Belbeden. Nadie duda que los principales autores que capitanearon estos alborotos fueron D. Vicente Plaza, comandante del Resguardo de Rutas y D. Domingo Baso, conocido alborotador, que han procurado aprovecharse de las suertes próspera y adversa de la Patria, apropiándose el primero de insignias y grados militares que no le correspondían, no habiendo sido más que un verdadero bandido, como el segundo, conocido ya de antiguo en esta ciudad como alborotador, que quiso tener parte en el Ayuntamiento intruso, nombrándose a sí mismo y a su suegro, escribano de profesión, regidores, con otros de su facción..." A.D.P.V. Actas. Libro de actas del 31 de mayo de 1814. 
Saavedra". No vuelve a incorporarse a su trabajo y, desde junio de 1842 hasta septiembre del mismo año, actúa de intendente interino el contador de Rentas Arsenio Rosique.

\section{Perales, Juan}

[Presidente de 25-VIII-1849 a 15-I-1850]

El día 25 de agosto de 1849, el mismo real decreto que notificaba el cese del anterior jefe político, también anunciaba que "el Sr. D. Juan Perales es nombrado jefe político de la provincia de Valladolid, procedente de la Jefatura Política de Navarra". Toma posesión de su cargo el 1 de octubre y se presenta en la Diputación en la sesión que se celebra el día 23 del mismo mes, tomando igualmente posesión del cargo de trigésimo primer presidente de la Corporación. Se mantiene en el cargo hasta el 29 de diciembre de 1849, asistiendo en este tiempo a cinco sesiones como presidente de la Diputación. Es el último jefe político de la provincia, pues a partir de su cese aparece la figura del gobernador de la provincia "en sustitución del jefe político y del intendente". El 15 de enero de 1850, es nombrado nuevamente gobernador de la provincia de Navarra.

\section{Pérez, Juan Diego}

[Presidente interino de 18-X-1854 a 26-XII-1854]

Es el primer secretario del Gobierno Civil que desempeña el cargo de gobernador interino. A la dimisión del titular Nicolás María Rivero, acaecida en octubre de 1854, en su condición de secretario, es nombrado gobernador interino de la provincia, ejerciendo el cargo en los meses de octubre, noviembre y diciembre. En este período asiste a dieciséis sesiones de la Diputación, aunque no las preside. Deja el cargo a la llegada del nuevo gobernador Manuel Gusano. En el año 1855, justifica la utilización que se hizo de los 4.000 reales, que el gobernador Rivero sacó de la caja de la provincia y que reclama la Dirección General del Tesoro.

\section{Ponzoá, José Antonio}

\section{[Presidente de 7-IX-1835 a 31-X 1835]}

Ejerce sus funciones de gobernador civil de la provincia desde septiembre de 1835, según refleja la real orden que publica el Boletín Oficial de la Provincia de Valladolid $n^{\circ} 72$ de fecha 7 del citado mes y año. En consecuencia, el día 26 de octubre preside la sesión de instalación de la Diputación provincial convirtiéndose de esta forma en el primer presidente de la Diputación en este nuevo período y el noveno presidente de la institución desde su fundación. Su presencia en el cargo es efímera, pues asiste a las cuatro primeras sesiones que se celebran en los cuatro primeros días de legislatura, siendo cesado en sus funciones el día 31 del mismo mes de octubre y año de 1835. En octubre de 1838, es nombrado secretario de Estado, Marina, Comercio y Gobernación de Ultramar.

\section{Porro López de Ulloa, Antonio}

[Vicepresidente de 28-X-1836 a 16-XII-1837]

El 28 de octubre de 1836, la Intendencia de la provincia comunica a la Diputación el nombramiento de intendente a favor de D. Antonio Porro, en sustitución del Marqués de Casa-Pizarro. En la sesión que celebra la Diputación el día 22 de noviembre, se presentó en la misma, juró el cargo y tomó posesión como vicepresidente. Se mantiene en el puesto hasta el mes de mayo de 1837, asiste a catorce sesiones de la Diputación, aunque su presencia no es regular debido a las numerosas ausencias en el ejercicio de su cargo. Estas faltas le obligan a comunicar con frecuencia que "en su ausencia queda encargado del despacho de la Intendencia el contador de Rentas Sr. Copeiro del Villar". Su puesto es ocupado el 16 de diciembre por el recién nombrado intendente Pedro Sánchez Ocaña. 
Quirós y Contreras, Benigno de

[Presidente de 22-VIII-1843 a 24-IX-1843]

Por decreto del gobierno de 22 de agosto de 1843, es nombrado jefe político de la provincia de Valladolid, presentándose y tomando posesión de la presidencia de la Diputación como vigésimo tercer presidente de la misma en la sesión celebrada el día 2 de septiembre. Su presidencia de la Diputación es muy corta, pues en la sesión que se celebra el día 26 del mismo mes de septiembre, se lee una comunicación suya, en la que manifiesta "la renuncia a su destino". Desde entonces ya no vuelve a aparecer en la Diputación, en la que apenas asistió a tres sesiones. El Boletín Oficial de la Provincia de 20 de agosto de 1863 comunica su nombramiento como gobernador de Badajoz, pero no llega a tomar posesión al presentar la dimisión por enfermedad el 27 de agosto.

\section{Reguera, Eugenio}

[Secretario de Gobierno. Presidente interino en IX-1872 y I y III-1873]

Es nombrado secretario del gobierno en el 18 de junio de $1872 \mathrm{y}$, como viene siendo habitual, coincide con el cambio de gobernador, en esta ocasión es secretario en la segunda etapa del mandato de Vicente Lobit. Ejerce las funciones de gobernador interino en septiembre de 1872 y en enero y marzo de 1873. En este último mes convoca la sesión extraordinaria de la Diputación, aunque no la llega a presidir, puesto que la llegada del nuevo gobernador González-Alegre ocasiona su cese.

\section{Reynoso y Oscariz, Mariano Lino de [Presidente de 11-I-1875 a 17-III-1875]}

Diputado provincial entre los años 1850 a 1854 . Diputado a Cortes y senador en varias legislaturas. Importante hombre de negocios de la provincia. Culmina su carrera política con el nombramiento de gobernador civil de Valladolid, en los primeros días de la Restauración. Toma posesión del cargo el día 11 de enero de 1875 y dimite el 17 de marzo del mismo año, por diferencias con la dirección provincial de su partido. Al tomar posesión nombra como secretario del Gobierno a Marcelino Diez Bueno, que ejerció como diputado provincial en las últimas legislaturas del Sexenio, y también abandona el cargo el 17 de marzo de 1875. Ver biografía en el índice biográfico de diputados.

\section{Rivero, Nicolás María \\ [Presidente de 24-VIII-1854 a 18-X-1854]}

Nació en Sevilla el 3 de febrero de 1815. Estudió Medicina y Derecho en su ciudad natal, aunque no ejerció en ninguna de las dos carreras, y se dedicó de lleno a la política. Destacado progresista defensor de los ideales de libertad y opuesto a la monarquía. Desde 1847 es diputado a Cortes. El 24 de agosto de 1854 es nombrado gobernador civil de Valladolid, tomando posesión del cargo en el mismo día. El día 31 preside por vez primera las sesiones de la Diputación. Su permanencia en el cargo es breve puesto que el 18 de octubre comunica a la Diputación su cese en el cargo. En este período asistió a veinte sesiones. Es el presidente trigésimo séptimo de la Corporación. El día 2 de julio de 1855, en la sesión que celebra la Diputación, se da lectura a un expediente presentado por la Dirección General del Tesoro "para que se reintegren 4.000 reales que, con destino a Sanidad, sacó de las arcas de esta provincia el anterior gobernador D. Nicolás María Rivero, de los que data D. Juan Die go Pérez, su secretario y gobernador interino, cuyo reintegro exige la comisión de Gastos Provinciales". Ante esa reclamación, la Diputación nombró una comisión para conocer el destino del dinero, su posible recuperación y su reintegro al Tesoro Público.

En el año 1856 fundó el periódico "La Discusión". En 1868 es nombrado alcalde de Madrid. En 1869 es el presidente de las Cortes Constituyentes. Se retiró de la vida pública en 1873 y falleció en Madrid el 5 de mayo de 1878, a los 63 años de edad. Era tenido por "hombre público, gran político, defensor de la democracia, hizo 
públicas sus ideas avanzadas de libertad y oposición a la monarquía, contribuyendo de manera eficaz a la Revolución de 1868" "950.

\section{Rodríguez Camargo José}

[Vicepresidente de 2-IX-1813 a 25-VI-1814]

Intendente del Ejército y de la provincia, que, en correspondencia con este cargo, actúa como vicepresidente de la Diputación en los inicios de su actividad, entre el 2 de septiembre de 1813 y el 25 de junio de 1814. Su mayor ocupación se centró en transmitir las órdenes económicas del Gobierno y en procurar que se cumplieran las intenciones recaudatorias del Ministerio de Hacienda. Es el responsable de realizar los repartimientos de las contribuciones entre todos los pueblos de la provincia y solventar en lo posible las dificultades de cobro y las quejas que los mismos ocasionan. A esto hay que añadir los trabajos que originan los suministros al Ejército, así como su instalación y mantenimiento. Estas actividades le llevan a protagonizar continuas controversias y enfrentamientos con los diferentes Ayuntamientos de la provincia. Son especialmente llamativos sus desacuerdos con el Ayuntamiento de Valladolid, quejándose ante el pleno de la Corporación Provincial "por el mal tratamiento hecho a su persona por el $\mathrm{Sr}$. alcalde constitucional y dos individuos del Ayuntamiento de esta Ciudad"

Es una de las personas más asiduas y constantes en las sesiones de la Diputación. Demostraba que su misión no estaba centrada en el trabajo y el progreso de la provincia, sino en la de conseguir un satisfactorio cobro de los impuestos, y también la de cubrir las necesidades de los Ejércitos Reales. La gran dificultad para cumplir estos objetivos estaba centrada en la penuria y la pobreza en las que estaba sumida la provincia. Fue sobre todo un gestor y representante de los poderes centrales. En este período de vigencia de la Diputación, asiste a cuarenta y siete de las cincuenta y dos sesiones que se celebran.

\section{Romero Leal, Bartolomé}

[Presidente de 12-III-1875 a 17-III-1875]

Es nombrado gobernador civil de la provincia por real decreto publicado el 12 de marzo de 1875. Toma posesión del cargo el 17 del mismo mes y el 19 preside la última sesión que celebra la Diputación en esta legislatura, legislatura que se inicia en el Sexenio Revolucionario y que finaliza en la Restauración. En esta sesión anuncia el nombramiento de los nuevos diputados y convoca para el 5 de abril la sesión de instalación de la primera Diputación de la Restauración. No hay constancia de su continuidad al frente del Gobierno Civil en fechas posteriores.

\section{Romo y Gamboa, Francisco}

[Presidente de 31-X-1835 a18-VI-1836]

Es el décimo presidente de la Diputación, que inicia su mandato con la toma de posesión que se celebra el 31 de octubre de 1835. Se mantiene en el puesto hasta el 18 de junio de 1836, asistiendo en todo este tiempo a cincuenta y dos sesiones de la Diputación. En la sesión del 10 de junio, se refleja en el acta que "una vez abierta la correspondencia oficial del Ministerio, el Sr. presidente hizo saber a la Diputación que tenía el sentimiento de manifestar que S.M. se había servido por real orden de 8 del actual, trasladarlo de gobernador civil a la provincia de Zaragoza. Solicitó retirarse para comunicar a su familia la novedad". El día 18 de junio, ante la ausencia de su sucesor y la necesidad de trasladarse a su nuevo destino, avisa de que "deja el Gobierno de la provincia en manos del oficial primero del Gobierno Civil D. Joaquín Bernárdez". 323.

951 A.H.M.V. Libro de actas $n^{\circ} 107$. Pág. $181 \mathrm{v}$. 
El día 8 de mayo de 1838, en el Boletín Oficial de la Provincia, se publica su nombramiento como director general de Montes. En los meses de abril y mayo de 1842, siendo diputado en Cortes, forma parte como secretario de la comisión encargada de redactar el proyecto de "Organización de las Diputaciones".

\section{Rubí, Eugenio}

[Secretario de Gobierno. Presidente interino de 28-II-1865 a 14-III-1865 y de 20 a 25-VI-1865]

El Boletín Oficial de la Provincia de 28 de febrero de 1865 publica el nombramiento como secretario del Gobierno Civil de Valladolid, pasando en el mismo momento de su toma de posesión, en la fecha citada, a desempeñar el cargo de gobernador accidental, por cese del titular Sr. Dacarrete. Ejerce la interinidad hasta el mes de mayo, en que llega el nuevo gobernador, José de la Fuente Alcántara. En junio del mismo año 1865 vuelve a ejercer de gobernador accidental entre los días 20 y 25. Por real decreto del 30 de junio de 1865 es cesado en su cargo.

\section{Rubio Campos, Toribio}

[Presidente de 18-III-1863 a 20-VIII-1863]

El real decreto de 18 de marzo de 1863 le nombra gobernador de la provincia de Valladolid, "cesando en el mismo destino en la de Oviedo". Toma posesión del cargo el día 30 del mismo mes y año. El día 15 de abril preside la sesión de la Diputación como el cuadragésimo quinto presidente de la misma, asistiendo a las tres sesiones que se celebran en este mes. El día 15 de mayo toma posesión y preside el Consejo provincial y el 21 de junio "es autorizado para tomar las aguas de Panticosa". Delega el mando en el secretario del Gobierno Ramón de Mazón y Valcárcel y se reincorpora a su trabajo a finales del mes de julio. El 20 de agosto, en el Boletín Oficial se lee el "acuerdo del Consejo de Ministros, admitiendo la dimisión de Toribio Rubio Campos como gobernador de la provincia de Valladolid, lo declaran cesante con el haber que le corresponde y le proponen utilizar oportunamente sus servicios". No hay más noticias sobre sus actividades políticas.

\section{Ruiz Cermeño, Juan}

[Presidente de 24-VI-1843 a 22-VIII-1843]

Nacido el 27 de octubre de 1795 en Arenas de San Pedro, provincia de Ávila, hijo de Antonio Ruiz, que ejerce como abogado y de Avelina Cermeño, que formaron una familia de ocho hijos. Se casó con María Dávila Zenzano. No tiene estudios universitarios y se dedicó a la carrera administrativa, lo que le llevó a recorres numerosas ciudades, aunque finalmente fue a recalar a su ciudad de origen.

En diciembre de 1820 ya ejercía como escribiente en la Dirección General del Reino. En 1836 es secretario del Gobierno Político de Lérida, en 1837 pasa a Huesca y en 1839 a Salamanca. En el año 1840 continúa como secretario de Gobierno en las provincias de Álava, Toledo y Zaragoza, en 1841 está en Segovia, en 1842 en Ávila y en 1843 en Santander. El fin de la Regencia de Espartero propicia la creación de la Junta Provisional del Gobierno de la Provincia y la citada Junta, con fecha 24 de junio de 1843, hace público un oficio en el que se cesa al anterior jefe político Sr. Llamas, y a la vez notifica el nombramiento de Juan Ruiz Cermeño como "jefe político interino". Se presenta en la Diputación y toma posesión como vigésimo segundo presidente de la misma, en la sesión que se celebra el día 10 de julio. Con fecha 22 de agosto del mismo año 1843, anuncia su despedida de Valladolid por haber sido nombrado jefe político de Oviedo. En el breve tiempo de su estancia en la provincia preside la Diputación en once sesiones. En junio de 1844 continuaba al frente de la Diputación de Oviedo (ver Boletín Oficial de la Provincia de Valladolid $\mathrm{n}^{\circ} 70$ de 11 de junio de 1844). En 1846 es nombrado Inspector General de Administración Civil, cargo que deja al ser nombrado diputado a Cortes por Arévalo. En 1849 vuelve a su puesto de Inspector General y en el año 1850 es nuevamente elegido diputado a Cortes, en esta 
ocasión por Piedrahita ${ }^{952}$. A la muerte de su mujer y de su hijo, abandona la política y pasa a residir en Arenas de San Pedro, ciudad en la que falleció el 4 de febrero de 1874.

\section{Ruiz de Mendoza, Mariano}

[Vicepresidente de 8-VIII-1839 a 16-XII-1839]

Por comunicación que se recibe en la Diputación el día 8 de agosto de 1839, se anuncia la toma de posesión como contador de Rentas, y a la vez ejerce de intendente interino ante el cese del titular Sánchez Ocaña. Mantiene la Intendencia interina entre agosto y diciembre de 1839, tiempo en que está suspendido de funciones el titular Sánchez Ocaña, y asiste en este período a trece sesiones de la Diputación. En el mes de diciembre vuelve a sus actividades de contador de Rentas en Valladolid, aunque con fecha 6 de marzo de 1840, por real decreto "S.M. la Reina Gobernadora, se le concede la categoría de intendente", sin llegar a ejercerlo en la provincia.

\section{Saavedra, Domingo}

[Presidente de 21-V-1856 a 5-VII-1856]

En el año 1842 ya ejerce como secretario del Gobierno Político de Valladolid. Por comunicación del gobernador interino de fecha 22 de junio del citado año, anunciando que "teniendo que ausentarse de la provincia por asuntos de servicio, queda encargado del Gobierno Político el secretario Domingo Saavedra". No se conocen más detalles de su trayectoria profesional y política, hasta que, por real decreto de 21 de mayo de 1856, es nombrado gobernador civil de la provincia de Valladolid, aunque no llega a tomar posesión como presidente de la Diputación, por estar cerrado el período de sesiones. Su única actuación conocida relativa a la Diputación está referida a la publicación, conjuntamente con los nueve diputados provinciales y con el secretario Sr. Callejo, de un "Manifiesto a la Provincia", que vio la luz el 3 de julio, donde "se lamentaban de los desórdenes del día 22 de junio, acaecidos en la capital, en Rioseco y en Palencia, con motivo de la carestía de los cereales". Desórdenes conocidos con el nombre del "Motín del pan".

El mismo día 3 de julio, cede el mando de la provincia al capitán general Joaquín Armero y Peñaranda, que declara el estado de guerra. El día 5 de julio publica en el Boletín Oficial de la Provincia un comunicado anunciando que "el ministro de la Gobernación, accediendo a los deseos del gobernador civil y en uso de sus facultades extraordinarias, suspende a V.S. del cargo de gobernador, nombrando a D. Patricio de Azcárate, que lo es de Vizcaya". Su paso por el Gobierno de la provincia tuvo una duración de cuarenta y cinco días y, aunque en este tiempo no presidió ninguna sesión de la Diputación, se le considera como el cuadragésimo presidente de la Corporación.

\section{Sagasti García-Herreros, Luis}

[Presidente de 13-I-1843 a 14-II-1843]

Nació en Pamplona el día 21 de Junio de 1808. Hijo de Juan Gerónimo Sagasti y de Micaela García-Herrero. Abogado y periodista, perteneciente a una conocida familia de conocida trayectoria política de ideología liberal. A los quince años es subteniente de la Milicia Nacional. Exiliado en Francia durante el período absolutista de 1824 a 1832. Ejerció la abogacía en Pamplona y posteriormente fue catedrático de la Universidad de Oñate. Se casa el 14 de febrero de 1839 con Ramona de Castilla Fernández.

Inicia su actividad política como alcalde de Pamplona en el año 1840 y se manifiesta afín a las ideas progresistas de Espartero. En 1841es elegido diputado a Cortes por Navarra. Por real orden de 13 de enero de 1843, es nombrado jefe político de la provincia de Valladolid y presidente de su Diputación, de la que toma posesión

\footnotetext{
${ }^{952}$ CARAS A SOTO, Pedro (Dir.). Diccionario biográfico de parlamentarios ... ob. cit. pág. 940.
} 
en la sesión que se celebra el día 25 del mismo mes. Su mandato es muy corto, puesto que el 17 de febrero de 1843, en la sesión que celebra la Diputación, anuncia su cese como jefe político de la provincia y su nombramiento como fiscal de la Audiencia de Granada. Como vigésimo presidente de la Diputación asiste a once sesiones de la misma. Al poco tiempo de tomar posesión como fiscal de Granada, y en las elecciones para diputado a Cortes, resultó elegido por Valladolid. Posteriormente fue nombrado jefe político de Valencia. En 1846 es elegido diputado a Cortes por Medina de Rioseco (Valladolid). Es uno de los reorganizadores del partido progresista y en agosto de 1845 es detenido y acusado de conspirador. En 1854 es diputado a Cortes por Navarra ${ }^{953}$ y poco después pasó a ejercer la alcaldía de Madrid, ciudad en la que falleció, víctima de la epidemia de cólera el 8 de octubre de 1855.

\section{Sánchez Gata, Julián}

[Presidente de 28-V-1842 a 1-I-1843]

Con anterioridad a su nombramiento, en los libros de actas de la Diputación, con fecha 10 de febrero de 1841 , se refleja la recepción de una comunicación de la Diputación Provincial de Badajoz, dirigida a la de Valladolid, "quejándose del comportamiento del jefe político Julián Sánchez Gata". Esto ocurre en una época en la que la Jefatura Política estaba ocupada por el Sr. Juan Gutiérrez. No se encuentra otra explicación a no ser que se refiera a que el citado jefe político lo sea de Badajoz, y su Diputación se queje, no sólo informando al Ministerio de la Gobernación, sino que al mismo tiempo quiere que su queja llegue a otras Diputaciones.

Julián Sánchez Gata es nombrado jefe político de la provincia por decreto del Regente de fecha 28 de mayo de 1842. Su nombramiento es publicado en el Boletín Oficial de la Provincia de 5 de julio del mismo año. Su toma de posesión como presidente de la Diputación tendrá lugar en la sesión de 14 de septiembre del citado 1842. Como vemos, desde diciembre de 1841 hasta febrero de 1842 preside las sesiones el vicepresidente marqués de Casa Pizarro y entre marzo y septiembre de 1842 preside el vicepresidente Lorenzo Perabeles. Se mantiene como decimonoveno presidente hasta los primeros días de enero de 1843, en que es cesado de su cargo. En el tiempo que ejerció la Jefatura asistió a quince sesiones de la Diputación.

\section{Sánchez Ocaña, Pedro}

[Vicepresidente de 16-XII-1837 a 30-VII-1939 y 7-XII-1939 a 22-II-1840. Presidente de 15-I-1939 a 24-VI-1839]

$\mathrm{Su}$ primera actividad en la provincia de Valladolid es la de intendente de Rentas, cargo para el que es designado en diciembre del año 1837. Se presenta en la Diputación y jura el cargo de vicepresidente en la sesión que se celebra el día 16 del mismo mes y año, asistiendo a las dos últimas sesiones que se celebran. A partir del 26 de diciembre de 1837, ya en marcha la nueva Diputación, continúa ejerciendo el cargo de intendente y vicepresidente de la Diputación, haciéndose cargo también de la presidencia interina durante las ausencias de los jefes políticos.

El día 21 de enero de 1839, en la sesión extraordinaria convocada, el Sr. Sánchez Ocaña anuncia que "por Real Decreto de 15 del actual, S.M. la Reina Gobernadora, ha dispuesto conferirme el desempeño de este Gobierno Político, que hoy he tomado a mi cargo". A partir de esta fecha, simultanea el Gobierno Político y la Intendencia, y en consecuencia se convierte en el decimoquinto presidente de la Diputación, además de la Vicepresidencia, manteniendo ambos cargos hasta el 24 de junio. En esta fecha se nombra a Jacinto Manrique como nuevo jefe político y Ocaña continúa con la Intendencia. Pero por poco tiempo, ya que el 30 de julio del mismo año de 1839 se hace pública una real orden, expedida por el Ministerio de Hacienda, "manifestando haber sido del desagrado de Su Majestad la disposición dada por el Sr. intendente, como presidente de esa Corporación, en virtud de la cual se hizo a la

\footnotetext{
${ }^{953}$ CARASA SOTO, Pedro (Dir.). Diccionario biográfico de parlamentarios ... ob.cit.pág.966.
} 
provincia un repartimiento del grano el 14 de junio anterior". Información que es completada con la comunicación del propio Sánchez Ocaña a la Diputación, "trasladando la real orden citada por la que se le declara cesante de la Intendencia de esta provincia" "954. A partir del 30 de julio está ausente tanto de la Diputación como de cualquier otro cargo provincial, hasta el 7 de diciembre de 1839 , en que por real orden "S.M. se digna reponerle en el cargo de intendente de la provincia". Se mantiene en el puesto hasta el 22 de febrero de 1840, fecha en la que comunica a la Diputación "que por S.M. le ha sido concedido permiso por un mes", aunque en realidad, este permiso parece una excusa, pues no volvió a hacerse cargo del puesto. A lo largo de estos años en la Diputación, asistió a cuarenta y siete sesiones como jefe político/ presidente y a ciento veintiocho como intendente/vicepresidente. El día 1 de mayo de 1840 envía una comunicación a la Diputación "dando cuenta de su toma de posesión como diputado a Cortes por la provincia de Cáceres y ofreciendo sus servicios”.

\section{Santander, Genaro}

[Presidente de 1-X-1868 a 21-X-1868]

Diputado provincial por el partido de Nava del Rey en la décima Diputación isabelina que transcurre entre julio y agosto de 1854. Repite como diputado por el mismo partido en la duodécima Diputación entre agosto y noviembre de 1856. En este período del Sexenio es presidente de la Junta Revolucionaria Provincial y gobernador interino de la provincia del 1 al 21 de octubre de 1868 fecha en la que preside la sesión instalación de la nueva Diputación a la vez que presenta al nuevo gobernador y presidente Manuel Somoza y Cambero. Ver su biografía en el capítulo de diputados provinciales.

\section{Sardina, Ramón}

[Intendente de 10-V-1848 a 25-V-1848]

Por real decreto de 10 de mayo de 1848, es nombrado intendente de Rentas de Valladolid "a comisión", cargo en el que apenas dura unos días, puesto que con fecha 25 del mismo mes, es decir a los 15 días, se publica el cese de su cargo. En este corto período de tiempo no llegó a tomar posesión y no asistió a ninguna sesión de la Diputación.

\section{Sayró, Esteban}

[Vicepresidente de 14-IX-1839 a 7-XII-1939]

En octubre de 1836, por real decreto firmado el día 14, es nombrado administrador de Rentas de Barcelona. En la sesión celebrada el 14 de septiembre de 1839 por la Diputación Provincial de Valladolid, se presenta como nuevo intendente, presta juramento y toma posesión del cargo de vicepresidente. Su presencia en el puesto es corta, puesto que permanece en el mismo el tiempo de suspensión de Sánchez Ocaña, es decir, hasta el 7 de diciembre, fecha en la que es cesado en el cargo al "notificar S.M. la reposición de Sánchez Ocaña en la Intendencia de Valladolid". En el tiempo que ejerció la Intendencia acudió a cuatro sesiones de la Diputación. En el año 1850 se publica su nombramiento como vocal de la "Junta de Clasificación de Derechos de Clases Pasivas".

\section{Seriñá, Primitivo}

\section{[Presidente de 8-IV-1871 a 15-VIII-1871]}

El 8 de abril de 1871, el Consejo de Ministros presidido por el general Serrano le nombra gobernador de la provincia de Valladolid. Toma posesión del cargo el día 20 del mismo mes. La Diputación conoce su nombramiento en la sesión del día 22 en la que se lee "el oficio del día 20 remitido por el nuevo gobernador D. Primitivo Seriñá ofreciéndose a la Corporación". El nuevo gobernador se ofrece, pero no participa en los trabajos de la Diputación. No se presenta ni asiste a las sesiones hasta

954 A.D.P.V. Actas. Libro de actas del 8 de agosto de 1839. 
prácticamente el final de su mandato, en los días 20 y 21 de julio, siendo en las dos únicas ocasiones que hace acto de presencia. El 15 de agosto de 1871 anuncia su cese como gobernador en nota publicada en el Boletín Oficial, "autorizado por el ministro de la Gobernación y de acuerdo con el artículo trece de la Ley Provincial vigente, entrega el mando del Gobierno de la provincia al secretario del mismo D. Abdón de Paz".

\section{Sicilia, Felipe}

[Vicepresidente de 20-V-1840 a 31-XII-1840 y 16-XII-1842 a 14-II-1843]

Pertenece a la Sociedad Económica de Amigos del País de Murcia y Ciudad

Real. Secretario honorario de S.M, es nombrado intendente de la provincia de Valladolid por real decreto de 20 de mayo de 1840. Tomó posesión como vicepresidente de la Diputación en la sesión extraordinaria que se celebra el 20 de junio. Se mantiene en el cargo hasta diciembre del mismo año de 1840, y asiste en este tiempo a ocho sesiones de la Diputación. Es nombrado intendente y jefe político interino de la provincia de Segovia con fecha 28 de abril de 1842, ejerciendo en ese destino hasta fin de año. El 16 de diciembre de 1842 se comunica en la Diputación de Valladolid su nombramiento, de nuevo, como intendente de la ciudad, "de acuerdo con el decreto de Su Alteza el Regente de fecha 17 de octubre anterior". Se presenta en la Diputación y toma posesión de su cargo en el mes de enero de 1843 aunque su presencia tiene una duración muy corta pues el 14 de febrero, es decir, al mes de ser posesionado de su cargo, es cesado. En el tiempo de su presencia asiste a nueve sesiones.

\section{Sierra, Bernardo}

[Secretario de Gobierno. Presidente interino de 15-IV-1866 a 2-V-1866]

Por real orden de 30 de junio de 1865 es nombrado secretario del Gobierno Civil de Valladolid. En abril de 1866 ejerce de gobernador accidental y presidente interino, ante la ausencia del titular José Gallostra y Frau. Se mantiene en el cargo hasta septiembre de 1866.

\section{Somoza y Cambero, Manuel \\ [Presidente de 6-IV-1866 a 17-VII-1866 y de 21-X-1868 a 10-II-1869]}

Nació en el pueblo de San Cosme de Friollada, en la provincia de Lugo, en el año 1815. Hijo de Francisco Javier y de Teresa. Estudió latín, retórica, filosofía y matemáticas en el colegio de Humanidades de Monforte de Lemos. En el año 1832 da por finalizada su formación académica, entrando a trabajar como "meritorio" en la Intervención Militar. En 1836 se alista como voluntario en la Milicia Nacional y llega al grado de sargento. En 1837 es teniente del batallón de Cazadores de la Milicia Activa de Cáceres, concediéndosele en el año 1838 el grado de teniente por méritos de guerra. En 1843 se casó con Carlota Gutiérrez de los Ríos. En el año 1845, por real decreto de 26 de septiembre, es nombrado archivero general de Galicia.

En el año 1854 es nombrado comandante de Infantería por méritos de guerra y en este mismo año inicia su carrera política, al presentarse y salir elegido diputado a Cortes por la provincia de Lugo, escaño que deja al ser nombrado gobernador civil. Es en este cargo en el que se desenvuelve por toda la geografía peninsular a lo largo de veinte años. El 6 de agosto de 1854 es nombrado gobernador de Pontevedra. En 1856 pasa al mismo cargo en Zamora. En 1858 es nombrado gobernador de Guipúzcoa. En 1859 lo es de Logroño. En 1862 pasa a Teruel. En 1863 es elegido gobernador de Salamanca. En 1865 vuelve a ser gobernador de Teruel. En el año 1866 es gobernador de la provincia de Toledo, cuando por real decreto de fecha 6 de abril pasa a desempeñar el mismo cargo en la provincia de Valladolid.

El 2 de mayo toma posesión de su cargo en Valladolid y publica un "Manifiesto a la Provincia" con la intención de calmar la tensa situación social que se inicia en estos tiempos. El 23 de junio vuelve a publicar otro bando contra el intento del 
levantamiento de la población. Pero en el mismo día y en el Boletín Oficial de la Provincia se publica otro bando del capitán general de Castilla la Vieja, D. José de Orozco y Zúñiga, "declarando el estado de sitio en todo el territorio de Castilla la Vieja, tomando el mando de la provincia que le ha resignado el gobernador civil".

La dimisión del gobierno presidido por O’Donell y la suspensión de las garantías constitucionales, así como la formación de un nuevo gobierno presidido por Narváez, provoca numerosos cambios en los Gobiernos Civiles, al que no es ajeno el de Valladolid. "Por real decreto publicado en el Boletín Oficial de la Provincia del 17 de julio de 1866, se cesa en el cargo al gobernador civil de la provincia de Valladolid D. Manuel Somoza y Cambero". Su paso por el Gobierno de la provincia ha sido muy breve, tanto que no ha tenido ocasión de tomar posesión de la presidencia de la Diputación, pero ello no es obstáculo para que se reconociera su buen hacer al frente de la provincia, porque "siendo gobernador de Valladolid, contribuyó a mantener el orden y salvaguardar grandes intereses gracias a su tino y talento en las difíciles circunstancias por las que atravesó nuestra capital" $" 555$.

En el año 1868 ejerce de gobernador civil en Cádiz, hasta el final de la época isabelina. Por decreto de 13 de octubre de 1868, publicado en el Boletín Oficial de la Junta Revolucionaria de Valladolid de fecha 16 de octubre, vuelve a ser nombrado gobernador civil de la provincia, tomando posesión de su cargo el día 21 del mismo mes y presidiendo el día 22 la segunda sesión de la nueva Diputación. Es el primer gobernador del Sexenio. Se mantiene en el cargo hasta el 10 de febrero de 1869, fecha en la que se publica el decreto por el que "es nombrado gobernador de la provincia de Cádiz, cesando en el mismo cargo en la de Valladolid". En este período asiste a once sesiones de la Diputación, aunque no está considerado como presidente de la institución, ya que como tal figura el vicepresidente, Sr. Rodríguez Rubio, de acuerdo con lo dispuesto en la nueva "Ley Orgánica Provincial de 21 de octubre de 1868".

En 1870 pasa a regir los destinos de la provincia de Málaga. En 1871 vuelve a ser nombrado gobernador de Cádiz, puesto en el que se mantiene hasta el año 1874, que con la llegada de la Restauración se dio por terminado su carrera política de matiz progresista. Murió en Valladolid el 16 de febrero de 1893 a los 78 años.

\section{Teijón y Rodríguez, Agustín Víctor}

[Secretario de Gobierno de 5-I-1874 a 20-II-1874]

Nació en Valladolid el 23 de marzo de 1848, y es bautizado en la parroquia del Salvador. Hijo de Juan Bautista y de Florentina. Su padre es nombrado diputado provincial por el distrito de Santiago de Valladolid entre marzo y mayo de 1874. "Estudió en la Universidad de Valladolid, ingresando en el año 1866 en la Facultad de Leyes. En el año 1869 solicitó ser examinado y alcanzó el grado de bachiller en Derecho. En el año 1873 presenta la solicitud y los certificados de los cursos probados entre 1869 y 1873 , para acceder al examen de licenciado en Derecho Civil y Canónico y presentado a examen el 11 de noviembre, fue aprobado" ${ }^{956}$. Recién terminada la carrera, ingresa en el Colegio de Abogados de Valladolid, y al mismo tiempo ejerce como profesor en la Facultad de Ciencias de la Universidad.

El 5 de enero de 1874, el capitán general de Castilla la Vieja teniente general Eulogio González publica un bando por el que, "en virtud de las facultades que me confiere el poder ejecutivo de la República queda Vd. nombrado por la presente disposición secretario del Gobierno Civil de Valladolid". Toma posesión del cargo en el mismo día de su nombramiento y, como es habitual en estos años en que el país tiene suspendidas las garantías constitucionales, al poco tiempo de acceder al cargo, tiene que asumir el gobierno de la provincia de forma interina. Tal ocurre el 19 de febrero del mismo año en que anuncia que "en el día de hoy he tomado posesión del cargo de gobernador interino, por delegación del propietario conforme al artículo trece 
de la Ley Provincial de 20 de agosto de 1870". El cargo le dura un día, puesto que el 20 de febrero se anuncia la toma de posesión del nuevo secretario y gobernador interino.

Entre 1875 y 1880 , ejerce como abogado en Valladolid, y en el año 1881 es nombrado secretario del Gobierno Civil de Huesca y posteriormente de Pontevedra. En el año 1884 vuelve a Valladolid y ejerce de nuevo la abogacía. Es nombrado tesorero del Colegio de Abogados. Es autor de la "Colección legislativa sobre cárceles, presidios, arsenales y demás establecimientos penitenciarios". Está afiliado al Partido Constitucional que es liderado por Sagasta, siendo elegido en el año 1890 diputado provincial, como "fusionista" por el distrito de Peñafiel "en unas elecciones donde abundaron las presiones del gobernador a favor de Teijón". En los dos años de diputado estuvo en la oposición, y en 1891 es nombrado miembro de la Comisión Permanente, en la que siguió en la oposición, lo que le supuso su aislamiento del resto del Consejo. Fallece en Valladolid el 17 de diciembre de 1895 y sus compañeros del Colegio de Abogados celebran un homenaje en su memoria ${ }^{957}$.

\section{Torres Estelá, Matías}

[Secretario de Gobierno de 5-II-1857 a 31-I-1860. Presidente interino de 7-XII-1857 a 9-XII-1857]

El Boletín Oficial de la Provincia de Valladolid de fecha 5 de febrero de 1857, publica su nombramiento como secretario del Gobierno Civil de Valladolid. Se mantiene en este cargo hasta enero de 1860, y ejerce como gobernador interino en el tiempo que transcurre entre la salida del gobernador Bustos y la llegada de Clemente Linares en el mes de diciembre de 1857.

\section{Trillo y Figueroa, Rafael}

[Secretario de Gobierno de 20-VI-1864 a 30-IX-1864 y de 1-X-1866 a 30-VII-1867. Presidente interino en enero y abril-1967]

Nombrado secretario del Gobierno Civil de Valladolid por R. O. de 20 de junio de 1864, tomó posesión del cargo el 19 de julio del citado año y cesó en el mismo por otra R.O. de 26 de septiembre del repetido año, en la que al mismo tiempo se nombraba sucesor a Rafael de la Guardia, que a su vez era cesado el 19 de octubre del repetido 1864 y al mismo tiempo se nombraba nuevo secretario en la persona de Mauricio Trapelía. Ni De la Guardia ni Trapelía ejercieron de interinos. En octubre de 1866 Rafael Trillo y Figueroa, es nuevamente nombrado secretario del Gobierno de Valladolid, y como tal actúa como gobernador accidental en los meses de enero y abril de 1867 ante la ausencia del titular Mariano Herrero. Vuelve a ser cesado en el cargo por real orden de 30 de julio de 1867.

\section{Ureña Cádenes, Manuel de \\ [Presidente de 25 a 28-VI-1865 y 22-V-1867 a 20-IX-1868]}

Nació en Oviedo el 1 de enero de 1824, hijo de Blas de Ureña, abogado originario de Trigueros, provincia de Valladolid y de María del Carmen Cádenes. Estudió Humanidades y Leyes en la Universidad de Oviedo entre los años 1834 y 1843. En 1845 inicia su carrera política, dentro del partido moderado, al ser nombrado subgobernador de Jaca, en la provincia de Huesca. En 1847 es nombrado oficial $1^{\circ}$ del Gobierno Civil de León, ciudad en la que se casa con Juana Barthe. Se mantiene en este cargo hasta el año 1859. En 1860 es nombrado secretario del Gobierno Civil de Lérida. En el año 1862 pasa a ejercer el cargo de secretario en el Gobierno Civil de Palencia, cargo en el que permanece un corto espacio de tiempo, puesto que en el mes de mayo de ese mismo año es nombrado alcalde de Valladolid, donde permanece hasta julio de 1863. En el año 1864, según publica el Boletín Oficial de la Provincia con fecha 1 de mayo es nombrado gobernador civil de la provincia de Palencia, siendo

957 FERRERO MAESO, Concepción y BERZAL DE LA ROSA, Enrique.Historia del Colergio de Abogados de Valladolid. Ed. Colegio de Abogados. Valladolid. 2008. 
trasladado en enero de 1865 al mismo cargo en la provincia de Ávila ${ }^{958}$. En el mes de junio del mismo año 1865, es nombrado gobernador civil de la provincia de Valladolid, toma posesión del cargo el día 25. "En este día he tomado posesión del Gobierno de la Provincia que S.M. la Reina se ha dignado concederme por real decreto de 15 del presente mes... Valladolid 25 de junio de 1865. Firmado Manuel Ureña". Sin tiempo para situarse en su nuevo destino, a los tres días de su toma de posesión, por otro real decreto de 28 de junio de 1865, "se cesa en su cargo de gobernador de Valladolid a D. Manuel Ureña". Tras su cese en Valladolid, se traslada a vivir a León, donde es nombrado "Notario Mayor Eclesiástico", y donde permanece hasta mediados de 1866, en que vuelve a ejercer cargos políticos. El 17 de Julio de 1866 es nombrado gobernador civil de Ávila. En el año 1867, el 22 de mayo, cesa como gobernador de Ávila y es nombrado para el mismo cargo en la provincia de Valladolid. El 4 de junio toma posesión de su cargo y el 8 de julio se presenta y preside la sesión que celebra la Diputación. Es el quincuagésimo segundo presidente de la Corporación. En el mes de agosto, recién llegado, por real decreto de 28 de julio, se le concede un mes de licencia "para el restablecimiento de su salud", y en su ausencia se declara el estado de guerra en toda la provincia, con lo que el gobernador interino, Vicente Álvarez Cossío, "resigna el mando en el capitán general D. Francisco de Paula y Garrido". En septiembre del mismo año 1867 vuelve a hacerse cargo del mando de la provincia, en el que se mantiene hasta el mes de septiembre de 1868, al final del período isabelino. En todo este tiempo presidió las sesiones de la Diputación en treinta y cuatro ocasiones de un total de cincuenta y dos que se celebraron a lo largo de esta última Diputación isabelina.

Con la llegada del Sexenio Revolucionario y la formación de la Junta Revolucionaria de la provincia de Valladolid, no quiso secundar el movimiento revolucionario, por lo que fue destituido, detenido y encerrado durante quince días en el "Fuerte de San Benito". Una vez liberado, se retiró a León donde ejerció la abogacía, y también se dedicó a la política, encuadrado en el partido moderado con el que fue elegido diputado provincial entre los años 1869 y 1885, además de ser nombrado gobernador de Salamanca durante un corto tiempo. Falleció en Madrid el 22 de mayo de 1891 a los 67 años.

\section{Villarías Ruiz, Gaspar}

[Secretario de Gobierno de 1-I-18169 a 11-I-1870]

Es nombrado secretario del Gobierno Civil de Valladolid, de acuerdo con la orden ministerial publicada en el Boletín Oficial el día 1 de enero de 1869. Permanece en el puesto hasta el 11 de enero de 1870, fecha en la que se publica un comunicado anunciando su cese en Valladolid y su traslado al mismo puesto en el Gobierno Civil de Oviedo. Durante su estancia en Valladolid no asumió ninguna interinidad. Hasta que llega su sucesor, ocupa el cargo de secretario interino el oficial $1^{\circ}$ Benito Santos Guerra. Será nombrado diputado provincial en mayo de 1874 y ejercerá a lo largo de la quinta Diputación del Sexenio, hasta la llegada de la Restauración. Ver una breve biografía en el capítulo de diputados provinciales.

\section{Villava, Ambrosio de}

[Presidente de 25-V-1874 a 4-I-1875]

El 25 de mayo de 1874, el Gobierno Civil publica un bando en el que se anuncia la toma de posesión de D. Ambrosio de Villava como nuevo gobernador de Valladolid. El cual en el mismo día convoca "para el día 30 de mayo, y los siguientes que sean necesarios, a la Diputación Provincial, en el salón donde celebra sus sesiones con objeto de continuar las sesiones suspendidas el 10 del corriente" ${ }^{959}$. El citado 30 de mayo se inician las actividades de la quinta Diputación, y aunque el gobernador la

${ }_{958}^{959}$ CARAS A SOTO, Pedro (Dir.). Diccionario biográfico de alcaldes ... ob. cit. pág. 618.

959 B.O.P.V. n 79 de 28 de mayo de 1874. 
convoca, no se presenta en la Diputación y en su lugar remite un oficio que se lee en la sesión. En él se dice que "no siéndome posible asistir a la apertura de las sesiones de la Excma. Diputación, como fuera mi deseo, por impedírmelo asuntos urgentes del servicio, ocupará la presidencia interina el diputado de más edad, conforme a la ley". No llega a presidir ninguna sesión y a lo más que llega es a presentarse en la Corporación el 3 de noviembre de 1874 y, según reflejan las actas, "abierta la sesión por el Sr. gobernador, éste se retiró porque así lo exigían los urgentes y graves asuntos del servicio". Permanece en el cargo hasta el 4 de enero de 1875 , ya en los inicios de la Restauración. Entonces, por un decreto de la citada fecha, "la Regencia del Reino admite la dimisión que del cargo de gobernador civil de la provincia de Valladolid ha presentado D. Ambrosio de Villava, declarándole cesante con el haber que por clasificación le corresponde. Fdo. A. Cánovas del Castillo.”

\section{Villaverde, Manuel de}

[Vicepresidente de 5-I-1844 a 18-VII-1847 y 25-V-1848 a 29-XII-1849]

En el año 1844, por real decreto del 5 de enero, es nombrado intendente de la provincia de Valladolid, tomando posesión del cargo de vicepresidente de la Diputación en la sesión que se celebra el 3 de febrero del mismo año. Es caballero de la Real Orden de Carlos III. Tomó parte activa en los trabajos que desarrolla la Diputación, asistiendo a setenta sesiones entre febrero de 1844 y junio de 1847 . En el mes de marzo de 1844 ejerce como presidente interino, ante la ausencia del titular, Sr. Arrieta. El 18 de julio de 1847 se publica una real orden, por la que se le cesa en el cargo, despidiéndose de la Diputación en la sesión celebrada el día 23 del mismo mes, a la vez que anuncia la Intendencia interina a favor del contador de Rentas D. Eustaquio García. El 25 de mayo de 1848 vuelve a ser nombrado intendente de la provincia, tomando posesión del cargo el 8 de junio, y del cargo de vicepresidente el 14 de septiembre. Se mantiene en el puesto hasta el mes de diciembre de 1849, en que por reales decretos de los días 28 y 29 , se acuerda la desaparición de la figura del intendente y la aparición del nuevo gobernador de provincia, que asume tanto las funciones del jefe político como las del intendente. En este período asiste a cinco sesiones, siendo el último intendente de la provincia que como tal desempeña el cargo de vicepresidente de la Diputación. En el tiempo que media entre junio de 1847 y mayo de 1848, es decir, en el año que pasó entre el cese y la nueva toma de posesión, pasaron por la Intendencia de la provincia tres intendentes.

\section{4.- LOS DIPUTADOS PROVINCIALES}

Estamos en los inicios de la puesta en marcha de las Diputaciones. Las Cortes han legislado que el jefe político sea nombrado por el gobierno de turno, y que los diputados provinciales sean nombrados por "los electores de partido al otro día de haber nombrado los diputados de Cortes", según se estipula en el artículo trescientos veintiocho de la Constitución. En un principio el número de electores es reducido y está conformado en función de su capacidad económica, al igual que ocurre con los candidatos a diputados, y estas limitaciones reducen el número de individuos y facilitan la elección de los que se consideran más idóneos para el cargo, aunque esta limitación se irá corrigiendo con el paso de los años, hasta alcanzar un máximo número de electores en los años del Sexenio. Para un mejor conocimiento de los diferentes diputados que pasaron por la Diputación vallisoletana, y también para mejor conocer sus inquietudes, tanto desde un punto de vista social, como cultural y político, hemos dividido este período de estudio en seis etapas. En su totalidad abarcan desde el año 1813 hasta 1875, con las consecuentes interrupciones de los períodos absolutistas, los seis apartados que coinciden con los seis momentos políticos diferentes que transcurren a lo largo de estos años: El liberalismo constitucional (1813-1814 y 18201823), los inicios de la época isabelina (1835-1840), las etapas progresistas (18401843 y 1854-1856), la época moderada (1844-1854), la época isabelina (1856-1868) y 
la etapa revolucionaria (1868-1874). En cada uno de estos períodos, los diferentes personajes que conforman la Diputación son un fiel reflejo de la ideología política de la mayoría gobernante.

\subsection{1.- LOS DIPUTADOS LIBERALES DE 1813-1814 Y 1820-1823}

Todavía no se han apagado los ecos de la Guerra de la Independencia y ya se inician los trabajos de las nuevas Diputaciones, con los primeros diputados elegidos a través de elecciones. En el caso de la Diputación de Valladolid, estos primeros individuos que la conforman sobresalen por el interés de trabajar por la mejora de la provincia, por lo destacado de su posición económica en comparación con los habitantes del partido por el que se presentan, por un acendrado sentido liberal, lo que conlleva un interés por el progreso político, y también, y es lo más importante, por un fuerte sentido de paternalismo y hegemonía en su jurisdicción.

La Constitución de 1812 exigía una serie de condiciones para acceder al cargo de diputado provincial. Su artículo trescientos treinta señala con claridad que para ser diputado se requiere "ser mayor de veinticinco años, natural o vecino de la provincia, con residencia a lo menos de siete años y que tenga lo suficiente para mantenerse con decencia”. En definitiva, la comisión legisladora quería decir que era necesario que el diputado conociera el territorio y sus necesidades y sobre todo tenía que tener una capacidad económica desahogada ya que al ser un cargo no remunerado debía de dedicar una parte importante de su tiempo a la gestión de los problemas provinciales sin menoscabo de su patrimonio, aspecto este del que también se discutió su procedencia, admitiendo que "aparte de las rentas de los capitales propios también se podían admitir las rentas de los establecimientos mercantiles y fabriles". Otra cualidad, que aunque no quedó reflejada en el articulado, sí fue objeto de discusión fue la de que "convenía que los diputados fueran personas instruidas, no necesariamente de conocimientos científicos sino más bien de prácticos"

Estas condiciones hacen que los veintidós diputados que trabajaron por y para la provincia en los primeros años de vigencia de la Diputación y que conformarían tanto la primera Diputación de la Constitución, como las tres Diputaciones del Trienio Liberal sean personajes relevantes dentro de una provincia caracterizada por su escasa formación económica y cultural. Por profesiones destacamos a ocho licenciados, seis hacendados, tres presbíteros, tres agricultores, un suministrador de víveres al ejército y un diputado del que no conocemos el origen de sus bienes. Otro de los aspectos que llama la atención es la de que parte de estos personajes continuarán la gestión de la política provincial en la época isabelina, ya sea personalmente o por medio de sus descendientes, y uno de ellos, Alonso González Rodríguez, pasará a la política nacional como diputado a Cortes.

\subsection{2.- LOS DIPUTADOS DE LOS PRIMEROS AÑOS ISABELINOS: 1835-1840}

La actividad política en el inicio de la época isabelina se encuentra con la falta de una autoridad provincial y en consecuencia, la necesidad de establecerla, por lo que, como indicaba el preámbulo de la ley de Restablecimiento de las Diputaciones "urge la creación de los cuerpos provinciales protectores inmediatos de los intereses de los pueblos". La necesidad y la urgencia por poner a punto las instituciones provinciales obligan a los primeros gobiernos isabelinos a restablecer tanto la Constitución de 1812 como el resto de leyes liberales relativas a las Diputaciones, motivo por el cual los diputados provinciales elegidos en estos primeros años lo son en las mismas condiciones tanto sociales como económicas que las tenidas en los años liberales. La promulgación de la Constitución de 1837 no incide en la legislación relativa a las Diputaciones puesto que para estas Corporaciones como también para los Ayuntamientos, lo único que legisla es "la existencia de las Diputaciones y Ayuntamientos formados por el número de individuos que determine la ley y cuya organización y funciones estarán determinadas por ley", y estas citadas leyes que debían de completar la legislación no fueron aprobadas en estos años. 
A lo largo de estas tres primeras Diputaciones de la época isabelina, que transcurren entre octubre de 1835 y diciembre de 1840, son treinta y tres los diputados que se suceden en la gestión de la Corporación. Unos de ellos, Argüello, González Perotes y Maldonado, son "los tres viejos conocidos" de los años constitucionales 1813-14 y liberales 1820-23. Otros son nuevos en estos años, pero serán los primeros de una serie de "sagas familiares" que se mantendrán en la política provincial y en la nacional a lo largo de los años. Son los casos de Millán Alonso, de Manuel Alday, de Cabeza de Vaca, de Gómez Rozas, de las Moras, de Pérez Cantalapiedra, de Pimentel, de Fernández Vítores, de Manuel Llamas, de Martín Lozar, etc. Individuos todos ellos con una buena situación económica, con un buen control del territorio por el que son elegidos, que alternarán su presencia en la Diputación provincial, con su presencia en el Congreso de los Diputados, en el Senado o en el Gobierno de la Nación, y sobre todo en los Ayuntamientos de sus ciudades de residencia. En este conjunto de diputados, por su profesión destacan los ocho diputados que son abogados, nueve hacendados, tres industriales, nueve agricultores, dos comerciantes, un médico y un catedrático. Desde la perspectiva de la dedicación política tenemos que seis de los diputados también ejercerán o ejercieron el cargo de alcaldes y otros tantos desarrollarán su actividad política a partir del cargo de diputado a Cortes.

En sus respectivas biografías que reseñamos más adelante veremos su evolución en las diversas actividades industriales, comerciales económicas y políticas, pero en su conjunto tenemos que destacar en esta primera "hornada" de diputados provinciales una gran dedicación en apoyo de los ciudadanos, una gran preocupación por el desarrollo y mantenimiento de la política, aunque a veces están más controlados de lo que quisieran por el gobierno central y sobre todo un gran interés por participar y por aprender la política especialmente a nivel nacional, con el consiguiente dominio y participación en el manejo de las elecciones, de los distritos y de una incipiente propaganda a la hora de ejercer el voto. Entre todos ellos hay que destacar a Millán Alonso del Barrio por su proyección política, tanto de él mismo como de sus sucesores y a Miguel de las Moras Ortega, por ser el más constante en el desarrollo de su labor como diputado provincial, labor que se extendió a lo largo de ocho legislaturas que tuvieron lugar entre 1837 1860. La actividad política de estos diputados tendrá su continuación a través de sus hijos o de otros familiares.

\subsection{3.- LOS DIPUTADOS PROGRESISTAS: 1840 - 1843 Y 1854 - 1856}

El progresismo en la época isabelina está dividido en dos períodos, que tienen como nexos de unión, a nivel nacional el protagonismo del general Espartero, y a nivel provincial la aparición mayoritaria de los diputados provinciales de carácter progresista. En el primer período son nombrados por "decreto de la Regencia" y en el segundo período son reclamados para hacerse cargo de la Diputación "los diputados que ya lo eran en 1843." El total de individuos que conformaron estas Diputaciones fueron de once en el primer período, formado por una sola Diputación y dieciocho en el segundo, constituido por dos legislaturas y de estos dieciocho, seis son los que repiten de la legislatura del 43 , lo que hacen un total de veintitrés diputados diferentes en los dos períodos progresistas.

Dos son las "ocurrencias" más llamativas a lo largo de estos períodos progresistas. La primera es la del rescate en ambos períodos, de la legislación que estuvo operativa a lo largo de los años liberales de 1813-14 y 1820-23. Ya sea porque no les dio tiempo a legislar de acuerdo con las nuevas tendencias progresistas en estos años, aunque no nos podemos olvidar de los proyectos de ley de Diputaciones de 1840 y de la Constitución non-nata de 1856, o porque consideraban que la legislación anterior cubrías las expectativas ideológicas del progresismo, lo cierto es que durante estos años se repusieron y mantuvieron las leyes de organización de las Diputaciones que se aprobaron el 3 de febrero de 1823. La segunda "ocurrencia" de estos años progresistas esta referida a la presencia de los diputados provinciales, que si en la legislatura de 1840 fue a través de elecciones en las dos legislaturas de Bienio no 
fueron así, que habría sido lo más natural sobre todo pensando en gobiernos progresistas sino que por el contrario fueron nombramientos hechos por la autoridad política, es decir, nombramientos interesados y escogidos en función de la ideología predominante. Esto no evitó por otro lado, la aparición o el mantenimiento de diputados de carácter conservador pero con un gran poder de elección en sus respectivos distritos. Así tenemos conviviendo a progresistas como Alderete, Gusano, Alonso García, Benito Moreno, Quiroga Martínez o Genaro Santander con elementos moderados como son Juan Manuel Arévalo, Cantalapiedra, López Puga, Miguel de las Moras Ortega y su hijo Juan Antonio de las Moras Gala.

Los primeros diputados progresistas, que dominan y se mantienen en la institución, son los elegidos durante los años 1840 a 1843, es decir, durante todo el primer período progresista. En el segundo período de 1854 a 1856, vuelven a aparecer, en principio, los mismos personajes que fueron nombrados en la anterior Diputación. Posteriormente son relevados, con la particularidad de que en esta ocasión, los nuevos diputados presentan ya una cierta dependencia de los partidos políticos y de las directrices emanadas desde los centros de decisión de los mismos. Esta nueva situación no impide que también se mantengan en la Diputación, y sigan manejando los resortes económicos de la provincia los diputados de tendencia moderada, que por sus relaciones y el control que ejercen en sus respectivos territorios, además de su influencia política, económica y social continúan controlando y manejando la institución. Si nos atenemos a las actividades profesionales que concurren en los veintitrés diputados de este período, estos se dividen en doce licenciados, siete hacendados dos agricultores un industrial y un escribano.

\subsection{4.- LOS DIPUTADOS DE LA DÉCADA MODERADA: 1844-1854.}

El 1 de noviembre de 1843 es el inicio de la legislatura con la que comienza la Década Moderada, y el 8 de enero de 1845 se publica la nueva ley de "Organización y Atribuciones de las Diputaciones Provinciales", ley en la que se modifican las condiciones para acceder a la Diputación y en la que se mantienen una serie de exigencias, en especial las económicas. Por esta ley, para ser diputado provincial se necesita "ser español mayor de veinticinco años, residir y llevar por lo menos dos años de vecindad en la provincia o tener en ella propiedades por las cuales se paguen mil reales de contribuciones directas, y tener una renta anual procedente de bienes propios que no baje de ocho mil reales de vellón o pagar quinientos de contribuciones directas". Con estas condiciones se sigue manteniendo unas altas exigencias económicas que frenan el acceso al cargo provincial a la mayoría de los vecinos de la provincia y por el contrario, facilitan su acceso a las élites económicas.

A lo largo de estos años, un total de veintinueve diputados se suceden en representación de los nueve partidos judiciales en que está dividida la provincia y que actúan a lo largo de las cinco corporaciones que se establecen en estos años de la Década Moderada, y solamente tres de ellos, Mllán Alonso, Manuel Gusano y Miguel de las Moras, han sido diputados en legislaturas anterores. La mayoría de estos personajes se caracterizan por su pensamiento político de carácter moderado. Se mantienen y se consolidan los representantes de las familias más poderosas y representativas de la provincia, como son Millán Alonso del Barrio por Peñafiel, Arévalo por Rueda y La Mota, García Pizarro por Rioseco, Garzón por Villalón, Madrueño y Quintero por Valoria junto con De las Moras y así se podían ir encuadrando la mayoría de los diputados como representantes de las "familias provinciales".

Los diputados progresistas, que se encuentran en minoría, mantienen su voz reivindicativa en las sesiones que celebran las sucesivas Diputaciones. Entre ellos destacan Manuel Fernández Montealegre, diputado por Medina, Manuel Gusano, diputado por Villalón y Dionisio Nieto que, en representación de Valladolid, se enfrentó a sus colegas de la Corporación por "su servilismo monárquico". 
Un dato significativo es el que de los veintinueve diputados que formaron estas legislaturas, dieciocho de ellos han cursado estudios universitarios, en su mayoría en la Facultad de Derecho, siete son hacendados dos se dedican a la industria, un comerciante y un escribano. Es una demostración de la alta capacidad económica y cultural de todos ellos, de acuerdo con las exigencias de acceso al cargo

\subsection{5.- LOS ÚLTIMOS DIPUTADOS ISABELINOS: 1856-1868.}

Con esta etapa unionista se da por finalizada la época isabelina, con un total de cuarenta y cinco diputados que se sucederán en la gestión de las ocho diferentes Diputaciones que transcurren entre 1856 y 1868. Como reacción al recién finiquitado Bienio Progresista, la primera Diputación vallisoletana de este período es "tomada" por los hombres más conservadores del espectro provincial, que son designados, sin ningún tipo de elecciones, por el capitán general del Distrito Militar. En las sucesivas legislaturas se accede al cargo de diputado a través de elecciones y de acuerdo con las condiciones vigentes según la ley de 8 de enero de 1845. Ley que se mantendrá vigente hasta que el 25 de septiembre de 1863 se promulga una nueva ley "Para el Gobierno y Administración de las Provincias", ley tan conservadora como la anterior y que tiene pocas diferencias en el tema de elección de diputados. Se mantiene la obligación de ser mayor de veinticinco años, residir y llevar al menos dos años de vecindad en la provincia y con respecto a las capacidades económicas se exige tener una renta anual de seis mil reales de vellón o pagar una cuota anual de contribución directa de al menos de seiscientos reales.

Se suceden ahora en la Corporación los diputados componentes de la nueva burguesía harinera y de los negocios, generalmente dotados de poder económico, en su mayoría compradores de bienes nacionales, controladores de los negocios, defensores de la agricultura y de una clara ideología conservadora. Burguesía que se va diluyendo con el paso de los años, a causa de la crisis económica y que en la Diputación van siendo sustituidos paulatinamente por los nuevos progresistas enfrentados a la monarquía. En definitiva, durante este tiempo pasan por la Diputación representantes de todos "los colores políticos" de la provincia. A diferencia de las Diputaciones anteriores, en estos años, el control político está compartido entre los dirigentes provinciales y los nacionales. Ya no se percibe una peculiaridad tan provincial como la que destacaba en las anteriores Diputaciones. Como datos estadísticos, de los cuarenta y cinco diputados que pasan por la Corporación a lo largo de estos años, sólo seis de ellos proceden de Diputaciones anteriores y cinco volverán a presentarse en la época del Sexenio. El resto, es decir, treinta y cuatro diputados ejercerán únicamente en este período, en una o varias Diputaciones. Con respecto a sus ocupaciones tenemos a veinticuatro diputados que son licenciados y como en años anteriores la mayoría lo son en Derecho, aunque ello no quiere decir que todos ellos se dediquen a la abogacía, sino que también se dedican a la administración de sus bienes tanto agrícolas como industriales y comerciales, diez son hacendados, seis agricultores, tres propietarios y comerciantes y de dos no conocemos su ocupación.

\subsection{6.- LOS NUMEROSOS DIPUTADOS DEL SEXENIO: 1868-1874}

La Ley Electoral y la Ley Orgánica Provincial, ambas publicadas el 20 de agosto de 1870 suponen un cambio importante tanto en el número de electores como en las condiciones de las elecciones. En el primer caso se generaliza la posibilidad de ser elector, fijando la edad mínima en veintiún años y en el segundo caso desaparecen en su totalidad las condiciones económicas que existían para alcanzar el cargo de diputado provincial.

A lo largo de estos años, en los que prevalece la ideología progresista, entre las cinco Diputaciones que se suceden, desfilan un total de noventa y cuatro diputados Es un número elevado a causa del aumento de componentes en la formación de las Diputaciones, que pasan de los nueve diputados con que están formadas las dos primeras a los treinta y cinco diputados con que se forman las tres últimas 
Diputaciones; a lo que hay que añadir una serie de ceses y dimisiones provocad as por la inestabilidad política. De dichos diputados, hay que tener en cuenta que cincuenta y séis lo ejercieron en una sola legislatura, diecisiete lo fueron en dos, veinte diputados repitieron en tres Diputaciones y un solo diputado estuvo presente en cuatro de las cinco Diputaciones que funcionaron en el Sexenio. Otro detalle de estos diputados es el de que únicamente siete de ellos fueron diputados en las anteriores Diputaciones isabelinas.

Otro dato llamativo nos dice que la ampliación del número de diputados benefició a los partidos políticos situados en la oposición, es decir, a los conservadores y moderados. Porque al ser elegidos por distritos con un ámbito territorial más reducido, el control de los votos se conseguía con una mayor facilidad. Por este motivo, vemos que en las diferentes Diputaciones aparecen elegidos "individuos con un talante conservador", sin olvidarnos de que los electores y votantes de ideología progresista son minoría en el espectro electivo provincial.

Finalmente en este numeroso grupo, cuarenta y nueve diputados son licenciados, seis son propietarios, ocho comerciantes, quince hacendados, cuatro funcionarios, ocho agricultores y cuatro industriales.

\section{5. - ÍNDICE ONOMÁSTICO DE LOS DIPUTADOS PROVINCIALES}

A continuación presentamos una relación de los doscientos veintiún diputados que han ejercido el cargo en la Diputación Provincial de Valladolid desde el 2 de septiembre de 1813, fecha de su primera implantación hasta el 18 de marzo de 1875 día en el que se da por finalizada la última legislatura del Sexenio. En este Índice reflejamos en primer lugar el nombre del diputado, a continuación el distrito, que se corresponde con la población en la que ha sido elegido, con las puntualizaciones de que en las legislaturas que se suceden hasta el año 1870, los diputados son elegidos en las cabezas de partido, que oscilan entre 7 y 9 y a partir de 1870 la elección es a través de los 35 distritos en que se divide la provincia, sigue la columna de meses que está referida al tiempo total en meses que ha ejercido el diputado en las diversas legislaturas en las que fue elegido y finalmente la columna de legislaturas indica las diferentes Diputaciones por las que fue elegido, correspondiendo el dígito al número de legislatura y la letra a su período. Así la $\mathrm{C}$ se identifica con el período constitucional gaditano, la $\mathrm{T}$ se corresponde con el Trienio, la Y esta señalada para la época isabelina y la $\mathrm{S}$ para el Sexenio.

\section{NOMBRE}

A

Alday García, Manuel

Alderete, Faustino

Alonso del Barrio, Millán

Alonso Burgueño, Luis

Alonso García, Andrés

Alonso García, Félix

Alonso Martín, Luis

Alonso Martín, Manuel Cruz

Alonso Pesquera, Eusebio

Alonso Pesquera, Miguel

Álvarez de Casas, Isidro

Álvarez Guerra, Pedro

Álvarez López, Laureano

Álvarez Vicente, Agustín

\section{DISTRITO}

Valladolid

Valladolid

Peñafiel

Peñafiel

Peñafiel

Campaspero

Tordesillas

Rioseco

Peñafiel

Quintanilla

Peñafiel

Nava del R.

Santiago

Rioseco
M ES

$\begin{array}{cl}10 & 2 \mathrm{Y} \\ 52 & 4 \mathrm{Y}-11 \mathrm{Y} \\ 50 & 1 \mathrm{Y}-5 \mathrm{Y} \\ 1 & 4 \mathrm{~S} \\ 56 & 4 \mathrm{Y}-10 \mathrm{Y}-11 \mathrm{Y} \\ 55 & 2 \mathrm{~S}-3 \mathrm{~S}-4 \mathrm{~S} \\ 57 & 17 \mathrm{Y}-18 \mathrm{Y}-19 \mathrm{Y} \\ 51 & 1 \mathrm{~S}-3 \mathrm{~S}-4 \mathrm{~S} \\ 37 & 16 \mathrm{Y}-17 \mathrm{Y} \\ 47 & 3 \mathrm{~S}-4 \mathrm{~S}-5 \mathrm{~S} \\ 84 & 13 \mathrm{Y} 14 \mathrm{Y} 15 \mathrm{Y} 17 \mathrm{Y} 18 \mathrm{Y} \\ & \\ 12 & 4 \mathrm{~S}-5 \mathrm{~S} \\ 26 & 3 \mathrm{~S}-4 \mathrm{~S} \\ 36 & 17 \mathrm{Y}-18 \mathrm{Y}\end{array}$

LEGISLAT. 
Allue Allue, Anselmo

Antona Semolinos, Luis

Arévalo, Juan Manuel

Arévalo Miera, Felipe María

Arévalo Miera, Fernando

Arévalo Miera, Ignacio M.

Argüello, Joaquín Antonio de

Aspes Álvarez, Ignacio de

Ayllón, Juan Gualberto

B

Basanta, Donato

Bayón Cano, Toribio

Bendito Carrillo, Agustín

Berdonces, José

Bergaz, Juan Manuel

Blanco, Francisco

Blas Ramirez, Francisco de

Botella, Federico

Burgueño, Eusebio

Burgos Pérez, Hermenegildo

C.

Cabeza de Vaca, Fernando

Cabeza de Vaca Pelayo

Cabrejas de la Plaza, Felipe

Cafranga, Isidoro Mariano

Calderón Mantilla, Francisco

Calvo Asensio, Francisco

Camino, Venancio

Campesino, Mariano

Cantalapiedra, Pedro Paulino

Cantalapiedra Maestro S.

Capdevila Pedrero, Mariano

Castilla de Lanuza, Enrique

Clemente Herrero, Máximo

Conde Bravo, Santiago

Conde Camazón, Jerónimo

Corral, José del

Criado, Pedro

Cuadrillero Herce, Hermeneg.

Cuadrillero Nájera, José M.

D

Daniel, Manuel

Delgado Rico, Vicente

Díaz, Cesáreo

Díez

Díez Bueno, Marcelino

Díez Quijada, Lázaro

Díez del Río, Benito

Díez Salcedo, Sebastián

Díez Serrano, Francisco

Domínguez de la Mata, And.

Dueñas, Miguel de

Dueñas Rodríguez, Celestino

E
S. Miguel

Catedral

Olmedo

Rueda

Torrelobatón

Mota del M.

Rioseco

Medina

Olmedo

Olmedo

Rueda

Valoria

Valladolid

Nava del R.

Valoria

Valoria

Matapozuelo

Salvador

Nava del R.

V.Audiencia

Mota del M.

Olmedo

Nava del R.

Mayorga

Mota del M.

Mota del M.

Valladolid

Medina

Matapozuelo

Peñafiel

Catedral

Cuenca de $\mathrm{C}$

Cigales

S.Nicolás

Villalón

Villalón

Rioseco

Palazuelos

Villalón

Nava del R.

Olmedo

----i?----

Tordesillas

V.Audiencia

Nava del R.

Rioseco

Valladolid

Villadefrade

Medina

Medina
$3 \mathrm{~S}-4 \mathrm{~S}$

$4 \mathrm{~S}-5 \mathrm{~S}$

4Y-11Y

$3 \mathrm{~S}$

$3 \mathrm{~S}-4 \mathrm{~S}-5 \mathrm{~S}$

$7 \mathrm{Y}-8 \mathrm{Y}$

1C-1T-1Y

$1 \mathrm{~S}-2 \mathrm{~S}$

$1 \mathrm{~S}$

$19 Y$

$4 \mathrm{~S}$

15Y-16Y-19Y

$1 \mathrm{C}-1 \mathrm{~T}$

$2 \mathrm{Y}$

$3 \mathrm{Y}$

$12 \mathrm{Y}$

$5 \mathrm{~S}$

4S-5S

$18 \mathrm{Y}$

$16 \mathrm{Y}$

$3 \mathrm{Y}$

$6 \mathrm{Y}-14 \mathrm{Y}-15 \mathrm{Y}$

$11 \mathrm{Y}$

$4 \mathrm{~S}-5 \mathrm{~S}$

$1 \mathrm{~S}$

$2 \mathrm{Y}$

$3 Y$

4Y-11Y

$4 \mathrm{~S}-5 \mathrm{~S}$

$1 \mathrm{~S}$

$5 \mathrm{~S}$

1S-2S-3S-4S

$2 \mathrm{~T}$

$4 \mathrm{~S}$

$1 \mathrm{Y}$

$1 \mathrm{~S}$

3T

$3 S-4 S-5 S$

15Y-16Y

15Y-16Y-17Y

$2 \mathrm{Y}$

$13 \mathrm{Y}$

$3 S-4 S-5 S$

$1 \mathrm{~S}$

$6 \mathrm{Y}$

14Y-15Y-16Y

$2 \mathrm{Y}$

$3 S-4 S-5 S$

6Y-7Y-8Y

$19 \mathrm{Y}$ 
Enríquez, Dionisio

Escudero, Eusebio

Espinosa Rico, Rafael

\section{F}

Fernández, Cristóbal Magdal.

Fernández, José

Fernández Fernández, Andr.

Fernández González, Juan

Fernández Miranda, Sebast.

Fernández Montealegre, Man.

Fernández Montero, Francis.

Fernández Rico, José Manuel

Fernández de la Torre, Calixt.

Fernández de Velasco, Domi.

Fernández Vítores, Juan M.

Flores, Paulino

Francos, Juan

Fuente, Eusebio de la

\section{G}

Galván, José

García Casasola, Ildefonso

García Duque, Francisco

García Escobar, Joaquín

García Escobar, Ventura

García Galán Pascasio

García Pizarro, Luis

García Serrano, José

Gardoqui Fernández, José

Garzón San Juan, Domingo

Gavilán de Gavilán, Mariano

Girón y Rodríguez, Laureano

Gómez de Rozas, Pedro

Gómez de Rozas Reynero P.

Gómez Villavedón, Luis

González, Baltasar

González, Facundo

González García, Manuel

González Perotes, José A.

González Rodríguez, Alonso

Guerra Franco, Lucas

Gusano, Manuel

Gutiérrez Barquín, Manuel

Gutiérrez Cañas Gutiérrez, D.

Guzmán Lucas, Liborio

H

Haro, Bernardino de

Herrero López, Miguel

I

Ibáñez Martín, Miguel

Izquierdo, Venancio

J

Jofre de Villegas Villar, F.M.

L

Lara, Francisco

\begin{tabular}{|c|c|c|}
\hline Rioseco & 45 & $5 \mathrm{Y}$ \\
\hline Valoria & 2 & $1 \mathrm{~S}$ \\
\hline Peñafiel & 21 & $19 \mathrm{Y}$ \\
\hline Valladolid & 2 & $4 Y$ \\
\hline Peñafiel & 14 & $2 \mathrm{Y}$ \\
\hline Tiedra & 10 & $5 \mathrm{~S}$ \\
\hline Villavelliz & 10 & $3 \mathrm{~T}$ \\
\hline Medina & 15 & $3 \mathrm{~S}$ \\
\hline Medina & 45 & $5 \mathrm{Y}$ \\
\hline Rioseco & 14 & $2 \mathrm{Y}$ \\
\hline S. Pedro & 3 & $5 \mathrm{~S}$ \\
\hline Valladolid & 64 & $13 \mathrm{Y}-14 \mathrm{Y}-15 \mathrm{Y}$ \\
\hline Campaspero & 10 & $5 \mathrm{~S}$ \\
\hline Valladolid & 12 & $1 \mathrm{Y}$ \\
\hline Medina & 10 & $5 \mathrm{~S}$ \\
\hline Villalón & 12 & $18 \mathrm{Y}$ \\
\hline Medina & 14 & $2 \mathrm{Y}$ \\
\hline Alaejos & 10 & $3 \mathrm{~T}$ \\
\hline Nava del R. & 37 & $3 \mathrm{Y}-11 \mathrm{Y}$ \\
\hline Olmedo & 1 & $4 \mathrm{~S}$ \\
\hline Rioseco & 0 & Suplente 1S \\
\hline Rioseco & 3 & $10 \mathrm{Y}-11 \mathrm{Y}$ \\
\hline Nava del R. & 21 & $19 \mathrm{Y}$ \\
\hline Rioseco & 27 & $8 Y-9 Y$ \\
\hline Peñafiel & 0 & Suplente 1S \\
\hline V.Plaza & 17 & $2 \mathrm{~S}$ \\
\hline Villalón & 76 & $6 Y-7 Y-11 Y$ \\
\hline Castronuño & 28 & $4 S-5 S$ \\
\hline Rioseco & 56 & $6 Y-7 Y$ \\
\hline Mota del M. & 3 & $3 \mathrm{Y}$ \\
\hline Tordesillas & 3 & $5 \mathrm{~S}$ \\
\hline Nava del R. & 12 & $1 \mathrm{Y}$ \\
\hline Nava del R. & 33 & $4 \mathrm{Y}$ \\
\hline Villalón & 14 & $2 \mathrm{Y}$ \\
\hline Villalón & 33 & $3 S-4 S$ \\
\hline Peñafiel & 83 & 1C1T2T3T3Y \\
\hline Sanabria & 21 & $2 \mathrm{~T}$ \\
\hline V. Plaza & 3 & $1 \mathrm{~S}$ \\
\hline Villalón & 83 & 4Y5Y10Y11Y \\
\hline S. Nicolás & 36 & $3 S-4 S$ \\
\hline S. Martin & 20 & $3 \mathrm{~S}$ \\
\hline Nava del R. & 17 & $2 \mathrm{~S}$ \\
\hline Villalpando & 0 & $3 \mathrm{~T}$ \\
\hline Valladolid & 4 & $12 \mathrm{Y}$ \\
\hline S. Pedro & 45 & $3 \mathrm{~S}-4 \mathrm{~S}-5 \mathrm{~S}$ \\
\hline Villabrágima & 18 & $4 \mathrm{~S}$ \\
\hline Mota del M. & 21 & $19 \mathrm{Y}$ \\
\hline Valladolid & 27 & $8 Y-9 Y$ \\
\hline
\end{tabular}


Llamas Gómez, Manuel

López Flores, Francisco

López Morales, Tomás

López-Puga y Viguero, M.

López-Puga y Viguero, Tad.

López Redondo, Nemesio

López de Tejada y Navia, Joa.

Lorenzo Frontaura, Federico

Lozano Villanueva, Mariano

\section{M}

Macho Mesones, Francisco

Macho Soto, Fernando

Madrueño López-Puga, Gabi.

Maldonado, Joaquín

Maldonado Gimeno, Baltasar

Mantilla, Francisco Antonio

Marquina, Quirino

Martín, Braulio

Martín García, Eugenio

Martín Lozar, Manuel

Martín Ortiz, Manuel

Martín Torés Francisco T.

Martín Vargas, Antonio

Mata Jaques, Mariano de la

Melero, Laureano

Miranda González, Fernando

Montalvo, Gil

Montalvo, Pedro

Moras Gala, Juan A. de las

Moras Gil, Pedro R. de las

Moras Ortega, Miguel de las

Moreno Redondo, Benito

Moyano Sánchez, José

Moyano Zamora, Cándido

Mozo, José

Muñoz Zapata, Ulpiano

Muro López-Salgado, José

$\mathbf{N}$

Nájera, Alejandro

Nava, Ramón María

Nieto, Dionisio

\section{O}

Ocejo Bringas, Remigio

Olivares, Galo

Osorio Casasola, Mariano

$\mathbf{P}$

Palmero Olea, Carlos

Pastor, Ángel

Pérez, Manuel

Pérez Cantalapiedra Atanasio

Pérez Cantalapiedra, Julián

Pérez Minayo, Fructuoso
Villalón

Medina

Olmedo

Valoria

Valoria

Peñafiel

Mota del M.

Palazuelos

Salvador

Rueda

Valladolid

Valoria

Medina

Medina

Almanza

Mucientes

Medina

Quintanilla

Valladolid

Olmedo

Olmedo

Castronuño

Mota del M.

Vilavicencio

S. Nicolás

Medina

Carpio

Valoria

Valoria

Valoria

Rioseco

Nava del R.

Peñafiel

S. Miguel

Nava del R.

S. Andrés

Rioseco

Tordesillas

Valladolid

S. Andrés

Medina

Nava del R.

Villalón

Villalón

Valoria

Olmedo

Matapozuelo

Alaejos
$34 \quad 3 \mathrm{Y}$

110 14Y15Y16Y17Y18Y5S

$17 \quad 2 \mathrm{~S}$

$33 \quad 4 \mathrm{Y}$

$10 \quad 2 \mathrm{Y}$

83 6Y-7Y-8Y-9Y

$4 \quad 12 \mathrm{Y}$

$14 \mathrm{~S}$

$20 \quad 3 S$ 
Pestaña, José

Pimentel Arévalo, Pedro A.

Pimentel Bayón, Vicente

Pinilla García, Pablo

Pizarro Cuadrillero, Vicente

Pizarro Díez, José María

Prado Martínez, Justo Rufino

Prieto, José Luis

Prieto Rodríguez, Félix

Q

Quijada y Calderón, Juan A. Quintero Martínez, Eladio

Quintero Rodríguez, Manuel

Quiroga Martínez, Santiago

R

Rábago de los Ríos, Juan A.

Real Alonso, Bernardo

Recio del Castillo, Fidel

Reoyo, Francisco

Reoyo Pérez, Telesforo

Represa, Agustín de

Reynoso Oscáriz, Mariano L.

Riva Espiga, Ángel de la

Rodríguez, Rafael

Rodríguez, Valentín

Rodríguez Monroy, Teodoro

Rodríguez Rubio, Francisco

Rodríguez Villamandos, Áng.

Romero Peláez, Pedro

Romero y Díez, Pedro R.

Rúa, Casto María de la

Rúa de la Rúa, Faustino de la

Rueda Lorenzo, Tomás de

Ruiz Dávila, Tomás

Ruiz Merino, Eduardo

S

Salcedo, Luciano

Samaniego Samaniego, Bern.

Santana Santana, Claudio

Santana Santos, Antonio

Santander, Genaro

Santander, Juan José

Sanz, Niceto

Sanz, Norberto

Serrano Foronda, José

T

Tablares Maldonado, Felipe

Tamariz, Serapio

Teijón, Juan Bautista

Temes y Prado, Juan Andrés

Ternero Garrido, Isidoro

Tordesillas y Villagómez, P.

Torre Mínguez, Eustaquio

Torres, Isidro
Benavente

Olmedo

C-1T-2T-3T

Medina

Mota del M.

Rioseco

Rioseco

Villalón

Valladolid

Gradefes

Mayorga

S. Andrés

Valoria

Valladolid

S. Andrés

Mota del M.

Mucientes

Villalón

Rioseco

Rioseco

Nava del R.

Villabrágima

Medina

V. Plaza

V.Audiencia

Mota del M.

Catedral

Medina

Valladolid

Mota del M.

Viladefrades

Olmedo

Olmedo

V. Plaza

Rioseco

Mota del M.

Nava del R.

Nava del R.

Nava del R.

Medina

Olmedo

Olmedo

Rioseco

Encinas

Mota del M.

Santiago

Valladolid

Tordesillas

Olmedo

Peñafiel

Villalón
16Y17Y18Y5S

$3 \mathrm{Y}-12 \mathrm{Y}-13 \mathrm{Y}$

$3 \mathrm{~S}-4 \mathrm{~S}$

$19 \mathrm{Y}$

$13 \mathrm{Y}$

$19 \mathrm{Y}$

$6 \mathrm{Y}-7 \mathrm{Y}$

$1 \mathrm{C}-1 \mathrm{~T}$

$2 \mathrm{~T}$

4S

$5 \mathrm{Y}$

$10 \mathrm{Y}$

2S-4S-5S

17Y-18Y

$4 \mathrm{~S}-5 \mathrm{~S}$

$4 \mathrm{~S}$

2S-3S-5S

$4 \mathrm{Y}$

$7 \mathrm{Y}-8 \mathrm{Y}$

$3 S-4 S-5 S$

$3 \mathrm{~T}$

$1 \mathrm{~S}$

$1 \mathrm{~S}$

4Y11Y1S2S

$3 \mathrm{~S}$

$1 \mathrm{~S}$

$1 \mathrm{C}$

$1 \mathrm{Y}$

$4 \mathrm{~S}$

$5 \mathrm{Y}$

$2 \mathrm{~T}$

15Y16Y17Y18Y19Y

2T-Suplente

$6 \mathrm{Y}$

1S-3S-4S

$5 \mathrm{Y}$

10Y-12Y

$10 \mathrm{Y}$

$1 \mathrm{~S}$

$7 \mathrm{Y}-8 \mathrm{Y}$

$12 \mathrm{Y}$

3S-4S-5S

9Y-10Y

$4 \mathrm{~S}$

1C-1T-2T

$14 \mathrm{Y}$

12Y-13Y

3S-4S-5S

3T 


\begin{tabular}{llcl} 
Torres López, Patricio & Mayorga & 20 & $3 \mathrm{~S}$ \\
V & & & \\
Valbuena, Toribio & Villalón & 21 & $14 \mathrm{Y}$ \\
Valdés, Pablo & Portillo & 48 & $3 \mathrm{~S}-4 \mathrm{~S}-5 \mathrm{~S}$ \\
Valdés, Toribio & La Pedraja & 0 & $2 \mathrm{~T}-$ Suplente \\
Velasco y Franco, Manuel de & Rioseco & 3 & $3 \mathrm{Y}$ \\
Velasco Neira, Miguel & Mojados & 48 & $3 \mathrm{~S}-4 \mathrm{~S}-5 \mathrm{~S}$ \\
Villalba, Benigno & S. Martin & 18 & $4 \mathrm{~S}$ \\
Villanueva, Tomás & V.Audiencia & 57 & $17 \mathrm{Y}-18 \mathrm{Y}-19 \mathrm{Y}$ \\
Villarías Ruiz, Gaspar & S. Martin & 10 & $5 \mathrm{~S}$ \\
Z & & \multicolumn{2}{|}{} \\
Zorita Alonso, Juan de Mata & & 9 & $17 \mathrm{Y}-1 \mathrm{~S}$
\end{tabular}

\section{6.- BIOGRAFÍAS DE LOS DIPUTADOS PROVINCIALES}

Como complemento a la anterior relación, a continuación presentamos una breve biografía de todos y cada uno de los diputados reseñados.

\section{Alday García, Manuel}

Nace en la ciudad de Valladolid el día 2 de febrero del año 1792. Hijo de Roque Alday, de Ochandiano y de Rosa García Pardo, de Valladolid, fue bautizado en la iglesia de Santiago Apóstol. Su familia destaca por su dedicación al comercio. Su hermano Roque fue regidor del Ayuntamiento. Se casó con María del Sagrario Guijarro.

Inicia sus estudios en el convento de San Pedro Mártir de Rioseco, donde cursa estudios de Lógica y Física, Metafísica y Filosofía Moral. En el año 1819 "fue examinado y aprobado para oír facultad D. Manuel Alday García, natural de Valladolid, de 27 años poco más o menos, pelo y ojos castaños... incorpora con autorización del Sr. rector los cursos ganados en el convento de San Pedro Mártir..."960. En el año 1821, "en los exámenes de bachiller en Leyes celebrado el 6 de diciembre, es aprobado némine discrepante" ${ }^{961}$. En el mismo año 1821 es nombrado "Maestro Revisor de Letra Antigua". En 1825 tiene que volver a repetir los exámenes de bachiller en Leyes, "porque los efectos de aquel grado quedaron nulos por real decreto que S.M. se dignó expedir luego de haber vuelto a la plenitud de sus derechos... y presentado al examen, se aprobó sin discusión..." ${ }^{962}$. Acabados sus estudios, recibió la autorización de la Real Chancillería para ejercer como abogado e ingresó acto seguido en el "Colegio de Abogados de Valladolid", donde llegó a ser decano en los años 1839, 1847, 1850 y 1851. En el año 1835, destacó por su interés en mantener abierta la Universidad, ya que el Gobierno tenía previsto la supresión. Fue un abogado de gran prestigio. En el año 1850 ingresa en la Real Academia de Bellas Artes de la Purísima Concepción.

Aparte de su actividad profesional, continuó con las actividades comerciales de la familia, que fueron ampliadas con el montaje de una industria de aguardientes y la compra de fincas procedentes de Bienes Nacionales. Su posición económica era desahogada, vivía en la plaza de San Miguel y contaba con cuatro criados y un coche con dos caballerías. Una vez abandonada su actividad política se centra en su trabajo como abogado en Valladolid, a la vez que mantiene sus propiedades de Simancas. En el año 1842 es nombrado director de la Caja de Ahorros y Monte de Piedad de Valladolid, año en el que "adquirió un almacén desamortizado en Simancas por 5.000 
reales, y el amillaramiento le concede 11.500 reales de renta" ${ }^{963}$. En el año 1852, es el vigésimo sexto mayor contribuyente de la provincia "propietario y con dos casas en la ciudad".

Inició sus actividades políticas a una edad muy temprana, puesto que en el año 1809 , siendo estudiante y gracias a su dominio del idioma francés, acompaña como intérprete a la comisión del Ayuntamiento "que sale a recibir al Emperador Napoleón I". Durante el Trienio Liberal participó en las actividades políticas afines con la ideología liberal, entre las que destaca la de miembro fundador de la Sociedad Patriótica de Valladolid. En el año 1822 es nombrado síndico municipal. Durante el período absolutista, tuvo dificultades para ejercer su profesión, ya que fue obligado a un nuevo examen para poder ejercer como abogado. En el año 1834 se integra en los grupos liberales e ingresa en la Milicia Nacional de Valladolid.

En el año 1836 es elegido procurador en Cortes por Valladolid. En 1837 es nombrado alcalde primero constitucional, y el 9 de marzo del mismo año es nombrado diputado provincial. "Comunicación del jefe político, dando cuenta de haber sido nombrado por la Junta Provincial, que tuvo efecto el 5 del corriente, diputado provincial al licenciado Manuel Alday, alcalde $1^{\circ}$ constitucional de esta capital. Se acuerda oficiar inmediatamente a dicho señor diputado para que se sirviera presentarse a la mayor brevedad posible a tomar posesión de su destino y participar en las grandes ocupaciones de esta corporación...". 964

Entra a formar parte de la segunda Diputación isabelina con tres meses de retraso y se mantiene en el cargo hasta el final de la legislatura, que se cierra el 24 de diciembre de 1837, asistiendo en este tiempo a veintiséis sesiones. No volverá a presentarse a las elecciones para diputado provincial, pero a nivel nacional se presentará y obtendrá acta de diputado a Cortes con el partido progresista en las elecciones de diciembre de 1843, aunque no volverá a repetir su candidatura. Falleció en Valladolid el 27 de diciembre de 1852.

\section{Alderete, Faustino}

Es vecino e industrial de Valladolid, ciudad en la que ejerce de ebanista. En sus comienzos "está considerado de clase urbana baja", pero con los años alcanzó una buena posición tanto económica como social. "No tiene criados y declara en 1841 una renta de 1.600 reales en el amillaramiento. Profesional de prestigio, se le encargó la formación del Museo de Santa Cruz con las obras recogidas de los conventos y monasterios desamortizados. Compra una casa en Valladolid procedente de los bienes nacionales por la que pagó 1.300 reales" 965 .

Como primera actividad política, en el año 1837, ejerce como teniente alcalde de Valladolid, ciudad en la que está encuadrado en la Milicia Nacional. En el año 1841, en las elecciones que se celebran en la capital para cubrir la vacante de diputado provincial causada por el fallecimiento de Cristóbal Magdaleno Fernández, en la cuarta Diputación isabelina, obtiene la mayoría de votos y en consecuencia el 26 de junio presenta en la Diputación su acta de diputado. "Pero ante las protestas de la mesa de Tudela, mediante a que tanto las mesas de Tudela como de Valladolid no se habían constituido correctamente, por parte de los señores diputados se discutió su nulidad o validez y una vez que opinaron todos se declaró nula la elección por pluridad de votos" ${ }^{\$ 66}$. Aunque fue declarada nula la elección y no se celebró otra, volvió a presentarse el día 15 de julio y ante la falta de protestas "entró, juró y tomó posesión del asiento". Se mantuvo en el cargo durante el resto de legislatura, que se

\footnotetext{
963 RUEDA HERNANZ, Germán. La desamortización. ob. cit. Pág. 279.

964 CARASA SOTO, Pedro (Dir.) Diccionario biográfico de Alcaldes... ob. cit. pág. 270. CARASA SOTO, Pedro (Dir.). Diccionario biográfico de Parlamentarios... ob. cit. pág. 42.FERRERO MAESO, Concepción y BERZAL DE LA ROSA, Enrique. Historia del Colegio de Abogados .. ob. cit. Pág. 227. A.D.P.V. Actas. Libro de actas del 9 de marzo de 1837.

966 A.D.P.V. Actas. Libro de actas del 26 de junio de 1841.
} 
dio por finalizada en octubre de 1843 , asistiendo en este período a ciento cincuenta y seis sesiones. El 24 de junio de 1843 fue nombrado vocal de la Junta Provisional del Gobierno de la Provincia.

En el año 1854, de acuerdo con el real decreto de 7 de agosto, es nombrado nuevamente diputado provincial por el partido de Valladolid, en la undécima Diputación, "porque lo era en 1843". Presta juramento y toma posesión en la sesión de instalación celebrada el 17 del mismo mes, permaneciendo en el puesto hasta el final de la legislatura y también del Bienio Progresista en 18 de agosto de 1856. Asiste a ciento treinta de las ciento cuarenta y ocho sesiones que se celebraron. En este período es nombrado miembro de las Juntas de Sanidad y Beneficencia y de la comisión de Venta de Bienes Nacionales. Su actuación en las Diputaciones de los dos períodos progresistas le identifica con su militancia política en el Partido Progresista. También en este tiempo 1854-56 está preocupado por la situación social, debido a la carestía de la vida. En consecuencia, apoya en la Diputación la petición del Ayuntamiento de la capital de invertir 20.000 reales en la compra de reses y en habilitar un horno de pan, por razones de carestía de la vida y el abuso de los expendedores.

\section{Allue Allue, Anselmo}

Natural y vecino de Valladolid, perteneciente a una conocida familia, con buen nivel tanto social como económico, e integrada en la élite vallisoletana. El 17 de febrero de 1871 se presenta en la sesión de instalación de la tercera Diputación del Sexenio, con su acta de diputado electo por el distrito de San Miguel, primero de Valladolid. Fue aprobada en la sesión del día siguiente, en la que tomó posesión del cargo. Se mantiene en la Diputación durante toda la legislatura, asiste a cincuenta y seis de las setenta sesiones que se celebraron. Preside la sesión de la Diputación en una ocasión, ante la ausencia del presidente y vicepresidente y en su calidad de diputado decano. En el sorteo que se celebra en la sesión del 25 de julio de 1872, le correspondió continuar como diputado. La cuarta Diputación inicia sus sesiones el 2 de noviembre de 1872 y se presenta en ese día en la sesión de instalación; volvió a hacerse cargo de su escaño de diputado por el distrito de San Miguel de Valladolid. En el mismo día es nombrado vocal de la Junta de Beneficencia.

El 9 de marzo de 1874, el capitán general le comunica que, "de acuerdo con las facultades extraordinarias en que me hallo investido le anuncio su cese como diputado". Abandona el cargo en el mismo día y no vuelve a presentarse en ninguna otra elección. En el tiempo que actuó como diputado asistió a veinticuatro sesiones.

\section{Alonso del Barrio, Millán}

Nació en Quintanilla de Abajo, el 12 de noviembre de 1795, hijo único de Miguel Alonso y de Faustina del Barrio. En el año 1812, con 17 años, quedó huérfano, heredando "un buen número de propiedades, dos fábricas de papel en Quintanilla, y dinero". En el año 1813 invirtió todo el dinero en montar otra fábrica de papel en Sardón, para lo cual "tuvo que canalizar un arroyo desde Traspinedo con cuatro kilómetros de longitud". La fábrica le resultó muy rentable y en el año 1895 todavía estaba en funcionamiento.

No realizó estudios superiores, pero estuvo formado y asesorado en lengua francesa y en economía por un profesor acusado de afrancesado. Se casó en el año 1828 con Mamerta Pesquera y tuvieron siete hijos, dos de los cuales continuaron con la carrera política. Eusebio, que será diputado provincial en los años 1862 a 1865 y sobre todo Miguel, que ejercerá de diputado en el período del Sexenio Revolucionario, alcanzando la presidencia de la Diputación con la llegada de la Restauración. Otro hijo, Rafael, alférez del Regimiento de Coraceros del Rey, morirá en Madrid durante las revueltas revolucionarias del año 1871. Los matrimonios de sus hijos acrecentaron el ya de por sí amplio patrimonio económico y sobre todo continuaron con el control político de la familia. Su hijo Eusebio se casó con Clotilde Lasheras, hija de uno de los más destacados propietarios de la ciudad. Francisca se casó con Pedro Antonio 
Pimentel, rico propietario de la zona de Olmedo, diputado provincial entre 1862 y 1864 y entre 1874 y 1877, diputado a Cortes en 1882 y senador en 1893 . Teodosio se casó con Everilda Pombo, perteneciente a una próspera familia de fabricantes de harina. Toda su vida profesional la dedicará a la administración de su hacienda y de sus fábricas de papel, aumentando de modo considerable su capital y sus fincas.

En el Trienio Liberal compró 928 hectáreas amortizadas y entre 1839 y 1848 adquirió 645 hectáreas en las zonas de Peñafiel, Esgueva y Tierra de Pinares, por las que pagó 202.099 reales ${ }^{967}$. Es promotor y uno de los principales accionistas del ferrocarril Alar-Santander, accionista del Crédito Castellano, y su presidente en el año 1862. En el año 1846 se queja a la Diputación "por el repartimiento de la contribución de inmuebles por ser el dueño de Retuerta y del coto de Valbuena". Tiene casas abiertas en Quintanilla, Sardón y Valladolid, aunque siempre se considerará como vecino de Quintanilla. En 1855 es el mayor contribuyente del partido de Peñafiel con 5.016 reales. En 1860 es el décimo noveno mayor contribuyente de la provincia con 5.649 reales y en 1861 es el décimo quinto con 6.713 reales. En 1866 la Diputación Provincial le compra dos casas en la calle Herradores de Valladolid para ampliar el Hospital de Dementes por 84.580 reales. En 1871 es el décimo tercero mayor contribuyente de la provincia por contribución de inmuebles con 3.282 pesetas, como vecino de Quintanilla. En 1872 es el décimo tercero mayor contribuyente por territorial con 3.287 pesetas y propiedades en Valbuena, Sardón, Cogeces, Quintanilla y Valladolid. Fue un defensor de su provincia y destacó por su afán de mejorar las comunicaciones, en especial los ferrocarriles. También, con su influencia, evitó el cierre de la Universidad de Valladolid, en unos años en los que estuvo amenazada por decisión del Gobierno.

En política fue defensor de la causa liberal, lo que no es obstáculo para que mantuviera el control político en Peñafiel "con maneras caciquiles". Inicia su carrera política en el año 1821, al ser elegido procurador en Cortes. Su entusiasmo por la causa liberal hizo que al final del período, en 1823, fuese encarcelado y posteriormente liberado al pagar una fuerte multa. En el año 1834, con la puesta en marcha de la Diputación, es elegido diputado provincial en la primera legislatura isabelina, entre octubre de 1835 y octubre de 1836, desarrollando una gran actividad y asistiendo a noventa y dos de las ciento veintidós sesiones que se celebran, siendo un o de los diputados más asiduos. En el año 1836 se presenta como candidato para diputado a Cortes por Valladolid, siendo elegido con 1.539 votos (junto a Mariano Miguel de Reynoso, Lorenzo Arrazola y Luis Rodríguez Camaleño). Volvió a ser elegido diputado a Cortes en las elecciones del año 1839 con 2.831 votos, y en 1840 en el que consiguió 3.839 votos. En noviembre de 1843, finalizado el período de la Regencia de Espartero, es elegido nuevamente diputado provincial por Peñafiel, manteniéndose en su puesto hasta finales de 1846, fecha en la que dimite para volver a presentarse como diputado a Cortes. En este su último período político provincial asiste a ciento cuarenta y siete plenos de la corporación, siendo uno de los diputados más inquietos y preocupados por el desarrollo de la provincia, al igual que hizo en su anterior periplo provincial. A partir del año 1847 toda su actividad política se centra a nivel nacional en el Congreso de los Diputados, donde resultó elegido en las elecciones celebradas a principios de este año, al igual que sucedió en las posteriores elecciones a las que se presentó y que se alargaron hasta el año 1857,todas ellas por el distrito de Peñafiel ${ }^{968}$. En el año 1858 , por real decreto de 14 de julio, es nombrado senador del Reino, cargo en el que se mantuvo hasta 1871. Renunció a presentarse en nuevas elecciones, alegando motivos de salud. Falleció en Valladolid el 16 de marzo de 1873 a los 78 años de edad.

RUEDA HERNANZ, Germán. La desamortización... ob. cit. Pág. 302.

${ }_{968}$ CARAS A SOTO, Pedro (Dir.). Diccionario biográfico de Parlamentarios ... ob. cit. pág. 47 


\section{Alonso Burgueño, Luis}

Natural y vecino de Peñafiel. Sus padres son Eleuterio Alonso y Salvadora Burgueño. Es propietario y agricultor.

Se presenta en la Diputación el 11 de mayo de 1874, al final de la cuarta Diputación del Sexenio, sesión en la que se da lectura al oficio del gobernador interino de la provincia del 28 de abril, comunicando su nombramiento como diputado provincial por el distrito de Peñafiel, en sustitución del cesado Eustaquio de la Torre. Es a la única sesión a la que asiste, ya que el mismo día y sesión se da por finalizada la legislatura. Por otro lado, tampoco será nombrado diputado para la siguiente Diputación. Sí volverá a ser elegido diputado por Peñafiel en la Diputación que se forma en el año 1884, siendo relegido hasta el año 1890. El 4 de agosto de 1890, la Comisión Permanente anuncia "el fallecimiento del diputado por Peñafiel Luis Alonso Burgueño".

\section{Alonso García, Andrés}

Nacido en Peñafiel en el año 1804, perteneciente en estos años a la diócesis de Palencia. Asistió a la escuela de "Primeras Letras" en su pueblo natal y a los 13 años pasó a estudiar en el Seminario Conciliar de Segovia, desde donde pasó a la Universidad de Valladolid. "El 15 de noviembre de 1820 solicita el ingreso en la Facultad de Derecho de la Universidad de Valladolid. El 27 de febrero de 1824 solicita ser examinado para recibir el grado de bachiller en Leyes, certificando los cursos de Lógica y Física que ganó en el Seminario de Segovia en 1819 y 1820, Filosofía Moral aprobada en esta Universidad en 1821, Derecho Natural en 1822 y Derecho Romano en 1823 y 1824. Examinado, fue aprobado "némine discrepante". En 1823 solicita el testimonio de buena conducta y se examina y aprueba el grado de licenciado en Leyes" $" 969$. Ejerce la abogacía en Peñafiel.

En política es progresista y es miembro de la Milicia Urbana. El 9 de febrero de 1841 toma posesión del cargo de diputado provincial por el partido de Peñafiel para la cuarta Diputación isabelina. Gana las segundas elecciones celebradas, pues las primeras se declararon nulas, debido a que "el individuo" que resultó elegido, Pedro Fernández de Velasco, ejercía de promotor fiscal, actividad incompatible con el cargo de diputado. Se mantiene en el puesto hasta que el 30 de julio de 1843 es cesado en sus funciones por la Junta Provisional del Gobierno de la Provincia. En este tiempo de actividad ejerce como miembro de la comisión de Repartimientos y asiste a ciento treinta y una sesiones.

El 30 de julio de 1854, es nombrado diputado por Peñafiel por la Junta Provisional de Gobierno de la Provincia, Junta formada en el inicio del Bienio Progresista. Es una Diputación provisional, la décima Diputación isabelina, de muy corta duración, que se extiende entre el 30 de julio y el 14 de agosto, es decir, quince días. Asiste a catorce de las quince sesiones celebradas. El 17 de agosto del mismo año 1854, volvió a tomar posesión de su cargo de diputado, en la sesión de instalación de la undécima Diputación isabelina, que se celebra este día, también por el partido de Peñafiel. Lo hizo, como se repitió en otros casos, de acuerdo con el real decreto de 7 de agosto "por ser diputado provincial en 1843". Se mantiene en el puesto durante toda la legislatura que se extiende hasta agosto de 1856, asiste a noventa y cuatro sesiones y ejerce como presidente interino en dos ocasiones ante las ausencias del gobernador civil y del decano Arévalo. Su hermano Félix ejercerá como diputado provincial durante el Sexenio Revolucionario, entre 1868 y 1874, siendo nombrado presidente de la institución en la tercera Diputación, en los años 1871 y 1872.

\section{Alonso García, Félix}

Nació en Peñafiel el 19 de septiembre de 1832. Estudió en la Universidad de Valladolid, en la Facultad de Leyes alcanzó el grado de licenciado en Jurisprudencia. 
Su hermano Andrés fue también diputado provincial por el partido de Peñafiel en los años progresistas de 1840-1843 y 1854-1856.

El capitán general de Castilla la Vieja le comunica su nombramiento como diputado provincial por el partido de Peñafiel para la segunda Diputación del Sexenio, presentándose y tomando posesión del cargo en la sesión de instalación que se celebra el 18 de octubre de 1869. Se mantiene en el puesto, hasta el final de la legislatura, que tiene lugar el 16 de febrero de 1871, asistiendo a cien de las ciento veintisiete sesiones que se celebran. Continúa como diputado en la tercera Diputación, al resultar elegido en las elecciones celebradas, presentándose en la sesión de instalación que se celebra el 17 de febrero de 1871, acompañado por el acta de elección correspondiente al distrito de Campaspero, del partido de Peñafiel. En la sesión del 20 de febrero, una vez aprobada su acta, sale elegido presidente de la Diputación con veintiún votos a favor de los veintiocho diputados presentes.

Es el quincuagésimo cuarto presidente en toda la historia de la Corporación y el primero que es elegido por los componentes de la Diputación y al mismo tiempo es el primero que accede a la presidencia sin ser gobernador de la provincia. Ejerce su cargo hasta el final de la legislatura, el 30 de octubre de 1872, asistiendo a sesenta y cuatro sesiones de las setenta que se celebraron y presidiendo las sesiones en cincuenta y dos ocasiones. El 25 de julio de 1872 se celebró el sorteo de los diputados a los que correspondía cesar, y le tocó continuar.

El 2 de noviembre de 1872 se inician las actividades de la cuarta Diputación y continúa, como es lógico, representando al distrito de Campaspero. Ejerce hasta el 11 de mayo de 1874, fecha en la que es disuelta la Diputación, por orden del gobernador interino de la provincia. Asiste a veinticuatro de las cuarenta y dos sesiones celebradas. No se presenta a más elecciones.

\section{Alonso Martín, Luis}

Natural del pueblo de San Salvador, provincia de Valladolid, nacido el día 10 de junio de 1835. Hijo de Tomás y de María. "Ingresó en la Universidad de Valladolid en el año 1846, matriculándose en la Facultad de Leyes. El 8 de junio de 1857 solicita ser examinado para alcanzar el grado de licenciado en Jurisprudencia, presentando los certificados de los cursos probados desde 1846. Entró a examen y salió aprobado por unanimidad"970. Se estableció en el pueblo de Villalar, como abogado, de allí pasó a los pocos años a Tordesillas, donde continuó ejerciendo la abogacía y en la que inició su carrera política como diputado entre diciembre de 1863 hasta septiembre de 1868 .

En las elecciones celebradas en diciembre de 1863 para la decimoséptima Diputación isabelina, salió elegido por el partido de Tordesillas, tomando posesión del cargo en la sesión de instalación que se celebra el 1 de enero de 1864. En la misma sesión es nombrado miembro de la comisión de Estudios de Validez de las Actas de Nava del Rey. Ejerce el cargo a lo largo de toda la legislatura, que finaliza en diciembre de 1865, habiendo asistido a cuarenta y tres sesiones de las cuarenta y nueve que celebra la Diputación. Se vuelve a presentar en las siguientes elecciones que se celebran para cubrir el puesto, también por el partido de Tordesillas, las cuales volvió a ganar. El 1 de enero de 1866 se presenta en la sesión de instalación de la decimoctava Diputación, para tomar posesión del cargo, pero su Acta no fue aprobada, ya que se había presentado una reclamación a la elección. "Protesta de Julián Rodríguez Vega contra el diputado electo de Tordesillas Luis Alonso, alegando que el electo Luis Alonso era consocio del arrendatario del ramo de consumos de la villa de Tordesillas. La Diputación acuerda que lo estudie la comisión formada por los Sres. diputados Pimentel, López y Álvarez Vicente". Al día siguiente, la comisión presenta sus conclusiones: "Examinados por la comisión los documentos presentados por el Sr. Rodríguez Vega contra la elección en Tordesillas del Sr. Alonso, la comisión admitió como diputado a Luis Alonso, mediante a que justificaba la aptitud legal que para el 
desempeño de su cargo, exigía la ley. Se comprobó que el Sr. Alonso obtuvo ciento setenta y tres votos de ciento setenta y cinco electores, y que el Sr. Rodríguez le acusó de ser arrendador, cuando en realidad es fiador" ${ }^{971}$. Aprobada la propuesta de la comisión por el Pleno de la Diputación, prestó juramento y tomó posesión del cargo de diputado, en el que continuó hasta el final de la legislatura en diciembre de 1866, asistiendo a las dieciocho sesiones que se celebraron.

En las elecciones a diputados para la decimonovena y última Diputación isabelina, que se realizan los días 25 y 26 de noviembre de 1866 , se presenta nuevamente por el partido de Tordesillas y volvió a ser elegido, por lo que el 1 de enero de 1867 vuelve a tomar posesión del cargo. En la misma sesión es nombrado "Representante de la Provincia en Juicios". En julio de 1867 es nombrado secretario de la Diputación, cargo que mantiene hasta el final de la legislatura, excepto en la última sesión que se celebra el 20 de septiembre de 1868, en la que es nombrado presidente de la reunión, que se corresponde con la única y última sesión de la legislatura. Es el diputado más constante en su presencia en las sesiones, ya que en esta última legislatura asiste a cincuenta y una de las cincuenta y dos que se celebran.

No se presenta a más elecciones durante el Sexenio Revolucionario, pero sí vuelve a ejercer en la política provincial y nacional a partir de la Restauración. A partir del año 1875 aparece como afiliado al Partido Liberal Dinástico o Partido Fusionista. En el año 1882 vuelve a ser elegido diputado provincial por el distrito de Nava-Tordesillas. En el año 1883 es nombrado vicepresidente de la Diputación. En 1884 es nombrado presidente de la Institución y ejerce hasta el año 1885, en que es nombrado gobernador interino de Valladolid. Ante su buen hacer, tanto en la Diputación como en el Gobierno, S.M. el Rey le nombra "Caballero Comendador de la Real Orden de Carlos III" y el periódico El Norte de Castilla "manifiesta el deseo de que se quede en el cargo de forma definitiva, porque puede hacer lo que no es dable a otros que no reúnan semejantes circunstancias" $" 972$.

En el año 1886 es nombrado gobernador de La Habana. En 1888, de vuelta a Valladolid, es nombrado diputado provincial por el distrito de Audiencia. Fallece en Valladolid el 6 de diciembre de 1891. Su hijo Enrique Alonso Rodríguez es nombrado Registrador de la Propiedad gracias a la influencia de los conservadores que se lo pidieron a Maura, invocando "por ser hijo de Luis Alonso, de pura cepa gamacista"

\section{Alonso Martín, Manuel de la Cruz}

Nació el 16 de julio de 1826 en el pueblo de Palacios de Campos, del partido judicial de Rioseco, hijo de Modesto Alonso y de Teresa Martín. Licenciado en Jurisprudencia por la Universidad de Valladolid ${ }^{974}$. Ejerce como abogado en Rioseco y en Palacios de Campos. El 6 de diciembre de 1869, el presidente de la Audiencia le nombra juez municipal de Palacios de Campos, cargo que mantiene hasta febrero de 1871.

En septiembre de 1868 acabada la época isabelina, se forma en Valladolid la Junta Provincial Revolucionaria, siendo elegido miembro de la misma y como tal, forma parte de la Comisión Especial, que se establece el 14 de octubre para cubrir el vacío de la disuelta Diputación, asistiendo a la primera y única sesión que celebra la

A.D.P.V. Actas. Libro de actas de los días 1 y 2 de enero de 1866.

El Norte de Castilla del día 4 de diciembre de 1885.

PASTRANA MORILlA, Heliodoro. La Diputación de Valladolid... ob. cit. pág. 419.

"Solicita su ingreso en la Universidad de Valladolid siendo aprobado el 25 de octubre de 1838 . Se matriculó en la Facultad de Artes. El 21 de junio de 1841 se presenta a examen para alcanzar el grado de bachiller en Artes, saliendo aprobado némine discrepante. En el mismo año de 1841 ingresa en la Facultad de Leyes, cursando estudios hasta 1845, año en el que con fecha 15 de julio solicita ser examinado para alcanzar el grado de bachiller en Jurisprudencia y examinado salió aprobado en votación secreta. En el año 1847 solicitó ser examinado para alcanzar el grado de licenciado en Jurisprudencia, acompañando los certificados de los cursos probados. Fue aprobado y tomó posesión del grado en el claustro celebrado el 11 de julio" A.H.U.V.A. Cajas 471 (doc. 190 a 195), 504 (doc. 507 a 510) y 673-37. 
citada Comisión. Es el inicio de su carrera política. El 21 de octubre del mismo año 1868 es elegido por la misma Junta Revolucionaria diputado provincial de la primera Diputación del Sexenio en representación del partido de Rioseco, tomando posesión del cargo en la sesión que se celebra el citado día. En el mes de noviembre, el ex diputado Benito Moreno presenta una reclamación en la Diputación, solicitando ser nombrado diputado por Rioseco "por tener más derechos que el Sr. Alonso", petición que fue rechazada. En abril de 1869 es nombrado miembro de la comisión de Ventas de Bienes Nacionales. Continúa como diputado hasta el final de la legislatura, en octubre de 1869 , asistiendo en este tiempo a setenta sesiones de la noventa y ocho que se celebran.

No se presenta a las elecciones para diputado en la tercera Diputación del Sexenio, que inicia sus actividades el 17 de febrero de 1871. Pero en la sesión del día 25 del citado mes "se aprueba el nombramiento de diputado por Rioseco de Manuel de la Cruz Alonso, en detrimento de Telesforo Reoyo, cuya candidatura queda anulada". Se incorpora, por lo tanto, a las actividades de la Diputación, ejerciendo hasta el final de la legislatura, el 30 de octubre de 1872, asistiendo a cincuenta y tres de las setenta sesiones celebradas. En la sesión del 25 de julio de 1872 se celebró el sorteo de los diputados a los que correspondía cesar y le tocó continuar.

Se presenta por lo tanto, en la sesión de instalación de la nueva Diputación, la cuarta del Sexenio, que se celebra el 2 de noviembre de 1872, posesionándose del cargo de diputado por el distrito y partido de Rioseco, siendo en la misma sesión nombrado miembro de la comisión de Peticiones. En la sesión del 7 de noviembre de 1872 es nombrado vicepresidente de la Diputación y se hace cargo de la presidencia a partir del 30 de mayo de 1873, por dimisión del presidente Laureano Álvarez, que deja la Diputación al ser nombrado diputado a Cortes. Finaliza su actuación en la Diputación el 11 de mayo de 1874 al ser disuelta en ese día por el gobernador interino. Asistió a treinta y nueve de las cuarenta y dos sesiones celebradas, presidiéndola en quince ocasiones. No vuelve a presentarse como diputado ni en el resto del Sexenio ni en la Restauración.

\section{Alonso Pesquera, Eusebio}

Nació en Quintanilla de Abajo, en la provincia de Valladolid, el 5 de marzo de 1832. En el bautizo se le impuso el nombre de Eusebio Gregorio. Es el mayor de los siete hijos de Millán Alonso y de Mamerta Pesquera ${ }^{975}$. "Ingresó en la Universidad de Valladolid en el año 1844, matriculándose en la Facultad de Filosofía y Letras. El 26 de mayo de 1847 solicita ser examinado para alcanzar el grado de bachiller en Filosofía, y examinado el 15 de junio, salió aprobado. En octubre de 1847 se matricula en la Facultad de Leyes. En el año 1851 solicita ser examinado para alcanzar el grado de bachiller en Jurisprudencia. Entró al examen el 6 de junio y salió aprobado por unanimidad. En el año 1854 presenta la instancia para ser examinado del grado de licenciado en Jurisprudencia, y celebrado el examen el 13 de julio, resultó aprobado. Posteriormente alcanzó el grado de doctor" ${ }^{\text {976 }}$. Se casó con Clotilde Lasheras, hija de José Ruperto, uno de los más importantes propietarios de Valladolid. Con importante hacienda en Sardón y Quintanilla, reside en Valladolid, en la calle León $\mathrm{n}^{\mathrm{o}} 6$ y pertenece al Ilustre Colegio de Abogados de la ciudad, aunque no ejerce la profesión, por actuar como magistrado, además de administrar sus posesiones. En el año 1861 aparece como el cuadragésimo noveno mayor contribuyente de la provincia por industria con una cuota anual de 649 reales.

En política pertenece al partido conservador. Presentado a las elecciones para diputado provincial por el partido de Peñafiel, resultó elegido para la decimosexta

\footnotetext{
975 Su padre Millán Alonso del Barrio ya ejerció como diputado provincial en 1835, recién instaurada la Diputación, y en 1843. También fue diputado a Cortes y senador, industrial y propietario en Quintanilla. Su hermano Miguel Alonso Pesquera ejercerá de diputado provincial en la época del Sexenio Revolucionario.

976 A.H.U.V.A. Cajas 475 (doc. 407 a 411 ), 506 (doc. 427 a 429) y 683-2.
} 
Diputación isabelina y presente en la sesión de instalación que se celebra el 1 de abril de 1862, prestó juramento y tomó posesión del cargo. En la misma sesión es nombrado diputado-secretario, cargo que mantiene durante toda la legislatura, que se da por finalizada en diciembre de 1863, asistiendo en este tiempo a diecinueve de las veintidós sesiones que se celebran. En la siguiente Diputación, la decimoséptima, se vuelve a presentar como diputado, saliendo elegido también en representación del partido de Peñafiel. En la sesión de instalación celebrada el 1 de enero de 1864, prestó juramento y tomó posesión del cargo, siendo nombrado en la misma sesión "Representante de la provincia en juicios y otras actividades". También es nombrado miembro de la comisión de Establecimientos Benéficos y de la comisión de Revisión de las Actas de las Elecciones. Se mantiene en la Diputación hasta el mes de abril de 1865 , fecha en la que presenta la dimisión y comunica a la Diputación que, "habiendo aceptado el cargo de abogado fiscal de la Audiencia Territorial, renunciaba al cargo de diputado provincial por Peñafiel". En este período asiste a treinta y una sesiones de las cuarenta y nueve que celebró la Diputación. Posteriormente es nombrado "Comisario Regio de Agricultura" y por su excelente trabajo se le concede el grado de "Comendador de la Orden de Isabel la Católica". En la época de la Restauración y entre los años 1878 y 1883 , vuelve a ejercer de diputado provincial por el distrito de Campaspero. Falleció en Valladolid el 25 de septiembre de 1884, a los 52 años de edad.

\section{Alonso Pesquera, Miguel}

Nace en Sardón de Duero, el día 1 de septiembre de 1842, hijo de Millán Alonso y de Mamerta Pesquera. Su padre es un importante industrial y propietario de Quintanilla, que fue diputado provincial en las primeras Diputaciones de la época isabelina años 1835-1836 y también entre 1843 y 1847 en representación del partido de Peñafiel. Su hermano Eusebio fue diputado provincial por el mismo partido entre 1862 y 1865.

Inició sus estudios en el Real Seminario de Vergara, de donde pasó al Instituto de Segunda Enseñanza de Valladolid, en el que recibió el grado de bachiller en Artes en el año 1859. También alcanzó el grado de bachiller en Ciencias y la licenciatura en Jurisprudencia, aunque no esté registrado en la Universidad de Valladolid.

Propietario con grandes posesiones en Quintanilla y Sardón, continúa y acrecienta el patrimonio familiar como industrial y empresario, siendo uno de los principales promotores y accionistas del ferrocarril de Valladolid a Ariza, en el que invirtió 700.000 reales. También fue comprador de bienes nacionales, aunque no en gran cuantía. En el año 1867 es el trigésimo noveno mayor contribuyente de la provincia por contribución industrial.

En política es un reconocido conservador y monárquico alfonsino, declarado como "el menos revolucionario de los diputados del Sexenio". Sus contemporáneos consideraban "que tenía todos los componentes de un buen cacique: terrateniente, pequeño industrial, influencias en el gobierno central y amigo de Cánovas del Castillo" $" 977$.

Inicia su carrera política el 17 de febrero de 1871, fecha en la que se presenta en la sesión de instalación de la tercera Diputación del Sexenio. En ella es aprobada su acta de elección en representación del distrito de Quintanilla de Abajo, del partido judicial de Peñafiel. En el mes de marzo es nombrado diputado-secretario y en el mes de abril vocal de la comisión de Beneficencia. Pronto destaca por su oposición "a las arbitrarias decisiones que toma el gobernador apoyado por los diputados progresistas", en especial en temas de beneficencia y presupuestos. Culmina con una exposición en la que "se considera el representante de once miserables pueblos y residente en la 
capital, pidiendo mantener la beneficencia en el Hospital de la Resurrección, después de 314 años de existencia"978.

En el año 1872 presenta al pleno de la Diputación una serie de interesantes propuestas sobre "la descentralización administrativa". Vuelve a criticar la actuación del gobernador, por su intento de nombrar otro diputado para la Comisión Permanente en lugar del elegido por la Diputación, el diputado Benito Moreno, presentando una propuesta de "censura a la actuación del Gobierno". En el sorteo que se celebra el 25 de julio de 1872, para conocer los diputados que debían cesar, le correspondió ser uno de ellos. Finaliza la legislatura el 30 de octubre de 1872, en la que asiste a sesenta y cinco de las setenta sesiones, siendo el diputado más perseverante.

En las elecciones que se celebran a finales de septiembre de 1872, para cubrir las vacantes de los diputados que les correspondía cesar, se presenta de nuevo por el distrito de Quintanilla de Abajo. Fue elegido por 877 votos contra 170 que consigue su competidor Mariano Capdevila, que fue diputado en 1868-69, con lo que demuestra su poder e influencia en su distrito electoral. Se presenta en la sesión de instalación de la cuarta Diputación que se celebra el 2 de noviembre de 1872, en la que es aprobada su acta y es nombrado miembro de la comisión de Aprobación de Actas. El 9 de noviembre es ratificado como vocal de la Junta de Beneficencia. Continúa manteniendo una gran actividad en la institución como lo acredita su presencia en treinta y nueve sesiones de las cuarenta y dos que se celebran a lo largo de la legislatura. En ellas sigue siendo crítico con las actividades del gobernador y hace gala de su inclinación monárquica y conservadora. Este talante crítico hace que el 27 de abril de 1874 se anuncie que "es relevado de su cargo por decreto del gobernador de la provincia en uso de sus atribuciones excepcionales". La publicación de su cese coincide el 11 de mayo de 1874, con la disolución de la Diputación ordenada por el mismo gobernador interino. La quinta y última Diputación inicia sus actividades el 30 de mayo de 1874, con el decreto de nombramientos de diputados, en la que si el gobernador interino le cesó, el titular recién estrenado en el cargo, "por las facultades que le confiere el Poder Ejecutivo de la República, le nombra diputado provincial por el distrito de Quintanilla". Asiste a la sesión de instalación, en la que es nombrado vocal de la comisión de Presupuestos. Continúa con su visión crítica de la política del gobernador, y ante el acuerdo del día 31 de "enviar una exposición al gobierno, haciendo ver el interés de la Diputación por conseguir el bien y la prosperidad del país", sin oponerse al envío de la citada exposición, critica que sea sólo una exposición de intenciones sin ninguna medida práctica. Insiste en que lo que debería de procurar el gobierno, es mejorar la situación del país "y conseguir la terminación de una guerra inspirada por provincias exclusivistas y enemigas del resto de España" $"$ g79.

En el mes de junio vuelve a ser nombrado vocal de la Junta de Beneficencia, aunque cansado de su continua lucha en la oposición, en el mes de noviembre del mismo año 1874 presenta la dimisión. La Diputación, en el pleno del día 7, "acuerda pasar al gobernador la renuncia presentada por los Sres. Pimentel y Alonso Pesquera, rogando que no sea admitida". Consejo que es aceptado por el gobernador que no admite la renuncia.

En enero de 1875 , ya en las postrimerías del Sexenio y recién restaurada la Monarquía en el Rey Alfonso XII, la Diputación le nombra miembro de la comisión de "ir a visitar al Rey e invitarle a visitar nuestra ciudad". En marzo de 1875, se da por finalizada la quinta Diputación del Sexenio, en la que asistió a las dieciocho sesiones que se celebraron.

978 A.D.P.V. Actas. Libro de actas del día 1 de mayo de 1871. En la discusión de los presupuestos 1871-1872, se cuestiona la gratuidad del Hospital Provincial, en especial ante la propuesta del diputado Juan Antonio de las Moras, en la que abogaba por que "el Hospital atendiera a los enfermos que envían los Ayuntamientos, y que éstos corrieran con los gastos de la estancia, a lo que Alonso Pesquera se opone.

979 A.D.P.V. Actas. Libro de actas del día 31 de mayo de 1874. 
En la primera Diputación de la Restauración es nuevamente nombrado diputado provincial por Quintanilla, siendo elegido el quincuagésimo séptimo presidente de la Diputación. Deja la institución en el año 1876, al ser elegido diputado a Cortes por Peñafiel. Es relegido diputado a Cortes en las elecciones celebradas en los años 1879 , 1881 y 1884, destacando por su lucha por conseguir la rebaja de los aranceles en la exportación de las harinas castellanas a Cuba. Para lo cual se ayudó al ser nombrado secretario de la comisión de Aranceles.

Fallece en Madrid, siendo diputado a Cortes en el año 1887.

\section{Álvarez de Casas, Isidro}

Es natural y vecino de la villa de Peñafiel. "En el año 1836 inicia sus estudios en el Seminario Conciliar de Segovia. En 1839 solicita el ingreso en la Universidad de Valladolid, matriculándose en la Facultad de Leyes. En 1844 solicita ser examinado para alcanzar el grado de bachiller en Jurisprudencia. Entró a examen el 3 de julio y salió aprobado por unanimidad" ${ }^{980}$.

Su actividad política se centra en el ejercicio del cargo de diputado provincial entre diciembre de 1856 y diciembre de 1866. Recién finalizado el Bienio Progre sista, es nombrado diputado provincial por el Sr. gobernador, en representación del partido de Peñafiel, presentándose en la sesión de instalación de la decimotercera Diputación isabelina que se celebra el 3 de diciembre de 1856, en la que presta juramento y toma posesión de su cargo. Se mantiene en la Diputación durante toda la legislatura, que finaliza en julio de 1858, asistiendo a diecinueve de las veintisiete sesiones que se celebran. Continúa como diputado por Peñafiel, en la siguiente Diputación, la decimocuarta, que se forma, tomando posesión del cargo en la sesión de instalación celebrada el 18 de julio de 1858. En esta Diputación que dura hasta marzo de 1860 está presente en veintiuna sesiones de las cuarenta celebradas. En la decimoquinta Diputación, que se inaugura el 1 de abril de 1860, continúa como diputado por Peñafiel. El día 16 de abril es nombrado miembro de la comisión de Bagajes. El 30 de marzo de 1862 se da por finalizada la legislatura. Asiste en dieciséis de treinta y una sesiones que se celebran.

En las dos siguientes Diputaciones que se inician en abril de 1862 y enero de 1864, el diputado electo por Peñafiel es Eusebio Alonso Pesquera, que en abril de 1865 renuncia al cargo al ser nombrado fiscal de la Audiencia. En las elecciones celebradas para cubrir la baja, vuelve a salir elegido diputado y en la sesión del 22 de julio de 1865 de la décimo séptima Diputación, al ser aprobada su acta de elección, presta juramento y toma posesión del cargo. La legislatura se da por finalizada en diciembre del mismo año, asistiendo a cuatro sesiones. Continúa como diputado provincial por el partido de Peñafiel en la siguiente Diputación, la decimoctava, que inicia sus actividades el 1 de enero de 1866. Se mantiene en el cargo hasta el final de la misma, que se sitúa en el 30 de diciembre del mismo año, asistiendo a la mitad de las dieciocho sesiones que se celebran. Finalizada esta Diputación y después de representar a Peñafiel en cinco de las seis últimas legislaturas, no vuelve a presentarse como candidato.

\section{Álvarez Guerra, Pedro}

Natural y vecino de Tordesillas, villa en la que nació en el año 1818. "Solicita el ingreso en la Universidad de Valladolid el 30 de octubre de 1833, matriculándose en la Facultad de Leyes. El 23 de junio de 1840, se presentó a examen para alcanzar el grado de bachiller en Jurisprudencia, y salió aprobado némine discrepante siendo decano Pelayo Cabeza de Vaca y rector Blas Pardo. El 24 de junio de 1842, es examinado para alcanzar el grado de licenciado en Jurisprudencia, siendo 
aprobado" ${ }^{981}$. Se instala en Nava del Rey, donde ejerce como abogado y propietario. En el año 1879 paga por contribución rústica 1.585 pesetas ${ }^{982}$.

Se inicia en la vida política cuando, cerca del final de la cuarta Diputación del Sexenio, en la sesión extraordinaria convocada y celebrada el 9 de marzo de 1874, se lee una comunicación del capitán general de Castilla la Vieja en la que dice que "en uso de las facultades extraordinarias de que me hallo investido, acuerdo nombrar nuevos diputados de la Corporación". De esta forma, es nombrado diputado por el distrito de La Nava de la Libertad en sustitución del cesado Mariano Osorio. Toma posesión del cargo en la misma sesión del día 9 y actúa en las siete sesiones que se celebran hasta el final de la legislatura que tiene lugar el 11 de mayo de 1874. Continúa como diputado, por nombramiento del gobernador, en la quinta y última Diputación del Sexenio, en representación del mismo distrito de La Nava y, presente en la sesión de instalación que se celebra el día 31 de mayo de 1874, es nombrado vocal de la comisión de Presupuestos. En junio de 1874 sustituye a Pedro Montalvo, como vocal de la Comisión Permanente, continuando en ese puesto hasta el final de la legislatura en marzo de 1875. Asiste en este tiempo a trece sesiones de la Diputación de las dieciocho que se celebraron. Continúa como diputado provincial en representación del partido de Nava del Rey en la primera Diputación de la Restauración que se inicia el 19 de marzo de 1875 y finaliza en el año 1877

\section{Álvarez López, Laureano}

Es natural de Orense, nacido el 1 de enero de 1844, hijo de Cayetano Álvarez y de Gertrudis López. Se traslada a vivir a Valladolid, donde establece una industria de curtidos en la plaza de las Tenerías. Actúa como cónsul de Venezuela en Valladolid. Se casó con Franca Guerra Itúrvide y tuvieron cuatro hijos ${ }^{983}$.

$\mathrm{Su}$ carrera política se inicia en septiembre de 1868, finalizado el período isabelino, cuando es nombrado vocal de la Junta Revolucionaria de Valladolid. Hasta su disolución, que tuvo lugar el 14 de octubre, actuó como secretario de la misma. Es miembro del partido republicano

En las elecciones celebradas a principios de febrero de 1871, para diputado provincial de la tercera Diputación, se presentó por el distrito de Santiago, séptimo de Valladolid, por el que resultó elegido. Se presenta con el acta en la sesión de instalación que se celebra el 17 del mismo mes, y una vez aprobada, tomó posesión del cargo. En marzo del citado año presenta y apoya en la Diputación una reclamación de Juan Pombo, "en la que solicitaba ser nombrado senador, a la vez que se quejaba del abandono de la oficina administrativa de la Diputación" ". En la sesión del 25 de julio de 1872 se celebra el sorteo de los diputados que debían de cesar y le tocó continuar. En esta legislatura que finaliza el 30 de octubre asistió a treinta y nueve de las setenta sesiones celebradas. La cuarta Diputación inicia sus sesiones el 2 de noviembre de 1872, con la aprobación de las actas de los nuevos diputados. El día 7 del mismo mes se establece la Diputación definitiva, cuando es elegido el quincuagésimo quinto presidente de la Diputación. Se mantiene en su puesto hasta el 29 de mayo de 1873, en cuya sesión "se lee en la Diputación un comunicado de su presidente, anunciando su renuncia al cargo, por haber sido nombrado diputado a Cortes". En este tiempo asistió a veintitrés sesiones, de las que actuó como presidente en quince de ellas.

982 PASTRANA MORILlA, Heliodoro. La Diputación Provincial... ob. cit. pág. 407.

983 CARAS A SOTO, Pedro (Dir.). Diccionario biográfico de parlamentarios... ob. cit. pág. 67

984 Juan Pombo, es un importante industrial harinero y propietario, segundo mayor contribuyente de la provincia por territorial con 6.445 pesetas de cuota anual y propiedades en Esguevillas, Cigales, Villalón y Valladolid. Consideraba que tiene derecho a ser senador "por ser uno de los mayores contribuyentes de la provincia" y se lamentaba que la Diputación no le apoyara. 
En el Congreso de los Diputados representó al distrito de Nava de la Libertad, y no volvió a presentarse como diputado ni a nivel nacional ni provincial. Falleció en Valladolid el 21 de diciembre de 1889.

\section{Álvarez Vicente, Agustín}

Es elegido diputado provincial por el partido de Rioseco, en las elecciones celebradas el 25 y 26 de noviembre de 1863. Presta juramento y toma posesión del cargo en la sesión de instalación que celebra la decimoséptima Diputación el 1 de enero de 1864. En la misma sesión es nombrado miembro de la comisión de Obras. La legislatura se da por finalizada en diciembre de 1864, habiendo asistido en este tiempo a cuarenta y cinco de las cuarenta y nueve sesiones que se celebran.

En el sorteo celebrado para conocer a los diputados a los que corresponde dejar el puesto en la siguiente Diputación le corresponde seguir en representación de Rioseco, y toma nuevamente posesión del cargo en la sesión de instalación que se celebra el 1 de enero de 1866. Ejerce el cargo a lo largo del año en que está vigente, ya que se dan por finalizadas las actividades el 31 de diciembre de 1866. En la sesión de instalación es elegido miembro de la comisión de Estudio del Acta de Tordesillas. En esta Diputación asiste a diecisiete de las dieciocho sesiones que celebra. En el año 1869 es alcalde de Rueda (B.O.P.V. del 17/11/69) y en 1874 es alcalde de Rioseco (B.O.P.V. del 18/10/74). Vuelve a ser elegido diputado provincial en 1883 por el distrito de Rioseco-Villalón, y fue nombrado miembro de la Comisión Permanente.

\section{Antona Semolinos, Luis}

Es elegido diputado provincial por el distrito de La Catedral, segundo de Valladolid, en las elecciones celebradas entre el 10 y 13 de septiembre de 1872 . Se presenta en la sesión de instalación de la cuarta Diputación del Sexenio, que se celebra el día 2 de noviembre, siendo nombrado en la misma sesión pre sidente interino de la Corporación, como diputado de mayor edad. Actúa en el cargo hasta que el 7 del mismo mes se constituyó la Diputación definitiva. Se mantiene como diputado hasta el final de la legislatura en mayo de 1874, como vocal de la comisión de Instrucción Pública. Asiste a treinta y ocho de las cuarenta y dos sesiones que se celebran y en cuatro ocasiones como presidente interino, ante la ausencia del titular. En la quinta Diputación es ratificado en su cargo de diputado por el distrito de La Catedral, tomando nuevamente posesión del mismo en la sesión de instalación celebrada el 31 de mayo de 1874. Permanece en el cargo hasta el 22 de enero de 1874, día en que "por orden del Sr. gobernador civil cesa en el cargo". Asiste en este tiempo a quince sesiones, siendo el presidente de una de ellas, ante las ausencias del presidente y vicepresidente, y por ser el diputado decano. No vuelve a ser elegido diputado.

\section{Arévalo, Juan Manuel}

Nació en Matapozuelos, provincia de Valladolid, en el año 1802, pueblo en el que vivió en sus primeros años. Tiene una relación de parentesco con los Arévalo Miera, también diputados provinciales y oriundos de zonas próximas de la provincia. Inició sus estudios de "Primeras Letras" en su pueblo natal, pasando posterior mente a Valladolid capital, donde "solicita el ingreso en la Real Universidad en octubre de 1817. En febrero de 1824, teniendo probados los cursos correspondientes, se le admitió a examen para alcanzar el grado de bachiller en Leyes, y examinado el día el día 7 fue aprobado némine discrepante" ${ }^{985}$. Una vez finalizados sus estudios, no ejerció la abogacía, sino que se dedicó a la agricultura, siendo considerado el mayor propietario de Mojados, su lugar de residencia. Pertenece a la Asociación de Propietarios Territoriales de España. Es rentista y accionista del ferrocarril AlarSantander y elector en 1846. "Entre 1841 y 1844 compró una finca procedente de bienes desamortizados de 131 hectáreas por la que pagó 112.211 reales. También 
compró una casa y un almacén en Mojados. Su hermano Francisco, vecino de Matapozuelos, compró en este pueblo una finca desamortizada de 65 hectáreas por 76.340 reales" "986. Posteriormente se trasladó a vivir a Valladolid. Casó a una hija con Eladio Quintero, abogado y diputado provincial en 1872-1874. Pertenece al Batallón de la Milicia Nacional.

Se inicia en la política al ser elegido diputado provincial por el partido de Olmedo en la cuarta Diputación isabelina. Jura y toma posesión de su cargo en la sesión de instalación celebrada el 1 de enero de 1841 y permanece hasta el final de la legislatura, el 30 de octubre de 1843. En este período asistió a ciento ochenta y ocho sesiones, y actuó como miembro de la comisión de Estadística. Además, presidió las sesiones de la Diputación en veintisiete ocasiones, ante la ausencia del jefe político. Se caracteriza por su tendencia liberal. En el año 1850 ejerce el cargo de alcalde de Mojados, hasta 1852. El 17 de agosto de 1854 vuelve a tomar el cargo de diputado en la undécima Diputación, por el partido de Olmedo, de acuerdo con el real decreto de 7 de agosto "por el que se nombran diputados a los que lo eran en 1843". Es nombrado diputado-decano y como tal preside las sesiones ante la ausencia del gobernador, como era frecuente en este período. Se mantiene como diputado hasta el final de la legislatura en agosto de 1856, asiste a ciento veinte sesiones de las ciento cuarenta y ocho que se celebran y actúa en cuarenta y ocho de ellas como presidente. En esta Diputación es nombrado miembro de las Junta de Beneficencia y Sanidad y miembro de la comisión de Venta de Bienes Nacionales.

\section{Arévalo Miera, Felipe María}

Natural y vecino de Rueda, pueblo en el que nació en el año 1815. Hijo de Francisco Solano y de Antonia. Su hermano Fernando es diputado provincial y coinciden en la misma Diputación en los años del Sexenio. Su otro hermano Ignacio María también ejerció como diputado entre 1850 y 1854, siendo elegido también como diputado a Cortes en 1850 y 1865. Finalmente, su pariente Juan Manuel Arévalo, fue diputado provincial por Olmedo, en los períodos progresistas de 1840-43 y 1854-56. Está emparentado con Vicente Pimentel Bayón, casado con su hermana Casilda, con Millán Alonso del Barrio, consuegro de Vicente y con Cándido Pimentel Arévalo, hijo de Vicente, todos ellos diputados provinciales y nacionales en varias legislaturas

Estudió en la Universidad de Valladolid, en su Facultad de Leyes, en la que alcanzó el grado de bachiller en Jurisprudencia en Septiembre de 1835. Ejerce como abogado y propietario en Rueda.

En la sesión de instalación de la tercera Diputación del Sexenio, que tiene lugar el 17 de febrero de 1871, se presenta como diputado electo por el distrito de Rueda. Su acta de elección es aprobada en el Pleno del día 19, tomando acto seguido posesión del cargo. En el transcurso de la legislatura asiste a treinta de las setenta sesiones que se celebran hasta el 30 de octubre de 1872, fecha en la que se da por finalizada. No vuelve a tener más cargos públicos, aunque pertenece a una familia que ha estado presente en la vida política provincial, tanto en la época isabelina, como en el Sexenio y lo estará también en la Restauración.

\section{Arévalo Miera, Fernando}

Nació en Rueda en el año 1810, hijo de Francisco Solano Arévalo y de Antonia Miera. Es el mayor de los tres hijos del matrimonio y los tres ejercieron como diputados provinciales. Ignacio María fue diputado entre 1850 y 1854 , por el distrito de Mota del Marqués, siendo también en esos años diputado a Cortes. Felipe María, es diputado en el Sexenio a lo largo de la tercera Diputación en 1871-72, por el distrito de Rueda, legislatura en la que coinciden los dos hermanos. Su pariente Juan Manuel Arévalo fue diputado provincial por Olmedo en los períodos progresistas de 1840-43 y 1854-56. También tiene lazos familiares con Vicente Pimentel, con Millán Alonso del 
Barrio y con Cándido Pimentel Arévalo, todos ellos diputados a lo largo de estos años. Pertenece a una acomodada familia de propietarios con numerosas fincas en Rueda, Matapozuelos, Olmedo, Medina, Mojados y Torrelobatón

"Inició sus estudios en la Universidad de Valladolid en el año 1822, matriculándose en la Facultad de Leyes. El 21 de julio de 1827, se examinó para alcanzar el grado de bachiller en Jurisprudencia, presentando los certificados de los cursos probados. Entró a examen y salió aprobado" 987. Acabados sus estudios se dedicó a la administración de sus propiedades. En 1885 paga por contribución rú stica 1.106 pesetas.

Su inicio en la vida política provincial tiene lugar el 17 de febrero de 1871, fecha de inicio de actividades de la tercera Diputación del Sexenio. En dicha sesión se presenta como diputado electo por el distrito de Torrelobatón, del partido judicial de Tordesillas y en la misma sesión es nombrado presidente interino de la Diputación, al ser el diputado de mayor edad. Preside las cuatro primeras sesiones, hasta la constitución definitiva una vez aprobadas todas las actas. Es nombrado vicepresidente de la Comisión Provincial, organismo de ayuda a la Diputación, que se forma el 25 de febrero del mismo año 1871. Desarrolla su actividad en ambas instituciones hasta el final de la legislatura, que tiene lugar el 30 de octubre de 1872. Asiste a sesenta y cuatro de las setenta sesiones que celebra la Diputación y a las ciento setenta y ocho sesiones que celebra la Comisión Permanente. En el sorteo celebrado el 25 de junio de 1872 , le correspondió continuar ejerciendo el cargo, y por tanto está presente en la sesión de instalación de la cuarta Diputación que tiene lugar el 2 de noviembre de 1872. En esta ocasión no es relegido como miembro de la Comisión Provincial, manteniéndose como diputado, hasta que finalizan las sesiones de esta Diputación que tiene lugar el 30 de mayo de 1874. Asiste en este tiempo a dieciocho de cuarenta y dos sesiones celebradas. Sigue de diputado por Torrelobatón, al haber sido designado por el gobernador de la provincia, en la quinta y última Diputación del Sexenio, que inicia sus actividades el 31 de mayo de 1874 y que finalizarán, ya en la Restauración, el 18 de marzo de 1875. En este tiempo sólo asiste a cuatro sesiones de las dieciocho que se celebran. Continúa como diputado por el mismo distrito en la primera Diputación de la Restauración, formada a partir del 19 de marzo de 1875 y que estará operativa hasta 1877.

\section{Arévalo Miera, Ignacio María}

Es natural de Torrelobatón, villa en la que nació el día 31 de julio de 1821. Hijo de Francisco Solano Arévalo y de Antonia Miera. Pertenece a una acaudalada familia castellana. Sus riquezas se acrecentaron a través de las relaciones parentales, tanto por su parte y la de sus hermanos, como también por su descendencia. Su hermana Casilda se casó con Vicente Pimentel Bayón, que a su vez es consuegro de Millán Alonso del Barrio. Su hermano Felipe es diputado provincial en el año 1871 por el distrito de Rueda y su otro hermano, Fernando, también es diputado provincial por el distrito de Torrelobatón, en cuyo distrito se mantiene en el cargo hasta los años de la Restauración. Su sobrino Cándido Pimentel Arévalo fue diputado a Cortes. Finalmente su pariente Juan Manuel Arévalo, fue diputado provincial en los dos períodos progresistas de 1840-43 y 1854-56.

Estudió las primeras letras en su pueblo natal. "En el año 1834, a los 13 años de edad, solicitó el ingreso en la Universidad de Valladolid, matriculándose en la Facultad de Derecho el 6 de noviembre del citado año. En el año 1841 solicita ser examinado para alcanzar el grado de bachiller en Leyes, siendo aprobado. En el 1843, acabados los estudios, solicita el grado de licenciado en Jurisprudencia, y examinado el día 31 fue aprobado némine discrepante" $" 988$.

987 A.H.U.V.A. Cajas 453 (doc. 228 a 237) y 563

988 A.H.U.V.A. Caja 467 (doc. 182 a 187) y Expediente 670-36. 
Se casó en el año 1847, con Rosa Bayón Martínez-Feijoo, hija y heredera de los condes de Troncoso y marqueses de Bosque Florido, nobles de origen gallego. Su padre formó parte del Ayuntamiento de Valladolid en 1807. El matrimonio tuvo dos hijos, Quintín y Dolores, que se casó con el marqués de la Valdavia. Tanto Quintín como su cuñado fueron diputados a Cortes en los años de la Restauración por la provincia de Palencia. Una vez acabada la carrera universitaria, ejerce por un tiempo como abogado en Valladolid, pero finalmente se inclina por administrar su amplio patrimonio compuesto por 53 fincas situadas en Rueda y los pueblos limítrofes, dedicadas al cereal y a los viñedos y otras 46 fincas en la provincia de Palencia, que fueron adquiridas en 1878 por 286.725 pesetas. Además administraba los bienes de su esposa. En el año 1860 aparece como el vigésimo séptimo mayor contribuyente de la provincia con un montante de 5.144 reales (B.O.P.V. de 20 -enero-1860), y en 1861 es el decimoctavo mayor contribuyente con 5.585 reales (B.O.P.V. de 4-octubre-1861. En estos citados años ya reside en Madrid.

Inicia su carrera política con la vitola de independiente, pero con tendencia moderada. Se presenta como candidato a diputado provincial en las elecciones que se celebran en el año 1850, para la séptima Diputación isabelina y resulta elegido por el partido judicial de La Mota del Marqués. Toma posesión y presta juramento en la sesión del 6 de octubre, asiste únicamente a dos sesiones, en el mismo mes de octubre, ya que el día 16 comunica a la Diputación su elección como diputado a Cortes por la provincia de Valladolid. No se vuelve a presentar en la Diputación y en las actas no queda constancia de que haya presentado la dimisión. Tampoco su plaza vacante por La Mota fue cubierta por otro diputado. En el año 1851 vuelve a ser elegido diputado a Cortes por el distrito de Mota del Marqués, elecciones en las que derrotó a Benito Díez del Río, exdiputado provincial. En el año 1852 se vuelve a presentar y de nuevo es elegido diputado provincial por el mismo partido de La Mota, en la octava Diputación. En esta ocasión se mantiene en el puesto a lo largo de toda la legislatura, desde abril de 1852 hasta marzo de 1854, aunque no fue muy constante en su labor de diputado, puesto que sólo asistió a una sesión, en febrero de 1852, de las veintitrés que se realizaron en el período. Siendo diputado provincial, se volvió a presentar a las elecciones de diputado a Cortes, pero en esta ocasión es derrotado por Claudio Moyano. En el año 1865 se volvió a presentar a las elecciones para las Cortes, por la provincia de Orense, y resultó elegido ${ }^{989}$. Fijó su residencia en Madrid, ciudad en la que falleció el 25 de abril de 1888 .

\section{Argüello, Joaquín Antonio de}

Es natural de la villa de Valdenebro de los Valles, diócesis de Palencia, donde nació en el año 1782. Inicia sus estudios en el "Estudio General de San Pedro Mártir" de la Orden de Predicadores en Medina de Rioseco. Concluidos éstos, solicita su ingreso en la Universidad de Valladolid el día 8 de noviembre de 1799, a la edad de 17 años. .En el año 1804 finaliza sus estudios en la "Facultad de Cánones, Volumen, Código y Quinario de Leyes, siendo aprobado némine discrepante. En el año 1806 solicita y recibe el grado de bachiller en Cánones, por reunir los requisitos de los estatutos de la Facultad de Cánones, según certifica D. Vicente Díaz de la Quintana y Quevedo, secretario del Claustro de la Universidad" "990. Una vez concluidos los estudios, regresa a Valdenebro, donde se hace cargo de la hacienda familiar y al mismo tiempo ejerce como abogado. Al dejar la Diputación en 1820, aparece como abogado y comisionado de la villa de Villanueva de San Mancio y, ante su solicitud, "la Diputación acordó recomendar al Consejo de Estado los méritos de D. Joaquín Antonio de Argüello, abogado de la villa de Villanueva de San Mancio, para que sea atendido y colocado en una plaza de magistratura o judicatura, tanto por su distinguida literatura y probidad, cuanto por los importantes servicios a la provincia en el

${ }^{989}$ CARASA SOTO, Pedro (Dir.). Diccionario biográfico de parlamentarios.... Ob. cit. pág. 95 990 A.H.U.V.A. Cajas 400 (doc. 59 a 65) y 402 (doc.123 a 131). 
desempeño como individuo de la Diputación en la primera y última época, cuando fuera relevado por el nombramiento actual" ${ }^{\prime 91}$. Es miembro de la Milicia Nacional

En las elecciones celebradas el 30 de agosto de 1813 para la formación de la primera Diputación Provincial, es elegido diputado en representación del partido judicial de Rioseco, cargo en el que se mantiene durante toda la vigencia de la Diputación, es decir, desde el 2 de septiembre de 1813 hasta el 25 de junio de 1814, asistiendo a diecisiete de las cincuenta y dos sesiones celebradas. En el año 1820, de acuerdo con los "Reales Decretos de 7 de marzo y sucesivos", es convocado para asistir a la sesión de instalación de la primera Diputación del Trienio, celebrada el día 21 de marzo, siendo confirmado como diputado provincial por el partido de Rioseco. Se mantiene en el cargo el tiempo de vigencia de esta Diputación, es decir, desde el 21 de marzo al 5 de junio de 1820. En este período asiste a veintitrés de las treinta y cuatro sesiones celebradas.

Es nuevamente elegido diputado provincial por el partido de Rioseco, en la primera Diputación del nuevo período isabelino, tomando posesión y prestando juramento en la primera sesión que se celebra el día 22 de octubre de 1835. Se mantiene en el cargo hasta el final de la legislatura que se efectúa el 5 de octubre de 1836. En este período asiste a noventa y ocho de las ciento veintidós sesiones que se celebran, y es nombrado individuo de la comisión de Plantillas. Durante los meses de junio a octubre de 1836, y ante la ausencia de los Sres. Jefe Político e Intendente, actuó como presidente interino en diez de las sesiones celebradas en estos días. Se presenta candidato a las elecciones de diputado a Cortes por la provincia, pero no salió elegido y su nombre no vuelve a aparecer en referencia a su actividad pública ó política.

\section{Aspes Álvarez, Ignacio de}

Es natural de Mojados, partido judicial de Olmedo, donde nació en el año 1816. Bachiller en jurisprudencia por la Universidad de Valladolid ${ }^{992}$.Pasa a residir al pueblo de Pollos, donde ejerce como abogado, a la vez que propietario, pues es comprador de una finca de cinco hectáreas procedente de bienes desamortizados, situada en Tierra de Medina por la que pagó 4.730 reales. En el año 1853 residía en Medina. En el año 1869 es juez interino en Carpio. En el mes de agosto del mismo a ño de 1869 es nombrado juez interino de Primera Instancia de Medina

En el año 1870, una comunicación en el Boletín Oficial de la Provincia comunica que "Ignacio de Aspes y Álvarez, Comendador de la Real Orden Americana de Isabel la Católica, condecorado con varias cruces, diputado provincial, abogado de los Tribunales del Reino, perteneciente al ilustre Colegio de Abogados de Medina y La Nava, socio corresponsal de la Academia Nacional Greco-Latina es nombrado fiscal en el procedimiento de ingreso en la Orden Civil de Beneficencia de los internos del Hospital de la Resurrección que trabajaron en el período epidémico de la fiebre tifoidea" ${ }^{993}$. En septiembre de 1870, el Ayuntamiento de Medina le agradece la donación de cincuenta y ocho libros a la Biblioteca Popular.

En política pertenece al partido progresista. Es nombrado alcalde de Medina en el año 1853. El 1 de octubre de 1868 entra a formar parte de la Junta Revolucionaria Local de Medina, en la que fue nombrado secretario. Es nombrado diputado suplente por el partido de Medina en la primera Diputación del Sexenio, que inicia sus actividades el 21 de octubre de 1868. En el mes de febrero de 1869, en la sesión del día 1, se presenta en la Diputación para suplir la baja del diputado titular de Medina, Pedro Romero. Ejerce en las siete sesiones que se celebran en el citado mes. Es

991 A.D.P.V. Actas. Libro de actas del 31 de julio de 1820.

992 "Estudió en la Universidad de Valladolid, en la que ingresó el 21 de octubre de 1828, de pelo rojo y ojos garzos, a los 12 años, matriculándose en la Facultad de Leyes. En el año 1835, solicitó ser examinado para alcanzar el grado de bachiller en Jurisprudencia, examen al que entró el 6 de junio y salió aprobado némine discrepante" A.H.U.V.A. Caja 460 (doc. 392 a 398).

993 B.O.P.V. n 72 del 13 de mayo de 1870. 
nombrado otra vez diputado provincial en la segunda Diputación del Sexenio, en representación del partido de Medina, "a través de la comunicación pasada por el Sr. capitán general, al hallarse declarado el estado de guerra en todo el territorio". Toma posesión del cargo en la sesión de instalación celebrada el 18 de octubre de 1869. En la misma sesión es nombrado vocal de la Comisión Permanente y vocal de la Junta de Beneficencia. En la sesión del día 21 de octubre presenta en el Pleno de la Diputación un informe sobre el incendio que destruyó el pueblo de Carpio, el pasado 20 de septiembre, ya que en esos días ejercía como juez interino en el pueblo arrasado.Al finalizar la legislatura el 30 de octubre de 1872, contabiliza la asistencia a ciento diecinueve sesiones de las ciento veintisiete que en total se celebraron. En el año 1874 es nombrado de nuevo alcalde de Medina.

\section{Ayllón, Juan Gualberto}

Natural y residente en el pueblo de Matapozuelos. En la sesión que celebra la primera Diputación del Sexenio el 28 de noviembre de 1868, es nombrado diputado suplente por el partido de Olmedo. Se presenta por vez primera en la Diputación el 25 de febrero de 1869, para sustituir al diputado titular Niceto Sanz, que no asiste a las sesiones. Ejerce el cargo hasta el final de la legislatura en octubre de 1869, asistiendo en este tiempo a treinta y ocho sesiones. No vuelve a presentarse como diputado. En el año 1874 es nombrado alcalde de Matapozuelos.

\section{Basanta, Donato}

Natural de Mojados, donde nació en el año 1811. Es hijo de Pedro de Alcántara Basanta, secretario del Ayuntamiento de Valladolid y de la Universidad. Estudia en la Universidad de Valladolid ${ }^{994}$.

Acabados los estudios, pasa a residir al pueblo de Mojados donde es propietario, ejerciendo también de elector. Es socio de la Asociación de Propietarios Territoriales de España y accionista del ferrocarril Alar-Santander. "En el año 1841 compró una finca de bienes desamortizados de 33 hectáreas, de buena calidad, por la que pagó 62.295 reales. Compró, también procedente de bienes desamortizados, una casa en Valladolid, pagando 92.000 reales" ${ }^{995}$. En 1842 pasa a residir a la casa que compró en la capital. En el año 1844 tiene problemas económicos, pues el Boletín Oficial de la Provincia anuncia "la subasta de una finca, propiedad de Donato Basanta, comprada de bienes nacionales al clero regular, por falta de pago" ${ }^{996}$.

Su actividad política la inicia en el año 1849, cuando es nombrado vocal supernumerario del Consejo provincial, hasta que por real decreto de 29 de diciembre de 1852, es nombrado vocal consejero, manteniéndose en el cargo y asistiendo a los consejos hasta su disolución en 1854. El día 1 de enero de 1867, en la sesión de instalación de la decimonovena y última Diputación isabelina, se presenta como diputado provincial electo por el partido de Olmedo, presta juramento y toma posesión del cargo. En la misma sesión, es nombrado presidente de la primera reunión ordinaria, cargo que ejerce hasta el mes de marzo, presidiendo las tres sesiones que se celebran en ese tiempo. En febrero de 1868 es nombrado miembro de la comisión de Hospitales, y también vuelve a ser nombrado presidente de la Diputación para la primera reunión extraordinaria del año 1868. En este tiempo no llegó a ejercer la presidencia por la presencia en las sesiones del gobernador Ureña. Ejerce el cargo de

\footnotetext{
994 "El 9 de noviembre de 1824, solicita el ingreso en la Universidad de Valladolid, a los 13 años de edad, pelo rojo y ojos castaños, matriculándose en la Facultad de Filosofía. En el año 1827 solicita ser examinado para alcanzar el grado de bachiller en Filosofía, acompañando las notas de los cursos probados. Examinado el 17 de julio, salió aprobado némine discrepante. En el mismo año 1827 se matricula en la Facultad de Leyes. El 26 de julio de 1831 se presenta al examen para alcanzar el grado de bachiller en Leyes, saliendo aprobado" A.H.U.V.A. Cajas 456 (doc. 26 a 31) y 502 (doc. 203 a 211).

995 RUEDA HERNANZ, Germán. La desamortización... ob. cit. pág. 297.

996 B.O.P.V. Boletín de fecha 16 de mayo de 1844.
} 
diputado hasta el final de la legislatura, asistiendo a un total de cuarenta y dos sesiones de las cincuenta y dos celebradas, pero no vuelve a presentarse a ninguna otra elección para la Diputación.

\section{Bayón Cano, Toribio}

En las elecciones para la cuarta Diputación del Sexenio celebradas en septiembre de 1872 , es elegido diputado provincial por el distrito de Rueda, del partido judicial de Medina, con 689 votos por los 479 conseguidos por su opositor Cipriano Tejedor Rodríguez. Se presenta en la sesión de instalación que se celebra el 2 de noviembre de 1872, entrega el acta, que es aprobada el día 5, y toma posesión de la plaza. Sin tener gran actividad, se mantiene en el cargo hasta el final de la legislatura que se produce el 30 de mayo de 1874, asistiendo a veintiséis de las cuarenta y dos sesiones que se celebran. En este tiempo tiene más relevancia la noticia de su familiar Pedro Bayón Mogrovejo, también vecino de Rueda, que "Compró el Monte Carrascal de Montemayor de 825 hectáreas, procedentes de los propios de Montemayor y por los que pagó 1.600 .000 reales. Esta compra fue rechazada por el Ministerio de Hacienda, alegando que la finca estaba tasada en 3.500 .000 reales. El comprador alegó que la tasa se hizo con posterioridad a la compra y después de las mejoras introducidas. El pleito ante el Consejo del Estado dio por buena la venta del Monte al Bayón" "997.

\section{Bendito Carrillo, Agustín.}

Natural y vecino de Valladolid, ciudad en la que nació en el año 1827. Estudia Leyes en la Universidad de Valladolid ${ }^{998}$. Acabados los estudios pasa a residir a Cubillas de Santa Marta, donde se dedica a la agricultura. Se preocupa por la mejora del rendimiento de las cosechas y el aprovechamiento de nueva maquinaria y abonos. El Norte de Castilla, le trata de "ilustre agricultor" y le publica una carta "sobre el interés y rentabilidad obtenida por el güano artificial elaborado por fertilizantes $S$ an Isidro" "999. Amplía sus actividades agrarias comprando fincas procedentes de bienes desamortizados, situadas en Cubillas de Santa Marta y en Trigueros del Valle. Estas numerosas compras le provocan una falta de liquidez y las consiguientes dificultades económicas, situación que se hace pública a través del Boletín Oficial de la Provincia, que avisa del "anuncio de subasta de ocho fincas y casas propiedad de Agustín Bendito Carrillo, situadas en el pueblo de Cubillas de Santa Marta, por deudas a la Hacienda de más de 4.000 pesetas" ${ }^{1000}$. Situación que continúa en el año 1874 , cuando es denunciado por Víctor García Bendito, que le reclama deudas por importe de más de 11.000 pesetas.

En política está afiliado al partido moderado, por el que se presenta en noviembre de 1859 a las elecciones para diputado provincial, en la decimoquinta Diputación isabelina, por el partido de Valoria la Buena y resultó elegido después de diez años de estar controlado el partido por parte de Miguel de las Moras. Presta juramento y toma posesión en la sesión de instalación que se celebra el 1 de enero de 1860. El 3 de abril es nombrado vocal de la Junta de Beneficencia. Se mantiene en la Diputación hasta marzo de 1862, fecha en que se da por finalizada la legislatura habiendo asistido a las treinta y una sesiones que ha celebrado la Corporación.

Continúa ejerciendo el cargo de diputado provincial por Valoria en la decimosexta

997 A.D.P.V. Actas. Libro de actas del 12 de noviembre de 1872, con el informe de la comisión de Venta de Bienes Nacionales, que se presenta a la Comisión Provincial.

998 "En el año 1841, solicita el ingreso en la Universidad de Valladolid, matriculándose el mismo año en la Facultad de Leyes. En el año 1846, solicita ser examinado para alcanzar el grado de bachiller en Jurisprudencia, acompañando los certificados de los cursos probados. Se celebra el examen el 12 de septiembre, por espacio de dos horas, se hizo votación secreta y salió aprobado" A.H.U.V.A. Caja 471 (doc. 442 y 443).

999 Norte de Castilla de fecha 7 de agosto de 1858.

1000 B.O.P.V. n ${ }^{\circ} 187$ de fecha 7 de diciembre de 1873 
Diputación, que inicia sus actividades el 1 de abril de 1862, sesión en la que vuelve a tomar posesión del escaño. Se mantiene en el mismo hasta el 31 de diciembre de 1863, fecha en la que finaliza la legislatura y en la que asiste a diecisiete de las veintidós sesiones que se celebran. En la siguientes Diputaciones, que transcurren entre los años 1864 a 1866, no se presenta a las elecciones, pero sí lo hace en las elecciones que se celebran el 26 y 27 de noviembre de 1866, para la decimonona Diputación isabelina, en las que salió elegido de nuevo por el partido de Valoria. Presta juramento y toma posesión de su cargo en la sesión de instalación que se celebra el 1 de enero de 1867 . En la sesión del 30 de octubre es elegido "representante de la Provincia en Juicios y en el Exterior" y en el año 1868, en las reuniones extraordinarias de 4 de febrero y 17 de julio es elegido presidente de las mismas. Aunque por real decreto de 27 de junio de 1867 se suprime el partido judicial de Valoria la Buena, al igual que el de La Mota del Marqués, Bendito se acogió a la real orden de 4 de julio del mismo año, que le permitía mantenerse en el cargo. Por lo que continuó en el desempeño de sus funciones hasta el 20 de septiembre de 1868, final de la legislatura y del período isabelino. Asistió a treinta y dos de las cincuenta y dos sesiones que celebró la Diputación. En el año 1869 es elegido alcalde de Cubillas de Santa Marta.

\section{Berdonces, José}

Las primeras referencias que tenemos se remontan al día 6 de febrero de 1803 , día en el que es nombrado académico de la "Real Academia de la Purísima Concepción". Es en estos años presbítero y bibliotecario, "siendo un entusiasta de las obras de arte, protegió varios cuadros y esculturas durante la ocupación francesa" 1001 . En el año 1814 es nombrado prior de la Santa Iglesia Catedral de Valladolid. En el año 1820 ejerce el cargo de Canónigo Penitenciario. En el año 1834 aparece como secretario de la "Real Sociedad Económica de Valladolid" (B.O.P. de 27 de febrero). El 13 de mayo de 1840 es nombrado administrador interino de la Casa de Inocentes Dementes, cargo en el que se mantiene hasta octubre de 1840. En esta fecha la Junta Provisional del Gobierno de la Provincia le destituye, hecho que la enfrenta al Obispado, que exigía el derecho a nombrar administrador del Hospital.

$\mathrm{Su}$ actividad política la inicia en el año 1812, al ser nombrado regidor del Ayuntamiento de Valladolid, y en el año 1813 es elegido diputado suplente en la primera Diputación del período constitucional 1813-14, aunque no llegó a ejercer el cargo. El 21 de marzo de 1820 es convocado para posesionarse del puesto de diput ado provincial en la recién estrenada primera Diputación del Trienio. En su primera sesión se acuerda "que, por fallecimiento de D. Pedro Regalado Romero, corresponde ocupar su lugar al Sr. D. José Berdonces, canónigo de esta Santa Iglesia Catedral, primer suplente nombrado para este cargo"1002. Se mantiene en el puesto los cuatro meses que dura la Diputación, asistiendo a diecinueve de las treinta y cuatro sesiones que se celebran. Con el inicio de la época isabelina no tiene ninguna actividad política. Fallece el día 1 de noviembre de 1843.

\section{Bergaz, Juan Manuel}

En el año 1835 desempeñaba el cargo de alcalde de La Nava y en febrero de 1836 es nombrado elector de la provincia para las próximas elecciones de procuradores en Cortes. En las elecciones celebradas en diciembre de 1836 para la segunda Diputación isabelina, es elegido diputado provincial por el partido de La Nava del Rey. En la sesión de instalación de la Diputación celebrada el 24 de diciembre, no asiste y en consecuencia no toma posesión. La Diputación en enero de 1837 le remite un oficio "para que se presente a desempeñar su cargo". En el mes de marzo, en la Diputación se recibe una comunicación del Sr. Bergaz, en contestación al

1001 GONZÁlez GARCÍA-VALlADOLID, Casimiro. Datos para la Historia Biográfica ... ob. cit. Reseña del "canónigo Berdonces". Tomo I, pág. 198.

1002 A.D.P.V. Actas. Libro de actas del día 21 de marzo de 1820. 
oficio enviado, en la que expresaba "no serle posible concurrir en la actualidad a desempeñar sus funciones y acompañando justificante con la declaración de los facultativos que le habían reconocido, asegurando que padecía una enfermedad crónica que le imposibilitaba asistir al ejercicio de su cargo". La Diputación acordó llamar al diputado suplente Manuel de Alday, licenciado y alcalde de Valladolid, para que "desempeñe su destino con carácter de propietario". ${ }^{1003}$

\section{Blanco, Francisco}

Vecino de Cabezón, agricultor y mediano propietario, compra una finca rústica desamortizada en Cabezón de 22 hectáreas, por 9.840 reales. El 25 de octubre de 1840, es nombrado diputado provincial por el partido de Valoria, en la tercera Diputación isabelina, por la "Junta Provisional de Gobierno de la Provincia", en sustitución de Miguel de las Moras, que había sido destituido por la misma Junta. Permanece en el puesto hasta el 31 de diciembre del mismo año, fecha en la que se cierra la Diputación, aunque sólo asiste a la sesión de su investidura.

\section{Blas Ramírez, Francisco María de}

Nació en Castronuevo de Esgueva el 20 de noviembre de 1824, hijo de Juan de Blas y de María Ramírez. Estudió en la Facultad de Derecho ${ }^{1004}$. Recién finalizado el período del Bienio Progresista, es nombrado diputado provincial por el partido de Valoria, en la decimosegunda Diputación isabelina, "en virtud de las facultades que le confiere al capitán general Joaquín Armero y Peñaranda, la real orden de 26 de julio de 1856." Tomó posesión del cargo en la sesión de instalación que se celebra el 19 de agosto de 1856, siendo nombrado en la misma sesión miembro de la comisión de Mantenimiento y Conservación de la Sede y de la comisión de Visitas de las Cárceles. Ejerce como diputado hasta el 30 de noviembre del mismo año 1856, fecha en que se da por finalizada la legislatura y a la que asiste a veintiséis de las cincuenta y tres sesiones que se celebran. El 24 de octubre de 1856 es nombrado consejero interino del nuevamente reinstalado Consejo provincial, siendo confirmado como consejero titular en la sesión que se celebra el 4 de noviembre. Sigue ejerciendo de consejero hasta enero de 1861, en el que se le nombra vicepresidente del Consejo, tras la dimisión que hace el anterior, Cándido Moyano. En diciembre de 1863, por la nueva Ley de Ordenación Provincial de 25 de septiembre del citado año, es nombrado presidente del Consejo provincial. Se mantiene en el cargo hasta el 23 de enero de 1866, fecha en la que es destituido por real orden de 26 de diciembre de 1865 . No se le vuelve a conocer ningún otro cargo público.

\section{Botella, Federico}

Es propietario, afincado en Valladolid y con residencia en la plaza de San Miguel. En las postrimerías del Sexenio y "en virtud de las facultades extraordinarias concedidas al $\mathrm{Sr}$. gobernador, este acuerda nombrar diputado provincial por el distrito de Matapozuelos a Federico Botella”. Se presenta en la sesión de la quinta Diputación, que se celebra el día 22 de enero de 1875, tomando posesión del cargo, en sustitución del cesado Segundo Cantalapiedra Maestro. Es la última sesión y a la única a la que asiste. En la siguiente sesión que se celebra el 19 de marzo, y que se corresponde con la primera Diputación de la Restauración, continuará

1003 A.D.P.V. Actas. Libro de actas del día 11 de marzo de 1837.

1004 . "El 27 de octubre de 1835 , a los 12 años, solicita el ingreso en la Universidad de Valladolid, matriculándose en la Facultad de Leyes. En el mes de diciembre de 1842 solicita ser examinado para alcanzar el grado de bachiller en Jurisprudencia, entró a examen el día 23 y salió aprobado némine discrepante. En septiembre de 1848 solicita ser examinado para acceder al grado de licenciado en Jurisprudencia y examinado los días 10 y 12, fue aprobado. Acto seguido por el Sr. rector le fue conferido el grado de licenciado, prestando el juramento prevenido en el real decreto de 23 de mayo de 1843 " A.H.U.V.A. Cajas 468 (doc. 410 a 414) y 671-85. 
como diputado en representación del mismo distrito de Matapozuelos hasta el final de la legislatura en el año 1877.

\section{Burgueño, Eusebio}

Es vecino del pueblo de Villabáñez, en el que ejerce como fiscal. En el año 1864 compró una finca procedente de bienes nacionales, propiedad de la Congregación de San Felipe Neri de Valladolid, situada en Campiña de Esgueva, por la que pagó 21.000 reales. En las elecciones celebradas en septiembre de 1872, es elegido diputado provincial por el distrito de El Salvador, sexto de Valladolid, por 296 votos contra los 219 que obtuvo su oponente, el ex-alcalde de la capital José Barrasa. Se presenta en la sesión de instalación de la cuarta Diputación del Sexenio, que tiene lugar el 2 de noviembre de 1872, en la que entrega el acta, que es aprobada en la sesión del día 5. Ello "a pesar de las reclamaciones de los pueblos de Geria, Robladillo y Santibáñez, alegando que no habían remitido el censo electoral y que además el Sr. Burgueño es fiscal municipal en Villabáñez"1005. Se mantiene en el cargo hasta el final de la legislatura en mayo de 1874, asistiendo a treinta y cinco de las cuarenta y dos sesiones que se celebran.

En la quinta Diputación continúa como diputado provincial por el distrito de El Salvador. Es confirmado por el gobernador civil. Se presenta en la sesión de instalación que se celebra el 30 de marzo de 1874. En la citada sesión es nombrado vocal suplente de la Comisión provincial, asistiendo a las sesiones que se celebran en los meses de noviembre y diciembre del citado año. Finalizada la legislatura en marzo de 1875, ha asistido a dieciséis de las dieciocho sesiones celebradas. En la Restauración no vuelve a ser elegido diputado.

\section{Burgos Pérez, Hermenegildo}

Nació en Nava del Rey en el año 1823. "Estudió en la Universidad de Valladolid ${ }^{1006}$. Ejerció la abogacía en Nava del Rey, pueblo en el que residía. Se presenta como candidato para diputado provincial por el partido judicial de Nava del Rey en las elecciones de la decimoctava Diputación isabelina, celebradas en noviembre de 1865 y resultó elegido. En la sesión de instalación celebrada el 1 de enero de 1866 presta juramento y toma posesión del cargo, asistiendo hasta el final de la legislatura que tiene lugar en diciembre de 1866 a catorce de las dieciocho sesiones que celebra la Corporación. No vuelve a presentarse, ni en lo que queda de época isabelina, ni en el Sexenio, y será en los años de la Restauración, en la Diputación que se inicia en el año 1890, cuando aparezca nuevamente como diputado provincial por el distrito de La Nava-Tordesillas actuando hasta principios de 1892, ya que falleció en La Nava el 23 de marzo de 1892.

\section{Cabeza de Vaca, Fernando}

Nació en Valladolid, en el año 1823. "Estudió en la Universidad de Valladolid ${ }^{1007}$. No se conoce su participación en la compra de bienes desamortizados, pero sí que debió de efectuar alguna ya que en el Boletín Oficial de la Provincia del 10 de noviembre de 1871 aparece el anuncio del "embargo de un monte de 77

1005 A.D.P.V. Actas. Libro de actas del día 5 de noviembre de 1872.

1006 en la que solicitó el ingreso el 29 de agosto de 1837, a los 14 años de edad, de pelo rojo y ojos garzos, matriculándose en la Facultad de Leyes. En julio del año 1844, solicitó ser examinado para alcanzar el grado de bachiller en Jurisprudencia, siendo rector Claudio Moyano. Entró a examen el 5 de julio, resultando aprobado en votación secreta" A.H.U.V.A. Caja 470 (doc. 37 a 42 ).

1007 Institución a la que con fecha 29 de octubre de 1833 solicita el ingreso, y siendo admitido, se matriculó en la Facultad de Filosofía. Se presenta al examen para alcanzar el grado de bachiller en Filosofía el 15 de junio de 1836 y salió aprobado. El 17 de noviembre de 1836 se matricula en la Facultad de Leyes y el 17 de junio de 1841 solicita ser examinado para alcanzar el grado de bachiller en Jurisprudencia, acompañando los certificados de los cursos probados, siendo aprobado. En el año 1843, alcanza el grado de licenciado en Jurisprudencia, tras el examen efectuado el 19 de agosto y salió aprobado" A.H.U.V.A. Cajas 467 (doc. 38 a 42), 504 (doc. 169 a 173) y 670-71. 
hectáreas en el pueblo de Curiel, propiedad de D. Fernando Cabeza de Vaca, vecino de Valladolid, por reclamación de una deuda de 4.480 escudos", anuncio habitual por el impago a la Hacienda Pública.

Se presenta como candidato a diputado provincial por el distrito de la Audiencia de la capital en las elecciones celebradas en febrero de 1862. El día 1 de abril, fecha de la instalación de la decimosexta Diputación isabelina, presta juramento y toma posesión del cargo. En la misma sesión es nombrado vicesecretario de la Corporación, cargo que mantiene hasta el final de la legislatura en diciembre de 1863. En este período asiste a veinte de las veintidós sesiones que se celebran. No vuelve estar presente en política.

\section{Cabeza de Vaca y Gómez, Pelayo}

Nace en Valverde Enríquez, diócesis y provincia de León, el día 15 de noviembre de 1798, hijo de Francisco y de María. Se trasladó a vivir a Valladolid a temprana edad, e inició sus estudios en la misma ciudad. "Ingresó en la Universidad de Valladolid el 30 de octubre de 1813 a los 15 años de edad. Alcanza el grado de bachiller en Leyes en 1820. Aprobó los exámenes del grado de licenciado en Leyes el 18 de marzo de 1824. Es nombrado catedrático de Derecho Romano por real orden de 30 de abril de 1826. Es nombrado catedrático de Derecho Civil y Mercantil el 28 de septiembre de 1845. Es decano de Jurisprudencia en el 17 de diciembre de 1848. En el año 1846 ejerce como vicerrector y es nombrado rector en 1850 . Se jubila de su cátedra universitaria el 29 de abril de 1858, por hallarse suficientemente probada su incapacidad física" ${ }^{1008}$.

Se casó en Valladolid, el 14 de enero de 1823, con María Alonso Cieza, y tuvieron cinco hijos, que a través de lazos matrimoniales emparentaron con importantes familias políticas como las de Gutiérrez Calderón, Francos ó Álvarez Taladriz.

Además de sus actividades como catedrático, ejerció como abogado, y estaba considerado como "propietario de alto nivel de vida con casa abierta en Valladolid y tres sirvientes". En el año 1836 es nombrado director de la "Sociedad de Seguros Mutuos de Casas contra Incendios". Entre los años 1841 a 1843 compró bienes desamortizados en las Comarcas de Campiña de Pisuerga y Montes Torozos, con un total de once parcelas de 16 hectáreas, por 31.451 reales y dos casas desamortizadas en Valladolid por 210.000 reales" ${ }^{1009}$. En el año 1847 es nombrado director de la Caja de Ahorros y Monte de Piedad de Valladolid.

En política es un reconocido militante del partido progresista, iniciando su actividad en este campo en diciembre de 1837, fecha en la que es elegido diputado provincial en la tercera Diputación isabelina por el partido de La Mota del Marqués, manteniéndose en el cargo hasta febrero de 1840. En este período asiste a ciento ochenta y dos sesiones. En el año 1839 es nombrado comandante del $2^{\circ}$ Batallón de la Milicia Nacional de Valladolid. En febrero de 1840 anuncia su abandono de la Diputación al haber sido elegido diputado a Cortes con 2.248 votos, "ofreciendo sus servicios para el bien de la provincia", y luchando para reforzar el papel de la Diputación frente al jefe político. En el año 1841 es elegido diputado a Cortes suplente. El 1 de enero de 1842 es nombrado alcalde de Valladolid, presentando al poco tiempo un oficio a la Diputación "Reclamando que el jefe político interino Lorenzo Perabeles no tiene autoridad para suspenderle en sus funciones" ${ }^{1010}$. También en esta época de alcalde, "según Ortega y Rubio publicó un bando llamado "de los Bigotes" por el cual se prohibía usar bigotes y otros distintivos propios del Ejército y de la Milicia a los civiles ${ }^{1011}$. Cuando en enero de 1843 abandona la Alcaldía de la

\footnotetext{
1008 A.H.U.V.A. Cajas 325 bis (doc. 17 a 25), 345 y 874 (doc. 27).

1009 RUEDA HERNANZ, Germán. La Desamortización... ob. cit. Págs. 272 y 279 y Anexo 6.

1010 A.D.P.V. Actas. Libro de actas del 13 de marzo de 1842.

1011 GONZÁLEZ GARCÍA VALLADOLID, Casimiro. Datos para la Historia... ob. cit. ver Cabeza de Vaca. Tomo I, págs. 235 y 236.
} 
capital, es nombrado vocal de la "Junta Provisional del Gobierno de la Provincia", institución que coincide con el fin del período de la Regencia de Espartero ${ }^{1012}$. Al disolverse la Junta, con la normalización política, no volvió a ostentar ningún otro cargo político. En 1846, es nombrado elector. Murió en Valladolid el 12 de diciembre de 1867.

\section{Cabrejas de la Plaza, Felipe}

Nacido en 1810 en el pueblo de Pedrajas de San Esteban, en la provincia de Valladolid. "Estudió tres años de Filosofía, privadamente, con el elector del convento de la Fuente Santa de la villa de Portillo en los años 1821 a 1823. Solicitó el ingreso en la Universidad Literaria de Valladolid, siendo admitido el 2 de noviembre de 1840, a los 30 años de edad, poco más o menos, matriculándose en la Facultad de Leyes. En octubre de 1844 solicita ser examinado del grado de bachiller en Jurisprudencia, acompañando las certificaciones de haber asistido a las explicaciones, certificado de buena conducta y el recibo de haber hecho la consignación. Salió aprobado" 1013 . Acabados sus estudios, fija su residencia en Valladolid, ciudad en la que ejerce de escribano.

"Entre los años 1841 y 1848 se dedica a comprar bienes desamortizados: un molino en los Páramos de Esgueva, 352 hectáreas de tierras en las zonas de Campiña del Pisuerga, Páramos de Esgueva y Tierra de Pinares por un importe de 373.616 reales. También adquirió varias fincas urbanas. En el año 1843 se le reclama como deudor de 14.100 reales, por la compra de una heredad en Santovenia, del convento de San Pablo, procedente de bienes nacionales. Se le da el calificativo de especulador, porque se dedica a la venta de las fincas compradas de bienes desamortizados" ${ }^{1014}$. En el año 1860 es el cuadragésimo séptimo mayor contribuyente de la provincia con 3.363 reales. En el año 1861 es el cuadragésimo noveno con 3.248 reales. En el año 1862 la Diputación rechaza un expediente de compra de 42 hectáreas de prado en el pueblo de La Zarza, que pretendía adquirir como procedente de bienes nacionales. En 1867 es el trigésimo séptimo mayor contribuyente con 486 escudos de renta y en 1871 aparece como el cuadragésimo octavo mayor contribuyente con unas rentas de 1.633 pesetas.

Su filiación política es moderada. Inicia su carrera política el 25 de septiembre de 1847, día de instalación de la sexta Diputación isabelina, cuando se presenta en la sala, toma asiento y presta juramento, como diputado provincial en representación del partido de Olmedo, a la vez que es nombrado miembro de la comisión de Monumentos Artísticos. Asiste a treinta sesiones de las cuarenta y cinco que celebra la Diputación hasta marzo de 1850, fecha en la que se da por finalizada la legislatura. En junio de 1858 se celebran elecciones a diputados para la decimocuarta Diputación isabelina, en la que se vuelve a presentar como candidato por el partido de Olmedo. El periódico El Norte de Castilla del 1 de julio de ese año, publica la siguiente noticia: "Olmedo - 27. La elección de diputado provincial puede citarse como modelo de orden, legalidad y tolerancia. El candidato vencido Francisco Solano Juárez, a quien los electores de la villa han negado su sufragio, sabía que no era antipático y que la oposición no era a su persona... Los electores celebraron una reunión y decidieron dar su voto a Felipe Cabrejas". Tomó posesión del cargo en la sesión de 18 de julio, manteniéndose en la Diputación hasta marzo de 1860, final de la legislatura, en la que asistió a veintitrés de las cuarenta sesiones celebradas.

El día 1 de abril de 1860, se inician las actividades de la decimoquinta Diputación, en la que continúa como diputado por Olmedo, al no haberle correspondido cesar. Su actuación se da por finalizada en marzo de 1862. En este

1012 CARAS A SOTO, Pedro (Dir.). Diccionario biográfico de alcaldes ... ob. cit. pág. 299 y sigs.

CARASA SOTO, Pedro (Dir.). Diccionario biográfico de parlamentarios ... ob. cit. Pág. 188

1013 A.H.U.V.A. Caja 470 (doc. 358 a 363). Llama la atención su ingreso tan retrasado en la Universidad, para lo que era habitual en la época, de 13 a 16 años.

1014 RUEDA HERNANZ, Germán. La Desamortización... ob.cit. página 275 y Anexo 6. 
periodo está presente en quince sesiones de las treinta y dos que se celebran. No vuelve a presentarse a ningún otro cargo.

\section{Cafranga, Isidoro Mariano}

La temprana dimisión del diputado por La Nava del Rey, Ildefonso García Casasola, al poco de quedar instalada la undécima Diputación isabelina, en agosto de 1854, hace que el gobernador convoque en el citado partido elecciones a diputado provincial, para cubrir la baja. En la sesión del 26 de septiembre se leyeron las actas de las elecciones, en las que queda reseñado que "en las elecciones celebradas el 10 del corriente resultó un empate entre los candidatos Isidoro Mariano Cafranga y el alcalde del Coto de Cubillas. En la votación del día 11 el gobernador anuló los votos del alcalde del Coto y en consecuencia resultó elegido el Sr. Cafranga". El mismo día 26 tomó posesión del cargo, manteniéndose en el mismo durante toda la legislatura. Asiste a ochenta y ocho de las ciento cuarenta y ocho sesiones que se celebran, hasta su disolución en agosto de 1856. No vuelve a ejercer como diputado.

\section{Calderón Mantilla, Francisco}

Nació el 31 de mayo de 1824, en el pueblo de Mayorga, del partido judicial de Villalón, hijo de Dámaso Calderón y de Josefa Mantilla. Su abuelo materno, Francisco Antonio Mantilla, fue diputado provincial en la tercera Diputación del Trienio Liberal en 1822-1823, en representación del partido judicial de Gradefes, que en aquellos años pertenecía a la provincia de Valladolid y que con la reforma posterior de Javier de Burgos pasó a depender de León. Su hermano Félix, propietario residente en Mayorga, representó a este distrito en la Diputación entre los años 1880 y 1883. "Inició sus estudios en el Seminario de Valderas, en el que cursó tres años de Filosofía. Ingresa en la Universidad de Valladolid en el año 1841, matriculándose en la Facultad de Leyes. ${ }^{1015}$. Ejerce la abogacía en Mayorga conjuntamente con la administración de sus propiedades.

En política es liberal e inicia su actividad a partir de las elecciones que se celebran en septiembre de 1872, para cubrir las vacantes, en la cuarta Diputación del Sexenio. Se presenta como único candidato del distrito de Mayorga, del partido de Villalón, siendo elegido con 1.135 votos. Asiste a la primera sesión, el 4 de noviembre de 1872 , en la que es aprobada su acta y toma posesión del cargo. Se mantiene en el mismo hasta el final de la legislatura en mayo de 1874 , asistiendo a treinta de las cuarenta y dos sesiones que se celebran. En la quinta Diputación continúa como diputado, por nombramiento del gobernador civil, en representación de Mayorga. Presente en la sesión de instalación que se celebra el 31 de mayo de 1874 , es nombrado vocal de la comisión de Presupuestos. No vuelve a asistir a ninguna otra sesión hasta el mes de noviembre y después a las dos sesiones que se celebran en el mes de enero de 1875. En total finaliza su actuación como diputado en marzo de 1875, asistiendo únicamente a seis sesiones. No vuelve a aparecer como diputado en la Restauración.

\section{Calvo Asensio, Francisco}

Es natural y residente en La Mota del Marqués. Hijo de Leonardo y de María Francisca, labradores acomodados del pueblo. Su hermano Pedro fue un polifacético personaje, farmacéutico, escritor y sobre todo periodista, fundador del periódico "La

1015 En el año 1845, solicita ser examinado para alcanzar el grado de bachiller en Jurisprudencia, presentando los certificados de los cursos probados entre 1841 y 1845 . Examinado el 26 de julio después de dos horas y media de duración del examen, en votación secreta, salió aprobado. En 1847, solicita presentarse a examen para obtener el grado de licenciado en Jurisprudencia. Fue aprobado el 27 de julio, siendo conformado en el claustro celebrado el día 1 de agosto" A.H.U.V.A. Cajas 471 (doc. 360 a 365) y 673-62. 
Iberia". Destacado político progresista y diputado a Cortes por Valladolid en 1854 y por Madrid en $1858^{1016}$.

La Junta Revolucionaria de Valladolid, en sesión que celebra el 17 de octubre de 1868, acuerda nombrar a Francisco Calvo diputado provincial en la primera Diputación del Sexenio, en representación del partido de La Mota, tomando posesión del cargo en la sesión del día 28 del mismo mes. Es la única sesión a la que asiste, ya que en la del 24 de noviembre de 1868 se deja sin efecto su nombramiento, al publicarse un decreto del gobierno por el que se anulan los partidos judiciales de La Mota y Valoria. En el año 1873, ejerce como procurador de los Tribunales en Mota del Marqués.

\section{Camino, Venancio}

Vecino de Casasola de Arión. En el año 1841 compra una pequeña finca desamortizada de dos hectáreas, en los páramos de Esgueva, por la que pagó 5.370 reales. Es elegido diputado provincial por el partido de La Mota del Marqués en la segunda Diputación isabelina que inicia sus trabajos el 7 de octubre de 1836. Prestó juramento y tomó posesión de su cargo en la sesión que se celebra el 8 de noviembre, manteniéndose en el puesto hasta el final de la legislatura, en diciembre de 1837. Asiste en este período a treinta sesiones de las setenta y dos que se celebran. No vuelve a participar en otras actividades políticas, ni locales ni provinciales.

\section{Campesino Hernando, Mariano}

Nace en Valladolid el 14 de agosto de 1784, hijo de Sebastián y de Fermina. Su padre es médico y miembro de la Real Academia de Medicinas y Cirugía. "Inicia sus estudios en su ciudad natal, en cuya Universidad solicitará el ingreso el 13 de noviembre de 1797, a los 13 años, de pelo rojo y ojos pardos, en su Facultad de Medicina. El 14 de junio de 1806 presenta la solicitud para recibir el grado de bachiller en Medicina, siendo examinado, salió aprobado "némine discrepante"._El 6 de mayo de 1820 se examinó del grado de licenciado y doctor en Medicina. Catedrático de Patología en la Universidad de Valladolid en 1825. En febrero de 1827 toma posesión de la Cátedra de Medicina Legal en la Universidad de Santiago. En 1830 vuelve a su cátedra de Valladolid a la vez que ejerce de decano de la Facultad de Medicina. Es elegido presidente de la Real Academia de Medicina y Cirugía de Castilla la Vieja" 1017 .

Se casó el 11 de noviembre de 1806 con Magdalena Miranda y no tuvieron descendencia. Es uno de los promotores de la Caja de Ahorros y Monte de Piedad de Valladolid, fundada en el año 1841, año en el que ejercía como alcalde de la ciudad. En el año 1843 compró una casa desamortizada en Valladolid por un importe de 82.000 reales.

Político liberal y progresista, inicia su actividad en este campo al final del período absolutista y centrado especialmente en el tema municipal. Pertenece a la Milicia Nacional, en la que llegó a ejercer como ayudante del capitán. En 1836 accede al Ayuntamiento de Valladolid como alcalde $2^{\circ}$. En 1837 es nombrado alcalde $1^{\circ}$, en una época difícil e incierta en la que tuvo que hacer frente al recrudecimiento de la guerra carlista en Castilla y que culminó con la entrada de las tropas de Zariategui en la capital. El 25 de octubre de 1840 es nombrado diputado provincial, en la tercera Diputación isabelina por el partido de Valladolid, para cubrir la baja de Manuel Martín Lozar, destituido por la Junta Provisional del Gobierno de la Provincia. Permanece en el cargo hasta el 24 de diciembre del mismo año, fecha en la que es disuelta la Diputación. En estos dos meses asiste a cinco sesiones. Vuelve a ser elegido alcalde a finales de 1840, cuando finaliza el breve tiempo que ejerce como

1016 CARASA SOTO, Pedro (Dir.). Diccionario biográfico de Parlamentarios ...ob. cit. pág. 204.

1017 CARASA SOTO, Pedro. (Dir.). Diccionario biográfico de alcaldes....ob. cit. págs. 306 y sig. A.H.U.V.A. Cajas 340, 520 (doc. 438 a 444) y 581 (doc. 1 a 6). 
diputado provincial En esta su segunda etapa como alcalde tuvo lugar el hundimiento de la torre de la catedral ocurrido el 31 de mayo de 1841. También trabajó para conseguir del gobierno la cesión de iglesias conventuales desamortizadas para convertirlas en parroquias. Con el fin del trienio esparterista y la llegada de los moderados al poder, deja de actuar en política y se centra en la enseñanza y en la medicina. Fallece en Valladolid el 16 de febrero de 1852.

\section{Cantalapiedra, Pedro Paulino}

La Diputación celebra una sesión el día 4 de junio de 1841 , con el único objetivo, según anunció el presidente, "de proceder al examen y aprobación del acta de nombramiento de diputado provincial por el partido de Medina, que había recaído en D. Pedro Paulino Cantalapiedra, vecino de la villa. Examinada y aprobada, fue reconocido como diputado, entró en el salón, prestó juramento y tomó asiento". Con este nombramiento se cubría la baja ocasionada en la cuarta Diputación de la era isabelina, por la dimisión de Atanasio Pérez Cantalapiedra, elegido diputado a Cortes, con el que no se le relaciona parentesco alguno a pesar de la similitud en los apellidos. Se mantiene en el cargo hasta el final del período en octubre de 1843, y asiste a ciento quince sesiones. En junio de 1842, en el transcurso de la sesión, expuso que "ante la presión contributiva que estaba sufriendo la provincia a causa de los impuestos del Estado, más los generados por la provincia, inmersa en la construcción de carreteras, solicitó una demora de cuatro años en la construcción de las carreteras para dar un respiro al contribuyente". Vuelve a la Diputación en la época del Bienio Progresista, tomando posesión de su cargo de diputado por Medina, en la undécima Diputación, en la sesión celebrada el 18 de agosto de 1854 en virtud del real decreto de 7 del mismo día "por ser diputado en 1843." Se mantiene en su puesto hasta agosto de 1856, fin de la legislatura y del Bienio, y asiste a cuarenta y tres sesiones de las ciento cuarenta y ocho sesiones que se celebran.

\section{Cantalapiedra Maestro, Segundo}

Nació el día 1 de junio de 1843 en Pozaldez, perteneciente al partido judicial de Olmedo, hijo de Eugenio Cantalapiedra y de Teresa Maestro. "Inicia sus estudios en la Universidad de Salamanca en el año 1859 y pasa posteriormente a la Universidad de Valladolid. En el año 1864 solicita ser examinado para alcanzar el grado de bachiller en Cánones ${ }^{1018}$. Se establece como abogado en Pozaldez, su lugar de residencia.

Político de carácter liberal, se presenta a las elecciones para diputado provincial que se celebran en septiembre de 1872, por el distrito de Matapozuelos, siendo elegido por 1.111 votos, al no presentarse ningún otro candidato. El 2 de noviembre de 1872 , toma posesión del cargo en la sesión de instalación de la cuarta Diputación del Sexenio en la que es nombrado diputado secretario interino, al ser el miembro más joven de la Corporación. El día 5, al constituirse la Diputación definitiva, deja de actuar como secretario y es nombrado miembro de la Junta de Beneficencia. En el mes de febrero de 1874, el capitán general "en uso de sus atribuciones extraordinarias" le nombra vocal de la Comisión provincial, en lugar del diputado Gutiérrez Barquín, que deja el cargo al ser nombrado gobernador civil de Pontevedra. Se mantiene en la Diputación y en la Comisión hasta el 30 de mayo de 1874, día en que se da por finalizada la legislatura en la que asiste a treinta y seis de las cuarenta y dos sesiones que se celebraron. Continúa como diputado provincial por Matapozuelos en la quinta Diputación, que inicia sus actividades el 31 de mayo de 1874. En la misma sesión de instalación, presenta una petición para que se admita su

1018 Entró a examen el 27 de abril, y salió aprobado. En el año 1865, solicita ser examinado para alcanzar el grado de licenciado en Leyes, Cánones y Derecho Civil, señalándole el 13 de junio día en que entró a examen y desarrolló durante tres horas el tema: "¿Qué efectos producen las donaciones en los cónyuges?". Resultó aprobado en votación secreta” A.H.U.V.A. Cajas 482 (doc. 424 a 430$)$ y 686 (doc.7 y 19). 
dimisión. Aunque la Diputación rechaza su solicitud, no vuelve a presentarse en las sesiones hasta el mes de noviembre, mes en el que asiste a las siete sesiones que se celebran. Es nombrado en la primera de ellas vocal de la comisión de Peticiones. El 22 de enero de 1875, sesión en la que "excusa su asistencia por enfermedad" y última que celebra la Diputación, es cesado en sus funciones por el nuevo gobernador. En el año 1890, siendo alcalde de Pozaldez, es elegido diputado provincial y en 1894 vuelve a ser nombrado por el distrito de Olmedo. Es elegido vicepresidente de la Comisión permanente, manteniéndose en el cargo hasta 1898. Fallece en Pozaldez el 24 de noviembre del citado año.

\section{Capdevila Pedrero, Mariano}

Natural y vecino de Peñafiel, es hijo de Alejandro Capdevila, que fue el primer secretario que tuvo la Diputación en la época Constitucional 1813-14 y en el Trienio Liberal 1820-23. En el año 1855, pretende ser concejal por el Ayuntamiento de Peñafiel, y reclama a la Diputación por el "indebido nombramiento que se ha hecho de otra persona". El 17 de octubre de 1868 es nombrado por la Junta Revolucionaria diputado provincial por el partido de Peñafiel. Toma posesión del cargo en la sesión de instalación de la primera Diputación del Sexenio, que se celebra el 21 de octubre y se mantiene en el cargo hasta octubre de 1869, fecha final de la legislatura y en la que asiste a sesenta y seis de las noventa y ocho sesiones que se celebran. No vuelve a presentarse como diputado.

\section{Castilla de Lanuza, Enrique}

Nació en Madrid el 21 de enero de 1837 y bautizado el día 23 "se le impusieron los nombres de Enrique Fructuoso Francisco Tomás", es hijo de Joaquín Castilla y de Ana Vicenta de Lanuza. Su abuelo Tomás Castilla es natural de Tordesillas. Reside en Valladolid en cuya Universidad inicia sus estudios de Filosofía y Leyes. ${ }^{1019}$. Ejerce como abogado en Valladolid.

E1 22 de enero de 1875, "por orden del gobernador civil", es elegido diputado provincial por el distrito de La Catedral, segundo de Valladolid, en sustitución del cesado Luis Antona Semolinos. Es la única sesión a la que asiste, pues no se vuelve a convocar a más sesiones de la quinta Diputación, hasta el 19 de marzo fecha de constitución de la nueva Diputación de la Restauración. No vuelve a ejercer en la política provincial.

\section{Clemente Herrero, Máximo.}

Nació en Tamariz de Campos, partido judicial de Villalón, en el año 1819. Estudia Filosofía y Leyes en la Universidad de Valladolid ${ }^{1020}$. Se establece como abogado y propietario en Cuenca de Campos. En 1861 es el cuadragésimo mayor contribuyente de la provincia con 3.741 reales de cuota. En 1863 cotizó 4.135 reales, siendo el trigésimo quinto mayor contribuyente. En 1871 es el trigésimo primer mayor contribuyente con 2.205 pesetas de cuota anual y en 1872 es el vigésimo noveno con 2.319 y propiedades en Cuenca de Campos y Tamariz de Campos.

1019 “En el año 1850 solicita el ingreso, matriculándose en la Facultad de Filosofía. En 1853, se examina para alcanzar el grado de bachiller en Filosofía. Entró a examen el 17 de junio y salió aprobado por unanimidad. En el mismo año 1853, se matricula en la Facultad de Leyes. En 1861, solicita ser examinado para alcanzar el grado de licenciado en Derecho Civil y Canónico. Se señala el 17 de junio para el examen, en el que fue aprobado" A.H.U.V.A. Cajas 510 (doc. 381 y 382) y 684-44.

1020 "Se matricula en la Facultad de Filosofía el 21 de octubre de 1833. Se examinó para alcanzar el grado de bachiller en Filosofía el 13 de junio de 1836, siendo aprobado némine discrepante. Continuó sus estudios matriculándose en la Facultad de Leyes el 20 de noviembre de 1836. En el año 1840, solicitó ser examinado para alcanzar el grado de bachiller en Jurisprudencia. Entró a examen el 7 de julio, y salió aprobado" A.H.U.V.A. Cajas 466 (doc. 578 a 583) y 504 (doc. 144 a $148)$. 
Es alcalde de Cuenca de Campos en los años 1854 y 1865. Inicia su actividad política provincial en la primera Diputación del Sexenio, al ser nombrado en la sesión del 26 de noviembre de 1868 diputado suplente por el partido de Villalón. Se presenta en la sesión del día siguiente, en la que toma posesión del cargo, en sustitución del diputado titular Pedro Criado, al que se le ha concedido licencia "para restablecer su salud". Se mantiene en la Diputación hasta el final de la legislatura en octubre de 1869, asistiendo en el tiempo que ha ejercido a sesenta sesiones de la Corporación.

Continúa como diputado provincial, representando a Villalón, en la segunda Diputación del Sexenio, que inicia sus actividades el 18 de octubre de 1869. Es en esta legislatura un asistente asiduo, ya que estuvo presente en ciento cuatro de las ciento veinticuatro sesiones que se celebran, firmando las actas junto al presidente y secretario, en su calidad de diputado decano, hasta el final de la vigencia que tiene lugar en febrero de 1871. Si en las dos primeras Diputaciones del Sexenio su presencia en la Diputación era consecuencia de la decisión del capitán general, en la tercera Diputación es elegido diputado por el distrito de Cuenca de Campos, en los comicios celebrados en los primeros días de febrero. Presenta su acta en la sesión de instalación que se celebra el 17 de febrero de 1871 y al día siguiente "es aprobada el acta del diputado por Cuenca de Campos Clemente Herrero, por 17 votos contra 14, ya que la comisión consideraba de que se debía de aprobar, a pesar de la imposición de la fuerza ocurrida en Juan Manuel García y Manuel García Lajo, secretarios escrutadores del Colegio de Villabaruz y la queja de que en Bustillo de Chaves no se habían celebrado elecciones por causas independientes a la voluntad de los electores" ${ }^{\prime 1021}$. Se mantiene en la Diputación durante toda la legislatura, asistiendo a cuarenta y cuatro de las setenta sesiones que se celebran hasta su finalización en octubre de 1872. Tiene garantizada su continuación como diputado, ya que en el sorteo celebrado el 25 de julio de 1872, le correspondió continuar. Se presenta el 4 de noviembre de 1872, en la sesión de la cuarta Diputación, en la que toma posesión y continúa representando al distrito de Cuenca de Campos. Es el único diputado que se mantiene en el cargo durante cuatro Diputaciones del Sexenio. Pero mientras en las tres anteriores fue un diputado colaborador que asistía regularmente a todas las sesiones, en esta Diputación sólo asiste a las cinco primeras sesiones del mes de noviembre de 1872 y después no vuelve a asistir a ninguna otra en el resto de la legislatura que finaliza en mayo de 1874. No tenemos referencia del motivo, aunque está claro que no dimitió ni fue cesado, ya que su escaño no se cubrió a lo largo de la legislatura. Tampoco vuelve a estar presente en ninguna otra actividad política.

\section{Conde Bravo, Santiago}

Nace en el año 1773 en la villa de Cigales, diócesis de Valladolid. Solicita su ingreso en la Universidad de Valladolid el 20 de octubre de 1791. "Fue aprobado, previo juramento de obediencia, ganar cursos, asistir a quinarios, revalidar la matrícula en principio de cada curso antes del día de Santa Catalina, y probar con las correspondientes certificaciones los que ganare dentro del año de su asistencia y antes del día de San Lucas, en que da principio el curso siguiente" ${ }^{1022}$. El día 1 de junio de 1797 obtiene el grado de bachiller en Leyes, al ser aprobado "nemine discrepante".

Como hacendado de la villa de Cigales, es elegido diputado en representación del antiguo partido de Simancas, ejerciendo su cargo durante la segunda Diputación del Trienio que se extiende entre el 7 de junio de 1820, hasta el 28 de febrero de 1822 . Asiste en este período a un total de ciento cincuenta y nueve sesiones del total de ciento setenta y tres que se celebran.

1021 A.D.P.V. Actas. Libro de actas del 18 de febrero de 1871.

1022 A.H.U.V.A. Caja 438 (doc. 11 a 24) 


\section{Conde Camazón, Jerónimo}

Nació en Cigales, el 24 de noviembre de 1818, hijo de Mateo Conde y de Nicanora Camazón. "Estudió en la Universidad de Valladolid, en la que solicitó el ingreso el 28 de octubre de 1833, matriculándose en la Facultad de Medicina ${ }^{1023}$. Finalizados sus estudios se establece como médico en Valladolid.

El 27 de abril de 1874, es nombrado diputado provincial por el distrito de San Nicolás, en sustitución del Sr. Gutiérrez Barquín, recién nombrado gobernador civil de Pontevedra. Su paso por la cuarta Diputación del Sexenio se limita a asistir a la sesión del día 27 en la que tomó posesión del cargo y a la sesión del 11 de mayo del mismo 1874, en la que lo único que se hace es leer el oficio del gobernador, nombrando nuevos diputados y disolviendo a continuación la Diputación. No vuelve a aparecer como diputado.

\section{Corral, José del}

Es elegido diputado provincial por el partido de Villalón en la primera Diputación de la era isabelina. En la sesión de instalación que se celebra el día 22 de octubre de 1835, presta juramento y toma posesión de su cargo. Es elegido miembro de las comisiones de "Búsqueda de Casa y Enseres" y de "Armamento y Defensa". En el mes de mayo de 1836 actúa a lo largo de cinco sesiones, como presidente interino, ante las ausencias del jefe político y del intendente. Se mantiene en el cargo hasta el 5 de octubre de 1836, fecha en que se cierran las actividades. En este tiempo asiste a noventa y seis sesiones de ciento veintidós celebradas, siendo uno de los diputados más asiduos por su presencia en las sesiones de trabajo de la Diputación. Finalizado este período, no vuelve a aparecer ni como diputado provincial ni desempeñando otro cargo político.

\section{Criado, Pedro}

Es vecino y labrador en Villalón de Campos, que en los años 1841 a 1843 , fue comprador de bienes desamortizados. "Poseía 13 hectáreas de terreno, 3 casas y 30 ovejas, con unas ganancias de 1.000 reales. Compró una finca de 36 hectáreas de bienes desamortizados, en Tierra de Campos, por las que pagó 61.500 reales" 1024 .

La Junta Provincial Revolucionaria de Valladolid, le nombró diputado provincial por el partido de Villalón en la primera Diputación del Sexenio y toma posesión en la sesión del día 4 de noviembre de 1868. Asiste a cinco sesiones a lo largo del mes y en la sesión del día 26 la Diputación acuerda "conceder un mes de licencia al diputado por Villalón D. Pedro Criado, para restablecer su salud, y se da posesión al suplente Máximo Clemente mientras dure la licencia" ${ }^{1025}$. No vuelve a presentarse en la Diputación y no se dan más noticias de su situación.

\section{Cuadrillero Herce, Hermenegildo Fernando}

Es natural de Medina de Rioseco, encuadrada en estos años en la diócesis de Palencia, donde nace en el año 1783. Es miembro de una distinguida familia de la Tierra de Campos, con una gran influencia en el ámbito comarcal tanto desde un punto de vista agrícola como económico y político. Inicia sus estudios en el "Estudio General de San Pedro Mártir" de Rioseco en los cursos de Lógica y Filosofía Moral. Solicita su ingreso en la Universidad de Valladolid el 11 de noviembre de 1800, y es admitido en la Facultad de Leyes en el mes de junio de 1805. Se examinó para alcanzar el grado de bachiller en Leyes y en el año 1807 del grado de bachiller en

1023 El 5 de junio de 1840, solicita ser examinado para alcanzar el grado de bachiller en Medicina y convocado el día 22 fue aprobado némine discrepante, siendo rector Blas Pardo. El 24 de septiembre de 1848, solicita acceder al grado de licenciado en Medicina, y fijado el día 6 de octubre pasa el examen de cirujano, resultó admitido" A.H.U.V.A. Cajas 524 (doc. 428 a 435) y 582 (doc. 419 a 422).

1024 RUEDA HERNANZ, Germán. La desamortización ... ob. cit. pág. 342.

1025 A.D.P.V. Actas. Libro de actas del día 26 de noviembre de 1868. 
Cánones. ${ }^{1026}$ Acabados sus estudios, se dedica a la gestión de la hacienda agrícola familiar, tarea que simultanea con el ejercicio de la abogacía. En el año 1839 actúa como representante de un comprador de bienes nacionales, en defensa de sus derechos contra el acuerdo del Ayuntamiento de Rioseco, sobre la venta de la finca denominada "La Vega de Santiago" "1027. También ejerce como teniente de la Milicia Urbana.

Inicia su carrera política cuando se presenta a las elecciones y es elegido diputado provincial por el partido de Rioseco en la tercera Diputación del Trienio. Toma posesión el día 1 de marzo de 1822, ejerciendo el cargo hasta el final de la legislatura en abril de 1823. Asiste a un total de cincuenta y siete sesiones de las ciento cincuenta y siete que celebra la Diputación. En el año 1835, es elegido elector por el partido de Rioseco, para las elecciones de procuradores a Cortes. En las elecciones que se celebran en el año 1840 se presenta como candidato, pero no salió elegido, terminando de esta forma su actividad política. Sin embargo, no acabó su influencia tanto social como política en el distrito al que representó, ya que la mantuvo a través de sus sobrinos. El primero fue Vicente Pizarro Cuadrillero, que será diputado provincial en 1867 y 1884 por el partido conservador, siendo nombrado presidente de la Corporación en este último año. El segundo fue José Manuel Cuadrillero Nájera, que ejerció como diputado provincial en la época del Sexenio. En tercer lugar Gaspar Cuadrillero Oteo de Tejada, llegará a la política nacional al ser elegido diputado a Cortes por Valladolid en marzo de 1857.

\section{Cuadrillero Nájera, José Manuel}

Natural y vecino de Palazuelo de Vedija, perteneciente al partido judicial de Rioseco. Tiene relaciones de parentesco con Hermenegildo Cuadrillero Herce y con Vicente Pizarro Cuadrillero, que fueron diputados provinciales en los períodos del Trienio Liberal y en la Década Moderada . Es labrador y propietario y en el año 1844, procedente de bienes desamortizados, compró una panera en Palazuelo por la que pagó 650 reales y una finca de 19 hectáreas en Tierra de Campos por 33.005 reales.

En política tiene buenas relaciones con Cánovas del Castillo, que le nombra coordinador de las actividades del Partido Conservador en Valladolid. Se presenta a las elecciones para diputado provincial en la tercera Diputación del Sexenio, que se celebran en febrero de 1871, siendo elegido por el distrito de Palazuelo. En la sesión de instalación que se celebra el día 17 del citado mes es aprobada su acta. Se mantiene activo hasta el final de la legislatura en octubre de 1872. Asiste a cuarenta y seis sesiones de las setenta celebradas. Continúa como diputado de la cuarta Diputación, ya que en la sesión del 25 de julio de 1872, en el sorteo celebrado, le correspondió continuar. Se presenta en la sesión de instalación que se celebra el 2 de noviembre de 1872, representando al mismo distrito de Palazuelo. Asiste a veintitrés sesiones de las cuarenta y dos que se celebran, hasta que, en la sesión del día 11 de mayo de 1874 se da lectura a un comunicado del gobernador, en el que notifica "Que en uso de las facultades que le concede la circular del Poder Ejecutivo de la República de 5 de febrero, he tenido a bien relevar del cargo de diputado provincial por el distrito de Palazuelo de Vedija a José Manuel Cuadrillero" ${ }^{1028}$. Es cesado en la última sesión de la Diputación y se nombra en su lugar a Federico Lorenzo y Frontaura Cacho. Esto no es obstáculo para que así como el gobernador interino, le cesó el día 11 de mayo, el recién nombrado gobernador titular le repone en el cargo el día 30 del repetido mes de mayo. En consecuencia, se presenta en la sesión de instalación de la quinta Diputación del Sexenio que se celebra el 31 de mayo, en la que vuelve a tomar posesión como diputado por Palazuelo, y se mantiene hasta el final de la legislatura y del Sexenio en marzo de 1875, asistiendo a trece de las dieciocho sesiones. Volverá a ejercer como

1026 A.H.U.V.A. Cajas 400 (doc. 436 a 443), 442 (doc.321 a 328) y 500 (doc. 121 a 126).

1027 A.D.P.V. Actas. Libro de actas del 21 de diciembre de 1839. El comprador, José Garrido se queja a la Diputación de que el Ayuntamiento de Rioseco no le admitió "la mejora"

1028 A.D.P.V. Actas. Libro de actas del día 11 de mayo de 1874. 
diputado provincial en la segunda Diputación de la Restauración entre 1877 y 1880 . A partir de este último año, se presenta y es elegido en varias ocasiones como diputado a Cortes ${ }^{1029}$

\section{Daniel, Manuel}

Es natural y vecino de Urones de Castroponce, pueblo perteneciente al partido judicial de Villalón. Propietario y agricultor, en el año 1846 compró una finca de 62 hectáreas, situadas en Tierra de Campos y un almacén en Urones, procedentes de bienes desamortizados. Es accionista del ferrocarril Alar-Santander.

Se presentó como candidato a diputado en las elecciones de la decimoquinta Diputación isabelina, por el partido de Villalón y resultó elegido, pero no acudió el 1 de abril de 1860 a la sesión de instalación porque el Consejo provincial, con fecha 10 de marzo declaró nulas las elecciones. La decisión es refrendada por el real decreto que se publica en el Boletín Oficial de la Provincia con fecha 30 de septiembre de 1860 por el que "se declara nula la elección de diputado provincial por Villalón, celebrada el 26 de febrero último, por lo hechos cometidos en la celebración de la misma, los cuales afectan a su validez". Se ordena repetir las elecciones el 15 de octubre, en las que volvió a salir elegido. Se presenta a la Diputación en la sesión de 10 de noviembre de 1860 , presta juramento y toma posesión del cargo. Se mantiene en el mismo, hasta el final de la legislatura en marzo de 1862, asistiendo en este tiempo a veintidós sesiones de las treinta y una que se celebran. En calidad de diputado-decano, presidió la Diputación, como presidente interino, ante la ausencia del titular en la sesión celebrada el 20 de septiembre de 1861. Continúa representando como diputado al partido de Villalón en la siguiente Diputación, la decimosexta, que inicia sus actividades con la sesión de instalación que se celebra el 1 de abril de 1862 . Al mismo tiempo mantiene su calidad de decano, por lo que sigue presidiendo las sesiones ante la ausencia del gobernador, haciéndolo a lo largo de esta legislatura en siete ocasiones. En diciembre de 1863 se dan por finalizadas las actividades de esta legislatura, a la que asiste a catorce de las veintidós sesiones que se celebran. No volvió a ejercer como diputado ni en la época isabelina ni en el Sexenio, pero sí es diputado electo en la primera Diputación de la Restauración, en marzo de 1875.

\section{Delgado Rico, Vicente}

Natural de La Nava del Rey, villa en la que nació el 19 de abril de 1814. Es hijo de Carlos Delgado, de Rueda, y de Brígida Rico, de la Nava. "Estudió en la Universidad de Valladolid ${ }^{1030}$. Ejerce como abogado y propietario en Nava del Rey, su pueblo natal.

Se presenta como candidato a diputado provincial por el partido de La Nava, en las elecciones efectuadas para cubrir las vacantes de la decimoquinta Diputación isabelina, resultando elegido. Presta juramento y toma posesión del cargo en la sesión de instalación que se celebra el 1 de abril de 1860. Esta legislatura se mantiene hasta el 30 de marzo de 1862 y en ella asiste a veintidós de las treinta y una sesiones que se celebran. Continúa representando al partido de La Nava del Rey en la siguiente Diputación, la decimosexta del período isabelino, que inicia sus actividades el 1 de abril de 1862, aunque Delgado Rico no se presenta a tomar posesión hasta la sesión del 9 de mayo. En esta legislatura que está vigente hasta el 30 de diciembre de 1863, sólo asiste a nueve sesiones de las veintidós que se realizan, siendo el diputado que menor presencia tiene en las actividades provinciales. Su escasa presencia en la Diputación no es obstáculo para que se vuelva a presentar como candidato en las

1029 PASTRANA MORILlA, Heliodoro. La Diputación Provincial... ob. cit. pág. 409, donde se cita la información procedente del periódico "El Norte de Castilla".

1030 "Donde solicitó el ingreso el 4 de noviembre de 1827, a los 13 años de edad, matriculándose en la Facultad de Leyes. El 14 de junio de 1834, solicita ser examinado para alcanzar el grado de bachiller en Leyes, acompañando los certificados de los cursos probados. Entró a examen el 17 de junio y salió aprobado némine discrepante" A.H.U.V.A. Cajas 459 (doc. 89 a 95) y 566. 
elecciones de la decimoséptima Diputación que se celebran en noviembre de 1863, en las que volvió a ser elegido diputado por La Nava. En la sesión de instalación de la nueva legislatura que se celebra el 1 de enero de 1864, se presenta como diputado electo, pero no toma posesión al no ser aprobada su acta de elección ante la reclamación presentada por el vecino de Alaejos Fructuoso Pérez Minayo, individuo que será diputado provincial en 1874 .

En la misma sesión la Diputación acuerda formar una comisión que estudie las reclamaciones. En la sesión del día 4 de enero se da lectura por una parte a la "exposición de Fructuoso Pérez Minayo, vecino de Alaejos, en la que pide la nulidad de las elecciones en Nava del Rey porque no habían concurrido a la misma la mayoría absoluta de electores, ya que siendo el número de electores 383, sólo aparecían 183 votantes". Por otra parte, en la misma sesión la comisión presenta el siguiente dictamen: "Examinado el asunto de acuerdo con la nueva ley, se ratifica que la elección se celebró con todos los requisitos que marca la ley. En los dos días de elecciones votaron 183 electores, 180 a Vicente Delgado y los otros tres a diferentes personas. En las actas se consigna que el número de electores es de 383, de acuerdo con las listas de 15 de mayo de 1862. La ley dice que se necesita tomar parte la mayoría absoluta de electores, pero la comisión constata el fallecimiento de veinte electores desde la promulgación de la lista, y dedujo esa cantidad del número de electores, quedando 363 en lugar de 383 , de los que 183 han tomado parte, por lo que considera justa y legítima la elección, al ser el número de votantes de mayoría absoluta de electores" ${ }^{1031}$. Una vez leído el dictamen, la Diputación aprobó el acta y en el mismo acto el gobernador tomó juramento y dio posesión del cargo de diputado a Delgado Rico

El Sr. Pérez Minayo no quedó conforme y reclamó en exposición al Gobierno Central, reclamación que tuvo su contestación a través de la real orden que publica el Boletín Oficial el 26 de junio de 1864, en la que "se suspende el acuerdo de la Diputación admitiendo a Vicente Delgado como diputado por Nava del Rey y se ordena celebrar nuevas elecciones los días 17 y 18 de julio". De nuevo el 24 de julio se vuelve a notificar el acuerdo tomado por el gobierno "de declarar nulas las elecciones celebradas en el partido de La Nava los días 17 y 18, al no haber tomado parte la mayoría absoluta, y se resuelve celebrar nuevas elecciones los días 31 de julio y 1 de agosto de 1864 ".

En estas elecciones resulta elegido diputado Juan de Mata Zorita Alonso, por lo cual, es elegido diputado provincial y toma posesión del cargo en la sesión que se celebra el 6 de agosto. Permanece en el cargo y asiste a las sesiones que se celebran en agosto, septiembre y octubre, hasta que por real orden de 31 de octubre, se vuelven a anular las elecciones y el nombramiento de Zorita como diputado, y se volvían a convocar nuevas elecciones a celebrar los días 18 y 19 de noviembre. El 20 de diciembre de 1864, la Diputación, "de acuerdo con el resultado de las elecciones celebradas los días 18 y 19 de noviembre para cubrir la plaza de diputado provincial por el partido de Nava del Rey, aprueba el nombramiento de Vicente Delgado, de acuerdo con el artículo veintitrés de la ley de 25 de septiembre de 1863 " ${ }^{1032}$. Toma posesión en la misma sesión del 20 de diciembre y sin más inconvenientes, continúa como diputado hasta el 31 de diciembre de 1865, fecha en la que finalizan las actividades de la Diputación, asistiendo a veinte de las cuarenta y nueve sesiones que se celebran. No vuelve a tomar parte en ninguna elección.

\section{Díaz, Cesáreo}

Vecino de Mojados, es elegido diputado provincial por el partido de Olmedo, en las elecciones celebradas para cubrir el cupo de la segunda Diputación isabelina. Toma posesión de su cargo en la sesión de instalación que se celebra el 7 de octubre

1031 A.D.P.V. Actas. Extracto del libro de actas del 4 de enero de 1864

1032 A.D.P.V. Actas. Libro de actas del 20 de diciembre de 1864. 
de 1836. En la sesión del 7 de octubre de 1837, en la Diputación se da lectura a una instancia en la que "el diputado Cesáreo Díaz se dirige al Gobierno de S.M. solicitando se le releve del cargo de diputado provincial". La Diputación acuerda estudiar el asunto, pero como en el mes de diciembre se da por finalizada la vigencia de la Diputación, no se llegó a tomar ningún acuerdo, con lo que finalizó el período manteniéndose en el cargo. En este año asistió a cincuenta y ocho sesiones.

\section{$\operatorname{Diez}(i ?)$}

La decimotercera Diputación de la era isabelina inicia sus actividades el 2 de diciembre de 1856 y en la sesión de instalación, prestan juramento y toman posesión del cargo los diputados provinciales elegidos por cada partido judicial. Excepto el correspondiente a Mota del Marqués, que si en las anteriores Diputaciones estuvo representada por el Marqués de Gallegos, en la Diputación que se inicia en estos días no tiene representación. Sólo actúan ocho diputados y en los plenos que se celebran ninguno de los diputados presentes ni tampoco el gobernador-presidente hacen alusión a esta falta.

Las actividades de la Diputación y sus componentes se mantienen en los mismos planteamientos que en los inicios de la legislatura, hasta que en las sesiones en los días 28, 30 y 31 de mayo de 1858, que se corresponden con las últimas sesiones que se celebran en esta legislatura, aparece al margen de las Actas, en la zona donde habitualmente se reseñan, la relación de los nueve diputados asistentes, y entre ellos, el nombre de Diez, al final de la lista, sin ningún tipo de indicación o aclaración sobre su presencia en la sesión. En definitiva, se ha considerado a Diez como diputado por La Mota del Marqués, aunque no hay razones ni datos que lo aseveren, y sin tener conocimiento de su identidad ni de la razón por las que aparece.

\section{Diez Bueno, Marcelino}

Nació en la villa de Tordesillas el 26 de abril de 1843, hijo de Mariano Diez y de María Bueno. "Estudió en la Universidad de Valladolid, en la que ingresó en el curso 1858, matriculándose en la Facultad de Derecho ${ }^{1033}$. Una vez acabados los estudios, se establece como abogado en Tordesillas, siendo nombrado en 1869 juez de paz, y en 1870, el presidente de la Audiencia le nombra juez municipal de Tordesillas. En sus actividades profesionales, además de su trabajo como abogado y de sus propiedades en Tordesillas, entra en los negocios de la industria y de la banca, alcanzando a ser uno de los más importantes accionistas de la Sociedad Industrial Castellana y del Banco Castellano.

Considerado de carácter liberal, aunque bien visto por el partido conservador, inicia su carrera política al presentarse en los primeros días de febrero de 1871 a las elecciones para diputado provincial por el distrito de Tordesillas, en la tercera Diputación del Sexenio. Habiendo sido elegido, presentó su acta en la sesión de instalación que se celebra el día 17 de febrero de 1871. En la misma sesión es nombrado secretario interino, al ser el diputado más joven de la Corporación. El día 20 se aprueba su acta y el día 21 se constituye la Diputación definitiva, de la que es nombrado diputado-secretario, cargo que desempeña hasta el mes de abril del mismo año. Vuelve a ser nombrado secretario en febrero de 1872 y en la sesión del 25 de julio, en el sorteo para determinar los diputados que debían de continuar, le correspondió cesar. Finaliza la legislatura en octubre de 1872, a la que asistió a veintidós sesiones de las setenta celebradas.

En septiembre de 1872, en las elecciones que se celebran para cubrir las bajas de los diputados cesantes, para la cuarta Diputación, se presenta como candidato, por

1033 El 6 de junio de 1863 presentó la solicitud para ser examinado y alcanzar el grado de bachiller en Derecho, sección de Leyes y Cánones y examinado el día 11, en votación secreta fue calificado con la nota de sobresaliente. El 13 de junio de 1865 solicita ser examinado para alcanzar el grado de licenciado en Derecho Civil y Canónico y convocado el día 14, fue calificado con la nota de aprobado" A.H.U.V.A. Cajas 482 (doc. 129 a 134) y 686-21. 
el distrito de Tordesillas. Resulta elegido por 794 votos, contra los 599 que consiguió el opositor Eugenio Bueno Goicoechea. Se presenta en la sesión de instalación, que se celebra el 2 de noviembre de 1872, presenta su acta y al mismo tiempo es nombrado secretario interino, cargo que ejerce hasta el día 5, al ser establecida la Diputación definitiva. También el día 4 se aprueba su acta, con la puntualización que hace la comisión de Actas de que "se aprueba el acta del diputado por Tordesillas D. Marcelino Diez Bueno, a pesar de las protestas del pueblo de San Román de Hornija, por la coacción a favor del diputado, que hizo D. Juan de Mata Zorita, ex -diputado por Tordesillas, estando presente en el salón e invitando a los electores a puros y licores" "1034. El 18 de abril de 1873, se tuvo que suspender la sesión de la Diputación por falta de diputados, noticia que publica El Norte de Castilla el día 19. En la sesión del día 21, varios diputados se quejaron de la publicación de la noticia, a lo que Diez Bueno contestó que había sido él, el que informó al periódico. Se mantiene en la Diputación hasta finales de mayo de 1874, cuando finalizan los trabajos de la institución y en la que asiste a veinticuatro de las cuarenta y dos sesiones celebradas.

Continúa como diputado por Tordesillas en la quinta Diputación del Sexenio, que inicia sus actividades el 30 de mayo de 1874, en virtud del nombramiento que realiza el Sr. gobernador, sesión en la que es nombrado vocal de la Comisión provincial, cargo del que toma posesión el día 31 de mismo mes y en el que se mantiene hasta el mes de enero de 1875. En la sesión del día 22 el gobernador civil Mariano Lino Reynoso, "en uso de sus facultades extraordinarias", le comunica el cese como diputado provincial. En este tiempo asiste a seis de las dieciocho sesiones. El gobernador Reynoso le cesa y al mismo tiempo le nombra secretario del Gobierno Civil y en consecuencia actúa como gobernador interino. Así lo publica el Boletín Oficial del día 23 de febrero del citado 1875: "Gobierno Civil: por ausencia del gobernador, se hace cargo accidentalmente del Gobierno, como gobernador interino, el secretario del Gobierno D. Marcelino Diez Bueno, de acuerdo con el artículo trece de la Ley Provincial".

En la primera Diputación de la Restauración, que inicia sus actividades el 19 de marzo de 1875, es nombrado nuevamente diputado por Tordesillas, siendo en la misma sesión nombrado vicepresidente de la institución. Se mantiene en la Diputación de una forma ininterrumpida hasta el año 1883. Fallece en Valladolid el 1 de mayo de 1905.

\section{Diez Quijada, Lázaro}

Es natural y vecino de Cigales, pueblo en el que se dedica a la agricultura. "Estudió en la Universidad de Valladolid, en la que se certifican cursos probados de lógica, elementos de matemáticas, $2^{\circ}$ de física, metafísica y filosofía moral con fecha 24 de abril de $1827^{\prime \prime 1035}$. En los archivos universitarios no hay constancia de la obtención de los grados de bachiller o licenciado.

El 10 de diciembre de 1868, en los inicios de la primera Diputación del Sexenio, es nombrado diputado suplente por el partido de Valladolid-Audiencia. En la sesión del día 11, se presenta y toma posesión del cargo, ante la dimisión que ha presentado el titular Sr. Rodríguez Monroy, manteniendo su actividad hasta el final de la legislatura, que tiene lugar en octubre de 1869. Asiste a cuarenta y ocho de noventa y ocho sesiones celebradas y no vuelve a estar presente como diputado.

\section{Díez del Río, Benito}

Es natural de Villamayor de Campos, en la provincia de Zamora, pueblo en el que nació el 21 de marzo de 1814, trasladándose a vivir a Nava del Rey. No realiza estudios universitarios y se dedica a la agricultura, convirtiéndose en uno de los más ricos propietarios de la provincia. En el año 1872 aparece como el décimo cuarto

1034 A.D.P.V. Actas. Libro de actas del 5 de noviembre de 1872 .

1035 A.H.U.V.A. Caja 566. 
contribuyente, por territorial, con unas rentas de 3.004 pesetas, por sus propiedades en La Nava del Rey, según el Boletín Oficial de la Provincia del 27 de marzo de 1872.

En política, está afiliado al partido moderado. Inicia sus actividades en el año 1844 cuando es nombrado concejal del Ayuntamiento de Nava del Rey. En el año 1846 se presenta a las elecciones para el Congreso, siendo elegido por el distrito de Mota del Marqués, en las filas del partido moderado. En el año 1847, en la sesión de instalación de la sexta Diputación isabelina, celebrada el día 15 de agosto, toma posesión y presta juramento como diputado provincial por el partido de Nava del Rey, desempeñando las funciones que le corresponden a lo largo de toda la legislatura, que se da por finalizada en marzo de 1850. En este período asiste a once de las cuarenta y cinco sesiones que se celebran. Es elegido miembro de la comisión de Consumos.

En las elecciones del año 1850 para diputado a Cortes, se vuelve a presentar por la misma demarcación de Mota del Marqués, pero fue derrotado por el también moderado y también ex-diputado provincial, Ignacio Arévalo Miera. No se vuelve a presentar como diputado en Valladolid, pero sí lo hace por el distrito de Benavente en la provincia de Zamora, por el que es elegido diputado a Cortes en las elecciones que se celebran el 11 de octubre de 1863 y el 22 de noviembre de $1864^{1036}$.

\section{Diez Salcedo, Sebastián}

Nació en la ciudad de Medina de Rioseco el 20 de enero de 1829, hijo de Dámaso Diez, de Tordesillas y de Antonia Salcedo de Rioseco. Inició sus estudios en la Universidad de Valladolid ${ }^{1037}$. Ejerce la abogacía en Rioseco, actividad que comparte con la de comerciante y comisionista de granos. A los que hay que añadir la agricultura, pues en estos años compró una serie de bienes nacionales, entre los que destaca una finca en Aguilar de Campos, procedente del Cabildo Eclesiástico y una tierra en Bolaños de Campos, que pertenecía a la Cofradía de las Ánimas. Se casó con Antonia Serrano, hija del diputado provincial y senador José Serrano Foronda. Tuvieron dos hijos, Saturnino que fue alcalde de Valladolid y José que ostentó el mismo cargo en Medina de Rioseco.

En el año 1862 traslada su residencia a Valladolid, ciudad en la que se sigue dedicando a la abogacía y al comercio. Director del periódico El Norte de Castilla de 1865 a 1868 y de 1875 a 1893 . La crisis tanto agrícola como industrial y comercial, que se genera al final de los años sesenta, repercute en sus negocios como se ve en la comunicación publicada en el Boletín Oficial de la Provincia del 26 de enero de 1865, haciendo público que "el Tribunal de Comercio de Valladolid, declara en quiebra al comerciante y vecino de Valladolid Sebastián Diez Salcedo".

Inicia su carrera política, de tendencia conservadora, presentándose como candidato a diputado provincial por el partido de Rioseco, siendo elegido en las elecciones celebradas en junio de 1858. El 18 de julio de 1858, en la sesión de instalación que celebra la decimocuarta Diputación isabelina, presta juramento y toma posesión del cargo, siendo nombrado en la misma sesión vicesecretario, cargo que ejerce hasta el 1 de mayo de 1859. También es elegido miembro de la comisión de Presupuestos y de la comisión de Hospitales. En marzo de 1860 se da por finalizada la legislatura a la que asiste a veintiséis de las cuarenta sesiones que se celebran. Continúa representando como diputado a Rioseco en la decimoquinta Diputación que se inicia el 1 de abril de 1860 y que se mantiene hasta marzo de 1862 asistiendo a

${ }^{1036}$ CARASA SOTO, Pedro (Dir.). Diccionario biográfico de parlamentarios ... ob. cit. Pág. 319.

1037 "Previa solicitud formulada el 27 de octubre de 1841, a los 13 años de edad, de pelo rubio y ojos azules, matriculándose en la Facultad de Filosofía. El 9 de julio de 1844 solicita ser examinado para alcanzar el grado de bachiller en Filosofía, acompañando los certificados de los cursos probados. Entró a examen el 10 de julio y salió aprobado némine discrepante. En el mismo año de 1844, ingresa en la Facultad de Leyes. El 7 de junio de 1849 se examina para alcanzar el grado de bachiller en Jurisprudencia, para lo cual acompaña certificados de los cursos ganados. Celebrado el examen fue aprobado en votación secreta. En el año 1851 se presenta a examen para alcanzar el grado de licenciado en Jurisprudencia y entró a examen el 12 de junio, siendo aprobado" A.H.U.V.A. Cajas 473 (doc. 372 a 376), 505 (doc. 145 a 148) y 676-7. 
dieciséis de las treinta y una sesiones celebradas. En esta legislatura es nombrado miembro de la comisión de Bagajes y vocal de la Junta de Beneficencia. En 1862, aunque reside en Valladolid, se presenta nuevamente a las elecciones para diputado provincial por el partido de Rioseco, en la decimosexta Diputación, y vuelve a salir elegido. El 1 de abril de 1862, en la sesión de instalación, jura el cargo y toma posesión del mismo. Trabaja durante toda la legislatura, que se da por finalizada en diciembre de 1863, asistiendo a dieciséis de las veintidós sesiones que se celebran. Finalizada esta legislatura no se vuelve a presentar a nuevas elecciones.

\section{Diez Serrano, Francisco}

Es natural del pueblo de Adalia, "de la provincia de Valladolid y diócesis de Palencia". Una vez cursados los estudios "de primeras letras", ingresa en la Universidad de Valladolid en su Facultad de Leyes, presentándose y aprobando el grado de bachiller en Cánones el 16 de junio de 1806, dedicándose al ejercicio de la abogacía en la capital.

El 7 de octubre de 1836, en la sesión de instalación que celebra la segunda Diputación isabelina, toma posesión del cargo de diputado provincial para el que ha sido elegido, manteniéndose en su puesto hasta el final de la legislatura, que se cierra el 24 de diciembre de 1837. En este período asiste a setenta y una de las setenta y dos sesiones que celebra la Diputación, siendo con gran diferencia el diputado más asiduo en su presencia en la corporación. Es la única referencia de su actividad política y no vuelve a estar presente en ninguna otra legislatura.

\section{Domínguez de la Mata, Andrés}

Nació el 1 de abril de 1825 en el pueblo de Villanueva de los Caballeros, hijo de Ignacio Domínguez, de San Pedro de Latarce y de María Isabel de la Mata, natural de Villanueva. Estudió licenciatura en Jurisprudencia en la Universidad de Valladolid ${ }^{1038}$. Ejerce como abogado en Villardefrades.

En política está afiliado al partido conservador. En las elecciones a diputados provinciales, que tienen lugar entre el 1 y el 4 de febrero de 1871 , sale elegido diputado por el distrito de Villardefrades. Presenta su acta en la sesión de instalación de la tercera Diputación del Sexenio, que se celebra el 17 de febrero de 1871 y en la misma sesión es elegido vocal de la Comisión de Actas. El día 23 es nombrado miembro de la Comisión permanente, presidiendo las sesiones de la Comisión en ausencia del presidente Arévalo. En el sorteo que se celebra en la sesión del 25 de julio de 1872, le correspondió cesar. Finaliza la legislatura en octubre de 1872 en la que asiste a cincuenta de las setenta sesiones que se realizan. En las elecciones a celebrar en septiembre de 1872 para cubrir las bajas de diputados, se vuelve a presentar en representación de Villardefrades, siendo elegido por 873 votos, contra 526 que consiguió su contrincante Santiago de la Riva. Se presenta por tanto en la Diputación, el día 2 de noviembre de 1872, en la sesión de instalación en la que hace entrega de su acta de elección, acta que fue aprobada el día 5. Se mantiene en el cargo hasta el 27 de abril de 1874, fecha en la que el gobernador interino le comunica que "he tenido a bien relevarle de su cargo de diputado provincial como titular del distrito de Villar de Frades"1039, por lo que es cesado del cargo en la sesión del día 11 de mayo, última que celebra la Diputación. Asistió en su tiempo de permanencia a diez sesiones de las cuarenta y dos celebradas.

1038 En la que ingresó el 16 de noviembre de 1837, matriculándose en la Facultad de Leyes. El 17 de julio de 1845, presenta la solicitud para acceder al grado de bachiller en Jurisprudencia, y convocado a examen el día 26 salió aprobado. En el año 1847, presenta solicitud de examen para alcanzar el grado de licenciado en Jurisprudencia, presentando igualmente los certificados de los cursos probados. Se fijan los exámenes para los días 26 de septiembre y 7 de octubre, siendo aprobado, y tomando posesión del grado en el Claustro celebrado el 17 de octubre" A.H.U.V.A. Cajas 471 (doc. 366 a 371) y 673-68.

1039 A.D.P.V. Actas. Libro de actas del 11 de mayo de 1874. 
En la quinta Diputación del Sexenio, a pesar de haber sido cesado pocos días antes, vuelve a ser nombrado diputado de Villardefrades, se presenta en la sesión de instalación, que tiene lugar el 30 de mayo de 1874, siendo nombrado, en la misma sesión, vocal de la Comisión provincial. Se mantiene hasta el final de la legislatura y del Sexenio en marzo de 1875, asistiendo a once de las dieciocho sesiones que se celebraron. Continúa como diputado en la primera Diputación de la Restauración, que inicia sus actividades el 19 de marzo de 1875, en representación de Villardefrades, siendo nombrado también, miembro de la Comisión y manteniéndose como diputado hasta el año 1883. En el año 1884, pasa como diputado a representar al distrito de Audiencia-La Mota y en 1887 es nombrado miembro de la Comisión Permanente. Deja la Diputación en el año 1888.

\section{Dueñas, Miguel de}

Natural y vecino de Medina, villa en la que desarrolla sus actividades como hacendado, estando considerado como uno de los mayores propietarios de la provincia. En el año 1872 según el Boletín Oficial del 27 de marzo de 1872, es el décimo quinto mayor contribuyente de la provincia por territorial con una renta de 2.920 pesetas y propiedades en Medina, Fresno y Valladolid.

Se inicia en la política al ser elegido diputado provincial por el partido judicial de Medina a partir de la constitución de la sexta Diputación isabelina, en 1847. Presta juramento y toma posesión del cargo en la sesión de instalación que se celebra el día 15 de agosto, legislatura que se alarga hasta marzo de 1850 y a la que asiste a treinta y siete sesiones de las cuarenta y cinco que se celebran. Según el sorteo celebrado en la sesión del 23 de octubre de 1849 para proceder a elegir a los diputados que deben de cesar en la renovación que tendrá lugar en el mes de febrero de 1850, debía de cesar, pero en la sesión de instalación que se celebra el día 1 de abril se presenta y continúa como diputado por Medina, al haber sido relegido. En esta séptima Diputación, que se prolonga hasta marzo de 1852, asiste únicamente a ocho sesiones de las treinta y dos que se realizan. El 1 de abril de 1852 se inician las actividades de la nueva Diputación, la octava isabelina, en la que continúa como diputado por Medina y se mantendrá hasta marzo de 1854 y asiste a siete de las veintitrés sesiones. Después de este período de tres Diputaciones en las que representó al partido de Medina, no volvió a ejercer ningún otro cargo público.

\section{Dueñas Rodríguez, Celestino}

Vecino y agricultor de Medina del Campo. En el año 1871 es el cuadragésimo tercer mayor contribuyente de la provincia por contribución de inmuebles con 1.759 pesetas de cuota anual y en 1872 es el cuadragésimo quinto por contribución territorial con cuota de 1.759 pesetas y propiedades en Medina y La Nava.

Se presenta como candidato para diputado provincial por Medina en las elecciones para la decimonovena y última Diputación de la era isabelina, que se celebran en noviembre de 1866, donde resultó elegido. El 1 de enero de 1867 en la sesión de instalación presta juramento y toma posesión del cargo. En septiembre de 1867 es nombrado presidente de la tercera reunión extraordinaria. Se mantiene como diputado hasta el final de la legislatura, el 20 de septiembre de 1868, que coincide con el final del período isabelino, asistiendo a cuarenta y tres de las cincuenta y dos sesiones que se celebran. En el año 1871 es elegido alcalde de Medina.

\section{Enríquez, Dionisio}

Natural de la ciudad de Rioseco, donde reside y ejerce como propietario y comerciante, con una buena posición social "pues tiene dos criados". Es comprador de bienes desamortizados. "Inició las compras en la época del Trienio 1820-23. Entre 1842 y 1843, compró tres conventos y dos almacenes desamortizados en Montes Torozos y en Tierra de Campos, por los que pagó 2.035.000 reales. También compró una finca de 76 hectáreas en Tierra de Campos por 238.438 reales. En la época de la 
desamortización de Madoz, volvió a comprar diversos bienes nacionales. En el año 1852 se le conoce en la comarca como comisionista en la compra de granos ${ }^{1040}$. Como apoderado del vecino de Rioseco, Pedro Corcea, reclama a la Diputación que "es preferible que pague los réditos de su apoderado como acreedor censualista antes de crear fondos para gastos de la Milicia Nacional" 1041 .

Inició su actividad política en la quinta Diputación isabelina, como moderado, al resultar elegido para el cargo de diputado provincial por Rioseco, en las elecciones celebradas en octubre de 1843 . Toma posesión en la sesión de instalación celebrada el 1 de noviembre y se mantiene en el cargo a lo largo de toda la legislatura, que finaliza en junio de 1847. Asiste a ciento cuarenta y tres sesiones de las doscientas cuarenta que se celebran. Es nombrado miembro de la comisión de Liquidación de Atrasos y en marzo de 1847 y hasta el final de la legislatura, actúa como secretario de la Corporación. No vuelve a tener ninguna otra actividad política.

\section{Escudero, Eusebio}

Nació en Mucientes en el año 1815. "Solicitó el ingreso en la Universidad de Valladolid el 25 de octubre de 1828, matriculándose en la Facultad de Leyes ${ }^{1042}$.

Es nombrado diputado provincial por la Junta Revolucionaria Provincial, en la sesión que celebra el 18 de octubre de 1868, en representación del partido judicial de Valoria la Buena en la primera Diputación del Sexenio. Toma posesión del cargo en la sesión del día 23 del citado mes de octubre. A los pocos días la Diputación, al conocer el texto de las nuevas "Ley Electoral" y "Ley Provincial", ambas del 21 de octubre de 1868, solicita su dimisión al quedar reflejada, según estas leyes, la supresión del partido judicial de Valoria, al igual que el de La Mota. Su negativa a dimitir la recoge el libro de actas, en el que se refleja que "el diputado por Valoria, Eusebio Escudero no presenta su dimisión, porque aun considerando que Valoria no sea considerada como partido judicial, él puede ser el segundo diputado por Peñafiel, por el número de almas que tiene" ${ }^{1043}$. A pesar de su negativa, la Diputación en acuerdo tomado el 24 de noviembre, consideró que no debía de continuar en el cargo. En definitiva, su paso por la Corporación fue poco efectivo y de corto espacio de tiempo, prácticamente un mes, en el que asistió a diez sesiones. No volvió a presentarse como diputado.

\section{Espinosa Rico, Rafael}

Nació el 15 de octubre de 1826 en el pueblo de Pesquera de Duero, del partido judicial de Peñafiel. Hijo de Jerónimo Espinosa y de María Rico. "Estudió en la Universidad de Valladolid ${ }^{1044}$. Finalizados sus estudios, fija su residencia en su pueblo de origen, donde ejerce como abogado, además de administrar sus posesiones agrícolas.

En el año 1854 entra en política al ser elegido alcalde de Pesquera de Duero. Se presenta como candidato a diputado provincial, para la decimonovena Diputación

1040 RUEDA HERNANZ, Germán. La Desamortización... ob. cit. pág. 300.

1041 A.D.P.V. Actas. Libro de actas del 9 de julio de 1855.

1042 En 1836, presenta la solicitud para ser examinado del grado de bachiller en Jurisprudencia, presentando los certificados de los cursos probados. Entró a examen el 14 de junio y salió aprobado némine discrepante" A.H.U.V.A. Caja 462 (doc. 497 a 503).

1043 A.D.P.V. Actas. Libro de actas del día 4 de noviembre de 1868.

1044 “...en la que solicitó el ingreso el 31 de octubre de 1838 , a los 12 años de edad, matriculándose en la Facultad de Filosofía. El 15 de junio de 1841, solicita ser examinado para alcanzar el grado de bachiller en Filosofía y examinado el día 21 fue aprobado némine discrepante. En octubre de 1841, se matricula en la Facultad de Leyes. El 13 de junio de 1845, solicita ser examinado a Claustro Pleno para obtener el grado de bachiller en Jurisprudencia y entró a examen el día 16 y salió aprobado. El 26 de marzo de 1847, solicita ser examinado para obtener el grado de licenciado en Jurisprudencia, para lo cual acompaña calificaciones y cursos ganados. Celebrado el examen los días 6,8 y 26 de junio es aprobado en todos ellos por unanimidad, recibiendo el citado grado, en la reunión del Claustro celebrada el día 27 de junio” A.H.U.V.A. Cajas 471 (doc. 47 a 62 ), 504 (doc. 487 a 489) y 673-29. 
isabelina, por el partido de Peñafiel, en las elecciones que se celebran los días 25 a 27 de noviembre de 1866, en las que resulta elegido diputado el alcalde de Peñafiel Pedro Burgoa Álvarez, aunque el acta fue rechazada en la sesión de instalación que se celebra el 1 de enero de 1867 por incompatibilidad de ambos cargos. El gobernador convoca nuevas elecciones para los días 20 a 23 de enero en las que "Pedro Burgoa vuelve a salir elegido diputado por Peñafiel como único candidato con 217 votos" 1045 . Se vuelven a declarar nulas las elecciones y el gobernador convoca nuevas elecciones para los días 13 y siguientes del mes de abril. El 21 del citado mes se hacen públicos los resultados y se dieron por válidos, con la elección de Rafael Espinosa con un total de 516 votos. Aunque en el mes de abril de 1867 se da por válida la votación, hasta la sesión del 6 de mayo de 1868 no se acordó aprobar el acta por el Pleno de la Diputación. En este tiempo se rechazaron una serie de alegaciones de Pedro Burgoa sobre que Espinosa Rico era juez de paz y lo consideraba también incompatible y otra de Diego Morales que reclamaba que no eran válidas las elecciones porque no fue convocado. En definitiva, en la citada sesión del 6 de mayo de 1868, estando presente en el salón de sesiones, Espinosa Rico prestó juramento y tomó posesión de su cargo. El 2 de agosto de 1868 es nombrado presidente de la reunión extraordinaria y continúa como diputado hasta el 20 de septiembre de este año, fecha en la que finaliza la legislatura, asistiendo a doce sesiones de las cincuenta y dos que se celebraron.

\section{Fernández, Cristóbal Magdaleno}

Natural y vecino de Valladolid, en cuya Universidad estudió, alcanzando el grado de bachiller en la Facultad de Filosofía en el año 1805. Es elegido diputado provincial por el partido de la capital, tomando posesión de su cargo en la sesión de instalación de la cuarta Diputación isabelina, que se celebra el día 1 de enero de 1841. Es nombrado miembro de las comisiones de Presidios y de Contribuciones Extraordinarias. Asiste únicamente a diez sesiones de la Diputación, ya que falleció en el mes de mayo del mismo año de 1841.

\section{Fernández, José}

Vecino de Torrescárcela, de tendencia liberal, es elegido diputado por el partido de Peñafiel, en la segunda Diputación del período isabelino. Toma posesión de su cargo en la sesión de instalación celebrada el día 7 de octubre de 1836. Se mantiene en su puesto hasta el final de la legislatura, que tiene lugar el 24 de diciembre de 1837, asistiendo en este tiempo a cincuenta y tres de las setenta y dos sesiones celebradas. Miembro de la Milicia Nacional en su pueblo de residencia, no vuelve a aparecer en ningún otro cargo político de la provincia.

\section{Fernández Fernández, Andrés}

Nació el 30 de noviembre de 1821, en el pueblo de La Mota del Marqués, hijo de Pedro y de María Antonia. En el año 1837 solicitó el ingreso en la Universidad de Valladolid matriculándose en la Facultad de Leyes ${ }^{1046}$.

Su actividad política se inicia cuando el gobernador civil "en uso de sus facultades extraordinarias", el 11 de mayo de 1874, le nombra diputado provincial por el distrito de Tiedra, que pertenece al partido judicial de Tordesillas. Se presenta en la sesión de instalación de la quinta Diputación del Sexenio, que tiene lugar el 30 de mayo del mismo año, para tomar posesión de su cargo. En la sesión del 31 de mayo, es nombrado vocal de la comisión de Presupuestos y en la del 17 de junio, vocal de la comisión Inspectora de Establecimientos de Enseñanza. En la sesión del 4 de noviembre, presenta su renuncia al cargo, y ante esta petición la Diputación "acuerda

1045 A.D.P.V. Actas. Libro de actas del 21 de marzo de 1867.

1046 En 1843 solicita ser examinado para alcanzar el grado de bachiller en Jurisprudencia. Entró a examen el día 3 de julio y salió aprobado. En 1845, solicita recibir el grado de licenciado en Jurisprudencia, presentando todos los requisitos que manda la ley. Se celebran los exámenes los días 17 y 23 de septiembre, resultando aprobado" A.H.U.V.A. Cajas 469 (doc. 232 a 235) y 671-96. 
remitir al Sr. gobernador, la renuncia del diputado por La Mota del Marqués, Andrés Fernández, por ser escribano del juzgado. Como ha sido el gobernador el que le ha nombrado y no ha sido por elecciones, que sea el gobernador el que acepte su renuncia" ${ }^{1047}$. El gobernador no admitió su renuncia y continuó en el cargo hasta el final de la legislatura que tuvo lugar el 18 de marzo de 1875, tiempo en el que asistió a doce de las dieciocho sesiones celebradas. No vuelve a aparecer como diputado.

\section{Fernández González, Juan}

Vecino de Villavellid, es elegido diputado y ejerce en la Diputación Provincial de Zamora, al pertenecer su pueblo a esa provincia. Pero a partir de la aprobación de la "nueva división territorial" pasa a ejercer su cargo en la Diputación de Valladolid en representación del partido judicial de La Mota del Marqués. Se presenta y presta juramento en la sesión del 29 de mayo de 1822, asistiendo hasta el fin de la legislatura, el 25 de abril de 1823 a sesenta y dos sesiones de las ciento cincuenta y siete que se celebran. No se le conocen más actividades de carácter político provincial.

\section{Fernández Miranda, Sebastián}

Sebastián Fructuoso Fernández Miranda nació en Medina del Campo, el 21 de enero de 1832, hijo de Alejandro Fernández y de María Ana de Jesús Miranda. "En el año 1845, inició sus estudios en la Universidad de Valladolid, matriculándose en la Facultad de Filosofía y después en la de Leyes ${ }^{1048}$. Acabados sus estudios, se estableció como abogado en Medina, compaginando este trabajo con la administración de su patrimonio, formado por propiedades rústicas y comerciales. Permaneció soltero y, a su muerte, legó sus bienes a sus sobrinos Hermenegildo y Sebastián. Sus numerosas fincas estaban distribuidas por diferentes pueblos del entorno de Medina, como El Campillo, Fuentelapiedra, San Vicente del Palacio y en la propia Medina, donde también poseía diversas fincas urbanas.

Se inicia en la política en el año 1866, al ser nombrado alcalde de Medina. En el mes de febrero de 1871, se presenta a las elecciones para diputado provincial que se celebran los días 1, 2 y 3, donde sale elegido por el primer distrito de Medina, y en consecuencia se presenta en la Diputación el 17 de febrero, día en que se celebra la sesión de instalación de la tercera Diputación del Sexenio, con su acta de diputado, que es aprobada en la sesión del día 19. El día 23 es elegido vocal de la Comisión provincial y mantiene su actividad hasta el 20 de abril de 1872. En el tiempo que estuvo en la Diputación asistió a cincuenta y cinco sesiones del Pleno y a ciento trece de la Comisión. En abril de 1872 presenta la dimisión en el Pleno de la Diputación por haber sido elegido diputado a Cortes por el distrito de Medina y en representación del partido moderado ${ }^{1049}$. En el año 1875 y en la primera Diputación que se forma en la Restauración, vuelve a ser elegido diputado provincial por Medina, a través de nombramiento gubernamental. Fallece en Medina el 3 de diciembre de 1887.

\section{Fernández Montealegre, Manuel}

Es vecino de Medina del Campo, donde ejerce de hacendado, propietario y comerciante. "Miembro de la Asociación de Propietarios Territoriales de España.

1047 A.D.P.V. Actas. Libro de actas del 4 de noviembre de 1874.

1048 El 21 de junio de 1850, solicitó ser examinado para alcanzar el grado de bachiller en Filosofía, acompañando los certificados de las asignaturas probadas. Celebrado el examen los días 26 y 28 de junio es aprobado por unanimidad en el primer ejercicio y por 4 votos en el segundo. En octubre de 1850, se matriculó en la Facultad de Leyes y en el año 1856, solicitó ser examinado para alcanzar el grado de bachiller en Jurisprudencia. Entró a examen el 16 de junio y salió aprobado. El 12 de junio de 1858, presenta la solicitud de examen para el grado de licenciado en Jurisprudencia, acompañando los certificados de los cursos probados. Examinado los días 15, 26 y 30 de junio resultó aprobado por unanimidad, confirmando el grado en la sesión del Claustro que se celebra el 4 de julio" A.H.U.V.A. Cajas 477 (doc. 217 a 218), 509 (doc. 143 a 147) y 670 (doc. 170 a 173). 1049 CARAS A SOTO, Pedro (Dir.). Diccionario biográfico de Parlamentarios ... ob. cit. pág. 369. 
Administrador de las fincas del Marqués de Bedana. En 1840 compró 500 hectáreas de tierras desamortizadas en la zona de Medina y en Tierra de Campos. En 1858 ejerce como contratista de las obras del ferrocarril del Norte ${ }^{1050}$.

En política está considerado como liberal progresista y partidario de Espartero (colaboró en la suscripción de la estatua del duque en Logroño). Se presenta a las elecciones, en el inicio de la Década Moderada, en la quinta Diputación de la época isabelina. Es elegido diputado provincial por Medina, tomando posesión del cargo, en la sesión de instalación que se celebra el 1 de noviembre de 1843. Asiste a un total de ciento cincuenta y tres sesiones de las doscientas cuarenta que se celebran hasta el final de la legislatura en junio de 1847. En este tiempo fue elegido miembro de la Junta de Clasificación de Objetos Artísticos y de la comisión de Puentes y Caminos Vecinales. Destacado defensor del campo castellano, solicitó "el proteccionismo para los cereales castellanos". En el año 1854 es elegido alcalde de Medina (B.O.P.V. de 30-11-54).

\section{Fernández Montero, Francisco}

Vecino de Villanueva de los Caballeros, es elegido diputado provincial, en la segunda Diputación isabelina, por el partido de Rioseco en octubre de 1836. Presta juramento y toma posesión de su cargo en la sesión de instalación que se celebra el día 7 del citado mes y año. Asiste a lo largo de la legislatura que finaliza el 24 de diciembre de 1837 a sesenta y siete sesiones, actuando en ocasiones como presidente interino ante la ausencia del jefe político. No vuelve a desempeñar ningún otro cargo político.

\section{Fernández Rico, José Manuel}

Natural y vecino de Valladolid, ciudad en la que destaca como uno de los más importantes comerciantes e industriales. En el año 1860 es el tercer mayor contribuyente de la provincia por comercio, con una cuota anual de 3.956 reales. En la sesión que celebra la Diputación el día 8 de abril de 1862 "acuerda comisionar al Sr. D. José Manuel Fernández Rico, socio de la fábrica de fundición, para asistir a la Exposición de Londres, junto a los Sres. Villanueva y Melero y les emplaza a que en el mes de septiembre presenten una memoria-resumen del viaje" ${ }^{1051}$.

En enero de 1875, ya en el final de la legislatura de la quinta Diputación del Sexenio Revolucionario "por orden del Sr. gobernador civil" es nombrado diputado provincial por el distrito de San Pedro de Valladolid. Toma posesión del cargo en la sesión del día 22, sustituyendo al cesado Miguel Ibáñez Martín. Es a la única sesión a la que asiste, ya que es la última que se celebra antes de la disolución de la Diputación. En la citada sesión es nombrado vocal de la comisión "para ir a saludar al Rey e invitarle a la visita de la ciudad". No vuelve a ejercer como diputado.

\section{Fernández de la Torre, Calixto}

Nace en Valladolid el 14 de octubre der 1820, ciudad en la vivió y en la que desarrolló una intensa actividad comercial y financiera. No se le conocen estudios universitarios. Se casó con Paula Moran, con la que tuvo seis hijos. Teniente de la Milicia Nacional. Tesorero de la Caja de Ahorros en 1853 y director en 1857. Miembro de la Real Academia de la Purísima Concepción de la que llegó a ser presidente. Presidente de la Sociedad Filantrópica Artística de Valladolid. Administrador del Banco de Valladolid.

Su actividad política la inicia en el año 1847 al ser nombrado concejal del Ayuntamiento de Valladolid, posteriormente pasó a ser teniente de alcalde hasta que en diciembre de 1851 fue elegido alcalde, cargo que ocupó hasta junio de 1853. Durante estos años se llevaron a cabo diversas actuaciones como el traslado a

${ }^{1050}$ RUEDA HERNANZ, Germán. La desamortización... ob. cit. pág. 299.

1051 A.D.P.V. Actas. Libro de actas del 8 de abril de 1862. 
Valladolid de la Academia de Caballería, el proyecto del Puente Colgante o el acuerdo sobre el trazado de la línea del ferrocarril ${ }^{1052}$.

En el año 1856 es elegido diputado provincial por la capital, en las elecciones para cubrir las vacantes de la decimotercera Diputación isabelina. Presta juramento y toma posesión del cargo en la sesión de instalación que se celebra el 2 de diciembre del citado año. Es nombrado miembro de la comisión de "Recepción de S.M. en su viaje a Valladolid". Es nombrado vicesecretario en la misma sesión de instalación, ejerciendo el citado cargo hasta mayo de 1857. La legislatura finaliza en julio de 1858 , a la que asiste en veinticuatro ocasiones de las veintisiete sesiones celebradas. El 18 de julio de 1858, fecha de inicio de la decimocuarta Diputación, continúa representando a Valladolid en la Corporación provincial. En la sesión de instalación es nombrado miembro de la comisión de Festejos. En esta legislatura que finaliza el 30 de marzo de 1860, asiste a treinta y siete de las cuarenta sesiones celebradas. Se vuelve a presentar como candidato a diputado provincial por el partido de Valladolid en las siguientes elecciones para la decimoquinta Diputación y saliendo elegido, tomó posesión en la sesión de instalación que se celebra el 1 de abril de 1860. Es nombrado miembro de la Comisión para el encauzamiento del Esgueva. Asiste a veintiséis sesiones de las treinta y una que se celebran hasta su disolución el 30 de marzo de 1862. Abandona a partir de este año toda actividad política aunque sigue con sus actividades sociales hasta 1877 , año en el que se retira de todas las actividades públicas. Fallece en Valladolid el 22 de enero de 1903.

\section{Fernández de Velasco, Domingo}

Natural y vecino de Peñafiel. Estudió en la Universidad de Valladolid, como lo certifica la solicitud que presentó en el año 1852 al Sr. Rector para examinarse de bachiller en Filosofía ${ }^{1053}$.

Es elegido "en uso de las facultades concedidas al Sr. gobernador", como diputado provincial en la quinta Diputación del Sexenio, por el distrito de Campaspero, del partido judicial de Peñafiel. Se presenta y toma posesión en la sesión de instalación que se celebra el 30 de mayo de 1874. En la sesión del 17 de junio es nombrado vocal de la comisión de Cuentas. Ejerce como tal diputado durante toda la legislatura, aunque sólo asiste a cuatro sesiones de las dieciocho celebradas. Finaliza su actuación el 18 de marzo de 1875, día en la que también finalizan la legislatura de la Diputación y el Sexenio Revolucionario. No vuelve a estar presente en la política provincial.

\section{Fernández Vítores, Juan Manuel}

Nació el 27 de diciembre de 1796 en Fresneda de la Sierra, provincia de Burgos, hijo de Bernardo y de Francisca, labradores en el pueblo. En el año 1812 se traslada a Valladolid para "hacerse cargo de un almacén de Coloniales y un molino de chocolate", negocios que eran propiedad de su hermano Buenaventura, que además poseía otros negocios en Madrid. No siguió ninguna carrera, ya que a los 16 años había iniciado sus trabajos en el ámbito comercial, aunque se formó con su hermano, que era canónigo en Salamanca. Dos de sus hijos sí se licenciaron en la Facultad de Derecho de Valladolid. En el año 1818 se casó en Valladolid con Gregoria Guerra y Aragón, vecina de Villarramiel, de la provincia de Palencia.

En el año 1834 es el tesorero de la Mutua contra Incendios de Valladolid. En el año 1841 es uno de los más importantes propietarios y es el primer contribuyente de la capital con 31.000 reales de renta. "Entre los años 1841 y 1843, compró importantes

1052 CARASA SOTO, Pedro (Dir.). Diccionario biográfico de alcaldes ... ob. cit. pág. 346.

${ }^{1053}$ En ella expone que "habiendo estudiado y perseverado en el Instituto adjunto a esta Universidad los años de la Segunda Enseñanza, y teniendo por consiguiente los requisitos necesarios para poder optar al grado de bachiller en Filosofía suplica a V.S. se digne admitirle a los correspondientes ejercicios para recibir el citado grado. Se presentó al examen el día 21 de junio, y fue aprobado por unanimidad" A.H.U.V.A. Caja 510 (doc. 266 a 270). 
propiedades de fincas desamortizadas: 359 hectáreas en las zonas de Campiña del Pisuerga, Tierra del Vino, y Páramo de Esgueva, por las que pagó 863.000 reales, cuatro casas en la ciudad de Valladolid por 291.000 reales y una finca, como testaferro de su convecino político Mariano Miguel de Reynoso" ${ }^{1054}$.

A partir del año 1837 realiza una gran labor social, con la puesta en marcha de la Casa de Beneficencia. También en el ámbito particular desarrolló una gran actividad comercial, formando parte de la Junta de Comercio de Valladolid y llegando a ser nombrado presidente de la "Asociación de Propietarios Territoriales de España". También realizó viajes profesionales a París y Londres. En estos años permanece alejado de la política, tanto municipal como provincial, dedicándose por entero a la faceta de promotor industrial y comerciante, "viviendo en el Palacio de los Almirantes con cuatro criados. En el año 1846 instaló una moderna fábrica de harinas en Renedo y en 1849 pone en marcha una fábrica de chocolate. Miembro de la "Comisión Promotora del Ferrocarril Alar-Santander", es uno de sus accionistas más importantes. En 1847 es vocal de la Junta de Agricultura. En 1852 es nombrado vocal del Sindicato de Mantenimiento del Cauce del Río Esgueva. En 1855 es el mayor contribuyente de la capital con 9.036 reales de renta. En 1860 es el décimo quinto ma yor contribuyente de la provincia con 6.814 reales y en 1861 es el vigésimo octavo, con 4.655 reales. En el año 1856, con ocasión de las revueltas por la carestía de la vida que se sucedieron en la capital, conocidas con el nombre del "Motín del Pan", un numeroso grupo de personas intentó quemar su casa. En el año 1857 presenta un estudio para el abastecimiento de agua a Valladolid.

Su actividad política se inicia entre los años 1820 a 1823, años en los que fue voluntario de la Milicia Nacional, militando ya en estos años en el partido moderado. Al final del Trienio y a causa de sus ideas políticas, tuvo que exiliarse en Paris. Entre los años 1833 a 1835, ya iniciado el período isabelino, fue elegido concejal del Ayuntamiento de Valladolid. El 16 de octubre de 1835 es nombrado alcalde de Valladolid, cargo que tiene que dejar el 22 del mismo mes al ser nombrado diputado en la recién instaurada Diputación provincial, en representación de Valladolid. Toma posesión de su cargo en la sesión de instalación de la primera Diputación isabelina que se celebra el día 22 de octubre de 1835 y permanece en la corporación hasta el final de la legislatura que tiene lugar el 5 de octubre de 1836. En este tiempo, asiste a ciento quince sesiones de las ciento veintidós que se celebran, pertenece a las comisiones de Plantillas, Fomento y Hacienda, y actúa de presidente interino en las ausencias del jefe político.

En octubre de 1837, perteneciendo a la "Junta Local de Armamento y Defensa", lucha contra la facción de Zariategui, en los días en que la ciudad, abandonada por el jefe político y el Ejército, fue ocupada por los carlistas. En el año 1838, siendo alcalde $2^{\circ}$ de Valladolid, se enfrentó a la Diputación por considerar que "era el Ayuntamiento de la ciudad, el único con derecho a nombrar al administrador del Hospicio". El 31 de marzo de 1844, vuelve a ser nombrado alcalde de Valladolid y ejerce el cargo hasta el 31 de diciembre de $1845^{1055}$. Falleció en esta ciudad el 3 de septiembre de 1863 , a los 67 años.

\section{Flores, Paulino}

Es propietario y vecino de Siete Iglesias de Trabancos. En el año 1871 es el vigésimo quinto mayor contribuyente de la provincia por territorial, con una cuota de 2.385 pesetas al año, y en 1872 es el vigésimo sexto con 2.397 pesetas. En el año 1878 , continúa ampliando sus propiedades al comprar "unos pedazos de tierra en Evan de Abajo".

En política está afiliado al partido conservador y es partidario de Gamazo. Su primer cargo político lo ejerce en 1863 , al ser nombrado alcalde de Sieteiglesias. En la

1054 RUEDA HERNANZ, Germán. La Desamortización... ob. cit. pág. 261 y 321.

${ }^{1055}$ CARAS A SOTO, Pedro. (Dir.), Diccionario biográfico de alcaldes.... Ob. cit. pág. 356. 
sesión de instalación de la quinta Diputación del Sexenio, que se celebra el 30 de mayo de 1874 "se da lectura al oficio del Sr. gobernador del 26 del corriente, en el que resulta que por dicha superior autoridad se le nombra diputado provincial por el distrito y partido de Medina en sustitución de Galo Olivares". No se presenta en la Diputación hasta el 17 de junio, en cuya sesión se le nombra vocal de la comisión de Cuentas. Sólo asiste a tres sesiones en el mismo mes de junio y no vuelve a aparecer por la Diputación hasta que da por finalizada su legislatura en marzo de 1875. Continúa como diputado provincial por Medina en la primera Diputación de la Restauración que se mantuvo entre 1875 y 1877. Fallece en Medina el 6 de abril de 1889, siendo presididos los funerales por Gamazo y López Flores. Sus hijos, Paulino y Moisés Flores Alonso, continuaron su estela política representando a Siete Iglesias en la Diputación entre los años 1884 a 1915, siempre dentro del partido conservador. El periódico "La Libertad" (22-11- 1903) dice de Paulino, hijo, "que es el cacique indiscutible de los conservadores de Nava, y de arraigo gamacista".

\section{Francos, Juan}

Es natural y vecino de Aguilar de Campos, donde ejerce como agricultor y propietario. En el año 1855 es considerado el segundo mayor contribuyente del partido de Villalón por propiedad territorial con 5.171 reales de cuota. En el año 1872 aparece como el trigésimo octavo mayor contribuyente de la provincia por propiedad territorial con 2.054 pesetas de contribución, y propiedades en Aguilar de Campos. Se presenta a las elecciones para diputado provincial en la decimoctava Diputación isabelina, celebradas en noviembre de 1865, en las que sale elegido por el partido de Villalón. En la sesión de instalación celebrada el 1 de enero de 1866 presta juramento y toma posesión del cargo, en el que se mantiene hasta el final de la legislatura que tiene lugar el 31 de diciembre de 1866, asistiendo a las dieciocho sesiones que se celebran. No vuelve a presentarse como candidato en ninguna otra elección.

\section{Fuente, Eusebio de la}

Es natural de Medina del Campo. Licenciado en Derecho, inició sus estudios universitarios en la Facultad de Leyes de Salamanca, en la que se matriculó en el año 1818 y en la que permanece hasta el año 1825, aprobando en estos años los cursos de Lógica, Metafísica, Filosofía, Derecho Español e Instituciones Canónicas. El 18 de diciembre de 1825 presenta los certificados de los cursos aprobados, en la Facultad de Leyes de la Universidad de Valladolid y solicita ser examinado del grado de bachiller en Leyes y aprobó "némine discrepante". Se establece en Medina, donde ejerce la abogacía.

Su actividad política se inicia en febrero de 1836, al ser nombrado alcalde de Medina y elector en las elecciones para diputados a Cortes. En octubre del mismo año 1836 es elegido diputado provincial por el partido de Medina. Se mantiene en el cargo el tiempo de vigencia de esta segunda Diputación isabelina, desde octubre de 1836 hasta diciembre de 1837, y asiste en este tiempo a treinta y seis sesiones. No está presente en ninguna otra elección.

\section{Galván, José}

Vecino de Alaejos, es elegido diputado provincial en la tercera Diputación del Trienio, por la provincia de Zamora, a la que pertenecía su pueblo. A raíz de la aprobación de la ley de la" nueva división del territorio", al pasar Alaejos a la provincia de Valladolid, continúa en el ejercicio de su cargo en esta provincia. En la sesión que celebra la Diputación el 23 de mayo de 1822 presta juramento y toma posesión de su cargo, en cuyo ejercicio se mantiene hasta el 25 de abril de 1823, final de la legislatura. Asiste a cincuenta y siete de las ciento cincuenta y siete sesiones que se celebran y con el fin del Trienio y la vuelta del absolutismo no tiene oportunidad de presentarse más veces. 


\section{García Casasola, Ildefonso}

Vecino de Nava del Rey, en febrero de 1836 es teniente de alcalde de su Ayuntamiento y también es elector del partido para las elecciones de diputados a Cortes. Pertenece a la Milicia Nacional. En diciembre de 1837 es elegido diputado provincial por el partido judicial de La Nava para la tercera Diputación isabelina. Las primeras elecciones se declararon nulas, "en atención a que, en diametral oposición a la ley, los electores que en ella tomaron parte habían votado dos diputados en vez de uno solo y por consiguiente aparece duplicado el número de votos" ${ }^{1056}$. En la sesión que celebra la Diputación el 13 de enero de 1838, se aprobaron las actas de las segundas elecciones y en la misma sesión juró el cargo y tomó posesión del mismo. Se mantiene en el puesto hasta el final de la legislatura en diciembre de 1840, asistiendo en este tiempo a cincuenta sesiones, aunque desde abril de 1839 deja de asistir, justificando su ausencia "por enfermedad, al estar atacado de re uma".

En el año 1854 es nuevamente convocado para participar como diputado en la primera Diputación del Bienio Progresista, de acuerdo con el real decreto de 7 de agosto "por ser diputado en 1843." La realidad es que no era diputado en los años 1843, sino que lo fue en la Diputación anterior que transcurrió entre finales de 1837 y finales de 1840. En el año 1843 era diputado provincial por el partido de La Nava del Rey, Baltasar González, "individuo" que tenía que haber sido diputado pero que no fue convocado en 1854 y en su lugar apareció García Casasola. Su presencia en esta Diputación fue realmente testimonial, pues si sus actividades se inician con la sesión de instalación el 17 de agosto, no tomó posesión hasta el día 2 de septiembre. Es la única sesión a la que asiste y en la que, al mismo tiempo que tomaba posesión, presentaba la renuncia de su cargo "por su edad septuagenaria y los achaques que padece". Aceptada la renuncia, el gobierno provincial convocó elecciones para cubrir la vacante, siendo elegido Isidoro Mariano Cafranga.

\section{García Duque, Francisco}

Es nombrado diputado provincial por el distrito y partido de Olmedo, a finales de la cuarta Diputación del Sexenio, "en uso de las facultades que al gobernador le concede la circular del Poder Ejecutivo de la República de 5 de febrero de 1874". Se presenta en la Diputación el 11 de mayo de 1874, para tomar posesión del cargo en lugar del cesado Francisco Martín Torés. Es a la única sesión a la que asiste, pues en la misma se da por finalizada la legislatura, y no vuelve a ser ni elegido ni nombrado diputado

\section{García Escobar, Joaquín}

Natural de Medina de Rioseco, es hijo de Antonino y Raimunda. De acuerdo con la Ley Orgánica Provincial de 21 de octubre de 1868, en la sesión que celebra la primera Diputación del Sexenio, el 27 de noviembre del mismo año, es nombrado diputado suplente por el partido judicial de Rioseco. A lo largo de la legislatura, que finaliza en octubre de 1869, no tiene opción de asistir a las sesiones de la Diputación, ya que no remplazará al diputado titular Manuel de la Cruz Alonso. Su hermano Ventura ejerció como diputado por Rioseco en el Bienio Progresista, en los años 1854 a 1856.

\section{García Escobar, Ventura}

Nació en la ciudad de Rioseco el 16 de septiembre de 1817, hijo de Antonino y Raimunda. Su hermano Joaquín ejerció como diputado provincial suplente por Rioseco, en la primera Diputación del Sexenio en 1868. Ingresó como cadete en el Regimiento de León, pero pronto abandonó el Ejército e inició sus estudios en Valladolid. "El 12 de diciembre de 1831, a los 14 años de edad y pelo rojo, solicita su ingreso en la Universidad de Valladolid, siendo aceptado y matriculándose en la

1056 A.D.P.V. Actas. Libro de actas del 26 de diciembre de 1837. 
Facultad de Leyes. En el año 1836 alcanza el grado de bachiller en Leyes. En 1837 se matricula en la Facultad de Filosofía. En 1841 es examinado para alcanzar el grado de bachiller en Filosofía, siendo aprobado némine discrepante" ${ }^{1057}$. Se estableció en Rioseco, donde ejerció la abogacía, destacando también como autor literario.

Pertenece a la Milicia Urbana de la ciudad y es conocida su tendencia liberal. En el año 1854, es nombrado diputado provincial por Rioseco, según acuerdo de la "Junta Provisional del Gobierno de la Provincia", prestando juramento y tomando posesión en la sesión de instalación de la décima Diputación provisional, celebrada el 30 de julio. Asistió a nueve de las quince sesiones que se celebran hasta el 14 de agosto del mismo año, fecha de su disolución. Continuó como diputado en la undécima Diputación, que inicia sus actividades el 17 de agosto, también por Rioseco. En la sesión de instalación el Sr. gobernador aclaraba "que se mantiene en el cargo por haber fallecido los diputados del partido que lo fueron en los años 1840-4142 y 43"1058. Sólo permanece en el puesto durante el mes de agosto, asistiendo únicamente a dos sesiones y en la segunda de ellas, presenta la dimisión de su cargo "por motivos de salud", dimisión que le fue aceptada. Falleció en Rioseco el 6 de noviembre de 1859.

\section{García Galán, Pascasio}

Es elegido diputado por el partido de Nava del Rey, prestando juramento y tomando posesión del cargo en la sesión de instalación de la decimonovena Diputación isabelina, que se celebra el 1 de enero de 1867. Es nombrado presidente de la reunión extraordinaria, que se inicia el 13 de septiembre de 1868 y en consecuencia preside la sesión que se celebra el día 14. En la última sesión de esta legislatura del 20 de septiembre se celebra el sorteo para la renovación de cargos y le correspondió continuar, pero los acontecimientos políticos propiciados con la llegada del Sexenio no se lo permitieron. En este período asistió a cuarenta y cuatro de las cincuenta y dos sesiones. No se vuelve a presentar a nuevas elecciones.

\section{García Pizarro, Luis}

Nació en el año 1817, en la ciudad de Rioseco, hijo de Cayetano García de la Maza y de Buenaventura Pizarro, ambos procedentes de familias acomodadas dedicadas a la agricultura y al comercio. Su padre es propietario de una fábrica de tintes además de comprador de fincas desamortizadas por valor de 437.461 reales y fue elegido diputado a Cortes en 1834. Su tío José María Pizarro fue alcalde de Rioseco en 1834 y diputado provincial en 1856. Su primo Vicente Pizarro Cuadrillero también fue diputado provincial al final de la época isabelina. "En el año 1832 solicita el ingreso en la Universidad de Valladolid, matriculándose en la Facultad de Filosofía, en la que estudió y aprobó los cursos de los años 1832-1833 y 1834. Alcanzó el grado de bachiller en junio de 1833. Su hermano Enrique estudia Leyes en la Facultad de Derecho de la misma Universidad." 1059.

Se casó con Josefa de Lara, sobrina de Mariano Miguel de Reynoso, alcalde, diputado a Cortes, senador y ministro de Fomento. Es cuñado de Cástor Ibáñez de Aldecoa, gobernador civil de Valladolid. En política está considerado como moderado.

Es elegido diputado provincial por Rioseco, en la octava Diputación isabelina y toma posesión del cargo en la sesión de instalación que se celebra el día 1 de abril de 1852. En la misma sesión es nombrado vicesecretario de la Corporación. A partir del 1 de noviembre de 1853 es elegido secretario y mantiene el cargo hasta el final de la legislatura que tiene lugar el 30 de marzo de 1854. En este tiempo asiste a diecisiete de las veintitrés sesiones celebradas. Continúa como diputado en representación del

1057 A.H.U.V.A. Cajas 462 (doc. 319 a 327) y 504 (doc. 464 a 467).

1058 A.D.P.V. Actas. Libro de actas del 17 de agosto de 1854.

1059 A.H.U.V.A. Cajas 458 (doc. 93 a 96) y 468 (doc. 1). 
mismo partido, en la novena Diputación, que se inicia el 1 de abril de 1854 y que sólo tendrá vigencia hasta el 18 de julio del mismo año, fecha de inicio del Bienio Progresista. En este corto período, sólo asiste a una sesión de las cuatro que se celebran, y no vuelve a aparecer en ninguna otra actividad política.

\section{García Serrano, José}

El artículo veintitrés de la nueva Ley Orgánica Provincial de 21 de octubre de 1868 señala la nueva organización de las corporaciones provinciales, con el nombramiento "de tantos suplentes como titulares tenga la Diputación". Por ese motivo, en la sesión del día 10 de diciembre de 1868, de la primera Diputación del Sexenio, es nombrado diputado suplente por el partido de Peñafiel. Pero a lo largo de la legislatura, que finaliza en octubre de 1869, no tiene oportunidad de sustituir al diputado titular Mariano Capdevila Pedrero. Tampoco se presenta a ninguna otra elección de diputados.

\section{Gardoqui Fernández, José}

Nacido en Valladolid el 4 de septiembre de 1838, fue bautizado en la Iglesia de San Miguel el día 7, y se le impusieron los nombres de José Joaquín Cándido Regino, hijo de Manuel y de Hipólita. Su padre, Manuel, había nacido en Zamora en 1802 y de joven se trasladó a vivir a Valladolid, en donde se casó. En el año 1843 adquirió 859 hectáreas de fincas rústicas desamortizadas por las que pagó 927.000 reales, situadas en Tierra de Campos y en Campiña del Pisuerga.

Inicia sus estudios en la Universidad de Valladolid, en el año 1851, obteniendo el grado de bachiller en la Facultad de Filosofía y el de licenciado en la de Leyes. ${ }^{1060}$ Se establece como abogado en Valladolid, ingresa en el Colegio de Abogados y al mismo tiempo se dedica a la administración de sus propiedades. Se casó con Enriqueta Alau, "cuyo padre, nacido en Oviedo en 1813, ejerció la medicina en Valladolid, de cuya Universidad fue nombrado catedrático en 1844, y rector en 1870 ". Fue

comprador de una finca procedente de bienes desamortizados de 6 hectáreas, próxima a Valladolid, por la que pagó 114.000 reales" ${ }^{1061}$. Aparte de sus propiedades también se dedicó a administrar las numerosas propiedades adquiridas por su padre durante la desamortización de Mendizábal. En el año 1889 es nombrado "Académico de la Real Academia de Bellas Artes de la Purísima Concepción".

En política está afiliado al partido conservador y es amigo personal de Santiago Alba. Su actividad política se inicia con su nombramiento de alcalde $5^{\circ}$ del Ayuntamiento de Valladolid en octubre de 1868, recién estrenado el Sexenio y permanece hasta octubre de 1869 , al ser nombrado diputado provincial en la segunda Diputación del Sexenio por el partido de Valladolid-Plaza, "de acuerdo con la comunicación pasada por el Sr. capitán general, por hallarse declarado el territorio en estado de guerra". Toma posesión del cargo en la sesión de instalación que se celebra el 18 de octubre de 1869. Es nombrado miembro de las comisiones de Beneficencia y de Venta de Bienes Nacionales.

El 12 de junio de 1870, en la sesión de la Diputación, se lee: "Una exposición del Ayuntamiento de Valladolid, en la que presentaban la dimisión todos sus miembros, por la desautorización que le había hecho el gobierno, a su petición de implantación de arbitrios, base de los ingresos municipales". La Diputación, por mayoría de votos, acordó rechazar la dimisión y al mismo tiempo solicitaba al

1060 "El 20 de septiembre de 1854, entró a examen para alcanzar el grado de bachiller en Filosofía y salió aprobado. En el mismo año 1854 se matricula en la Facultad de Leyes. En 1861, presenta la solicitud para ser examinado del grado de bachiller en Jurisprudencia, para lo cual acompaña los certificados de los cursos probados en los años anteriores. Entró a examen el 15 de junio y salió aprobado. El 30 de septiembre de 1862, solicita ser examinado para alcanzar el grado de licenciado en Leyes y Cánones, y examinado el 3 de octubre, fue declarado aprobado" A.H.U.V.A. Cajas 480 (doc. 403 a 408), 511 (doc. 61 a 63) y 684-19.

1061 RUEDA HERNANZ, Germán. La desamortización... ob. cit. págs. 276 y 282. 
gobierno la anulación de la circular que prohibía los arbitrios. El voto de Gardoqui fue contrario a rechazar la dimisión, por el contrario, su propuesta fue que en la Diputación también debía de presentar la dimisión; él mismo la presentó en ese momento. No hay constancia de que la Diputación admitiera su dimisión, pero la realidad es que no volvió a presentarse en ninguna otra sesión hasta el final de la legislatura en febrero de 1871. En el tiempo que actuó como diputado asistió a cincuenta y una sesiones. El 12 de julio de 1874 es nombrado segundo teniente de Alcalde en el nuevo Ayuntamiento. El 19 de marzo de 1875, vuelve a ser nombrado diputado provincial, por el distrito de Valladolid-Plaza en la primera Diputación de la Restauración, pero dimite el 5 de abril, al ser nombrado alcalde de la capital ${ }^{1062}$. En 1877, al dejar la alcaldía, vuelve a ejercer como diputado provincial hasta el año 1880. En 1883, regresa a la Diputación de la que es nombrado vicepresidente. En 1886 es nombrado vicepresidente de la Comisión provincial y en 1888 es designado presidente de la Diputación

Falleció el 29 de octubre de 1890, siendo presidente de la Corporación.

\section{Garzón San Juan, Domingo}

Natural y vecino de Villalón, pueblo en el que ejerce como escribano y propietario. Su vida profesional viene marcada por su trabajo como escribano, pero sobre todo por su actividad como comprador de numerosas fincas rústicas y urbanas procedentes de bienes desamortizados y bienes nacionales, los cuales a la larga le condujeron a la ruina. "En el año 1840, en la subasta de bienes desamortizados, adquiere el convento de los Dominicos de Villalón. En el año 1847 realiza una serie de compras por 855.000 reales: un molino en Roales sobre el río Cea, 762 parcelas, con un total de 670 hectáreas en Tierra de Campos, seis casas, un molino y un almacén. En el mismo año 1847 compra una finca al testaferro que actúa por amistad, Juan Fernández Alegre, comerciante de Valladolid. En el año 1854 es considerado como uno de los mayores propietarios de la provincia, y abre casa en Valladolid, aunque continúa viviendo en Villalón"1063. Toda esta masiva compra de bienes desamortizados tiene que ser cubierta en parte a través de créditos, con los riesgos y dificultades que ello conlleva, por lo que no es extraño que su nombre aparezca con cierta frecuencia en las relaciones de deudores por compras de fincas nacionales, monasterios y conventos. De esta forma, ya en el año 1847 se le reclama "por tierras y heredades de los términos de Villanueva y Zorita, de las monjas Benitas de Vega de la Serrana por 5/8 partes vencidas, 1.617 reales de vellón. Por cuatro heredades y viñas en los términos de Mayorga, Herrín de Campos, Villanueva y Melgar de Arriba, de las monjas de San Pedro Mártir de Mayorga, frailes Bernardos de Benavides y San Claudín de León y Dominicos de Triano, por un total de 7.544 reales de vellón" ${ }^{1064}$. En el año 1864 adquiere nuevas fincas de bienes nacionales "procedentes del Cabildo de Aguilar de Campos, por 16.610 reales, del Curato de Santa María de Villavicencio, por 141.210 reales, y del Cabildo de la Encarnación de Mayorga por 90.000 reales. En el año 1872 se inicia en el Juzgado de Villalón un pleito "contra los herederos de D. Domingo Garzón San Juan, Rogelio, Arturo, Federico y Julio Garzón Laiz, por la posesión del territorio de Valparaíso en Santervás, a causa de la falta de pago de un censo, que se dejó de pagar a la muerte de Domingo Garzón en 1869 y que viene de escritura fechada en 22 de abril de $1527 " 1065$. Finalmente, en 1873 se anuncia "la venta judicial en pública subasta para el pago de una deuda de 41.600 escudos más réditos y costas de 343 tierras y heredades de D. Domingo Garzón" ${ }^{1066}$. También es un importante accionista del ferrocarril Alar-Santander.

${ }^{1062}$ CARASA SOTO, Pedro. (Dir.). Diccionario Biográfico de Alcaldes... ob. cit. pág.381. PASTRANA MORILLA, Heliodoro. La Diputación provincial... ob. cit. pág. 411.

1063 RUEDA HERNANZ, Germán. La Desamortización... ob. cit. págs. 103-305 y 359.

1064 B.O.P.V. $n^{\circ} 80$ de fecha 6 de julio de 1847.

1065 B.O.P.V. $n^{\circ} 141$ de 17 de septiembre de 1872

1066 B.O.P.V. n ${ }^{\circ} 91$ de fecha 19 de junio de 1873. 
Su actividad política se centra en su actuación como diputado provincial en representación del partido judicial de Villalón. Es elegido diputado por vez primera vez en las elecciones para cubrir los cargos de la sexta Diputación isabelina, tomando posesión y prestando juramento en la sesión de constitución que se celebra el 15 de agosto de 1847. Se mantiene en el cargo hasta el final de la legislatura, que tiene lugar el 30 de marzo de 1850. Asiste a veintitrés sesiones de las cuarenta y cinco que se celebran. Continúa como diputado por Villalón en la siguiente Diputación, la séptima isabelina, que se inicia el 1 de abril de 1850 y ejerce hasta marzo de 1852 , fecha en la que concluye su vigencia, asistiendo a once sesiones de las treinta y dos que se realizan. El día 17 de agosto de 1854 se inician las actividades de la undécima Diputación isabelina, día en el que se presenta el diputado por Villalón, Manuel Gusano, que se mantiene en el puesto hasta diciembre del mismo año, en el que anuncia que "he sido elegido gobernador de la provincia". En consecuencia, se convocan elecciones en el partido de Villalón para cubrir la vacante. El 16 de enero de 1855, en el pleno de la Diputación, se trata el tema de "dar lectura al acta de elección de diputado por Villalón para cubrir la vacante dejada por Manuel Gusano y resultó elegido Domingo Garzón por veintidós votos de treinta y cinco. La elección fue rechazada por la mayoría de los diputados al considerar que el Sr. Garzón es recaudador de contribuciones". La vacante continuó hasta que la controversia fue zanjada por real orden de 15 de junio de 1855, en la que "se declara a Domingo Garzón legalmente electo diputado por el partido de Villalón”. Toma posesión en la sesión que se celebra en julio de 1855 y actúa como tal diputado hasta agosto de 1856, fecha en la que finalizan las actividades de la Diputación, asistiendo a cuarenta y siete de las ciento cuarenta y ocho sesiones celebradas.

En el año 1863 es alcalde de Villalón y es su última actividad pública de carácter político, función que intentó ser continuada por uno de sus hijos, Arturo, licenciado en Derecho, que se presentó a las elecciones para diputado provincial por Villalón en septiembre de 1872 . Pero no las ganó, ya que consiguió 462 votos por los 472 que consiguió el candidato electo Manuel González García. Su hija Marcela se casó con Telesforo Reoyo, presidente de la Diputación, en 1874 y su otra hija Adelaida se casó con Ángel de la Riva Espiga, también diputado provincial en el Sexenio. Fallece en Villalón en el año 1869.

\section{Gavilán de Gavilán, Mariano}

Nació en la ciudad de Toro, provincia de Zamora, en el año 1818. "En el año 1832, ingresó en la Universidad de Salamanca, matriculándose en la Facultad de Filosofía. El 28 de noviembre de 1836, solicita ser examinado para oír facultad de la Universidad de Valladolid, en la que se aprueba su ingreso y se incorporan los cursos probados en la Universidad de Salamanca. El 30 de mayo de 1837 solicita ser examinado para alcanzar el grado de bachiller en Leyes, y realizado el examen el 5 de junio fue aprobado némine discrepante" 1067 .

En política es de tendencia liberal y, en el mes de septiembre de 1872, se presenta a las elecciones para diputado provincial por el distrito de Castronuño, del partido judicial de Nava de la Libertad. Consigue 440 votos contra 381 de su oponente Pascasio García Galán, siendo nombrado, por lo tanto, diputado electo. En la sesión de instalación de la cuarta Diputación del Sexenio, que tiene lugar el 2 de noviembre de 1872, presenta su acta, que es aprobada el día 5. Toma posesión del cargo, ejerciéndolo a lo largo de toda la legislatura, que se da por finalizada en la sesión del 11 de mayo de 1874. Asiste a treinta y cuatro de las cuarenta y dos sesiones que se celebran. Para la quinta y última Diputación del Sexenio es nombrado diputado por el distrito de Castronuño "por la superior autoridad del gobernador civil". Toma posesión en la sesión del 30 de mayo de 1874, y se mantiene hasta el final de la legislatura en marzo de 1875, ya en el período de la Restauración, asistiendo en este 
tiempo a seis sesiones de dieciocho celebradas. Continuará como diputado por Castronuño en la primera Diputación de la Restauración, entre 1875 y 1877.

\section{Guerra Franco, Lucas}

Nació el 17 de octubre de 1819, en Valladolid, hijo de Miguel Guerra y de Lucía Franco. "Ingresó en la Universidad de Valladolid, el 6 de septiembre de 1832, a los 12 años, matriculándose en la Facultad de Medicina. El 20 de junio de 1840, solicitó ser examinado para obtener el grado de bachiller en Medicina, en 1858 alcanzó la licenciatura y en 1869 el grado de doctor ${ }^{1068}$. En el año 1858, pasó a trabajar en el Hospital de Dementes, en el que desarrolló la mayor parte de su vida profesional y en el que alcanzó el puesto de director.

El 1 de octubre de 1868 es elegido miembro de la Junta Revolucionaria de Valladolid, y forma parte de la Comisión Especial que sustituye a la disuelta Diputación en los primeros días del Sexenio. En la única sesión de trabajo que celebra la Comisión, actúa de presidente. El 21 de octubre del mismo año 1868, se celebra la sesión de instalación de la primera Diputación del Sexenio, cuyos miembros están nombrados por la Junta Revolucionaria y en la que Lucas Guerra es el diputado progresista en representación del distrito de Valladolid-Plaza. En la sesión del 24 de noviembre "el diputado por Valladolid-Plaza D. Lucas Guerra, presenta la dimisión, al ser el director del Hospital de Dementes, y según el decreto de 12 de noviembre, no puede ejercer el cargo por recibir su sueldo del Estado". La petición de dimisión es rechazada por mayoría de los diputados que consideraban que "el sueldo del $\mathrm{Sr}$. Guerra no procede del Estado". Los de parecer contrario, con el diputado por Olmedo, Niceto Sanz, a la cabeza, vuelven a pedir su dimisión "por ser incompatible con su cargo de director del Hospital de Dementes". La Diputación no aclara si acepta o no su dimisión, pero lo cierto es que ya no vuelve a estar presente en las sesiones y sólo asistió a las diez primeras que celebró la Diputación. No vuelve a aparecer en ningún otro tipo de cargo político. El 23 de noviembre de 1872, es nombrado director económico, además de facultativo del Hospital de Dementes.

\section{Girón y Rodríguez, Laureano}

Natural y vecino de Rioseco, ciudad en la que inició sus estudios, para pasar posteriormente a la Universidad de Valladolid en cuya Facultad de Derecho se matriculó, alcanzando el grado de licenciado en Leyes en junio de 1820. Una vez acabados los estudios, se establece en Rioseco como procurador, llegando a actuar en 1845 como juez de Primera Instancia con carácter interino en ausencia del titular. Simultanea este trabajo con la administración de sus bienes, que se estimaban de cierta importancia, ya que las referencias que se tienen con respecto a su posición económica así lo indican. En el año 1860 es el trigésimo quinto mayor contribuyente de la provincia con 4.501 reales, según publica el Boletín Oficial de la Provincia de 20 de enero de 1860. En el año 1861 aparece como el trigésimo tercer mayor contribuyente, con una renta de 4.272 reales, según el mismo Boletín Oficial de 4 de octubre de 1861.

En el año 1835 el Consejo de Disciplina del batallón de la Milicia Nacional de Rioseco al que pertenece, ante la apertura de un expediente contra el alcalde José Pizarro y el procurador Laureano Girón, "manifestaba que no resultaban en el Consejo datos de desafección al gobierno de parte de D. Laureano Girón y que se verá, por el contrario, que era sargento de la Guardia Nacional, individuo del Consejo de

1068 “examinado los días 22 y 28 de junio, salió aprobado némine discrepante. En el año 1858, solicita el acceso al grado de licenciado en Cirugía, siendo como es licenciado en Medicina, y habiendo cursado el único año de Cirugía que determina el R.D. de 10 de diciembre de 1857 y celebrados los ejercicios los días 9 y 10 de septiembre fue aprobado por unanimidad. El 26 de agosto de 1869 solicita el grado de doctor en Medicina" A.H.U.V.A. Cajas 524 (doc. 529 a 537), 582 (doc. 231 a 234) y 587-298. 
Administración y Disciplina y propuesto en primer lugar para comandante..." ${ }^{1069}$. Es de ideología liberal.

En el año 1845 da comienzo a su actividad política al ejercer como alcalde de Rioseco. En el año 1847, el día 15 de agosto, en la sesión de instalación de la sexta Diputación isabelina, tomó posesión y prestó juramento como diputado provincial por el partido de Rioseco. En la misma sesión es nombrado miembro de la comisión de Enajenación de Bienes Nacionales. Ejerció el cargo hasta el final de la legislatura en marzo de 1850, asistiendo a cuarenta y una de las cuarenta y cinco sesiones celebradas. En la siguiente Diputación, la séptima isabelina que inicia sus actividades el 1 de abril de 1850 , continúa como diputado por el mismo partido, hasta el final de la legislatura en marzo de 1852, estando presente en diecisiete de las treinta y dos sesiones que se celebran. No vuelve a desempeñar ningún otro cargo político.

\section{Gómez de Rozas, Pedro}

Rentista y rico propietario de Tordesillas, pueblo en el que vive habitualmente, aunque tiene "casa abierta" en Madrid. Compró una importante cantidad de fincas desamortizadas. Entre 1820 y 1823, compró una finca de 47 hectáreas. Entre 1840 y 1843 compró 407 hectáreas en fincas desamortizadas en Campiña del Pisuerga, Tierra de Pinares y Montes Torozos. Pertenece a la Asociación de Propietarios Territoriales de España ${ }^{1070}$.

El 25 de octubre de 1840, vigente la tercera Diputación isabelina, es nombrado, por la Junta Provisional de Gobierno de la Provincia, diputado provincial por el partido de La Mota del Marqués en sustitución de Pelayo Cabeza de Vaca, que había sido elegido diputado a Cortes. Tomó posesión del cargo el mismo día y permanece hasta el 7 de diciembre, fecha en que se cierra la legislatura en la que asiste a las cinco sesiones que se celebran. Su presencia en la política es breve, ya que no vuelve a aparecer su candidatura en ninguna otra elección. Su hijo Pedro también se dedicará a la política provincial, al ser nombrado diputado en el año 1875.

\section{Gómez de Rozas Reynero, Pedro}

Natural y vecino de Tordesillas, posee un gran patrimonio, procedente en su mayoría de las compras de bienes desamortizados, tanto en Tierra de Pinares como en Montes Torozos, que realizó su padre Pedro Gómez de Rozas, que también fue diputado en la tercera Diputación isabelina entre 1837 y 1840 . Se estrena en política cuando, el 22 de enero de 1875, a finales de la quinta Diputación del Sexenio, el gobernador civil le nombra diputado por el distrito y partido de Tordesillas, en sustitución del cesado Marcelino Diez Bueno. Es la única sesión a la que asiste, ya que en la misma sesión y con posterioridad al nombramiento de diputados se dio por cerrado el período de sesiones.

En la primera Diputación de la Restauración, que se inicia el 19 de marzo de 1875, es nombrado diputado por su distrito de Tordesillas y continúa en sucesivas Diputaciones hasta el año 1881, en que es derrotado en las elecciones por Higinio Lajo. En 1905 es elegido alcalde de Tordesillas. Fallece en Madrid el 7 de abril de 1913.

\section{Gómez Villavedón, Luis}

Vecino y propietario en Nava del Rey. De ideas liberales, en el año 1834 es alférez de Caballería de la Milicia Urbana de La Nava y comandante de su sección de Caballería. Con la instalación de la primera Diputación isabelina el 22 de octubre de 1835, es elegido diputado provincial por La Nava del Rey, permaneciendo en el cargo hasta el final de la legislatura en octubre de 1836. Asiste en este tiempo a noventa y siete sesiones y es nombrado miembro de la comisión de "Búsqueda de Casa y de

1069 A.D.P.V. Actas. Libro de actas del 11 de diciembre de 1835

1070 RUEDA HERNANZ, Germán. La Desamortización... ob. cit. pág. 296. 
Efectos" y de la comisión de "Armamento y Defensa". En el año 1850 aparece como alcalde de Nava del Rey, no volviendo a tener ningún otro cargo político. Su hermano Bonifacio, en el año 1856, es alcalde de La Nava "al que se le concede el nombramiento de Caballero de la Orden de Isabel La Católica por sus trabajos para erradicar el cólera morbo".

\section{González, Baltasar}

Vecino y agricultor de Alaejos, es elegido diputado provincial por el partido de Nava del Rey en la cuarta Diputación de la era isabelina. Toma posesión de su escaño en la sesión de instalación que se celebra el 1 de enero de 1841 y permanece en el cargo hasta octubre de 1843, es decir, durante toda la legislatura, asistiendo a ciento ochenta y cinco de las doscientas treinta y ocho sesiones que se celebran. En este período es nombrado miembro de las comisiones de Presidios y de Estadística. Como diputado-decano, presidió las sesiones de la Diputación en noventa ocasiones ante las numerosas ausencias tanto del jefe político como del intendente. No hay referencias para saber por qué no fue convocado para la Diputación que se instaló en principios del Bienio Progresista en el año 1854 y que le correspondía por haber pertenecido en 1843 ,aunque pudo estar motivado por causas de enfermedad o posible fallecimiento, ya que no podemos olvidar que en 1843 era el decano.

\section{González, Facundo}

Nace en el año 1803 en el pueblo de Villalón, "diócesis de León". Inició los estudios de primeras letras en su pueblo natal y los continuó en el colegio Santo Tomás de Madrid entre los años 1818 y 1820 y en el colegio de Aragón en 1821. En noviembre de 1822 solicita su ingreso en la Facultad en Leyes de la Universidad de Valladolid, donde continúa sus estudios hasta el año 1825, en cuyo mes de septiembre solicita "ser examinado para conseguir el grado de bachiller en Leyes, siendo aprobado por unanimidad" 1071 . Ejerce la profesión de abogado en Villalón, por cuyo partido es elegido diputado provincial en las elecciones que se celebran en el mes de octubre de 1836, para la segunda Diputación isabelina, "presentándose en la sesión del día 9 de noviembre donde juró y tomó posesión del cargo". Se mantiene en el mismo durante toda la legislatura, que finaliza en diciembre de 1837 , asistiendo a un total de treinta y tres sesiones. No se le vuelve a conocer ejerciendo cargo político alguno.

\section{González García, Manuel}

Natural y vecino de Cuenca de Campos. Bachiller en Leyes por la Universidad de Valladolid ${ }^{1072}$. Su actividad política se inicia en las elecciones que se celebran en febrero de 1871, para cubrir las vacantes de la tercera Diputación del Sexenio, donde es elegido por el distrito de Villalón Ángel de la Riva Espiga. Pero en la sesión de instalación celebrada el 17 de febrero, es rechazada su acta, ordenando la Diputación la repetición de las elecciones. Se celebran entre el 29 y el 31 de agosto y en ellas es elegido diputado Manuel González García. El 6 de noviembre de 1871 se presenta con el acta en la sesión de la Diputación y, una vez aprobada, toma posesión como nuevo diputado por Villalón. Asiste hasta el final de la legislatura en octubre de 1872 a las veintidós sesiones que se celebran. En la sesión del 25 de julio de 1872, se celebra el sorteo para conocer los diputados que debían de continuar en el cargo, y a él le tocó cesar. Al verse cesante se decide presentar como candidato por Villalón a las elecciones que se celebran en septiembre de 1872 para la cuarta Diputación del Sexenio, siendo elegido por 472 votos contra 462, que consiguió su oponente Arturo Garzón Laiz, hijo de Domingo Garzón, que fue diputado en 1854-1856. Se aprueba su

1071 A.H.U.V.A. Cajas 449 (doc. 288 a 294) y 569.

1072 "Inició sus estudios en la Universidad de Valladolid en el año 1832, en el que se matriculó en la Facultad de Leyes. El 18 de agosto de 1836, solicita ser examinado para alcanzar el grado de bachiller en Leyes, acompañando los certificados de los cursos probados, y realizado el examen el día 22, a claustro pleno, fue aprobado némine discrepante" A.H.U.V.A. Caja 463 (doc. 485 a 492 ). 
acta y se presenta en la sesión del día 4 de noviembre de 1872, manteniéndose en el cargo hasta el 11 de mayo de 1874, día en que se celebra la última sesión de la legislatura. En ella es cesado por orden del gobernador civil, siendo sustituido por Francisco Reoyo.Asiste a once de las cuarenta y dos sesiones de la legislatura, No vuelve a presentarse como candidato a ninguna otra elección.

\section{González Perotes, José Antonio}

Hacendado de Peñafiel, es elegido diputado provincial por este partido en las elecciones celebradas el 30 de agosto de 1813 , en el arranque de la primera Diputación. Asiste a las primeras seis sesiones que se celebran y después no vuelve a aparecer por la Corporación. Como todos los primeros diputados es de ideas liberales. En el año 1820, con la nueva puesta en marcha de la Diputación, vuelve a ser nombrado diputado provincial por su partido de Peñafiel, y toma posesión en la sesión de instalación que se celebra el 21 de marzo. Se mantiene en el escaño hasta el día 5 de junio del mismo año de 1820. Asiste a ocho sesiones de las treinta y cuatro que celebra la Diputación. En las elecciones celebradas el 22 de mayo de 1820, para cubrir los siete puestos de diputado provincial, se presenta y es elegido nuevamente, continuando con la representación del partido de Peñafiel. En esta legislatura asiste a sesenta y una de las ciento setenta y tres sesiones que celebra la Diputación entre los días 7 de junio de 1820 al 28 de febrero de 1822. Es miembro de la Milicia Urbana. En la tercera y última legislatura del período del Trienio vuelve a ser elegido diputado por Peñafiel. En esta legislatura, que se extiende entre el 1 de marzo de 1822 hasta el 26 de abril de 1823, asiste a sesenta y tres plenos de la Diputación de los ciento cincuenta y siete que se celebran. Destaca por su espíritu liberal y poco acomodaticio, pues es prácticamente el único diputado que disiente en los plenos de la institución. Destacó con su voto a favor de la abolición de diezmos o por su petición de ampliación de la Secretaría provincial. En 1836 (B.O.P. 122 de 4/10/36) es elector de la provincia para las elecciones de procuradores a Cortes.

Con la llegada de la Década Ominosa y la desaparición de la Diputación, no se vuelven a tener más noticias sobre su actividad política hasta el año 1837, cuando el 26 de diciembre se celebra el acto de constitución de la tercera Diputación de la época isabelina en la que vuelve a ser elegido diputado provincial por el mismo partido de Peñafiel, aunque en estos años ya reside en Valladolid. En esta legislatura, que se prolonga hasta el 31 de diciembre de 1840, asiste a doscientas dieciséis sesiones de las doscientas veintitrés que se celebran, dato que llama la atención, puesto que en las primeras legislaturas tanto en la Constitucional como en el Trienio apenas asistió a las sesiones. Su residencia en la capital le facilitó la asistencia a los actos de la Diputación.

\section{González Rodríguez, Alonso}

Natural y vecino de La Puebla de Sanabria. Hacendado y proveedor de suministros al Ejército. Luchó en la defensa de Puebla de Sanabria ante el asedio del Ejército francés. Tuvo que huir a las montañas cuando las tropas napoleónicas entraron en La Puebla y sufrió la incautación de sus bienes. Su conocimiento del territorio facilitó el movimiento de las tropas portuguesas a través de la frontera.

Su carrera política de clara ideología liberal, se inicia en 1813 con la liberación de su localidad y su presentación como candidato, en las primeras elecciones que se realizan con la nueva Constitución el 24 de agosto, en las que fue elegido diputado a Cortes, estando presente en la primera sesión que se celebró en Madrid. Una vez finalizada la legislatura, fijó su residencia en la Corte al conseguir un puesto de funcionario en la Secretaría de Hacienda. En el año 1816 se jubiló y se volvió a su localidad natal ${ }^{1073}$. Retomó sus actividades políticas cuando se presentó y resultó elegido diputado provincial por el partido de La Puebla de Sanabria, a la sazón,

\footnotetext{
${ }^{1073}$ CARASA SOTO, Pedro. (Dir.). Diccionario biográfico de parlamentarios ... ob. cit. pág. 489.
} 
perteneciente a la provincia de Valladolid, en la segunda Diputación del Trienio. Toma posesión de su cargo el 7 de junio de 1820, en el que permanece hasta el final de la legislatura el 28 de febrero de 1822. Es un hombre asiduo a la presencia en la Diputación, puesto que asiste a ciento veintisiete de las ciento setenta y tres sesiones que se celebran. Fallece en Puebla de Sanabria el 30 de noviembre de 1823.

\section{Gusano, Manuel}

Natural y vecino de Villalón, villa en la que nació en el año 1814. Inició los estudios primarios en su pueblo natal, pasando posteriormente a Valladolid, en cuya Universidad inició los estudios superiores. "Con fecha 6 de junio de 1836 se presentó a examen público para obtener el grado de bachiller en Leyes, siendo aprobado némine discrepante. En el año 1839 alcanzó el grado de licenciado en Leyes por la Universidad de Madrid, en la que había continuado los estudios. En noviembre del mismo año 1839 presenta en la Universidad de Valladolid una solicitud para alcanzar el grado de licenciado por esta Universidad, para lo cual aduce el título de licenciado otorgado por la Universidad de Madrid. Se le concede y se incorpora a esta Universidad el 20 de diciembre de 1839" ${ }^{1074}$. Alcanza el título de doctor en Jurisprudencia. Es caballero de la Real Orden de Carlos III y académico de la Real Academia de Bellas Artes de Valladolid. En el año 1836, cuando todavía era estudiante, pertenece a la Guardia Nacional en Villalón con el cargo de capitán. A partir de 1839, ejerce la abogacía en Villalón, y a la vez se ocupa de la explotación de sus propiedades agrícolas, pues está considerado como un importante propietario en la comarca de Tierra de Campos. Sin embargo, apenas invirtió en la compra de bienes y fincas desamortizadas, puesto que sólo se le conoce la compra de una pequeña finca de una hectárea en Villalón. Es también un importante accionista del ferrocarril AlarSantander.

En política está considerado como uno de los pioneros del progresismo en Villalón, y su carrera está centrada en la Diputación Provincial, de la que es elegido diputado por vez primera en la cuarta Diputación isabelina. Toma posesión el día 1 de enero de 1841 y se mantiene en el cargo hasta el 30 de julio de 1843, fecha en la que es cesado por orden de la Junta Provisional del Gobierno de la Provincia, institución que se formó a raíz de la dimisión de Espartero. En el tiempo en que actuó como diputado asistió a ciento ochenta y nueve sesiones, perteneciendo a las comisiones de Instrucción Pública y Suministros. Es elegido diputado provincial en la siguiente Diputación, la quinta del período isabelino, también por el partido de Villalón, tomando posesión en la sesión de instalación que se celebra el 1 de noviembre de 1843. Se mantiene en el cargo hasta junio de 1847, y asiste a ciento noventa y nueve sesiones de las doscientas cuarenta que se celebran. En este período y de acuerdo con la Ley de Ordenación Provincial aprobada el 8 de enero de 1845, es nombrado vicesecretario de la Corporación en el año 1845, y secretario en 1846. También es nombrado miembro de las comisiones de Culto y Clero, de Gobierno Interior y de Estudio de Construcción de Puentes y Caminos Transversales.

En los inicios del Bienio Progresista es nuevamente nombrado diputado provincial en la primera Diputación del Bienio y décima de la época isabelina, por la Junta Provisional del Gobierno de la Provincia y continúa representando al partido de Villalón. Toma posesión en la sesión de instalación que se celebra 20 de julio de 1854 y permanece en el cargo hasta el 14 de agosto, fecha en la que se da por finalizada su actividad. Tiene una vigencia de 15 días en las que se celebran quince sesiones, una por día, de las cuales asiste a ocho. El 17 de agosto de 1854, fecha de inicio de actividades de la nueva Diputación, segunda del Bienio y undécima del periodo isabelino, continúa de diputado, representando al partido de Villalón, "porque era diputado en el año 1843". Se mantiene en el cargo hasta el mes de diciembre del mismo año 1854, asistiendo a veintiuna sesiones en este tiempo. El 26 de diciembre de

1074 A.H.U.V.A. Cajas 462 (doc. 124 a 132) y 669 (doc. 47). 
1854, comunica a la provincia "que ha sido nombrado gobernador civil de la provincia en comisión" por lo que ejerce como trigésimo octavo presidente de la Diputación, cargo que ocupa hasta agosto de 1855. En esta fecha, por real decreto del día 9, la Reina "en conformidad con lo propuesto por mi Consejo de Ministros, declara cesante a D. Manuel Gusano, gobernador en comisión de Valladolid". En este tiempo preside cuarenta y cinco sesiones de la Diputación.

\section{Gutiérrez Barquín, Manuel}

Natural de Espinosa de los Monteros, de la provincia de Burgos. Siendo niño se trasladó con su familia a vivir a Valladolid. Sus hermanos Vicente y Tomás cursaron la carrera de Leyes en la Universidad de Valladolid, pero de él no se conocen estudios.

El día 1 de octubre de 1868 es elegido miembro de la Junta Revolucionaria de Valladolid, y se mantiene en la misma, hasta su disolución acordada el día 30 del mismo mes. El 7 de noviembre es nombrado vocal de la Junta de Instrucción Pública. Es elegido diputado provincial por el distrito de Valladolid-San Nicolás en las elecciones que se celebran entre los días 1 a 3 de febrero de 1871, para cubrir las vacantes de la tercera Diputación del Sexenio. Se presenta en la sesión de instalación que tiene lugar el 17 del mismo mes y en ella es nombrado vocal de la segunda comisión de Actas.

Es uno de los diputados más progresistas de la Corporación. Son notorios sus enfrentamientos con el gobernador Oller y Cánovas, motivados por la intromisión de éste en temas específicos de la Diputación. "El gobernador veta el nombramiento de un diputado para la Comisión permanente y su actitud es recriminada por el diputado Barquín". Aunque el enfrentamiento más molesto se produce en la sesión del día 19 de abril de 1872, cuando "el Sr. Barquín solicita hacer uso de la palabra, y el Sr. gobernador le pregunta que para qué. El Sr. Barquín le contestó que cuando le concediera la palabra se lo diría. El Sr. gobernador le negó el uso de la palabra y levantó la sesión". A los dos días de este enfrentamiento, el gobernador anuncia su dimisión. En el mes de abril es nombrado vocal de la Junta de Beneficencia, y en julio de 1872, en el sorteo celebrado en la sesión del día 22, le correspondió continuar como diputado. Asistió en esta legislatura que finaliza en octubre de 1872 a cincuenta y una de las setenta sesiones celebradas. El 2 de noviembre de 1872, se presenta en la sesión de instalación de la cuarta Diputación del Sexenio, para continuar como diputado en representación del distrito de San Nicolás de Valladolid. En la sesión del día 8, es nombrado miembro de la Comisión permanente, cargo que ocupa el día 13, fecha en la que se inician sus actividades. En el mes de febrero de 1874 presenta su dimisión tanto en la Comisión como en la Diputación, al haber sido nombrado gobernador civil de Pontevedra. En el tiempo en que ejerció como diputado asistió a veintitrés sesiones de la Diputación y a ciento nueve de la Comisión permanente.

\section{Gutiérrez-Cañas Gutiérrez, Demetrio}

Nació en Zaratán, provincia de Valladolid, el 22 de diciembre de 1833, hijo del tercer matrimonio de Domingo Gutiérrez-Cañas, natural de Reinosa y de María Gutiérrez, vecina de Zaratán.

"Ingresó en la Universidad de Valladolid en el año 1845, donde obtiene el grado de bachiller en Filosofía y de licenciado en Jurisprudencia. En el año 1858, alcanza el grado de licenciado en Jurisprudencia por la Uni versidad de Madrid. En el año 1867 es investido con el grado de licenciado en Derecho Administrativo en examen celebrado en la Universidad de Valladolid el día 14 de junio" ${ }^{1075}$. En el año

1075 El 25 de junio de 1849, solicita al Sr. rector, ser examinado para acceder al grado de bachiller en Filosofía, acompañando los certificados de las notas probadas en los 5 años de la $2^{a}$ Enseñanza de 1845 a 1849. Entró a examen el 28 de junio y salió aprobado. Se matricula en la Facultad de Leyes. El 8 de junio de 1855 solicita ser examinado para alcanzar el grado de bachiller en Jurisprudencia y examinado el día 11 resultó aprobado por unanimidad. El 2 de junio de 1857 
1866 es abogado de los Tribunales Nacionales, juez de paz del distrito de la Audiencia de Valladolid, y juez de Primera Instancia accidental. Es nombrado catedrático de Derecho Civil en la Universidad de Valladolid, pasando entre 1873 y 1875 a las Universidades de Santiago de Compostela y Salamanca, también como catedrático en la Facultad de Leyes. En 1876 vuelve a la Universidad de Valladolid, a su Cátedra de Derecho Civil, en la que ejerce la enseñanza hasta el año 1893 en que pasa como catedrático a la Universidad de Zaragoza.

Su actividad política comienza cuando en las elecciones a diputado provincial celebradas los días 1, 2 y 3 de febrero de 1871, para la tercera Diputación del Sexenio, sale como diputado electo por el distrito de Valladolid-San Martín. El día 17 del mismo mes y año, presenta su acta que es aprobada el día 26. En la sesión del 15 de marzo, es nombrado diputado-secretario, cargo que mantiene a lo largo de la legislatura. El 29 de noviembre de 1871 solicita autorización para trasladarse a Madrid "por motivos literarios". En el sorteo que se celebra en la sesión del 25 de julio de 1872 , le correspondió cesar en el cargo, el cual abandona al final de la legislatura que tiene lugar en octubre de 1872, habiendo asistido a cincuenta y cinco sesiones de las setenta celebradas, y no tiene más intervenciones en política.

\section{Guzmán Lucas, Liborio}

Natural de Tordesillas, villa en la que nació el 18 de mayo de 1816, hijo de Ramón Guzmán y de Victoria Lucas. "Ingresó en la Universidad de Valladolid el 10 de diciembre de 1831, matriculándose en la Facultad de Filosofía. El 4 de junio de 1834, solicitó ser admitido a examen para alcanzar el grado de bachiller en Filosofía, y examinado el día 7, salió aprobado" ${ }^{1076}$.

Contrajo matrimonio con Modesta Andrés, vecina de Cantalpino. Ejerció en su pueblo natal la profesión de farmacéutico, hasta que en el año 1858, se trasladó a Valladolid, donde abrió una oficina de farmacia en la Acera de San Francisco. Al mismo tiempo que ejercía en la farmacia, también se dedicaba a la política, siendo uno de los directivos del partido progresista en Valladolid.

Su actividad política se inicia en octubre de 1868, al ser nombrado vicepresidente de la Junta Revolucionaria que se formó en los primeros días del Sexenio. En 1869, con ocasión de la puesta en marcha de la segunda Diputación del Sexenio, es nombrado diputado provincial por el partido de La Nava de la Libertad por el capitán general "por hallarse declarado el territorio en estado de guerra". Toma posesión del cargo en la sesión de instalación que se celebra el 18 de octubre. En el mes de noviembre, y siendo diputado provincial, el mismo capitán general le nombra alcalde de Valladolid, nombramiento que fue cuestionado por la mayoría de los diputados al considerar incompatible el mantenimiento de los dos cargos. Con el argumento de que había sido nombrado por "una autoridad superior" se mantuvo con las dos actividades hasta el 16 de enero de 1870, fecha en la que abandonó la alcaldía. Comisionado por la Diputación para tratar el tema de los funcionarios de la Secretaría, el 3 de diciembre de 1869 presenta al pleno un dictamen "declarando cesantes a todos los empleados de la Secretaría que cobran sueldo, excepto al secretario, y que continúen como interinos hasta que se realice una nueva plantilla". Se aprobó su dictamen por cinco votos a favor y cuatro en contra, aunque se tuvo que anular con posterioridad "ante la pérdida de efectividad en los trabajos de la Secretaría". Es nombrado vocal de la Junta de Beneficencia y también es comisionado para la búsqueda de una sede para la Diputación. Finalizada la legislatura en febrero de 1871, no volvió a presentarse como diputado, asistiendo en este tiempo a ochenta y seis de las ciento veintisiete sesiones que se celebraron.

solicita optar al grado de licenciado en Jurisprudencia, presentando los certificados de los cursos probados. Examinado los días 10, 13 y 17, resultó aprobado, confirmando la investidura en el claustro del día 25. A.H.U.V.A. cajas 477 (doc. 80 y 81), 508 (doc. 326 a 330), 679-82, 687-13 y 352-1.

1076 A.H.U.V.A. Caja 503 (doc. 296 a 299). 
Se presenta como candidato al Congreso por el distrito de La Nava, en las elecciones de agosto de 1872 y resulta elegido. Finalizada la legislatura, se volvió a presentar, en esta ocasión bajo las siglas del partido republicano, aunque no logró ser relegido, por lo que optó por retirarse de la política, hasta que en 1880 volvió en un intento de reorganizar el republicanismo en Valladolid ${ }^{1077}$.

\section{Haro, Bernardino de}

Vecino de Villalpando, es elegido diputado provincial por su partido judicial en la Diputación de Zamora. Pero con la modificación territorial contemplada en la "ley de 22 de enero de 1822", esta localidad y su entorno pasan a pertenecer a la provincia de Valladolid, con lo cual le correspondía un asiento en su Diputación. El Sr. Haro, en oficio remitido a la Diputación, solicita "ser liberado de su asistencia por su absoluta imposibilidad de presentarse por encontrarse enfermo y en cuya consideración ya había pedido su absoluta exoneración al Congreso Nacional" ${ }^{1078}$. Petición a la que accedió la Diputación, por lo cual no llegó a tomar posesión de su escaño.

\section{Herrero López, Miguel}

Es natural de Villamuriel de Campos, en la provincia de Palencia, nacido el 8 de mayo de 1812, hijo de Juan Bautista Herrero y de Celedonia López. Se trasladó a vivir a Valladolid en los inicios de 1840, ciudad en la que desarrolló su vida profesional al mismo tiempo que en la localidad de Tordehumos, villa en la que tenía grandes propiedades. No hay constancia de su paso por la Universidad. Propietario, fabricante y comerciante, es uno de los más importantes empresarios vallisoletanos, que protagonizan el auge económico de la ciudad. Ya en el año 1836 destacaba por ser uno de los más importantes compradores de bienes desamortizados de la provincia, tanto en su nombre y también como testaferro de otros compradores. "Entre 1836 y 1848 compró 1.709 hectáreas en Tierra de Pinares, Tierra de Medina y Montes Torozos, por los que pagó 2.733.000 reales. Compró igualmente cuatro casas y un convento en Valladolid, Montes Torozos y Tierra de Campos por los que pagó 108.000 reales. Actúa de testaferro en otras varias subastas. Propietario de una agencia dedicada a la compra de bienes nacionales en la que asesora a treinta y dos clientes en la compra de fincas. Junto a Blas López Morales, son los dos principales compradores de bienes desamortizados de la provincia" ${ }^{1079}$. Es accionista del ferrocarril AlarSantander. Industrial harinero, montó una fábrica de harinas en Tordehumos, y posteriormente construyó otra en Valladolid, bajo la denominación de "Hijos de Herrero López".

Se casó con Andrea Olea San Julián, con quien tuvo dos hijos, Sabino y Juan, que fueron ambos diputados en el Congreso en el Sexenio y en la Restauración. Además, Sabino fue el primer director del periódico El Norte de Castilla ${ }^{1080}$. En 1855 es el mayor contribuyente por territorial de Rioseco con 10.333 reales de renta anual. En 1860 es el undécimo mayor contribuyente de la provincia con 9.469 reales de cuota anual. En 1861 es el séptimo mayor contribuyente por propiedad rural y pecuaria con 10.714 reales y el trigésimo quinto por industria con 933 reales. En 1863 es el quinto mayor contribuyente por propiedad rural y pecuaria con 10.947 reales, por sus propiedades en Tordehumos. En 1871 es el sexto mayor contribuyente por territorial con 4.595 pesetas. En 1872 es el tercer mayor contribuyente con una cuota de 5.935 pesetas y propiedades en Tordehumos, Villabrágima y Valladolid. En 1873 es el primer contribuyente de la provincia por propiedad territorial e industrial.

1077 CARASA SOTO, Pedro. (Dir.). Diccionario biográfico de parlamentarios... ob. cit. pág. 520. CARASA SOTO, Pedro. (Dir.). Diccionario biográfico de Alcaldes ... ob. cit. pág.426.

1078 A.D.P.V. Actas. Libro de actas del 23 de mayo de 1822

1079 RUEDA HERNANZ, Germán. La desamortización... ob. cit. págs. 258, 261 y 325.

1080 Sabino Herrero Olea, director de El Norte de Castilla, es abogado, propietario, vocal de la Mutua Hispano Portuguesa de Seguros, y fundador de la Sociedad de Crédito Mutuo. 
En política pertenece al partido progresista. En el año 1843 "comunicó a la Diputación su nombramiento como diputado a Cortes, y ofreciéndola sus servicios" ${ }^{1081}$, aunque ya había sido suplente en 1841. En el año 1856, coincidiendo con el final del Bienio Progresista, el capitán general de Castilla la Vieja, Joaquín Armero y Peñaranda, le nombra diputado provincial por el partido de Valladolid, en la duodécima diputación isabelina. En la sesión de instalación que se celebra el 19 de agosto presta juramento y toma posesión de su cargo. En la misma sesión es nombrado vocal de la comisión de Venta de Bienes Nacionales y miembro de la comisión de Cuentas. En noviembre de 1856 se da por finalizada la legislatura, en la que asiste a treinta y una de las cincuenta y tres sesiones que se celebran y no vuelve a ser diputado. Es elegido senador en las elecciones celebradas en los años 1871 y 1872. Fallece en Madrid el 2 de mayo de 1893.

\section{Ibáñez Martín, Miguel}

Nació en Tudela de Duero el 7 de mayo de 1832 y bautizado el día 9 se le impusieron los nombres de Miguel Estanislao. Hijo de Mariano Ibáñez y de Luisa Martín. Ingresó en la Universidad de Valladolid en el año 1848, donde consiguió ser bachiller en Filosofía, licenciado en Leyes y en Administración ${ }^{1082}$. Se establece en Valladolid donde ejerce la abogacía.

Se presenta a las elecciones para la tercera Diputación del Sexenio que se celebran los días 1, 2 y 3 de febrero de 1871, por el distrito de San Pedro, quinto de los de la capital, y resultó elegido. En la sesión de instalación que se celebra el 17 de febrero presenta su acta de elección, que es aprobada al día siguiente y toma posesión del cargo. Es nombrado miembro de la comisión de Actas y también miembro de la Comisión provincial, a la que se incorpora el 25 del mismo mes de febrero fecha de inicio de las actividades, hasta el 10 de abril de 1872 fecha en la que se renuevan los vocales, asistiendo en este tiempo a ciento doce sesiones. En la Diputación se mantiene hasta el final de la legislatura en octubre de 1872. Es un diputado asiduo pues asistió a sesenta y siete de las setenta sesiones que se celebraron. En el sorteo celebrado el 25 de julio de 1872, le correspondió continuar en la Diputación. El 2 de noviembre de 1872, día en el que se inician las actividades de la cuarta Diputación del Sexenio vuelve a presentarse para continuar como diputado por el distrito de San Pedro de la capital. Al establecerse el día 7 la Diputación definitiva, es nombrado diputado-secretario cargo que ocupa a lo largo de toda la legislatura que se da por finalizada en mayo de 1874. En este tiempo asistió a treinta y una de las cuarenta y dos sesiones. Vuelve a ser elegido diputado en la quinta Diputación del Sexenio "en virtud de la autoridad concedida al Sr. gobernador", asistiendo a la sesión de instalación que se efectúa el 30 de mayo de 1874 y continúa representando al distrito de San Pedro. En la misma sesión es nombrado secretario interino y sorpresivamente al día siguiente presenta la dimisión, que es rechazada por la Diputación, pero que no es obstáculo para que no vuelva a estar presente en las sesiones. El 22 de enero de 1874, ya en los inicios de la Restauración, es cesado por el gobernador. No vuelve a ejercer como diputado.

1081 CARASA SOTO, Pedro (Dir.). Diccionario biográfico de parlament5atrios... ob. cit. pág. 536. A.D.P.V. Actas. Libro de actas del 15 de noviembre de 1843.

1082 En la Facultad de Filosofía, el 3 de junio de 1854 solicitó ser examinado para alcanzar el grado de bachiller en Filosofía. Entró a examen el día 16, y salió aprobado por unanimidad. En el mismo año 1854 se matriculó en la Facultad de Leyes. El 13 de junio de 1860, solicita ser examinado para alcanzar el grado de bachiller en Leyes presentando los certificados de los cursos probados entre 1855 y 1860. Examinado el día 15, salió aprobado. En el año 1861, solicita ser examinado para alcanzar el grado de licenciado en Leyes y Cánones, y celebrado el examen el 19 de junio fue declarado aprobado. El 10 de junio de 1862 presenta la solicitud para acceder al título de licenciado en Administración, siendo aprobado en el examen realizado el día 17 del citado mes" A.H.U.V.A. Cajas 479 (doc. 445 a 450), 480 (doc. 59 a 64), 511 (doc. 247 y 248), 684-63 y 684-111. 


\section{Izquierdo, Venancio}

En el año 1867, está avecindado en Valladolid, siendo el vigésimo sexto mayor contribuyente de la provincia por contribución territorial. En el año 1869, se inicia en la política al ser elegido alcalde de Villabrágima, cargo que desempeña también en los años 1870 y 1871. Se presenta a las elecciones de la cuarta Diputación del Sexenio, que se celebran en septiembre de 1872 y sale elegido diputado provincial por el distrito de Villabrágima, del partido judicial de Rioseco, con 684 votos contra los 516 que consiguió su oponente Juventino Cebrián. En la sesión de instalación, que tiene lugar el 2 de noviembre de 1872, presenta su acta de diputado, que es aprobada en la sesión del día 3 "a pesar de las reclamaciones que tiene contra su gestión y las deudas en el cargo como alcalde en los años 1869 a 1871 ”. Permanece en el cargo hasta el 11 de mayo de 1874, en cuya sesión de la Diputación se da lectura al "oficio del gobernador interino de fecha 27 de abril de 1874, por el que se le releva del cargo de diputado provincial por el distrito de Villabrágima". En este tiempo asiste a treinta y nueve de las cuarenta y dos sesiones que se celebran, siendo el diputado que asiste a más sesiones.

Como ocurrió con otros compañeros, si el gobernador interino le cesa en la última sesión de la cuarta Diputación, el titular le vuelve a nombrar diputado por el mismo distrito de Villabrágima para la quinta Diputación del Sexenio. Se presenta en la sesión de instalación que se celebra el 30 de mayo de 1874. El día 31 de mayo es nombrado miembro de la comisión de Presupuestos, y el 17 de junio, lo es de la comisión de Cuentas y de la Junta de Beneficencia. Finaliza la legislatura en marzo de 1875, habiendo asistido a quince de las dieciocho sesiones celebradas. El 19 de marzo de 1875, fecha de inicio de la primera Diputación de la Restauración es ratificado su nombramiento como diputado por el mismo distrito de Villabrágima hasta el año 1877 , en que finaliza esta legislatura.

\section{Jofre de Villegas y Villar, Francisco María}

Nació en el pueblo de Villar de Frades, el 4 de diciembre de 1832, hijo de Vicente y de Librada. Estudió en la Universidad de Valladolid ${ }^{1083}$. En noviembre de 1866 se celebran elecciones a diputados provinciales para la decimonovena Diputación isabelina y presentado como candidato por el partido judicial de Mota del Marqués, resultó elegido. Presente el día 1 de enero de 1867, en la sesión de instalación, prestó juramento y tomó posesión del cargo. En la misma sesión es nombrado secretario, cargo que desempeña hasta el 25 de abril de 1867. También se le nombra miembro de la comisión Inspectora de Establecimientos Benéficos. En estos primeros meses de funcionamiento de la Diputación asiste regularmente a las sesiones hasta el mes de julio de 1867, ya que por real decreto de 27 de junio del mismo año se suprimen los partidos judiciales de Valoria la Buena y Mota del Marqués. A pesar de que el gobierno en otro nuevo real decreto de fecha 4 de julio dispone que "los diputados cuyos partidos se hayan suprimido continuarán en el desempeño de su cargo hasta nuevas elecciones", el diputado Jofre no se vuelve a presentar y deja de asistir a las sesiones, aunque la Diputación continúa sus actividades hasta el 20 de septiembre de 1868. En definitiva, sólo asiste a trece sesiones de las cincuenta y dos celebradas. No vuelve a aparecer en ningún otro acontecimiento político.

\section{Lara, Francisco}

Es elegido diputado provincial por el partido de Valladolid, en la octava Diputación isabelina. Toma posesión y presta juramento en la sesión de instalación

1083 “Se matriculó en la Facultad de Leyes en el año 1847. El 2 de junio de 1851, solicita ser examinado para alcanzar el grado de bachiller en Jurisprudencia, y presentado el día 6 del mismo mes, salió aprobado. El 6 de junio de 1854, solicita se le conceda el grado de licenciado en Jurisprudencia, presentando los certificados de los cursos probados. Se celebran los exámenes los días 12 y 14 y resultó aprobado por unanimidad" A.H.U.V.A. Cajas 475 (doc. 397 a 401 ), 506 (doc. 343 a 345$)$ y $678-39$. 
que se celebra el día 1 de abril de 1852. Actúa como tal diputado a lo largo de toda la legislatura, que se da por finalizada el 30 de marzo de 1854. Está presente en diecinueve de las veintitrés sesiones que se celebran. Continúa como diputado por la capital en la siguiente Diputación, novena de la era isabelina, que inicia sus actividades el 1 de abril de 1854 y finaliza con la llegada del Bienio Progresista, el 18 de julio del mismo año. Asiste a las cuatro sesiones que se celebran. No vuelve a ejercer ninguna otra actividad pública.

\section{Llamas Gómez, Manuel}

Es natural de Villalón de Campos, nacido el 25 de febrero de 1810, hijo de José y de Manuela, ambos también naturales de Villalón. Se traslada a Valladolid para estudiar en su Facultad de Leyes. En el año 1833 alcanza el grado de bachiller en Leyes y el grado de licenciado en septiembre de 1836. Se instala en Valladolid, en una casa de la calle Cantarranas, donde ejerce la profesión de abogado y además una actividad industrial al montar una imprenta. Está casado con Cecilia Moro. En el año 1842 es nombrado profesor de Jurisprudencia en la Facultad de Derecho de la Universidad vallisoletana. Entre los años 1840 y 1843 compró una pequeña finca desamortizada de 6 hectáreas, próxima a Valladolid, por la que pagó 56.340 reales y compró también una finca urbana. En el año 1843 desempeña el cargo de magistrado en la Audiencia de Granada.

En su primera actividad política, es elegido diputado provincial por el partido de Villalón, en las elecciones celebradas en diciembre de 1837, para la tercera Diputación isabelina. Pero al presentarse en la sesión de instalación no pudo hacerse cargo de su puesto al no aprobarse su acta de diputado, "porque el acto no fue lo público que debía de ser, debido a que el portero cerró la puerta y no permitió la entrada a dos individuos, porque pensó que la elección ya había terminado y que debía de avisar a la Mesa antes de permitir su entrada" ${ }^{1084}$. Una vez aclarado el asunto, pudo jurar el cargo y tomar posesión del mismo. El 13 de septiembre de 1840, a partir del "Pronunciamiento de Espartero", la Junta Provisional del Gobierno de la Provincia le nombra jefe político interino y en consecuencia ejerce como presidente de la Diputación por lo que "envía una comunicación a la Diputación dando parte de su nombramiento y anuncia su toma de posesión". Desempeña el cargo hasta el mes de noviembre, en que volvió a su puesto de diputado provincial, al haber sido nombrado un nuevo jefe político "en propiedad", manteniéndose en el cargo hasta la clausura de la Diputación a finales de diciembre del mismo año 1840. En este período as iste a ciento cuarenta y nueve sesiones como diputado y además en cinco sesiones ejerce como presidente interino.

Es un político liberal de tendencia progresista, miembro de la Milicia Urbana, que en el año 1841 será nombrado diputado a Cortes por la provincia de Valladolid. Vuelve nuevamente a la política cuando, por real orden de la Regencia del Gobierno de 14 de febrero de 1843, es nombrado jefe político de la provincia, tomando posesión de su cargo el día 19 del mismo mes, en la sesión plenaria que celebra la Diputación. Se mantiene en el cargo hasta 29 de junio de 1843, cuando la Junta Provisional del Gobierno de la Provincia publica su cese. En este período presidirá las actividades de la Diputación a lo largo de dieciséis sesiones como vigesimoprimer presidente de la Corporación. A la finalización del mandato de Espartero, deja la política y se retira a Villalón ${ }^{1085}$.

\section{López, Eduardo}

Es nombrado por el gobernador civil diputado provincial por el distrito de Cuenca de Campos, del partido de Villalón, para la quinta Diputación del Sexenio, en lugar de Máximo Clemente Herrero, que lo había representado en las cuatro anteriores

1084 A.D.P.V. Actas. Libro de actas del 26 de diciembre de 1837.

${ }^{1085}$ CARASA SOTO, Pedro. (Dir.). Diccionario biográfico de parlamentarios... ob. cit. pág. 585. 
Diputaciones. Toma posesión del cargo en la sesión de instalación que se celebra el 30 de mayo de 1874. El día 31 es nombrado vocal suplente de la Comisión permanente, asistiendo a varias sesiones durante los meses de octubre y noviembre de 1874. Sólo está presente en esta legislatura, que finaliza en marzo de 1875 , asistiendo a catorce de las dieciocho sesiones que se celebran. No repite como diputado en la Restauración.

\section{López Flores, Francisco}

Natural y vecino de Medina del Campo, es propietario, comerciante y también posee una compañía de seguros. En el año 1879 paga por impuestos de la propiedad agraria 901 pesetas y en 1885 este pago asciende a 1.135. Vive en la calle Padilla. Es miembro de la "Comisión Promotora del Ferrocarril Alar-Santander", y uno de los principales accionistas del mismo.

Desarrolla una gran actividad política a nivel local y provincial, perteneciendo al partido conservador. En el año 1854 desempeña la alcaldía en Medina. En junio de 1858 se celebran elecciones para cubrir las vacantes de diputados provinciales para la decimocuarta Diputación isabelina, en la que se presenta como candidato y es elegido en representación del partido judicial de Medina. En la sesión de instalación celebrada el 18 de julio, presta juramento y toma posesión del cargo. Asiste a veintinueve sesiones de las cuarenta que se celebran hasta el final de la legislatura en marzo de 1860. En la siguiente legislatura, la decimoquinta, que se inicia el 1 de abril de 1860 , continúa como diputado en representación de Medina, siendo nombrado miembro de la comisión de Bagajes. En marzo de 1862 se da por finalizada la vigencia de esta Diputación, a la que asiste a veintiséis de las treinta y una sesiones celebradas. El día 1 de abril de 1862, se presenta nuevamente en la sesión de instalación al ser elegido nuevamente diputado por Medina en la decimosexta Diputación, legislatura que finaliza el 31 de diciembre de 1863, en la que asiste a dieciséis de las veintidós sesiones que se celebran. En noviembre de 1863, se vuelve a presentar a las elecciones de la decimoséptima Diputación isabelina y vuelve a ser elegido. En su sesión de instalación, que se celebra el 1 de enero de 1864, después de prestar jurament o y tomar posesión, es nombrado presidente de la $1^{\text {a }}$ reunión del año "de acuerdo con la ley de 25 de septiembre de 1863 ". Mantiene la presidencia hasta abril de 1864, preside las sesiones durante este tiempo en tres ocasiones. En diciembre de 1865 se da por finalizada la legislatura en la que asiste a cuarenta y dos sesiones de las cuarenta y nueve celebradas. En la decimoctava Diputación, que inicia sus actividades el 1 de enero de 1866, según sorteo celebrado con anterioridad, le corresponde continuar, y sigue representando como diputado al partido de Medina. En la primera sesión es nombrado miembro de la comisión de "Estudio de la Validez del Acta de Tordesillas". En esta legislatura, que finaliza en diciembre de 1866, asiste a trece de las dieciocho sesiones realizadas. Presente en la Diputación como representante de Medina, desde 1858 a 1866, no se presenta a las elecciones para la última Diputación del período isabelino.

${ }^{\circ}$ Tampoco se presenta a las elecciones de diputados en el período del Sexenio. En la quinta y última Diputación que inicia sus actividades el 30 de mayo de 1874, son elegidos diputados Paulino Flores por Medina y Pedro Montalvo por el distrito de Carpio. A la muerte de este último, notificada a la Diputación el 20 de junio de 1874, es nombrado por el gobernador para ocupar su puesto. Se presenta en la Diputación el 3 de noviembre de 1874 y toma posesión del cargo. Se mantiene en el mismo hasta el final de la legislatura en marzo de 1875, ya en la época de la Restauración. En este tiempo asiste a siete sesiones. El 5 de abril de 1875 tiene lugar el inicio de actividades de la primera Diputación de la Restauración, en la que continúa ejerciendo como diputado por el partido de Medina, cargo que ejerce hasta el año 1877. En el año 1883 
es elegido diputado a Cortes. En el año 1895, es nuevamente nombrado alcalde de Medina ${ }^{1086}$.

\section{López Morales, Tomás}

Industrial, residente en Valladolid, miembro del partido conservador. Es hermano de Blas López Morales, importante propietario y comerciante de Valladolid, considerado como el más importante comprador de la provincia de bienes nacionales. Destaca la compra del convento de San Francisco en la Plaza Mayor de Valladolid.

Es nombrado diputado provincial, en la segunda Diputación del Sexenio, en representación del partido de Olmedo "en comunicación pasada por el Sr. capitán general, al hallarse la provincia en estado de guerra". Toma posesión en la sesión de instalación que se celebra el 18 de octubre de 1869 y se mantiene hasta el final de la legislatura en febrero de 1871, asistiendo a ciento dieciocho sesiones de las ciento veintisiete que se celebran y no vuelve a ejercer ningún otro cargo público.

\section{López Puga y Viguero, Manuel}

Natural de Valoria la Buena, de cuya población es vecino, aunque también tiene casa en Valladolid. Propietario y terrateniente en la zona del Páramo de Esgueva, es miembro de la Asociación de Propietarios Territoriales de España. Compró una serie de fincas procedentes de bienes desamortizados. En el año 1843 adquirió 117 hectáreas y en 1856 volvió a comprar otras 142 hectáreas, todas ellas en la zona de Tierra de Esgueva. Es hermano de Tadeo López Puga, que fue elegido diputado provincial por el partido de Valoria en la Diputación que se formó en el año 1836, aunque no llegó a tomar posesión alegando "estar enfermo de reuma".

Elegido diputado provincial por el partido de Valoria, se presentó en la sesión de instalación de la cuarta Diputación isabelina que se celebra el día 1 de enero de 1841. Manifiesta "que, aunque le constaba haber sido nombrado diputado por el partido de Valoria, no se le había hecho entrega de la copia del acta de escrutinio y a pesar de esta grave falta cometida por el alcalde de Cabezón, no había tenido inconveniente en presentarse...". Pero el pleno de la Diputación acuerda no admitirle hasta que no presente el acta, cosa que no sucede hasta el 10 de febrero en cuya sesión, "el diputado por Cabezón, se presenta con el acta, juró y tomó asiento". Se mantiene en el cargo hasta octubre de 1843, fecha en que se da por finalizada la legislatura. Fue nombrado miembro de la comisión de Estadística y de la de Enajenación de Bienes del Clero Secular. Asistió a ciento dieciséis sesiones. En el año 1847 es nombrado vocal de la Junta de Agricultura de la provincia. En el año 1852, por real decreto de 17 de marzo, es nombrado vocal del Consejo provincial, permaneciendo en el cargo hasta el 18 de enero de 1854. El 31 de agosto de 1854 reclama ser nombrado diputado provincial por el partido de Valoria, por haberlo sido en 1843, pero no se le llega a nombrar "por las circunstancias particulares del diputado en 1843", según se refleja en el Libro de Actas, aunque no se dan detalles de las citadas circunstancias que justificaban el rechazo a ser admitido como diputado. No vuelve a aparecer en ningún otro cargo público.

\section{López Puga y Viguero, Tadeo}

Natural y vecino de Valoria la Buena. En las elecciones para cubrir las plazas de diputados provinciales, en la segunda Diputación isabelina, que se celebran en el mes de octubre de 1836, es elegido diputado suplente. En la sesión que celebra la Diputación el 9 de marzo de 1837, se lee una comunicación del jefe político "dando parte de haber sido nombrado por la Junta Provincial que tuvo efecto el 5 del corriente, según lo dispone la ley de 15 de enero anterior, D. Tadeo López Puga, vecino de Valoria, como sustituto de D. Manuel Bergaz. Se acordó oficiar a dicho

1086 CARASA SOTO, Pedro (Dir.). Elites castellanas de la Restauración. Ed. Junta de Castilla y León. Valladolid. 1997. Pág.346. 
señor para que se presente a la mayor brevedad a tomar posesión de su destino y participar de las grandes ocupaciones de esta corporación" ${ }^{1087}$. La petición no llegó a materializarse, ya que en la sesión del 8 de mayo se lee un oficio en la Diputación, firmado por el propio Tadeo López Puga, manifestando "que la enfermedad de reuma que padece no le permite presentarse en la Diputación". En conclusión, es nombrado diputado pero no llega a tomar posesión y en consecuencia no asiste a ninguna sesión. Su hermano Manuel, también vecino de Valoria, será diputado provincial en el período de la Regencia de Espartero (cuarta Diputación) entre los años 1840 y 1843.

\section{López Redondo, Nemesio}

Nace en Valladolid el 19 de diciembre de 1804, hijo de Félix y de Micaela. Inicia sus estudios de primera enseñanza en Valladolid y en Burgo de Osma. En el año 1820, a los catorce años, regresa a Valladolid e ingresa en la Universidad, matriculándose en la Facultad de Leyes. En 1823 presenta la solicitud para ser admitido a examen para alcanzar el grado de bachiller en Leyes, acompañando otra solicitud para admitirle de gracia para recibir el grado a causa, no tan sólo de la escasez del sueldo de su padre, sino también por la tardanza en cobrarlo. Aceptada la solicitud y examinado el 16 de octubre, salió aprobado némine discrepante. Continuó sus estudios entre 1824 y 1828 , alcanzando en 1829 el grado de licenciado en Leyes. Se casó en el año 1831 con Micaela San Martín. Ejerció la abogacía en Valladolid, perteneciendo al Colegio de Abogados y siendo su decano durante los años 1841 a 1848 y en los años 1872-1873. Abogado consultor del Tribunal de Comercio. Presidente de la Junta de Agricultura Industria y Comercio. Presidente de la Casa de Beneficencia. Magistrado auxiliar de la Audiencia Territorial. Académico de la Real Academia de Bellas Artes de la Purísima Concepción, fue elegido presidente en el año 1874. Comendador de la Real Orden Americana de Isabel La Católica. Capitán de la Milicia Nacional entre 1839 y 1851. Miembro de la "Comisión Promotora del Ferrocarril Alar-Santander". En 1841 se le asigna en el amillaramiento una renta de 6.000 reales. En 1842 adquirió varias fincas urbanas procedentes de bienes nacionales, así como una finca rústica en los Montes Torozos ${ }^{1088}$.

Su actividad política se inicia en el año 1823, en los inicios de la Década Ominosa, cuando ingresa en las filas de Voluntarios Realistas, de claro matiz absolutista, aunque eso no implica que con los años se sitúe en posiciones conservadoras moderadas. Procurador síndico del Ayuntamiento de 1841 a 1843. Es nombrado alcalde de Valladolid entre enero de 1846 y agosto de 1847. Abandonada la Alcaldía en 1847, es elegido diputado provincial por el partido de Peñafiel y toma posesión del cargo en la sesión de instalación que se celebra el 15 de agosto, inicio de actividades de la sexta Diputación isabelina. En la misma sesión es nombrado secretario de la Corporación, y también miembro de la comisión de Enajenación de Bienes Nacionales. Ejerce como diputado y secretario hasta el final de la legislatura en marzo de 1850, asistiendo en este tiempo a treinta y ocho de las cuarenta y cinco sesiones que se celebran. Vuelve a ser elegido en la séptima Diputación, también por el partido de Peñafiel, toma posesión en la sesión del 3 de abril de 1850 y ejerce el cargo hasta el final de la legislatura en marzo de 1852. Está presente en veintiocho de las treinta y dos sesiones celebradas. Continúa como diputado en la nueva corporación, la octava isabelina, que se forma el 1 de Abril de 1852. A partir de noviembre de 1853 ejerce de vicesecretario hasta el final del período en marzo de 1854, asistiendo a veinte de las veintitrés sesiones que se celebran. En la última Diputación previa a la llegada del Bienio Progresista, es decir, la novena Diputación de la era isabelina, continúa representando como diputado al partido de Peñafiel. En

1087 A.D.P.V. Actas. Libro de actas del 9 de marzo de 1837.

1088 FERRERO MAESO, Concepción y BERZAL DE LA ROSA, Enrique. Historia del Colegio de Abogados... ob. cit. pág. 227. CARASA SOTO, Pedro. (Dir.). Diccionario biográfico de alcaldes... ob. cit. pág. 479. A.H.U.V.A. Cajas 445 (final) y 571 (doc. 1 y 2). 
este período, muy corto, que sólo dura desde abril a julio de 1854, es nombrado miembro de la comisión de Instrucción Pública y asiste a dos de las cuatro sesiones que se celebran. El 1 de enero de 1859 vuelve a ser nombrado alcalde de Valladolid, permaneciendo en su puesto hasta el 9 de enero de 1861. A partir de estos años, no vuelve a aparecer en ningún otro cargo político, aunque mantuvo una gran actividad social y cultural. Falleció en Valladolid el 29 de diciembre de 1875.

\section{López de Tejada y Navia, Joaquín. Marqués de Gallegos}

Nació en el pueblo de Honcalada, aunque sus padres Joaquín y Juana eran naturales de Valladolid. Vivió en Tordesillas, villa en la que permaneció y ejerció la agricultura. Perteneciente a la nobleza rural, heredó el título de Marqués de Gallegos de Huebra en el año 1850. Estaba orgulloso de su condición de aristócrata y del cuidado y atención que prestaba a la agricultura. Como importante propietario agrícola, aumentó sus tierras con la compra de una finca de 60 hectáreas procedente de bienes desamortizados, situada en la Tierra de Pinares, por la que pagó 57.010 reales. Era accionista del ferrocarril Alar-Santander. En el año 1855 era el segundo mayor contribuyente del partido de Mota del Marqués con una cuota anual de 3.527 reales. En 1860 paga 4.732 reales, es el vigésimo séptimo mayor contribuyente de la provincia por propiedad territorial y pecuaria en Tordesillas. En 1861, es el trigésimo primer mayor contribuyente con 3.794 reales.

No está muy interesado por la política, pero el 14 de agosto de 1856, el capitán general de Castilla la Vieja, teniente general Armero y Peñaranda, le nombra diputado provincial, al finalizar el período del Bienio Progresista, en la decimosegunda Diputación isabelina. El 19 de agosto de 1856, en la sesión de instalación, toma posesión del cargo en representación del partido judicial de Mota del Marqués. En la misma sesión es nombrado representante de la Diputación en la Milicia Nacional. Se mantiene en el cargo los cuatro meses que está vigente la Diputación y asiste a trein ta y una de las cincuenta y tres sesiones que se celebran entre agosto y noviembre de 1856. El 24 de octubre del repetido 1856, con la nueva puesta en marcha del Consejo provincial, es nombrado consejero interino, cargo que deja al instalarse el Consejo de manera definitiva en la sesión del 4 de noviembre. Este es su fugaz paso por la política, y no vuelve a actuar en este campo.

Falleció en Tordesillas el 4 de septiembre de 1863, sucediéndole en el marquesado su nieto Ángel Coronado y López de Tejada. El 10 de enero de 1867 por edicto del juez de Primera Instancia de Tordesillas, Francisco Hernández de la Gándara, "se cita a todos los que se crean con derecho a los bienes que dotan las 40 vinculaciones, fundadas por los sujetos que a continuación se dirán, vacantes por el fallecimiento de Joaquín López de Tejada, Marqués de Gallegos, ya que así lo tengo acordado con Cándido Gutiérrez de Matallana, apoderado de Luisa López de Tejada, esposa de Marciano Gómez de Bonilla (sigue la relación de los 40 vínculos y mayorazgos desde el año 1540 a 1700). Tordesillas a 17 de diciembre de 1866 "1089. Es el inicio de la desmembración de sus bienes que continúan con el anuncio que se publica en el Boletín Oficial con "la subasta de la casa que perteneció al Marqués de Gallegos, situada en Tordesillas" $" 1090$.

\section{Lorenzo y Frontaura Cacho, Federico Tomás}

Nació en Villafrechós, partido judicial de Rioseco, el 20 de diciembre de 1834. Hijo de José Lorenzo y Frontaura y de Policarpa Cacho. Estudió en la Universidad de Valladolid, en su Facultad de Leyes, en la que alcanzó el grado de licenciado en Jurisprudencia, en el año 1856.

El día 11 de mayo de 1874 , en la última sesión que celebra la cuarta Diputación del Sexenio, se da lectura al oficio del gobernador interino de fecha 27 de

1089 B.O.P.V. no 166 de fecha 10 de enero de 1867.

1090 B.O.P.V. no 194 de fecha 12 de febrero de 1867. 
abril "participando de que en uso de las facultades que le concede la circular del Poder Ejecutivo de la República de 5 de febrero pasado, comunica el nombramiento de Federico Frontaura como diputado provincial por el distrito de Palazuelo de Vedija, del partido de Rioseco, en sustitución del cesado José Manuel Cuadrillero". Estando presente en la sesión, tomó posesión del cargo por este único día, pues en la misma sesión el gobernador "suspende las actividades de la Diputación hasta nueva orden". Es uno de los diputados que, como es lógico, ha estado menos tiempo en el cargo y no vuelve a figurar en posteriores Diputaciones.

\section{Lozano Villanueva, Mariano}

Nació en Valladolid el 28 de marzo de 1817, siendo bautizado, el día 30 en la Iglesia de San Lorenzo. Hijo de Ambrosio Lozano, de Mucientes, y de María Villanueva, natural de Valladolid. "El día 13 de octubre de 1827, a los once años, solicita el ingreso en la Universidad de Valladolid, matriculándose en la Facultad de Leyes. El 2 de junio de 1834, se presentó a examen para alcanzar el grado de bachiller en Jurisprudencia, y salió aprobado némine discrepante" ${ }^{1091 .}$

Se inicia en la política al presentarse a las elecciones para diputado provincial que se celebran los días 1, 2 y 3 de febrero de 1871, por el sexto distrito de Valladolid, parroquia de El Salvador. Sale electo, por lo que se presenta en la sesión de instalación de la tercera Diputación del Sexenio que tiene lugar el 17 de febrero y en la que presenta su acta de elección que es aprobada al día siguiente. Se mantiene en el ejercicio de su cargo hasta que en el mes de febrero de 1872, se da cuenta en la Diputación de su fallecimiento. En el año 1871 asistió a treinta y una sesiones de la Diputación.

\section{Macho Mesones, Francisco}

Natural de Rueda, villa en la que nació el 2 de septiembre de 1841. Es hijo de José Macho Bustamante, labrador y propietario, natural de Santander y de Elena Mesones, nacida en Rueda. "Su padre se trasladó a vivir a Rueda, donde se casó. Entre los años 1838 y 1843 adquirió en once compras 141 parcelas de bienes desamortizados, con un total de 263 hectáreas, por las que pagó 332.000 reales. Su tío, Pedro Mesones, en los mismos años compró 229 hectáreas en Tierra de Pinares y una casa en Valladolid, también de bienes desamortizados" ${ }^{1092}$. Inició sus estudios en la Universidad de Valladolid, matriculándose en la Facultad de Leyes en el año 1857 y obteniendo el grado de licenciado ${ }^{1093}$. Ejerce en Rueda como abogado, a la vez que administra sus propiedades.

El 30 de mayo de 1874, fecha de inicio de las actividades de la quinta Diputación del Sexenio, es nombrado diputado provincial por el distrito de Rueda, presentándose y tomando posesión en la misma sesión Al día siguiente, es nombrado miembro de la comisión de Presupuestos. Se mantiene en el cargo hasta el final de la legislatura en marzo de 1875, asistiendo en este tiempo a siete sesiones de las dieciocho que se celebran. Continúa representando a Rueda en la primera Diputación de la Restauración, que se inicia el 19 de marzo de 1875, finalizando en 1877 y no presentándose a más elecciones.

\section{Macho Soto, Fernando}

Natural de la villa de Cigales, de la diócesis de Valladolid, nacido en el año 1763. Cursó sus estudios mayores en la Universidad de Valladolid. "Se graduó de

\footnotetext{
1091 A.H.U.V.A. Cajas 459 (doc. 350 a 356) y 571.

1092 RUEDA HERNANZ, Germán. La desamortización... ob. cit. pág. 296.

1093 "El 11 de junio de 1862, solicita ser examinado para alcanzar el grado de bachiller en Jurisprudencia, presentando los certificados de los cursos probados entre 1858 y 1862 . Examinado el día 14 salió aprobado. El 13 de junio de 1864 solicita presentarse a examen para alcanzar el grado de licenciado en Jurisprudencia y examinado el día 17, fue aprobado" A.H.U.V.A. Cajas 481 (doc. 289 a 294) y 685-84.
} 
bachiller en Artes el 3 de julio de 1782. Fue bachiller en Teología el 22 de agosto de 1787. Acabó licenciado y doctor en Sagrada Teología el 20 de enero de 1793. Fue sustituto de las Cátedras de Lógica y Metafísica ente 1784 y 1788. En 1791 es presbítero y "Beneficiado de Preste" en Cigales. Nombrado catedrático de Teología Moral el 18 de abril de 1797 y posteriormente de Sagrada Escritura. Terminó como canónigo lectoral de la Santa Iglesia Catedral y conservador apostólico de su Real Estudio" "1094.

En el mes de octubre de 1823, en los primeros momentos del absolutismo y actuando como rector de la Universidad de Valladolid, en una exposición enviada al Claustro, manifiesta que quería "conocer los nombres de los escolares que fueron voluntarios en el Gobierno Constitucional.... Gobierno intruso de los tres últimos años que echó por tierra nuestras leyes académicas tan necesarias para contener a la juventud en sus excesos y síntomas de corrupción..."1095.

Se presenta como candidato a las elecciones para diputado provincial, siendo elegido para la segunda Diputación del Trienio. Toma posesión y presta juramento en la sesión del 7 de junio de 1820, y se mantiene en su puesto hasta el fin de la legislatura el 28 de febrero de 1822. Representa al partido judicial de Valladolid, y en esta segunda Diputación asiste a ciento cincuenta y nueve sesiones de las ciento setenta y tres celebradas. Vuelve a salir elegido diputado provincial en la tercera Diputación que transcurre entre marzo de 1822 y abril de 1823, asistiendo a ciento veinticinco de ciento cincuenta y siete sesiones.

En el mes de mayo de 1823, con la Diputación ya disuelta, es encargado junto con el secretario Alejandro Capdevila, de recoger todos los papeles y documentos de la Diputación y ponerles a disposición del capitán general O'Donell. Este, a su vez, manda que sean guardados por el "repostero" del Ayuntamiento D. Pedro de la Reguera. El día 22 de marzo de 1827 el rector de la Universidad D. Tomás Morchón anuncia la oposición a la Cátedra de Sagrada Escritura "por fallecimiento de D. Fernando Macho Soto".

\section{Madrueño López- Puga, Gabino}

Nació en Valoria la Buena el 19 de febrero de 1819, hijo de Juan José y de Águeda. "Solicita el ingreso en la Universidad de Valladolid en diciembre de 1831, a los 12 años de edad, y siéndole concedido se matricula en la Facultad de Leyes. Entre los años 1831 a 1837, sigue los diferentes cursos de la Facultad, solicitando en julio de 1837 el ser examinado para alcanzar el grado de bachiller en Leyes y examinado el día 15 salió aprobado. En el año 1841 alcanzó el grado de licenciado en Leyes" ${ }^{1096 .}$ Acabados los estudios, ejerce la abogacía en Valoria y en Cabezón. En el año 1844 se casó con Leonor Quintero, hermana de Manuel Quintero, diputado provincial por Valoria en el año de su boda. También tiene parentesco con los diputados por el mismo partido, los hermanos Tadeo y Manuel López Puga y Viguero, el primero electo en el año 1836 y el segundo en los años 1841-43. Trasladó su residencia a Valladolid en el año 1848, ciudad en la que continuó ejerciendo la abogacía. Entre 1849 y 1868 ejerce como promotor fiscal, cargo del que es suspendido en este último año por la Junta Revolucionaria que gobierna la provincia, por "ser simpatizante del partido moderado". Nombrado decano del Colegio de Abogados de Valladolid entre 1870-1875. En el año 1875 es nombrado juez municipal y en 1882 es el teniente fiscal de la Audiencia. Comprador de bienes desamortizados en la zona de Campiña de Esgueva.

Su actividad política, como diputado provincial, la inicia el 15 de agosto de 1847, fecha en la que toma posesión y presta juramento en representación de Valoria,

\footnotetext{
1094 A.H.U.V.A. Cajas 331 (doc. 1 a 22), 337 (doc. 10 a 23), 355, 494 (doc. 312 a 316), 539 (doc. 264 a 274) y Libro 230 (Fol. 70v a 74).

1095 A.H.U.V.A. Caja 335

1096 A.H.U.V.A. Caja 464 (doc. 348 a 354).
} 
en la sesión de instalación de la sexta Diputación isabelina, que se celebra dicho día. Es nombrado en la misma sesión vicesecretario de la Institución. En marzo de 1848 es nombrado secretario durante la "primera época" y ejerce hasta septiembre, y en 1849 es vicesecretario desde enero a junio. Se mantiene en la Diputación hasta el 12 de junio de 1849, cuando el jefe político "admite la renuncia al cargo presentada por el diputado por Valoria D.Gabino Madrueño, por incompatibilidad con el cargo de promotor fiscal" ${ }^{1097}$. Durante su actividad como diputado asiste a treinta y cinco de las cuarenta y cinco sesiones que se celebran en la Diputación. Vuelve a ejercer como diputado provincial por el partido de Valoria, durante los años 1877 a 1883 y "nombrado para formar parte de la Diputación interina de 1884, presenta la dimisión por motivos de salud, falleciendo el 15 de junio de $1894 " 1098$.

\section{Maldonado, Joaquín}

Nació en Rueda en el año 1796. Pasó a vivir a Iscar, villa en la que inició sus actividades profesionales. Sus hijos Joaquín y Rafael Maldonado Macanaz, continuarán la tradición familiar y ejercerán como diputados provinciales en los años de la Restauración. En el año 1836 se le considera como el hacendado y mayor contribuyente de Iscar con 889 reales de vellón de renta. En la villa lleva sus asuntos profesionales de una manera directa, aunque tiene como representante en Valladolid al notorio personaje Blas López Morales. En el año 1838, es procurador síndico de Iscar y Olmedo y, como comisionado de Bagajes de Olmedo, se queja a la Diputación "por los graves apuros en que se veía la comisión por falta de fondos para hacer los suministros que diariamente se le reclamaban, y por la dificultad de que los pueblos de Pozaldez y Ataquines se negaban a satisfacer los cupos que les había cabido en el repartimiento" (A.D.P.V. Actas. Fecha 16 de enero de 1838). Entre los años 1840 y 1843 "compró 213 hectáreas desamortizadas en Tierra de Pinares y Medina, por las que pagó 193.978 reales de vellón" ${ }^{1099}$. En el año 1860 se traslada a vivir a Valladolid. Es miembro de la "Asociación de Propietarios Territoriales de España" y accionista del ferrocarril Alar-Santander. En 1862, se declara "propietario con tres criados" y es el apoderado del duque de Alba en la provincia.

Desempeña el cargo de comandante de la Guardia Nacional y es considerado en política como "un liberal activo". Inicia su actividad política en el año 1813, cuando el 2 de septiembre, con ocasión de la instalación de la Diputación Provincial, toma posesión del cargo de diputado en representación del partido de Medina. Destaca por ser uno de los diputados que menos participa en las sesiones, asistiendo únic amente a siete de las cincuenta y dos que se celebran en este período que finaliza en junio 1814. En el año 1820, en la nueva apertura de la institución provincial, es citado para participar en la nueva Diputación, como "doctor perteneciente al Gremio y Claustro de la Universidad de Valladolid", aunque su nombre no aparece en los archivos universitarios ${ }^{1100}$. Continúa representando al partido de Medina y asistiendo a once de las treinta y siete sesiones celebradas en esta legislatura encuadrada entre marzo y junio de 1820. No reaparecerá en su actividad política hasta la llegada del período isabelino, siendo elegido diputado provincial en la primera Diputación que se inicia en octubre de 1835 y finaliza en octubre de 1836. Representa al partido de Olmedo, aunque continúa residiendo en Iscar. Asiste a ochenta de las ciento veintidós sesiones celebradas.

1097 A.D.P.V. Actas. Libro de actas del 12 de junio de 1849.

1098 PASTRANA MORILlA, Heliodoro. La Diputación Provincial de Valladolid... ob. cit. Pág. 413.

1099 RUEDA HERNANZ, Germán. La desamortización de Mendizábal ... ob. cit. pág. 295.

1100 En el Archivo Histórico Universitario, aparece información sobre su hijo: "Joaquín Maldonado Macanaz, natural de Iscar, solicita el grado de bachiller en Filosofía con fecha 4 de junio de 1851". El B.O.P.V. n ${ }^{\circ} 31$ de 5 de agosto de 1866 le sitúa como oficial $1^{\circ}$ del Ministerio de Ultramar. Otro hijo, Rafael Maldonado Macanaz, formó parte de la primera Diputación de la Restauración por Rueda. 
Es elegido diputado a Cortes por la provincia de Valladolid en las elecciones celebradas en julio-agosto de 1836, alcanzando 484 votos en la segunda vuelta "con la participación de un total de 1.253 electores de la provincia". En el año 1840 se presenta a las elecciones para senador aunque no sale elegido. En el año 1857, es alcalde de Iscar ${ }^{101}$.

\section{Maldonado Jimeno, Baltasar}

Es natural y vecino de Rueda. Licenciado en Derecho, ejerce la abogacía en su pueblo de residencia, según queda reflejado en el "acuerdo de la Real Chancillería para ejercer la abogacía, aprobado el día 22 de mayo de 1823". Tiene relación de parentesco con Joaquín Maldonado, diputado y senador entre 1813 y 1843 , y con Rafael Maldonado Macanaz, diputado de 1875-77, en la primera Diputación de la Restauración.

En política es de tendencia liberal. En el año 1851 ejerce como alcalde de Rueda. El día 1 de abril de 1854 inicia sus actividades como diputado, en la novena Diputación isabelina por el partido de Medina, prestando juramento y tomando posesión del cargo. Asiste a las cuatro sesiones que se celebran, dos en el mes de abril y dos en mayo, manteniéndose en el cargo hasta el 18 de julio del mismo año, fecha en la que es disuelta la Diputación por la Junta Provisional del Gobierno en la Provincia.

\section{Mantilla, Francisco Antonio}

Es natural de Almanza, diócesis de León, en donde nació en el año 1767.

Inicia sus estudios en la villa de Almanza en las materias de Lógica Moral y Metafísica. En el año 1787 solicita su ingreso en la Universidad de Valladolid, donde le catalogan "de 20 años, pelo negro y ojos castaños" $" 1102$. En el mes de junio de 1893 es aprobado como bachiller en Cánones, consiguiendo posteriormente el grado de licenciado en Leyes. Ejerce como abogado y es hacendado en Almanza, villa en la que está afiliado a la Milicia Nacional. Se presentó como candidato en las elecciones de junio de 1820, en las que quedó como diputado suplente, en la segunda Diputación del Trienio. Se volvió a presentar en las elecciones de la tercera Diputación, saliendo elegido diputado por el partido judicial de Gradefes. Tomó posesión de su cargo el primero de marzo de 1822, asistiendo a diez sesiones. En el mes de mayo del mismo año cesa en sus funciones en la Diputación de Valladolid, y pasa como diputado a León, a cuya provincia pasa a pertenecer el partido de Gradefes, de acuerdo con la "Nueva Ley de División Provisional del Territorio de 22 de enero de 1822".

Nada más llegar a León y ante la revuelta situación política, sucede que "Francisco Antonio Mantilla, político y diputado liberal, fue maltratado por un destacamento de tropas realistas portuguesas, que ocuparon León por unos días en mayo de $1823 " 1103$. Su nieto, Francisco Calderón Mantilla, será diputado provincial por Mayorga entre los años 1872 a 1875, en el período del Sex enio Revolucionario.

\section{Marquina, Quirino}

Vecino de Mucientes, labrador y propietario, se presenta a las elecciones que se celebran en los primeros días de febrero de 1871, por el distrito de Mucientes, noveno de Valladolid, resultando elegido. Se presenta en la sesión de instalación, que se celebra el 17 de febrero de 1871, en la que entrega su acta, que es aprobada en la sesión del día 21. En el mes de abril es nombrado miembro de la Junta de Beneficencia. En el año 1872, en la sesión del 25 de julio, se celebra sorteo para conocer a los diputados a los que correspondía continuar en la Diputación, y le correspondió cesar. Deja la Diputación al final de la legislatura, en octubre de 1872,

\footnotetext{
${ }^{1101}$ B.O.P.V. $\mathrm{n}^{\circ} 97$ de 9 de agosto de 1836, $\mathrm{n}^{\circ} 15$ de 4 de febrero de 1840 y $\mathrm{n}^{\mathrm{o}} 38$ de 6 de marzo de 1857.

1102 A.H.U.V.A. Cajas 388 (doc. 194 a 204) y 433 (doc. 443 a 454).

1103 CARANTOÑ ÁlVAREZ, Francisco. Historia de la Diputación de León. ob. cit. pág. 33.
} 
asistiendo a cuarenta y nueve sesiones de las setenta que se celebran. No vuelve a presentarse a más elecciones.

\section{Martín, Braulio}

En los inicios de la época isabelina y en las primeras elecciones que se celebran a diputados provinciales en el mes de octubre de 1835, es elegido diputado suplente por el partido judicial de Medina. A los pocos días de instalada esta primera Diputación, en la sesión que se celebra el día 31 del mes de octubre, se acuerda "conceder la excedencia al diputado Gil Montalvo y ordenar que se presente en su lugar el sustituto Braulio Martín". En la siguiente sesión presta juramento y toma posesión de su cargo, siendo nombrado, al mismo tiempo, miembro de la comisión de Ayuntamientos. Se mantiene en el puesto hasta octubre de 1836, fecha en la que finaliza la legislatura, y está presente en setenta y seis sesiones de las ciento veintidós que se celebran.

\section{Martín García, Eugenio}

Natural de Olivares de Duero, del partido judicial de Peñafiel, pueblo en el que nació en el año 1815. Bachiller en Jurisprudencia por la Universidad de Valladolid ${ }^{1104}$.

El 11 de mayo de 1874, a finales de la cuarta Diputación del Sexenio, se lee en la misma el oficio del gobernador interino de fecha 27 de abril, por el que se le nombra diputado provincial por el distrito de Quintanilla de Abajo, en sustitución del cesado Miguel Alonso Pesquera. Toma posesión el mismo día 11, sesión en la que al mismo tiempo es disuelta la Diputación, por lo que solamente es diputado por este día. No vuelve a ser nombrado diputado ni se presenta a las elecciones.

\section{Martín Lozar, Manuel}

Manuel Martín Alfonso Lozar nació el 8 de septiembre de 1797, en Villamuriel de Campos, hijo de Bernardino Martín Lozar y de Luisa Alfonso. Es conocido y él personalmente se identifica y firma con los apellidos paternos de Martín Lozar. Inició sus estudios en el Seminario de San Froilán de León, donde estudió Teología y Cánones, pasando posteriormente a ingresar en la Facultad de Leyes de la Universidad de Valladolid, donde continuó los estudios hasta alcanzar la Licenciatura en Leyes.

Se casó con María Acosta Ceballos, que falleció en el año 1835 a causa de la epidemia de "cólera morbo", volviéndose a casar con su hermana Gregoria. Ejerció la abogacía en Valladolid de cuyo colegio profesional fue nombrado decano en los años 1834 y 1840. En marzo de 1840 es nombrado magistrado de la Audiencia de Granada, cargo que no llegó a ejercer, y en septiembre del mismo año se anuncia "la separación de su destino". Su vida profesional está ligada a Valladolid, en donde es nombrado fiscal de la Audiencia Territorial. Ejerce la Presidencia de la "Junta Clasificadora de Objetos Artísticos". Y además es nombrado "Individuo de honor de la Academia de Nobles Artes de la Purísima Concepción”. En 1846 es nombrado director del Monte de Piedad. Su gran actividad social y cultural fue recompensada con el nombramiento de Caballero Comendador de la Real Orden de Carlos III ${ }^{105}$.

En política militó en el partido moderado, y su primera actividad pública se sitúa en febrero de 1837 , fecha en la que es nombrado "alcalde $3^{\circ}$ de la capital". Abandona el cargo y la ciudad en septiembre del mismo año ante la entrada en la ciudad de las tropas de Zariategui, retirándose a su pueblo de Villamuriel. En las

1104 “E1 23 de octubre de 1829, presentó la solicitud para ingresar en la Universidad de Valladolid, matriculándose en la Facultad de Leyes. El 24 de mayo de 1835, solicita ser examinado para alcanzar el grado de bachiller en Jurisprudencia, para lo que acompaña los certificados de los cursos probados entre 1829 y 1835 . Examinado el 21 de agosto, y a su conclusión, pasaron a votar por AA y RR y se hallaron en el cántaro bueno diez AA y una $R$ y en el malo diez RR y una A, con lo que salió aprobado concordemente" A.H.U.V.A. Caja 461 (doc. 438 a 447). A es aprobado y R es rechazado.

${ }^{1105}$ CARASA SOTO, Pedro (Dir.). Diccionario biográfico de alcaldes ... ob. cit. pág. 495. 
elecciones a la tercera Diputación isabelina, celebradas en diciembre de 1837, es elegido diputado provincial por Valladolid, tomando posesión de su cargo en la sesión de instalación celebrada el día 26. Se mantiene en el puesto hasta el mes de septiembre de 1840, fecha en la que es destituido por la recién instalada Junta Provisional del Gobierno de la Provincia. En este tiempo asiste a ciento ochenta y tres sesiones.

El día 8 de enero de 1843 , toma posesión del cargo de "alcalde $1^{\circ}$ constitucional de Valladolid", cargo del que es desposeído el 31 del mismo mes por la Diputación Provincial, que nombra en su lugar a Atanasio Pérez Cantalapiedra. El 29 de julio de 1845 se forma el Consejo provincial, del que es nombrado vicepresidente. Con tal motivo, preside las actividades de la Diputación de forma interina, durante cinco sesiones que se celebran en el mes de marzo de 1847, por ausencia del jefe político. Se mantiene en el cargo de vicepresidente hasta el 22 de marzo de 1848, fecha en la que el jefe político, admite su renuncia al cargo, abandonando a partir de esta decisión toda actividad política. Falleció en Valladolid el 25 de mayo de 1857 a los 59 años.

\section{Martín Ortiz, Manuel}

Natural de la villa de Olmedo, pueblo en el que nació en el año 1819 y donde inició sus estudios de "primeras letras". "En el año 1832, a los 13 años de edad, solicita el ingreso en la Universidad de Valladolid, matriculándose en su Facultad de Leyes. En el año 1838 solicita ser examinado para alcanzar el grado de bachiller en Leyes, y presentado a examen el 5 de julio, salió aprobado némine discrepante" ${ }^{1106}$.

Es elegido diputado provincial por el partido de Olmedo en la novena legislatura isabelina, que se inicia el 1 de abril de 1854. En la primera sesión es nombrado vicesecretario de la institución. Asiste a tres de las cuatro sesiones que se celebran, dándose por finalizada la legislatura en julio del mismo año, ante la llegada del nuevo período progresista. La Junta Provisional del Gobierno de la Provincia, formada en los primeros días del Bienio, le ratifica en el puesto de diputado provincial por Olmedo en la décima Diputación, y toma posesión en la sesión del 30 de julio. Asiste a las quince sesiones que se celebran hasta el 14 de agosto, a sesión diaria, día en que nuevamente es disuelta. Es la primera Diputación progresista con una corta duración de quince días. En definitiva, es diputado provincial en dos cortas legislaturas que se suceden entre el 1 de abril y el 14 de agosto de 1854 .

\section{Martín Torés, Francisco Tomás}

Nació en Olmedo el 4 de diciembre de 1840, hijo de Juan Martín Carreño y de Francisca Torés, naturales ambos de Olmedo. Es licenciado en Leyes y Cánones por la Universidad de Valladolid ${ }^{1107}$. Instalado en Olmedo, ejerció la abogacía hasta que en el año 1870, es nombrado por el presidente de la Audiencia, juez municipal de la villa.

Se presenta a las elecciones para diputado provincial que se celebran los días 1,2 y 3 de febrero de 1871, y es elegido por el distrito y partido de Olmedo. Asiste el día 17 de febrero de 1871 a la sesión de instalación de la tercera Diputación del Sexenio, en la que presenta su acta que es aprobada en la sesión del siguiente día. Hasta el final de la legislatura en octubre de 1872, no asiste a muchas sesiones, veintisiete sobre setenta, y tampoco es elegido para ninguna comisión. En la sesión del 25 de julio de 1872, en el sorteo celebrado, le correspondió continuar en la Diputación. El 2 de noviembre de 1872, fecha de inicio de las actividades de la cuarta

\footnotetext{
1106 A.H.U.V.A. Caja 465 (doc. 570 a 577).

1107 "Estudió en la Universidad de Valladolid, matriculándose en el año 1858 en la Facultad de Leyes. En el año 1863, solicita ser examinado para alcanzar el grado de bachiller en Jurisprudencia, para lo cual acompaña los certificados de los cursos probados entre 1859 y 1863 , y el pago de las tasas. Examinado el 12 de junio, fue calificado de aprobado. El 15 de septiembre de 1865, solicita ser examinado para alcanzar el grado de licenciado en Derecho, Sección de Leyes y Cánones, y examinado el 7 de octubre, fue aprobado" A.H.U.V.A. Cajas 482 (doc. 187 a 193) y 686-30.
} 
Diputación del Sexenio, se presenta nuevamente por el partido de Olmedo. A semejanza de la Diputación anterior, su presencia en los plenos es esporádica, pues sólo asiste a cuatro sesiones de las cuarenta y dos que se celebran hasta el final de la legislatura en mayo de 1874. Es posible que esta falta de asistencia esté justificada por el fallecimiento de su esposa, noticia que es conocida en la sesión del día 3 de diciembre de 1872. En la última sesión de la cuarta legislatura que se celebra el 11 de mayo, es cesado por decisión del gobernador interino, pero al igual que ocurrió con otros colegas, este cese no es inconveniente para que el gobernador titular le vuelva a nombrar diputado por Olmedo en la quinta Diputación que inicia sus actividades el 20 de mayo de 1874. En la misma sesión es nombrado diputado secretario y actúa en el cargo durante toda la legislatura, que se da por finalizada en marzo de 1875 y en la que asiste a ocho de las dieciocho sesiones que se celebran. Continúa como diputado por Olmedo en la primera Diputación de la Restauración que se inicia el 19 de marzo de 1875 y finaliza en 1877, en la que es nombrado secretario. No vuelve a estar presente en la Diputación.

\section{Martín Vargas, Antonio}

Convocadas las elecciones a la Diputación en los primeros días del mes de febrero de 1871 se presenta como candidato por el distrito de Castronuño. Sale elegido y se presenta en la sesión de instalación de la tercera Diputación del Sexenio, que tiene lugar el 17 de febrero de 1871. Su acta es aprobada en la sesión del día 19, siendo nombrado en la misma sesión como diputado-secretario, cargo que desempeña en febrero y marzo y volviendo a ejercerlo en enero de 1872, hasta el final de la legislatura en octubre del mismo año. En este tiempo asistió a treinta y una de las setenta sesiones que se celebran. En la sesión del 25 de julio de 1872, en el sorteo celebrado le correspondió cesar, por lo que no se vuelve a presentar a más elecciones.

\section{Mata Jaques, Mariano de la}

Mariano Roque de la Mata Jaques nació en Valladolid el 16 de agosto de 1814. "Fue bautizado en la catedral de Valladolid el 18 de agosto, hijo de Silvestre y Florentina, siendo apadrinado por Luis Rodríguez Camaleño, alcalde de la capital. Estudió en la Universidad de Valladolid, donde se matriculó en su Facultad de Leyes, cursando los estudios entre los años 1831 y 1836. En el año 1833 alcanzó el grado de bachiller en Jurisprudencia y en 1836 aprobó el examen de grado de licenciado en Leyes" ${ }^{1108}$. Acabados los estudios, trasladó su residencia a Tordesillas. Se casó en Rueda con Paula López Arce el 29 de mayo de 1839. En el año 1843 compró 133 hectáreas de fincas desamortizadas en tierras de Medina y en los Montes Torozos, por las que pagó 90.000 reales ${ }^{1109}$.

Inicia su actividad política cuando es elegido diputado provincial por el partido de La Mota del Marqués, en la quinta Diputación isabelina. Presta juramento y toma posesión del cargo en la sesión de instalación que se celebra el día 1 de noviembre de 1843. "Aunque en la misma sesión también se presenta por el partido de La Mota, Fernando Cabezudo, que había tomado asiento con los demás señores electos y que alegaba sus derechos a ser diputado. Fue rechazado por el resto de diputados" ${ }^{1110}$. Es nombrado miembro de las comisiones de Cultura y Clero y de Gobierno Interior. En el año 1845 es nombrado vicesecretario de la Corporación y en 1846 pasa a desempeñar el cargo de secretario. Dentro de la Diputación trabajó en defensa del proteccionismo de los cereales castellanos. Se mantuvo en el cargo hasta el final de la legislatura en julio de 1847, asistiendo en este período a ciento cuarenta y siete sesiones de las doscientas cuarenta que se realizaron.

\footnotetext{
1108 A.H.U.V.A. Cajas 458 (doc. 101 y 102) y 572 (doc. 12)

1109 RUEDA HERNANZ, Germán. La Desamortización... ob. cit. pág. 305.

1110 A.D.P.V. Actas. Libro de actas del 1 de noviembre de 1843.
} 
Falleció muy joven, en el año 1848, a los 34 años de edad. Conocemos sus detalles a través de un aviso que publica la "Sociedad de Socorros Mutuos de Jurisconsultos", en el que "se solicita el derecho a la pensión de 20 reales diarios solicitados por doña Paula López Arce, viuda del socio Mariano de la Mata y Jaques, que nació en Valladolid el 16 de agosto de 1814, casó en Rueda el 29 de mayo de 1839 y falleció en Madrid el 26 de abril de 1848. Ha residido en Tordesillas y se inscribió en la Sociedad el 8 de agosto de 1842, a los 27 años de edad" ${ }^{1111}$.

\section{Melero, Laureano}

Natural y vecino de Villavicencio de los Caballeros, pueblo en el que se dedica a la agricultura. En el año 1860 es el trigésimo mayor contribuyente de la provincia por contribución territorial y pecuaria con una cuota anual de 4.758 reales. En 1861 es el quincuagésimo mayor contribuyente con 3.354 reales. En 1862, en el acta que celebra la Diputación el día 28 de septiembre, se da lectura a "la memoria que los comisionados a la Exposición de Londres, los Sres. Fernández Rico, Tomás Villanueva y Laureano Melero han hecho. En la citada memoria se explican los objetos de industria y agricultura presentados y la compra de arados y semillas que han realizado...". En el año 1871, está considerado como el vigésimo tercer mayor contribuyente de la provincia por contribución de inmuebles con 2.492 pesetas de cuota anual y en el año 1872 es el vigésimo segundo con las mismas 2.492 pesetas, y posesiones en Villavicencio y Becilla de Valderaduey.

A la finalización del Bienio Progresista, es nombrado diputado provincial por el capitán general de Castilla la Vieja, teniente general Armero y Peñaranda. Con ese motivo se presenta en la decimosegunda Diputación de la era isabelina, el 19 de agosto de 1856, en ella presta juramento y toma posesión del cargo de diputado en representación del partido judicial de Villalón. En la misma sesión es nombrado vocal de la Junta Económica de Obras Públicas. Ejerce el cargo hasta noviembre del mismo año en que se da por finalizada la legislatura, asistiendo a treinta y una de las cincuenta y tres sesiones que se realizan. No vuelve a presentarse como candidato en ninguna otra convocatoria en el resto del período isabelino, dedicándose de lleno a la agricultura y a la mejora de los sistemas de cultivo y recolección.

En el año 1871, vuelve a la actividad política al presentarse a las elecciones de diputados provinciales y, aunque no estaba inscrito en ningún partido, se le puede considerar cercano a los conservadores. El 18 de febrero fecha de inicio de las actividades de la tercera Diputación del Sexenio, se presenta, presta juramento y toma posesión del cargo de diputado en representación del distrito de Villavicencio de los Caballeros, del partido de Villalón. Ejerce el cargo hasta el final de la legislatura que tiene lugar el 30 de octubre de 1872, asistiendo a treinta y siete de las setenta sesiones celebradas. Continúa ejerciendo como diputado en la cuarta Diputación del Sexenio, tomando posesión el día 2 de noviembre de 1872, representando al mismo distrito de Villavicencio. En esta Diputación, que dura hasta el 29 de mayo de 1874 y que celebra cuarenta y dos sesiones, no asiste a ninguna de ellas y no se indica ningún nombramiento en las diferentes comisiones de la Corporación. Tampoco se reseña en las actas los motivos de esta ausencia. La total ausencia en los trabajos de la Diputación anterior, no es óbice, para que en la quinta y última Diputación del Sexenio sea ratificado, por el gobernador civil de la provincia, como diputado provincial por el distrito de Villavicencio. Las sesiones de la Diputación se inician el 30 de mayo de 1874, presentándose en la sesión del 19 de junio, siendo a la única sesión a la que asiste, sin prestar su colaboración en ningún trabajo ni comisión. La Diputación da por finalizados sus trabajos el 18 de marzo de 1875 con treinta y cinco sesiones celebradas. No aparece como diputado en la época de la Restauración.

1111 B.O.P.V. no 79, de fecha 1 de julio de 1848. 


\section{Miranda González, Fernando}

Por oficio del gobernador civil de 26 de mayo de 1874 "en uso de las facultades que le confiere la circular del Poder Ejecutivo de la República de 5 de febrero" es nombrado diputado provincial por el octavo distrito de Valladolid, Parroquia de San Nicolás. Toma posesión del cargo en la sesión de instalación de la quinta Diputación del Sexenio, que se celebra el 30 del mis mo mes de mayo, sesión en la que es nombrado diputado-secretario. Mantiene el cargo a lo largo de la legislatura, que finaliza en marzo de 1875 y en la que asiste a la totalidad de las dieciocho sesiones que se celebran. También es nombrado miembro de la comisión de Presupuestos y vocal de la Junta de Beneficencia. Continúa como diputado provincial en representación del distrito de San Nicolás en la primera Diputación de la Restauración que se instala el 19 de marzo de 1875 y finaliza en el año 1877 . No vuelve a ser diputado.

\section{Montalvo, Gil}

Natural y vecino de Medina, es elegido diputado provincial en la primera Diputación de la era isabelina, tomando posesión de su cargo en la sesión de instalación celebrada el día 22 de octubre de 1835. En la misma sesión "hizo presente que se le había nombrado para este cargo, no obstante su impedimento físico crónico de absoluta falta de oído que le imposibilita enteramente para desempeñar las funciones de diputado, pues en las discusiones no oía de qué se trataba por lo que, no obstante sus conocidos sentimientos patrióticos y deseos de coadyuvar en cuanto esté de su parte en el mayor servicio de S.M. y de la Patria, se veía con harto pesar suyo reducido a la nulidad, por lo que solicitaba se le eximiese del cargo de diputado por su partido". Su petición es aceptada en la sesión del 31 del mismo mes, y se acordó la presencia del diputado suplente Braulio Martín. En este corto espacio de tiempo asistió a ocho sesiones.

\section{Montalvo, Pedro}

Es elegido diputado por el distrito de Carpio, del partido judicial de Medina, en las elecciones celebradas los días 1, 2 y 3 de febrero de 1871, para la tercera Diputación del Sexenio, presentando su acta en la sesión de instalación que se celebra el 17 y siendo aprobada en la del 19 del citado febrero de 1871 . No participa en ninguna comisión y asiste a cuarenta y cuatro de las setenta sesiones que se celebran hasta el final de la legislatura en octubre de 1872. En la sesión del 25 de julio de 1872, y en el sorteo celebrado, le correspondió continuar en la siguiente Diputación. La cuarta Diputación inicia sus actividades el 2 de noviembre de 1872, presentándose en la citada sesión para continuar como diputado en representación de Carpio. Asiste a veinte sesiones de las cuarenta y dos realizadas en esta legislatura que da por finalizada sus actividades el 11 de mayo de 1874.

El gobernador civil le confirma como diputado por Carpio para la quinta Diputación, por lo que presente en la sesión de instalación que se celebra el 30 de mayo de 1874 toma posesión del cargo. Al día siguiente es nombrado vocal de la Comisión permanente, en sustitución del dimitido vocal Juan Antonio de las Moras. Sólo está presente en estas dos sesiones de los días 30 y 31. En la sesión del 20 de junio, convocada para aprobar los presupuestos, "se notificó el fallecimiento del diputado Pedro Montalvo, del distrito de Carpio, comunicada por el alcalde Toribio Díaz".

\section{Moras Gala, Juan Antonio de las}

Es natural de Castronuevo de Esgueva, pueblo en el que nació en el año 1821. Es hijo de Miguel y Escolástica. Su padre, Miguel de las Moras Ortega, fue diputado provincial a lo largo de una dilatada carrera política y además también ejerció como diputado a Cortes. "Estudió en la Universidad de Valladolid, en la que solicita su ingreso en el año 1832, a los once años, siendo admitido en la Facultad de Filosofía. 
En el año 1834, solicitó ser examinado para alcanzar el grado de bachiller en Filosofía, justificando los cursos probados, y realizado el examen fue aprobado por unanimidad. En el mismo año 1834, continuó sus estudios en la Universidad, matriculándose en la Facultad de Leyes, cursando los estudios correspondientes hasta el año 1837. El 24 de mayo de 1837 solicita ser examinado a claustro pleno para alcanzar el grado de bachiller en Leyes, presentando los certificados de los cursos probados en los años 1834 a 1837. Admitido a examen el 1 de junio, fue aprobado némine discrepante" $" 1112$.

Ejerció la abogacía en Valladolid, ciudad en la que reside, sin abandonar la administración de sus propiedades agrícolas en el valle del Esgueva, zona en la que, además de las propiedades familiares, había adquirido en 1843 una finca de 95 hectáreas procedente de bienes desamortizados. Se casó con una hija de Severiano del Amo, alcalde de Valladolid, de cuyo matrimonio tuvo dos hijos que mantuvieron la tradición política de la familia, ya que ambos ejercieron como alcaldes en los años de la Restauración. Mantiene el control político de la zona de Valoria, iniciado por su padre, dentro del partido moderado. Su hijo Francisco María ejercerá como diputado provincial a partir de 1880 , actividad que alternó con la alcaldía de Valladolid y el gobierno civil en varias provincias.

Su carrera política se inicia en el año 1854, cuando a principio del Bienio Progresista y recién instalada la undécima Diputación, el 14 de agosto del citado año, el diputado por Valoria, que era su padre, presentó su dimisión con fecha 7 de septiembre. El 16 del mismo mes, en la sesión que celebra la Diputación, "se da lectura al acta de elección de diputado provincial por Valoria a favor de Juan Antonio de las Moras, elegido por los 24 alcaldes del partido, tomando posesión de su cargo y prestando juramento a continuación" ${ }^{1113}$. Es miembro activo de la Milicia Urbana. En el año 1855 es nombrado vocal de Sanidad. Se mantiene en el cargo hasta el final de la legislatura, en agosto de 1856, asistiendo a noventa de las ciento cuarenta y ocho sesiones que celebra la Diputación. No vuelve a actuar en política durante el resto de la época isabelina, aunque se le conoce el desempeño de cargos públicos ligados con la judicatura. Así en 1869 actúa como juez de paz en Castronuevo y el 6 de diciembre de 1870, la Audiencia Provincial le nombra juez municipal en la misma villa. En el Sexenio Revolucionario aparece nuevamente como diputado provincial en la tercera Diputación de este período, en representación del distrito décimo de la capital que corresponde al antiguo partido de Valoria. El 7 de febrero de 1871, en la sesión de instalación, presenta su acta de elección, que es aprobada el 19 del mismo mes. En la sesión de constitución definitiva de la Diputación, una vez aprobadas todas las actas, que se celebra el 21 de febrero, es elegido vicepresidente de la corporación, de acuerdo con el artículo veintiocho de la recién aprobada "Ley Orgánica Provincial" de 20 de agosto de 1870. En abril de 1872 es elegido miembro de la Comisión permanente en sustitución del diputado Miguel Ibáñez. En el sorteo para decidir los diputados que continuarían ejerciendo el cargo, celebrado el 25 de julio de 1872, le tocó continuar en el puesto. En esta legislatura, que finaliza en octubre de 1872, asistió a cincuenta y tres sesiones de las setenta celebradas.

El día 2 de noviembre de 1872 se inician los trabajos de la nueva Diputación, la cuarta del Sexenio, en la que continúa representando al distrito décimo de Valladolid, siendo elegido en la sesión vocal de la comisión Auxiliar de Actas. El 13 de noviembre se da por finalizada la aprobación de las actas y se inician las actividades de la Diputación. En esta sesión es nombrado nuevamente vicepresidente de la Corporación. Se mantiene activo durante toda la legislatura, que termina en mayo de 1874, y asiste a treinta y tres de las cuarenta y dos sesiones.

Nuevamente es elegido diputado provincial por el distrito de Valoria, décimo de la capital, en la quinta Diputación y última del Sexenio. En la sesión de instalación

1112 A.H.U.V.A. Cajas 503 (doc. 317 a 321 ) y 464 (doc. 240 a 246).

1113 A.D.P.V. Actas. Libro de actas del 16 de septiembre de 1854. 
que se celebra el 30 de marzo de 1874, es nombrado vocal de la Comisión provincial, aunque en la misma sesión presenta su renuncia tanto al cargo de vocal de la Comisión como al de diputado, siendo rechazada por el pleno su renuncia al cargo de diputado, aunque le admitió la renuncia como vocal de la Comisión. Se mantiene en el puesto hasta el 18 de marzo de 1875, fecha final de la legislatura, en la que asiste a seis de las treinta y seis sesiones que se celebran, y fecha en la que es disuelta la Diputación.

\section{Moras Gil, Pedro Regalado de las}

Nació el 13 de mayo de 1815, en el pueblo de San Martín de Valvení, hijo de Manuel de las Moras Ortega y de María Teresa Gil. "Y habiendo nacido con pocas esperanzas de vida, yo el infrascrito cura le bauticé con agua de socorro y el día 15 fue solemnemente bautizado en la iglesia”. En el año 1830, solicitó su ingreso en la Universidad de Valladolid y siendo aceptado se matriculó en la Facultad de Leyes. El 15 de junio de 1833, solicitó ser examinado para alcanzar el grado de bachiller en Leyes y examinado el día 22 fue aprobado némine discrepante. En junio de 1836, solicitó el examen para alcanzar el grado de licenciado en Leyes, para lo que presentó certificados de los cursos probados entre 1831 y 1836. Presentado a examen fue aprobado por unanimidad" ${ }^{1114}$. En el año 1842, compró una finca en San Martín de 25 hectáreas, procedente de bienes desamortizados, por la que pagó 20.000 reales.

Sobrino de Miguel de las Moras Ortega, es también su sucesor en el cargo de diputado provincial por el partido de Valoria. Su hermano Manuel es escribano en Valoria la Buena. Su primo Juan Antonio de las Moras Gala ejerció como diputado provincial en los años del Bienio Progresista.

Inicia su actividad política, de matiz moderado, cuando se presenta como candidato a diputado provincial por Valoria en las elecciones que se celebran los días 25 a 27 de noviembre de 1863, en las que resultó elegido. El 1 de enero de 1864, en la sesión de instalación de la decimoséptima Diputación isabelina, presta juramento y toma posesión del cargo, manteniéndose en el mismo hasta el 31 de diciembre de 1865 , fecha en la que se da por finalizada la legislatura, asistiendo a cuarenta y cuatro de las cuarenta y nueve sesiones que se efectúan. Ejerció como miembro de la comisión de Obras. Vuelve a ser elegido diputado provincial por Valoria, en la siguiente Diputación, la decimoctava, tomando posesión el 1 de enero de 1866 y ejerciendo el cargo hasta el final de la legislatura que se produce el 31 de diciembre del mismo año. Asiste a dieciséis de las dieciocho sesiones celebradas. No vuelve a presentarse en más elecciones.

\section{Moras Ortega, Miguel de las}

Natural de San Martin de Valvení, de la provincia de Valladolid, y nacido en el año 1799, hijo de Manuel y de Manuela. Vecino de Castronuevo, ejerce de escribano y es un importante propietario en la zona de "Páramo de Esgueva". Es miembro de una importante familia con amplios intereses políticos y económicos en el valle del Esgueva. Se casó con Escolástica Gala, hija de un compromisario en la Junta de Electores de diputados a las Cortes de Cádiz.

Fue comprador de Bienes desamortizados en la época de Mendizábal, lo que acrecentó su ya de por sí amplio patrimonio agrícola. En el año 1833 se trasladó a vivir a Valladolid, donde compró una casa en la plaza de San Miguel. En el año 1855 aparece como el mayor contribuyente del partido de Valoria con 3.334 reales de renta (B.O.P.V. $\mathrm{N}^{\mathrm{o}} 66$ de 2 de junio de 1855) y en el año 1861 alcanza el puesto cuadragésimo octavo de los mayores contribuyentes de la provincia con 3.100 reales (B.O.P.V. N ${ }^{\circ} 157$ de 4 de octubre de 1861). Defensor del valle y del río Esgueva, en febrero de 1852 es nombrado vicepresidente del "Sindicato de Mantenimiento del Cauce del Esgueva" y el 4 de abril de 1860 publica un artículo en el Norte de Castilla

1114 A.H.U.V.A. cajas 458 (doc. 89 y 90) y 573. 
en "defensa del encauzamiento del Esgueva y de la importancia del valle del Esgueva en la producción agrícola provincial".

En política perteneció al partido moderado y fue el diputado provincial de más larga trayectoria en la vida política de la institución, pues ejerció como tal entre los años 1837 a 1860. Perteneció a ocho legislaturas diferentes, tanto en períodos progresistas como moderados, siempre en representación del partido de Valoria, aunque en los últimos años tuviera su residencia en Valladolid. También se le puede considerar como el iniciador de una saga familiar que controló la vida política del partido judicial de Valoria. El control fue continuado por su sobrino Pedro Regalado de las Moras Gil, al final de período isabelino, por su hijo Juan Antonio de las Moras Gala en los años del Sexenio, y por su nieto Francisco María de las Moras Amo a partir de los años de la Restauración.

La cronología de sus actividades provinciales es la siguiente:

$1^{\circ}$.- El 26 de diciembre de 1837 es elegido por vez primera diputado provincial en la tercera Diputación isabelina. Ejerce el cargo hasta el 25 de octubre de 1840, fecha en la que es destituido por orden de la Junta Provisional del Gobierno de la Provincia en los inicios del período progresista de Espartero. Asiste en este tiempo a ciento treinta y tres sesiones.

$2^{\circ}$.- El día 3 de abril de 1850 , es nuevamente elegido diputado provincial en la séptima Diputación de la época isabelina, ejerciendo sus funciones hasta el final de la legislatura en marzo de 1852, asistiendo a veinticinco de las treinta y dos sesiones que se celebran. En el año 1851 actuó como secretario de la Corporación.

$3^{\circ}$.- Con fecha de 1 de abril de 1852 , vuelve a ser nombrado diputado en la octava Diputación isabelina, estando en el cargo hasta el 8 de marzo de 1854, fecha en la que se celebra la última sesión. Asiste a dieciséis de las veintitrés sesiones que se celebran y actúa como vicepresidente del Sindicato para la Conservación del Cauce del Esgueva.

$4^{\circ}$.- El 1 de abril de 1854 aparece nuevamente como diputado provincial en la sesión de instalación de la novena Diputación isabelina. Diputación anormalmente corta que termina en junio del mismo año 1854, con la llegada del Bienio progresista. Asiste a tres de las cuatro sesiones que se celebran.

$5^{\circ}$.- El 30 de julio de 1854 se inician las actividades de la primera Diputación del Bienio y décima de la época isabelina, continuando en su puesto de diputado de acuerdo con la decisión de la Junta Provisional del Gobierno de la Provincia "de reponer en la Diputación a los diputados existentes en 1843". Esta es también otra Diputación de corta duración que se mantiene hasta el 14 de agosto del mismo año 1854. Asiste a diez de las quince sesiones celebradas.

6.- Por real decreto de 7 de agosto de 1854, se le vuelve a nombrar diputado provincial por el partido de Valoria para la undécima Diputación isabelina "por ser el diputado de 1840 y por las circunstancias particulares del diputado de 1843, Manuel López Puga" ${ }^{1115}$. Aunque su nombramiento vuelve a tener muy corta duración, pues en el mes de septiembre, en la Diputación, se recibe la noticia de que "por el Gobierno de la provincia se ordena celebrar elecciones en Valoria y La Nava para cubrir las vacantes de estos distritos" ${ }^{1116}$. Vacante en la que es sustituido por su hijo Juan Antonio de las Moras Gala, asistiendo en este tiempo a tres sesiones de la Diputación.

$7^{\circ}$.- Recién finalizado el período progresista, de nuevo aparece como diputado provincial por Valoria en la decimotercera Diputación isabelina, que inicia sus actividades el 2 de diciembre de 1856. En esta fecha toma posesión y presta juramento y se mantiene en la institución hasta el final de la legislatura en junio de 1858. Asiste a veintiséis de las veintisiete sesiones efectuadas. Actúa como vicesecretario desde junio de 1857 hasta junio de 1858 y también es nombrado vocal de la comisión de Instrucción Pública.

1115 A.D.P.V. Actas. Libro de actas del 17 de agosto de 1854

1116 B.O.P.V. n ${ }^{\circ} 107$ de fecha 7 de septiembre de 1854. 
$8^{\circ}$.- El 18 de julio de 1858 se inician las actividades de la decimocuarta Diputación isabelina, estando nuevamente presente en esta legislatura y como en todas las anteriores, por el partido de Valoria. Asiste a treinta y cuatro de las cuarenta sesiones que se mantienen en hasta el final de la legislatura en 30 de marzo de 1860.

$9^{\circ}$.- En 1864 es elegido diputado a Cortes por el distrito de Peñafiel, estando únicamente durante esa legislatura. A partir de esta fecha no se vuelve a tener noticias de su actividad política. Sin lugar a dudas la más larga de todos los individuos que han pasado por la institución provincial ${ }^{1117}$.

Falleció en Valladolid el 1 de septiembre de 1882.

\section{Moreno Redondo, Benito}

Natural de Villabrágima, en la provincia de Valladolid, nacido el 26 de marzo de 1818, hijo de Antonio y de Isabel. Se dedica a la agricultura, en su villa natal, donde poseía un gran número de fincas, por herencia de su madre, que en su día fueron valoradas en 113.631 reales. Durante la desamortización adquirió varios lotes de fincas a través del testaferro Miguel Herrero López, su socio en la fábrica de harinas de Tordehumos.

En el plano político se consideró un progresista que militó en el partido radical, e inició su actividad en este ámbito cuando fue elegido alcalde de Tordehumos. El 14 de agosto 1854 se inician los trabajos de la segunda Diputación del Bienio y undécima de la era isabelina, ejerciendo como diputado por Rioseco Ventura García Escobar, que presenta la dimisión en la segunda sesión que se celebra. Por eso, en la sesión del 31 de agosto "se aprueba el acta de elección de diputado provincial por el partido de Rioseco a favor de Benito Moreno, alcalde de Tordehumos". El día 2 de septiembre se presenta en la Diputación, donde toma posesión de su cargo y presta el correspondiente juramento. En la sesión del 27 de noviembre de 1854 se da lectura en el Pleno a un expediente en el que se reflejan" las diligencias del Juzgado de Primera Instancia de Rioseco, en el que se presenta causa criminal contra Benito Moreno. La Diputación acuerda que, dado el carácter de diputado provincial del alcalde de Tordehumos, ni en la Diputación ni en el Sr. gobernador existen atribuciones para autorizar su procesamiento, por cuya razón es de dictamen que se consulte al Gobierno de Su Majestad"1118. Sobre este tema no se volvió a pronunciar la Diputación, siendo de suponer que el juicio fue sobreseído, pues no volvió a aparecer ninguna otra requisitoria y el Sr. Moreno continuó con sus trabajos en la Diputación. El 12 de abril de 1855 es nombrado, conjuntamente con Juan Antonio de las Moras, diputado por Valoria y José Pérez Delgado, subinspector de la Milicia Nacional, "para ir a Rioseco y hacer efectiva la eliminación de los 43 milicianos excluidos, según el acuerdo del pasado día 2 de marzo, y proceder sin levantar la mano a la reorganización completa del batallón" ${ }^{1119}$. Se mantiene en el cargo hasta el final de la legislatura, en agosto de 1856, asistiendo a lo largo del período a noventa y tres de las ciento cuarenta y ocho sesiones que se celebran.

No vuelve a presentarse como diputado en el resto de la época isabelina, aunque no dejó de actuar políticamente al reclamar una serie de responsabilidades políticas y aprovechar el descontento popular en el año 1864, a causa de la crisis financiera y económica. En el año 1868, en el inicio del Sexenio Revolucionario, aparece nuevamente "solicitando a la Junta Revolucionaria ser nombrado diputado provincial por el partido de Rioseco, en lugar del diputado elegido Manuel de la Cruz Alonso, siendo rechazada su petición" ${ }^{1120}$. Es elegido diputado provincial en la tercera Diputación del Sexenio, presentando su acta de diputado en representación del distrito de Villabrágima, del partido de Rioseco, en la sesión que se celebra el 17 de febrero

1117 CARASA SOTO, Pedro (Dir.). Diccionario biográfico de parlamentarios ... ob. cit. pág. 708.

1118 A.D.P.V. Actas. Libro de actas del 27 de noviembre de 1854.

1119 A.D.P.V. Actas. Libro de actas del 12 de abril de 1855.

1120 A.D.P.V. Actas. Libro de actas del 5 de noviembre de 1868. 
de 1871. Su acta es aprobada en la sesión del día siguiente, en la que es nombrado vocal de la comisión de Examen de Actas. El 21 de febrero de 1872, el Pleno de la Diputación le nombra vocal de la Comisión permanente, elección que es rechazada por el gobernador, al estimar que "no pueden ser miembros de la Comisión dos diputados pertenecientes al mismo partido y por Rioseco ya lo era el diputado Andrés Domínguez". La Diputación no está de acuerdo con la decisión del gobernador, al mantener que "el distrito de Villabrágima no pertenece al partido de Rioseco, sino al recién instalado partido de La Mota del Marqués". El problema se resuelve a través del real decreto de 9 de abril de 1872, por el que "se suprime el acuerdo de la Diputación y se anula el nombramiento del Sr. Moreno como vocal de la Comisión permanente".

En el sorteo celebrado el 25 de julio de 1872, le corresponde cesar en el cargo por lo que abandona la Diputación al final de la legislatura en octubre de 1872, habiendo asistido a sesenta y tres de las setenta sesiones que se celebraron. En el año 1872 se presenta a las elecciones para diputado a Cortes por el distrito de Rioseco, derrotando a Gaspar Villarías, que ejerció de diputado provincial. Se volvió a presentar en 1873, y nuevamente salió elegido, esta vez sin oposición ${ }^{1121}$. Falleció en Tordehumos el 17 de Mayo de 1889.

\section{Moyano Sánchez, José}

Nació en Valladolid, el 10 de marzo de 1821, hijo de Esteban Moyano Cantalapiedra y de Isabel Sánchez del Villar. Su padre fue un convencido absolutista, que tuvo dificultades tanto por sus ideas políticas como por su licenciosa vida privada. Su abuelo, Tomás Moyano Rodríguez, originario de Serrada, fue doctor en Derecho por la Universidad de Valladolid y diputado a Cortes en 1813. Su hermano Pedro fue diputado a Cortes y su tío Gregorio Barahona, alcalde de Valladolid en 1848.

"Ingresó en la Universidad Literaria de Valladolid en el año 1832, a los 11 años de edad, siendo matriculado en su Facultad de Leyes, siguiendo los cursos correspondientes hasta el año 1838, en el que solicitó ser examinado para alcanzar el grado de bachiller en Leyes, y presentado a examen el 25 de junio, fue aprobado por unanimidad"1122. Finalizados sus estudios, trasladó su residencia a Nava del Rey, villa en la que ejerció como abogado, pero sobre todo se dedicó a la administración de sus numerosas propiedades, heredadas de su padre en Serrada y de su madre en Nava del Rey. Contrajo matrimonio el 19 de abril de 1850 con Soledad Montoya Caballero, en la iglesia de Santo Tomé, en Salamanca y tuvieron cinco hijos, una de las cuales se casó con un sobrino de Mariano Miguel de Reynoso. Disfrutó de los títulos nobiliarios de marqués de Caballero y conde de Villahermosa del Pinar, heredados de su cuñado Fernando Montoya, que falleció sin herederos directos. Fue el presidente provincial de la "Compañía Aseguradora de Cereales y Ganados Hispano-Portuguesa" 1123 .

Inicia su carrera política, vinculado al partido moderado, en abril de 1854, cuando es nombrado diputado provincial por el partido de La Nava del Rey, en la novena Diputación isabelina. Toma posesión en la sesión de instalación del 1 de abril y asiste a las cuatro sesiones que se celebran, puesto que la legislatura se da por finalizada el 18 de julio del mismo año, fecha en la que se inicia el Bienio Progresista. Durante el período de vigencia, ejerce como secretario de la Corporación. Con la vuelta del período moderado, vuelve a ser elegido diputado por el partido de La Nava en la decimotercera Diputación, toma posesión y presta juramento en la sesión de instalación celebrada el 2 de diciembre de 1856. En la misma sesión es nombrado secretario de la Diputación, cargo que desarrolló a lo largo de toda la legislatura, que se dio por finalizada en junio de 1858. Asistió a veintiséis de las veintisiete sesiones

\footnotetext{
${ }^{1121}$ CARASA SOTO, Pedro (Dir.). Diccionario biográfico de parlamentarios ... ob. cit. pág. 714. 1122 A.H.U.V.A. Caja 465 (doc. 519 a 526).

${ }^{1123}$ CARASA SOTO, Pedro (Dir.). Diccionario biográfico de parlamentarios ... ob. cit. pág. 725.
} 
que se celebran. Es nombrado vocal de la comisión de Recepción de S.M. en el viaje a Valladolid.

En la decimocuarta Diputación que se forma en el mes de julio de 1858, continúa en el cargo de diputado por La Nava del Rey, y en la sesión de instalación celebrada el día 18, es confirmado en el cargo de secretario, cargo que desempeñó a lo largo de la legislatura, hasta su fin, en marzo de 1860. Asistió a treinta y cinco de las cuarenta sesiones que se celebran. Fue nombrado miembro de la comisión de Festejos ante la visita de SS.MM. En el año 1867 es elegido diputado a Cortes por Valladolid, en las últimas elecciones celebradas en la época isabelina.

\section{Moyano Zamora, Cándido}

Nació el 3 de octubre de 1824, en el pueblo de Serrada, hijo de Ventura y de Inocencia. "Inicia sus estudios en la Universidad de Valladolid, en la que solicita el ingreso el 17 de noviembre de 1837, a la edad de 13 años, matriculándose en la Facultad de Filosofía. Es bachiller en Filosofía y Jurisprudencia por la Universidad de Valladolid ${ }^{1124}$.

Es nombrado diputado provincial, en la decimosegunda Diputación isabelina, por el partido de Peñafiel, por orden del capitán general de Castilla la Vieja, general Armero y Peñaranda, al finalizar el Bienio Progresista. El 19 de agosto de 1856, presta juramento y toma posesión del cargo, manteniéndose en el mismo en el corto período que dura esta legislatura, ya que finaliza el 30 de noviembre del mismo año. Es nombrado miembro de la comisión de Cuentas y asiste a treinta y una de las cincuenta y seis sesiones que se celebran. El día 24 de octubre de 1856 reinicia sus actividades, con carácter interino, el Consejo provincial del que es nombrado vocal, nombramiento que es ratificado en la sesión de instalación definitiva del Consejo celebrada el 4 de noviembre. El 27 de agosto de 1858 es nombrado vicepresidente del Consejo, cargo que desempeña hasta el mes de enero de 1861, fecha en la que abandona la institución. Como vicepresidente del Consejo, actúa como gobernador interino, en ausencia del titular, desde noviembre de 1858 hasta abril de 1859 y en este período preside las cuatro sesiones que celebra la Diputación.

\section{Mozo, José}

Natural y vecino de Valladolid, estudió en la Facultad de Medicina de la Universidad vallisoletana, en la que ingresó en el año 1831. Finalizados los estudios en el año 1838, "solicitó al Sr. rector el 30 de mayo de 1838 ser examinado para alcanzar el grado de bachiller en Medicina, para lo cual presenta los certificados de los cursos probados desde 1831 a 1838. Entró a examen el 18 de junio y salió aprobado némine discrepante" ${ }^{, 125}$. Ejerce la medicina en Valladolid.

Su actividad política da comienzo el 9 de marzo de 1874, al final de la cuarta Diputación del Sexenio, cuando "en uso de las facultades extraordinarias de que se halla investido", el capitán general le nombra diputado provincial del primer distrito de Valladolid, Parroquia de San Miguel, en sustitución del cesado Anselmo Allue. El mismo día 9 toma posesión del cargo, en el que está hasta el 11 de marzo del citado año de 1874 , día en que se da por finalizada la legislatura, asistiendo en este tiempo a cinco sesiones. En la quinta Diputación del Sexenio, que inicia sus actividades el 30 de mayo de 1874 , el gobernador civil le ratifica en el cargo de diputado por el distrito

1124 El 14 de mayo de 1842, solicita ser examinado para alcanzar el grado de bachiller en Filosofía, y examinado el día 16 fue aprobado por unanimidad. En el mismo año 1842, se matriculó en la Facultad de Leyes. El 22 de junio de 1845, solicita ser examinado para alcanzar el grado de bachiller en Jurisprudencia, acompañando certificado de los cursos probados. Examinado el 12 de julio, salió aprobado. El 26 de mayo de 1847, solicita ser examinado para alcanzar el grado de licenciado en Jurisprudencia, siendo aprobado en los exámenes realizados y tomando posesión de su grado en el claustro del 27 de junio" A.H.U.V.A. Cajas 471 (doc. 178 a 183), 505 (doc. 1 a 4) y 672-27.

1125 A.H.V.A. Caja 523 (doc. 574 a 583). 
de San Miguel de Valladolid y estando asistente a la citada sesión, presentó su dimisión, que fue rechazada por el Pleno de la Diputación. En junio es nombrado vocal de las Juntas de Beneficencia y de Sanidad. Continúa como diputado hasta el final de la legislatura en marzo de 1875, asistiendo a quince de las dieciocho sesiones que se celebran. No está presente en las Diputaciones de la Restauración.

\section{Muñoz Zapata, Ulpiano}

Natural y vecino de La Nava de la Libertad, estudió en la Facultad de Leyes de la Universidad de Valladolid, en la que alcanzó el grado de licenciado en Derecho Civil y Canónico. Es nombrado diputado provincial por La Nava en la sesión que la Junta Revolucionaria Provincial celebra el 17 de octubre de 1868. Se presenta en la sesión del 4 de noviembre para tomar posesión del cargo en esta primera Diputación del Sexenio, en la que permanece hasta el 30 de octubre de 1869. En esta fecha acaba la legislatura a la que asiste en cuarenta y cuatro ocasiones de las noventa y ocho sesiones que se celebran. No vuelve a presentarse en más elecciones, ni fue nombrado para ello.

\section{Muro López-Salgado, José}

Nació en Valladolid el 21 de diciembre de 1842, hijo de José Muro Martínez, natural de Benavente, abogado de la Audiencia y catedrático de la Universidad de Valladolid y de María Ángeles López-Salgado, natural de Santiago de Compostela. Contrajo matrimonio con Heliodora García de Lomana, hija del magistrado de la Audiencia de Valladolid, Heliodoro García de Lomana. Tuvieron dos hijas.

Inició sus estudios en la Universidad de Valladolid, en el año 1857, licenciándose en la Facultad de Leyes ${ }^{1126}$. Además de estar matriculado en la Universidad de Valladolid, en 1858 pasó a estudiar Filosofía y Letras en la Universidad Central, donde recibió el grado de doctor en Filosofía en el año 1863, en que volvió a retomar sus estudios de Derecho en Valladolid. El 7 de noviembre de 1868 es nombrado vocal de la Junta de Instrucción Pública. En el año 1869 es nombrado catedrático de Metafísica de la Universidad. En 1870, es profesor de Historia en la Facultad de Filosofía y Letras, ejerciendo además como abogado del "Ilustre Colegio de Valladolid" del que formó parte de la Junta de Gobierno como secretario en 1873. Decano del Colegio en los años 1877 y 1878. También será nombrado presidente de la Real Academia de Bellas Artes. En 1875 vuelve como catedrático en la Universidad, y a ejercer la abogacía, siendo nombrado decano del Colegio de Abogados en $1877^{1127}$. En junio de 1894, es nombrado "hijo predilecto" de Valladolid

Su carrera política se inicia en los comienzos del Sexenio Revolucionario, como líder del partido republicano. Es elegido concejal y síndico del Ayuntamiento de Valladolid, en el primer consistorio que se celebra a partir de la implantación del Sexenio, aunque es destituido en 1869, al negarse a obedecer las órdenes del capitán general. En el mes de febrero de 1871, se presenta a las elecciones para diputado provincial por el distrito de San Andrés de Valladolid, en la tercera Diputación del Sexenio. Resulta elegido y en la sesión de instalación que se celebra el 17 de febrero de 1871 presentó su acta, que fue aprobada al día siguiente, siendo nombrado en la misma sesión vocal de la comisión de Actas. Sólo asiste a las sesiones del mes de febrero, en la que se convoca a la Diputación en diez ocasiones.

1126 El 17 de mayo de 1863 solicita ser admitido al examen para alcanzar el grado de bachiller en Derecho y acompaña los certificados de los cursos probados desde 1858 a 1863 . Examinado el 20 de mayo, resultó aprobado. El 9 de junio de 1865 solicita el grado de licenciado en Derecho y acompaña los documentos necesarios. Entró a examen el día 12 y salió aprobado" A.H.U.V.A. Cajas 482 (doc. 43 a 48 ) y 686-9.

1127 FERRERO MAESO, Concepción y BERZAL DE LA ROSA, Enrique. Historia del Colegio de Abogados... ob. cit. pág. 229. CARASA SOTO, Pedro. (Dir.). Diccionario biográfico de parlamentarios... ob. cit. pág. 738. 
El 30 de mayo del mismo año de 1871, el Boletín Oficial de la Provincia publica que la Comisión permanente de la Diputación Provincial ha declarado la vacante del diputado provincial por el tercer distrito de Valladolid, denominado San Andrés, en atención a que el electo José Muro López ha optado por el cargo de diputado a Cortes". A partir de esta fecha su actividad política se centra en el Congreso de los Diputados en donde será elegido diputado en trece legislaturas diferentes entre los años 1871 a 1907, siempre en representación del partido republicano y por el distrito de Valladolid.

En el año 1873 es nombrado ministro de Estado en el gobierno formado por Pi y Margall, cargo en el que se mantuvo durante tres semanas y tras haber promovido la ruptura de relaciones con el Vaticano. Con la llegada de la Restauración se retiró de la política temporalmente, ya que volvió al Congreso a partir de las convocatorias del año 1884, manteniéndose prácticamente en el mismo hasta el año 1907. Falleció en Madrid el 18 de junio de 1907.

\section{Nájera, Alejandro}

Con residencia en el pueblo de Villafrechós, es elegido diputado provincial en la tercera Diputación isabelina, por el partido de Rioseco, prestando juramento y tomando posesión de su cargo en la sesión de instalación celebrada el día 26 de diciembre de 1837. Su gran preocupación, que transmite a la Diputación, es la de activar en lo posible los trabajos de construcción del ramal del Canal de Castilla y su llegada a Rioseco. No vio el final de las obras ni completó la legislatura, ya que en la sesión que se celebra en la Diputación el 10 de enero de 1840 , se dio lectura a una comunicación del alcalde de Villafrechós "dando parte de haber fallecido el día 4 del actual el Sr. diputado D. Alejandro Nájera". La Diputación toma el acuerdo de notificarlo al jefe político "y pasar a la viuda la más profunda sensación con la noticia de la muerte de uno de sus más dignos compañeros y que en su obsequio estaban dispuestos a prestarla toda la protección posible" ${ }^{1128}$.

\section{Nava, Ramón María}

Rico propietario y labrador de Tordesillas, que en el año 1860 aparece como el cuarto mayor contribuyente de la provincia por propiedad rural y pecuaria, con 13.769 reales de cuota anual. En el año 1861 es el quinto mayor contribuyente con 12.942 reales.

Es elegido diputado provincial por Tordesillas en la decimoquinta Diputación, prestando juramento y tomando posesión del cargo en la sesión de instalación que se celebra el día 1 de abril de 1860. Es nombrado en la misma sesión diputado vicesecretario, cargo que desempeña hasta el final de la legislatura, que tiene lugar el 30 de marzo de 1862. También es elegido vocal de la Junta de Beneficencia. Asiste a treinta sesiones de las treinta y una que se celebran. Continúa como diputado en la siguiente legislatura, la decimosexta de la era isabelina, en representación asimismo del partido judicial de Tordesillas. Toma posesión en la sesión de instalación que se celebra el día 1 de abril de 1862, ejerce el cargo hasta el final de la legislatura que tiene lugar el 31 de diciembre de 1863, asiste en este tiempo a las veintidós se siones que se celebran. Es el diputado de presencia más asidua a las sesiones, pues entre los dos períodos sólo deja de asistir a una sesión. No vuelve a ejercer como diputado.

\section{Nieto, Dionisio}

Nace en Valladolid en el año 1795. En el año 1822 es funcionario de la Audiencia como "oficial de pluma". En el año 1840 se le conoce como comerciante y propietario. Procedente de bienes desamortizados compró una finca urbana en Valladolid y 39 hectáreas en la Tierra del Vino de Medina por 59.049 reales. Su hermano Manuel actúa de testaferro en la compra de bienes nacionales. Es accionista

1128 A.D.P.V. Actas. Libro de actas del 10 de enero de 1840. 
del ferrocarril Alar-Santander. En el año 1823, con 29 años de edad, ya se dedicaba a la política activa como jefe del partido progresista. Alcanzó el grado de comandante de Caballería de la Milicia Nacional. En el año 1835 es regidor del Ayuntamiento de Valladolid. Elegido diputado provincial por Valladolid, toma posesión de su cargo en la sesión de instalación de la quinta Diputación isabelina, que se celebra el 1 de noviembre de 1843, siendo nombrado en la misma sesión miembro de la comisión de Liquidación de Suministros y miembro de la "Junta de clasificación para conceder a los milicianos la Cruz acordada en el real decreto de 21 de septiembre de 1843". El 14 de noviembre, a los pocos días de su toma de posesión, se enfrenta al jefe político, y a los diputados conservadores, por oponerse al envío por parte de la Diputación de una felicitación a la Reina con motivo de la declaración de su mayoría de edad. El enfrentamiento continuó siempre que se trataba de enviar cualquier tipo de felicitación a la Reina y también ante las situaciones de rebeldía en que se encontraba la población. Llegó a amenazar con dejar de asistir a las sesiones de la Diputación, como lo refleja el Libro de Actas del 12 de marzo de 1844, "a causa de la situación de inseguridad en que vive la ciudad". En octubre de 1845 es nombrado secretario de la corporación, cargo que ejerció hasta febrero de 1846.

El 19 de enero de 1847 el Boletín Oficial de la Provincia publica una sentencia en la que "se absuelve a D. Dionisio Nieto de la denuncia presentada por el promotor fiscal del Juzgado de Primera Instancia de Valladolid, por la alocución dirigida a los electores progresistas". Finaliza su presencia en la Diputación en julio de 1847, fecha en la que acaba la legislatura, asistiendo en este período a ciento setenta y tres de las doscientas cuarenta sesiones celebradas.

En octubre de 1854 vuelve al Ayuntamiento como alcalde $3^{\circ}$, y en 1855 ejerce como alcalde accidental "portándose heroicamente, salvando infinidad de personas, con exposición de su propia vida, en la gran inundación que ocurrió dicho año y en la invasión colérica que en el mismo tuvo lugar" ${ }^{1129}$. En 1856, como alcalde en propiedad de la ciudad, "fue maltratado por la turba de mujeres que produjo gran alboroto y perturbación del orden público, con incendio de casas, cuarteles y talleres y robo y saqueo de las moradas de las principales personas de la ciudad" ${ }^{1130}$. Después de estos sucesos, conocidos con el nombre del "Motín del Pan", dimitió de su cargo el 29 de junio de 1856. A lo largo de su carrera pública fue condecorado con la Gran Cruz de Isabel La Católica, la Cruz del Valor Cívico, la Cruz de Carlos III y la Cinta de la Legión de Honor. En el Boletín Oficial de fecha 23 de agosto de 1867, se publica un anuncio sobre "la venta del oficio de procurador de la Audiencia que pertenece a Dionisio Nieto". Murió en Valladolid en el año 1871.

\section{Ocejo Bringas, Remigio}

Comerciante y vecino de Valladolid, que en el año 1867 es el trigésimo tercer mayor contribuyente de la provincia por comercio, con una renta de 286 escudos anuales.

En las elecciones que se celebran en el distrito de San Andrés de Valladolid entre los días 14 y 17 de junio de 1871, para cubrir la baja del Sr. Muro López, en la tercera Diputación del Sexenio, es electo diputado por 310 votos contra 4 de otros candidatos. Fue aprobada su acta en la sesión que se celebra el 20 de julio de 1871 y asiste por vez primera a las sesiones de la Diputación el 11 de diciembre del repetido año 1871. A partir de esa fecha asiste a doce sesiones hasta el final de la legislatura en octubre de 1872. En la sesión del 25 de julio de 1872, en el sorteo celebrado entre los diputados, le tocó cesar y no vuelve a estar presente en más Diputaciones.

1129 GONZALEZ GARCÍA-VALlADOLID, Casimiro. Datos para la historia... ob. cit. Tomo II, pág. 133.Igualmente figura como alcalde en la Lista de los Señores Vecinos que han constituido sus Corporaciones Municipales desde 1800 a 1900 inclusive. Imprentas Zapatero. Valladolid. 1901.

1130 Ibídem. Tomo II, pág. 134. 


\section{Olivares, Galo}

En los años 1869 y 1870 es elegido alcalde de Villaverde de Medina. En las elecciones que se celebran para cubrir las vacantes de la cuarta Diputación del Sexenio, que tienen lugar en el mes de septiembre de 1872, se presenta como candidato a diputado provincial por el distrito y partido de Medina. Es elegido por 479 votos contra 473, que consigue el alcalde de Medina y diputado provincial en los años 1867-68, Celestino Dueñas. Se presenta en la sesión de instalación que se celebra el 2 de noviembre de 1872 con su acta, que es aprobada en la sesión del día 4 . El 8 del mismo mes es elegido miembro de la Comisión permanente, de la que toma posesión el 13 de noviembre. Se mantiene en la Diputación hasta el final de la legislatura que tiene lugar el 11 de mayo de 1874. Asiste en este tiempo a treinta y seis de las cuarenta y dos sesiones de la Diputación, y a ciento una sesiones de la Comisión permanente de las ciento setenta y seis que se celebran en este período.

\section{Osorio Casasola, Mariano}

Es elegido diputado provincial por el distrito y partido de La Nava de la Libertad, en las elecciones que se celebran los días 1,2 y 3 de febrero de 1871 , en representación del partido carlista. En la sesión de instalación de la tercera Diputación del Sexenio que se celebra el día 17 de febrero presentó su acta de elección, siendo en la misma sesión nombrado secretario interino, al ser el diputado más joven. En la sesión del día 23 se aprueba su acta de diputado por 21 votos a favor y 2 en contra, "en medio de una fuerte discusión, porque varios diputados contrarios a la aprobación, pidieron la anulación del acta de elección porque el diputado electo Mariano Osorio, representante de la candidatura Carlista, había forzado la votación con amenazas y con gente armada en la puerta del colegio electoral. Además se apoyó en el párroco, que amenazó con la condenación eterna a todos los que no apoyaran la candidatura carlista" ${ }^{1131}$. En la legislatura asistió a treinta y una sesiones de las setenta que se celebraron, la mayoría de ellas en el año 1871 y desde febrero de 1872 hasta octubre del mismo año en que finaliza la legislatura no asiste a ninguna sesión. En la sesión del 25 de julio de 1872 , le tocó por sorteo cesar en el cargo

En las elecciones de septiembre de 1872, para diputados provinciales de la cuarta Diputación, se presenta de nuevo como candidato por el partido y distrito de La Nava de la Libertad. Vuelve a ser elegido con 490 votos, siendo candidato único en representación del partido carlista. Se presenta en la Diputación el día 4 y presentada su acta es aprobada "porque no tiene protestas de ninguna clase". Apenas asiste a las sesiones de la Diputación, sólo a siete, todas en los primeros meses de la legislatura. El 9 de marzo de 1874, el Sr. capitán general informa a la Diputación que "en uso de las facultades extraordinarias de que se haya investido anuncia el cese de varios diputados y el nombramiento de los que les sustituyen". Y entre los que se encuentra Osorio. No vuelve a presentarse como diputado.

\section{Palmero Olea, Carlos}

Nació en el pueblo de Villabrágima en el año 1821. En 1843 alcanza el grado de Bachiller en Jurisprudencia por la Universidad de Valladolid ${ }^{1132}$.

En noviembre de 1863 , se presenta a las elecciones para diputado provincial, por el partido de Villalón, y resulta elegido en la decimoséptima Diputación isabelina. Se presenta en la sesión de instalación que se celebra el 1 de enero de 1864, en la que presta juramento y toma posesión del cargo. En la misma sesión es nombrado miembro de la comisión de Obras. Permanece en el cargo a lo largo de la legislatura que se da por finalizada el 31 de diciembre de 1865 , en la que asiste a treinta y una de las

1131 A.D.P.V. Actas. Libro de actas del 23 de febrero de 1871.

1132 "Solicitó el ingreso en la Universidad de Valladolid el 30 de octubre de 1833, a la edad de 12 años, matriculándose en la Facultad de Leyes. El 23 de junio de 1841, presenta la solicitud para ser examinado del Grado de bachiller en Jurisprudencia y examinado el 17 de julio, salió aprobado némine discrepante" A.H.U.V.A. Caja 467 (doc. 288 a 292). 
cuarenta y nueve sesiones que se celebran. No vuelve a presentarse en otras elecciones.

\section{Pastor, Ángel}

Es natural de Mayorga, perteneciente al partido judicial de Villalón, y a la sazón, a la diócesis de León. Cursó estudios universitarios en la Facultad de Derecho de la Universidad de Valladolid, en la que ingresó en el año 1827 y en la que se mantuvo hasta 1835, año en el que aprobó el examen de grado de bachiller en Leyes

Inicia su actividad política como diputado provincial por el partido de Villalón, tomando posesión del cargo el 1 de abril de 1852, fecha en la que se celebra la sesión de instalación de la octava Diputación isabelina cuando prestó el juramento correspondiente. Se mantiene en el cargo a lo largo de la legislatura, que finaliza el 30 de marzo de 1854, asistiendo a catorce de las veintitrés sesiones celebradas. Continúa como diputado por el mismo partido en la siguiente Diputación, la novena, que comienza el 1 de abril de 1854 hasta el 24 de julio del mismo año, aunque en este período no asiste a ninguna de las catorce sesiones que se celebran. Una vez finalizado el período del Bienio Progresista, es nuevamente llamado para representar como diputado provincial, al partido de Villalón. Toma posesión del cargo en la sesión de instalación de la decimotercera Diputación, que se celebra el 2 de diciembre de 1856, se mantiene hasta el 30 de junio de 1858, fecha en la que finaliza la legislatura. Asiste a diecinueve de las veintisiete sesiones que se celebran. A partir de esta fecha no vuelve a ejercer ningún otro cargo político.

\section{Pérez, Manuel}

Es elegido diputado provincial por el partido de Valoria en la primera Diputación de la época isabelina. Se presenta y toma posesión de su cargo en la sesión de instalación celebrada el 22 de octubre de 1835. Es nombrado vocal de la comisión de Fomento y Hacienda, y asiste a ochenta y dos de las ciento veintidós sesiones celebradas. En el mes de marzo de 1836, y ante la ausencia del jefe político, actúa como presidente interino de la Diputación en siete sesiones. Su actividad política provincial finaliza con la legislatura de esta Diputación en octubre de 1836, no volviendo a estar presente en ninguna otra legislatura.

\section{Pérez Cantalapiedra, Atanasio}

Nació en Pozaldez, el 2 de mayo del año 1806, hijo de Juan Pérez Maestro y de Laureana Cantalapiedra de Castro. Su padre era el médico de Pozaldez. Tuvo dos hermanos: Julián, propietario y labrador en Matapozuelos, que fue diputado provincial en el Sexenio Revolucionario, y Antonio, juez de Primera Instancia en Nava del Rey. La mayor parte de su vida la pasó en Valladolid, ciudad a la que se traslada para iniciar sus estudios y en la que posteriormente desarrollará su vida profesional. En octubre de 1820 solicita su ingreso en la Facultad de Teología de la Universidad de Valladolid, alcanzando el grado de bachiller en 1824. Continúa sus estudios en la Facultad de Leyes, en la que se gradúa como bachiller en julio de 1826 y licenciado en octubre de 1829. Pasa a la Facultad de Filosofía, en la que consigue el grado de bachiller en 1833. En 1835 es confirmado como doctor en Filosofía, siendo nombrado catedrático de la misma Facultad, ocupando la Cátedra hasta 1869, año de su jubilación. Entre 1863 y 1869 ocupa los cargos de vicerrector y rector de la institución ${ }^{1133}$.

Es un importante propietario agrícola, con la mayoría de su patrimonio centrado en su pueblo natal. En 1840 compró 40 hectáreas de fincas desamortizadas en

1133 A.H.U.V.A. Cajas 451 (doc. 59 a 67), 503 (doc. 203 a 204), 557 (doc. 358 a 364 ), 575 y 699 (doc.21). 
la zona de Tierra de Pinares, por las que pagó 21.125 reales y además adquirió una finca urbana en Valladolid ${ }^{1134}$.

En política es considerado como liberal-progresista y esparterista de convicción. Es oficial de la Milicia Nacional. Inicia su carrera en la Diputación Provincial de Valladolid, cuando en diciembre de 1837, es elegido diputado provincial por el partido de Olmedo en la tercera Diputación isabelina. Toma posesión en la sesión de instalación celebrada el día 26 y se mantiene en el cargo hasta el final de la legislatura, que tiene lugar el 31 de diciembre de 1840. Asiste en este período a cien to noventa y siete sesiones de un total de doscientas veintitrés que se celebran. El día 2 de enero de 1841 se inician las actividades de la cuarta Diputación isabelina, en la que vuelve a ser elegido diputado provincial, en esta ocasión en representación del partido de Medina. Se mantiene en el cargo hasta el mes de abril del mismo año, mes en el que presenta la dimisión por haber sido elegido diputado a Cortes por la provincia vallisoletana. En su período de diputado provincial asiste a veintidós sesiones. Durante los años 1841 y 1842 ocupa el cargo de diputado en Cortes "ofreciendo sus servicios a la Diputación para trabajar en Madrid por el bien de la provincia" y defendiendo en las Cortes la necesidad de inversiones en la provincia vallisoletana. En especial insistió en la construcción de carreteras, entre las que se encontraba la que unía a Olmedo con Valladolid, que atravesaba su pueblo natal. En el año 1843, el 3 de febrero, tomó posesión del cargo de alcalde $1^{\circ}$ constitucional de Valladolid "al haber sido exonerado el elegido Manuel Martín Lozar". En mayo de 1843 vuelve nuevamente a ser elegido diputado a Cortes, anunciando el día 28 su toma de posesión. Al finalizar la legislatura y con el final de la Regencia de Espartero se aleja temporalmente de la política. Con el inicio del Bienio Progresista vuelve a la actividad política cuando el 18 de julio de 1854, con ocasión del Pronunciamiento de Espartero es nombrado vocal de la Junta Provisional del Gobierno de la Provincia. En octubre del mismo año es elegido nuevamente diputado a Cortes por la provincia alcanzando un total de 6.440 votos y anuncia "la promesa de trabajar durante toda la legislatura para llevar a cabo la línea del ferrocarril del Norte" ${ }^{" 135}$. El fin del período progresista le hace nuevamente alejarse temporalmente de la política. En el año 1863 es nombrado rector de la Universidad, medida que es acogida con satisfacción en los medios universitarios por su carácter abierto y liberal.

En el año 1868 se declara partidario del movimiento revolucionario del Sexenio, se vuelve a presentar a las elecciones de diputados a Cortes y consigue un escaño con 16.366 votos. En esta legislatura defiende la candidatura de Espartero al trono de España. En el año 1871 se presentó y fue elegido senador, manteniéndose en el cargo hasta 1875. Falleció en Pozaldez el 8 de febrero de 1876.

\section{Pérez Cantalapiedra, Julián}

Vecino, propietario y labrador de Matapozuelos, es hermano de Atanasio, rector de la Universidad, y diputado provincial en la tercera y cuarta Diputación isabelina que transcurre entre 1837 y 1843. Su otro hermano, Antonio, es juez de Primera Instancia en Nava del Rey.

En febrero de 1871, se presenta a las elecciones para diputado provincial, por el distrito de Matapozuelos, del partido judicial de Olmedo, y resultó elegido. Presenta su acta en la sesión de instalación de la tercera Diputación del Sexenio, que tiene lugar el 17 de febrero de 1871, y es aprobada en la sesión del día 19. El 25 de julio de 1872, en la sesión de la Diputación se efectúa el sorteo para conocer a los diputados

\footnotetext{
1134 RUEDA HERNANZ, Germán. La Desamortización... ob. cit. pág. 292.

${ }^{1135}$ B.O.P.V. $\mathrm{n}^{\circ} 125$ de fecha 19 de octubre de 1854. CARASA SOTO, Pedro (Dir.). Diccionario biográfico de parlamentarios... ob. cit. pág. 818. CARASA SOTO, Pedro (Dir.). Diccionario biográfico de alcaldes... ob. cit. pág. 537.
} 
que les corresponde cesar, siendo uno de ellos, por lo que deja la Diputación al final de la legislatura en octubre de 1872, habiendo asistido a veintinueve de las setenta sesiones que se celebran. No vuelve a presentarse como candidato en ninguna otra elección.

\section{Pérez Minayo, Fructuoso}

Nació en Urueña, del partido judicial de La Nava y provincia de Valladolid, en el año 1820. "Inició sus estudios en el Seminario de Burgos en los años 1833 a 1836. El 25 de noviembre de 1836 solicita el ingreso en la Universidad de Valladolid, matriculándose en la Facultad de Leyes. El 20 de junio de 1840 es examinado para alcanzar el grado de bachiller en Jurisprudencia, siendo aprobado némine discrepante. El 23 de enero de 1843, solicita ser examinado para alcanzar el grado de licenciado en Jurisprudencia, y fijado el día 1 de febrero para el examen, salió aprobado" "1136. Se traslada a Alaejos, pueblo en el que fija su residencia, donde ejerce la abogacía, actividad que mantiene hasta el año 1884, como lo refleja el Anuario del Colegio de Abogados de Medina-Olmedo-Nava de dicho año, que le señala "como colegiado que no ejerce".

En el año 1864, reclama a la Diputación a favor de la validez del acta de diputado por el partido de Nava del Rey de Vicente Delgado, en oposición al otro candidato, Juan de Mata Zorita. Presenta "una exposición pidiendo la nulidad de las elecciones en Nava del Rey, porque no habían concurrido a las elecciones la mayoría absoluta de electores, ya que siendo 383 electores, sólo aparecían 183 votantes. La Diputación estudiados los informes, dio como buena la elección de Vicente Delgado" 1137.

Inicia su actividad política, como diputado provincial, en la quinta Diputación del Sexenio, cuando es nombrado por el gobernador civil, en representación del distrito de Alaejos, partido judicial de Nava de la Libertad. Toma posesión del cargo en la sesión de instalación que se celebra el 30 de mayo de 1874, siendo nombrado en la sesión del siguiente día vocal suplente de la Comisión permanente. Ejerce el cargo a lo largo de toda la legislatura que finaliza en marzo de 1875 y en la que asiste a quince de las dieciocho sesiones que se celebran. Vuelve a ser nombrado diputado provincial por Alaejos en la primera Diputación de la Restauración, que transcurre entre 1875 y 1877. En el año 1883 vuelve a la Diputación, al ser elegido por los "fusionistas" en representación del distrito Nava-Tordesillas. Su hijo Manuel continuará su trayectoria política en la Diputación, al ser nombrado a partir de 1886 y en varias legislaturas, diputado por el distrito de Audiencia-Mota.

\section{Pestaña, José}

Párroco de Manganeses de la Polvorosa, perteneciente al partido de Benavente. Eselegido diputado provincial en las elecciones que se celebran el día 30 de agosto de 1813, por el partido judicial de Benavente en la primera Diputación. Es uno de los diputados más activos de la institución asistiendo a treinta y cinco sesiones de las cincuenta y dos que se celebran a lo largo de la legislatura (en detrimento de la atención a su parroquia).

En el año 1820, con la nueva puesta en marcha de la Diputación, es llamado a formar parte de la misma, representando igualmente al partido de Benavente. En esta primera Diputación del Trienio, marzo a junio de 1820, asiste a veinticinco de las treinta y cuatro sesiones celebradas. Para la segunda Diputación del Trienio, es elegido nuevamente, asistiendo a noventa y siete de las ciento setenta y tres sesiones entre julio de 1820 y febrero de 1822 . Se presenta y es elegido para la tercera Diputación del Trienio, como diputado por Benavente en la Diputación de Valladolid, aunque no llega a asistir a los plenos, porque con ocasión de la nueva "Ley sobre la

1136 A.H.U.V.A. Cajas 466 (doc. 337 a 342) y 670.

1137 A.D.P.V. Actas. Libro de actas del día 4 de enero de 1864. 
División Provisional del Territorio Peninsular" promulgada en enero del mismo año 1822, el partido judicial de Benavente pasa a depender de la provincia y Diputación de Zamora, y en consecuencia el diputado Pestaña pasa a desarrollar su trabajo en la Diputación zamorana.

Es un convencido liberal al que le gusta la política provincial y que se mantendrá como diputado en Zamora hasta el final de las actividades de la Diputación y del período del Trienio Liberal en abril de 1823. Un detalle de su afán por participar en la vida política provincial, lo tenemos en la queja que envía a la Diputación de Zamora, lamentándose de "la imposibilidad de trasladarme a la toma de posesión a causa de las amenazas e insultos que he recibido del faccioso Rojo de Valderas" ${ }^{1138 .}$

\section{Pimentel Arévalo, Pedro Antonio}

Natural de Rueda, villa en la que nació el 7 de junio de 1830, hijo de Vicente Pimentel Bayón y de Cándida Arévalo. Su padre, Vicente Pimentel Bayón, ha sido diputado provincial en diferentes legislaturas desde el año 1837 y ha ejercido como vicepresidente del Consejo provincial, actuando como tal como gobernador interino. También ha sido diputado a Cortes y senador del Reino. Su hermano Cándido fue diputado a Cortes por el distrito de Medina en 1863 y por el distrito de Nava de la Libertad en 1873. Por parte de su madre es sobrino de los Arévalo Miera, de los cuales Ignacio María fue diputado provincial entre 1850 y 1854 y sus tíos Felipe y Fernando serán diputados en el periodo del Sexenio Revolucionario. No se le conoce relación de parentesco con Juan Manuel Arévalo, también diputado provincial por Olmedo en el Bienio Progresista.

"Estudia en la Universidad de Valladolid, en la que ingresa en el año 1844 matriculándose en la Facultad de Leyes. El 3 de junio de 1848, solicita ser examinado para alcanzar el grado de bachiller en Jurisprudencia y acompaña los certificados de los cursos probados. Examinado el día 14, salió aprobado. El 2 de junio de 1851 solicita ser examinado para alcanzar el grado de licenciado en Jurisprudencia y examinado el día 21 fue aprobado por unanimidad" "1139. Es miembro del Colegio de Abogados "aunque no ejerce" según consta en las "Listas de Abogados del Ilustre Colegio de los Partidos de Medina, Olmedo y Nava del Rey del año 1884-85"

Se casó con Francisca Alonso Pesquera, hija del importante industrial y propietario de Quintanilla, Millán Alonso del Barrio. Pertenece a una rica familia de agricultores y propietarios, con posesiones en Valladolid, Villanueva, Sardón, Quintanilla y Olmos. Reside en Valladolid, aunque también tiene casas en Quintanilla y Sardón. Compró en Olmos una finca de 25 hectáreas procedentes de bienes desamortizados por la que pagó 34.400 reales. Es Vocal de la Junta de Agricultura y miembro del consejo de administración de la Compañía Hispano-Portuguesa de Seguros de Cereales y Ganados, Presidente del Centro de Labradores y socio fundador del Círculo de Recreo de Valladolid. En el año 1862, actúa como asesor del Ayuntamiento de Valladolid con la finalidad de "encontrar la forma de cubrir el déficit municipal". En el mismo año es el trigésimo segundo mayor contribuyente de la provincia por comercio con 315 reales de cuota anual.

El día 1 de abril de 1862, inicia su carrera política al tomar posesión, en la sesión que celebra la decimosexta Diputación de la época isabelina, del cargo de diputado provincial por el partido judicial de Olmedo. Actúa a lo largo de la legislatura, que finaliza el 31 de diciembre de 1863, asistiendo a la totalidad de las veintidós sesiones que se celebran. Continúa ejerciendo como diputado provincial por Olmedo en la decimoséptima Diputación, que se inicia el 1 de enero de 1864. En esta sesión toma posesión del cargo y es nombrado miembro de la comisión de Estudio del Acta de Nava del Rey y también miembro de la comisión de Establecimientos Benéficos. En la primera reunión ordinaria de 1865, que se celebra el 18 de abril, es

1138 MARTÍN BOBILLO, Pablo. Los orígenes de la Diputación ... ob. cit. pág. 98.

1139 A.H.U.V.A. Cajas 474 (doc. 76 a 80 ) y 676-38. 
nombrado "Representante de la Provincia en el Exterior". En esta legislatura, que finaliza en diciembre de 1865 , asiste a cuarenta y seis de las cuarenta y nueve sesiones que se celebran. Se presenta y vuelve a ser elegido diputado provincial por Olmedo en la decimoctava Diputación que inicia sus actividades el 1 de enero de 1866. En la sesión de instalación es nombrado miembro de la comisión de Estudios del Acta de Tordesillas. Se mantiene en el cargo hasta el final de la legislatura en diciembre del mismo año 1866, asistiendo a quince de las dieciocho sesiones que se celebran.

No vuelve a presentarse como candidato ni en la última Diputación de la era isabelina ni en las cuatro primeras Diputaciones del Sexenio Revolucionario. El 30 de mayo de 1874, fecha de la instalación de la quinta y última Diputación del Sexenio, "se presenta en la Diputación convocado por el Sr. gobernador civil de la provincia, que en uso de sus facultades acuerda su nombramiento como diputado provincial por el distrito séptimo de Valladolid, parroquia de Santiago, tomando posesión de su cargo" 1140 . En la sesión del 17 de junio es nombrado miembro de la comisión de Cuentas y de la comisión Inspectora de Establecimientos de Enseñanza. Se mantiene en la Diputación hasta el final de la legislatura, que tiene lugar el 18 de marzo de 1875, aunque en noviembre de 1874 "presenta su renuncia al cargo, con el acuerdo de la Diputación de pasarlo al Sr. gobernador, con el ruego de que no fuera admitido" "1141 Asiste a trece de las dieciocho sesiones celebradas. Continúa como diputado provincial en la primera Diputación de la Restauración que se inicia el 1 de abril de 1875, es elegido presidente de la Corporación en 1876 en sustitución de Alonso Pesquera que pasa como diputado a Cortes. No se presenta en las elecciones de 1877. En 1882 es elegido diputado a Cortes por Nava del Rey, dentro de las filas "gamacistas" y en 1893 es senador del Reino y solicita ser nombrado senador vitalicio ${ }^{1142}$. Fallece en Valladolid el 29 de enero de 1910.

\section{Pimentel Bayón, Vicente}

Natural y vecino de Rueda, donde nació el 22 de enero de 1803, hijo de Juan Nepomuceno y de Catalina. Es el iniciador de una importante y poderosa saga familiar, tanto en la faceta económica como en la política. Es cuñado de Ignacio Arévalo, consuegro de Millán Alonso, padre de Cándido y Pedro Antonio Pimentel Arévalo y abuelo de Julio Pimentel Alonso-Pesquera, todos ellos diputados provinciales y parlamentarios en los años isabelinos y en la Restauración. Se casó con Cándida Arévalo. Reside en Rueda donde desarrolla su trabajo de agricultor y propietario. Promotor y accionista del ferrocarril Alar-Santander. Miembro de la Asociación de Propietarios Territoriales de España. En el año 1848 compró un convento desamortizado en Tierra de Pinares por el que pagó 944.000 reales también adquirió el palacio de los marqueses de Castromonte de Valladolid. En el año 1860 aparece como el sexto mayor contribuyente de la provincia con una renta de 12.640 reales y en el año 1861 está considerado como el primer contribuyente con 15.465 reales. En 1863 pagó 18.758 reales por impuestos de la propiedad rural y pecuaria ${ }^{1143}$,

En política está catalogado en principio con la etiqueta de conservador. Inicia sus actividades cuando es elegido diputado provincial por el partido judicial de Medina en la tercera Diputación de la era isabelina que comienza el 26 de diciembre de 1837, sesión en la que toma posesión y presta juramento. Se presentó una reclamación porque "la elección se había protestado en razón a que varios sujetos habían votado sin derecho, pero el número total de votos obtenido, menos los que se decían no debían ser incluidos, le resultaba una gran mayoría a su favor, por lo que se

1140 A.D.P.V. Actas. Libro de actas del 30 de mayo de 1874.

1141 A.D.P.V. Actas. Libro de actas del 7 de noviembre de 1874.

1142 PASTRANA MORILLA, Heliodoro. La Diputación provincial de ... ob. cit. pág. 415

1143 RUEDA HERNANZ, Germán. La Desamortización... ob. cit. pág. 248. B.O.P.V. nº 9 de 20 de enero de 1860 y n $^{\circ} 157$ de 4 de octubre de 1861. 
rechazó la reclamación" ${ }^{1144}$. Se mantiene en el cargo hasta el final de la legislatura en diciembre de 1840 , asiste a ochenta y seis sesiones.

En el año 1844 es elegido diputado a Cortes por Valladolid con 3.817 votos. Se vuelve a presentar en 1846 pero es derrotado por el candidato gubernamental. En 1847 es vocal de la Junta de Agricultura. El 8 de enero de 1851 es nombrado senador vitalicio. No vuelve a ejercer ninguna otra actividad política hasta el año 1856, con el final del Bienio Progresista y la publicación de la real orden de 26 de julio por la que "se ordenaba la disolución de la Diputación y su remplazo por otra nueva". Y de acuerdo con lo ordenado, el capitán general le nombra diputado provincial de una Diputación, la duodécima de la época isabelina, de "claro matiz conservador". Toma posesión el día 19 de agosto, también por el partido de Medina, se mantiene en el cargo los cuatro meses que dura la legislatura, asiste en este tiempo a cuarenta de las cincuenta y tres sesiones que se celebran, y preside la Diputación en dos ocasiones, por ausencia del gobernador y en calidad de presidente interino. En octubre de 1856 es nombrado vicepresidente interino del Consejo provincial, organismo puesto en marcha nuevamente a raíz del restablecimiento de la Ley Provincial de 8 de enero de $1845^{1145}$, cesando en el cargo el 18 de noviembre del mismo año.

En diciembre de 1856 se renueva la Diputación y se inician los trabajos de la decimotercera Diputación isabelina, continuando en su puesto de diputado por el partido de Medina, se mantiene en el cargo hasta junio de 1858, fecha en la que termina la legislatura. En este período sólo asiste a las cuatro primeras sesiones de las veintisiete que se celebran. Su ausencia de la Diputación tiene un paralelismo con su salida del Consejo provincial, que sucede a primeros de 1857, cuando deja de asistir a las sesiones. En abril de 1859, aparece nuevamente en política, en esta ocasión a nivel nacional, al ser nombrado senador. En su ejercicio como tal, la Diputación Provincial le remite un oficio por el que le solicita que "la represente ante el Ministerio de Fomento para discutir las deudas de la carretera Burgos-Berceda, que se imputan a la provincia" 1146 . Su hijo Pedro Antonio Pimentel Arévalo, será diputado provincial a partir del año 1862, y repite en el Sexenio y en la Restauración. Fallece en Valladolid el 15 de febrero de 1868.

\section{Pinilla García, Pablo}

Nació en el año 1846 en el pueblo de Casasola de Arión. Licenciado en Derecho Civil y Canónico por la Universidad de Valladolid ${ }^{1147}$.

Se presenta como candidato a diputado provincial por el distrito de La Mota, del partido judicial de Tordesillas, en las elecciones que se celebran los días 1 a 3 de febrero de 1871 para cubrir las vacantes de la tercera Diputación del Sexenio. Al resultar elegido, presenta su acta en la sesión de instalación que tiene lugar el 17 de febrero de 1871, siendo aprobada en la sesión del día 19. No es elegido para ninguna comisión y asiste a cincuenta y cinco de las setenta sesiones que se celebran hasta el final de la legislatura en octubre de 1872. En la sesión del 25 de julio de 1872, en el sorteo celebrado para decidir los diputados que debían de cesar, le correspondió continuar en el cargo.

El 2 de noviembre de 1872, fecha de instalación de la cuarta Diputación, se presenta en la sesión para iniciar las actividades de la nueva legislatura, en la que continúa ejerciendo la representación del distrito de La Mota. El 8 de noviembre es

1144 A.D.P.V. Actas. Libro de actas del 26 de diciembre de 1837.

1145 B.O.P.V. no 127 de fecha 21 de octubre de 1856.

1146 A.D.P.V. Actas. Libro de actas del 9 de abril de 1859. CARASA SOTO, Pedro (Dir.). Diccionario biográfico de parlamentarios ... ob. cit. pág. 804.

1147 "Solicitó el ingreso en la Universidad de Valladolid en el año 1861, matriculándose en la Facultad de Leyes. El 8 de junio de 1866, solicita ser examinado para alcanzar el grado de bachiller en Derecho Civil y Canónico, para lo cual adjunta los certificados de los cursos probados entre 1861 y 1866. Examinado el día 12, resultó aprobado. El 4 de junio de 1868, solicita ser examinado para conseguir el grado de licenciado en Derecho Civil y Canónico. Entró a examen el día 17, y salió aprobado" A.H.U.V.A. Cajas 483 (doc. 360 a 366) y 687-33. 
nombrado vocal de la Comisión permanente y en febrero de 1874, vicepresidente de la citada Comisión. Finaliza su actuación como diputado el 11 de mayo de 1874, fin de la legislatura, habiendo asistido a treinta y tres de las cuarenta y dos sesiones de la Diputación y a ciento cincuenta y una de ciento setenta y dos que se celebran en la Comisión permanente. No se vuelve a presentar a más elecciones.

\section{Pizarro Cuadrillero, Vicente}

Nació en Valderas, provincia de León, el 22 de enero de 1826, bautizado en el mismo pueblo el 28 de enero, se le impusieron los nombres de Vicente Agustín Hermenegildo. Hijo de José María Pizarro Diez, natural de Valencia de Don Juan en León y de Venancia Cuadrillero de Rioseco en Valladolid. Su padre fue diputado provincial por Rioseco en los años 1856 a 1858 (ver a continuación.). Su tío y padrino Hermenegildo Cuadrillero Herce también representó como diputado provincial a Rioseco en la tercera Diputación del Trienio 1822-1823. Tanto por línea paterna como materna, pertenece a dos importantes familias de Rioseco, los Cuadrillero son una familia de la baja nobleza rural de Palazuelo de Vedija y los Pizarro son una familia noble e ilustre radicada de tiempo del antiguo Régimen en Rioseco ${ }^{1148}$.

"Estudió en la Universidad de Valladolid en la que solicitó el ingreso el 31 de octubre de 1838 , matriculándose en la Facultad de Leyes ${ }^{1149}$. Fija su residencia en Rioseco, ciudad en la que en el año 1865 compra una casa procedente de bienes desamortizados y que perteneció a la Beneficencia de Rioseco. Es uno de los principales propietarios de fincas con un total de 195 hectáreas.

Afiliado al partido conservador, se presenta a las elecciones para diputado provincial por Rioseco, en las que resultó elegido. El 1 de enero de 1867 en la sesión de instalación de la decimonovena y última Diputación, se presenta, presta juramento y toma posesión del cargo. En la sesión extraordinaria celebrada en julio de 1867 es nombrado "Representante de la Diputación en el Exterior", cargo que ostenta hasta el final de la legislatura. En febrero de 1868 es nombrado miembro de la comisión de Hospitales. El 20 de septiembre de 1868, se da por terminada la legislatura a la que asistió a cuarenta y cinco de las cincuenta y dos sesiones celebradas. Durante el período del Sexenio no participa en política. A partir de la Restauración, vuelve a ser elegido diputado provincial entre 1877 y 1883 por el distrito de Rioseco y en 1884 en representación del distrito Rioseco-Villalón, estando considerado en estos años como uno de los conservadores de mayor prestigio. En la nueva Diputación de 1886 es renovado en el cargo y accede a la presidencia como diputado de más edad, en una Diputación dividida entre gamacistas y conservadores. Al autorizar unos pagos sin ser "ordenador de pagos" es denunciado por los gamacistas, y al ser exculpado vuelve a la Diputación en la que se mantiene hasta $1888^{1150}$. En 1890 actúa de gobernador interino.

\section{Pizarro Diez, José María.}

Natural del pueblo de Valencia de Don Juan, en la provincia de León. Pasó muy joven a residir a la ciudad de Rioseco, donde se casó con la vecina de la localidad Venancia Cuadrillero ${ }^{151}$. Ambas familias, los Cuadrillero y los Pizarro, como hemos puesto de manifiesto en la biografía de su hijo Vicente Pizarro Cuadrillero, son destacadas representantes de las élites agrícolas industriales y comerciales de la

1148 CANO GARCIA, Juan Antonio.” La transmisión familiar del poder político en Valladolid durante la época contemporánea" en CONTRERAS CONTRERAS, Jaime. Familia, poderes, instituciones y conflictos. Edium. Murcia. 2010. págs. 235 a 248.

${ }^{1149}$ El 21 de junio de 1845 solicita ser admitido a examen para alcanzar el grado de bachiller en Jurisprudencia y celebrado el examen el 18 de julio, salió aprobado. El 26 de mayo de 1847, solicita se le conceda el grado de licenciado en Jurisprudencia y en los exámenes celebrados los días 2, 9 y 16 de julio, fue aprobado por 4 votos, tomando posesión del grado en el Claustro celebrado el 18 de julio de 1847" A.H.U.V.A. Cajas 471 (doc. 244 a 249) y 673-50.

${ }^{1150}$ PASTRANA MORILLA, Heliodoro. La Diputación provincial de ... ob. cit. pág. 445

${ }^{1151}$ CANO GARCIA, Juan Antonio. La transmisión familiar del poder polít... ob. cit. págs. 235 y sig. 
ciudad, y en consecuencia también controlan el poder político. El matrimonio tuvo tres hijos, Frutos, Vicente y Julián. Su hijo Vicente ejercerá también como diputado provincial en los períodos isabelino y de la Restauración (ver biografía anterior). No se le conocen estudios universitarios, y desde un principio se dedicó a la agricultura y el comercio. En el año 1860, es el trigésimo noveno mayor contribuyente de la provincia por propiedad territorial y pecuaria con una cuota anual de 4.020 reales. En 1861 es el trigésimo segundo contribuyente provincial con 4.209 reales y en el año 1867 es el cuadragésimo primero mayor contribuyente con 470 escudos.

En el año 1835 inicia su carrera política, de ideología liberal, al ejercer como alcalde de Rioseco, donde se enfrenta al Consejo de Disciplina de la Milicia Nacional de la ciudad, que pretendía que dejase la alcaldía ante la que consideraban una mala gestión por su parte, en relación con la Milicia. "Ante la queja del batallón de la Milicia Nacional en orden a la reducción de quintos, la Diputación acordó que no había motivo para anular la elección del alcalde Pizarro" "1152. En noviembre de 1856 se presenta a las elecciones para diputado en la decimotercera Diputación isabelina y al resultar elegido, se presentó el día 2 de diciembre de 1856, en la sesión de instalación, donde juró el cargo y tomó posesión del mismo, en representación del partido judicial de Rioseco. La legislatura se da por finalizada en diciembre de 1858, y en este tiempo asiste a quince de las veintisiete sesiones que se realizan. No vuelve a presentarse en ninguna otra elección.

Falleció en Rioseco el 2 de junio de 1869, y con posterioridad aparecen una serie de anuncios judiciales que cuestionan la gestión de su hacienda. Así el 28 de julio de 1871, "Frutos Pizarro Cuadrillero, reclama la posesión de los bienes de su padre José Pizarro Diez...". Anuncio que se completa con la petición del Juzgado de Rioseco que con fecha 10 de octubre de 1873, publica un anuncio en el Boletín Oficial de la Provincia en el que "emplaza a Frutos, Vicente y Julián Pizarro Cuadrillero para que se presenten en juicio por las deudas de su padre".

\section{Prado Martínez, Justo Rufino de}

Nació el 19 de julio de 1815, en el pueblo de Santervás de Campos, provincia de Valladolid. Es hijo de Pedro de Prado y María Martínez. Fue licenciado en Jurisprudencia por la Universidad de Valladolid ${ }^{1153}$.

Es elegido diputado provincial por el partido de Villalón en las elecciones celebradas en noviembre de 1866 para cubrir las vacantes de la decimonovena Diputación isabelina y presentado en la sesión de instalación que se realiza el 1 de enero de 1867, prestó juramento y tomó posesión del cargo. Ejerce el mismo hasta el final de la legislatura, que tiene lugar el 20 de septiembre de 1868, asistiendo a cuarenta y ocho de las cincuenta y dos sesiones que se celebran. En el curso de esta Diputación fue elegido presidente en la reunión extraordinaria de abril y septiembre de 1867 y "Representante de la Provincia en el Exterior" a partir de julio de 1867 hasta el final de la legislatura. No vuelve a ejercer como diputado en ninguna otra convocatoria.

\section{Prieto, José Luis}

El día 15 de agosto de 1847 se inician los trabajos de la sexta Diputación isabelina.En esta sesión, el diputado electo por Valladolid no toma posesión, situación que se prolonga hasta el mes de diciembre. En esta fecha "el Gobierno Político de la

1152 A.D.P.V. Actas. Libro de actas del día 11 de diciembre de 1835.

1153 "Estudió en la Universidad de Valladolid, en la que solicitó el ingreso en el año 1836, matriculándose en la Facultad de Leyes. El 2 de diciembre de 1842, solicita ser examinado para alcanzar el grado de bachiller en Jurisprudencia, acompañando certificados de los cursos probados entre 1836 y 1842 . Entró a examen el 10 de diciembre y salió aprobado. El 3 de septiembre de 1844 , solicita ser examinado del grado de licenciado en Jurisprudencia, al haber probado los cursos necesarios. Examinado los días 10 y 16 de septiembre salió aprobado y le fue conferido el citado grado" A.H.U.V.A. Cajas 468 (doc. 380 a 384) y 671-43. 
provincia de Valladolid, habiendo decidido de acuerdo con el Consejo provincial, que D. Eugenio Díez, electo diputado provincial por el partido de la capital, no tiene las cualidades que para este cargo exige la ley de 8 de enero de 1845 , y no habiendo reclamado dicho señor, ha acordado que se proceda a nuevas elecciones a celebrar los días 29,30 y 31 del actual" ${ }^{1154}$. Una vez celebradas las elecciones en la fecha prevista, salió elegido diputado José Luis Prieto, que tomó posesión en la sesión que se celebró el 12 de marzo de 1848. En la misma sesión es nombrado vicesecretario de la Corporación. En septiembre de 1848 es nombrado secretario y en octubre de 1849 es nuevamente nombrado vicesecretario, cargo que mantiene, hasta el 30 de marzo de 1850 , fecha en la que finaliza la legislatura. En este tiempo asiste a treinta y cuatro de las cuarenta y cinco sesiones que se celebran.

Vuelve a ser elegido diputado provincial por Valladolid en la siguiente Diputación, la séptima, que se inicia el 3 de abril de 1850 y finaliza el 30 de marzo de 1852. En esta legislatura asiste a la totalidad de las treinta y dos sesiones celebradas, actuando como presidente interino de la Diputación en el mes de abril de 1851, ante la ausencia del Sr. gobernador. También se le nombra miembro de la comisión de Enajenación de Bienes Nacionales. En febrero de 1852 es nombrado vicepresidente del "Sindicato para el Mantenimiento del Cauce del Esgueva".

\section{Prieto Rodríguez, Félix}

Es natural de Salio, en la diócesis y provincia de León. En el año 1780 inicia sus estudios en la Universidad de Valladolid, a la que envía una solicitud en el año 1783 en la que expone que "habiendo estudiado los tres cursos de Filosofía y siendo forzoso graduarme y hallándome falto de posibles para el coste del grado, suplica se digne admitirle al grado de bachiller en Filosofía por pobre y se le señale día y hora. Valladolid a 7 de noviembre de 1783 " ${ }^{1155}$. Entre los años 1783 y 1787 sigue cursando estudios en la Universidad, cuyos resultados se reflejan en los correspondientes "certificados de aprovechamiento académico". El 26 de mayo de 1787 presenta la solicitud de examen de grado en la Facultad de Leyes, en la que alcanzará la licenciatura. En el año 1813 ejerce como abogado, y es hacendado en la villa de Rueda de los Almirantes. En las elecciones para la primera Diputación Provincial, es elegido para la misma en representación del partido de Gradefes (perteneciendo actualmente a la provincia de León). Se mantiene en el cargo durante la vigencia de la legislatura desde septiembre de 1813 a junio 1814, asistiendo a veintitrés sesiones de las cincuenta y dos realizadas. En el año 1820 con la puesta en marcha de la primera Diputación del Trienio, es convocado a participar nuevamente, por lo que vuelve a ser nombrado diputado provincial por el mismo partido de Gradefes. En este corto período de vigencia, de marzo a junio de 1820 , asiste a veintidós de las treinta y cuatro sesiones de la Diputación.

No volvió a presentarse en las siguientes candidaturas, pero a los pocos días de cesar como diputado al igual que ocurrió con su colega Joaquín Antonio de Argüello, solicitó ayuda a la Diputación. Ésta no tuvo inconveniente en "recomendar al Consejo de Estado los méritos de D. Félix Prieto, abogado de Gradefes, individuo de la Junta Provisional de Castilla la Vieja para que sea atendido y colocado en una plaza de magistratura o judicatura, tanto por su distinguida literatura y probidad cuanto por los importantes servicios prestados a la provincia en el desempeño de su labor como individuo de esta Diputación... hasta que fue relevado..."1156. A partir de este momento no se vuelven a tener noticias políticas de este diputado.

1154 B.O.P.V. n ${ }^{\circ} 152$ de 21 de diciembre de 1847.

1155 A.H.U.V.A. Caja 495 (doc.107 a 110).

1156 A.D.P.V. Actas. Libro de actas del 31 de julio de 1820. 


\section{Quijada y Calderón, Juan Antonio}

Natural del pueblo de Villagrá, partido judicial de Mayorga. Inicia sus estudios en el colegio de San Mateo de Valderas. Solicita su ingreso en la Universidad de Valladolid el 7 de diciembre de 1777, matriculándose en la Facultad de Leyes y los finaliza el 26 de junio de 1782, con la aprobación de los exámenes celebrados para alcanzar el grado de bachiller en Cánones ${ }^{157}$. Es miembro de la Milicia Urbana, de ideología liberal y se presenta y es elegido diputado provincial por el partido de Mayorga, en la segunda Diputación del Trienio, prestando juramento el 7 de junio de 1820. Se mantuvo en el puesto hasta el 28 de febrero de 1822, fecha en la que finaliza la legislatura. Asistió a ciento seis de las ciento setenta y tres sesiones celebradas, y no se vuelve a presentar en ninguna otra ocasión.

\section{Quintero Martínez, Eladio}

Nació en Valladolid, el 18 de febrero de 1839, hijo de Alonso Quintero, natural de Tórtoles y escribano en Valladolid, y de María Victoria Martínez, de Serrada. Bautizado el día 19 en la parroquia de la Magdalena se le impusieron los nombres de Eladio Gabino Raimundo. Bachiller en Filosofía y licenciado en Derecho Civil y Canónico por la Universidad de Valladolid ${ }^{1158}$. Se establece como abogado en Valladolid y se casa con una hija de Juan Manuel Arévalo, que fue diputado provincial en los períodos progresistas de 1841-43 y 1854-56. En el año 1881 es elegido decano del Colegio de Abogados de Valladolid ${ }^{159}$. Ejerce también en estos años como director del periódico La Libertad, "de ideología demócrata-progresista" ${ }^{1160}$. El 11 de marzo de 1874, el vicepresidente de la Comisión permanente le nombra abogado "para poner al día los cobros y bonos y créditos a favor del Hospicio". Este nombramiento es criticado por parte de la Diputación, ya que, con anterioridad, había sido cesado.

Se presenta a las elecciones para diputado provincial, en la cuarta Diputación del Sexenio, que se celebran en el mes de septiembre de 1872. Es elegido por el distrito de San Andrés de Valladolid, por 220 votos contra 46 de su opositor Nemesio Reiren. Presente en la sesión de instalación que tiene lugar el 2 de noviembre de 1872, es nombrado en la misma sesión vocal de la comisión de Actas. Su acta es aprobada en la sesión del día 4. El día 9 es nombrado vocal de la comisión de Peticiones y de la comisión de Venta de Bienes Nacionales. El 9 de marzo de 1874, el capitán general "en uso de las facultades extraordinarias de que se halla investido" ordena su cese como diputado. En el tiempo que ejerció asistió a veintisiete sesiones.

\section{Quintero Rodríguez, Manuel}

Nació en Valladolid en el año 1817. Es hijo de Manuel y de Nemesia. "El 13 de diciembre de 1829, a los doce años de edad, solicita el ingreso en la Universidad de Valladolid. Inicia sus estudios en la Facultad de Filosofía, aprobando los cursos entre los años 1829 a 1832. El 5 de septiembre de 1832, alcanza el grado de bachiller en Filosofía. Se matricula en la Facultad de Leyes en 1832, cursando estudios hasta 1835. El 5 de junio de 1835 se presenta a examen para alcanzar el grado de bachiller en Leyes, siendo aprobado. El 30 de septiembre de 1838 recibió el grado de licenciado. El 16 de agosto de 1832 solicitó un certificado de "buena conducta", como

\footnotetext{
1157 A.H.U.V.A. Caja 380 (doc. 431 a 447).

1158 "Solicita el ingreso en la Universidad de Valladolid en el año 1849, matriculándose en la Facultad de Filosofía, y alcanzando el grado de bachiller en el examen realizado el 2 de junio de 1855 . Se matricula en la Facultad de Leyes en 1855, y el 4 de junio de 1860 , solicita ser examinado para alcanzar el grado de bachiller en Derecho Civil y Canónico. Examinado el día 8 fue aprobado. El 6 de junio de 1861, solicita ser examinado para alcanzar el grado de licenciado en Derecho Civil y Canónico. Celebrado el examen el día 12, en votación secreta fue declarado aprobado" A.H.U.V.A. Cajas 511 (doc. 150 y 151), 479 (doc. 62 a 67) y 684-7.

1159 FERRERO MAESO, Concepción y BERZAL DE LA ROSA, Enrique. Historia del Colegio de Abogados... ob. cit. pág. 109.

${ }^{1160}$ ALMUIÑA FERNÁNDEZ, Celso. La Prensa Vallisoletana en el Siglo XIX. Tomo 2º Pág. 244.
} 
clérigo tonsurado y feligrés de San Benito el Viejo ${ }^{1161}$. Su hermana Leonor se casó en 1844 con Gabino Madrueño, que será diputado provincial por Valoria en el año 1847. Es accionista del ferrocarril Alar-Santander y comprador de una pequeña finca de 12 hectáreas procedentes de la desamortización por la que pagó 3.550 reales.

Es elegido diputado provincial por el partido de Valoria, prestando juramento y tomando posesión de su cargo en la sesión de instalación de la quinta Diputación isabelina que se celebra el 1 de noviembre de 1843. Permanece en el cargo hasta junio de $1847 \mathrm{y}$ asiste en este período a un total de ciento ochenta sesiones de la Corporación. Es el más joven e inquieto de los diputados, remplazando al secretario en sus ausencias. Es elegido miembro de la comisión de Presidios. Reclamó en numerosas ocasiones el que las sesiones de la Diputación fueran de carácter público, en especial las relacionadas con los temas de carreteras y acuerdos con los contratistas de las mismas. Protestó en el pleno la dificultad de poner sustitutos a los mozos sorteados y así "privar a los que tenían la desgracia de salir soldados de la posibilidad de redimir su destino de acuerdo con la ley"1162. Se quejó al jefe político, cuando fue enviado como representante de la Diputación a un Te Deum en la Catedral y se le colocó detrás del resto de autoridades, por lo que decidió retirarse del acto. En septiembre de 1846 es nombrado vicesecretario de la Diputación y en marzo de 1847 es elegido secretario, manteniendo el cargo hasta el final de la legislación. No volvió a ejercer ningún otro tipo de cargo público.

\section{Quiroga Martínez, Santiago}

Natural de Madrid, villa en la que nació el 23 de julio de 1803, hijo de Santiago Quiroga y de Teresa Martínez. Pasó a vivir a Valladolid muy joven, iniciando los estudios en la Universidad vallisoletana. "El 26 de octubre de 1816, a los 13 años de edad, solicita su ingreso en la Universidad Literaria de Valladolid, matriculándose en la Facultad de Filosofía. Cursó estudios entre 1816 y 1819. En 1819, solicitó ser examinado para alcanzar el grado de bachiller en Filosofía y presentado el 8 de junio fue aprobado némine discrepante. En el mismo año se matricula en la Facultad de Leyes, alcanzando el grado de bachiller en Leyes en junio de $1822 " 1163$.

En el año 1828 consigue la licencia para ejercer la abogacía y al poco tiempo es nombrado juez de Primera Instancia en Rioseco. En 1845 vuelve a Valladolid y se casa con Estefanía Gante Pereda. Instalado en Valladolid, ejerció la profesión de abogado, además de administrar sus propiedades. Es accionista del ferrocarril AlarSantander. En el amillaramiento de 1841 se le conoce una renta de 4.000 reales. Es también comprador de bienes desamortizados, "en 1839 compró 30 hectáreas en Campiña del Pisuerga y Tierra de Pinares por 118.000 reales. También compró una finca urbana" "1164. En el mes de febrero de 1856 toma posesión como vocal de la Junta de Beneficencia, cargo para el que había sido nombrado por real orden de 18 de diciembre de 1855.

En política es conocido por su carácter progresista y destacado miembro de la Milicia Nacional. En 1854 es nombrado diputado provincial por el partido de Valladolid, según acordó la "Junta Provisional del Gobierno de la Provincia". Se mantiene en el cargo de esta décima Diputación el corto tiempo de vigencia que se extiende entre el 30 de julio y el 14 de agosto del citado 1854, asiste a las quince sesiones que se celebran y no vuelve a ejercer como diputado. El 2 de octubre de 1854 es elegido alcalde de Valladolid. Durante su mandato tiene lugar en febrero de 1856 la inauguración del ferrocarril en la ciudad, acto al que dio realce la presencia de

1161 A.H.U.V.A. Cajas 460 (doc. 55 a 65), 503 (doc. 171 y 172), 575 y $669 / 42$.

${ }^{1162}$ A.D.P.V. Actas. Libro de actas del 17 de mayo de 1844.

1163 A.H.U.V.A. Cajas 501 (doc. 159 y 160), 575 (2 doc.) y 874/19.

1164 RUEDA HERNANZ, Germán. La desamortización... ob. cit. pág. 274. 
Espartero. Deja la Alcaldía el 1 de julio de 1856, tras los sucesos ocurridos conocidos como "el motín del pan"1165. Fallece en Valladolid el 20 de agosto de 1871.

\section{Rábago de los Ríos y Terán, Juan Antonio}

Nace el 11 de junio de 1806, en Reinosa, que en aquella época pertenecía a la provincia de Palencia. Hijo de Santos y de Isabel. Su padre es coronel del Ejército. "Inicia sus estudios en Reinosa, pasando posteriormente a Valladolid, donde solicitó el ingreso en su Universidad el 4 de noviembre de 1822, a los 16 años de edad, matriculándose en la Facultad de Leyes, donde obtuvo el grado de bachiller ${ }^{1166}$.

Se casa en Palencia, en el año 1832, con Gregoria Abad Alonso. En el año 1833, se establece en Valladolid como comerciante e industrial adquiriendo en poco tiempo un reconocido prestigio. En el año 1848 es el propietario del edificio que fue "Hospedería del Colegio de Santa Cruz" y negocia con la Diputación su venta para instalar en el edificio el Instituto de Enseñanza Media. En el mes de enero de $1856^{1167}$ se le expropian varios terrenos en la calle del Obispo, por lo que mantendrá un desacuerdo en el precio de la expropiación hasta el año 1866.

Afiliado al partido liberal, es perseguido y desterrado en el período de la Década Ominosa. Forma parte desde su creación de la Milicia Nacional, destacando en la persecución de las partidas carlistas. Su actividad política empieza en el año 1856, cuando es elegido alcalde $2^{\circ}$ de Valladolid y en el ejercicio de su cargo, se tiene que enfrentarse a los revoltosos que protestan por la carestía de la vida en los incidentes conocidos como "el motín del pan", incidentes que se desarrollaron en el mes de junio. En noviembre es elegido $1^{\circ}$ Teniente de Alcalde en las nuevas elecciones y en enero de 1857 es nombrado regidor, cargo en el que se mantiene hasta finales de 1858.

El 18 de octubre de 1869, se presenta en la sesión de instalación de la segunda Diputación del Sexenio al haber sido nombrado por el capitán general, "por hallarse declarado el territorio en estado de guerra", como diputado provincial en representación del distrito de la Audiencia de Valladolid, tomando posesión del cargo en el citado día. Es nombrado miembro de la Comisión permanente y también es vocal de la Junta de Beneficencia, en la que posteriormente llegará a ser nombrado presidente. El 13 de septiembre de 1870, es comisionado para buscar nueva sede para la Diputación. Finaliza la legislatura en febrero de 1871 a la que asiste a ciento cinco sesiones de las ciento veintisiete que celebra la Diputación. No se presenta a las elecciones para cubrir las vacantes de la tercera, ni de la cuarta Diputación del Sexenio, aunque el 9 de marzo de 1874, ya al final de la cuarta Diputación, "en uso de sus facultades extraordinarias" el capitán general le nombra diputado provincial por el distrito de San Andrés en sustitución del cesado Eladio Quintero. Asiste a seis sesiones entre marzo y mayo de 1874. Es confirmado por el gobernador civil para continuar como diputado por el distrito de San Andrés de Valladolid en la quinta Diputación del Sexenio. Se presenta en la sesión de instalación que se celebra el 30 de mayo de 1874, en la que toma posesión del cargo, siendo en esta primera sesión elegido presidente interino de la Diputación, al ser el diputado de mayor edad. El 17 de junio de 1874 es nombrado miembro de la comisión Inspectora de Establecimientos de Enseñanza. Finaliza la legislatura en marzo de 1875 , y asiste a catorce de las dieciocho sesiones que se realizaron.

En la Restauración se presenta a las elecciones de diputado a Cortes, como candidato del partido progresista, aunque no consigue ser elegido. Fallece en Valladolid el 7 de mayo de 1882 a los 76 años.

\footnotetext{
${ }^{1165}$ CARAS A SOTO, Pedro (Dir.). Diccionario biográfico de alcaldes ... ob. cit. pág. 552.

1166 El 5 de mayo de 1827, solicita ser examinado para alcanzar el grado de bachiller en Leyes, presentando los certificados de los cursos probados desde 1822, a 1827. Examinado el día 21 de junio, salió aprobado némine discrepante" A.H.U.V.A. Cajas 453 (doc. 28 a 36) y 576.

${ }^{1167}$ B.O.P.V. n 8 de 17 de enero de 1856
} 


\section{Real Alonso, Bernardo}

Nace en el año 1814, en el pueblo de Peñaflor de Hornija, perteneciente al partido judicial de Mota del Marqués. Bachiller en Leyes por la Universidad de Valladolid ${ }^{1168}$. Una vez acabados sus estudios, se establece en Peñaflor de Hornija. En el año 1842 compró una finca de 31 hectáreas, procedente de bienes desamortizados y situada en Montes Torozos, por la que pagó 19.095 reales.

El día 1 de enero de 1864, en la sesión de instalación de la deecimoséptima Diputación, se presentó como electo por el partido de Mota del Marqués, y una vez aprobada el acta, prestó juramento y tomó posesión del cargo. En la misma sesión es nombrado miembro de la comisión de Obras. En diciembre de 1865, se da por finalizada la legislatura en la que asiste a cuarenta y seis sesiones de un total de cuarenta y nueve que se celebran. En las elecciones para la decimoctava Diputación, celebradas en noviembre de 1865, vuelve a salir elegido diputado por el mismo partido de Mota del Marqués. Presente en la sesión de instalación el 1 de enero de 1866, toma posesión del cargo y se mantiene a lo largo de todo el año, ya que el 30 de diciembre finaliza la legislatura. Asiste a catorce de las dieciocho sesiones que se celebran y no vuelve a presentarse a nuevas elecciones.

\section{Recio del Castillo, Fidel}

Nacido en Valladolid en el año 1838, en cuya Universidad cursa la carrera de Derecho. Ejerce como procurador de los Tribunales y pertenece al Colegio de Abogados de la ciudad. Industrial harinero y comprador de bienes desamortizados, adquirió 173 hectáreas procedentes del clero en Mayorga y Quintanilla. También actuó como agente de negocios e intermediario en la compra de Bienes Nacionales.

Pertenece al partido republicado en el que llega a ser nombrado presidente del Comité Constitucional. Se presenta a las elecciones que se celebran en septiembre de 1872, para cubrir la plaza de diputado provincial por el distrito de Mucientes, perteneciente al partido de Valladolid. Es electo al conseguir 552 votos contra 534 que consiguió su opositor Antonio Revilla y Revilla. En la sesión de instalación de la cuarta Diputación del Sexenio, que se celebra el 2 de noviembre de 1872 se presenta, entrega su acta de nombramiento y toma posesión del cargo. En la sesión del día 8 se aprueba su acta "a pesar de las reclamaciones del pueblo de Corcos". Posteriormente la aprobación es rechazada, como lo indica la publicación en el Boletín Oficial del día 17 de noviembre, en el que "la Diputación de acuerdo con el artículo veintinueve de la Ley Provincial, ha resuelto declarar nula la elección de diputado por el distrito de Mucientes, partido judicial de Valladolid, que había recaído en Fidel Recio. Se fijan los días 28, 29 y 30 del actual para la elección del diputado que ha de cubrir la vacante". La Diputación no aclara los motivos de la anulación de las primeras elecciones, pero lo que sí refleja en la sesión del día 6 de diciembre de 1872, es una propuesta de la comisión de Actas, para "que sea aprobada el acta del diputado por Mucientes, Fidel Recio del Castillo" sin tener en cuenta que en las segundas elecciones celebradas ha conseguido mayoría de votos Antonio Revilla. Tampoco se toma una decisión al respecto, ya sea por uno o por otro candidato. Se inicia el año 1873 con discusiones a la hora de definir al diputado por Mucientes, hasta que el 19 de abril del citado año, "la comisión de Actas mantiene el nombramiento del diputado por Mucientes en la persona de Fidel Recio, porque aunque en la segunda votación resultó elegido el Sr. Revilla, la Audiencia ha ratificado la legalidad del nombramiento de la primera elección". En definitiva, el 19 de abril puede tomar posesión del cargo, en el que se mantiene hasta el final de la legislatura, que tiene

\footnotetext{
1168 "El 30 de octubre de 1828, solicita el ingreso en la Universidad de Valladolid, matriculándose en su Facultad de Leyes. E1 22 de mayo de 1834, solicita ser examinado para alcanzar el grado de bachiller en Leyes, presentando los certificados de los cursos probados entre 1828 y 1834. Entró a examen el 11 de junio, y salió aprobado némine discrepante"
} 
lugar el 11 de mayo de 1874, asistiendo en el tiempo que ejerció a dieciséis sesiones.

En la quinta Diputación es ratificado por el gobernador civil, como diputado por Mucientes, tomando posesión en la sesión de instalación que se celebra el 30 de mayo de 1874. Es nombrado vocal de la comisión de Presupuestos y de la comisión de Cuentas. En noviembre es nombrado miembro de la comisión de Peticiones. Finaliza su actividad política con el fin de esta legislatura en marzo de 1875, habiendo asistido a trece de las dieciocho sesiones celebradas. Vuelve a ser elegido diputado en los años 1892-96 y en 1901-05, presidiendo la Diputación en 1904. Su testigo será recogido por su hijo Lucio que representará en la Diputación al distrito de Peñafiel entre 1905 y 1923. Fallece en Valladolid el 8 de julio de 1908 a los 70 años de edad.

\section{Reoyo, Francisco}

Natural y vecino de Villalón, ejerce en esta villa la profesión de escribano. En el año 1871 figura como alcalde de la misma.

El 11 de mayo de 1874, es nombrado por el gobernador interino de la provincia, diputado provincial por el distrito y partido de Villalón, en la cuarta Diputación del Sexenio, en sustitución del cesado Manuel González García. El mismo día 11 toma posesión del cargo y al mismo tiempo el gobernador disuelve la Diputación, sin tratar ningún tema del orden del día, por lo que resulta diputado por unas horas. No es ratificado en la siguiente Diputación.

\section{Reoyo Pérez, Telesforo}

En la época del Sexenio es vecino de Rioseco, pero con anterioridad residió en diferentes pueblos de la comarca y Tierra de Campos.

En 1854 vende el oficio de escribano de Lomoviejo, "que le pertenece por legítimos títulos". En 1861, aparece como propietario de Santa Eufemia, al que le expropian unos terrenos para la construcción de la carretera de Villafrechós a Villalpando. En 1868 ejerce como procurador de los Tribunales de Rioseco" ${ }^{1169 .}$

Está casado con Marcela Garzón Laiz, hija de Domingo Garzón San Juan, escribano de Villalón y diputado provincial en los años 1847 a 52 y 1854 a 56. También está emparentado con Ángel de la Riva Espiga, casado con una hermana de su mujer, diputado en el Sexenio. A causa de este parentesco, ambos diputados, en el año 1873 tienen que hacer frente a una sentencia de la Audiencia de Valladolid que les condena a pagar los intereses de un censo que gravaba el "monte de Valparaíso" comprado de bienes nacionales por su suegro Domingo Garzón. En 1878 compra una propiedad en Valverde de Campos, procedente de bienes nacionales.

En 1855 es elegido alcalde de Rioseco, acto con el que inicia su carrera política. En 1869 el capitán general, "al hallarse el territorio declarado en estado de guerra", le nombra diputado provincial por el partido de Rioseco, tomando posesión del cargo en la sesión de instalación de la segunda Diputación del Sexenio, que se celebra el 18 de octubre de 1869. Se mantiene en el cargo hasta el final de la legislatura que tiene lugar en febrero de 1871, asistiendo en este tiempo a ciento cuatro de las ciento veintisiete sesiones que se celebran. Se presenta a las elecciones a diputados provinciales de la tercera Diputación del Sexenio, que se celebran los días 1,2 y 3 de febrero de 1871 y es elegido en representación del distrito y partido de Rioseco, con lo que presenta el acta en la sesión de instalación que tiene lugar el 17 de febrero de 1871. El día 21 del mismo mes se celebra la constitución definitiva de la Diputación y el "diputado Reoyo protesta porque no han sido aprobadas la totalidad de las actas", la suya entre ellas. El día 25 la comisión de Actas rechaza la validez de su acta, acuerdo que es aprobado por el Pleno de la Diputación. Queda así invalidado su nombramiento y aceptado por otro lado el de su opositor Manuel de la Cruz Alonso.

${ }^{1169}$ B.O.P.V. no 30 de 11 de mayo de $1854 . \mathrm{n}^{\circ} 137$ de 30 de agosto de 1861 y n 14 de 5 de mayo de 1868 . 
En el año 1872 no se presenta a las elecciones para la nueva legislatura. En la sesión de instalación de la quinta Diputación del Sexenio, que se celebra el 30 de mayo de 1874, "en uso de las facultades que le concede al gobernador la Circular del Poder Ejecutivo de la República", es nombrado diputado provincial por el distrito y partido de Rioseco. En la misma sesión, por elección, se le nombra presidente de la Diputación, siendo el quincuagésimo sexto presidente, en toda su historia, y el cuarto que es elegido por los diputados. Ejerce la presidencia de forma efectiva a lo largo de la legislatura, que se da por finalizada en marzo de 1875, asistiendo a catorce sesiones y presidiéndolas en diez ocasiones. En la Restauración no es elegido diputado.

\section{Represa, Agustín de}

Es vecino de Rioseco, por cuyo partido es elegido diputado en la cuarta Diputación de la época isabelina. Toma posesión de su cargo en la sesión de instalación que se celebra el 1 de enero de 1841, a pesar de que en la sesión del 10 de febrero se lee en el pleno de la corporación "la exposición que varios electores de Rioseco presentan al Regente Provisional del Reino, solicitando la nulidad del nombramiento del diputado Agustín de Represa". Reclamación que fue rechazada y el diputado continuó en el cargo hasta el final de la legislatura, en octubre de 1843. Fue nombrado miembro de la comisión de Estadística y estuvo presente en ciento sesenta y ocho sesiones de la Diputación. No volvió a ejercer ningún otro cargo político.

\section{Reynoso y Oscariz, Mariano Lino}

Nació en Valladolid el 24 de septiembre de 1818, en el seno de una importante familia de industriales y propietarios de la ciudad. Hijo de José María Reynoso y Abril y de Josefa Oscariz. Sobrino de otro insigne miembro de la familia, Mariano Miguel de Reynoso y Abril, que destacó en la política nacional como diputado a Cortes, senador, comisario regio y ministro de Fomento. Su hermano Manuel fue senador por Salamanca en la Restauración, y su otro hermano Rafael fue magistrado.

"Inicia sus estudios en la Universidad de Valladolid en el año 1829, matriculándose en la Facultad de Filosofía, el 14 de octubre, a los 11 años. El 12 de septiembre de 1832, alcanza el grado de bachiller en Filosofía. En el mismo año 1832 inicia nuevos estudios en la Facultad de Leyes. El 16 de junio de 1835 aprobó el examen y alcanzó el grado de bachiller en Leyes. Entre los años 1835 y 1839 estudia en la Facultad de Leyes de la Universidad de Madrid, en la que alcanzó el grado de licenciado. En el año 1839 solicita al rector de la Universidad de Valladolid la incorporación como licenciado por haber alcanzado el grado en la Universidad de Madrid. Se le admitió el 7 de julio. Alcanzó el grado de doctor en Leyes en la Universidad de Valladolid"1170.

Se casó el 1 de enero de 1849 con María Ignacia de la Fuente, de Medina, viuda de Fermín Loyzaga, tuvieron cuatro hijos, uno de ellos se casó con Asunción Silió, hermana del diputado y ministro César Silió. Ejerce su actividad profesional de abogado, simultaneándola con otras actividades agrícolas e industriales. "Propietario de la fábrica de Utensilios y Maquinaria de Valladolid. Consejero de la Sociedad General del Crédito Industrial, Agrícola y Mercantil. Miembro de la Asociación del Crédito Mutuo. Miembro de la comisión de Monumentos Artísticos de Valladolid, y de otras varias instituciones cívicas como la sección de Música del Liceo. Académico de la Real Academia de las Nobles Artes de Valladolid. Delegado de la cría caballar. Vocal de la Caja de Ahorros. Consejero del Banco de Valladolid (que en su época de crisis en 1864 ofreció su fortuna para salvarlo). Fabricante de harinas" ${ }^{1171}$.

Fue comprador, conjuntamente con su madre y sus hermanos, de fincas procedentes de bienes desamortizados: "500 hectáreas de tierra en las comarcas de Campiña de Pisuerga y Tierra de Campos. Como testaferro de otros compradores,

1170 A.H.U.V.A. Cajas 461 (doc. 89 a 98) y 669/50

1171 GONZALEZ GARCÍA-VALLADOLID, Casimiro. Datos par la Historia... ob. cit. pág. 295 y sig. 
remató la compra de fincas en cuarenta subastas Compró una pequeña finca en Valladolid de 4 hectáreas, en el lugar de La Flecha, donde en 1846 instalaría una fábrica de harinas" ${ }^{1172}$. Mantiene un alto nivel de vida en correspondencia con sus numerosas propiedades, como nos indica el Boletín Oficial de la Provincia de fecha 10 de diciembre de 1871, cuando publica el siguiente anuncio: "Se arriendan extraoficialmente las aceñas de Otea, Torrepesquera, Villanueva de Duero y Villamarciel. La subasta se realizará en la fábrica de harinas de La Flecha, según el pliego de condiciones que están en la casa de Mariano Lino Reynoso, de calle Prado $\mathrm{n}^{\circ} 2$ de Valladolid". Residía en Valladolid, en la calle citada y además tenía en propiedad otro edificio situado en la Acera de San Francisco.

En política fue liberal. Comenzó como progresista y evolucionó a moderado, pero siempre estuvo al lado de la monarquía isabelina. Inició su carrera política en el año 1834, siendo todavía estudiante, al ser nombrado sargento de la brigada de la Milicia Urbana, recientemente creada para la defensa del Trono de Isabel II. En el mismo año es elegido porta-estandarte en la Milicia Nacional de Valladolid.

Es elegido diputado provincial por el partido de Nava del Rey, en las elecciones realizadas en marzo de 1850, para la séptima Diputación isabelina, Presta juramento y toma posesión del cargo en la sesión de instalación que se celebra el día 3 de abril. En la misma sesión es nombrado miembro de la comisión de Instrucción Pública y secretario de la corporación, ejerciendo este último cargo hasta julio de 1851. En febrero de 1852 es nombrado presidente del "Sindicato para la conservación del cauce del Esgueva". En esta legislatura, que se mantiene hasta el 30 de marzo de 1852, asiste a veintiséis de las treinta y dos sesiones que se realizan. El 1 de abril de 1852 se inician las actividades de la octava Diputación, en la que repite el cargo de diputado por La Nava del Rey. En el mismo día de la instalación se le nombra nuevamente secretario, desempeñando el cargo hasta noviembre de 1853. En esta legislatura que se extiende hasta marzo de 1854, asiste a dieciséis de las veintitrés sesiones que se celebran, dando por finalizada su actividad política provincial.

A nivel nacional, inicia su actividad cuando en el año 1863 es elegido diputado a Cortes por la provincia de Valladolid, en representación del partido moderado. Repite el mismo escaño en las legislaturas de los años 1865 y 1866. Durante el Sexenio, al igual que ocurrió en el Bienio Progresista, abandonó la política activa, manteniéndose fiel a la Monarquía Isabelina. Con la llegada de la Restauración, vuelve nuevamente a la actualidad política, siempre relacionada con la provincia de Valladolid. Se publica el 4 de enero de 1875 un decreto del Ministerio de la Regencia, en el que, "atendiendo a las circunstancias que concurren en Mariano Lino Reynoso, el Ministerio de la Regencia del Reino ha tenido a bien nombrarle gobernador civil de la provincia de Valladolid. Madrid a 4 de enero de 1875. Firmado. Antonio Cánovas del Castillo" ${ }^{1173}$. Toma posesión del cargo el 11 de enero y su primera disposición es la de dirigir una "proclama a los habitantes de Valladolid" solicitando la ayuda "de todos los hombres honrados de la provincia para el buen desempeño de mi cargo y para que podamos concurrir a la gloria y ensalzamiento del trono de D. Alfonso XII y prosperidad y sosiego de nuestra desgraciada Patria" Sólo presidirá la Diputación en la sesión del 22 de enero, y no tendrá éxito como gobernador, ya que al poco tiempo, el 17 de marzo del mismo 1875, publica un manifiesto anunciando su dimisión. Es nombrado senador en los años 1876-1877. ${ }^{1174}$

Falleció en Valladolid el 16 de enero de 1882.

\section{Riva Espiga, Ángel de la}

Nació en Valladolid el 17 de mayo de 1831 y bautizado el día 20, con los nombres de Ángel Patricio, es hijo de Herminio de la Riva y de Práxedes Espiga. Es

1172 RUEDA Y HERNANZ, Germán. La Desamortización... ob. cit. pág. 274-287-328.

1173 B.O.P.V. n 6 del 10 de enero de 1875 y. nº 8 de 14 de enero de 1875.

1174 CARAS A SOTO, Pedro. (Dir.). Diccionario biográfico de parlamentarios ... ob. cit. pág. 879. 
licenciado en Jurisprudencia por la Universidad de Valladolid ${ }^{1175}$. Acabados sus estudios, ejerce la abogacía en Valladolid. Se casa con Adelaida Garzón Laiz, de Villalón, hija de Domingo Garzón San Juan, que fue diputado provincial en los años 1847 a 1852 y en 1854 a 1856 . Es cuñado del también diputado provincial Telesforo Reoyo Pérez.

En el año 1871, con ocasión de su elección como diputado provincial, se encuentra con dificultades de aceptación del acta, por motivos judiciales. Los problemas se alargan hasta el año 1873, al estar involucrado en los juicios provocados por la suspensión de pagos de su suegro Domingo Garzón, a causa del impago de los intereses de un censo con que estaba gravado el "Monte de Valparaíso", propiedad procedente de bienes desamortizados de Santervás de Campos ya que, a su fallecimiento, sus sucesores no hicieron frente a la deuda. En la misma situación se encuentra su cuñado Telesforo Reoyo, vecino de Rioseco, con el que compartirá Diputación en el Sexenio.

El 24 de agosto de 1858, inicia el desempeño de su primer cargo político, al ser nombrado miembro del Consejo provincial, en el que se mantiene hasta su disolución el 20 de septiembre de 1868. Es candidato a las elecciones de diputado provincial en la tercera Diputación del Sexenio, celebradas en los días 1, 2 y 3 de febrero de 1871, en las que salió elegido por el distrito y partido de Villalón. Se presenta en la Diputación en la sesión de instalación que se celebra el día 17 de febrero de 1871, donde hizo entrega del acta. En la sesión del día 19 presenta una propuesta, haciéndose eco de una petición realizada por el periódico El Norte de Castilla "para hacer públicas las sesiones, y que los periodistas puedan tomar nota de los asuntos tratados". En la sesión del día 22, todavía no se había aprobado su acta y el pleno acuerda "aplazar hasta el día siguiente las discusiones sobre la aceptación del acta del diputado por Villalón Ángel de la Riva, para tener tiempo de estudiar el dictamen y las alegaciones, al estar el Sr. De la Riva en trámite de juicio por causa criminal”. En la sesión del día 23 no se toma ninguna decisión y sólo se acuerda aplazar la aprobación del acta hasta que se reciban en la Diputación y se estudien las actas del Juzgado de Villalón. En el mes de febrero asiste a las diez sesiones que se celebran, aunque no está aprobada el acta y en el mes de abril, en la reapertura de las sesiones, se queja al Sr. presidente de la Diputación de que ésta corporación "no haya solucionado el tema de su acta en los cincuenta y dos días que dura la legislatura". En los meses de mayo y junio, se sigue reclamando la documentación al Juzgado de Villalón. Finalmente el 20 de julio de 1872, "después de una serie de discusiones se aprobó la nulidad de las elecciones en Villalón por lo cual queda anulada la elección del diputado Ángel de la Riva y en consecuencia se convocan nuevas elecciones a celebrar los días 28,29,30 y 31 de agosto".

En la cuarta Diputación no se presenta a las elecciones de septiembre de 1872, pero al final de la legislatura, por oficio del 28 de abril de 1874, el gobernador interino "en uso de sus facultades extraordinarias" le nombra diputado por el distrito de Villabrágima, del partido judicial de Rioseco, en sustitución del cesado Venancio Izquierdo. No se presenta a la sesión del 11 de mayo, por lo tanto no asiste a ninguna sesión de esta legislatura, pues el mismo día 11, la Diputación es disuelta por el gobernador. La quinta Diputación inicia sus sesiones el 30 de mayo de 1874, y en la misma fecha es nombrado por el gobernador, diputado provincial por el partido de Villalón, tomando en el mismo día posesión de su cargo. El 17 de junio es nombrado miembro de la comisión de Bienes Nacionales y vocal de la Junta de Beneficencia. Se mantiene en el cargo hasta el final de la legislatura en marzo de 1875, en cuyo tiempo

1175 “En el año 1845, solicita el ingreso en la Universidad de Valladolid, matriculándose en la Facultad de Leyes. El 2 de junio de 1849, solicita ser examinado para alcanzar el grado de bachiller en Jurisprudencia. Acompaña los certificados de los cursos probados entre 1845 y 1849 y señalado el día 5 para el examen, salió aprobado por unanimidad. El 19 de mayo de 1852, solicita optar al grado de licenciado en Jurisprudencia y examinado el día 21, salió aprobado" A.H.U.V.A. Cajas 474 (doc. 180 a 184$)$ y $677-7$. 
asiste a catorce de las dieciocho sesiones celebradas. No vuelve a ser elegido diputado a partir de la Restauración.

\section{Rodríguez, Rafael}

Es elegido diputado provincial para la tercera Diputación del Trienio, toma posesión de su cargo el 1 de marzo de 1822, y asiste a las sesiones hasta el final de la vigencia de la Diputación en abril de 1823. Está presente en ciento cuarenta y cuatro sesiones de las ciento cincuenta y siete realizadas. No ha quedado constancia del partido por el que fue elegido, ni su lugar de residencia, posiblemente sea de Valladolid o resida en la ciudad, por el gran número de sesiones a las que asiste. Otra posibilidad no contrastada es que sea vecino de Medina, al no tener representación ese partido en la Diputación. No vuelve a estar presente en la corporación.

\section{Rodríguez, Valentín}

Vecino de Piña de Esgueva, perteneciente al partido judicial de Valladolid por haber sido anulado el de Valoria, es nombrado diputado suplente por el partido de Valladolid-Plaza, en la sesión que celebra la primera Diputación del Sexenio, el 10 de diciembre de 1868. No asiste a las sesiones hasta el 1 de febrero de 1869 , fecha en la que dimite el diputado titular Lucas Guerra. A partir de esta fecha asiste regularmente a las actividades de la Diputación estando presente en cincuenta y siete de las noventa y ocho sesiones que se celebran. No vuelve a participar en ninguna otra actividad política.

\section{Rodríguez Monroy, Teodoro}

Nació en León el día 9 de noviembre de 1806, hijo de Manuel Rodríguez y de Isabel Monroy. Inició sus estudios en las Escuelas Pías de León, institución en la que estudió Gramática Latina entre los años 1818 y 1821. Pasó a estudiar a continuación en el Seminario de León, donde estuvo entre 1821 y 1823 y donde cursó estudios de Matemáticas y Lógica. En el mismo año de 1823 pasó a la Universidad de Valladolid, en la que obtuvo el grado de bachiller en Filosofía y el título de licenciado en Cirugía En 1862 es profesor de la Facultad de Medicina en la Universidad de Valladolid y en 1867 es nombrado catedrático de la misma Facultad ${ }^{176}$. En el año 1844, además de ejercer la medicina, es nombrado profesor de Historia Natural en la Universidad de Valladolid. En 1853 es director del Hospital de Dementes y se tiene que enfrentar a una denuncia "por dar de alta a un paciente, que luego mató a un vecino" 1177.

$\mathrm{Su}$ actividad política provincial es corta y se inicia en los primeros días del Sexenio Revolucionario, cuando el 17 de octubre de 1868, la Junta Provincial Revolucionaria le nombró diputado provincial por el partido de Valladolid-Audiencia. Toma posesión del cargo en la sesión de instalación de la primera Diputación del Sexenio, que se celebra el día 21 del mismo mes y en la que es nombrado diputadodecano. El 7 de noviembre es nombrado vocal de la comisión de Instrucción Pública.

1176 "El 27 de diciembre de 1823 presentó la solicitud de ingreso en la Universidad, matriculándose acto seguido en la Facultad de Filosofía. El 19 de noviembre de 1826, expone que hallándose con 3 cursos de Filosofía ganados y con los demás requisitos necesarios, suplica se sirva fijar fecha para recibir el grado de bachiller en Filosofía. Entró a examen el día 11 y salió aprobado némine discrepante. El 1 de junio de 1828, solicita ser admitido a examen para recibir el grado de bachiller en la Facultad de Medicina, acompañando certificados de los estudios probados entre los años 1824 y 1828. Entró a grado el 7 de junio, siendo decano José Hervás y examinadores los doctores Campesino y Sangrador, y catedrático de Anatomía, Luis Mesía. Salió aprobado por unanimidad. Es autorizado para ejercer la medicina en 1830 por el Colegio de San Carlos de Madrid. Se establece para ejercer la profesión en Mayorga. El 5 de Enero de 1842, solicita ser examinado para alcanzar el grado de licenciado en Medicina, siendo aprobado. Alcanzó en el mismo año el grado de doctor. El 22 de septiembre de 1858, solicita alcanzar el grado de licenciado en Cirugía y examinado los días 27 y 28 salió aprobado por unanimidad. A.H.U.V.A. Cajas 361-2, 502 (doc. 102 a 104), 522 (doc. 46 a 60 ), 577,581 (doc. 136 a 140) y 542 (doc. 325 a 329 ).

1177 B.O.P.V. ${ }^{\circ} 57$ de fecha 9 de abril de 1853. 
Su actividad como diputado finaliza el 24 de noviembre del mismo año 1868, cuando en la sesión del citado día "el diputado Teodoro Rodríguez Monroy presenta su dimisión de acuerdo con el decreto de 12 de noviembre, por el que no pueden ejercer el cargo los individuos que reciban el sueldo del Estado o de la provincia”. El pleno de la Diputación aceptó la renuncia, ya que por ser catedrático recibía el sueldo del Estado y el interesado en el mismo día abandonó la sesión. En el tiempo que estuvo en la Diputación asistió a doce sesiones. No se volvió a presentar como diputado.

\section{Rodríguez Rubio, Francisco}

Natural y vecino de Tordesillas, es elegido diputado provincial por el partido de La Mota del Marqués, para la cuarta Diputación isabelina que inicia sus actividades en la sesión de instalación que se celebra el día 1 de enero de 1841. En esta citada sesión su acta es rechazada "por irregularidades en la elección de Tordesillas ya que aparecen 745 votos, cuando sólo hay 742 electores". En unas segundas elecciones es elegido un nuevo diputado en la persona de Julián Maestro, pero las reclamaciones presentadas por Rodríguez Rubio son admitidas, con lo que se anulan las segundas elecciones y se ratifica su nombramiento. En la sesión de la corporación del 17 de febrero todavía se continuaba discutiendo sobre la validez de las elecciones. El diputado Gusano argumentaba que la existencia de los tres votos de más invalidaba la elección, porque "los votos obtenidos por Rubio eran 374, y la mitad más uno de los 742 electores, necesario para ser elegido, eran de 372. Si se quitan los tres votos que se reclaman como no correctos, quedaría el número de votos válidos en 371, cifra que no llega a la mayoría exigida, por lo que no puede considerarse elegido". Finalmente en la votación efectuada se rechazó el argumento del diputado Gusano por cinco votos contra tres, por lo que el Sr. Rubio entró en el salón, prestó juramento y tomó posesión de su cargo, manteniéndose en el mismo durante toda la legislatura, hasta octubre de 1843. Asiste a ciento treinta y nueve sesiones y es elegido miembro de la comisión de Contribuciones. No hay constancia de su ideología política, pero sin duda, al ser rechazada su candidatura por el diputado Gusano, declarado progresista, nos inclina a pensar en que su tendencia era moderada, aunque su presencia en la corporación, coincide con las épocas progresistas.

Vuelve a ser nombrado diputado provincial, en la undécima Diputación que se forma en los inicios del Bienio Progresista, por haberlo sido en 1843. Toma posesión en la sesión de instalación que se celebra el 17 del mismo mes de agosto, y continúa representando al partido de La Mota del Marqués. Se mantiene en el ejercicio del puesto hasta el final de la legislatura, en octubre de 1856, asiste en este tiempo a ciento dos sesiones de las ciento cuarenta y ocho celebradas.

En los primeros momentos del Sexenio, la Junta Provincial Revolucionaria, en sesión celebrada el 17 de octubre de 1868, procedió al nombramiento de los diferentes diputados provinciales que debían de conformar la primera Diputación del Sexenio Revolucionario. Entre ellos vuelve a aparecer como diputado por Tordesillas el Sr. Rodríguez Rubio, decisión que se toma sin mediar elecciones, sino más bien se trata de una decisión de la Junta para cubrir con "individuos afines" los puestos de la Corporación. Su trayectoria como diputado provincial coincide con los diferentes períodos progresistas. En la cuarta Diputación de 1841-43, correspondiente al período de la Regencia de Espartero. En la undécima Diputación 1854-56, que coincide con el Bienio Progresista. En la primera y segunda Diputaciones del Sexenio, años 1868 a 1871. En la sesión de instalación de la primera Diputación del Sexenio, que se celebra el 22 de octubre de 1868, presta juramento y toma posesión de su cargo. En la misma sesión, "de acuerdo con el artículo veintisiete de la Ley Orgánica Provincial de 21 de octubre de 1868 , se le nombró vicepresidente". Como tal vicepresidente preside las sesiones de la Diputación en cuarenta y una ocasiones, asistiendo a un total de ochenta y siete sesiones de las noventa y ocho que se celebran a lo largo de la legislatura, que se cierra el 17 de octubre de 1869. Está considerado como el quincuagésimo tercer presidente de la Institución, aunque el gobernador presidiera las sesiones en once 
ocasiones. En la segunda Diputación del Sexenio, que se forma a partir del 18 de octubre de 1869, vuelve a ser nombrado diputado provincial por el partido de Tordesillas. En esta ocasión a través de una comunicación del Sr. capitán general "al hallarse la provincia en estado de guerra". Presta juramento y toma posesión en la sesión de instalación que se celebra el mismo día 18 y también en la misma sesión vuelve a ser nombrado vicepresidente de la institución. En esta legislatura, que se prolonga hasta el mes de febrero de 1871 , asiste a ciento veinticuatro de las ciento veintisiete sesiones celebradas, presidiendo las sesiones en cien ocasiones. Lo que hace resaltar que los gobernadores cada vez asisten a menos sesiones y van dejando la responsabilidad del funcionamiento ordinario de la Diputación en manos de los señores diputados, aunque en temas controvertidos siempre tienen la última palabra. Finalizada esta Diputación, no vuelve a ser nombrado diputado y abandona la política provincial.

\section{Rodríguez Villamandos, Ángel}

Nació en Valladolid en el año 1816. Es bachiller en Filosofía y en Leyes por la Universidad de Valladolid ${ }^{1178}$.

Se presenta a las elecciones para diputado provincial que se celebran los días 1,2 y 3 de febrero de 1871 , en representación del distrito de La Catedral, de Valladolid. Habiendo resultado electo, se presentó en la sesión de la tercera Diputación del Sexenio, del día 17 del mismo mes de febrero, día en que se inician las actividades y en la que entrega su acta. En la sesión del día 20 "la aprobación del acta se hizo con retraso, porque la comisión, en la sesión del día 18 la rechazó a petición de un vecino que alegaba que su apellido no era Villamandos, sino Castro y por lo cual se le pidió que se presentara con la partida de bautismo" ${ }^{1179}$. El 25 de abril de 1871 es nombrado vocal de la Junta de Beneficencia y el 18 de mayo miembro de la comisión de Venta de Bienes Nacionales. En la sesión del 25 de julio de 1872, en el sorteo que se celebra para conocer los diputados que continuaban, le correspondió cesar, y no se presentó a más elecciones. Finaliza la legislatura en octubre de 1872 y asiste a cincuenta y tres de setenta sesiones celebradas.

\section{Romero y Díez, Pedro Regalado}

Nació en Valladolid en el año 1772. Inició sus estudios en la Universidad de Valladolid en el año 1786 "a la edad de 14 años". Su historial académico refleja los siguientes cursos. En 1787 cursa $1^{\circ}$ de Instituciones Filosóficas con el catedrático Juan García Beltrán. En 1788 hace 2 de Filosofía con el mismo catedrático. En 1789 supera $3^{\circ}$ de Filosofía Moral con el catedrático Juan de San Felices. En 1790 sigue el curso $1^{\circ}$ de Instituciones Locales con el Rector Primo. En 1791 hace $2^{\circ}$ de Instituciones Locales con los catedráticos José Mañas y Tomás Moyano. En 1792 hace $2^{\circ}$ de Leyes y $1^{\circ}$ de Digesto con el catedrático Vicente García Cavero. En 1793 cursa $2^{\circ}$ de Digesto con el catedrático Vicente García Cavero. Por fin, el 16 de mayo de 1793, el bedel Pedro Antonio Aguilar certifica la veracidad de todos los asientos del presente expediente académico. En el año 1794 recibe el grado de bachiller en Leyes" 1180 . Una vez concluidos sus estudios es nombrado relator de la Audiencia.

En el año 1813 es elegido diputado provincial en representación de Valladolid, asistiendo durante su vigencia a cuarenta y una sesiones de las cincuenta y dos

1178 “Ingresó en la Universidad de Valladolid en el año 1830, matriculándose en la Facultad de Filosofía. El 23 de enero de 1833, con el mayor respeto, hace presente que habiéndose instruido el expediente para recibir el grado de bachiller en Filosofía, suplica le sea admitido. Examinado el 25 de enero, salió aprobado némine discrepante._El 2 de mayo de 1835 solicita recibir el grado de bachiller en Leyes y acompaña los certificados de los cursos probados entre 1832 y 1835. Examinado el 4 de junio salió aprobado por unanimidad de votos" A.H.U.V.A. Cajas 460 (doc. 218 a 227) y 503 (doc. 201 y 202).

1179 A.D.P.V. Actas. Libro de actas del 18 de febrero de 1871.

1180 A.H.U.V.A. Caja 435 (doc.214 a 232). 
celebradas en la primera Diputación lo que le convierte en el diputado más asiduo y trabajador de la legislatura. Junto con el "decano Temes" y el secretario Capdevila, es encargado de la recopilación y recogida de los documentos de la secretaría de la Diputación, una vez que ésta es disuelta y efectúan su entrega en la Contaduría Provincial, de acuerdo con las consignas que se dictan sobre la disolución de la institución. En la re-instalación de la Diputación del año 1820, en la primera sesión que se celebra, y según queda reseñado en el libro de actas del día 21 de marzo, ser comunica que "por haber fallecido D. Pedro Regalado Romero, individuo de esta Diputación, corresponde que ocupe su lugar el canónigo Berdonces".

\section{Romero Peláez, Pedro}

Es natural de Villardeciervos, en la provincia de Zamora. Nació en el año 1817, hijo de Miguel y de Francisca. Permaneció soltero. Trasladó su residencia a Medina junto con su hermano Antonio, donde se establecieron y destacaron como comerciantes "en paños". Accionista del ferrocarril de la Compañía del Norte. Se trasladó a vivir a Valladolid en el año 1903, y continuó en la ciudad con la tradición comercial textil.

Es miembro del partido republicano y forma parte de la Junta Revolucionaria Provincial, que se constituye el 14 de octubre de 1868. La misma Junt a le nombra, de acuerdo con la instrucción del 13 de octubre del Ministerio de la Gobernación, diputado provincial por el partido de Medina. En la sesión del 27 de octubre, se presenta y toma posesión de su cargo en la primera Diputación del Sexenio.

En el mes de enero de 1869, presentado como candidato a las elecciones municipales, resultó elegido alcalde de Medina. Al no ser compatible con el cargo de diputado, toma provisionalmente su puesto en la Diputación el suplente Ignacio de Aspes, que ejerce durante el mes de febrero. Finalmente, Romero decide continuar, por lo que en el mes de marzo, rechaza la alcaldía de Medina y retoma sus funciones de diputado. Se mantiene hasta el final de la legislatura en octubre de 1869, asistiendo a cuarenta y nueve de las noventa y ocho sesiones que se celebran.

En el año 1873 es elegido diputado a Cortes por el distrito de Valladolid, tras retirar su candidatura Germán Gamazo ${ }^{1181}$. Fallece en Valladolid, el 30 de abril de 1905, dejando en su testamento dispuesto que su entierro se realice en el cementerio civil.

\section{Rúa, Casto María de la}

Natural de Pozoantiguo, provincia de Zamora, trasladó su residencia a San Pedro de Latarce. Su hijo, Faustino de la Rúa de la Rúa, fue diputado provincial en la época del Sexenio. Se dedica a la explotación de una empresa agrícola y ganadera. Preocupado por la mejora y el progreso en el ámbito rural, en 1835 publicó en el Boletín Oficial de la Provincia $\mathrm{n}^{\circ} 110$, una memoria sobre "El medio más adecuado y menos dispendioso y más seguro de extender el arbolado en Castilla la Vieja". En los años 1838 y 1839 compró 175 hectáreas de fincas desamortizadas, situadas en Tierra de Campos por las que pagó 153.290 reales ${ }^{1182}$.

Capitán retirado de la Milicia Nacional y de ideas liberales. Su actividad política se circunscribe a su elección como diputado provincial en las elecciones para la primera Diputación isabelina, por el partido de La Mota. Toma posesión y presta juramento en la sesión de instalación que se celebra el 22 de octubre de 1835 y en la misma sesión es nombrado diputado-secretario, hasta el día 29 en que toma el puesto el titular José María Cano. Es elegido miembro de la comisión de Búsqueda de Casa y Enseres, de la comisión de Plantilla y de la comisión de Fomento y Hacienda. Se mantiene hasta el final de la legislatura en octubre de 1836, asistiendo a ochenta y ocho sesiones y no volviendo a estar presente en ninguna otra actividad política.

\footnotetext{
${ }^{1181}$ CARASA SOTO, Pedro (Dir.). Diccionario Biográfico de parlamentarios.... ob. cit. pág. 929.
} 1182 RUEDA HERNANZ, Germán. La Desamortización... ob. cit. pág. 246. 


\section{Rua de la Rua, Faustino de la}

Nació en el pueblo de San Pedro de La Tarce en el año 1848. Es hijo de Casto María de la Rua, diputado provincial por el partido de La Mota del Marqués en la primera Diputación isabelina, vigente en el año 1835-36. "Solicitó el ingreso en la Universidad de Valladolid en el año 1864 matriculándose en la Facultad de Leyes. El 26 de septiembre de 1868, solicita ser examinado para alcanzar el grado de bachiller en Jurisprudencia y acompaña los certificados de los cursos probados entre 1864 y 1868. Examinado el día 29, salió aprobado" 1183.

Por decreto del gobernador interino de Valladolid, de fecha 27 de abril de 1874, es nombrado diputado provincial, en la cuarta Diputación del Sexenio, por el distrito de Villardefrades del partido judicial de Rioseco, en sustitución del cesado Andrés Domínguez de la Mata. Se presenta en la sesión del 11 de mayo, en la que toma posesión del cargo y en la misma sesión, el propio gobernador disuelve la Diputación, por lo que es la única sesión a la que asiste. No es elegido por el gobernador titular para continuar como diputado. Hasta el año 1893, no volverá a ser diputado provincial, elegido por los conservadores "gamacistas" en representación del distrito de la Audiencia, de la capital.

\section{Rueda Lorenzo, Tomás de}

Es natural de Pozaldez, pueblo en el que nació en el año 1798. Estudió en la Universidad de Valladolid, ingresando en su Facultad de Filosofía en el año 1815, alcanzando el grado de bachiller en Filosofía, en el examen que se celebra el 1 de septiembre de 1818. En el año 1840 compró una finca de 4 hectáreas, procedente de bienes desamortizados, por la que pagó la cantidad de 2.350 reales.

Su actividad política se inicia en la quinta Diputación isabelina, el día 1 de noviembre de 1843, con la toma de posesión del cargo de diputado provincial por el partido de Olmedo, ejerciéndolo hasta junio de 1847, fecha en la que finaliza la legislatura. En este tiempo asiste a ciento sesenta y una de las doscientas cuarenta sesiones que se celebran. En marzo de 1847 es nombrado vicesecretario, cargo que mantiene durante la vigencia de la Diputación. En el año 1848 es nombrado alcalde de Pozaldez. En el año 1854 solicita a la Diputación que "como vecino de Pozaldez y terrateniente en Pozal de Gallinas, pide que se le permita nombrar un guarda" ${ }^{1184}$. Y no se vuelve a tener noticias de su actividad política, aunque sí se conoce que su hermano Eleuterio "rico propietario de Pozaldez", es diputado provincial en representación de Matapozuelos entre los años 1875 y 1880, actuando como vicepresidente en 1876.

\section{Ruiz Dávila, Tomás}

Hacendado y vecino de Olmedo, es elegido diputado provincial por el mismo partido judicial en la segunda Diputación del Trienio. Toma posesión de su cargo en la sesión de apertura celebrada el 7 de junio de 1820, y se mantiene en su puesto a lo largo de la legislatura hasta el 28 de febrero de 1822. Asiste a ochenta y seis sesiones de las ciento setenta y tres que celebra esta legislatura y no vuelve a participar en política.

\section{Ruiz Merino, Eduardo}

Nace en Villarta Quintana, provincias de La Rioja a finales de 1818 hijo de Blas Cesáreo y de Dionisia. En su juventud se traslada a Valladolid, ciudad en la que ejerce como comerciante e industrial, o como se le denomina en el Boletín Oficial de la Provincia del 24 de julio de 1863, "importante comerciante de comestibles, con fábricas de chocolate y de pastas". En el año 1844 se casa en Madrid con Lucía Fernández, sobrinas de Juan Manuel Fernández Vítores, alcalde y diputado provincial

1183 A.H.U.V.A. Caja 484 (doc. 373 a 379).

1184 A.D.P.V. Actas. Libro de actas del 18 de octubre de 1854. 
de Valladolid en los primeros años de la época isabelina. En el año 1861 está considerado como el trigésimo sexto mayor contribuyente de la provincia por contribución fabril e industrial. A lo largo de los años continúa ampliando y progresando en sus negocios particulares, como industrial y comerciante. El Boletín Oficial del 17 de abril de 1873 anuncia que "la compañía propietaria del Teatro Calderón, Ruiz Merino y Cía., se convierte en Teatro Calderón de la Barca, S.A”. Es una señal de la progresión de los negocios y de su diversificación.

Su primer cargo público conocido es el de alcalde $3^{\circ}$ de Valladolid, cargo para el que es elegido el 1 de julio 1856. Es nombrado Alcalde $1^{\circ}$ el 15 de noviembre del mismo año, como se refleja en las actas, de dicho 15 de noviembre, del Consejo provincial que trata sobre "la petición de exoneración del alcalde de Valladolid D. Eduardo Ruiz Merino" ${ }^{1185}$.El 1 de enero de 1857 es ratificado como Alcalde Constitucional, ejerciendo el cargo hasta el 12 de marzo del citado año.

Inicia su andadura como diputado provincial al presentarse a las elecciones de la decimoquinta Diputación isabelina que se celebran en el mes de febrero de 1860. Es elegido diputado por el distrito de "la Plaza" de la capital, prestando juramento y tomando posesión del cargo en la sesión de instalación que se celebra el 1 de abril de 1860. En la misma sesión de instalación es nombrado diputado-secretario, cargo que mantiene hasta el final de la legislatura que tiene lugar el 30 de marzo de 1862. Asiste en este tiempo a veintiocho de las treinta y una sesiones que se celebran. Es la primera Diputación a la que asiste como diputado de las cinco en total en que representará al mismo distrito de la capital, y que finalizará en septiembre de 1868 , coincidiendo con el fin del periodo isabelino. Continúa ejerciendo las funciones de diputado provincial en la decimosexta Diputación, también representando al mismo distrito de la Plaza. Se presenta y toma posesión del cargo en la sesión de instalación que se celebra el 1 de abril de 1862. Ejerce el cargo hasta el final de la legislatura que tiene lugar el 31 de Diciembre de 1863. En marzo y junio de 1863 preside las sesiones de la Diputación, ante la ausencia del gobernador y del diputado decano. En esta Diputación asiste a veinte de veintidós sesiones.

La decimoséptima Diputación es la tercera consecutiva en la que sigue representando al citado distrito de la Plaza, tomando posesión del cargo en la sesión de instalación que tiene lugar el 1 de enero de 1864. Es nombrado en la misma sesión miembro de la comisión de Beneficencia. A partir del mes de abril de 1864, es nombrado presidente tanto de la reunión ordinaria como de la extraordinaria que se inician en ese mes. Repite los nombramientos en las diferentes reuniones que se realizan en el año $1865^{1186}$. Asiste a treinta y ocho de las cuarenta y nueve sesiones que se celebran, ejerciendo como presidente en nueve de ellas, hasta el final de la legislatura que tiene lugar el 31 de diciembre de 1865. En la Diputación que se inicia el 1 de enero de 1866, la decimoctava de la época isabelina, continúa con su cargo de diputado provincial. En la primera sesión es nombrado presidente de la reunión, nombramiento que se repite en las siguientes reuniones que se celebran hasta el final de año que coincide con el final de la legislatura. Asiste en este período a las dieciocho sesiones que se celebran y las preside en las cinco ocasiones que no asiste el gobernador. Es nuevamente elegido diputado provincial en la decimonovena y última Diputación de la era isabelina, en la que toma posesión del cargo en la sesión que se celebra el 1 de enero de 1867, siendo nombrado en la misma miembro de la comisión de Establecimientos Benéficos. Es elegido como presidente en la reunión que se inicia en julio de 1867 y en las de abril y agosto de 1868. En la última sesión que celebra la Diputación, el 20 de septiembre de 1868, es nombrado diputadosecretario. En total asiste a cuarenta y nueve de las cincuenta y dos sesiones que se

${ }^{1185}$ CARASA SOTO, Pedro (Dir.). Diccionario biográfico de Alcaldes... ob. cit. pág. 574.

1186 De acuerdo con la Ley de 25 de septiembre de 1863 "sobre el Gobierno y Administración de las Provincias", al inicio de los periodos de sesiones se nombrará un presidente de la reunión, aunque ante la presencia del gobernador, éste seguirá manteniendo la prioridad. 
celebran. En definitiva, se mantiene como diputado ininterrumpidamente desde abril de 1860 a septiembre de 1868 .

En el período revolucionario no ejerce cargo público y tampoco en la Restauración vuelve a intervenir en política ni local ni provincial, posiblemente por que haya establecido su residencia en Madrid.

\section{Salcedo, Luciano}

Hacendado del pueblo de Villabrágima, del partido de Rioseco, se presenta a las elecciones para diputado provincial en junio de 1820, siendo elegido diputado suplente, pero no llegó a formar parte de la segunda Diputación del Trienio.

\section{Samaniego Samaniego, Bernardo}

En las elecciones para la sexta Diputación isabelina en el año 1847, es elegido diputado provincial por el partido de La Mota del Marqués. En la sesión de instalación que se celebra el 15 de agosto, envía un comunicado manifestando "no poder asistir por hallarse enfermo". Se presenta en la sesión del 16 de octubre en la que toma posesión y jura el cargo. A lo largo de la legislatura que estará vigente hasta el 30 de marzo de 1850, asistirá a once sesiones de las cuarenta y cinco que se celebran. No vuelve a presentarse a ninguna otra elección. Su hermano José es nombrado bibliotecario de Santa Cruz en 1843.

\section{Santana Santana, Claudio}

Natural de Alaejos, su padre es Victoriano Santana y su madre Joaquina Santana Santos, hermana de Antonio, diputado provincial por el partido de La NavaAlaejos, que ejerció el cargo entre 1843 y 1847, durante la quinta Diputación isabelina. No se le conocen estudios universitarios, y se dedica en su pueblo natal a la compra-venta de fincas, en su mayoría procedentes de bienes desamortizados y nacionales. "Claudio Santana, corredor de fincas en Alaejos, donde tiene el estudio en el que se aceptan propuestas para la venta de una finca en Torrecilla de la Orden" ${ }^{1187}$. En el año 1867 es alcalde de Alaejos y su hermano Pedro lo será en el año 1872. Sus otros dos hermanos, Demetrio y Cipriano, estudian en la Universidad de Valladolid, el primero Leyes y el segundo Teología.

El 10 de diciembre de 1868 es nombrado diputado-suplente por el partido de La Nava de la Libertad, aunque en esta primera legislatura del Sexenio no llegó a ejercer el cargo ya que no tuvo que suplir al titular Ulpiano Muñoz. Se presenta a las elecciones para diputado provincial, que se celebran los días 1,2 y 3 de febrero de 1871, saliendo elegido por el distrito de Alaejos. Presenta el acta en la sesión de instalación de la tercera Diputación del Sexenio, que tiene lugar el 17 de febrero de 1871. Se aprueba su acta al día siguiente y a continuación es nombrado vocal de la comisión de Actas. El 15 de diciembre es nombrado diputado secretario, con carácter de suplente pues firma las actas en ausencia de cualquiera de los titulares, actuando hasta el final de la legislatura. El 25 de julio de 1872, en el sorteo que se celebra en la sesión, le correspondió continuar en su cargo de diputado y finaliza la legislatura en octubre de 1872 asistiendo a cuarenta y nueve de las setenta sesiones que se celebran, a pesar de que se había quejado con anterioridad "de la poca presencia de diputados en las sesiones y reclama se exija su presencia de acuerdo con la Ley" ${ }^{1188}$.

El 2 de noviembre de 1872 se celebra la sesión de instalación de la cuarta Diputación del Sexenio, en la que continúa como diputado representando nuevamente al distrito de Alaejos. En la sesión del día 9 es nombrado miembro de la comisión de Peticiones. Si en la anterior legislatura se quejaba de la falta de presencia de sus colegas en las sesiones, en ésta no destaca precisamente por su presencia, pues sólo

1187 B.O:P.V. $n^{\circ} 222$ de 23 de julio de 1865 , en la que se inserta el citado anuncio.

1188 A.D.P.V. Actas. Libro de actas de 12 de diciembre de 1871. 
asiste a dieciocho de las cuarenta y dos sesiones que se celebran y que finaliza el 11 de mayo de 1874 . No vuelve a presentarse como diputado.

\section{Santana Santos, Antonio}

Es natural de Salamanca, ciudad en la que nació el 26 de febrero de 1805 y en cuya Universidad inició los estudios, matriculándose en 1819 en la Facultad de Leyes. En el año 1823, solicitó la continuación de sus estudios en la Universidad de Valladolid, alcanzando el grado de bachiller en Leyes el 10 de agosto de 1824 . Se casó con María Teresa López, vecina de Toro, con la que tuvo tres hijos, Enrique, Julio y Ezequiel, todos ellos alcanzaron el grado de licenciados en Leyes. Su sobrino Claudio Santana será diputado provincial en los años del Sexenio. Se estableció en Valladolid, ciudad en la que ejerció como abogado, ingresando en el Colegio de Abogados, donde fue nombrado secretario de la "Asociación de Socorros Mutuos de los Jurisconsultos" y decano en 1857.

Su etapa política se inicia en el Ayuntamiento de Valladolid, al ser nombrado síndico presidente el 5 de abril de 1838 y lo ejerció hasta el 1 de enero de 1840. Es militante del partido progresista, aunque no es afín a las ideas del general Espartero, por lo que es relegado de la política entre los años 1840 y 1843 . Se presentó a las elecciones para la quinta Diputación isabelina y resultó elegido diputado provincial por el partido de La Mota del Marqués. Toma posesión en la sesión que se celebra el 1 de noviembre de 1843, aunque su acta fue protestada, porque "en el acto de instalación, un grupo de vecinos de Alaejos presentó una reclamación sobre su elección y en defensa de la candidatura de Silvestre Rodríguez, alegando que los votos de Alaejos habían sido para el candidato Antonio Santana, vecino de Alaejos y diferente a Antonio Santana Santos. La reclamación es rechazada por el Pleno" ${ }^{1189}$. En la misma sesión es elegido miembro de las comisiones de Instrucción Primaria y de Gobierno Interior. En los meses de febrero y marzo de 1844, se enfrenta al jefe político, al proclamar este último el estado de excepción en la capital, con la finalidad de desarmar a la Milicia Nacional. En protesta, abandona la Diputación, actitud que le recrimina el jefe político, "que reclama su presencia en la corporación, a lo que el diputado se niega, alegando tener mucho trabajo" ${ }^{1190}$. Reintegrándose finalmente a las actividades provinciales en el mes de abril del mismo año 1844. En julio de 1846 es nombrado vicesecretario de la Diputación, ejerciendo el cargo hasta octubre del mismo año. Se mantiene activo hasta el final de la legislatura, que tiene lugar en julio de 1847, asistiendo a doscientas quince sesiones de las doscientas cuarenta que se celebraron.

En el año 1854 es elegido diputado a Cortes por Valladolid, alcanzando 3.302 votos. Aunque fue elegido por el partido progresista, no dejó de ser crítico con el gobierno durante su permanencia en el Congreso. Se presentó nuevamente a las elecciones del año 1865, pero la oposición del ministro de la gobernación Posada Herrera, impidió su elección ${ }^{1191}$. A partir de este momento, abandona la política.

\section{Santander, Genaro}

Natural y vecino de Alaejos. En el año 1841 reclama a la Diputación por agravio en el repartimiento de las contribuciones y al no ser atendido, solicitó la devolución de los documentos enviados para recurrir en petición a las Cortes.

En el año 1854 la Junta Provisional del Gobierno de la Provincia le nombra diputado provincial por el partido de La Nava del Rey en la undécima Diputación que está vigente entre el 30 de julio y el 14 de agosto del citado año. Se presenta en la Diputación el 14 de agosto, día en el que presta juramento, toma posesión y asiste a la última sesión de la misma. En definitiva es diputado por un día y asiste a una sesión.

\footnotetext{
1189 A.D.P.V. Actas. Libro de actas del 1 de noviembre de 1843.

1190 A.D.P.V. Actas. Libro de actas del 12 de marzo de 1844.

${ }^{1191}$ CARAS A SOTO, Pedro (Dir.). Diccionario biográfico de parlamentarios... ob. cit. pág. 1016.
} 
Finalizado el período del Bienio Progresista, el 19 de agosto de 1856, en la sesión de instalación de la duodécima Diputación, vuelve a representar como diputado provincial al partido de La Nava del Rey, "en virtud del nombramiento efectuado por el Excmo. Sr. capitán general de acuerdo con la real orden de 26 de julio de 1856 " 1192 . En esta sesión la Diputación acordó que "en caso de ausencia del Sr. gobernador, se nombre al Sr. Santander como decano para presidir las sesiones".

Esta legislatura está vigente entre agosto y noviembre de 1856, tiempo en el que se celebran cincuenta y tres sesiones. Asiste a cuarenta y ocho de ellas, de las cuales y ante la frecuente ausencia del gobernador civil, la presidió en cuarenta y seis ocasiones; también fue nombrado miembro de la "Comisión Superior de la Provincia" y representante de la Diputación en la Milicia Nacional.

En los comienzos del Sexenio Revolucionario, y con fecha 3 de octubre de 1868, es nombrado presidente de la Junta Revolucionaria de Valladolid. Como tal actúa de gobernador interino, cargo por el cual preside la sesión de instalación de la primera Diputación del Sexenio, celebrada el 21 del mismo mes y año. En el mismo día da posesión del cargo al nuevo gobernador, Manuel Somoza, con lo que deja de actuar como interino, aunque continúa como presidente de la Junta Revolucionaria hasta el 30 de octubre, fecha en la que se acuerda su disolución. El 1 de noviembre de 1868 es nombrado presidente de la comisión de Instrucción Pública.

\section{Santander, Juan José}

Natural de Rueda, villa en la que nació en el año 1813. Estudia en la Universidad de Valladolid. "Ingresa en la Facultad de Leyes el 24 de noviembre de 1824. Cursó estudios entre los años 1824 a 1831, solicitando en julio de 1831 ser examinado para alcanzar el grado de bachiller en Leyes y presentando los certificados de los cursos probados. Presentado a examen el 2 de agosto de 1831, resultó aprobado" 1193 .

Es elegido diputado por el partido de Medina, para la décima Diputación isabelina, en virtud de la orden de la Junta Provisional del Gobierno de la Provincia. Ejerce como tal en el tiempo de vigencia de la legislatura que se extiende entre el 30 de julio al 14 de agosto de 1854, asistiendo a las quince sesiones celebradas en 15 días. No vuelve a presentarse como diputado.

\section{Sanz, Niceto}

El 14 de octubre de 1868 es nombrado miembro de la recién constituida Junta Provincial Revolucionaria. La citada Junta en el mismo día, de acuerdo con la instrucción del 13 de octubre de 1858 del Ministerio de la Gobernación, le nombra diputado provincial por el partido de Olmedo en la primera Diputación del Sexenio. Toma posesión del cargo en la sesión del 22 de octubre, firmando las actas, junto con el presidente y el secretario en su calidad de diputado-decano. En marzo de 1869, sin justificación alguna conocida, deja de asistir a las sesiones, y su puesto es cubierto por el suplente Sr. Ayllón. En su tiempo de permanencia asistió a veintisiete sesiones.

\section{Sanz, Norberto}

Nació en el pueblo de Aldea de San Miguel en el año 1804, pasando posteriormente a residir en Mojados. "Ingresó en la Universidad de Valladolid el 5 de noviembre de 1818, matriculándose en su Facultad de Leyes. Cursó los estudios correspondientes, hasta alcanzar el grado de bachiller en Leyes en febrero de 1824" "194. Ejerció la abogacía en Mojados, al mismo tiempo que explotaba sus propiedades agrícolas. Es accionista del ferrocarril Alar-Santander. Entre los años

\footnotetext{
1192 A.D.P.V. Actas. Libro de actas del 19 de agosto de 1956.

1193 A.H.U.V.A. Cajas 456 (doc. 72 a 80) y 578.

1194 A.H.U.VA. Caja 446 (doc. 141 a 144).
} 
1840 a 1843 compró varios bienes desamortizados, "una casa en Mojados y una finca de 84 hectáreas en Tierra de Pinares" $" 1195$.

En el año 1850 es elegido diputado provincial por el partido de Olmedo, tomando posesión y prestando juramento en la sesión de instalación de la séptima Diputación isabelina, que se celebra el día 3 de abril. En la misma sesión es nombrado vicesecretario de la corporación, cargo que mantiene hasta el final de la legislatura en marzo de 1852. En este período asiste a veintiuna de las treinta y dos sesiones que se celebran. Continúa como diputado provincial por el mismo partido en la siguiente legislatura, la octava isabelina, que se inicia el 1 de abril de 1852 y que se alarga hasta el 30 de marzo de 1854. En este período son once a las sesiones que asiste de un total de veintitrés que se celebran. En esta legislatura, aunque es diputado por Olmedo, defiende el trazado del ferrocarril Madrid-Valladolid por Ávila en lugar de hacerlo por Segovia, teniendo en cuenta que si se realiza por esta segunda opción, Olmedo y sus comarcas se verían beneficiadas, con el paso del ferrocarril por sus tierras. No vuelve a salir como representante en la Diputación.

\section{Serrano Foronda, José}

Es natural de Villalón pero se trasladó a vivir a Palazuelo de Vedija, pueblo en el que se estableció como labrador. Una de sus hijas, Antonia, se casó con Sebastián Díez Salcedo, abogado, periodista y diputado provincial por Rioseco entre 1858 y 1863. Posteriormente fijó su residencia en Rioseco, manteniendo también la casa de Palazuelos. En Rioseco, además de la agricultura, se dedicó al comercio de granos. Entre los años 1838 y 1842, compró varias fincas procedentes de bienes desamortizados, con un total de 223 hectáreas por las que pagó 277.595 reales. Es accionista del ferrocarril Alar-Santander. En el año 1862 es arrendatario del monte Carrascal de Villalba. En 1871 es el noveno mayor contribuyente de la provincia por contribución de inmuebles con 4.103 pesetas de cuota anual, y sigue residiendo en Rioseco. En 1872 es el décimo mayor contribuyente por territorial con 3.866 pesetas de cuota y propiedades en Bolaños, Rioseco, Villalón y Villafrechós.

Su actividad política se inicia en el año 1855, al ser elegido alcalde de Rioseco, cargo que sigue manteniendo en junio de 1856, cuando tiene que hacer frente a la revuelta ciudadana provocada por la carestía de la vida. El 19 de agosto de 1856, finalizado el Bienio Progresista, el capitán general de Castilla la Vieja, Joaquín Armero y Peñaranda, le nombra diputado provincial por el partido judicial de Rioseco en la duodécima Diputación, tomando posesión del cargo en la sesión que se celebra el mismo día. Es nombrado miembro de la comisión de Conservación y Mantenimiento del Edificio de la Diputación y también miembro de la comisión de Cuentas. En noviembre de 1856 , se da por finalizada la legislatura, que tiene una corta duración de cuatro meses, en la que asiste a treinta y cinco de las cincuenta y tres sesiones que celebran. No volverá a ser elegido diputado, ni tampoco se presentará a más elecciones.

\section{Tablares Maldonado, Felipe}

Propietario e ingeniero, con residencia en Valladolid, en la plaza de Fabio Nelli, tiene grandes intereses en fincas rústicas situadas en su mayoría en la zona de Campiña de Esgueva. Fue testaferro en la compra de bienes desamortizados. Entre 1856 y 1864 adquirió numerosas fincas tanto a título personal como por cuenta de otros en Torre de Esgueva, Piña, Encinas, Canillas y Villarmentero. También desarrolla su actividad profesional en puestos cercanos a la Administración, ya que en el año 1854 actúa como perito agrónomo de la Diputación, como lo refleja en las Actas en las que "la Diputación acuerda no pagar en lo sucesivo al perito agrónomo de la institución Sr. Tablares" ${ }^{1196}$. Sigue trabajando para la Diputación, sin recibir el

1195 RUEDA HERNANZ, Germán. La Desamortización .... Ob. cit. Pág. 248.

1196 A.D.P.V. Actas. Libro de actas del 17 de agosto de 1854. 
salario, por lo que en febrero de 1855 reclama el pago de los salarios atrasados. En 1856 es nombrado director provincial de Caminos Vecinales, cargo en el que se mantiene hasta 1866, al acordar la Diputación "su cese como director de Caminos Vecinales". En abril de 1872 tiene dificultades para hacer frente al pago de los plazos de la compra de fincas procedentes de bienes nacionales, como refleja el interdicto que presenta el juez de Olmedo "contra el Sr. Tablares por falta de pago de fincas compradas al Estado". El Boletín Oficial de la Provincia de 2 de diciembre de 1875 le da como adjudicatario de varias fincas asignadas por la Dirección General de Propiedades del Estado procedentes de "propios del Clero" 1197.

Su carrera política la inicia en las filas del partido conservador, presentándose a las elecciones que se celebran los días 1, 2 y 3 de febrero de 1871, para cubrir las vacantes de la tercera Diputación del Sexenio. Es elegido por el distrito de Encinas, del partido judicial de Peñafiel, presentándose en consecuencia, en la sesión de instalación que se celebra el 17 de febrero. Hace entrega de su acta, que fue aprobada en la sesión del día 20. Se mantiene en la Diputación hasta el final de la legislatura en octubre de 1872, habiendo asistido a cincuenta y una de las setenta sesiones que se celebran. En el sorteo que se celebra en la sesión del 25 de julio de 1872 , le correspondió cesar en el cargo, pero se volvió a presentar en las elecciones que se celebran en septiembre de 1872. Es nuevamente elegido diputado por Encinas, como único candidato con 999 votos. Presente en la sesión de instalación de la cuarta Diputación, que tiene lugar el 2 de noviembre de 1872, es nombrado vocal de la comisión Auxiliar de Actas y resulta aprobada su acta en la sesión del día 4. Ejerce como diputado hasta el final de la legislatura, en mayo de 1874, asistiendo a treinta y cuatro de las cuarenta y dos sesiones celebradas.

En la quinta Diputación del Sexenio no se celebran elecciones, pero es de nuevo nombrado diputado por el mismo distrito de Encinas "por orden del gobernador civil". Está presente en la sesión de instalación que se celebra el 30 de mayo de 1874 . En la sesión del siguiente día es nombrado vocal suplente de la Comisión permanente, asistiendo a las sesiones en las que falta alguno de los titulares. En la sesión del 17 de junio es nombrado miembro de la comisión de Ventas de Fincas del Estado ${ }^{1198}$.En marzo de 1875 se dan por finalizadas las actividades de esta última Diputación del Sexenio a las que asiste a nueve sesiones de las dieciocho celebradas.

Continúa como diputado provincial en las primeras Diputaciones de la Restauración, en representación a lo largo de todo el tiempo por el mismo distrito de Encinas. Hasta que el 1 de diciembre de 1880, en la sesión de la Diputación "se comunica el fallecimiento del diputado por Encinas, Felipe Tablares Maldonado, celoso defensor de los intereses de sus administrados y digno y simpático compañero".

\section{Tamariz, Serapio}

Natural de Valladolid, ciudad en la que reside y en la que cursa sus estudios de Derecho, hasta alcanzar el grado de bachiller en Leyes en el examen celebrado el 9 de agosto de 1832.

Es elegido diputado provincial por el partido de La Mota del Marqués, en las elecciones que se celebran para renovar la novena Diputación isabelina, en el año 1854. Toma posesión y presta juramento en la sesión celebrada el día 1 de abril. Asiste a las cuatro sesiones que se celebran en esta legislatura, dos en abril y dos en mayo, finalizando la legislatura el 18 de julio del mismo año 1854, al quedar disuelta la Diputación por orden de la Junta Provisional del Gobierno de la Provincia, a raíz del pronunciamiento del general Espartero. En la décima Diputación que se forma a

1197 “En Valladolid, tierras por 2.600 pesetas y 2 casas. En Iscar, tierras por 6.500 pesetas y 2 quiñones de tierras. En Megeces, tierras por 501 pesetas. En Corrales 1 quiñón de 5 tierras”. B.O.P.V. Boletín de fecha 2 de diciembre de 1875 .

1198 Este nombramiento es de suponer que sea debido a su experiencia como comprador de bienes nacionales, aunque también es un trampolín para conocer en detalle las fincas y las condiciones más interesantes que se presentan, como lo demuestra la serie de fincas que compró en el año 1875. 
partir del 30 de julio de 1854, ya en el período del Bienio Progresista, es nombrado diputado por el mismo partido de La Mota del Marqués por la misma Junta Provisional. Toma posesión el mismo día 30 de julio y ejerce el cargo hasta el 14 de agosto, es decir 15 días, en los que se celebran y asiste a quince sesiones, al ser disuelta nuevamente la Diputación por la citada Junta Provisional. En definitiva, entre abril y agosto de 1854 es diputado de dos legislaturas diferentes. No vuelve a aparecer en política.

\section{Teijón, Juan Bautista}

Es natural y vecino de Valladolid, ciudad en la que nació en el año 1824. "El 28 de octubre de 1833, a los 9 años de edad, poco más o menos, solicitó el ingreso en la Universidad de Valladolid, matriculándose en la Facultad de Artes y luego en la de Leyes. ${ }^{1199}$. Ejerce como abogado en Valladolid. El 7 de noviembre de 1868 es nombrado vocal de la Junta Provincial de Instrucción Pública. Comprador de bienes nacionales, adquirió una finca de 191 hectáreas, alternando su administración con el ejercicio de la abogacía. Su hijo Agustín Víctor, en enero de 1874, es nombrado secretario del Gobierno Civil, actuando como gobernador interino durante un breve tiempo.

El 9 de marzo de 1874, en la sesión extraordinaria que celebra la cuarta Diputación del Sexenio, "en uso de las facultades extraordinarias de que se halla investido", el Sr. capitán general le nombra diputado provincial por el distrito séptimo de Valladolid, parroquia de Santiago en sustitución del cesado Laureano Álvarez. Ejerce como diputado entre marzo y mayo de 1874, fecha en la que finaliza la legislatura, asistiendo en este tiempo a tres sesiones y no vuelve a ser elegido diputado.

\section{Temes y Prado, Juan Andrés de}

Nacido en el año 1751 en Madernas, "lugar de Riobo", perteneciente a la Diócesis de Orense. Es "hijo legítimo de Andrés Benito de Temes y Mosquera y de María Teresa de Prado y Ulloa, hijosdalgo notorios de sangre". Aunque nacido en Galicia, realiza su formación académica en diversos centros de enseñanza. "Estudió Gramática y retórica en el colegio de las Escuelas Pías de Getafe durante cuatro años. En el año 1766 inició los estudios de Leyes en el Colegio Imperial de San Miguel de la Universidad de Granada, alcanzando el grado de bachiller en Cánones. Continuó sus estudios en la Universidad de Valladolid a partir del año 1769, y durante cuatro años realizó los cursos de las Cátedras de Derecho, Civil, Real y Canónico. Continuó en la Universidad durante otros cinco años dando clases en la Facultad de Derecho en sustitución de sus titulares, "con asistencia a los Gimnasios con diferentes defensas, lecciones y argumentos". Ejerció como pasante durante tres años en el despacho del abogado D. Felipe Blanco Caballero. Fue licenciado en la Facultad de Cánones con fecha 27 de septiembre de 1778, doctor en Cánones el 11 de junio de 1779. Era abogado de la Real Chancillería y catedrático de Instituciones Canónicas, nombrado el 26 de septiembre de 1780. Fue Rector de la Universidad entre los años 1780 a 1782, "año en el que solicita una "Relación de Méritos" a los 31 años de edad y 18 de estudios mayores. El 2 de diciembre de 1793 es nombrado catedrático de Prima de Cánones. Ejerce como rector de la Universidad entre los años 1795-96 y desde 1804 a $1806^{\prime 1200}$.

1199 El 16 de junio de 1836, solicita ser examinado para conseguir el grado de bachiller en Filosofía y examinado el día 18 fue declarado aprobado, némine discrepante. El 30 de noviembre de 1836 se matriculó en la Facultad de Leyes, y el 24 de agosto de 1840, fue examinado del grado de bachiller en Leyes y salió aprobado por votación secreta. El 29 de septiembre de 1843, presenta la solicitud para acceder al grado de licenciado en Jurisprudencia y examinado el día 5 de octubre, salió aprobado" A.H.U.V.A. Cajas 466 (doc. 631 a 636), 504 (doc. 154 a 158 ) y 670-103.

1200 A.H.U.V.A. Cajas 331 (doc.8 a 10), 364 y 375 (doc.184 y 185). 
Toda su vida profesional estuvo dedicada a la abogacía, pero sobre todo a la enseñanza como catedrático de la Universidad de Valladolid, de la que llegó a ser rector. En el año 1819, con 68 años de edad, tiene que abandonar la Presidencia del Tribunal Examinador a la Opción de la Cátedra de Teología, "por su quebrantada salud". El día 23 de abril de 1826, teniendo en esta fecha 75 años, solicita la jubilación de su Cátedra de Cánones "por su avanzada edad y el desempeño de la Cátedra por 32 años. Enterado de ello S.M., con presencia de los informes que había estimado convenientes, había tenido a bien jubilarle en la indicada Cátedra, concediéndole las dos terceras partes del sueldo que disfrutaba por ella" ${ }^{1201}$.

$\mathrm{Su}$ actividad política se inicia en el año 1812, cuando en uno de los cortos períodos en que los franceses abandonan la ciudad es elegido corregidor del Ayuntamiento en sustitución de Pedro Pascasio Calvo, que es destituido por el general Santocildes recién nombrado capitán general de Castilla la Vieja, acusándole de colaborar con los franceses. El 30 de agosto de 1813, en las elecciones celebradas, es elegido como diputado por el partido de Valladolid en la recién creada Diputación Provincial, puesto en el que se mantiene hasta su disolución en junio de 1814, asistiendo a treinta y una sesiones de las cincuenta y dos que se celebran.

Durante "los sucesos de mayo", al final de la legislatura "es detenido por las autoridades intrusas nombradas en aquellos días" ${ }^{1202}$, en referencia a los partidarios del absolutismo, que se hicieron con el control de la ciudad y que le acusaron de "liberal", como en realidad lo era. En el tiempo de permanencia en la Diputación destaca por ser uno de los diputados que más trabaja por solucionar los numerosos problemas y "expedientes" que se presentan en la corporación. Está a su favor el que es uno de los pocos diputados que viven en la ciudad y que también es conocido por su destacada actividad académica en la Universidad. En el año 1817, en el período absolutista es nombrado procurador del Común en la ciudad de Valladolid. Está afiliado a la Milicia Nacional.

En el año 1820, con la puesta en marcha de nuevo de la Diputación, la primera del Trienio, continúa ejerciendo como diputado provincial, a pesar de su avanzada edad, y realiza una gran labor y dedicación puesto que, entre marzo en que se inician las actividades y junio en que finaliza esta Diputación, asiste a treinta y dos de las treinta y cuatro sesiones celebradas. En las elecciones celebradas para cubrir las plazas de diputados en la segunda Diputación del Trienio, vuelve a ser elegido diputado provincial, presentándose en la sesión de instalación que se celebra el 7 de junio de 1820, única y última sesión a la que asiste, ya que no vuelve a presentarse en la Diputación ${ }^{1203}$.

\section{Ternero Garrido, Isidoro}

Es natural de Redecilla del Camino, en la provincia de Burgos, donde nació en el año 1834. Fue bachiller en Jurisprudencia por la Universidad de Valladolid ${ }^{1204}$. Pasa a residir a Tordesillas, donde ejerce la abogacía.

Se presenta a las elecciones para diputado provincial convocadas en mayo de 1858, para la decimocuarta Diputación y salió elegido. El 18 de julio de 1858, en la sesión de instalación, presta juramento y toma posesión del cargo. El 1 de mayo de 1859 es nombrado diputado-vicesecretario, cargo que mantiene hasta el final de la

1201 A.H.U.V.A. Caja 314 (doc.15 a 19).

1202 ORTEGA y RUBIO, Juan. Noticias de Casos particulares... ob. cit. pág. 245.

1203 ALMUIÑA FERNÁNDEZ, Celso. Historia de Valladolid... ob. cit. pág. 140, en las que mantiene que "las primeras elecciones se declararon nulas por no haberse observado estrictamente la normativa. Se repitieron los días 16 y 17 y se confirmaron a todos los elegidos salvo a Juan Andrés de Temes que es sustituido por Fernando Macho Soto.

1204 "Solicitó el ingreso en la Universidad de Valladolid en el año 1848, matriculándose en la Facultad de Leyes. El 2 de junio de 1854, solicita ser examinado para alcanzar el grado de bachiller en Jurisprudencia, presentando los certificados de los cursos probados entre 1848 y 1854 . Fue examinado el 6 de junio y habiendo durado un tiempo de hora y media en preguntas, se hizo votación secreta y resultó aprobado por unanimidad" A.H.U.V.A. Caja 476 (doc. 195 a 198). 
legislatura, que tiene lugar el 30 de marzo de 1860. Asiste en este tiempo a veintiocho de las cuarenta sesiones que se celebran. Es su única actividad política conocida, ya que no vuelve a presentarse como diputado.

\section{Tordesillas y Villagómez, Pedro de Alcántara. Conde de Patilla}

Natural de Palencia, ciudad en la que nació el 16 de octubre de 1809. Sus padres fueron Diego de Tordesillas, mariscal de campo, natural de Paredes de Nava en Palencia, e Isabel Alfonso Lorenzana, de Valderas en León. Contrajo matrimonio en 1832, con Rafaela Carlota, hija del general José O’Donell y de Rafaela Clavería. Su suegro, en esos años del absolutismo, era capitán general de Castilla la Vieja, siendo severo en la represión liberal. De este matrimonio nacieron tres hijos. El primogénito, Enrique, es el heredero del título y ejerce como abogado en Mojados, actividad que comparte con la de industrial y propietario. Aristócrata rural, fija su residencia en el pueblo de Mojados, donde desarrolla sus actividades agrícolas e industriales, entre las que destaca la propiedad de la fábrica de harinas "San Enrique" sobre el rio Cega.

En política, es conocida su tendencia absolutista. Participa en el movimiento contra el general Espartero en 1843 y su colaboración con los sublevados es premiada con el hábito de la Orden de Santiago y el título de conde de Patilla

El 19 de agosto de 1856, el capitán general de Castilla la Vieja, general Armero y Peñaranda, le nombra diputado provincial por el partido de Olmedo, en la duodécima Diputación isabelina, tomando posesión del cargo en el mismo día 19, en que se celebra la sesión de instalación. Se mantiene en el cargo hasta noviembre del mismo año 1856 , en que se da por finalizada la legislatura a la que asiste a treinta y una sesiones de las cincuenta y tres que se celebran. Es nombrado miembro de la comisión de Mantenimiento y Conservación de la Sede. El 24 de octubre de 1856, al constituirse de forma interina el Consejo provincial, es nombrado con el mismo carácter interino consejero de la institución, hasta el 4 de noviembre, fecha en la que es constituido de forma definitiva, no es elegido. Continúa como diputado provincial por Olmedo, en la decimotercera Diputación que inicia sus actividades el 2 de diciembre de 1856 y se mantiene en el cargo hasta el final de la legislatura, que tiene lugar en julio de 1858. Asiste en este tiempo a seis de las veintisiete sesiones celebradas.

Finalizada esta Diputación no se presenta a la relección, aunque sí se presenta y es elegido en el mismo año de 1858, como diputado a Cortes por Medina del Campo, cargo para el que será nuevamente elegido en los años 1864 por Medina y 1865 por Valladolid, en estas últimas elecciones, como miembro de la Unión Liberal ${ }^{1205}$.

Fallece en Madrid el 2 de mayo de 1868. Con posterioridad a su fallecimiento, en el año 1870, el Boletín Oficial de la Provincia anuncia "la venta de la fábrica de harinas San Enrique y 595 obradas de terreno, en Mojados, propiedad del Conde de Patilla".

\section{Torre Mínguez, Eustaquio de la}

Nació en Peñafiel el día 20 de septiembre de 1842, hijo de Pedro de la Torre, natural de Roa, y de María Mínguez de Peñafiel. "Ingresó en la Universidad de Valladolid en 1858, matriculándose en la Facultad de Leyes donde acabó obteniendo el grado de licenciado en Jurisprudencia ${ }^{1206}$. Ejerce como abogado en Peñafiel, además de administrar sus propiedades.

${ }^{1205}$ CARASA SOTO, Pedro (Dir.). Diccionario biográfico de parlamentarios ... ob. cit. pág. 1107.

1206 En el año 1862 solicita ser examinado para obtener el grado de bachiller en Derecho Civil y Canónico, teniendo aprobados 4 años en la Facultad de Leyes y acompañando los certificados de los cursos probados entre 1858 y 1862 . Entró a examen el 13 de junio y después de votación secreta resultó aprobado. En el año 1863, solicita al rector de la Universidad ser examinado para alcanzar el grado de bachiller en Filosofía, presentando al mismo tiempo los certificados de los cursos probados. Examinado el 10 de junio, salió aprobado. En el año 1864, presenta la solicitud para 
En política, pertenece al partido liberal, corriente gamacista, controlando en todo momento las actividades del partido en toda la comarca de Peñafiel. Inicia su carrera política, a nivel provincial, en el año 1871 al presentarse a las elecciones para diputado provincial por el distrito de Peñafiel, que se celebran en los días 1,2 y 3 de febrero, y sale elegido. Se presentó en la sesión de instalación de la tercera Diputación del Sexenio, que se celebra el 17 del mes de febrero de 1871, llevando el acta, que es aprobada en la sesión del día 20. El día 23 es elegido vocal de la Comisión permanente, trabaja tanto en la Comisión como en los Plenos de la Diputación hasta el final de la legislatura que se produce en octubre de 1872. Asiste en este período a cincuenta y cinco sesiones de la Diputación y a ciento diecisiete de la Comisión. El 25 de julio de 1872 se celebra el sorteo para decidir los diputados a renovar, y le correspondió cesar en el cargo.

Se vuelve a presentar a las elecciones que se celebran en septiembre del mismo año y es nuevamente elegido, por lo que se presenta en la sesión de instalación de la cuarta Diputación del Sexenio, que se celebra el 2 de noviembre de 1872. Entrega su acta de elección, también por el distrito de Peñafiel, que será aprobada en la sesión del día 4. Es nombrado vocal de la comisión de Actas y en la sesión del día 11 del mismo mes de noviembre, el Pleno de la Diputación nombra "vocal de la Comisión provincial al Sr. Barquín, en sustitución del Sr. de la Torre, que en esta fecha ha presentado la dimisión de su cargo". Se mantiene como diputado hasta que en la sesión del 11 de mayo de 1874 el gobernador interino "en uso de las facultades que le concede la circular del Poder Ejecutivo de la República" le cesa en el cargo, siendo remplazado por Luis Alonso Burgueño. En este tiempo asiste a veinticinco sesiones de las cuarenta y dos celebradas. Aunque el gobernador interino le cesó, el gobernador titular, recién tomada posesión del cargo, le nombra el 30 de mayo, nuevamente diputado provincial por Peñafiel, en la quinta Diputación del Sexenio. Se presenta en la sesión de instalación que se celebra el mismo día 30, siendo nombrado en la mis ma sesión vocal de la Comisión provincial y seguidamente, en la sesión de constitución de la Comisión, es nombrado vicepresidente de la misma. Se mantiene en ambos cargos hasta el final de la legislatura y del Sexenio en marzo de 1875, asistiendo en este tiempo a trece sesiones de las dieciocho que celebra la Diputación y a sesenta y cinco de las ciento treinta y cinco que celebra la Comisión.

Vuelve a ser elegido diputado provincial en la primera Diputación de la Restauración, deja la vicepresidencia de la Comisión permanente en manos de Marcelino Díez Bueno y continúa como vocal. El 1 de junio de 1875, al poco de iniciarse la primera Diputación de la Restauración, presenta su dimisión como diputado "no pudiendo estar conforme con la política que hace el Gobierno y rindiendo mi tributo de merecido respeto a la actitud digna en que se ha colocado el partido constitucional al que tengo la honra de pertenecer". En las elecciones que se celebran en 1877 para la segunda Diputación de la Restauración es derrotado por Damián Álvarez y solicita en el Pleno de la Diputación se le permita defender la impugnación presentada, a lo que la presidencia se niega, "produciéndose un gran alboroto entre el público". En 1878, tras las nuevas elecciones, sale diputado y es elegido presidente de la Diputación, cargo que detenta hasta 1880. En 1883 vuelve a ser relegido presidente y acepta "si se le permite renunciar a las dietas que le corresponden" "207.En 1884 deja la Diputación y su puesto en la Diputación en representación de Peñafiel es asumido por su hermano Juan, que se mantiene en el mismo hasta $1892^{1208}$. Abandona la política en 1903, cuando a la muerte de Gamazo se enfrenta a los jóvenes líderes del partido por su control, siendo derrotado por Eloy

alcanzar el grado de licenciado en Leyes y examinado el día 13, fue aprobado" A.H.U.V.A. Cajas 481 (doc. 255 a 261 ), 514 (doc. 225 a 230 ) y 685-67.

1207 Norte de Castilla de 17 de abril de 1883.

${ }^{1208}$ PASTRANA MORILlA, Heliodoro. La Diputación Provincial de Valladolid... ob. cit. pág. 417. 
Silió, uno de los nuevos dirigentes. Fallece en Peñafiel el 9 de septiembre de 1913, a $\operatorname{los} 71$ años.

\section{Torres, Isidro}

Diputado provincial, sin conocerse su procedencia y el partido judicial al que representa. Toma posesión de su cargo en la tercera Diputación del Trienio, el día 1 de marzo de 1822 y se mantiene en el puesto hasta el fin de la legislatura en abril de 1823, asistiendo a ciento doce sesiones de un total de ciento cincuenta y siete. Como posibilidad de procedencia y sin ningún dato que lo avale, es posible que pertenezca y habite en Mayorga, y se le da también como posible diputado por Valladolid.

\section{Torres López, Patricio}

Nació en Villalón, el 17 de marzo de 1833, hijo de Lorenzo y de Cecilia, vecinos de la villa. "Ingresó en la Universidad de Valladolid en el año 1848, matriculándose en la Facultad de Leyes ${ }^{1209}$. Se instala en Villalón, donde ejerce como abogado.

El comienzo de su carrera política tiene lugar cuando en el año 1866 es elegido alcalde de Villalón. En el año 1871, a principios del mes de febrero, se presenta a las elecciones para diputado provincial en representación del distrito de Mayorga, del partido de Villalón, en la tercera Diputación del Sexenio. Resultó elegido, por lo que presentó su acta en la sesión que se celebra el 24 de febrero, siendo aprobada. En la sesión del 25 de julio de 1872, se celebra el sorteo de los diputados a los que corresponde continuar y le tocó cesar, por lo que al finalizar la legislatura en octubre de 1872, no se presenta a la relección. En el tiempo que ejerció como diputado asistió a cuarenta y dos sesiones de las setenta que se celebraron. No vuelve a ser diputado.

\section{Valbuena, Toribio}

Natural y vecino de Becilla de Valderaduey, del partido de Villalón, pueblo donde nació el 8 de abril de 1817. Es eclesiástico exclaustrado. Se dedica a la agricultura y a la industria, ya que es poseedor de una serie de fincas rústicas y de una fábrica de harinas.

$\mathrm{Su}$ verdadera vocación es la política. Es el representante y organizador del partido progresista en Tierra de Campos, tarea que inicia a partir de los años 1840 y en la que arriesgó su fortuna, por lo que fue encarcelado en varias ocasiones y llegó a ser desterrado. Se inicia en la actividad política con ocasión de la publicación del real decreto de 23 de mayo de 1858, que fija la fecha y condiciones para celebrar las elecciones a diputados provinciales y celebradas estas, sale elegido diputado por el partido de Villalón, en la decimocuarta Diputación isabelina. El 18 de julio de 1858 se celebra la sesión de instalación en la cual se presenta, presta juramento y toma posesión del cargo. En la misma sesión es nombrado miembro de las comisiones de Presupuestos y de Estudio de Nueva Cárcel. Una vez tomada posesión de su acta de diputado, en el año 1858, se presenta a las elecciones de octubre para el Congreso de diputados por el distrito de Rioseco, siendo derrotado por su contrincante de la Unión Liberal, Antonio Méndez Vigo. Continúa como diputado provincial en la legislatura, que se mantiene hasta finales de marzo de 1860, asiste a treinta y una de las cuarenta sesiones que se celebran y acabada esta legislatura no se presenta como candidato a más elecciones para diputados provinciales.

Se presenta de nuevo como candidato de diputado a Cortes en las elecciones al Congreso en los años 1864 y en 1869, pero no tuvo éxito, y además sus enemigos

1209 En el año 1852 solicita ser examinado para alcanzar el grado de bachiller en Jurisprudencia. En e año 1854 solicita se le examine para acceder al grado de licenciado en Jurisprudencia y examinado los días 14 y 17 de junio resultó aprobado por unanimidad, recibiendo la investidura del grado en la reunión del Claustro celebrada el día 18 de junio" A.H.U.V.A. Cajas 678-51. 
políticos le acusaron del impago de deudas. La noticia fue corroborada a través de un anuncio del Boletín Oficial de la Provincia del día 8 de enero de 1869, en el que "el Juez de Villalón, avisa a todos los acreedores de Toribio Valbuena, vecino de Becilla de Valderaduey, para que presenten sus derechos". Negó estas "habladurías" y continuó trabajando para alcanzar la elección de diputado al Congreso, meta que finalmente consiguió en las elecciones del 8 de marzo de 1871 por el partido de Villalón ${ }^{1210}$. Volvió a ser elegido en las del 10 de mayo de 1873 y en esta ocasión en la candidatura del partido republicano. Finalizada la legislatura, se retira de la política activa, aunque continuó publicando en El Norte de Castilla artículos en los que reclamaba reformas y criticaba las actuaciones del gobierno. Falleció en Becilla el 25 de octubre de 1877 , dejando como heredero a su hermano.

\section{Valdés, Pablo.}

Es vecino del pueblo de Portillo, por el que se presenta para diputado provincial en las elecciones de 1, 2 y 3 de febrero de 1871. Resulta electo y presenta su acta en la sesión de instalación de la tercera Diputación del Sexenio, que tiene lugar el 17 de febrero de 1871. El 24 del mismo mes, la Diputación "acuerda declarar nula la elección del diputado por Portillo en la persona de Pablo Valdés". No se especifican los motivos por los cuales ha sido rechazada el acta. El paso siguiente se da cuando en el Boletín Oficial del 23 de marzo de 1871 se anuncia que "por acuerdo de la Diputación Provincial sobre la nulidad de la elección de diputado provincial verificada en el distrito de Portillo, partido judicial de Olmedo, en cumplimiento del artículo treinta y cinco de la Ley Electoral, se convoca a los electores para nuevas elecciones a celebrar el día 31 de marzo y siguientes". Sin haber anunciado el resultado, la Diputación en su acta del 17 de abril de 1871 reseña que "se aprueba el acta de elección de diputado por Portillo de Pablo Valdés". Sin más problemas, se presenta en la Diputación en la sesión del día 20, en la que toma posesión del cargo, manteniéndose en el mismo hasta el final de la legislatura en octubre de 1872, tomando parte en cincuenta de las setenta sesiones que se celebran.

Se vuelve a presentar en las elecciones de septiembre de 1872, para la cuarta Diputación del Sexenio, ya que en el sorteo celebrado el 25 de julio, le correspondió cesar. Sale nuevamente elegido por Portillo. Se presenta en la sesión del 5 de noviembre para tomar posesión y permanece como diputado a lo largo de toda la legislatura que se da por finalizada el 11 de mayo de 1874, asistiendo a treinta y una sesiones de las cuarenta y dos celebradas. En la quinta Diputación del Sexenio continúa como diputado por Portillo en virtud del nombramiento realizado por el gobernador civil. Se presenta en la sesión del 31 de mayo de 1874, sesión en la que es nombrado vocal de la comisión de Presupuestos y vocal suplente de la Comisión provincial. Finaliza esta legislatura en marzo de 1875, a la que asiste a catorce de las dieciocho sesiones que se celebran. Se mantiene en el cargo de diputado por Portillo en la primera Diputación de la Restauración que inicia sus actividades el 19 de marzo de 1875 y que finaliza en 1877. No vuelve a estar presente en la Diputación.

\section{Valdés, Toribio}

Se presentó a las elecciones de diputado provincial en las elecciones celebradas en mayo de 1822, en la segunda Diputación del Trienio, siendo elegido suplente, aunque no llegó a actuar. Es hacendado y vecino de La Pedraja del Portillo.

\section{Velasco y Franco, Manuel de}

Vecino de Rioseco, en las elecciones celebradas a la tercera Diputación isabelina en diciembre de 1837 es elegido diputado suplente por el citado partido de Rioseco. Con ocasión de la muerte del diputado titular Alejandro Nájera, ocurrida en el mes de enero de 1840 , es requerido para cubrir su puesto. Pero no toma posesión

\footnotetext{
${ }^{1210}$ CARASA SOTO, Pedro (Dir.). Diccionario biográfico de Parlamentarios... ob. cit. pág. 1135.
} 
del mismo hasta la sesión que se celebra el 25 de octubre del mismo año 1840 , asistiendo únicamente a tres sesiones de la Diputación, pues la legislatura se cierra en el mes de diciembre. En el año 1841 es elegido componente de la terna para la elección de senador de la provincia, aunque finalmente no salió elegido.

\section{Velasco Neira, Miguel}

Nació en Alcazarén, el 8 de mayo de 1834, hijo de León Velasco y de Margarita Neira. "Ingresa en la Universidad de Valladolid en el año 1847, graduándose primero en la Facultad de Artes y licenciándose luego en la de Leyes ${ }^{1211}$. Acabados los estudios se establece como abogado en Alcazarén, pueblo del que es nombrado juez municipal en el año 1870, por el presidente de la Audiencia. Recibe la condecoración de Caballero de la Orden de Isabel La Católica.

En política, está afiliado al partido conservador, por el que se presenta a las elecciones para diputados provinciales, que se celebran los días 1,2 y 3 de febrero de 1871. Resultó elegido por el distrito de Mojados, perteneciente al partido judicial de Olmedo. El 17 de febrero de 1871 se inician las actividades de la tercera Diputación del Sexenio, sesión en la que presenta su acta, que es aprobada en la sesión del día siguiente. El 20 de abril de 1872 entra a formar parte como vocal de la Comisión permanente en sustitución de Sebastián Fernández Miranda. Finaliza la legislatura en octubre de 1872, asistiendo a cincuenta ydos sesiones de las setenta que celebra el Pleno de la Diputación y a once de la Comisión Permanente.

Sigue como diputado por Mojados en la cuarta Diputación al corresponderle continuar en el sorteo celebrado el 25 de julio de 1872. Se presenta en la sesión de instalación que se celebra el día 2 de noviembre del citado 1872. El 13 de noviembre es relegido miembro de la Comisión provincial y se mantiene tanto en la Diputación como en la Comisión hasta el 11 de mayo de 1874, fecha en la que queda disuelta la Diputación. En este tiempo asiste a dieciséis sesiones de la Diputación y a sesenta y nueve de la Comisión permanente. El 30 de mayo de 1874, el gobernador civil le ratifica como diputado por Mojados en la quinta Diputación del Sexenio, y presente en la misma sesión es nombrado vicepresidente de la Corporación. Preside las sesiones que se celebran en diciembre de 1874, ante la ausencia del presidente Reoyo. Asiste a trece de las dieciocho que celebra la Diputación, pero de enero a marzo de 1875 , deja de asistir a las sesiones.

Continúa como diputado por Mojados en la primera Diputación de la Restauración entre 1875 y 1877 . En las elecciones de 1877 es derrotado por Sanz Villapecellín, aunque impugna el nombramiento por ser el electo juez municipal de Olmedo. Consigue ser nombrado diputado y se mantiene hasta el año 1883. Fallece en Alcazarén el 26 de agosto de 1885, a los 50 años.

\section{Villalba, Benigno}

Agente de negocios en Valladolid y procurador de los Tribunales, tiene su domicilio en el $\mathrm{n}^{\circ} 10$ de la Plaza Mayor. En el año 1842 compró 15 hectáreas de tierras desamortizadas, situadas en Tierra de Medina por 16.165 reales. En 1861 es subdirector de la "Caja Nacional Compañía de Seguros Mutuos". En el año 1863 se anuncia en el Boletín Oficial que "Benigno Villalba, procurador de número de los

1211 El 15 de mayo de 1851, solicita optar al grado de bachiller en Filosofía, acompañando los certificados de los cursos probados entre 1847 y 1851. Examinado el 20 de mayo en votación secreta, resultó suspenso por unanimidad, señalando el plazo de 3 meses para entrar en nuevo ejercicio. El 20 de septiembre de 1851 presenta nuevamente la solicitud de examen para bachiller en Filosofía, y examinado los días 27 y 30 resultó aprobado. En octubre de 1851 se matricula en la Facultad de Leyes y en el año 1856 presenta la solicitud de examen para alcanzar el grado de bachiller en Jurisprudencia, acompañando los certificados de los cursos probados entre 1851 y 1856. Examinado el 5 de junio, fue aprobado por unanimidad. En el año 1858, solicita el examen para el grado de licenciado en Jurisprudencia. Examinado los días 23 y 27 de junio, salió aprobado por unanimidad, y se le confirmó en el claustro del día 4 de julio de 1858" A.H.U.V.A. Cajas 477 (doc. 129 a 131), 509 (doc. 440 a 443), 510 (doc. 62 a 64) y 679 (doc. 143 a 146). 
Juzgados de Primera Instancia de Valladolid y el más antiguo de los agentes de negocios de la capital, domiciliado en la Plaza Mayor $\mathrm{n}^{\circ} 10$, ace pta los asuntos que se le confíen en uno u otro concepto y continúa sirviendo a las municipalidades de la provincia en cuantos trabajos le encarguen, así como verificar cobranzas en tesorería por réditos de láminas o en concepto de anticipos por bienes vendidos a las corporaciones" 1212 .

El año 1870 es el punto de partida de su actividad política al ser elegido regidor del Ayuntamiento de Valladolid. En las elecciones celebradas en septiembre de 1872, para la renovación de la Diputación, es elegido diputado por el distrito cuarto de Valladolid, parroquia de San Martín, por 305 votos contra 142 de su oponente Ezequiel Ortiz. En la sesión de instalación de la cuarta Diputación del Sexenio, que se celebra el 2 de noviembre de 1872, es nombrado miembro de la comisión Auxiliar de Actas, siendo aprobada la suya en la sesión del día 4. El 7 del mismo mes de noviembre es nombrado diputado-secretario, ejerciendo el cargo a lo largo de toda la legislatura que finaliza el 21 de mayo de 1874. Asiste en este tiempo a treinta y ocho de las cuarenta y dos sesiones que se celebran. En la sesión del 11 de marzo de 1874, "a petición del vicepresidente de la Comisión provincial y para poner al día los censos $\mathrm{y}$ créditos a favor del Hospicio, de acuerdo con la Memoria redactada por Ignacio $\mathrm{M}^{\mathrm{a}}$ Bueno, se nombran abogado y procurador para poner al día el cobro de los citados censos y créditos. Abogado Eladio Quintero y procurador Benigno Villalba". Y en la sesión del 5 de noviembre del mismo año 1874 , cuando ya había abandonado la Diputación, "la Comisión provincial critica el nombramiento que se hizo de dos diputados como abogado y procurador de los créditos del Hospicio". No vuelve a estar presente en más Diputaciones.

\section{Villanueva, Tomás}

Natural y vecino de Valladolid, nacido en el año 1820. Es labrador y ganadero, preocupado por mejorar los sistemas agrícolas y la cabaña ganadera. En el año 1856 compra una pequeña finca de 9 hectáreas procedente de bienes nacionales, junto con una casa en Valladolid por las que pagó 22.020 reales. Accionista del ferrocarril AlarSantander. En el año 1862 es comisionado por la Diputación Provincial de Valladolid para que, junto a los señores José Manuel Fernández Rico y Laureano Melero, asistan a la Exposición Internacional de Londres, en la cual adquieren una serie de máquinas agrícolas y semillas, para realizar ensayos con el objeto de mejorar la agricultura provincial.

En noviembre de 1863 se presenta a las elecciones para diputado provincial en la decimoséptima Diputación, por el distrito de la Audiencia de la capital, resultando elegido. El 1 de enero de 1864, en la sesión de instalación, presta juramento y toma posesión del cargo. En la misma sesión es nombrado miembro de la comisión de Establecimientos Benéficos. Asiste a cuarenta y ocho de las cuarenta y nueve sesiones que celebra la Diputación hasta el final de la legislatura en diciembre de 1865. En el sorteo para la renovación parcial de la Diputación, le corresponde continuar, en la decimoctava Diputación, representando igualmente al distrito de la Audiencia. Se inician las actividades el 1 de enero de 1866 y se mantiene hasta el 31 de diciembre del mismo año, fecha en la que termina la legislatura, en la que asiste a dieciséis de las dieciocho sesiones que se celebran. En noviembre de 1866 se celebran nuevas elecciones para la decimonovena Diputación, en las que vuelve a salir elegido, prestando juramento en la sesión de instalación que se celebra el 1 de enero de 1867. En la misma sesión es nombrado miembro de la comisión inspectora de Establecimientos Benéficos. En esta legislatura es nombrado presidente en las reuniones extraordinarias de julio de 1867 y en las de mayo y junio de 1868, aunque no llegó a presidir ninguna sesión ante la presencia del Sr. gobernador. Se mantiene en la Diputación hasta el final de la legislatura que tiene lugar el 20 de septiembre de

1212 B.O.P.V. $\mathrm{n}^{\circ} 14$ de 23 de enero de 1863 donde aparece la publicado el citado anuncio. 
1868, asistiendo a cuarenta y siete del total de cincuenta y dos sesiones que se celebran. No vuelve a presentarse a más elecciones ni en el Sexenio, ni en la Restauración.

\section{Villarias Ruiz, Gaspar}

Es natural de Villarcayo, en la provincia de Burgos, donde nació el 10 de enero de 1830, hijo de Fernando Villarias y de Úrsula Ruiz de la Plaza, vecinos de Villarcayo. "En el año 1843 solicitó el ingreso en la Universidad de Valladolid, y se matriculó en la Facultad de Filosofía, donde fue bachiller, y en la Leyes, donde alcanzó al licenciado en Jurisprudencia ${ }^{1213}$. Se establece como abogado en Valladolid.

No se tienen noticias de su actividad política hasta que con fecha 1 de enero de 1869 es nombrado secretario del Gobierno Civil de Valladolid. Permanece en el cargo hasta enero de 1870 y ejerce en ocasiones como gobernador interino por ausencia del titular. En enero de 1870 pasa a ocupar el mismo cargo en el Gobierno Civil de Oviedo.

Vuelve a aparecer en Valladolid en la sesión de instalación de la quinta Diputación del Sexenio, que se celebra el 30 de mayo de 1874 y en la que es nombrado diputado provincial por el distrito de San Martín de Valladolid, por orden del gobernador civil. En la misma sesión es nombrado vocal de la Comisión provincial. En noviembre de 1874 presenta la dimisión como vocal del Consejo, petición que es rechazada. El 22 de enero de 1875, es nombrado miembro de la comisión "de ir a visitar al Rey e invitarle a la ciudad". Finaliza la legislatura en marzo de 1875, habiendo asistido a diecisiete de las dieciocho sesiones que se celebraron y a setenta y tres sesiones de la Comisión permanente de un total de ciento treinta y cinco celebradas. No vuelve a ser nombrado diputado.

\section{Zorita Alonso, Juan de Mata}

Natural de Castronuño, provincia de Valladolid, pueblo en el que nació el 6 de febrero de 1829, hijo de Matías Zorita y de Josefa Alonso. "En el año 1842, solicita el ingreso en la Universidad de Valladolid, matriculándose en la Facultad de Filosofía. En 1845, solicita ser examinado para alcanzar el grado de bachiller en Filosofía. Entró a examen el 4 de octubre y salió aprobado. En el mismo año 1845, se matricula en la Facultad de Leyes. En el mes de junio de 1849 solicita ser examinado para alcanzar el grado de bachiller en Jurisprudencia, acompañando los certificados de los cursos probados desde 1842 a 1849. Examinado el 6 de junio por los profesores Vaca, Domingo y López Gómez salió aprobado por unanimidad. En 1852, se presenta a examen para el grado de licenciado en Jurisprudencia. Entró a examen el 27 de mayo y salió aprobado por unanimidad" ${ }^{1214}$.

Estableció su residencia en Castronuño, donde ejerció la abogacía, ocupación que comparte con la agricultura. Es comprador de una pequeña finca de 4 hectáreas procedente de bienes nacionales por la que pagó 2.744 reales.

En política pertenece al partido conservador. En las elecciones a diputados provinciales de la decimoséptima Diputación celebradas en noviembre de 1863 sale electo por el partido de Nava del Rey el candidato Vicente Delgado. En la sesión de instalación celebrada el 1 de enero de 1864, su acta fue rechazada y el gobernador civil ordenó celebrar nuevas elecciones los días 31 de julio y 1 de agosto de 1864 , en

1213 En el año 1846, solicitó ser examinado para alcanzar el grado de bachiller en Filosofía. Entró a examen el 8 de julio y salió aprobado. En el mismo año 1846 se matriculó en la Facultad de Leyes. En 1850 solicita el examen para acceder al grado de bachiller en Jurisprudencia, acompañando los certificados de los cursos probados entre 1843 y 1846 y 1847 a 1850 . Entró a Grado el 10 de junio y salió aprobado. El 1 de Junio de 1853 solicita ser examinado para acceder al grado de licenciado en Jurisprudencia. Fijados los exámenes los días 11 y 15 de junio fue aprobado por unanimidad, recibiendo la investidura en el claustro celebrado el 19 de junio de 1853 " A.H.U.V.A. Cajas 475 (doc. 173 a 177), 506 (doc. 62 a 64) y 678-1.

1214 A.H.U.V.A. Cajas 505 (doc. 301 a 303) y 677-9. 
las que resultó elegido Zorita Alonso, que tomó posesión del cargo en la sesión que celebra la Diputación el 6 de agosto. Asiste a esta sesión del mes de agosto y a las dos que se celebran en el mes de octubre, hasta que por real orden de 31 de octubre "se anula la elección de D. Juan de Mata Zorita como diputado provincial por el partido de Nava del Rey". Por lo cual dejó la Diputación según se le ordenaba y no volvió a presentarse en otras elecciones.

El 14 de octubre de 1868 asiste a la sesión de instalación de la comisión especial de la Junta Revolucionaria Provincial de Valladolid, en representación del distrito de Tordesillas. Esta comisión es un paso previo a la instalación de la nueva Diputación, con la finalidad de mantener las actividades provinciales ante la disolución de la anterior. El 21 de octubre se efectúa la instalación definitiva de la Diputación en la que no aparece como diputado. Es alcalde de Tordesillas durante los años 1869 y 1870 . En el año 1872, con ocasión de las elecciones que se celebran a diputados provinciales en la sesión del 5 de noviembre, "fue aprobada el acta de elección del diputado por Tordesillas Marcelino Diez Bueno, a pesar de las protestas del pueblo de San Román de Hornija, por la coacción que a favor del diputado hizo Juan de Mata Zorita, estando presente en el salón e invitando a los electores a puros y licores" $" 1215$

\section{7.- ANÁLISIS POLÍTICO, SOCIAL Y CULTURAL DE LOS DIPUTADOS PROVINCIALES.}

Desde 1813 a 1874, pasan por la Diputación de Valladolid doscientos veintiún individuos, que fueron elegidos o nombrados diputados provinciales, tanto titulares, que son la mayoría, como suplentes. Unos, los menos, ejercieron solamente por el espacio de un día, y otros durante varios años, pero todos tuvieron la misma intención y todos trabajaron por la misma finalidad, que fue la de hacer progresar a la provincia. Este conjunto de diputados han trabajado a lo largo de veintiocho legislaturas, lo que representa una media de nueve diputados por legislatura, teniendo en cuenta que las primeras Diputaciones estuvieron formadas por siete diputados, tantos como partidos judiciales, y las tres últimas por treinta ycinco, tantos como distritos.

La permanencia en el cargo es un dato interesante que nos puede indicar el afán de los diputados por mantenerse en el puesto, teniendo en cuenta de que es un trabajo no remunerado y con una dedicación mínima de noventa días de sesiones por legislatura. Un seguimiento de los diputados y de las legislaturas nos dan los siguientes resultados:

Ciento veintinueve individuos han ejercido el cargo durante una legislatura, cuarenta y seis lo han ejercido en dos legislaturas, treinta y tres se han mantenido a lo largo de tres legislaturas, ocho lo han hecho durante cuatro ocasiones, tres han permanecido durante cinco legislaturas, uno se ha mantenido en seis Diputaciones y otro ha sido el más constante al mantenerse en siete legislaturas.

El resultado nos dice que más del $58 \%$ de los diputados sólo ejercieron durante una legislatura y aquí no valoramos si en realidad hubo una continuación de la presencia de otros familiares que dieron continuidad al control de determinadas familias en el seno de la Diputación durante buena parte de estos años.

En los cuadros que a continuación se adjuntan, vamos a repasar y condensar las actividades de todos ellos, en principio desde un punto de vista social, es decir, de su profesión, de su situación social, de su influencia en su entorno territorial, en definitiva, de su poder y de su dominio económico. También nos parece interesante conocer la evolución de la formación cultural y académica de los diputados y veremos cómo, con el paso de las legislaturas, se va generalizando una mayor formación en los componentes de la Diputación, a la vez que se constata una mayor inquietud y un

1215 A.D.P.V. Actas. Libro de actas del 5 de noviembre de 1872. 
mayor interés en la extensión de la enseñanza y la cultura a la población.

Finalmente, un tercer e importante análisis que también quedará plasmado en los citados cuadros, está referido a la ideología política de los diputados, y a cómo cambia su evolución con el paso de los años. Es interesante ver la politización progresiva de la Diputación, a partir de los primeros años liberales, pasando por períodos moderados y progresistas hasta desembocar en el período revolucionario.

Para realizar este análisis, sin distorsionar los resultados, por el paso de los años, hemos dividido este período en seis etapas, que coinciden con la evolución de la política a nivel nacional y que coincide con una evolución similar que tiene lugar en la política provincial. Estas etapas son las siguientes: Los primeros años liberales 1813 14 y 1820-23. Los primeros diputados isabelinos 1835-40. Los años progresistas, 1840-43 y 1854-56. La Década moderada, 1844-54. El "período gris" 1856-68. El

Sexenio, 1868-74.

Un primer resumen de los diferentes parámetros que se contemplan en estos períodos nos da que:

En los primeros años liberales 1813-14 y 1820-23 tienen lugar cuatro legislaturas con treinta y seis diputados de los cuales veintidós estrenan escaño y catorce repiten en las citadas legislaturas. Se efectúan un total de cuatrocientas dieciséis sesiones con una media de nueve diputados por sesión y ciento cuatro sesiones por legislatura.

En los primeros años isabelinos, entre 1835 y 1840 , son tres las legislaturas treinta y tres el número de diputados de los cuales sólo tres repiten. El total de sesiones es de cuatrocientas diecisiete con once diputados por sesión y ciento treinta y cuatro sesiones por legislatura de media.

En los dos períodos progresistas 1840-43 y 1854-56, tienen lugar otras tres legislaturas con treinta y tres diputados de los cuales diecisiete son nuevos y dieciséis repiten. El número de sesiones es de cuatrocientas una con medias de nueve diputados por sesión y sesenta y nueve sesiones por legislatura.

La Década moderada nos da unas cifras de cinco legislaturas con cuarenta y cinco diputados de los que veintiséis son nuevos. El total de sesiones es de trescientas cuarenta y cuatro con nueve diputados asistentes por sesión y sesenta y nueve sesiones por legislatura de término medio.

En los años del "período gris" 1856 a 1868 tenemos ocho legislaturas con ochenta y dos diputados de los cuales cuarenta y tres repiten y treinta y nueve estrenan trabajo. Solamente doscientas noventa y dos sesiones en estos años con unas medias de diez diputados `por sesión y treinta y seis sesiones por legislatura.

Finalmente, en los años del Sexenio, 1868-74, tienen lugar cinco legislaturas con ciento cincuenta y cuatro diputados de los que ochenta y siete son nuevos. Con trescientas treinta y cinco sesiones y treinta y un diputados de media por sesión y setenta y una sesiones por legislatura.

Las cifras totales del conjunto de estos años nos dan veintiocho legislaturas, doscientos veintiún diputados y dos mil doscientas veinticinco sesiones. 


\section{DIPUTADO}

Diputados 1813-14 y 1820-23

Arguello, Joaquín Antonio de

Berdonces, José

Conde Bravo, Santiago

Cuadrillero Herce, H. Fernando

Fernández González, Juan

Galván, José

González Perotes, José Antonio

González Rodríguez, Alonso

Haro, Bernardino de

Macho Soto, Fernando

Maldonado, Joaquín

Mantilla, Francisco Antonio

Pestaña, José

Prieto Rodríguez, Félix

Quijada y Calderón, Juan Ant.

Rodríguez, Rafael

Romero y Diez, Pedro Regalado

Ruiz Dávila, Tomás

Salcedo, Luciano

Temes y Prado, Juan Andrés

Torres, Isidro

Valdés, Toribio

Diputados 1835-40

Alday García, Manuel

Alonso del Barrio, Millán

Bergaz, Juan Manue

Blanco, Francisco

Cabeza de Vaca y Gómez, Pelayo

Camino, Venancio

Campesino, Mariano

Corral, José

Díaz, Cesáreo

Diez Serrano, Francisco

Fernández, José

Fernández Montero, Francis.

Fernández Vítores, Juan Manuel

Fuente, Eusebio de la

\section{ESTUDIOS \\ PROFESIÓN B.N \\ OTRA ACTIVID}

PART.POLIT

$\mathbf{N}^{\circ}$ D. M.N.

Leyes

Teología

Leyes

Leyes

$-$

$--$

Hacendado

A gricultor

Teología-Arte

Leyes

Filosof.-Leyes Abogado

Leyes

Filosof.-Leyes

$--$

Leyes

$--$

Leyes

Francés-Eco.

Leyes

Medicina

$-$

Leyes

--

$--$

Leyes
Hacendado

Canónigo

Hacendado

Agricultor

Catedrático

Hacendado

Presbítero

or Aud.

Hacendado

Hacendado

Catedrático

Abogado

Hacendado

Hacendado

Propietario

Catedrático

Propietario

Médico

Propietario

Propietario

Abogado

Propietario

Propietario

Comerciante

Abogado
Abogado

Académico

Abogado

--

$--$

$--$

Presbítero

Accionista Alar-Sant

Abogado

Magistrado

$--$

$-$

Abogado. Rector

$-$

Director Caja Ahorr Industrial. Accionis

$$
--
$$

Rector. Abog. Prop.

Liberal

$-$

Liberal

Liberal

Liberal

Absolutista

Liberal

Liberal

Liberal

Liberal

--

$-$

Liberal

Liberal

Liberal

Progresista

Propietario

--

$-$

Ind.Prop Accionista Moderado

Progresista

Liberal
OTROS CARGOS

Regidor municipal

Elector

Elector

Congreso

$-$

Congreso. Senado

--

Alcalde

Síndico. Alcal.Congr

Congreso. Senado

Alcalde

Elector. Alcalde.Congr

--
Alcalde

Concejal. Alcalde

Alcalde. Elector 


\section{DIPUTADO}

García Casasola, Ildefonso

Gómez Rozas, Pedro

Gómez Villavedón, Luis

González, Facundo

López Puga y Viguero, Tadeo

Llamas, Manuel

Martín, Braulio

Martín Lozar, Manuel

Montalvo, Gil

Moras Ortega, Miguel de las

Nájera, Alejandro

Pérez, Manuel

Pérez Cantalapiedra, Atanasio

Pimentel Bayón, Vicente

Rua, Casto María de la

Velasco y Franco, Manuel

Diputados 1840-43 y 1854-56

Alderete, Faustino

Alonso García, Andrés

Arévalo, Juan Manuel

Cafranga, Isidoro Mariano

Cantalapiedra, Pedro Paulino

Fernández, Cristóbal Magdaleno

García Escobar, Ventura

González, Baltasar

Gusano, Manuel

López Puga y Viguero, Manuel

Moras Gala, Juan Antonio de las

Moreno Redondo, Benito

Quiroga Martínez, Santiago

Represa, Agustín de

Rodríguez Rubio, Francisco

Santander, Juan José

Santander, Genaro

Diputados 1844-54

Arévalo Miera, Ignacio María

Cabrejas de la Plaza, Felipe

Diez del Río, Benito

Dueñas, Miguel de

\begin{tabular}{|c|c|c|c|c|c|c|c|}
\hline ESTUDIOS & PROFESIÓN & B.N & OTR ACTIVID & PART.POLÍT & $\mathbf{N}^{0} \mathrm{D}$. & M.N. & OTROS CARGOS \\
\hline-- & Propietario & -- & -- & -- & 2 & Sí & Alcalde. Elector \\
\hline-- & Terrateniente & Sí & Rentista & -- & 1 & -- & -- \\
\hline-- & Propietario & -- & -- & Liberal & 1 & Sí & Alcalde \\
\hline Leyes & Abogado & -- & -- & -- & 1 & -- & -- \\
\hline -- & Propietario & -- & -- & -- & 1 & -- & -- \\
\hline Leyes & Abogado & Sí & Impresor. Magistrado & Liberal & 1 & Sí & Gobernador. Congreso \\
\hline-- & -- & -- & -- & -- & 1 & -- & -- \\
\hline Leyes & Abogado & -- & Fiscal Aud. Académic & Moderado & 1 & -- & Alcalde \\
\hline-- & -- & -- & -- & -- & 1 & -- & -- \\
\hline-- & Escribano & Sí & Propietario & Moderado & 8 & -- & Congreso \\
\hline-- & -- & -- & -- & -- & 1 & -- & -- \\
\hline-- & -- & -- & -- & -- & 1 & -- & -- \\
\hline Filosof.-Leyes & Catedrático & Sí & Propietario Agrícola & Progresista & 2 & Sí & Alcalde. CongrSenado \\
\hline -- & Propietario & Sí & Accionista Alar-Sant. & Conservador & 4 & -- & Congreso. Senado \\
\hline-- & Industrial & Sí & Agrícola-Ganadero & Liberal & 1 & Sí & -- \\
\hline-- & -- & -- & -- & -- & 1 & -- & -- \\
\hline-- & Ebanista & Sí & -- & Progresista & 2 & Sí & Alcalde \\
\hline Leyes & Abogado & -- & -- & Progresista & 3 & Sí & -- \\
\hline Leyes & Hacendado & Sí & Rentista. Accionista & Liberal & 2 & Sí & Alcalde. Elector \\
\hline-- & -- & -- & -- & -- & 1 & -- & -- \\
\hline-- & -- & -- & -- & -- & 2 & -- & -- \\
\hline Filosofía & -- & -- & -- & -- & 1 & -- & -- \\
\hline Leyes & Abogado & -- & Autor Literario & Liberal & 2 & Sí & -- \\
\hline-- & -- & -- & -- & -- & 1 & -- & -- \\
\hline Leyes & Abogado & Sí & Hacendado.Alar-San. & Progresista & 4 & Sí & Gobern.Académic \\
\hline-- & Terrateniente & Sí & Rentista & Moderado & 1 & -- & Consejo Provincial \\
\hline Filosof.-Leyes & Abogado & Sí & Hacendado. Juez & Moderado & 4 & Sí & Consejo Provincial \\
\hline-- & Hacendado & Sí & Industrial harinero & Progresista & 2 & Sí & Alcalde. Congreso \\
\hline Filosof.-Leyes & Abogado & Sí & Propt. AcciAlar-Sant. & Progresista & 1 & Sí & Alcalde \\
\hline-- & -- & -- & -- & -- & 1 & -- & -- \\
\hline-- & -- & -- & -- & Moderado & 4 & -- & Presidente Diputación \\
\hline Leyes & -- & -- & -- & -- & 1 & -- & -- \\
\hline -- & -- & -- & -- & Progresista & 3 & Sí & Gobernador \\
\hline Leyes & Terrateniente & Sí & Abogado & Moderado & 2 & -- & Congreso \\
\hline Filosof.-Leyes & Escribano & Sí & Hacend.Corre Fincas & Moderado & 3 & -- & -- \\
\hline-- & Propietario & -- & -- & Moderado & 1 & -- & Alcalde. Congreso \\
\hline-- & Hacendado & -- & -- & -- & 3 & -- & -- \\
\hline
\end{tabular}


DIPUTADO

Enríquez, Dionisio

Fernández Montealegre, Manuel

García Pizarro, Luis

Garzón San Juan, Domingo

Girón y Rodríguez, Laureano

Lara, Francisco

López Redondo, Nemesio

Madrueño López Puga, Gabino

Maldonado Gimeno, Baltasar

Martín Ortiz, Manuel

Mata Jaques, Mariano de la

Moyano Sánchez, José

Nieto, Dionisio

Pastor, Ángel

Prieto, José Luis

Quintero Rodríguez, Manuel

Reynoso y Oscáriz, Mariano Lino

Rueda Lorenzo, Tomás de

Samaniego Samaniego, Bernardo

Santana Santos, Antonio

Sanz, Norberto

Tamariz, Serapio

Diputados 1856-68

Alonso Martín, Luis

Alonso Pesquera, Eusebio

Álvarez de Casas, Isidro

Álvarez Vicente, Agustín

Basanta, Donato

Bendito Carrillo, Agustín

Blas Ramírez, Francisco María

Burgos Pérez, Hermenegildo

Cabeza de Vaca, Fernando

Daniel, Manuel

Delgado Rico, Vicente

Díez

Díez Salcedo, Sebastián

Dueñas Rodríguez, Celestino

Espinosa Rico, Rafael

Fernández de la Torre, Calixto

$\begin{array}{lll}\text { ESTUDIOS } & \text { PROFESIÓN } & \text { B. } \\ -- & \text { Propietario } & \text { Sí } \\ -- & \text { Hacendado } & \text { Sí } \\ \text { Filosofía } & -- & -- \\ -- & \text { Escribano } & \text { Sí } \\ \text { Leyes } & \text { Procurador } & -- \\ -- & -- & -- \\ \text { Leyes } & \text { Abogado } & \text { Sí } \\ \text { Leyes } & \text { Abogado } & -- \\ \text { Leyes } & \text { Abogado } & -- \\ \text { Leyes } & -- & -- \\ \text { Leyes } & \text { Abogado } & \text { Sí } \\ \text { Leyes } & \text { Abogado } & -- \\ \text { Leyes } & \text { Procurador } & \text { Sí } \\ \text { Leyes } & -- & -- \\ -- & -- & -- \\ \text { Filosof.-Leyes } & \text { Abogado } & \text { Sí } \\ \text { Leyes } & \text { Abogado } & \text { Sí } \\ \text { Filosofía } & \text { Terrateniente } & \text { Sí } \\ -- & -- & -- \\ \text { Leyes } & \text { Abogado } & -- \\ \text { Leyes } & \text { Abogado } & \text { Sí } \\ \text { Leyes } & -- & -- \\ & & \\ \text { Leyes } & \text { Abogado } & -- \\ \text { Filosof.Leyes } & \text { Magistrado } & -- \\ \text { Leyes } & -- & -- \\ -- & -- & -- \\ \text { Leyes } & \text { Propietario } & \text { Sí } \\ \text { Leyes } & \text { Propietario } & \text { Sí } \\ \text { Leyes } & -- & -- \\ \text { Leyes } & \text { Abogado } & -- \\ \text { Filosof.-Leyes } & \text { Abogado } & -- \\ --- & \text { Propietario } & \text { Sí } \\ \text { Leyes } & \text { Abogado } & -- \\ --- & -- & -- \\ \text { Filosof.-Leyes } & \text { Abogado } & \text { Sí } \\ --- & \text { Agricultor } & -- \\ \text { Filosof.-Leyes } & \text { Agricultor } & -- \\ -- & -- & -- \\ & & \end{array}$

OTR A CTIVID
Comerc granos

Comerc Contratista

Propietario. Accionis

Propietario. Juez

Propietario. Accioni Juez. Fiscal

Propietario

Propietario

Propietario. Accion

$-$

Propietario, Accion

Industrial. Propietario

Propietario. Accionis

Terratenien. Industr

$-$

Accionista Alar-Sant.

Propietario

Accionista Alar-Sant.

Propietario

Propietario. Comerc.

--

Abogado

Administrad Banco
Moderado

Progresista

Moderado

Libera

onservador

Moderado

Liberal

Moderado

Progresista

--

Libera

Liberal

Progresista

$-$

Liberal Fusio

Conservador

Moderado

Moderado

--

$--$

$--$

$--$

$--$

Conservador

$--$

$--$
$\mathrm{N}^{\circ}$ D. M.N. OTROS CARGOS

Alcalde

Alcalde

Alcalde

Alcalde. Académico

Alcalde

$-$

Congreso

Alcalde

Clérigo

Gobern. Congr-Sen

Alcalde

Alcalde. Congreso

Gobernador

Comisario Reg.Agric

Alcalde

Elector. Consej.Prov

Alcalde

Consejero Provincia

Alcalde

Alcalde 


\section{DIPUTADO}

Francos, Juan

García Galán, Pascasio

Herrero López, Miguel

Jofre de Villegas

López Flores, Francisco

López de Tejada yNavia, Joaquín

Melero, Laureano

Moras Gil, Pedro Regalado de

Moyano Zamora, Cándido

Nava, Ramón María

Palmero Olea, Carlos

Pimentel Arévalo, Pedro Antonio

Pizarro Cuadrillero, Vicente

Pizarro Díez, José María

Prados Martínez, Justo Rufino

Real Alonso, Bernardo

Ruiz Merino, Eduardo

Serrano Foronda, José

Ternero Garrido, Isidoro

Tordesillas y Villagómez, Pedro

Valbuena, Toribio

Villanueva, Tomás

Zorita Alonso, Juan de Mata

\section{Diputados 1868-74}

Alonso Burgueño, Luis

Alonso García, Félix

Alonso Martín, Manuel de la Cruz

Alonso Pesquera, Miguel

Álvarez López, Laureano

Álvarez Guerra, Pedro

Allue Allue, Anselmo

Antona Semolinos, Luis

Arévalo Miera, Felipe María

Arévalo Miera, Fernando

Aspes Álvarez, Ignacio de

Ayllón, Juan Gualberto

Bayón Cano, Toribio

Botella, Federico

Burgueño, Eusebio

\begin{tabular}{ll} 
ESTUDIOS & PROFESIÓN \\
--- & Agricultor \\
-- & -- \\
-- & Propietario \\
Leyes & -- \\
-- & Propietario \\
-- & Agricultor \\
-- & Agricultor \\
Leyes & Abogado \\
Filosof.-Leyes & -- \\
-- & Agricultor \\
Leyes & -- \\
Leyes & Terrateniente \\
Leyes & Agricultor \\
-- & Comerciante \\
Leyes & -- \\
Leyes & Abogado \\
-- & Comerciante \\
-- & Agricultor \\
Leyes & Abogado \\
-- & Agricultor \\
-- & Agricultor \\
-- & Agricultor \\
Filosof.-Leyes & Abogado \\
& \\
-- & Agricultor \\
Leyes & Abogado \\
Artes- Leyes & Abogado \\
Artes- Leyes & Hacendado \\
-- & Industrial \\
Leyes & Abogado \\
--- & -- \\
-- & -- \\
Leyes & Abogado \\
Leyes & Hacendado \\
Leyes & Abogado \\
--- & -- \\
--- & -- \\
-- & Propietario \\
Leyes & \\
\hline & \\
\hline
\end{tabular}

\section{O'T}

Propietario

Industrial. Comerc.

Comercian. Seguros

Accionista Alar-Sant

Agricultor. Propiet

Propietario

Abogado

Abogado

Propietario

Agricultor

Industrial

Comerciante granos

Fábrica de Harinas

Industrial

Ganadero. Accionist

Agricultor

Propietario

Juez Municipal

Industrial. Accionista

Fábrica de Curtidos

Propietario

Propietario

Propietario. Juez

Propietario
P.POLÍt.

$-$

Progresista

Conservador

Conservador

Moderado

$-$

Gamacista

Conservador

Liberal

$-$

$--$

$--$

Absolutista

Republicano

Conservador

Conservador

Progresista

Conservador

Republicano

$-$

Moderado

Moderado

Progresista

--

$-$

$\begin{array}{ccl}\mathbf{N}^{0} \text { D. } & \text { M.N. } & \text { OTROS CARGOS } \\ 1 & -- & -- \\ 1 & -- & -- \\ 1 & -- & \text { Congreso. Senado } \\ 1 & -- & -- \\ 3 & -- & -- \\ 1 & \text { Si } & \text { Consejero Provincial } \\ 3 & -- & -- \\ 2 & -- & -- \\ 1 & -- & \text { Consejero Provincial } \\ 2 & -- & -- \\ 1 & -- & -- \\ 4 & -- & \text { Congreso. Senado } \\ 1 & -- & \text { Dip. Restauración } \\ 1 & -- & \text { Alcalde } \\ 1 & -- & -- \\ 2 & -- & -- \\ 5 & -- & \text { Alcalde } \\ 1 & -- & \text { Alcalde } \\ 1 & -- & -- \\ 2 & -- & \text { Consej.Prov.Congreso } \\ 1 & -- & \text { Congreso }\end{array}$

Congreso

Alcalde

Diputado Restauración Presidente Diputación

Congreso. Pres.Diputa Congreso. Cóns. Venez Diputado Restauración

Diputado Restauración

Alcalde

Alcalde

Diputado Restauración 


\section{DIPUTADO}

Calderón Mantilla, Francisco

Calvo Asensio, Francisco

Cantalapiedra Maestro, Segundo

Capdevila Pedrero, Mariano

Castilla de Lanuza, Enrique

Clemente Herrero, Máximo

Conde Camazón, Jerónimo

Criado, Pedro

Cuadrillero Nájera, José Manuel

Díez Bueno, Marcelino

Díez Quijada, Lázaro

Domínguez de la Mata, Andrés

Escudero, Eusebio

Fernández Fernández, Andrés

Fernández Miranda, Sebastián

Fernández Rico, José Manuel

Fernández de Velasco, Domingo

Flores, Paulino

García Duque, Francisco

García Escobar, Joaquín

García Serrano, José

Gardoqui Fernández, José

Gavilán de Gavilán, Mariano

Guerra Franco, Lucas

Gómez de Rozas Reynero, Pedro

González García, Manuel

Gutiérrez Barquín, Manuel

Gutiérrez-Cañas Gutiérrez, Demetrio

Guzmán Lucas, Liborio

Ibañez Martín, Miguel

Izquierdo, Venancio

López, Eduardo

López Morales, Tomás

Lorenzo y Frontaura Cacho, Fede.

Lozano Villanueva, Mariano

Macho Mesones, Francisco

Marquina, Quirino

Martín García, Eugenio Leyes

\begin{tabular}{ll} 
ESTUDIOS & PROFESIÓN \\
Filosof.-Leyes & Abogado \\
Leyes & Procurador \\
Leyes & Abogado \\
-- & -- \\
Filosof.-Leyes & Abogado \\
Filosof.-Leyes & Abogado \\
Medicina & Médico \\
-- & Labrador \\
-- & Labrador \\
Leyes & Abogado \\
-- & Labrador \\
Leyes & Abogado \\
Leyes & Abogado \\
Leyes & Escribano \\
Filosof.-Leyes & Abogado \\
-- & Comerciante \\
Filosofía & -- \\
-- & Propietario \\
-- & -- \\
-- & -- \\
-- & -- \\
Filosof.-Leyes & Abogado \\
Leyes & Abogado \\
Medicina & Médico \\
-- & Terrateniente \\
Leyes & -- \\
-- & -- \\
Filosof.-Leyes & Abogado \\
Filosofía & Farma céutico \\
Filosof.-Leyes & Abogado \\
-- & -- \\
--- & -- \\
\hline-- & -- \\
Leyes & -- \\
Leyes & -- \\
Leyes & Abogado \\
-- & Labrador \\
-- & -- \\
&
\end{tabular}

\section{OTR ACTIV}

$--$

Propietario

Propietario

Juez. Acc. Ind. Banc.

$-$

Fábrica de Fundición

$-$

$-$

Labrador. Administ

Director Manicomio

$--$

Juez. Catedrático

$--$

$-$

Agricultor

--

\begin{tabular}{|c|c|c|c|}
\hline P.POLÍTIC & $\mathbf{N}^{\circ} \mathbf{D}$. & M.N. & OTROS CARGOS \\
\hline Liberal & 2 & -- & - \\
\hline Progresista & 1 & -- & -- \\
\hline Liberal & 3 & -- & Alcalde. CongrDipRest \\
\hline -- & 1 & -- & -- \\
\hline -- & 1 & -- & -- \\
\hline -- & 4 & -- & Alcalde \\
\hline -- & 1 & -- & -- \\
\hline -- & 1 & -- & -- \\
\hline Conservador & 3 & -- & Congreso. Diput.Resta \\
\hline Liberal & 3 & -- & Secr Pol. Diputado Resta \\
\hline-- & 1 & -- & -- \\
\hline Conservador & 3 & -- & Diputado Restauración \\
\hline -- & 1 & -- & -- \\
\hline -- & 1 & -- & -- \\
\hline Moderado & 1 & -- & Alcal.Congr.Diput Rest \\
\hline-- & 1 & -- & -- \\
\hline-- & 1 & -- & -- \\
\hline Conservador & 1 & -- & Alcalde. Diput.Restaur \\
\hline-- & 1 & -- & -- \\
\hline-- & 1 & -- & -- \\
\hline-- & 1 & -- & -- \\
\hline Conservador & 1 & -- & Alcalde. Diput.Restaur. \\
\hline Liberal & 2 & -- & Diputado Restauración \\
\hline Progresista & 1 & -- & -- \\
\hline-- & 1 & -- & Alcalde. Diput.Restaur \\
\hline-- & 2 & -- & -- \\
\hline Progresista & 2 & -- & Gobernador \\
\hline-- & 1 & -- & -- \\
\hline Republicano & 1 & -- & Congreso \\
\hline-- & 3 & -- & -- \\
\hline-- & 2 & -- & Alcalde. Diput.Restaur \\
\hline -- & 1 & -- & -- \\
\hline Conservador & 1 & -- & -- \\
\hline-- & 1 & -- & -- \\
\hline-- & 1 & -- & -- \\
\hline-- & 1 & -- & Diputado Restauración \\
\hline-- & 1 & -- & -- \\
\hline & 1 & -- & -- \\
\hline
\end{tabular}




\section{DIPUTADO}

Martín Torés, Francisco Tomás

Martín Vargas, Antonio

Miranda González, Fernando

Montalvo, Pedro

Mozo, José

Muñoz Zapata, Ulpiano

Muro López-Salgado, José

Ocejo Bringas, Remigio

Olivares, Galo

Osorio Casasola, Mariano

Pérez Cantalapiedra, Julián

Pérez Minayo, Fructuoso

Pinilla García, Pablo

Quintero Martínez, Eladio

Rábago de los Ríos y Terán, J.Anton.

Recio del Castillo, Fidel

Reoyo, Francisco

Reoyo Pérez, Telesforo

Riva Espiga, Ángel de la

Rodríguez, Valentín

Rodríguez Monroy, Teodoro

Rodríguez Villamandos, Ángel

Romero Peláez, Pedro

Rúa de la Rúa, Faustino de la

Santana Santana, Claudio

Sanz, Niceto

Tablares Maldonado, Felipe

Teijón, Juan Bautista

Torre Mínguez, Eustaquio de la

Torres López, Patricio

$\checkmark$ aldés, Pablo

Velasco Neira, Miguel

Villalba, Benigno

Villarías Ruiz, Gaspar

\begin{tabular}{ll} 
ESTUDIOS & PROFESIÓN \\
Leyes & Abogado \\
-- & -- \\
-- & -- \\
-- & -- \\
Medicina & Médico \\
Leyes & Abogado \\
Filosof.-Leyes & Catedrático \\
-- & Comerciante \\
-- & -- \\
-- & -- \\
-- & Labrador \\
Leyes & Abogado \\
Leyes & Abogado \\
Filosof.-Leyes & Abogado \\
Leyes & Comerciante \\
Leyes & Procurador \\
-- & Escribano \\
-- & Escribano \\
Leyes & -- \\
-- & -- \\
Medicina & Médico \\
Filosof.-Leyes & Abogado \\
-- & Comerciante \\
Leyes & Abogado \\
--- & Propietario \\
-- & -- \\
Perito Agrón. & Propietario \\
Filosof.-Leyes & Abogado \\
Leyes & Abogado \\
Leyes & Abogado \\
-- & -- \\
Filosof.-Leyes & Abogado \\
-- & Procurador \\
Filosof.-Leyes & Abogado \\
& \\
\hline
\end{tabular}

OTR ACTIV

Juez Municipal

$--$

Abogado. Académico

Propietario

--

Periodista

Industrial. Propietar

Industrial harinero

Propietario. Procura

Catedrático

Accionista

--

Dtr Provi Caminos

Propietario

Propietario

$-$

Juez Municipal

Propiet. AgenFincas

\section{P.POLÍtic $\mathbf{N}^{\circ}$ D. M.N. OTROS CARGOS}

Diputado Restauración

Diputado Restauración

Congreso. Ministro

Alcalde

Diputado Restauración.

Alcalde. Congreso

Diputado Restauración

Alcalde

Alcalde. Presid.Diput

Consejero provincial

Alcalde. Congreso

Alcalde

Dip Restauración

Diputado Restauración. Alcalde

Diputado Restauración

Diputado Restauración Concejal

Secretario Gobierno

Leyenda.- B.N.: Comprador de Bienes Nacionales. $N^{\circ}$ D.: Número de Diputaciones en las que participó. M.N.: Miembro de la Milicia Nacional. 


\subsection{1.- RESUMEN Y ANÁLISIS DE LAS ACTIVIDADES}

Al resumir los cuadros que hemos reflejado con anterioridad, podemos estudiar el reparto de las actividades e ideologías de los doscientos veintiún diputados que han desfilado por la Corporación en estos años. Para un mejor análisis, dividimos el resumen en dos partes: En la primera veremos, a través de un análisis social de los diputados, las predominancias en los estudios y en la dedicación profesional, y en un segundo apartado analizaremos la tendencia política de los mismos.

\section{ANÁLISIS SOCIAL Estudios}

Es de destacar, en primer lugar, cómo uno de los datos llamativos de este análisis, el alto número de licenciados que componen la nómina de todos los individuos que pertenecieron a las diferentes Diputaciones a lo largo de este período: Son ciento diecisiete licenciados, lo que representa el 53\% del total de diputados. siguiente:

El reparto entre las diferentes facultades por las que se decantan, es el 101 individuos han estudiado Leyes 5 individuos han estudiado Filosofía 2 individuos han estudiado Teología 5 individuos han estudiado Medicina 2 individuos han estudiado Arte 1 individuo ha estudiado Economía 1 individuo ha estudiado Perito Agrónomo.

Son importantes los porcentajes de los licenciados en Leyes, que representan el $45^{\prime} 7 \%$ del total de diputados y el $866^{\prime} 3 \%$ de los diputados licenciados.

\section{NUMERO DE ESTUDIOS REALIZADOS Y SU PORCENTAJE}

\section{Estudios}

Francés-Económicas

Perito agrónomo

Teología

Artes

Filosofía

Medicina

Filosofía y Leyes

Leyes

Sin estudios superiores

Número
1
1
2
2
5
5
26
75
104

Datos elaborados con información procedente de los Libros de Actas y del Archivo Histórico Universitario.

\section{Profesión principal}

En este punto tenemos registrados un total de ciento sesenta y dos diputados con actividades profesionales conocidas, lo que representa el $73,3 \%$ del conjunto. El desconocimiento de la actividad de los cincuenta y nueve individuos que faltan viene dado por la dificultad de controlar y conocer a los que han pertenecido a la Diputación durante un corto período de tiempo. Hay que recordar la existencia de diputados que han ejercido durante un único día y no han dejado referencia de su trayectoria.

De los ciento sesenta y dos personajes con actividades conocidas, se pueden subrayar unos datos significativos: sesenta y cinco individuos tienen como profesión principal una actividad ligada a la tierra como son los terratenientes y hacendados, poseedores de grandes propiedades de tierras, los propietarios rústicos, también poseedores de grandes fincas que habitualmente tienen en renta y los agricultores y labradores que son los que trabajan directamente sus posesiones, que no tienen grandes propiedades y que viven directamente de los rendimientos de sus tierras. Este apartado relacionado con la propiedad supone el $29^{\prime} 4 \%$ del total de diputados. 
Una primera caracterísitica de estos individuos está referida a la procedencia de sus propiedades, ya que de todo este colectivo, cincuenta y nueve de ellos, es decir el $90 \%$ de los diputados provinciales que se dedican a la agricultura, son compradores de Bienes Nacionales o de fincas desamortizadas. Esta proporción puede sugerirnos dos consideraciones: la primera es que los diputados provinciales son elegidos entre los más ricos del lugar, y la segunda es que gracias a su posición política tuvieron ventaja en las compras de los bienes desamortizados.

Otra característica a destacar es que sesenta diputados, cantidad muy similar a la de los que se dedican a la agricultura, son los que ejercen la abogacía, con el porcentaje del $27^{\prime} 1 \%$ sobre la totalidad de los diputados. El resto de profesiones principales conocidas, con una cantidad de treinta y siete se reparten de la siguiente forma: 1 magistrado, 7 comerciantes, 6 escribanos, 5 procuradores, 5 catedráticos, 5 médicos, 3 industriales, 2 clérigos, 1 boticario, 1 relator, 1 fiscal.

Nos ayuda a identificar a las cincuenta y nueve personas de las que no conocemos su actividad, el hecho de tener constancia de que trece de ellas estudiaron la carrera de leyes, nueve son diputados suplentes que no completaron una legislatura, otras seis personas dejaron el cargo por enfermedad ó fallecimiento, y la mayoría del resto de este grupo sólo ejercieron el cargo durante una Diputación y por un período muy corto.

\section{PROFESIONES PRINCIPALES DE LOS DIPUTADOS}

\section{Profesión}

Canónigos y presbíteros

Industriales

Catedráticos

Escribanos

Médicos-Boticarios

Comerciantes

Magistrados-Fiscales-Procuradores

Abogados

Terratenientes-Hacendados-Propietarios

Agricultores-Labradores

Total profesiones

Datos elaborados con información procedente de los Libros de Actas y del Boletín Oficial de la Provincia.

\section{Otras profesiones y actividades}

Si la mayoría de los diputados desarrollan una actividad principal relacionada con la agricultura y la abogacía, este apartado de otras actividades es un complemento a esas dos mayoritarias. Es decir, una parte importante de los propietarios ejercen como abogados y al contrario, una parte importante de los abogados ejercen a la vez una segunda actividad relacionada con la agricultura. Son cuarenta y tres los relacionados con la propiedad que ejercen la abogacía, y treinta y cuatro los abogados que también tienen relación con la tierra.

Dentro de este apartado, y aunque no se le puede dedicar el título de segunda actividad, un cierto número de diputados se dedican a las inversiones financieras, en su mayoría relacionadas con la inversión en las compañías de ferrocarriles, en especial las más principales en la provincia, Alar-Santander, la Compañía del Norte y la Línea de Ariza. Son veintiuna personas, 9,5\% de los diputados, que en su mayoría tienen como ocupación principal la de agricultor. El resto de las segundas ocupaciones están repartidas entre comerciantes, industriales, agentes de venta de granos, corredores de fincas, contratistas, impresores y empleados de banca. Como dato curioso, tenemos la dedicación del diputado Ventura García Escobar, como autor literario. 
Sobre el significado de la numerosa presencia de diputados que se dedican tanto a la agricultura como a la abogacía se pueden sacar dos conclusiones que pueden estar relacionadas con la transformación tanto social como económica que se produce en estos años. Por un lado, las mejoras que se producen en el ámbito agrícola, ocasionadas tanto por la llegada de gran cantidad de tierras procedentes tanto de la desamortización como del progreso de los rendimientos agrícolas, dan la oportunidad a las nuevas generaciones de dedicarse a los estudios. Por otro lado tenemos que admitir que los diputados provinciales de estos años, habitualmente son los personajes con la mayor capacidad económica de la provincia. El dato llamativo nos lo dan los nuevos estudiantes procedentes de estas familias ligadas al campo que no escogen para sus estudios carreras afines a la agricultura o ganadería. Prefieren las leyes, posiblemente porque tengan un mayor prestigio social.

\section{ANÁLISIS POLÍTICO \\ Partidos políticos}

La ideología política es otro de los análisis interesantes para conocer las tendencias de los diversos períodos ó de las diferentes Diputaciones que transcurren a lo largo de estos años. Sobre todo, porque los diputados provinciales, en especial en la primera mitad del siglo, aunque tienen una ideología definida no la expresan con claridad por la falta de los canales de comunicación idóneos a nivel provincial, es decir, por las delegaciones provinciales de los partidos políticos organizados. Son los centros de poder políticos instalados en la capital los que forman gobiernos y los que marcan la tendencia. La impresión es la de que los primeros diputados provinciales se mueven tanto por sus ideologías políticas cuanto por consolidar su dominio económico y el control territorial de su área de influencia. Tampoco podemos olvidar que las primeras Diputaciones estaban dominadas por los liberales, pero no hacían de su creencia un proselitismo político. A partir de 1840 se inicia un desarrollo de las ideologías y un avance del progresismo sobre todo a nivel municipal lo que provoca una mayor politización de la vida pública, que incide, como es lógico, en las Diputaciones, aunque la presencia de los representantes de las grandes fortunas provinciales en la Diputación hace que, aún en períodos progresistas, los conservadores mantienen el control de la institución.

Hemos llegado a conocer la tendencia política de noventa y siete diputados sobre los doscientos veintiuno contabilizados, lo que representa el $43^{\prime} 9 \%$ del número total. Aunque es difícil la tarea de conocer las intenciones políticas de los diputados que sólo han pertenecido a la Diputación por un corto período de tiempo. Los resultados y sus porcentajes son los siguientes: Tres absolutistas, que representan el $1{ }^{\prime} 4 \%$ del total de diputados. Siete republicanos, que representan el 3'2\%.

Diecinueve moderados, que representan el $8,6 \%$ del total. Veinte progresistas, que representan el 9\%. Veintiún conservadores, que representan el 9'5\%. Veintisiete liberales, que representan el $12 \% 2 \%$. Ciento veinticuatro sin filiación conocida que representan el $56^{\prime} 1 \%$ del total. Como datos a tener en cuenta, hay que resaltar que los liberales son mayoría en las Diputaciones del Trienio y no suelen apellidarse políticamente de manera explícita. Los moderados y progresistas se mantienen equilibrados a lo largo de los años. Los absolutistas y los carlistas sólo aparecen como una minoría de tipo radical. Los republicanos inician su aparición en la vida política en los años previos a la llegada del Sexenio Revolucionario y el partido conservador aparece en la escena política con este nombre en los años del Sexenio. En esta etapa es cuando se inicia la verdadera identidad política de los diputados, y se ve la necesidad de que éstos estén afiliados a algún partido político, si quieren salir elegidos. Al mismo tiempo, el control de los territorios de influencia en la provincia pasa de ser el dominio de los "poderosos" provinciales y locales, a ser controlado por los partidos políticos centrales.

Finalmente, otro dato de la escasa identidad política dentro de la Diputación lo tenemos en la presencia conocida de treinta y dos diputados que a lo largo de estos 
años pertenecieron a la Milicia Nacional. Este es un dato que no nos debe de enga ñar y por el que no debemos de caer en el error de minusvalorar la importancia de la Milicia Nacional. Si debemos de tener en cuenta dos posturas diferentes en relación con esta institución. La primera es la de la consideración de la milicia como una entidad básicamente urbana es decir dependiente y controlada por los Ayuntamientos, con un sentido liberal y progresista de su actuación. Los Ayuntamientos controlan la política local y no permiten la injerencia de otras instituciones y con su mayor experiencia saben que deben de afianzar la doctrina liberal si quieren mantener la evolución social hacia el progreso en contra de las posturas absolutistas y carlistas de índole inmovilista. En segundo lugar, está claro que la Diputación es una institución de nueva creación, que está formada en su mayoría por las élites sociales y económicas y que no sienten la necesidad de hacer política, entre otras razones porque, como hemos reflejado anteriormente, los municipios son los que controlan los movimientos políticos y han dejado sin espacio a las Diputaciones. Este problema estará latente en la mayoría de este período.

\section{Otros cargos}

En el arranque de las Diputaciones, el principal cargo político que funcionaba en todas las poblaciones era el de alcalde, por lo que no es extraño que los primeros diputados provinciales provengan de las actividades municipales. Posteriormente, la mayoría de los ciudadanos interesados en la política iniciarán el camino a partir de los Ayuntamientos para pasar después a la política provincial con la Diputación, y los más capaces y mejor "apadrinados" darán el salto a la política nacional. Por este motivo es normal que cincuenta y uno de los diputados nombrados, esto es el $23 \%$, procedan de la política municipal al haber ejercido como alcaldes. También es normal que de los doscientos veintiún diputados provinciales, cuarenta y nueve pasen a la vida política nacional como congresistas y senadores, es decir, el $22 \% 2 \%$ de los diputados. Finalmente, como proceso de una intensificación de la vida política de la provincia y de creación de generaciones de políticos, registramos el dato de que veintitrés diputados, la mayoría de la época del Sexenio, continuaron su actividad política en las Diputaciones de la Restauración.

Del resto de otros cargos políticos conocidos, tenemos a siete diputados que han sido consejeros provinciales $\left(5^{\prime} 6 \%\right)$, siete electores $\left(5^{\prime}, 6 \%\right)$, cinco gobernadores $(4 \%)$, dos académicos $(1,5 \%)$, dos secretarios políticos $(1,5 \%)$, un comisario regio $\left(0^{\prime} 8 \%\right)$, un cónsul $\left(0^{\prime} 8 \%\right)$ y un ministro $\left(0^{\prime} 8 \%\right)$. Sin olvidarnos de que cinco diputados ejercieron durante el Sexenio como presidentes de la corporación, y fueron los primeros presidentes nombrados de entre los miembros de la misma

Destacamos que, entre estos datos, la cifra de diputados con capacidad de electores no es muy fiable y posiblemente sea mucho mayor, ya que por posición económica, que es la que regía para acceder a este cargo la mayoría de los diputados, deberían entrar en este apartado, aunque no están reflejados en las actas de la institución.

Otro dato complementario interesante es el de la evolución generacional a lo largo de este primer período de vigencia de la Diputación. Con el inicio de la actividad política provincial arranca también la aparición de los promotores de las primeras familias políticas. Las grandes familias, en un principio controladoras del poder económico y social y que posteriormente se harían con el control político, tienen en esta época a sus primeros representantes. Una de las principales características de este fenómeno está representada por el mantenimiento de estos diputados y de sus familiares en el poder a lo largo de varios años y de varias legislaturas.

Tenemos a tres diputados que iniciaron su carrera política en los años de la Constitución y del Trienio y que continuaron ejerciendo en los años isabelinos, llegando uno de ellos ejercer como diputado en el Sexenio. Nos referimos a Joaquín Antonio de Argüello, José Antonio González Perotes y Joaquín Maldonado. Los 
diputados de la época isabelina que continuaron ejerciendo en el Sexenio son cinco, a saber: Francisco Lopez Flores, Juan Antonio de las Moras Gala, Pedro Antonio Pimentel Arévalo, Francisco Rodriguez Rubio y Juan de Mata Zorita Alonso. Los diputados que del período isabelino pasaron a los años de la Restauración fueron nueve y los que desde el Sexenio continuaron ejerciendo en la Restauración fueron un total de veintiséis individuos, entre los que destacamos a Eusebio y Miguel Alonso Pesquera, Francisco Lopez Flores, Pedro Antonio Pimentel Arévalo, Vicente Pizarro Cuadrillero, Marcelino Diez Bueno, Andrés Dominguez de la Mata, Paulino Flores, José Gardoqui, Pedro Gomez de Rozas, Eustaquio de la Torre Minguez. En definitiva, son los hombres poderosos de la provincia y los iniciadores en unos casos y continuadores en otros de las principales familias políticas vallisoletanas.

Los diputados que pasaron de los años liberales a la época isabelina fueron tres de veintidós, el 13'7\%. De la época isabelina al Sexenio y a la Restauración catorce de ciento doce, el 12,5\%. Del Sexenio a la Restauración veintiséis de ochenta y siete, el $29^{\prime} 9 \%$.

Otro dato relevante es el de la permanencia en las diferentes legislaturas a lo largo de todos estos años. Esta permanencia oscila entre los diputados que $h$ an permanecido en el puesto por un solo día, hasta los que han llegado a disfrutar del cargo por espacio de veintitrés años de una forma intermitente. Del mismo modo que hay diputados con una estancia en el cargo de una legislatura hasta los que han ejercido durante ocho legislaturas diferentes.

En detalle tenemos:

\begin{tabular}{|c|c|c|c|c|c|c|}
\hline & & & & 101 & senta el & $00,5 \%$ \\
\hline 3 & “ & “ & 5 & “ & “ & $01^{\prime} 4 \%$ \\
\hline 8 & “ & “ & 4 & “ & “ & $03^{\prime} 6 \%$ \\
\hline 34 & “ & “ & 3 & “ & “ & $15^{\prime} 4$ \\
\hline 45 & “ & “ & 2 & “ & “ & $20{ }^{\prime} 4 \%$ \\
\hline 130 & “ & “ & 1 & “ & “ & $58^{\prime} \gamma^{\prime}$ \\
\hline
\end{tabular}

Datos procedentes de los Libros de Actas de la Diputación

\subsection{2.- LAS SAGAS FAMILIARES.}

El cargo de diputado provincial es, en estos años estudiados, un puesto sin remuneración económica. Además la presencia en la capital obliga a los diputados que no residen en la misma a ausentarse durante amplios períodos de tiempo de su casa y de sus ocupaciones profesionales. Por ese motivo el interés por mantenerse en el cargo tiene dos vertientes. Por un lado tenemos el interés social y económico del individuo que controla su distrito a partir de la posesión de la tierra, lo que le da el poder y el dominio sobre el resto de los pobladores. Por otro lado, el ánimo de mantenerse en el cargo está relacionado con el afán de controlar la vida política en su área de influencia y de esta manera mantener la supremacía en todas las facetas, tanto sociales, como económicas y políticas.

De esta práctica es de donde surgen las diferentes "sagas familiares" que se mantienen en los cargos durante amplios períodos de tiempo. Con el paso de los años y la aparición de los partidos políticos esta primera intención familiar se transforma en una más amplia de control de la vida política provincial desde los centros del poder político nacional y no desde el distrito o la provincia. Esta deriva del control hacia instancias nacionales facilitará la práctica del caciquismo que tendrá su máxima expresión en los años de la Restauración. Creemos que la práctica caciquil no es tan determinante en el control político, en este período estudiado, por lo menos, en lo que respecta al nivel provincial.

Así vemos que en los primeros años, los iniciadores de las sagas familiares, aun teniendo una ideología política clara, están sobretodo dedicados al trabajo, al afianzamiento de su posición social y económica y al inicio del control de sus 
distritos correspondientes. A pesar de que ya han sido identificadas en el decurso de las biografías anteriores, la docena de familias más significativas que hemos encontrado en estos años son mencionadas a continuación.

\section{Alonso Pesquera}

Es una de las familias más importantes de la provincia, tanto a nivel económico como político. El iniciador de esta saga es Millán Alonso del Barrio, liberal destacado, que ya en el año 1821 es procurador en Cortes. Diputado provincial en 1835 y 1843 . Diputado a Cortes en 1836 a 1857 . Senador en 1858 y 1871.

Reside en Quintanilla de Abajo y Sardón, desde donde administra sus posesiones agrícolas e industriales situadas en la zona de Peñafiel, Campiña de Esgueva y Tierras de Pinares. Es comprador de Bienes Desamortizados y dueño de la Hacienda de Retuerta y del Coto de Valbuena.

Tuvo siete hijos, todos ellos continuadores en mayor ó menor grado de la trayectoria política y económica del fundador, acrecentada a través de los matrimonios con otras importantes familias, tanto desde un punto de vista económico como político y social. Eusebio Alonso Pesquera, uno de sus hijos, continúa la tradición ejerciendo como diputado provincial, afiliado al partido conservador, entre 1862 y 1865 y entre 1878 y 1883. Por su matrimonio con Clotilde Lasheras, hija de un importante propietario de la capital, vio acrecentado su capital. Miguel Alonso Pesquera, otro de sus hijos y el más destacado en el ámbito político, actuará como diputado provincial, también por el partido conservador, en los años del Sexenio, y continuará en la Restauración, siendo elegido presidente de la Diputación. Su hija Francisca se casará con Juan Antonio Pimentel Arévalo, hijo de Vicente, cabeza de una de las familias más poderosas de la zona de Olmedo-Medina. Teodosio Alonso Pesquera, otro de sus hijos, casó con Evelinda Pombo hija de uno de los más importantes harineros del norte de la provincia vallisoletana y de la palentina.

La saga tuvo su continuidad con la presencia en la vida política de los descendientes de Millán Alonso, así vemos a los Pombo Alonso Pesquera, a los Pimentel Alonso Pesquera y a los Alonso Pesquerra Lasheras, en todos los eventos políticos, tanto locales como provinciales y nacionales.

\section{Arévalo}

Juan Manuel Arévalo es el primer miembro de esta familia que aparece como diputado provincial en 1841 y 1854. Alcalde en 1852. Una de sus hijas se casó con Eladio Quintero Martinez, diputado provincial en 1872. Ignacio María Arévalo Miera es pariente de Juan Manuel, y el más importante miembro de la familia, tanto en su vertiente económica como política. Es diputado provincial, dentro del partido moderado en los años 1850 y 1852 y diputado a Cortes en 1850 y 1865 . Se casó con la hija del conde de Troncoso, aristócrata de origen gallego y afincado en Valladolid y Palencia, y sus hijos continuaron la carrera política al ser diputados en Cortes durante la Restauración. Sus hermanos, Felipe María Arévalo Miera es diputado provincial en 1871 y Fernando Arévalo Miera también es diputado provincial en el Sexenio, y continuará en el cargo durante los primeros años de la Restauración, aunque no progresaron en su carrera política a nivel nacional.

Casilda Arévalo Miera, hermana de los anteriores, casó con Vicente Pimentel Bayón, rico propietario de Tierra de Pinares y Tierra de Medina, uno de cuyos hijos a su vez se casó con una hija de Millán Alonso del Barrio, matrimonio qur propició la unión de las más importantes familias de la zona sur y este de la provincia. Alonso Pesquera, junto a los Pimentel y los Arévalo, son tres de las familias más poderosas de la provincia que se unen a través de los matrimonios.

\section{Cuadrillero-Pizarro}

Hermenegildo Fernando Cuadrillero Herce es el pionero en las actividades de la Diputación. Pertenece a una poderosa familia de propietarios de Tierra de Campos, 
con residencia en Rioseco, y que tiene una gran influencia tanto económica como política en la comarca. Ejerce como diputado provincial en los años del Trienio. Es liberal.

José María Pizarro Diez es alcalde de Rioseco en 1835 y diputado provincial en 1856 , perteneciente al partido moderado. Se dedica a la agricultura y al comercio y posee uno de los capitales más fuertes de Rioseco. Emparentó con la familia Cuadrillero al casar a su hijo con Venancia, hermana de Hermenegildo Cuadrillero. Vicente Pizarro Cuadrillero, hijo de José María y sobrino de Hermenegildo, es diputado provincial en 1867 y en 1884, etapa en la que ejerce como Presidente. Es conservador. Ejerce la abogacía en Rioseco, al mismo tiempo que administra un importante patrimonio rústico. José María García Pizarro es hijo de Cayetano García de la Maza, diputado a Cortes y de Buenaventura Pizarro Díez, hermana de José María Pizarro Díez, casado con Josefa de Lara hija del diputado provincial Francisco Lara y sobrina de Mariano Miguel de Reynoso. José Manuel Cuadrillero Nájera, emparentado con Hermenegildo y con Alejandro Nájera, es diputado provincial en 1837. Actúa como diputado provincial, con la vitola de conservador, entre 1871 y 1874. Gaspar Cuadrillero Oteo de Tejada, también sobrino de Hermenegildo, es diputado a Cortes en 1857 por el partido conservador.

\section{Flores}

Es una de las importantes familias, tanto por su poder económico como político, de la comarca de Medina. Francisco López Flores es el iniciador de las actividades políticas de la familia, perteneciente al partido conservador. Es propietario y comerciante. Con una economía saneada, es accionista del ferrocarril AlarSantander. En el año 1854 es alcalde de Medina. En 1858 es diputado provincial, actuando en el cargo hasta 1866. Continúa como diputado en 1874 y en la primera Diputación de la Restauración de 1875. También es Diputado a Cortes en 1883.

Paulino Flores, primo de Francisco, perteneciente al partido conservador, es alcalde de Sieteiglesias de Trabancos en 1863. Diputado provincial en 1871 y también en 1875, durante la Restauración ejerce una gran influencia en la comarca. Sus hijos Paulino y Moisés continuaron su estela como diputados provinciales entre 1884 y 1915 , dentro de las filas del partido conservador, en representación de los distritos de Sieteiglesias y de Nava del Rey.

\section{Garzón}

Domingo Garzón San Juan es escribano y propietario en Villalón. Fue comprador de numerosas fincas procedentes de bienes desamortizados y nacionales, operación que realizó con carácter especulativo y que al final le llevó a la ruina al no poder hacer frente a los pagos. Inicia las actividades políticas de la familia cuando es nombrado diputado provincial en 1847, repitiendo en 1850 y 1854. En 1863 es alcalde de Villalón. Su hijo Arturo intentó continuar con la actividad política, pero salió derrotado en las elecciones para diputados provinciales celebradas en el año 1872. Su hija Marcela casó con Telesforo Reoyo, alcalde de Villalón, en 1855, y diputado provincial durante el Sexenio, siendo elegido presidente de la Diputación en 1874. Adelaida, su otra hija, se casó con Ángel de la Riva Espiga, consejero provincial en 1858 y elegido diputado provincial entre 1871 y 1874.

\section{Gómez de las Rozas}

Pedro Gómez de las Rozas es el iniciador de la saga, con residencia en Tordesillas. Es un rico propietario a partir de la compra de fincas desamortizadas. Su posición económica le facilita el control político de la comarca. Es elegido diputado provincial en 1840. Su hijo y sucesor, tanto de sus bienes como de la posición política, Pedro Gómez de las Rozas y Reynero, es diputado provincial en 1875 y en la primera Diputación de la Restauración, hasta el año 1881. Es alcalde de Valladolid en 1905. La familia sigue manteniendo su presencia en la Diputación a través de 
Tertulino Fernandez Reynero, que ejerce como diputado entre 1907 y 1915 por el distrito de Tordesillas y por el partido liberal.

\section{Maldonado}

Joaquín Maldonado es uno de los pioneros en la política provincial, ya que ejerce como diputado en la primera Diputación que se forma en 1813. Continúa en el cargo en 1820, durante la primera Diputación del Trienio y también en la primera Diputación que se forma en la era isabelina en 1835, siempre en representación del partido judicial de Medina. Es Diputado a Cortes en 1836 y 1843, Senador en 1840 y alcalde de Iscar en 1857. Es liberal. Su hijo, Joaquín Maldonado Macanaz, ejerce como alto funcionario ministerial y su otro hijo Rafael continuará la tradición familiar al ser elegido diputado provincial en la primera legislatura de la Restauración en 1875.

\section{Mantilla}

Francisco Antonio Mantilla, propietario y abogado en Almansa, es diputado provincial en los años del Trienio. Es liberal. Con la nueva división territorial de las provincias, su distrito pasó a pertenecer a la provincia de León, y de esta forma pasó a ejercer en la Diputación leonesa. Su nieto Francisco Calderón Mantilla continúa la tradición política al ser nombrado diputado provincial entre 1871 y 1874 , por el distrito de Mayorga, en la provincia de Valladolid.

\section{Moras}

Miguel de las Moras Ortega es el primer miembro de la familia en acceder al cargo de diputado provincial. Lo que más llama la atención es su larga estancia en la Diputación, que se extiende entre 1837 hasta 1858, ejerciendo el cargo durante ocho legislaturas, dentro de la ideología moderada. Es el diputado más perseverante en el cargo, siempre en representación del partido judicial de Valoria la Buena, pueblo en el que ejerce como escribano, además de su dedicación a la agricultura, ya que era un importante propietario agrícola que había acrecentado sus bienes con la compra de fincas desamortizadas. Mantiene el dominio político del distrito de Valoria la Buena durante los años en que controló el distrito en el que no tuvo oposición. Continuó su carrera política a nivel nacional como diputado a Cortes a partir del año 1864 por el distrito de Peñafiel.

Pedro Regalado de las Moras Gil, sobrino y sucesor político de Miguel, actuará como diputado provincial en los años 1863 a 1866, también dentro del partido moderado, en representación del distrito de Valoria. Su hijo Juan Antonio de las Moras Gala continuará la tradición familiar, sucediendo a su padre y a su primo en la representación del mismo partido de Valoria, durante el Bienio Progresista y en el Sexenio, dentro del partido moderado. Francisco María de las Moras Amo, nieto de Miguel e hijo de Juan Antonio, continuará la actividad política de la familia como diputado provincial en los años de la Restauración a partir de 1880. También fue elegido alcalde de Valladolid en 1891 y gobernador civil de La Coruña en 1907.

\section{Pimentel}

Vicente Pimentel Bayón es el punto de partida de una rica familia del sur de la provincia, que a través de los matrimonios se unirá a otras familias no menos poderosas como Alonso Pesquera y Arévalo. Inicia su actividad política dentro de las filas conservadoras, con el nombramiento de diputado provincial en 1837 y en 1856. En el año 1844 es diputado a Cortes y en 1851 es senador.

Pedro Antonio Pimentel Arévalo, su hijo, es el continuador de la saga, casado con una hija de Millán Alonso y sobrino de Ignacio Arévalo. Inicia su andadura política como diputado provincial de carácter conservador en 1866. En 1875 y en la primera Diputación de la Restauración, es elegido presidente de la corporación. Diputado a Cortes en 1882 y senador en 1893. 
Julio Pimentel Alonso-Pesquera, nieto de Vicente Pimentel y de Millán Alonso, es el continuador de la saga de "los Pimentel" y de "los Alonso Pesquera" en la política, tanto a nivel provincial como nacional.

\section{Reynoso.}

Son dos los principales protagonistas de esta saga familiar: Mariano Miguel y Mariano Lino. Mariano Miguel de Reynoso y Abril, nació en Valladolid el 8 de mayo de 1799, hijo de Mariano Reynoso y de Lucía Abril. Es un destacado comprador de bienes desamortizados. Perteneciente al partido moderado, es alcalde de Valladolid en 1840 y en 1844. Jefe de la Milicia Urbana de Valladolid en 1835. Diputado a Cortes entre los años 1836 a 1847. Consejero regio de Agricultura en 1848 y ministro de Fomento en 1851. No ejerció como diputado provincial. A partir de 1855 ya retirado de la vida política, se centró en el manejo de las actividades industriales y agrícolas al montar dos fábricas de harina en La Flecha y en el fomento de los ferrocarriles, siendo uno de los principales accionistas de la línea Alar-Santander. También mantuvo una importante actividad financiera como director de la Sociedad de Seguros Mutuos y de la Caja de Ahorros de la provincia, como ha quedado señalado en su biografía anterior.

Mariano Lino de Reynoso y Oscáriz, sobrino del anterior, ejerce como abogado a la vez que desarrolla una gran actividad industrial y agrícola. Perteneciente al partido moderado, continúa con la actividad política iniciada por su tío. Es diputado provincial en 1850, diputado a Cortes en 1863 y 1866, gobernador civil de Valladolid en 1875 y senador en 1876. Uno de sus hijos se casó con Asunción Silió, hermana del diputado y ministro Cesar Silió. Su hermano Manuel fue senador por Salamanca en la Restauración.

\section{Santana}

Antonio Santana Santos es diputado provincial en 1843. En 1854 es elegido diputado a Cortes. Es progresista. Claudio Santana Santana es sobrino de Antonio, alcalde de Alaejos en 1867 y diputado provincial entre 1871 y 1874. 


\section{6.- CONCLUSIONES}

Si retomamos los motivos del nacimiento de las Diputaciones, vemos que los redactores de la Constitución de 1812 tienen entre sus principales preocupaciones, la de reordenar el territorio a través de una nueva administración para suplir y olvidar el obsoleto "antiguo régimen". De esta forma pretendían iniciar una nueva y moderna gestión de las actividades del Estado. En definitiva, las Diputaciones son unas instituciones liberales creadas para:

-Mejorar la organización administrativa del país, a través de una institución que canalice las decisiones y actuaciones que, emanadas del gobierno de la Nación, lleguen lo más rápidamente posible a todos los rincones de la geografía nacional.

- Mejorar el nivel de vida de los habitantes de la provincia, desde un punto de vista económico y social a partir de los progresos conseguidos por la gestión de la Diputación.

- Controlar el flujo de la economía, a través del cobro de los impuestos, de la formación de los repartimientos y de la reducción de la morosidad. A este fin, entra en juego el nombramiento del intendente de la provincia, como vicepresidente de la Diputación.

-Controlar desde un punto de vista político, las actividades de la provincia, dentro de la línea marcada por el gobierno. Para ello establece la figura del jefe político/gobernador, que para un mejor seguimiento de las directrices centrales, es a la vez nombrado presidente de la Diputación.

En definitiva, la Diputación es considerada como el enlace entre el poder central y el ciudadano, con la finalidad de conseguir los beneficios y mejoras propuestas, tanto por el gobierno como por la propia Diputación.

Por otra parte, teniendo en cuenta las preguntas que nos hicimos en la hipótesis de trabajo, podemos tratar ahora de responderlas en estas conclusiones. Efectuado un recorrido por el conjunto de actividades y actuaciones que realiza la Diputación Provincial de Valladolid, desde su instalación el día 2 de septiembre de 1813, hasta el 18 de marzo de 1875, fecha en la que finaliza las actividades la última Diputación del Sexenio, destacamos una serie de conclusiones que pueden deducirse del análisis de las actividades de la institución:

-La instalación de las Diputaciones fue un hecho con efectos dinamizadores para la provincia. Uno de los mejores argumentos es el de su permanencia hasta nuestros días. Es evidente la necesidad que tenía el país de articular la administración provincial, a partir de un nuevo organismo, que nace imbuido y condicionado por la doctrina liberal. Su puesta en marcha no es fácil, y es contestada por otras instituciones y en especial se producen conflictos con los Ayuntamientos, principalmente el de la capital. Estas corporaciones locales, cuya génesis y funcionamiento proceden del medievo, ven en la Diputación un contrincante en el dominio y control de una serie de actividades, que se le conceden a las Diputaciones y que son detraídas del ámbito concejil.

-La Diputación trabajó y se esforzó por mejorar la situación de la provincia y de sus habitantes, pero este trabajo y esfuerzo se quedó a "medio camino" de lo previsto y deseado, al toparse con una serie de dificultades que la institución no supo o no pudo superar y que entorpecieron su labor. Nos referimos a:

a).- Una gran penuria económica. No sólo de la provincia, sino también de la Diputación, que no es capaz de conseguir, ya sea a través de los presupuestos estatales, ya sea por medio de impuestos y arbitrios provinciales, el dinero necesario para desarrollar una labor eficaz. En verdad, tanto las arcas del Estado como la de los 
habitantes de la provincia, estaban más bien vacías, lo que representaba una dificultad insuperable para la Diputación.

b).- Una gran dificultad política para el desarrollo de su trabajo. La Diputación tiene que hacer frente al lastre que representa el control ejercido por la jefatura política de la provincia, severa vigilante de las actividades de la institución y de la gestión de los diputados. En este punto, creo que la Diputación no pudo desembarazarse de la presión política que ejercía el gobierno central. En la mayoría de los casos se plegó a los deseos y decisiones del jefe político, aunque no estuviera de acuerdo con los mismos. Únicamente se nota una mayor autonomía a partir de la presencia como presidente de la Diputación de uno de los diputados electos, y esto sólo sucede a partir del Sexenio. A esta nueva situación, hay que añadir la progresiva vinculación política de los diputados a los partidos, lo que ocasiona que la Diputación esté controlada por el partido político mayoritario. En definitiva, el resultado es que la Diputación, cuando consigue zafarse del control del gobernador de turno, pasa a estarlo bajo el partido político gobernante, en función de la mayoría que se consiga en las elecciones.

c).- Un desconocimiento de los trabajos a desarrollar. La falta de recursos técnicos y hábitos administrativos, la carencia de experiencia y de formación de los diputados provinciales, y también de los funcionarios de la institución, a lo que se añade el individualismo que caracteriza a los primeros diputados, fue un freno al progreso y al trabajo de la Diputación, actitud que irá mejorando lentamente con el paso de los años.

d).- Un continuo enfrentamiento con las demás instituciones con las que comparte el ámbito provincial, es decir, con el Obispado, la Capitanía General, y sobre todo con el Ayuntamiento, en especial el de la capital, como ya hemos reseñado anteriormente. Esto es debido a la lucha por el control, tanto de las parcelas del poder político como por las del económico. También tiene su importancia la "animadversión" que las instituciones más "veteranas" sienten hacia la "recién llegada", que además las resta una parte importante de poder y de prestigio. Estos enfrentamientos en algunas ocasiones son sobre temas puntuales, como por ejemplo los roces con el Obispado en relación con el control de los centros asistenciales benéficos. En otros casos se trata de disputas y enfrentamientos con la Capitanía General sobre el pago de los gastos de mantenimiento de las tropas o la cesión de edificios para cuarteles.

Pero es con los Ayuntamientos con los que la Diputación tiene a menudo unos continuos enfrentamientos en la mayoría de las actividades en las que ambas instituciones participan o tienen relación. Ello es debido a que, en mayor o menor medida, la Diputación detrae de los Ayuntamientos parte de sus actividades. Además, pasa a ser el organismo controlador de la gestión municipal, especialmente en el caso de las cuentas municipales. En el fondo, es el control tanto político como económico el que pasa a la Diputación y eso no es del agrado del Ayuntamiento. También hay una latente oposición entre ambas instituciones, nacida de la tendencia rural de las Diputaciones, que gobiernan mirando a la provincia y sus instituciones locales, y la tendencia urbana de los Ayuntamientos de las capitales, que es con quien entra en colisión la Diputación. Hay también otro elemento diferenciador entre Ayuntamientos y Diputaciones, aquéllos son preferidos por los partidos más liberales o progre sistas, con cierta inclinación a la autonomía y la descentralización, y éstas son apetecidas por los más moderados o conservadores, a disposición del centralismo y dependencia del gobierno central. Es clara en este sentido la rivalidad entre el municipalismo de los progresistas con el provincialismo de los moderados, que dibujan una permanente tensión entre las leyes municipales y las provinciales.

Independientemente de estas primeras valoraciones sobre la Diputación y su asentamiento en la provincia, al hacer un repaso por todos los acontecimientos que se suceden alrededor de la institución, y que tienen su influencia en la misma, destacamos algunas constantes dignas de mención en cuatro áreas básicas de su actuación:

$1^{\circ}$.- Una evolución legislativa, abundante y cambiante, que afecta a la Diputación y modifica su funcionamiento, una veces con una tendencia abierta y 
liberal, en contraposición a otras ocasiones, en las que sufre un "encorsetamiento" más propio de los moderados, que dificulta sus movimientos. $2^{\circ}$.- Una evolución institucional física y política tanto de la provincia como de la corporación, que se ofrece a través de las diferentes Diputaciones que se sucedieron a lo largo de estos años, entre 1813 y 1874. Los cambios de los límites provinciales que tuvieron lugar en los primeros años de vida de la institución. Las cambiantes sedes donde se establecieron y trabajaron los diputados y funcionarios durante estos años. Los diferentes personajes que las protagonizaron, las vicisitudes de sus nombramientos y sus actuaciones.

$3^{\circ}$.- Las actividades institucionales, es decir, la serie de actividades que se enmarcan en el trabajo específico de la Diputación, y que tienen por finalidad el conseguir una mejora en el nivel de vida provincial. Es el desarrollo de todas las actividades encomendadas a la institución, que ha ido calando hondo en la identidad territorial y política. Particularmente en Castilla, fue muy intensa la vida provincial que giró en torno a las Diputaciones, y la fuerte identidad provincianista que generó, que aún en la actualidad la estructura autonómica del Estado español no ha conseguido superar. Vemos hoy que ha quedado perviviendo una estructura provincial paradójicamente incrustada en la estructura autonómica que no se logra superar.

$4^{\circ}$.- Las élites provinciales con la presencia, conocimiento y actuación de un numeroso grupo de personajes que protagonizaron la vida de la Diputación, repartidos entre gobernadores y diputados, representan las cabezas visibles de la institución y se suceden a lo largo de estos años. Todos ellos trabajan para la Diputación, para sus convecinos y en ocasiones, para ellos mismos. En cualquier caso fueron una cantera de personal político que actuó en el ámbito municipal o en el marco de la representación nacional, así como en los cargos intermedios de los diferentes niveles administrativos. Las Diputaciones pueden considerarse igualmente como unas escuelas de formación de las élites políticas que jugaron un importante papel en los procesos de toma de conciencia y de experimentación de la política en los dos primeros tercios del siglo XIX.

\section{EVOLUCIÓN LEGISLATIVA}

La evolución legislativa está marcada por una legislación intensa y variada, aunque no siempre en un sentido beneficioso para la Diputación, en especial en lo relativo a su autonomía con respecto al poder central. En líneas generales, toda la legislación está en correspondencia con la orientación política que predomina en el momento de su publicación, y tiene un carácter oscilante en correspondencia con el gobierno de turno.

A lo largo de estos años se pone de manifiesto el continuo enfrentamiento de dos posturas políticas que se acentúan con el paso del tiempo. Por un lado tenemos a los liberales y progresistas, preocupados por dar una mayor autonomía a las instituciones, y por otro lado tenemos a los conservadores que se empeñan en mantener el control y dominio del país desde una perspectiva centralizadora. Este enfrentamiento se trasmite y se refleja en las instituciones de tipo provincial y municipal, entre los que defienden la supremacía de las Diputaciones y los que luchan por mantener la hegemonía municipal sobre la provincial. Estas diferencias, en un principio centradas en la parcela política, se pasarán al ámbito económico y al social con la aparición al final de este período de las primeras organizaciones de tipo sindical, tanto desde el lado monárquico demócrata como desde el republicano. Y como es lógico, estas diferencias también se plasman en la actividad legislativa.

Así vemos que en la legislación, tanto del período Constitucional gaditano como en la del Trienio, predomina el carácter liberal propio de la primera generación radical. En primer lugar, a partir de la promulgación de la Constitución de 1812, en la que se fijan las bases del funcionamiento de las Diputaciones y que posteriormente se completará su desarrollo a partir de dos leyes que marcarán las pautas de la nueva 
institución. Nos referimos a la "Instrucción para el Gobierno Económico-Político de las Provincias" de 23 de junio de 1813 y a la "Ley de 3 de febrero de 1823 sobre el Gobierno Económico-Político de las Provincias". Son dos leyes de carácter liberal, representativas de este primer período, la primera de ellas "la Instrucción de 1813", aparte de legislar sobre Ayuntamientos y gobiernos políticos y sus relaciones con la Diputación, detalla las actividades de las que se tiene que responsabilizar, pero sobre todo pone de manifiesto la dependencia de la Diputación con relación al gobierno a través del jefe político. En resumen, ni los Ayuntamientos pueden hacer nada sin consultar a la Diputación y ésta no puede hacer nada sin consultar al gobierno. La segunda, "Ley de 3 de febrero de 1823", llega un poco tarde para ser aplicada en el Trienio y se convertirá en la ley por excelencia hasta la llegada de la nueva legislación que acompaña a la Constitución de 1845 y que volverá a estar vigente durante el Bienio Progresista. Mantiene la tendencia de la anterior con una mayor carga progresista en su redacción y pone de manifiesto las actividades que la corresponden, separando las funciones de carácter político que se centran en el jefe político y las de carácer económico que se confían a la Diputación.

Una segunda oleada legislativa se produce a partir de 1835, con la llegada del período isabelino y con el predominio a lo largo de estos años, de las opciones políticas conservadoras. Destaca en especial por su interés e incidencia en el funcionamiento de las Diputaciones el real decreto de 21 de septiembre de 1835 por el que se "constituyen las Diputaciones provinciales", que junto al real decreto de 30 de noviembre de 1833 "sobre la división territorial de las provincias", serán los puntos de partida y asentamiento definitivo de la Diputación en la vida política nacional.

Junto a estos decretos destacamos en estos años la promulgación de las Constituciones de 1837 y 1845 , acompañadas por las consiguientes leyes complemen tarias relativas a las Diputaciones. Así es la "Ley de Organización y Atribuciones de las Diputaciones provinciales" de 8 de enero de 1845 , que reemplaza a la liberal ley de 23 de febrero de 1823 y en la que hay que destacar como primera característica la del protagonismo que se da a la figura del jefe político en detrimento de la autonomía de la Diputación, Su segunda característica es la acentuación del centralismo y la pérdida de la gestión de parte de las actividades que son traspasadas al recién creado Consejo provincial, además de la pérdida de gestión que supone la supresión de la Secretaria General y de todos los funcionarios de la institución.

Por otro lado, la "Ley para el Gobierno de las Provincias" de 2 de abril de 1845, es la segunda ley de este período legislativo, que completa la legislación conservadora y mantiene el carácter centralista y hegemónico del gobierno central. En ella se define al jefe político como la "autoridad suprema de la provincia", sin resquicio posible para el resto de las instituciones. Estas leyes estarán vigentes hasta el 25 de septiembre de 1863, fecha en la que son sustituídas por la nueva "Ley para el Gobierno y Administración de las Provincias", que mantiene su línea conservadora, agravada en esta ocasión por la situación política nacional y la radicalización de las posturas políticas tanto por el lado progresista como por el moderado. Esta radicalización se traspasa a las leyes con el resultado de que la Diputación sigue manteniendo un perfil bajo de actividad y autonomía y un control alto por parte del gobernador.

Todas estas leyes se caracterizan por su lógico carácter conservador y sobre todo por el afán centralizador, es decir, por el control que por parte del gobierno se ejerce sobre todo tipo de decisiones que se toman en la Diputación. El control está ejercido por el gobernador, personaje encargado de fiscalizar y "vigilar" las actuaciones y actividades que desarrollan los políticos provinciales y locales. En los períodos progresistas intercalados en estos años moderados no se producen cambios en la legislación, sobre todo porque en la corta vigencia de estos períodos no da tiempo a poner en marcha los proyectos previstos. Lo único que es posible hacer es retomar las leyes liberales más características como son la Constitución de 1812 y la ley de 3 de febrero de 1823, sobre el "Gobierno económico político de las provincias". 
El Sexenio Revolucionario marca una nueva época con otra serie de leyes que destacan por su carácter progresista. La legislación se inicia en los comienzos del periodo con la "Ley de Organización y Atribuciones de las Diputaciones Provinciales" de 21 de octubre de 1868 , ley de corta duración y que tiene la misión de descentralizar la actividad política de carácter provincial y de "desahogar" la presión que las leyes conservadoras introducían a la Diputación. Los actos que se producen son la supresión del Consejo provincial, la reposición de la Secretaría y sus correspondientes funcionarios y en la que el gobernador pasa de ser "la autoridad superior de la provincia a ser el representante del gobierno en la provincia". La legislación continuará con la promulgación el 6 de junio de 1869 de la nueva Constitución y se complementará el 20 de agosto de 1870 con la publicación de la "Ley Orgánica Provincial". En ésta se estipula la ampliación del número de diputados que pasan de nueve a treinta y cinco, en función del número de distritos, y sobre todo legisla qu e "la Diputación nombrará a un presidente de entre sus miembros", con lo que resultará que el gobernador, cuando asista a las sesiones, las presidirá pero sin voto.

Todas estas leyes destacan por la concesión de una mayor autonomía provincial, sin perder el dominio y control de la institución. En definitiva, son leyes que articulan y mejoran, dentro de unos límites lógicos, las actividades de la Diputación con la finalidad de hacer progresar a la provincia. Como síntesis y conclusiones de esta visión legislativa desarrollada a lo largo de estos años, destacamos que:

- Las leyes que se suceden en este período tienen en cuenta que la Diputación es el punto de partida para la organización administrativa, económica, social y política de la provincia.

-La legislación, ya sea hecha con una tendencia liberal, conservadora ó progresista, no acepta perder el control de la institución por parte del gobierno, ya sea por desconfianza ó por temor a una pérdida de dominio sobre la mísma. Ni siquiera la legislación del periodo democrático llegó a independizar del todo la institutción.

-Las Diputaciones influyeron en la redacción de las leyes, a través de peticiones y reclamaciones, pero no se atrevieron o no pudieron enfrentarse con el gobierno cuando estas leyes coaccionaban ó coartaban su quehacer, ó perjudicaban, de alguna forma, a las instituciones.

-En particular, la Diputación de Valladolid, no protestó y apenas se quejó, excepto en los temas de los límites provinciales, de las importaciones de trigo, de los aranceles o cuando peligraba la existencia de la Universidad.

-Por último, los legisladores no fueron muy generosos y no se atrevieron a legislar dando una mayor autonomía y financiación para las Diputaciones.

\section{EVOLUCIÓN INSTITUCIONAL}

Desde un punto de vista institucional, hemos seguido la evolución de la Diputación fijándonos en tres aspectos. El primero se refiere a la "evolución territorial", Hemos repasado todas las gestiones que se hicieron para adecuar la provincia a unos límites racionales, tanto en extensión como en distribución, y para evitar, como muy bien señaló uno de los individuos que redactó el proyecto de división provincial, "la monstruosa circunscripción de la provincia de Valladolid" . El segundo aspecto está referido a los cambios en la "evolución física" de la institución, es decir, al conocimiento de los diferentes edificios en los que ha estado ubicada la sede de la Diputación. El paso de los años y el afianzamiento de la institución, hicieron que se trasmitiera esa consolidación a la búsqueda de un adecuado edificio en el que estuviera bien situada la corporación. Como tercer aspecto, vemos una "evolución política", reflejada en las diferentes y variadas coloraciones políticas de las Diputaciones que se sucedieron en todos estos años, con sus diferentes diputados, sus diversas legislaturas, sus distintos funcionarios, en resumen, una visión política de las Diputaciones y sus componentes.

La evolución territorial viene marcada por la necesidad de "hacer una provincia" lo más racional y asequible posible, tanto para los ciudadanos y su facilidad 
de acceso a cualquier parte de la provincia, como para mejorar el trabajo de la administración provincial. En esta tarea, dos son las personas encargadas de llevar a cabo la redistribución provincial. Felipe de Bauzá, en 1813 y 1820, fue el pionero de esta reforma y el que marcó la tendencia y se aproximó a la conformación definitiva realizada en 1835 por Javier de Burgos. Las autoridades vallisoletanas no estuvieron muy de acuerdo con los nuevos límites, por la pérdida de territorio que suponía, pero finalmente aceptaron la propuesta y reconocieron la mejora, de una forma sustancial, de la accesibilidad, la rapidez en las comunicaciones y la consolidación administrativa final y definitiva.

Con respecto a la evolución física, hemos hecho un recorrido por las distintas sedes que tuvo la Diputación. Se inicia en el año 1813, con su instalación en el Palacio Real. En el Trienio Liberal, una vez que no se la permitió volver a las dependencias anteriores, se asentó en el Palacio del Conde de Polentinos. En la época isabelina, después de una breve y precaria estancia en el Palacio Real, pasó a ocupar el Palacio de Osuna, el del Marqués de Villasante, el Colegio de San Gregorio y el Palacio de Pimentel. Entre 1813 y 1875 ocuparon seis edificios, todos ellos amplios y representativos del Valladolid del siglo XIX, destacando el Palacio de Pimentel, edificio que continúa en la actualidad como sede de la Diputación.

En lo concerniente a la evolución política, entre el 2 de septiembre de 1813 y el 18 de marzo de 1875 , se sucedieron un total de veintiocho Diputaciones diferentes. Si las distribuimos por los períodos políticos en las que estuvieron vigentes, nos dan el siguiente resultado:

Una Diputación constitucional entre 1813-1814.

Tres Diputaciones liberales entre 1820-1823.

Diecinueve Diputaciones isabelinas entre 1835-1868.

Cinco Diputaciones revolucionarias 1868-1875.

De las diecinueve Diputaciones que se suceden en la época isabelina, dieciséis son de tipo conservador y tres lo son de carácter progresista.

Si queremos reparar en su carácter más ó menos representativo, vemos que del total de veintiocho Diputaciones, veintiuna de ellas, se formaron a partir de las correspondientes elecciones y las siete restantes lo fueron por "nombramiento superior". Como dato relevante, señalamos que de estas siete nombradas, sólo una de ellas lo fue en el periodo denominado conservador, en el año 1856, una vez finalizado el Bienio Progresista en el que fueron nombrados los correspondientes diputados por el capitán general. Las seis Diputaciones representativas restantes lo fueron en los períodos más o menos progresistas: una en el Trienio Liberal, dos en el Bienio Progresista y tres en el Sexenio Revolucionario. El gobernador, el capitán general y la Junta Revolucionaria Provincial son los responsables de estos nombramientos.

Otro dato que puede ilustrar la estabilidad institucional es el de la duración de las Diputaciones. Teniendo en cuenta que por ley la duración estaba establecida en dos años, la media de duración fue bastante inferior. Tenemos siete Diputaciones que tuvieron una duración inferior a un año, doce lo fueron entre uno y dos años, y nueve lo fueron durante un período superior a los dos años. Destaca por su corta duración la primera Diputación progresista, que sólo estuvo vigente durante quince días en el mes de agosto de 1854 , y en sentido contrario tenemos a la primera Diputación de la Década Moderada, que se mantuvo operativa entre noviembre de 1843 y julio de 1847 , es decir, casi cuatro años.

Los individuos que de una forma o de otra tienen relación con la Diputación y sus trabajos están repartidos entre:

-Los diputados provinciales, que fueron los "motores" de la actividad de la Diputación. De acuerdo con la evolución de la legislación, van modificando su número, pasando de los siete diputados de las primeras Diputaciones a los treinta y cinco que formaron las últimas. 
-Los gobernadores y asimilados, que actuaron como "contrapeso" de los diputados, son los encargados de mantener la línea política ordenada por la superioridad.

-Los funcionarios, con el secretario de la Diputación a la cabeza, actuaron en el área administrativa para tener a punto los acuerdos, expedientes, inquietudes y reclamaciones de todos los ciudadanos, trabajos que quedaron plasmados en los libros de actas. No siempre bien tratados y no siempre, o mejor dicho, casi nunca, bien pagados.

-Intervinieron otros personajes, que con su actividad representaron a la provincia y fueron parte activa en la gestión de la Diputación. Léase militares, políticos locales, propietarios, terratenientes, industriales, comerciantes, etc., es decir, "las fuerzas vivas de la provincia" que entraron en relación con élla.

En conclusión, y como resumen de este punto de vista institucional, las Diputaciones se van consolidando lentamente, y sobre todo van adquiriendo experiencia. Al mismo tiempo, se van vinculando políticamente a los partidos, pasando de un primer individualismo liberal de las primeras Diputaciones a un control, tanto de las instituciones como de los diputados, por parte de los partidos políticos. En este sentido, parece interesante sugerir que las corporaciones provinciales han tenido un papel importante en el proceso de formación e identificación de los partidos políticos, y ha servido asimismo para establecer un camino lento de identificación ideológica de la élite política.

\section{ACTIVIDADES DE LA DIPUTACIÓN}

Las actividades que desarrolla la Diputación son sin duda la razón de ser y de existir de la institución. Son el medio que tiene para cumplir con la finalidad para la que fue creada. Son la forma de hacer realidad el lema de "hacer progresar a la provincia". La pregunta que en principio surge es si la Diputación cumplió con el deber para el que fue creada, en definitiva, es saber si la institución estuvo a "la altura de las circunstancias" y consiguió que la provincia progresase a partir de su entrada en funcionamiento.

Desde luego, no tenemos razones para dudar de la intención y de los esfuerzos de la institución y de los individuos que la conforman, por conseguir el bienestar de los habitantes de la provincia. Pero tan importante como este servicio a los intereses de los ciudadanos, que fueron identificándose despacio y con mucho esfuerzo por parte de las élites provinciales, fue la intención de trabajar por los intereses de los grupos concretos que representaban, los más capaces económica y socialmente, y los beneficios propios de los individuos y las familias de los diputados mismos.

Al mismo tiempo, tenemos que admitir que no consiguió sus objetivos, sobre todo, en opinión de sus "gobernados". No podemos olvidar que cuando las cosas fueron bien, es decir, cuando la economía prosperó, fue especialmente motivado por la coyuntura positiva, que se comportó de una forma dinamizadora, $y$, en consecuencia, la Diputación aprovechó el empuje para "apropiarse" de la autoría de la prosperidad provincial. En estos años y en este contexto, hay que tener presente que el bienestar y la satisfacción de los vallisoletanos estaban ligados a las subsistencias, a la precariedad del trabajo y a las dificultades de las comunicaciones y de alguna manera todos estos elementos dependían entonces de la agricultura de manera muy importante. Aunque no era la política agraria la única determinante de la prosperidad provincial, también tenemos que reflejar a la política de subsistencias y quintas, a la de la beneficencia, a la política de construcción de canales, carretereas y ferrocarriles, en definitiva, a todas las políticas capaces de ilusionar y de mejorar la sociedad. De este modo puede decirse que la Diputación promovió la prosperidad de la provincia, sobre todo en los buenos años agrícolas, pero por otro lado debió ejercer el permanente papel fiscal de recaudadora de impuestos y controladora de cuentas municipales, que limitaron esa percepción de satisfacción ciudadana. 
Dos razones importantes pueden hacernos explicar los discutidos resultados que la Diputación obtiene, y también la satisfacción que genera en los administrados. Por una parte, tenemos que, entre los trabajos a los que se enfrenta, destacan, como los más importantes pero también los más impopulares, los dedicados a los "repartimientos de los impuestos" y a los "sorteos y repartimiento de los quintos". Son dos actividades que llegan a representar el $50 \%$ de la ocupación de la institución, y que como es lógico acarrea un sentimiento de rechazo hacia la misma por parte de los habitantes de la provincia. Éstos la ven simplemente como a la "institución encargada de reclamar a los ciudadanos su dinero y sus hijos".

Por otra parte, otra dificultad añadida para alcanzar los objetivos propuestos es la de la precaria situación económica en la que se desenvuelve, no sólo la provincia, sino también la Diputación, a lo largo de estos años. Sus presupuestos son el ejemplo de sus problemas, siempre desfasados y siempre deficitarios. Las causas están motivadas por la penuria de la Hacienda Pública, que no provee de los fondos necesarios, y por la penuria de los habitantes de la provincia, que no son capaces de hacer frente a sus obligaciones impositivas.

En definitiva, el querer superar el atraso en el desarrollo provincial, provoca una mayor necesidad económica que la provincia no está en disposición de asumir. Otra serie de conclusiones complementarias nos irán surgiendo a lo largo del siguiente recorrido por las diversas actividades y actuaciones de la Diputación que vamos a recorrer.

Así tenemos que, dentro de los trabajos realizados por la Diputación, podemos considerar a las Obras Públicas, como una de las más interesantes. La Diputación es consciente de que las comunicaciones son una de las "mejores armas" para dar una imagen de progreso. Por eso se esforzó por conseguir una mejora y ampliación de las mismas, sobre todo al constatar que un retraso secular en este tema hacía que cualquier mejora suponía un progreso importante.

En un principio, su dedicación está centrada en rematar las obras del Canal de Castilla, la vía de comunicación más importante, iniciada en el siglo XVIII e interrumpida su construcción en los años en los que la Diputación inicia sus actividades. Era la vía en la que estaba centrado el interés de los agricultores por ser la más idónea para agilizar la salida de los productos agrícolas. Después serán las carreteras y caminos vecinales. Las primeras con continuas demoras en su construcción ocasionadas por el abandono en su financiación por parte del gobierno y por la falta de recursos provinciales y los segundos se beneficiarán del "interés social" de dar "trabajo a los jornaleros en los años de malas cosechas agrícolas". No podemos dejar de destacar el importante esfuerzo en el diseño de carreteras provinciales y locales que realiza la Diputación, que tuvieron una gran incidencia en la consolidación de la provincia, en la buena comunicación para el movimiento de granos y personas, y en la capacidad que el mismo Estado adquiría de llegar a los ciudadanos a la hora de cobrar impuestos y demandar controles políticos y administrativos.

Finalmente, y en la segunda parte de estos años, hay que destacar la buena gestión de la Diputación en el fomento y promoción del ferrocarril, superando todas las graves dificultades que se presentaron, en especial en el tema económico. Y si en el tema del Canal y en el de las carreteras, la Diputación tuvo que "bregar" en solitario para la culminación de las obras, es llamativo que en el tema del ferrocarril, el apoyo económico de las burguesía provincial fue fundamental para llevar a buen término su construcción, sin olvidarnos de la estimada colaboración, tanto social como económica, del Ayuntamiento de Valladolid.

En el tema de los impuestos, que recordamos como una de las actividades más importantes de la Diputación, se luchó por la disminución de la presión contributiva y se preocupó de que los repartimientos fueran lo más asumibles para su prestigio y relación con los ciudadanos, admitiendo a su vez, la cuota de impopularidad que conllevaba esta gestión. Uno de los temas a los que tuvo que hacer frente era al de los continuados datos fraudulentos en las declaraciones de los bienes a efectos 
contributivos, por no disponer de datos exactos y por el afán de reducir la cuantía impositiva por parte de los contribuyentes. Además, en este asunto, otro problema añadido es el de las repercusiones de los repartimientos. Se tenía que dar curso y solucionar las numerosas reclamaciones que se recibían, tanto por parte de los Ayuntamientos como de los ciudadanos, inconformes con las liquidaciones practicadas. También se tenía que hacer frente a los problemas que ocasionaba la alta morosidad, lo que provocaba un considerable retraso en el cobro, un enfrentamiento entre morosos y cobradores, y llegado el caso, la petición de ayuda de la Diputación al Ejército para hacer efectiva la deuda. Como es lógico, estas actuaciones no beneficiaban la imagen de la Diputación, por mucho que se esfuerce por pedir a "los dóciles castellanos viejos que se esmeren en pagar sus contribuciones".

En definitiva, el tema del cobro de los impuestos no es una de las actividades gratificantes de la Diputación. La institución se veía además en la necesidad de aumentar la presión fiscal con los arbitrios provinciales suplementarios para intentar cuadrar sus presupuestos. Hay que reconocer que fue la actividad que consiguió el más alto cumplimiento por parte de la institución, y también el mayor rechazo por parte de la población.

Otra de las actividades de las que se tiene que hacer cargo la Dipùtación está relacionada con el Ejército. La misión que tiene que llevar a cabo se centra en las tareas de alistamiento, tallaje y reclutamiento, asumiendo que este trabajo generaba una gran antipatía en la población. Fue una actividad añadida a partir de la ley de 3 de febrero de 1823, en la que se asigna a las Diputaciones "el repartimiento de los reemplazos del Ejército", y al mismo tiempo se la responsabiliza de la puesta en marcha de la Milicia Nacional. Al igual que pasa con los impuestos, en los repartimientos de los "quintos" alcanza un alto porcentaje de ocupación en relación con los restantes trabajos de la Diputación. Además, también tienen que hacer frente a las numerosas e interminables sesiones de reclamaciones, tanto por parte de los Ayuntamientos como por los interesados, que esgrimen una serie de motivos, ya sea por agravios comparativos, por defectos físicos, ó por motivos familiares. En conclusión, una actividad impopular y generadora de tensiones que no mejora la imagen de la Diputación, pero que ésta lleva a la práctica de una forma rigurosa.

Sanidad y Beneficencia son otras dos actividades tendentes a conseguir la mejora de la situación social de la provincia. Su actuación se puede considerar satisfactoria para el conjunto de la población, que veía cómo poco a poco mejoraba las atenciones sanitarias y benéficas. Es importante destacar que cuando la Diputación se hace cargo de la gestíon benéfica, lo hace con la finalidad de mejorar la situación asistencial y esa mejora pasa por reducir el número de instituciones y por la mejoría y modernización de los centros que permanecen.

En lo que concierne a la Sanidad, está claro, que las actividades de la Diputación tuvieron ciertos efectos positivos, porque con su gestión, partiendo de una sanidad incipiente, fue dominando, controlando y mejorando las dificultades sanitarias, en especial en lo referente a las epidemias y a la atención médica primaria. Aunque sus limitaciones son más que evidentes y su progresión lenta, teniendo en cuenta las dificultades económicas tanto de la Diputación como de los Ayuntamientos para hacer frente a los costes sanitarios.

Con respecto a la Beneficencia, la Diputación se encontró con numerosas instituciones, con muchos años de existencia y en su mayoría vinculadas a la Iglesia y a los Ayuntamientos. La labor de la Diputación es, en un principio, la de velar por la buena gestión de los establecimientos benéficos, paso que posteriormente se complementará con la progresiva secularización de las repetidas instituciones, para llegar, finalmente, a la "provincialización en sus manos de buena parte de los recursos que las viejas fundaciones tenían dispersos por toda la provincia". Estas actuaciones produjeron un fuerte enfrentamiento con los Ayuntamientos y los obispados, habituales patronos de la mayoría de los centros de beneficencia y caridad. No cabe duda de que los hospicios y hospitales mejoraron en gran medida a partir del control que sobre los 
mismos hizo la Diputación, actuación que fue bien recibida por la población. En este sentido, es preciso matizar que los principales beneficiarios de la acción asistencial y sanitaria de la Diputación fueron los habitantes rurales de la provincia.

La agricultura es la actividad económica más importante que se desarrolla en la provincia. En esta área y en los primeros años la Diputación, se contagió del conformismo de los agricultores y de su mentalidad, arraigada en el atesoramiento de las rentas agrícolas en lugar de su inversión en la mejora de los cultivos y en el progreso técnico. La Diputación mejoró sus actividades a partir de los años 50 y fruto de esta tendencia se pueden destacar las exposiciones agrícolas, que con carácter regional se inician en el mismo año 1850, destacando por el éxito conseguido la celebrada en 1859. Asimismo hay que imputarla la petición de creación de la GranjaEscuela que se solicita en los años del Sexenio. También tuvo interés en que labradores de la provincia tuvieran noticia de la Exposición Agrícola de Londres en 1862, para lo cual subvencionó a una comisión que visitó la Exposición y presentó posteriormente sus resultados y una serie de productos y maquinarias adquiridos en nombre de la institución. Un punto especial en el que la Diputación se centró y se interesó en referencia a la cuestión agrícola estuvo relacionado con el incipiente proteccionismo, como fue la lucha contra la imposición de aranceles a la exportación. Insistió asimismo en la petición de cerrar el país a la entrada de cereales, o en su defecto, gravar con impuestos la importación. Para tratar estos dos temas, solicitó la ayuda de los diputados a Cortes elegidos por la provincia y de otras varias personalidades vallisoletanas residentes en Madrid. Son unos años de crecimiento agrícola, que algunos autores han denominado como el reino de Ceres, truncados a partir de 1864 a causa de la sequía, de las malas cosechas y de la crisis económica general.

En industria y comercio, actividades muy ligadas a la agricultura, debió de fomentar la construcción de maquinaria agrícola, en lugar de comprarla en las ferias extranjeras, y en este punto fue siempre a remolque de otras regiones y de otros países. Tampoco supo aprovechar los años de bonanza agrícola y de la eclosión de la industria harinera para potenciar el desarrollo industrial, ni tampoco se preocupó de la creación de industrias relativas a la transformación de los productos agrarios, que estuvo más bien protagonizada por las iniciativas particulares de las fuerzas vivas de la ciudad y la provincia. Con respecto al comercio, no realizó actividad alguna tendente a la formación y mejora de los canales de distribución de los productos agrícolas, que fuera más allá de lo conseguido por el Canal de Castilla, condicho ya por la iniciativa privada. En definitiva, poca actividad puede imputarse en su haber en un área que estaba considerada como la más importante de la provincia.

En relación con la Enseñanza, la Diputación divide sus esfuerzos en los tres niveles en los que esta materia está dividida: Enseñanza primaria, media y universitaria. Tres niveles muy diferenciados entre sí, y en consecuencia con unos problemas y soluciones también muy diferentes. La enseñanza primaria es el sector en el que la Diputación tiene una mayor influencia, ya que la generalización de esta enseñanza es un mandato contenido en la Constitución de 1812, que encargaba su desarrollo preferente-mente a los Ayuntamientos, y a la Diputación la correspondía velar por su cumplimiento. Para llevar a buen término esta generalización, la Diputación, aunque procuró cumplir con el compromiso de llevar la escolarización a todos los rincones de la provincia, se encontró con dos dificultades que enturbiaron los resultados. La primera está referida a las escuelas, que habitualmente estaban ubicadas en locales que no reunían un mínimo de comodidad, ni eran idóneas para la enseñanza, ya que en la mayoría de los casos se trataban de viejas paneras, cárceles y almacenes. En mínimas ocasiones se construyeron edificios específicos para la enseñanza. La segunda dificultad, se centraba, como es de suponer, en la grave penuria económica de los Ayuntamientos, lo que suponía el incumplimiento de sus obligaciones en el pago de los salarios de los maestros, cosa que sucedía de una manera sistemática. En estas dos situaciones, la Diputación no puede resolver el problema de la falta de dinero para hacer posible la mejora de las instalaciones y el pago de una forma puntual y regular a 
los maestros. El dicho popular que dice que "tiene más hambre que un maestro de escuela" se supone que proviene de estos años y de estas dificultades.

La enseñanza media, en este período, tiene poca importancia entre la población, porque habitualmente los estudios finalizaban con la enseñanza primaria, y únicamente la cursaban los alumnos que pensaban continuar sus estudios en la Universidad. En este nivel, tanto las competencias como la preocupación de la Diputación son muy escasas, y únicamente se centró en buscar un edificio idóneo en el que instalar, tanto el In stituto como la Escuela Normal, trabajo al que se dedican en algunos de los años analizados.

Finalmente, en el tema de la Universidad vallisoletana, la Diputación trabaja para mantener su permanencia, pues a pesar de su antigüedad, se debate continuamente con el temor de ser clausurada. En este aspecto y ante esta situación, la corporación luchó por conseguir su permanencia y su estabilidad. A tal fin, movilizó a todas las personalidades vallisoletanas con ascendencia en el gobierno y en las Cortes para alcanzar sus propósitos, cosa que consiguió. Pero tampoco aquí sus competencias eran importantes, de forma que el control de la institución universitaria por parte del gobierno central estuviera bajo el control del gobernador civil por encima del rector en la mayor parte de los periodos moderados.

Como resumen de este capítulo de actividades, hay que reconocer que es en el que más se pone de manifiesto el interés de la Diputación por trabajar en beneficio de la provincia y donde se demuestra el esfuerzo por conseguir el progreso deseado. En todas estas variadas actividades, la Diputación consiguió que la provincia mejorase, aunque no con la intensidad y el deseo que tanto los individuos pertenecientes a la institución pretendieron, como los habitantes de la provincia esperaron. En definitiva, los resultados fueron discretos y demostraron que la existencia de la Diputación era una palanca conveniente para hacer progresar a la provincia y sus habitantes en los asuntos económicos y sociales más urgentes, pero sus logros fueron probablemente más beneficiosos para las élites políticas que gestionaron la institución y para el Estado central que los controlaba que para los habitantes de la provincia.

\section{LAS ÉLITES PROVINCIALES}

El capítulo que trata sobre las élites provinciales es uno de los más importantes de este estudio, porque es en el que a lo largo de sus páginas desfilan todos los individuos que han conformado las diferentes Diputaciones y que han sido los protagonistas de los trabajos y de los progresos de la institución. A ellos les corresponde buena parte de la responsabilidad por los trabajos hechos y por las mejoras alcanzadas, y seguramente que fueron ellos mismos los más favorecidos por el balance final de su gestión.

Presidentes/gobernadores, vicepresidentes/intendentes y diputados provinciales son las tres referencias en las que se sustenta la Diputación en su vertiente humana y política. Los dos primeros grupos son sistemáticamente nombrados por el gobierno central. El tercero y más importante para la vida de la Diputación, es decir, el de los diputados provinciales, es el producto, en la mayoría de los casos, de las elecciones provinciales, aunque en otras pocas ocasiones es debido al nombramiento de orden superior. En cualquiera de los dos casos, la importancia de los diputados es básica para el desarrollo de los trabajos y el mantenimiento de la actividad de la Diputación, también para el establecimiento de los partidos políticos, para la consolidación del Estado liberal, para la formación de élites políticas que abastecieron la administración local, provincial y general, y para el control estatal de las elecciones municipales y de los presupuestos y cargos de los Ayuntamientos.

Al cargo de jefe político/gobernador se accede a través de nombramiento directo por parte del Ministerio de la Gobernación, ejerciendo prioritariamente como jefes políticos ó gobernadores. De acuerdo con la legislación, asumen al mismo tiempo la Presidencia de la Diputación. Este nombramiento dual es un obstáculo para el normal funcionamiento de la institución, debido sobre todo a la precariedad del mandato, a su corta duración y a que el cargo de presidente está supeditado al de 
gobernador. Estos inconvenientes ocasionan una falta de integración en la vida provincial y una prioridad al tomar decisiones, a favor del gobierno político y en detrimento de la Diputación. En definitiva, no se perciben a sí mismos como gestores provinciales, no viven la política provincial, dan más importancia y relevancia al cargo de gobernador, que es por el que pueden seguir progresando en la política. A partir del Sexenio, los gobernadores dejan de ser, en razón del cargo, presidentes de la Diputación, lo que supone una mayor autonomía en la gestión provincial.

Los vicepresidentes/intendentes son, sobre todo, técnicos económicos, y su presencia en la Diputación está supeditada al cargo de representante en la provincia de la Hacienda Pública. Su influencia en la Diputación es prácticamente nula y centrada en el tema de los repartimientos de la contribución y en las consiguientes reclamaciones ante la falta de pago de los contribuyentes. En los numerosos casos en los que ejercieron la presidencia interina, no tuvieron influencia en la toma de decisiones.

Los diputados provinciales son los auténticos protagonistas de la evolución política de la provincia y los más interesados por mejorar la situación económica y social de la misma. En los primeros años se caracterizan por su liberalismo, individualismo y autonomía personal, y con el tiempo van evolucionando hacia la integración en los partidos políticos. Es destacable la influencia que tienen los diputados provinciales en el ámbito de su demarcación electoral, es decir, en el partido judicial ó distrito al que representan y por el que son elegidos, territorio que en principio es controlado a nivel económico y social, para pasar a serlo también desde un punto de vista político. La figura del diputado, con total dominio en el distrito, se irá consolidando a lo largo de estos años y tendrá su eclosión en el período de la Restauración, con la consolidación del cacique, como máximo controlador del distrito.

También es llamativo el afán de algunos prohombres provinciales por presentarse a las elecciones de diputados. Son conscientes de que su elección y su implicación en la provincia les comportará un alejamiento de sus ocupaciones habituales, un distancia-miento en la mayoría de los casos de su lugar de residencia. Además, saben que es un trabajo en el que tienen que estar implicados en al menos noventa días de sesiones al año y de que es un trabajo por el que no reciben remuneración alguna. Una contestación a este interrogante puede consistir en que las élites perciben el cargo de diputado provincial como un escalafón importante en la carrera política del interesado. El primer paso es el de alcalde del Ayuntamiento, demostrado al ser numeroso el grupo de alcaldes que acceden al cargo de diputado, y notable el número de diputados que alcanzan la alcaldía de la capital. El segundo paso es el diputado provincial como cargo que es casi necesario desempeñar previamente si se quiere llegar al tercer paso, que es el de diputado a Cortes, pasando de esta forma del ámbito político local al provincial y al nacional.

Otra característica es la de la consolidación de los diputados en sus escaños y en sus distritos, es decir, se presentan y se mantienen durante varias legislaturas y llegan con ello a formar generaciones o familias políticas que llegan a adquirir altas cotas de poder. Sucede a menudo que, llegado el caso por motivos de edad ó de salud, la elección recae en un familiar. Ello llega a potenciar la presencia de las sagas familiares a lo largo de los años en los mismos puestos de la política provincial. A la vista de estos hechos podemos considerar que la Diputación es, en estos años, una escuela de políticos.

En definitiva, los diputados provinciales son los que sin duda han jugado el papel más importante en la vida de la Diputación. Se han preocupado por sus intereses y por los de la provincia y han tenido una cierta importancia en el progreso provincial. La mayoría de ellos disfrutaban, con anterioridad a alcanzar la elección, una situación económica desahogada y una situación social destacada. Estos dos factores, su intervención en la vida política provincial y su situación económica y social, les han favorecido para ampliar y consolidar su poder y su patronazgo territorial. Han tendido sus redes de parentesco y de contactos sociales, y llegado el caso, han conseguido 
acceder a la política nacional, o en otras ocasiones les ha beneficiado para incrementar y consolidar su patrimonio personal.

Como balance final, puede decirse que la Diputación de Valladolid nació por la necesidad de ordenar administrativamente a la provincia. Se esforzó para conseguir unos objetivos de mejora social y económica, aunque quedó a medio camino de conseguirlo a causa de las dificultades económicas en las que se desenvolvía la provincia. No tuvo opción en sus diferencias con el gobierno y se amoldó a sus órdenes. No pudo influir en los trabajos legislativos y se conformó con lo que se aprobaba por las Cortes. Con referencia a las actividades que ejerce, se constata un balance económico y social bastante modesto, algo más ventajoso en los beneficios políticos para el Estado y para las élites gestoras. El progreso de la provincia en el auge económico de los años 60 tiene su base en el trabajo de la burguesía, puede decirse que la Diputación apenas acompañó complementariamente.

Los diputados trabajaron para la provincia y a veces se aprovecharon del trabajo. Controlaron su distrito, al principio de una forma individual y familiar, que se puede considerar como el germen del caciquismo, pero en estos años en la Diputación de Valladolid no destaca de manera clara el clientelismo y el patronazgo de hombres y partidos políticos hasta formar un caciquismo tal como cristalizará después en la Restauración. 


\section{7.-ARCHIVOS, FUENTES IMPRESAS Y BIBLIOGRAFÍA.}

\section{ARCHIVOS}

- Archivo de la Diputación Provincial de Valladolid (ADPV).

- Archivo Histórico Municipal de Valladolid (AMVA).

- Archivo de la Real Chancillería. Sección Fondos Municipales (AMVA.Chancillería).

- Archivo Histórico Universitario de Valladolid (AHPV).

\section{FUENTES IMPRESAS.}

Boletín Oficial de la Provincia de Valladolid. Desde 1833 hasta 1875.

Colección de Decretos y Órdenes Generales que han expedido las Cortes. Desde 1810 a 1823 (10 volúmenes). Imprenta Nacional. Madrid. 1820-1823.

Colección de Decretos del Rey Nuestro Señor Don Fernando VII. Desde 1814 a 1820 . Imprenta Nacional. Madrid. 1820.

Colección Legislativa de España. Desde el año 1860. Imprenta del Ministerio de Gracia y Justicia. Madrid. 1963.

Colección de Órdenes Reales. Entre 1820 y 1823 (13 volúmenes). Imprenta Nacional. Madrid. 1823.

Colección de Reales Decretos de la Reina Nuestra Señora Doña Isabel II. Años 1834-18351836. Imprenta Real. Madrid. 1836.

Constitución Política de la Monarquía Española de 1812 e Instrucción para el Gobierrno Económico-Político de las Provincias de 3 de febrero de 1823, en MARTINEZ ALCUBILLA, Marcelo.Diccionario de Administración Española. Madrid. 1886.

Gaceta de Madrid. Años 1813-1820-1821-1822-1823.

Recopilación legislativa de España entre los años 1810 y 1859 en CASAS Y MORAL, Antonio de. Imprenta de M. Garrido. Granada. 1859.

\section{BIBLIOGRAFÍA.}

ABAD, Juan José y TRIGO, Lorenzo. Historia de España. Club internacional del libro. Madrid.1989

ALCOCER MARTINEZ, Mariano. Historia de la Universidad de Valladolid. Imprenta Castellana. Valladolid. 1922.

ALMUIÑA FERNÁNDEZ, Celso. Valladolid en el Siglo XIX. Ateneo. Valladolid. 1985. Tomo VI.

ALMUIÑA FERNÁNDEZ, Celso. La prensa vallisoletana durante el Siglo XIX (2 vol.). Institución Cultural Simancas. Valladolid. 1977.

ALMUIÑA FERNÁNDEZ, Celso. El Valladolid de ayer. Universidad de Valladolid. Valladolid. 1993.

ALONSO ORTEGA, José Luis. El Canal de Castilla. Junta de Castilla y León. Valladolid. 1987.

ÁLVAREZ JUNCO, José. "La difícil nacionalización de la Derecha Española". Hispania. Revista Española de Historia, Vol. LXI/3. (2001). Págs. 831-858.

ANTOLINEZ DE BURGOS, Juan. Historia de Valladolid. Grupo Pinciano. Valladolid. 1987 (Facsímil de la Imprenta de H. de José Rodríguez. 1887).

ARA GIL, Clementina Julia. Escultura gótica en Valladolid y su provincia. Instituto Cultural Simancas. Ed. Diputación de Valladolid. Valladolid. 1977.

ARIAS MARTINEZ, Benito (Coord.). De Escuela Normal a Facultad de Educación. 150 años de innovaciones educativas en Valladolid. Universidad de Valladolid. Valladolid. 1998.

ARTOLA, Miguel. Partidos y programas políticos 1808-1936. Ed. Aguilar Madrid. 1974.

ARTOLA, Miguel. Enciclopedia de Historia de España. Alianza Editorial. Madrid. 1991. 
BELLOGIN, Ángel y otros. La revolución liberal en Valladolid entre 1808 y 1874. G.Pinciano. Valladolid. 1993.

BERMEJO MARTÍN, Francisco y DELGADO IDARRETA, José Miguel. La administración provincial española. La Diputación de La Rioja. Ed. Gobierno de la Rioja. Logroño. 1989.

BRAVO MURILlO, Juan. (José Luis COMELLAS ed. lit.). Política y administración en la España Isabelina. Ed. Marcea. Madrid. 1972.

BURDIEL, Isabel. Isabel II. No se puede reinar inocentemente. Espasa. Madrid. 2004.

BURDIEL, Isabel. Liberales, agitadores y conspiradores: biografías heterodoxas del Siglo $X I X$. Espasa. Madrid. 2000.

BURDIEL, Isabel. Literatura e historia cultural. Ed. Episteme. Valencia. 1996.

BURDIEL, Isabel. La política de los notables (1834-1836). Ed. Alfonso el Magnánimo. Valencia. 1987.

CALERO AMOR, Antonio María. La división provincial de 1833. Bases y antecedentes. Ed. I.E. Administración Local. Madrid. 1987.

CANO BUESO, Juan. Material para el estudio de la Constitución. Tecnos. Madrid. 1989.

CANO GARCÍA, Juan Antonio. Gamacistas y Albistas. La vida política en Valladolid durante la Restauración. Universidad de Valladolid, Secretariado de Publicaciones. Valladolid. 2008.

CANO GARCIA, Juan Antonio. El poder político en Valladolid durante la Restauración. La figura de César Silió. Secretariado de Publicaciones de la Universidad de Valladolid. Valladolid. 1996

CANO GARCIA, Juan Antonio. "La trasmisión familiar del poder político en Valladolid durante la época contemporánea" en CONTRERAS CONTRERAS, Jaime. Ed. Familia, poderes, instituciones y conflictos. Murcia. 2010. Págs. 235 a 248.

CARANTOÑA ÁlVAREZ, Francisco. Historia de la Diputación Provincial de León (2 vol.). Instituto Leonés de Cultura. León. 1995.

CARANTOÑA ÁlVAREZ, Francisco. La Guerra de la Independencia en Asturias. Ed. Cañada. Madrid. 1989.

CARASA SOTO, Pedro. "La recuperación de la historia política y la prosopografía". En Elites: Prosopografía contemporánea. Universidad de Valladolid. Valladolid. 1994. Págs.41-52.

CARASA SOTO, Pedro. "Los pósitos en España en el Siglo XIX". Investigaciones históricas, .4 (1983) 247-304.

CARASA SOTO, Pedro. "Estructura socio profesional y socio económica de Valladolid en 1840-41 como prototipo de una ciudad de Castilla la Vieja". Investigaciones históricas, $\mathrm{n}^{\circ} .4$ (1983). Págs.305-350.

CARASA SOTO, Pedro. "Las élites políticas vallisoletanas durante la Restauración”. En Valladolid. Historia de una ciudad. III. Época Contemporánea. Valladolid. 1999. Págs. 909963.

CARASA SOTO, Pedro. "El giro local”. Alcores. Revista de Historia Contemporánea, 3 (2007). Págs.13-35.

CARASA SOTO, Pedro. "Élites castellanas de la Restauración: Diputados y senadores entre 1876-1923”. Investigaciones históricas. Época Moderna y Contemporánea, nº.15 (1995). Págs. 13-18.

CARASA SOTO, Pedro. Pauperismo y revolución burguesa (Burgos, 1750-1900). Universidad de Valladolid: Secretariado de Publicaciones. Valladolid. 1987.

CARASA SOTO, Pedro. 150 años del ferrocarril en la ciudad de Valladolid. Ed. Ayuntamiento de Valladolid. Valladolid. 2006.

CARASA SOTO, Pedro. La reina en la ciudad. Usos de la historia en la visita de Isabel II a Valladolid. Ed. Ayuntamiento de Valladolid. Valladolid. 2007.

CARASA SOTO, Pedro. La ciudad y el tren. Talleres y ferroviarios en Valladolid (1856-1936) Ed. Ayunta miento de Valladolid. Valladolid. 2003.

CARASA SOTO, Pedro (Dir.). Diccionario biográfico de alcaldes de Valladolid. Ed. Ayuntamiento de Valladolid. Valladolid., 2010.

CARASA SOTO, Pedro. (Dir.). Diccionario biográfico de parlamentarios castellanos y leoneses. Ed. Universidad de Valladolid. Valladolid. 2011.

CARASA SOTO, Pedro. (Dir.). Elites castellanas de la Restauración. Ed. Junta de Castilla y León. Salamanca. 1997.

CARASA SOTO, Pedro (Coord.). La Enseñanza Secundaria y el Instituto Zorrilla. Ed. Instituto Zorrilla. Valladolid. 2009.

CASAS Y MORAL, Antonio. Recopilación legislativa desde 1810 a 1859. Granada. 1857. 
CASTRO, Concepción de. La Revolución liberal y los municipios españoles. Alianza Universidad, n²49. Madrid. 1979.

COLOMER VIADEL, Antonio. El sistema político de la Constitución española de 1837. Madrid. 1989.

COMELLAS, José Luis. Los moderados en el poder 1844-1854. Escuela de Historia Moderna. Madrid. 1970.

COMELLAS, José Luis (Coord.). Historia de España y América. Ed. Rialp. Madrid. 1985.

CHUST, Manuel (Dir.). Historia de la Diputación de Valencia. Prólogo de F. Tomás y Valiente. Diputación P. de Valencia. Valencia. 1995.

DIEZ ESPINOSA, José Ramón. Desamortización y economía agraria en Valladolid (18551868). Institución Cultural Simancas. Valladolid. 1986.

DIEZ ESPINOSA, José Ramón. Revolución liberal en Castilla. Universidad de Valladolid. Valladolid. 1987.

DIEZ ESPINOSA, José Ramón. “Opinión pública y desamortización en el Valladolid de Isabel II”. Investigaciones Históricas, no 4. Valladolid. 1983. Págs. 351-390.

DIEZ ESPINOSA, José Ramón. "Agricultura, industria y comercio" en ALMUIÑA FERNANDEZ, Celso. Valladolid en el Siglo XIX. Ed. Ateneo de Valladolid. Valladolid. 1985. DUQUE LUCAS, Luis Carlos (Coord.). La enseñanza Secundaria y el Instituto Zorrilla. Ed. I.E.S. Zorrilla. Valladolid. 2009.

ESPADA BURGOS, Manuel y URQUIJO GOITIA, José Ramón. Historia de España. Gredos. Madrid. 1985.

ESTRADA NERIDA, Julio y TRAPOTE SINOVAS, María del Carmen. "Sobre la prensa periódica en Palencia y Valladolid, durante la Guerra de la Independencia". Separata 63 de la publicación Tello Téllez de Meneses. Palencia. 1992.

ESTRADA SÁNCHEZ, Manuel. El significado político de la legislación electoral en la España de Isabel II. Universidad de Cantabria. Santander. 1999.

FERNÁNDEZ SEGADO, Francisco. Las constituciones históricas españolas. Ed. Cívitas. Madrid. 1986.

FERRATER Y FERIGLE. Recopilación de las leyes de 1833 a 1841 y extractadas desde 1808 a 1833" (4 vol.).

FERRERO MAESO, Concepción. BERZAL DE LA ROSA, Enrique. Historia del Colegio de Abogados de Valladolid. Ed. Ilustre Colegio de Abogados de Valladolid. Valladolid. 2008.

FULGOSIO, Fernando. "Crónica de la provincia de Valladolid". En Crónica General de España. Historia ilustrada y descriptiva de sus provincias. Imprenta de Rubio, Grilo y Viteri. Madrid. 1869

GARCÍA de la RASILlA, María del Carmen. El Ayuntamiento de Valladolid. Política y gestión (1899-1936). Fundación Municipal de Cultura. Ayuntamiento de Valladolid. Valladolid. 1991.

GAROFARO SÁNCHEZ, Rafael. La Constitución Gaditana de 1812. Diputación de Cádiz. Cádiz. 1983.

GARRIGÓS PICÓ, Eduardo. La economía española a fines del Antiguo Régimen. Alianza Univ. Madrid. 1982.

GONZALEZ GARCÍA-VALLADOLID, Casimiro. Datos para la historia biográfica de la M.L.M.N.H. y Excma. Ciudad de Valladolid. Imprenta de H. Rodríguez. Valladolid. 1894.

GONZALEZ GARCÍA-VALLADOLID, Casimiro. Valladolid, sus recuerdos y sus grandezas. Imp. H. Gutierrez. Valladolid. 1894.

GONZÁlEZ MARIÑAS, Pablo. Las Diputaciones Provinciales en Galicia. Diputación Provincial de La Coruña. La Coruña. 1978.

HELGUERA QUIJADA, Juan y otros. El Canal de Castilla. Junta de Castilla y León. Valladolid. 1990.

IGLESIAS ROUCA, Lena Saladina. Urbanismo y arqueología en Valladolid. Primera mitad del S. XIX. Ayuntamiento de Valladolid. Valladolid. 1978.

LACARRA, José María. Estructura político-administrativa de Navarra.Ed. Príncipe de Viana.Pamplona. 1963.

LEMUS LOPEZ, Encarnación. Extremadura (1923-1930). La historia a través de las Diputaciones Provinciales. Diputacion de Badajoz. Badajoz. 1994.

LOARCE GÓMEZ, José Luis. Historia de la Diputación Provincial de Ciudad Real (18351999). Biblioteca de Autores Manchegos. Diputación Provincial de Ciudad Real. Ciudad Real. 1999. 
LOPEZ GARRIDO, Diego. La Guardia Civil y los orígenes del estado centralista. Alianza Editorial. Madrid. 2004.

LORCA SIERO, Antonio. Bases de la Constitución de 1856. Ed. Domo. Madrid. 1991.

LUENGO SÁNCHEZ, Jorge. "Historias alemanas. Localismo y Estado Nación en el relato sobre la Alemania decimonónica”. Alcores. Revista de Historia Contemporánea, 3 (2007). Págs.37-49.

LUENGO SÁNCHEZ, Jorge. El nacimiento de una ciudad progresista. Valladolid durante la regencia de Espartero (1840-1843). Ayuntamiento de Valladolid. Valladolid. 2005.

LLORCA, Carmen. Isabel II y su tiempo. Istmo. Madrid. 1984.

MADOZ, Pascual. Diccionario Geográfico-Estadístico-Histórico de España y sus posesiones de Ultramar. Madrid. 1850.

MARCOS MARTÍNEZ, Pablo y otros. Crisis demográfica y tensiones sociales en Castilla en el S. XIX. Universidad de Valladolid. Valladolid. 1987.

MARICHAL, Carlos. La Revolución Liberal y los primeros partidos políticos en España (1834-1844). Cátedra. Madrid. 1980.

MARTÍN BOBILlo, Pablo. Origen de la Diputación Provincial de Zamora (1813-23). Diputación Provincial de Zamora. Zamora. 1988.

MARTÍN GONZÁLEZ, Juan José y TORREMOCHA HERNÁNDEZ, Margarita. La Universidad de Valladolid. Ed. Universidad de Valladolid. Valladolid. 1997.

MARTÍN JIMENEZ, Ignacio. La educación primaria y secundaria en la provincia de Valladolid (1857-1875).Ed. Diputación de Valladolid. Valladolid. 2008.

MARTÍNEZ ALCUBILlA, Marcelo. Diccionario de administración española. Imprenta del Asilo de Huérfanos. Madrid. 1915.

MARTÍNEZ CUADRADO, José. Estudio constitucional en 1812. Unión Editorial. Madrid. 1982.

MARTÍNEZ DIEZ, Gonzalo. "Génesis histórica de las provincias españolas”. Anuario de Historia del Derecho Español, no.51 (1981). Págs. 524-593.

MARTÍNEZ MARTEL Y ABADÍA, Demetrio. Diario de Valladolid desde 1810 a 1834. Imp.de H. Gutiérrez. Valladolid. 1887.

MARTÍNEZ SOSPEDRA, Manuel. La Constitución de 1812. Universidad de Valencia. Valencia. 1978.

MAZA ZORRILLA, Elena. "Crisis y desamortización en el S. XIX”. En Investigaciones Históricas, no 4 (1983). Págs.185-246.

MAZA ZORRILLA, Elena. Valladolid, sus pobres y la respuesta institucional. Universidad de Valladolid. Valladolid. 1985.

M.E.C. Historia de la educación en España. De las Cortes de Cádiz a la Revolución de 1868. Servicio de Publicaciones. Madrid. 1985.

MELÓN RUIZ de GORDEJUELA, Amancio. "Inmediata génesis de las provincias españolas". En Anuario de Historia del Derecho Español no 27-28. (1957-58). Págs. 17 a 59.

MELÓN RUIZ de GORDEJUELA, Amancio. "El mapa prefectural de España. 1810”. En Revista de Estudios Geográficos no 46 (1952). Págs. 6 a 72.

MILLÁN y GARCÍA VARELA, Jesús. "Las burguesías europeas del siglo XIX”. Ed. J.M. Fradera. Madrid

MORENO LAZARO, Javier. Los empresarios harineros castellanos (1765-1913). Ed. Universidad de Valladolid. Valladolid. 1999.

MUÑOZ DEL BUSTILlO ROMERO, Carmen. "Asturias: Cuerpo de Provincia” en Anuario de Historia del Derecho español. LXII, (1992).

NIDO y SEGALERVA, Juan del. Antología de las Cortes desde 1840 a 1848 . Ed.Analecta, reproducción facsímil de Establecimiento tipográfico Hijos de J.A. García. Madrid. 1910.

NIETO, Alejandro. Los primeros pasos del Estado constitucional. Ed. Ariel Derecho. Barcelona. 1996.

NIEVA, José María. Recopilación de las Leyes de 1833 a 1841. Madrid. 1836.

ORDUÑA REBOLLO, Enrique. Evolución histórica de la Diputación Provincial de Segovia. Diputación P. de Segovia. Segovia. 1991.

ORDUÑA REBOLLO, Enrique. “Antecedentes poblacionales del municipio constitucional”. En Revista de Estudios de Administración Local y Autonómica, no 233 (Enero-Marzo 1987). Págs. 85 a 97.

ORTEGA Y RUBIO, Juan. Noticias y casos particulares ocurridos en Valladolid. Años de 1808 a 1814. Imp. H. de Rodríguez. Valladolid. 1886.

ORTEGA Y RUBIO, Juan. Historia de Valladolid. Imp. H. de H. Gutierrez. Valladolid. 1881. 
ORTEGA Y ZAPATA, José. Solaces de un vallisoletano sesentón. Valladolid de 1830 a 1847. Valladolid, 1895 (Edición facsímil de 1984. UVA).

ORTEGO GIL, Pedro. Evolución legislativa de la Diputación Provincial en España 18121845. Diputación de Guadalajara (2 vol.). Universidad Complutense de Madrid. Madrid. 1990. PALOMARES IBÁÑEZ, Jesús María. Temas vallisoletanos del S. XIX. Universidad de Valladolid. Valladolid. 1976.

PALOMARES IBAÑEZ, Jesús María. La asistencia social en Valladolid. El Hospicio de Pobres y la Real Casa de Misericordia (1724-1847). Ed. Diputación Provincial. Valladolid.1975.

PALOMARES IBAÑEZ, Jesús María (Coord.). Historia de la Universidad de Valladolid. Universidad de Valladolid. Valladolid. 1989.

PASTOR PETIT, Domingo. El bandolerismo en España Barcelona. $1979 .$.

PASTRANA MORILlA, Heliodoro. La Diputación Provincial de Valladolid (1875-1930). Política y gestión. Diputación Provincial de Valladolid. Valladolid. 1997.

PASTRANA MORILLA, Heliodoro. "El control de las Diputaciones por los caciques regionales. La Diputación vallisoletana de la Restauración”. En Investigaciones históricas, $\mathrm{n}^{\circ}$ 15 (1995). Págs. 55-66.

PAYNE, Stanley G. Ejército y sociedad en la España liberal (1808-1936). Ed. Akal. Madrid. 1977.

PÉREZ CHINARRO, José María. Edificios municipales en la provincia de Valladolid. Institución Cultural Simancas. Valladolid. 1986.

PÉREZ GARCÍA, María del Pilar. La bancarrota de un banco emisor: el Banco de Valladolid. Ed. Instituto de Contabilidad y Auditoría de Cuentas. Madrid. 1991.

PÉREZ GARZÓN, Juan Sisinio. Milicia nacional y revolución burguesa. El prototipo madrileño 1808-1874. Ed. Instituto Jerónimo Zurita. Madrid. 1978.

POSADA, Adolfo. Evolución legislativa del régimen local en España (1812-1909). Madrid. 1982.

PRIETO CANTERO, Amalia. Historia de la Real Academia de Nobles y Bellas Artes de la Purísima Concepción de Valladolid. Institución Cultural Simancas. Valladolid. 1983.

REBOREDO OLIVENZA, José Daniel. "El motín del pan en 1856 en Castilla la Vieja". En Crisis demográfica y tensiones sociales en Castilla en el siglo XIX. Págs. 121 y sig.

REYNOSO, Mariano Miguel de. Política administrativa del Gabinete Bravo Murillo en el ramo de fomento. Imprenta de Tejada. Madrid. 1857.

RICO Y AMAT, Juan. Diccionario de los políticos. Institución Alfonso el Magnánimo, edición facsímil. Madrid. 1855.

RIVERA BLANCO, José Javier. El Palacio Real de Valladolid. Institución Cultural Simancas. Valladolid. 1981.

RUEDA HERNANZ, Germán. La desamortización de Mendizábal en Valladolid (1836-1853). Ed. Cátedra. Madrid. 1986.

RUEDA HERNANZ, Germán. Isabel II. Ed. Arlanza. Madrid. 2001.

RUIZ BERRIO, Julio. Política escolar de España en el siglo XIX (1808-1833).C.S.I.C. Madrid. 1970 .

SALCEDO IZU, Joaquín José. La Diputación del Reino de Navarra. (2 vol.) Universidad de Navarra. Pamplona. 1969.

SAN MIGUEL BENITO, María Begoña. El Instituto de Segunda Enseñanza de Valladolid. Desde su establecimiento hasta 1930. Memoria de licenciatura inédita. Universidad de Valladolid.

SANZ, Federico. L a Segunda Enseñanza oficial en el siglo XIX (1834-1874) Tesis doctoral. Valladolid.1981.

SERRANO GARCÍA, Rafael. La Revolución de 1868 en Castilla y León. Universidad de Valladolid. Valladolid. 1992.

SERRANO GARCÍA, Rafael. El Sexenio Revolucionario en Valladolid. Cuestiones sociales (1868-1874). Junta de Castilla y León. Valladolid. 1986.

SERRANO GARCÍA, Rafael. Revolución liberal y asociación agraria en Castilla 1886-1974. Universidad de Valladolid. Valladolid. 1997.

SERRANO GARCÍA, Rafael. Valladolid, un siglo de cuestión social. Grupo Pinciano. Valladolid. 1995.

SERRANO GARCÍA, Rafael. "La exposición castellana de 1859". En "Altares. Revista de Historia Contemporánea. $\mathrm{n}^{\circ}$ 1(2006). 
SERRANO GARCIA, Rafael. Castilla la Vieja y León (1808-1936). Ed. Universidad de Valladolid. Valladolid. 2008.

SERRANO GARCÍA, Rafael. "La quiebra de un modelo expansivo" en YUN CASALILLA, Bartolomé. Estudio sobre el capitalismo agrario, crédito e industria en Castilla. Siglos XIX y $X X$. Valladolid. 1991.

SINOVA, Germán (Coord.). VI Centenario de la Facultad de Medicina de Valladolid. Ed. Junta de Castilla y León. Valladolid. 2006.

TANSKI, Joseph. La guerra civil carlista de 1833-1840.Ed. Ministerio de Defensa. Madrid. 2011.

TIEDRA, José de. El Hospital de Santa María de Esgueva de Valladolid. Impr. Casa Martin. Valladolid. 1937.

TOMÁS Y VALIENTE, Francisco. "La Diputación en las Cortes de Castilla”. En Anuario de Historia del Derecho Español, no 32 (1962). Págs. 347-469.

TOMÁS VILlaRROYA, Joaquín. El Estatuto Real y la Constitución de 1837. Fundación S.María. Madrid. 1985.

TOMÁS VILLARROYA, Joaquín. Breve historia del constitucionalismo español. Centro de Estudios Constitucionales. Madrid. 1981.

TORTELLA CASARES, Gabriel. Los orígenes del capitalismo en España". Ed.Tecnos. Madrid. 1973.

TUÑÓN DE LARA, Manuel (Dir.) Historia de España (13 vol.). Editorial Labor. Barcelona. 1987.

URREA FERNÁNDEZ, Jesús. Arquitectura y nobleza. Casas y palacios de Valladolid. Ayuntamiento de Valladolid. Valladolid. 1996.

VALDEÓN BARUQUE, Julio (Dir.). Valladolid, historia de una ciudad (3 vol.). Ámbito. Valladolid. 1999.

VILLENA ESPINOSA, Rafael. Revolución democrática y administrativa provincial. La Diputación de Ciudad Real. Diputación Provincial de Ciudad Real. Ciudad Real. 1991.

V.V.A.A. Historia de Valladolid. (6 tomos) Ed. Ateneo de Valladolid. Valladolid. 1985.

V.V.A.A. La comisión de reformas sociales y la condición obrera en Valladolid (1883-1903). Universidad de Valladolid. Valladolid. 1985.

V.V.A.A. Los LXXV años del Instituto Zorrilla (1907-1982). Ed. Ayuntamiento de Valladolid. Valladolid. 1986.

YUN CASALILLA, Bartolomé (Coor.). Estudios sobre capitalismo agrario, crédito e industria en Castilla. Siglos XIX y XX. Valladolid. 1991. 